
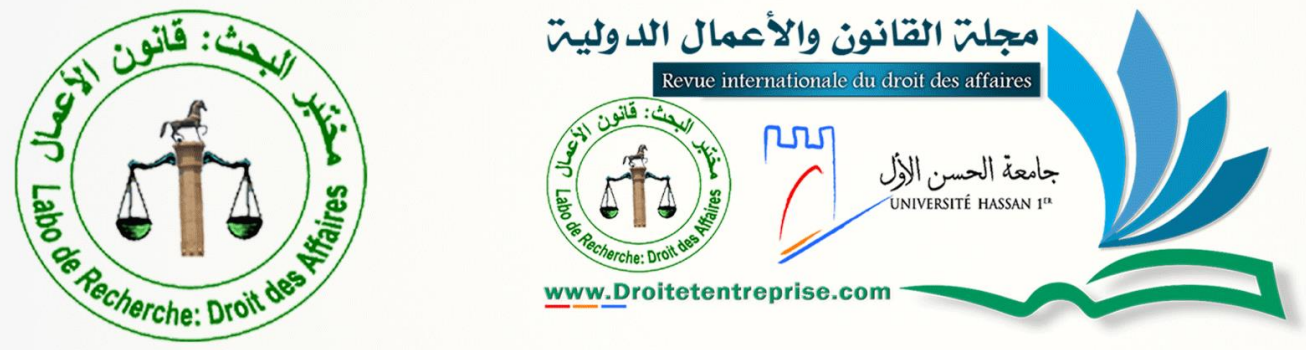

جامعة الحسن الأول UNIVERSITÉ HASSAN $1^{\text {ER }}$

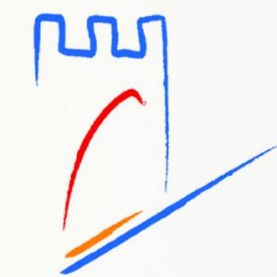

مجلة علميـة محكمة تعنى بالدراسـات والأبحاث في القانون والأعمال، تصدر عن مختبر البحث قانون الأعمال

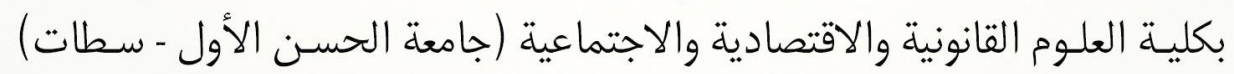

الإدارة العلمية: الدكتور رياض فـخري - المـدير المسؤول: الدكتور مصطفى الفوركي - إدارة التحرير: الأسـتاذ محمد أفقير
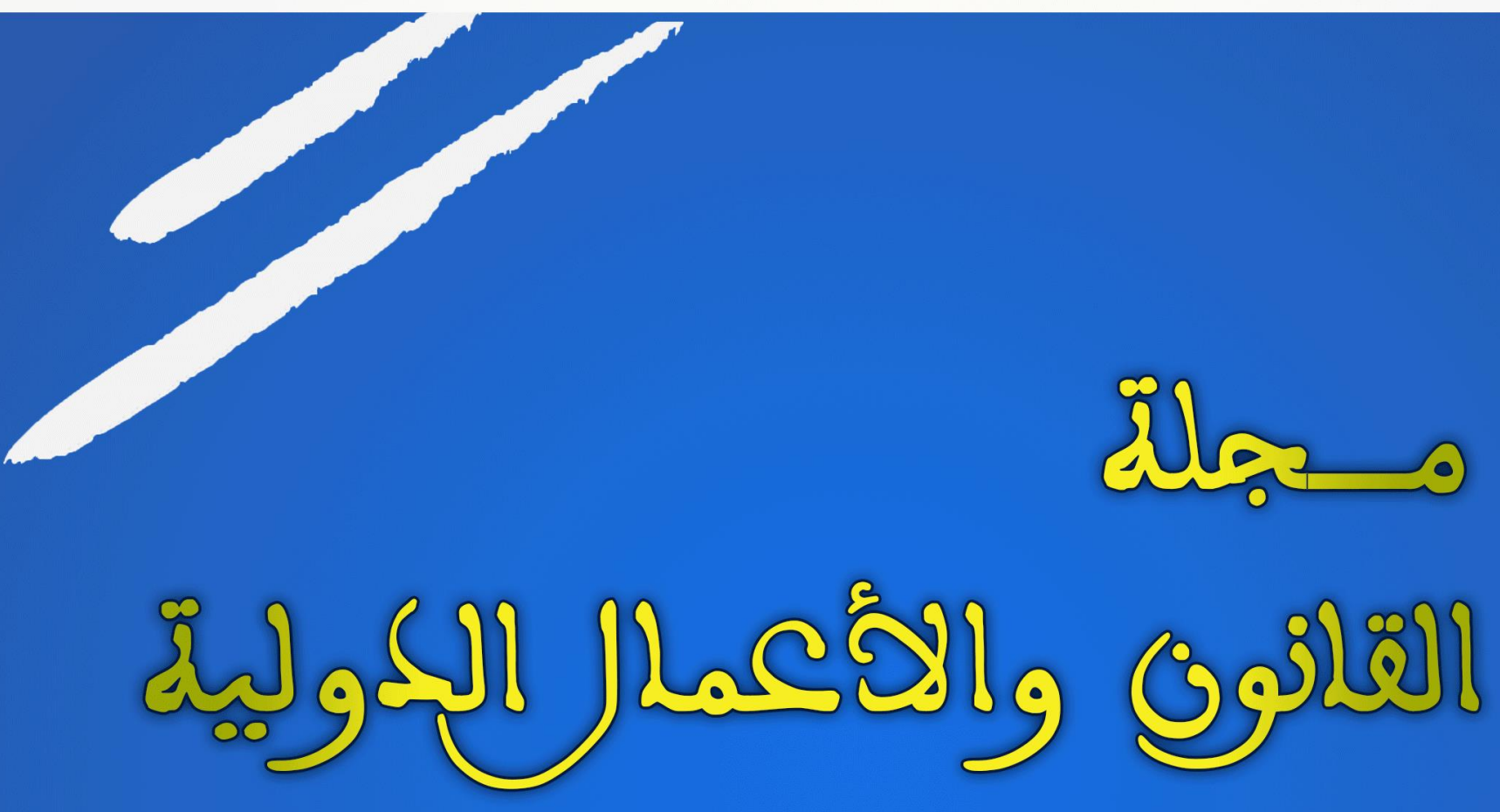

الفكلم 25 - عممنير2019 


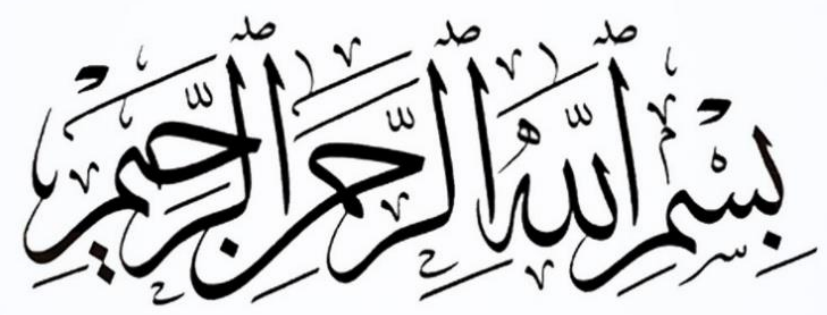




\section{تم نشر هذا المؤلف بتمويل من ميزانية}

جامعة الحسن الأول بسطات لأجل دعم البحث العلمي

\section{مجلة القانون والأعمال}

$$
\begin{aligned}
& \text { ISSN: 2665-7910 - } 2019 \text { PE0018 : الإيداع القانوني }
\end{aligned}
$$

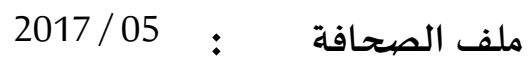

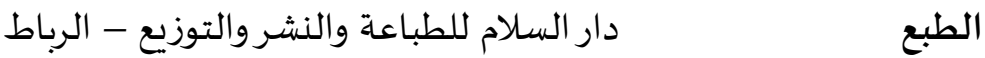

$$
\begin{aligned}
& \text { شارع الحسن الثاني زنقة طونكان عمارة 23، رقم 2، ديور الجامع الرباط المغرب } \\
& \text { الهاتف: 05.37.72.58.23 } \\
& \text { 06.61.10.65.51: : } \\
& \text { الفاكس: 05.37.72.13.32 - الفئ } \\
& \text { البريد الإلكتروني: contact@darassalam.ma } \\
& \text { الموقع الإلكتروني: www.darassalam.ma }
\end{aligned}
$$

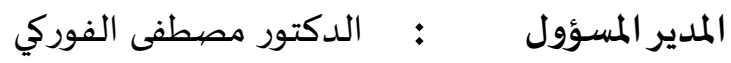

$$
\begin{aligned}
& \text { الهاتف } \\
& \text { Mforki22@gmail.com : البريد الإلكتروني }
\end{aligned}
$$

جميع الحقوق محفوظة - مجلة القانون والأعمال الدولية 2019 


\section{ME: HNTENATONAL

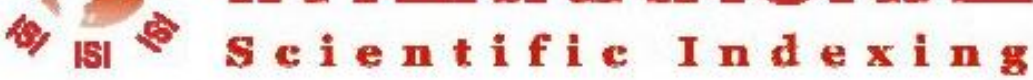 \\ Fresh Ideas for Growing your Citations}

\section{$\underline{\text { Certificate }}$}

This is to certify that مجلـة القـاتون والأعمـال is indexed in International Scientific Indexing (ISI). The Journal has Impact Factor Value of $\mathbf{0 . 8 2 1}$ based on International Citation Report (ICR) for the year 2018-19. The URL for journal on our server is https://isindexing. com/isi//journaldetails.php?id=8854

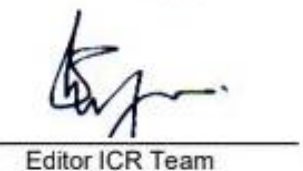

(ISI)

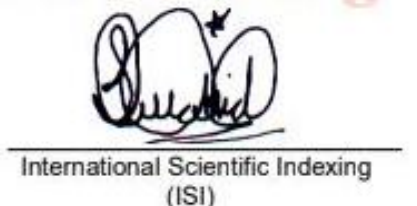

(ISI)

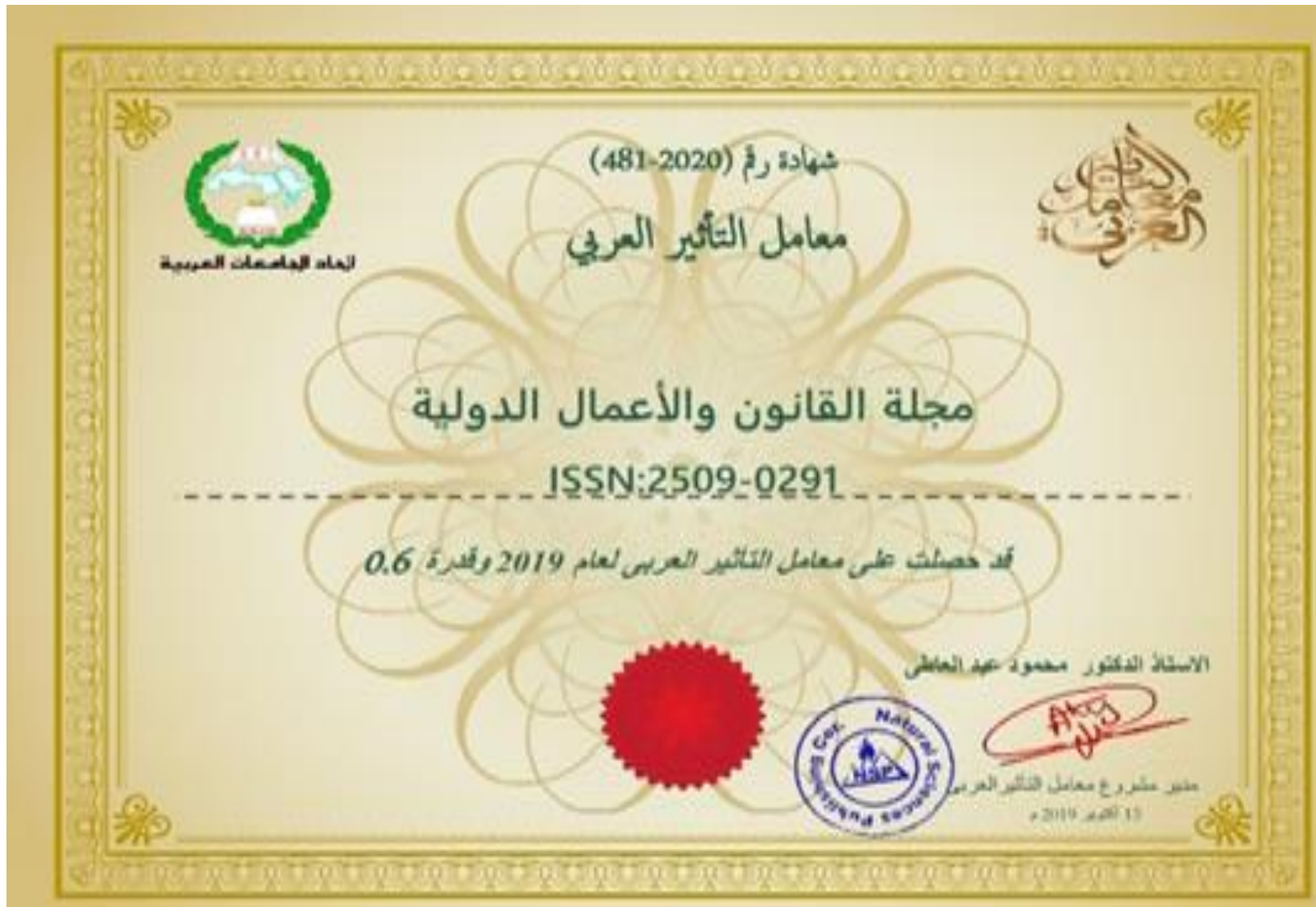


اللجنة العلمية والاستشارية لمجلة القانون والأعمال الدولية

د: عبد القادرالتعلاتي: أستاذ التعليم العالي جامعة الحسن الأول بسطات

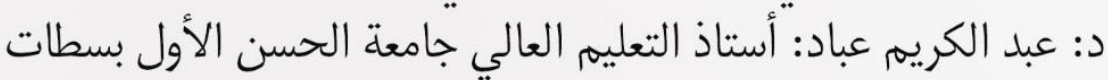

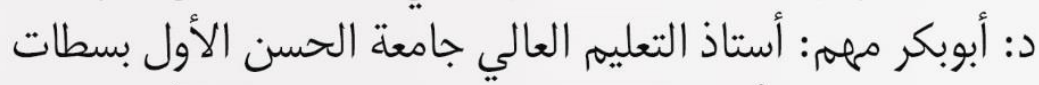

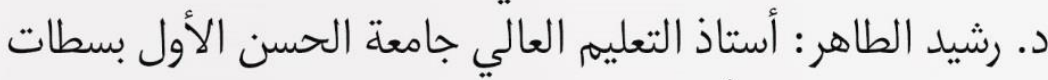

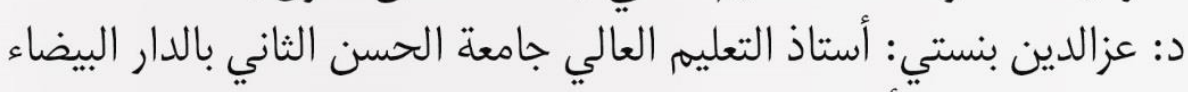

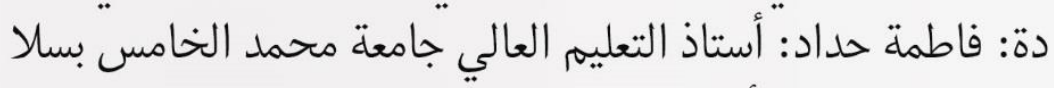

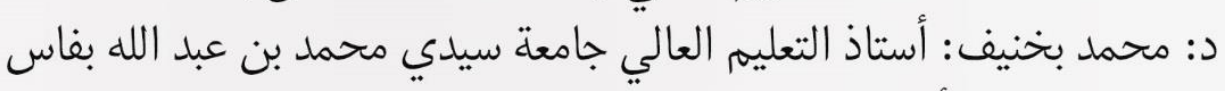

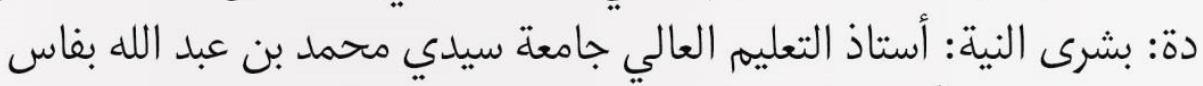

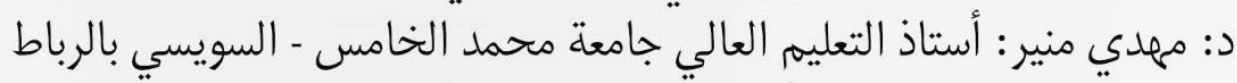

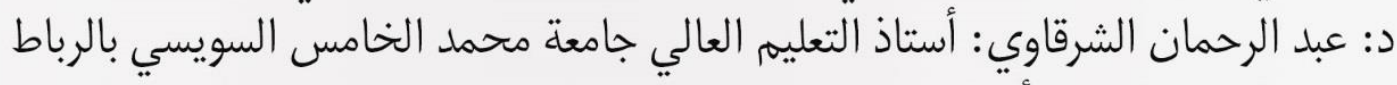

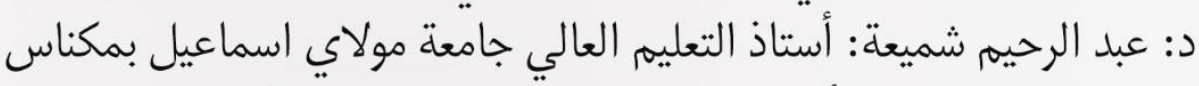

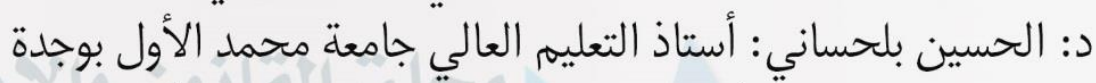

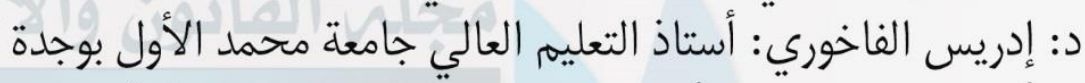

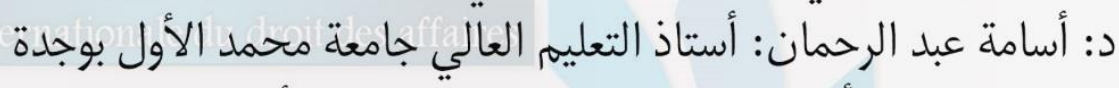

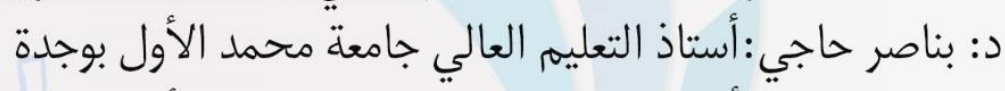

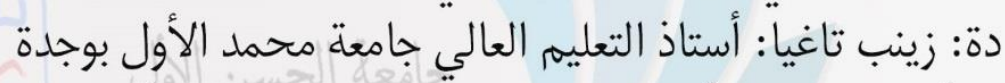

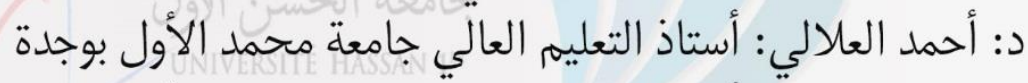

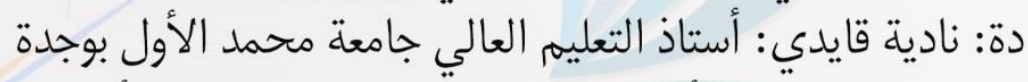

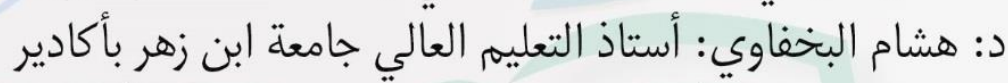

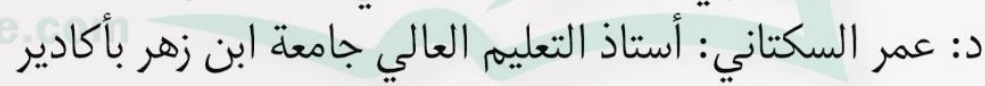

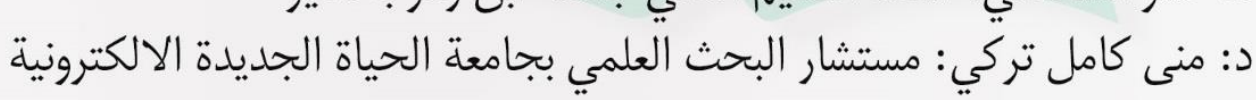

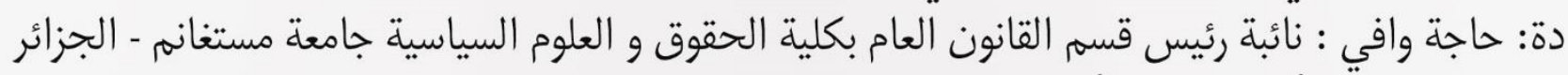

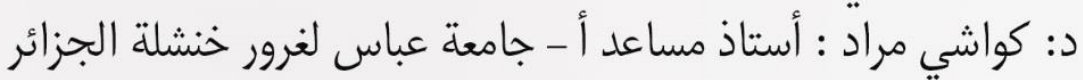

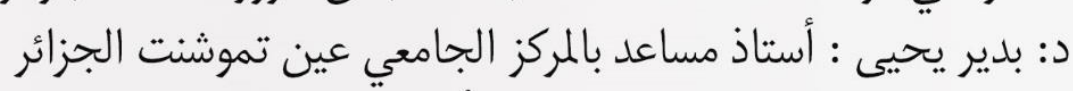

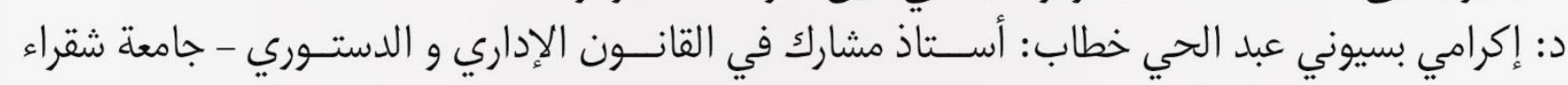
المملكة العربية السعودية دئية

د: رياض فخري: نائب رئيس جامعة الحسن الأول بسطات د: طارق مصدق: أستاذ التعليم العالي جامعة الحسن الأول بسطات

د. مصطفى الفوركي: أستاذ زائر بكليات الحقوق

ذ. محمد أمين اسماعيلي: باحث في مجال العلوم القانونية
الإدارة العلميـــة

المديـــر المســؤول 
ذ. محمد أفقير: باحث في مجال العلوم القانونية

رئيــس التحـريـــر

\section{هيئـــة تحريـــر مجلة القانــون والأعـمال الدولية}

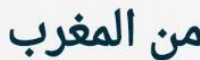

• د. سعد بهتي : دكتور في الحقوق أستاذ القانون الخاص بكلية الشريعة بالسمارة

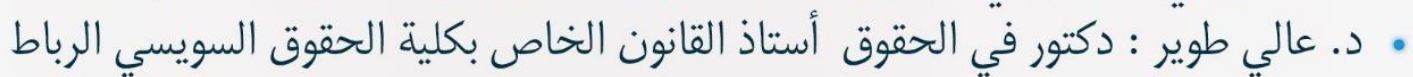

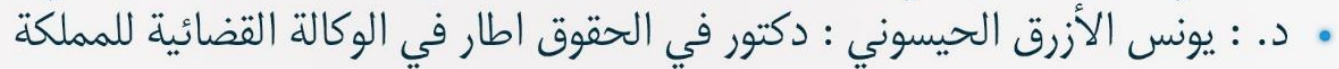

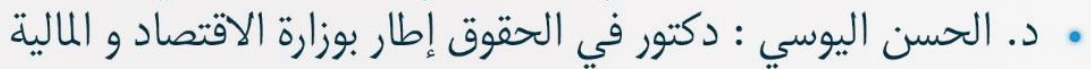

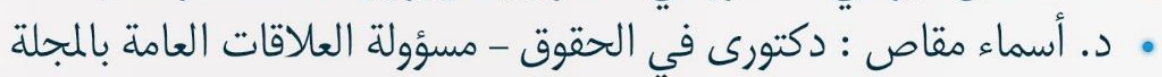

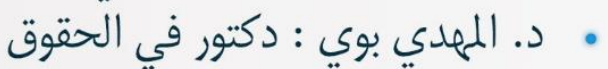

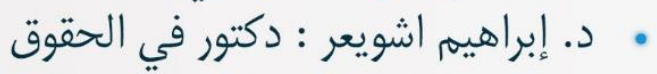

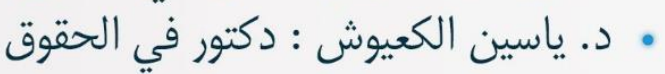

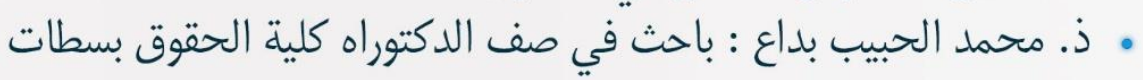

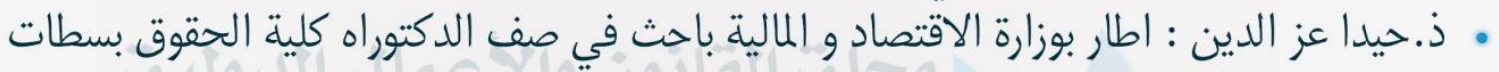

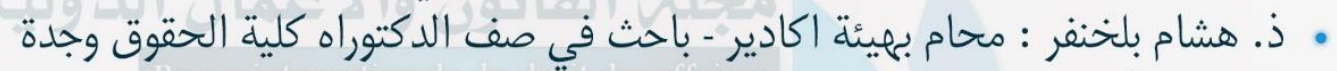
• ذ. ذ. محمد أوبالاك : محام بهيئة الرباط

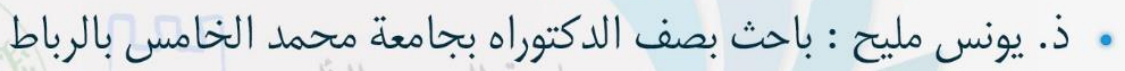

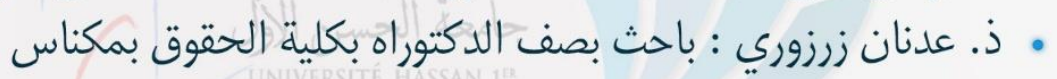

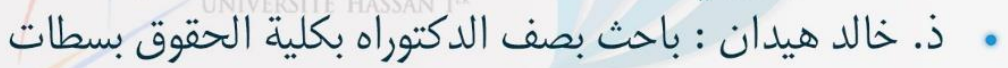

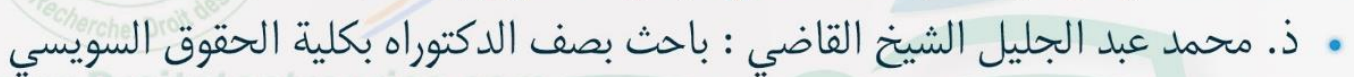

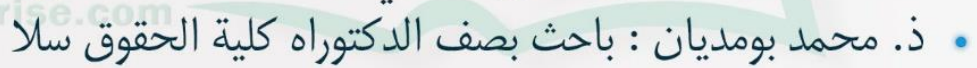

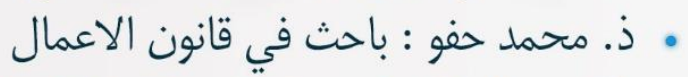

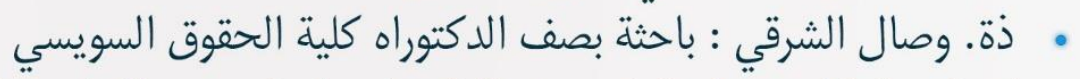

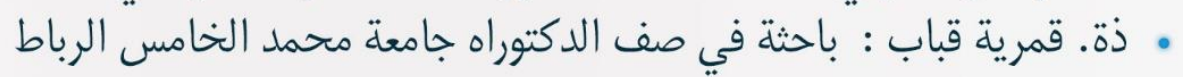

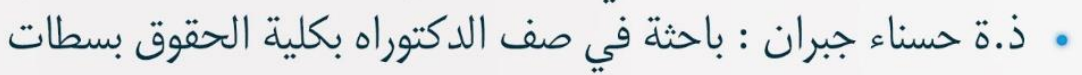

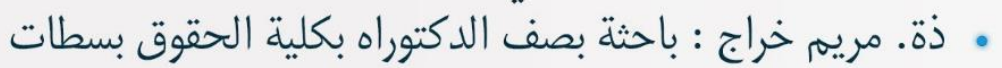

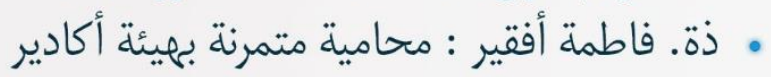

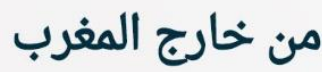

• ذ. محمد يحظيه ولد البكاي : باحث بصـف الدكتــوراه بجامعة انواكشــــوط العصــرية موريتانـيا ممثل المجلة في موريتانيا

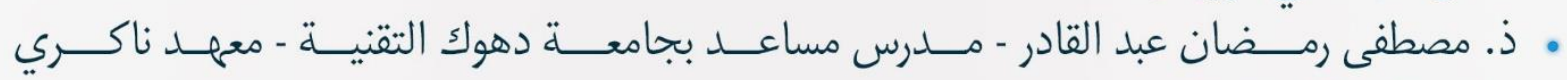
ممثل المجلة في العراق

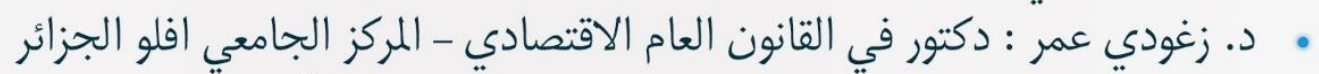

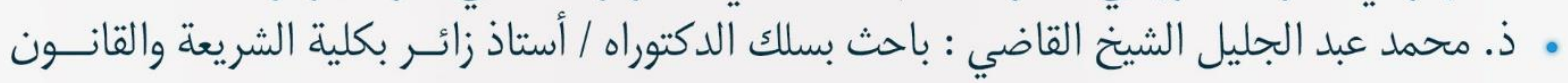
بجامعة العلوم الإسلامية بالعيون-موريتانيا 


\section{محور الدراسات والأبحاث باللغة العربية}

الكفالة في القانون المدني القطري: تأمين شخصي لحماية حق الدائن المدني عبدالله عبدالكريم عبدالله

سلطة تدبير جمعيات حماية المستهلك ذات المنفعة العامة من خلال الملحق بالمرسوم رقم 2.12.462 بتاريخ 14 نوفمبر 2012، القاضي بتحديد النظام الأساس النموذجي لجمعيات حماية المستهلك التي يمكن الاعتراف لما بصفة المنفعة العامة

27

53

63

التحقيق الابتدائي في تقنية الاتصال عن بعد - دراسة في قانون الإجراءات الجزائية الاتحادي رقم (35) لسنة 1992، المعدل بالمرسوم بقانون 17 لسنة 2018

71

87

108

122 المصطفى بوزمان

$$
\text { موقف القانون الدولي من اللجوء البيئي }
$$

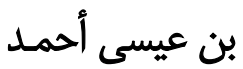

المَوِْنِ وأثره في أعمال السلطة التشريعية (دراسة في مدى دستورية انعقاد مجلس النواب بمدينة طبرق) عـادل عبد الحفيظ كندير

$$
\text { الحماية الجنائية للأطفال ضحايا الاستغلال في القانون المغربي }
$$

$$
\text { شرعية الدفاع الآلي عن الأموال على ضوء الفقه القضاء }
$$

$$
\begin{aligned}
& \text { عبد الواحد الدافي. } \\
& \text { العمل لأجل المنفعة العامة كعقوبة بديلة في ضوء مشروع القانون الجنائي }
\end{aligned}
$$

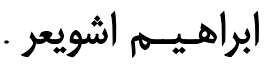

$$
\begin{aligned}
& \text { تكوين اتفاق التحكيم الداخلي }
\end{aligned}
$$


دراسة في المقتضيات الجديدة الضابطة لعمل البنوك الإسلامية في موريتانيا على ضوء التجربة المغربية

146

159

170

184

208

231

241

255

282

288

323

338

علي الدوه

$$
\text { مسؤولية الصحفي المدنية إثر الاعتداء على الحق في الصورة في القانون الجزائري }
$$
محمد سليه حمادي - نورة رمدوم . مان. المعاملات التجارية الالكترونية و مسألة إثباتها بين التقييد والحرية وفق التشريع الجزائري

تفاعل المغرب مع الشرعة الدولية لحقوق الإنسان

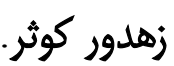

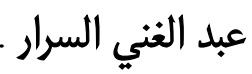
مؤسسة المفوض الملكي بالمحاكم الإدارية يوسف صنبي إشكالية تنفيذ الأحكام ضد الادارة الضريبية بين المقتضيات القانونية والعمل القضائي الحسن المير دور الريئات المتدخلة في سوق الشغل في حماية الأجير المؤقت عبد المنعم ازكاغ تعويضات نظام الضمان الاجتماعي المغربي لطيفة جبران قصور الحماية الإدارية للمجال العمراني أسماء حسيني دور التوقع في تحديد المسؤولية الجنائية عن الخطأ عباس عبد الرزاق السعيدي . الغش في مرحلة تنفيذ عقد البيع أحمد خيري أحمد عواد - سعد حسين عبد ملحم الحلبوسي .. النزاعات العقارية الجماعية : الإجراءات والاختصاص

زينب عبد الله المصطفى 


\section{محور الدراسات والأبحاث باللغة الفرنسية}

Péripéties historiques de l'arbitrage

Elkbir MESHALI

351

Douane et commerce électronique

Elfaique Amine

La récente loi $n^{\circ} 73-17$ : un dispositif pro-débiteur mis à l'épreuve?

Oussama CHEKAUD

La démocrature politico-économique : Stratégie endogène du développement de l'Empire du Milieu

NOUR Mohammed Rida

La hausse de la dette publique marocaine : Causes et solutions en comparaison avec les économies avancées

ATTAHIR Oussama

$$
\begin{aligned}
\text { تقرير حول ندوة "دور العدالة في تحسين مناخ الاعمال" محور تقارير الندوات واللقاءات العلمية }
\end{aligned}
$$

409 عبدالرزاق الإدريسي - زكرياء الشويخي لـ ندين

\section{تخلي أسرة تحرير المجلة مسؤوليتها عن أي انتهاك لحقوق الملكية الفكرية جميع الحقوق محفوظة لمجلة القانون و الأعمال الدولية 2019 هـ}




\section{كلمة (فتتلحية}

بسم الله والحمد لله والصلاة والسلام على رسول الله ... وبعد،

تكريسا لأهداف مجلة القانون و الاعمال الدولية كأحد روافد الثقافة القانونية و البحث العلمي في العالم العربي ، نبادر الى تقديم العدد الخامس و العشرون من مجلة القانون والاعمال الدولية الذي اكتمل بجهود ثلة من خيرة الباحثين العرب ، اللذين حرصوا على تقديم عمل علمي متكامل و رصين آملين أن يثري رصيد المعرفة القانونية لدى القراء و

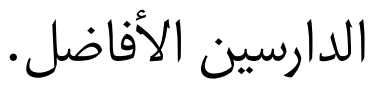

إن ادارة مجلة القانون والأعمال الدولية تحرص على استمرار سياستها في السعي إلى

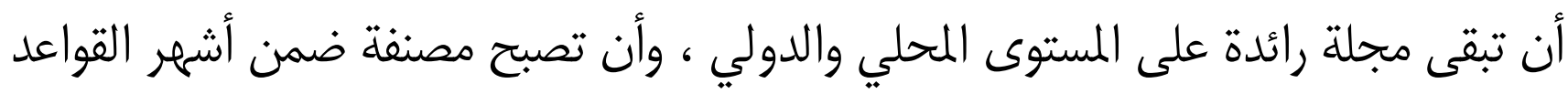

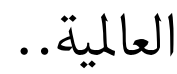

وتود ادراة مجلة القانون و الأعمال الدولية من قرائها أن يتفاعلوا معها من خلال موقعها على شبكة الإنترنت وبريدها الإلكتروني بإبداء ملاحظاتهم وتقديم مقترحاتهم التي يرون أنها يمكن لها مردود جيد على تطوير المجلة والارتقاء بها. والله ولي التوفيق والنجاح..... والله من وراء القصد وهو يمهدي السبيل

إلخارة مجلة القانونوالأعمال لالحولية 


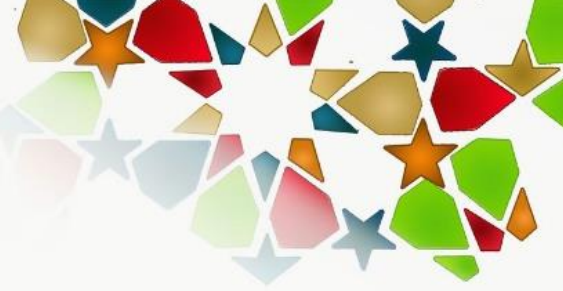

مجلت القانون والأعمال الدوليت

Revue internationale du droit des affaires
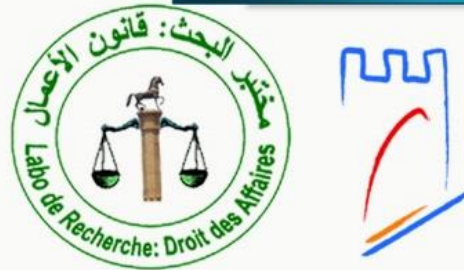

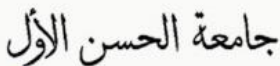
UNIVERSITÉ HASSAN $1^{\text {Da }}$

www.Droitetentreprise.com

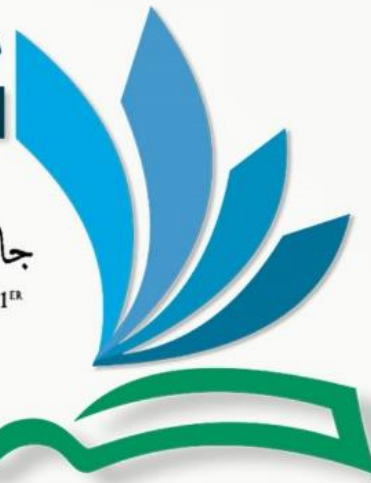

محور الدراسـات والأبحاث باللغة العربية

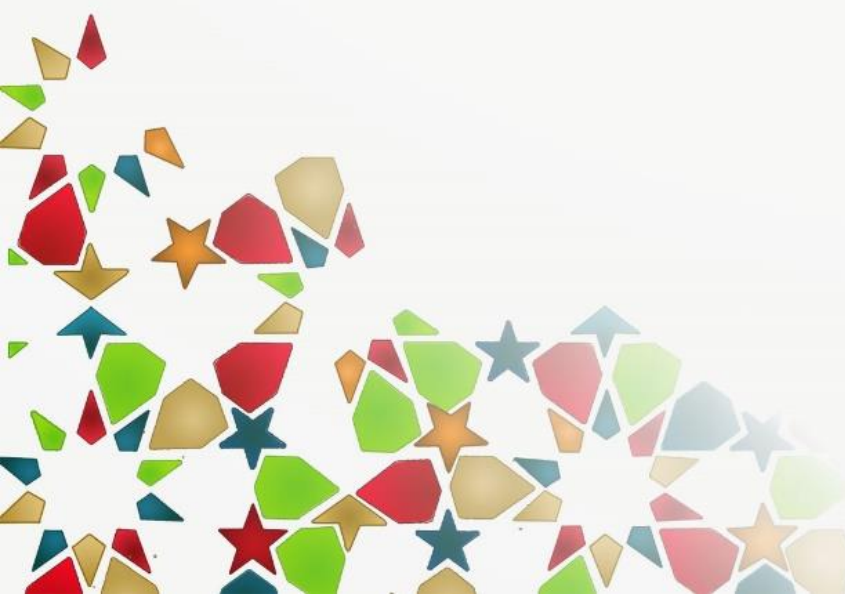




\title{
الكفالة في القانون المدني القطري: \\ تأمين شخصي لحماية حق الدائن المدني
}

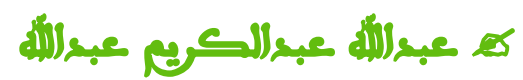 \\ أستاذ القانون المدني، كلية القانون - جامعة قطر
}

\section{مقدمة}

ما فتأت الدول تقدم الضمانات الحمائية لحقوق الدائنين والمدينين لتعزيز فكرة الائتمان لمالمانها من اثر بالغ الأهمية

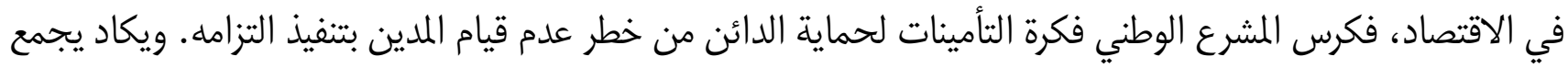

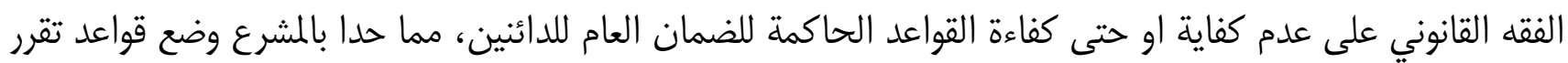

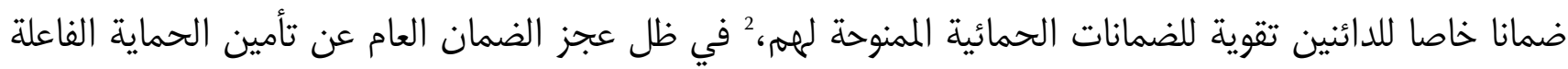
للدائن.

ويتمثل الضمان الخاص المشار اليه بتأمين يحصل عليه الدائن سواء ارتبط هذا التامين بشخص يقوم بكفالة حماية

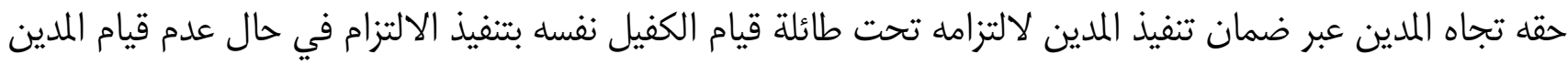

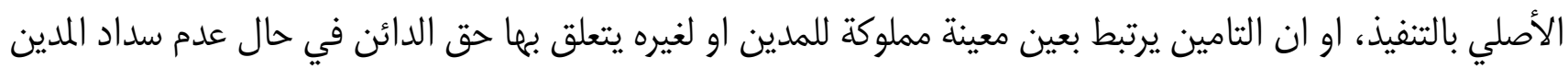
لدينه.

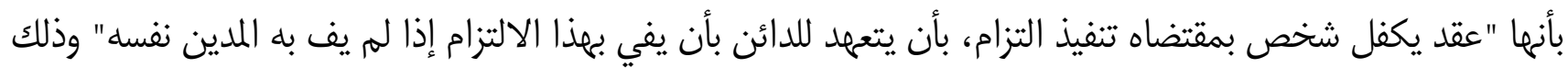

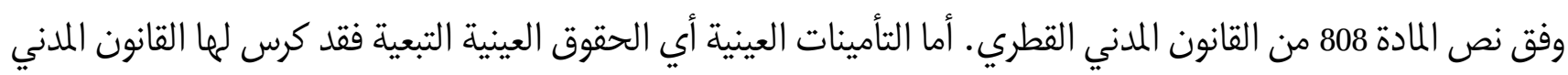

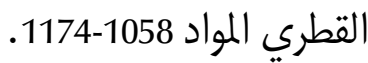

1 - انجز هذا البحث ضمن اطار مشروع بحثي مشترك ممول من الصندوق القطري لرعاية البحث العلمي - برنامج الأولويات الوطنية للبحث العلمي- الدورة 11 - التابع لمؤسسة قطر Qatar Foundation، والمشروع البحثي بعنوان " نحو تطوير الأدوات التشريعية الاقتصادية لتحقيق الأمن القانوني في ضوء السياسات الوطنية لدولة قطر" رقم : NPRP11S-0101-180160 "Toward Reforming the Economic Legislative Mechanisms for Achieving Legal Security in light of the National Policies of the State of Qatar" ويعد البحث الماثل ضمن الأوراق البحثية المرتبطة بمخرجات المشروع البحثي المشار اليه والممتد لثلاث سنوات (2019 -2022). 2عبد الرزاق السنهوري، الوسيط في شرح القانون المدني، الجزء العاشر، في التأمينات الشخصية والعينية، دار النهضة العربية، القاهرة، 1970، 33 سمير تناغو، التأمينات الشخصية والعينية، منشورات منشأة المعارف، الإسكندرية، دون ذكر سنة النشر، ص8. 
نركز بحثنا هذا - ضمن منهج تحليلي - في الكفالة من منظور القانون المدني القطري باعتبارها نظاما عقديا خالصا نظمه

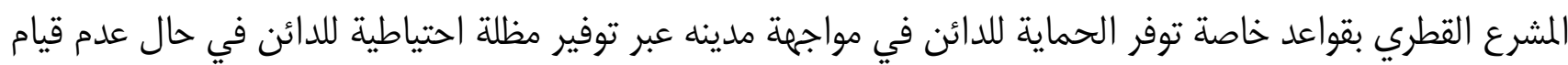

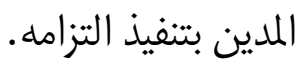

وتتمثل إشكالية البحث في مدى اعتبار الكفالة بانواعها وخصائصما آلية ناجعة لحماية الدائن وناجحة كتامين شخصي لهذا الأخير في مواجهة أي مخاطر قد تلحق بحقوقه قبل المدين.

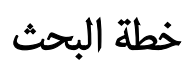

- المطلب الأول: مركز الكفالة ضمن نظام التامينات وتطورها

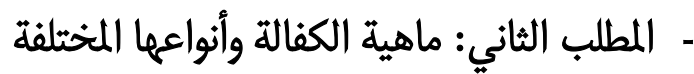

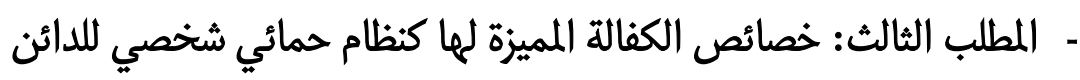

\section{المطلب الأول: مركز الكفالة ضمن نظام التامينات وتطورها} نعرض فيما يلي للكفالة كإحدى صور التأمينات عموما والتأمينات الشخصية تحديدا ثم نتفام التناول تطور الكفالة تاريخيا

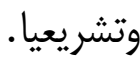

\section{الفرع الأول: ظهور التأمينات الشخصية وتطور الكفالة قبل ظهور التأمينات العينية}

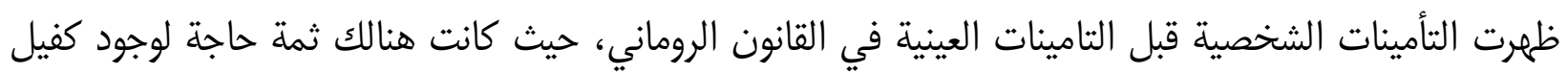

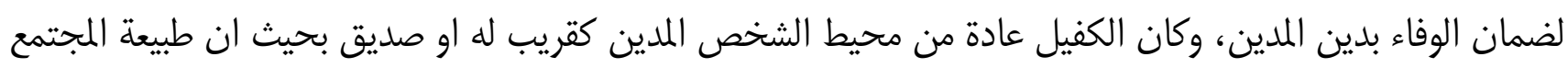
اقتضت وجود كفلاء لضمن الوفاء بالديون.

بيد أن المركز القانوني للكفيل حينها كان أسوأ من مركز المدين حيث كان الدائن يستطيع اتخاذ الإجراءات التنفيذية

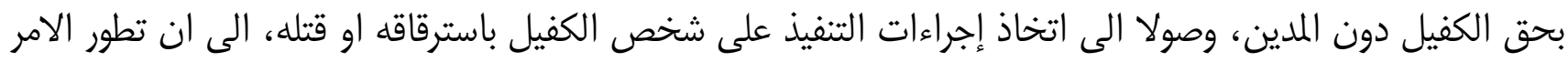

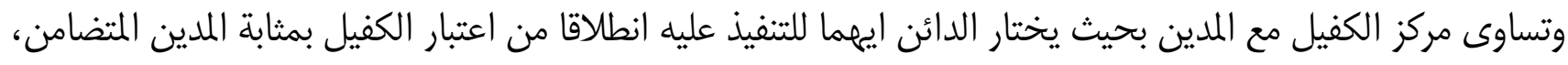

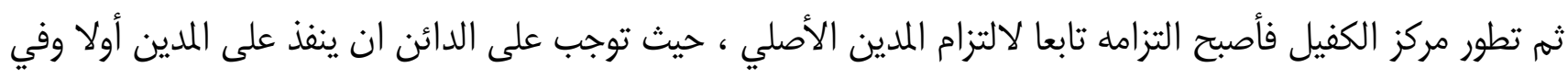

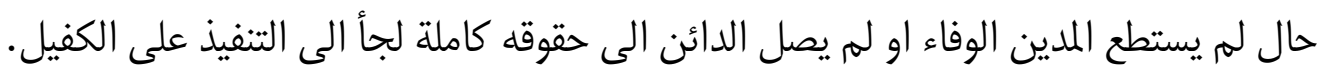
اما التأمينات العينية فقد ظهرت متأخرة في القانون الروماني وتمثلت ابتداء في نقل ملكية الشيء محل التأمين الى الى الى الثي

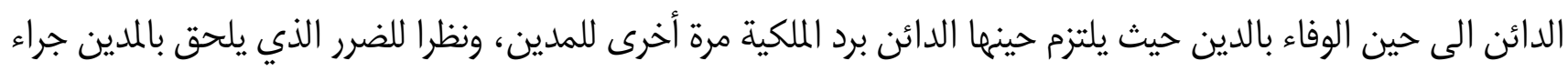

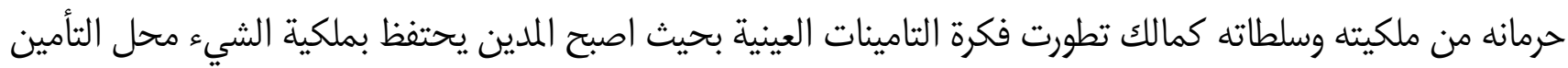

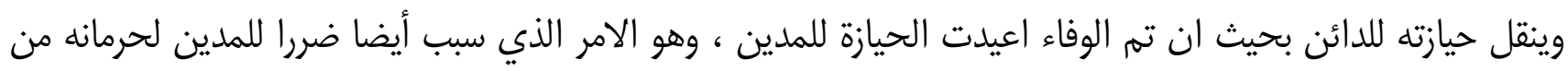

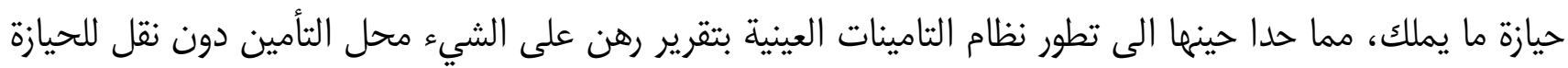


ضمن ضوابط معينة ـ ومع تطور التشريعات عرف القانون الحديث نظهم الكفالة كتامين شخصي وكذا نظم الرهن الحيازي والرهن الرسمي كتامينات عينية سواء ورد الرهن على عقار او منقول.

\section{الفرع الثاني: أنواع التأمينات الشخصية وموقع الكفالة ضمنها}

ينطوي مفهوم التامينات الشخصية على الالتزامات الشخصية التي تضاف الى التزام المدين الأصلي عبر ضم ذمة شخص الى ذمة المدين الأصيل تحقيقا لضمان حق الدائن. ${ }^{5}$ وقد يكون هذا الضم للذمم على سبيل المساواة مع ذمة المدين الأصلي بحيث يستطيع الدائن مطالبة المدين الأصلي او أي شخص اخر ارتضي إتى ضمى ذمته الى هذا المدين كما في التضامن

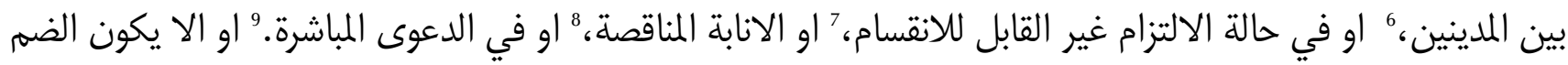

4 سمير تناغو، المرجع السابق، ص 10 و11.

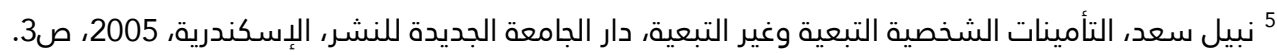
6 تنص المادة 307 من القانون المدني القطري على أنه " 1- يجوز للدائن مطالبة المدينين المتضامنين بالدين مجتمعين أو منفردين، ويراعى في ذلك ما يلحق برابطة كل مدين من وصف يعدل من أثر الدين. وإذا طالب الدائن أحد المدينين ابتداءً لم يمنعه ذلك من مطالبة الباقين. 2- ولا يجوز للمدين الذي يطالبه الدائن بالوفاء أن يحتج بأوجه الدفع الخاصة بغيره من المدينين، ولكن يجوز له أن يحتج بأوجه الدفع الخاصة بنفسه وبالأوجه

المشتركة بين المدينين جميعاً".

7 تنص المادة 321 من القانون المدني القطري على أن "يكون الالتزام غير قابل للانقسام في الحالتين التاليتين: 1- إذا ورد على محل لا يقبل

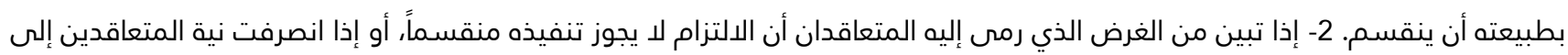
ذلك"، كما تنص المادة 322 على أنه " إذا تعدد المدينون في التزام غير قابل للانقسام، كان كل منهم ملزماً بوفاء الالتزام كاملاً. وللمدين الذي وفى حق الرجوع على الباقين كل بقدر حصته إلا إذا تبين من الظروف غير ذلك". اما المادة 323 فتنص على انه " إذا تعدد الدائنون في التزام غير قابل للانقسام، أو تعدد ورثة الدائن في هذا الالتزام، جاز لكل دائن أو وارث أن يطالب بأداء الالتزام كاملاً. فإذا اعترض أحد أحد الدائنين أو أو

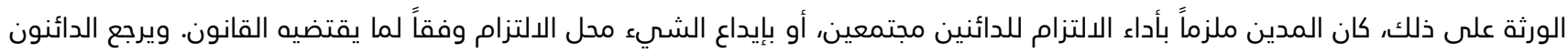

على الدائن الذي استوفى الالتزام كل بقدر حصته" .

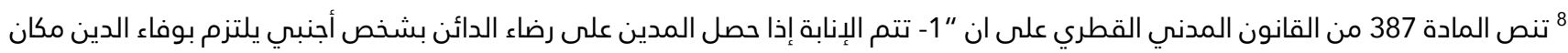

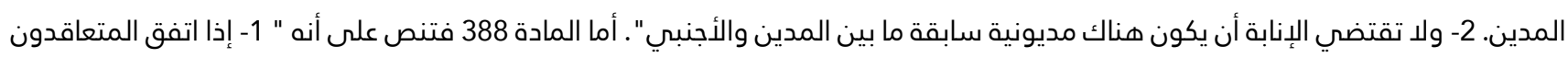

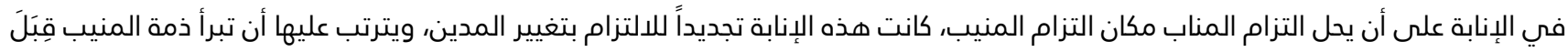

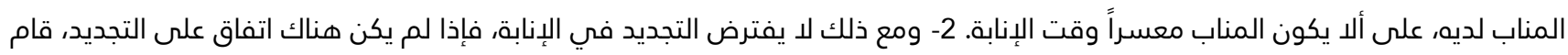
الالتزام الجديد إلى جانب الالتزام الأول". فالاصل ان ما يترتب على الإنابة في الوفاء هو نشوء التزام جديد بوفاء الدين على عاتق المناب، يقوم إلى جانب التزام المنيب -أى المدين الأصلي - بحيث يكون أمام الدائن مدينان يلتزم كل منهما بأداء كامل الدين وبما يضمن للدائن حصوله على حقه كاملا، إبحيث يحق للدائن مطالبة أي منهما بالوفاء الدين، وفي حال قيام أحد هذين المدينين (المناب وهو المدين الجديد أو المنيب وهو المدين الأصلي) بوفاء الدين فإن الدين ينقضي. حيث الإنابة في هذه الحالة تعتبر إنابة ناقصة، بعكس الانابة الكاملة والتي يقصد أطراف الإنابة

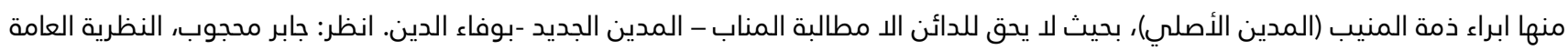

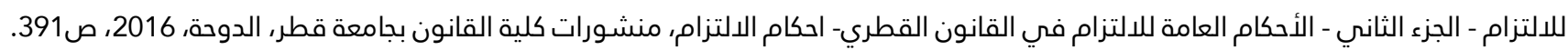
9 كرس المشرع الدعوى المباشرة لاعتبارات خاصة تفضيلا لبعض الدائنين ، فأجاز لهم في حالات خاصة أن يطالبوا بحقوق مدينيهم مباشرة، أي بأسمائهم ولحسابهم، وليس باسم المدين ونيابة عنه وبديث ان الدعوى التي يرفعها الدائن على مدين مدينه باسمه الخاص ولحسابه الخاص

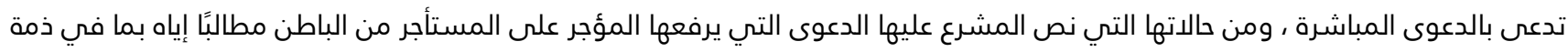
هذا الاخير للمستأجر الأصلي ، حيث تنص المادة 623/ 2 من القانون المدني القطري على أنه " 1- في حالة الإيجار من الباطن تبقى العلاقة

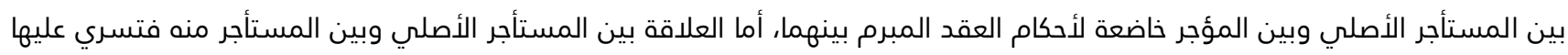

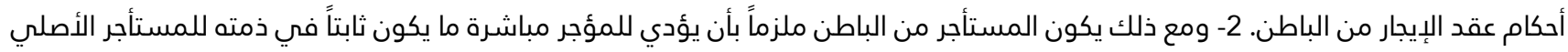

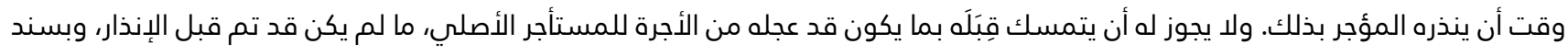
ثابت التاريخ". كما ان المشرع نص على حالة أخرى من حِالات الدعوى المباشرة هي دعوى المقاول من الباطن والعمال الذين يستخدمهم 
اللذمه على سبيل المساواة مع ذمة المدين الأصلي بحيث يكون الرجوع على من ضم ذمته الى ذمة المدين الأصلي على سبيل

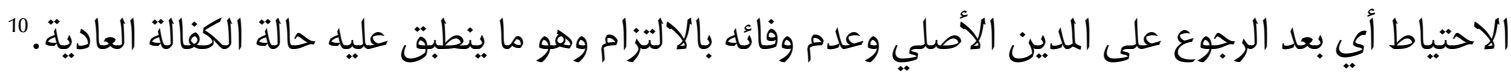

\section{المطلب الثاني: ماهية الكفالة وأنواعها}

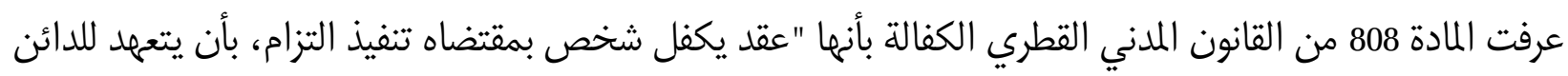
بأن يفي بهذا الالتزام إذا لم يف به المدين نفسه" ـ ونعرض فيما يلي لماني لشرح مفهوم الكفالة وأنواعها.

\section{الفرع الأول: ماهية الكفالة}

استنادا الى نص المادة 808 سالفة الذكر فإن الكفالة هي عبارة عن عقد يتم ابرامه بين الكفيل من جهاة والدائن من

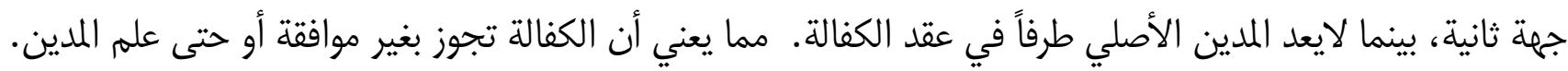

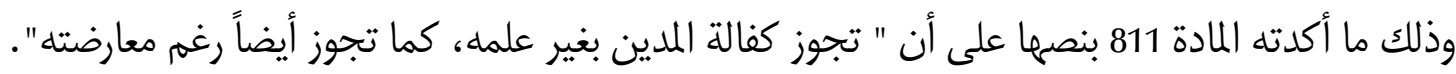

والكفالة ترد على التزام المدين حيث أن هذا الالتزام هو الذي يضمن الكفيل تنفيذه في حال عدم تنفيذ المدين الأصلي

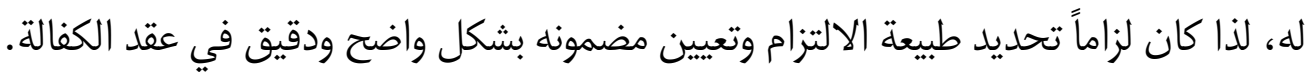

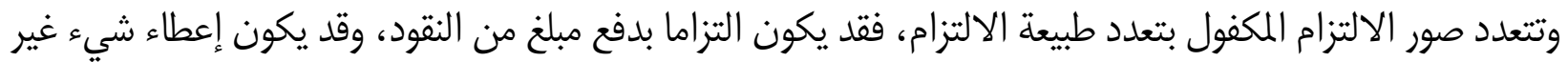

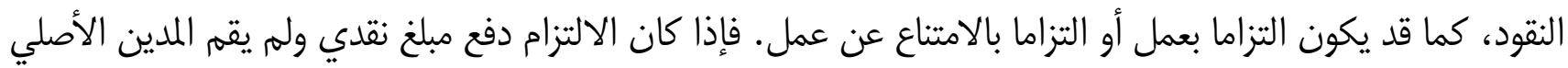

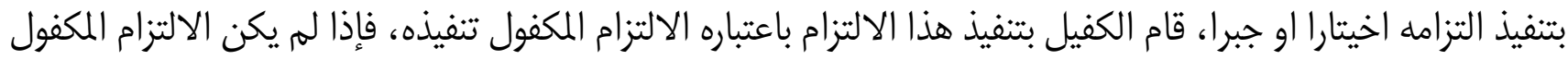

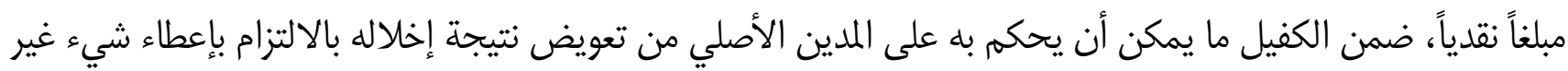

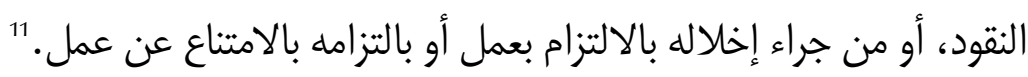

المقاول الأصلي للرجوع مباشرة على رب العمل ومطالبته ببلمبلغ الذي يكون مدينًا به للمقاول الأصلي وقت إقامة الدعوى ، حيث تنص المادة

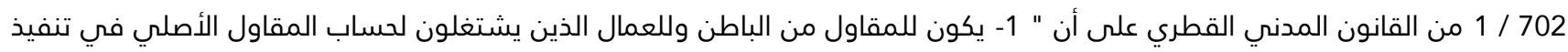

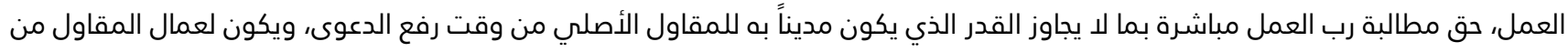

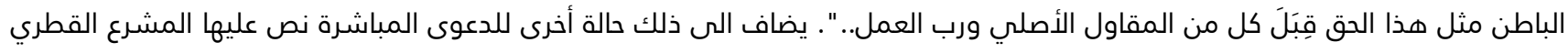

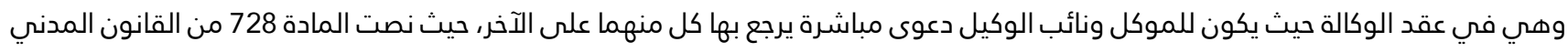
القطري على أن " 1- إذا أناب الوكيل غيره في تنفيذ الوكالة دون أن يكون مرخصاً له في ذلك، كان مسئولاً عن عمل النائب كما لو كان هذا

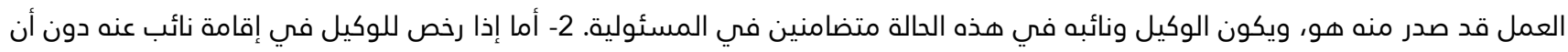

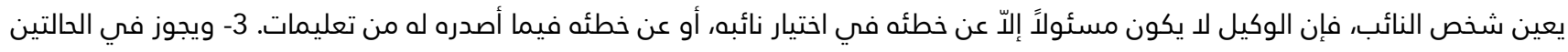

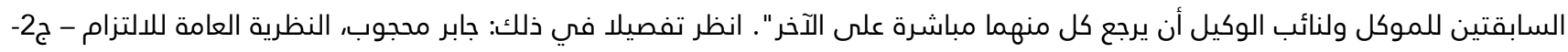

الاحكام العامة للالتزام في القانون القطري، مرجع سابق، ص 115

10 نبيل سعد، التامينات العينية والشخصية، منشورات الحلبي الحقوقية، بيروت، 2010، ص295.

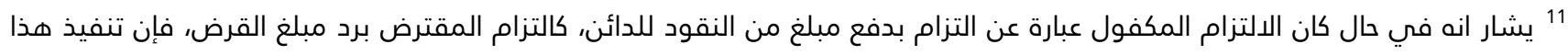

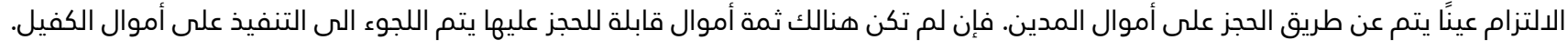
ويقاس على ذلك حالة الالتزام بنقل ملكية شيىعغير نقدي، وفي حال كان الالتزام هو التزام بعمل فإن المادة 251 من القانون المدني القطري

تنص على على أنه ": 1- في الالتزام بعمل، إذا لم يقم المدين بتنفيذ التزامه، جاز للدائن أن يطلب إذناً من القاضي في تنفيذ الالتزام على نفقة المدين إذا كان هذا 
فالكفالة إذن تفترض اولا وجود التزام أصلي مكفول يقع على عاتق المدين الأصلي به ايفاءه للدائن، كما تفترض

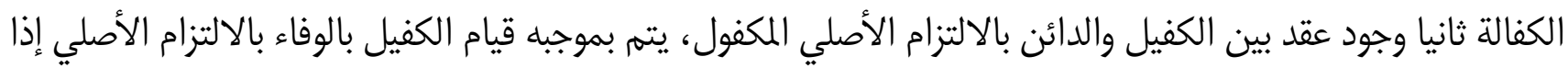

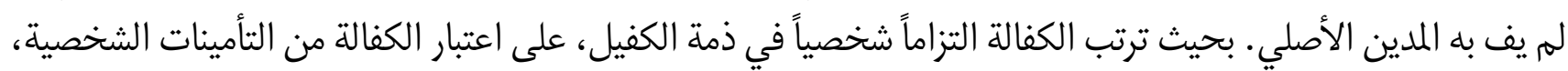

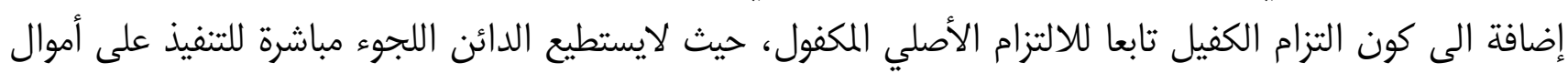

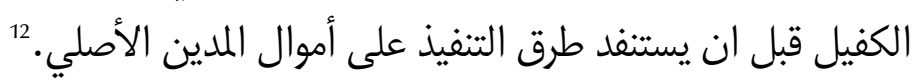

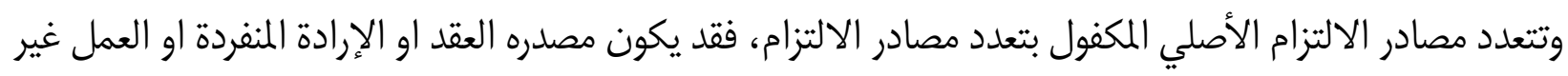

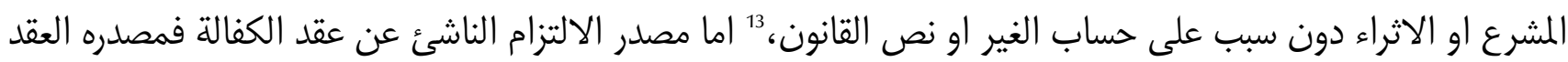

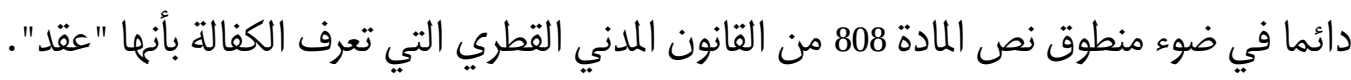

\section{الفرع الثاني: أنواع الكفالة}

نعرض فيما يلي لتقسيم الكفالة، استنادا لمصدر التزام المدين بتقديم الكفيل، سواء كان القانون او الاتفاق او القضاء، ثم استنادا لطبيعة الكفالة سواء كانت مدنية او تجارية.

\section{أولا: أنواع الكفالة بحسب مصدرها}

تقسم الكفالة بحسب مصدرها او الأساس الذي تستند اليه الى كفالة قانونية وكفالة قضائية وكفالة اتفاقية، ولهذا

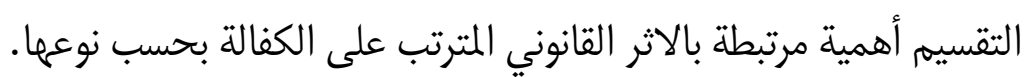

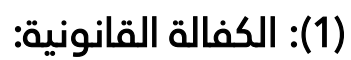

تكون الكفالة قانونية في حال كان القانون هو الذي نص على أن يقدم المدين لدائنه كفيلاً. وتكون الكفالة على هذا

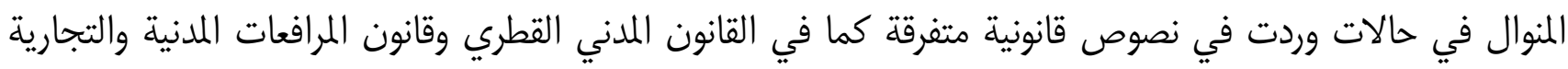
القطري وقانون التجارة القطري.

\section{(أ) تطبيقات الكفالة القانونية في القانون المدني:}

2- ويجوز في حالة الاستعجال أن ينفذ الدائن الالتزام على نفقة المدين، دون إذن من القضاء" فغن لم يتم ذلك ولم تتوفر ضوابطه كما لو كان

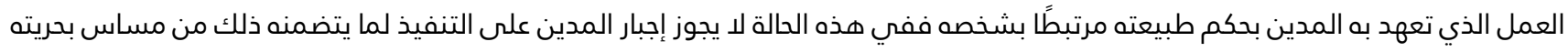

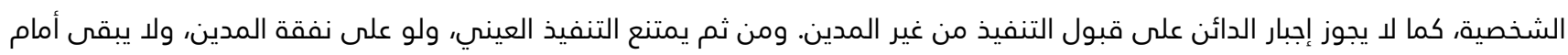

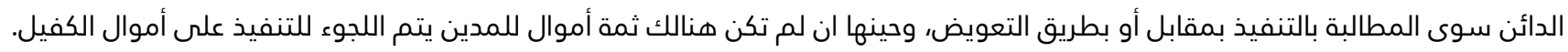

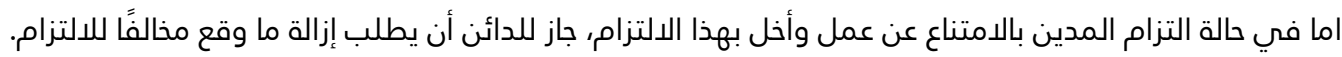

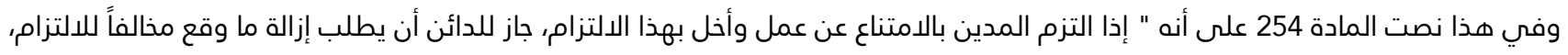

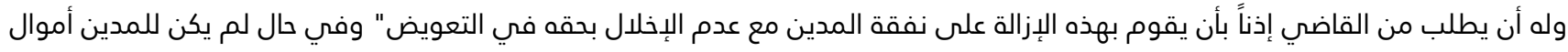
لدفع نفقات الازالة والتعويض فإن الكفيل هو الذي سيقوم بتسديد هذه النفقات المستحقة. 12 عبد الرزاق السنهوري، الوسيط في شرح القانون المدني، الجزء العاشر، في التأمينات الشخصية والعينية، دار النهضة العربية، القاهرة، 1970، 
نص القانون المدني في العديد من المسائل على تطبيقات عديدة للكفالة القانونية، ففيما يتعلق بتعويض الضرر عن

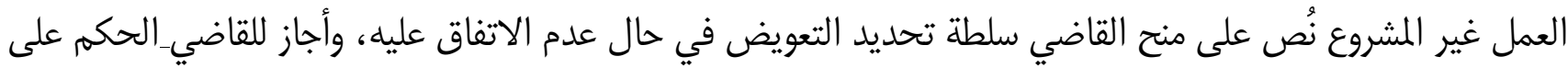

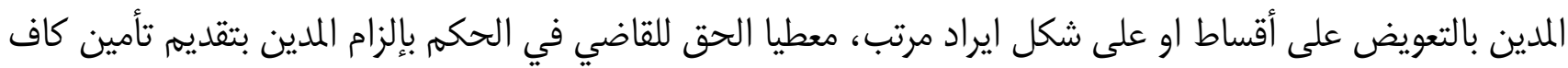

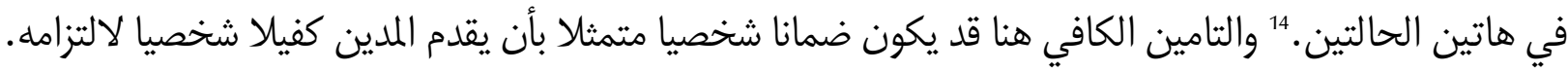

كما نجد تطبيقا للكفالة القانونية في أحكام عقد البيع وفيما يتعلق بضماني التعرض والاستحقاق الذين يلتزم بهما

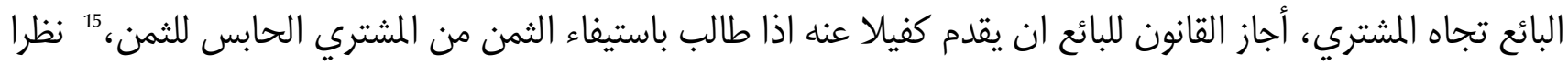

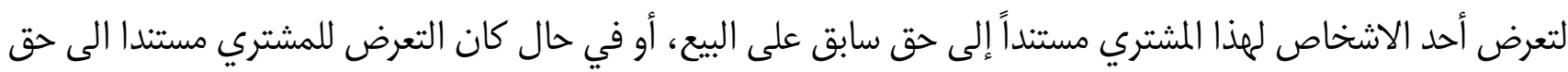

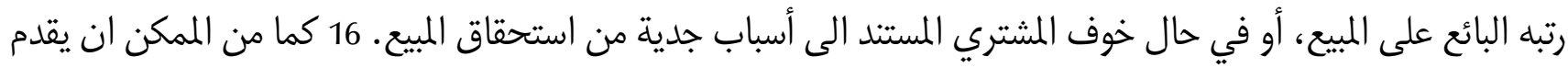

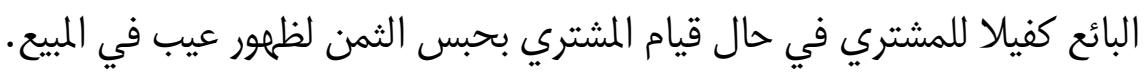
كما نجد تطبيقا للكفالة القانونية في أحكام عقد الايجار في القانون المدني وفيما يتعلق بانتقال ملكية العين المؤجرة،

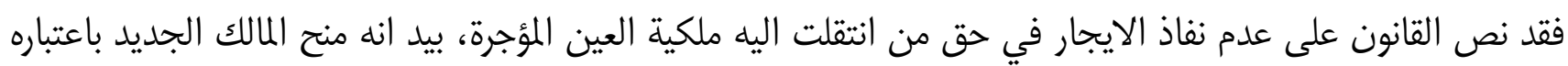

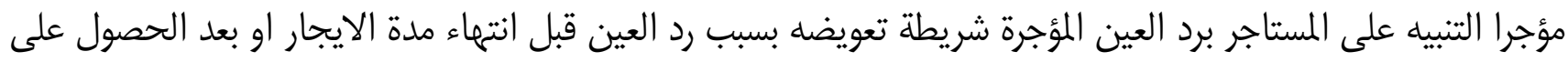

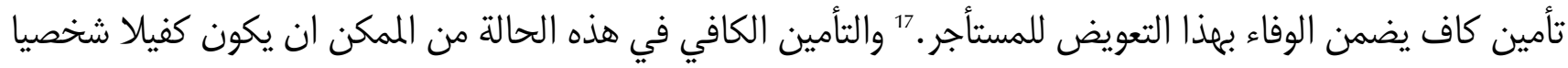

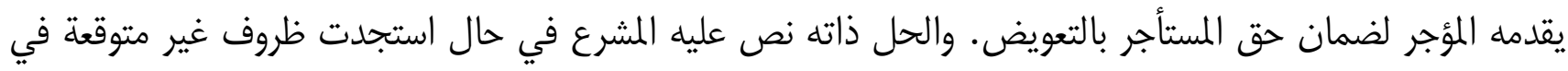

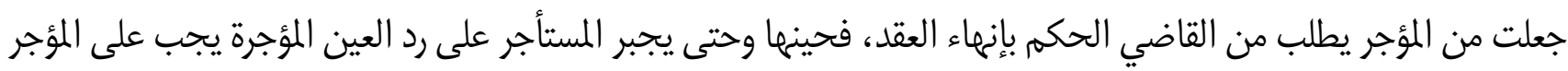

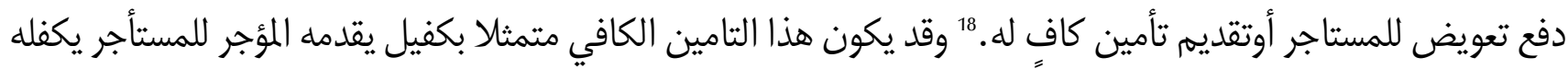
في دفع التعويض المستحق للمستاجر في هذه الحالة.

كما نجد تطبيقا إضافيا للكفالة القانونية في أحكام حيازة العقار كسبب لكسب الملكية في القانون المدني، فقررت ان

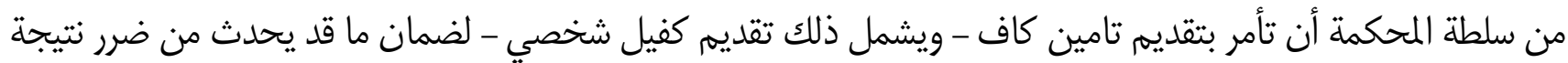

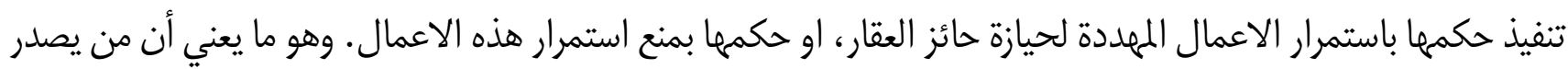
لمصلحته الحكم هو الذي سيقدم التأمين (اوالكفيل).

14 15 اجاز المشرع للمشتري حبس الثمن في هذه الحالات، بيد أنه قيد ذلك بعدم وجود شرط في العقد يمنعه من حبس الثمن. ويسري حكم البند السابق إذا ظهر عيب في المبيع 16 17 18 19 المادة 959 من القانون المدني القطري: " 1- لحائز العقار إذا استمرت حيازته سنة كاملة، وخشي لأسباب معقولة التعرض له نتيجة أعمال جديدة تهدد حيازته، أن يرفع خلال السنة التالية لبدء هذه الأعمال دعوى بوقفها طالما أنها لم تتم. 2- وللمحكمة أن تحكم بمنع استمرار الأعمال أو أن تأذن باستمرارها، ولها في الحالين أن تأمر بتقديم تأمين كاف ضماناً لما قد يحدث من ضرر نتيجة تنفيذ الحكم. 
ومن التطبيقات الأخرى للكفالة القانونية ما نص عليه في احكام حق الانتفاع في القانون المدني، حيث الزم القانون

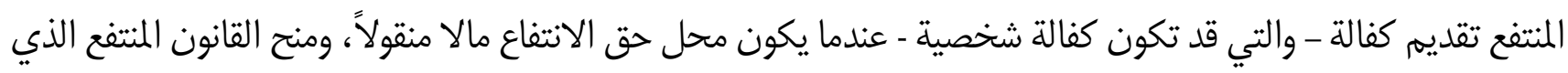

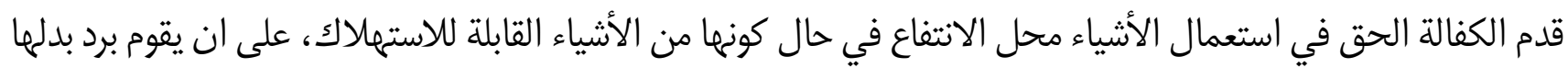
عند انتماء حقه في الانتفاع.

ومن التطبيقات أيضاً للكفالة القانونية ما نص عليه في احكام حق الحكر في القانون المدني، حيث أن المشرع - وعندما

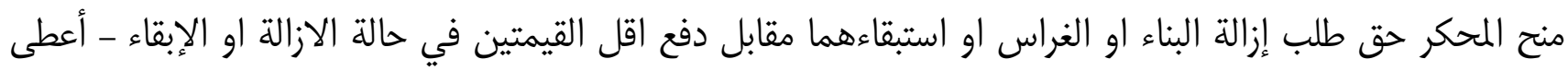

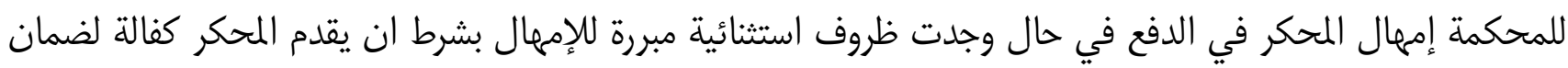

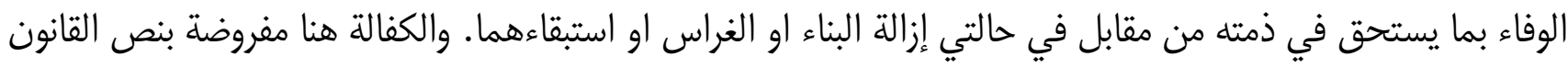
ان توفرت شروطها.

ومن التطبيقات التي اشارت اليها محكمة التمييز القطرية مسؤولية المتبوع عن الأعمال غبر المشروعة التي يقوم بها

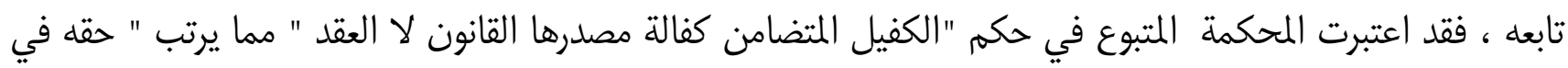

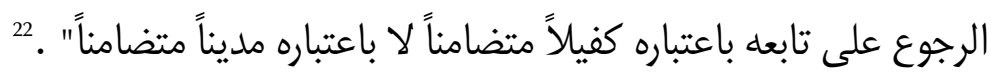

\section{(ب) تطبيقات الكفالة القانونية في قانون المرافعات المدنية والتجارية.}

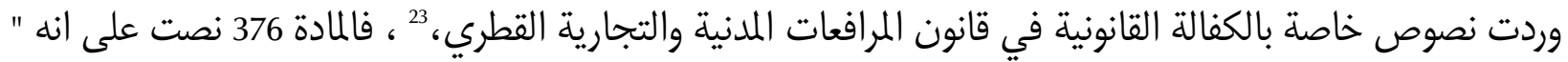

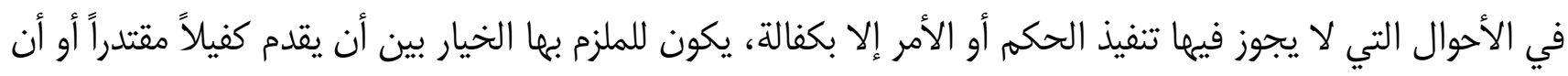

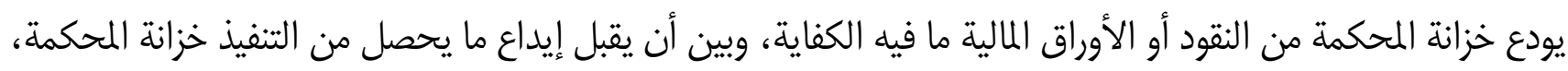

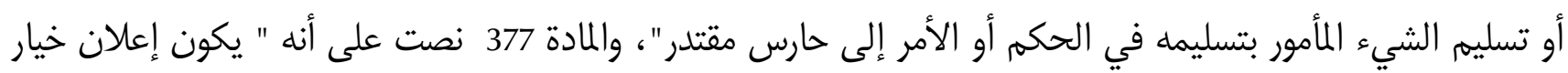

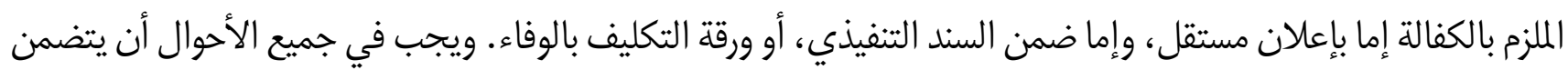

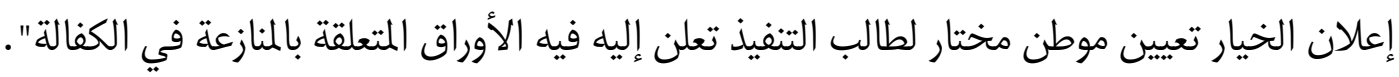

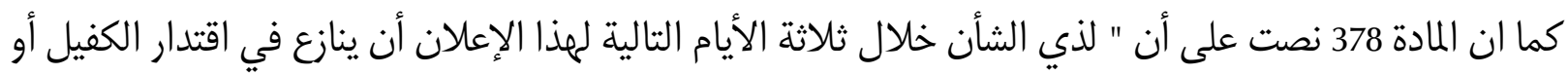

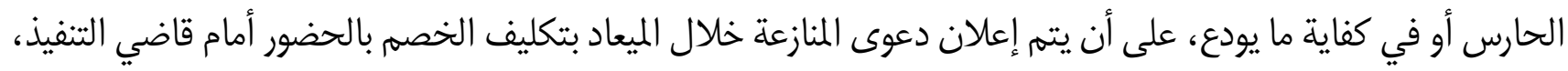

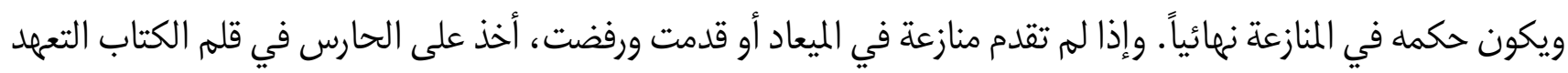

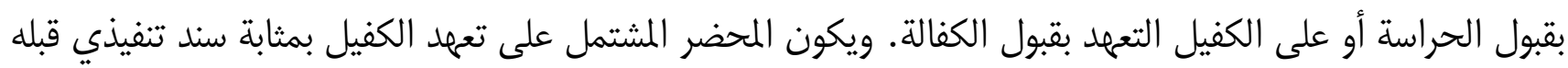
بالالتزامات المترتبة على تعهلده" .

20 المادة 1022 من القانون المدني القطري 21 المادة 1041 من القانون المدني القطري 22 قطر: محكمة التمييز القطرية، الدائرة المدنية والتجارية - الطعن رقم: 2016/2041 187 القاريخ الجلسة: 2016/06/20، انظر البوابة القانونية القطرية على الرابط: http://www.almeezan.qa/RulingPage.aspx?id=1500\&language=ar\&selection = 23 قطر: قانون رقم (13) لسنة 1990 بإصدار قانون المرافعات المدنية والتجارية وتعديلاته 
كما أن المادة 516 من قانون المرافعات المدنية والتجارية ذاته نصت على انه " لا يجوز إصدار أمر بحبس المدين في

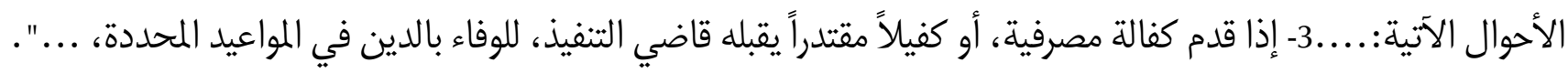

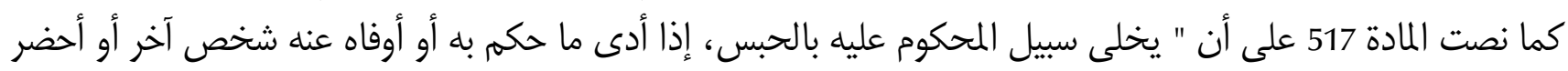
كفيلا مقبولاً، أو طلب الدائن إخلاء سبيله" .

\section{(ج) تطبيقات الكفالة القانونية في قانون التجارة القطري}

وردت نصوص خاصة بالكفالة القانونية في قانون التجارة القطري، ${ }^{24}$ فالبنسبة لأحكام الوفاء بالكمبيالة التهاتة وبعد ان ألجاز

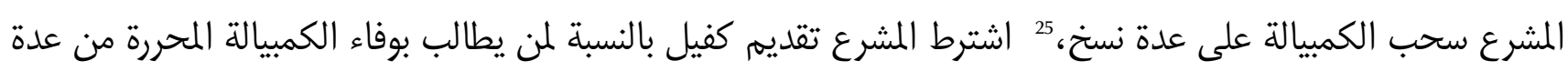

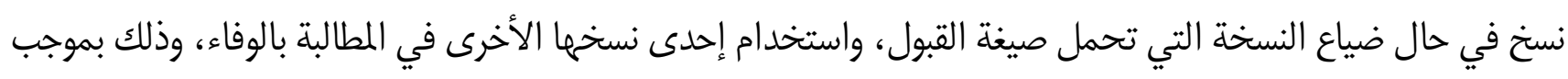
أمر من رئيس المحكمة. كما اشترط المشرع تقديم كفيل ممن ضاعت منه كمبيالة ولم يتمكن من تقديم إحدى نسخهما الأخرى، على أن يستصدر من رئيس المحكمة أمراً بوفائما، وأن يثبت ملكيته للكمبيالة.

والامر ذاته تطلبه المشرع في نص المادة 519 التي نصت على أنه "يجوز لمالك الكمبيالة الضائعة الحصول على نسخة

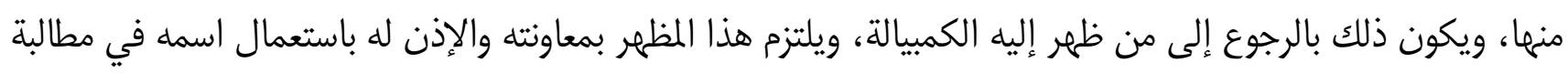

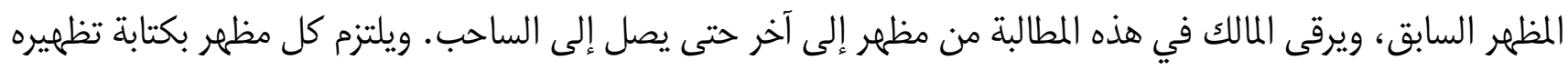

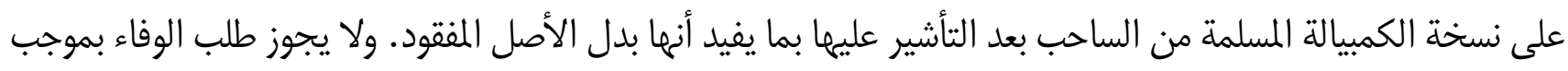

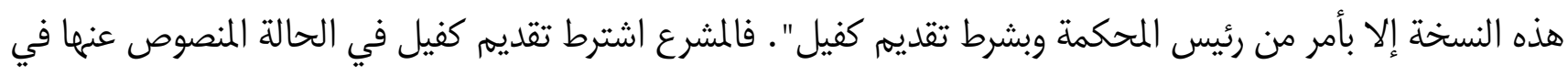
هذه المادة.

\section{(2): الكفالة القضائية}

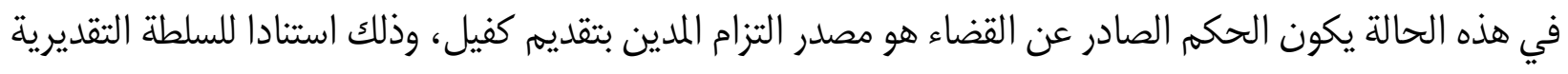

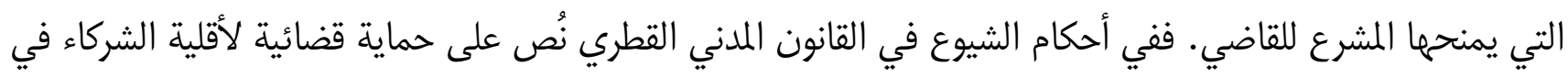

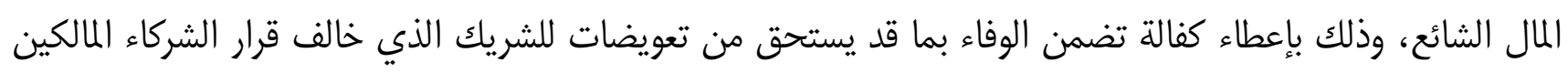

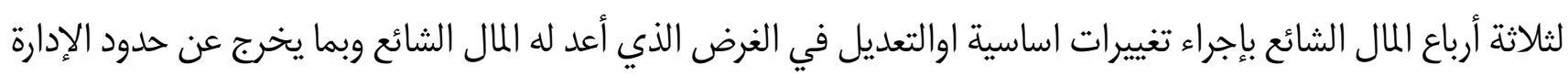

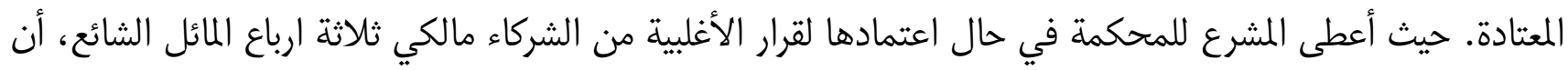

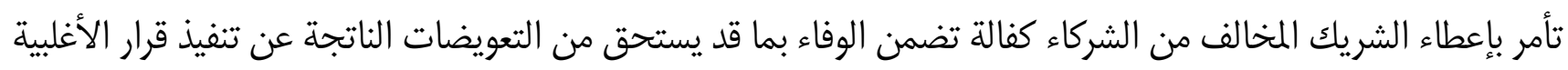

24 قطر: قانون رقم (27) لسنة 2006 بإصدار قانون التجارة، المعدل بموجب قانون 2010/7

25 المادة 464 من قانون التجارة القطري: يجوز سحب الكمبيالة من نسخ متعددة متطابقة، ... " 26 المادة 516 من قانون التجارة القطري. 27 المادة 517 من قانون التجارة القطري. 
المشار اليها.ت28 كما أن المشرع في القانون المدني - وفي معرض النص على أحكام تسوية ديون التركة - جعل للقاضي سلطة

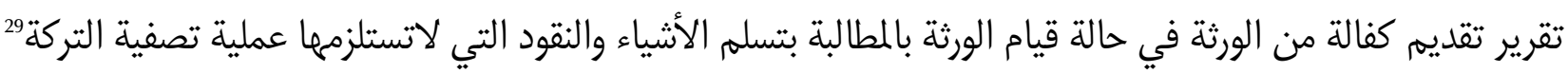
اما فيما خص الكفالة القضائية المشار اليها في قانون المرافعات المدنية والتجارية في القانون القطري، فنجد إشارة اليها

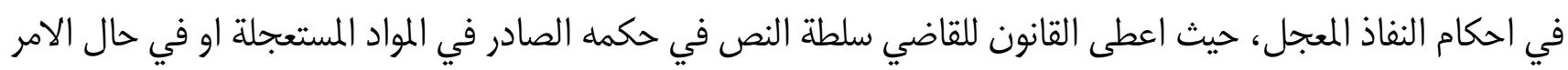

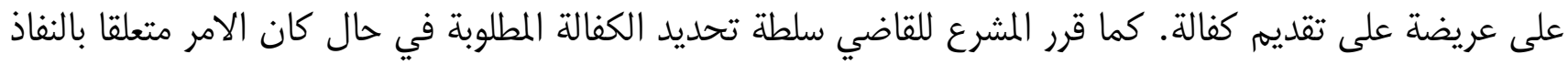

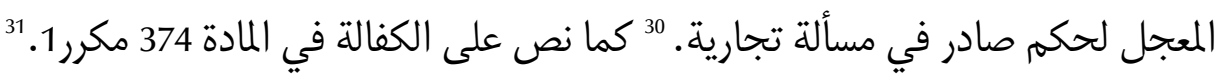
كما أجاز قانون المرافعات المدنية والتجارية لمحكمة الاستئناف في حال قررت وقف النفاذ المعجل أن تطلب تقديم كفالة لضمان حق المحكوم له.

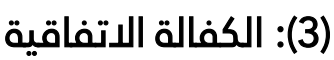

وهي الكفالة التي يكون مصدرها الاتفاق المبرم بين الكفيل والدائن دون ان يكون المدين ملزما قانونا او قضاءا بتقديم كفيل له لضمان تنفيذ التزامه.

\section{(4): نتائج التفرقة والتمييز بين أنواع الكفالة بحسب مصدرها.}

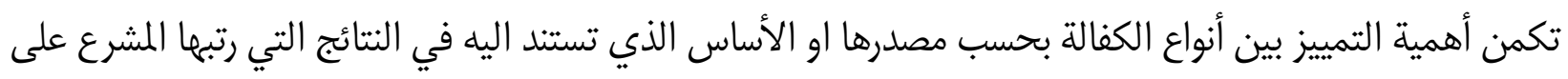

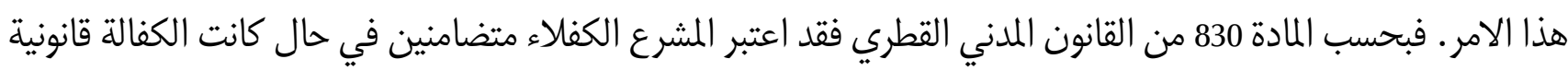

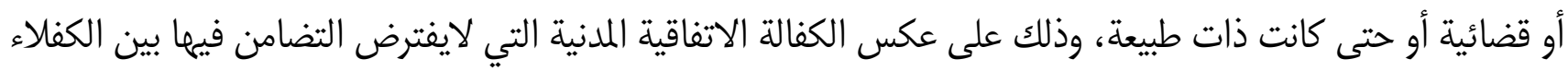
الا في حال اتفاقهم على ذلك، سواء عند ابرام عقد الكفالة او باتفاق لاحق.

\section{ثانيا: أنواع الكفالة بحسب طبيعتها}

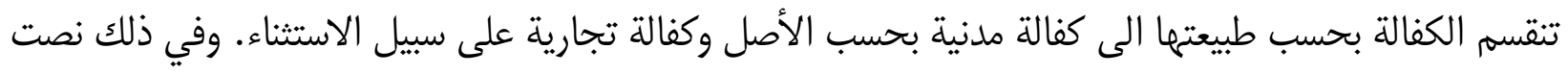

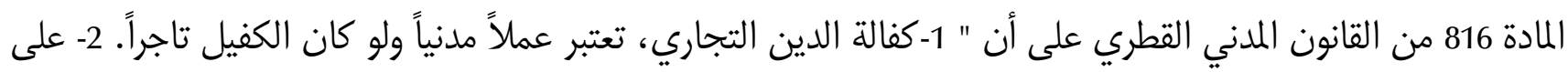

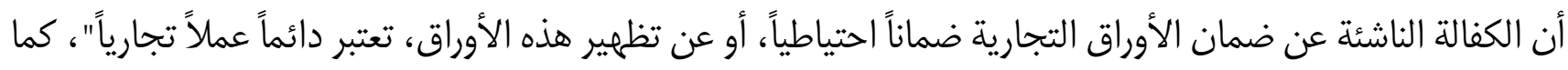

28 المادة 858 من القانون المدني القطري 29 المادة 998 من القانون المدني القطري: " يجوز للورثة، بمجرد انقضاء المئون المداد المقرر للمنازعات المتعلقة بالجرد، المطالبة بأن يتسلموا بصفة

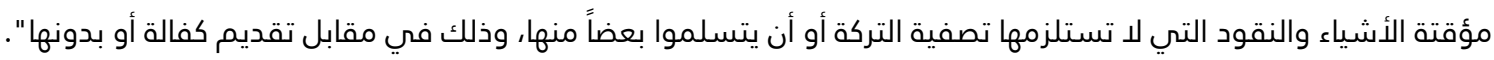
30 المادة 374 و374 مكرر 1 من قانون المرافعات المدنية والتجارية القطري والمعدلة بموجب قانون

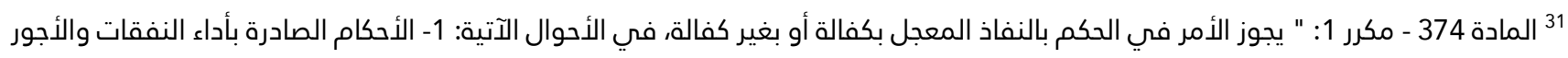
والمرتبات. 2- إذا صدر الحكم تنفيذاً لحكم سابق حائز لقوة الأمر المقضي أو مشمول بالنفاذ المعجل بغير كفالة أو كان مبنياً على سند رسمي لم يُطعن فيه بالتزوير، وذلك متس كان المحكوم عليه خصماً في الحكم السابق أو طرفاً في السند. 3- إذا أقر المحكوم عليه بنشأة الالتزام. 4إذا بُني الحكم على سند عرفي لم يجحده المحكوم عليه. 5- إذا صدر الحكم لمصلحة طلب التنفيذ في منازعة تتعلق به. 6- إذا كان يترتب على تأخير التنفيذ ضرر جسيم بمصلحة المحكوم له". يشار الى ان هذه المادة اضيفت بموجب القانون رقم 3 لسنة 2019. 32 المادة 375 من قانون المرافعات المدنية والتجارية القطري. 33 همام محمد زهران، التامينات العينية والشخصية، منشورات منشأة المعارف، الإسكندرية، 2002، ص44. 
تنص المادة 75 من قانون التجارة القطري على ان " تكون الكفالة تجارية إذا كان الكفيل يضمن ديناً تجارياً بالنسبة للمدين،

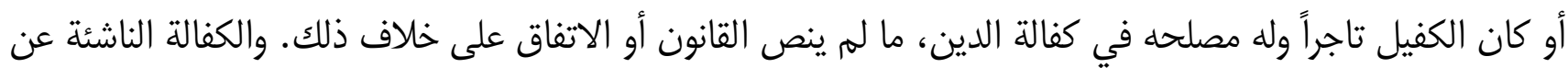

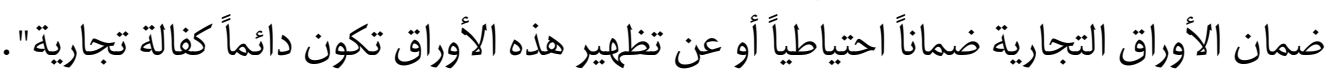

فالأصل أن الكفالة تعتبر من الاعمال المدنية، على الرغم من ان الالتزام المكفول من الممكن ان يكون تجاريا، وهذا

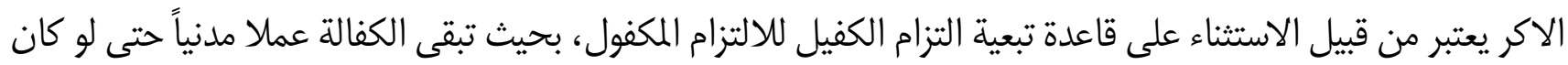

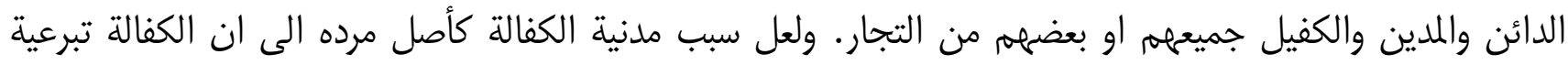

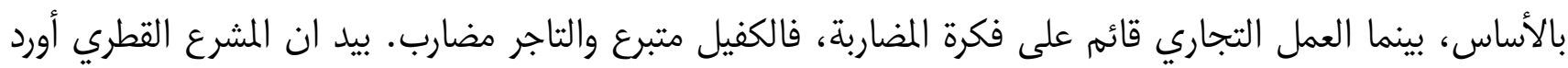

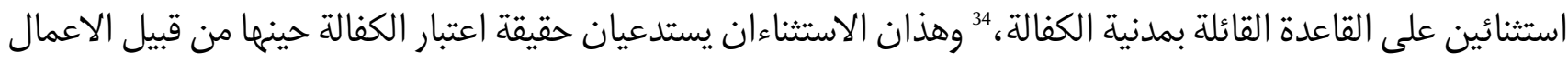

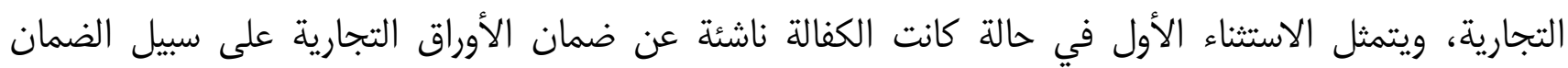

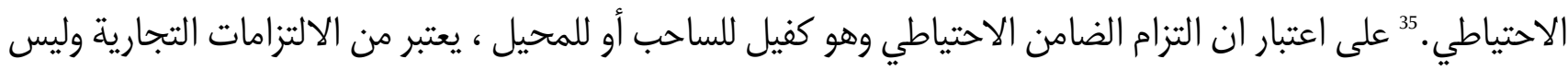

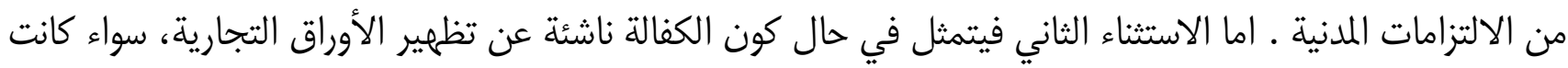

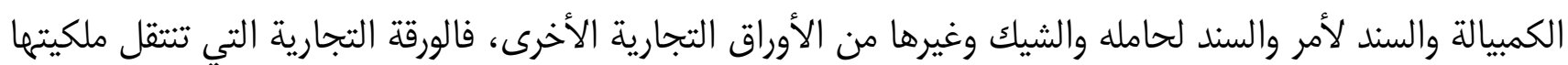

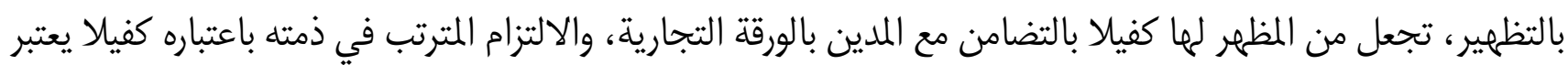

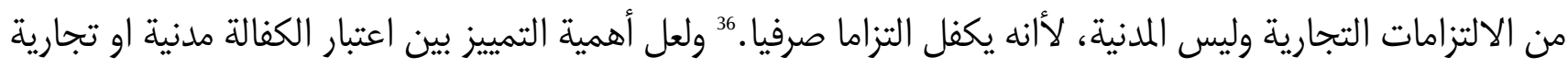

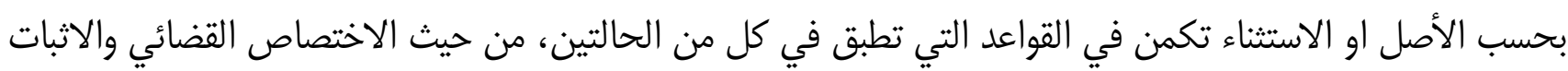

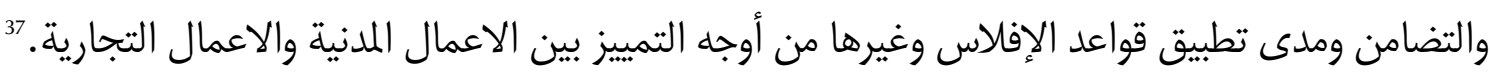

\section{المطلب الثالث: خصائص الكفالة المميزة لها كنظام حمائي شخصي للدائن}

نتناول في هذا المبحث الخصائص المميزة للكفالة، ثم نعرض لتمييز الكفالة عما يشتبه بهائ من نظهم قانونية مختلفة.

\section{الفرع الأول: خصائص الكفالة}

يتميز عقد الكفالة بخصائص تميزه عن غيره تتمثل في كونه من العقود المسماة من جهة أولى، وأنه من عقود الضمان

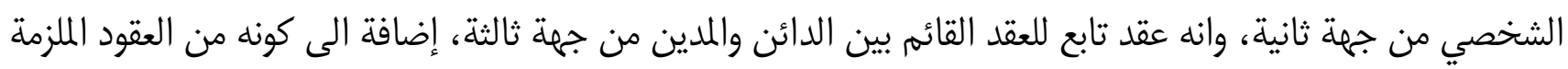

34 المادة 75 من قانون التجارة القطري : " تكون الكفالة تجارية إذا كان الكفيل يضمن ديناً تجارياً بالنسبة للمدين، أو كان الكفيل تاجراً وله مصلحه

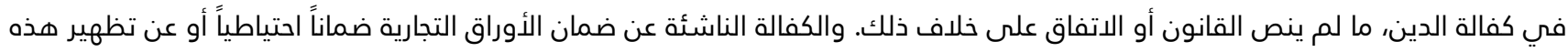

الأوراق تكون دائماً كفالة تجارية".

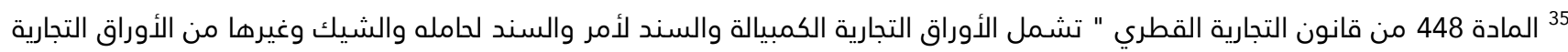
الأخرى أياً كانت صفة ذوي الشأن فيها أو طبيعة الأعمال التي أنشئت من أجلها " النها ". (36 السنهوري، مرجع سابق، ص 70. 3737 فاتن حوى، القانون التجاري: تطور المفهوم واستقلال القواعد القانونية "دراسة مقارنة في التشريعين القطري واللبناني"، بحث منشور

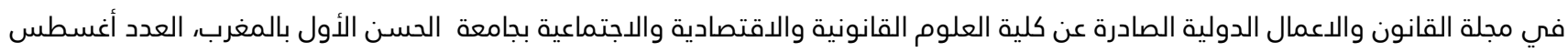

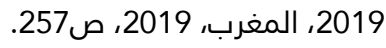


لجانب واحد من جهة رابعة، وأنه من العقود التبرعية من جهة خامسة، وكذلك انه من العقود الرضائية من جهة سادسة. وسنعرض لرزذه الخصائص تباعا فيما يلي.

\section{أولا: عقد الكفالة من العقود المسماة}

يعتبر عقد الكفالة وفق القانون المدني القطري من العقود المسماة التي خصما المشرع بتنظيم قانوني يحكمها. وقد خصص المشرع القطري الكتاب الثاني من القسم الأول من القانون المدني للعقود المسماة ويتضمن هذا الكتاب عدة أبواب، منها الباب الخامس الذي خصصه المشرع لعقد الكفالة باعتباره تأمينًا شخصيًا. حيث عرض لتسمية هذا العقد "الكفالة" وكذلك للتعريف به واحكامه التفصيلية من اركان واثار مترتبة على هذا العقد.

\section{ثانيا: عقد الكفالة من عقود الضمان الشخصي}

نظرا لان الكفالة من التامينات الشخصية ومؤداها التزام الكفيل شخصيا بتنفيذ التزام المدين في حال عدم قيام المدين بتنفيذ التزامه، على اعتبار ان التزام الكفيل الشخصي يضاف الى التزام المدين الأصلي، مما يمنح الدائن ضمانا شخصيا من الكفيل بالتزامه بالوفاء بالتزام المدين الأصلي عند عدم وفائه بالتزامه، فيكون كل من المدين وكفيه مسؤولين مسؤولية شخصية تجاه الدائن ، مع الاخذ بعين الاعتبار أن رجوع الدائن أولا يكون على المدين الأصلي اما رجوعه على الكفيل فيكون في حال عدم وفاء المدين وبما يجعل من مسؤولية الكفيل مسؤولية احتياطية. 39

ويترتب على كون الكفالة من عقود الضمان الشخصي أن خطر اعسار المدين لم يتضمن ضمانه تماما من قبل الكفيل، حيث ان الكفيل نفسه معرض لخطر الاعسار وعدم تنفيذ التزامه، لذلك يفضل في حالة الكفالة النظر الى درجة يسار الكفيل، وذلك لتقليل مخاطر اعساره، ولعل الكفالة التي تقدمها المصارف للمشروعات التجارية تعد نموذجا ناجحا للكفيل

وفي ذلك نصت المادة 810 على أنه " 1- إذا التزم المدين بتقديم كفيل، وجب أن يقدم شخصاً موسراً، ومقيماً في قطر،

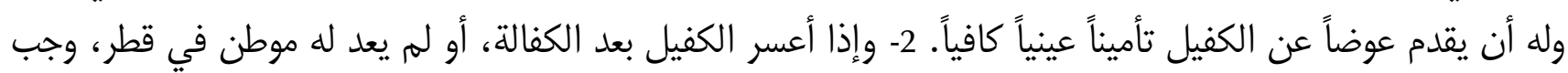
تقديم كفيل آخر أو تأمين عيني كاف"، بحيث اشترطت يسار الكفيل من ضمن الشروط الواجب توافرها في الكفيل.

\section{ثالثا: عقد الكفالة عقد تابع للعقد القائم بين الدائن والمدين}

يعتبر عقد الكفالة بين الكفيل والدائن عقدا تابعا للعقد القائم بين الدائن والمدين، لذلك فإن التزام الكفيل بالوفاء بالتزام المدين في حال عدم وفاء هذا الأخير بالتزامه يعتبر تابعاً لالتزام المدين الأصلي. "ويترتب على ذلك أن التزام الكين الكفيل لا يجوز أن يزيد على التزام المدين، او ان يكون اشد منه، حيث لايجوز مثلام كفالة الالتزام الطبيعي، ولا يجوز أن أن يكون

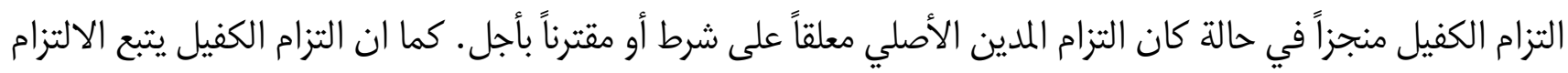

38 ${ }^{38}$ 39 نبيل سعد، التامينات العينية والشخصية ، مرجع سابق، صن 307 من 307. 40

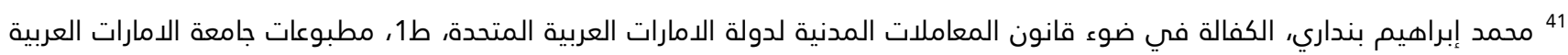

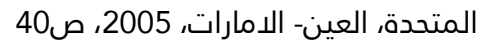


لأصلي للمدين في انعقاده وصحته وبطلانه، وكذلك مدى قابليته للفسخ، واوصافه ووجوده وانقضائه واثاره، وكذلك في الإني

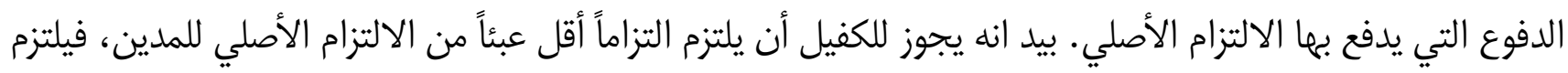

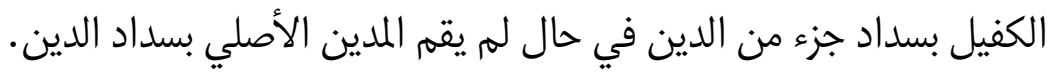
وفي ذلك نصت المادة 813 من القانون المدني القطري على أنه " 1- لا تكون الكفالة صحيحة إلا إذا كان الالتزام

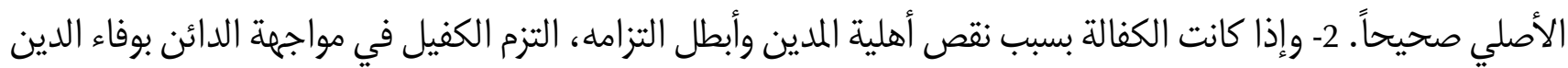

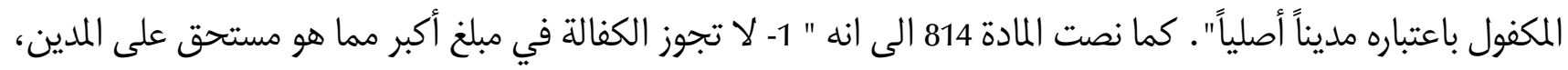

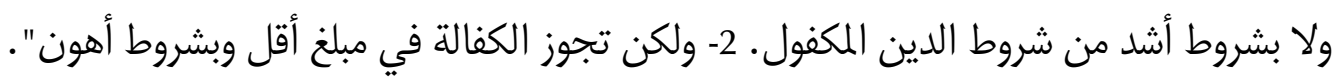

\section{رابعا: عقد الكفالة من العقود الملزمة لجانب واحد بحسب الاصل}

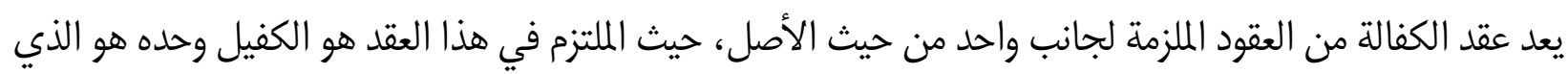

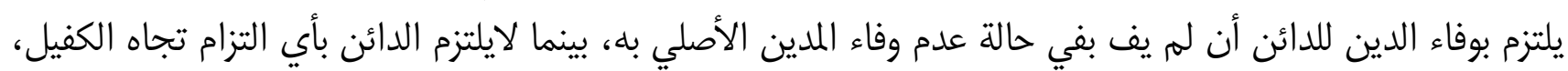

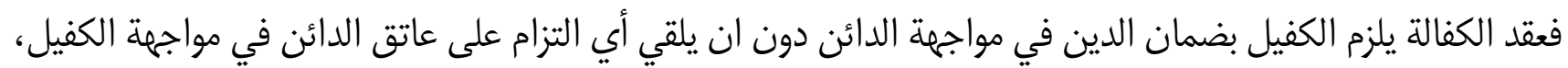

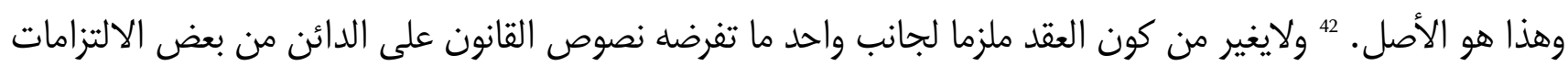

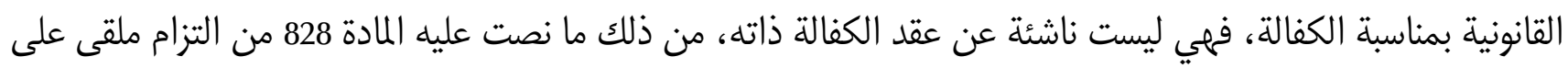

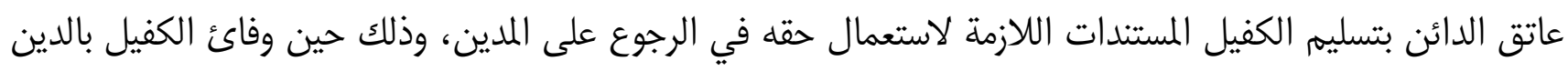

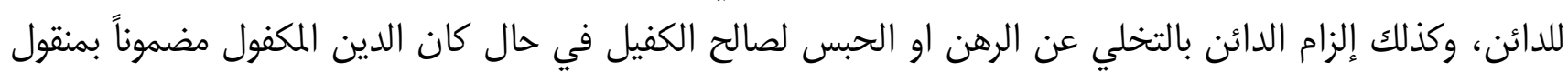

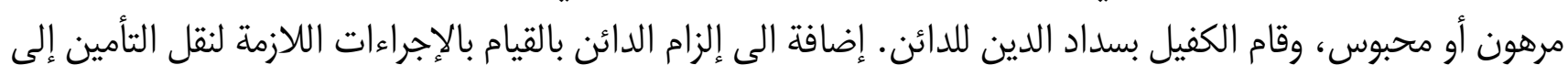

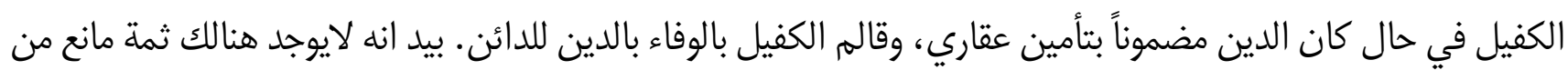

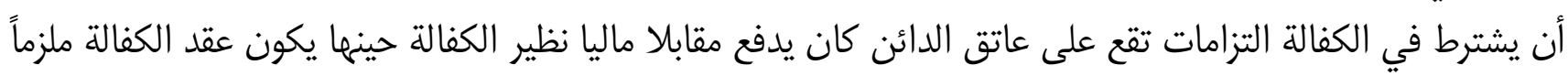

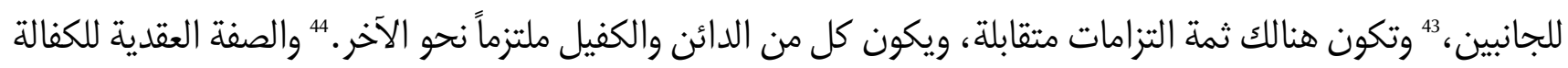

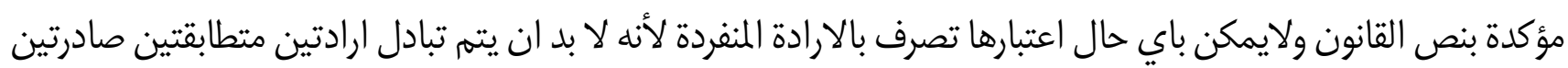
من طرفي الكفالة الكفيل والدائن.

\section{خامسا: عقد الكفالة من من عقود التبرع بالنسبة للكفيل بحسب الاصل}

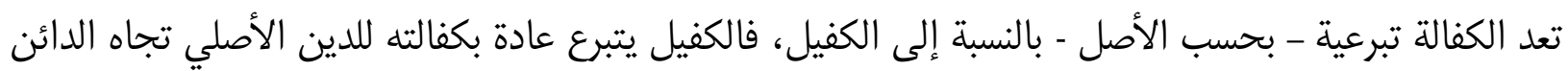

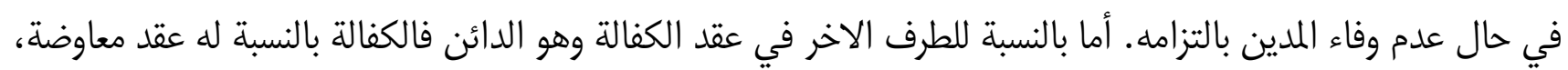

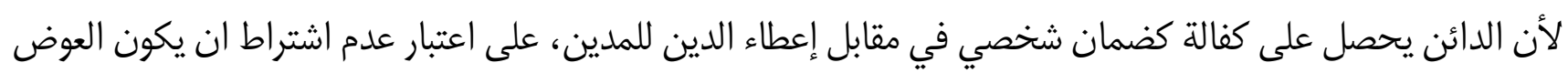

42 جابر محجوب، النظرية العامة للالتزامات - الجزء الأول -مصادر الالتزام، منشورات كلية القانون بجامعة قطر، الدوحة، 2006، ص 48. 43 44 نبيل سعد، التامينات العينية والشخصية، مرجع سابق، ص318 45 
لأحد طرفي العقد بل يمكن اعطاؤه للغير وهو المدين الأصلي. فيشترط في الكفيل عادة أهلية التبرع، 46 اما الاهلية المشترطة

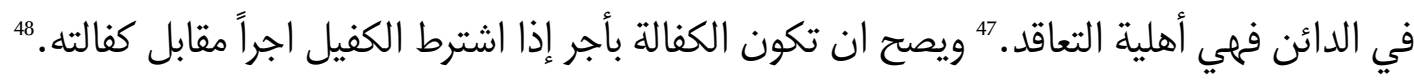

\section{سادسا: عقد الكفالة من العقود الرضائية}

لهم يشترط المشرع القطري شكلية خاصة لانعقاد عقد الكفالة، حيث ينعقد عقد الكفالة بمجرد التراضي ما بين الكفائة الكفيل

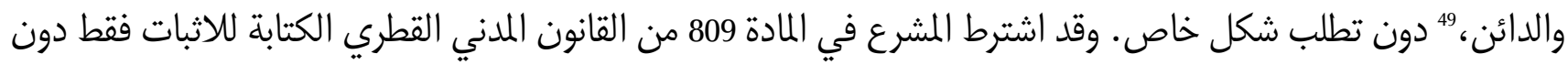

الانعقاد الذي يتم بمجرد التراضي.

\section{الفرع الثاني: تمييز الكفالة عما يشتبه بها من النظم القانونية}

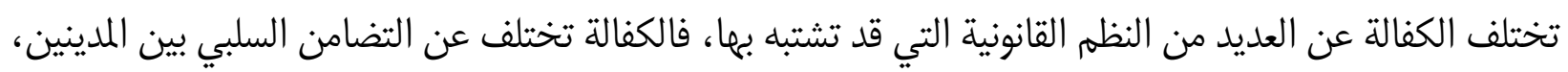

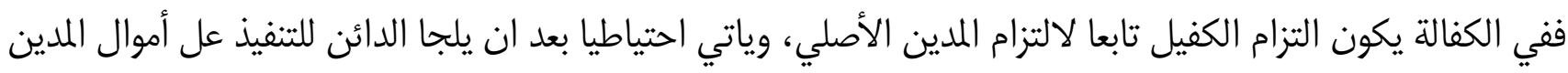

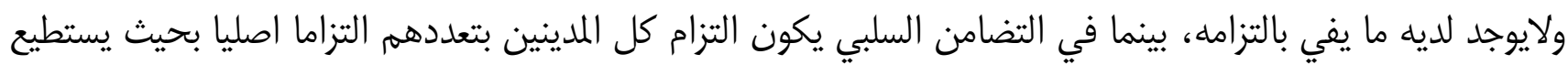

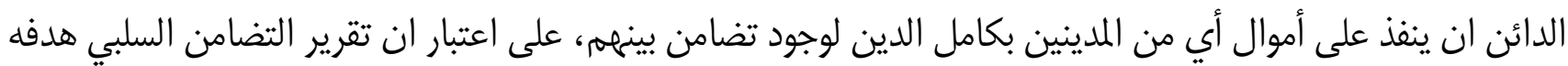

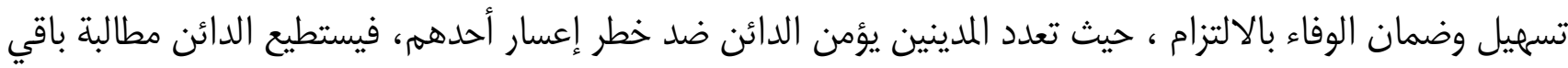

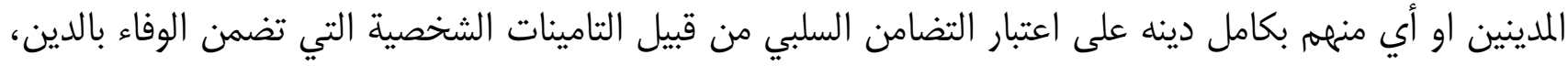

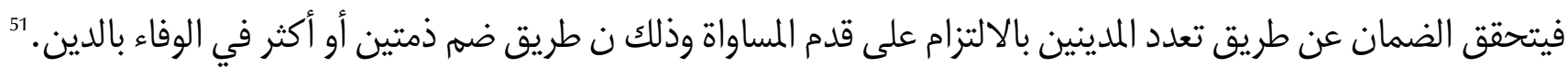

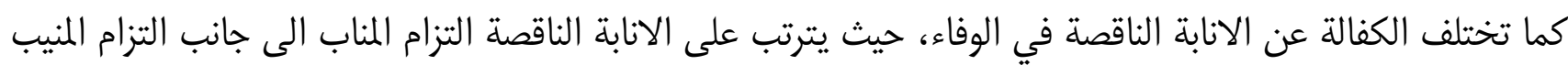

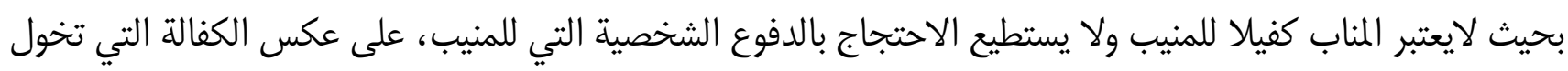

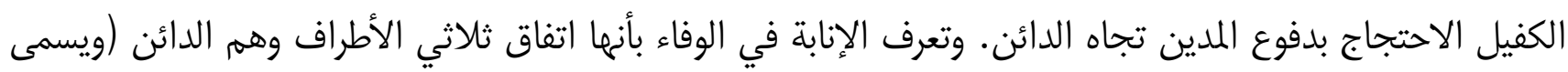

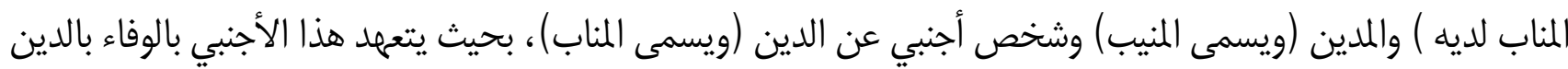

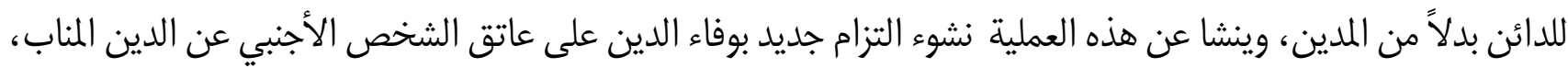

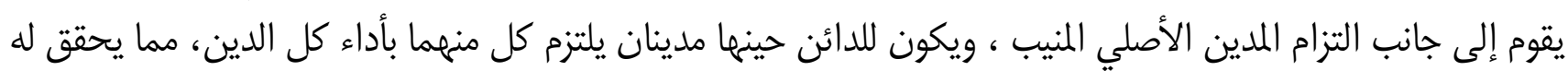

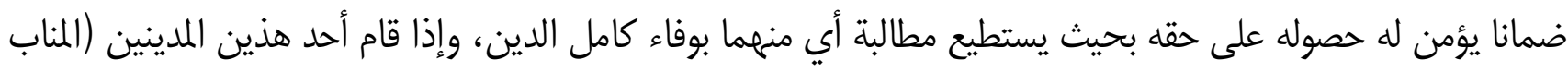

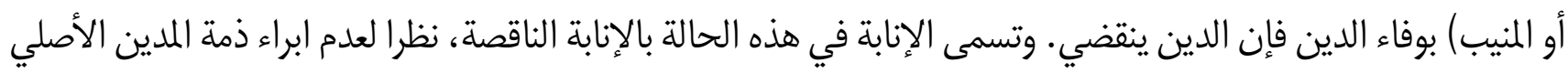

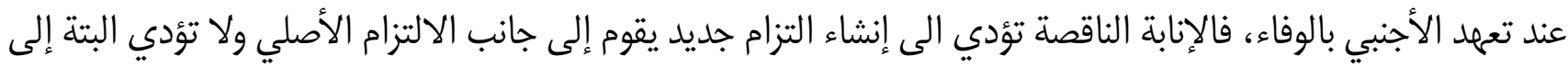

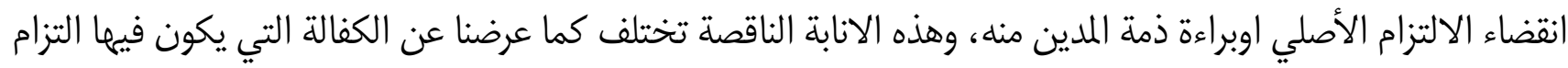

46 محمود جمال الدين زكي، التأمينات الشخصية والعينية، ط3، دون ذكر للناشر، القاهرة، 1979، ، ص35.

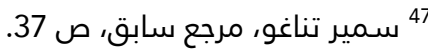
48 مصطفس حجازي، عقد الكفالة في القانون المدني، دار الكتب القانونية، المحلة الكبرى - مصر، 2006، ص32. 49 جوزف عجاقة، الكفالة وفقا لاحكام قانون الموجبات والعقود، دراسة منشورة في مجلة العدل التي تصدر عن نقابة المحامين في بيروت، العدد 4 - سنة 2002، بيروت، 2002، ص363.

50 سمير تناغو، مرجع سابق، ص28 جابر محجوب، النظرية العامة للالتزام - ج2- الاحكام العامة للالتزام في القانون القطري، مرجع سابق، ص 245 
أصلي قائم في ذمة المدين وفي حال لم يتهم الوفاء من قبله يلجأ الدائن الى الكفيل حينها لتنفيذ التزامه بالوفاء بدلا من المدين.52 وتختلف الكفالة أيضا عن فكرة التعهد عن الغير، حيث يترتب على التعهد عن الغير التزام المتعهد أصليا بجعل الغير

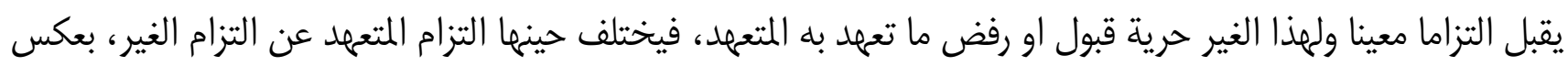
الكفيل الذي يستند التزامه الى التزام المدين الأصلي ويتبعه ويضمن تنفيذه. وفي ذلك نصت المادة 178 من القانون المدني القطري على أنه:

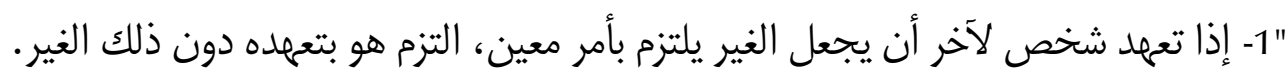

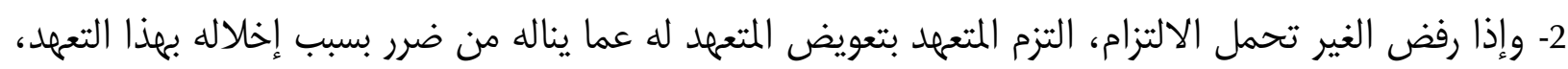

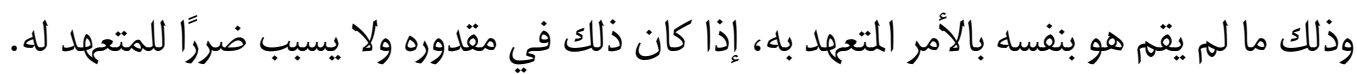

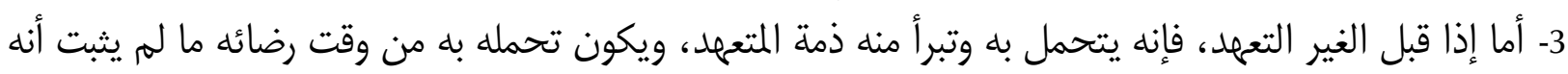

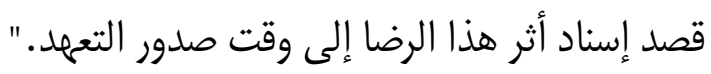
وهذا يعني تعهد شخص لشخص آخر بالحصول على موافقة شخص ثالث بأن يلتزم هذا الأخير بأمر معين، مما يعني

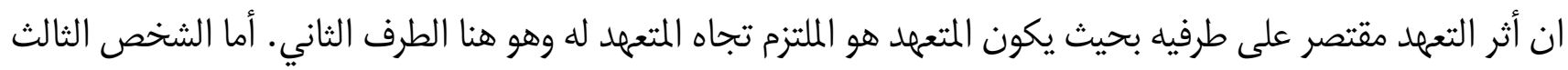

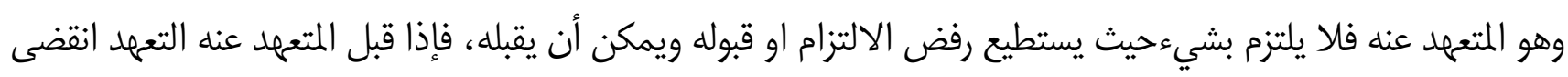

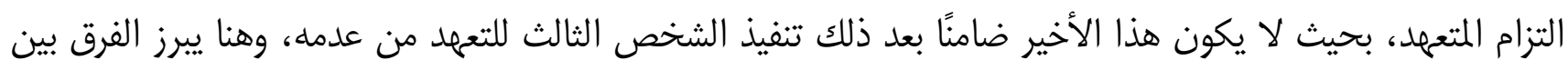

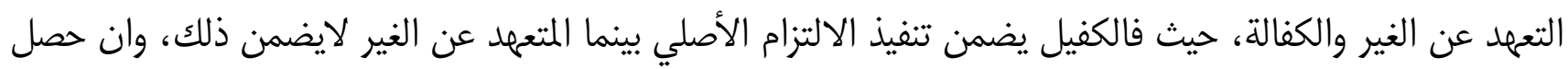
ذلك أي ضمن التنفيذ أصبح حينها المتعهد كفيلاً.

\section{خاتمة:}

عرضنا في هذه الدراسة للحماية القانونية التي كفلها المشرع للدائن من منظور احكام الكفالة في القانون المدني

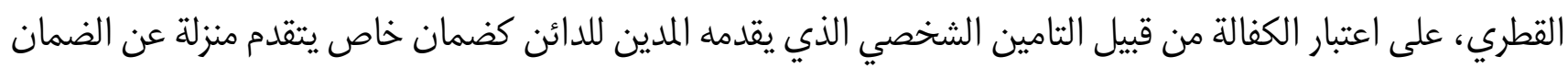
العام للدائنين الذي تكتنفه مخاطر عديدة. وفي خلاصة دراستنا هذه توصلنا الى مجموعة من النتائج والتوصيات كما يلي:

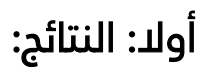
1- أن الكفالة من التامينات الشخصية التي يقدمها المدين للدائن كضمان خاص يتقدم منزلة عن الضمان العام للدائنين الذي تكتنفه مخاطر عديدة. 2- أن التأمينات الشخصية اسبق ظهورا من التامينات العينية ولعبت دورا هاما في حماية حقوق الدائن. 
3- ان الكفالة كنظام قانوني مؤداه ان يقوم الكفيل بتنفيذ الالتزام الأصلي في حال عدم تنفيذ المدين الأصلي له. 4- ان الكفالة تفترض تحديد طبيعة ومضمون الالتزام في عقد الكفالة ذاته.

5- ان صور الالتزام المكفول تتنوع حسب طبيعة الالتزام، فمن الممكن ان يكون الالتزام عبارة عن دفع مبلغ من النقود، او إعطاء شيء غير النقود، او يكون التزاما بعمل أو بالامتناع عن عمل.

6- ان مصادر الالتزام الأصلي المكفول تتعدد حسب مصادر الالتزام المختلفة، ارادية كانت او غير ارادية، اما مصدر الالتزام الناشئ عن عقد الكفالة فمصدره عقد الكفالة الاصني

7- ان الكفالة تتنوع بحسب مصدر التزام المدين بتقديم الكفيل، سواء كان القانون او الاتفاق او القضاء، او بحسب طبيعة الكفالة سواء كانت مدنية او تجارية.

8- ان تقسيمات الكفالة بحسب مصدرها تتقسم الى كفالة قانونية وكفالة قضائية وكفالة اتفاقية، ولهذا التقسيم أهمية

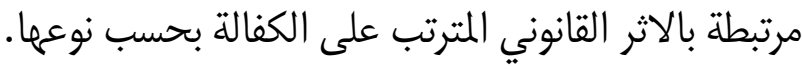

9- ان للكفالة خصائصما المميزة لها كنظام حمائي شخصي للدائن، والتي تنطلق من كون الكفالة من العقود التي

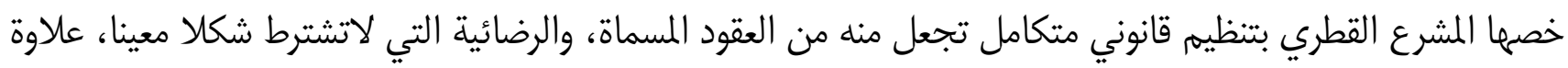

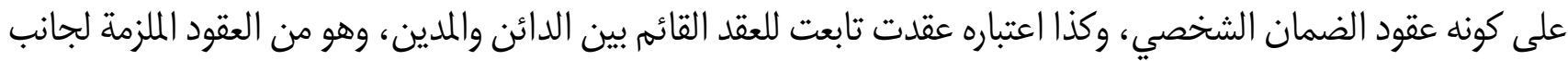

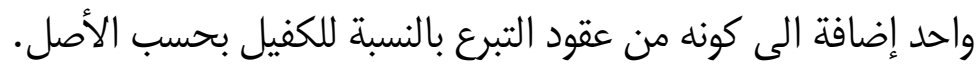

10 - ان الكفالة تتميز بخصائصها عن كثير من الأنظمة القانونية كالتضامن السلبي والانابة الناقصة في الوفاء وكذا

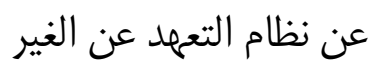

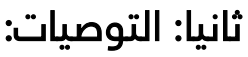

1- تطوير النظام القانوني للكفالة بتوفير مزيد من الضمانات لحماية مصالح الدائن خاصة فيما يتعلق بالحالات التي يتعثر فيها الكفيل عن القيام بالتزامه في حال له يف المدين الأصلي بالتزامه.

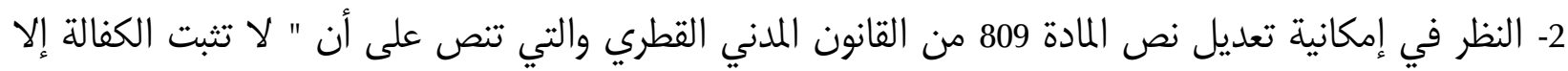

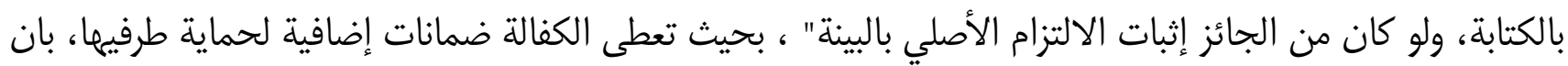
تكون الكتابة للانعقاد وليس فقط للاثبات. 3- النظر في إمكانية تعديل نص المادة 810 من القانون المدني القطري والتي تنص على أنه:

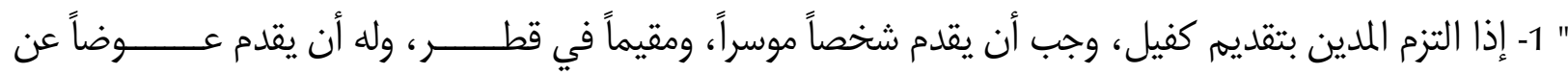

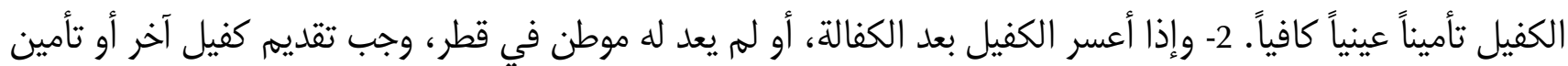

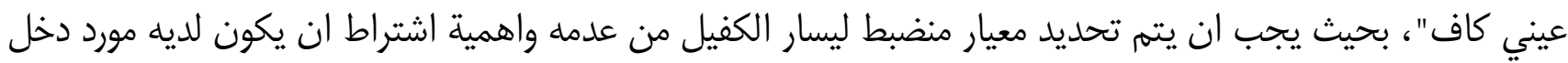

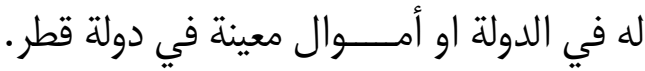


4- النظر في تدعيم فكرة الكفالة التضامنية وكذلك الكفالة العينية باعتبارها ضمانات اكثر قوة من الكفالة العادية. 


\section{سلطة تدبيد جمعيات حماية المستهلك ذات المنفعة العامة}

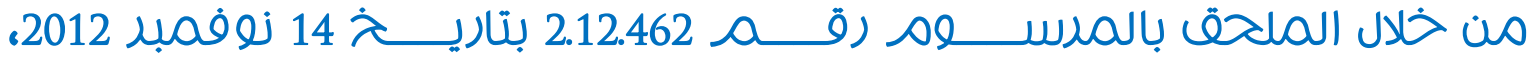
القاضي بتحديد النظام الأساس النمعزجي لجمعيات حماية المستهلك التي يمكن الاعتراف لها بصفة المنفعة العامة

\section{نbies \\ أستاذ بكلية العلوم القانونية والاقتصادية والاجتماعية - السويسي

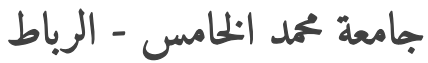

\section{المقدمة}

عرفت الساحة الدولية، بشكل عام والوطنية بشكل خاص، تنامي ظاهرة تدخل المجتمع المدني في جل مناحي الحياة

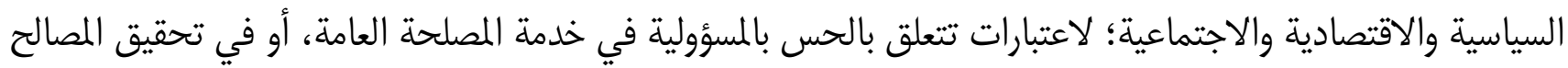

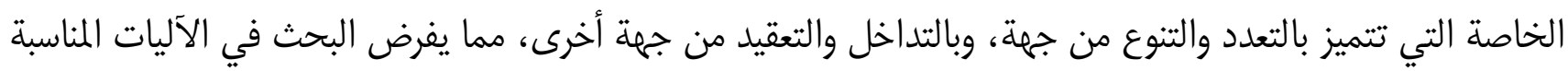

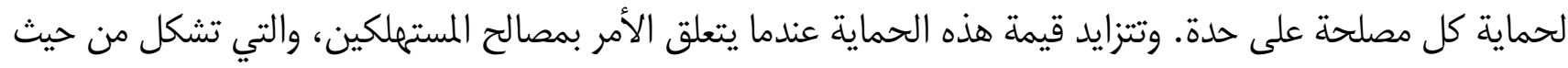

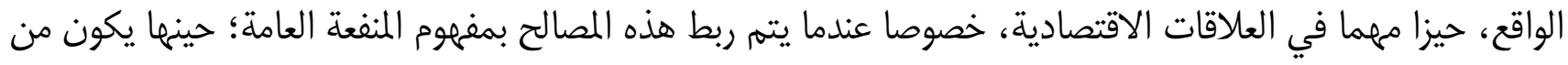

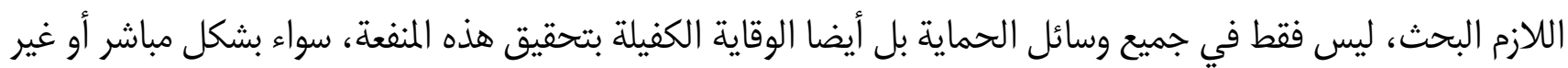

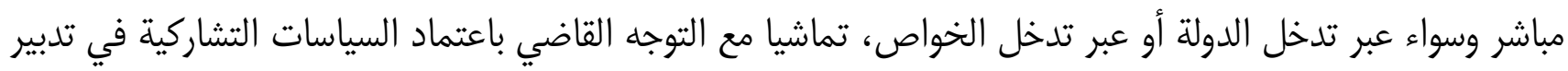

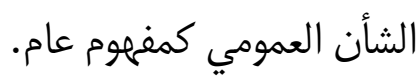

وتبعا لذلك، سعى المشرع المغربي إلى البحث في آليات حماية المستهلك، فوضع لما مجموعة من القواعد القانونية،

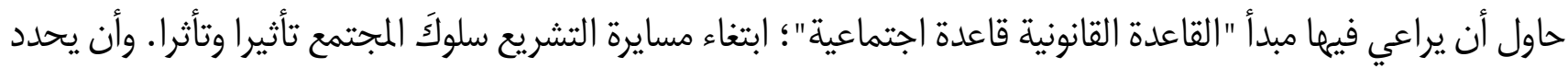

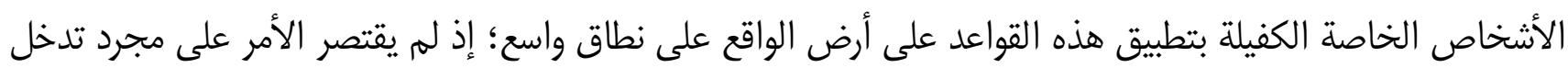

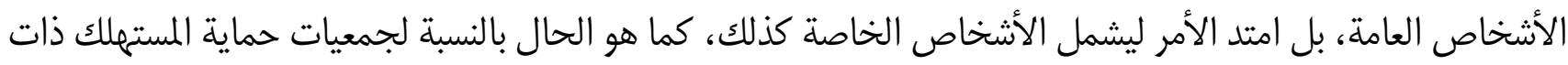

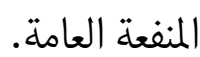

$$
\text { وتحقيقا لمذه الغاية، تم وضع القوانين الآتية: }
$$

الظهير الشريف رقم 1.58 .376 الصادر بتاريخ 27 نونبر 1958 المتعلق بحق تأسيس الجمعية: (55)؛

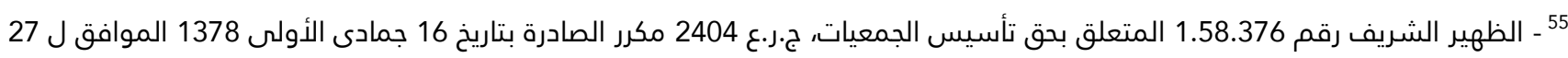

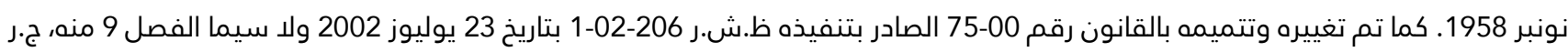
عدد 5046 في 10 أكتوبر 2002، ص. 2898. 
المرسوم رقم 2.12.462 الصادر بتاريخ 15 نوفمبر 1958 المنظم لحق تأسيس الجمعيات (56)؛ المرسوم رقم 969-04-209 الصادر بتاريخ 10 يناير 2005 القاضي بتطبيق الظهير الشريف أعلاه(57)؛ القانون رقم 31.08 القاضي بتحديد تدابير لحماية المستهلك، الصادر بتاريخ 18 فبراير 2011 (58)؛ الملحق بالمرسوم (رقم 462-12-2) الصادر بتاريخ 14 نونبر 2012 القاضي بتحديد النظام الأساس النموذجي لجمعيات حماية المسترلك التي يمكن الاعتراف لمها بصفة المنفعة العامة (59). ويلاحظ تميز الإطار التشريعي، الذي خص به المشرع مساهمة الخواص في حماية المسترلك، بالتعدد والتنوع والتدرج؛ إذ يشتمل على قانونين وظهير ومراسيم وملحق بمرسوم، مع استحضار بعض الإحالات المباشرة على قوانين أخرى مثل ظطير الالتزامات والعقود (60)، كل ذلك ارتبط بأزمنة مختلفة تمثلت في السنوات 1913 و1958 و2005 و2011 ثم 2012، كما تضمن مقتضيات تنحو نحو الانسجام لكنها تبقى غير متكاملة في جزئياتها. والمُستنَج من هذا، أنه ما كان هذا التعدد والتنوع والتدرج على مستوى المرجعية القانونية، إلا ليشكل دليلا على أهمية هذه جمعيات حماية المسترلك بداية، وعلى تفردها دون سواها من الأشخاص الخاصة، في تحقيق غاية المشرع المغربي الرامية إلى حمايت المستهلك انتهاء؛ وهي غاية لا يمكن بلورتها على أرض الواقع إلا عبر تمكين هذه الجمعيات من مجموعة من الصلاحيات التي تتطلب ربطها بنوع من السلطة التي لا يمكن أن تخرج في جميع الأحوال من دائرة التقرير والتنفيذ والرقابية، كما هو متعارف عليه في الأنظمة ذات التركيبة الجماعية (61). والسلطة التي تعني موضوع هذه الدراسة؛ هي السلطة التنفيذية لجمعية حماية المستهلك والتي تمكنها من تحقيق أهدافها؛ سواء المشتركة بينها وبين أي نوع آخر من

26.12.462 الصادر بتاريخ 17 من ذي المرسوم رقدة 1433 (14 نونبر 2012) القاضي بتحديد النظام الأساسي النموذجي لجمعيات حماية المستهلك التي يمكن الاعتراف لها بصفة المنفعة العامة، ج.ر.ع 6017 بتاريخ 25 محرم 1434 (10 دجنبر 2012). المرسوم رقم 2.12.462 الذي تنص المادة 1 منه على أنه: تؤسس بين المنخرطين في هذا النظام الأساسي والذين سينخرطون لاحقا، جمعية طبقا لأحكام الظهير الشريف رقم 1.58 .376 الصادر في 3 جمادى الأولى 1378 ( 15 نوفمبر 1958) المنظم لحق تأسيس الجمعيات. كما تم تغييره وتتميمه؛

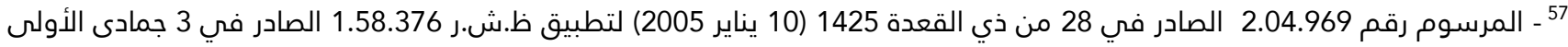
1378 (15 نونبر 1958) المتعلق بحق تأسيس الجمعيات، ج.ر.ع 5339 الصادرة بتاريخ 1 غشت 2005 المن 2005.

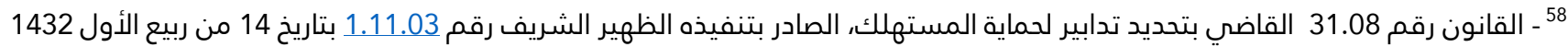

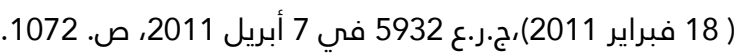
59 ـ الملحق بالمرسوم رقم 2.12 .462 الصادر في 17 من ذي الحجة 1433 (14 نوفمبر 2012) بتحديد النظام الأساس النموذجي لجمعيات حماية

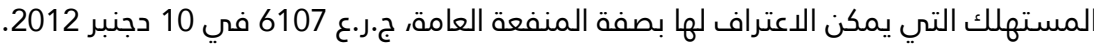
60 - تنص الفقرة الثانية من الفصل 1 ظ.ش رقم 1.58 .376 المتعلق بحق تأسيس الجمعيات، على أنه: "وتجري عليها (أي الجمعيات) فيما يرجع لصحتها القواعد القانونية العامة المطبقة على العقود والالتزامات". مما يقتضي الرجع إلى ظهير الالتزامات والعقود الصادر في 9 رمضان 1331 (12 أغسطس 1913) كما تم تعديله آخر مرة بموجب القانون رقم 21.18 المتعلق بالضمانات المنقولة الصادر بتنفيذه الظهير الشريف رقم 1.19 .76 بتاريخ في 11 شعبان 1440 (17 أبريل 2019)؛ الجريدة الرسمية عدد 6771 بتاريخ 16 شعبان 1440 (22 أبريل 2019) ص 2058.

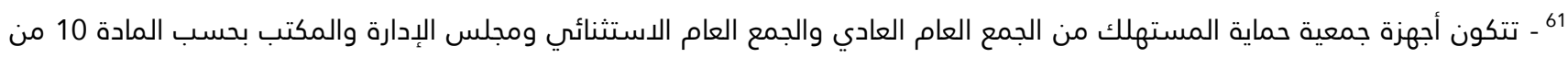
الملحق أعلاه. ويعتبر الجمع العام العادي أو الجمع العام الاستثنائي أعلى جهاز تقريري في الجمعية، ...". تبعا للمادة 11 من الملحق عينه. 
أنواع الجمعيات (62) أو الخاصة بها دون غيرها(63.) وهي السلطة المعبر عنها تشريعيا بسلطة التدبير، والموكلة إلى مجلس إدارة جمعية حماية المسترلك ذات المنفعة العامة (64).

وتأتي أهمية دراسة سلطة تدبير هذه الجمعيات (65)؛ اعتبارا لتعلقها بإحدى أهم السلط التي يتصف بها أي نظام ذا تركيبة جماعية يقوم على المبادئ الديموقراطية، والتي يعتبر مجلس الإدارة أهم وأقوى جهاز فيها، على الأقل من الناحية

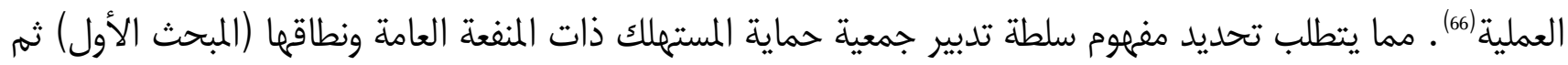

شروط ممارستها (المبحث الثاني).

\section{المبحث الأول: مفهوم سلطة التدبير وأهدافها}

اتخذ التدبير أو التسيير عدة مفاهيم، اختلفت بحسب الزاوية التي يُنظر منها إليه؛ سواء اقتصادية أكانت أم اجتماعية

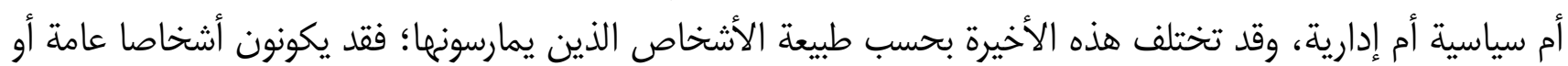
أشخاصا خاصة.

ويمكن تحليل هذه الوضعيات بالاستناد إلى عدة تيارات فكرية (67) تُخضع التسيير؛ من جهاة، إلى قوانين أو قواعد أو أصول علمية قابلة للتطبيق على مختلف النشاطات الإنسانية، وتعتبره من جهة أخرى، علما وفنا؛ لارتباطه بباقي المعارف في جميع الدراسات، مثل علوم الاقتصاد والمحاسبة والرياضيات والاجتماع والنفس والسياسة والاتصال والإعلام الآلي والأثثروبولوجيا. وأنه ذا دلالة وظيفية؛ لتعلقه بعمليات التنظيم والإدارة والتخطيط والقيادة والرقابة. وأنه يتميز بالتطور؛ لتعلق

62 - وينص الفصل 1 من ظ.ش لسنة 1958 -المعدل- بشكل عام على أن: "الجمعية هي اتفاق لتحقيق تعاون مستمر بين شخصين أو عدة أشخاص لاستخدام معلوماتهم أو نشاطهم لغاية غير توزيع الأرباح فيما بينهم.

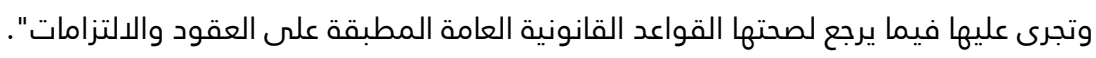

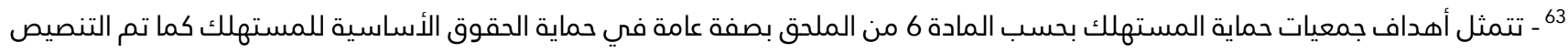

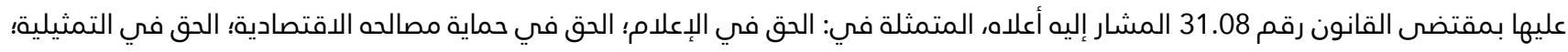
الحق في التراجع؛ الحق في الاذتيار؛ الحق في الإصغاء إليه. 64 - تنص المادة 14 من الملحق بالمرسوم رقم 2.12 .462 على أنه " يتولى إدارة الجمعية مجلس مكون من خمسة عشر متصرفا على الأكثر، ينتخبون جميعا من طرف الجمع العام لمدة أربع سنوات قابلة للتجديد مرة واحدة.

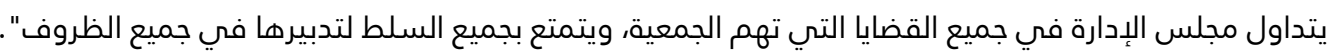
65 - تنص المادة 1 من الملحق على أنه: "تؤسس بين المنذرطين في هذا النظام الأساسي والذين سينخرطون لاحقا، جمعية طبقا لأحكام الظهير الشريف رقم 1.58.376 الصادر في 3 جمادى الأولى 1378 ( 15 نوفمبر 1958) المنظم لحق تأسيس الجمعيات، كما تم تغييره وتتميمه، والقانون رقم 31.08 القاضي بتحديد تدابير لحماية المستهلك، ولا سيما المادة 154 منه". مع العلم أن الفقرة 3 من الفصل 5 من ظ.ش أعلاه استعملت مصطلح "القوانين الأساسية" بدل الأنظمة الأساسية، وهي تسمية معيبة،

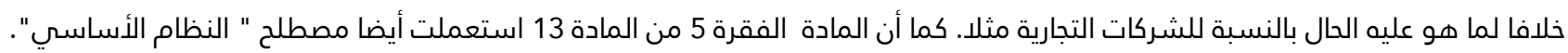

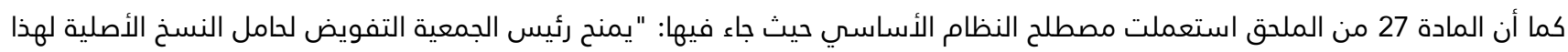

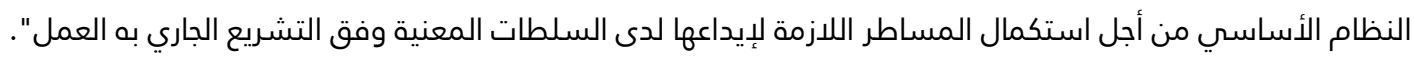
66 - تتكون أجهزة جمعية حماية المستهلك من الجمع العام العادي والجمع العام الاستثنائي ومجلس الإدارة الجارة والمكتب بحسب الجمائ المادة 10 من

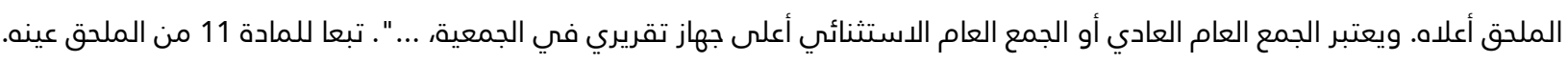
67 - يمكن الرجوع في ذلك إلى المدرسة الكلاسيكية ومدرسة العلاقات الإنسانية ومدرسة التسيير. 
استمراريته بوجود إدارة في حد ذاتها، بل وبحكامة التسيير كذلك. كما أنه يجمع بين معطيي العقلانية والإنسانية، بالإضافة إلى قيامه على عنصر حسن الأداء (68).

هذا عن التدبير بشكل عام، لكن ارتباطا بموضوع الدراسة، تتطلب مناقشة سلطة التدبير في علاقتها بجمعيات حماية المسترلك ذات المنفعة العامة (المطلب الأول) وفي ارتباطها بأهداف منح هذه السلطة (المطلب الثاني)، مع لفت الانتباه إلى التمييز الحاصل بين التسيير "gestion" باعتباره مفهوما ضيقا لا يشير في حقيقته إلا إلى مجموعة من تقنيات عمليات

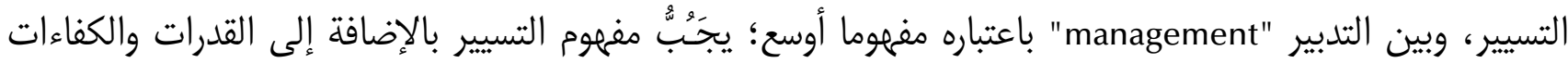
القيادية التي يجب أن تتحقق في المسير.

المطلب الأول: مفهوم سلطة التدبير في جمعيات حماية المستهلك ذات المنفعة العامة سبقت الإشارة إلا أن مفهوم السلطة يتخذ أكثر من مظهر؛ فتكون السلطة بموجبه إما سلطة تقريرية وإما سلطة رقابية وإما سلطة تنفيذية التي يعبر عنها في مواقع أخرى بالسلطة الإدارية أو التسييرية أو التدبيرية. وقبل تحديد مفهوم سلطة التدبير هــــذه؛ باعتبارها موضوع هذا البحث (الفقرة الثانية)، لا بد مــــن الحديث عن

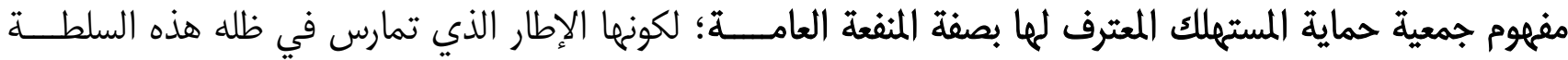

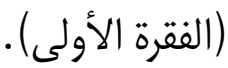

\section{الفقرة الأولى: مفهوم جمعية حماية المستهلك المعترف لها بالمنفعة العامة}

يتطلب لتحديد مفهوم جمعية حماية المسترلك المعترف لها بالمنفعة العامة، تفكيك عناصر هذه التسمية؛ من حيث تحديد مفهوم الجمعية (أولا) ومفهوم حماية المستهلك (ثانيا) ثم مفهوم المنفعة العامة (ثالثا).

أولا: مفهوم الجمعية

تُعتبر الجمعية اتفاقا لتحقيق تعاون مستمر بين شخصين أو عدة أشخاص لاستخدام معلوماتهم أو نشاطهم لغاية غير توزيع الأرباح فيما بينهم، بحسب الفقرة الأولى من الفصل 1 من ظ.ش لسنة 1958. ويعتبر عدم استهداف الربح ضابطا

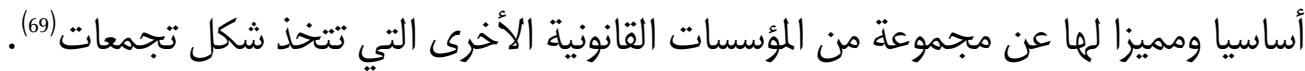

88 - ولمزيد من التفصيل، يراجع عبد الرزاق بن حبيب: اقتصاد وتسيير المؤسسة، ديوان المطبوعات الجامعية، الساحة المركزية بن عنكون، الجزائر، 2002؛ دياب إسماعيل محمد. الإدارة المدرسية. الإسكندرية : دار الجامعة الجديدة للنشر، (2001م)؛ حجان: محاضرات لمقياس علم المنضمات؛ سمير ميموني: محاضرات أستاذ المحاضر لمقياس تاريخ الوقائع الإقتصادية ثم http://etudiantdz.net/vb/t20723.html; http://www.social-team.com/forum/archive/index.php?t-3855.html 69 - يعد عدم استهداف تحقيق الربح لأعضائها يجعلها تشكل أقصى درجات التعاون، خلافا لما هو عليه الحال لبعض التجمعات الأخرى التي وإن كانت لا تستهدف تحقيق الربح لحسابها إلا أنها ترمي خدمة أعضائها مثل التعاونيات والتعاضديات، كما أنها تختلف بشكل كبير عن الشركات التجارية التي ترمي بالأساس تحقيق الأرباح استنادا إلى نص الفصل 982 من ظ.ل.ع الذي جاء فيه: " الشركة عقد بمقتضاه يضع شخصان أو أكثر أموالهم أو عملهم أو هما معا، لتكون مشتركة بينهم، بقصد تقسيم الربح الذي قد ينشأ عنها ". مع مراعاة أحكام القانون 75-17 المتعلق بشركات المساهمة والقانون 96-5 المتعلق بباقي الشركات التجارية الأخرى خصوصا الشركة ذات المسؤولية المحدودة المكونة من شريك وحيد. 
وتجري على صحة الجمعية، القواعد القانونية العامة الواردة في قانون الالتزامات والعقود، تبعا للفقرة الثانية من 1 الإن

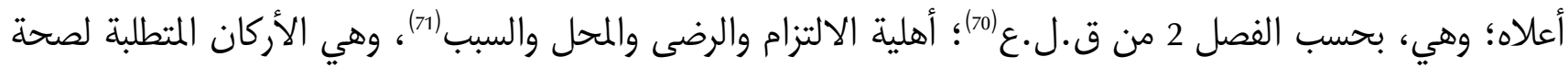

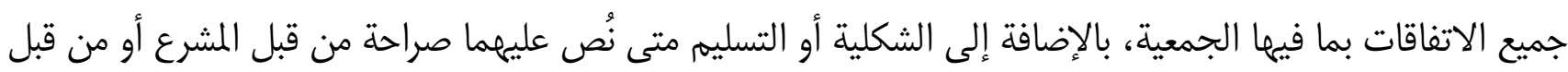

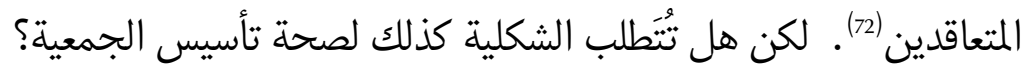

يعطي الفصل 2 من ظهير 1958 لكل شخص حرية تأسيس الجمعيات، لكنه يشترط في الوقت نفسه مراعاة مقتضيات

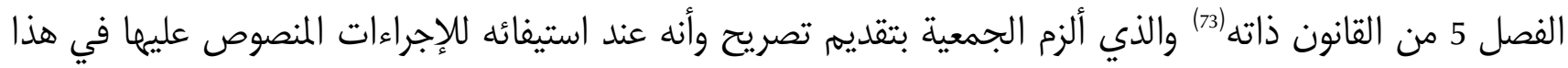

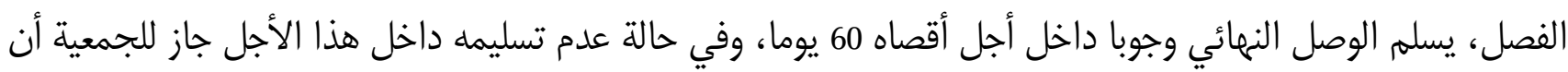
تمارس نشاطها وفق الأهداف المسطرة في قوانينها التهات.

70 - ـ ينص الفصل 2 من ق.ل.ع على أنه: "الأركان اللازمة لصحة الالتزامات الناشئة عن التعبير عن الإرادة هي: 1- 2- 2 - الأهلية للالتزام؛ 2- تعبير صحيح عن الإرادة يقع على العنصر الأساسية للالتزام؛ 3- شيء محقق يصلح لأن يكون محلا للالتزام؛

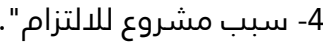
71 - الفصل 3 من ظ.ش لسنة 1958: "كل جمعية تؤسس لغاية أو لهدف غير مشروع يتنافى مع القوانين أو الآداب العامة أو قد يهدف إلى المس بالدين الإسلامي أو بوحدة التراب الوطني أو بالنظام الملكي أو تدعو إلى كافة أشكال التمييز تكون باطلة وينص الفصل 7 من ظهير 1958: "تختص المحكمة الابتدائية بالنظر في طلب التصريح ببطلان الجمعية المنصوص عليه في الفصل الثالث أعلاه. كما تختص أيضا في طلب حل الجمعية إذا كانت في وضعية مخالفة للقانون. وذلك سواء بطلب من كل من يعنيه الأمر أو بمبادرة من النيابة

العامة.

وللمحكمة بالرغم من كل وسائل الطعن أن تأمر ضمن الإجراءات التحفظية بإغلاق الأماكن ومنع كل اجتماع لأعضاء الجمعية".

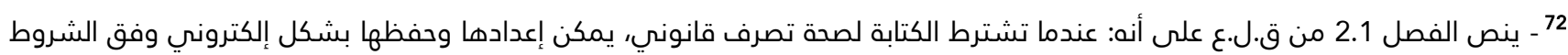

المنصوص عليها في الفصلين 1-417 و217-217 أدناه72. يمكن للملتزم، عندما يطلب منه بيان مكتوب بيده، أن يقوم بتحريره بشكل إلكتروني إذا كان من شأن شروط تحريره ضمان أنه الوحيد الذي يمكنه القيام بذلك. غير أن الوثائق المتعلقة بتطبيق أحكام مدونة الأسرة والمحررات العرفية المتعلقة بالضمانات الشخصية أو العينية، ذات الطابع المدني أو التجاري

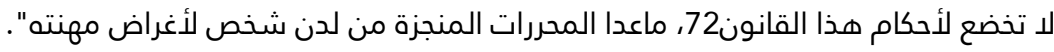
73- ينص الفصل 2 من ظهير 1958 على أنه: "يجوز تأسيس جمعيات الأشخاص بكل حرية ودون سابق إذن بشرط أن تراعى في ذلك مقتضيات

74- ينص الفصل 5 من ظهير 1958 على أنه: " يجب أن تقدم كل جمعية تصريحا إلى مقر السلطة الإدارية المحلية الكائن به مقر الجمعية مباشرة أو بواسطة عون قضائي يسلم عنه مؤقت مختوم ومؤرخ في الحال وتوجه السلطة المحلية المذكورة إلى النيابة العامة بالمحكمة الابتدائية المختصة نسخة من التصريح المذكور وكذا نسخا من الوثائق المرفقة به المشار إليها في الفقرة الثالثة بعده، وذلك قصد تمكينها من إبداء رأيها في الطلب عند الاقتضاء. وعند استيفاء التصريح للإجراءات المنصوص عليها في الفقرة اللاحقة يسلم الوصل النهائي وجوبا داخل أجل أقصاه 60 يوما وفي حالة عدم تسليمه داخل هذا الأجل جاز للجمعية أن تمارس نشاطها وفق الأهداف المسطرة في قوانينها. ويتضمن التصريح ما يلي:

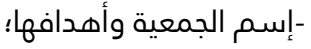
-لائحة بالأسماء الشخصية والعائلية وجنسية وسن وتاريخ ومكان ازدياد ومهنة ومحل سكنى أعضاء المكتب المسير؛ - الصفة التي يمثلون بها الجمعية تحت أي اسم كان؛ 
ويشترط الفصل 6 من ظهير 1958(75 أن يتهم التصريح بالجمعية بصفة قانونية؛

لكي يكون لها حق الترافع والتقاضي والتملك والتصرف في الإعانات العمومية والخاصة وفي واجبات الانخراط والاشتراك وفي المساعدات وفي المقرات والأدوات المخصصة لتسييرها وعقد اجتماعات أعضائما وفي الممتلكات الضرورية لممارسة وإنجاز أهدافها.

ويلاحظ أن هذا الفصل أخرج التسيير من دائرة الصلاحيات المتوقفة ممارستها على التصريح القانوني للجمعية. لكن هل يكفي في قيام الجمعية مجرد تقديم التصريح بها بشكل قانوني أم يتطلب قبول التصريح والموافقة عليه؟ إن الفصل 2 من ظهير 1958 أعلاه، لم يلزم الجمعية بتقديم تصريح وحسب، بل اشترط استيفاءه إجراءات محددة،

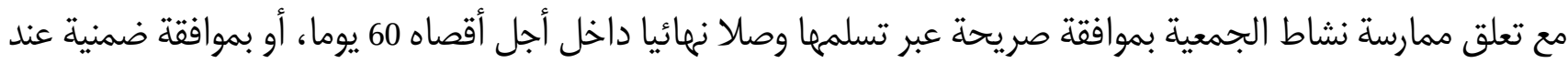
عدم تسلم هذا الوصل خلال هذا الأجل.

لذلك، حتى وإن تم استبعاد الكتابة كركن في تأسيس الجمعية، فما جدوى هذا الاستبعاد إن لم يمكنها من ممارسة أنشطتها، مما يجعل الكتابة أمرا حاسما بدون ينتفي الحديث عن وجود الجمعية على الأقل من الناحية الفعلية.

-صورا من بطائقهم الوطنية أو بطائق الإقامة بالنسبة للأجانب ونسها من بطائق السجل العدلي؛ -مقر الجمعية؛ -عدد ومقار ما أحدثته الجمعية من فروع ومؤسسات تابعة لها أو منفصلة عنها تعمل تحت إدارتها أو تربطها بها علائق مستمرة وترمي إلى القيام بعمل مشترك! وتضاف إلى التصريح المشار إليه في الفقرة الأولى من هذا الفصل القوانين الأساسية وتقدم ثلاثة نظائر عن هذه الوثائق إلى مقر السلطة الإدارية المحلية التي توجه واحدة منها إلى الأمانة العامة للحكومة. ويمضي صاحب الطلب تصريحه وكذا الوثائق المضافة إليه ويشهد بصحتها وتفرض على كل من القوانين الأساسية ولائحة الأعضاء المكلفين بإدارة الجمعية أو تسييرها حقوق التنبر المؤداة - بالنسبة للحجم ، باستثناء نظيرين. وكل تغيير يطرأ على التسيير أو الإدارة أو كل تعديل يدخل على القوانين الأساسية وكذا إحداث مؤسسات فرعية أو تابعة أو منفصلة، يجب أن تصرح به خلال الشهر الموالي وضمن نفس الشروط، ولا يمكن أن يحتج على الغير بهذه التغييرات والتعديلات إلا ابتداء من اليوم الذي يقع فيه التصريح بها. وفي حالة ما إذا لم يطرأ أي تغيير في أعضاء الإدارة يجب على المعنيين بالأمر أن يصرحوا بعدم وقوع التغيير المذكور وذلك في التاريخ المقرر له بموجب القوانين الأساسية. ويسلم وصل مختوم ومؤرخ في الحال عن كل تصريح بالتغيير أو بعدمه".

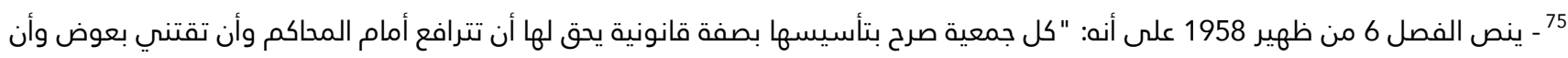
تمتلك وتتصرف فيما يلي: 1. الإعانات العمومية؛ 2. واجبات انخراط أعضائها؛ 3. واجبات اشتراك أعضائها السنوي؛ 4. إعانات القطاع الخاص؛ 5. المساعدات التي يمكن أن تتلقاها الجمعية من جهات أجنبية أو منظمات دولية مع مراعاة مقتضيات الفصلين 17 و32 مكرر من هذا القانون؛ 6. المقرات والأدوات المخصصة لتسييرها وعقد اجتماعات أعضائها؛ 7. الممتلكات الضرورية لممارسة وإنجاز أهدافها" . 


\section{ثانيا: مفهوم حماية المستهلك}

يقتضي الحديث عن حماية المستهلك التسليم مند البداية بوجود علاقة تعاقدية بين المستهلك والمورد، استنادا إلى نص الفقرة الأولى الملادة 2 من القانون رقم 08-31 القاضي بتحديد تدابير حماية المستهلك والتي جاء فيها: "يحدد هذا القانون العلاقات بين المستهلك والمورد". كما تم تعريفهما في المادة نفسها(76). وعن الحماية التي تُعنى بها هذه الجمعية، فقد أشار إليها هذا القانون الذي اعتبر من خلال ديباجته ، أنه يشكل إطارا مكملا للمنظومة القانونية في مجال حماية المستهلك بغية تعزيز الحقوق الأساسية لهذا الأخير، والمتمثلة أساسا في الحق في الإعلام والحق في حماية حقوقه الاقتصادية والحق في التمثيلية والحق في التراجع والحق في الاختيار والحق في الإصغاء إليه.

\section{ثالثا: مفهوم المنفعة العامة}

تتص الفقرة الأولى الفصل 9 من ظ.ش لسنة 1958 كما تم تعديله على أن: " كل جمعية باستثناء الأحزاب والجمعيات ذات الصبغة السياسية المشار إليها في الجزء الرابع من هذا القانون يمكن أن يعترف لما بصفة المنفعة العامة بمقتضى مرسوم بعد أن تقدم طلبا في الموضوع وتجري السلطة الإدارية بحثا في شأن غايتها ووسائل عملما" . كما تنص الفقرة السابعة منه على أنه: "وتتمتع الجمعية ذات المنفعة العامة بالامتيازات الناجمة عن المقتضيات الآتية بعده بصرف النظر عن المنافع المقررة في الفصل 6 أعلاه" (77). ويعتبر مفهوم المنفعة العامة مفهوما ذا بعد اقتصادي أكثر منه قانونيا، وتحيل المنفعة بذلك إلى القدرة على إشباع الحاجيات، وتتخذ عدة مظاهر أو أنواع؛ ترتبط بالشكلية أو بالمكانية أو بالتملك أو بالزمن أو بالخدمية أو بالكل (78). ويحيل

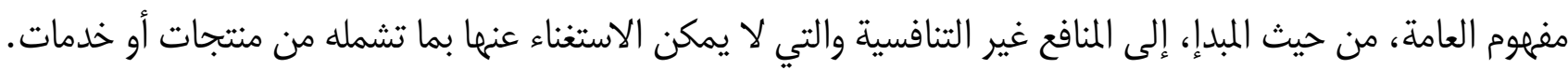

76 - و يقصد بالمستهلك كل شخص طبيعي أو معنوي يقتني أو يستعمل لتلبية حاجياته غير المهنية منتوجات أو سلعا أو خدمات معدة لاستعماله

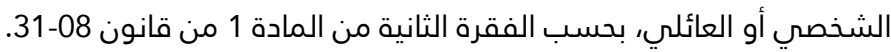

ويقصد بالمورد كل شخص طبيعي أو معنوي يتصرف في إطار نشاط مهني أو تجاري، بحسب الفقرة الثالثة من المادة 1 من قانون 08-08-31. 77 - وهذه المنافع هي: الترافع أمام المحاكم وأن تقتني بعوض وأن تتملك وتتصرف في الإعانات العمومية وواجبات انخراط أعضائها وواجبات اشتراك أعضائها السنوي أو إعانات القطاع الخاص والمساعدات التي يمكن أن تتلقاها من جهات أجنبية أو منظمات دولية مع مراعاة مقتضيات الفصلين 17 و32 مكرر من

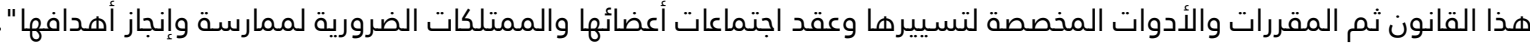

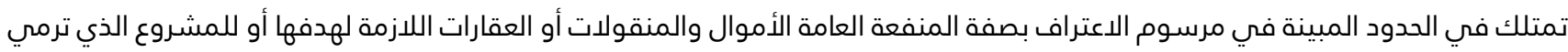
إلى بلوغه، بحسب الفصل 10 من الظهير.

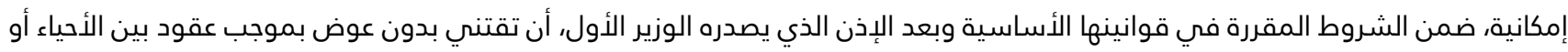

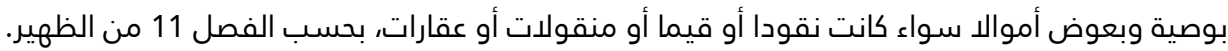
- - - يمكن تحديد أنواع المنافع بشكل عام في الآتي: - المنفعة الشكلية: وهي المنفعة التي تحصل نتيجة التغيير في شكل المادة. - - المنفعة المكانية: هي المنفعة التي تحصل نتيجة التغير في مكان المادة. - المنفعة التملكية: هي المنفعة التي تحصل نتيجة انتقال الملكية من شخص لمصنية لآخر. - المنفعة الزمنية: هي المنفعة التي تحصل نتيجة التفاوت في الزمن.

- المنفعة الخدمية: هي المنفعة التي تحصل نتيجة تقديم الخدمة، كخدمة المهندس، المدرس،....ألخ. - المنفعة الكلية: مجموع الوحدات من المنافع التي حصل عليها المستهلك من جراء اقتنائه مختلف الوحدات من السلع و الخدمات. - المنفعة الحدية: هي فرق المنفعة بين كميتين من سلعة ما عندما تتفاوت هاتين الكميتين بمقدار وحدة واحدة من السلعة المعينة. - المنفعة الحدية المتناقصة: هي تناقص المنفعة الحدية بالنسبة لشخص ما كلما زاد لديه عدد وحدات من سلعة ما. 


\section{الفقرة الثانية: مفهوم سلطة التدبير الجمعية}

اكتفى المشرع بمجرد الإشارة إلى مصطلح السلطة إلى جانب مصطلحي الإدارة والتدبير في الفقرة الثانية من المادة 14 من الملحق بالمرسوم التي نصت على أن مجلس الإدارة يتمتع بسلطة تدبير الجمعية، وفي الفقرة الأولى من المادة ذاتها التي جاء فيها أن مجلس الإدارة يتولى إدارة الجمعية. ولكنه له يحدد مفهوم أي واحد من هذه المصطلحات، مما يطرح معه

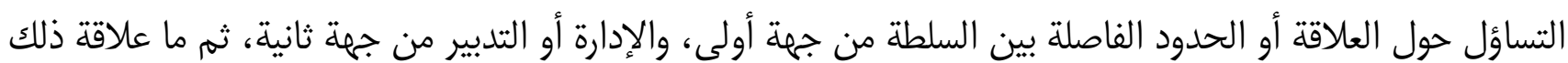
بالتسيير المشار إليه في الفقرة الثامنة من المادة عينها، من جهة ثالثة؟

ولا يكفي لسد هذا الفراغ المفاهيمي، الرجوع إلى القواعد العامة الواردة في قانون الالتزامات والعقود، بحسب ما تقتضي به إحالة الفصل 1 من ظهير 1958 (79). وما يمكن الإشارة إلى أنه غالبا ما تأتي مصطلحات الإدارة والتدبير والتسيير مترادفة، وغالبا ما تسترهدف المعنى نفسه، سواء في علاقتما بالجمعيات أو بباقي المؤسسات القانونية الأخرى (80). وبالرجوع إلى مقتضيات الفقرة الثامنة من المادة 14 من الملحق بالمرسوم، يتبين أن التسيير يوكل إلى مكتب مسير

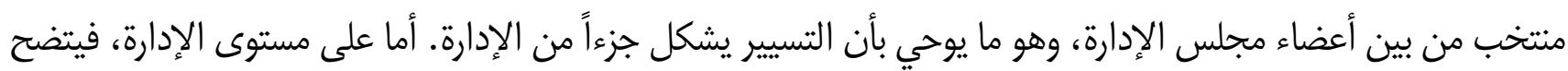

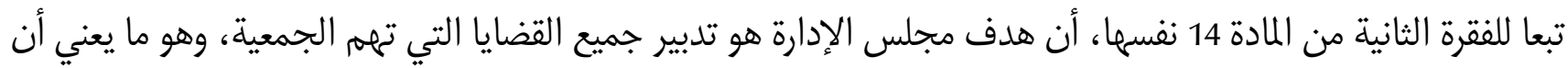
غاية هذا النص هي جعل التدبير صورة مطابقة للإدارة، بصرف النظر عن أي اختلاف يمكن تصوره في مجالات أخرى كالعلوم الاقتصادية مثلا.

وإذا كانت المادة 14 أعلاه توحي بأن منح سلطة التدبير يبقى حكرا على مجلس الإدارة، وهو ما يؤسس لمبدإ فصل السلط بين أجهزة الجمعية (81)، فإن المادة 19 من الملحق توحي بغير ذلك؛ حينما تحدثت بشكل صريح عن تفويض السلط مالط عبر تمكين أعضاء الجمعية من تمثيل بعضمهم. وهنا يطرح التساؤل حول هل يتعلق الأمر بتفويض مُكنة التصويت أم السلطة في حد ذاتها؟

79 - تنص الفقرة الثانية من الفصل 1 من ظ.ش المتعلق بحق تأسيس الجمعيات على أنه: "وتجري عليها (أي الجمعيات) فيما يرجع لصحتها القواعد القانونية العامة المطبقة على العقود والالتزامات"، وهذا ما يحيلنا إلى الحديث مثلا على الفصل 11 بخصوص إدارة أموال الغير، والفصلان 821 و822 في شأن إدارة الحارس للشيء وحفئ وحفظه، وعدم قيامه بأي عمل من أعمال التفويت إلا لما هو ضروري لمصلحة الأشياء المعهود إليه بدراستها، والفصل 971 فيما يتعلق بإدارة المال المشاع، ثم الفصول من 1015 إلى إلى 1026 بخصوص إدارة شؤون الشركة. 80 - يتعلق الأمر مثلا، بما تنص المادتان 69 و102 من القانون رقم 17.95 المتعلق بشركات المساهمة، الصادر بتطبيقه ظ.ش. رقم 124-96-

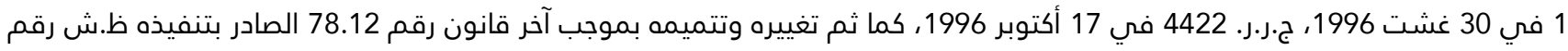

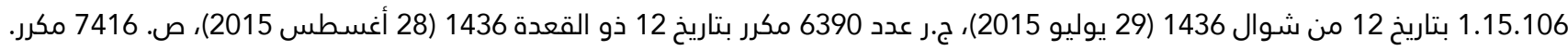
والمواد 6 و25 و35 ثم 62 من القانون رقم 5.95 المتعلق بشركة التضامن وشركة التوصية البسيطة وشركة التوصية بالأسهم والشركة ذات المسؤولية المحدودة وشركة المحاصة الصادر في الجريدة الرسمية عدد 4478 بتاريخ 23 ذي الحجة 1417 ( فاتح ماي 1997)، ص 1058، 1058، كما تم 10 الم

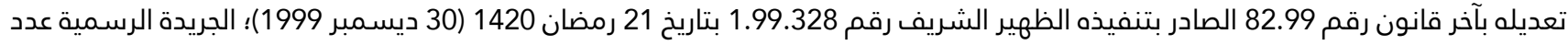

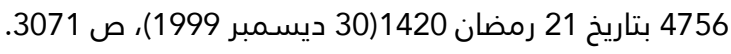
81 - حيث يقوم مجلس الإدارة بصلاحيات تنفيذية، على أساس أن توكل المهام التقريرية للجمع العام. 
وتحيل علاقة الأفراد بالسلطة في شموليتها، على أصحاب الحقوق سواء كانت حقوقا عينية أو شخصية(22)، وهو ما لا

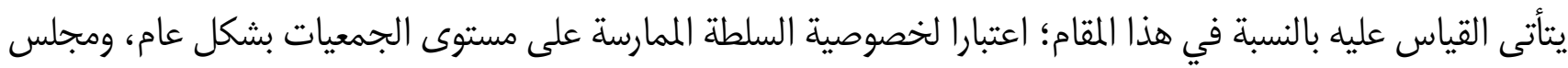

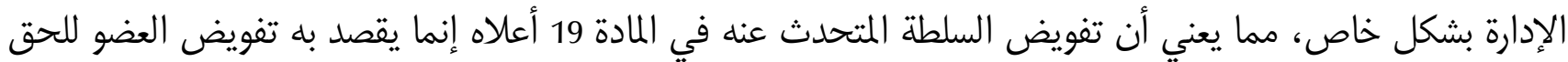

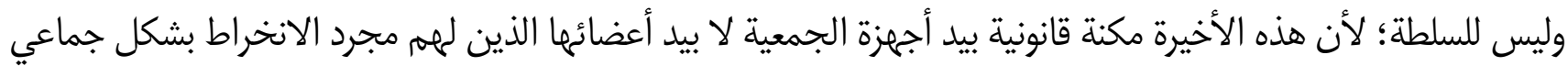

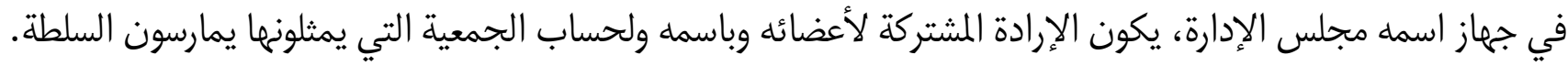
إن المقاربة أعلاه، هي التي تفتح الحديث حول مسألة احتكار سلطة التدبير من لدن مجلس الإدارة، بدليل الفقرة

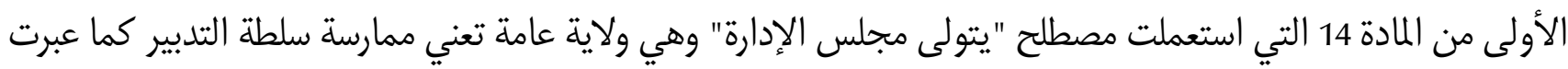

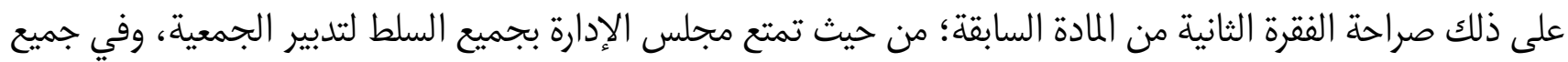

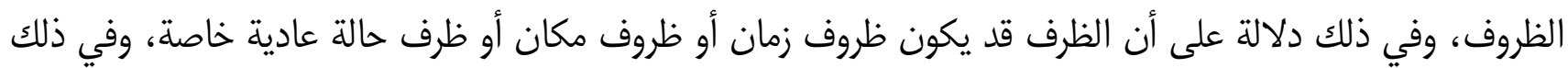

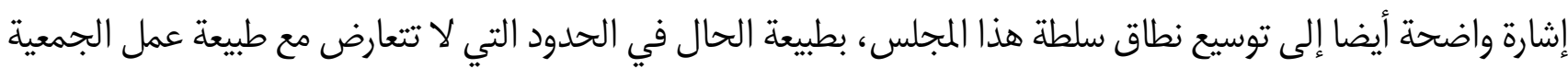

ولما اشترطت الفقرة الرابعة من المادة 14 عقد اجتماعين على الأقل في السنة، فهو حد قانوني أدنى لا يمكن النزول

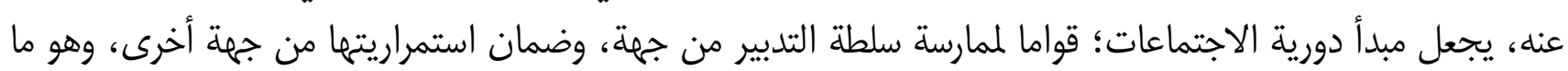

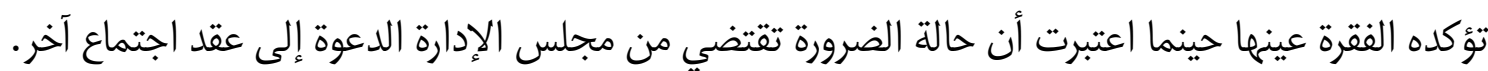
ولما كانت الفقرة الثانية من المادة 14 كذلك، تتحدث عن كون مجلس الإدارة يتداول في جميع القضايا التي تهمه

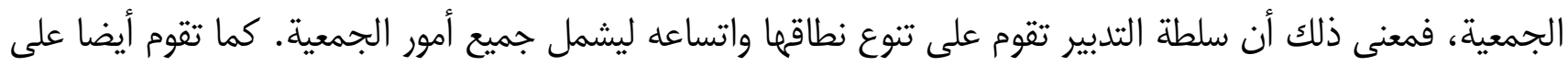

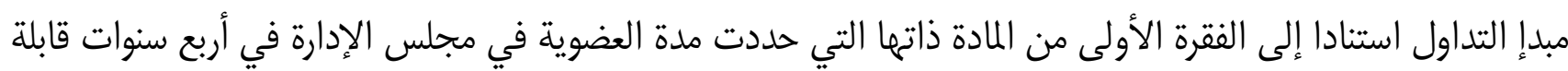

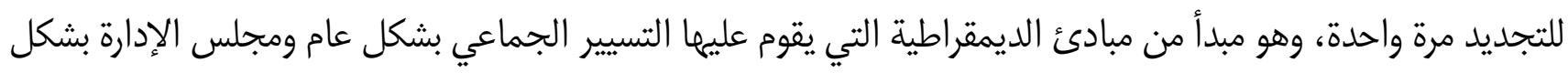

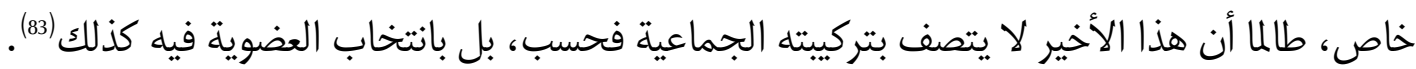

\section{المطلب الثاني: أهداف سلطة التدبير}

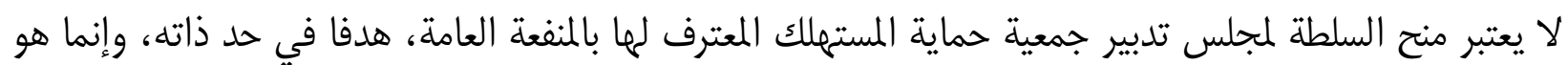

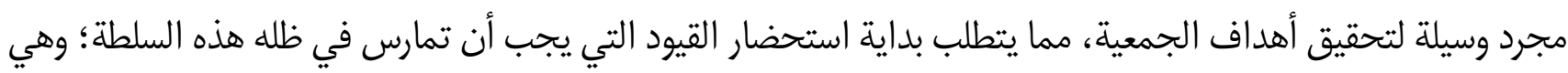
قيود قانونية (84) من جهة ونظامية من جهة أخرى (85).

82 ـ تكون لصاحب الحق العيني سلطة مباشرة يقرها القانون له على شيء معين بالذات ويمكن الاحتجاج به تجاه الكافة. في حين صاحب الحق

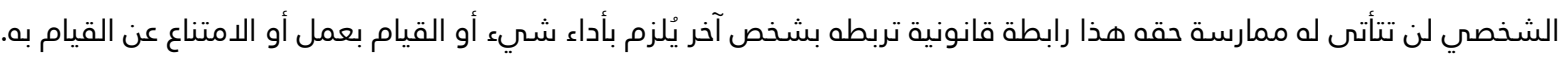
83 - تنص الفقرة الأولى من المادة 14 من الملحق على أنه: "يتولى إدارة الجمعية مجلس مكون من خمسة عشر متصرفا على الأكثر، ينتخبون جميعا من طرف الجمع العام لمدة أربع سنوات قابلة للتجديد مرة واحدة ". 84 - الفصل 3 من ظ.ش لسنة 1958: "كل جمعية تؤسس لغاية أو لهدف غير مشروع يتنافى مع القوانين أو الآداب العامة أو قد يهدف إلى

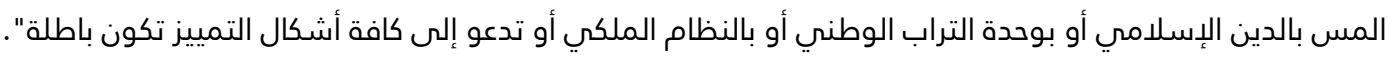
85 ـ أي التقيد بما تضمنه النظام الأساسي للجمعية من بنود، وعلى رأسها غرض الجمعية. 
ويتداول مجلس الإدارة بحسب الفقرة الثانية من المادة 14 من الملحق في القضايا التي تهم جمعية حماية المستهلك، وهو ما يحيل على مقتضيات المادة 6 التي تعتبر أن أهداف هذه الجمعية؛ هي حماية الحقوق الأساسية للمسترلك كما تم التنصيص عليما بمقتضى القانون رقم 31.08 والمتمثلة في:

\section{الفقرة الأولى: الحق في الإعلام والإصغاء}

أولا: الحق في الإعلام(86): يتهم الحق في الإعلام عبر تمكين المسترلك من القيام باختيار معقول يراعي حاجياته وإمكانياته، لذلك يتعين على المورد أن يقدم له جميع المعلومات الضرورية. ولهزه الغاية، يجب على الإنى المورد أن يضع رهن

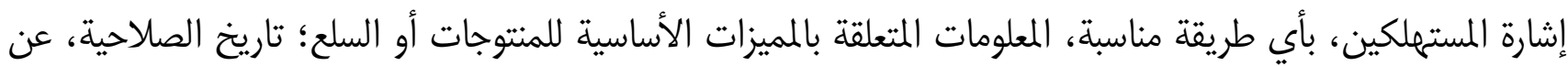
اقتضى الأمر ذلك؛ أسعار النتوج أو السلعة؛ تعريف الخدمات؛ طريقة الاستخدام الاستعمال؛ مدة وشروط الضمان؛ الشروط الخاصة بالبيع أو بتقديم الخدمة ؛ القيود المحتملة للمسؤولية التعاقدية، عند الاقتضاء. ثانيا: الحق في الإصغاء إليه(87): تجعل المقاربة الاقتصادية من المستهلك ملكا، يجب الإصغاء إلى كل متطلباته وتنفيذ الممكن منها عمليا وقانونيا.

\section{الفقرة الثانية: الحق في الاختيار والتراجع}

أولا: الحق في الاختيار (88): يخول القانونُ المسترهلكَ الحق في اختيار المنتوج أو السلعة أو الخدمة الأنسب لإمكانياته وحاجاته. وهكذا، يحق له التوفر على معلومات واضحة ودقيقة عن المنتوج أو الخدمة التي يبحث عنها، وله أن يتخذ قرار

86 - بخصوص الحق في الإعلام: يراجع كذلك، يوسف الزوجال: المنظومة الحمائية للمستهلك في عقود الخدمات عقد التأمين نموذجا، دراسة تحليلية وفق آخر المستجدات القانونية، دار الأمان، الرباط، 2013، ص.184 وما يليها؛ أحلام الكزيري: الاستراتيجية الوطنية لحماية المستهلك والإجراءات المتذذة لتفعيلها، بمناسبة أشغال اليوم الدراسي حول: حماية حقوق المستهلك الاقتصادية والتمثيلية والإنصات إليه، المنظم مكن قبل مختبر البحث، قانون الأعمال، بكلية الحقوق بسطات، في 14 مارس 2013، ص.21-22؛ أبو بكر مهم: حماية حقوق المستهلك الاقتصادية

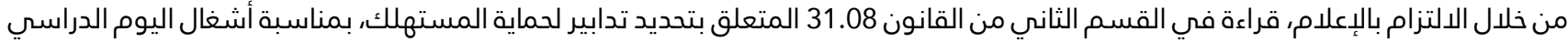
حول: حماية حقوق المستهلك الاقتصادية والتمثيلية والإنصات إليه، المنظم مكن قبل مختبر البحث, قانون الأعمال، بكلية الحقوق بسطات، في 14 مارس 2013، ص.75 وما يليها؛ أبو بكر مهم: الالتزام بالإعلام في عقد الرحلة، ضمانات حماية مستهلك الذدمات السياحية قراءة في القانون 31.08 والممارسة القضائية والعملية، الحق في الإعلام-الحق في الاختيار-الحق في الرجوع، أشغال اليوم الدراسي المنظم من قبل مختبر قانون الأعمال بكلية الحقوق بسطات بشركة مع مندوبية وزارة التجارة والصناعة والتكنولوجيا الحديثة بسطات وبنسلية التماتيمان، الجمعة 16 مارس 2012، ص. 19 وما يليها؛ عبد الرحمان الشرقاوي: حماية السائح في المرحلة السابقة عن التعاقد بين مقتضيات النصوص الخاصة وأحكام القانون رقم 31.08 القاضي بتحديد تدابير لحماية المستهلك، ضمانات حماية مستهلك الخدمات السياحية قراءة في القانون 31.08 والممارسة القضائية والعملية، الحق في الإعلام-الحق في الاختيار-الحق في الرجوع، أشغال اليوم الدراسي المنظم من قبل مختبر قانون الأعمال بكلية الحقوق بسطات بشركة مع مندوبية وزارة التجارة والصناعة والتكنولوجيا الحديثة بسطات وبنسليمان، الجمعة 16 مارس 2012، ص. 52 وما يليها؛ حمزة أنوي: حماية مستهلك الخدمات السياحية في التشريع المغربي، ضمانات حماية مستهلك الخدمات السياحية قراءة في القانون 31.08 والممارسة المارسة القضائية والعملية، الحق في الإعلام-الحق في الاختيار-الحق في الرجوع، أشغال اليوم الدراسي المنظم من قبل مختبر قانون الأعمال بكلية

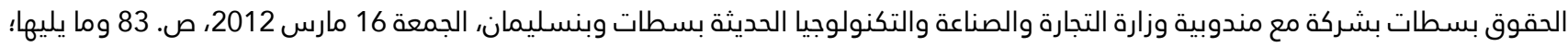
نزهة الخلدي: الالتزام بالإعلام ودوره في تنوير إرادة المستهلك، دراسة وأبحاث في ضوء مستجدات القانون رقم 31.08 القاضي بتحديد تدابير لحماية المستهلك، منشورات مجلة القضاء المدني، 2014، ص. 158 وما يليها. 87 - الحق في الإصغاء إليه: يراجع كذلك، 88 - الحق في الاختيار: يراجع كذلك، 
شراء المنتوج أو السلعة أو الخدمة أو أخذ قرض دون أن يخضع أو يجبر على ذلك. كما له كامل الخيار ليغير رأيه والتراجع عنه داخل أجل معقول. كذلك، يتعين على كل مورد للمنتوجات والخدمات أن يقدم للمستهلك المعلومات أو الوسائل التي من شأنها أن تساعده على القيام باختيار معقول، مراعاة لحاجياته وإمكانياته.

ويتعلق حق الاختيار هذا، سواء بعقود الاشتراك أو العقود المبرمة عن بعد أو عقود القرض الاستهلاكية أو اختيار المؤمن.

ثانيا: الحق في التراجع (89): ويكمن هذا الحق للمسترلك بحسب المادة 36 و المواد من 47 إلى 50 من القانون رقم 08-

$$
31 \text { في ثالاث حالات، وهي: حالة العقد المبرم عن بعد؛ }
$$

حالة البيع خارج المحلات التجارية؛ حالة عقد القرض الاسترهلاكي.

\section{الفقرة الثالثة: الحق في التمثيلية وحماية المصلحة الاقتصادية}

أولا: الحق في حماية مصالحه الاقتصادية (90) يتضمن القانون رقم 08-31 أحكاما تسمح بحماية الحقوق الاقتصادية للمستهلك، سواء تعلق الأمر بمواجهة الشروط التعسفية، أو الممارسات التجارية التي تتم عبر العقود المبرمة عن بعد أو التي تخص البيع خارج المحلات التجارية؛ البيع بالتخفيض؛ البيع أو الخدمة مع مكافأة؛ رفض البيع أو تقديم الخدمة أو تعليقهما؛ لئه البيع أو تقديم الخدمة بشكل هرمي؛ استغلال الضعف أو الجهل؛ المسابقات الاشهارية لأجل الربح.

89 - بذصوص الحق في التراجع: يراجع كذلك، يوسف الزوجال: المنظومة الحمائية للمستهلك في عقود الخدمات عقد التأمين نموذجا، دراسة

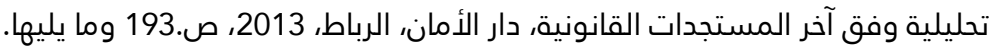
أيمن مساعدة وعلاء خصاونة: خيار المستهلك بالرجوع في البيوع المنزلية وبيوع المسافة، حماية المستهلك، دراسة وأبحاث في ضوء مستجدات القانون رقم 31.08 القاضي بتحديد تدابير لحماية المستهلك، منشورات مجلة القضاء المدني، 2014، ص. 64 وما يليها عبد الكريم عباد: حق المستهلك في الرجوع في قطاع الذدمات السياحية، ضمانات حماية مستهلك الذدمات السياحية قراءة في القانون 31.08 والممارسة القضائية والعملية، الحق في الإعلام-الحق في الاختيار-الحق في الرجوع، أشغال اليوم الدراسي المنظم من قبل مختبر قانوانون

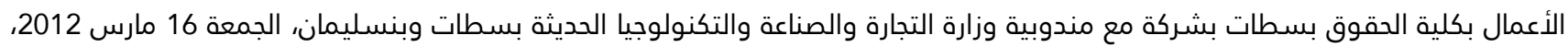
ص. 29 وما يليها. Jamal RABII : Le droit de rétraction dans la loi 31.08 édictant des mesures de protection du consommateur, Rejuciv Editions, 2014, p.5 au 21.

90 والمدنية، بمناسبة أشغال اليوم الدراسي حول: حماية حقوق المستهلك الاقتصادية والتمثيلية والإنصات إليه، المنظم مكن قبل مختبر البحث، قانون الأعمال، بكلية الحقوق بسطات، في 14 مارس 2013، ص.23 وما يليها؛ ضياء نعمان: حماية المستهلك في العقان العقد المبرم بشكل إلكتروني -الوفاء الإلكتروني نموذجا- بمناسبة أشغال اليوم الدراسي حول: حماية حقوق المستهلك الاقتصادية والتمثيلية والإنصات إليه، المنظم مكن قبل مختبر البحث، قانون الأعمال، بكلية الحقوق بسطات، في 14 مارس 2013، ص.59 وما يليها؛ عائشة فضيل: حماية السائح المستهلك في القانون المغربي والقانون المقارن، ضمانات حماية مستهلك الخدمات السياحية قراءة في القانون 31.08 والممارسة القضائية والعملية، الحق في الإعلام-الحق في الاختيار-الحق في الرجوع، أشغال اليوم الدراسي المنظم من قبل مختبر قانون الأعمال بكلية الحقوق بسطات بشركة مع الدان

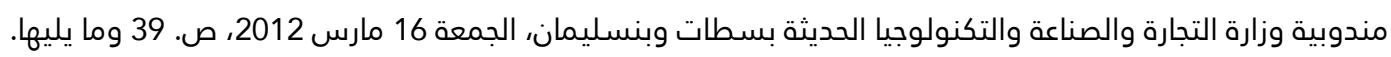
Lamyae SAHRANE : Lecture de la loi 31.08 sur la protection du consommateur au Maroc : Apports et insuffisances, Ed. 2014, p. 5 au 10 ; Chifae EL MOUDDEN : Le contrôle des opérations de concentration économique : Préservation de la concurrence ou entrave à la compétitivité? Ed. 2014, p.11 au 21. 
ثانيا: الحق في التمثيلية (91): يعترف القانون رقم 08-31 للمستهلك في حالة نزاعه مع المورد، من حق تمثيله من بل إحدى جمعيات حماية المستهلك للتقاضي عنه أو للتوصل إلى تسوية ودية لفائدته مع المورد.

وبشكل عام، يمكن تعزيز هذه حقوق المسترلك عبر تدخل القضاء (92) كإجراء علاجي، يمكن تعزيزه بإجراءات استباقية أو وقائية عبر تدخل جمعيات حماية المسترلك، في تربية المسترلكين وتوجيهرهم وتحسيسهمه حول الجوانب الصحية والغذائية والبيئية والتجارية، والحث على تطوير جودة المنتوجات والخدمات، والمساهمة في برامج تنمية الوعي بالمواطنة، لا سيما من خلال تنظيم لقاءات وعروض فنية ووصلات إشمارية وتظاهرات، وربط علاقات تعاون مع الجمعيات التي تعمل في المجال نفسه، سواء على الصعيد الوطني أو الدولي، والمساهمة في التسوية غير القضائية لنزاعات الاستهالك. ليبقى التساؤل مطروحا حول شروط ممارسة سلطة التدبير في جمعيات حماية المستهلك ذات المنفعة العامة.

\section{المبحث الثاني: شروط ممارسة سلطة التدبير في جمعيات حماية المستهلك ذات المنفعة العامة} يُلزم عند تكتل الأشخاص داخل مجموعة ما، كما هو الحال بالنسبة لجمعيات، من أجل القيام بعمل مشترك، أن مأن

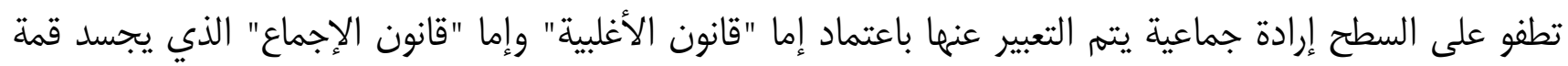
التوافق الجماعي ويتميز ببساطة التعامل به خلافا لسابقه، إلا أنه يحتوي على خطر تعطيل سير المجموعة أو حلمها عندما تكون للأشخاص المكونين لهذه المجموعة آراء متعارضة، فيصبح حينها قانون الاجماع "مبدأ ضعف لا قوة" (93.

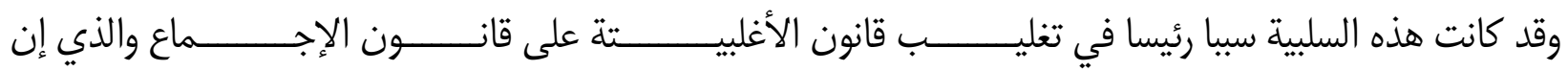

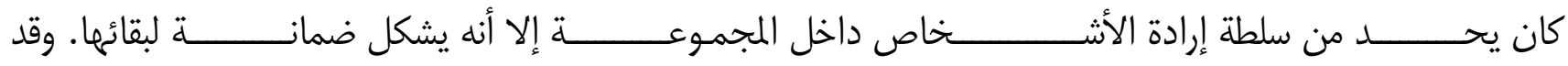

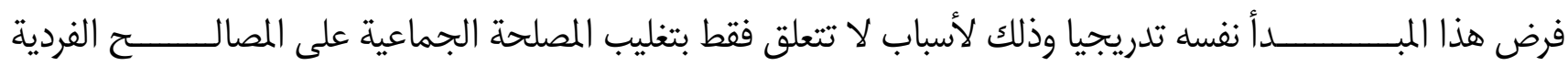

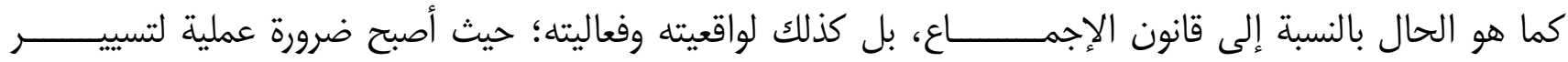
التجمعات الكبرى بما في ذلك الجمعيات، لكن دون الإخلال بالقيود التي تؤطر حقيقة تواجدها، سواء كانت قيودا قانونية(ول)

91

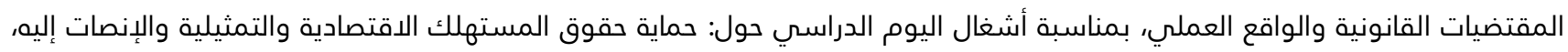
المنظم مكن قبل مختبر البحث، قانون الأعمال، بكلية الحقوق بسطات، في 14 مارس 2013، ص. 91 وما يليها. Chifae EL MOUDDEN : Op.cit, p.p. 129 au140.

92 9 - يراجع في ذلك، عبد الكريم عباد: دور القضاء في حماية المستهلك من الشروط التعسفية، بمناسبة أشغال اليوم الدراسي حول: حماية

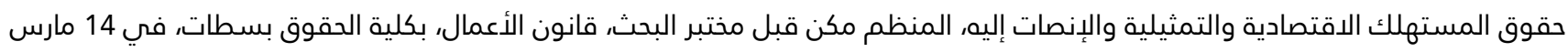

2013، ص.99 وما يليها.

93 - ـ بل إن الرأي الواحد المخالف قد يعطل سير المجموعة في هذه الحالة، من خلال إعماله "حق الفيتو".

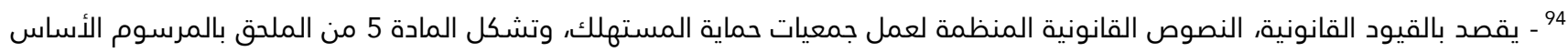
المباشر الذي يمكن اعتماده في هذا الإطار، والتي تمت عنونتها بحدود نشاط الجمعية؛ بحيث نصت الفقرة الثالثة منها على أنه يمكن للجمعية

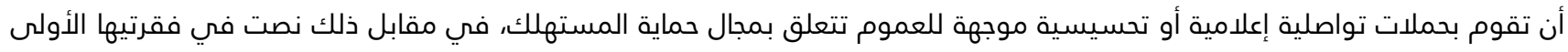
والثانية على أنه يجب على الجمعية أن تحافظ على الحياد التام تنفيذا لأهدافها المنصوص عليها في قانوان أنها الأساسي، وأنه يدظر عليها الخوض في أي نقاش سياسي أو ديني، أو ربط أي شراكات أو تعاون أو هما معا مع موردي السلع أو المنتوجات أو أو الذدمات ألفات كما يمنع عليها القيام بأي حملة تواصلية تجارية لفائدة سلعة أو منتوج أو خدمة. 
أو نظامية (95)، تحت طائلة الجــــــزاء (96).

فماذا عن النصاب (المطلب الأول) ثم قانون الأغلبية (المطلب الثاني) المتطلبين لصحة ممارسة سلطة التدبير في جمعية حماية المسترلك ذات المنفعة العامة.

\section{المطلب الأولى: النصاب شرط لممارسة سلطة التدبير}

يُعَد من القواعد العامة خضوع التجمعات لآليات التدبير الديموقراطي، خصوصا بالنسبة للتجمعات التي تكتسب الشخصية الاعتبارية، وما تستلزمه من فصل للسلط وتوزيعها بين مكونات هذه الشخصية، والتي تتخذ شكل سلطة تقريرية أو سلطة تنفيذية أو سلطة رقابية، وهو ما يتطلب استحضاره بمناسبة مناقشة موضوع الجمعيات بمان فئنما فيها جمعيات حماية المسترلك المعترف لها بصفة المنفعة العام.

وبخصوص السلطة التنفيذية لهذه الجمعيات أو ما يُعبر عنه تشريعيا بسلطة التدبير(97)، باعتبارها مجال هذا البحث، فإن صحة إعمال هذه السلطة يقتضي استحضار مجموعة من الشروط، تُحَدَدُ بداية في تحقق النصاب وما يشترطه من تحقق لحضور أعضاء مجلس الإدارة (الفقرة الثانية) عبر توجيه الدعوة إليعم (الفقرة الأولى).

\section{الفقرة الأولى: تعلق النصاب بتوجيه الدعوة}

تعتبر الدعوة إلى الاجتماع شرطا ضروريا لصحة مداولات مجلس إدارة الجمعية بحسب الفقرة 4 من المادة 14 من الملحق بالمرسوم، وتتطلب صحة انعقاد الدعوة بدورها تتحقق مجموعة من الشروط، التي يتم التساؤل حول مدى شموليتها وكفايتها انطالاقا مما نصت عليه المادة 14 من الملحق أعلاه، سواء في شقها المتعلق بتحقق الدعوة نفسها أو بموضوعها منا منها

95 - يقصد بالقيود النظامية، ما ضمن من بنود في النظام الأساسي للجمعية سواء عند تأسيسها أو بمناسبة تعديل نظامها، ويتم وضعه الأساسي أول مرة عند تأسيسها (المادة 1 من الملحق بالمرسوم)، ويمكن تعديله في حياة الشركة من لدن الجمع العام الاستثنائي(المادة 13

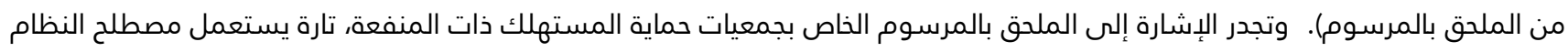
الأساسي كما هو الحال في المادة 7 بموجب حديثها عن العضوية في جمعيات حماية المستهلك في بندها الأول من الفقرة الأولى، والمادة

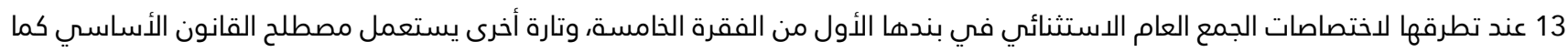

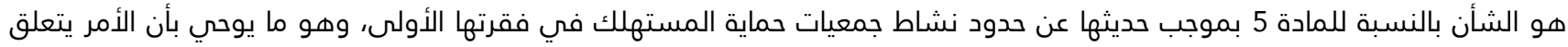

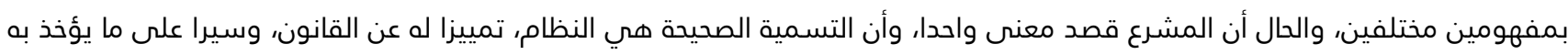
على مستوى مؤسسات قانونية أخرى من قبيل الشركات التجارية كما تشير إلى ذلك المادة 2 من قانون شركات المساهمة والمواد 5 و23 و32 و50 من قانون باقي الشركات التجارية). 96 ـ بنص الفصل 38 من ظهير 1958 على أنه: "كل جمعية تقوم بنشاط غير النشاط المقرر في قوانينها الأساسية يمكن حلها طبق الإجراءات المنصوص عليها في الفصل السابع، ويعاقب مسيرو الجمعية بغرامة تتراوح ما بين 1200 و5000 درهم، وذلك بصرف النظر عن العقوبات المحددة في التشريع الجنائي". وينص الفصل 7 من الظهير نفسه على أنه: "تختص المحكمة الابتدائية في طلب التصريح ببطلان الجمعية المنصوص عليه في الفصل الثالث

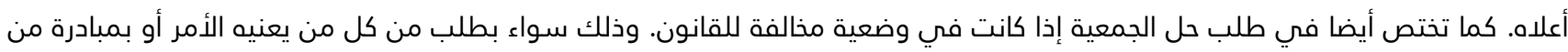

النيابة العامة. وللمحكمة بالرغم من كل وسائل الطعن أن تأمر ضمن الإجراءات التحفظية بإغلاق الأماكن ومنع كل اجتماع لأعضاء الجمعية".

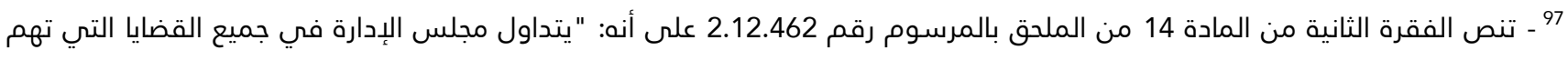
الجمعية، ويتمتع بجميع السلط لتدبيرها في جميع الظروف". 


\section{أولا: النطاق الشخصي للدعوة}

يُقصد بالنطاق الشخصي لدعوة مجلس الإدارة للانعقاد؛ الأشخاص أو الجمات الذين لهم صلاحية توجيه الدعوة أو

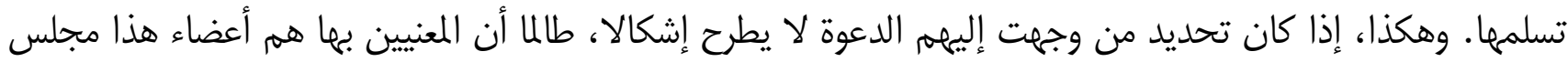
الإدارة من حيث المبداء وهمم المتصرفون بصفترهم أعضاء في مجلس الإدارة بحسب المادة 14 من الملحق بالمرسوم (98)، فإنه على خلاف ذلك بالنسبة لمن يوجه الدعوة؛ حيث اكتفت المادة 14 أعلاه بالتنصيص فقط على رئيس مجلس الإدارة، وهاره وهو تقييد يمس السير العادي لمجلس الإدارة، خصوصا أنه توجد واقعيا من الأسباب ما يحول دون قيام هذا الرئيس بمهمته هذه، مما يشكل فراغا تشريعيا، يطرح معه التساؤل عن مدى إمكانية تفويض صلاحيات الرئيس لسواه، سواء من بين

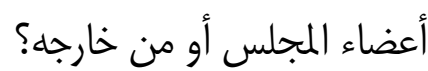
يمكن لرئيس مجلس الإدارة تفويض صلاحياته لنائبه (99) استنادا إلى المادة 16 من الملحق بالمرسوم (100) أو إلى أي عضو من أعضاء المجلس تبعا للمادة 19 من الملحق المرسوم ذاته (101)، وهي مكنة قانونية فعالة متى حالت أسباب خارجية دون تمكن رئيس المجلس من توجيه العوة إلى الأعضاء. لكن الأمر مختلف عندما يمتنع الرئيس أصلاء عن توجيه الدعوة، ليمثل بذلك أحد مظاهر سوء النية، التي لا يمكن معه إعمال مكنة التفويض هذه، طالما أنها بيد الرئيس، مما يشكل سببا وجيها لتعطيل سير أعمال مجلس الإدارة.

وأمام هذا القصور القانوني في ضمان استمرارية سير مجلس الإدارة، فإنه يتطلب اعتماد التوجه ذاته الذي أخذ به المشرع؛ حينما أحدث مؤسسة الكاتب العام المساعد إلى جانب الكاتب العام تبعا للمادة 17(102)، ومؤسسة أمين المال المساعد فئماند إلى جانب أمين المال بحسب المادة 18(103)؛ وأوكل إليهما حق الإنابة عمن يساعدانه حالة وجود عائق أو غياب. ويوجد ثمة فراغ قانوني آخر بخصوص الأشخاص الذين يحق لهم طلب توجيه دعوة انعقاد المجلس، شأنه في ذلك شأن انعقاد الجمع العام العادي(104)

98 - تنص المادة 14 من الملحق بالمرسوم رقم 2.12 .462 على أنه " يتولى إدارة الجمعية مجلس مكون من خمسة عشر متصرفا على الأكثر،

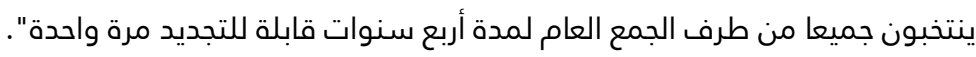
99 - تنص المادة 15 من الملحق بالمرسوم التي جاء فيها أنه: "يتألف المكتب إضافة إلى رئيسه، من نائب الرئيس والكاتب العام والكاتب العام

المساعد، وأمين المال وأمين المال المساعد، ينتخبون جميعا أثناء انعقاد الجمع العام العادي لمدة أربع سنوات قابلة للتجديد مرة واحدة" بأ. 100 - تنص المادة 16 من الملحق بالمرسوم على أنه: "يرأس الرئيس اجتماعات المكتب، ويسهر على سير الجمعية، وعلى تنفيذ القرارات المتخذة من طرف مختلف أجهزة الجمعية، ويقوم كذلك بتنسيق عملياتها وأنشطتها، كما يوقع المراسلات، ويوقع مع أمين المال الشيكات وأية وثيقة محاسباتية. يمثل الرئيس الجمعية إزاء الغير، ويمكن له أن يفوض جزء من صلاحياته إلى نائب الرئيس أو إلى عضو آخر يعينه لهذا الغرض من بين

أعضاء المكتب". 101 ـ تنص المادة 19 من الملحق بالمرسوم على أنه: "لا يمكن لأي عضو في الجمعية أن يمثل سوى عضو واحد آخر في اجتماعات أجهزة هذه الجمعية، وتمنح هذه التمثيلية من خلال وكالة موقعة من طرف الموكل".

102 - تنص الفقرة 5 من المادة 17 من الملحق بالمرسوم على فئم أنه: "ينوب الكاتب العام المساعد عن الكاتب العام إذا عاق هذا الأخير عائق". 103 ـ تنص الفقرة 3 من المادة 18 من الملحق بالمرسوم على أنه: "... ينوب أمين المال المساعد عن أمين المال عند غياب هذا الأخير" . 104 ـ تنص المادة 12 من الملحق بالمرسوم على أنه: "ينعقد الجمع العام العادي بدعوة من رئيس الجمعية مرة كل سنتين على الأقل، وكلما دعت الضرورة إلى ذلك. كما يمكن أن ينعقد بطلب من الأغلبية المطلقة لأعضاء المكتب أو مجلس الإدارة". 
وخلافا لما هو عليه الحال بالنسبة للجمع العام الاستثنائي (105)، وهو ما يكرس سلطة رئيس مجلس الإدارة، متى بقي

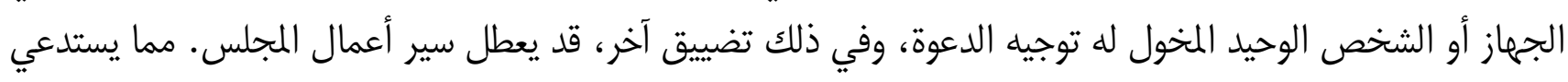

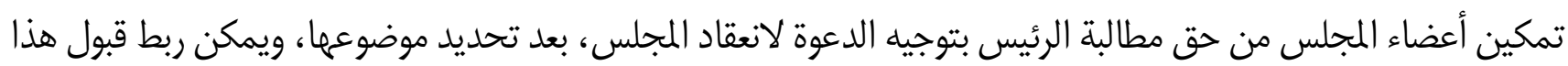
الطلب بصدوره عن ثلث أعضاء هذا المجلس.

\section{ثانيا: النطاق الموضوعي اللدعوة إن إنقاد}

لا يمكن تصور انعقاد اجتماع ما بدون توجيه دعوة بخصوصه، وهو ما أكدته المادة 14 أعلاه، كما أنه لا يمكن تصور

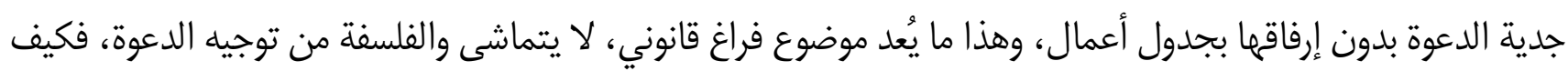

لا يُعتبر إرفاق الدعوة بجدول الأعمال مجرد شكلية ينبغي تحققها، بل يُشكل إعلاما أوليا بموضوع الاجتماع، ومنطلقا

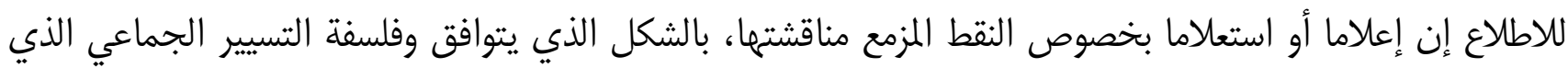

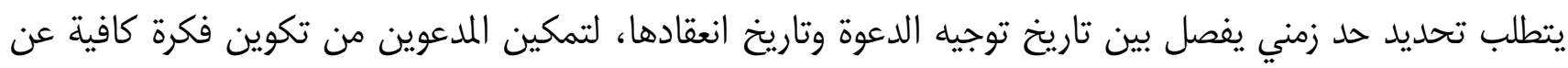

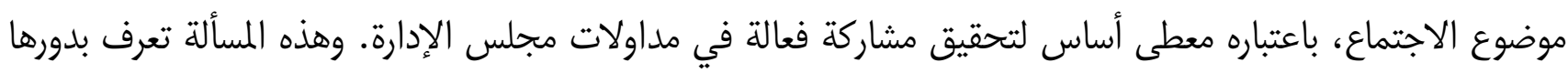

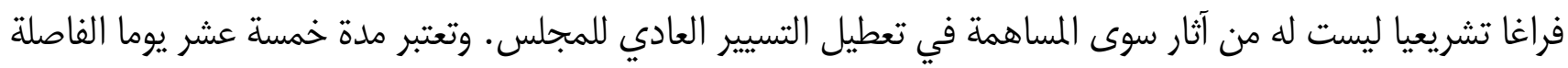

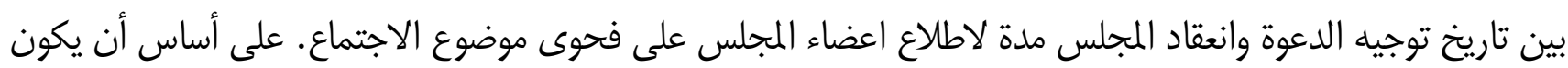
أجل أسبوع هو المدة الفاصلة تاريخ توجيه الدعوة الثانية وانعقادها.

وفي مقابل ذلك، لا يعد فراغا تشريعيا مؤثرا، عدم التنصيص على وسائل توجيه الدعوة؛ إذ يمكن إعمال جميع الوسائل

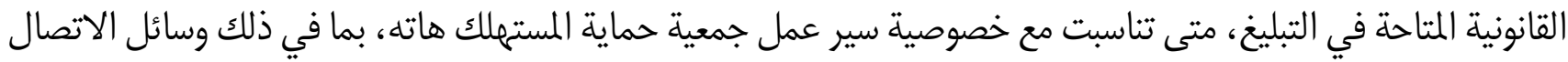

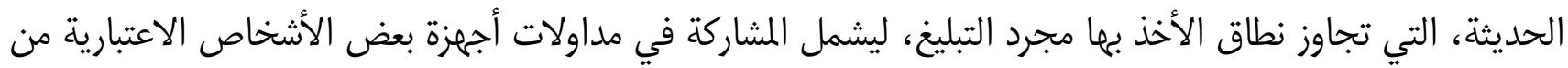
قبيل الشركات التجارية(106).

105 الإدارة أو بطلب من ثلث أعضاء الجمعية". 106 - تنص الفقرة الثالثة من المادة 50 من ق.ش.م على على أنه: "يمكن أن ينص النظام الأساسي على أنه يعتبر في حكم الحاضرين لأجل احتساب النصاب والأغلبية المتصرفين الذين يشاركون في اجتماع مجلس الإدارة بوسائل الاتصال عبر الصوت والصورة أو وسائل مماثلة تمكن من

التعريف بهم .ولا تطبق هذه القاعدة عند اتخاذ القرارات المنصوص عليها في المواد 63 و 67 المكررة و 67 المكررة مرتين و72 ".

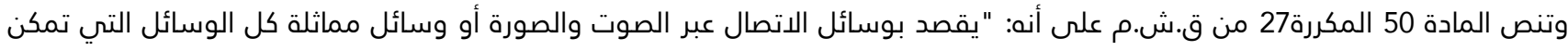
المتصرفين أو أعضاء مجلس الرقابة أو المساهمين في الشركة من المشاركة عن بعد في اجتماعات أجهزة تسيير الشركة أو أجهزتها الاجتماعية.

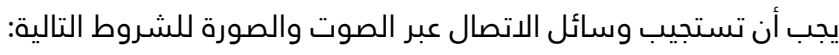
ـالتوفر على المميزات التقنية التي تضمن المشاركة الفعلية في اجتماعات أجهزة التسيير أو الأجهزة الاجتماعية التي يتم بث مداولاتها بطريقة غير متقطعة؛ -التمكين من التعريف مسبقا بالأشخاص المشاركين في الاجتماع بواسطة هذه الوسيلة؛ -التمكين من وضع تسجيل موثوق للمناقشات والمداولات، من أجل وسائل الإثبات. يجب أن تبين محاضر اجتماعات هذه الأجهزة كل طارئ تقني متعلق بوسائل الاتصال عبر الصوت والصورة عندما يحدث اضطرابا في سير الاجتماع". 


\section{الفقرة الثانية: تعلق النصاب بتحقق الحضور}

لا يمكن أن الحديث عن النصاب إلا عبر استحضار حضور من وُجهت إليهم الدعوة، سواء أكان الحضور حضورا

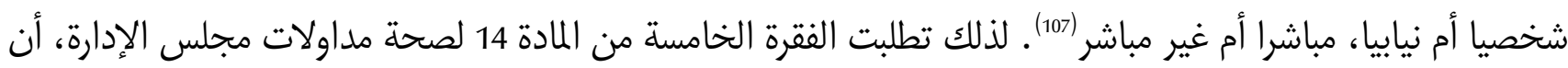

يحضر ما يزيد عن نصف أعضائه، وهو حضور جماعي سنده في ذلك؛ التركيبة الجماعية لمزذا المجلس، فكيف ذلك؟ مباك ويتكون مجلس الإدارة من تركيبة جماعية منتخبة تتمثل في خمسة عشر عضوا على الأكثر (108)، وهو ما يشكل أحد مقومات الديمقراطية المتطلبة في العمل الجماعي، وأن هذا الحد يشكل حدا قانونيا أقصى يمكن النزول عنه بموجب النظام الأساسي للجمعية، لكن ما هي حدود هذا النزول؟

إن الأصل في تركيبة الجمعية بشكل عام، وتركيبة مجلس الإدارة بشكل خاص أن تكون تركيبة جماعية، يستلزمها تسييرا جماعيا، تؤسس له مختلف القوانين ذات الصلة بأهداف الجمعية، وبنظامها الأساسي الذي من مستلزماته؛ تحديد غرض الشركة باعتباره ضابطا أساسيا يتماهى مع آليات تسيير الجمعية، سواء على مستوى أجهزتها التقريرية أو التنفيذية.

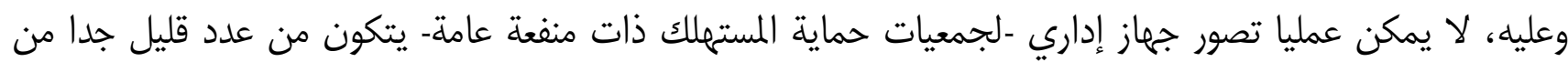

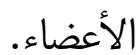

وحددت المادة 14 أعلاه مدة العضوية -في مجلس الإدارة- في أربع سنوات؛ وهي مدة معقولة يمكن تجديدها من تيسير

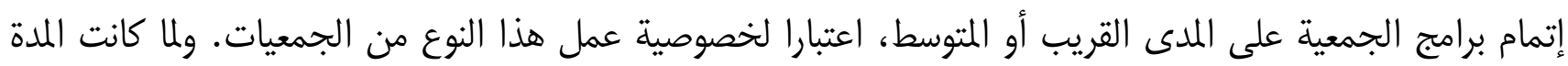
القصوى لهذه العضوية هي ثماني سنوات في جميع الأحوال، ففي ذلك دلالة واضحة على أن المشرع يعمل على تكريس من قواعد الديمقراطية في العمل الجمعوي، عبر الأخذ بمبدإ التداول بين أعضاء الجمعية في ممارسة سلطة التدبير.

107 - يقصد بالحضور المباشر؛ حضور الشخص إلى عين المكان المخصص لانعقاد مجلس الإدارة. ويقصد بالحضور غير المباشر؛ الحضور عن بعد

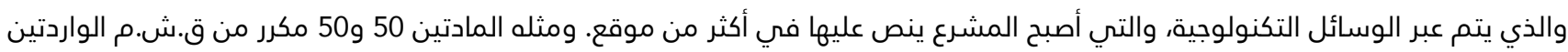
أسفله، ومن مزاياها أنها تسهم في مواجهة ظاهرة الغياب التي تعترض عمل أي عمل مشترك؛ لاعتبارات مادية أو نفسية. والقاعدة أنه -في حالة غياب أي نص قانوني مخالف- يمكن أن ينص النظام الأساسي اعتبارهم في حكم الحاضرين لأجل احتساب النصاب والأغلبية الأعضاء الذين يشاركون في اجتماع مجلس الإدارة بوسائل الاتصال عبر الصوت والصورة أو وسائل مماثلة تمكن من التعريف بهم.

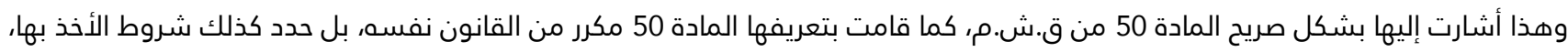
حيث نصت على أنه: " يقصد بوسائل الاتصال عبر الصوت والصورة أو وسائل مماثلة كل الوسائل التي تمكن المتصرفين أو أعضاء مجلس الرقابة أو المساهمين في الشركة من المشاركة عن بعد في اجتماعات أجهزة تسيير الشركة أو أجهزتها الاجتماعية. يجب أن تستجيب وسائل الاتصال عبر الصوت والصورة للشروط التمبن التالية: -التوفر على المميزات التقنية التي تضمن المشاركة الفعلية في اجتماعات أجهزة التسيير أو الأجهزة الاجتماعية التي يتم بث مداولاتير التها بطريقة غير متقطعة!

-التمكين من التعريف مسبقا بالأشخاص المشاركين في الاجتماع بواسطة هذه الوسيلة؛ - التمكين من وضع تسجيل موثوق للمناقشات والمداولات، من أجل وسائل الإثبات. يجب أن تبين محاضر اجتماعات هذه الأجهزة كل طارئ طارئ تقدئ متعلق بوسائل الاتصال عبر الصوت والصورة عندما يحدث اضطرابا في سير الاجتماع". 108 ـ تنص الفقرة الأولى من المادة المادة 14 من الملحق بالمرسوم رقم 2.12.462 على أنه " يتولى إدارة الجمعية مجلس مكون من خمسة عشر متصرفا على الأكثر، ينتخبون جميعا من طرف الجمع العام لمدة أربع سنوات قابلة للتجديد مرة واحدة". 
ومن الأوضاع التي تثير الانتباه كذلك؛ الحالة التي لا يتحقق فيها النصاب القانوني، إذ إن المشرع -خلافا لما هو عليه

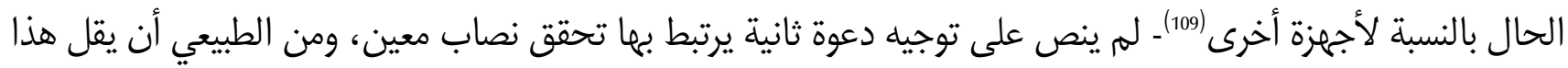

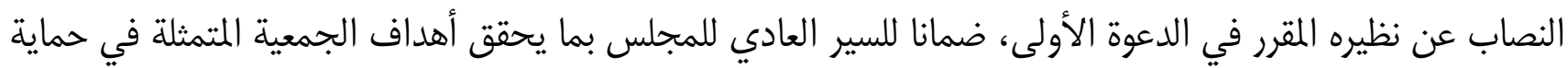

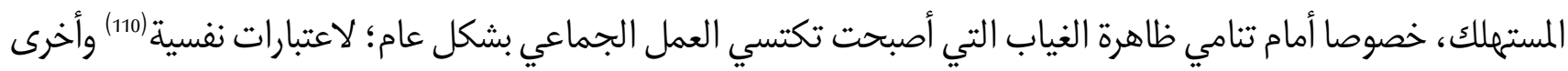
مادية (111).

ويمكن اعتبار التمثيلية بشكل عام (112) أو المنصوص عليها في المادة 19 من الملحق بالمرسوم، مكنة قانونية لمواجهة ظاهرة

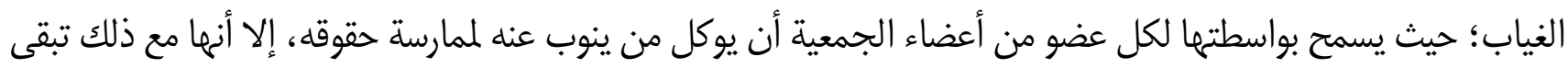

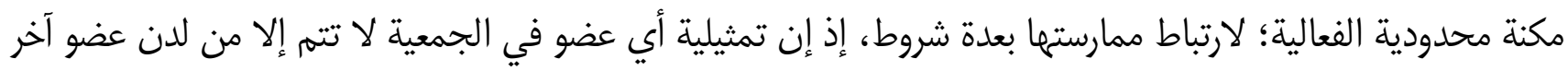

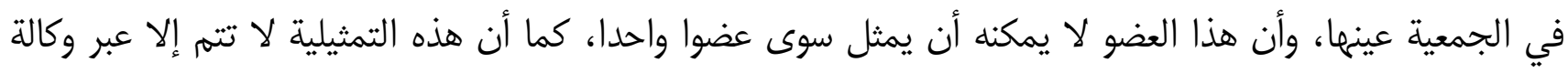
موقعة وتفاديا لهذا التضييق أو لهذه الإكراهات القانونية، يُطرح التساؤل حول مدى إمكانية إدراج بند في النظام الأساسي

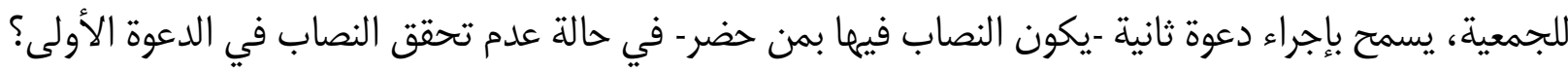

109 نصف الأعضاء المؤسسين والأعضاء العاملين حاضرين أو ممثلين وعند الاقتضاء توجه دعوة ثانية بنفس شروط الدعوة الأولى. وينعقد الجمع الداء

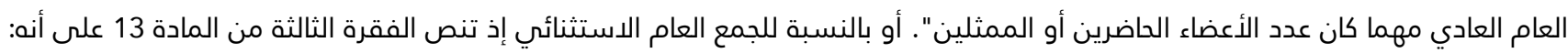
"لا تعتبر الاجتماعات صحيحة إلا بحضور ثلثي الأعضاء أو الممثلين وعند الاقتضاء، توجه دعوة ثانية بنفس شروط الدعاء الدوة الأولى، وينعقد الجمع العال العام الاستثنائي مهما كان عدد الأعضاء الحاضرين أو الممثلين".

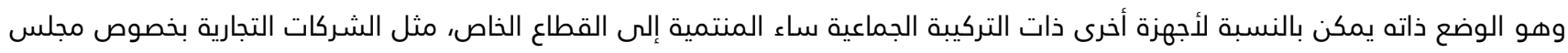
الإدارة؛ حيث تنص الفقرة الأولى من المادة 50 على أنه: "لا يتداول مجلس الإدارة بصورة صحيحة إلا بحضور نصف ألعال أعضائه على الأقل حضورا

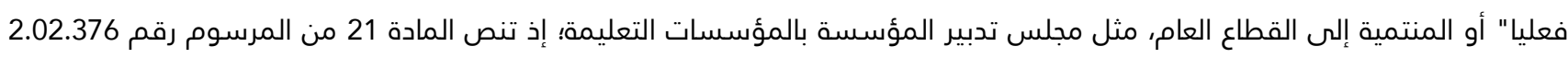

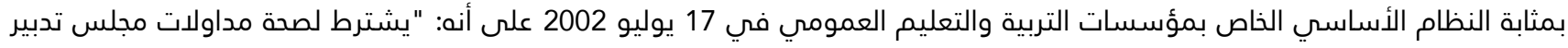

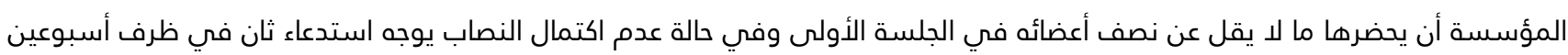

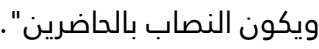
110 الاعتبار المعنوي، مقابل التضحيات التي يبدلها لفائدة العمل هذا العمل الجمعوي، أو إساسا منه بأن حضوره من عدمه غير مؤثر في القرارا الجماعي. 111 ـ ـ وقد ترتبط ظاهرة بأسباب مادية تتمثل في: البعد الجغرافي؛ تكلفة التنقل؛ ضيق الوقت أو في التقارب الزمني في لاجتماع المجلس. 112

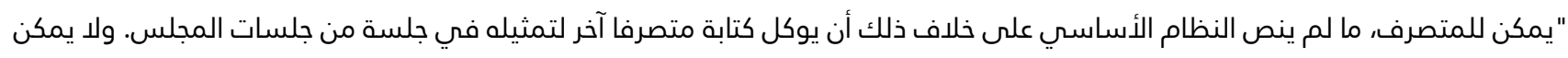

أن يكون لكل متصرف سوى توكيل واحد خلال نفس الجلسة". 113 العضوية في الوكيل: أي ألا يكون من خارج أعضاء مجلس الإدارة. 113 الجمعية، وتمنح هذه التمثيلية من خلال وكالة موقعة من طرف الموكل". 
تقتضي الإجابة عن هذا السؤال، البحث في مدى اعتبار قواعد النصاب من النظام العام أم لا؟ وبالرجوع إلى المادة 14

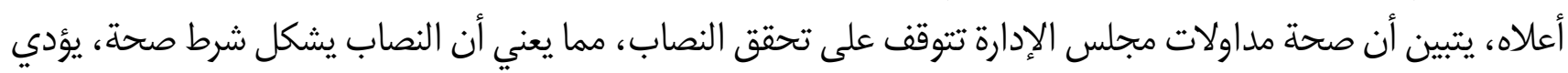

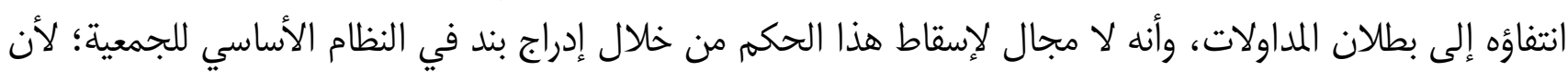

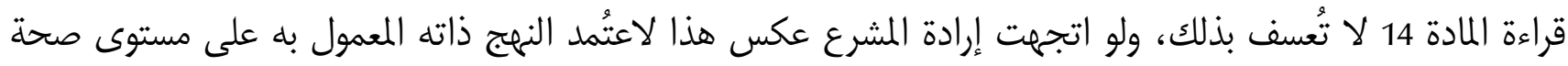
مداولات الجمع العام الاستثنائي للجمعية (114). ويمكن تصور انعقاد اجتماعات جمعية حماية المستهلك ذات المنفعة العامة بشكل عام ومجلس إدارة إدارتها بشكل

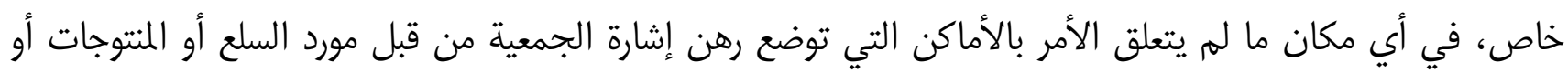

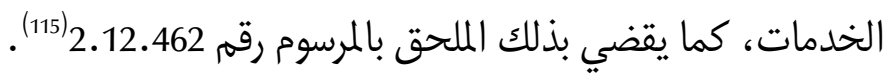
ويأتي هذا الاستثناء حفاظا على الاستقلالية والحياد المتطلب تحققهما في الجمعية في علاقتها بالمهنيين والذين يمكن أن يكونوا طرفا في النزاعات الحاصلة التي لها علاقة بحماية المستهلكين. ولما كانت التركيبة الجماعية لمجلس الإدارة ضابطا للأخذ بمبدإ التسيير الجماعي، فإن هذا الأخير يقتضي إعمال قانون

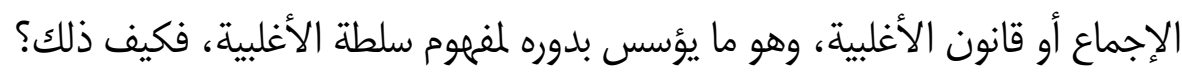

\section{المطلب الثاني: الأغلبية شرط لممارسة سلطة التدبير}

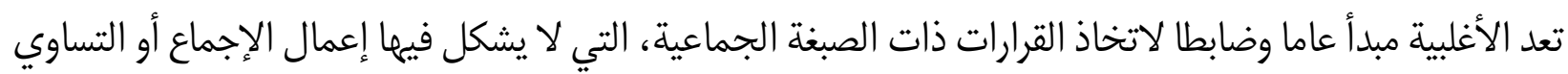

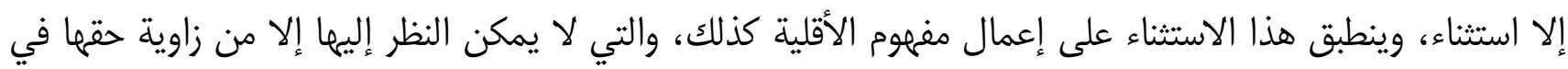
معارضة الأغلبية أو مواجهة تعسفها.

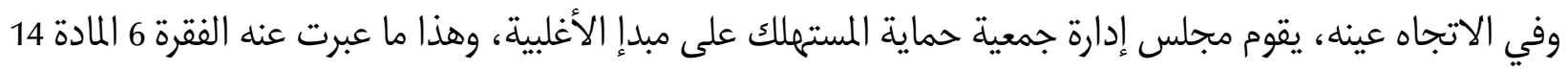

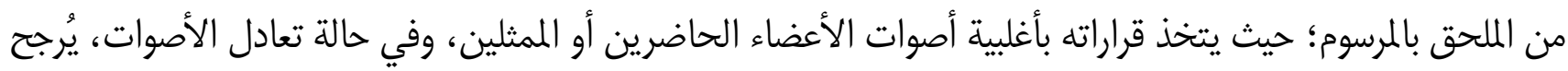

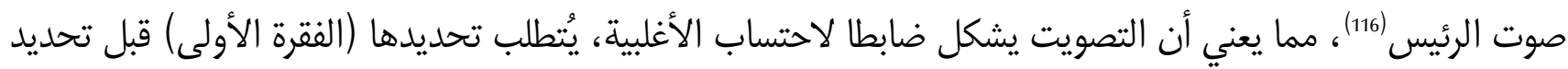

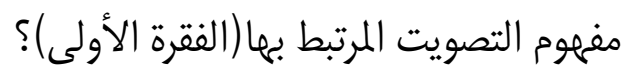

\section{الفقرة الأولى: الأغلبية شرط لممارسة السلطة}

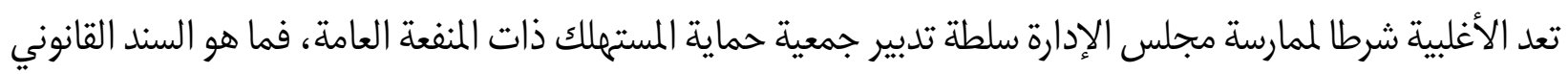

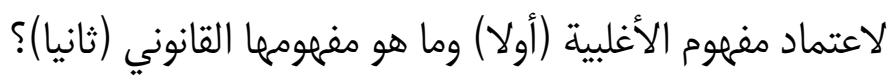

114 بنفس شروط الدعوة الأولى، وينعقد الجمع العام الاستثنائي مهما كان عدد الأعضاء الحاضرين أو الممثلين".

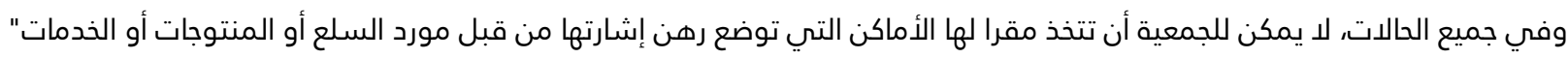

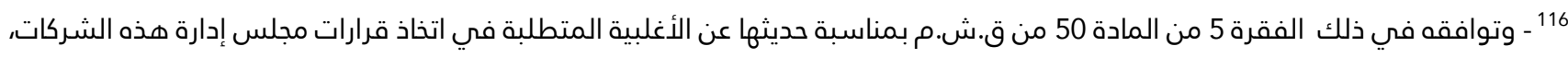

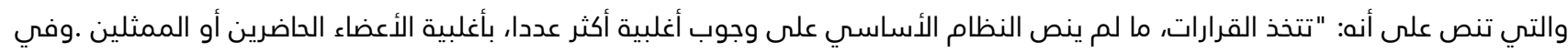
حالة تساوي الأصوات يرجح صوت الرئيس ما لم ينص النظام الأساسي على خلاف ذلك". 


\section{أولا: سند اعتماد الأغلبية}

تعتبر الجمعية اتفاقا يقوم على التعاون المستمر بين أعضائمها استنادا إلى الفصل 1 من ظهير تأسيس الجمعيات العامة (117)، لذلك لا يمكن تصور وجودها إلا عبر موافقة جميع مؤسسيها، لكن هل يُتطلب بقاء هذا الإجماع طيلة حياة الجمعية، خصوصا وأن هذا الفصل يحيل في فقرته الثانية على تطبيق قواعد الالتزامات والعقود، بما فيها الفصل 230 الذي ينص على أن الالتزامات التعاقدية المنشأة على وجه صحيح تقوم مقام القانون بالنسبة إلى منشئيها ولا يجوز فئل إلى إلغاؤها إلا بتراضي الأطراف أو في الحالات التي ينص عليها القانون، مما يُفهمم منه أن القواعد التي تحكم سير الجمعية، مند تأسيسما إلى غاية انتهائمها، ينبغي أن تخضع لقانون الإجماع؛ الذي ينبغي أن يتهم تمديد العمل به على مستوى سير أجهزة الجمعية

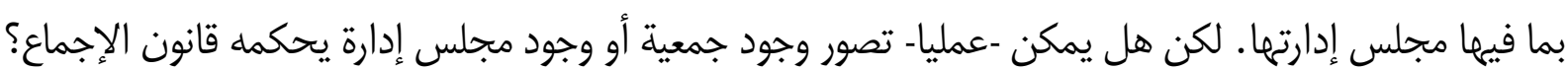
تنص الفقرة 6 المادة 14 السالفة على أنه: "يتخذ مجلس الإدارة قراراته بأغلبية أصوات الأعضاء الحاضرين أو الممثلين، وفي حالة تعادل الأصوات، يكون صوت الرئيس مرجحا". مما يتبين معه أن المشرع استبعد إعمال أحكام الاتفاق كما هي

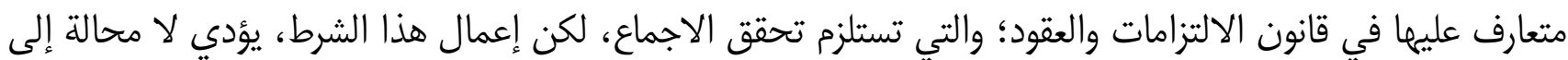
تعطيل عمل الجمعية؛ لأنه يتطلب أن تبني الرأي الواحد من قبل جميع أعضاء المجموعة، وهذا ما يصعب أو يستحيل تحققه عمليا خصوصا على مستوى التجمعات الكبرى.

\section{ثانيا: مفهوم الأغلبية}

أُشير سلفا إلى أن قرارات مجلس مفوم إدارة جمعية حماية المستهلك، تُتخذ بأغلبية أصوات الأعضاء الحاضرين أو الممثلين، ويُرجح صوت الرئيس في حالة تعادل الأصوات، بحسب المادة 14 التي نصت كذلك في فقرتها الأولى على أنه: "يتولى إدارة الجمعية مجلس إدارة مكون من خمسة عشر متصرفا على الأكثر، ينتخبون جميعا من طرف الجمع العام لمدة أربع سنوات قابلة للتجديد مرة واحدة". فماذا يقصد بهذه الأغلبية؟ وكيف أنها تجعل من حالة التساوي حالة أغلبية؟ وهل يمكن اعتبار

$$
\text { هذه الأغلبية أغلبية حسابية أو أغلبية تقريرية؛ فرهاه }
$$

يُستفاد من المادة 14 أعلاه، أنها جعلت من الأغلبية الحسابية أغلبية تقريرية، حينما استعمل عبارة "يتخذ مجلس الإدارة قراراته بأغلبية أصوات ..." ، وهو ما يعني أن اتخاذ القرار يتوقف على تحقق أكثر من نصف الأصوات، وهي الأغلبية التي

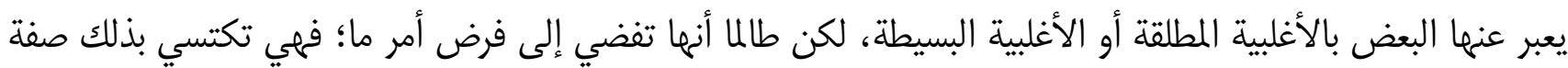
الأغلبية التقريرية. وتعد أغلبية حسابية؛ الأغلبية العددية التي تضم أكثر الأصوات. ويقصد بالأغلبية التقريرية؛ الأغلبية المتطلبة قانونا لتبني مشاريع القرارات، إذ ليست بالضرورة كل أغلبية حسابية أغلبية تقريرية (118).

117 أم ينص الفصل 1 من ظهير 1958 على أن: " الجمعية هي اتفاق لتحقيق تعاون مستمر بين شخصين أو عدة أشخاص لاستخدام معلوماتهم أو نشاطهم لغاية غير توزيع الأرباح فيما بينهم. وتجري عليها فيما يرجع لصحتها القواعد القانونية العامة المطبقة على العقود والالتزامات". 118 - ومثله إذا كان عدد أعضاء المجلس 15 عضوا، وكان عدد الحفاض الحاضرين منهم هو العدد نفسه، فإن الأغلبية الحسابية هي ما تجاوز النصف، وهو ثمانية في هذه الحالة. لكن يحدث في مواقع أخرى أن يشترط المشرع نسبة الثلثين عوض النصف زائد واحد، وهو ما يجعل الأغلبية المتطلبة هي 10 بدل 8. أي أن النسبة المتطلبة في الحالة الأولى صحيح أنها تشكل الأغلبية لأن 8 أكبر من 7، لكنها لا تسمح باتخاذ القرار في الحالة الثانية لأنها تقل عن 10. ومن هذا المنطلق، يتم التمييز في تحيد مفهوم الأغلبية، بين الأغلبية الحسابية التي يتم فيها الأخذ بالعدد الأكبر وبين 
وإذا كان قانون الأغلبية يؤدي إلى تشكيل فئتين وفي آن واحد داخل أعضاء مجلس الإدارة؛ إحداهما تشكل الأغلبية

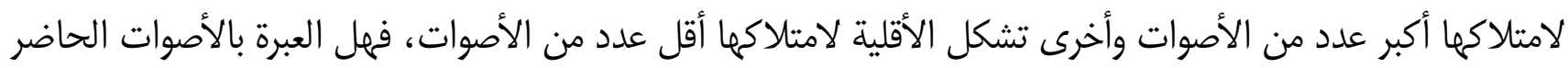

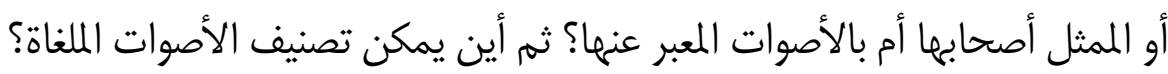

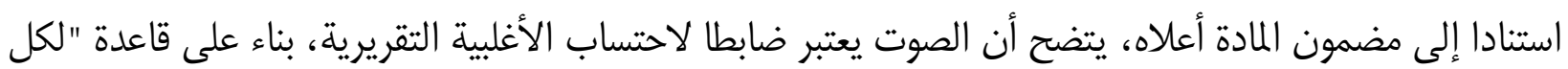

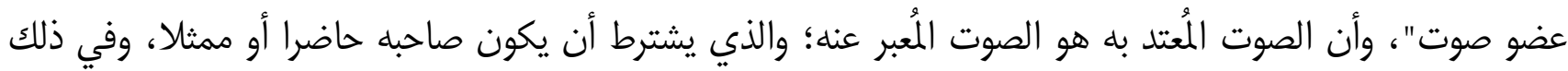

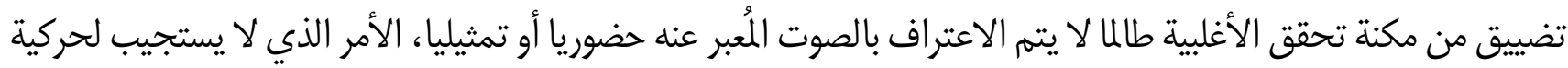
سير أعمال مجلس الإدارة الذي ينبغي أن يتميز بالنشاط.

إن مقاربة مفهوم الأغلبية بهذا الشكل، تقتضي تصنيف أعضاء مجلس الإدارة إلى فئات؛ فئة حاضرة أو ممثلة تقابلمها

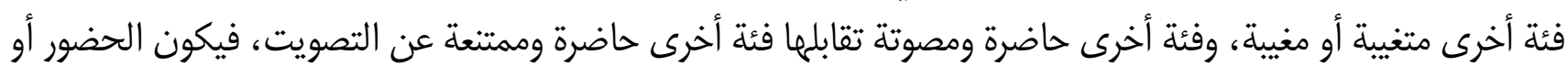

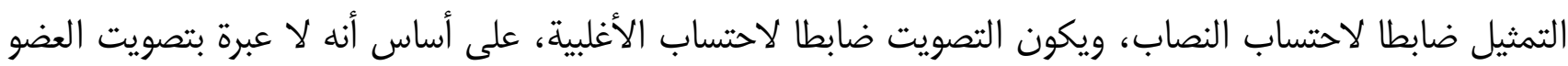

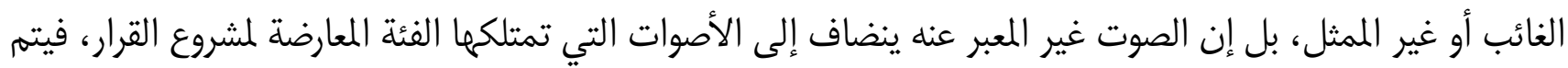

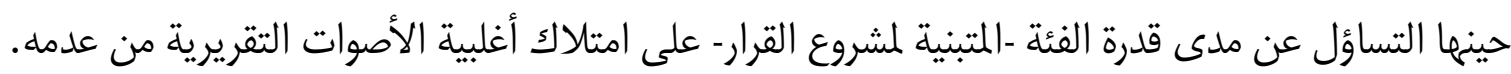
ويلاحظ كذلك أن المشرع يأخذ بمفهوم الصوت المُرجَح؛ وهو الصوت الذي لا يغير من احتساب الأغلبية العددية ولكنه

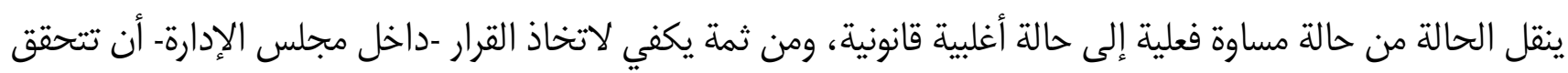

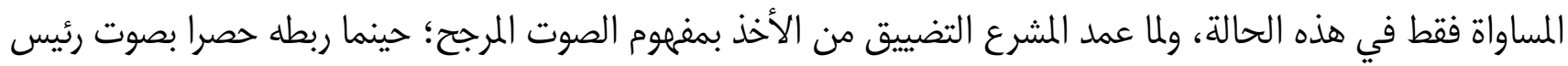

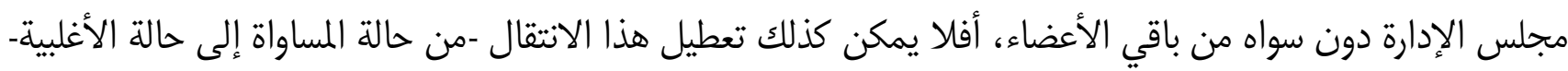

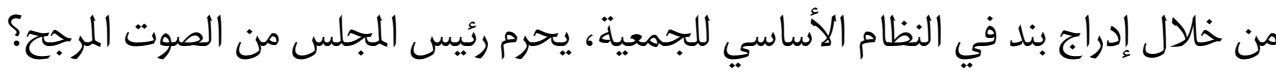
إن الجواب عن هذا السؤال يقتضي بدوره البحث في طبيعة التصويت؛ لتبيان الحدود التي يمكن عبرها استعمال التصويت، فكيف ذلك؟ إجن

\section{الفقرة الثانية: الطبيعة القانونية للتصويت}

نظرا إلى أهمية مجلس الإدارة في جمعية حماية المستهلك، من حيث ممارسته للعديد من الصلاحيات التي توكل إليه

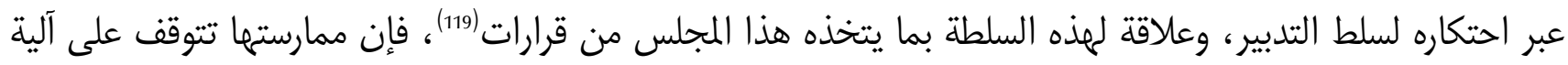

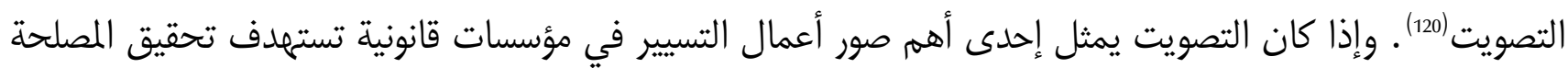

الأغلبية التقريرية التي لا يكفي فيا الحصول على أغلبية عددية بل يستلزم اعتماد نسبة معينة يحددها المشرع أو النظام الأساسي تسمح بتبني مشاريع القرارات. 119 بجميع السلط لتدبيرها في جميع الظروف". 120 الممثلين، وفي حالة تعادل الأصوات، يكون صوت الرئيس مرجحا". 
الخاصة، من قبيل شركات المساهمة(121)، أو يمثل ميكانيزمها الجوهري(1221)، أو الأداة الأكثر فعالية لممارسة السلطة داخلمبا(123)، بل المحور الرئيس الذي تدور حوله كل الصلاحيات الأخرى، أو كل التصرفات والممارسات الأساسية المتعلقة بسير الشركة (124)، وآلية لحمايتها (125)، فمن باب أولى أن ينطبق هذا الوصف على جمعيات حماية المستهلك ذات؛ اعتبارا لماله تسترهفه من تحقيق للمنفعة العامة، ليشكل بذلك التصويت الأداة القانونية الأكثر اتصالا بحماية مصلحة المستهلكين. إلا

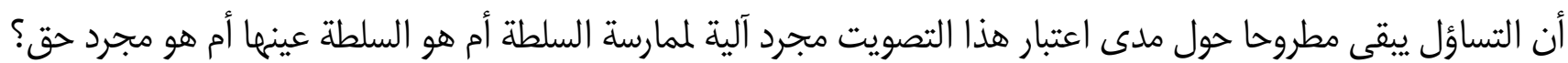
سبقت الإشارة إلى أن المادة 19 من الملحق بالمرسوم التي تحدثت عن تفويض السلط بين أعضاء الجمعية، وهو ما يوحي من -حيث الظاهر- بتمتع كل عضو من هؤلاء الأعضاء بسلطة التدبير، لكن بالرجوع إلى المادة ذاتها، يتبين بأن ممارسة هذا التفويض تتم عبر منح كل عضو من الأعضاء مكنة تمثيل غيره بناء على وكالة موقعة، وهو ما يجعل طبيعة هذا التفويض

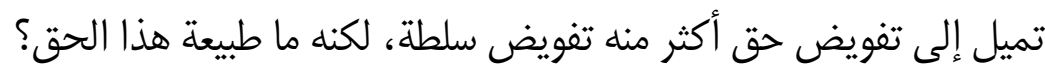
يشكل التصويت المظهر الرئيس للتعبير عن الإرادة، وتتويجا لحق أعضاء مجلس الإدارة في الاطلاع على جميع البيانات ذات الصلة بموضوع التصويت، ويمكن اعتبار التصويت حقا طالما أن غاية امتلاكه هي تحقيق مصلحة خاصة للمصوت، وعلى العكس من ذلك؛ يشكل سلطة حينما يكون هدفه تحقيق مصلحة الغير، مما يجعل الحق منفعة خاصة والسلطة مجرد وظيفة لتحقيق مصلحة الغير، فأين يمكن إذن تصنيف الحق في التصويت، أهو حق شخصي (أولا) أم هو حق وظيفي (ثانيا)؟

\section{أولا: مبررات إعمال نظرية الحق الشخصي وحدودها 1: مبررات إعمال نظرية الحق الشخصي وحددوها}

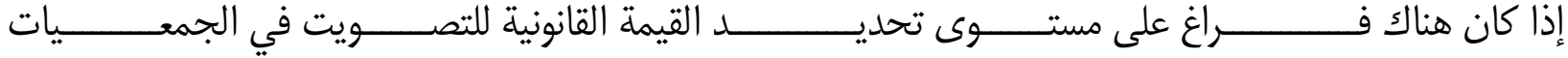

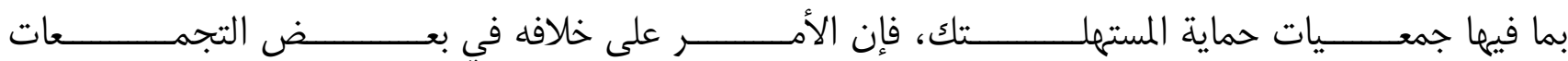

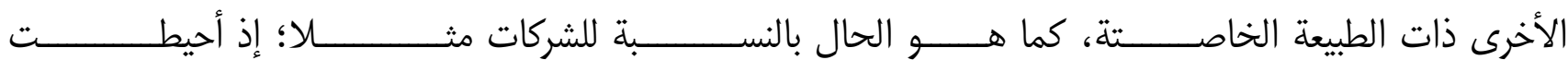

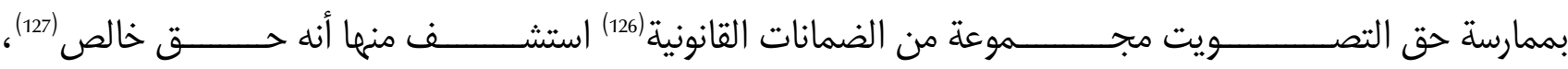

121 - G. Ripert par René Roblot : Traité élément de droit commercial, 13 éd, T1, LGDJ Paris, 1989, P. 822.

122 - عزيز إطوبان: حماية الحقوق الأساسية للمساهمين في شركة المساهمة في القانون المغربي، أطروحة لنيل الدكتوراه في القانون الخاص، كلية العلوم القانونية والاقتصادية والاجتماعية، جامعة محمد الخامس، أكدال، الرباط، س.ج. 2004-2005، ص. 44 و45. و40. 123 - J-M. Hauptmann :Le droit de vote de l'actionnaire en droit Français et en droit Allemand, Th. Nancy II, 1986, P. 31. 124 ـ رشيد بحير: أصول المسؤولية المدنية في شركة المساهمة في القانون المغربـي، أطروحة لنيل الدكتوراه في القانون الخاص، كلية العلوم القانونية والاقتصادية والاجتماعية، جامعة محمد الخامس، أكدال، الرباط، س.ج. 2004-2005، ص. 78. 125 - عبد الرحيم بنعيدة: مفهوم مصلحة الشركة كضابط لتحديد اختصاصات ومسؤولية مجلس الإدارة والجمعيات العامة، دراسة تحليلية مقارنة، رسالة لنيل الدكتوراه في الحقوق، كلية الحقوق عين شمس، القاهرة، مصر، س.ج 2001-2002، ص. 100. 126 - وتراجع في ذلك م.258 و259 و265 ثم 387 من ق.ش.م، تماشيا كذلك مع ما كان مسطرا في مشروع قانون الشركات المغربي لسنة

127 ـ عبد الواحد حمداوي: تعسف الأغلبية في شركات المساهمة، دراسة مقارنة، أطروحة لنيل الدكتوراه في القانون الخاص، كلية العلوم القانونية والاقتصادية والاجتماعية، جامعة محمد الأول، وجدة، س.ج. 2000-2001، ص. 226. 


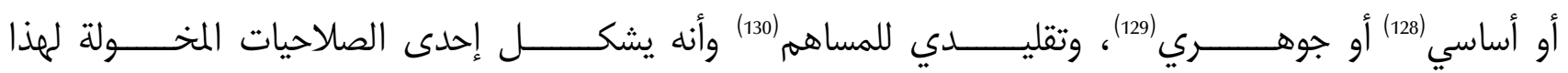

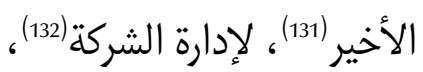

وإذا كان هذا التحديد المفاهيمي مسموح به على مستوى الشركات التجارية، فإن اعتماده على مستوى جمعية حماية

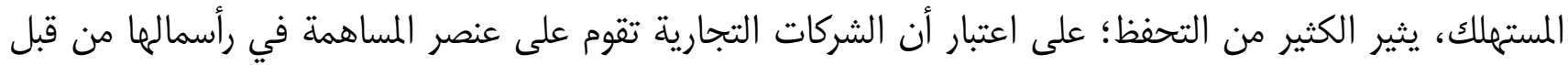

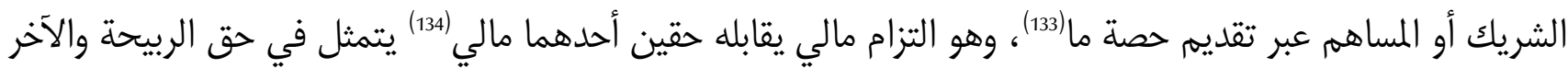

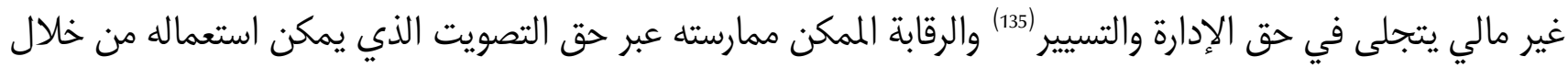

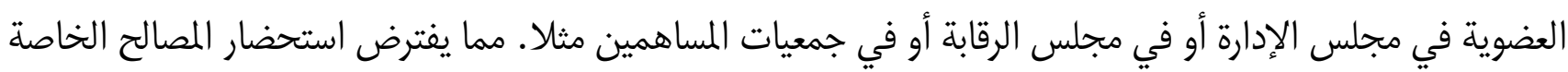
لمهؤلاء الشركاء أو المساهمين في الشركة (136).

وفي مقابل ذلك، فإنه على مستوى جمعيات حماية المستهلك، لا مجال للحديث عن أي ضمانات مالية لفائدة أعضاء

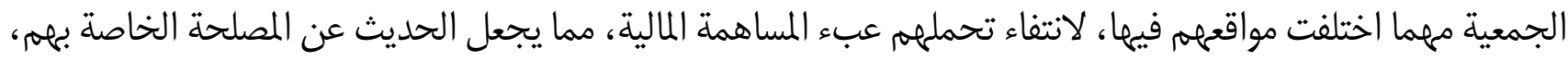

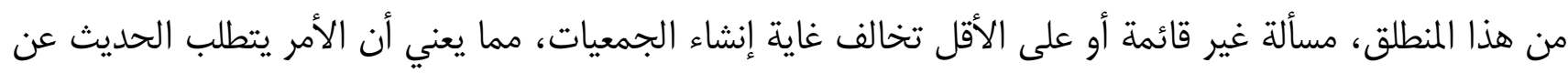

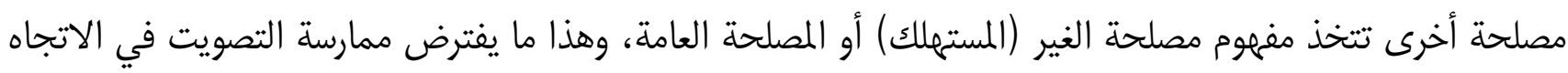
الذي يحمي أو يحقق هذه المصلحة لا المصلحة الخاصة للعضو في الجمعية.

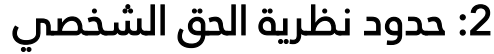

إن الحديث عن حدود النظرية الشخصية في علاقتها بمفهوم التصويت، يتجاوز مجرد ممارسة التصويت في جمعية

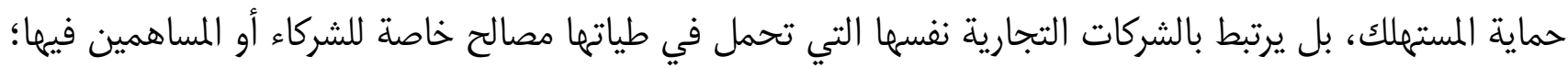

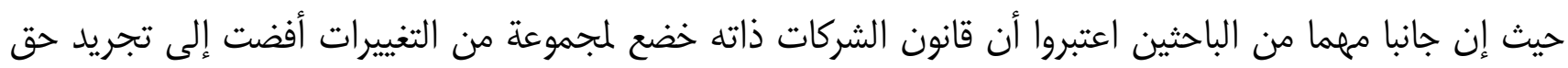

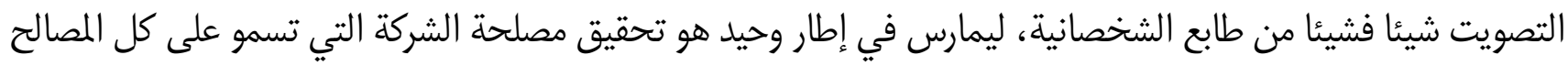

128 - المصطفى بوزمان: "تعسف الأقلية في الشركات التجارية"، في شأن الندوة تحت عنوان: "قانون الشركات التجارية، قراءة في النصوص

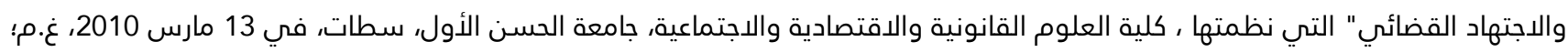

ويراجع في الاتجاه نفسه، رشيد بحير: م.س، ص. ص. وتعتبر حقوقا أساساً كذلك، حق المشاركة في الإدارة وحق الربيحة وحق الإعلام وحق الحضور وحق تداول الأسهم وحق بطلان الشركة، عبد الرحيم بنعيدة: م.س، ص. 129 - رشيد بحير: م.س، ص. ص. 84.

130 - J-M. Hauptmann : Th. cit, P. 49-51-159-161.

131 - Yves Guyon : Droit des affaires, T1, Droit commercial général et sociétés, 5ème éd, Economica, 1988, P. 289.

132 - عزيز إطوبان: م.س، ص. 53. 133 - وجدي سلمان حاطوم: دور إطور المصلحة الجماعية في حماية الشركات التجارية، دراسة مقارنة، منشورات الحلبي الحقوقية لبنان، 2007، ص.

135 - J-M. Hauptmann : Th. cit, P. 377.

136 - رشيد بحير: م.س، ص. 90. 
الشخصية (137)، أو بتعبير آخر فإن ممارسة هذا الحق تقتضي إشباع المصلحة الجماعية وليس مصلحة الفردية للمصوت (138)،

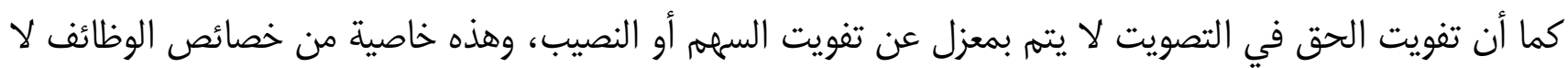

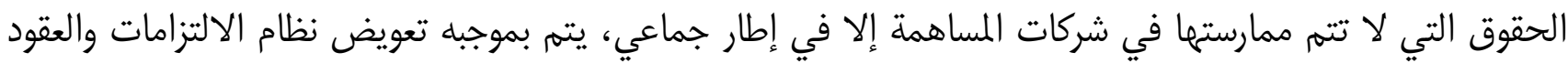

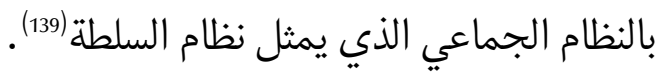

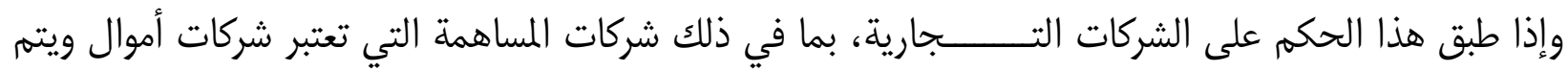

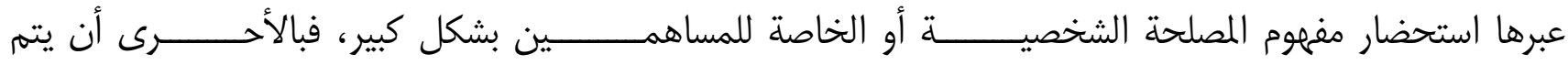

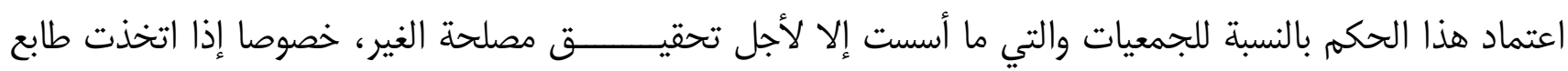

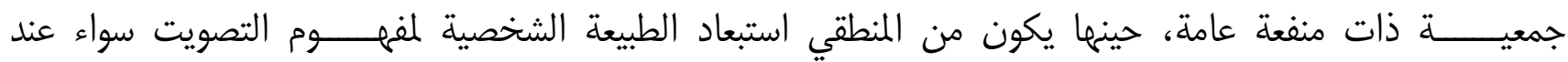

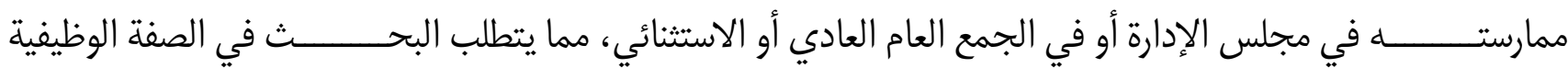
للتصويت في جمعية حماية المستهلك.

\section{ثانيا: مبررات إعمال نظرية الحق الوظيفي وحدودها 1: - 1 إبررات إعمال نظرية الحق الوظيفي ومضمونها}

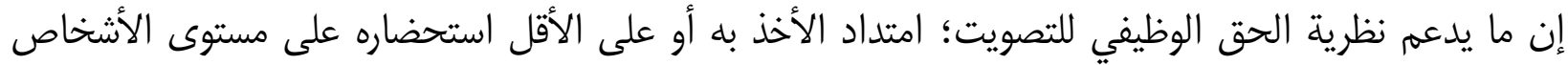

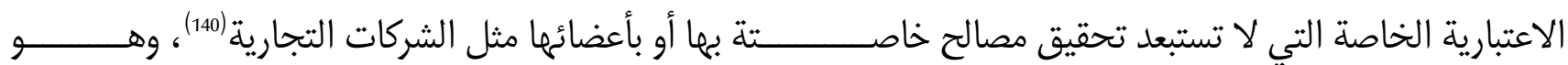

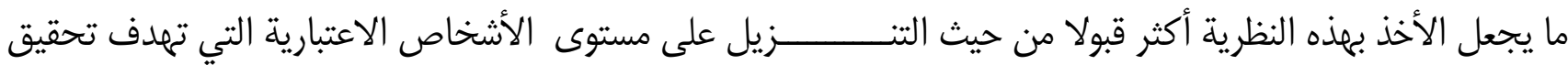

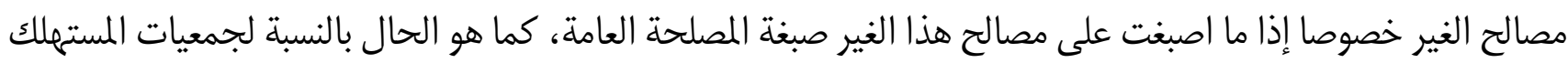
ذات المنفعة العامة.

ويمكن استخلاص الطبيعة الوظيفية لحق التصويت من عدم إمكانية التنازل عنه، ولا خضوعه للتعامل التجاري،

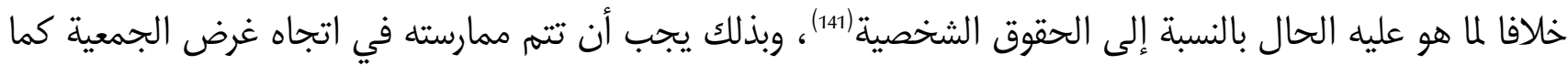

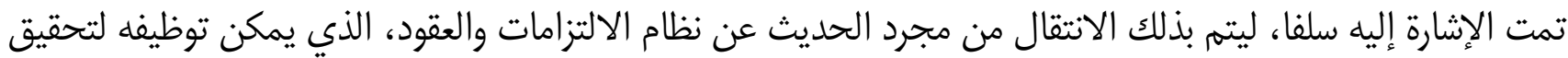
المصالح الخاصة، إلى نظام جماعي تكون غايته تحقيق المصلحة العامة.

137 ـ عبد الرحيم بنعيدة: م.س، ص. 100.

138 - «En exerçant son droit de vote, l'associé agit, non pour lui mais pour la société. Son vote doit être émis dans l'intérêt de la société et non dans son intérêt personnel », Joly. Sociétés. Traités. Voir. Décisions collectives. T II, P. 6.

أشار إليه، وجدي سلمان حاطوم: م.س، ص. 208.

139 - رشيد بحير: م.س، ص.

140 - بحيث إنه على الرغم من الاعتراف للشريك بشكل عام عام وللمساهم بشكل خاص بممارسة حق التصويت باعتباره حقا له، إلا أن هذا الحق بحسب إحدى الأحكام القضائية، أسبغت عليه سبغة الحق الوظيفي إذ تتوجب ممارسته في نطاق المصلحة المشتركة بعيدا عن الأغراض الأنانية والذاتية للشريك دون الإضرار بالشركاء الآخرين وبمصلحة الشركة نفسها. ويراجع في هذا الاتجاه حكم تجارية مراكش رقم 720 في 07 ماي

2001، في الملف ع. 2000/817، مجلة المحاكم المغربية ع. 91، 2001، ص.170؛ تعليق المهدي شبو في المرجع السابق نفسه، ص. 157. 141 - إذ يمكن مثلا للمساهم في شركات المساهم التصرف في حق التصويت عبر بيعه أحد الأسهم التي يملكها في الشركة، باعتبار أن السهم يضم حقين؛ أحدها مالي يتعلق بالربيحة وعائد التصفية والآخر معنوي يتعلق بالتصويت. 


\section{2: حدود نظرية الحق الوظيفي}

تستند نظريتة الحق الوظيفي إلى كون ممارسة الحق إنما تتم لتحقيق مصلحة الغير أو المصلحة الجماعية أو المصلحة العامة، وفي مقابل ذلك يوجد تصور آخر يعتبر هذا التفسير تفسيرا ضيقا يضع قطيعة تامة بين مصالح الشخص الاعتباري ومصالح الأعضاء المكونين له، إلا أن هذا التصور لا يمكن التسليم به على إطالاقه؛ لأنه ينبغي الرجوع إلى طبيعة الخلفية التي تم على أساسها إنشاء الشخص الاعتباري في حد ذاته. لذلك، عند استحضار الرهدف الذي أنشئت من أجله هذه جمعية حماية المسترلك، يقتضي تغييب مصلحة أعضاء الجمعية في حد ذاتهم، خلافا لما هو عليه الحال بالنسبة للعديد من التجمعات بما فيها التعاونيات؛ إذ تؤسس لتلبية الحاجيات الخاصة بأعضائها (142).

ويتطلب لكي يتصف الحق بالسلطة تحقق عنصر التمثيلية، وهو أمر متحقق في حق التصويت الممارس على مستوى جمعية حماية المستهلك، لكن عنصر السلطة يتطلب كذلك أن يصوت العضو باسم جمعية المستهلك، وهذا أمر محط نظر؛ لأن تصويت هذا العضو يقف عند حدود المشاركة في صنع قرار مجلس الإدارة وعبره تمثيل الجمعية. وعليه، فإن التمثيلة موكلة لمجلس الإدارة ذاته لا لأحد أعضائه. وهو ما يجعل التصويت أقرب إلى الحق منه إلى السلطة، لكن ارتباطا بأهدافه، فهو حق وظيفي لا شخصي؛ طالما أنه يستهدف تحقيق مصلحة المستهلكين وهي مصلحة عامة.

142

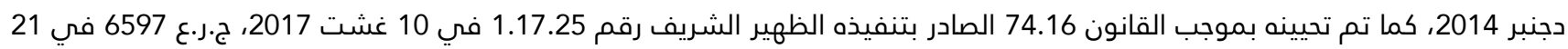
غشت 2017، ص. 4569، خصوصا المادة 4 في فقرته الأولى التي جاء فيها: "التعاونيات شخصيات اعتبارية تتمتع بالأهلية القانونية الكاملة وبالاستقلال المالي" ثم الفقرة الأولى من المادة 1 التي جاء فيها: "التعاونية مجموعة تتألف من أشخاص ذاتيين أو اعتباريين أو هما معا اتفقوا أن ينضم بعضهم إلى بعض لإنشاء مقاولة تتيح لهم تلبية حاجياتهم الاقتصادية والاجتماعية، وتدار وفق القيم والمبادئ الأساسية المتعارف

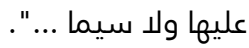


الخاتمة

تم الوقوف في هذه الدراسة على إرادة المشرع في حماية فئة معينة من أفراد المجتمع وهي فئة المستهلكين؛ عبر وضع مجموعة من القوانين، التي لم تقتصر فقط على القواعد العامة التي جاء بها ظهير تأسيس الجمعيات أو في المرسوم القاضي بتطبيق أو في المرسوم المنظم لحق تأسيس الجمعيات أو في ظهير الالتزامات والعقود كما أحال علية الظهير السابق، بل تعدت ذلك لتربط فئة المستهلكين بنوع خاص من الجمعيات تسمى جمعيات حماية المستهلك ذات المنفعة العامة، والتي تحكمها بالإضافة إلى القوانين السابقة، الملحق بالمرسوم النظم لتأسيس الجمعيات وكذا القانون القاضي بتحديد تبديد تدابير حماية المسترلك.

ومن خصوصية هذه الجمعيات شأنها في ذلك شأن باقي التجمعات القانونية، أنها ترتبط بنظام قانوني يقوم على تعدد الأجهزة المكونة له؛ سواء التقريرية أو التنفيذية الرقابية، وهو ما يؤسس لأحد مبادئ الديمقراطية في ممارسة العمل الجماعي بشكل عام، ومجلس إدارة الجمعية بشكل خاص؛ ليشكل هذا النظام ضمانة قانونية لحماية مصالح المسترلكين.

$$
\text { ويمكن تلخيص مظاهر هذا النظام في الآتي: }
$$

قواعد تنظيم وانعقاد مجلس تدبير المؤسسة، من القواعد الآمرة، وأن مخالفتها تجعل مداولات وقرارات المجلس

باطلة؛

العضوية في مجلس تدبير المؤسسة ضابط لتحديد النصاب؛

- العضوية والحضور الشخصي أو التمثيلي، في مجلس إدارة الجمعية، ضابطان للمشاركة في التصويت؛

- الأغليية ضابط لاتخاذ قرارات مجلس إدارة الجمعية؛

$$
\text { - "لكل عضو صوت" مبدأ لاحتساب الأغلبية. }
$$

ويعتبر التصويت حقا لكل عضو من أعضاء مجلس إدارة جمعية حماية المستهلك ذات المنفعة العامة، مصدره القانون لا لإمات الاتفاق، لكنه يبقى حقا وظيفيا لا ذاتيا؛ يجب استعماله لتحقيق مصلحة المسترلكين التي مصلحة عامة، وأنه لا يمثل

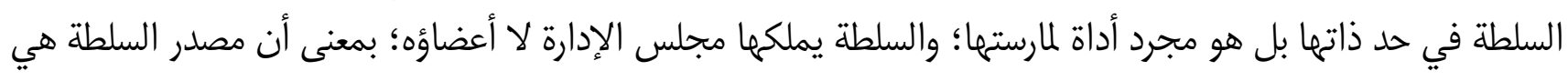
الإرادة المشتركة لأعضاء المجلس، تفعيلا لقانون الأغلبية، الذي ينبغي ممارسته في الحدود المسطرة قانونيا ونظاميا لعمل الجمعية.

وبصرف النظر عن إرادة المشرع في وضع أحكام عامة أو خاصة لسير الجمعيات بشكل عام ولجمعية حماية المستهلك ذات المنفعة العامة بشكل خاص، فقد بقيت أحكاما قاصرة لم تجب عن مجموعة من الأسئلة التي يمكن أن يفرزها الواقع

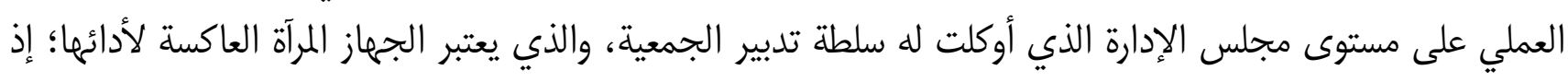
بواسطته تظهر مدى فعالية عمل الجمعية من عدمهيا. 
وتتعلق مظاهر القصور التي شابت الملحق بالمرسوم القاضي بتحديد النظام الأساس النموذجي لجمعيات حماية المستهلك التي يمكن الاعتراف لمها بصفة المنفعة العامة، في عدم التنصيص المروم على المسائل الآتية: - الأشخاص الموكل لهم المطالبة بعقد اجتماع مجلس الإدارة عدا الرئيس؛ - الأشخاص المخول لمهم دعوة مجلس الإدارة إلى الانعقاد حالة ما إذا تعذر ذلك على رئيس هذا المجلس؛ ـ الدعوة الثانية للانعقاد في الحالة الني لا يتحقق فيها النصاب في الدعوة الأولى؛ - الأجل الفاصل بين تاريخ تسله الدعوة وتاريخ انعقادها؛

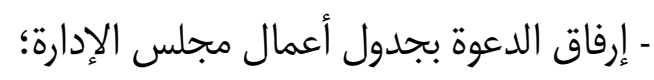
- الوسائل المعتمدة لتوجيه الدعوة. ولهزه الاعتبارات، يمكن التوصية بالآتي:

- توسيع نطاق الأشخاص الموكل لرمم حق المطالبة بعقد اجتماع مجلس الإدارة؛ ليشمل ثلث أعضائه.

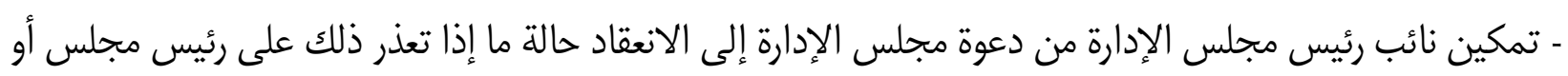

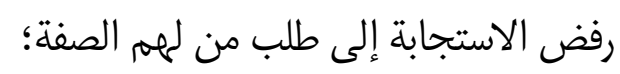
- توجيه دعوة ثانية للانعقاد واعتبار تحقق النصاب بمن حضر في الحالة التي لا يتحقق فيها النصاب في الدعوة الأولى؛

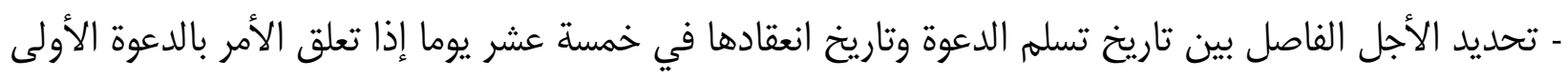

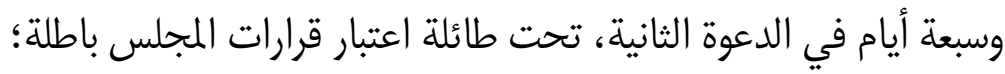
- ضرورة إرفاق الدعوة بجدول أعمال مجلس الإدارة، تحت طائلة اعتبار قرارات المجلس باطلة؛ - اعتماد جميع الوسائل القانونية بما في وسائل الاتصال الحديثة لتوجيه الدعوة ولإقرار الحضور والمشاركة في مداولات المجلس. 


\title{
موقف القانون الدولي من اللجعء البيئي
}

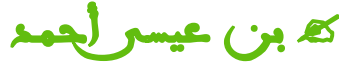 \\ أستاذ محاضر"|"ا"، كلية الحقوق والعلوم السياسية - بجامعة سعيدة - الجزائر

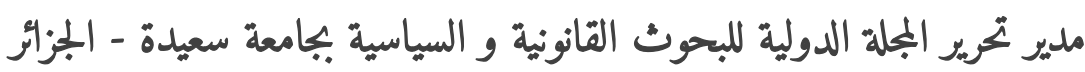 \\ محامي معتمد لدى المحاكم و المجالس القضائية
}

\section{مقدمة:}

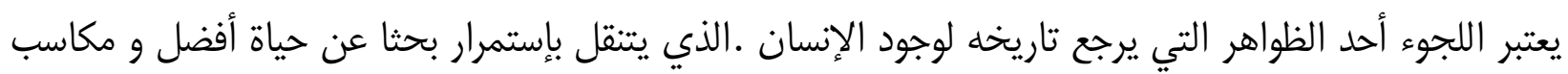

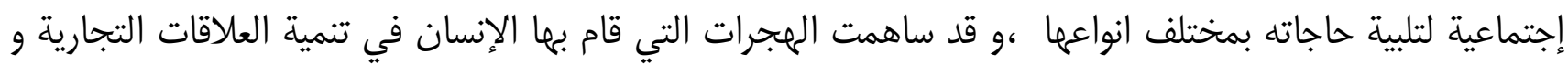

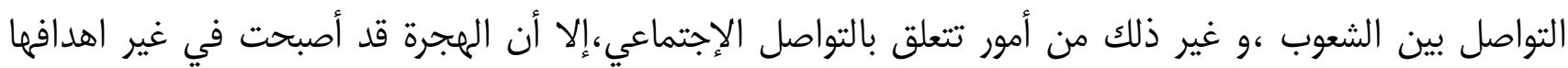

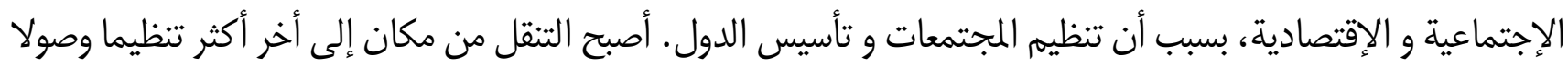

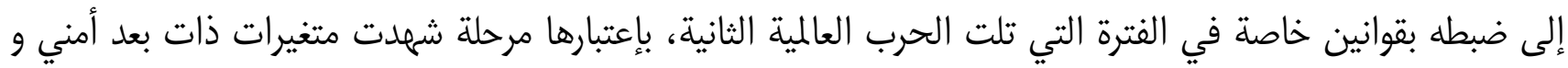

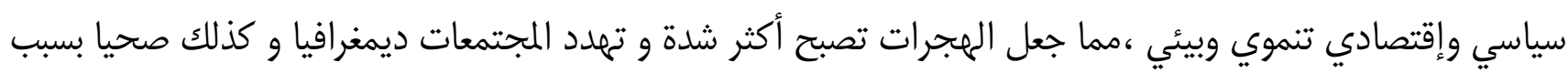

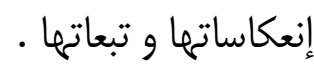

تحولت الهجرة الى لجوء وشهدت مرحلة العقدين الأخيرين كموجه غير منظمة، أطلق عليها في غالبها اللجوء السياسي

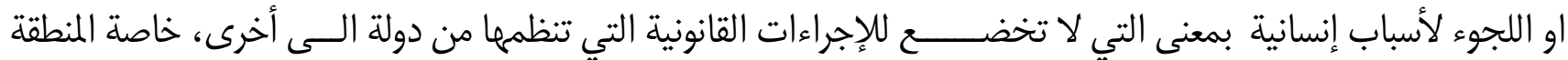

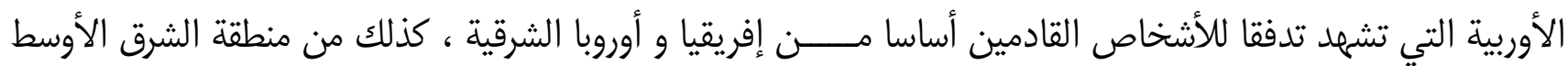
بسبب النزاعات و الحروب و الإضهاد السياسي و العرقي، بالإضافة إلى الولايات المتحدة من جهاتة و دول أمريكا اللاتينية و

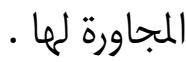

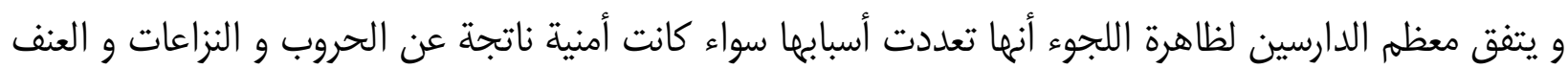
الطائفي و التمييز العنصري، و أخرى تتعلق بالجوانب الإقتصادية لقلة التنمية في البلدان المصدرة للأشخاص الناتئ اللاجئين. إلا أن هناك أسباب خارج إطار هذا الأمر لا يتم إثارتها في الغالب كونها تعطي إشكالية حقيقة لماته الظاهرة و هي البيئة و وإنعكاساتها على القاطنين في المناطق التي تشهر تغيرات مناخية تدفع بالأشخاص إلى الهجرة، إما نتيجة صعوبة الهابة

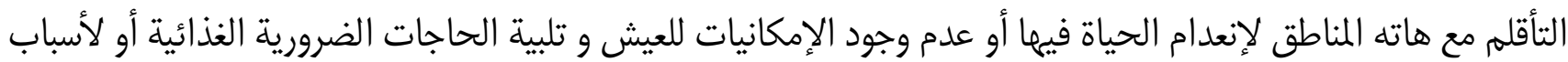

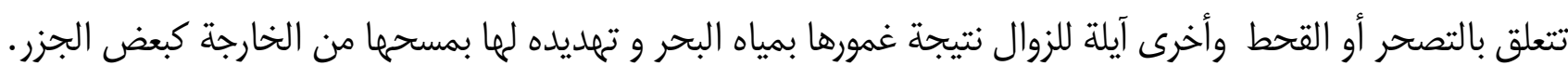
لقد أصبحت البيئة و متغيراتها المختلفة سببا رئيسيا في اللجوء بالتزامن مع المطالبة بتطبيق المواثيق الدولية لحقوق الإنسان التي تعطي حق العيش للإنسان . 
إن اللجوء و رغم كونه ظاهرة سلبية إلا أن التعامل معه في الدول الغربية لا يتوافق مع واقعية أسباب هاته كون أن أسبابها في الغالب ناتجة عن سياسة الدول الغربية في زعزعة إقتصاديات الدول و إستنزافها و خلق النزاعات الإثنية و الحروب و زعزعة الأنظمة السياسية لأجل الفوضى بما يجعل مصالحها باقية و بالمقابل تقوم بوضع الحواجر للمهاجرين إن إشكالية اللجوء البيئي و على الرغم من عدم إثارتها عمدا من طرف الدول المتقدمة على مستوى المؤتمرات التي أدت الى اقرار المواثيق الدولية المختلفة المتعلقة باللاجئين و تركيز مضمونها على الجوانب غير البيئية نظرا لصعوبة ضبط المصطلح من جهة و عدم الإقرار بضرورة جعل البيئة احد مسببات اللجوء و أساسه خاصة في ظل متغيرات مناخية تتسبب التبئ فيها الدول الصناعية و التي أدت إلى تغير مناخي إنعكس على البيئة في الدول لا سيما منها المتخلقة و أدى الى كوارث طبيعية و إنعدامإلى ظروف الحياة و إحداث التصحر و تلويث المناطق المائية و إستعمال المياه الجوفية في الصناعات البترولية على غرار الغاز الصخري .

إن المجتمع الدولي الأن هو مسؤول على هذا التغير البيئي الذي بالضرورة أدى إلى اللجوء البيئي أصبح من الضروري إيجاد أساس قانوني دولي له بما يجعله أكثر إستجابة لحق العيش في إطاره العام، كون أن الإتفاقيات الدولية الحالية لا تتلائم في معظمها مع السياق الخاص بالتأثير البيئي على اللجوء.

\section{المبحث الأول: المحددات المفاهمية للجوء وعلاقته بالبيئة المطلب الأول: مدى وجود مفهوم اللجوء البيئي}

إذا كان اللجوء في إطاره العام لقي إهتماما وتحديد لمعايير إعتماده. وهذا ما أخذت به إتفاقية اللاجئين لسنة 1951. والتي إعتبرت اللجوء لأسباب ذاتية لا موضوعية وربطته بالظروف الشخصية التي قد تطال اللاجئ وهي تتعلق أساسا

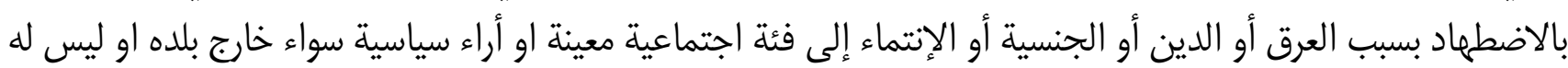
القدرة على العادية لها بسب ب الخوف

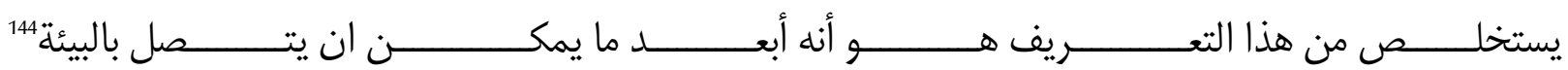

1431راجع: الإتفاقية الخاصة بوضع اللاجئين لسنة 1951 و التي دخلت حيز النفاذ سنة 1954 لا سيما المادة الأولى منها 144 تشكل البيئة و حمايتها تشكل إرهاصا دوليا ووطنيا و لذا كان الإهتمام بيها و تحديد مفهومها أولوية دولية عبر المواثيق الدولية و المؤتمرات المتخصصة و يمكن إيجاز بعض التعريفات في ذلك منها مؤتمر أستكهولم 1972 الذي عرف البيئة بأنها" هي ذلك ذلك الرصيد من الموارد المادية و

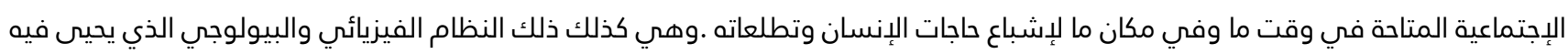
الإنسان والكائنات الأخرى،وهي كل متكامل وإن كانت معقدة تشمل على عناصر متداخلة ومترابطة وهناك شبه إتفاق بين المهتمين بالدراسات البيئية،على أن البيئة هي الإطار الذي يشمل جميع عناصر الحياة التي تحيط بالإنسان،وهو ماتوجه إليه مؤتمر أستكهولم حيث أعطى للبيئة مفهوما واسعا،بأنه كل شيء يحيط بالإنسان". للتفصيل حول مفهوم البيئة وفق مؤتمراستكهولم 1972 أنظر: :رشيد الحمد و محمد سعيد صابري،البيئة و مشكلاتها، الكويت, المجلس الوطني للثقافة والفنون، 1979،ص25 وما بعدها. كما تتعد التعريفات المختلفة للبيئة وفق اتجاهات متعددة والتي تركز علص البيئة بين العوامل التي تحيط بها كإطار عام و بين المكونات المادية و الطبيعية للبيئة و في هذا الصدد يمكن تعريف البيئة بأنها: "هي ذلك المديط الذي يعيش فيه الإنسان بما يشمله من ماء و هواء و تربة و كائنات حية و بذلك هي تضم كل من البيئة الطبيعية و "الاصطناعية 


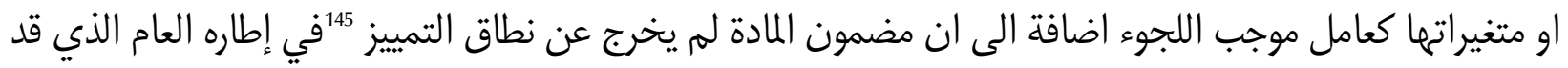

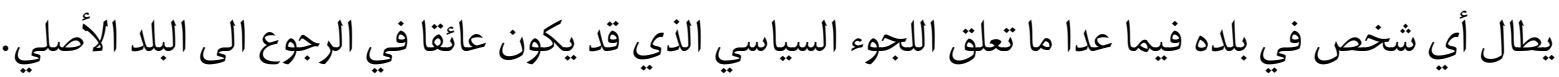

و بالرجوع الى إتفاقيات حماية البيئة لا سيما منها مؤتمر ستوكولم 1972 الذي يشكل أساسا مهما في مجال البيئة لما

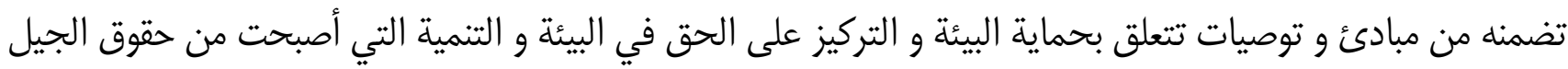

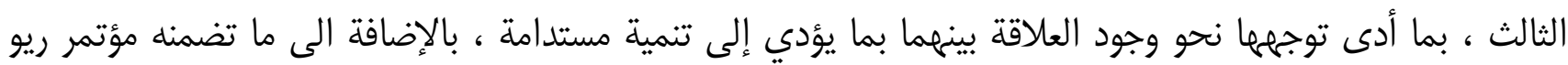

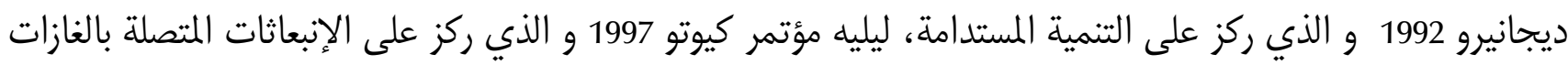
وربطها بالتغير المناخي .

إن تضمين الأسباب المتعلقة بالبيئة و ما قد يطالمها من أضرار نتيجة الكوارث أو الأخطار التي قد تقع نتيجة ظروف

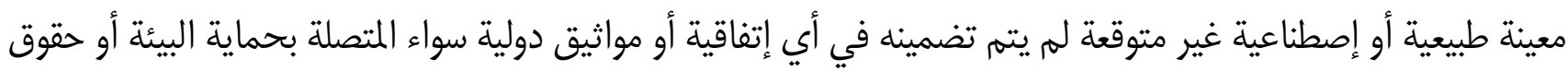

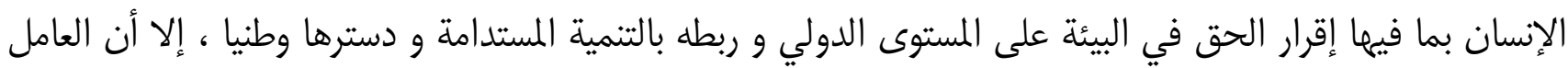
البيئي يبقى مغيبا على الرغم من كونه سبب كاف لطلب اللجوء خاصة و أن عوامله موضوعية لا يتدخل فيهيه الإنية الانسان

ويمكن تعريف البيئة بأنها :

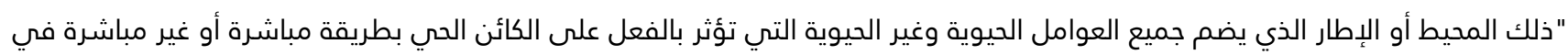
أي فترة من فترات حياتهويقصد بالعوامل الحيوية :جميع الكائنات الحية مرئية أو غير مرئية الموجودة في الأوساط البيئية المختلفة ،والعوامل

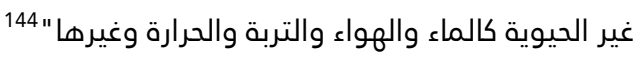
ومنه يمكن تعريف البيئة بأنها"مجموعة العوامل البيولوجية و الكيميائية والطبيعية و الجغرافية والمناخية المحيطة بالإنسان والمحيطة

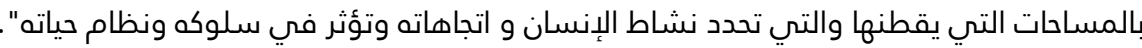
ويمكن تعريف البيئة بأنها المحيط المادي الذي يعيش فيه الإنسان بما يشمل من ماء وهواء،وفضاء وتربة و كائنات حية،ومنشآت أقامها لإشباع حاجاته"

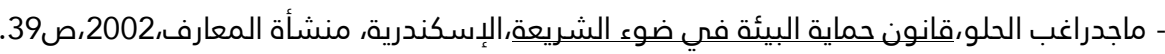
145 يقصد بتعبير "التمييز " طبقا للمادة الأولى فقرة أولى من الإتفاقية الدولية للقضاء علي جميع أشكال التمييز العنصري في 21 ديسمبر

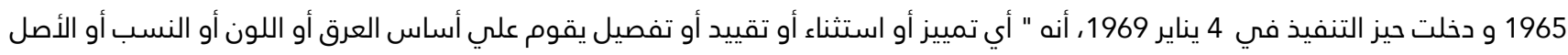
القومي أو الإثني ويستهدف أو يستتبع تعطيل أو عرقلة الإعتراف بحقوق الإنسان والحريات الأساسية أو التمتع بها أو ممارستها، علي قدم التمائ

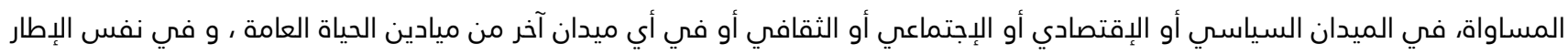

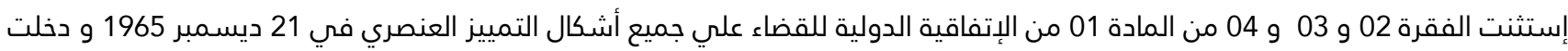

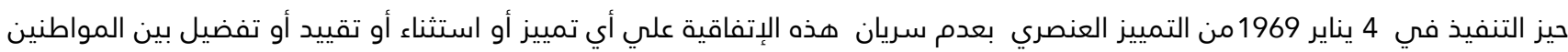
وغير المواطنين من جانب أية دولة طرف فيها. - يحظر تفسير أي حكم من أحكام هذه الاتفاقية بما ينطوي علي أي مساس بالأحكام القانونية السارية في الدول الأطراف فيما يتعلق بالجنسية

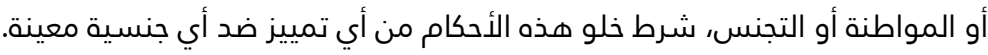

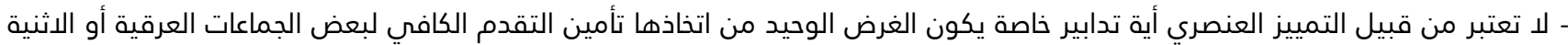
المحتاجة أو لبعض الأفراد المحتاجين إلي الحماية التي قد تكون لازمة لتلك الجماعات وهؤلاء الأفراد لتضمن لها ولهم المات المساواة في التمتع

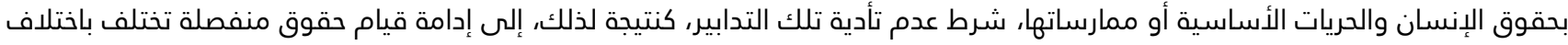

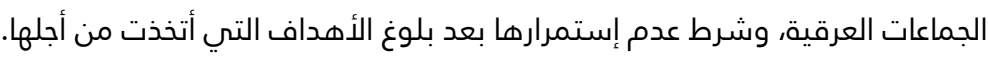
راجع : المادة 01 من الإتفاقية الدولية للقضاء علي جميع أشكال التمييز العنصري في 21 ديسمبر 1965 و دخلت حيز التنفيذ في 4 يناير 1969. 


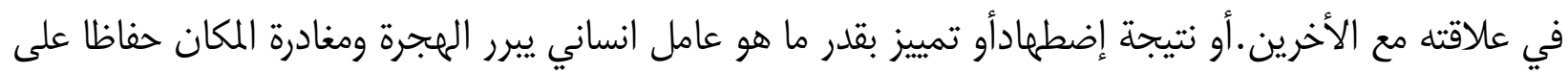
أهم حق وهو الحياة نتيجة الأخطار المهددة له.

إن اللجوء البيئي أصبح واقعا تفرضة الظروف لا سيما وأن التغيرات البيئية وتحدياتها المستمرة أصبحت أكثر إرغاما لإنسان على تحويل مسار حياته

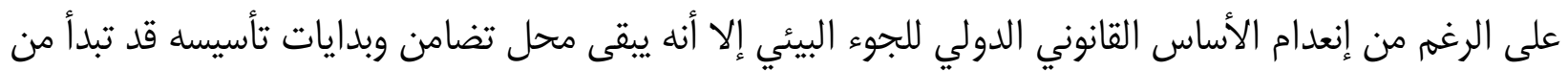

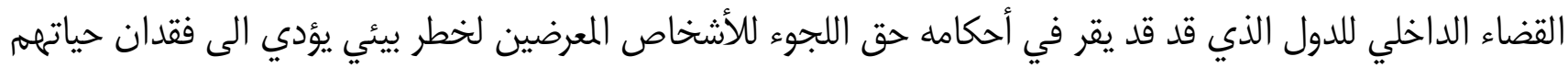

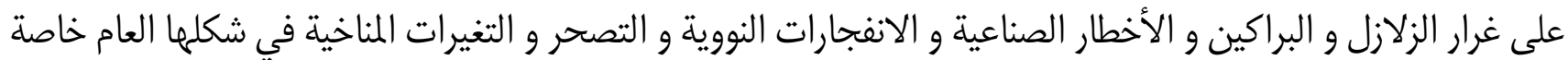
عندما يكون وراء ذلك تقارير لخبراء بيئيين.

و يمكن في هذا الصدد أن ذكر بدايات ذلك من خلال ما أثاره الخبير الإيكولوجي Willian Vogt حول اللجوء البيئي،

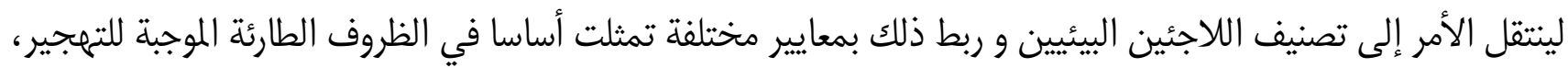
والتحويل الإداري نتيجة إعمال مشروعات تنموية معينة في مناطق مأهولة. 147

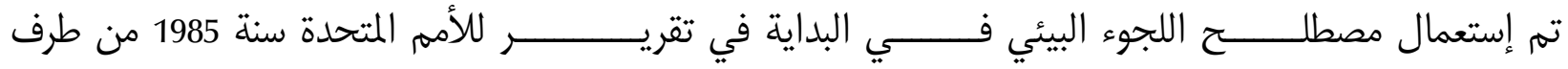

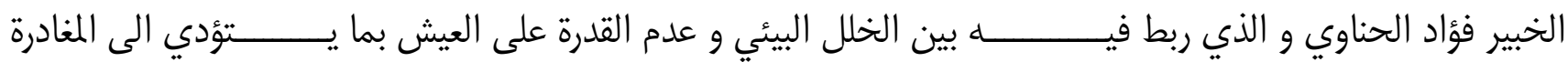

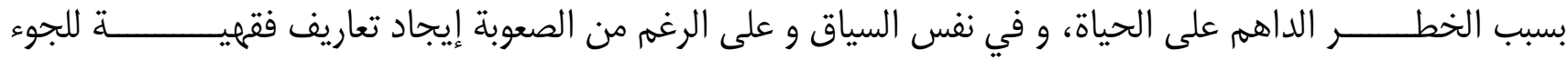

إلا أنه يمكن إيجاز تعريف عام له و هو ما قام به الخبيرين SUHRKE Astri, VISENTIN Annamaria اللذان ميزا

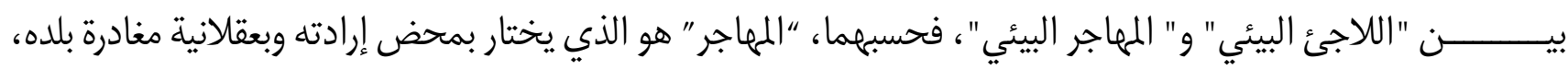

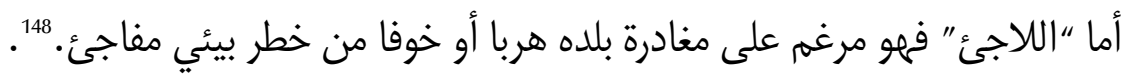

1461في واقعة هي الأولى من نوعها، طلب رجل يدعى إيوان تيتيوتا من محكمة في نيوزيلندا عام 2013 حق اللجوء البيئي له ولعائلته، بسبب ارتفاع مستوى مياه البحر والمخاطر البيئية التي يسببها الاحتباس الحراري في بلاده كيريباتي. فهذه الدولة الصغيرة في المديط الهادئ، القائمة على مجموعة جزر، هي موطن لنحو مئة ألف نسمة، لكن علماء يتوقعون أن تصبح غير صالحة للسكن خلال 20 عاماً بسبب ارتفاع مستوى البحر. إلا أن طلب هذا الرجل رُفض، بإعتبار أنه لا يوجد بند في القانون الدولي يختص بتنظيم شؤون اللاجئين البيئيين. رجل آخر يدعى سجيو أليسانا، من دولة توفالو القريبة في المحيط الهادئ التي تضم تسع جزر ويقطنها 11 ألف نسمة وهي مهددة أيضاً ألفار بارتفاع

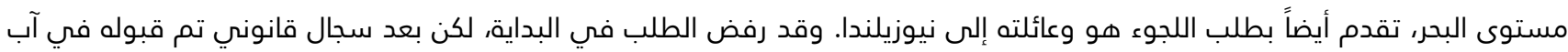
(أغسطس) 2014، وكان من مبررات القبول في المحكمة الآثار الإنسانية الاستثنائية الناتجة عن تغير المناخ. إيمان فخري باحثة إقتصادية في وزارة التعاون الدولي ، كلية الاقتصاد والعلوم السياسية في جامعة القاهرة.

متوفر على الموقع الإلكتروني: http://www.afedmag.com/web/ala3dadAlSabiaSections-details.aspx?id=1985\&issue=\&type=4\&cat=23

2018/02/10 على الساعة العاشرة ليلا الإطلاع عليه يوم:

147 بن فاطمة بوبكر ، حق اللجوء البيئي في القانون الدولي ، مجلة البحوث القانونية و السياسية ، عدد:02، تصدر عن كلية الحقوق و العلوم

السياسية بجامعة سعيدة ، 2014، ص 99 148 بن فاطمة بوبكر ، المرجع السابق، ص 99 


\section{المطلب الثاني: تصنيف اللجوء البيئي و عوامله}

على الرغم من كون أن نقطة الإشتراك في اللجوء هو المخاطر التي تتصل بالبيئة و ما يمكنه أن تسبب من أثار على الإنسان و تهلديده في حياته بما يؤدي الى ضرورة تغيير المكان نظرا لعدم القدرة على اصلاح الضرر أو استحالة العودة للمكان نظرا لخطورته كما في حالة الإنفجارات النووية و اخطارها أو في حالة غمور المياة لمساحة يابسة بكلماها و إختفائمها

$$
\text { يمكن تقسيم اللجوء البيئي الى قسمين : }
$$

\section{أ- اللجوء البيئي المؤقت :}

و هو الذي يحدث نتيجة كوارث طبيعية مفاجئة .و يؤدي إلى الإضرار بالمكان المفترض فيه العيش أو محيطه ،و يؤدي

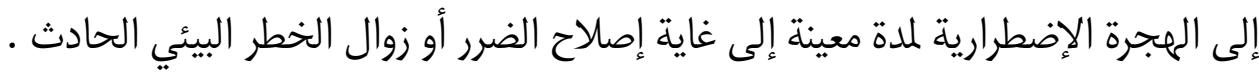

\section{ب- اللجوء البيئي الدائم :}

و هو الناتج عن التهديد البيئي الخطير للدرجة عدم القدرة على إصلاح الضرر أو العودة الى المنطقة محل الإقامة بما يجعله مستمر ، و ينتج عن :

ـ غمور المياه للجزر البحرية المأهولة و مسحها من الوجود نتيجة صعود نسبة مياه البحر أو بسبب ذوبان الجليد.

- حدوث إنفجارات بركانية مستمرة و مؤثرة على العيش في مكان ما

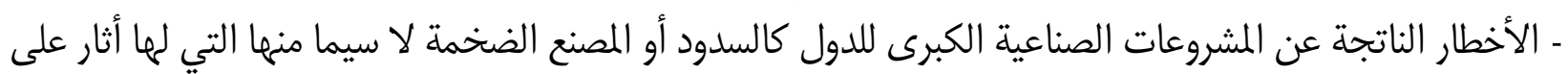

- الإنفجارات النووية و التجارب المتصلة بها ،و/ أو التسربات الإشعاعية النووية الخطيرة على نطاق واسع .

\section{المطلب الثالث: أسباب اللجوء البيئي أ- التغير المناخي:}

يشكل التغير المناخي الذي يصاحبه إضرار بالبيئة نظرا للعوامل المؤثرة على تغير المناخ و التي غالبا ما تؤدي إضطرابات جوية تؤدي إلى أخطار متعددة.

$$
\text { و ييرز مظاهر التغير المناخي في: }
$$

- زيادة حرارة الأرض بسبب الغازات المنبعثرة جراء المصانع المختلفة لا سيما منها الناتجة عن حرق الكربون و استعمال المواد الكيماوية و النفطية كالغاز و النفط، وتساهم الدول الصناعية في انبعاث الغازات الملوثة و المؤثرة بشكل مباشر على درجة الحرارة خاصة ولايات متحدة أمريكية بنسبة أكثر من 25 في المائة 149 - زيادة منسوب المياه في البحار بسبب ذوبان الجليد و الذي يؤدي إلى انحصار اليابسة و صولا إلى غمر مناطق بكاملها او مسحها من الوجود و تمهديدها بذلك

149 لطروش أمينة اللجوء البيئي كأثر للتغير المناخي ، مقال إلكتروني بمجلة القانون و الأعمال متوفر على الموقع الإلكتروني: www.droitetentprise.com/web/ala3dadAISabiaSections-

: تم الإطلاع عليه يوم 22/02/2018على الساعة العاشرة ليلا 
- تغير واضح في نظه سقوط الأمطار و درجات الحرارة و الرياح بما يسبب تغير في نمط الزراعة - إنبعاثات الغازات المسببة للإحتباس الحراري والتي تتسب في ظاهرة الإحتباس الحراري العالمية. وقد أدت هذه التغيرات إلى حدوث الكثير من المخاطر البيئية تجاه الصحة ، مثل نضوب الأوزون، فقدان التنوع الحيوي، الضغوط على الأنظمة المنتجة للغذاء وانتشار الأمراض المعدية بشكل عالمي .

إن تغير المناخ يؤدي إلى نزوح الأفراد من خلال العديد من الطرق و أكثرها وضوحاو مأساوية، يكون بسبب زيادة عدد

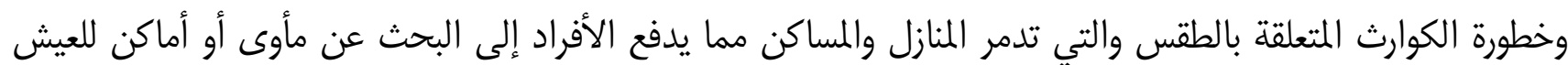
بمكان آخر . إن ظاهرة البداية البطيئة التي تتضمن تأثيرات التغير المناخي مثل التصحر وإرتفاع منسوب البحار يؤدي تدريجيًا إلى تدمير أسباب المعيشة وإجبار المجتمعات على التخلي عن أوطانها التقليدية لتذهب إلى بيئة أكثر ملائمة. ويحدث هذا حاليا في مناطق الساحل الإفريقية وحزام مناطق المناخ شبه الجاف الذي يمتد حول القارة أسفل صحرائما الشمالية تماما. ويمكن أن تؤدي البيئات المتدهورة نتيجة للتغير المناخي إلى مزيد من الصراعات حول الموارد والتي قد تؤدي بدورها إلى

\section{بـضعف محفزات التنمية الإقتصادية:}

إذا كان التغير المناخي يعد احد الأسباب الرئيسية في إحداث الرجرة البيئية نتيجة الأثار المترتبة على الكوارث الطبيعية فان الجانب الإقتصادي لا يخلو من هذا التأثر نتيجة الصعوبات التي يجدها الأفراد في المناطق التي تتضرر بيئيا لعدم توفر الموارد الأساسية للعيش أو شحها بسبب طبيعة المنطقة كالصحاري و مناطق الجليد و المناطق التي أصبحت غير قابلة للعيش

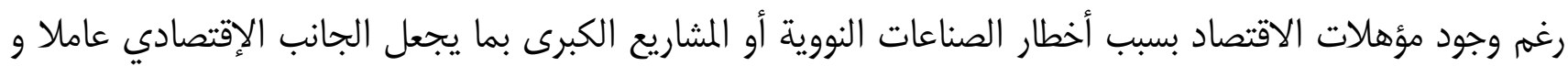
تحديات أمام الأفراد للمغادرة لأجل تحسين مستواهم المعيشي و الحفاظ على مواردهم و يمكن إيجاز عوائق التنمية لعامل البيئة كايلي:

$$
\text { - مقص الموارد الطبيعية و المائية أو إنعدامها }
$$

- تأثير العوامل الطبيعية على مخرجات الأراضي الزراعية كالجفاف و التصحر و التغير المناخي و تقدر الإحصائيات بأن 1.5 مليار يعانون من ذلك. - - نقص فرص العمل الناتج عن ضعف التنمية الإقتصادية لا سيما منها مجال الزراعة باعتباره قطاعا واسعا يحوي الملايين من مزاولو الزراعة خاصة في المناطق الريفية و تقدر الإحصائيات وجود 75 في المائة من الفقراء في هاته المناطق.

150 1طروش أمينة اللجوء البيئي كأثر للتغير المناخي ، مقال إلكتروني بمجلة القانون و الأعمال متوفر على الموقع الإلكتروني: www.droitetentprise.com/web/ala3dadAISabiaSectionsعلى الساعة العاشرة ليلا 22/02/2018 تم الإطلاع عليه يوم :

: ماجع أكثرحول العلاقة بين الهجرة و التنمية الريفية : www.fao.org/3/b-i6064a.pdf: منظمة الأغية و الزراعة للأمم المتحدة ،تقرير الهجرة و الزراعة و التنمية الريفية متوفر على الموقع الإلكتروني تم الإطلاع عليه بتاريخ 2018/02/22 على الساعة الرابعة بعد الزوال. 
- الفقر و إستنزاف الثروات لدى الشعوب بما يجعلمها غير قادرة على توفير المعيشة للأفراد داخل هاته الدول لا سيما منها الفقيرة

\section{ج- الكوارث الطبيعية و الصناعية:}

تشكل الكوارث البيئية الناتجة عن التغير المناخي أو عن عوامل شارك فيعاعية فيها الإنسان كالمصانع الكيماوية أو النووية التي

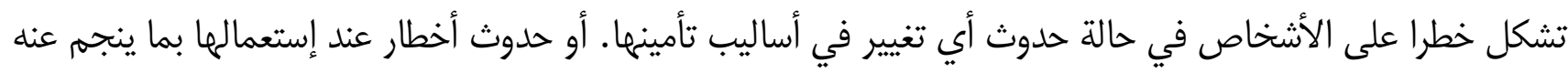
ضرر للبيئة قد تؤدي إلى التعجيل بالهجرة لعدم القدرة على التكيف مع الوضع أو انعدام الحياة فيها

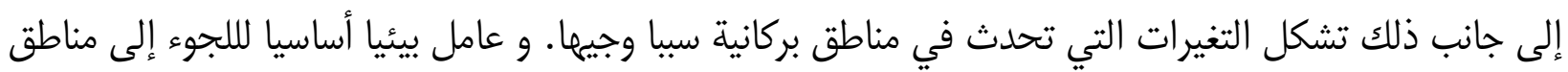

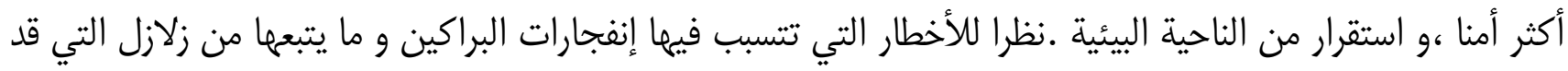

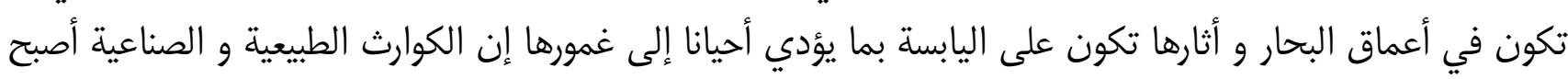
واقعا لا يمكن تجاهله و مؤثرا بيئيا

\section{المبحث الثاني:مدى وجود الأساس الدولي للجوء البيئي}

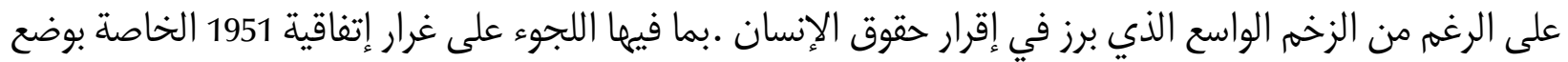

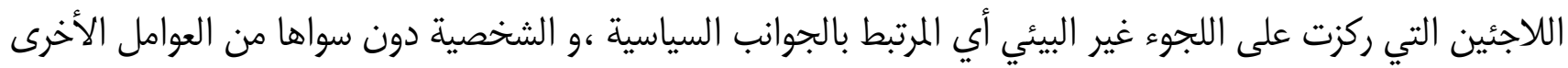

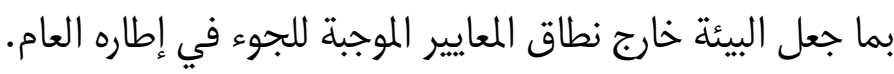

إن الأخذ بالمعيار الفردي في قضية اللجوء يجعل من الصعب بادرة إتجاه قانوني نحو إدخال البيئة كعامل للجوء بالمطابقة

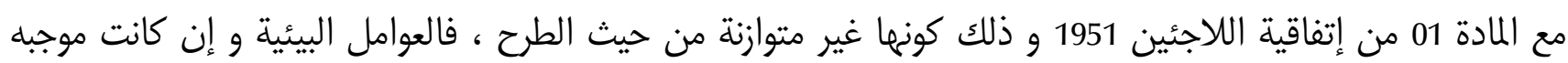

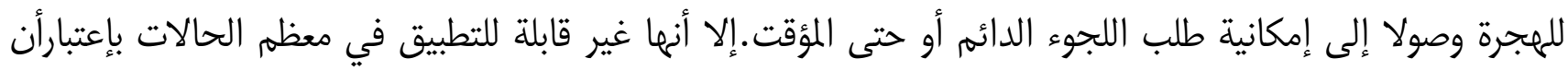

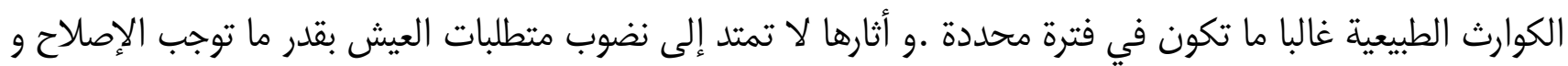

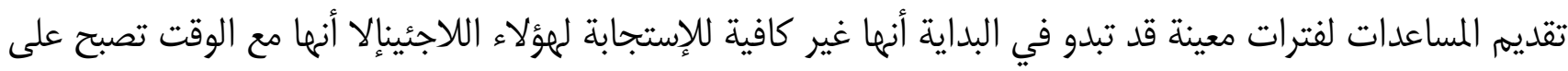

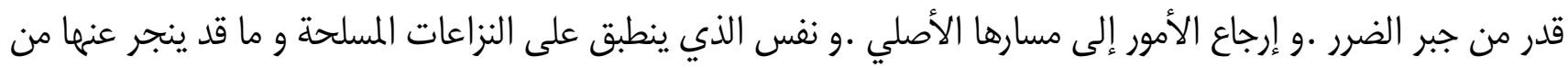

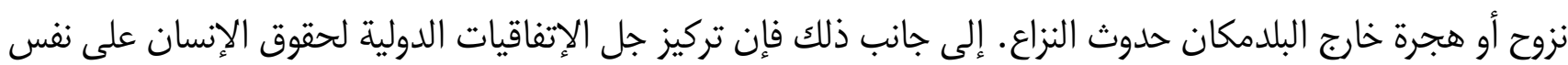

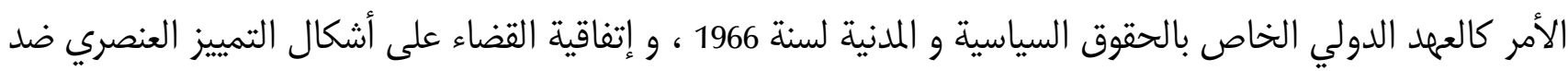

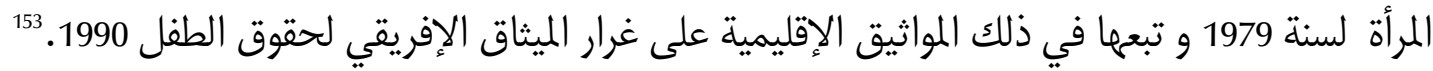

: منظمة الأغية و الزراعة للأمم المتحدة ،تقرير الهجرة و الزراعة و التنمية الريفية www.fao.org/3/b-i6064a.pdf: متوفر على الموقع الإلكتروني تم الإطلاع عليه بتاريخ 2018/02/22 على الساعة الرابعة بعد الزوال.

1531شكلت حقوق الإنسان السمة البارزة في المجتمع الدولي لذا سعت الدول عبر المنظمات الدولية و الإِقليمية إلى إقرار عشرات الإتفاقيات

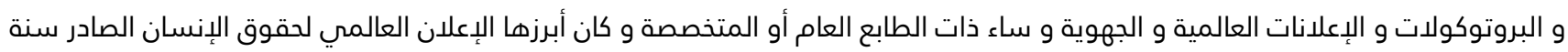

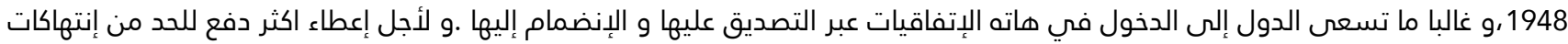


هاته الصكوك الحقوقية تضمنت في مجملها حق اللجوء و ضمانه عند حدوث الكوارث الطبيعية و ألزمت الدول بتقيد

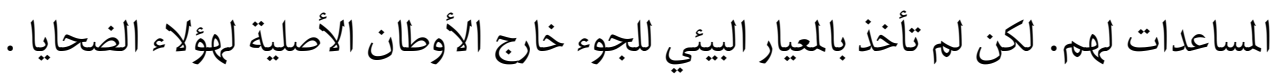

\section{المطلب الأول: اللجوء البيئي في الإتفاقيات الدولية المتعلقة بالبيئة و حمايتها}

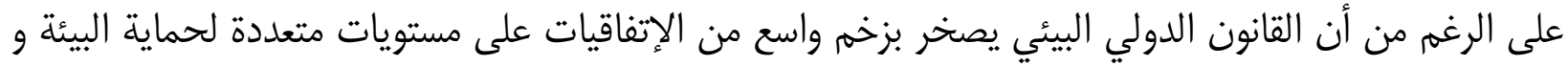

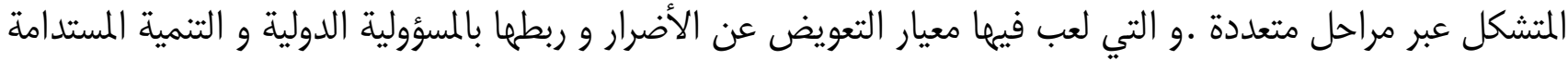

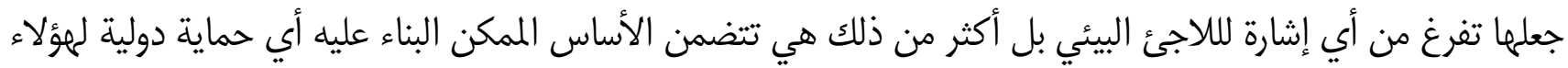

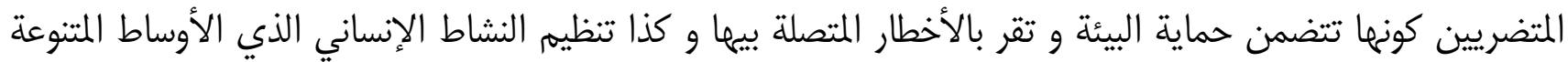

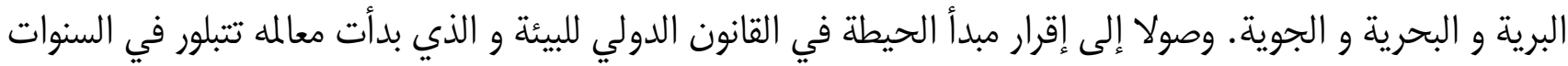

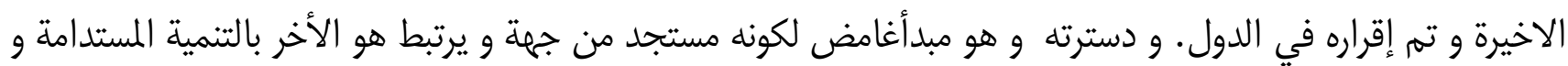

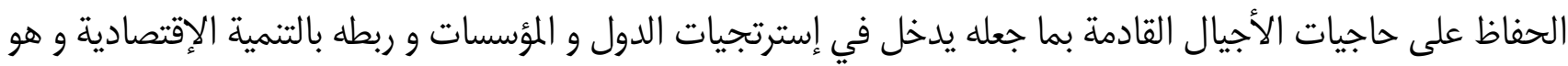

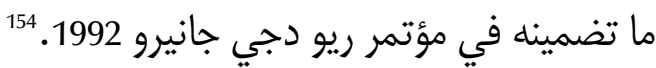

إن عدم الإهتمام الدولي بالبيئة كمعيار للجوء ليس كونه غير ممكن إقراره بل أن صعوبة الإعتراف به تكمن في مرونة

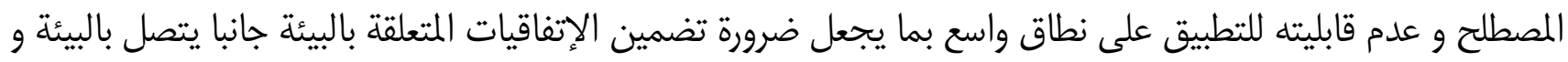

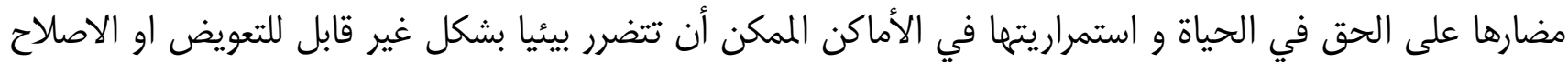
وصلا الى امكانية انعدام الحياة فيها.

\section{المطلب الثاني: حماية اللاجئين البيئيين "المنظمات الدولية والمساعدات الإنسانية"}

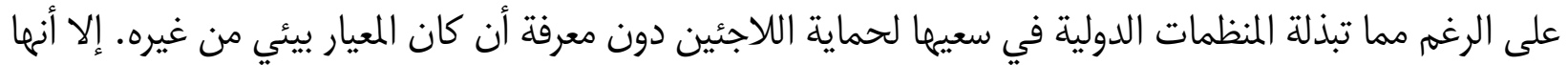
تسعى جاهدة لتطوير برامجها التدريبية الخاصة بالتأهب و الإنذار المبكر على غرار ما تقوم به المفوضية السامية لشؤون التهائ

حقوق الأفراد في المجتمع و الرقابة عليها ، و قد صادقت الجزائر على العديد من الإتفاقيات الدولية و الإقليمية منها :الإعلان العالمي لحقوق الإنسان 1948 / العهد الدولي الخاص بالحقوق المدنية و السياسية الصادر سنة 1966و الذي دخل حيز التنفيذ 1976/العهد الدولي الخاص بالحقوق الإقتصادية و الإجتماعية الصادر سنة 1966و الذي دخل حيز التنفيذ 1976/اتفاقية حقوق الطفل لسنة 1989/الاتفاقية الدولية للأشخاص لذوي الإعاقة الصادرة عن الجمعية العامة في لسنة2006 و التي دخلت حيز التنفيذ سنة2008/ و البروتوكول الإختياري لها /الميثاق الأفريقي لحقوق الإنسان والشعوب الذي تمت إجارته من قبل مجلس الرؤساء الأفارقة بدورته العادية رقم 18 في نيروبي كينيا جوان 1981/إتفاقية الحد من التمييز العنصري و العنف ضد المرأة ... وإتفاقيات أخرى و في سعي الأمم المتحدة و المنظمات المتخصصة و كذا الإقليمية لمراقبة إلتزامات الدول في مجال حماية حقوق الإنسان بشكل عام يأتي نظام التقارير للدول و الشكاوي للأفراد و الدول على حد السواء كإطار لإلتزامات أطراف إتفاقيات حقوق الإنسان من خلال إنشاءلجان متخصصة بموجب الاتفاقيات الدولية أو من خلال القرارات ،و يمكن أن نشير إلى أن نظام اللجان تقريبا مرتبط بكل إتفاقية في مجال حقوق الإنسان سواء العامة أو الخاصة.أنظر حول الآليات الدولية للرقابة على إلتزامات الدول في مجال حقوق الإنسان سواء كانت هاته لإتفاقيات ذات المضمون العان العام و الخاص المعنية بحقوق الإنسان : عبد العزيز قادري،حقوق الإنسان في القانون الدولي " المحتويات و الآليات"،الجزائردار هومة للطباعة و النشر،2003،ص و ما بعدها.

و أيضا :عمر سعد الله ،مدخل إلى القانون الدولي لحقوق الإنسان ، الجزائر: ديوان المطبوعات الجامعية، طبعة رابعة،2003،ص 187. 154 راجع حول مبدأ الحيطة :سماح محمد عبد الفتاح ، مبدأ الحيطة في البيئة ، مقال منشور بمجلة البحوث القانونية و السياسية ، عدد :07 ، كلية الحقوق و العلوم السياسية بجامعة سعيدة ،2016، ص 452 و ما بعدها 
اللاجئين التي تختص بحماية فيئة اللاجئين المنصوص عليها في اتفاقية 1951 و التي يدخل ضمنها اللاجئ البيئي بشكل

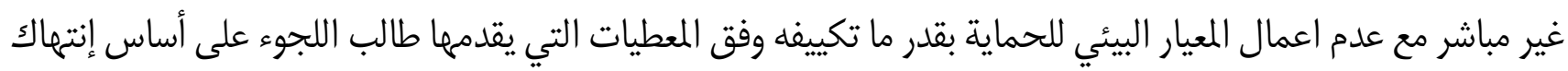

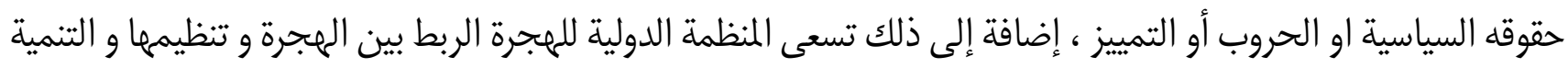

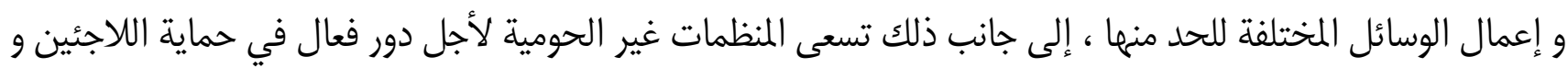

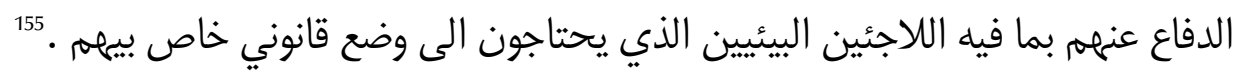

تشكل المساعدات الإنسانية أهم وسيلة لحماية اللاجئين عبر تقديم المعونة لمهم في أماكن تواجدهم نتيجة الكوارث

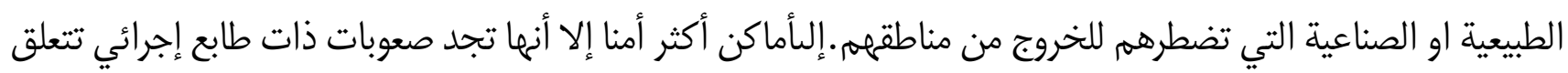
بالجمارك و تسهيلات العبور من طرف الدول.

\section{المطلب الثالث: نحو ضرورة إقرار إتفاقية دولية لحماية اللاجئين البيئيين}

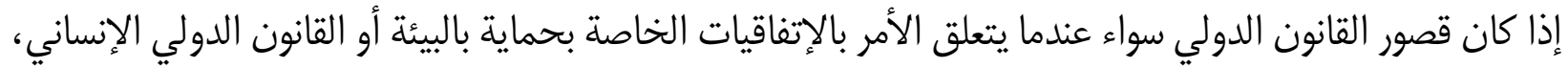

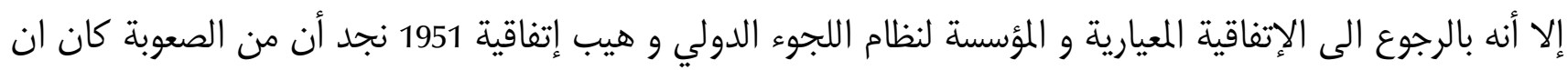

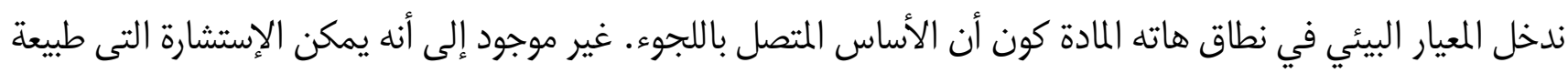

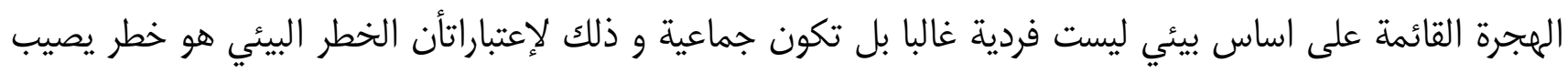

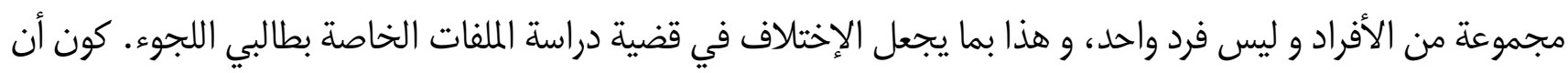

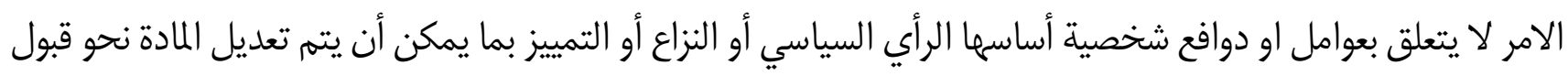

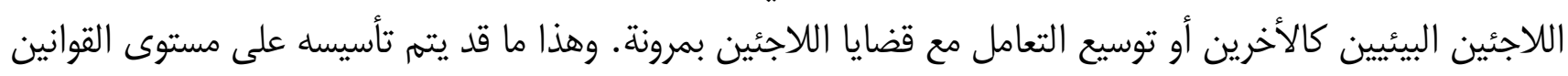

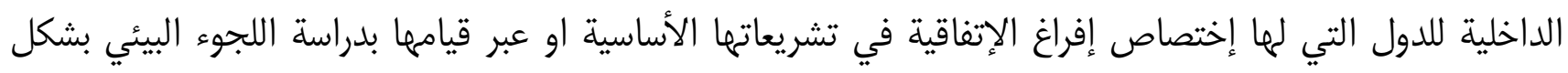

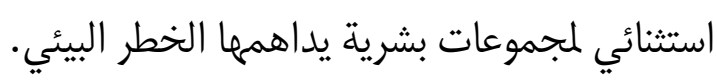
لا يمكن أن نتكلم على وضع قانوني للاجئ بيئي دون وجود أساس قانوني دولي على غرار ما يتم اقراه من التزامات

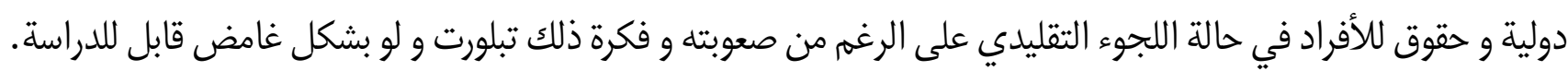

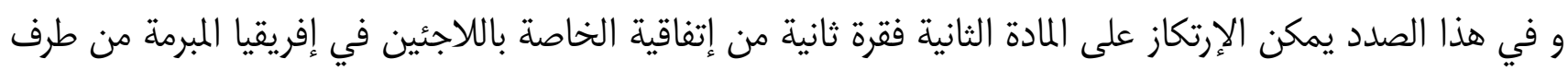

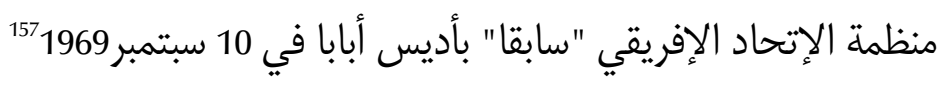
و التي تضمنت في المادة الثانية الأسباب الموجبة اللجوء التقليدي و إحتوت معيار يرتبط بالنظام العام و المتصل بامكانية

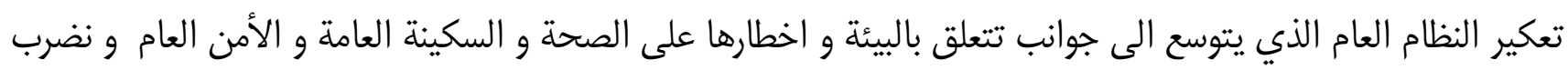

155نعم حمزة عبد الرضا حبيب ، الوضع القانوني للاجئ البيئي في القانون الدولي العام ، مذكرة ماجستير ،جامعة الشرق الأوسط ، السنة الجامعية يناير 2012، الأردن ،ص عزدة

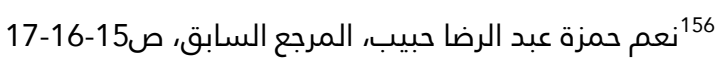
157ـ الإتفاقية التي تحكم الجوانب المختلفة لمشاكل اللاجئين في إفريقيا المعتمدة في أديس أبابا في 10 سبتمبر1969 دخلت حيز التنفيذ في 20 جوان 1974. راجع في هذا أيضا :بن فاطمة بوبكر ، المرجع السابق ، ص 102 
مثال ذلك بوقوع كارثة صناعية خطيرة كحادثة "شارنوبيل" التي تعتبر أسوأ كارثة للتسرب الإشعاعي والتلوث البيئي شهدتها

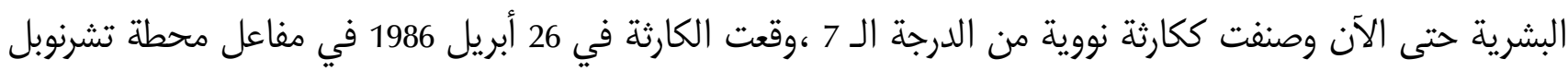

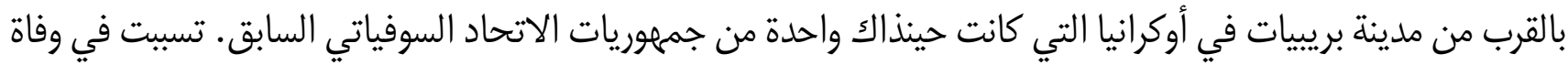

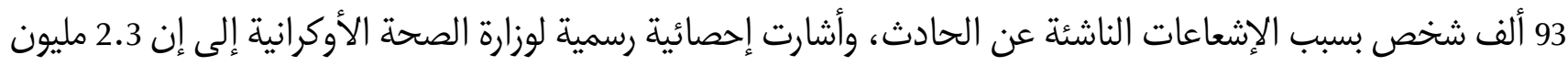

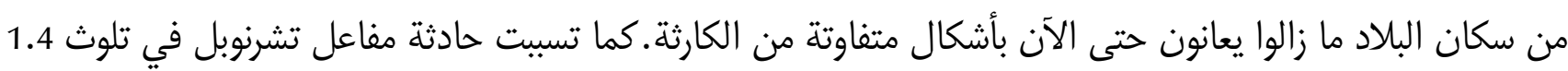

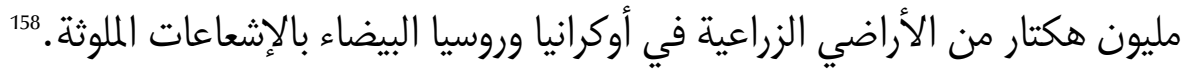

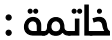

على الرغم من كون اللجوء البيئي لم ينل الإهتمام الدولي الذي بقي محصور في الإهتمام باللجوء التقليدي و تضمينه

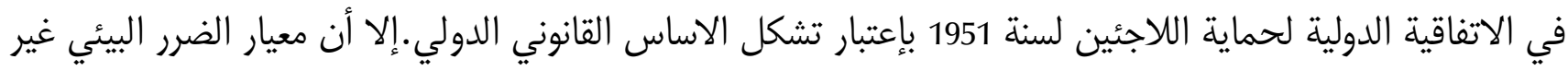

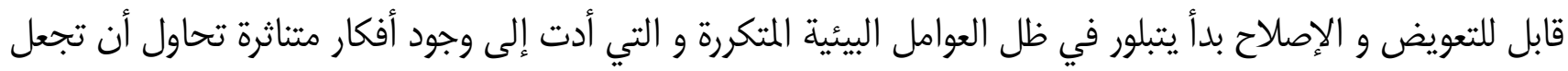

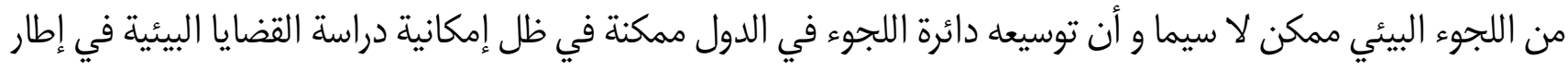

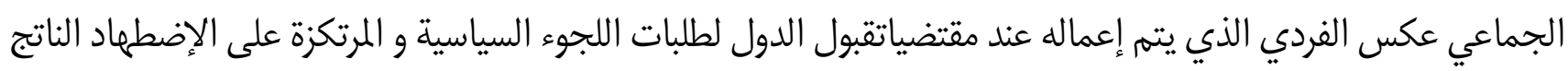
عن الحروب و التمييز. لقد أصبح من الضروري إعادة النظر في المواثيق الدولية سواء تلك المتصلة بحماية البيئة و تضمينها تأثير التغير المناخي

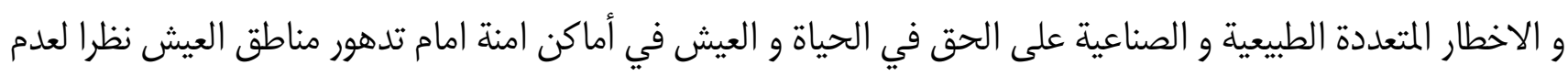

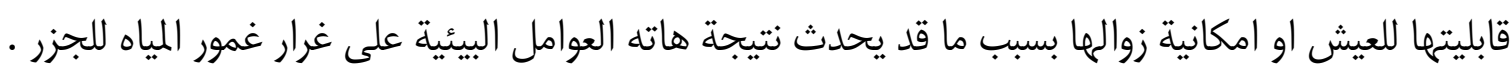

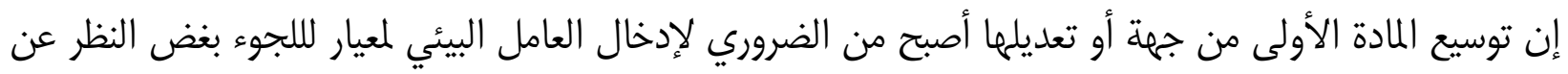

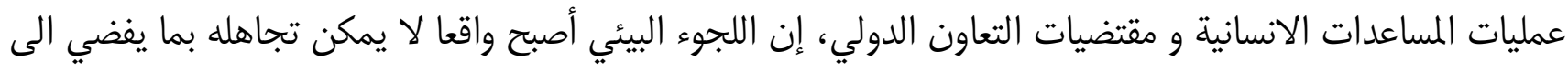

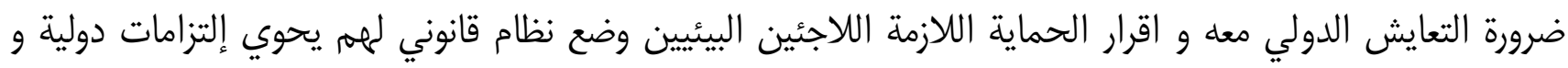
يعطيهم حقوق وواجبات للمه على غرار اللاجئين التقلديين. 


\section{المَفْفِن وأثنده في أعمال السلطة التشريعية}

\section{(دراسة في مدى دستورية انعقاد مجلس النعاب بمدينة طبرق)}

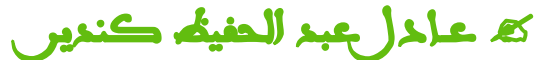

أستاذ مشارك كلية القانون جامعة طرابلس

\section{مقـدمـة}

جرت في ليييا بتاريخ 25 يونيو 2014 انتخابات برلمانية لاختيار مجلس النواب, المقرر انعقاده بمدينة بنغازي, وفقا للفقرة

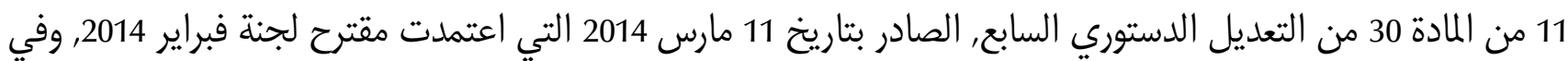

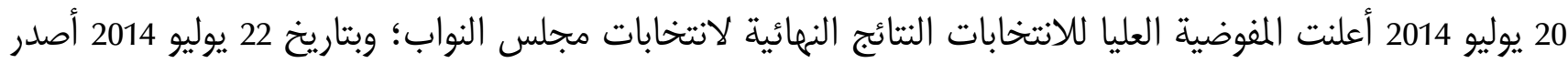
رئيس المؤتمر الوطني العام 159 القرار رقم 56 لسنة 2014 بدعوة المؤتمر الوطني العام ومجلس النواب للانعقاد ليتم التسليه

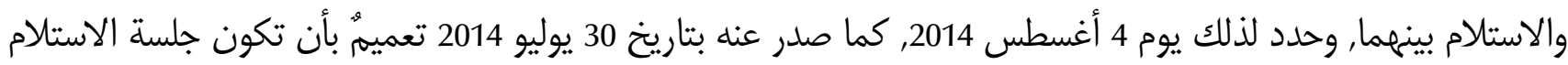
والتسليم بطرابلس.

استلم رئيس المؤتمر رسالتين هاتفيتين 160 بتاريخ 30 يوليو 2014 إحداهما من أكبر أعضاء مجلس النواب سنا, يعلمه بأن

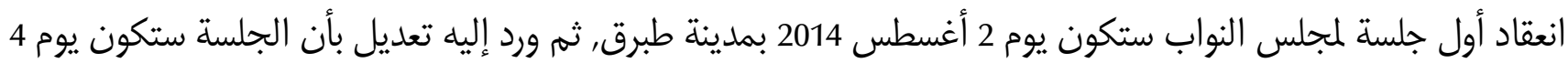

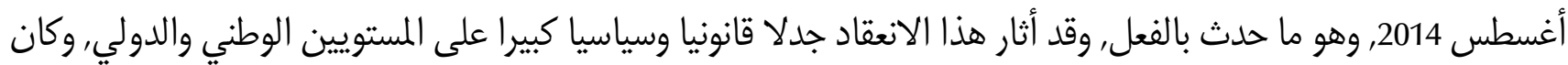

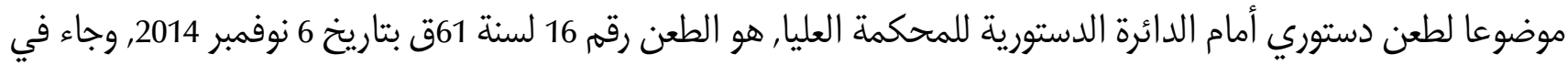

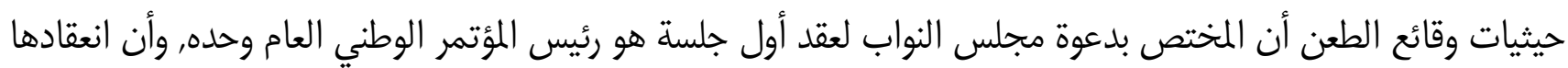

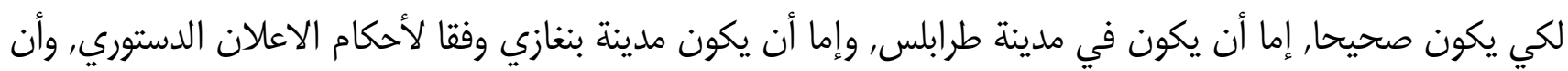

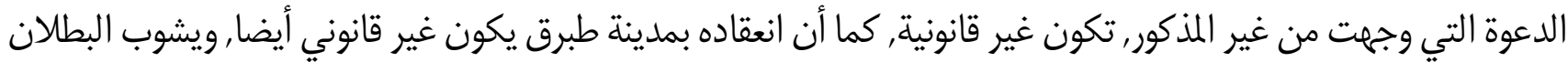

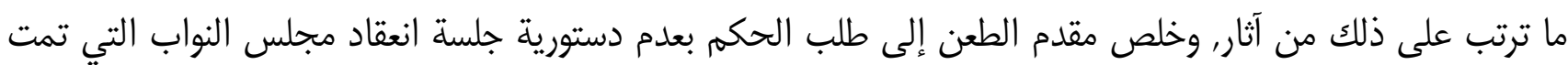

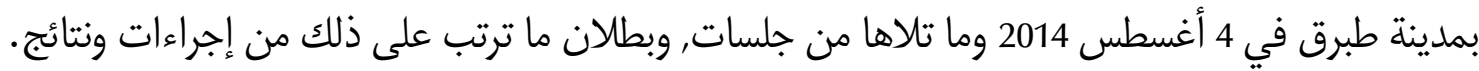

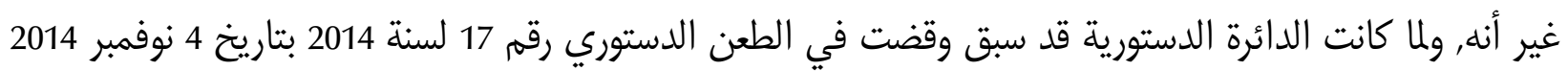
بعدم دستورية الفقرة 11 من المادة 30 من الإعلان الدستوري السابع, الصادر بتاريخ 11 مارس الدان 2014 وكافة الآثار المترتبة

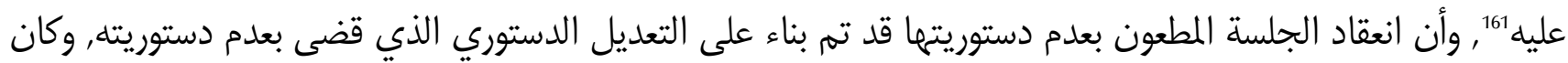

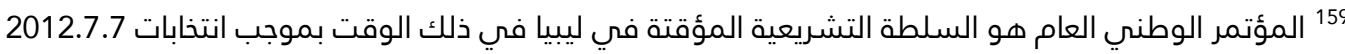
160 انظر وقائع الطعن الدستوري رقم 16 لسنة 61 قضائية بتاريخ 6 نوفمبر 2014. 161 جاء في حيثيات حكم المحكمة العليا في الطعن الدستوري رقم 17 لسنة 61 ق بتاريخ 6 نوفمبر 2014 ما يلي: " ... وحيث إن الأحكام الصادرة في الدعاوى الدستورية , وهي بطبيعتها دعاوى عينية توجه الخصوم فيها إلى النصوص التشريعية المطعون عليها بعيب دستوري تكون لها حجية مطلقة بحيث لا يقتصر أثرها على الخصوم في الدعاوى التي صدرت فيها, وإنما ينصرف هذا الأثر إلى الكافة وتلتزم به جميع سلطات 
لهذا القضاء حجية مطلقة حسمت الخصومة الدستورية؛ فقد قضت المحكمة بأن الخصومة الماثلة تكون غير ذات موضوع, الأمر الذي يتعين معه الحكم باعتبارها منتهية,

وبمعنى آخر , بالنظر إلى أن المحكمة قد قضت في الطعن الدستوري رقم 17 لسنة 61ق بعدم دستورية نص الفقرة 11 فإن المحكمة لم تفصل في دستورية الانعقاد بمدينة طبرق وعدمه, على اعتبار أن الخصومة الماثلة أمامها في الطعن الدستوري رقم 16 لسنة 61ق صارت منتهية, وبصرف النظر عما انتهى إليه حكم القضاء, فإن الأمر الذي يتطلب من الناحية الفقهية رفع الغموض والإبهام والجدل الذي أحاط بدستورية هذا الانعقاد وعدمهأ162, أي باختصار فإنه في هذه الدراسة سينظر في مدى صحة انعقاد مجلس النواب بمدينة طبرق, بمعزل عن مدى دستورية وجوده؟ عليه, يتطلب الفهم الجيد للإششالية القانونية المثارة بشأن انعقاد مجلس النواب في مدينة طبرق بالمخالفة لأحكام التعديل السابع للإعلان الدستوري المؤقت, ضرورة تأصيل المسألة تأصيلا قانونيا معمّقا, للوصول إلى نتيجة قانونية مقنعة, وهو ما يتطلب الحديث عن الموطن بكونه أحد محددات الشخصية القانونية للشخص الاعتباري؛ على اعتبار أن الإشكالية المثارة تتعلق بانعقاد مجلس النواب, وهو شخص اعتباري, في مدينة غير تلك المُحدَدَة في الإعلان الدستوري, مقرّاً لهزذا

ولذلك فإن الدراسة المعمّقة تتطلــب تناول الموضوع من شقين: يتهم في الأول دراسة أهــــم الأحكام العامة للموطن

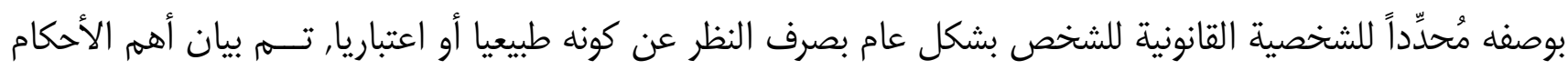
الخاصة بالموطن بوصفه مُحدِّداً للشخصية القانونية للشخص الاعتباري, وعليه سيتم تقسيم هذه الدراسة إلى مطلبين وفق بـن

\section{- المطلب الأول: الأحكام العامة للمَّْطن بوصفه محدِّدا للشخصية القانونية.} - المطلب الثاني: الأحكام الخاصة بمَوْطِن الشخص الاعتباري.

\section{المطلب الأول: الأحكام العامة للمَوْطِن بوصفه محدِّدا للشخصية القانونية}

سيته في هذا المطلب التعرض لبيان أحكام ذات صلة بالشخصية القانونية بشكل عام (أولا) ثم لبيان تلك الأحكام العامة ذات الصلة بتحديد المَوطن (ثانيا).

الدولة وفقا للمادة 31 من قانون المحكمة العليا سالف الذكر, سواء كانت هذه الأحكام قد انتهت إلى عدم دستورية النص التشريعي المطعون فيه أم إلى دستوريته, ورفض الدعوى على هذا الأساس ... " 162 رغم قضاء الدائرة الدستورية بالمحكمة العليا في الطعن الدستوري رقم 17 لسنة 61ق بتاريخ 4 نوفمبر 2104 بعدم دستورية الأساس القانوني الذي بني عليه مجلس النواب, وأن هذا الأخير صار والعدم سواء؛ فإن أهمية البحث في هذه المسألة تكمن في أنه بتاريخ 17 ديسمبر 2015 تم توقيع اتفاق سياسي بمدينة الصخيرات المغربية بين المؤتمر الوطني العام ومجلس النواب, أقر هذا الاتفاق بوجود مجلس النواب بأثر رجعي, وقضى في مادته 16 بمراجعة مقر الانعقاد المؤقت, وبرغم اعتماد المؤتمر الوطني العام للاتفاق في جلسة بتاريخ 6 إبريل 2016 بقصر ولي العهد بطرابلس، فإن مجلس النواب علق موافقته النهائية بالتحفظ على إحدى مواد الاتفاق, وذلك في جلسة له بتاريخ 5 يناير 2016 


\section{أولا: مفهوم الشخصية القانونية}

تُعرّف الشخصية القانونية بأنها: القدرة أو المكنة التي يكتسبها فرد أو كيان قانوني على اكتساب الحقوق وتحمل الالتزامات (أهلية الوجوب) وإبرام التصرفات القانونية (أهلية الأداء).

ووفقا لأساسيات علم القانون يتحدد نطاق الشخصية القانونية لأي فرد (الشخص الطبيعي) أو كيان قانوني (الشخص الاعتباري)163 في شقي الأهلية (الأداء والوجوب) بعناصر ثلاثة: الاسم والموطن والحالة الذي يلعبه المَوَِن - بوصفه معياراً جوهرياً - في تحديد الحقوق المكتسبة وتحمّل الالتزامات المفروضة, وكمعيار جوهري أيضا في تحديد مدى صحة الأعمال والتصرفات الصادرة عن الشخص, سواء أكان طبيعيا أم اعتباريا. وأهمية الموطن بوصفه مُحدِّداً للشخصية القانونية للشخص بشكل عام لا تنحصر فقط في إطار علاقات القانون الخاص, بل تمتد لتشمل علاقات القانون العام 165 ولهذه النقطة أهمية بالغة في مجال هذه الدراسة؛ لأن الإشكالية التي تعالجها هذه الدراسة تتعلق بأعمال السلطة التشريعية وهو موضوع ذو صلة بالقانون الدستوري الذي يشكل فرعا من فروع القانون العام, فمن خلال الالتزام بالموطن نستطيع أن نحدد ليس فقط مدى صحة ممارسة مجلس النواب لحقوقه ووفائه

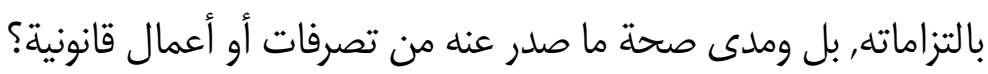
إذ سيتبينّ لاحقا أن مسألة الالتزام بالموطن تلعب دورا جوهريا في صحة أو بطلان أعمال السلطة التشريعية في أغلب دساتير العالم.

السؤال المرهم الآن, هو كيف يتحدد موطن الشخص بشكل عام وفق أساسيات علم القانون؟ الإجابة على هذا التساؤل ستجد لها حضور في الفقرة التالية:

\section{ثانيا: الأحكام العامة ذات الصلة بتحديد الموطن} تقول القواعد العامة في أساسيات علم القانون بحرية الشخص في اختيار المكان الذي يختاره موطنا له, إلا أن هذه القواعد ليست مطلقة من دون قيد أو شرط, فالاستثناء هو: أن القانون قد يتدخل في تحديد مكان معين موطنا محددا للشخص 166, وفي هذه الحالة يكون هذا المكان موطنا إلزاميا للشخص, وهو ما يسمى بالموطن القانوني أو الإلزامي أو

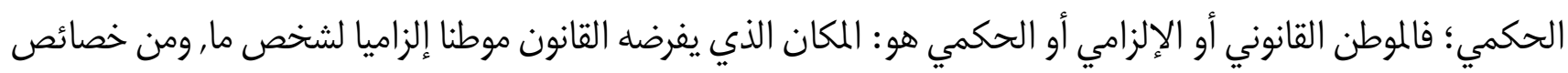
الموطن القانوني أو الإلزامي أو الحكمي التي تستنبط من التعريف: 1- أنه موطن اجباري لا اختياري؛ لأنه محدد أو معيّن بنص قانوني مانع.

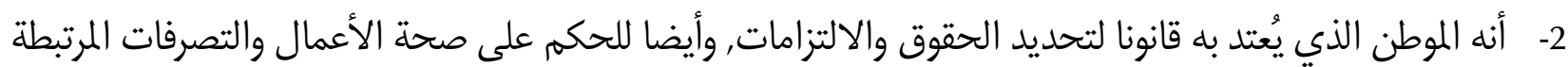
بعلاقات الشخص, سواء أكانت في إطار القانون الخاص أم العام.

163 المادة 53 من القانون المدني الليبي تقضي بأن يكون لكل شخص اعتباري موطن مستقل, وهو المكان الذي توجد فيه مقر أو مركز إدارته.

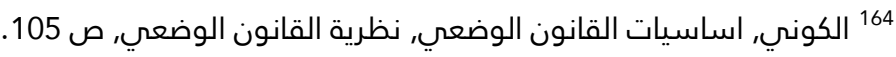
165 المرجع السابق, ص 113- 114. 166 الكوني, المرجع السابق, ص 118. 
3- أنه موطن لا يقبل التغيير بإرادة الشخص ما دام ظل سبب فرضه قائما, ولا يكون التغيير إلا في حال زوال السبب

$$
\text { ووفقا لما هو منصوص عليه في القانون } 167 .
$$

واستنادا إلى ما تقدم, يمكن القول: إن تحديد بنغازي موطنا لمجلس النواب لم يأتِ بموجب نص قانوني عادي, بل بموجب نص دستوري, فلقد جاء في المادة 16 من مقرح لجنة فبراير المعتمد بموجب التعديل السابع للإعلان الدستوري المؤقت الصادر بتاريخ 11 مــارس 2014 ما يلي:

$$
\text { ( يكون مقر مجلس النواب مدينة بنغازي, ويجوز له عقد اجتماعاته خارج مقره الرسمي (169. }
$$

لا شك أن النص السابق يجعل من المدينة المذكورة في النص (مدينة بنغازي) موطنا دستوريا إلزاميا حكميا لا اختياريا, وبعبارة أخرى فإن اختيار هذه المدينة موطناً لمجلس النواب, يشكل استحقاقا دستوريا لا يمكن تعديله أو تجاهله بإرادة

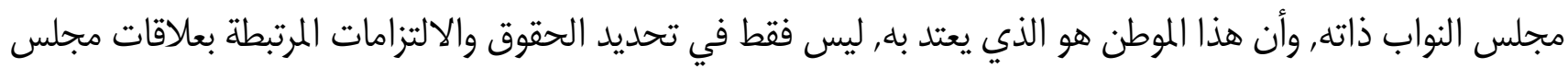
النواب, بل وفي الحكم على مدى صحة أعماله وتصرفاته في إطار القانون العام, وتحديدا القانون الدستوري؛ فهذا الموطن لا يقبل التغيير بإرادة رئيس مجلس النواب المنفردة, أو بإرادة أعضائه الجماعية إلا بتعديل الإعلان الدستوري, ووفقاً للإجراءات والشروط المنصوص عليها فيه ${ }^{170}$ كما لا يملك رئيس المؤتمر الوطني العام نفسه تغيير هذا الموطن, أو أن يفوّض

167 168 تم إقرار هذا التعديل من قبل المؤتمر الوطني العام في جلسة 11 مارس 119 مارس 2014 تمهيداً لإنهاء المرحلة الانتقالية التي يقودها المؤتمر الوطني العام بعد ظهور حراك لا للتمديد الذي كان يقول بانتهاء ولاية المؤتمر في 4 فبراير 2014.

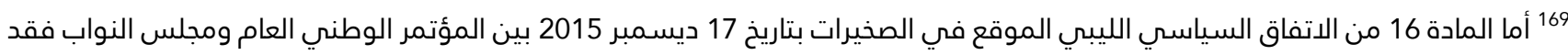
جاء فيه ما يلي: ( يعقد مجلس النواب, بعد التحاق من يرغب من النواب المقاطعين, جلسة تخصص للنظر في القضايا التالية:

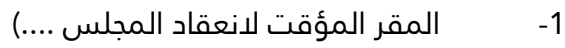
170 جاء في المذكرة الشارحة لأسباب الطعن الدستوري رقم 16 لسنة 61 قضائية ما يلي: ( .. وقد توفر هذا العيب عندما حددت الوثيقة الدستورية شكلا واجراءات معينة من قبل السلطة التشريعية المختصة "مجلس النواب" وهو أن يكون مقر الانعقاد الرسمي "مدينة بنغازي" وفقا للإعلان الدستوري, حيث نصت المادة 16 من مقترح لجنة فبراير المعتمد بموجب التعديل الدستوري السابع على أنه "يكون مقر مجلس النواب مدينة بنغازي ويجوز له عقد اجتماعاته خارج مقره الرسمي" , وخالف المجلس في في واقعة الحال هذه الشكلية "الشرط" بانعقاده خارج المقر الدستوري بدون قرار تشريعي صحيح يخوله ذلك, فلكي يكون الانعقاد خارج المقر صحيحا يجب أن يتخذ القرار من المؤتمر الوطني العام أو من مجلس النواب بقرار بعد انعقاده انعقادا صحيحا, ولا نخلط هنا بين جلسة التسليم والاستلام

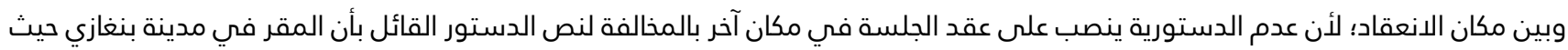
أن المقرر فقها وقانونا أنه يجب مراعاة جميع قواعد الاختصاص الشكلي عند مباشرة السلطة التشريعية "مجلس النواب" سلطاتهات الطان المخولة لها من قبل الدستور, وهناك العديد من القواعد والاجراءات الشكلية مثل: - مضور الأغلبية لصحة انعقاد الجلسة.

- ض ضرورة توافر نصاب معين حين اجراء التصويت لاتخاذ القرارات. - عدم جواز مناقشة مشروع قانون أو قرار قبل مناقشته من قبل اللجنة المختصة. - ضرورة إقرار مشروع القانون قبل عرضه. - متص يجوز تقديم مشروع القانون مرة ثانية.... ).

لمزيد التفصيل, انظر, الأستاذ المحامي أبوبكر علي الشريف: الطعن الدستوري رقم 61/16ق (من التقرير بالطعن حتى صدور الحكم, سنة . 1436هـ/2014م) 
غيره في ذلك؛ لاسيّما إذا ترتب على تغيير الموطن نقل مركز إدارة مجلس النواب ومركز نشاطه معا, على النحو الذي سيته بيانه في الفقرة التالية:

\section{المطلب الثاني: الأحكام الخاصة بمَوْطِنِ الشخص الاعتباري}

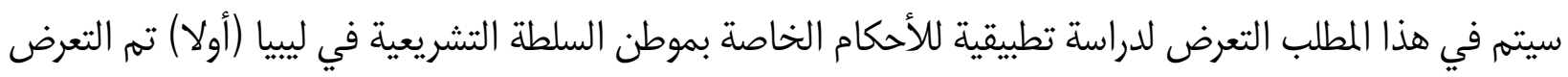
لدراسة مقارنة في هذا الخصوص (ثانيا).

\section{أولا: تطبيق الأحكام الخاصة بمَوْطِن السلطة التُّة التشريعية على الحالة الليبية}

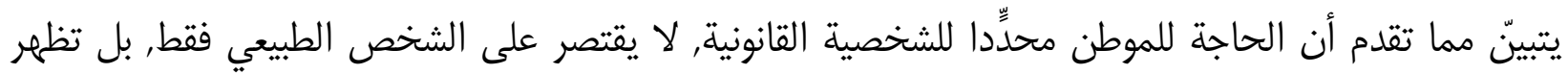

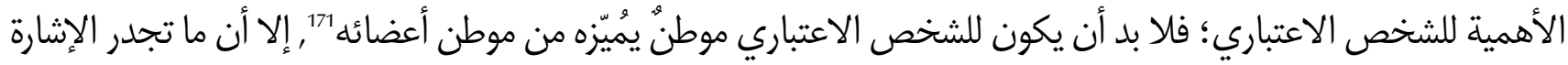

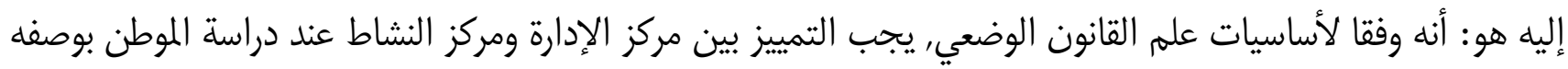

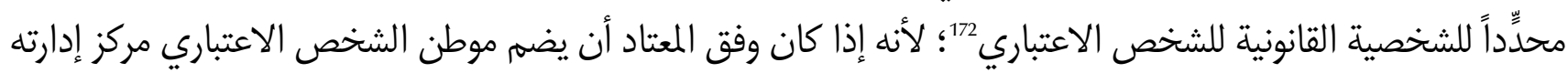

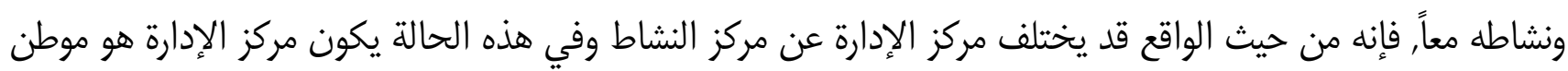

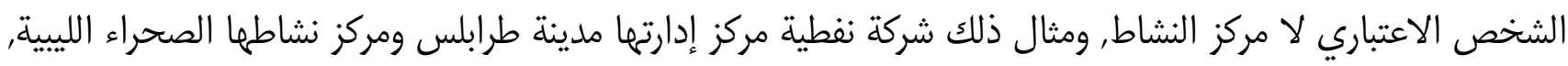

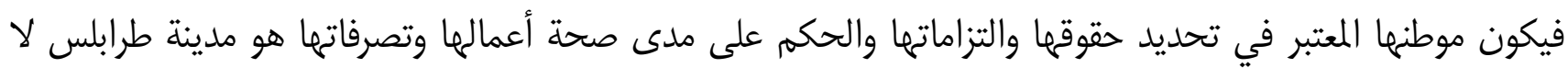

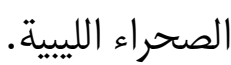

عليه, وفيما يتعلق بالسلطة التشريعية (مجلس النواب) فإنه في العادة يكون مركز إدارتها ومركز نشاطها في موطن

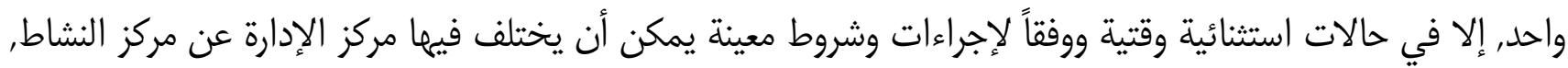

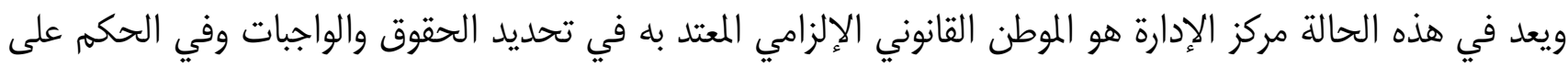
مدى صحة الأعمال والتصرفات الصادرة عن السلطة التشريعية.

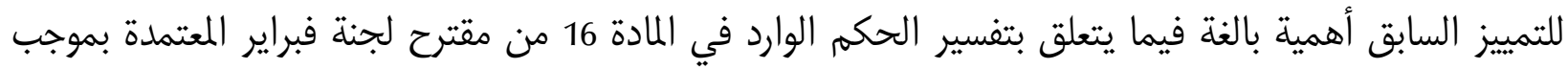

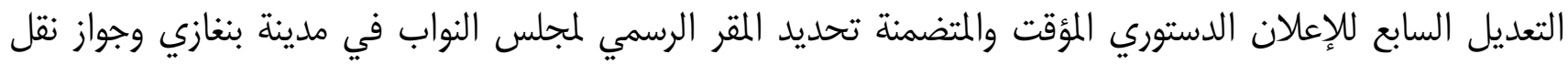

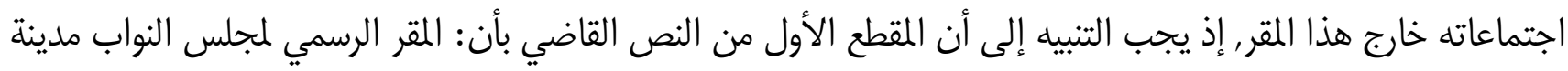

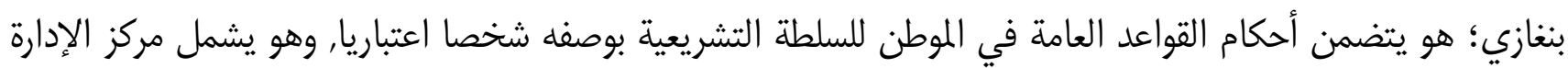

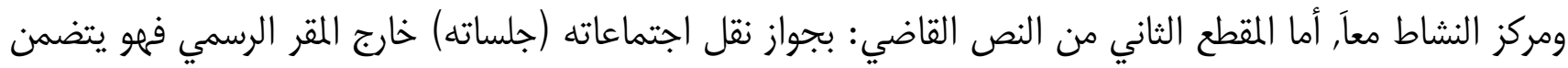

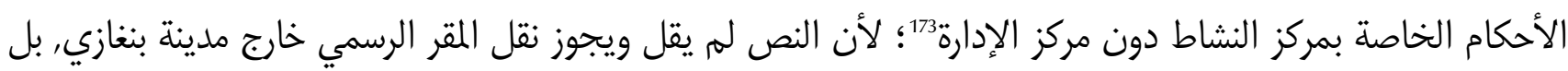

173 ذكر محامي عبد الباسط الحداد في مرافعته في الطعن رقم 16 لسنة 61 ق بجلسة 20 أكتوبر 2014 ما يلي:

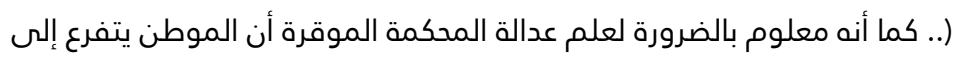

1- موطن الإدارة, وهو بالنسبة للبرلمان المقر الرئيس الذي يوجد به الديوان وقد تحدد هذا الموطن بنصص دستوري وهو مدينة ببنغازي. 2- موطن ممارسة النشاط, وهو المكان الذي يعقد فيه مجلس النواب جلساته ويصدر فيه قراراته. ومدلول ذلك أن موطن الإدارة وقد تحدد بنص دستوري فلا يجوز تعديله إلا بموجب تعديل دستوري لاحق. أما مكان ممارسة النشاط وعقد الجلسات فإنه وطبقا للمادة 16 من مقترح 
قضى بجواز نقل الاجتماعات (الجلسات) خارج المقر الرسمي, وهو ما يؤكد إلزامية بقاء المقر الرسمي (مركز الإدارة) في مدينة

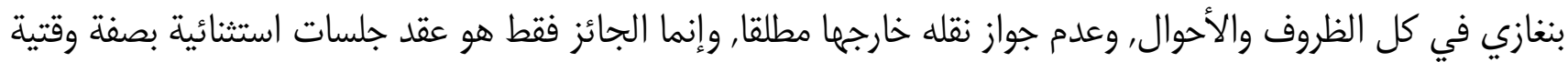

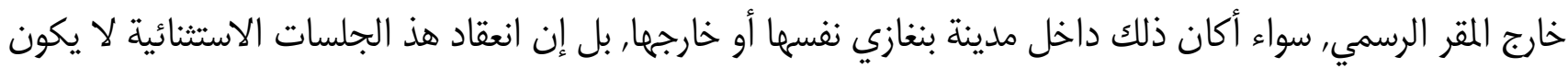

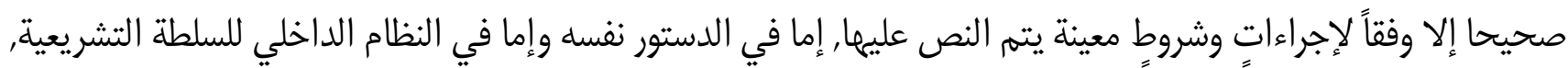

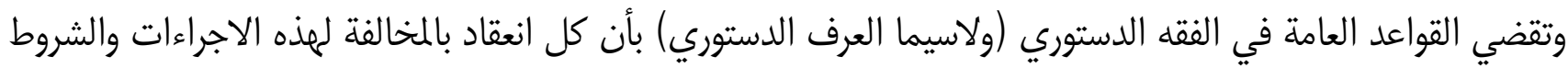
هو انعقاد باطل وأن البطلان يمتد ليشمل ما ترتب على الانعقاد من أعمال وتصرفات على نحو ما سيتم بيانه لاحقا. عليه, وبالنظر لما تقدم, يجب التمييز بين نقل المقر بمركزيه الإدارة والنشاط معا, وبين نقل مركز النشاط فقط؛ ففي الناطي

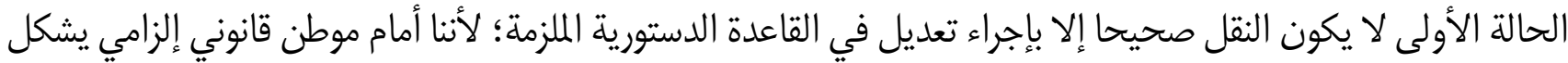

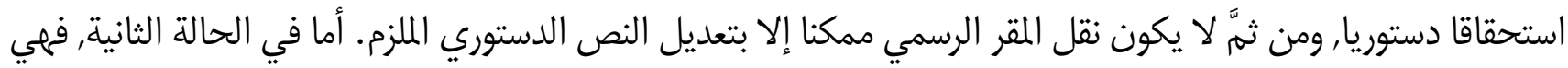

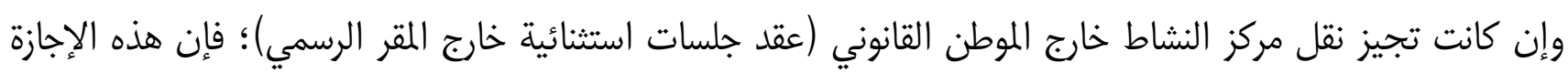

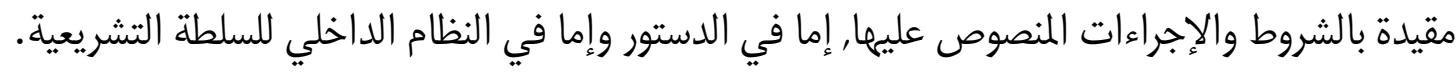

ورجوعا للحالة الليبية, نجد أن انعقاد مجلس النواب في مدينة طبرق بتاريخ 4 أغسطس 2014م لهم يقتصر على نقل

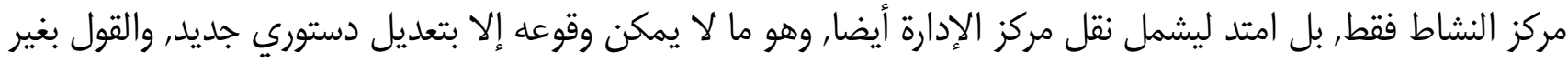

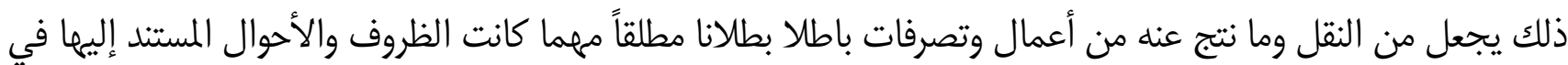

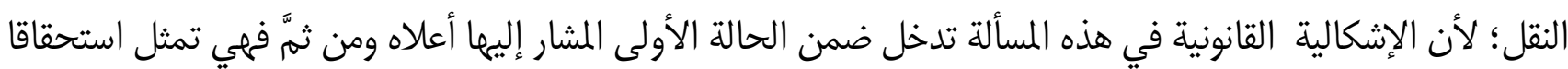

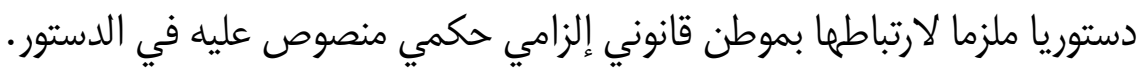

هذا فضلا عن أن نقل مركز النشاط فقط دون مركز الإدارة (عقد جلسات استثنائية خارج المقر الرسمي بمدينة بنغازي)

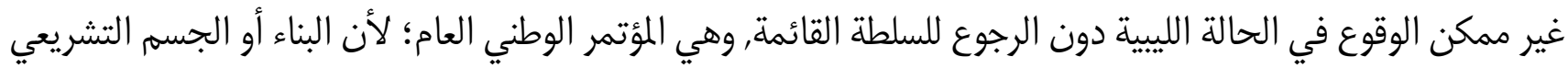

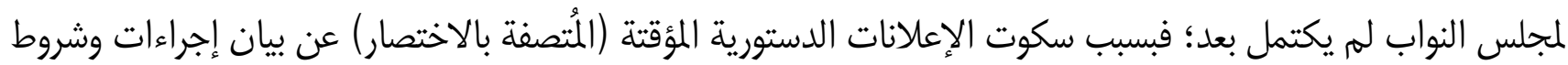

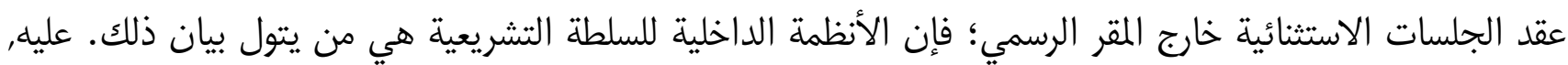

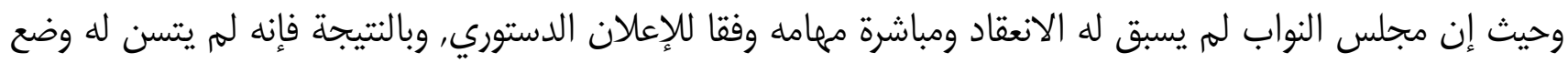

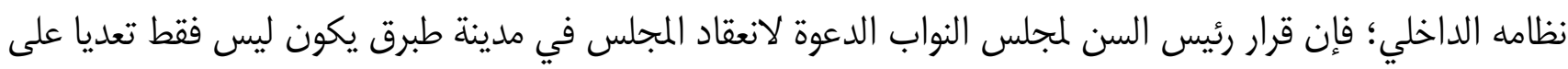

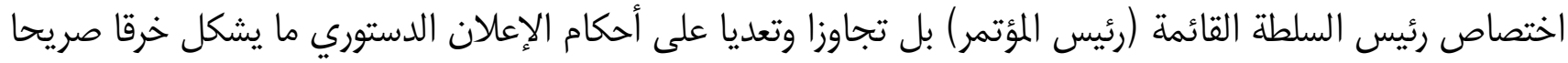

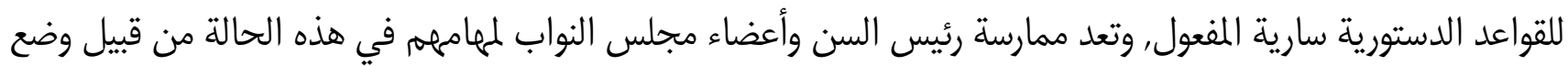
العربة أمام الحصان!

ولذلك كان على الأعضاء المنتخبين لمجلس النواب أن يتقدموا بطلب إلى المؤتمر الوطني العام بتعديل الإعلان

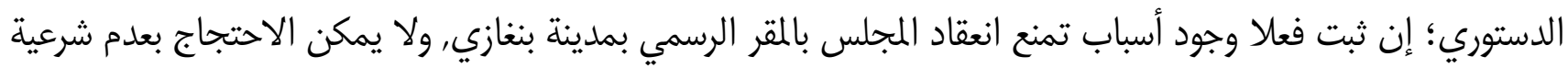

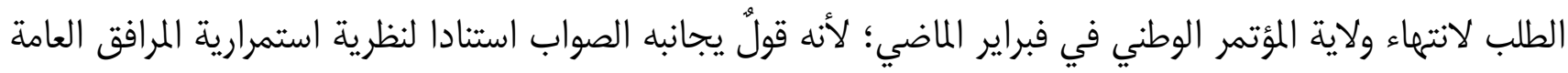

فبراير .. فقد أجازت "بقرار من مجلس النواب" عقد جلساته خارج مقره الرسمي, إلا أن ذلك مشروط بضوابط واجراءات وقرار يصدره المجلس في اجتماع منعقد طبقا للقانون..) . 
التي تقضي باستمرارية المؤتمر الوطني العام لأداء مهامه حتى تستلهم السلطة اللاحقة له مهامها, وذلك ضمانا لاستمرار الخدمة العامة, وتسيير الأمور اليوميت, وعدم ترك فراغ سياسي وفقا لما تقضيه المصلحة العامة.

\section{ثانيا: تطبيقات مقارنة ذات صلة بأحكام مّوْطِن السلطة التشريعية}

خلصت الدراسة فيما تقدم إلى أن نقل مقر مجلس النواب (بمركزيه الإدارة والنشاط) إلى مدينة طبرق, وكذلك انعقاد جلسات المجلس بهزه المدينة بناء على دعوة رئيس السن, هو إجراء باطل لمخالفته الصريحة لأحكام الإعلان الدستوري ويمتد البطلان ليشمل ما صدر عن المجلس من أعمال وتصرفات, وفقاً لما تقضي به الأعراف الدستورية السائدة في عالم لماته

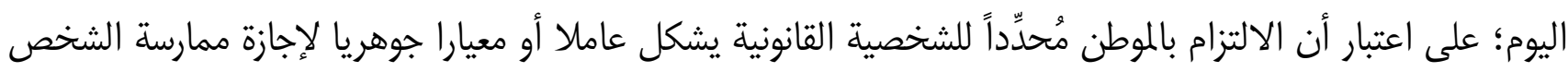
لحقوقه و الإقرار بالوفاء بالتزاماته, وإصباغ صفة المشروعية على أعمالد, ولتأكيد هذا القول سيتهم الاستشهراد بأحكام الدساتير المقارنة, وأهمما ما ورد في الباب الخامس, الفصل الأول من الدستور المصري الأخير الصادر في عام 2014, والذي جاء فيه أن مقر مجلس النواب مدينة القاهرة, وأنه يجوز في الظروف الاستثنائية عقد جلساته في مكان آخر بناء على طلب رئيس الجمهورية أو ثلث أعضاء المجلس, وأن أي اجتماع للمجلس على خلاف ذلك, وما يصدر عنه من قرارات باطل فئلـ فالجدير بالإشارة إليه في هذا النص أن نقل مركز النشاط (الجلسات الاستثنائية) بالمخالفة للشروط والاجراءات المحددة

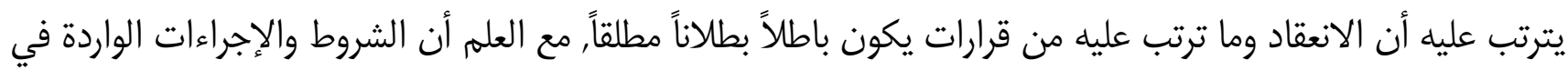
نص المادة 114 من الدستور المصري هي من قبيل الأحكام العامة التي سيأتي تفصيل بيانها في النظام الداخلي لمجلس النواب, فمثلا كيف يتولى رئيس الدولة تقديم الطلب؟ وإلى من؟ هل إلى رئيس المجلس منفردا أو إلى الأعضاء مجتمعين؟ ومتى؟ هل سيكون أثناء الانعقاد؟ أو عبر البريد المسجل؟ إلخ .. وكذلك الحال عندما يتعلق الأمر بطلب مقدم من ثلثي الأعضاء؛ فكل مثل هذه الأمور والإجراءات سيتكفل ببيانها النظام الداخلي لمجلس النواب؛ وإذا ما تم الانعقاد بالمخالفة لذلك؛ فإن الانعقاد وما نتج عنه من قرارات سيكون باطلاً بطألاناً مطلقاً.

عليه, ولما كان عقد الجلسات الاستثنائية (نقل مركز النشاط فقط) بالمخالفة للشروط والإجراءات المنصوص عليها في الدستور, أو في النظام الداخلي يجعل من الانعقاد وما ترتب عليه من قرارات باطلاً بطلاناً مطلقاً: فمن باب أولى إن نقل مقر مجلس النواب (بمركزيه الإدارة والنشاط) دون تعديل الإعلان الدستوري يجعل من هذا النقل وما ترتب عليه من قرارات باطلاً بطالاناً مطلقاً, وتجدر الإشارة إلى أن هذا الحكم منصوص عليه في جل الدساتير المصرية منذ العام 1971, وهو منصوص عليه في الدستورين الإماراتي والكويتي؛ حيث تقضي القواعد الدستورية في الإمارات العربية المتحدة بأن كل

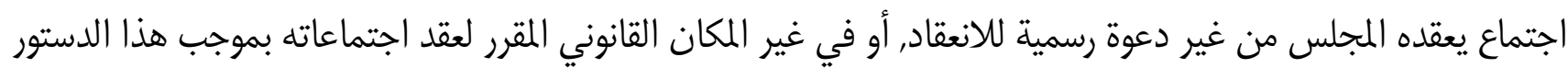
يعد باطلا ولا يترتب عليه أي أثر ${ }^{175}$ أما القواعد الدستورية في دولة الكويت فتقضي بأن كل اجتماع يعقده المجلس في غير

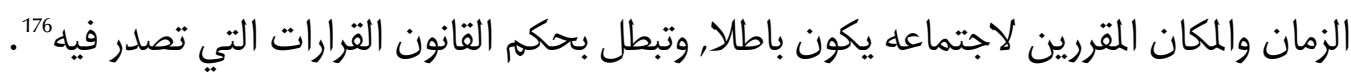


والذي تهدف الدراسة للوصول إليه من خلال ما تقدم, هو أن تكرار النص في أكثر من دولة على بطلان أعمال

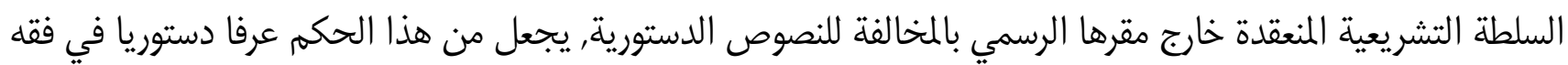

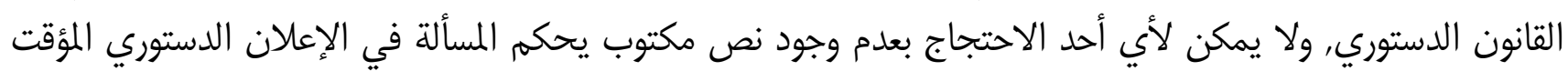

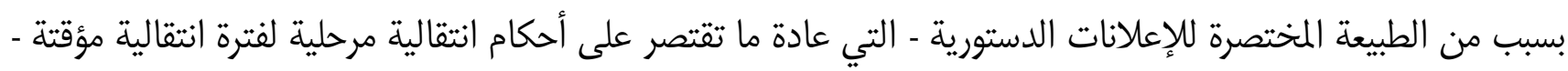

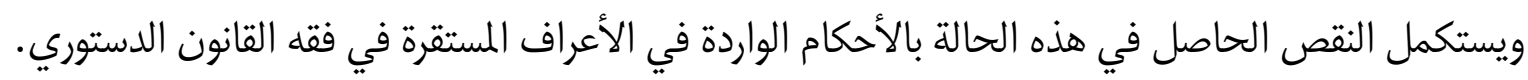

\section{الخــــاتمة}

نخلص مما تقدم إلى أن الأعمال والتصرفات الصادرة عن جلسات مجلس النواب المنعقد في مدينة طبرق بالمخالفة

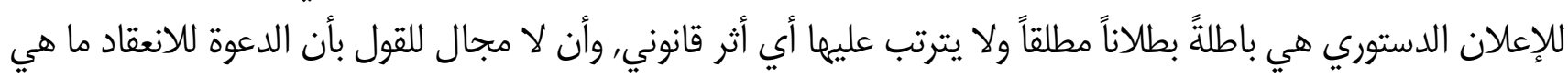

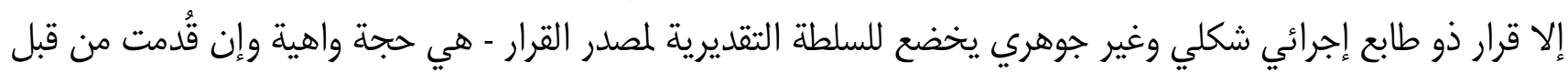

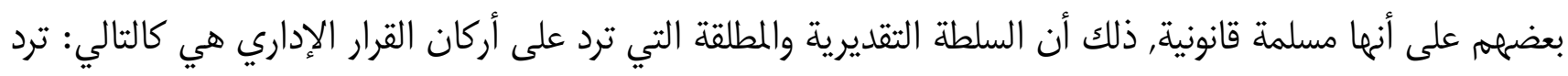

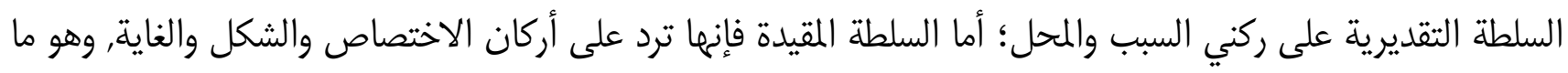

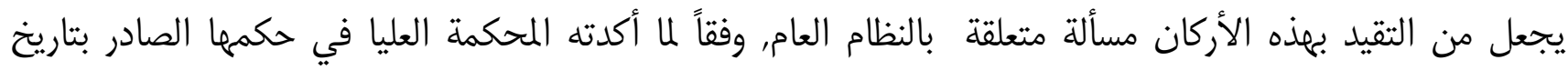
•1970/6/14

ذليه, فإذا كان الحكم على هذا النحو في حال صدور قرارات إدارية بالاستناد إلى قواعد قانونية عادية؛ فكيف الحال

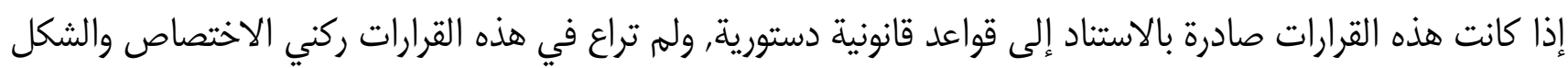
المنصوص عليه في مثل هذه القواعد الدستورية؟

ولا مجال للحديث عن نظرية الظاهر لتبرير صحة قرارات مجلس النواب هو استناد في غير محله؛ لكونها - أي نظرية

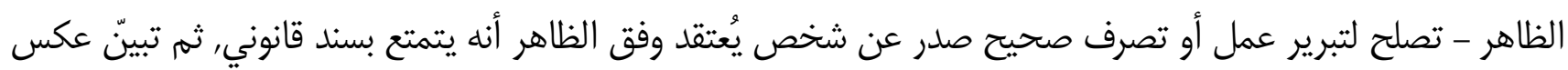

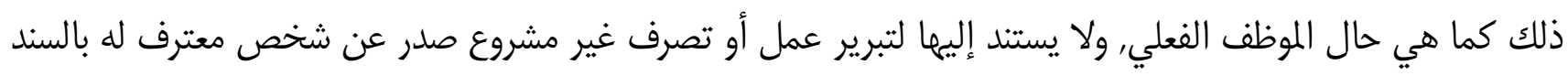

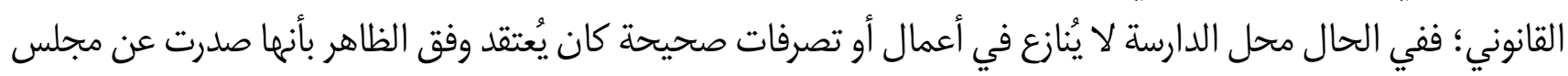

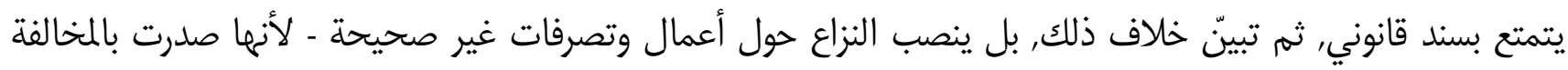

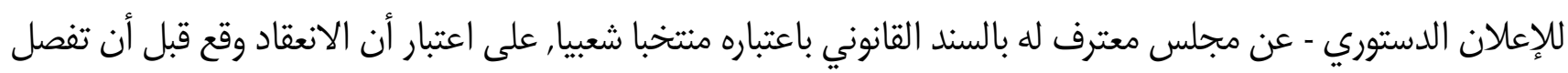

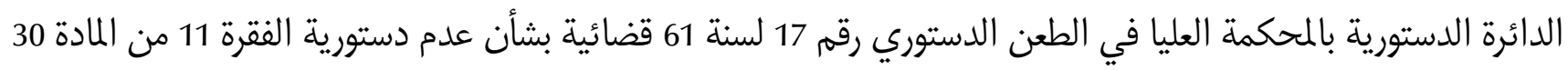

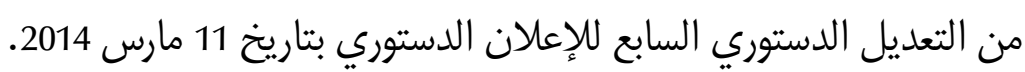


التحقيق الابتدائي في تقنية الاتصال عن بعد

دراسة في قانون الإجحاعات الجزائية الآنحادي رقم (35) لسنة 1992

المعدل بالمدسوم بقانون 17 لسنة 2018

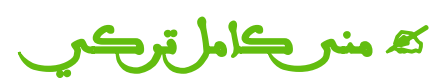

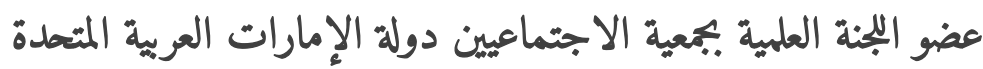

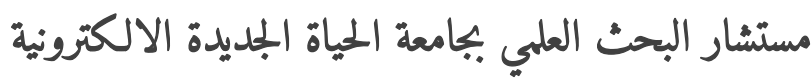

عضو فريق عمل مجلة القانون والأعمال

\section{ملخص الدراسة}

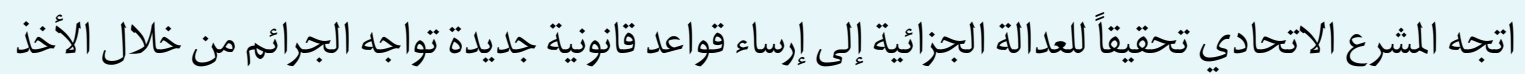

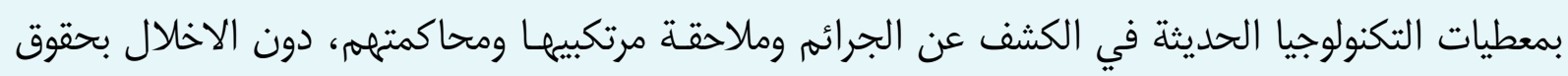

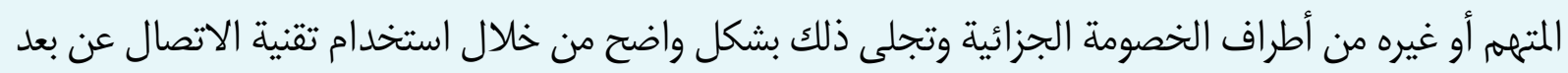

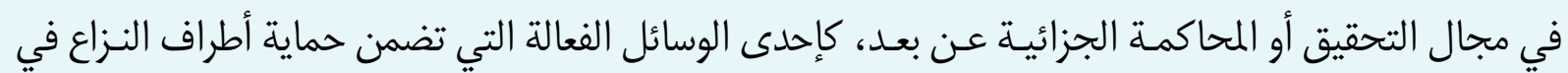
الخصومة الجنائية

وقد تبنت العديد من دول العالم استخدام الاتصال عن بعد؛ في التحقيقات الجنائية، نظرا للمزايا والفوائد

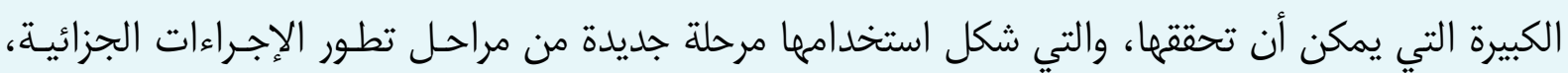

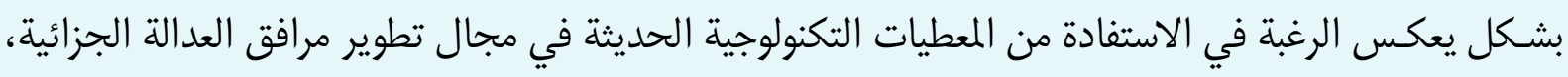

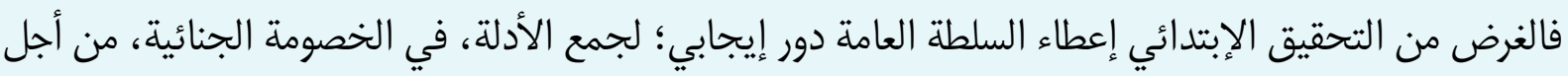

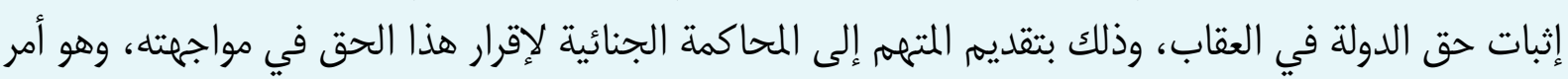

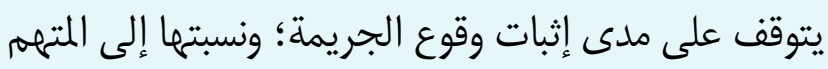

الكلمات الدالة: العدالة الجزائية، التحقيق عن بعد، تقنية الاتصال، الإجراءات الجزائية، الخصومة الجنائية 


\section{Abstract}

The federal legislator has directed criminal justice to establish new legal rules that confront crimes by introducing modern technology in detecting, prosecuting and prosecuting crimes, without prejudice to the rights of the accused or other parties to the criminal dispute. This is evident with remote criminal investigation or trial, as an effective means of ensuring the protection of the parties to the dispute in criminal disputes.

In criminal investigations, many countries have adopted the use of teleconferencing because of the advantages and benefits they can achieve. This is a new stage in the development of penal procedures, reflecting the desire benefit from the latest technological developments in the development of criminal justice facilities. The purpose of the preliminary investigation is to give the public authority a positive role; to collect evidence, in criminal litigation, in order to establish the right of the State to punishment; by bringing the accused to a criminal trial for the recognition of this right, to the accused.

Key words: criminal justice, remote investigation, communication technology, criminal proceedings, criminal litigation

\section{المقدمة}

نشأت مرحلة التحقيق الإبتدائي في ظل نظام التحري، بهدف إعطاء السلطة العامة دور إيجابي؛ لجمع الأدلة، في الخصومة الجنائية، من أجل إثبات حق الدولة في العقاب، وذلك بتحديد مبرر يقدم به المتهم إلى المحاكمة الجنائية لإقرار هذا الحق في مواجهته، وهو أمر يتوقف على مدى إثبات وقوع الجريمة؛ ونسبتها إلى المتهه، وبهذا يؤدي قضاء التحقيق

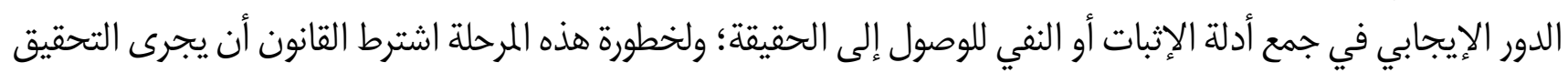
الابتدائي قبل رفع الدعوى وتقديمها إلى المحابلى الإكمة (177).

ومع التطور الفكري والتكنولوجي والذي انعكس بصورة إيجابية على كافة مناحي الدولة، والتي بدأت بالحكومة الذكية الإلكترونية، وسارت بسن التشريعات وتعديل قانون الإجراءات الجزائية رقم (35) لسنة 1992، بالمرسوم بقانون 17 لسنة 2018، والقرار الوزاري رقم 2017/220 بشأن إنشاء نيابة متخصصة لجرائم تقنية المعلومات، والقانون رقم 5 لسنة 2017 بشأن تقنية الاتصال عن بعد، والقرار الوزاري رقم 2018/259 بشأن الدليل الإجرائي لتنظيم التقاضي باستخدام الوسائل الإلكترونية والاتصال عن بعد في الإجراءات الجزائية، وذلك بهدف توفير نظام قضائي إلكتروني عادل، والانتقال بخدمات النيابة العامة والعدالة الجنائية إلى استغلال مستحدئ ولإثات العصر من الوسائل والتقنيات الحديثة في التحقيق والمحاكمة عن بعد سعياً لتحقيق العدالة (178).

(177) سرور، أحمد، الوسيط في قانون الإجراءات الجزائية، الأحكام العامة للإجراءات الجنائية، الكتاب الأول، (القاهرة : دار النهضة العربية، 2016)

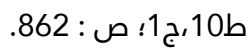

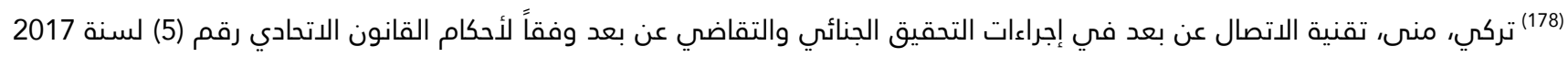
دولة الإمارات العربية المتحدة، (دراسة مقارنة) ، (الإمارات : دار النهضة العلمية، القاهرة : دار النهضة العربية,2019) ط1، ص : 68 
وأصبح من الممكن لقاضي التحقيق من أعضاء النيابة العامة مباشرة إجراءات التحقيق الابتدائي عن بعد، وبصفة خاصة

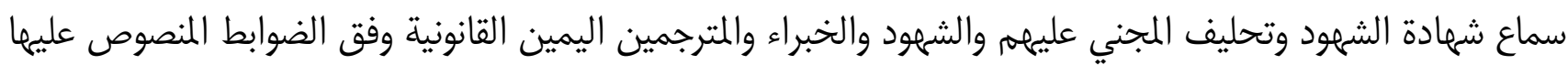
في الفقرة الثانية من المادة (91) والمادة (97) من قانون الإجراءات الجزائية وائية الاتحادي.

وقد تبنت العديد من التشريعات استخدام تقنية الاتصال المرئي والمسموع في مجال التحقيق الجنائي، مثل الولايات

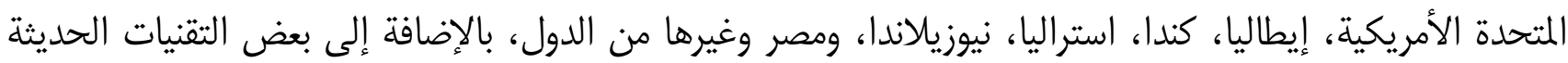
الأخرى في مباشرة التحقيق؛ لا سيما في مجال سماع شهادة الشهود وإفادات الخبراء (179).

\section{مشكلة الدراسة}

إن إشكالية هذه الدراسة تقوم على سؤال أساسي يتفرع منه مجموعة من التساؤلات الفرعية: ما مدى ملائمة الإجراءات الجزائية المتبعة بتقنية الاتصال عن بعد في مباشرة التحقيق الابتدائي بالقواعد العامة في الخصومة الجنائية؟ - الائمة

\section{وفي إثبات حق الدولة في العقاب؟}

\section{ومدى توافر المبرر لتقديم المتهم إلى المحاكمة الجنائية لإقرار هذا الحق ومواجهته؟}

ولإجابة على هذا التساؤل، فإن ذلك يتطلب منا الإجابة على التساؤلات الآتية:

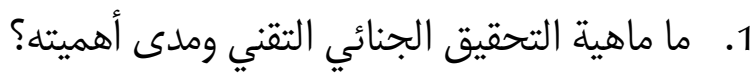

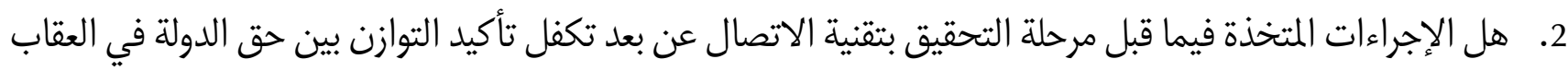

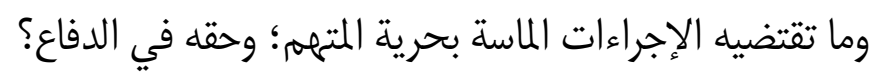

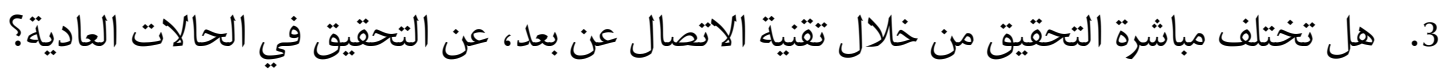

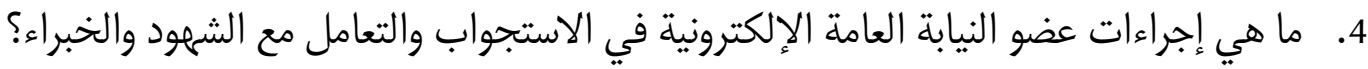

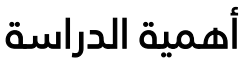

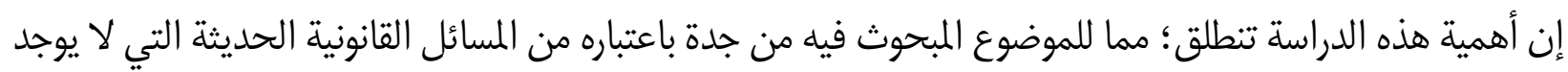

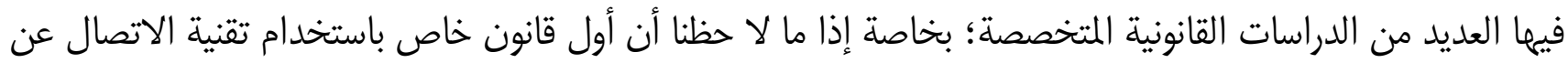

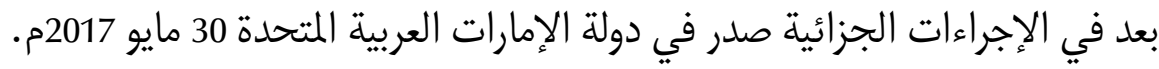

كما أن أهمية هذه الدراسة تنبع؛ مما يمكن أن تتمخض عنه من كشف النقاب عن مدى ملائمة الإجراءات الجزائية

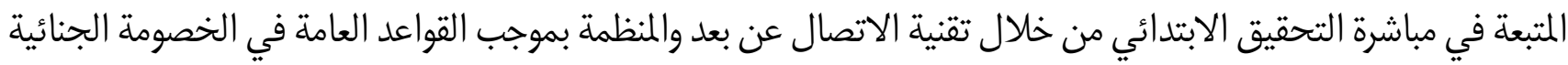

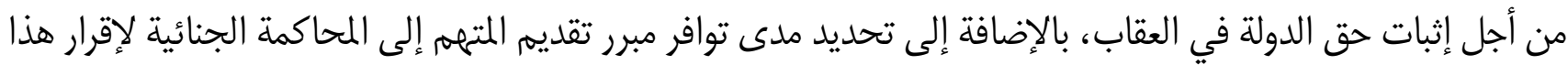
الحق في مواجهته

(179) يحيي، عادل، التحقيق والمحاكمة الجنائية عن بعد، دراسة تحليلية في المجال الجنائي، (القاهرة : دار النهضة العربية، 2006) ط1، ص : 16 


\section{أهداف الدراسة}

إن هذه الدراسة تهلدف إلى تحقيق مجموعة من الأهداف وهي:

1. تحديد ماهية التحقيق الجنائي التقني وفقاً لقانون تقنية الاتصال ومدى ملائمته مع الإجراءات الجزائية المتبعة في

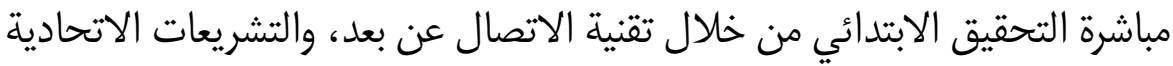

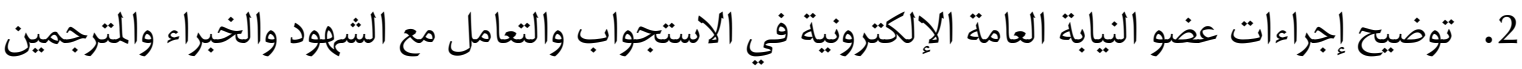
3. تحديد مدى حصر التحقيق الابتدائي بتقنية الاتصال عن بعد بعضو النيابة العامة

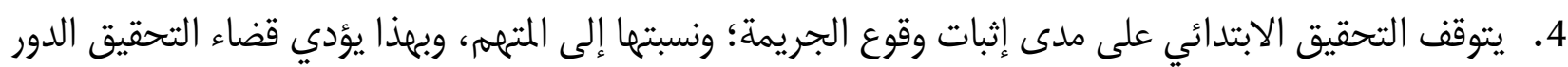
الإيجابي في جمع أدلة الإثبات أو النفي للوصول إلى التئي الحقيقة الجيقة

\section{حدود الدراسة}

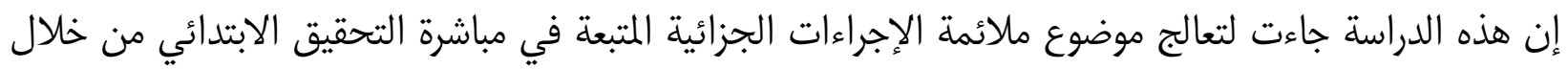
تقنية الاتصال عن بعد، ضمن نطاق قانون الإجراءات الجزائية الاتحادي رقم 35 لسنة 1992، والتعديلات الواردة عليه

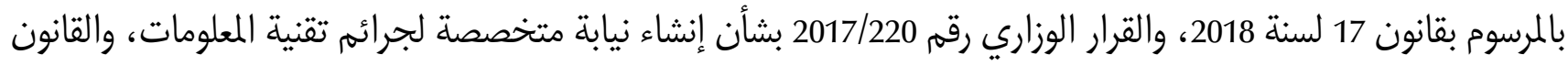

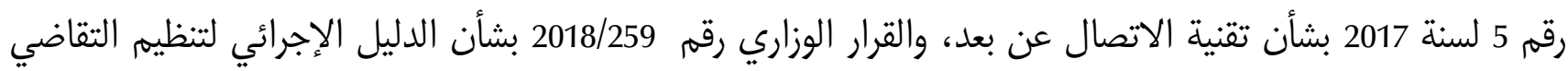
باستخدام الوسائل الإلكترونية والاتصال عن بعد في الإجراءات الجزائية عنية

\section{منهج الدراسة وتقسيمها}

إن الباحثة اتبعت في هذه الدراسة المنهج الوصفي التحليلي، بحيث تم من خلاله تحليل النصوص القانونية المتعلقة

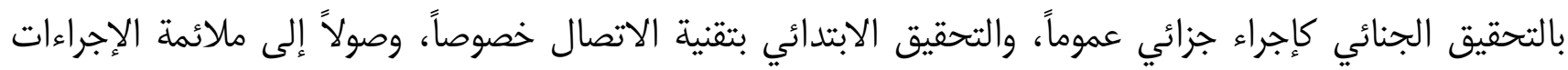

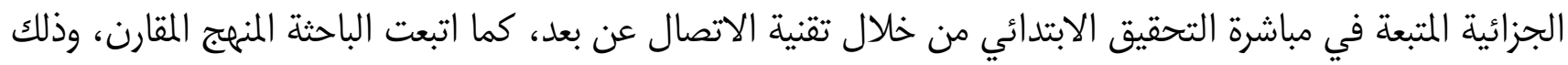

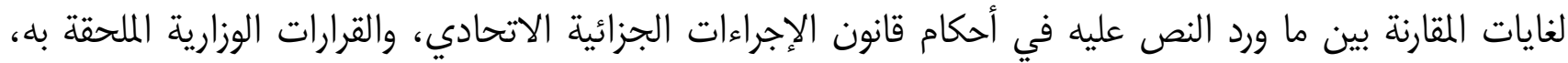

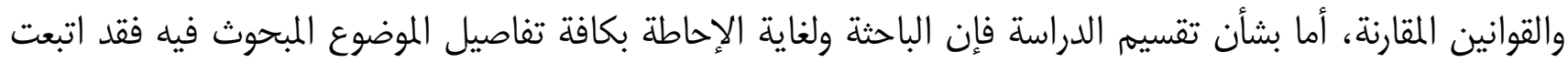

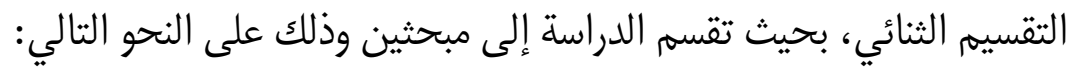

\section{المبحث الأول: تقنية الاتصال كوسيلة للتحقيق الجنائي}

\section{المبحث الثاني: عناصر التحقيق الابتدائي وضماناته في تقنية الاتصال عن بعدئ لاتئل}

المصطلحات الأساسية: تقنية الاتصال عن بعد، إجراءات ما قبل مرحلة التحقيق، واجبات والتزامات النيابة العامة،

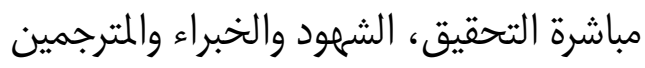

\section{المبحث الأول: تقنية الاتصال كوسيلة للتحقيق الجنائي}

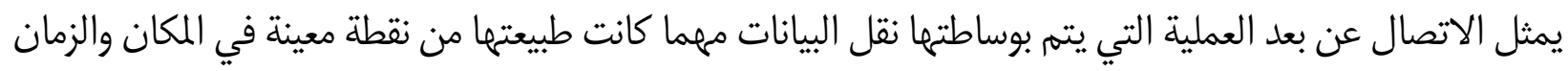

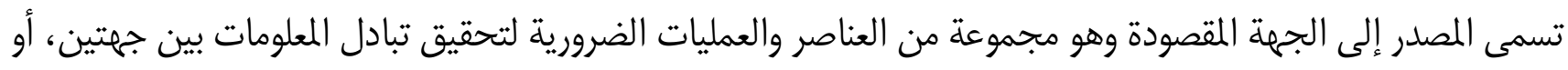


وسيلة تفعيل جميع المعلومات والاتصال في أي مكان وفي جميع الأوقات بطريقة آمنة وموثوقة بسرعة من خلال شبكة

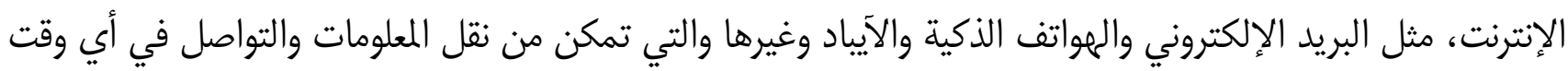

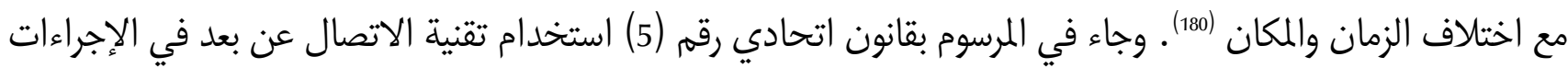

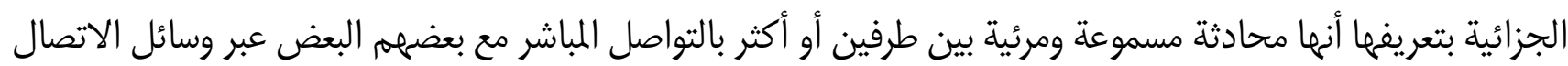

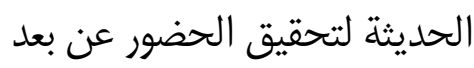

فإن استحداث نظام تقنية الاتصال عن بعد كنظام قضائي إلكتروني يتم من خلاله تسجيل القضايا وأرشفتما في

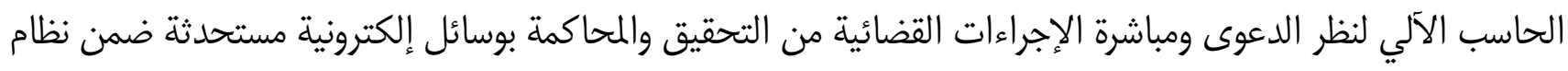

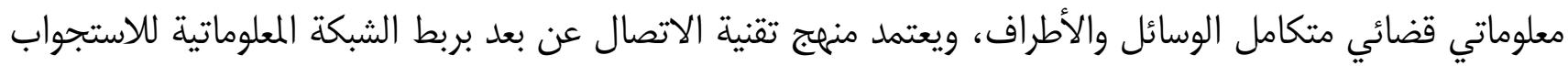

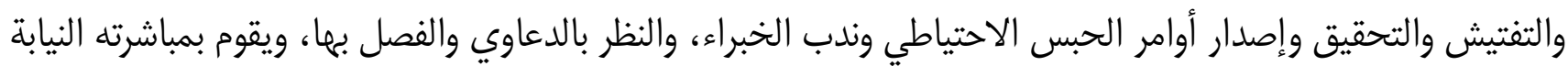

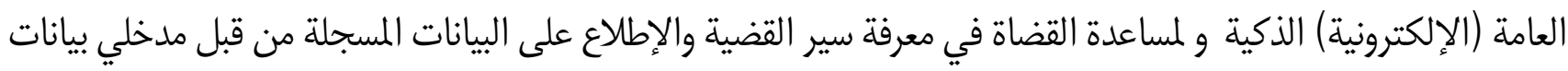

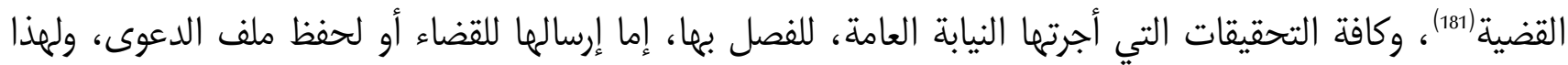

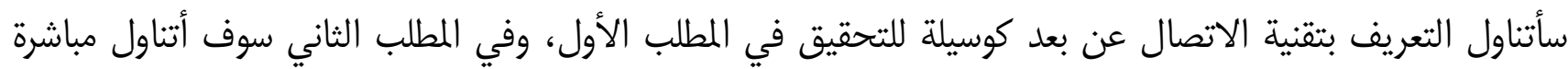
التحقيق الابتدائي من خلال تقنية الاتصال عن بعد.

\section{المطلب الأول: التعريف بتقنية الاتصال عن بعد كوسيلة للتحقيق}

أن تقنية الاتصال كنظام قضائي إلكتروني هي عملية نقل مستندات التقاضي إلكترونياً إلى المحكمة عبر البريد

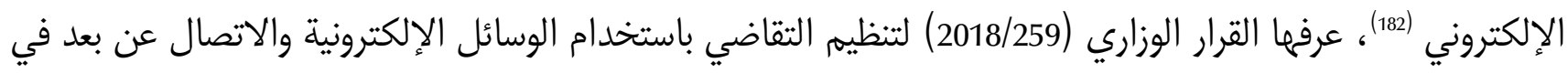

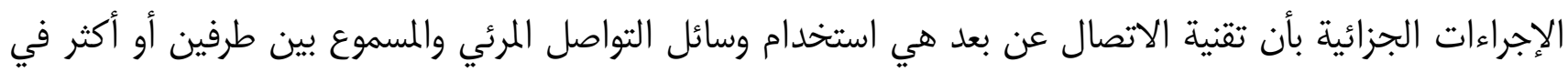

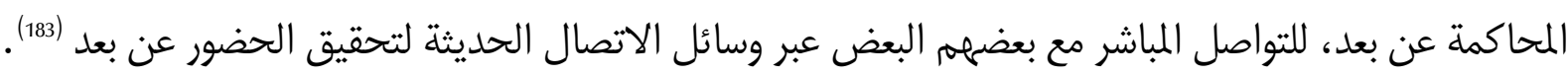

وتتجلى أهمية مرحلة التحقيق الإبتدائي في أنها تؤدي إلى تحضير الدعوى الجزائية وتحديد مدى قابليتها للنظر أمام

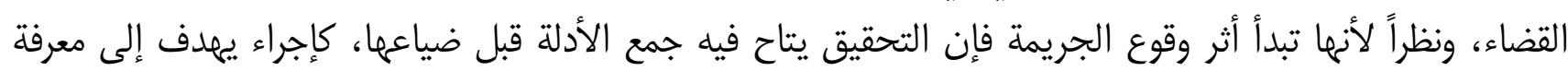

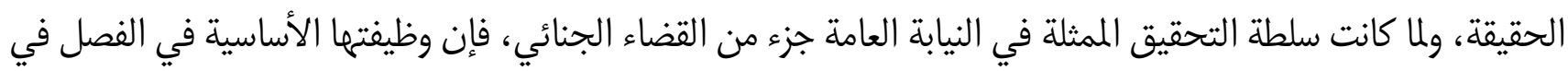

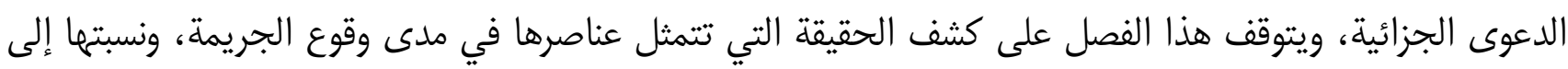

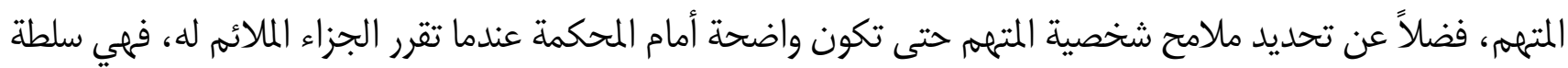
إتهام وسلطة تحقيق (184).

(180) الكرعاوي، نصيف، التقاضي عن بعد، دراسة مقارنة، (بيروت: منشورات الحلبي الحقوقية، 2017) ط1، 2017، ص: 25.

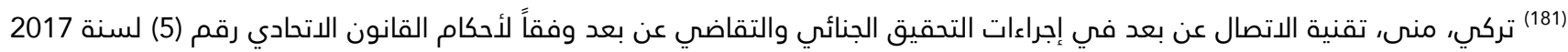
دولة الإمارات العربية المتحدة، مرجع سابق ص : 97.

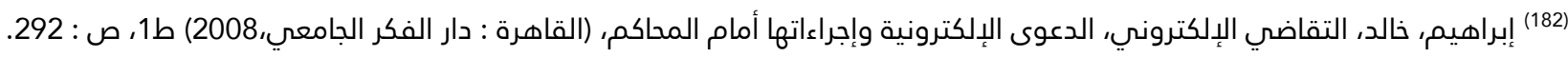

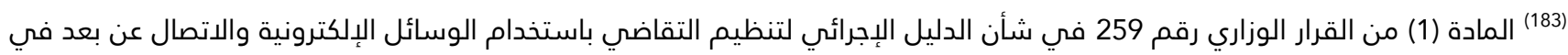

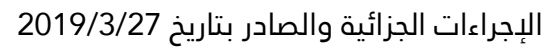
(184) سرور، أحمد، الوسيط في قانون الإجراءات الجزائية، مرجع سابق ، ص : 862. 


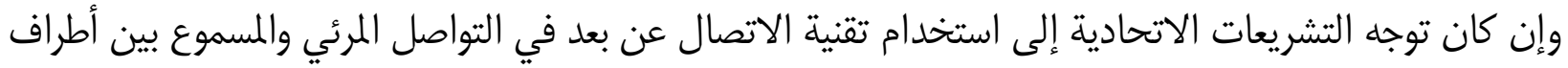

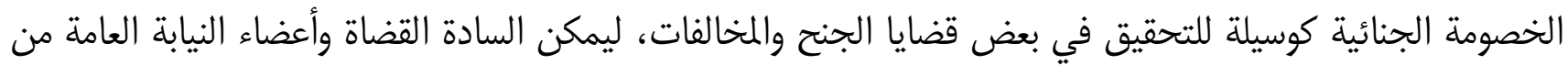

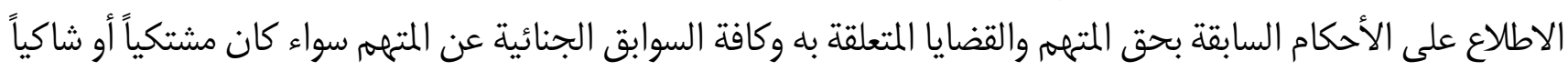

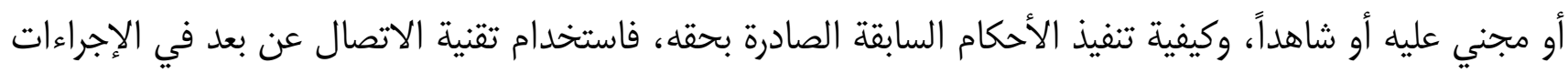

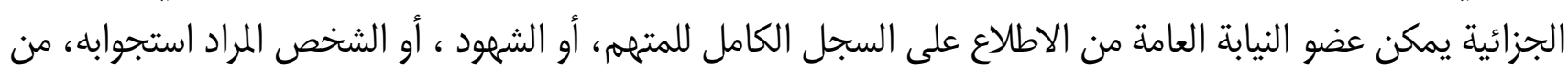

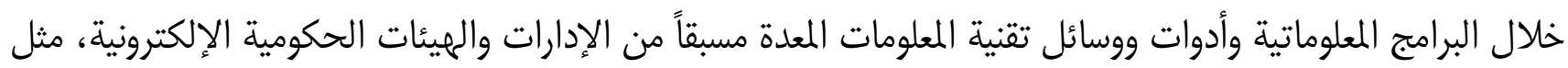

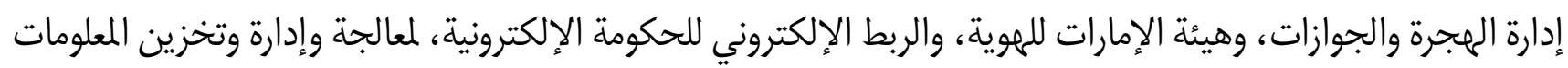

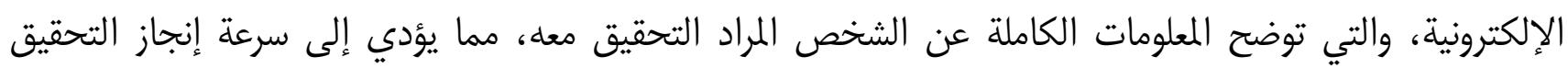

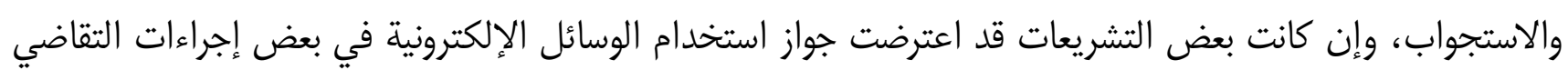
الجزائية (185).

وقد ألزم المشرع الاتحادي الجهات المختصة والتي حددها بالجهات الاتحادية أو المحلية المعنية بشؤون الأمن

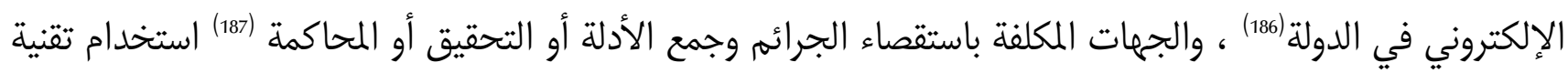

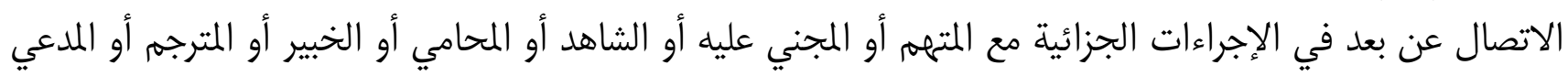

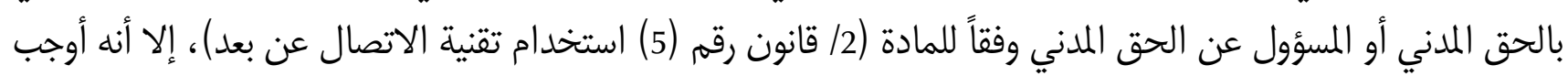

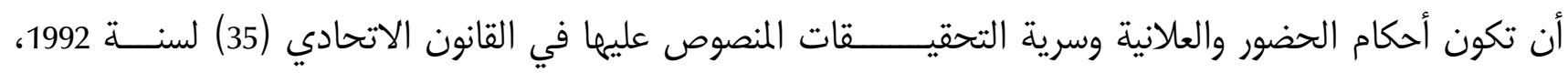

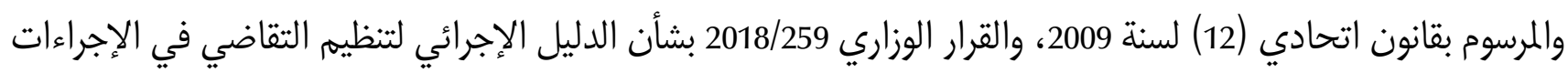

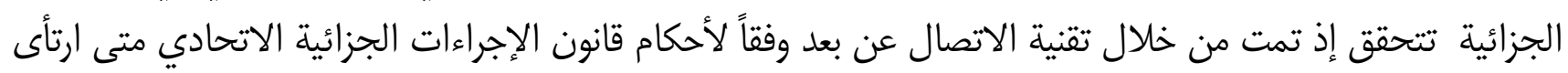

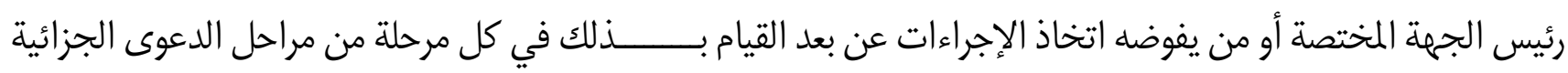

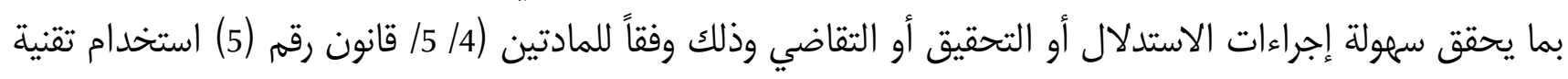
الاتصال عن بعد)

أما في التشريعات المقارنة فإن الاتجاه نحو استخدام تقنية الاتصال عن بعد في شتى المجالات على نطاق واسع ولا

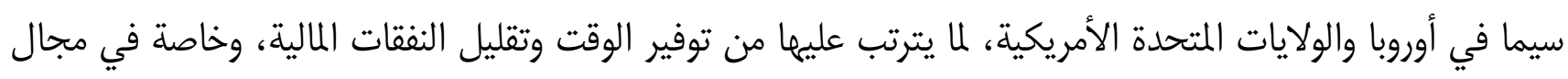

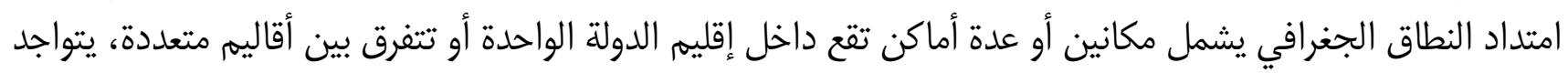

(185) تركي، منى، تقنية الاتصال عن بعد في إجراءات التحقيق الجنائي والتقاضي عن بعد وفقاً لأحكام القانون الاتحادي رقم (5) لسنة 2017 (5) دولة الإمارات العربية المتحدة، مرجع سابق ص : 205

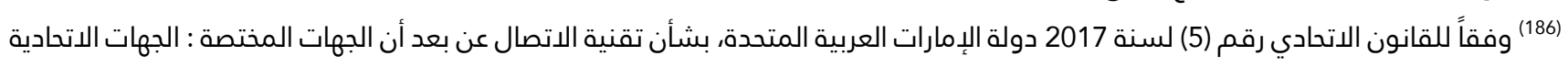

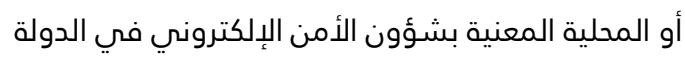

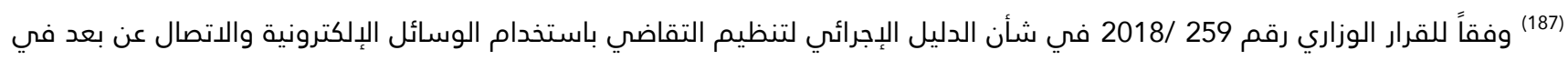

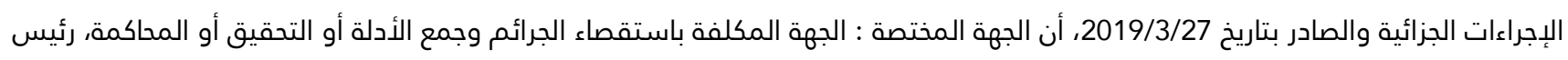
الجهة المختصة : رئيس المحكمة أو النائب العام أو رئيس الجهة المكلفة باستقصاء الجرائم وجمع الأدلة أو من يتم تفويضه من أي منهم 
فيها المترهم والشهود وغيرهم من أطراف الخصومة الجنائية فيستطيعون الاستعانة بهذه التقنية بحيث يتحقق مبدأ المواجهة بين الخصوم، دون الحاجة للتواجد الفعلي في أماكن انعقادها (188.).

وتأسيساً على ذلك فإن تقنية الاتصال عن بعد تعد وسيلة أو آلية حديثة لمباشرة التحقيق، ويتم الاستعانة بها في بعض الحالات لسماع شهادة الشهود، أو مع المتهمين أنفسهم المتواجدون في أماكن غير المحكمة مثل المؤسسات العقابية في حالة احتجاز المتره، وإذا كان المتهرم غير مقيد الحرية ولا تتوافر له أجهزة ووسائل الاتصال عن بعد، فيلتزم في هذه الحالة بالحضور شخصياً أمام النيابة العامة في الجلسة المحددة له لاستجوابه وذلك وفقاً للمادة (6/ القرار الوزاري 259 / 2018 في شأن الدليل الإجرائي لتنظيم التقاضي باستخدام الوسائل الإلكترونية) فالتحقيق الجزائي عن بعد أو تقنية الاتصـال عن بعد بأنه وسـيلة أو آليـة حديثـة لمبـاشرة إجـراءات التحقيـق أو المحاكمة الجزائية عن بعد أمـام محكمة الاختصاص، يتهم الاستعانة بها في بعض حـالات الجنح والمخالفات، لسماع شهمادة الشهود والمتهمين المتواجدين داخل المؤسسة العقابيـة، أو بمراكز الشرطة أو بمؤسسات عقابية في منطقة جغرافية أخرى، وبذلك بلك يعد التحقيق والمحاكمة الجزائية عن بعد؛ خروجا على القاعدة العامة في جلسات التحقيق والمحاكمة والتي تته في نطاق جغرافي متعدد (189).

\section{المطلب الثاني: مباشرة التحقيق الابتدائي من خلال تقنية الاتصال عن بعد}

يمر التحقيق الجنائي بمرحلتين متكاملتين هما مرحلة التحقيق الأولي وتختص به النيابة العامة، ومرحلة التحقيق النهائي وتختص به المحكمة الجزائية (190)، ففكرة التحقيق الابتدائي فكرة قديمة قدم الجريمة ذاتها، ومع التطورات التي واكبت الجريمة، والتطورات التي واكبت التشريعات الجزائية، أصبح بالإمكان إجراء التحقيق في بعض جرائي جرائم الجنح والمخالفات باستخدام تقنية الاتصال عن بعد (191).

ويعد التحقيق الابتدائي هو أول مراحل الدعوى الجزائية، وهو عبارة عن عدة إجراءات تتخذها السلطة المختصة بالتحقيق، من أجل التحقق من الأدلة التي أسفرت عنها مرحلة جمع الاستدلالات بهرف إما إثبات الجريمة أو نفيها (192)،

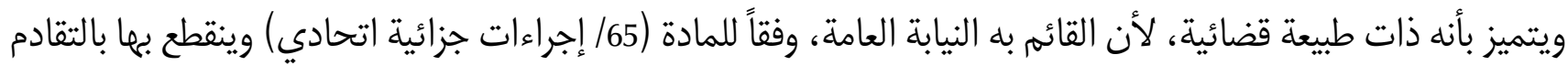
وفقاً للمادة (21/ إجراءات جزائية اتحادي)، ولعل ذلك أهم ما يميز التحقيق الابتدائي عن إجراءات الاستدلال. تباشر سلطة التحقيق بعض الإجراءات، منها ما يهدف إلى معرفة الحقيقة ومنها ما لا يهدف، وإنما إلى مجرد إدارة العدالة وتسهيل الوصول إليها، ولما كانت سلطة التحقيق هي جزء من القضاء الجنائي، فهي تقوم بأعمال إداريت معينة،

(188) يحيي، عادل، التحقيق والمحاكمة الجنائية عن بعد، دراسة تحليلية في المجال الجنائي، مرجع سابق ص : 16. (189) شديفات، صفوان، التحقيق والمحاكمة الجزائية عن بعد عبر تقنية الدراسات، (مجلة علوم الشريعة والقانون، جامعة العلوم الإسلامية، 2015)، العدد 1، المجلد 42، ص: 353 -364. (190) محمد، عوض، الإجراءات الجزائية المصري، (الإسكندرية ، دار المطبوعات الجامعية، 1998) ط1، ص ص : 441. (191) لويس، منذر، أثر التطور التكنولوجي على الدريات العامة، (الإسكندرية ، منشأة دار المعارف، بدون سنة نشر) ط1، صد : 165. (192) بلال، أحمد ، الإجراءات الجنائية المقارنة والنظام الإجرائي في المملكة العربية السعودية، (القاهرة : دار النهضة العربية، 1990) ط1، ص : 
وذلك للإسهام في الفصل في الدعوى الجنائية، وإن تلك الإجراءات تلتزم بها النيابة العامة من الشروط الشكلية التي يوجبها القانون (193).

هذا وقد أعطى المشرع الاتحادي الصفة القضائية للنيابة العامة بوصفها الجهاز القضائي المنوط به تحريك الدعوى

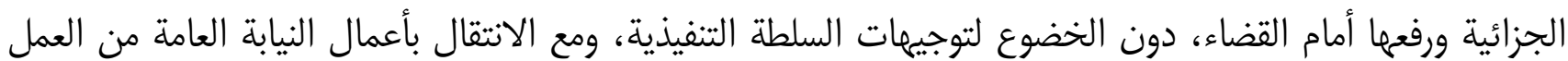
التقليدي إلى استخدام المستندات الإلكترونية وفق الأنظمة القضائية المعلوماتية المعتمدة على شبكة الانترنت، أصبح لديهيها

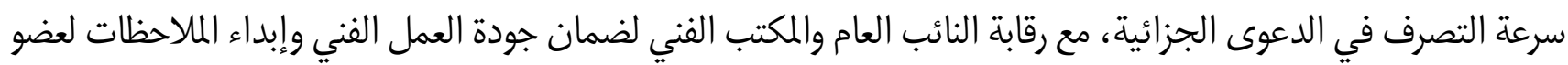
النيابة من خلال التطبيقات الإلكترونية الذكية، ويحدد عضو النيابة العامة المختص الذي يباشر التحقيق تاريخ وساعة نظرها بدقة، ويباشر إجراءات التحقيق بكاملها عبر تقنية الاتصال عن بعد في الوقت المحدد (194).

وقد أجاز المشرع الاتحادي للمجني عليهم والشهود والمبلغين ووكلائهم، بتطبيق نظام المحاكمة عن بعد أن يقدم طلب إلى رئيس المحكمة أو النائب العام أو رئيس الجهة المكلفة باستقصاء الجرائم وجمع الأدلة أو من يتم تفويضه من أي منهم، لمباشرة إجراء أو أكثر من إجراءات المحاكمة عن بعد، وفقاً لقانون الإجراءات الجزائية الاتحادي رقمم (35) لسنة 1992، وأحدث تعديلاته 2018، أنه في حالة توافر أسباب جدية من شأنها تعريض حياتهم أو مصالحرهم الأساسية للخطر إذا ما أدلو بشمادتهم أو إفادتهم، ولها قبوله أو رفضه، بحيث يكون ذلك القرار نهائياً

فعند مباشرة التحقيق من خلال تقنية الاتصال عن بعد يحدد عضو النيابة العامة المختص الذي يباشر التحقيق تاريخ وساعة نظرها بدقة، ويباشر إجراءات التحقيق بكاملما عبر تقنية الاتصال عن بعد في الوقت المحدد، ويتولى كاتب النيابة

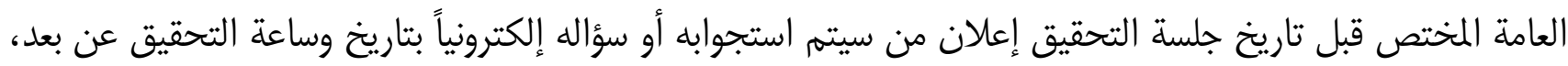

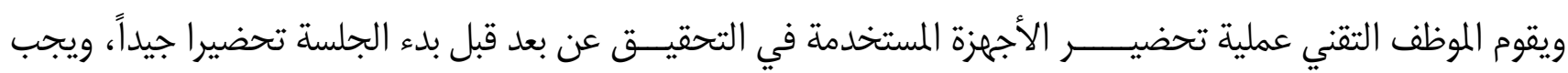
عليه التعامل السريع في حالات الانقطاع أو الخلل الفني إذا ما وقع أي منهما أثناء سير جلسة التحقيق (195). وعلى الرغم إغم من أن النيابة العامة تباشر إجراءات الاتمام، بجانب التحقيق، إلا أن الاتهام يأتي في مرحلة لاحقة على التحقيق، وفيه تقوم النيابة العامة برفع الدعوى الجزائية على المتهم، وذلك من خلال إحالته إلى المحكمة الجزائية المختصة في الجنح والمخالفات (196).

(193) محمد، عوض، الإجراءات الجزائية المصري، مرجع سابق ص : 445.

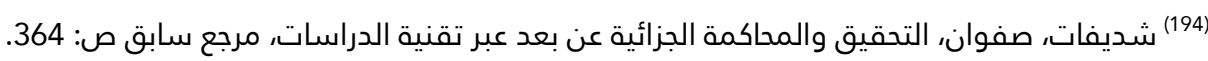
(1955) المادة (5) من القرار الوزاري رقم 259 في شأن الدليل الإجرائي لتنظيم التقاضي باستخدام فأدام الوسائل الإلكترونية والاتصال عن بعد في الإجراءات الجزائية والصادر بتاريخ 2019/3/27 ويجري التحقيق الإلكتروني باللغة العربية، ولعضو النيابة العامة الاستعانة بمترجم وفق الضوابط المنصوص عليها في المادة (13/ القرار الوزاري 2018/259) بعد تحليف المجني عليهم والشهود والخبراء والمترجمين اليمين القانونية وفق بـإن الضوابط المنصوص عليها في الفقرة الثانية من المادة (91) والمادة (97) من قانون الإجراءات الجزائية) وتسجل وقائع الجلسة إلكترونياً بمستند أو سجل إلكتروني، ويدون الكاتب وقائع وإجراءات التحقيق إلكترونياً، ويوقع عضو النيابة العامة والكاتب إلكترونياً على كل صفحة من محضر التحقيق الإلكتروني وتحفظ وفقاً لأحكام المادة (19/ القرار 259 بشأن الدليل الإجرائي لتنظيم التقاضي باستخدام الوسائل الإلكترونية والاتصال عن

بعد في الإجراءات الجزائية) (196) المادة (19) من القرار الوزاري رقم 259 في شأن الدليل الإجرائي لتنظيم التقاضي باستئي التخدام الوسائل الإلكترونية والاتصال عن بعد في الإجراءات الجزائية 
ومقارنة بإجراءات التحقيق الابتدائي للنيابة العامة بالطرق التقليدية عند سماع أقوال المترمين والشهود شفاهة والتي يدونها أحد كتاب النيابة العامة عملاً بنص المادة (66/ إجراءات جزائية) فإن النيابة ملزمة عند التحقيق مع من لا يعرف اللغة العربية أن تستعين بمترجم له وتحليفه اليمين، على أن يراعي المترجم قواعد الحيدة والعدالة، وفي ذلك قضت المحكمة الاتحادية العليا، باستبعاد الدليل الباطل ورفض الطعن لمنين (197).

\section{المبحث الثاني: عناصر التحقيق الإبتدائي وضماناته في تقنية الاتصال عن بعد}

إن فكرة التحقيق تقوم أساساً على عنصري الكشف عن الحقيقة، وعنصر الجبر والإكراه والتي خولها لهبا القانون، لذا لهاب كفل الدستور احترام حريات الأفراد، بيد أن الإكراه والمساس بالحريات الشخصية قد يكون مطلوباً في هذه الإجراءات حتى تلى إنى يتحقق التقيد بالقانون والامتثال به، ويبدو ذلك فيما تملكه سلطة التحقيق من أوامر الضبط والإحضار، والقبض والتفتيش، والحبس الاحتياطي، وتحليف الشهود والخبراء اليمين، ومعاقبة الشاهد لعدم الإدلاء بشمادته أو لعدم حلفه اليمين (198). ولما كان التحقيق الابتدائي ينطوي على إجراءات ماسة بالحرية، وقد يترتب عليه إحالة الدعوى إلى المحاكم الجزائية، وتوقيع العقاب على مرتكبيها، لذا يجب أن تكون هناك ضمانات تكفل سلامة إجراءات التحقيق الإبتدائي، وهذه الضمانات تتلخص في استقلال المحقق وحيدته في الاستجواب وإذن التفتيش، وتدوين التحقيق وسريته (199). ولهذا سأتناول مباشرة النيابة العامة الإلكترونية التحقيق والاستجواب في المطلب الأول، وفي المطلب الثاني سوف أتناول تدوين محضر التحقيق الإبتدائي الإلكتروني

\section{المطلب الأول: مباشرة النيابة العامة الإلكترونية التحقيق والاستجواب}

تباشر النيابة العامة إجراءات التحقيق والاتهام في الجرائم وفقاً لأحكام المادة (5/ إجراءات جزائية اتحادي)، وقد كفل

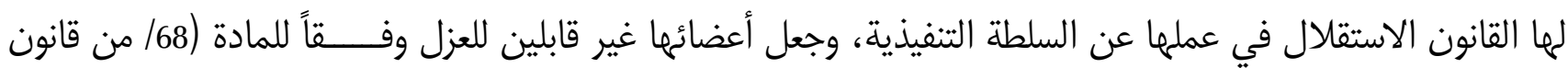
السلطة القضائية) وفي مقابل ذلك يتعين أن يتحلى عضو النيابة العامة أثناء التحقيـــق بالحياد في مباشرة التحقيق والاتهام، وأن يتصف بحسن الخلق واحترام الذات، واحترام أدميت وكرامة المتهم، وأن يحرص على إنجاز التحقيق في ئي جلسات متلاحقة (200).

رئريس المحكمة الاتحادية العليا الطعن 31 لسنة 21 ق، جلسة 1999/11/27، حيث قضت بأنه لما كان ذلك وكان الثابت من أوراق الملف أن السيد رئيس النيابة الذي حقق مع الطاعن بتاريخ 1997/10/14. استعان بالشرطي المترجم لقسم مكافحة المخدرات، دون أن يحلفه اليمين، أو يشير إلى أنه حلف مما يخالف المادة (70) من قانون الإجراءات الجزائية، مخالفة صريحة. فضلاً على أنه مترجم غير محايد يعمل لدى الجهة التي قامت بالضبط، وبالرجوع إلى مدونة أسباب الحكم المطعون فيه يتضح أن عول في نطاق أدلة إثبات الواقعة المدان بها الطاعن على أدلة منها اعترافه أمام النيابة العامة مع أنه أنكر تمام الإنكار لدى محكمتي الموضوع، وأنه لما كان اعترافه لدى النيابة العامة منقول عن طريق مترجم لم تكتمل فيه شروط الترجمة القانونية من الحياد وحلف اليمين فإنه يكون غير صالح للاعتماد عليه كدليل في الدعوى، وبانهياره ينهار الثبوت كله، لأن الأدلة في المجال الجزائي متساندة يتم الثبوت بها كلها مجتمعة. فإذا استبعد بعضها وكان لا يعرف أثر باقي الأدلة في عقيدة المحكمة إذا استبعد هذا الدليل الباطل. ومن ثم فإن الحكم المطعون فيه يكون معيباً يستوجب نقضه.

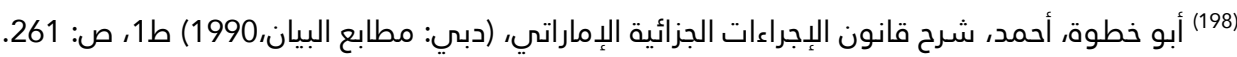

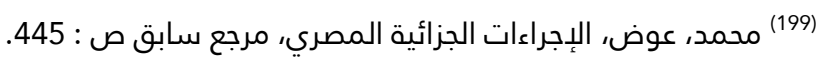
2018 2000 المادة (13) من القرار الوزاري رقم 259 


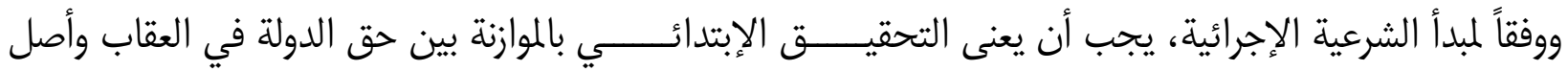

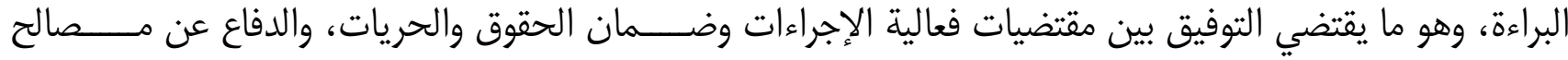

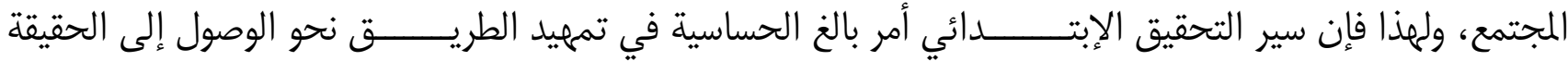

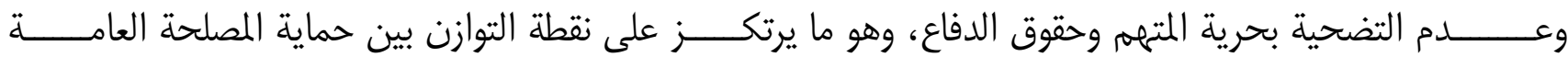

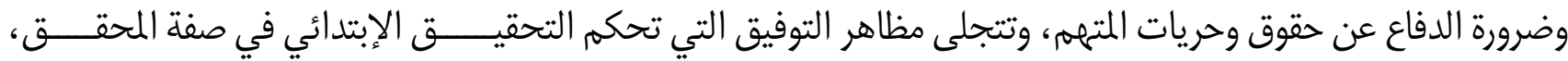
ومباشرة التحقيق والاستجواب (201).

وعلى ذلك فعند وورد محضر جمع الاستدلالات إلى النيابة العامة إلكترونياً، يقوم برنامج النيابة العامة الإلكترونى بإسناد

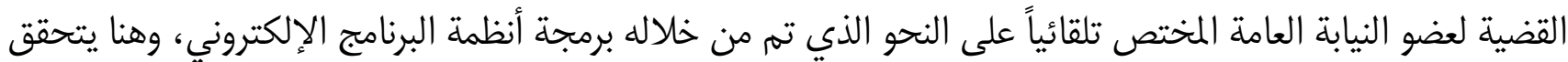

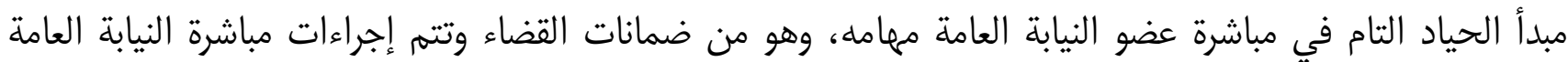

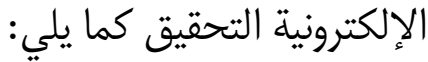

(1) استجواب المجني عليهم: يقصد بالاستجواب مواجهة المتهم بالأدلة الموجودة ومناقشته تفصيليا حتى يفندها، وهو إجراء تختص به سلطة التحقيق، وهو عمل من أعمال التحقيق تملكه النيابة العامة عند التحقيق في الجرائم ويعتبر

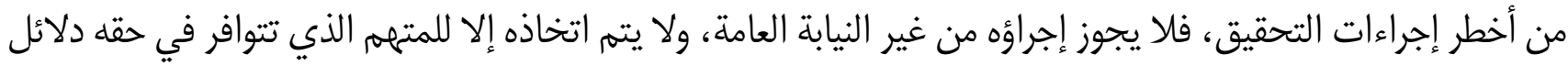

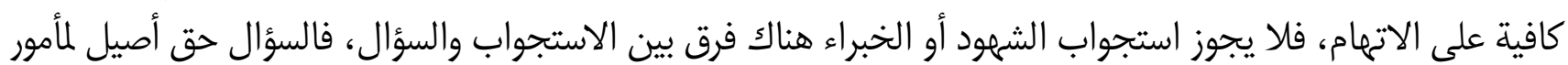

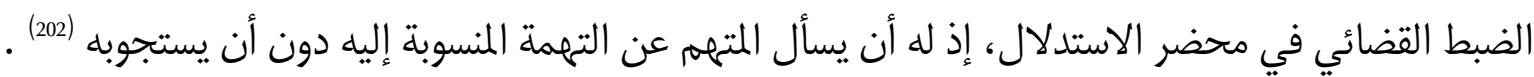

أما الاستجواب فهو كما عرفته محكمة دبي للتمييز بأنه مجابهاة المتهمه بالأدلة المختلفة ومناقشته مناقشة تفصيلية، كي

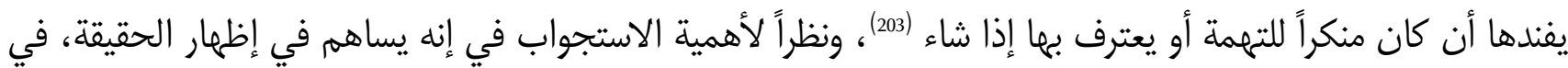

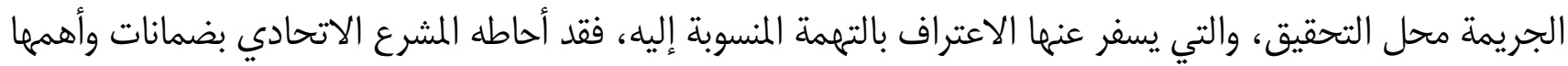
حظر الاستجواب إلا من السلطة المختصة بها وهي النيابة العامة، وذلك وفقاً لما صرحت به المادة (2/57 من القانون رقم 3

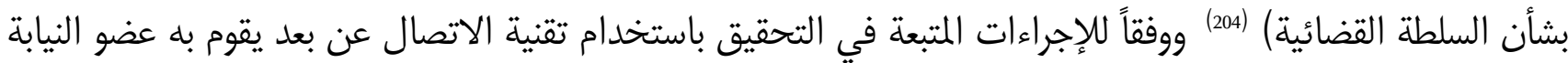

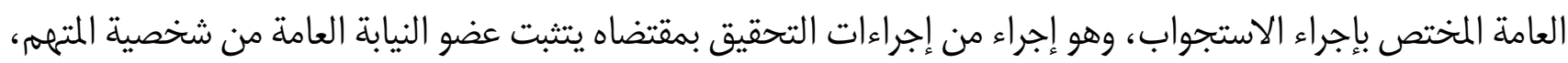

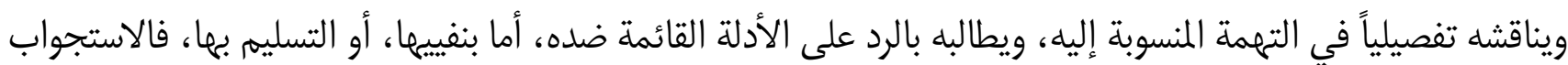

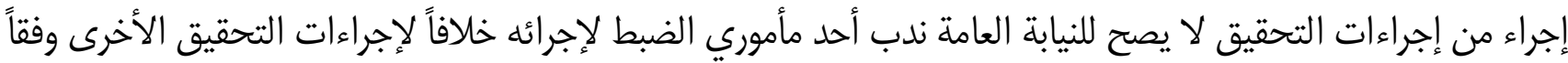
للمادة (90/ التعليمات القضائية للنيابة العامة الاتحادية) (205).

(201) سرور، أحمد، الوسيط في قانون الإجراءات الجزائية، مرجع سابق ، ص : 872. (202) عبد الستار، فوزية، شرح قانون العقوبات، القسم العام، الكتاب الأول، (القاهرة : دار النهضة العربية، 2016) ط6، ص : 352. (203) محكمة تمييز دبي، الطعن رقم 270، جزاء، جلسة 2002/11/9، (دبي : المكتب الفني، عام 2002) العدد 13 لسنة 2002 (204) المادة (57) البند(2) من القانون الاتحادي رقم (3) لسنة 1983، بشأن السلطة القضائية الإتحادية التادية بما ورد فيها النص : النيابة العامة جزء من السلطة القضائية، تباشر التحقيق والاتهام في الجرائم وفقاً لأحكام هذا القان القانون. دولة دولة الإمارات العربية المتحدة، مرجع سابق ص : 128. 
(2) إحاطة المتهم علماً بالتهمة الموجهة إليه: وهي ضمان من الضمانات الموجبة للمتهم أثناء استجوابه،

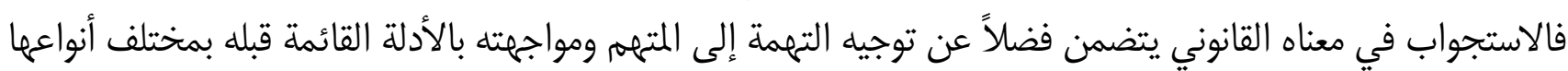

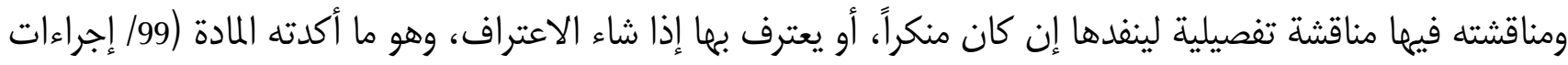

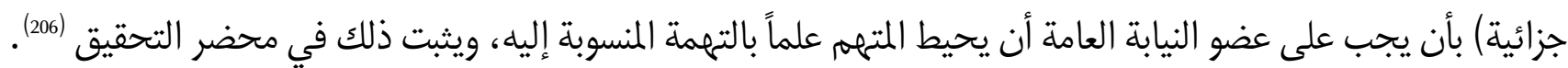
(3) سماع الشهود: أداء الشهادة من أهم إجراءات محضر التحقيق، ولأهمية الشهادة كإجراء من إجراءات التحقيق

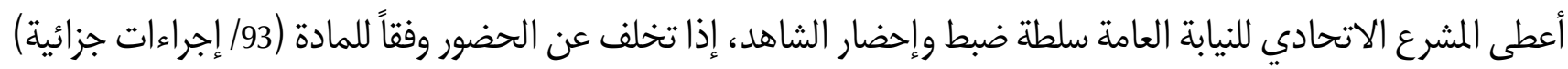

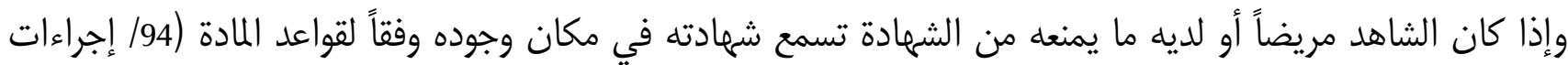

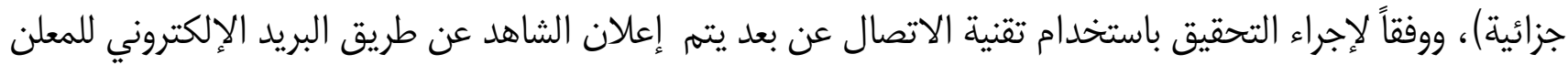

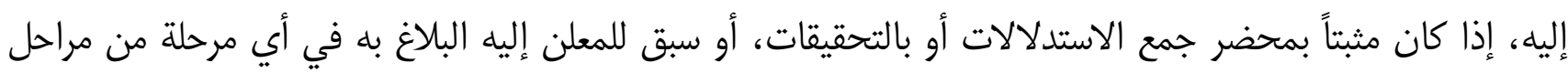

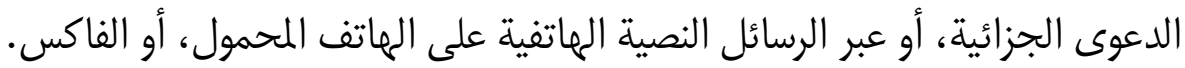

ويسمع عضو النيابة العامة شهادة الشهود الذين يطلب الخصوم سماعهم، ما لم يرى عدم الفائدة من سماعهم، وعلى

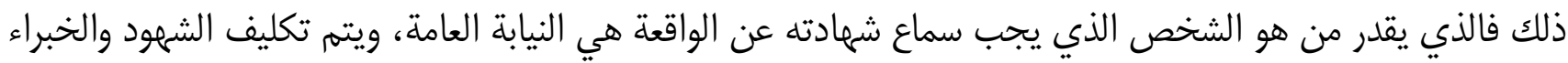

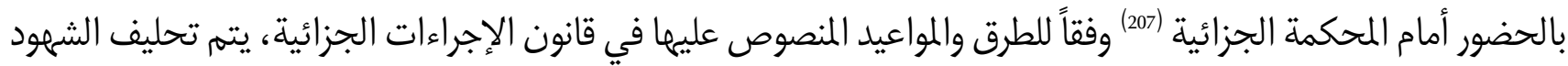

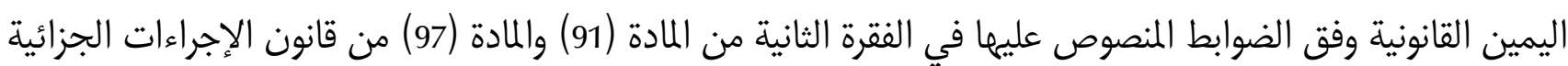

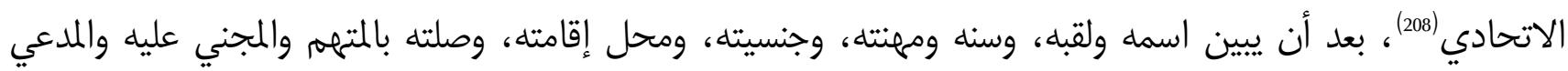
بالحقوق المدنية، ويتثبت من شخصيته، وتدون جميع التحقيقات إلكترونياً (209).

ولضمان حياد الشاهد وصدق روايته بشأن الواقعة يتعين على عضو النيابة أن يسمع كل شاهد على انفراد، ولو أن

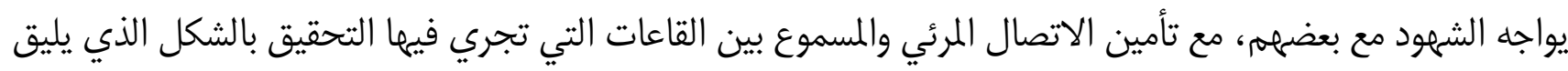

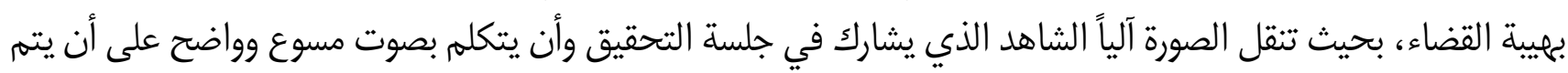

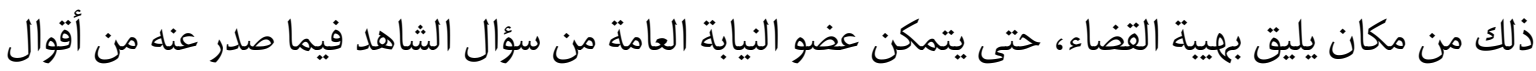
(4) حضور الذصوم: تتم مباشرة التحقيق في حضور الخصوم وذلك كأجراء من إجراءات التحقيق الإبتدائي يمثل

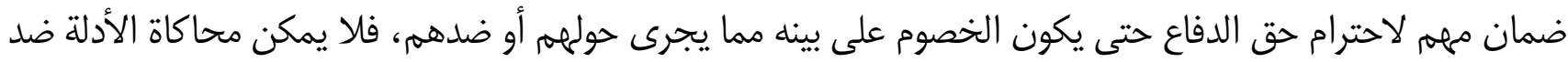

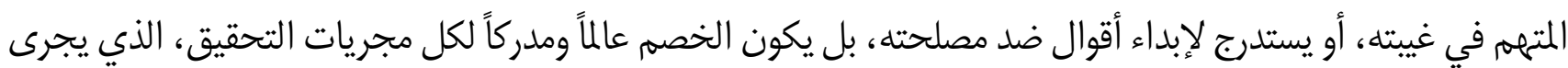

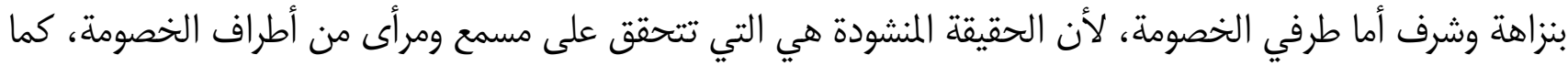

(206) عوض ، رمزي، حماية المتهم في النظام الأنجلو أمريكي، (القاهرة : دار النهضة العربية، 1998) ط1، ص : 58. (207) عوض ، رمزي، حماية المتهم في النظام الأنجلو أمريكي، مرجع سابق، ص ص : 69.

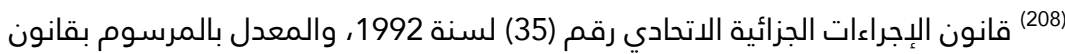
(209) تركي، منس، تقنية الاتصال عن بعد في إجراءات التحقيق الجنائي والتقاضي عن بعد وفقاً لأحكام القانون الاتحادي رقم (5) لسنة 2017 دولة الإمارات العربية المتحدة، مرجع سابق ص 145. 
ورد بنص المادة (4/1 من قانون تقنية الاتصال عن بعد 2017) أن تقنية الاتصال عن بعد هي محادثة مسموعة ومرئية بين

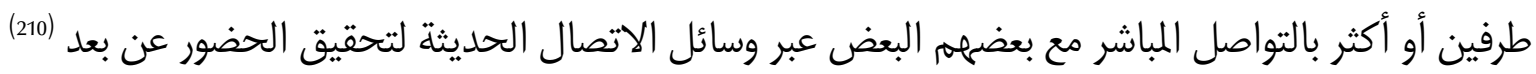
وقد اعتنق المشرع الاتحادي مبدأ حضور الخصوم التحقيق الابتدائي وأكد على ذلك في المادة (7/ من القرار الوزاري

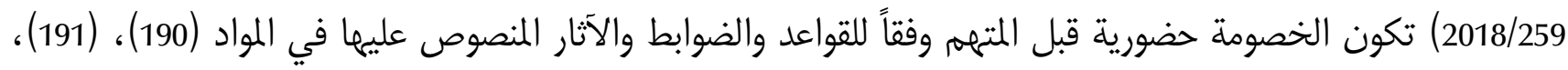

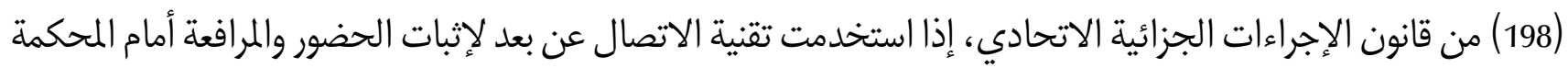

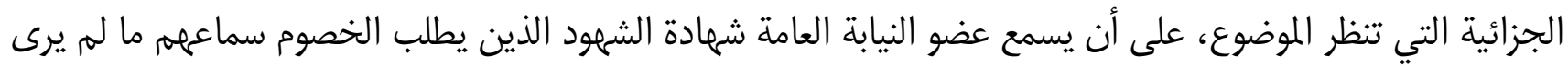

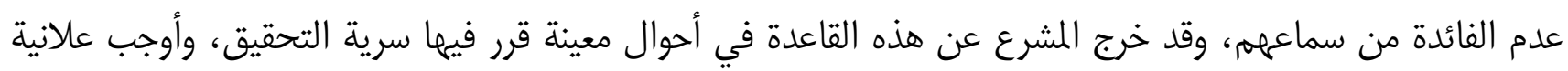
المحاكة بتقنية الاتصال عن بعد (211).

ويتم تحليف الخبراء والمترجمين اليمين القانونية، بعد إثبات كل منهم اسمه ولقبه وسنه ومهنته وجنسيته، وشخصيته،

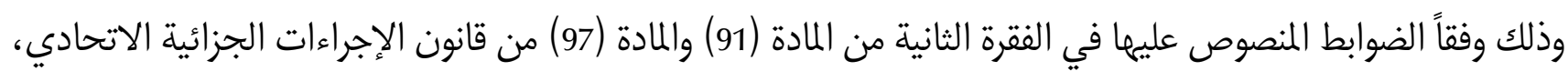

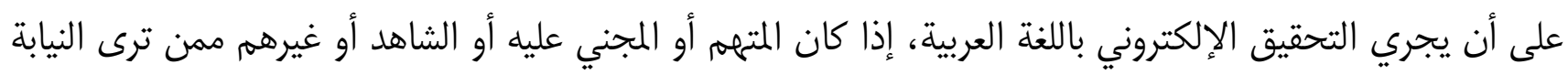

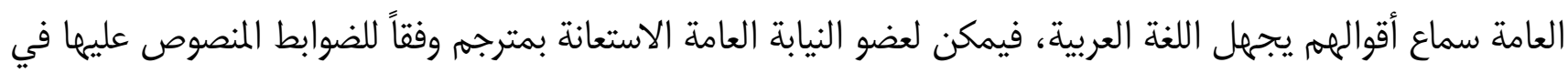

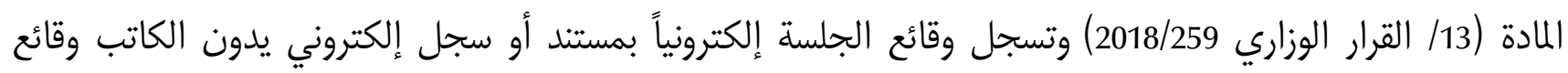
وإجراءات التحقيق إلكترونياً (212).

(5) حق المحامي في حضور التحقيق: يتفرع عن مبدأ حضور الخصوم للتحقيق الابتدائي السماح لوكلائمهم

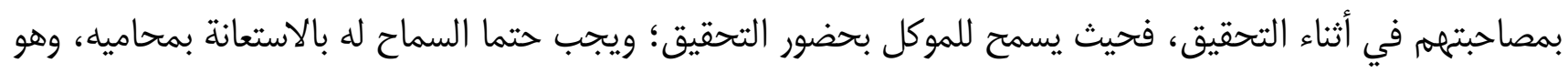

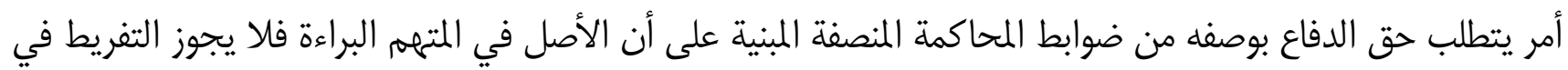

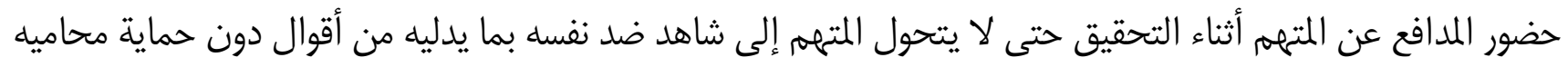

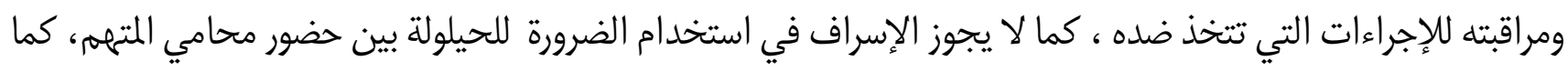

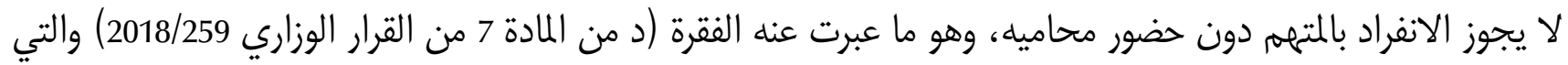

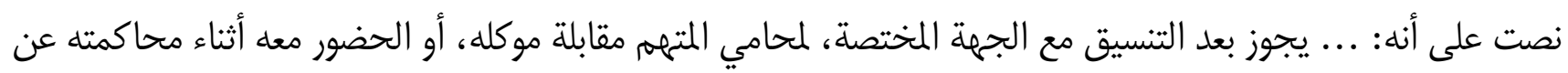

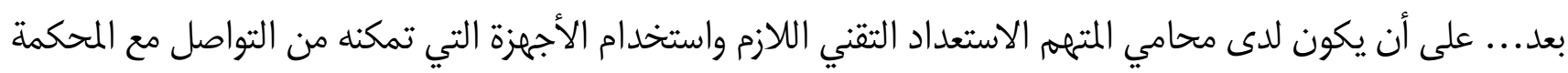

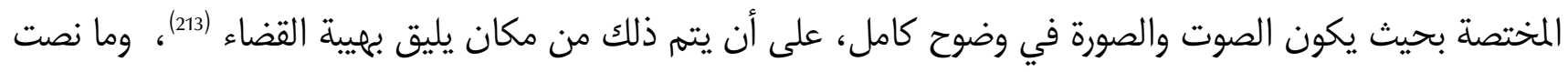

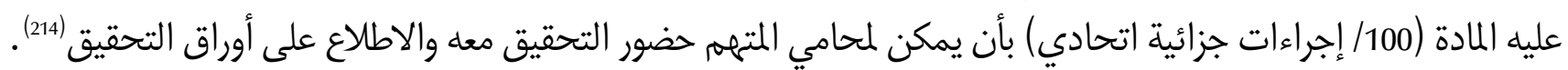

2018 (210) المادة (1) من القرار الوزاري رقم 259 (211) القرار الوزاري رقم 259 في شأن الدليل الإجرائي لتنظيم التقاضي باستخدام الوسائل الإلكترونية والاتصال عن بعد في الإجراءات الجزائية 2019/3/27 والصادر بتاريخ (212) ووفقاً لإجراءات التحقيق عن بعد إجراءات التحقيق عن بعد المنصوص عليها في المادة (5) و المادة (13) من القرار الوزاري رقم 259 /2018 (213) ووفقاً لإجراءات التحقيق عن بعد إجراءات التحقيق عن بعد المنصوص عليها في المادة (6) من القرار الوزاري رقم 259 /2018) (214) تركي، منس، تقنية الاتصال عن بعد في إجراءات التحقيق الجنائي والتقاضي عن بعد وفقاً لأحكام القانون الاتحادي رقم (5) لسنة 2017 دولة الإمارات العربية المتحدة، مرجع سابق ص : 125. 


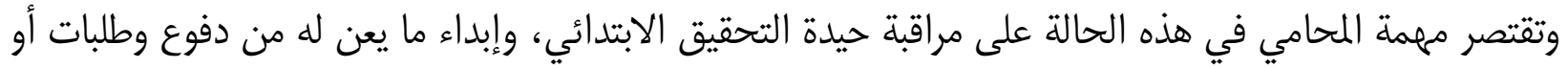

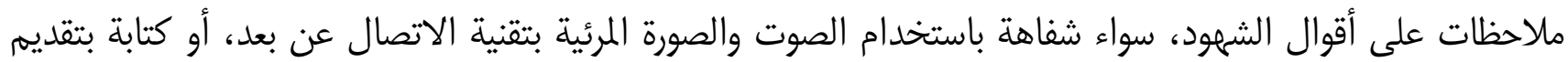

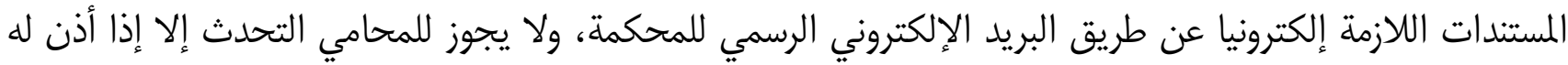

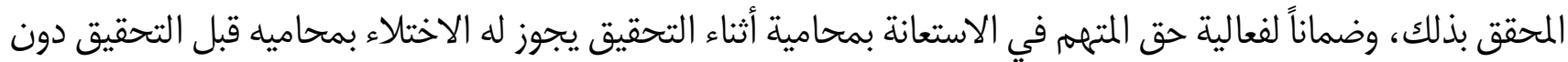

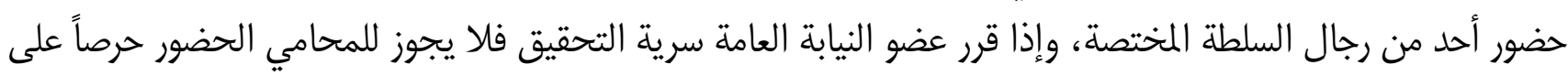
مصلحة التحقيق (215).

(6) حق الصمت: من ضمانات الاستجواب التي أحاطها المشرع بحماية المتهم أثناء استجوابه، حق الصمت وهو حق

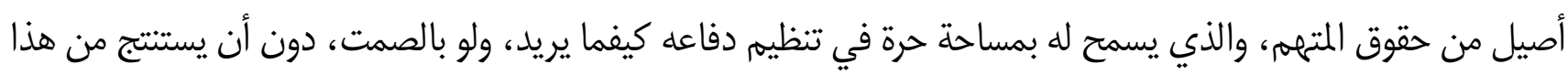
الصمت دليل على سلامة ما ينسب إليه من اتهام (216.).

فحق المتهم بالصمت حق طبيعي فطري، فإذا كانت الدولة هي صاحبة الحق في توقيع العقاب على من تثبت إدانته؛

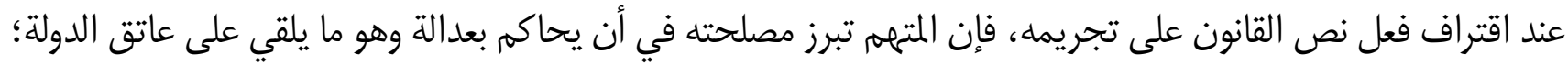

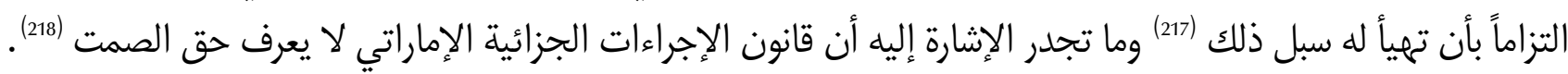
(7) اعتماد محاضر التحقيق: تقوم الجهة المختصة بتفريغ إجراءات التقاضي عن بعد في محاضر أو مستندات ورقية

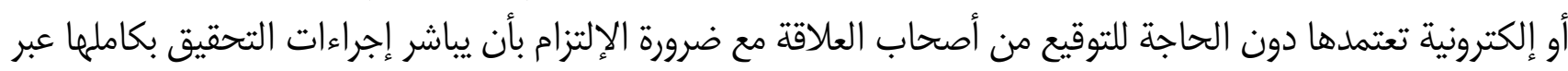

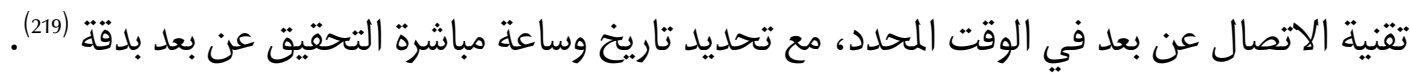

\section{المطلب الثاني: تدوين مدضر التحقيق الإبتدائي الإلكتروني}

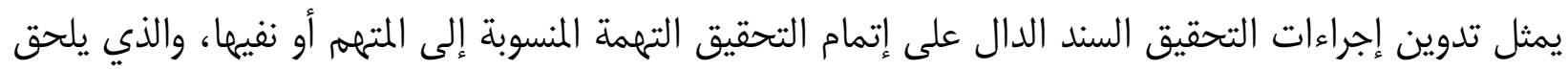

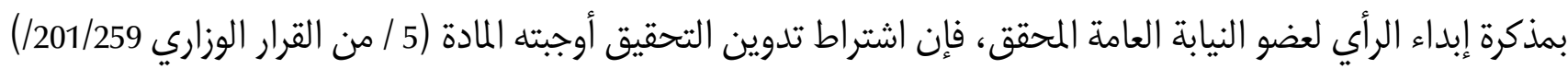
والمادة (66/ إجراءات جزائية).

ويته التدوين بواسطة أحد كتاب النيابة العامة، ويؤدي اشتراط كتابة وتدوين محضر التحقيق وكافة إجراءات التحقيق إلى وجوب توافر شكلين وهما التوقيع، وتاريخ إجراء التحقيق وهي من البيانات الجوهرية في محضر التوابه التحقيق التانئ الابتدائي ونتناولها كما يلي:

(215) سرور، أحمد، الوسيط في قانون الإجراءات الجزائية، مرجع سابق ، ص : 884.

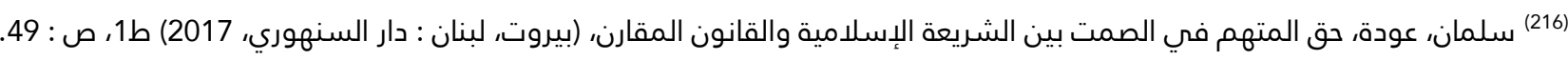

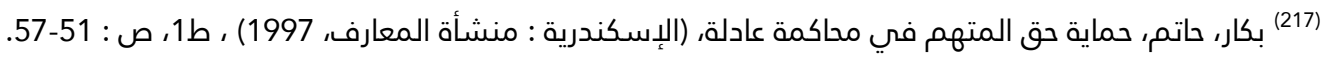

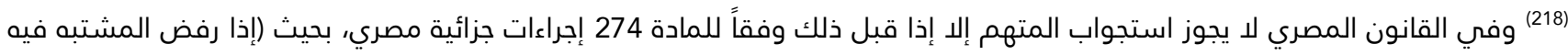

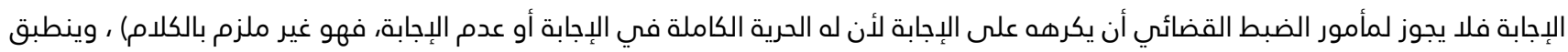
ذلك في مرحلة التحقيق الابتدائي، غير أن القاضي يستطيع أن يحتفظ داخلياً بدلالة عكسية من هذا الصمت دون أن يفصح عنها ويكون لها أثر 


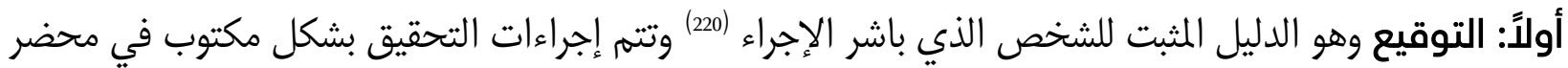

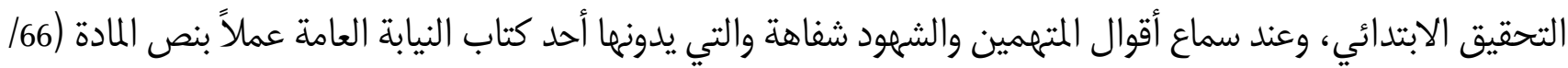

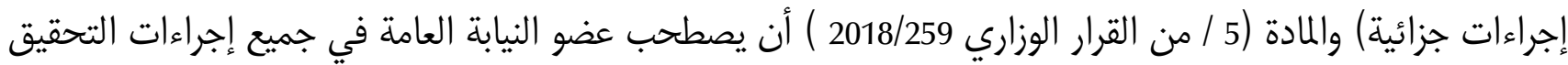

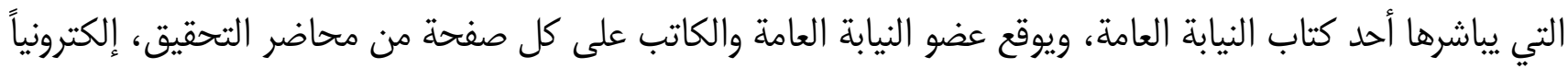

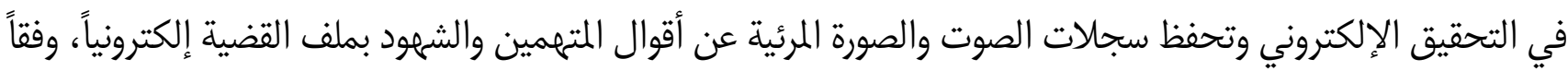

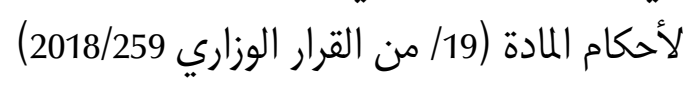

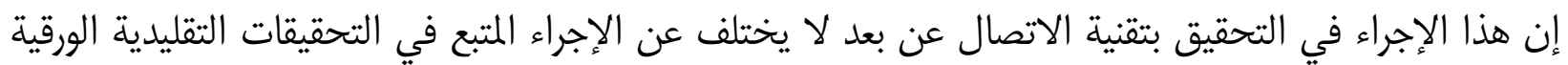

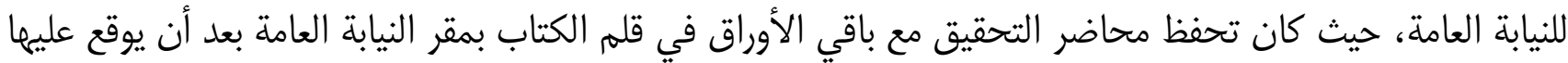

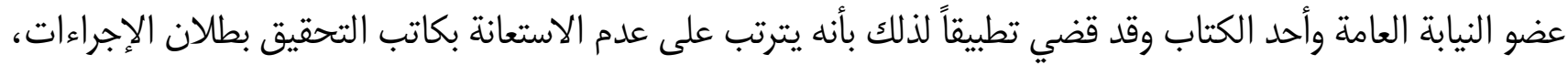

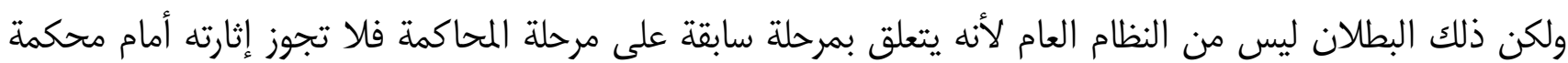
التمييز (221).

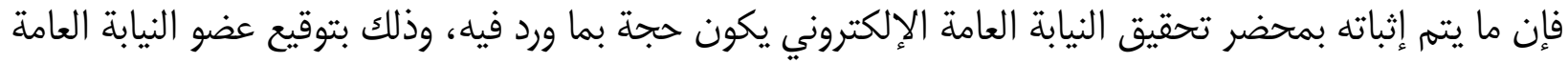

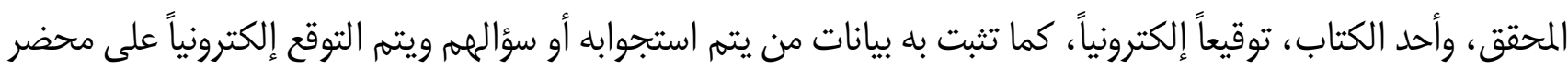

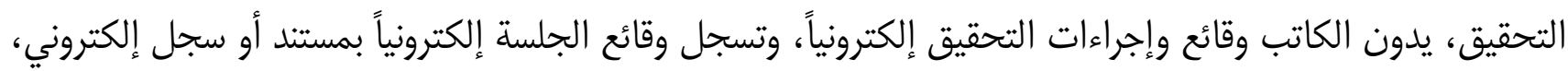
وفقاً لكافة الإجراءات والضوابط المنصوص عليها بقانيانون الإجراءاءتات الجزائية الاتحادي (222.).

وفي التحقيق الابتدائي بالطريقة التقليدية إذا استوفى محضر التحقيق الإلكتروني التدوين لإجراءاته وكان مصحوباً

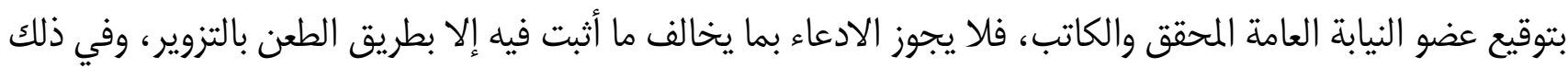

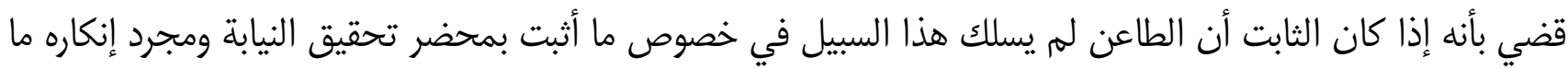

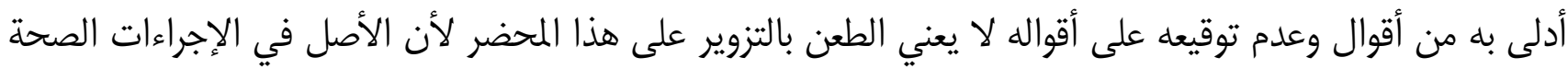

ثانياً: تاريخ مباشرة الإجراء: هو عنصر أساسي في جميع الإجراءات الجزائية سواء تم بالطريقة التقليدية أو بتقنية

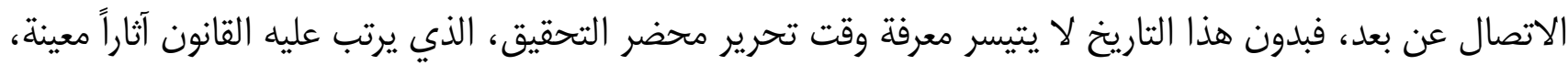

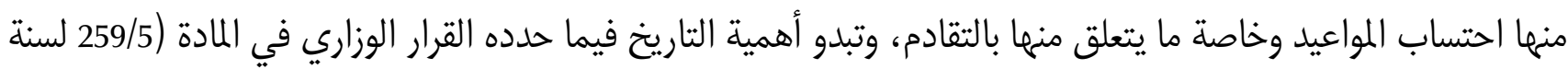

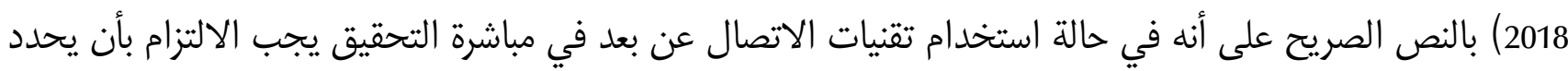
عضو النيابة العامة المختص الذي يباشر التحقيق تاريخ وساعة نظرها بدقة، ويباشر إجراءات التحقيق بكاملها عبر تقنية الاتصال عن بعد في الوقت المحدد.

(220) سرور، أحمد، الوسيط في قانون الإجراءات الجزائية، مرجع سابق ، ص : 886.

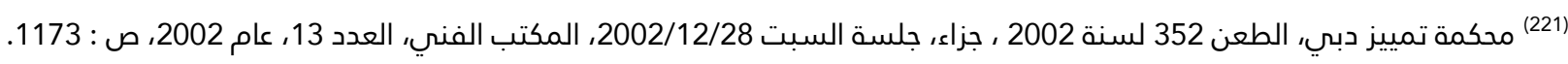

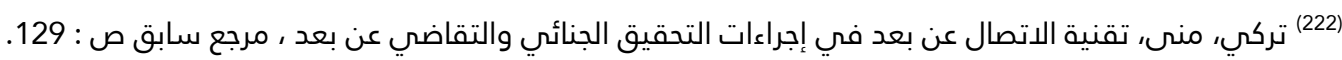

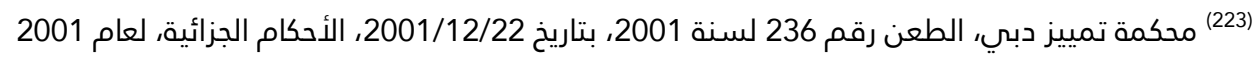


ثالثاً: البيانات التي يتعين إثباتها: حدد القرار الوزاري الخاص بتنظيم إجراءات التقاضي الإلكتروني في المادة (259/5 التان

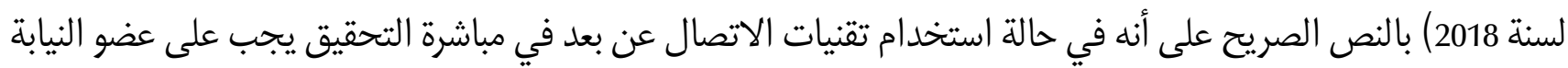

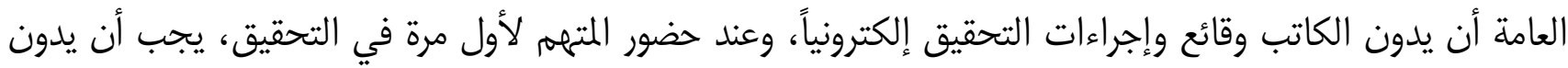

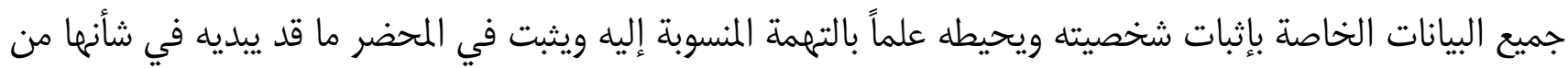
أقوال (224).

وهو ما أكده المشرع الاتحادي في نص المادة (99/ من قانون الإجراءات الجزائية) على أنه يجب على عضو النيابة

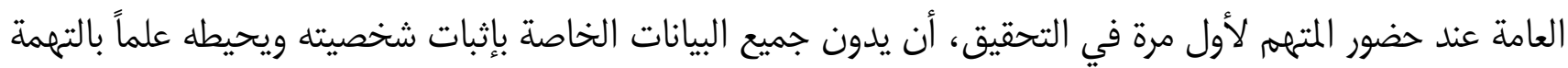

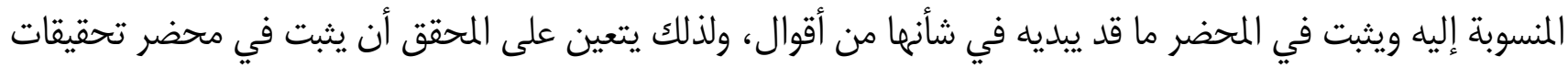

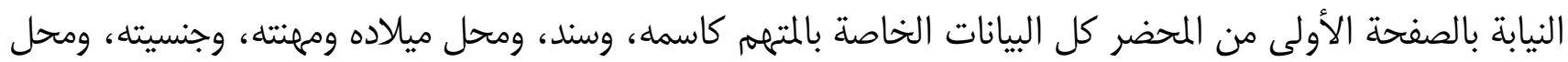

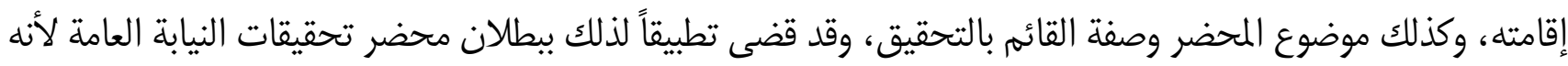

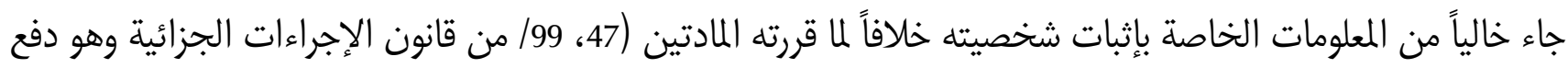

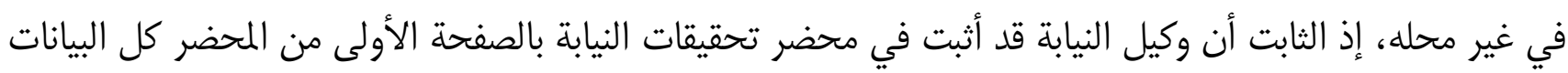

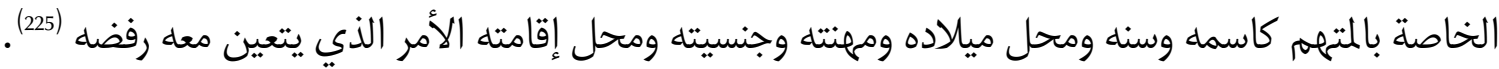
وعلى كل ما تقدم إن التحقيق الإبتدائي في مجال الإجراءات الجزائية الإلكترونية بتقنية الاتصال عن بعد حتى يتم

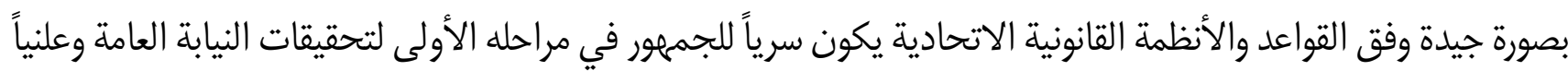

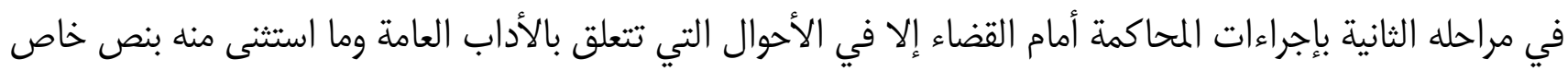

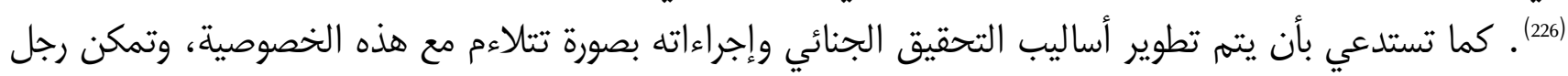

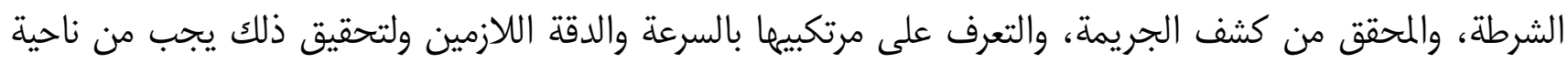

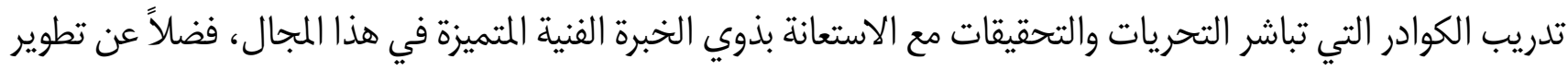

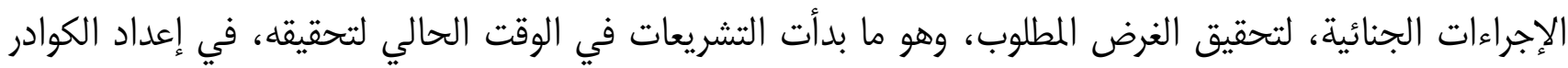
لمباشرة التحريات والتحقيقات الإلكترونية بتقنية الاتصال عن بعد، والاستعانة بالخبرة الفنية، وإجراء المعاينة المطلوبة،

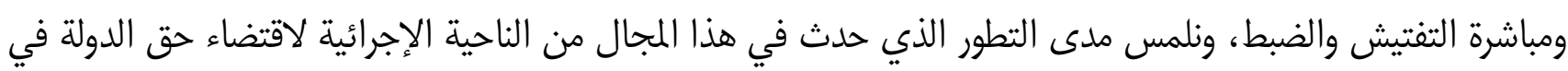

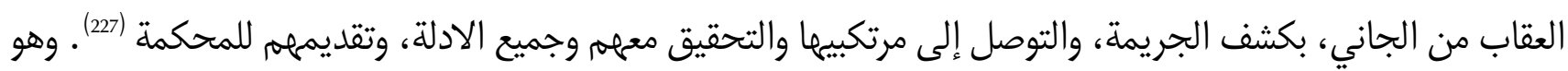

(224) سلامة، مأمون، الإجراءات الجنائية في التشريع المصري، (القاهرة : دار النهضة العربية، 2000) ط1، ج1، ص : 613. (225) المحكمة الاتحادية العليا في الطعن رقم 42 لسنة 31 قضائية أمن دولة، جلسة الاثنين الموافق 2002/6/2، السنة 25 قضائية، الأحكام الصادرة من المكتب الفني لعام 2003. (226) لما جاء في نص المادة (29) من القانون الاتحادي رقم 9 لسنة 1996، بشأن الأحداث الجانحين، على أنه تجرى محاكمة الحدث في غير العلانية ولا يجوز أن يحضرها إلا متولي أمره، والشهود والمحامون، ومندوبو وزارة الشؤون الاجتماعية ومعاهد الأحداث، ومن تأذن له المحكمة بالحضور. وللمحكمة إعفاء الحدث من حضور المحاكمة بنفسه، وأن تقرر سماع الشهود بغير حضوره، إذا رأت أن مصلحته تقتضي ذلك، على على أنه لا يجوز الحكم بالإدانة إلا بعد إفهام الحدث ما تم في غيبته من إجراءات ويجب أن يكون النطق بالحكم في جلسة علانية.

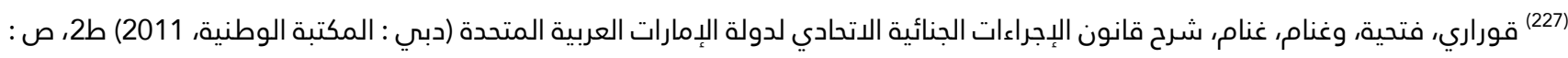




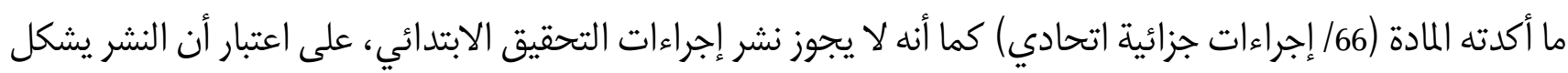

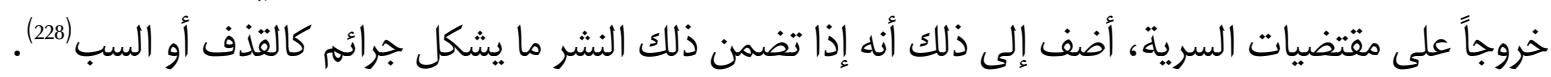
وترى الباحثة أن إجراءات التحقيق الجزائي في تقنية الاتصال عن بعد لا تختلف عن إجراءات التحقيق التقليدية في

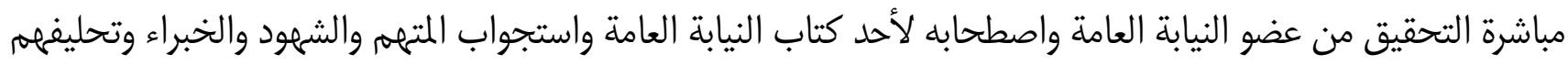

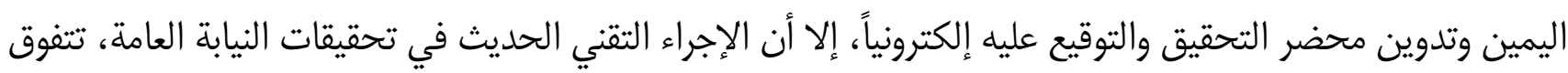
عن الإجراءات التقليدية في سرعة إنجاز والفصل في الدعوى الجزائية.

\section{الخاتمة}

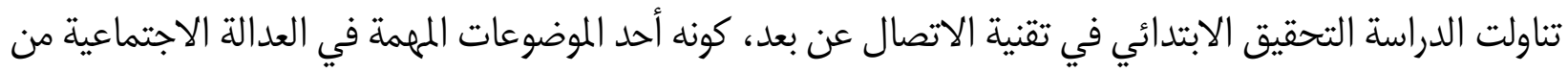

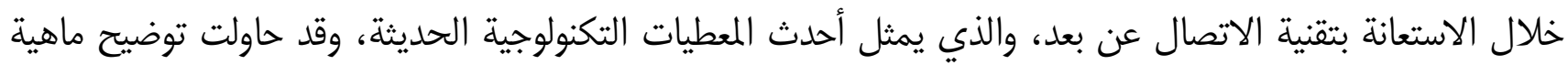

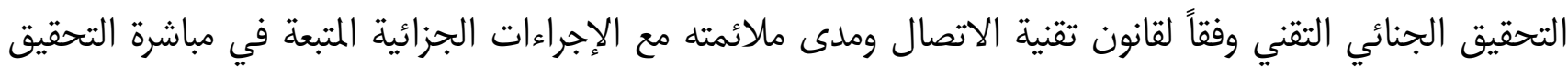

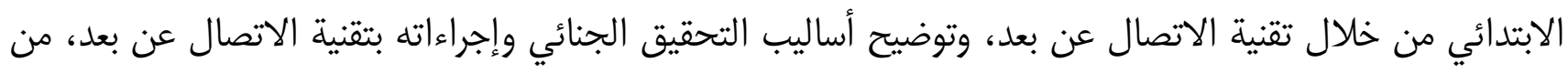

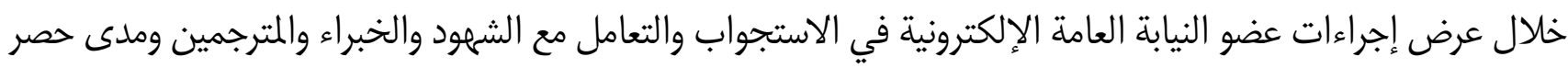

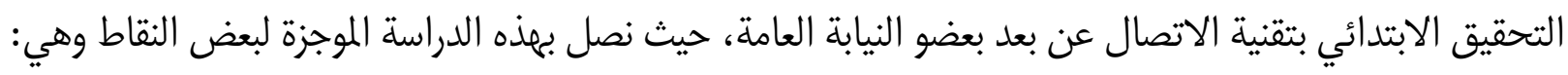
1. اتجه المشرع الاتحادي إلى إرساء قواعد قانونية جديدة تواجه الجرائم من خلال الأخذ بمعطيات التكنولوجيا الحديثة

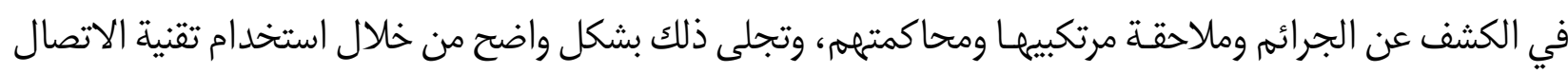
عن بعد في مجال التحقيق 2. أن إجراءات التحقيق الجزائي في تقنية الاتصال يتميز بالسرعة والدقة، في إنجاز الفصل في الدعوى الجزائية وتوفير

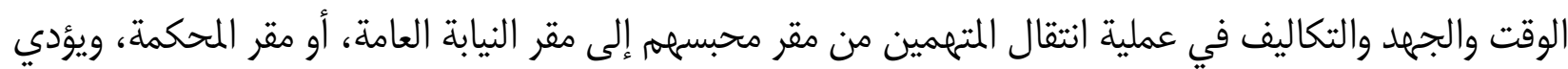
إلى سرعة سير الإجراءات الجزائية

3. إن إجراءات التحقيق بتقنية الاتصال تتم بصورة تتلاءم مع هذه الخصوصية، وتمكن المحقق من كشف الجريمة،

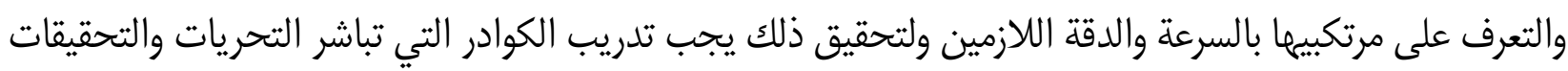

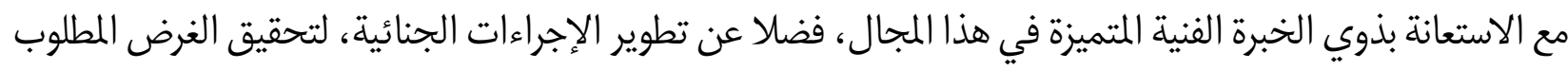
أملين أن تكون هذه الدراسة مفتاحية لغيرها من الدراسات المعمقة في مجال استخدام تقنية الاتصال عن بعد في الإجراءات الجزائي 


\title{
الحماية الجنائية للأطفال ضحايا الاستغلال في القانون المغربي
}

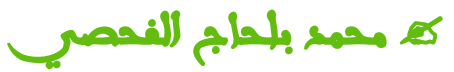

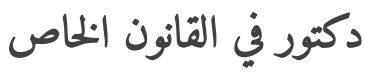 \\ منتدب قضائي من الدرجة الثانية بعمكة الاستئناف بطنجة \\ مدير ورئيس تحرير مجلة محيط للدراسات والأبحاث القانونية \\ مدير ورئيس تحرير مجلة المتوسط للدراسات القانونية والقضائية
}

مقدمة:

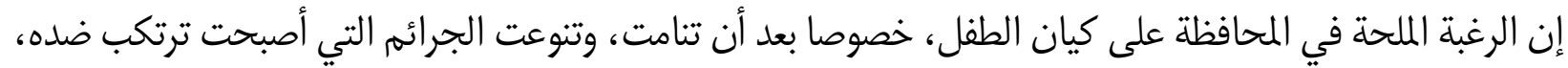
باعتباره شخصا ضعيفا عقليا وبدنيا يمثل رجل الغد الواعد أفرز إلى الوجود مجموعة من القواعل العدان والأحكام الزجرية لحماية هذا الطفل من كل أَذىً.

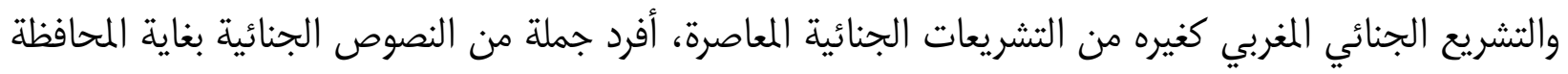

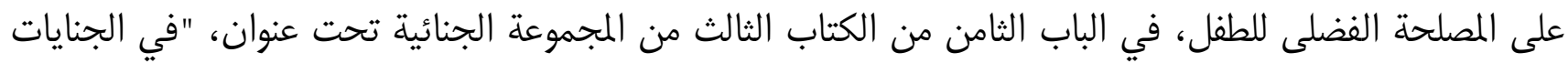

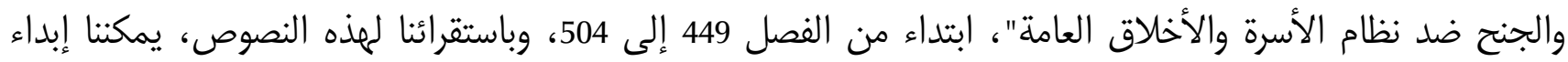

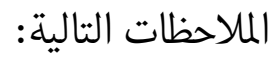

الملاحظة الأولى: قَسَّمَ المشرع المغربي الجرائم التي تمس بالطفل إلى جريمة الإجهاض، وهي التي من شأنها أن الن المباض

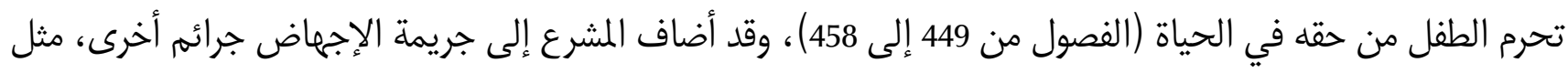

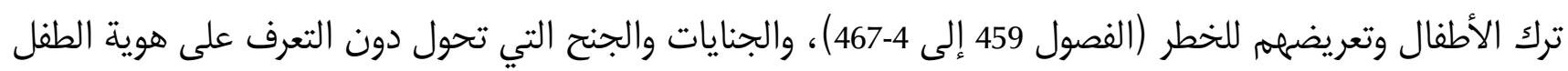

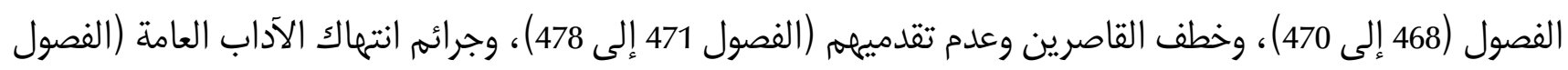
من 483 إلى 496)، وجرائم إفساد الشباب واستغلالمهم في البغاء (الفصول 497 إلى إلى 504).

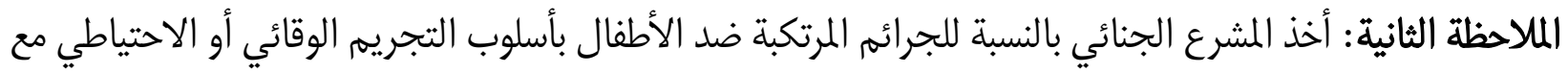

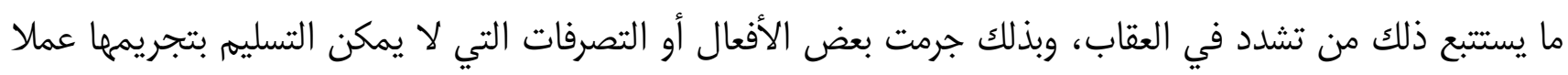

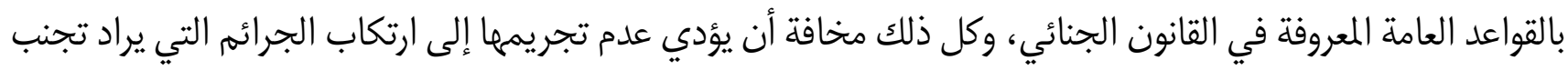

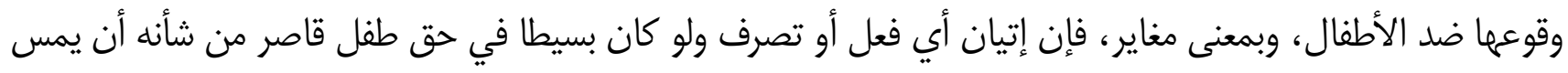

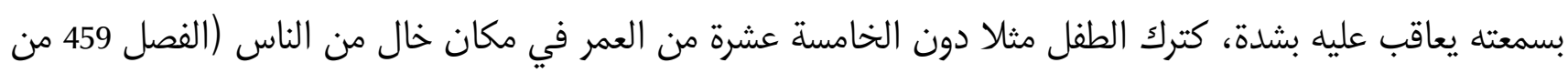
ق. ق.

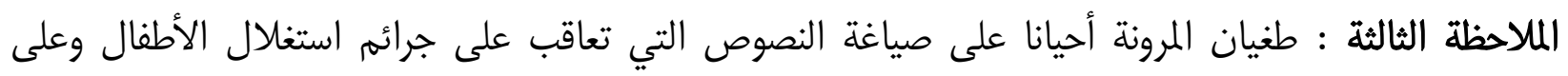

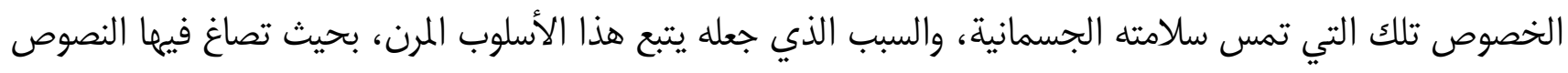




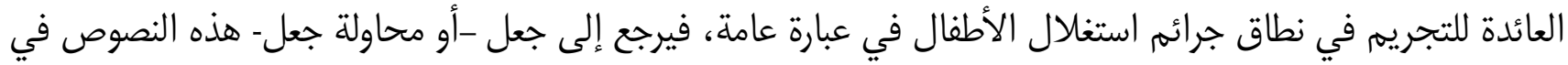

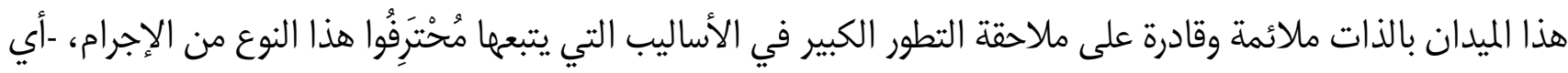

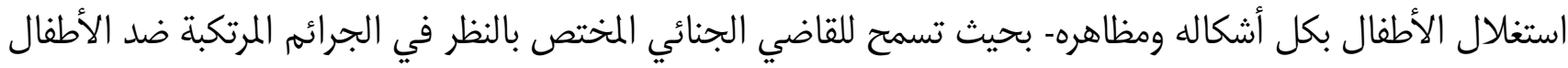

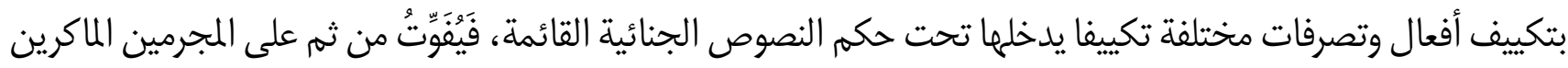

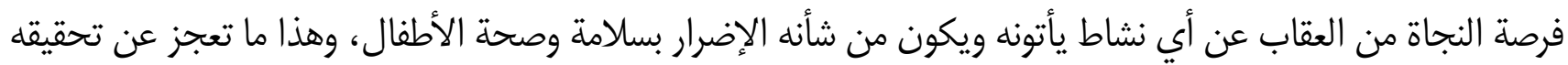

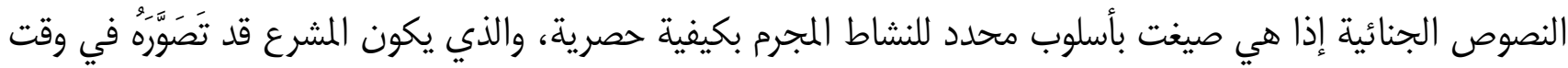

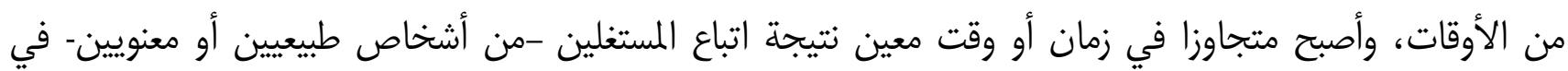

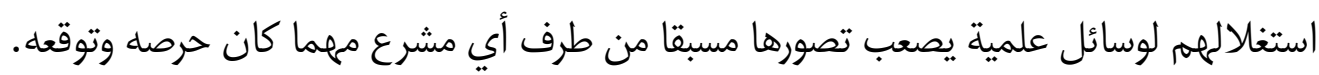

ولهم يقف اهتمام المشرع باعتباره السلطة المركزية التي تقوم بسن القوانين بشأن جرائم استغلال الأطفال من خلال الحماية الجنائية الموضوعية، وإنما امتد ذلك إلى الحماية الإجرائية أيضا. وللبحث في هذا الموضوع سنعمل على تقسيمه إلى مبحثين اثنين على الشكل التالي: المبحث الأول: الأساس القانوني الجنائي لاستغلال الأطفال. المبحث الثاني: الحماية الجنائية للأطفال ضحايا الاستغلال.

\section{المبحث الأول: الأساس القانوني الجنائي لاستغلال الأطفال}

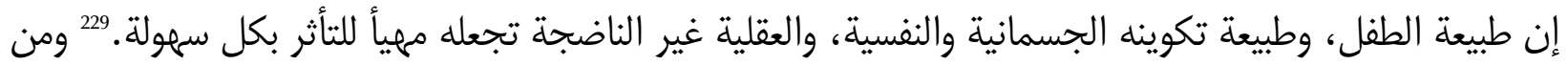

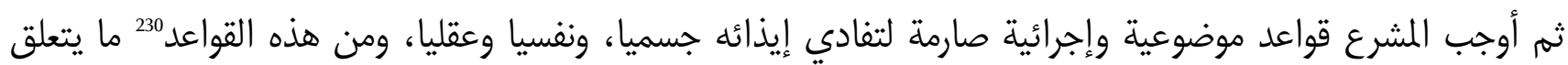

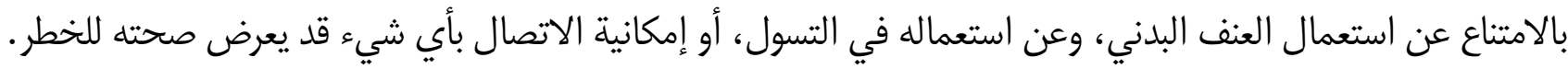
إن كل مرحلة من مراحل النموا231 الجسمي والعقلي لدى الطفل لها صفات وخصائص تميزها عن غيرها، ولكنها

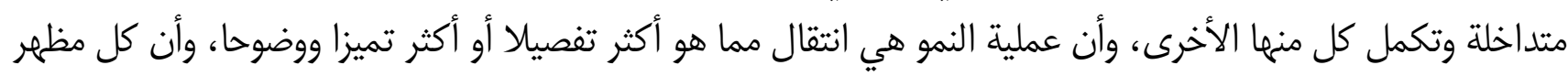

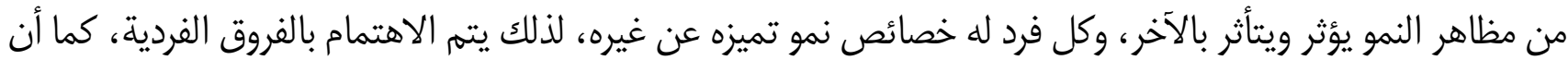
داخل الفرد الواحد تختلف سرعة النمو الجسمي عن العقلي.

229 وزارة العدل : "شرح قانون المسطرة الجنائية"، الجزء الثاني، منشورات جمعية نشر المعلومة القانونية والقضائية، سلسلة الشروح والدلائل، العدد 7، الطبعة الثالثة، يوليوز 2005، مطبعة فضالة المحمدية، ص: 229. 230أنظر الفرع الثاني، والثالث، والرابع، والسابع من الباب الثامن من الكتاب الثالث من مجموعة القانون الجنائي المغربي، أنظر كذلك القسم

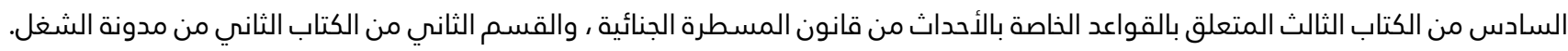
والفصول 59 و60 و65 من قانون الصحافة والنشر المغربي.

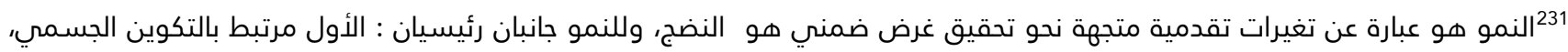
والثاني نفسي أو عقلي. أنظر : معتوق محمد عبد القادر المتنائي : "منهج رياض الأطفال"، دار الكتب الوطنية بنغازي، الطبعة الأولى 1986،

232 : 5حمد جاسم محمد : "النمو والطفولة في رياض الأطفال"، الناشر مكتبة دار الثقافة للنشر والتوزيع، عمان، الطبعة الأولى 2004، ص : 7. 


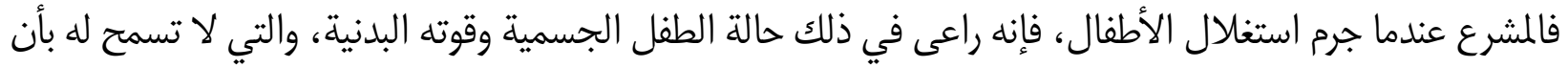

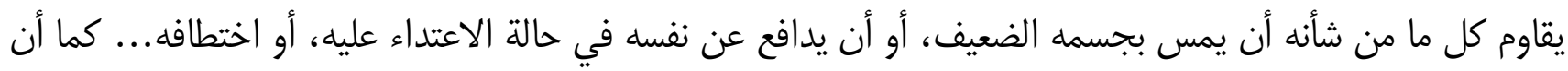

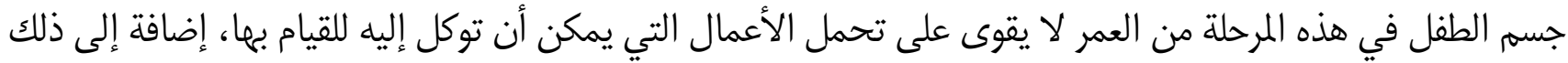

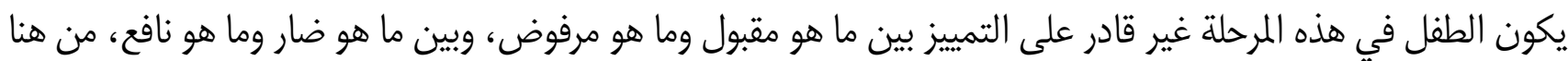

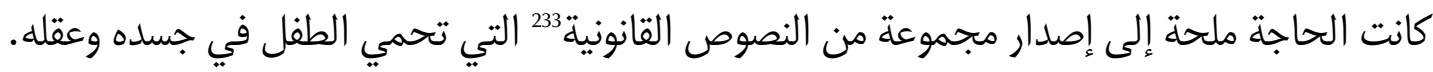

وقد كشفت البحوث والدراسات التربوية عن أن القاعدة الرئيسية التي يجب أن تقوم عليها أي خطة نظرية أو عملية

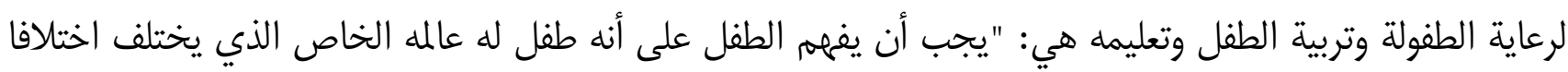
واضحا عن عالم الكبار والراشدين، فالطفل يشكل عنصرا مهما من عناصر المجتمع لم تكتمل شخصيته، ولمم يبلغ درجة

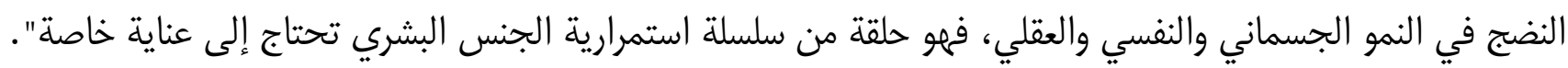

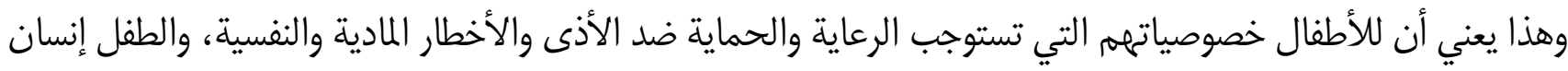

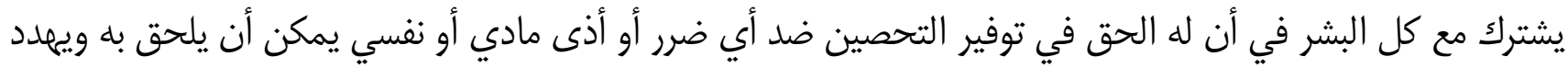

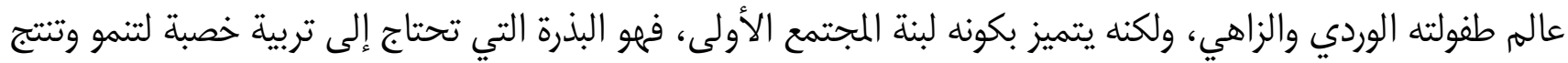

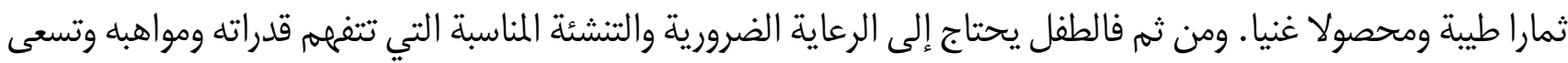
لتنميتها بشكل يكفل نمو الشخصية الصحيحة المستقيمة.

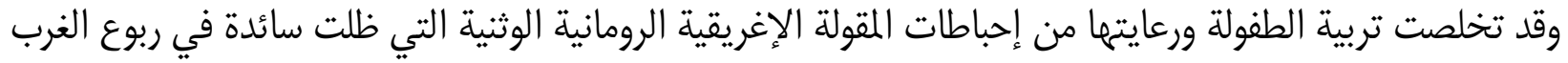

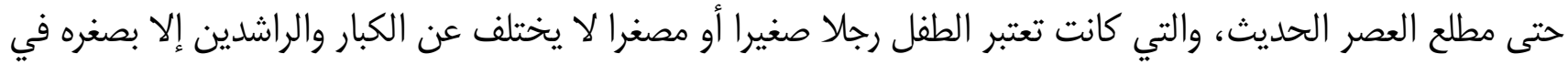

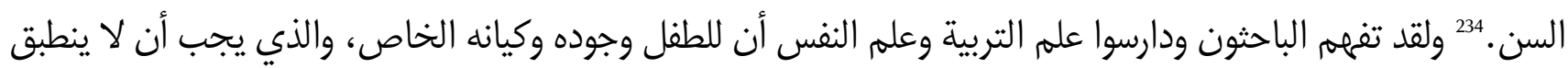

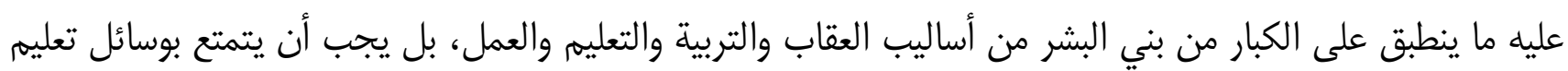
وعناية ورعاية تتناسب مع تركيبته السيكولوجية

فإذاكان "استغلال الأطفال" يقترن مفهومه بالاستفادة غير المشروعة على حساب حقوقهم، وذلك لإحداث ضرر

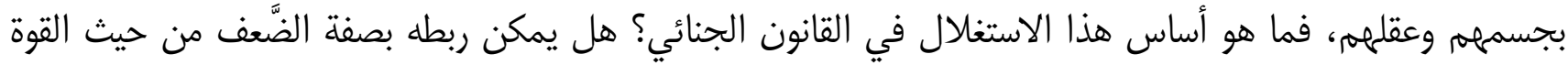

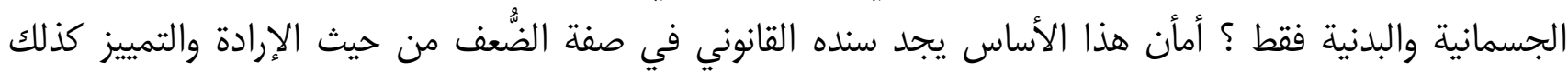

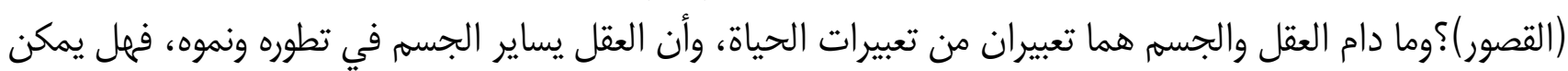
تصور فصل عقل الطفل عن جسمه ؟

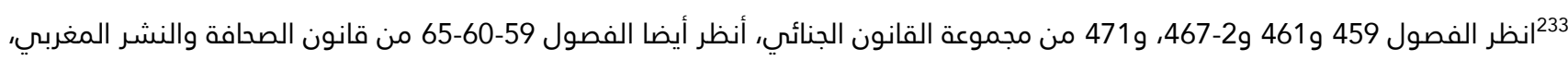
والمادتين 510 و 511 من قانون المسطرة الجنائية المغربية.

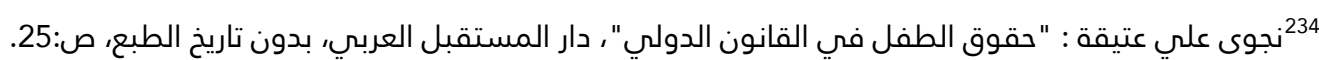

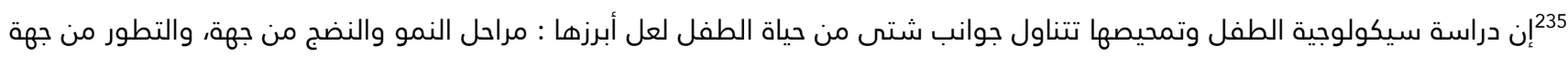
أخرى. لمزيد من الاطلاع حول هذا الموضوع أنظر في ذلك، عبد العالي الجسماني : "سيكولوجية الطفولة والمراهقة، وحقائقهما الأساسية"،

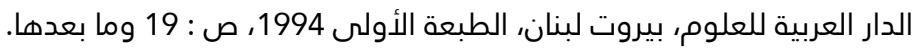
236 فتيحة حسن سليمان : "تربية الطفل بين الماضي والحاضر"، القاهرة، طبعة 1979، ص : 9. 
إن جوابنا على هذه الأسئلة سيكون من خلال تقسيم هذا المبحث إلى مطلبين اثنين كما يلي:

المطلب الأول: الأساس المرتبط بصفة الضَّعف من حيث القوة الجسمانية والبدنية المطلب الثاني: الأساس المرتبط بصفة/الضُّف من حيث الإرادةوالتمييز

\section{المطلب الأول : الأساس المرتبط بصفة الضَّعف237 من حيث القوة الجسمانية والبدنية}

إن حياة الطفل يوجد بها ما يطلق عليه بتعبير فرضية "الفترة الحرجة"، ومؤداها أن الانتقال من مرحلة نمو معينة إلى مرحلة أخرى، يجب أن لا تعترضه عوائق في نموه الجسمي، 238 فهذا الجانب التكويني الأخير هو نتاج التفاعلات الكيميائية التي تقود إلى نمو الأعضاء الخارجية، وكذلك الأعضاء الداخلية. 239

لذلك كان لابد للطفل أن يحظى بالعناية والرعاية التامتين، والتمتع بكل حقوقه في هذه المرحلة من عمره، وذلك حتى يتمكن جسمه من النمو في ظروف عادية. فحالة الطفل الجسمية والبدنية لا تسمح له بأن يقاوم كل ما من شأنه أن يمس بجسمه الضعيف أو أن يدافع عن نفسه في حالة الاعتداء عليه أو اختطافه.... كما سبق الذكر. كما أن جسم الطفل في هذه المرحلة لا يقوى على تحمل الأعمال التي يمكن أن يقوم بمها أثناء تشغيله سواء في نطاق العمل الزراعي أو في نطاق

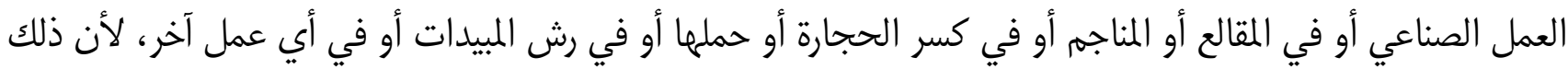
يؤثر سلبا لا محالة على جسم الطفل ونمو عضلاته. 240

فعندما نعتبر بأن "استغلال الأطفال" هو العمل على الجرح أو الضرب العمد، لطفل دون الخامسة عشرة من عمره، أو تعمد حرمانه من التغذية أو العناية حرمانا يضر بصحته أو ارتكب ضده أي نوع من العنف أو الإيذاء241 أو تعريض هذا الطفل للخطر أو تركه في مكان لا يستطيع أن يحمي نفسه بسبب حالته الجسدية أو العقلية242 أو تم بيعه أو شراؤه 243 أو استغلاله لممارسة عمل قسري، أو توسط أو حرض على ذلك أو أو حرضه على الدعارة أو البغاء أو شجعه عليها أو سهلمها لهـ244 أو أو أو استغلاله في الأعمال التي حذرها القانون عليه. 246 فإذا كان ذلك يعد استغلالا للطفل فإن الأساس القانوني السليم لهذا الاستغلال هو مصلحة الطفل الفضلى، وخاصة حمايته في جسده.

لقان استعملنا فـي المطلب الأول من المبدث الذي ندن بصدده مصطلح " الضَّعف"، وفي المطلب الثاني أوردنا مصطلح " الضُّعف"، والفرق

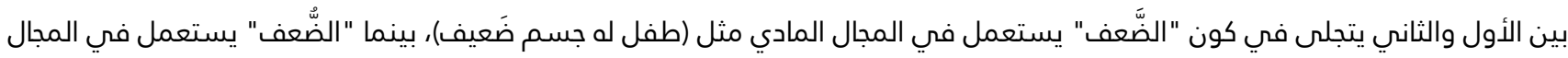
المعنوي، مثل انعدام أو نقصان الإرادة والتمييز، أو القصور. 238 239 محمد جاسم محمد : مرجع سابق، ص : 7. 240 عبد العالي الجسماني : مرجع سابق، نفس الصفحة السابقة : 19. 241انظر الفصل 408 من مجموعة القانون الجنائي المغربـي، كما تم تعديله وتتميمه بمقتضى القانون رقم 24.03. 242 243ر الفصل 459 من ق.ج. 243انظر الفصل 1-467 من ق.ج، والذي أضيف بمقتضى قانون 244انظر الفصل 2-467 من ق.ج، والذي أضيف بمقتضى قانون وقم 24.03 من 24.127 245انظر الفصل 497 من ق.ج. 246انظر الفصول 145 و146 و147 من من مدون من من الشغل. 
فجسم الطفل ينمو ببطء في الأجزاء العليا منه، وذلك في الوقت الذي تستمر فيه الساقان في النمو السريع، كما

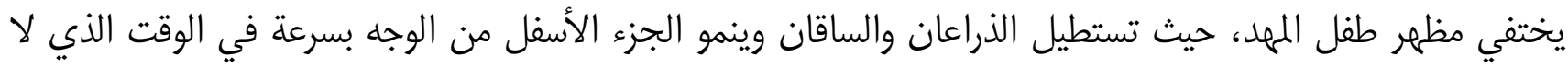

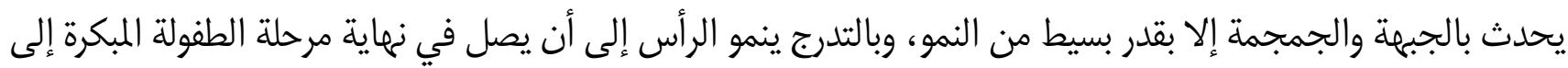

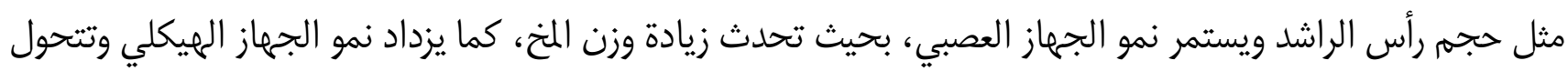

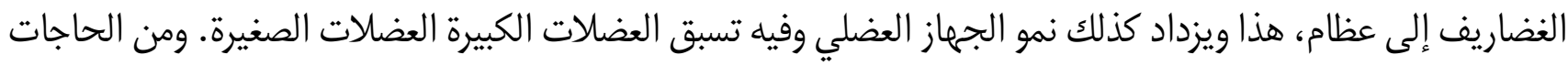
الفسيولوجية لدى الطفل والتي يسعى لإشباعها هي الحاجة إلى الغذاء الصحي. إن هذه المظاهر الجسمية السابقة تتفاعل مع مظاهر النمو الأخرى الأمر الذي يتطلب العناية بها ومراعاتها، لأن ذلك الك الكي

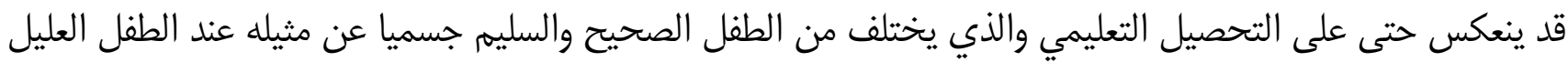

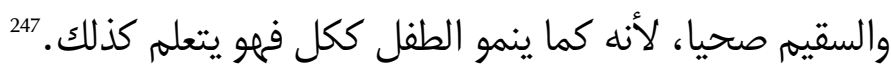

لذلك يجب الاهتمام بالطفل والعناية به ورعايته من الناحية الجسمية وهو ما فعله المشرع المغربي عندما أحاط هذا

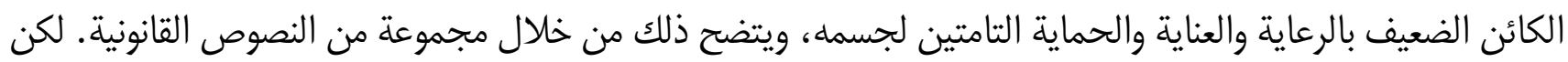

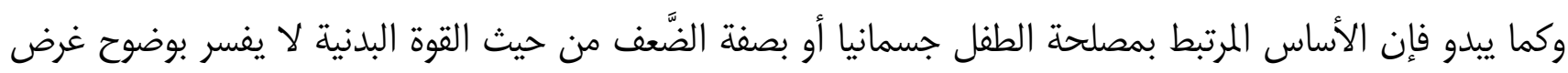

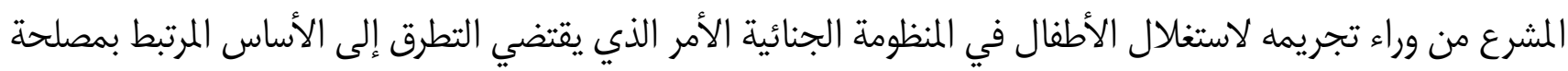
الطفل من حيث القدرة على الإدراك والتمييز، وهذا هو محور المطلب الثاني من هذا المبحث.

\section{المطلب الثاني: الأساس المرتبط بصفةالضُّعف من حيث الإرادة والتمييز}

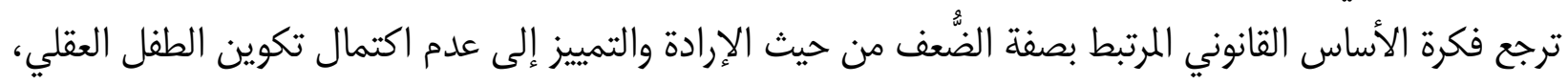

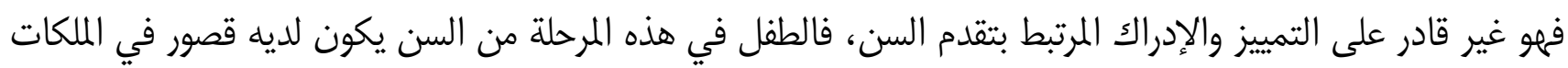

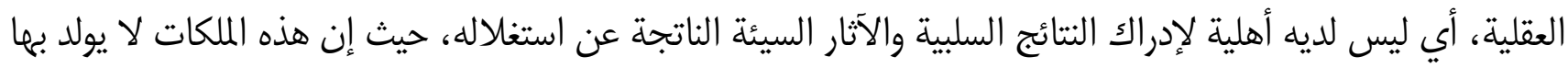

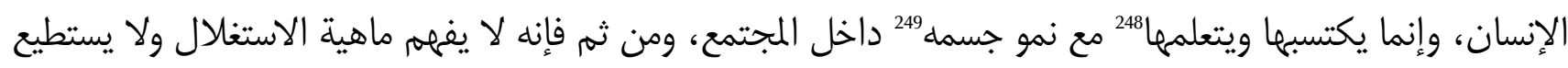

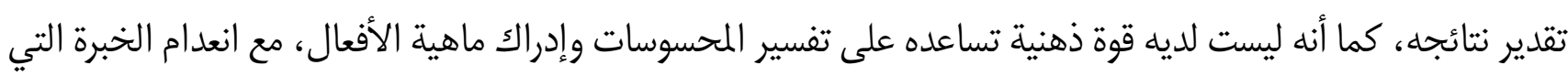
تساعده على تقدير خطورة ما يرتكب ضده.

ويمثل سن الطفل أهم الشروط لاستغلال الأطفال، فهو يعبر عن سلامة الملكات العقلية والنفسية 251 لدى الطفل المستغل

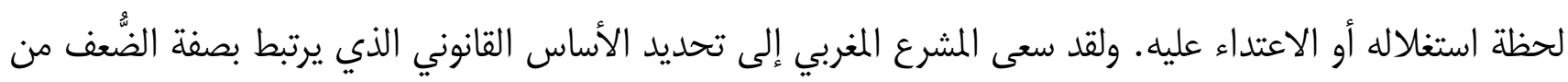

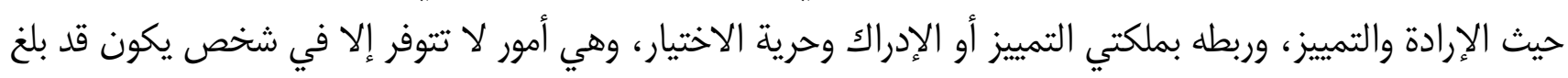

247 محمد جاسم محمد : مرجع سابق، ص : 13-13. 248 حمدي رجب عطية : "المسؤولية الجنائية للطفل في تشريعات الدول العربية والشريعة الإسلامية"، الناشر دار النهضة العربية، القاهرة، بدون تاريخ الطبع، ص : 47.

249 محمد جاسم محمد : مرجع سابق، ص ص : 13 : 13.

250 حمدي رجب عطية : مرجع سابق، نفس الصفحة السابقة : 47 : 251 25نان الدكالي : " الأهلية الجنائية للحدث"، دردية دراسة في التشريع المغربي والمقارن، رسالة لنيل دبلوم الدراسات العليا المعمقة في القانون الخاص، كلية العلوم القانونية والاقتصادية والاجتماعية، طنجة، السنة الجامعية 2006-2007، ص : 14. 
سنا معينة تؤهله لإدراك كونه سوف يقع ضحية للاستغلال، وهذا ما ذهب إليه المشرع المغربي حينما نص على معاقبة كل

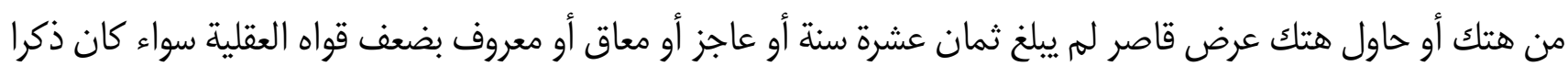

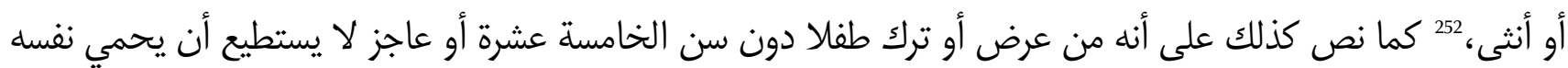
بسبب حالته الجسمية أو العقلية.

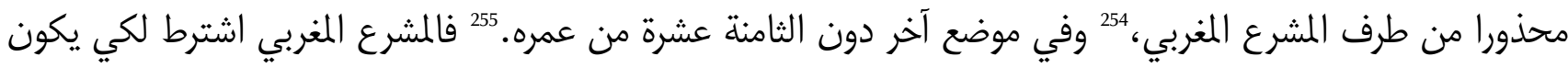

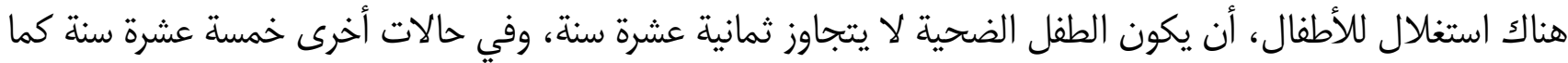
سبق الذكر.

فالنشاط الذهني أو العقلي عند الطفل لا ينمو على مستوى واحد بعينه نموا متصلا بل يتطور من نسق إلى نسق، 256

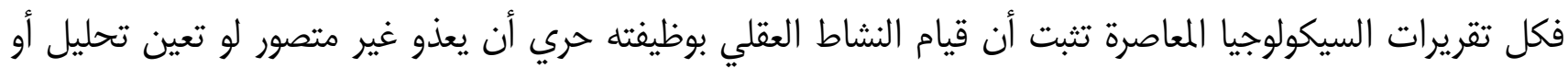

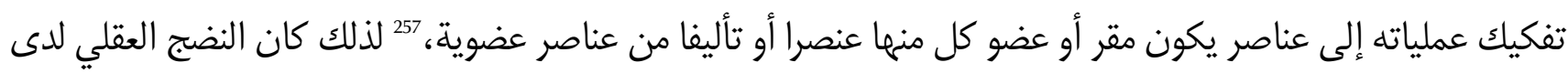

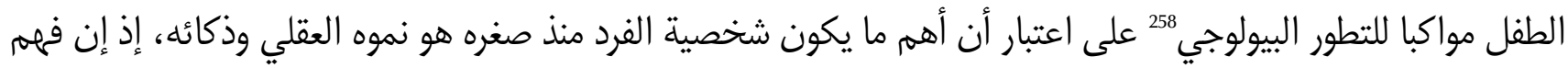

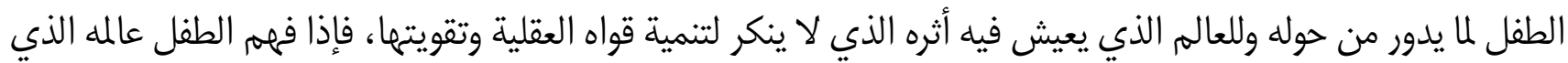

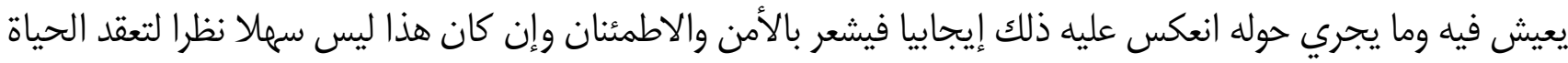
ولما طرأ عليها من ثورة معرفية وتكنولوجية معقدة.

ويطلق البعض على مرحلة الطفولة مرحلة السؤال، حيث تكثر أسئلة الطفل حول ما يثير انتباهه في البيئة من حوله،

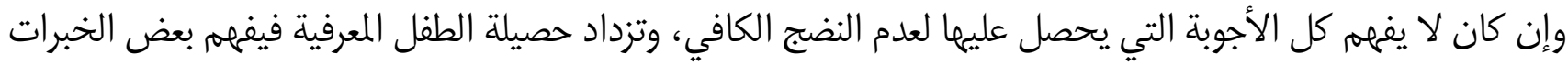

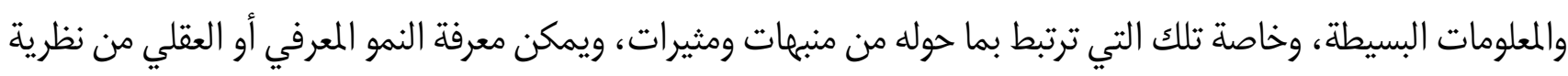

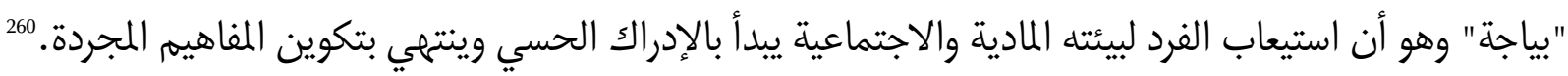
لكن السؤل هو كيف يتسنى تحقيق الصحة العقلية المنشودة عند الطفل والعناية بقدراته ؟ إن الجواب على هذا السؤال يجد سنده عند "هادفيلد"، الذي أكد أن: "الأهداف والغايات والمثل من أَلْزَم الضروريات

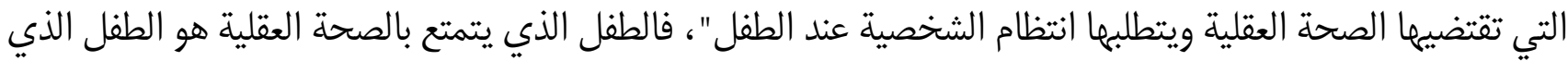

252انظر الفصل 484 من ق.ج، كما عدل وتمم بمقتضى القانون رقم 24.03. 253|نظر الفصل 459 من ق.ج، وذلك على سبيل المثال لا الحصر.

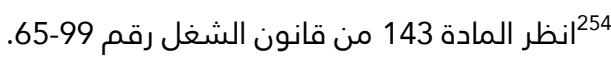
255انظر المادة 145 من ق.ش المذكور. 256 هنـــري فالون (المؤلف)، نظمـي لوقا (المترجم)، التطور السيكولوجي للطفل، الناشـــــر دار نهضة مصر للطبع والنشر، القاهرة، أبريل 1978،

257 هنري فالون (المؤلف)، نظمي لوقا (المترجم)، المرجع السابق، ص : 25. 258عبد العالي الجسماني : مرجع سابق، صون : 19 259محمد عبد الرحيم عدس، جميل أبو ميزردد : "المرشد في منهاج رياض الأطفال"، دار مجدلاوي للنشر والتوزيع، الطبعة الأولى 1993، ص : 
تكون قدراته واستعداداته قد أتيح لهها النمو الكامل، وهذا معناه أنه سيكون بوسعه استخدام تلك الطاقات على نحو يتمثل

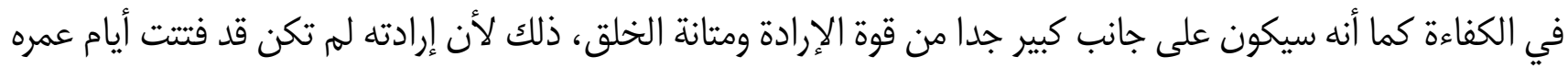

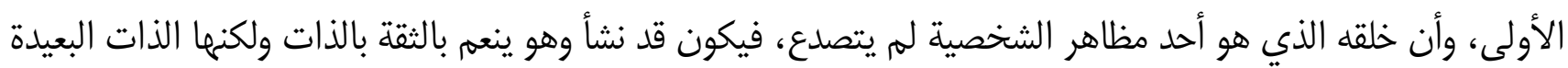
عن النزعة النرجسية بمعناها السلبي.

وكخلاصة لما سبق ذكره، فقد تم الانتهاء من هذا المبحث إلى أن الأساس القانوني "لاستغلال الأطفال" يتخذ وجهان،

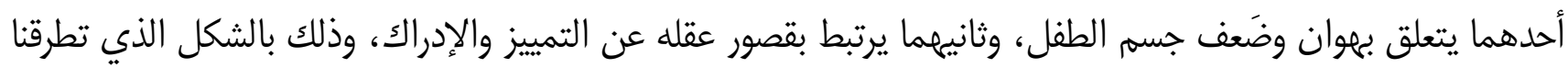
إليه آنفا.

لكن وفي نظرنا فإنه لا يمكن تصور قيام أحد هذين الأساسين دون الآخر مادام أن كل من العقل والجسم هما تعبيران

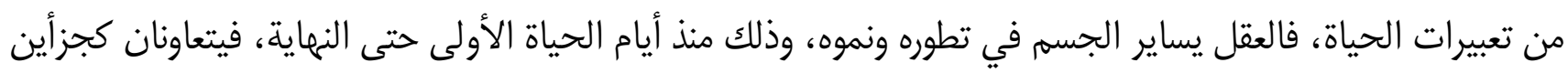

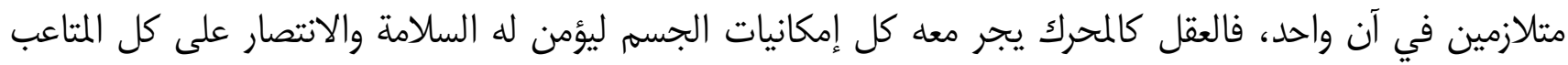
والصعوبات، ففي كل حركة من حركات الجسم أو في أي تعبير من تعبيراته يبدو تأثير أهدافه جلية. من هنا يتضح بأن المشرع المغربي في تعامله مع الأطفال ضحايا الاستغلال بكل أنواعه قد راعى عنصر الجسم والعقل

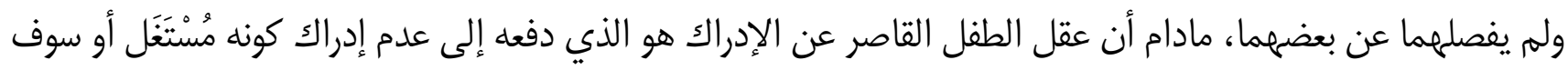

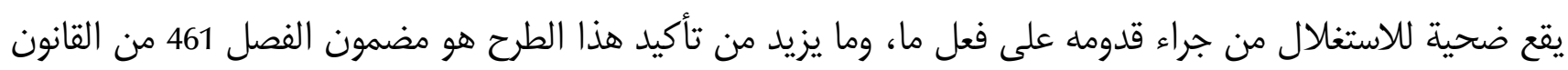

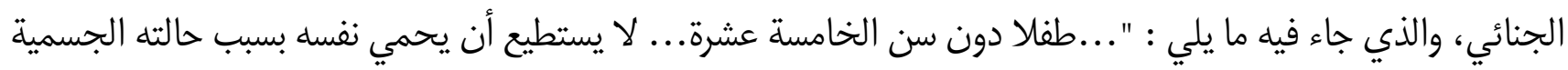

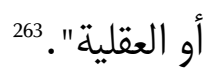

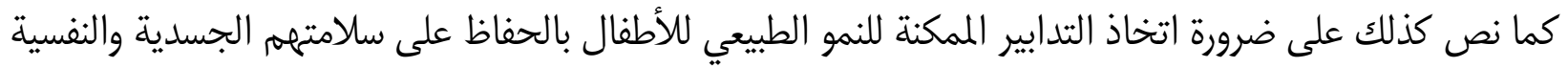

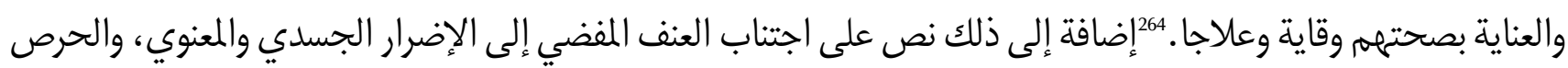
على الوقاية من كل استغلال يضر بمصالح الطفل. 265

\section{المبحث الثاني: الحماية الجنائية للأطفال ضحايا الاستغلال}

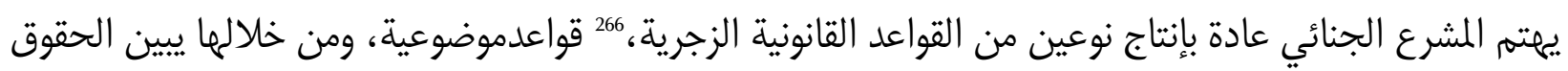
أو المصالح التي تقتضي الحماية التشريعية من الاعتداء عليها، مثل الحفاظ على مصلحة الطفل الفضلى، والمتمثلة في

(262 262 إن اكتشافات السيكولوجيا الفردية تزيل كثيرا من صعوبة الإشكال الذي يثور حول اعتبار العقل هو الذي يسيطر : الذي يسيطر على العقل، ولم يعد هذا الأمر مجرد مسألة "إما العقل أو الجسم"، للتوسع أكثر في هذا الموضوع، راجع محمد جاسم محمد:

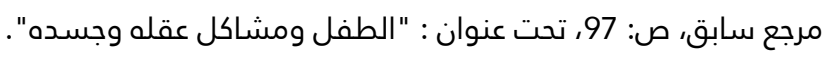
263انظر أيضا الفصل 459 من ق.ج الذي جاء فيه : "...طفلا دون سن الخامسة عشرة... لا يستطيع أن يحمي نفسه بسبب حالته الجسمية أو العقلية". 264 انظر الفقرة الخامسة من المادة 54 من مدونة الأسرة.

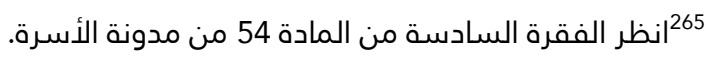
266محمد التغذويني: "إشكالية التجريم في التشريع الجنائي المغربي"، مطبعة أنفو-برانت فاس، الطبعة الثانية، 2005، ص : 9. 
سلامته العقلية والجسدية، وذلك على ضوء مبادئ قانونية تتبناها كل دولة في سياستها الجنائية يطلق عليها القانون الجنائي

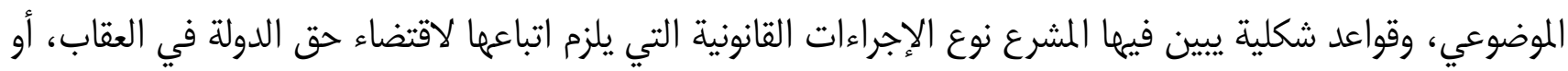

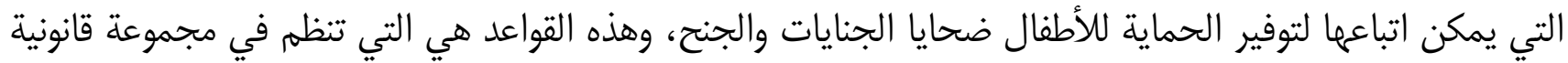

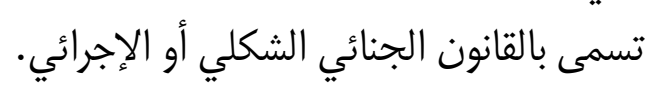
ولدراسة هذا المبحث يتعين علينا تقسيمه إلى مطلبين كما يلي: المطلب الأول: الحماية الجنائية الموضوعية للأطفال ضحايا الاستغلال في التشريع المغربي

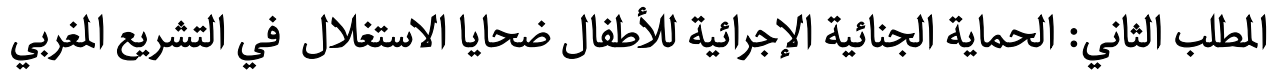

\section{المطلب الأول: الحماية الجنائية الموضوعية للأطفال ضحايا الاستغلال في التشريع المغربي}

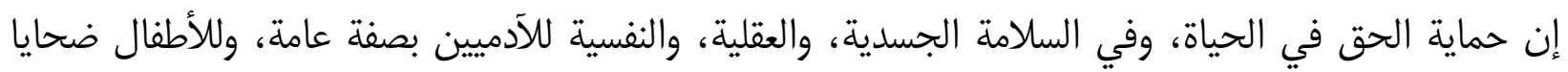

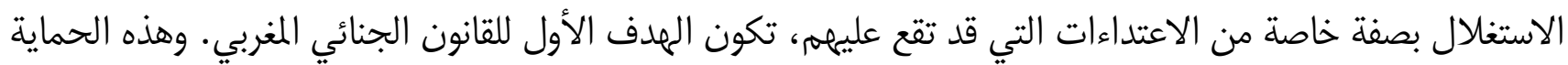

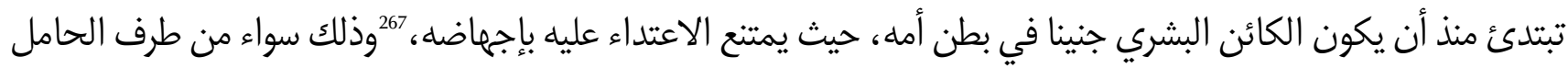

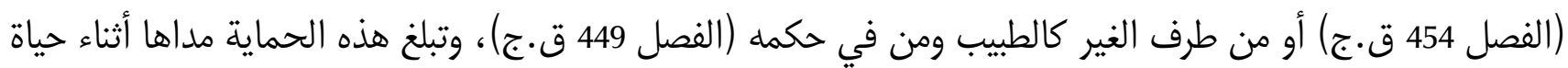

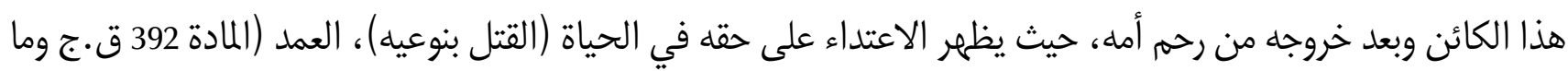

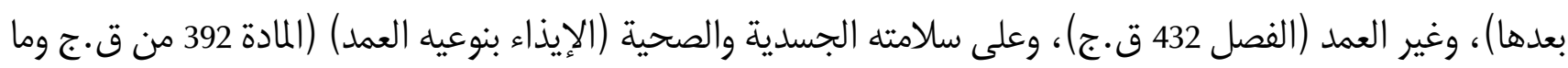

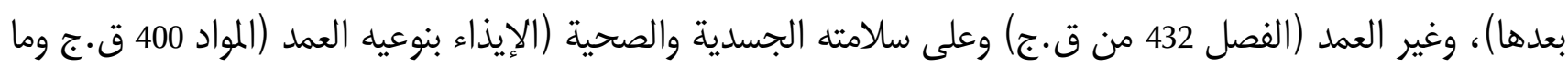

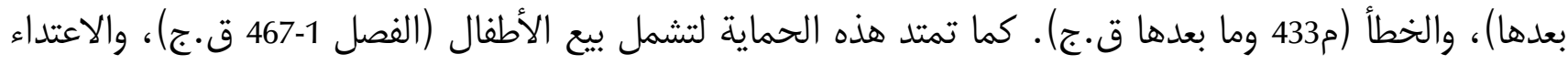

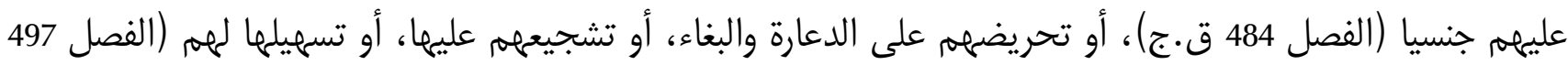
ق.ج)، وذلك على سبيل المثال.

وسنقف أثناء معالجتها لهذاالموضوع على مجموعة من الأحكام والقواعد الزجرية التي توفر الحماية الضرورية للأطفال

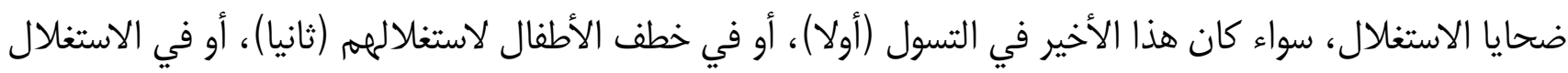

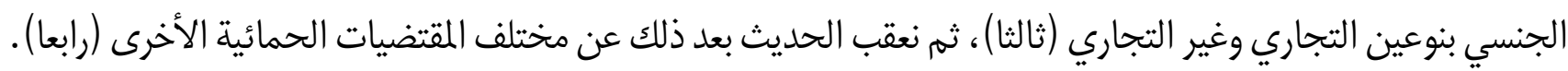

\section{أولا : تجريم استغلال الأطفال في التسول}

نص المشرع المغربي على التسول بصفة عامة، واستغلال الأطفال في التسول بصفة خاصة في الفصول من 326 إلى 323 إلى

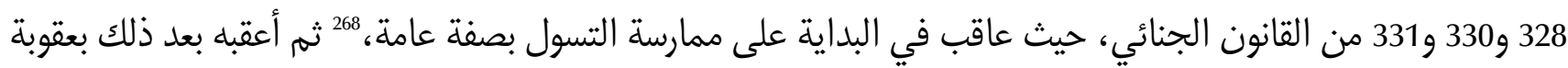

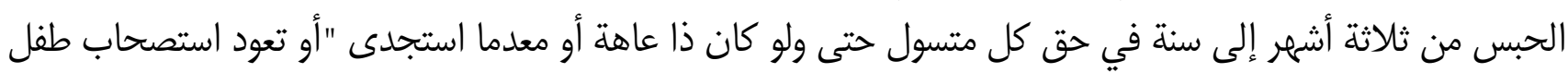

267 26بد الواحد العلمي : "القانون الجنائي المغربي القسم الخاص"، الطبعة الثالثة، 2003، بدون دار النشر، ص : 193. 268 جاء في الفصل 326 منق.ج ما يلي : "يعاقب بالحبس من شهر واحد إلى ستة أشهر من كانت لديه وسائل التعيش أو كان بوسعه الحصول : عليها بالعمل أو بأية وسيلة مشروعة، ولكنه تعود ممارسة التسول في مي أي مكان". 
صغير أو أكثر من غير فروعه" ، و269 كما يعاقب بنفس العقوبة المذكورة -أي بالحبس من ثلاثة أشهر إلى سنة- من يستخدم

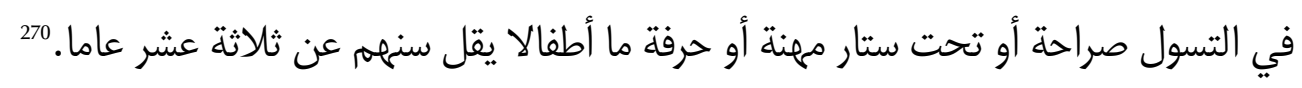

وبمناقشتنا لعبارة "تعود استصحاب طفل صغير أو أكثر من غير فروعه"، يتعين علينا إبداء الملاحظات الآتية :

الملاحظة الأولى: استعمل المشرع المغربي مصطلح "التعود"، وهو مصطلح يفيد الاعتيادية والاحتراف، أي كل من

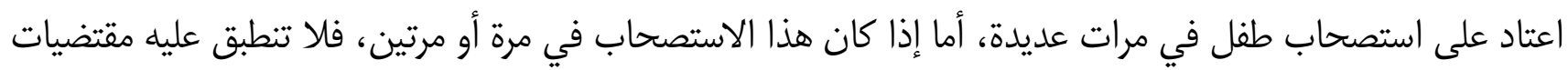

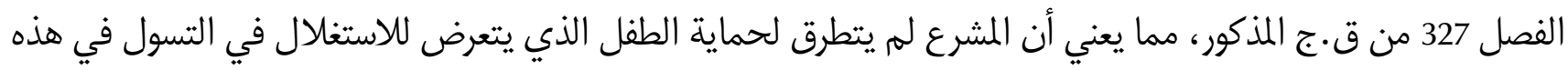

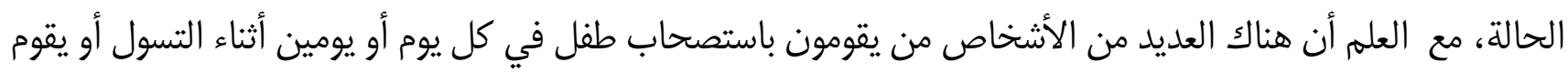

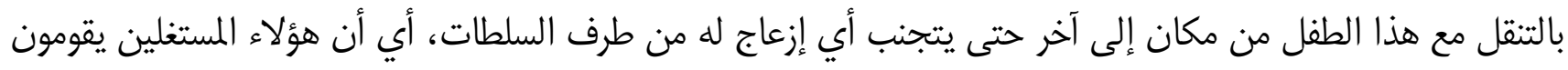

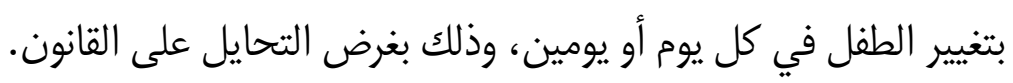

الملاحظة الثانية: كون المشرع الجنائي المغربي اشترط أن يكون هذا التعود باستصحاب طفل من غير الفروع، فمفاد

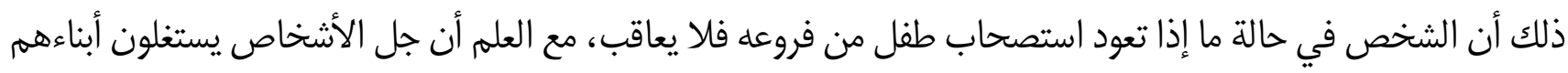

$$
\text { في التسول رغم يسرهم. }
$$

ونفس الملاحظة يمكن إبداؤها بخصوص الفقرة الخامسة من الفصل 327 من ق.ج، عندما عاقب المشرع على التسول

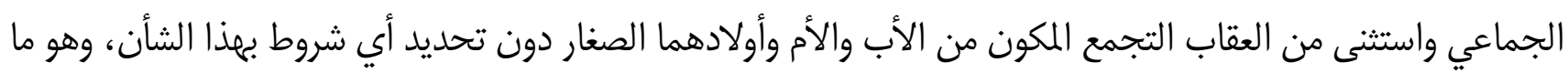

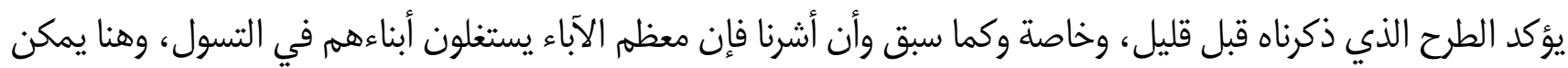

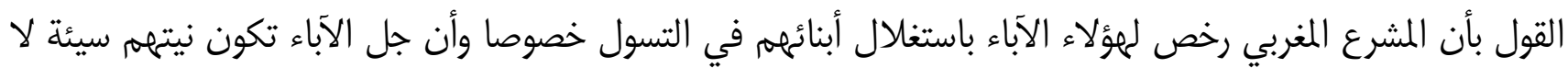

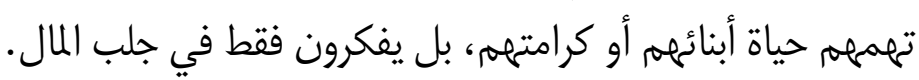

كما عاقب المشرع المغربي بالعقوبة المشار إلييا في الفصل 327 المذكور كل شخص قام باستخدام أطفال تحت سن 13

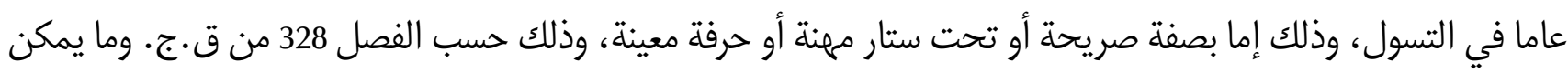

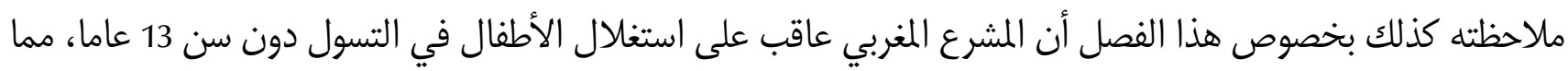

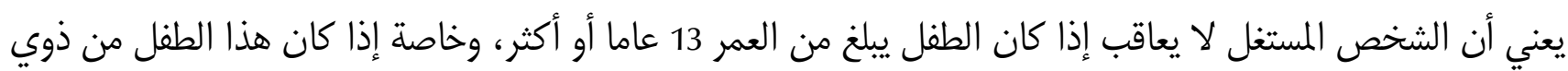

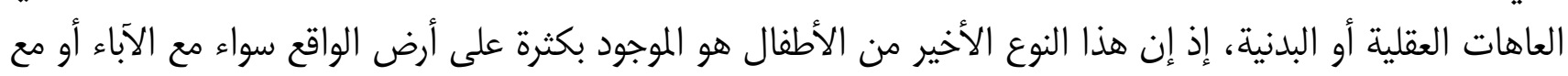

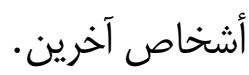

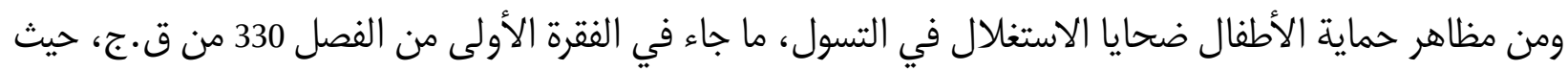

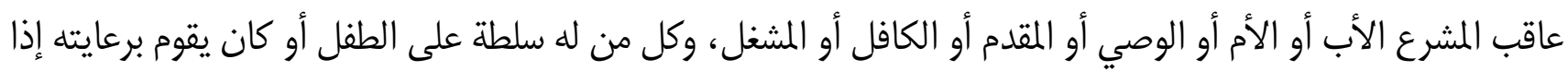

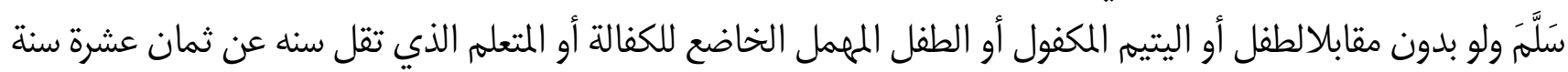
إلى متسول أو متسولين، وذلك بالحبس من ستة أشهر إلى سنتين. 
كما يعاقب بنفس العقوبة المذكورة كل من سله الطفل اليتيم أو المكفول أو الطفل الخاضع للكفالة أو المتعلم الذي تقل

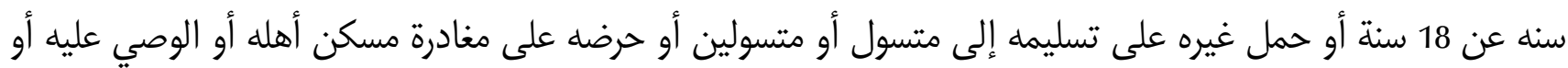
المقدم عليه أو كافله أو مشغله أو الشخص على تسليمه الذي يقوم برعايته ليتبع متسولا أو متسولين.

وباستقرائنا لمتضيات الفصلين 328 و330 من ق.ج، نلاحظ بأن المشرع المغربي لم يحدد عمرا محددا للأطفال ضحايا

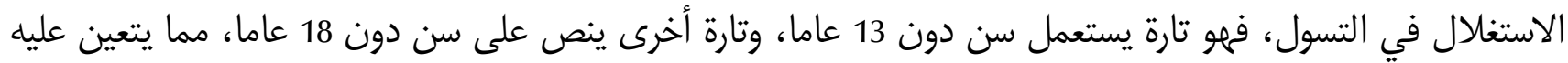
التدخل لإعادة صياغة مضمون الفصل 328 من ق.ج لرفع سن 13 عاما إلى 18 سنة.

\section{ثانيا : تجريم خطف الأطفال} تطرق المشرع المغربي لخطف الأطفال في الفصول من 471 إلى 478 من ق.ج، حيث جرم خطف الأطفال بصفة عامة،

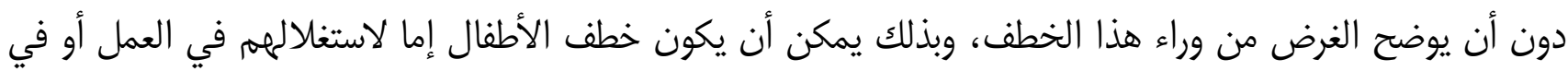
التسول أو في السياحة الجنسية أو في التبني أو في أخذ أعضائمه لبيعها....

وهكذا ينص الفصل 471 منق.ج على أنه: "من استعمل العنف أو التهديد أو التدليس لاختطاف قاصر دون الثامنة

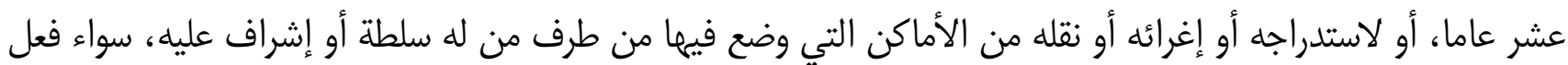

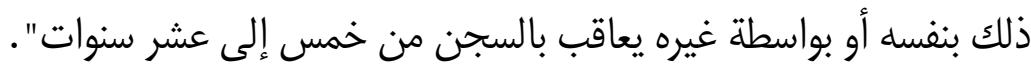

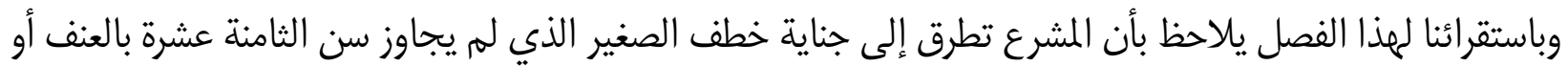

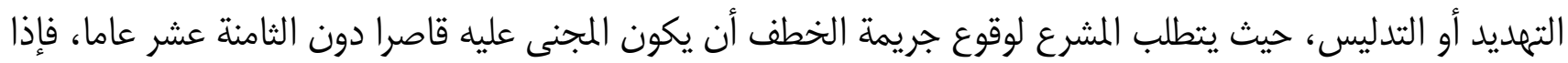

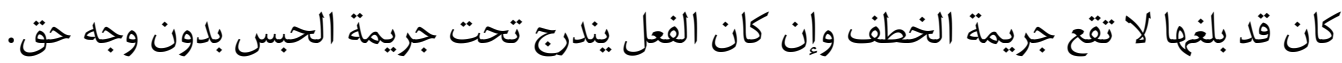
وتجب الإشارة هنا إلى أن المشرع قد خَرَجَ على القواعد العامة في المساهمة الجنائية، حيث سوى بين الفاعل وبين

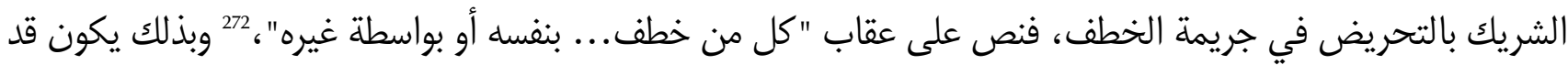
اعتبر كل منهما فاعلا أصليا في الجريمة، ومن ثم عاقب الاثنين بنفس العقوبة وهي السجن من خمس إلى على عشر سنوات. وإذا كان المشرع المغربي من خلال الفصل 471 منق.ج قد عاقب على اختطاف طفل دون 18 عاما، فإن الفصل من نفس القانون قد شدد من عقوبة خطف القاصر الذي يقل عمره عن اثني عشر عاما، حيث يعاقب الجاني الذي يرتكب جريمة الخطف المنصوص عليها بالفصل 472 المذكور بالسجن من عشر إلى عشرين سنة، وإذا تم العثور على القاصر حيا قبل صدور الحكم على الجاني، فإن العقوبة تكون السجن من خمس إلى عشر سنوات.

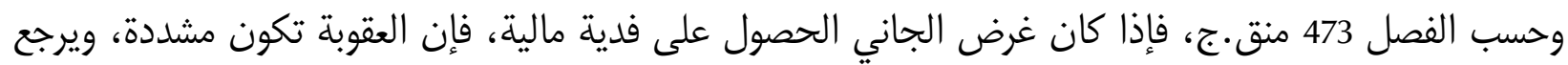

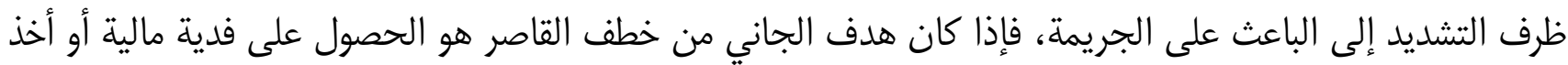

271 272 راجع الفصل 471 من ق.ج المغربي. جاء في هذا الفصل ما يلي: " إذا كان القاصر الذي وقعت عليه المغربي الجريمة المشار إليها في الفصل السابق (471) تقل سنه عن اثني عشر عاما، فعقوبة الجاني السجن من عشر إلى عشرين سنة". 
الفدية فعلا، كانت عقوبته السجن المؤبد بصرف النظر عن سن القاصر. وفي حالة ما إذا تم العثور على القاصر حيا274 قبل صدور حكم ضد الجاني، فإن العقوبة تكون السجن من عشر إلى عشرين سنة.

أما فيما يتعلق بجريمة الخطف بلدون استعمال العنف أو التهلديد أو التدليس أو المحاولة، فقد نص عليها المشرع المغربي في الفصل 475 من ق.ج، يكون قاصرا لم يبلغ ثماني عشرة سنة كاملة سواء كان ذكرا أم أنثى، والعبرة في تحديد سن المجنى عليه بوقت تنفيذ الجريمة دون وقت انتهائمها، فإذا كان الصغير دون الثامنة عشرة وقت أن انتزعه الجاني من بيئته ونقله إلى محل آخر قامت الجريمة ولو بلغ المجنى عليه ثماني عشرة سنة أثناء استمرار الجريمة، ويؤخذ في حساب سن الضحية بالتقويم الميلادي باعتباره التقويم الذي يعتد به القانون الجنائي.

ويجب أن يكون الحكم الصادر عن المحكمة المختصة معللا من الناحيتين الواقعية والقانونية وإلا كان باطلا، وأن نقصان التعليل يوازي انعدامه، مثل ما هو الشأن بالنسبة للمحكمة التي أدانت الطاعن بجريمة اختطاف قاصرة التي أنكرها

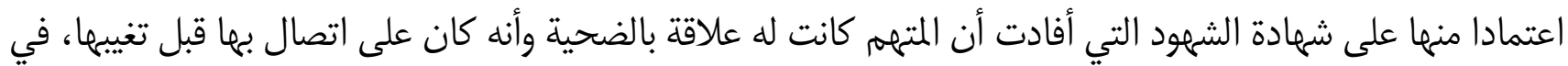
حين اعتبر المجلس الأعلى هذا غير كاف لإبراز عنصر الاختطاف مما جعل الحكم ناقص التعليل يوازي انعدامه. 276

\section{ثالثا : حماية الأطفال ضحايا الاستغلال الجنسي التجاري وغير التجاري.}

سنعرض من خلال هذه النقطة لأهم قواعد حماية الأطفال ضحايا هذا الشكل من الاستغلال البشع، وتتجلى أهم هذه الأحكام في تجريم الفعل الفاضح العلني (الفصل 483)، وتجريم هتك عرض أو محاولة ذلك بغير قوة أو تهلديد (الفصل 484)، ثم كذلك هتك العرض أو محاولة ذلك مع استعمال العنف (الفصل 485)، وأخيرا تجريم الاغتصاب (الفصل 486

\section{• الطبيعة القانونية لجريمة الفعل الفاضح العلني:}

نص المشرع على جريمة الفعل الفاضح العلني في الفصل 483 منق.ج، 277 وتعتبر هذه الجريمة من الجرائم المادية لا

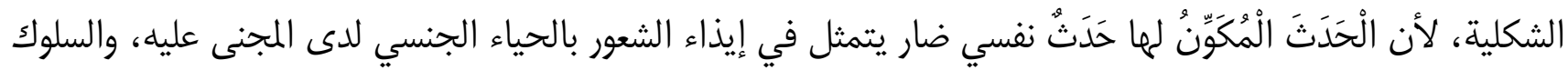
المكون لها والمفضي إلى هذا الحدث سلوك مادي ذو مضمون نفسي. كما تعتبر هذه الجريمة من الجرائم التعبيرية عن إلن

274وفي الحالات المنصوص عليها بالفصول 471 إلى 473 والمتعلقة بخطف القاصرين إذا نتج عن ارتكاب الجاني لأي جريمة من الجرائم المشار

إليها موت القاصر، فإن عقوبة الجاني تكون هي الإعدام، وذلك حسب الفصل 474 من ق.ج. 275 جاء في هذا الفصل ما يلي: "من اختطف أو غرر بقاصر تقل سنه عن ثمان عشرة سنة بدون استعمال عنف ولا تهديد ولا تدليس أو حاول ذلك، يعاقب بالحبس من سنة إلى خمس سنوات وغرامة من مائتين إلى خمسمائة درهم. ومع ذلك، فإن القاصرة التي اختطفت أو غرر بها إذا كانت بالغة وتزوجت من اختطفها أو غرر بها، فإنه لا يمكن متابعته إلا بناءا على شكوى من شخص لدم له الحق في طلب إبطال الزواج، ولا يجوز الحكم

بمؤاخذته إلا بعد صدور حكم بهذا البطلان فعلا".

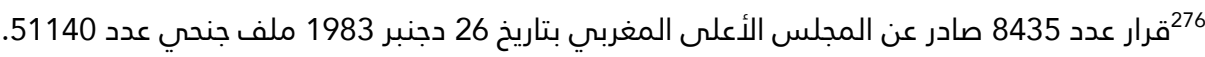

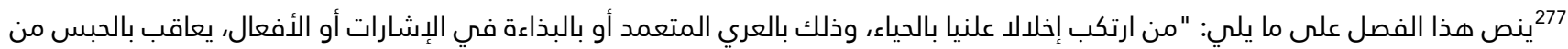

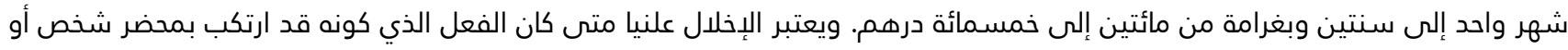
أكثر شاهدوا ذلك عفوا أو بمحضر قاصر دون الثامنة عشرة من عمره، أو في مكان قد تتطلع إليه أنظار العموم". 


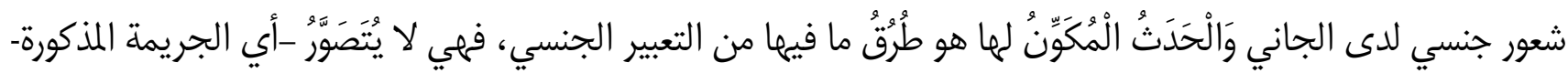

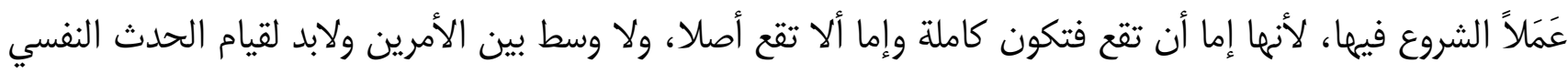
الضار المكون للجريمة من عنصر المباغتة التي لم يكن فيها محل لرضا المجنى عليه، حيث يتعين في التعبير المكون للفعل الفاضح أن يكون بحركة عضلية صادرة من جسم الجاني أو من عضو ما من أعضاء جسمه تتمخض عن فعل مادي لا مجرد القول.

والجريمة عمدية كما هو واضح من الوصف الوارد عنها في نموذجها بقاعدة التجريم وإن كانت الصورة غير العمدية فيها متصورة.278 ونتيجة لهذه التصرفات المخلة بالحياء كانت العقوبة هي الحبس من شهر واحد إلى سنتين وبغرامة من مائتين إلى خمسمائة درهما (الفصل 483 ق.ج).

\section{· جريمة هتك عرضأو محاولة ذلك بغير قوة أو تهديد:}

تصنف هذه الجريمة بطبيعتها ضمن الجرائم المادية لا الشكلية، لأن الحدث المكون لها حدث نفسي ضار، هو العدوان على حرمة القاصر الجنسية. ويعتبر هذا النوع من الاستغلال، استغلالا غير تجاري، الغرض منه قضاء الشهوة الجنسية. وقدعاقب المشرع الجاني على أفعاله المذكورة بالحبس من سنتين إلى خمس سنوات، هواء سواء كانت هذه الجريمة تامة أو مجرد محاولة.

\section{• جناية هتك العرض أو محاولة ذلك مع استعمال العنف:}

تطرق المشرع الجنائي المغربي لجناية هتك العرض أو محاولة ذلك مع العنف في الفصل 485 من ق.ج.

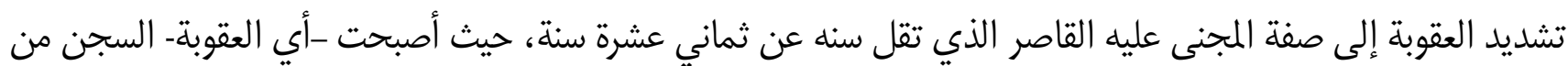
عشر إلى عشرين سنة.

ويتعين على المحكمة عند إدانتها المتهم أو الجاني بجناية هتك عرض قاصر بالعنف، أن تعتمد الوصف القانوني السليم المعطى للوقائع المادية المكونة للجريمة، وكيفية ارتكابها، وأن تبين ما تضمنته أوراق الملف، وذلك ليسهل على المجلس الأعلى التحقق من ذلك، ويحول ذلك دون تعرض قرارها للنقض. 281

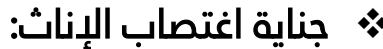

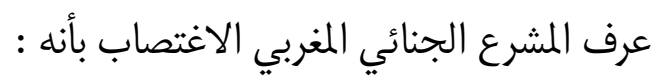

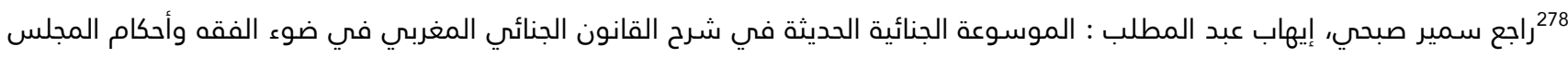
الأعلى المغربي ومحكمة النقض المصرية، المجلدين الثالثو الرابع، الشركة المغربية لتوزيع الكتاب صوماديل الطبعة الأولى 2010/2009،

ص : 13-12.

279 انظر الفصل 484 من مجموعة القانون الجنائي المغربي المذكور.

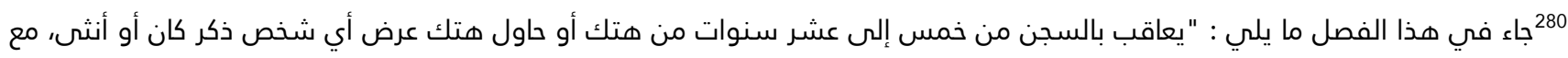
استعمال العنف. غير أنه إذا كان المجنى عليه طفلا تقل سنه عن ثماني عشرة سنة أو كان عاجزا أو معاقا أو معروفا بضعف قواه العقلية، فإن

الجاني يعاقب بالسجن من عشر إلى عشرين سنة". 281 قرار عدد 1924 الصادر عن المجلس الأعلى المغربي بتاريخ 04 أبريل 1983، ملف جنائي 26488. 


$$
\text { "هو مواقعة رجل لامرأة بدون رضاها، ويعاقب عليه بالسجن من خمس إلى عشر سنوات...".282 }
$$

إلا أنه ما يهمنا من الفصل 486 من ق.ج المذكور، هو ما ورد في فقرته الثانية، حيث نصت على أنه : "إذا كانت سن المجنى عليما تقل عن ثمان عشرة سنة أو كانت عاجزة أو معاقة أو معروفة بضعف قواها العان العقلية أو حاملا، فإن الجاني يعاقب إنب

$$
\text { بالسجن من عشر إلى عشرين سنة" . }
$$

ونظرا لخطورة جناية اغتصاب الطفلة القاصرة، شدد المشرع في العقوبة، ويرجع ظرف التشديد هذا إلى صفة المجنى عليها التي يقل عمرها عن ثماني عشرة سنة، حيث ترفع عقوبة الجاني إلى السجن من عشر إلى عشرين سنة، وذلك حسب إلى

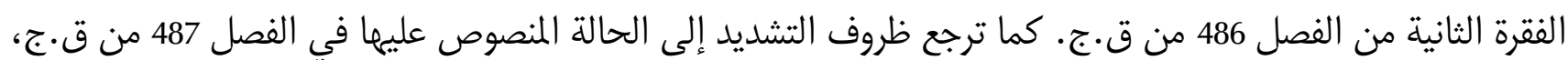
والعائدة لصفة الفاعل في الجريمة، حيث نجد المشرع شدد العقاب عليه فجعله من خمس إلى عشر سنوات284 أو من عشرين إلى ثلاثين 285 سنة بحسب الأحوال، فإذا كان الفاعل من أصول الضحية وهم من تناسلت منهم تناسلا حقيقيا كالأب والجد أو ممن لمهم سلطة عليها ويستوي في السلطة أن تكون قانونية أو فعلية وقوام هذه السلطة ما للشخص من مقدرة على تنفيذ

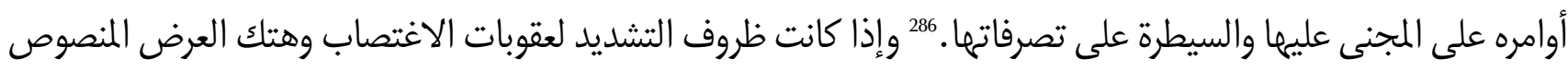
عليها في الفصل 484 والفقرة الثانية من الفصل 485، وكذلك الفقرة الثانية من الفصل 486 من ق.جترجع لصفة الجاني، فإن المشرع الجنائي المغربي لم يقف في تشديده للعقوبات عند هذا الحد فقط، بل أرجع ظرف تشديد الجناية محل التحليل

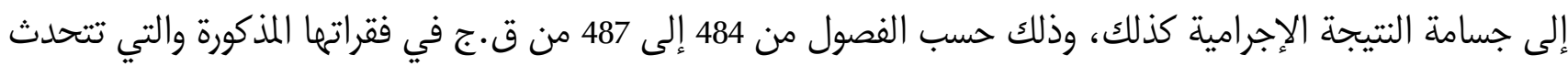
عن الطفلة القاصرة، وهذه الجرائم هي: الاغتصاب

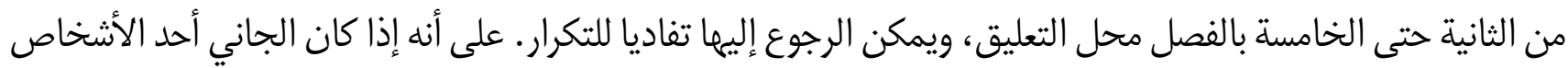
المشار إليعم في الفصل 487 من ق.ج، فإن الحد الأقصى المقرر للعقوبة في كل فقرة من فقراته يكون هو العقاب، أي أنه

282 اجع الفقرة الأولى من الفصل 486 منق.ج، وقد عرفه كذلك بعض الفقه بأنه : "مواقعة أنثى كرها عنها وبدون رضاها، أي الإتصال الجنسي : الجـي الطبيعي معها غير المشروع" .انظر : محمد صبحي نجم : "الجرائم الواقعة على الأشخاص"، المكتبة القانونية دار الثقافة، عمان، بدون تاريخ الطبع، ص : 185.

283 سمير صبحي، إيهاب عبد المطلب : مرجع سابق، المجلد الرابع، ص : 47.

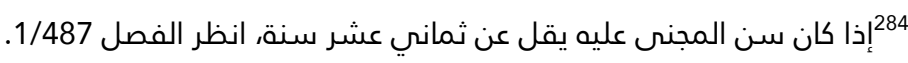
285 راجع الفقرة الخامسة من الفصل 487 منق.ج.

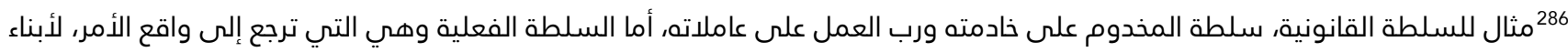

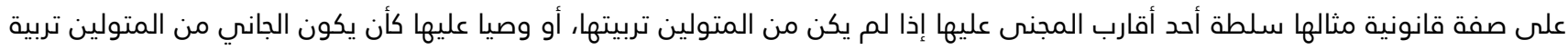

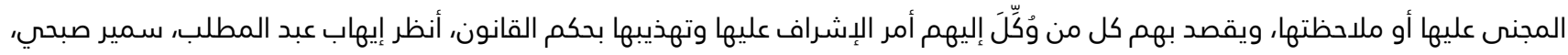
مرجع سابق، المجلد الرابع، ص : 52. 287 نظر عبد الواحد العلمي : مرجع سابق، ص : 176، راجع أيضا إيهاب عبد المطلب، سمير صبحي: مرجع سابق، المجلد الرابع، ص: 63-64.

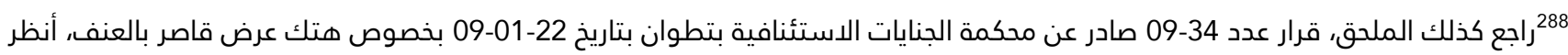
أيضا قرار عدد 277-08 صادر عن نفس المحكمة بخصوص نفس الجناية. 
في هذه الحالة لا يجوز للقاضي أن يستعمل سلطته التقديرية عند توقيع العقوبة، وإنما يكون ملزما بتطبيق الحد الأقصى المقرر للعقوبة عند ثبوت الجريمة.

انتهيينا قبل قليل من الحديث عن الحماية التي أقرها التشريع الجنائي للأطفال ضحايا الاستغلال الجنسي غير

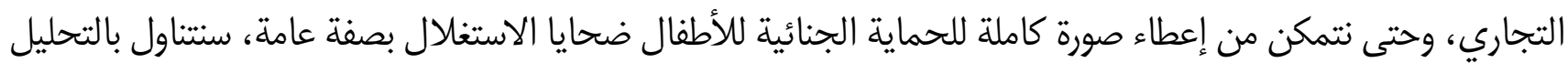

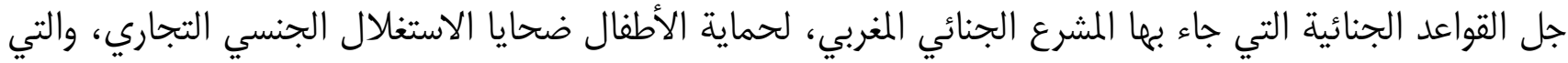

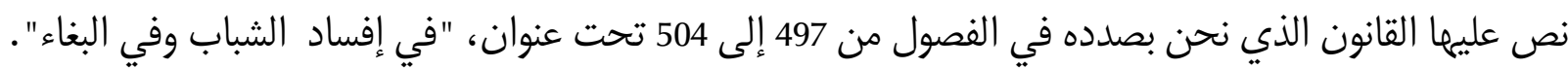
فبالنسبة لجريمة تحريض القاصرين دون الثامنة عشرة على الدعارة أو البغاء أو تشجيعهم عليها أو تسهيلما لمهم فقد

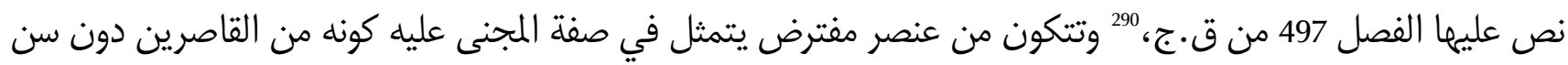
النامنة عشرة من عمره، كما تتكون من ركن مادي ومعنوي.

ونظرالكون الجريمة تتعلق بأطفال قاصرين، فإن المشرع عاقب على ذلك بالحبس من سنتين إلى عشر سنوات وبغرامة

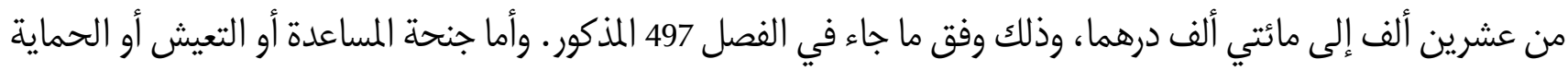

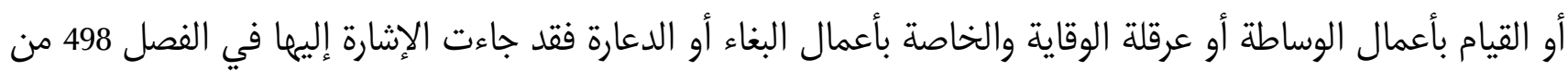

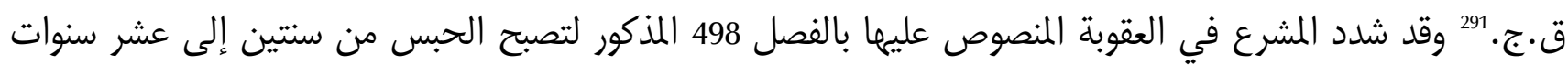

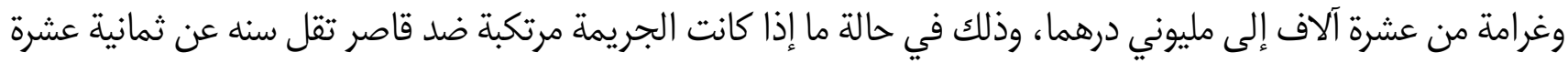

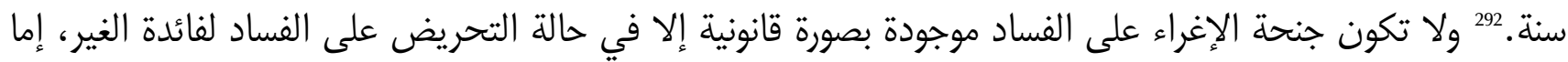

289 انظر الملحق قرار جنائي عدد 05-07 صادر عن محكمة الاستئناف بتطوان بتاريخ 03-01-2007، المتعلق بجريمة اغتصاب طفلة تبلغ من العمر 15 سنة. 290 ينص هذا الفصل على ما يلي : " يعاقب بالحبس من سنتين إلى عشر سنوات وبغرامة من عشرين ألف إلى مائتي ألف درهم كل من حرض

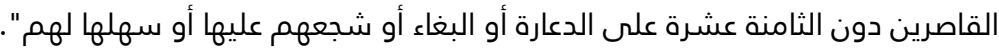
291 جاء في هذا الفصل ما يلي : " يعاقب بالحبس من سنة إلى خمس سنوات، وبالغرامة من خمسة آلاف إلى مليون درهم، ما لم يكن فعله جريمة أشد، كل من ارتكب عمدا أحد الأفعال الآتية : 1- أعان أو ساعد أو حمى ممارسة البغاء أو جلب الأشخاص للبغاء وذلك بأبل بأية وسيلة كانت. 2- أخذ بأي شكل كان نصيبا مما يحصل عليه الغير عن طريق البغاء أو الدعارة أو أخذ معونات من شخص اعتاد على تعاطي البغاء أو الدعارة وهو يعلم بذلك.

3- عاش مع شخص اعتاد على تعاطي البغاء وهو يعلم بذلك.

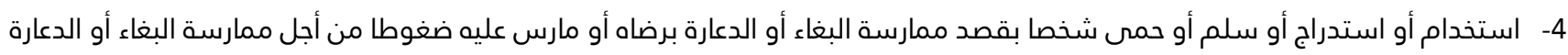
أو الاستمرار في ذلك. 5- مارس الوساطة، بأية صفة كانت بين من يتعاطع البغاء أو الدعارة وبين من يستغل بغاء الغير أو دعارته أو يؤدي مقابلا عن ذلك. 6- ساعد من يستغل بغاء أو دعارة الغير على إعطاء تبرير وهمي لموارده لمارده المالية. 7- عجز عن تبرير مصادر مالية ملائمة لمستوى معيشته في الوقت الذي يعيش فيه مع شخص اعتاد على تعاطي البغاء أو الدعارة أو له علاقات مشبوهة مع شخص أو عدة أشخاص يتعاطون البغاء أو الدعارة.

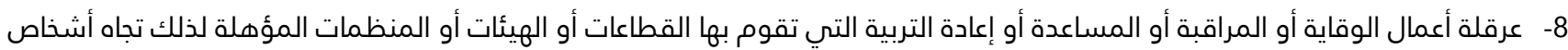
يمارسون البغاء أو الدعارة أو معرضين لتلك الممارسة. 292 202 اجع الفقرة الأولى من الفصل 499 منق.ج. 


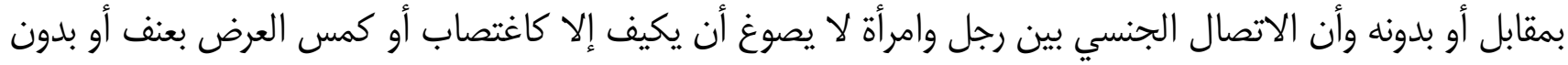

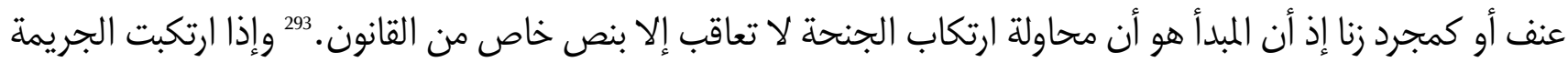

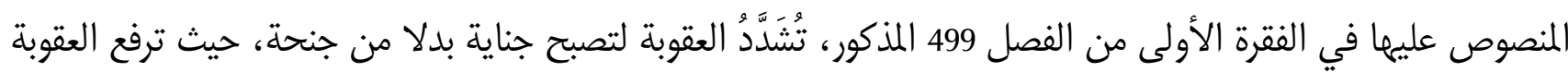

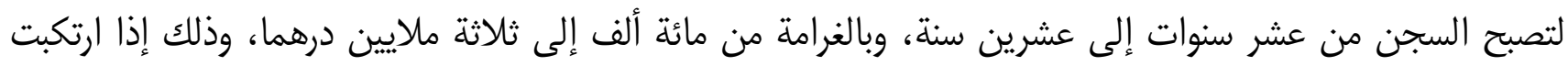

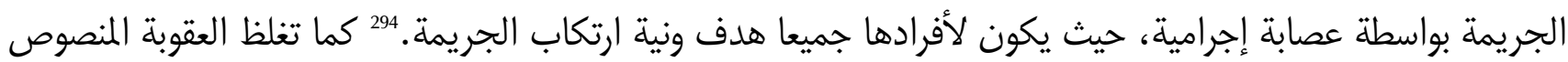

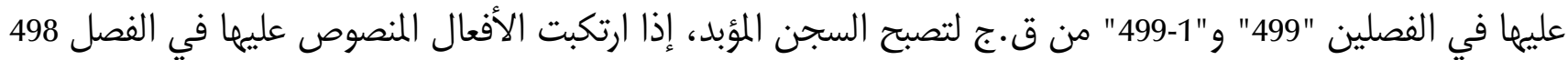

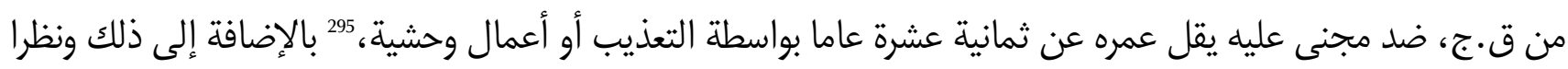

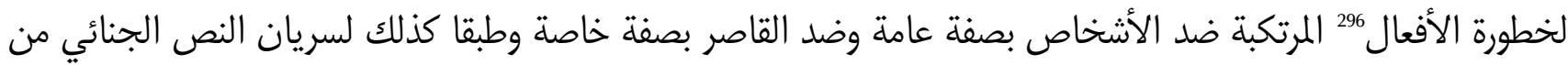

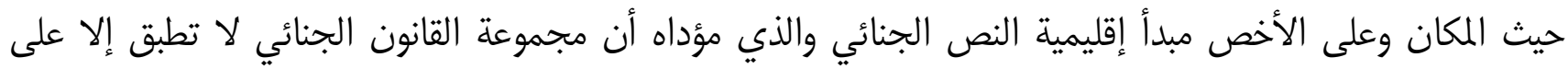

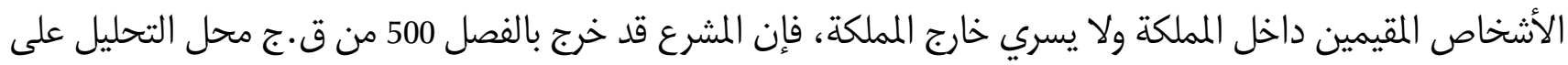

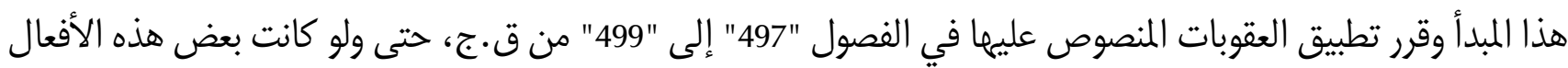
المرتكبة ضد القاصر والمكونة لعناصر الجريمة قد ارتكبت خارج المملكة.

وتأكيدا من المشرع الجنائي المغربي لحمايته للأطفال ضحايا الاستغلال الجنسي التجاري للأطفال من جهة، والتزاما

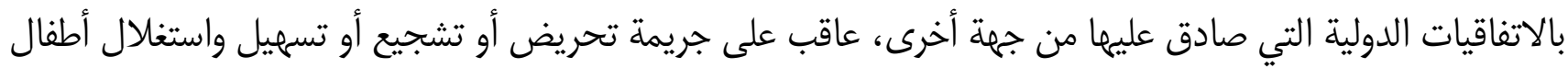

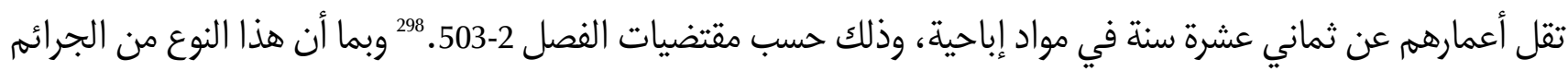

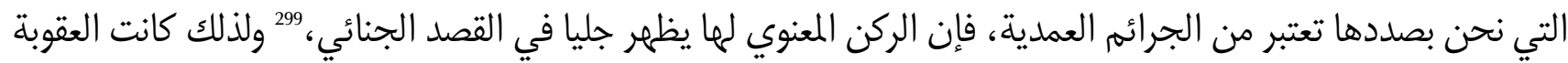

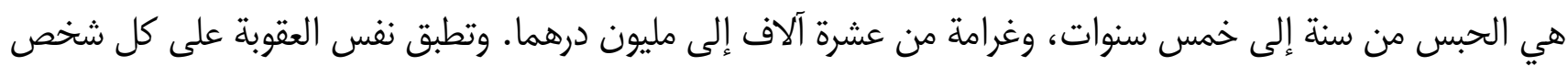

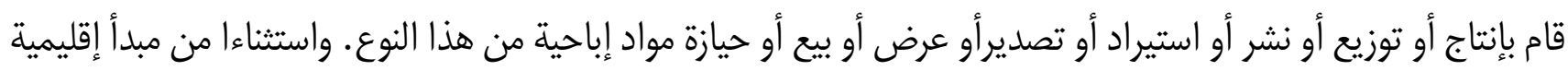

293قرار عدد 262 (س8) الصادر عن المجلس الأعلى في 18 شعبان 1384 الموافق لـ23 دجنبر 1964. 294 أنظر الفصل 199-1 299 من القانون الجنائي المغربي. 295 راجع الفصل 499-2 من مجموعة القانون الجنائي المغربي. 296 الأفعال المذكورة في الفصل 498 من ق.ج.

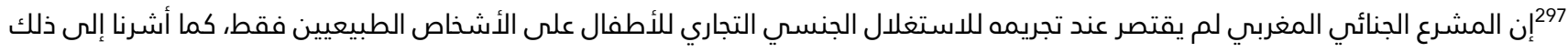

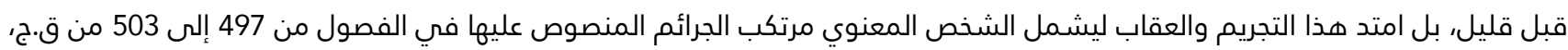
ضد الأشخاص عامة، وما يرتبط بالقاصرين خاصة، أنظر الفصل 1-501 من ق ق.ج.

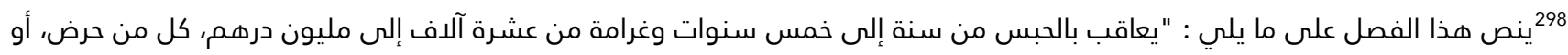

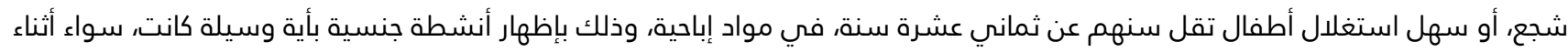
الممارسة الفعلية أو بالمحاكاة أو المشاهدة أو أي تصوير للأعضاء الجنسية للأطفال يتم لأغراض ذات طبيعة جنسية. تطبق نفس العقوبة على

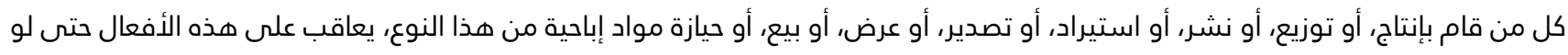
ارتكبت عناصرها خارج المملكة. تضاعف العقوبة المنصوص عليها في الفقرة الأولى من هذا الفصل إذا كان الفاعل من أصول الطفل، أو مكلفا برعايته، أو له سلطة عليه. تطبق نفس العقوبة على محاولة الأفعال المذكورة. يأمر الحكم الصادر بالإدانة بمصادرة وإتلاف المواد الماد الإبادية، ويمكن

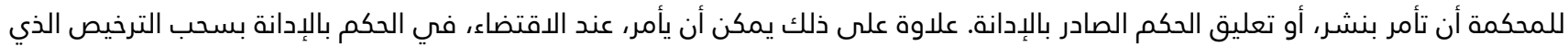

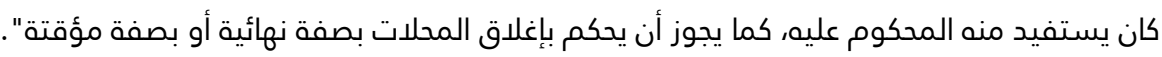
299 أنظر إيهاب عبد المطلب، سمير صبحي : مرجع سابق، المجلد الرابع، ص : 121. 


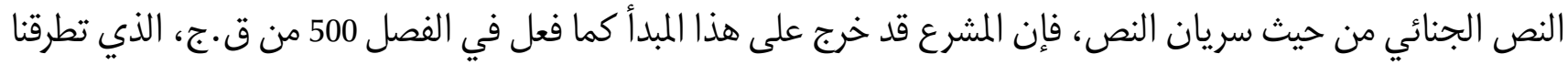

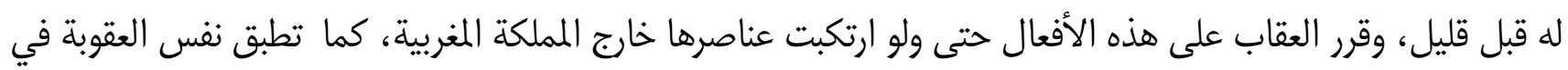

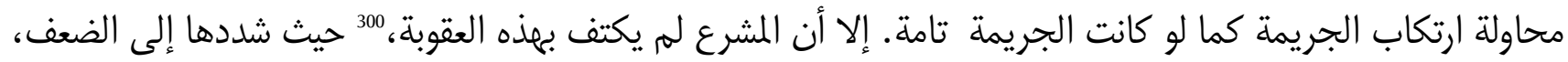

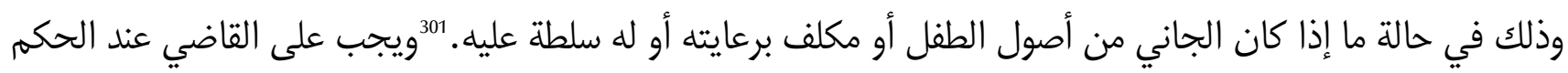
بالإدانة أن يحكم بمصادرة وإتلاف المواد الإباحية.

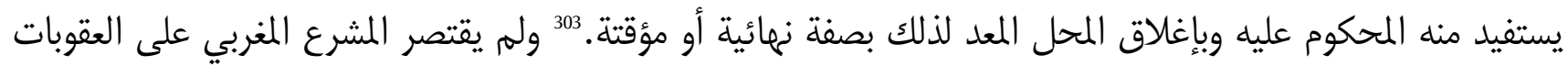

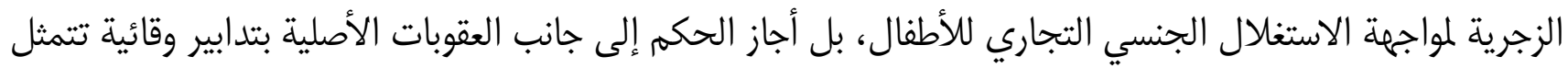

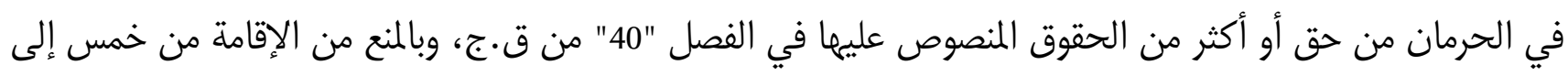

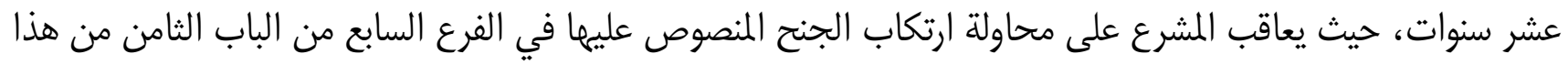

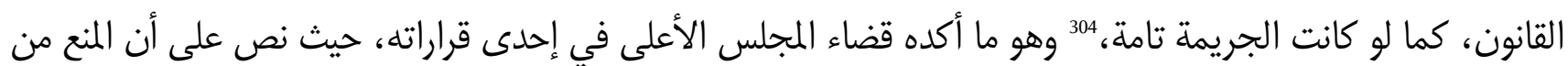

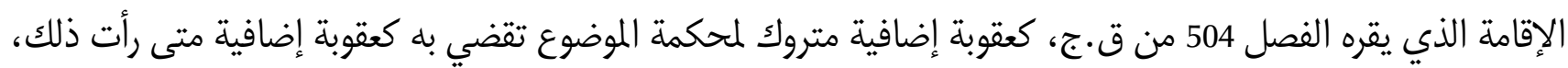
دون حاجة إلى أن تطلبه النيابة العامة، والمحكمة غير ملئ ملزمة الفة بأن تعلل قضاءها بالمنع من الإقامة بتعليل خاص.

\section{رابعا : بعض المقتضيات الحمائية الأخرى}

\section{- جريمة "تجارة رقيق الأطفال"، جريمة بيع أو شراء طفل يقل سنه عن 18 عاما:}

عرف المشرع الجنائي المغربي بيع الأطفال بقوله: "يقصد بييع الأطفال كل فعل أو تعامل يتم بمقتضاه نقل طفل من شخص أو مجموعة أشخاص إلى شخص آخر أو مجموعة أشخاص بمقابل كيفما كان نوعه" . وقد نص المشرع المغربي على هذه الجريمة في الفصل 1-467

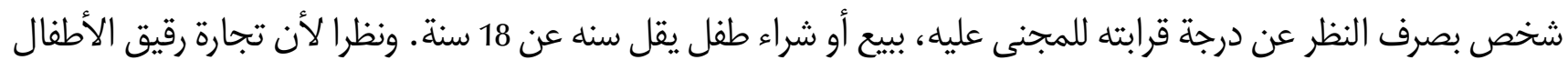

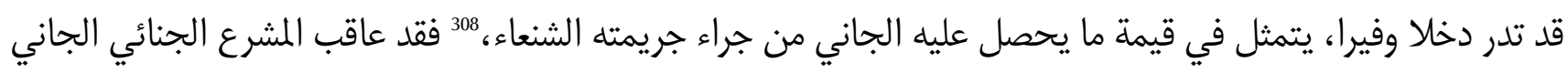

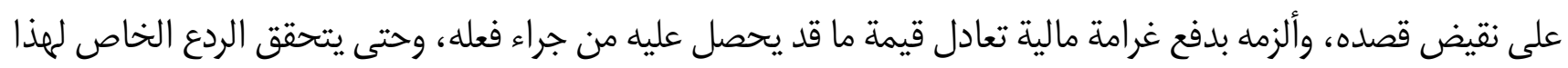

300 انظر الفقرة الأولى من الفصل 201-503 من ق.ج.

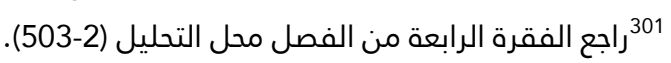

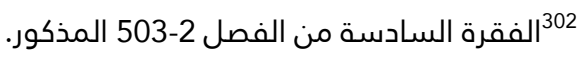
303 الفقرة الأخيرة من الفصل المذكور أعلاه. 304 انظر الفصل 504 منق.ج.

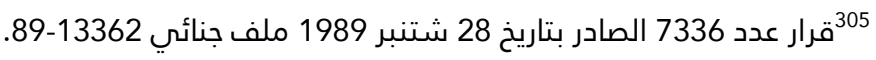
306 راجع الفقرة الثانية من الفصل 1-467 من مجموعة القانون الجنائي المغربي.

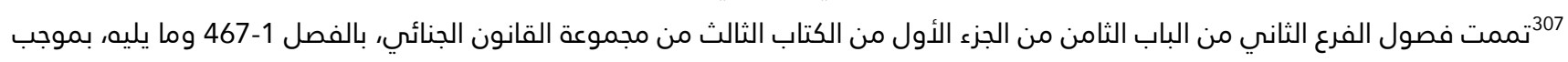
المادة الرابعة من القانون رقم 24.03 المتعلق بتغيير وتتميم مجموعة القانون الجنائي السالف الذكر. 308|يهاب عبد المطلب، سمير صبحي : مرجع سابق، المجلد الثالث، ص : 643. 
الجاني، ولمن تسول له نفسه في الإقدام على ارتكاب هذه الجريمة، فقرر المشرع عقوبة الجاني بالحبس من سنتين إلى 10 سنوات، وبغرامة من خمسة آلاف إلى مليوني درهم.

كما يعاقب بنفس العقوبة السالفة الذكر على مجرد تحريض الأبوين أو أحدهما، أو الكافل أو الوصي أو من له سلطة

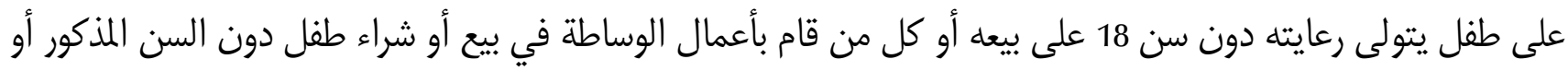
سمل ذلك أو أعان عليه بأية وسيلة من الوسائل.

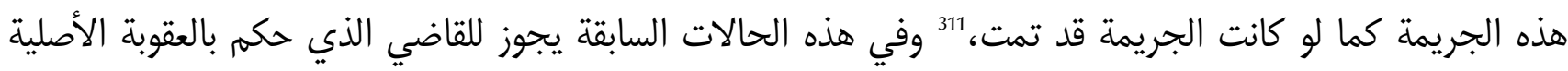

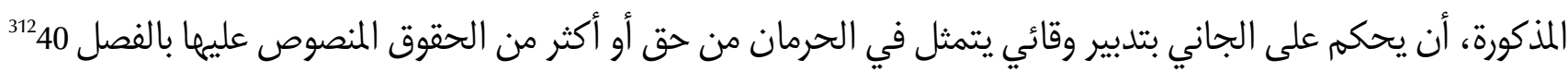
من ق.ج وبالمنع من الإقامة من 5 إلى 10 سنوات.

\section{-جريمة إجبار طفل دون 15 عاما على القيام بعمل قسري أو توسط أو حرض على ذلك:}

عرف كذلك المشرع الجنائي المغربي هذه الجريمة، حيث نص على أنه : "يقصد بالعمل القسري بمفهوم الفقرة السابقة

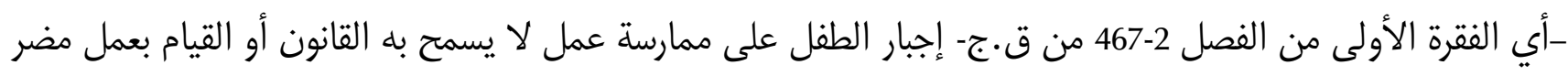
بصحته أو سلامته أو أخلاقه أو تكوينه". عنصر مفترض، ويتمثل في صفة المجنى عليه باعتباره طفل لهم يبلغ سن 15 عاما من عمره. وتتمثل هذه الجريمة في قيام الجاني عن قصد بإجبار الطفل الموصوف بالعنصر المفترض سلفا على ممارسته وقيامه

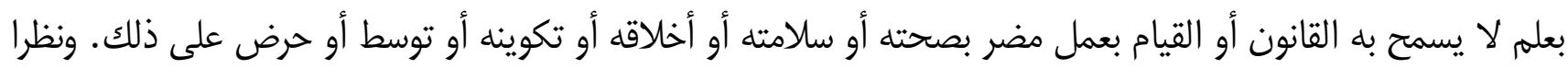

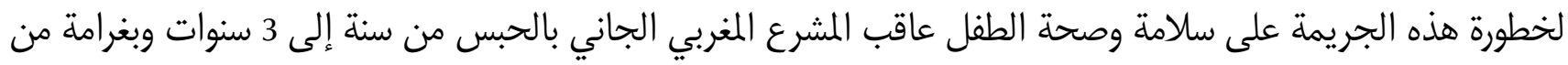

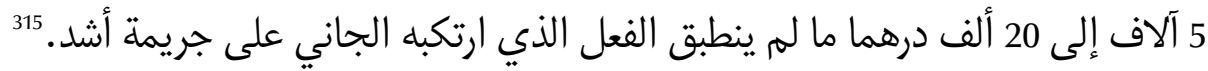

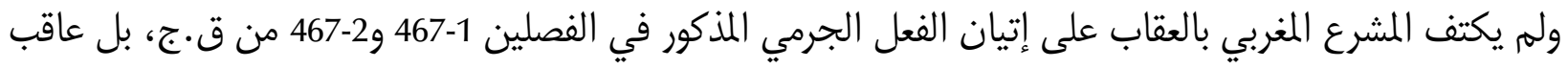

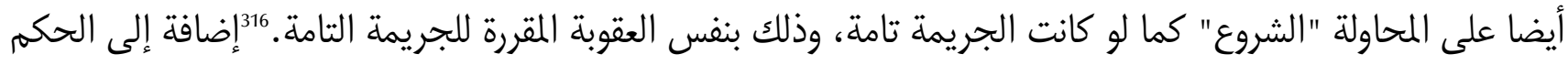

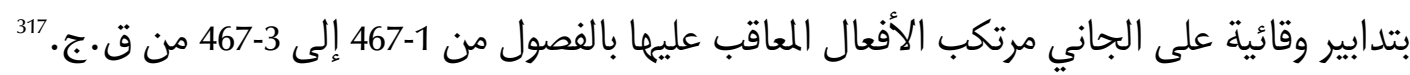

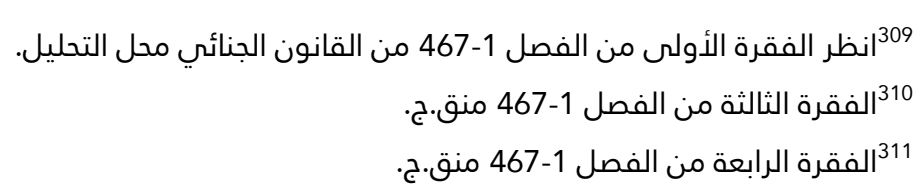

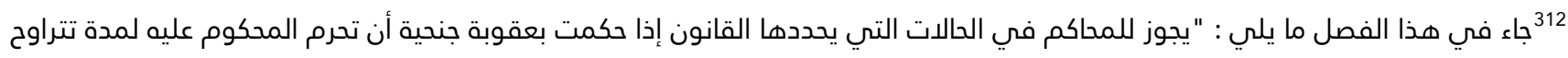

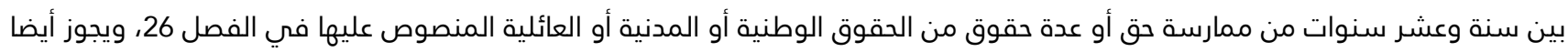

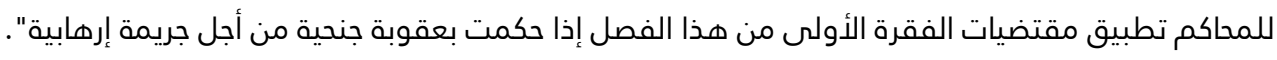

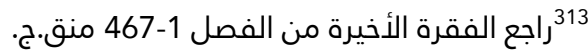

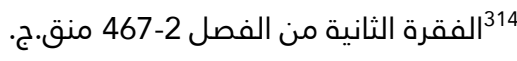
315 الفقرة الأولى من الفصل 216-2

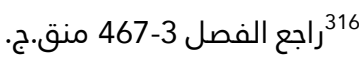

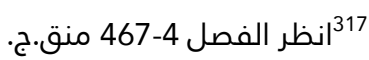




\section{المطلب الثاني : الحماية الجنائية الإجرائية للأطفال ضحايا الاستغلال.}

لم تقتصر حماية المشرع الجنائي للأطفال ضحايا الاستغلال من خلال الحماية الواردة في المجموعة الجنائية المتمثلة في القانون الجنائي الموضوعي، بل امتدت هذه الحماية لتشمل أيضا القانون الإجرائي أو الشكلي، حيث أفرد له نصوصا في قانون المسطرة الجنائية تتضمن قواعد تحرص على ضمان سلامته وحياته وترتبط هذه الأحكام بالأطفال ضحايا

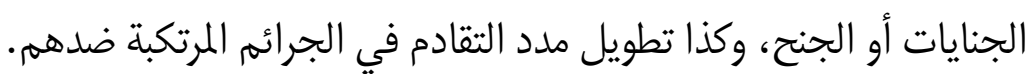

وعليه فإن دراستنا لهذا المطلب ستكون من خلال الفقرتين التاليتين:

الفقرة الأولى: الإجراءات المتبعة لحماية الأطفال ضحايا الجنايات والجنح الفقرة الثانية: تمديد آجال التقادم في الجرائم المرتكبة ضد الطفل ضحية الجنايات والجنح

الفقرة الأولى: الإجراءات المتبعة لحماية الأطفال ضحايا الجنايات والجنح.

إن الطفل بحكم بنيته الجسمانية غير الناضجة تجعله فريسة سهلة للجريمة، ومن أجل ذلك اعتنى المشرع الجنائي

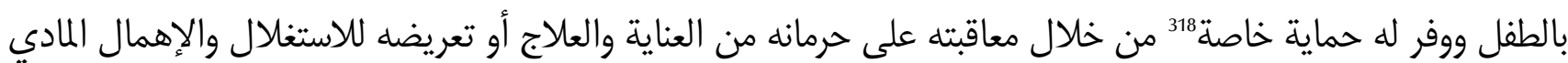
والمعنوي وتحريضه على ممارسة أفعال غير مشروعة.

وقد نظم المشرع حماية الأطفال ضحايا الجنايات والجنح في المادتين 510 و511 من ق.م.ج. وهكذا قضت المادة 510 منق ·م.ج على أنه:"إذا ارتكبت جناية أو جنحة وكان ضحيتها حدثا لا يتجاوز عمره 18 سنة، فلقاضي الأحداث أو المستشار المكلف بالأحداث، إما استنادا لملتمسات النيابة العامة وإما تلقائيا بعد أخذ رأي النيابة العامة أن يصدر أمرا قضائيا بإيداع الحدث المجنى عليه لدى شخص جدير بالثقة أو مؤسسة خصوصية أو جمعية ذات منفعة عامة مؤهلة لذلك أو بتسليمه لمصلحة أو مؤسسة عمومية مكلفة برعاية الطفولة إلى أن يصدر حكم نهائي في موضوع الجناية أو الجنحة وينفذ هذا الأمر رغم كل طعن. ويمكن للنيابة العامة أو لقاضي الأحداث أو المستشار المكلف بالأحداث الأمر بعرض الحداث على خلى خبرة طبية أو نفسية أو عقلية لتحديد نوع وأهمية الأضرار اللاحقة به وبيان ما إذا كان يحتاج إلى علاج ملائم لحالته حالا ومستقبلا" . وأضاف المشرع المغربي أنه يمكن للنيابة العامة في حالة صدور حكم من أجل جناية أو جنحة ارتكبت ضد حدث أن تُحِيلَ

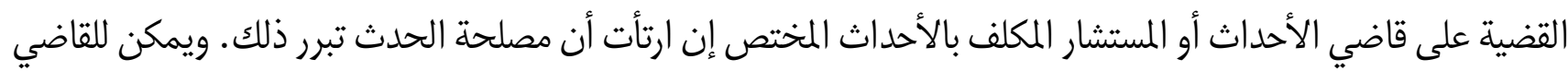

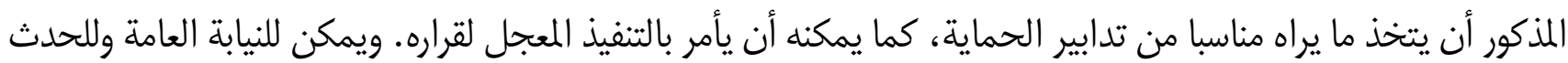

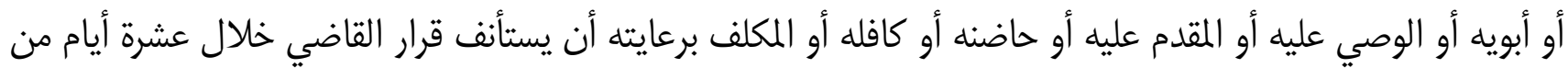
صدوره أمام الغرفة الجنحية للأحداث بمحكمة الاستئناف.

318 حميد الوالي : "آفاق جديدة لعدالة الأحداث"، مقال منشور بمجلة ندوات محاكم فاس، يناير 2005، العدد الثاني، ص : 135.

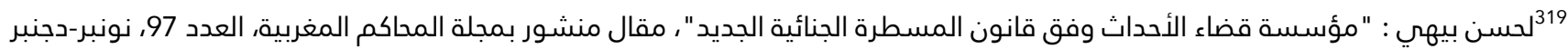


وبالرجوع إلى الفصلين المذكورين يتضح بأن توفير هذه الحماية خصه المشرع بالأطفال ضحايا الجنايات والجنح دون

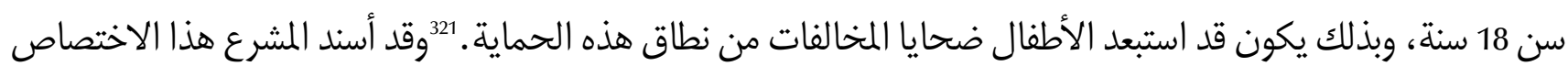

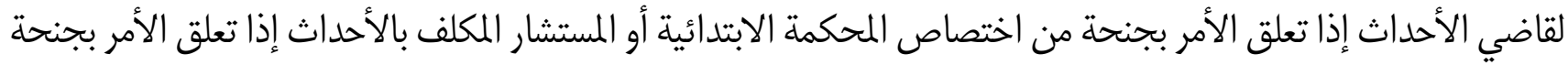

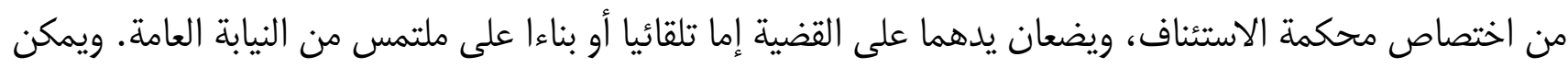

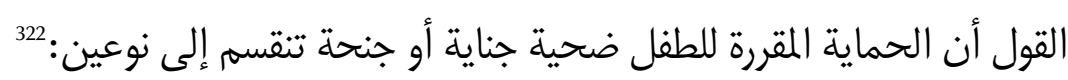

حماية مؤقتة: وتتمثل في إيداع الطفل لدى شخص جدير بالثقة أو مؤسسة خصوصية أو جمعية ذات منفعة عامة مؤهلة

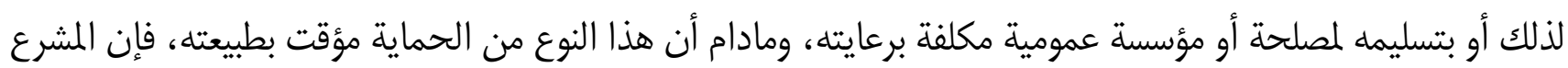
جعل الأمر باتخاذ التدبير نافذا رغهم كل طعن.

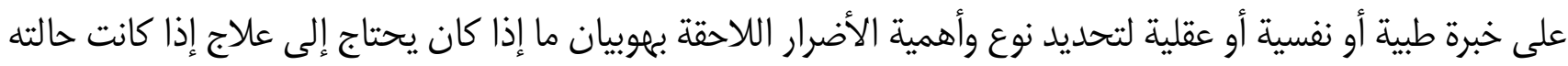
الصحية تستوجب فحصا طبيا. 324

وقد خُوّلَّ هذا الإجراء لكل من قاضي الأحداث أو المستشار المكلف بالأحداث أو النيابة العامة، وهذا الإجراء اختياري

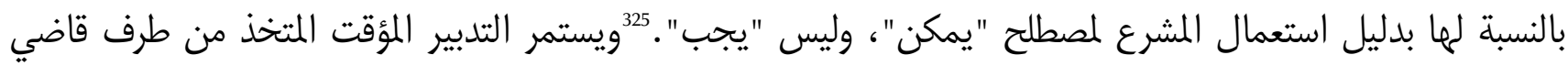

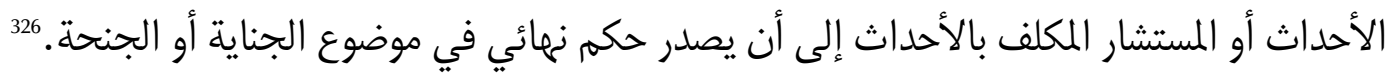

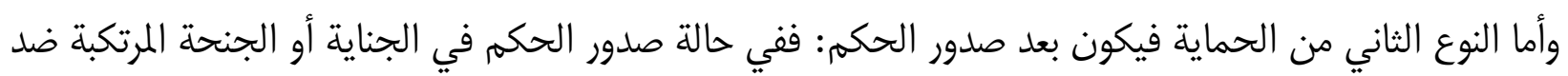

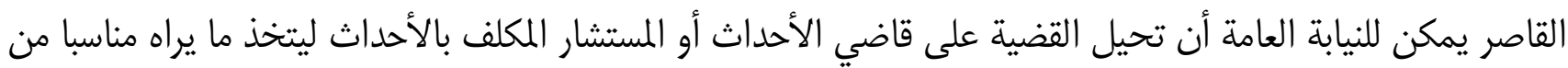

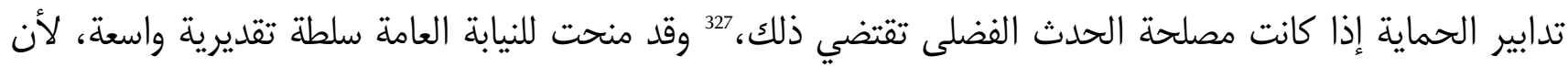
المشرع استعمل تعبير "إن ارتأت أن مصلحة الحدث تبرر ذلك الكاث .

ولضمان الفعالية والسرعة للتدابير الحمائية ${ }^{329}$ أعطى المشرع لقاضي الأحداث والمستشار المكلف بالأحداث إمكانية

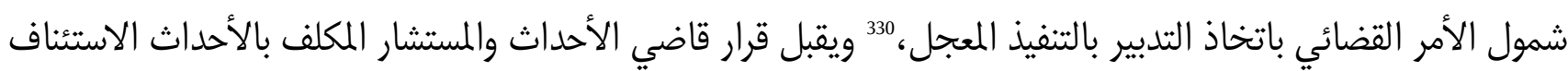

321

322 وزارة العدل : مرجع سابق، ص ص : 265.

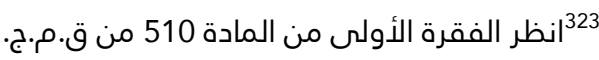
(324 راجع الفقرة الأخيرة من المادة 510 منق.م.ج. 325أمينة شايب : " دراسة قانونية حول حماية القاصرين في إطار ظهير المسطرة الجنائية الجديد"، مقال منشور بمجلة أنفاس حقوقية، العدد 2 و3، دجنبر 2003، ص : 155. 326 حميد الوالي : مرجع سابق، ص : 136. 327 يوسف أجبار: مرجع سابق، ص : 100. 328 أمينة شايب: مرجع سابق، ص : 156. 329 وزارة العدل : مرجع سابق، ص : 266. 330انظر الفقرة الأولى من المادة 511 من ق.م.ج. : مرجع : 
أمام الغرفة الجنحية للأحداث بمحكمة الاستئناف من طرف النيابة العامة والحدث أو أبويه أو الوصي عليه أو المقدم عليه أو أو الحا

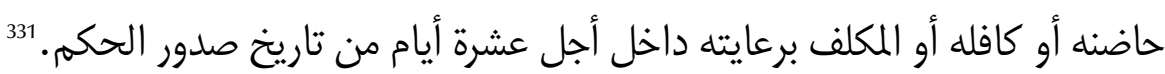

وما تجب الإشارة إليه هو أن المشرع من خلال هذا الإجراء خول للحدث حق استئناف القرار القضائي الصادر في

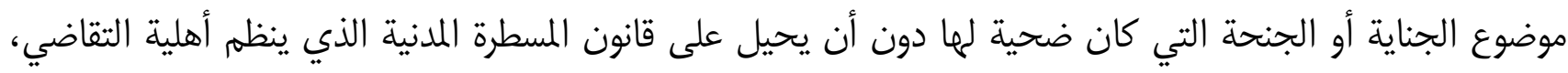

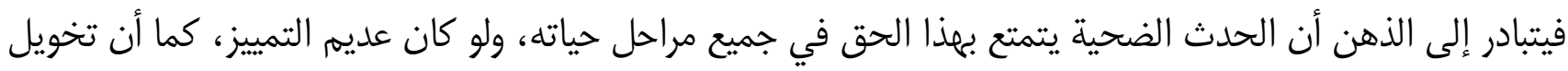

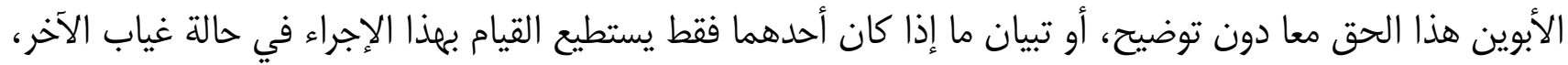

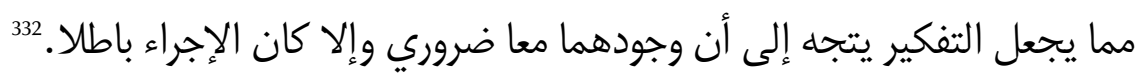

\section{الفقرة الثانية: تمديد آجال التقادم في الجرائم المرتكبة ضد الطفل ضحية الجنايات والجنح.}

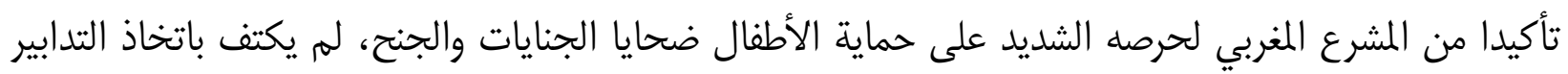

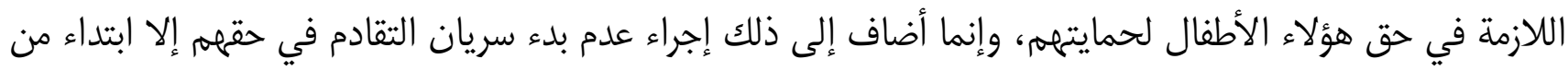

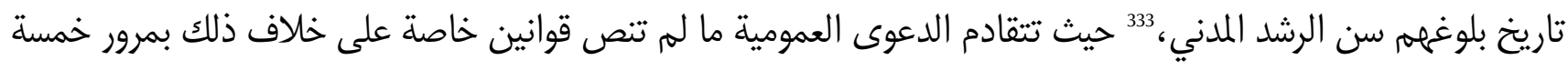

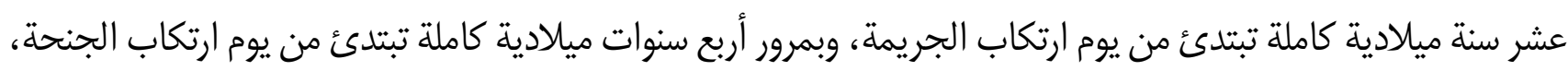

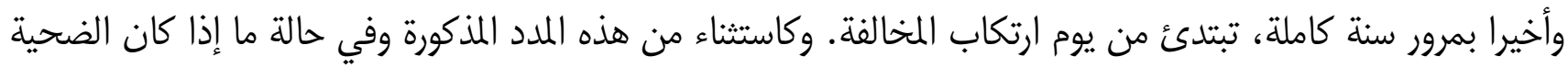

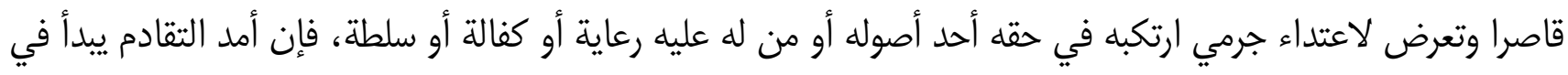

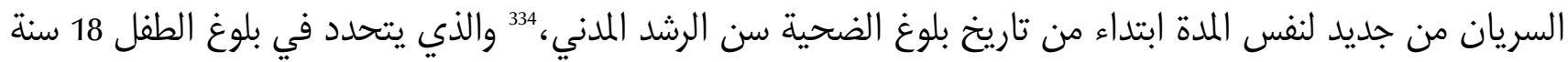

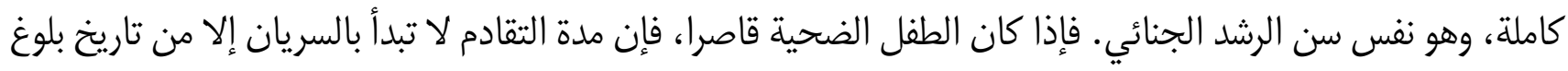

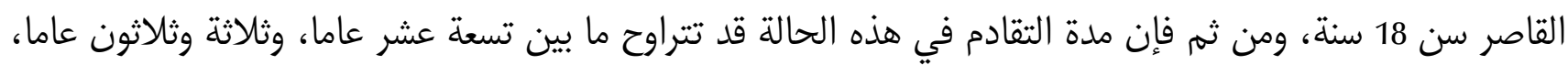
وذلك حسب الحالات الآتية:335 إن

- الحالة الأولى: لو كان الطفل حديث الولادة، وكانت الجريمة المرتكبة ضده جناية، فإن مدة التقادم التي هي خمسة

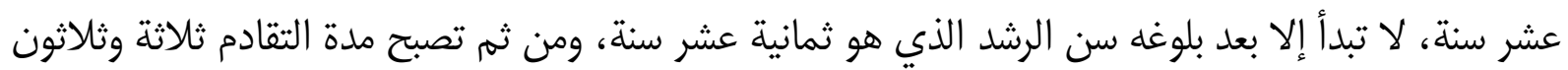

عاما.

- الحالة الثانية: إذا كان الطفل الضحية حديث الولادة كذلك، وكانت الجريمة المرتكبة ضده تشكل جنحة، فإن مدة

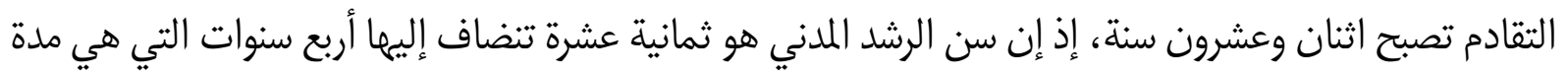

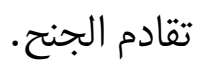


- الحالة الثالثة: عندما تكون الجريمة المرتكبة ضد الطفل الضحية المذكور مكيفة بكونها مخالفة، تصبح مدة التقادم تسعة عشر عاما، حيث تتضاف لسن الرشد سنة كمدة لتقادم المخالفات.

وإذا كان المشرع المغربي بإقراره لأحكام خاصة بتقادم الدعوى الجنائية الناشئة عن الجرائم المرتكبة ضد الأطفال،

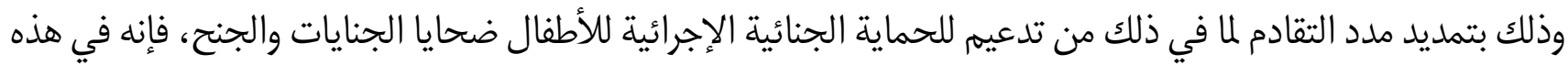

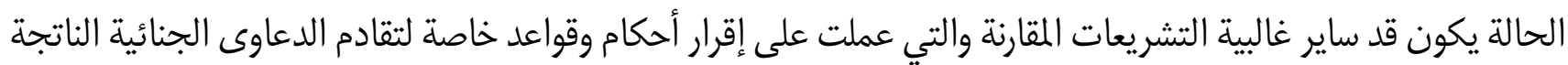

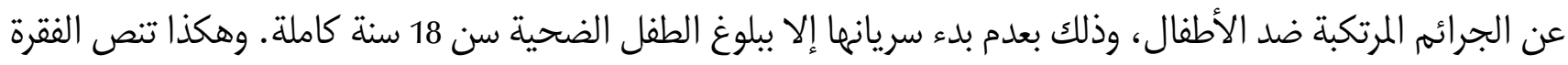

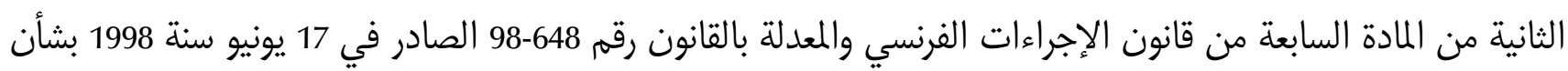

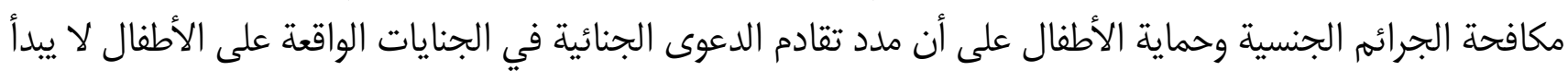
سريانها إلا ببلوغ الطفل المجنى عليه سن الرشد -أي بلوغه 18 سنة كاملة.

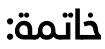

وكخلاصة لما سبق ذكره ومن أجل زيادة فعالة للحماية الجنائية للأطفال ضحايا الاستغلال، وذلك تدعيما لأخلاق

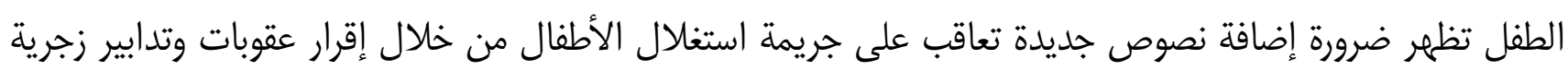

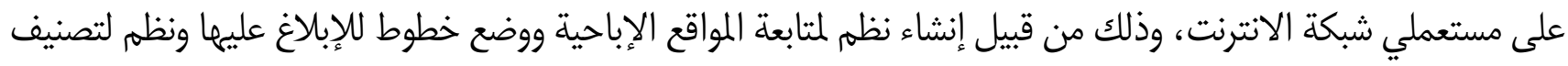

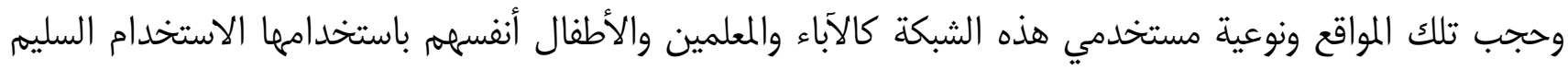

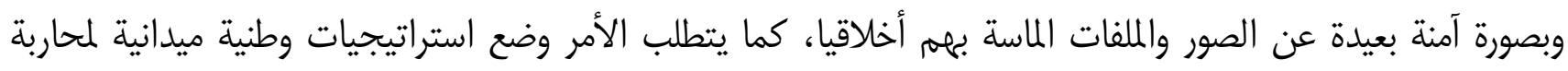
استغلال الأطفال بصفة عامةوالاستغلال الجنسي بنوعيه التجاري وغير التجاري بصفة خاصة.

كما يلاحظ من خلال دراستنا وتحليلنا لمزه الفصول التي جاء بها القانون الجنائي المغربي بخصوص حماية الأطفال

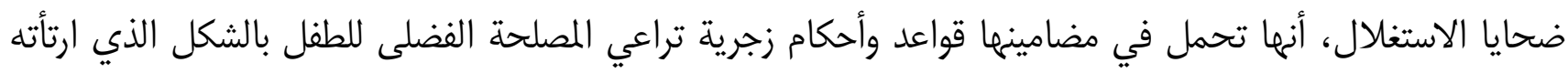

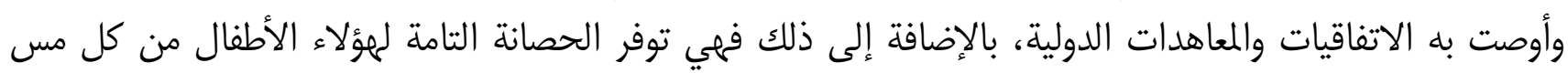
بكرامتهم وسلامتهمه. 


\section{شنعية الدفاع الآي عن الأمعال على ضهء الفقه القضاء

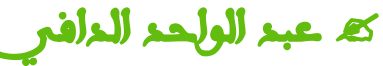$$
\text { دكتور في الحقوق }
$$

\section{مقدمة:}

يمكن تعريف الدفاع الآلي عن الأموال بأنه: "حظر المساس بمال مادي بواسطة تقنية تتحرك بفعل من المعتدي على إنى هذا المال، والتي قد تحدث ضررا يحول دون إنجاح مشروعه"

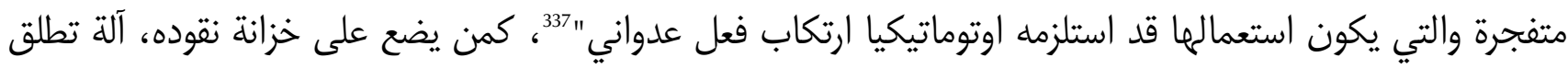

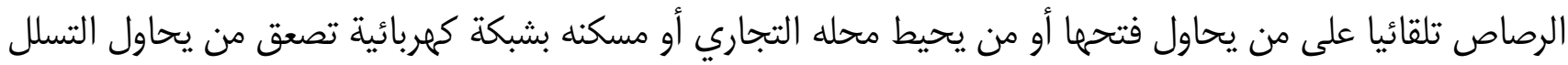

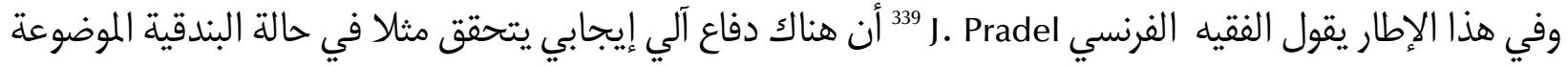

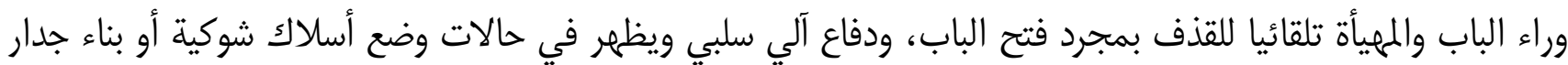
ووتثبيت ونصب قطع زجاجية حادة وغيرها من الوسائل المبتكرة.

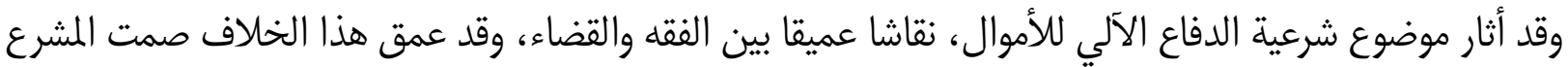

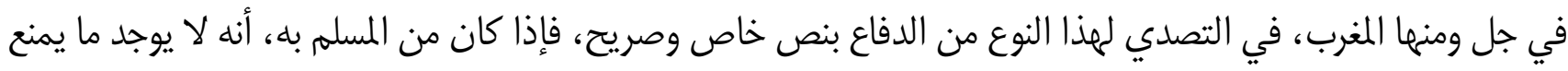

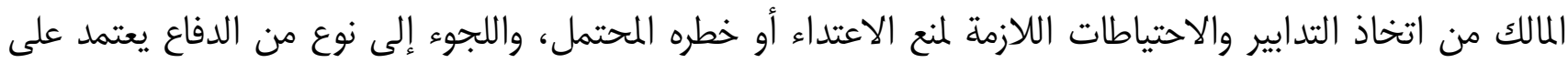

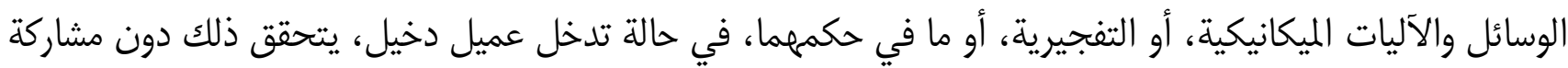

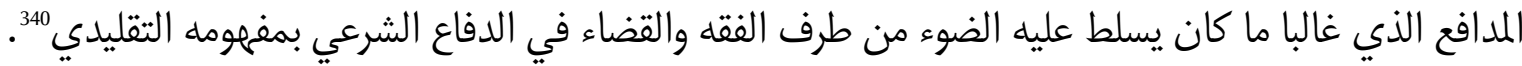
وإذا كان هذا الشكل الدفاعي متجدد في بعض مظاهره، فإن جدوره تضرب في عمق التاريخ الانساني، ففي العهد

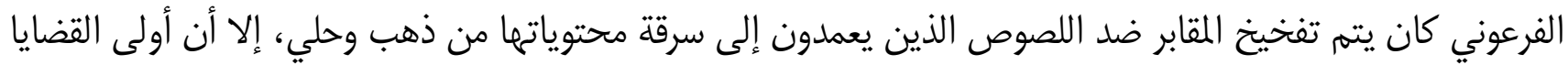

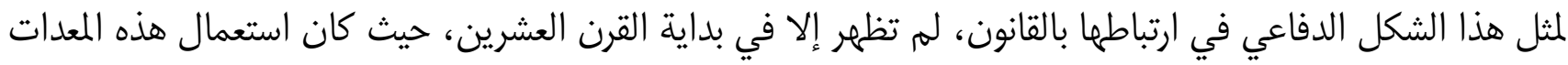

336J. Pradel:" La défense automatique des biens", In Mélange en I'honneur du doyen Pierre Bouzat, A. Pedone, Paris, 1980,p 218

${ }^{337}$ D. Saint-Hilaire: J .C.L pénal, art $327-329, N^{\circ} 121$

338 أحمد محمد مونس: التشريع الجنائي المقارن " القتل والجرح والضرب والدفاع الشرعي وجرائم الإجهاض في ضوء التشريعات الجنائية لدول مجلس التعاون الخليجي"، دار الفكر والقانون، المنصورة، 2013، ط. 1. 1. ص 370

${ }^{339} \mathrm{~J}$. Pradel: "La légitime défense automatique des biens ", op.cit, p 217

${ }^{340} \mathrm{D}$.Saint-Hilaire: Faits justificatifs,J. Larguier: Les limites de l'état de nécessité, RSC, 1982, p 765, J. Pradel: La défense automatique des biens, op.cit, p 217 - 238 


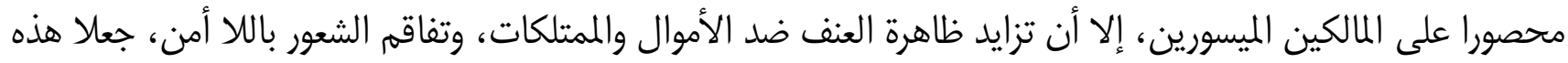

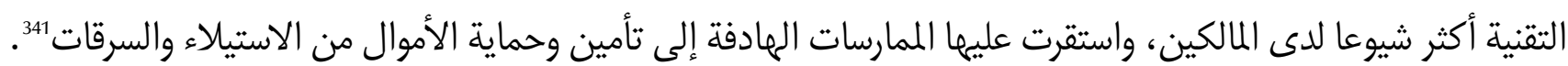
إن الإشكال المثار في هذا الخصوص، هو مدى مشروعية استعمال هذه الأجهزة في الدفاع عن الأموال، والتي بقيت

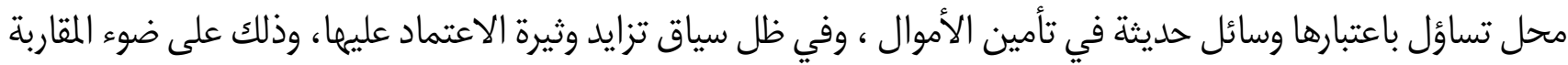
الفقهية، والمعالجة القضائية في ظل صمت المشرع؟

\section{المحور الأول: المقاربة الفقهية للدفاع الآلي عن الأموال}

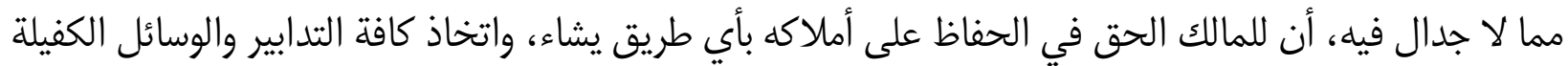

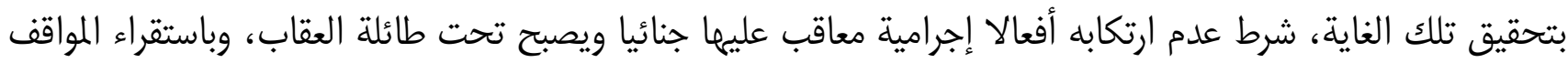

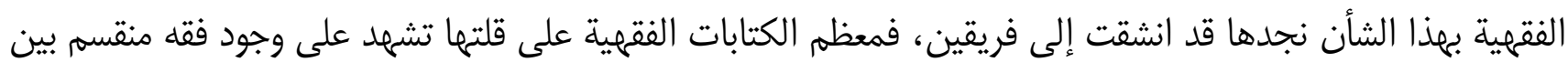

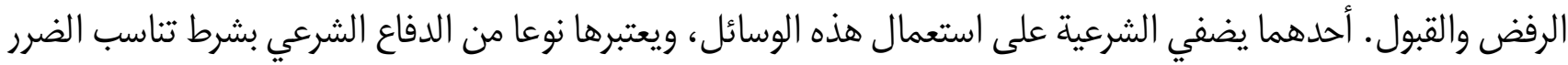

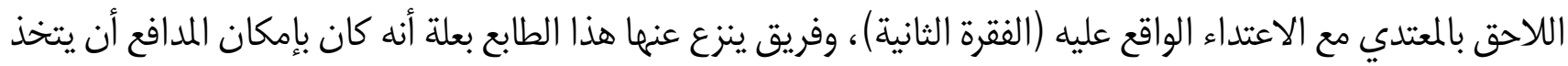
كافة التدابير لحماية المصلحة التي وقع عليها الاعتداء دون اللجوء إلى الوسائل الآلية لحمايتها (الفقرة الأولى).

\section{الفقرة الأولى: اتجاه الرافضين}

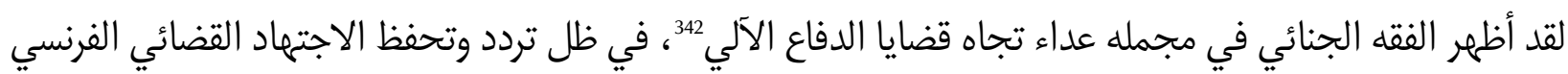

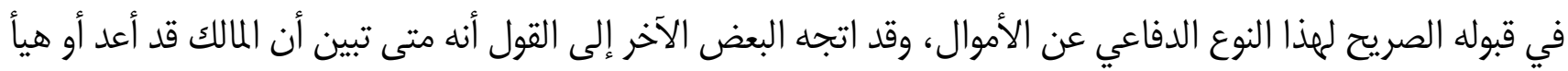

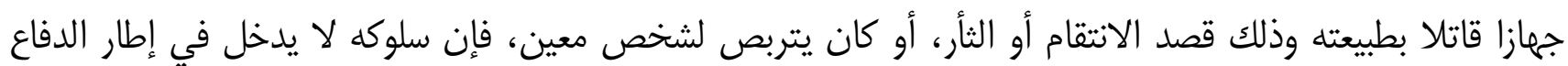
المشروع ويسأل مسؤولية عمدية كاملة.

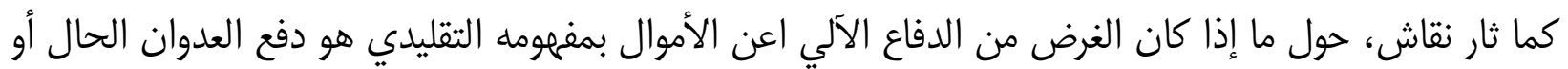

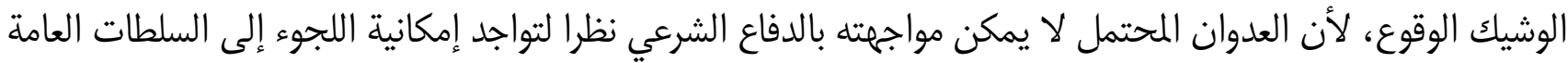

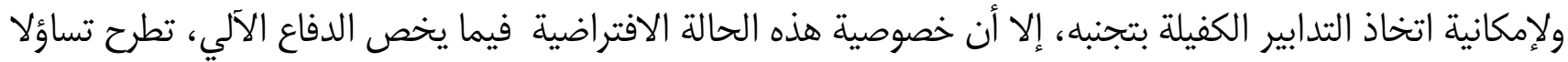
عريضا حول مدى مشروعية الآلات التي تعمل تلقائيا عند بدء العدوان. فالإصابات التي تحدثها الأجهزة التي تعمل ذاتيا وما على شاكلتها، تعتبر جرائم تتوافر فيها الأركان التي يتطلبها

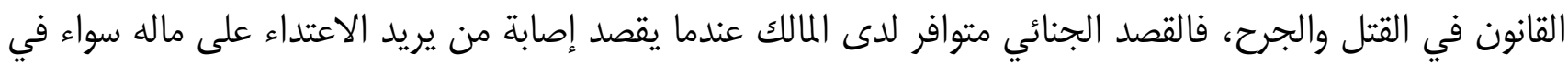

341 نجاح سعيد حمشو: البحث الجنائي الفني في الجرائم المرتكبة بواسطة الأسلحة النارية، دمشق، 1982، ط 1، ص 31 - 38 D .Drevelle: Du besoin de sécurité a la doctrine de la securité, Mémoire pour obtenu Diplôme d'études approfondies d'Administration Publique de la Faculté de Droit et des Sciences politiques et sociales d'Amiens, France, 1978 , p 28 - 51 ${ }^{342} \mathrm{D}$.de Vabres: Traité de droit criminel et de législation pénale comparé, Sirey, 1947, p 408, L. Jean - B. Claude: Rapport sur la règle "nul ne peut se faire justice soi-même" en droit Français, Travaux de l'Association Henri Capitant, T. XVIII, 1966, p $173-210$

${ }^{343}$ L. Hugueney: RSC, 1954, p 545 


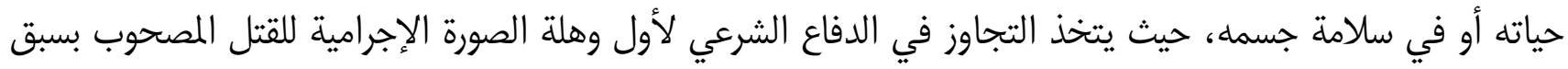

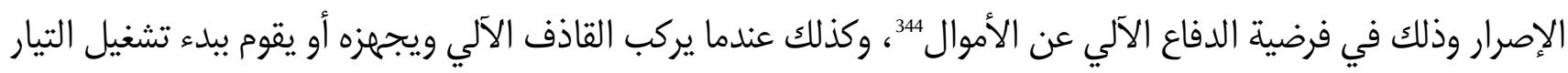

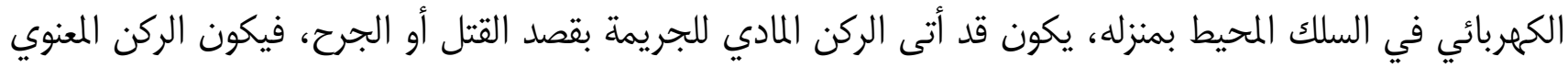

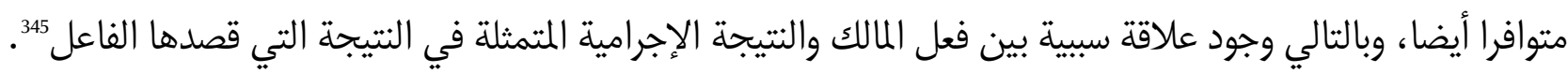
اتجاه فقهي آخر يرى أن مفهوم الدفاع الشرعي يتنافى مع الدفاع الآلي، حيث إنه من أجل قيام حالة الدفاع الشرعي

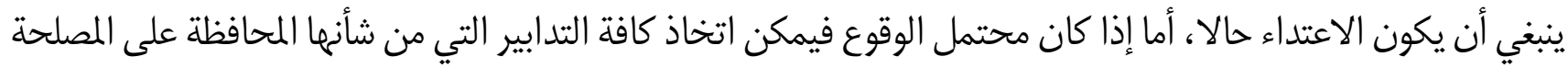

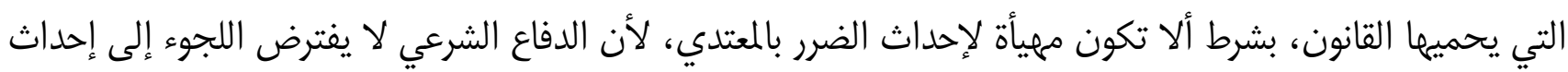

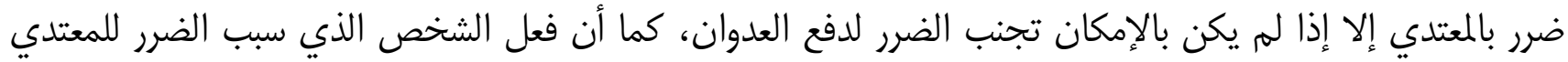

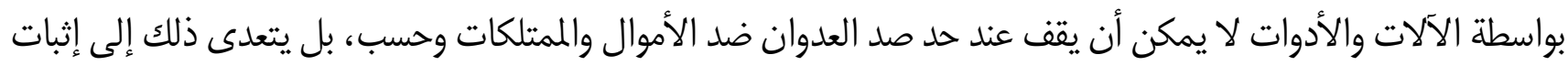

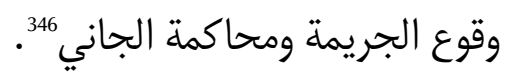

ويذهب بعض الباحثين في المجال الجنائي إلى القول بأن مسؤولية المالك ثابتة في مثل هذه الحالات، لعدم وجود

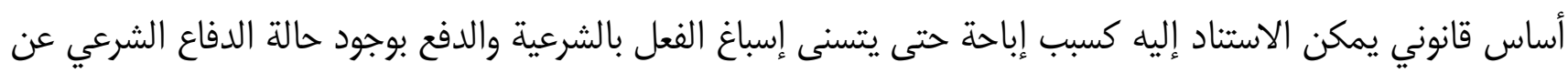

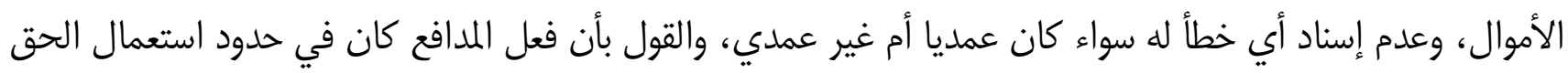

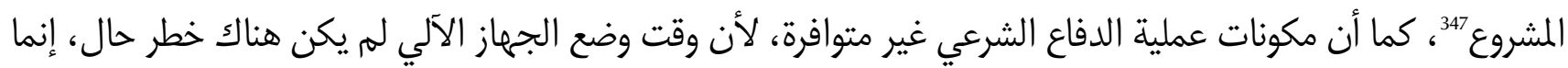

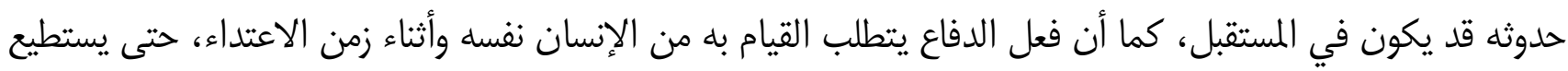

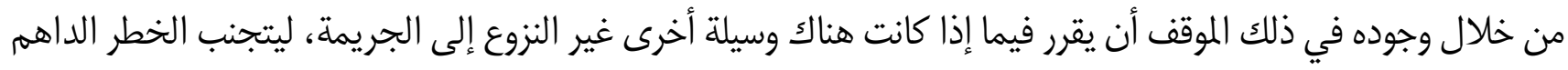

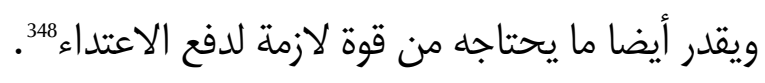

وفي تساؤل آخر هل يجوز الدفاع الشرعي عن طريق وسائل آلية إذا ما قتلت أو جرحت من يحاول الاعتداء؟

وكهذا نجد الفقيه Earçon E. Gen يعتبر أنه حين وضع الآلة من أجل قتل أو جرح اللص، فإن الدفاع الشرعي لا يمكن

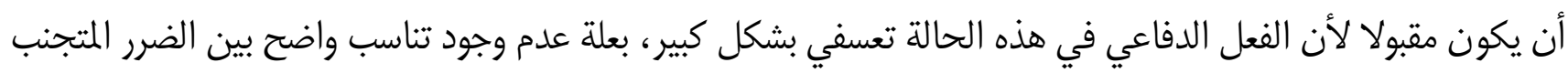

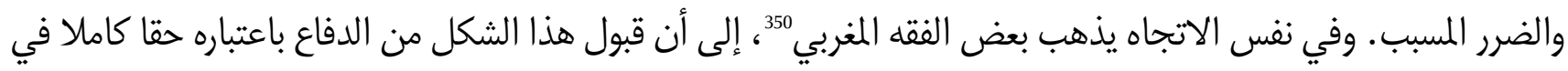

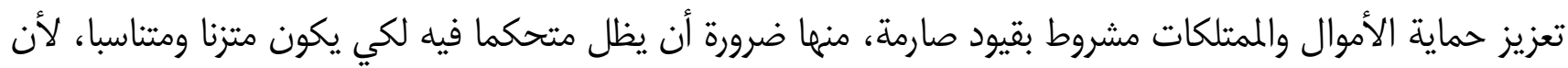

344 بن القائد امبارك السعيد: المسؤولية الجنائية للمتجاوز في الدفاع الشرعي، أطروحة لنيل دكتوراه الدولة في الحقوق، جامعة محمد الخامس،

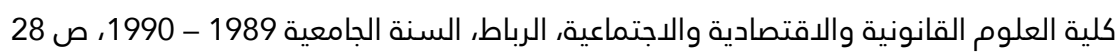
345محمد مصطفى القللي:المسؤولية الجنائية، مطبعة جامعة فؤاد، القاهرة، 1948، ص344

346 محمد سامي النصراوي: شرح قانون العقوبات "لقانون العقوبات الليبي"، منشورات جامعة قار يونس، بنغازي، 1995، ط. 3، ص ص 173 347أحمد محمد بونة: أسباب الإباحة وأسباب تخفيف العقاب "في القانونين الليبي والمغربي، دار الكتب القانونية - دار شتات للنشر والبرمجيات،

2010، ص ص 143

348 محمد مصطفى القللي:المسؤولية الجنائية، م.س، 340

${ }^{349}$ E. Garçon: Code penal annoté "article 328 et 329", Recueil Sirey, Paris, 1952, p 11

350 جعفر علوي: المعين في شرح القانون الجنائي العام المغربي، م.س، ص 109 
الحماية عبر الآلات ما هي إلا وسيلة لدرء خطر العدوان، وبالتالي يجب استعمالرها بالقدر اللازم لدرء الخطر • وتحقيق غايات آخرى من قبيل السقوط في متاهات العدالة الخاصة بشكل متطرف.

\section{الفقرة الثانية: اتجاه المؤيدين}

إن المالك الذي يضع الأجهزة الآلية بغاية حماية أمواله، لم يفعل ذلك إلا ترجمة واستعمالا لحقه المشروع المتمثل في نصب أجهزة آلية دفاعية، ومن ثم فليس للغير أن يتضرر من تلك المشروعية.351. وفي هذا الإطار يذهب بعض الفه الفقه إلى القول بشرعية نصب الوسائل الآلية لدفع الخطر المستقبل لأنه يجب النظر إلى الخطر في اللحظة التي تعمل فيها الآلة ضد المعتدي، وعندئذ يكون الخطر محدقا بمن أعد الوسيلة لدفع الاعتداء، وبالتالي يكون الدفاع عن الأموال بالوسائل الآلية، من قبيل لجوء صاحب الحق إلى أجهزة تعمل تلقائيا ضد كل من اقتحم حرمة ممتلكاته، فتصيبه بالأذى جراء محاولة

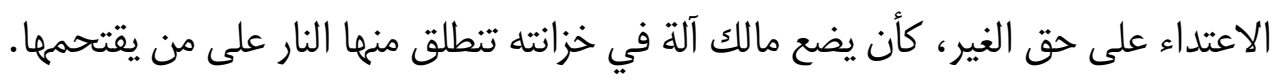
ويذهب الفقيه الفرنسي Rarraud حديدية أو نحو ذلك ضد من ليس له الحق في الدخول أو الفتح أو التصرف أو غيرها من الأفعال في ملك الغير، لا يعتبر مرتكبا لأية جريمة، شريطة توافر شرطين هما:

الأول: أن تقوم علاقة السبيية بين القتل أو الجرح المرتكب وسلوك الاعتداء.

$$
\text { الثاني: عدم تجاوز حدودالمشروعية. }
$$

وارتباطا بالرأي المشار إليه، يجوز لصاحب الحق المعتدى عليه، أن يحتج بالدفاع الشرعي إذا توافرت شروطه، ومن أهمها ألا تعمل هذه الوسائل إلا إذا حل الخطر بالحق، وأن يكون الأذى الذي تحلدثه داخلا في حدود الدفاع بمعنى تناسبه مع الخطر

واستنادا إلى الواقع العملي، فالمدافع الذي يقوم بفعل الدفاع عن أمواله باستعمال أجهزة آلية، سواء كان المالك أو من

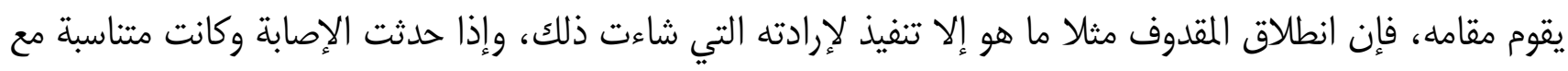
مقدار الخطر المطلوب دفعه، فهنا تغيب أهمية أن يكون المالك أو من يقوم مقامه هو الذي باشر فعل الدفاع بيده أو طريق

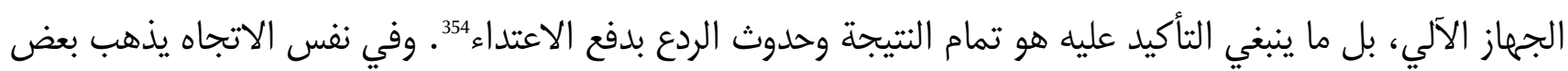
الفقه المصري 355 إلى القول، أن الدفاع الآلي عن المال، ممكن إذا توافرت عناصر وشروط الدفاع الشرعي، وأساسا ضابط

والمقدمد نعيم فرحان: النظرية العامة لعذر تجاوز حدود حق الدفاع الشرعي "دراسة تطبيقية لمبدأ المشروعية الجنائية في القانون المصري

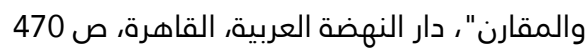

${ }^{352}$ R. Garraud: de la notion de responsabilité morale et pénale, Bulletin de 1, union international de droit penal, T. 6, 1897, p 25, R. Merle et A. Vitu:Problèmes généraux de la science criminelle "Droit pénal général", T. 1, Cujas, 1997,7 éd, p 313 353 عدلي خليل: جنح وجنايات الجرح والضرب "في ضوء الفقه والقضاء والطب الشرعي"، دار الكتب القانونية، المحلة الكبرى، مصر، 1996، ص 
التناسب وعدم تجاوز حدود الدفاع. غير أن الدفاع السلبي عن الأموال لا يثير نقاشا أو اختلافا كبيرا، ولا يرتب أي مسؤولية

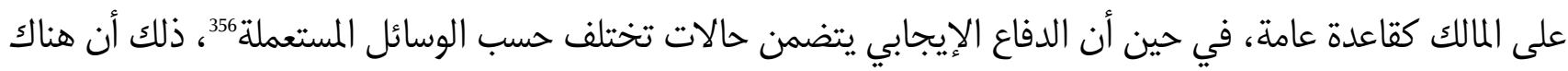
وسائل خطيرة يمكن أن تودي بحياة أي شخص أو أو أن تمس مسا بلين بلينا بسلامته الجسدية.

هذا الأمر، الذي فسح المجال أكثر لإثارة تجاوز حدود الدفاع الشرعي في الدفاع الشرعي الآلي عن الأموال، من قبيل

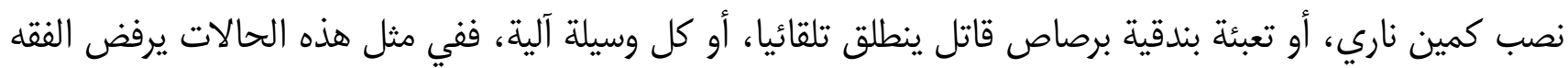

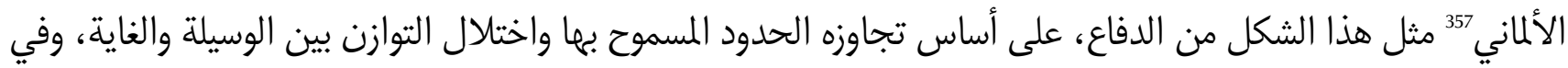

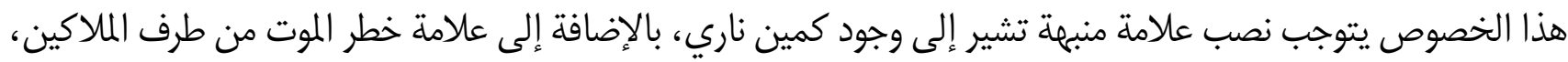

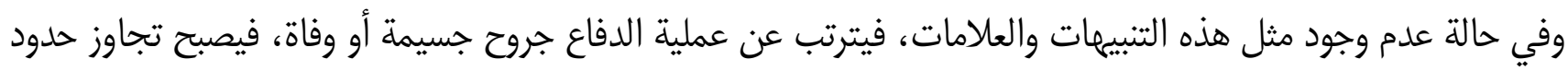

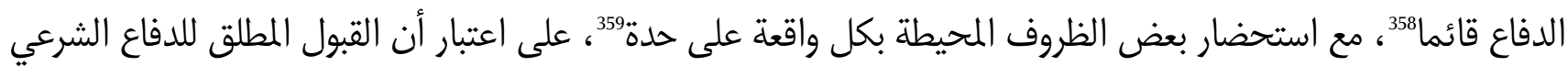

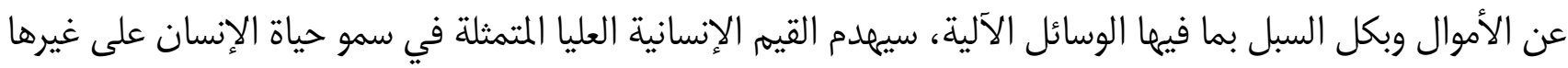

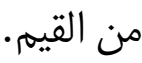

لكن هذا لا يجب أن ينسينا بروز وصعود قيمة المال وراهنيته في عالم اليوم، مع وجود مفهوم "جسدي - نفسي" للقيم

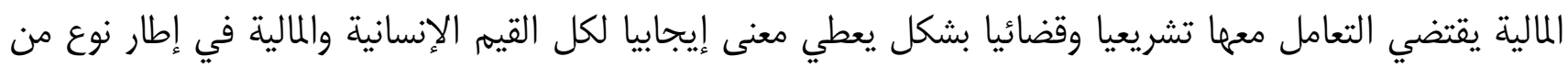

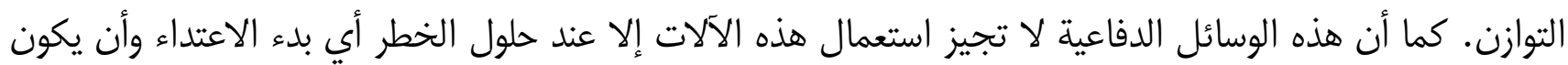

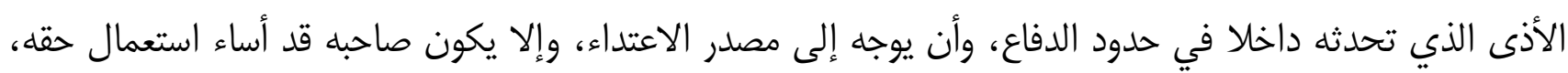

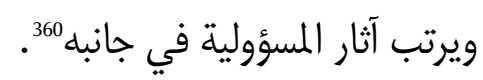

إن الدفاع عن طريق الوسائل الآلية لدفع خطر مستقبل يعتبر دفاعا شرعيا، مادام الخطر قد حل لحظة رد الآلة تجاه

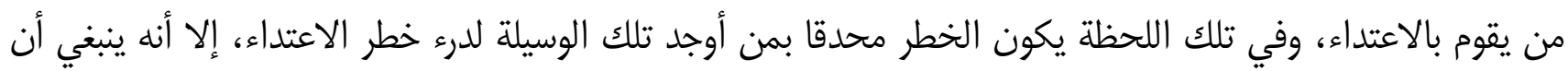
تكون الوسيلة المستخدمة متناسبة مع الضرر الذي يحدثه الاعتداء

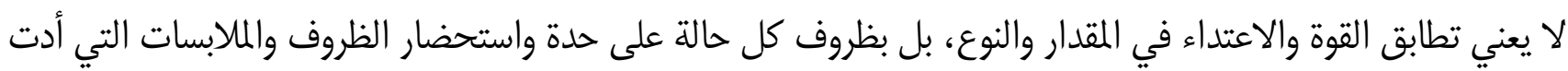

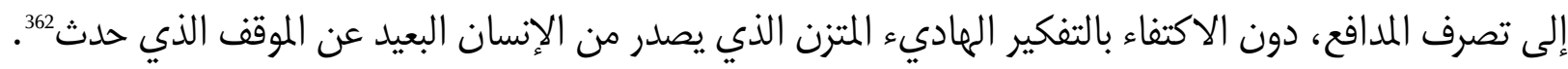

356 انظر ما تقدم بشأن موضوع الدفاع الآلي وعلى الخصوص السياق المحيط ببروز الدفاع الآلي للأموال كشكل عصري للدفاع 357بن القائد امبارك السعيد: نظرية التجاوز في الدفاع الشرعي في القانون الجنائي المغربي، م.س، ص 143 - 144

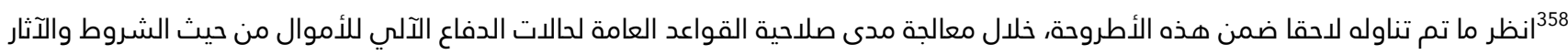
359 بن القائد امبارك السعيد: نظرية التجاوز في الدفاع الشرعي في القانون الجنائي المغربي، م.س، ص صدمة 145 - 146 360 عبد السلام بنحدو: الوجيز في القانون الجنائي المغربي "المقدمة والنظرية العامة: الجريمة - المجرم - العقوبة والتدبير الوقائي" المبائي ، المطبعة

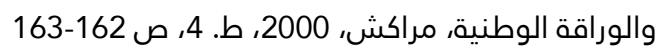
361 محمود نجيب حسني: شرح قانون العقوبات، القسم العام "النظرية العامة للجريمة والنظرية العامة للعقوبة والتدبير الاحترازي"، مرجع سابق، 220 ص

${ }^{362} \mathrm{~K}$. Sassy: la légitime défense en droit pénal marocain a la lumiere du droit musulman, Thése pour le doctorat de droit, Université de Perpignan Via Domita, Faculté Internationale de Droit Comparé des Etats Francophones, Perpignan, 2011 2012 , p $126-127$ 
إن ضرورة اعتبار المستجدات الحاصلة في الواقع العملي، وكذا التطورات الاجتماعية والاقتصادية وتصاعد دور المال، ومن شأن التحفظ في الإقرار بشرعية هذا النوع من الدفاع، فتح المجال واسعا أمام المجرمين في السطو والاستيلاء على الى الأموال والممتلكات بشكل غير مشروع، وبالرغم من أن بعض الباحثين يقيد شرعية الإقرار بالدفاع الآلي، بعدم التضحية

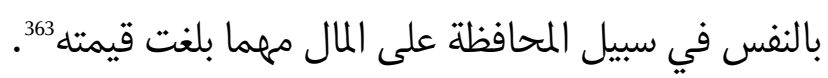

وفي رأينا، يجب التمييز بين الآلات التي تستعمل يدويا وبشكل يسمح لمستعملما بالتحكم فيها، وتلك التي يفقد مستعملما التحكم فيها بمجرد برمجتها، فالأولى يسري عليها حكم الأسلحة التقليدية، أما الثانية فتثير صعوبات جمة في بئي اعتبارها حالة دفاع شرعي من عدمها، وتتجلى هذه الصعوبات في الجواب عن الأسئلة التالية: هل كان بإمكان المالك اللجوء إلى وسيلة أخرى لرد العدوان؟ وهل الضرر الذي أحدثته الآلة الدفاعية يتناسب مع خطورة الاعتداء؟ وهل تم اتخاذ جميع التدابير التي تحذر من الخطر الذي يمكن أن يتعرض له المعتدي؟. في تقديرنا نعتقد، أنه يجب الإقرار بمشروعية الدفاع الآلي عن الأموال، في ظل التغييرات التي يعرفها عالم الجريمة، وفي ظل تزايد وتيرة جرائم الاعتداء على الحقوق المالية، كما أن المشرع أبدى حرصه لتعزيز الحماية التي يوفرها القانون الجنائي للحقوق المالية، خصوصا لملكية المنقولات والعقارات على الرغم من استفادته من الحماية التي توفرها له مختلف الفروع القانونية الأخرى الثغرات القانونية365، والتي تتجسد أهم تجلياتها في الاعتراف بشرعية الدفاع الآلي عن الأموال، ضمن مدونة القانية القانون الجنائي، ليتسنى تطبيق مقتضياتها قضائيا على الحالات المعروضة عليه.

\section{المحور الثاني: المعالجة القضائية لقضايا الدفاع الآلي عن الأموال}

إن تناول الحلول القضائية بشأن الدفاع الشرعي للأموال يعطي للموضوع بعدا عمليا للإشكالات التي يفرزها الواقع،

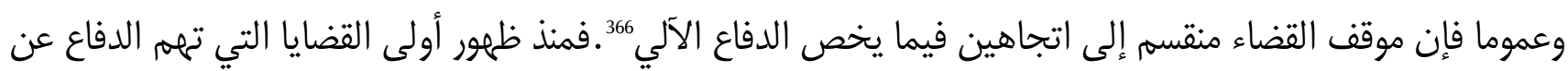
طريق المعدات الآلية بدا الاجتماد القضائي منقسما حول قبول هذا الشكل من الدفاع من عدمه. حيث أصبح يثير نقاشا في

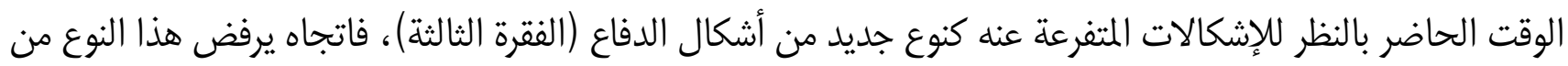
الدفاع، ويقضي بإدانة المالك إما بناء على خطأ عمدي إذا كان الأذى قد ألحق ضررا بلدنيا أو بناء على خطأ غير عمدي في حالة إذا تحققت الوفاة، (الفقرة الأولى)، واتجاه يرفض هذا النواء إنوع من الدفاع، ويقضي بإدانة المالك إما بناء على خطأ عمدي كلما كان الأذى المتحقق متمثلا في مجرد الضرب والجرح، أو بناء على خطأ غير عمدي إذا تحققت الوفاة كنتيجة للدفاع الآلي وقد فسر هذا الوضع بسعي القضاء إلى عقاب معتدل (الفقرة الثانية).

كالجة الجمالي محمد: الدفاع الشرعي في القانون الجنائي المغربي، رسالة لنيل دبلوم الدراسات العليا في القانون الخاص، جامعة الحسن الثاني،

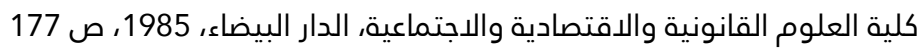
364 إدريس طارق السباعي: جرائم الأموال في ظل التشريعين المغربي والإماراتي، مطبعة الرسالة، الرباط، 2007، ص 83-93 365 عادل عبد إبراهيم العاني: جرائم الاعتداء على الأموال في قانون العقوبات "السرقة - الاحتيال - اساءة الائتمان"، دار الثقافة والنشر

والتوزيع، عمان، 1997، ص 10 - 11

${ }^{366}$ D. de Vabres: Traité de droit criminel et de législation pénale comparé, Sirey, 1947, p 408 


\section{الفقرة الأوله: الاتجاه المؤيد}

يؤسس هذا الاتجاه على أنه لا يوجد ما يمنع من اتخاذ الاحتياطات اللازمة لدرء الاعتداء عن طريق وسائل الدفاع الآلية ضد جرائم الأموال، ما دامت لا تعمل إلا إذا وقع من الجاني فعل يعد جريمة، لأن العبرة في قيام حق الدفاع تحدد بهزه اللحظة، ويشترط أن يكون الضرر المترتب عن فعل الدفاع متناسبا مع خطر العدوان، وإلا اعتبر المالك متجاوزا لحدود الدفاع الشرعي الشرعي فكرة لا تستقيم إلا مع وصف العمد للنتيجة المتحققة.

كما أن الأحكام والقرارات الصادرة عن القضاء الفرنسي، بشأن الدفاع عن الأموال باستخدام الأجهزة الآلية والشراك

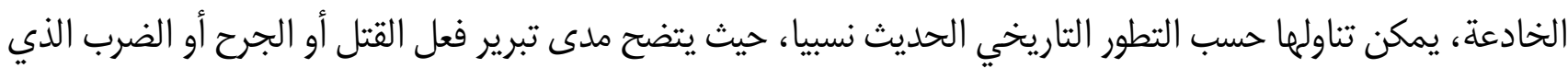
تحدثه الوسائل الدفاعية، واعتبارها تدخل ضمن إطار ممارسة الدفاع الشرعي دون تجاوز حدوده. لقد تضمنت الأحكام الصادرة قبل سنة 1959م بوجه عام تبريرالأفعال القتل أو الجرح المتأتية من ممارسة حق الدفاع الشرعي دون تقرير التجاوز لحدود ذلك الحق. ومنها الحكم الصادر بتاريخ 25 مارس 1902م 368 بفرنسا، حيث تتخلص وقائع الحادث في كون أحد الملاكك يحتفظ داخل حديقة منزله ببحيرة صغيرة بها بعض الأسماك النادرة، وخشية سرقتها، وضع داخل تلك البحيرة أجهزة قابلة للانفجار بمجرد لمسمها دون أن ينتج عنها ضرر، غير أن اللصوص قد علموا بذلك فسخروا من المالك وأرسلوا له خطابات تتضمن معنى التحدي، تظهر نية وإصرارا على فعل السرقة، مما جعل المالك يصعد هو الآخر من جانبه، فقرر وضع جهاز ناري ينتج عنه الموت أو الجروح البالغة عند وقوع الاعتداء أو خطره الحقيقي، وعزم أحد اللصوص سرقة الحديقة ليلا واقترابه من حوض السمك الموجود بحديقة منزلهونجم عنه اقتحام الدخيل انفجار الجهاز وتحطم ساقه اليمنى، فتقدم "اللص" المصاب بدعوى لئى لئه مدنية قصد المطالبة بالتعويض عن ما أصابه من ضرر، وقد رفضت المحكمة دفع المدعى عليه (المدافع) الذي تمسك بوجود حالة الدفاع الشرعي وحكمت عليه بالتعويض المالي، غير أن محكمة الاستئناف Dijon بفرنسا ألغت الحكم مثم، وأخذت في اعتبارها دفع المدافع بممارسة حق الدفاع الشرعي، ومن أهم الحيثيات الواردة في هذا الحكم ما يلي: حيث إن المقتضيات الواردة في الف. 329 ق.ج.ف تعد قرينة قانونية مرمة، لأن التسلق لحائط منزل مسكون أو توابعه أثناء الليل، يتحقق معه الاعتداء أو خطره الحقيقي فيلزم لمن يتهردده ذلك الاعتداء أن يدفعه بالوسيلة المتيسرة له في تلك اللحظة، كما أن عبارات هذه المادة تطبق ليس على الحالة التي يثبت أن فعل التسلق قد بدأ وإنما أيضا على تلك الحالة التي يكون فيها التسلق قد تم، وأن خطر الاعتداء أصبح أكثر تهلديدا. وحيث إنه لا يمكن أن ينسب خطأ ما، لشخص المدافع الذي انتهكت حرمة مسكنه في ظروف تشكل خطورة لأمنه، ومن ثم ليس من الواجب عليه أن ينتظر حدوث أفعال إجرامية جديدة تعد أكثر جسامة من التسلق خلال الليل.

367 ${ }^{368}$ Req. 25 mars 1902, S. 1903.1.5, note Lyon-Caen

369 محمد نعيم فرحات: النظرية العامة لعذر تجاوز حدود الدفاع الشرعي، م.س،ص 479 


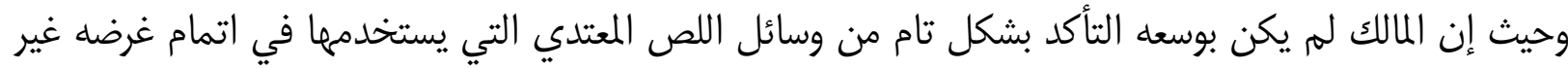
المشروع، مما يؤشر على عدم تجاوز حدود دفاع المالك، وخصوصا لتزامنه مع ظرف الليل الذي بطبيعته يمنع تقدير وملاحظة

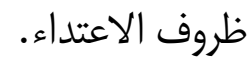
وحيث أنه قد تقرر للمالك حق الدفاع الشرعي، وبالتالي لا يهمنا كثيرا أن نبحث في مدى تدخله شخصيا في الوسائل

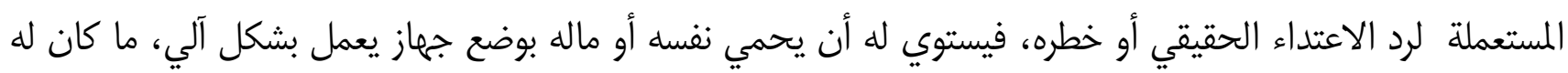
الحق أن يفعله هو بيده.

غير أن ما يمكن ملاحظته بهذا الخصوص هو أن وضع الجهاز قد تم بشكل مسبق، وليس في لحظة التسلق، بغرض الحف

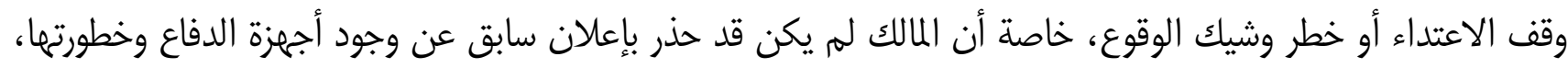
لكن رعم ذلك فقد أبدى بعض الفقه الفرنسي

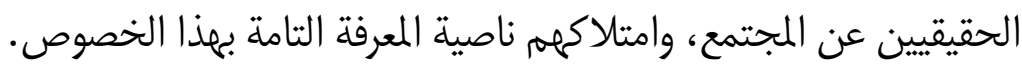

وهناك قرارات أخرى قبلت الدفاع الشرعي عن طريق الوسائل الآلية، منها حكم محكمة الاسئناف Amiens الصادر

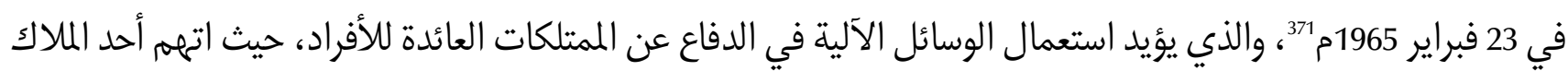

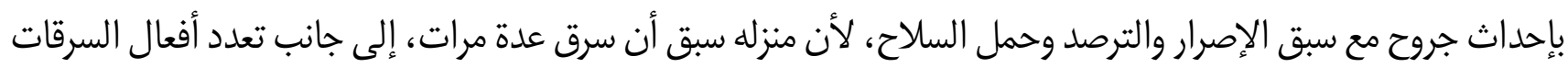

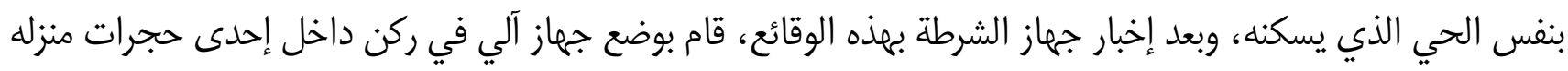

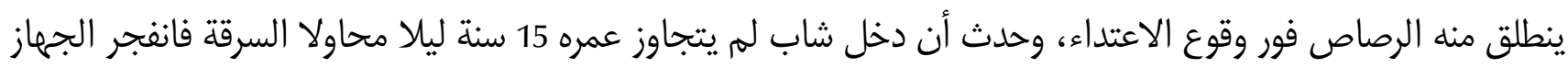

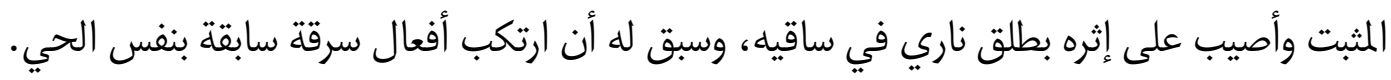
غير أن المحكمة قضت ببراءة المالك، واعتبرت أنه قام بممارسة حق الدفاع الشرعي عن مسكنه بعد أن نشأت له ضرورة

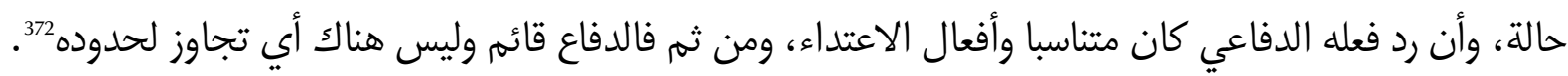
وهكذا نجد أن القضاء الفرنسي منذ البدايات الأولى لبروز هذا الشكل الدفاعي المستحدث، قد أبدى جرأة كبيرة في

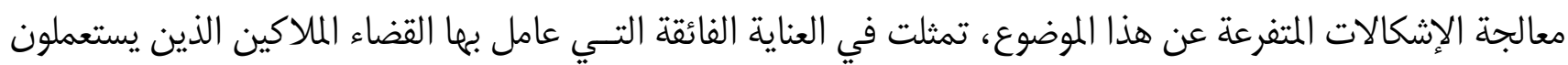

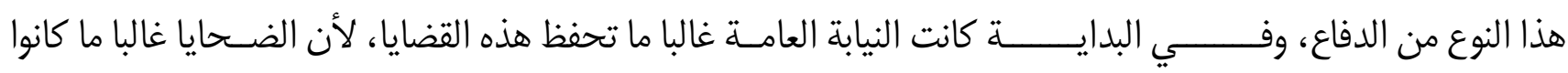

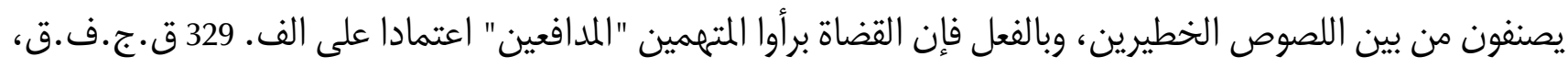

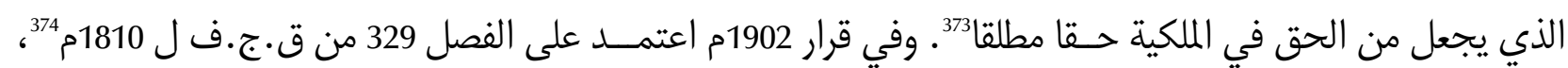

\footnotetext{
${ }^{370}$ P.Bouzat: op.cit, p159

${ }^{371}$ Les exemples sont rares: Tri. CAAmiens 23 Fevrier 1965, RSC, 1965, p 421, RSC, 1965, p 421

${ }^{372}$ Hugueney Louis: RSC, 1965, p 421

${ }^{373} \mathrm{~J}$. Pradel: la defense automatique des biens, op.cit, p 217

${ }^{374}$ L'affaire Jeufosse $C$ d'assises d'Evreux, 18 décembre 1857, Journal des débats 19 et 20 Décembre 1857, France, V. aussi, Journal de Toulouse, № 349, 18 Décembre 1857
} 
وكذلك قضية 29 مارس 1900م، وقرارات غرفة الجنايات لمحكمة النقض الفرنسية بتاريخ 26 مارس 1904م، أسست

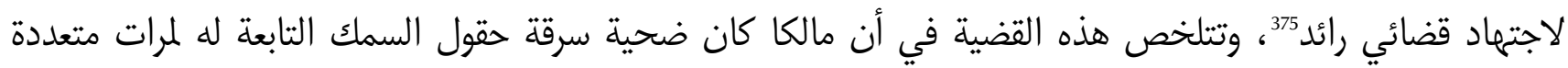

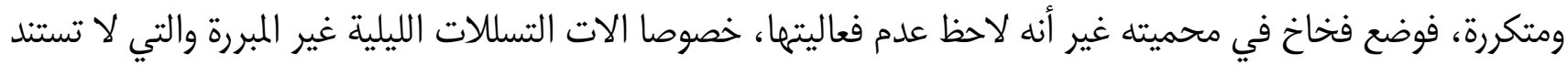

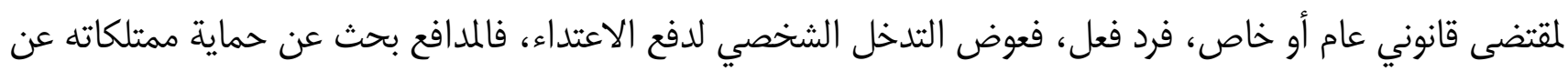

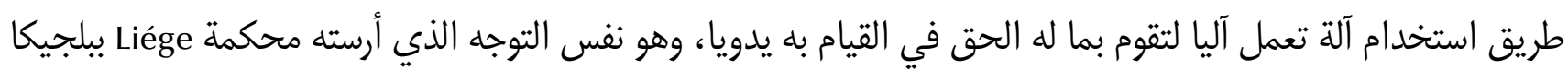

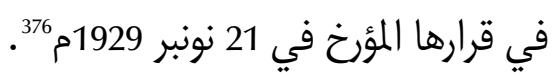

بالنسبة للقضاء أسس لمبدأ عدم أهمية أجهزة الدفاع الآلية، بل الأساس الذي اعتمد هو سبب وضع هذه الأجهزة، أي الي التي

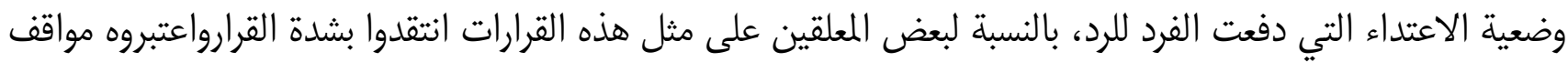

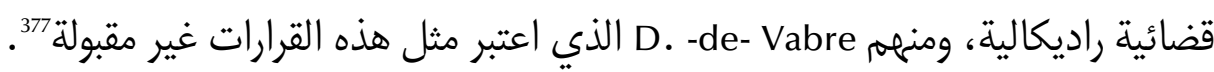
النقطة المركزية لهذا الإشكال تكمن في معرفة إلى أي مدى يمكن أن يذهب المالك في حماية مسكنه: هل يمكن أن يفعل ما يريد في منطقته؟ لقد أسس الاجتهاد القضائي لمبدأ شرعية الدفاع بالوسائل الآلية عن الأموال، وفقا لضوابط صارمة منها عنصر التناسب

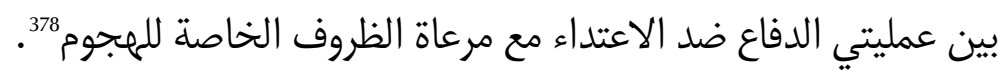

\section{الفقرة الثانية: الاتجاه الرافض}

من أهم الأحكام الصادرة في هذا الشأن والمصنفة في خانة رفض استعمال الوسائل الآلية في الدفاع، نجد حكم الهما

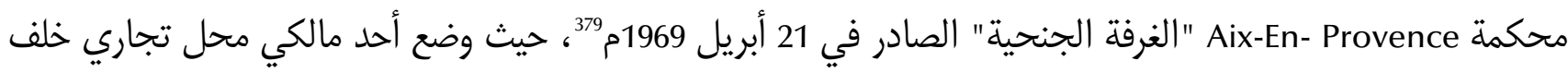

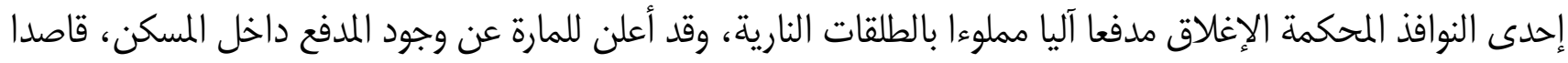

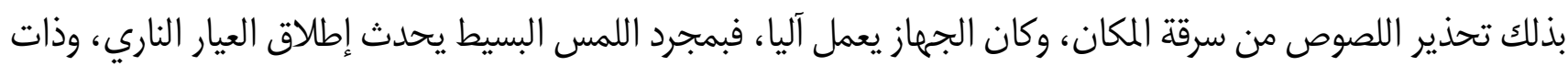

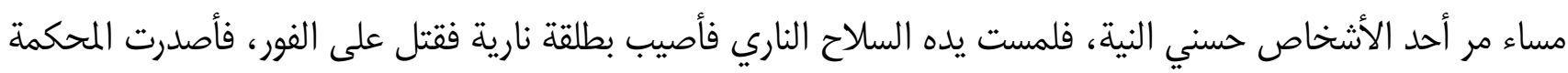

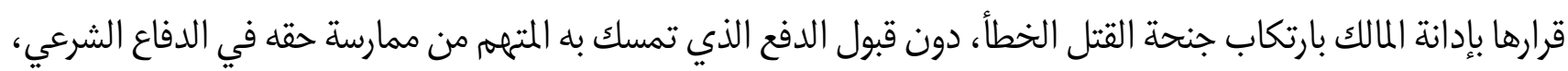

${ }^{375}$ Dijon 21 mars 1900, D. 1901.2.475, qui infirma une decision du Tribunal civil saisi de l'action en dommage et interest intentée par le voleur et qui avait condamné le propriétaire en rejetant le fait justificatif de légitime defense, arret du 25 mars 1902, S.1903.1.1, D. 1902.1.356

376 Jurisprudence belge, Cour de Cassation, p195 - 199

https://www.law.kuleuven.be/lib/plone/tijdschriften/cassatie/1905/1.pdf

Mise - a - jour le: $9-8$ - 2018

${ }^{377}$ R. Payen: De l'emploi d'engins automatiques pour la défense des proprieties et de la responsabilité pénale, Paris, 1905, p 233

${ }^{378}$ Cour de Cassation, arretRéminiac, crim. 19 Février 1959, D. 1959, p 161, RSC, 1959, p 839, Cassation Criminelle, 19 Mai 1904, France

${ }^{379}$ Tribunal correctionnel, Aix -en- Provence, France, 6 Octobre 1969, RSC, 1970, p 851, et RSC, 1970, p 375 
غير أن ما يعاب على هذا الحكم اقتناع المحكمة بتحقق الجريمة غير العمدية، دون نقاش مدى توافرعناصر وشروط الدفاع

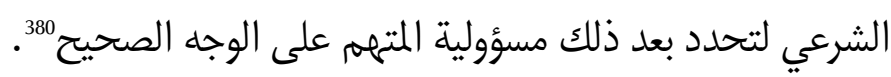

كما نشير أيضا في هذا الإطار أيضا لحكم محكمة Toulouse "الغرفة الجنحية" بفرنسا الصادر بتاريخ 8أكتوبر

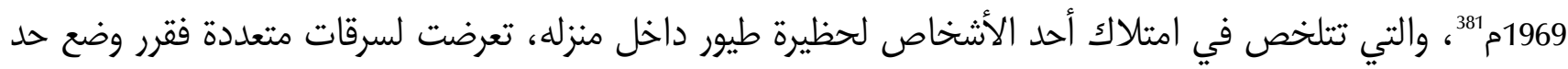

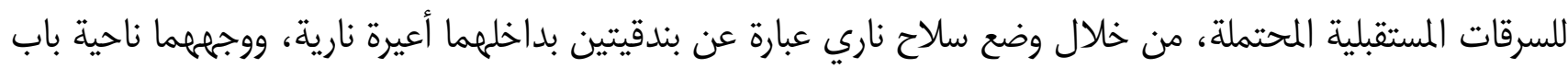

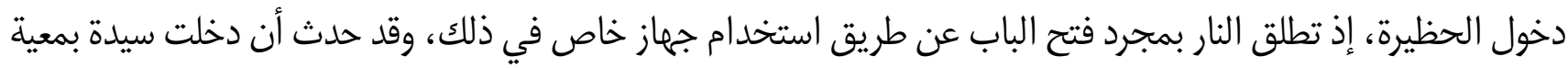

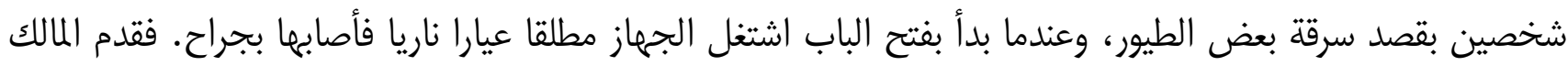

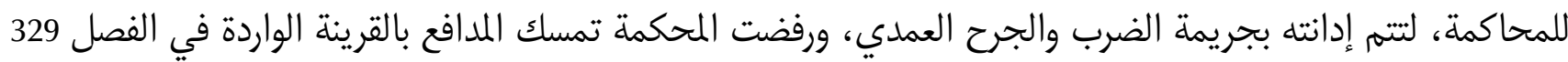

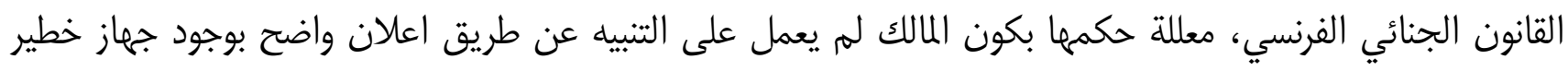
بمسكنه، وكذا ترك الباب الخارجي لمسكنه مفتوحا.

وكما نجد أيضا حكمم محكمة جنح Reins الصادر في 9 نونبر 1978م،3232، ومن بين ما ورد في الحكم، أنه ثبت للمحكمة

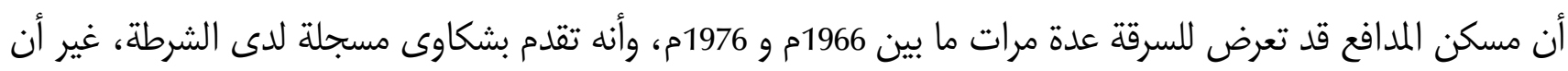

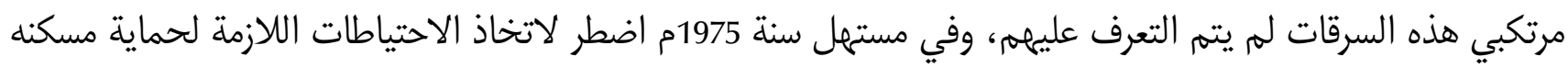

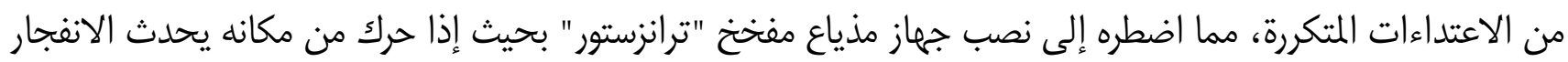

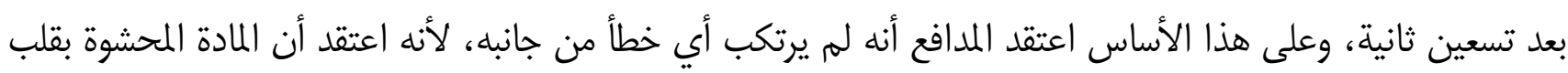

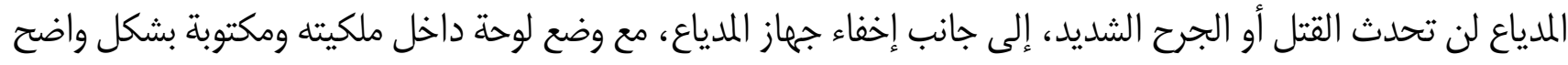

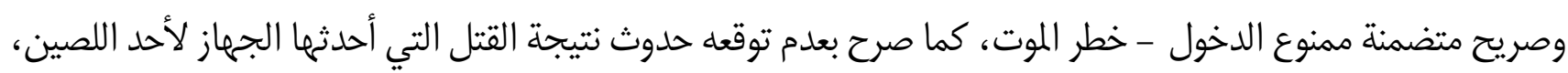
والجروح البالغة لأحدهما الآخر.

لقد سبق لقرار قضائي في 23 فبراير 1985م303، أن ناقش هذا الإشكال في القضية التالية "مالك كان ضحية محاولة

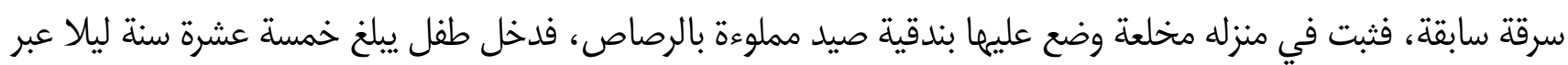

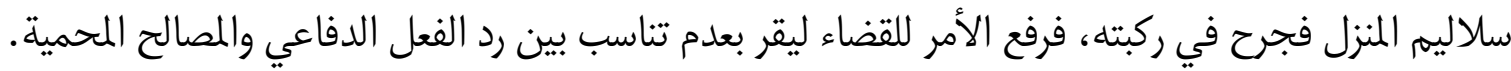

\section{الفقرة الثالثة: تقدير العمل القضائي}

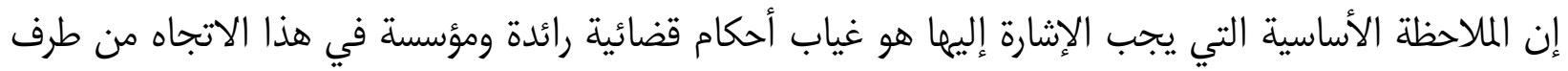

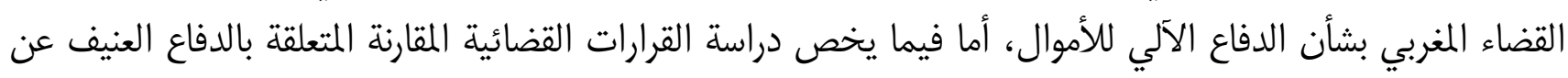

${ }^{380}$ Trib. Corr. Aix, 21 avril 1969, Gaz. Pal. 1969-II, 159, RSC, 1970, p 97,Legal, RSC, 1970, p 374

${ }^{381}$ Cour d'appel de Toulouse, France, 15 Novembre 1979 Tribunal Corr. Toulouse 8 octobre 1969, RSC, 1970, p 851, V. RSC, 1977, p 334,15 Octobre 1980, B. № 261

${ }^{382}$ P. Bouzat, JCP, 1979, 19046 II

${ }^{383} \mathrm{RSC}, 1965, \mathrm{p} 421$ 


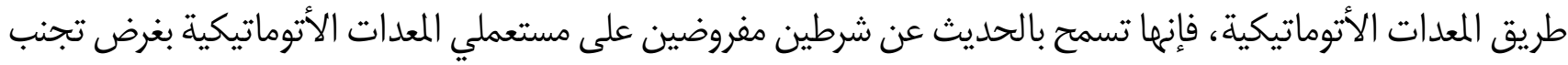

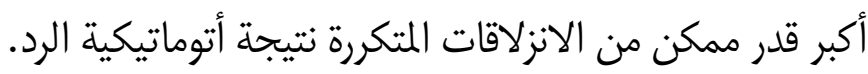

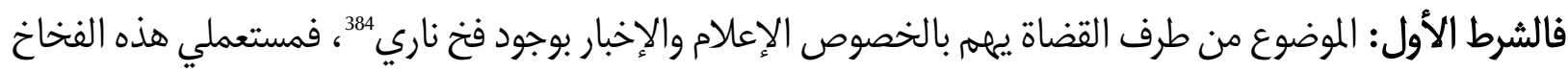

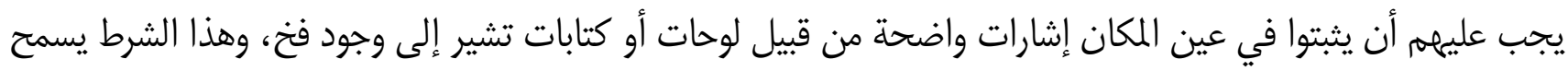

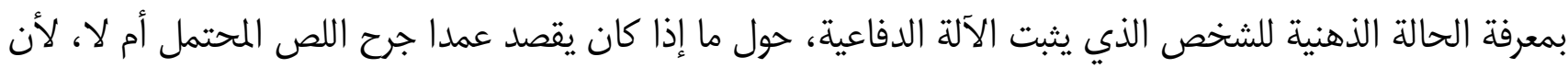

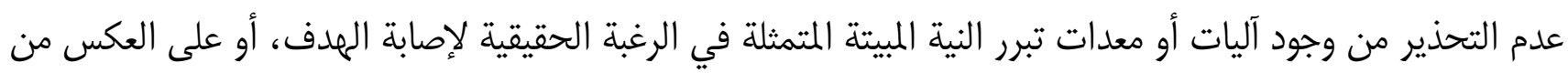

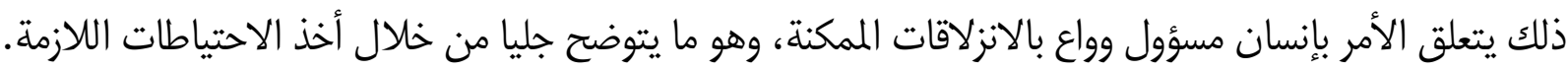
أما الشرط الثاني: الذي وضع من طرف القضاة هو أخذ تصريح من البلديات على غرار التصريح الإلزامي المفروض على مالكي الكلاب الخطيرة.

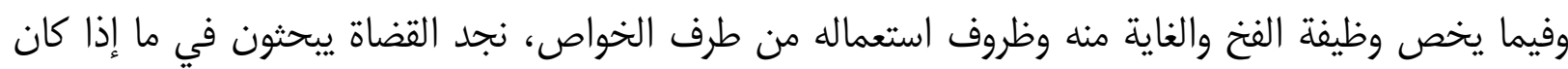

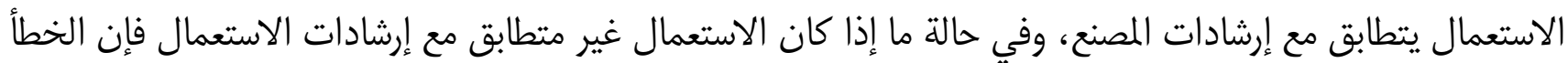

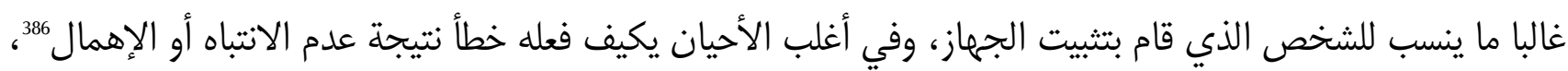

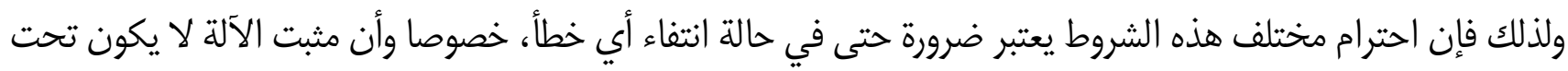

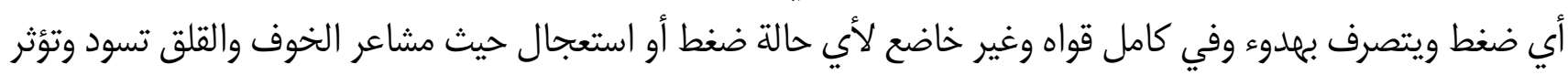
على العقل وفعاليته 387.

وهكذا نجد أن القضاء الفرنسي، يتشدد في التأكد من وجود مبرر لاستعمال الدفاع الآلي، كما يوجب على مستعمليه

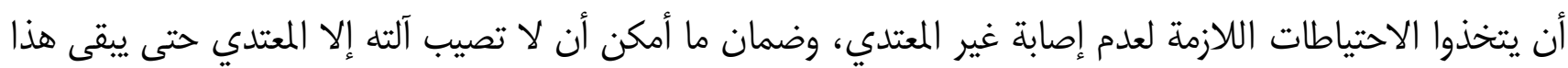

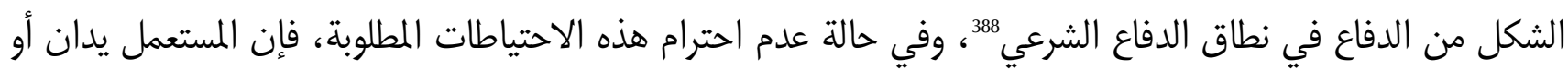

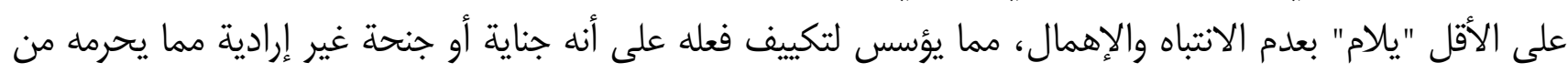

${ }^{384}$ D .Guy: légitime défense et auto-défense, RPN, N 109, 1979, p $17-25$, P. CHairoff: le guide de la légitime defense: protégez-vous, protégez vos biens, op.cit, p 149

${ }^{385}$ Cass.Crim., $N^{\circ}$ de pourvoi: 78-92653, du 15 octobre 1980, Publié au bulletin, $N^{\circ} 261$

https://www.legifrance.gouv.fr/affichJuriJudi.do?idTexte=JURITEXT000007061411

Mise - a - jour le: 17 - 04 - 2018

${ }^{386}$ Trib. Corr. Aix-en-Provence, 21 avril 1969, GP 1969.2.159, Cass. Crim. , du mardi 18 janvier 1977, N de pourvoi: 7691125 Publié au bulletin $N^{\circ} 21$

https://www.legifrance.gouv.fr/affichJuriJudi.do?idTexte=JURITEXT000007062695

Mise - a - jour le: 13 - 04 - 2018

${ }^{387} \mathrm{~J}$. Pradel: "la défense automatique des biens", op.cit, p 228

388 عبد السلام بنددو: الوجيز في القانون الجنائي المغربي "المقدمة والنظرية العامة - الجريمة - المجرم - العقوبة والتدبير الوقائي"، م.س، 


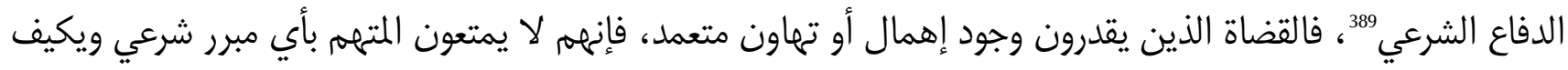

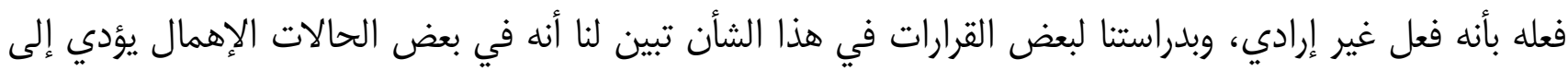

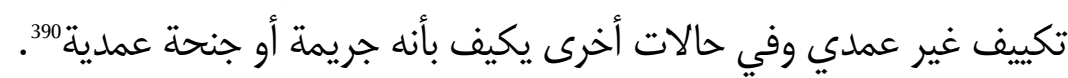

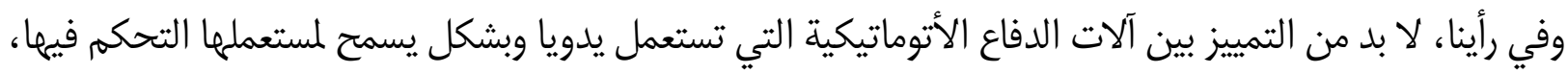

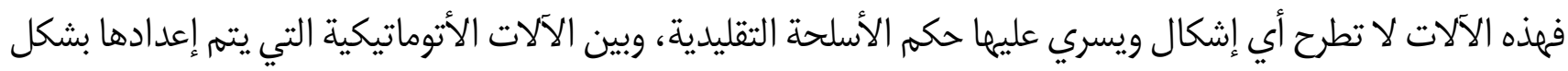

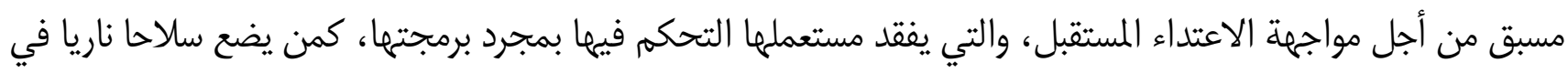

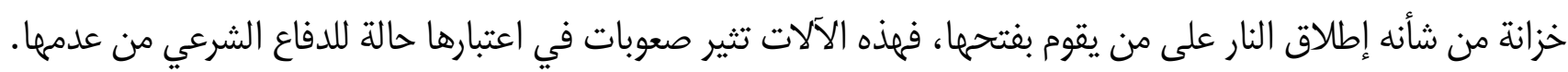

$$
\text { ولا يمكن لهزه الصعوبات أن تنجلي إلا بالجواب على التساؤلات التالية. }
$$

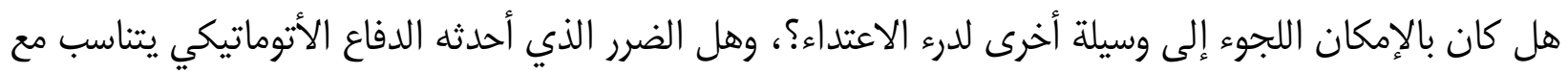

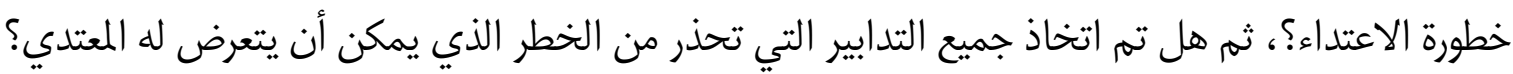
وبالرجع إلى توجه القضاة في هذا الموضوع فإنه في حالة وفاة الذخيل المعتدي، فإن القضاة غالبا ما يكيفون الفعل بأنه

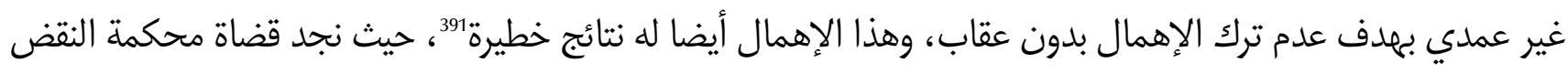

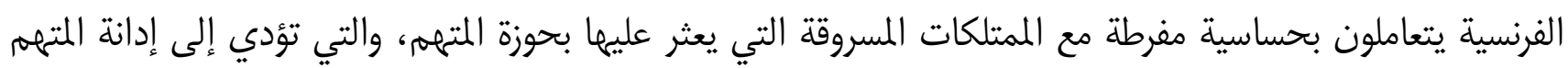

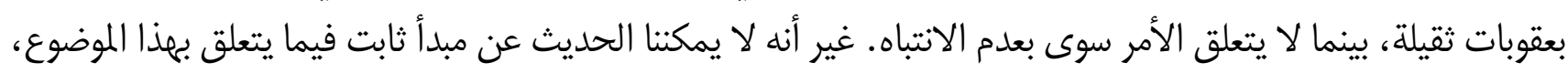

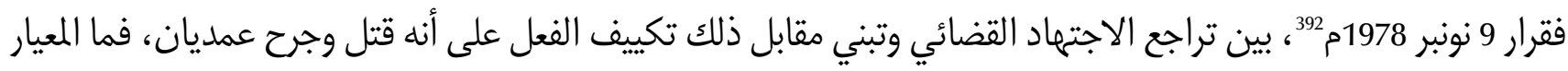
المستعمل في تبني هذا التكييف؟

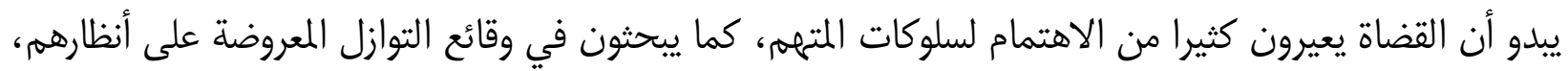

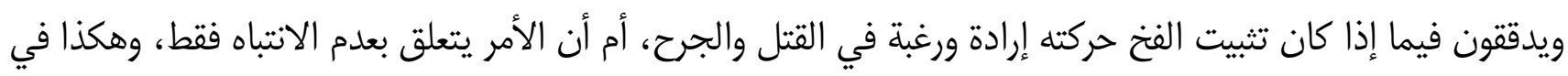

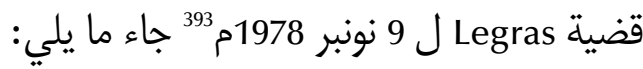
إن صناعة وتثبيت الفخ يشكلان قرينة خطيرة على أن الفعل عمدي، ويتضمن إرادة متعمدة سواء للقتل أو على الأقل

${ }^{389}$ ArretCousinet 16 Février 1967, RSC, 1967, p 659 et 854, Cass. Crim. du jeudi 16 février 1967 № de pourvoi: 6692071Publié au bulletin $N^{\circ} 70$

https://www.legifrance.gouv.fr/affichJuriJudi.do?idTexte=JURITEXT000007058652

Mise - a - jour le: 14 - 04 - 2016

J. Pradel - A. Varinard: Les grands arrets du droit pénal général, Dalloz, 2001, p 22

${ }^{390}$ Tribunal Corr. Aix-en- Provence 21 avril 1969, RSC, 1970, 97, Tribunal Corr. Toulouse 8 octobre 1969, RSC, 1970, p 851

${ }^{391} \mathrm{~J}$. Pradel: "la défense automatique des biens", op.cit, p 222

392 Affaire M. legras, CHambre criminelle, 9 Novembre 1978, Troyes, France, publié au RSC, 1979, p 329

${ }^{393}$ Affaire M. legras, op.cit, p 329 
ومهما كان المعيار المستعمل من طرف القضاة فإن الفقه وجه انتقادات لادعة تتركز خصوصا على عدم توافق الدفاع

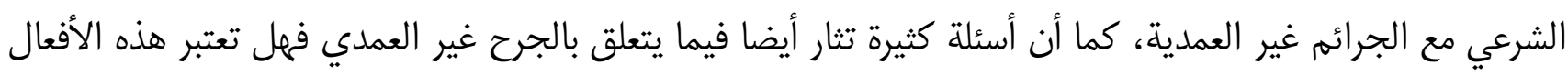
كجنح عمدية أو غير عمدية؟ الجر عير المدك

وفي هذا الإطار نجد جل الباحثين في هذا المجال 394، اعتبروا أن مسؤولية شخص عن ورشة بناء أو مبنى معرض للخطر

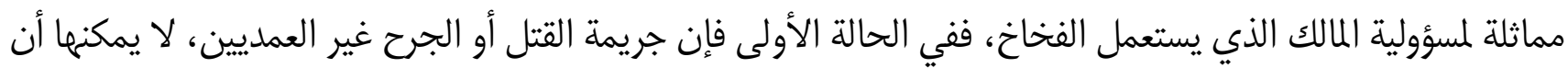

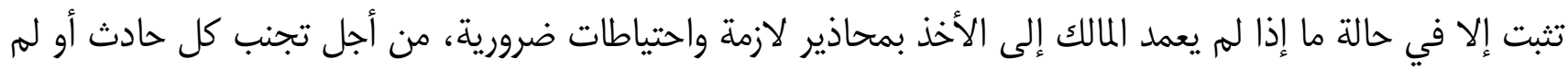

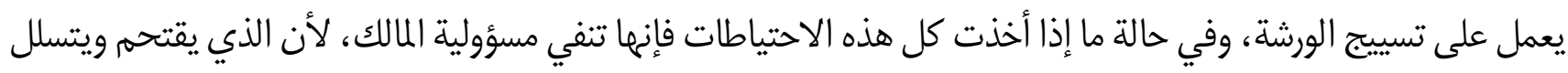

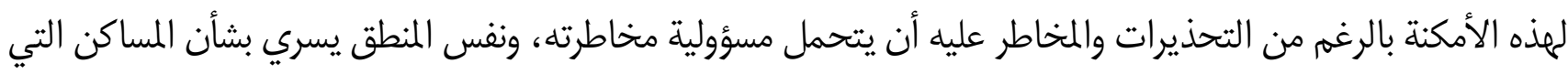

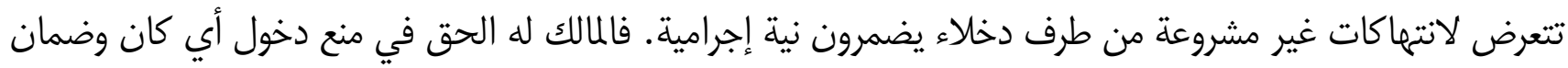

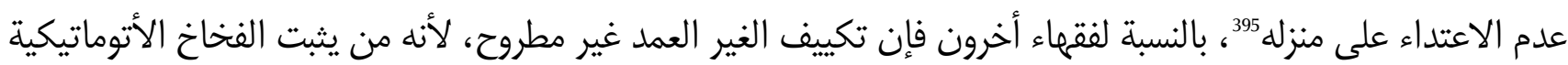

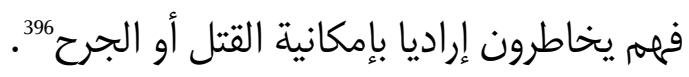
والملاحظ أن الدفاع الآلي عرف تغيرات مختلفة حسب الزمان، ففي البدايات الأولى الدفاع الشرعي عن طريق الآلات

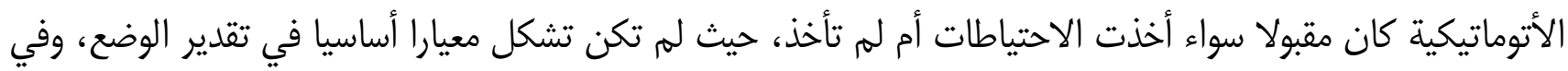

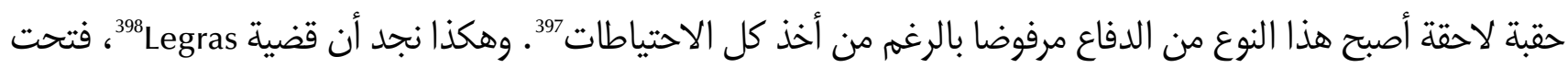

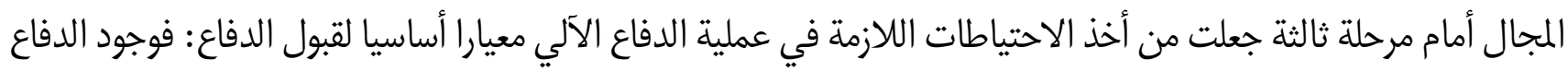

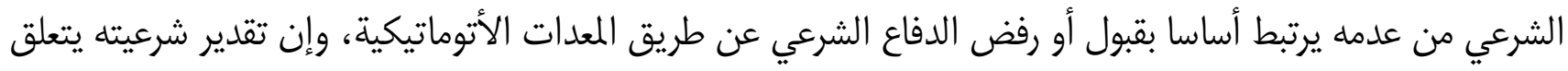
بكل حالة على حدة.

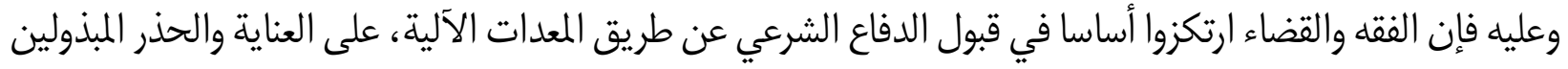

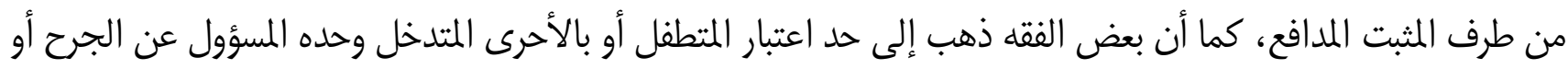

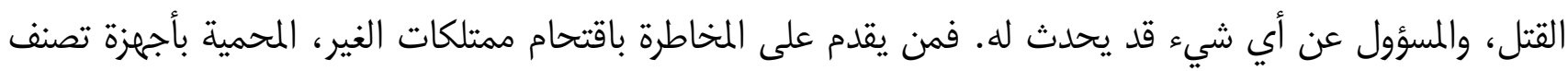
خطيرة إلى حد مالم

${ }^{394} \mathrm{P}$. Lamau :La place de la victime dans le procès pénal, Mémoire du Master en Droit pénal et sciences pénales, I'Université Panthéon-AssasParis-II, 2009-2010, p 74-76

${ }^{395}$ L. Lambert: Droit pénal spécial appliqué à l'information, Éd. Lyon, J. Desvigne, 1952, p 131, R. Payen: De I'emploi d'engins automatiques pour la défense des proprieties, Paris, 1905, p 67

${ }^{396} \mathrm{E}$. Lepointe: lediagnostique judiciaire des faits justificatifs, RSC, 1969

${ }^{397} 21$ avril 1969, Trib. Corr. Aix-en-Provence, GP 1969.2.159: le propriétaire d'un cabanon avait installé deerriére un volet un canon avertisseur chargé de poudre ainsi qu'une inscription sur le volet prévenant de la présence d'un piége à feu, un étranger tentant d'ouvrir le volet reçu la décharge en plein cœur., V. 8 Octobre 1969, RSC, 1970, p 851

${ }^{398}$ Cour d'appel Troyes, chambre criminelle, affaire M. Legras, 20 Novembre 1982, France

${ }^{399} \mathrm{G}$. Denis: légitime defense et auto-défense, GP, T. 1, 1979, p 74 - 80 


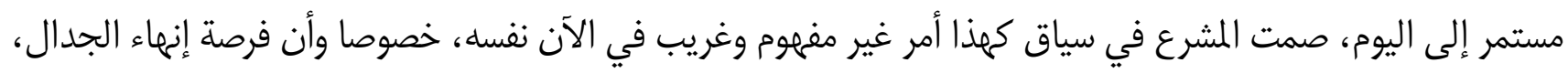

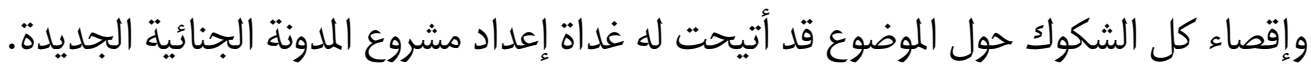

\section{خاتمة:}

وهكذا يتضح أن التدوين الحالي لمبدأ الدفاع الشرعي عن الأموال، لا ينص بشكل صريح على أسلوب الدفاع الآلي

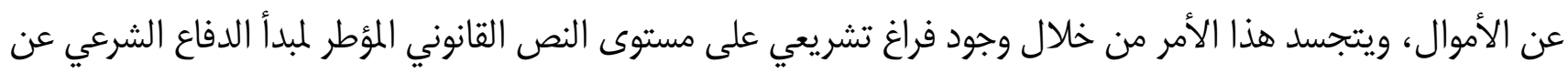

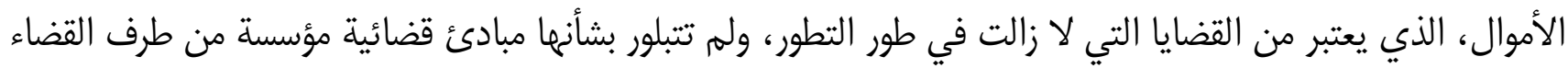

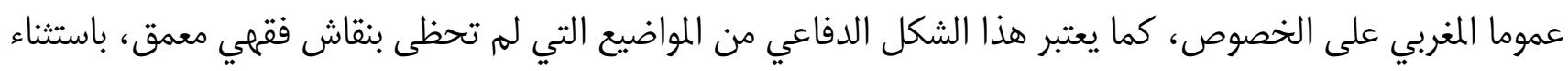

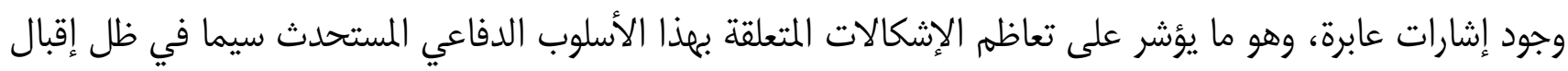

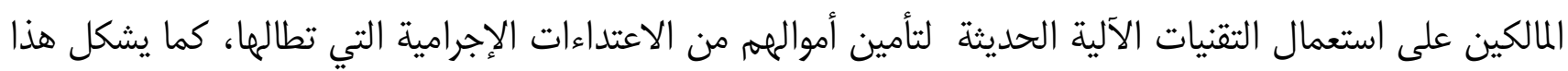

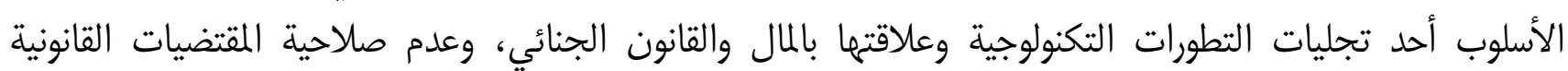

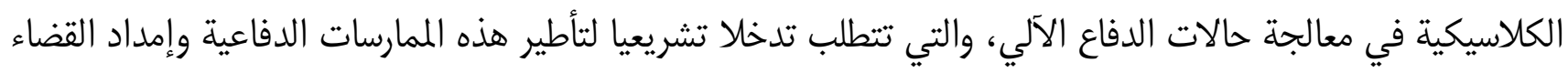

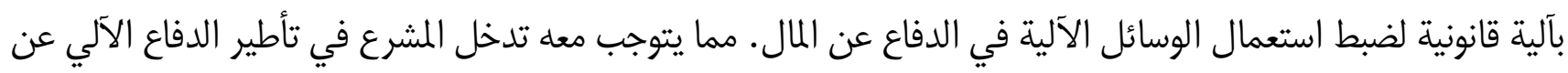

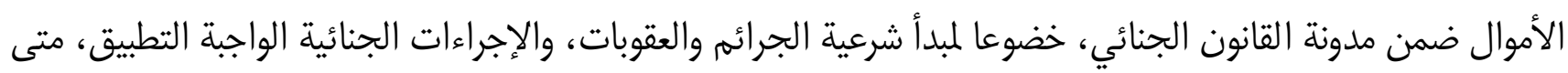

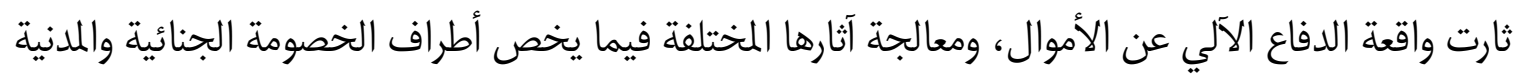




\section{العمل لأجل المنفعة العامة كعقعبة بديلة في ضعء مشنروع القانون الجنائي}

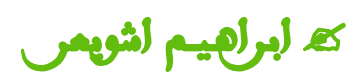

دكتوراه في القانون الخاص

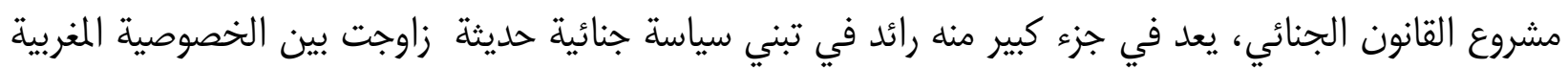

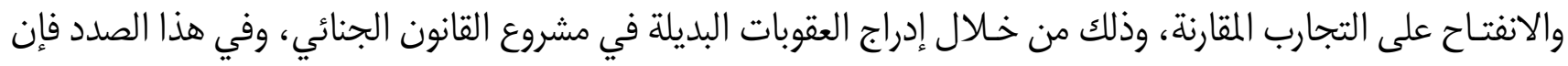

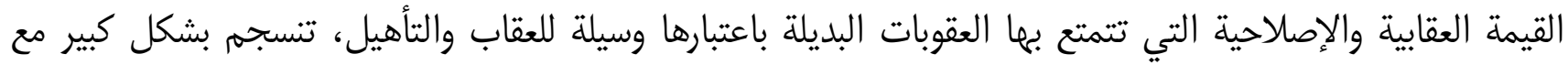

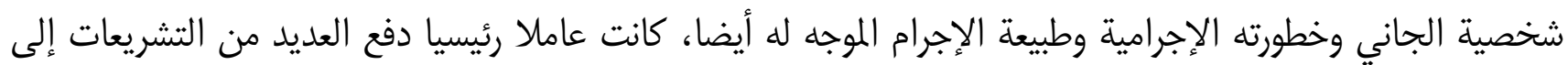

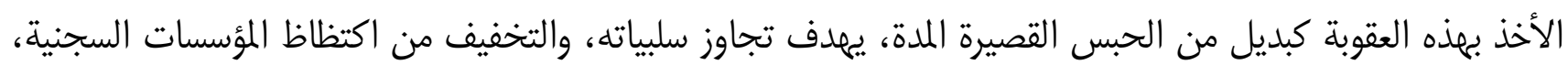

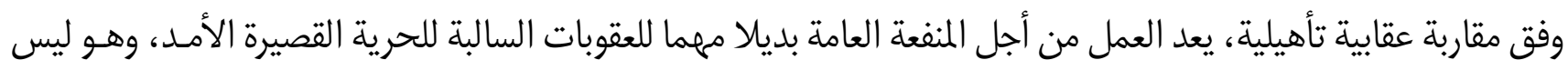

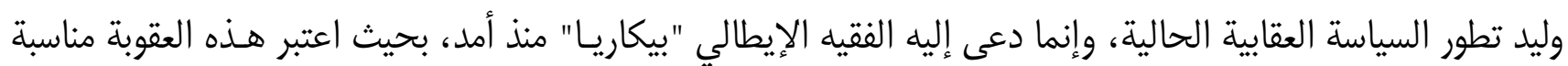

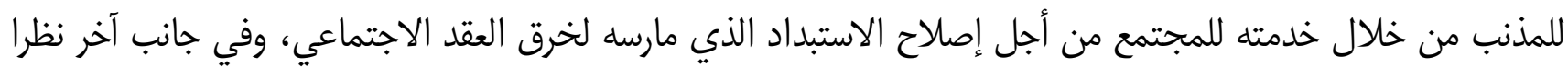

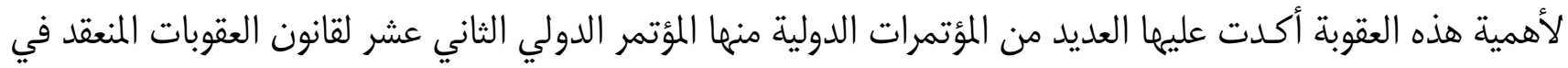

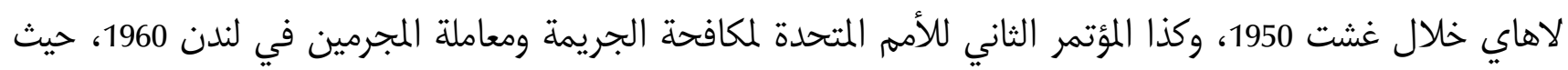

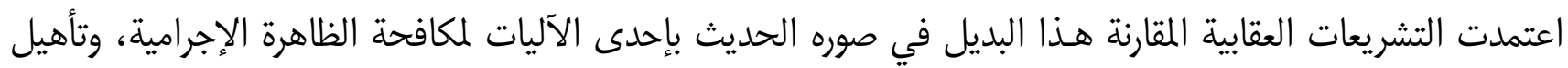

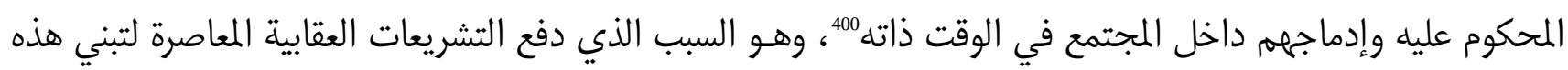

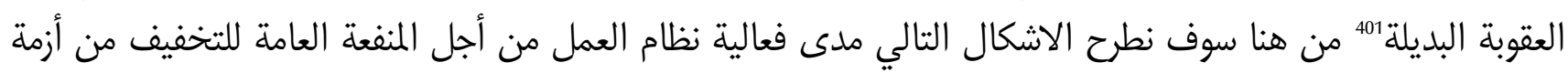

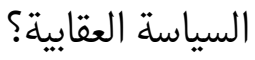

\section{المبدث الأول: القيمة العقابية للعمل من أجل المنفعة العامة}

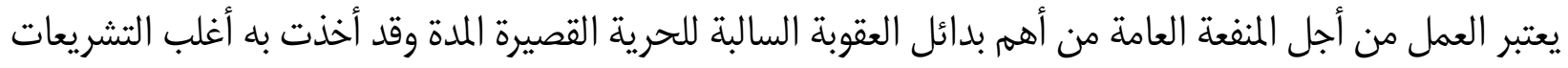

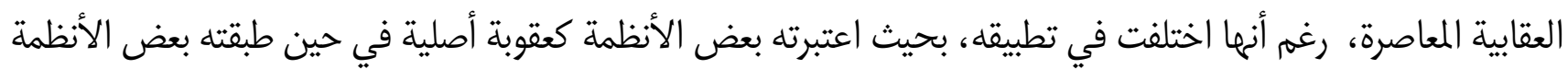
بوصفه عقوبة بديلة للعقوبة السالبة للحرية القصيرة المدة.

400 عبد الجليل عينوسي : تشغيل السجناء في المغرب بين القانون والواقع، دار أبي رقراق للطباعة والنشر، الرباط، الطبعة الأولى 2012.

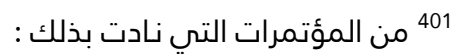
- مؤتمر الأمم المتحدة الخاصة للوقاية من الجريمة ومعاملة المجرمين المنعقد في جنيف سنة 1975 والذي كان من توصياته، اعتماد تدابير بديلة

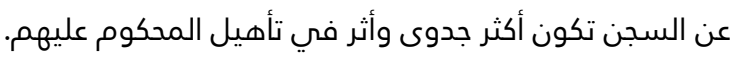
- مؤتمر الأمم المتحدة الثاني عشر لمنع الجريمة والعدالة الجنائية الذي انعقد في البرازيل سنة 2010، وقد تم تخصيص حلقة من حلقاته لمناقشة إشكالية اكتظاظ السجون وكان من توصياته توجيه دعوة إلى الدول بتحديث أنظمتها الوطنية واتخاذ إجراءات العمل ببدائل الاعتقال 


\section{المطلب الأول: ماهية عقوبة العمل من أجل المنفعة العامة}

يعد العمل للمصلحة العامة أو للمنفعة العامة أو العمل لخدمة المجتمع أحلد بدائل الحمبس الحمل القصير المدة، وهـو في الوقت ذاته أحسد أساليب المعاملة العقابية التي تطبق على الجناة خارج المؤسسة العقابية.

فقد ذهب البعض إلى تعريف هـذا النظام بأنه : " إلزام الشخص المحكوم عليه أو المسلوبة حريته بالقيام بأعمال معينة لخدمة المجتمع بدون مقابل خلال المدة التي تقررها المحكمة أو النيابة العامة، وذلك في الحدود المنصوص عليها قانونا "402. كما عرف هـذا النظام بأنه : " إلزام المحكوم عليه بالشغل مجانا خدمة للصالح العام في إحـدى المؤسسات العامة أو الجمعيات عـددا من الساعات خلال مدة معينة تحدد في الحكمم "403. كذلك فقد عرفه البعض بأنه : " تكليف المحكوم عليه بالقيام بأعمال معينة لخدمة المجتمع بدون مقابل خلال المدة التي ستقر رها المحكمة، وذلك في حدود المنصوص عليها قانونيا " ويلاحظ أنه وإن كانت هذه التعاريف تختلف في ألفاظها إلا أنها متفقة في دلالتها فهي تدور حول تكليف المحكوم عليه بعمل يعود بالنفع على المجتمع في أوقات معينة، وفقا للضوابط المبينة قانونا. ويعد عقوبة زجرية، تهدف إلى تعويض العقوبة البدنية، وتتجلى في قيام المحكوم عليه - بموافقة - بالقيام بعمل غير

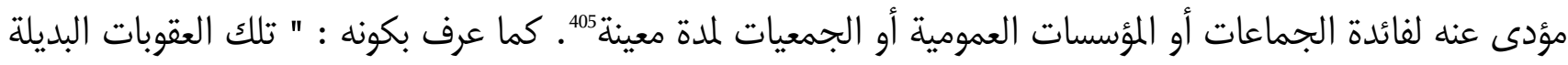
التي تقوم على إلزام الجاني بالقيام بالعمل في إحدى المؤسسات الحكومية بعدد معين من الساعات، خلال فترة العقوبة سواء بصفة يومية أو لعدد معين من الأيام خلال أشهر يحددها الحكم الصادر، والذي يحدي يحدد كذلك المؤسسة التي سيقوم المحكوم عليه بتنفيذ الحكم بها، وكذلك نمط العمل الذي سيقوم به وعدد ساعاته والفترة التي يجب عليه إتمام تنفيذ تلك الساعات ويجب أن يحدد القاضي نوع العمل الذي سيلزم به المحكوم عليه بأدائه في ضوء دراسته لخبرات الجاني وممارته الفنية وقدراته البدنية والصحية والنفسية ومؤهلاته العلمية التي يبينها ملف دراسة الحالة.406.

مع العلم أن العمل لأجل المنفعة العامة يتم برضاء المحكوم عليه، علاوة على أنه يختلف في مسألة الأجر، فبعض التشريعات تجعل العمل غير مؤدى عنه، وبعضما جعله بمقابل مبلغ قليل. ولعل هـذا التباين في هذه الناحية راجع إلى اختلاف التشريعات.

$$
\text { ويتجلى هـذا العمل عـادة فيما يلي : أمشاركة في أعمال يدوية أو مهنية. }
$$

- المشاركة في حملات نظافة البيئة بالتشجير والتنظيف من الأعشاب الضارة.

${ }^{402}$ P. Coouvart : Les traisvisayes du travail d'mterel généra rev.sc.Crim, 1989, P : 159.

403 محمد أبو العلا عقيدة : أحوال علم العقاب، دراسة تحليلية وتأصيلية للنظام العقابي المعاصر مقارنا بالنظام العقابي الإسلامس، دار الفكر العربي، الطبعة الخامسة، سنة 1995، ص : 439. 404 شريف سيد كامل : علم العقاب، دار النهضة العربية، القاهرة، الطبعة الأولى 1995، ص ص : 348.

405 بوجمعة الزناكي : بدائل العقوبات السالبة للحرية الشغل من أجل المنفعة العامة، مجلة الإشعاع، العدد 24، دجنبر 2011، ص ص : 92 - 93. 406 عبد الرؤوف حنان : العمل العام كبديل عن عقوبة الحبس، مذكرة مكملة من مقتضيات نيل شهادة الماستر في الحقوق، تخصص القانون الجنائي، جامعة محمد خيضر، بسكرة، كلية الحقوق والعلوم السياسية، السنة الجامعية : 2013 - 2014. ص : 41. 
- القيام بأعمال وأنشطة ثقافية لمصلحة الجماعة أو المؤسسة العمومية...

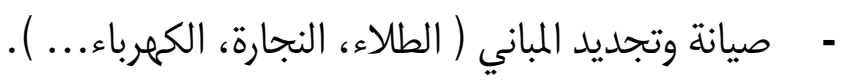

والجدير بالذكر أن جل التشريعات خصصت هذه العقوبة للجنح التي لا تكتسي خطورة كبيرة، فهناك تشريعات استبعدت جرائم العنف الخطير وجرائم العرض وهناك من التشريعات التي استبعدت الجرائم المقترنة بحالات العود ( المغرب من خلال مسودة مشروع القانون الجنائي ).

إن التعريفات التي أعطيت للعمل لفائدة النفع العام بصفته بديلا عن العقوبات الحبسية القصيرة المدة متعددة ومتتوعـة، وعليه يمكن اختيار التعريف التالي للعمل لفـائدة النفع العام : " العمل للنفع العام هو عبارة عن عقوبة صادرة من جهة قضائية مختصة، تكمن في إلزام المحكوم عليه القيام بعمل 407 بدون أجر بعد موافقته لفائدة المجتمع لـدى مؤسسة عمومية بدلا من إدخاله لمؤسسة عقابية لقضاء عقوبة سالبة للحرية قصيرة المدة وذلك بعد تحقق شروط حـددهـا القانون " وتبدو أهمية نظام العمل لخدمة المجتمع في كونه وسيلة إضافية من وسائل الكفاح ضد مساوئ العقوبات السالبة للحرية القصيرة المدة وتتضح أهمية هـذا الدور على وجع التحديد بالنسبة للمجرمين الذين لا يمثلون خطورة إجرامية كبيرة على المجتمع، ويتبين للمحكمة أنه ليس من الملائم الحكم عليهم بعقوبة الحبس لتجنبهم الأضرار المترتبة على الاختلاط لئه

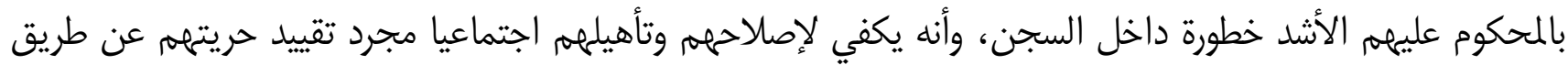

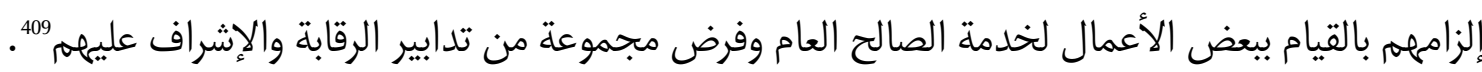
ومن ناحية أخرى، فإن العمل لخدمة المجتمع من شأنه أن ينمي قيمة العمل لدى المحكوم عليه ويعوده على ترك الكسل، وبذلك قد يكون العمل لخدمة المصلحة العامة سببـا للقضاء على عامل من العوامل المؤدية إلى ارتكاب المحكوم عليه للجريمة، وليكون هذا العمل لخدمة المجتمع فإن هذا بلا شك سيدرب المحكوم عليه على احترام القيم الاجتماعية والقوانين السائدة داخل المجتمع، الأمر الذي يساهم بشكل فعال في إصلاح المحكوم عليه وتأهيله اجتماعيا. ومن ناحية أخرى، يساهم نظام العمل لخدمة المجتمع في حل مشكلة اكتظاظ السجون، ويقلل من التكاليف الباهظة التي تنفقها الدولة على السجون وبرامج الإصلاح والتأهيل التي تطبق على المسجونين.

407 إن اختيار نوع العمل لا يتطلب موافقة المعني، بل يوكل أمر ذلك إلى القاضي، وخاصة فاضي تنفيذ العقوبات أو من يقوم مقامه حيث يتوفر على مساعدين اجتماعيين يطلعونه على نوعية الأعمال المتوفرة داخل الجماعة، وكما يقدمون له أبحاثا تتعلق بشخصية الظنيين لمعرفة مدى كفاءته البدنية ومؤهلاته وقدرته على العمل وانضباطه ومعتقداته الدينية. 408 يدخل ضمن الأعمال على سبيل المثال، الأعمال اليدوية والتي يمكن تنفيذها في إطار العمل للمنفعة العامة كحماية البيئة وهذا بالاشتراك في حملات النظافة، أعمال التشجير، صيانة وتجديد المباني العمومية، تصليح الأثاث المدرسي، العمل في المطاعم المدرسية. أنظر : - صفاء أوتاني : العمل للمنفعة العامة في السياسة العقابية المعاصر - دراسة مقارنة، مجلة دمشق للعلوم الاقتصادية والقانونية، المجلد 25، العدد الثاني - - 2009، ص: ص: 431. - محفوظ علي علي : البدائل العقابية للحبس وإعادة إصلاح المحكوم عليه، الطبعة الأولى، مكتبة الوفاء القانونية، الإسكندرية، 2016، ص : 
ومع ذلك فقد ذهب البعض إلى أن نظام العمل لمصلحة المجتمع يصادف عدة صعوبات : أولها، تتمثل في مدى تقبل

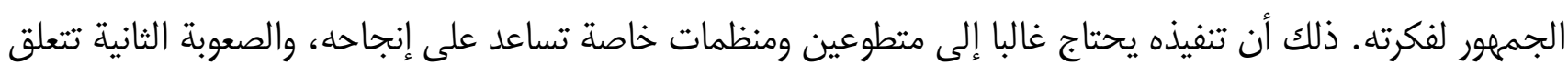

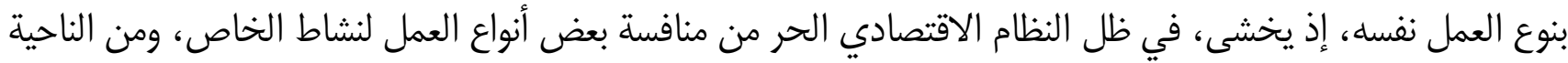

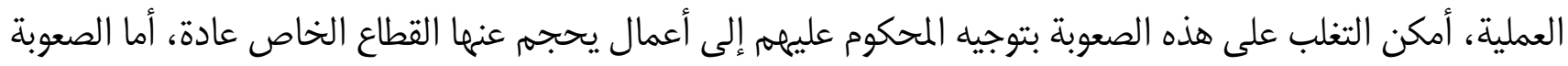

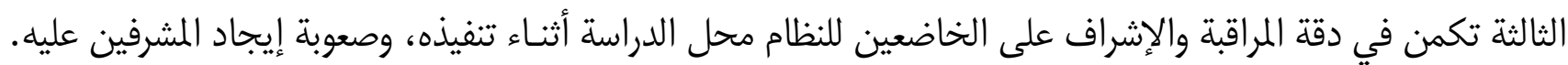

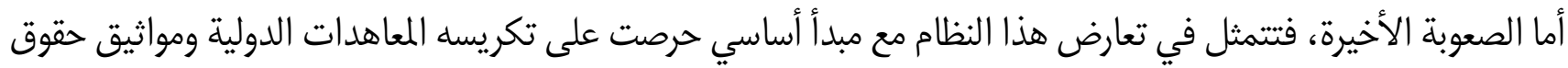

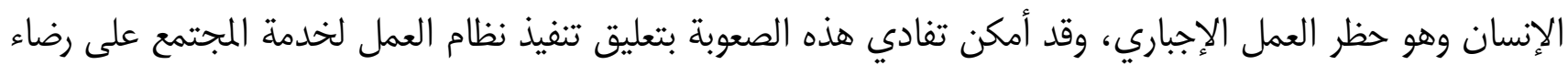

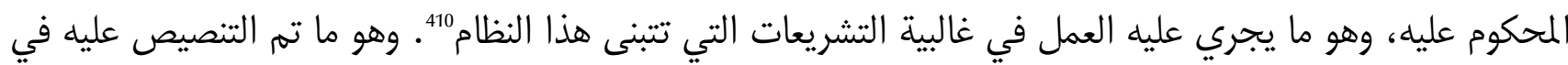
مسودة مشروع قانون المسطرة الجنائية (المواد 2647-2 / 647-2 / 2 / 647-7 ).

\section{الفقرة الثانية: خصائص عقوبة العمل من أجل المنفعة العامة}

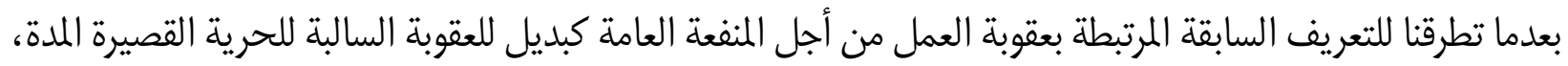
نجدهـا تتميز بعض الخصائص تشترك بها مع باقي العقوبات في حين تتفرد بخصائص تمييزها عن باقي العقوبات الأخرى.

\section{أولا- الخصائص العامة لعقوبة العمل من أجل المنفعة العامة}

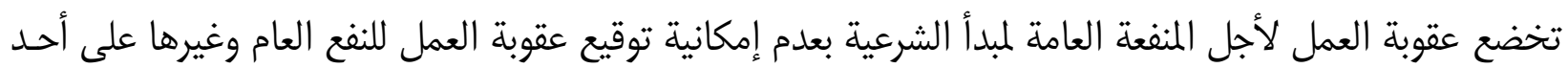

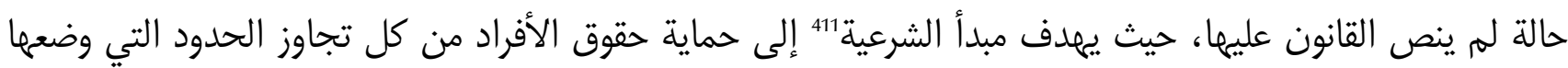

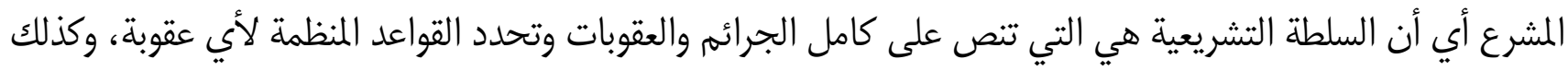

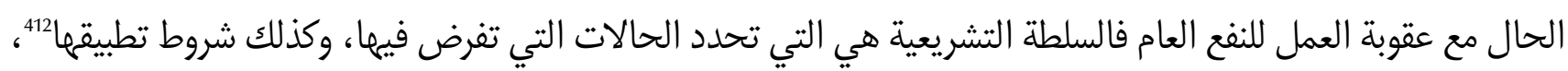

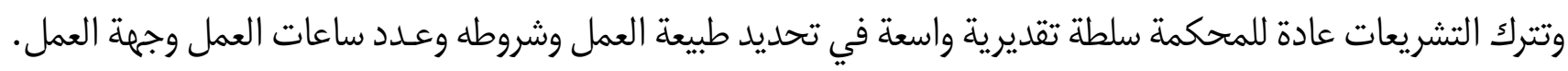

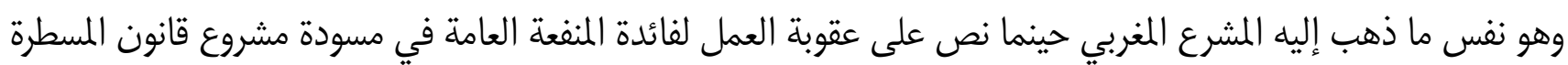

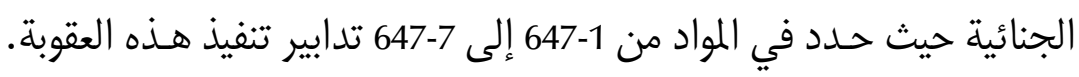

أما الخاصية الموالية فترتبط بضرورة صدور حكم قضائي لعقوبة العمل من أجل المنفعة العامة ذلك أن الجزاء الجنائي

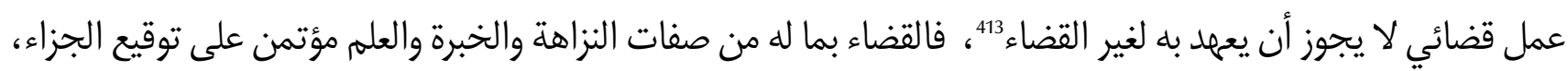

410 أحمد عوض بلال : علم العقاب، النظرية العامة والتطبيقات، دار الثقافة العربية، الطبعة الأولى 1983 - 1984، ص : 455 - 456. رامي متولي القاضي : المراقبة الإلكترونية في القانون الفرنسي والمقارن، مجلة الشريعة والقانون، كلية الحقوق، جامعة الإمارات العربية

المتحدة، العدد 63، يوليو 2015، ص : 40.

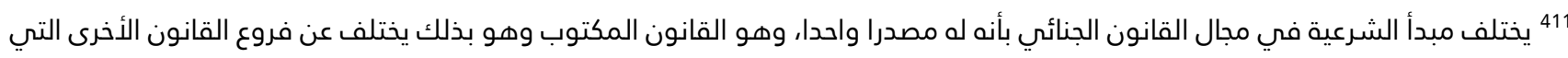
تضيف إلى نص القانون، مصادر أخرى كالعرف والشريعة الإسلامية. وللتوسع أكثر في مبدأ الشرعية راجع : ـ أحمد الرزاقي : محاضرات في القانون الجنائي، القسم العام، الطبعة الأولى، دار الفسيفساء للطباعة والنشر، طرابلس 2013، ص : 29 - 44.

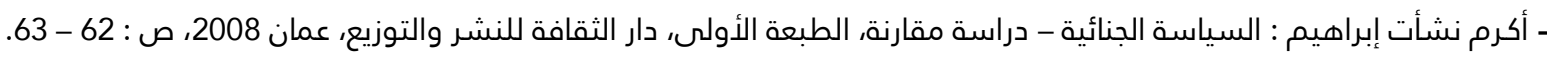

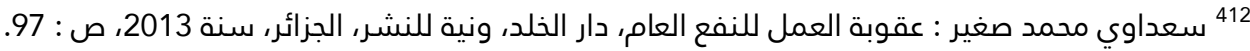
413 يعد العمل القضائي بمثابة ضمانة هامة للحريات العامة نص عليها الدستور في الفصل 112، يتولى القدائه القاضي حماية حقوق الأشخاص والجماعات... " n n n 


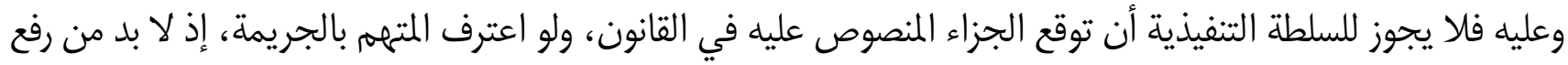

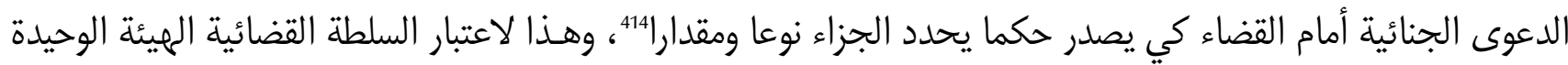

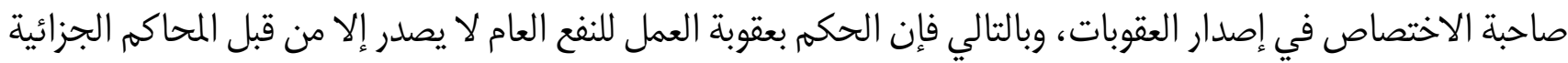

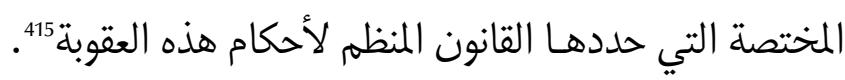

ما يميز عقوبة العمل للنفع العام، هو أن سلطة القاضي الجنائي في النطق بهذه العقوبة مقيدة بقيد لا يتوافر في العقوبة

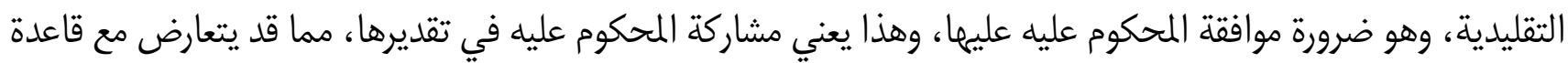

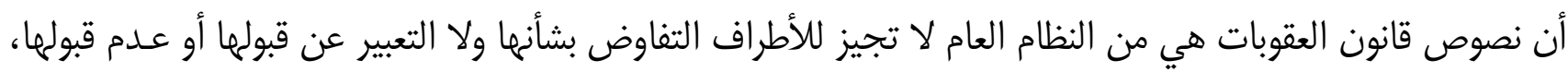

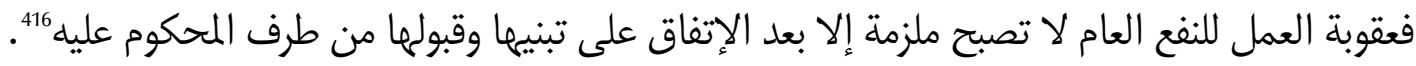

بالإضافة للمبادئ السابقة فإن عقوبة العمل من أجل المنفعة العامة تخضع لمبدأ الشخصية والمساواة ويقصد بشخصية

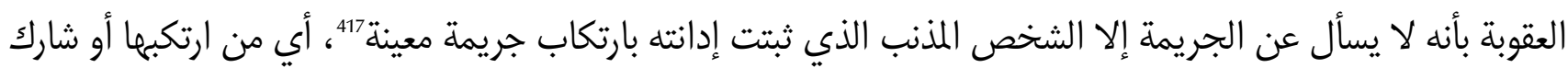

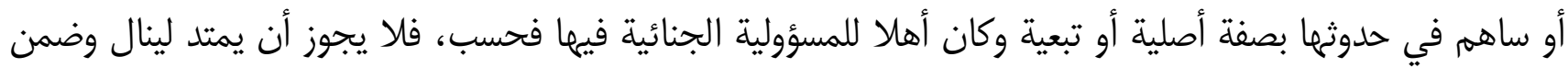

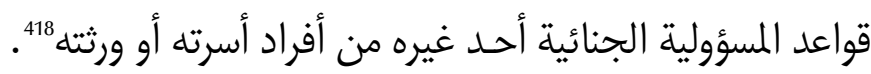

أما المساواة في العقوبة تتجلى في مخاطبة القاعدة الجنائية الناس كافة وتأمرهم بضرورة احترام السلوك الاجتماعي،

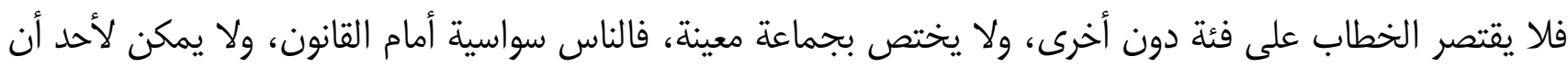

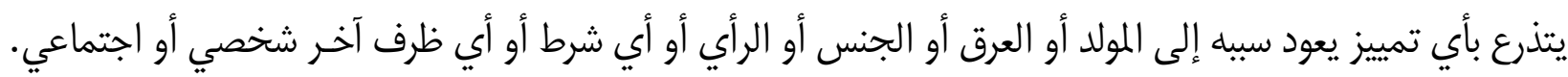
وعليه بمقتضى هذا المبدأ يفرض هذا النظام دون أي تمييز بين الأفراد ممن تنطبق علييهم شروط فرضه، وهو مبدأ لا يتعارض مع ما يترك المشرع للمحكمة من سلطة تقديرية في تحديد طبيعة العمل المفروض على المحكوم عليه نظرا لمؤهلاته،

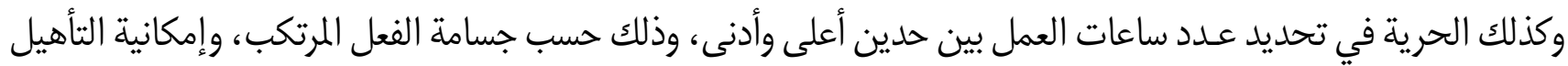

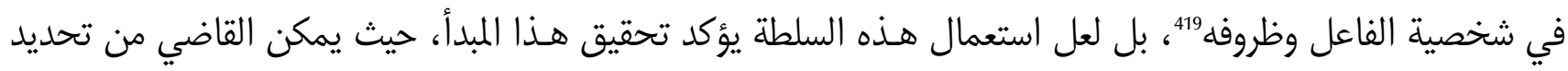

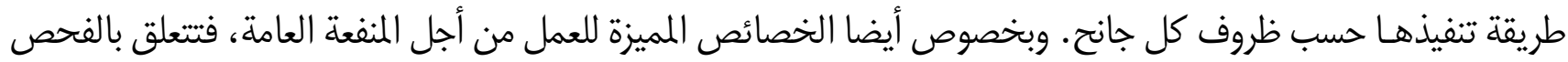

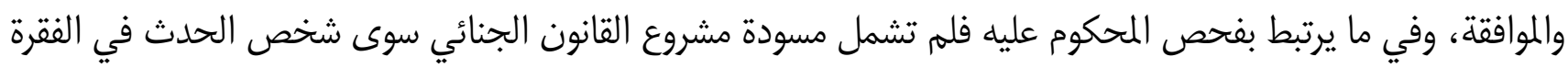

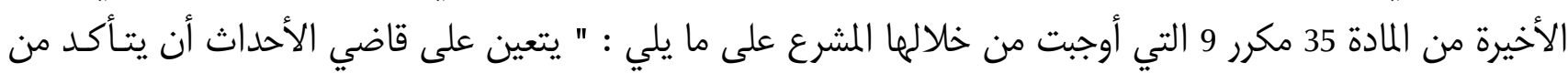

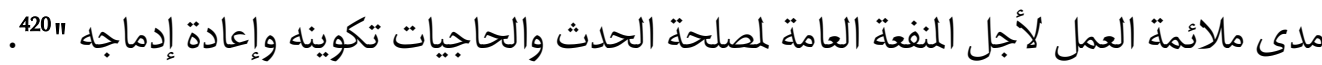

414 عبد الله سليمان : شرح قانون العقوبات، القسم العام، الجزء الأول، الطبعة الأولى 2005، ص : 407 - 408. 415 عثمانية لخميسي : عولمة التجريم والعقاب، الطبعة الثانية، دار هومة، الجزائر، 2008، ص : 161. 416 - طباش عز الدين : عقوبة العمل للنفع العام بين تارة الردع والإصلاح، الطبعة الأولى، المؤسسة الحديثة للعقاب، لبنان 2015.

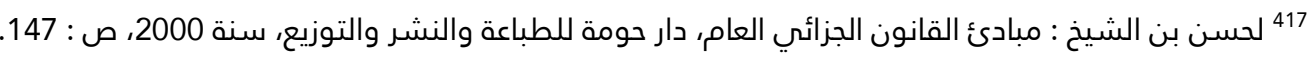

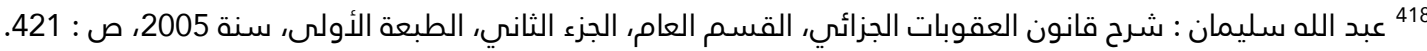
419 صفاء أوتاني : العمل للمنفعة العامة في السياسة العقابية المعاصر - دراسة مقارنة، مرجع سابق، ص ص : 437. 420 محمد العروصي : العمل لأجل المنفعة العامة وفقا لمسودة مشروع القانون الجنائي، مجلة العلوم الجنائية، العدد الثاني 2015، ص ص : 115. 
و ما تجب الإشارة إليه في هـذا الصدد أن المشرع المغربي نص في مشروع قانون المسطرة الجنائية في المادة (

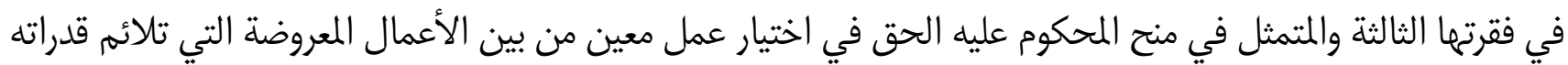

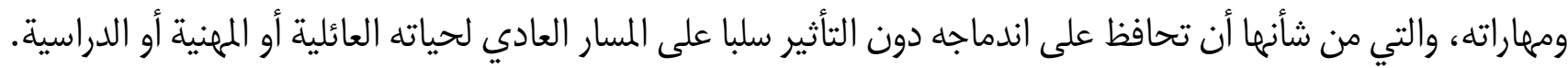

\section{ثانيا- الذصائص التي تنفرد بها عقوبة العمل من أجل المنفعة العامة}

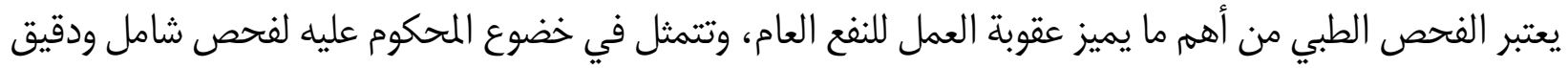
يسبق قيامه بأداء العمل المسند إليه، حيث توضح المادة (

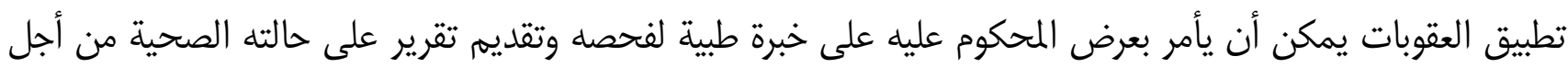

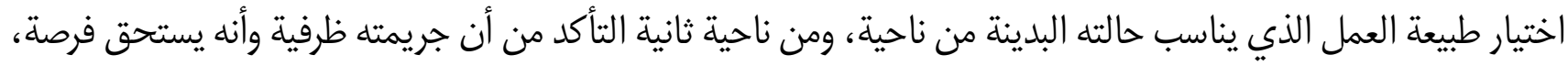

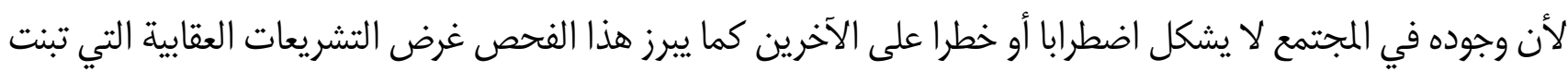

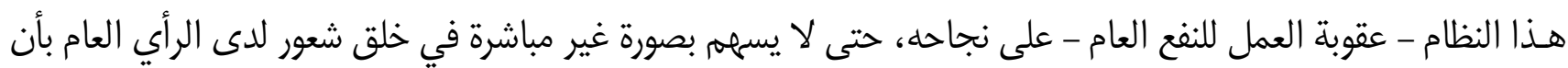

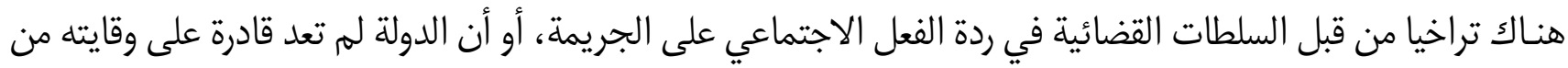

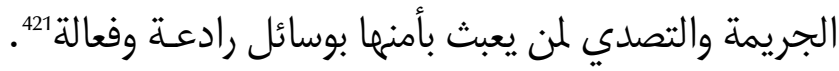

بالإضافة لتطبيق هذا البديل يتطلب المشرع ضرورة موافقة المحكوم عليه بالخضوع للعمل من أجل المنفعة العامة بعض

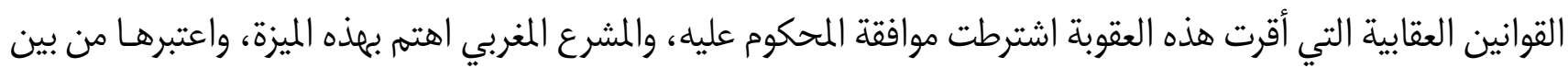
الشروط الأساسية لتطبيق العقوبة، حيث خصت هذه العقوبة بانفرادها بكونها لا نفذ إلا إذا أبدى المحكوم عليه موافقته الميته

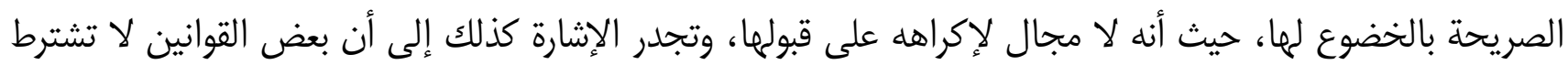

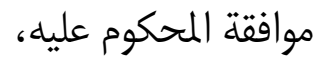

فقد اعتبرتها عقوبة أصلية وأعطت القضاء الحرية في الحكم بما منفردة أو مع عقوبة أخرى. إلا أن فكرة الرضا والاختيار

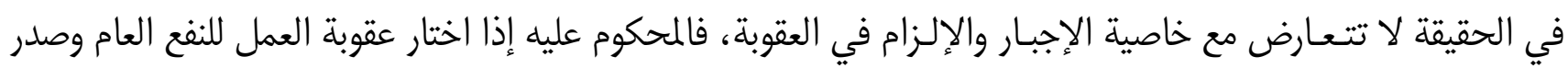

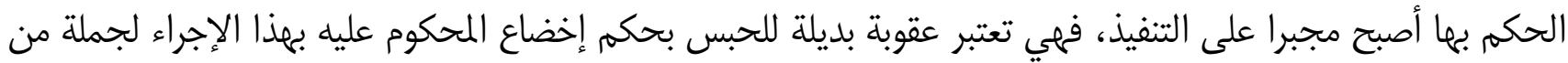

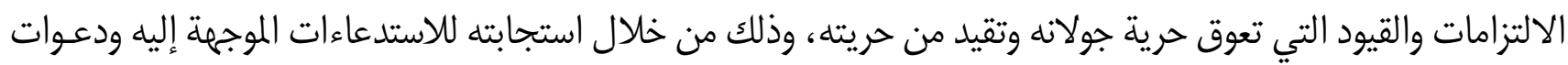

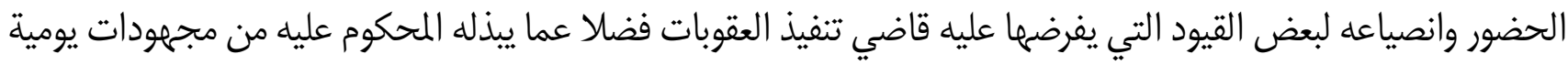

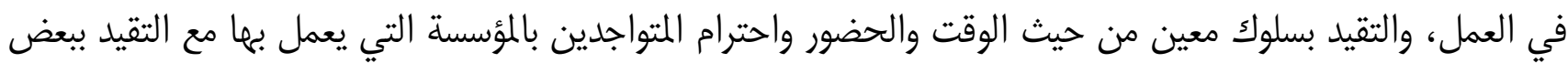
الضوابط حتى لا يستبدل عقوبة العمل بالحبس.

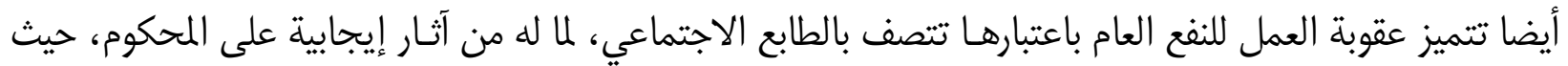

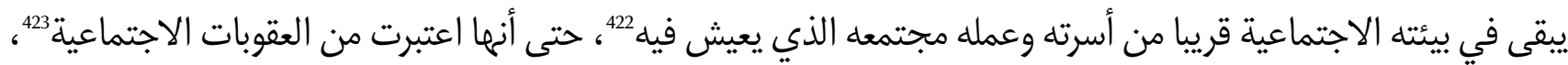

421 مصطفى العوجي : التأهيل الاجتماعي في المؤسسات العقابية، مؤسسة بحسون، بيروت، سنة 1993، ص : 190. 422 عائشة حسين على المنصوري : بدائل العقوبات السالبة للحرية قصيرة الأمد، دار النهضة العربية، القاهرة، 2016، صؤس : 13 423 بركاني أعمر : نحو ضرورة تعميم بدل عقوبة الحبس قصيرة الأمد، الطبعة الأولى، المؤسسة الحديثة للكتاب، لبنان، 2015، ص : 936. 
لأنه من خلال مجانية العمل الذي يقوم به المحكوم عليه تتتفع المؤسسة العمومية التي يتم تنفيذ العمل فيها، ويظهر تحقيق

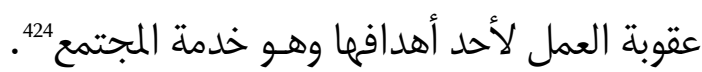

وباعتبار أن العمل المقدم من طرف المحكوم عليه مجاني، فهو بدون شك يحقق المصلحة العامة، وعليه فإن جوهر

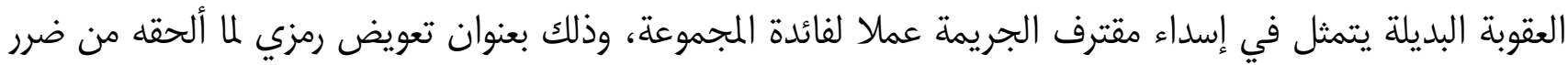
بالمجتمع.

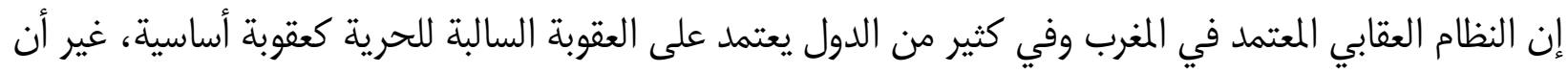

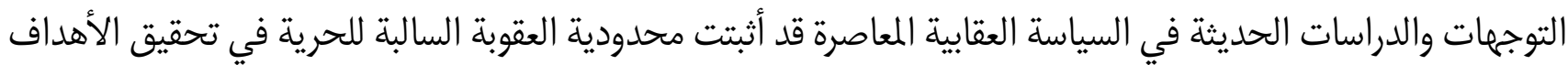

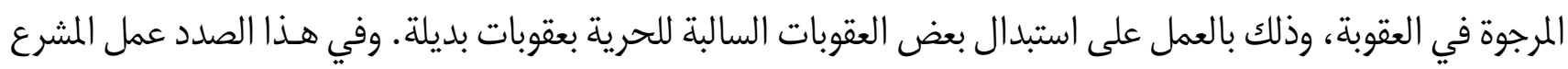
المغربي في إطار مسودة القانون الجنائي والمسطرة الجنائية بتضمين عقوبة العمل من أجلئ الجل المنفعة العامة.

\section{المبحث الثاني : العمل لأجل المنفعة العامة من خلال مسودة مشروع القانون الجنائي}

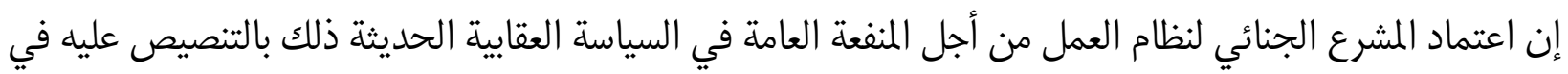

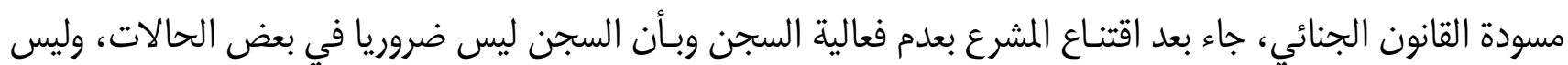

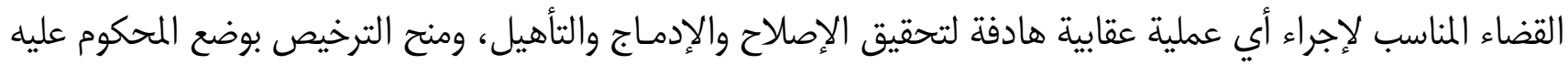

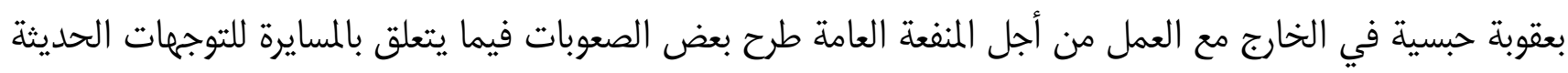
للسياسة العقابية من جهة، وفلسفة حقوق الإنسان من جهة ثانية.

\section{المطلب الأول : بديل عقوبة العمل من أجل المنفعة العامة في ضوء مشروع القانون الجنائي}

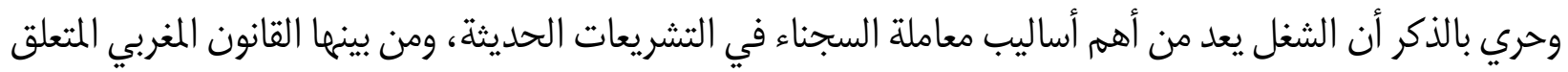

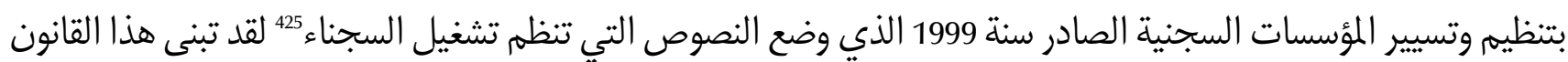

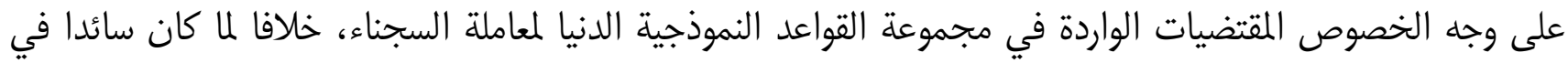

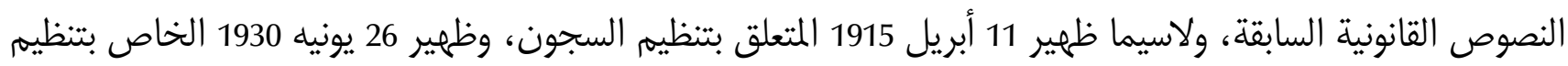

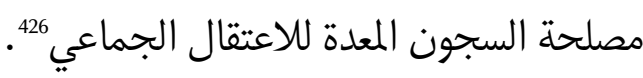

ولقد خصت مناظرة إفران لتدارس موضوع العقوبات البديلة عدة توصيات تحث على ضرورة اعتماد عمل من أجل

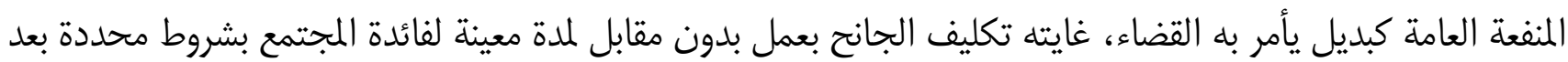
موافقة المعني

424 رضا خماخم : العدالة الجزائية في تونس، منشورات مركز الدراسات القانونية والقضائية، وزارة العدل، تونس، دون سنة نشر، ص : 200. "425 خصص المشرع المغربي الفرع الثالث من الباب الثالث من القانون المتعلق بتنظيم وتسيير المؤسسات السجنية لما سماه " عمل السجناء

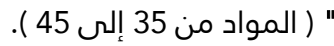
426 عبد الجليل العينوسي : تشغيل السجناء في المغرب بين القانون والواقع، دار أبي رقراق للطباعة والنشر، الطبعة الأولى 2012، ص : 29. 427 بوجمعة الزناكي : بدائل العقوبات السالبة للحرية الشغل من أجل المنفعة العامة، مرجع سابق، ص : 95. 


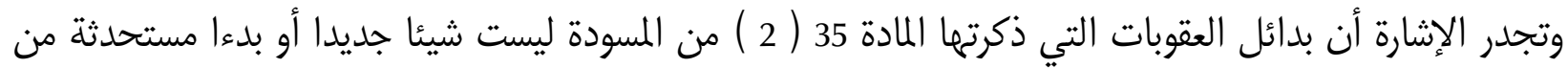

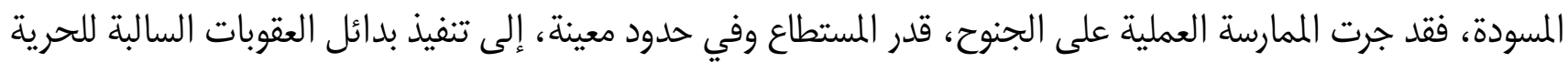

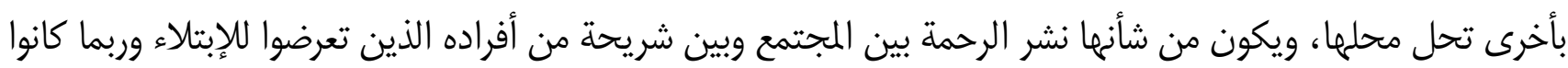

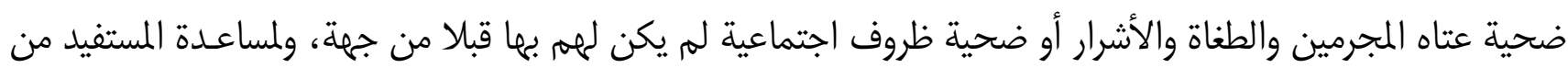

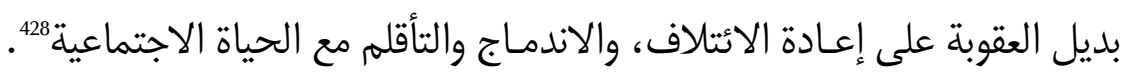

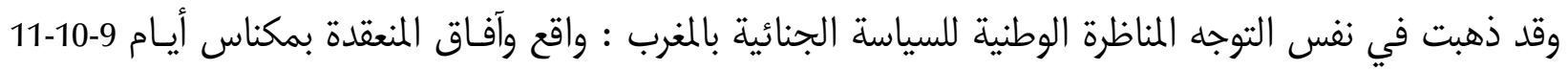
ديسمبر 2004 حيث أكدت على أهمية إيجاد عدالة جنائية بديلة تكون عقوبة الشغل من أجل المنافية المنفعة العامة أبرز ملامحهبا. ونظرا للأهمية القصوى لمزا البديل في السياسة العقابية الذي من خلاله يته إشراك الجاني في اختيار العقوبة المناسبة

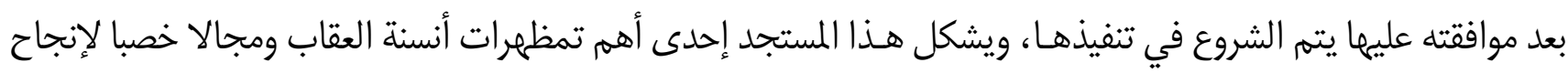

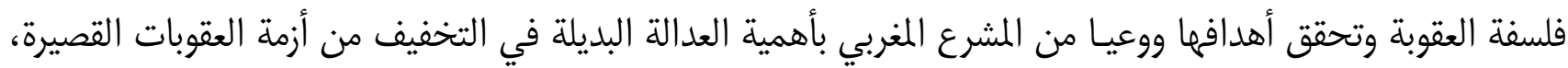

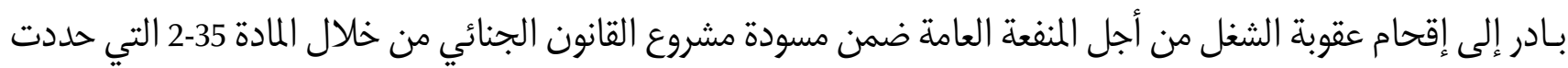
العمل من أجل المنفعة العامة من ضمن العقوبة العنات البديلة، وقد نظمت أحكام المقام العمل لأجل المنفعة العامة بالمواد (

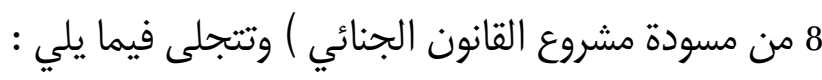
- - ضرورة وجود جريمة معاقب عليها بالحبس لمدة لا تتجاوز سنتين. - أن يكون المحكوم عليه بالغا من العمر 15 سنة على الأقل وقت ارتكاب الجريمة. - موافقة المحكوم عليه على القيام بالخدمة من أجل المنفعة العامة، وإشعاره بأنه في حالة عدم تنفيذه للالتزامات المفروضة عليه، فإنه سيتم تنفيذ العقوبة الأصلية المحكوم بها عليه المل ( المادة 35-4 ) .

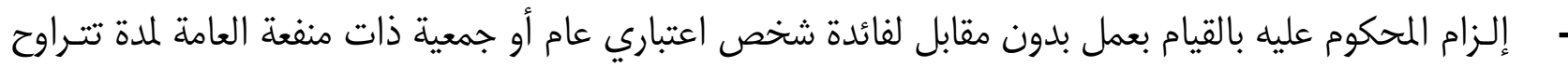

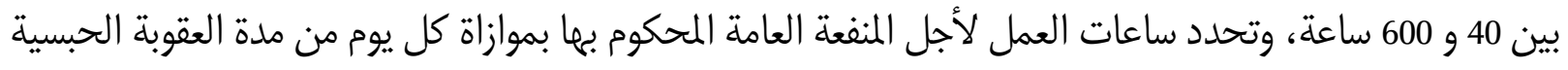

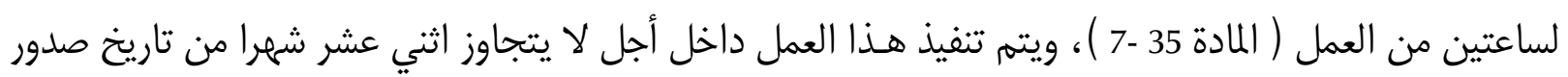

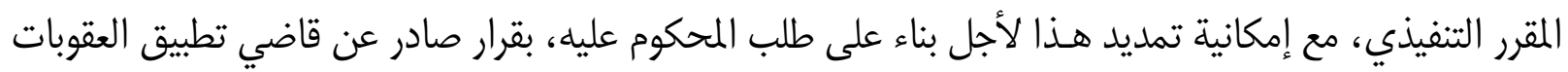
( المادة 7-35 ) من مشروع القانون الجنائي.

من خلال تفويض المشرع لقاضي تطبيق العقوبات صلاحية تتبع التنفيذ، وفي حالة خرق الالتزامات، ينفذ المحكوم عليه العقوبة الأصلية المحكوم بها بقرار صادر عن هذا لفألفي الأخير. وغني عن البيان أنه إذا تعلق الأمر بحدث فإن قاضي الأحداث هـ الذي يتولى هـذه المهام ( الفقرة الأخيرة من المادة 5-35 و 8-35 ) مراعيا في ذلك مصلحة الحدث وحاجيات تكوينه وإعادة إدمـاجه.

428 أحمد زوكاغي : ملاحظات حول الأحكام العامة في مسودة مشروع القانون الجنائي، مجلة العلوم الجنائية، العدد الثاني، 2015، ص : 261. 


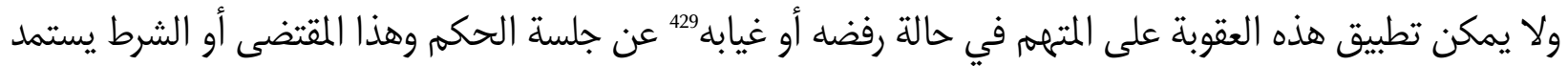

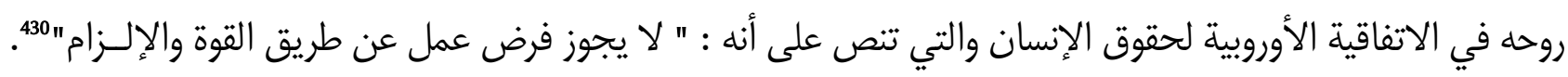

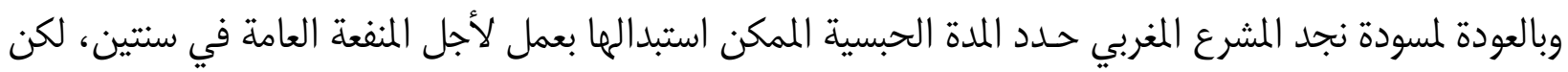

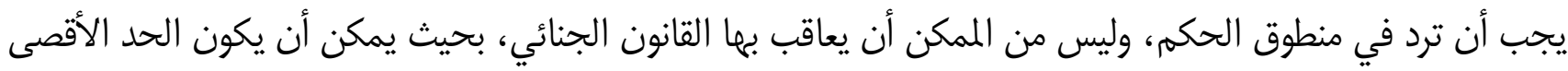

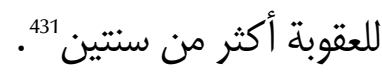

لكن الحد الأدنى يكون يساوي السنتين أو يقل عنها فيحكم بها، فيحق الحكم بالعمل للأجل المنفعة العامة في مثل

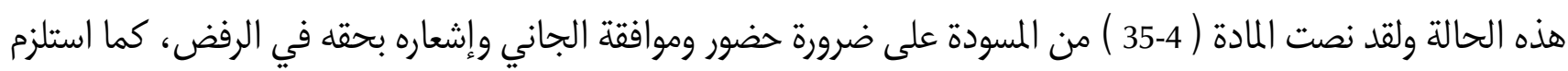

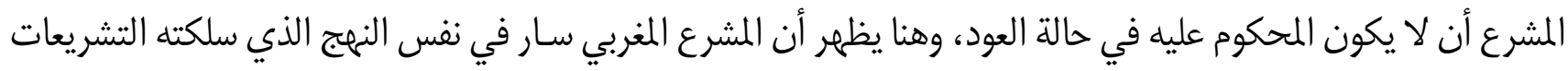

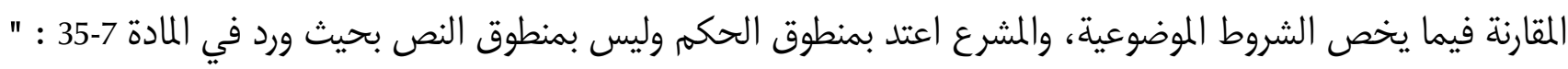

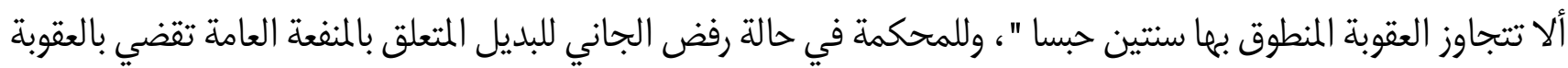

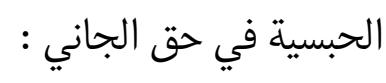

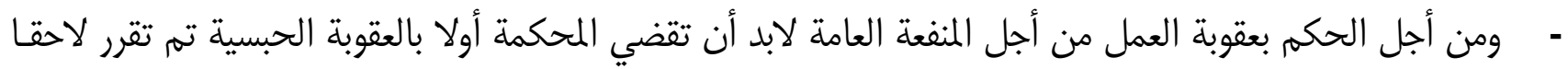

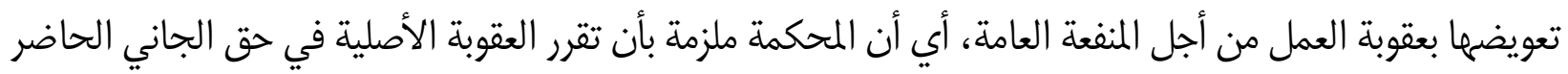

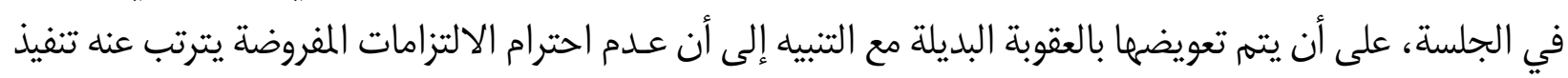
العقوبة الحبسية2432.

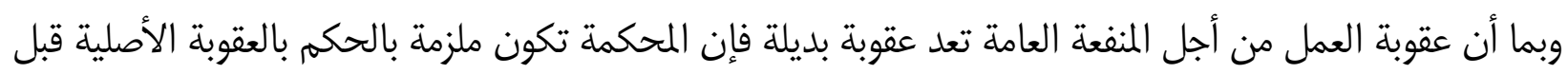
أن تقرر العقوبة البديلة وهو ما ذهب إليه المشرع حيث نص في المادة (

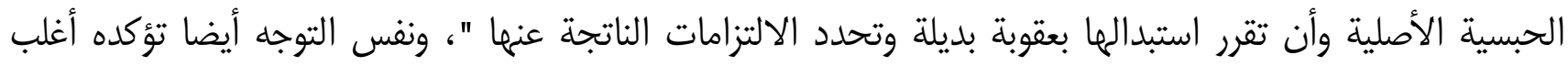

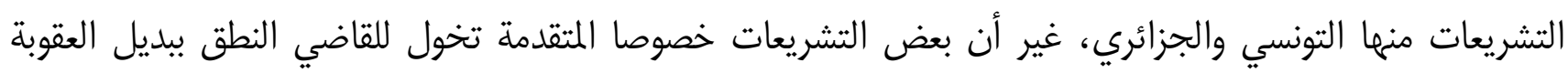
الحبسية بشكل مباشر

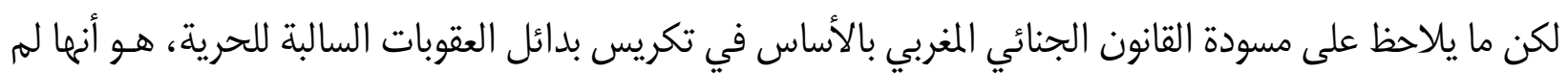

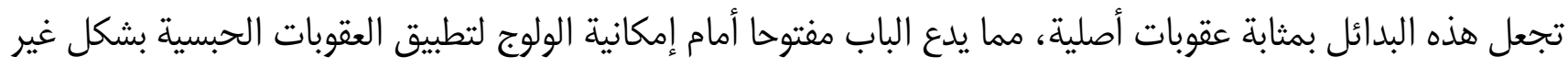

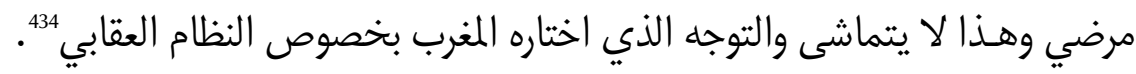

429 كما نصت الفقرة الأولى من الفصل 3-15 من المجلة الجزائية التونسية : " يشترط للتصريح بعقوبة العمل لفائدة المصلحة العامة أن يكون المتهم حاضرا بالجلسة ويعبر عن ندمه ولا يكون عائد ... ". 430 المادة الرابعة من الاتفاقية الأوروبية لحقوق الإنسان.

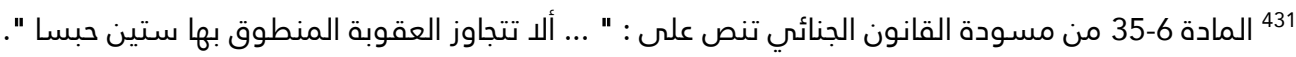

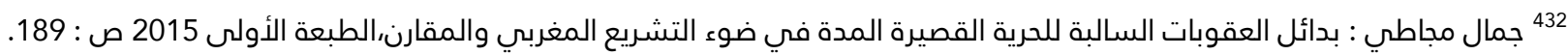

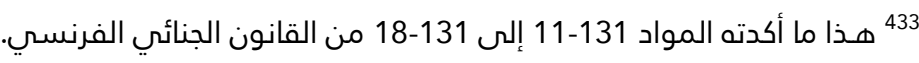
434 رضوان الصيكوكي : بدائل العقوبات السالبة للحرية قصيرة المدة في السياسة الجنائية المعاصرة، مرجع سابق، ص : 110. 
وبالرجوع أيضا لمقتضيات مشروع القانون الجنائي اشترط تحديد الغلاف الزمني لتنفيذ عقوبة العمل من أجل المنفعة

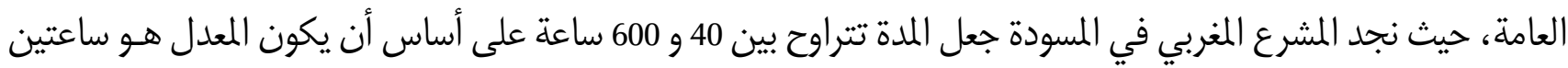
مقابل كل يوم حبسامدان.

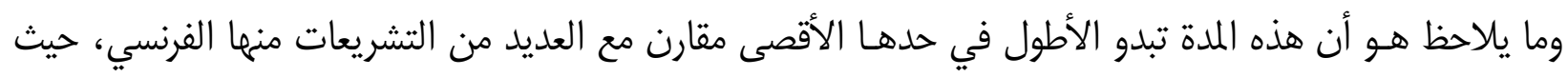

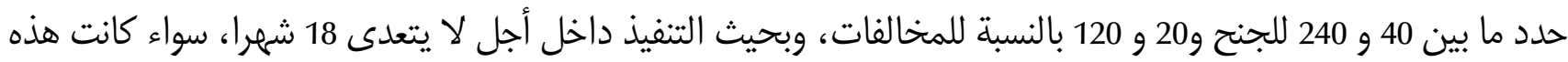

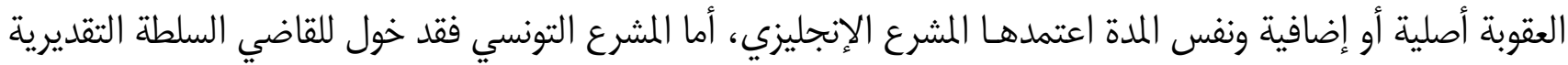

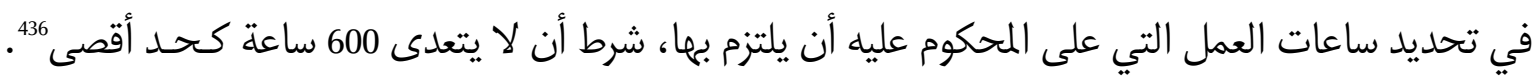
ولعـل المشرع المغربي رغم رفعه المدة لـ 600 ساعة فإن له نية ترك المجال بيد هيئة الحكم لتحديد المدة المناسب خصوصا

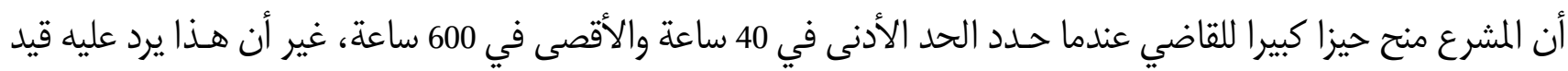

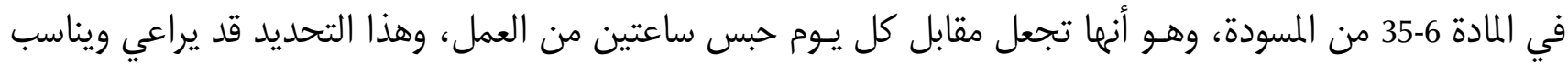

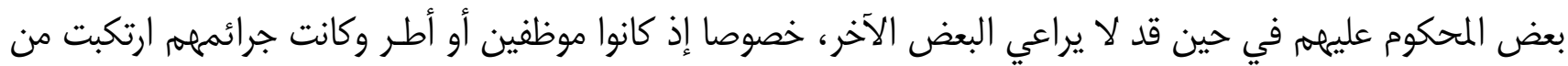
غير عمد.

ويمتاز العمل لفائدة المنفعة العامة بكونه يتهم في وسط مفتوح مما يسمح بسهولة إدماج المحكوم عليه في محيطه،

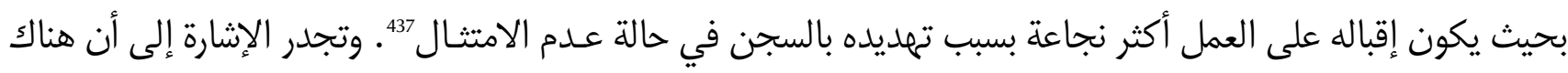

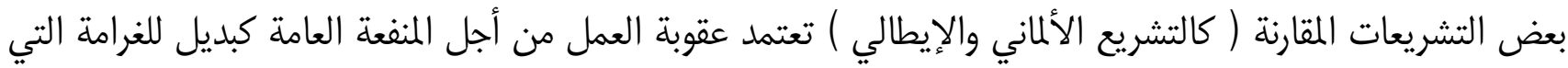

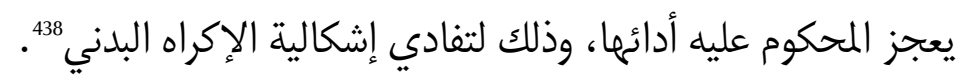

\section{المطلب الثاني: العمل لفائدة المنفعة العامة من خلال مشروع قانون المسطرة الجنائية}

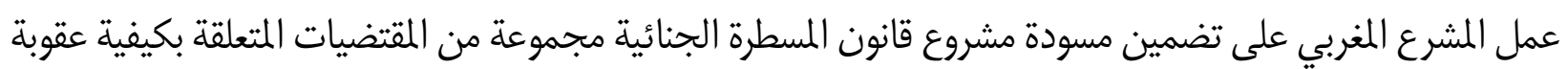

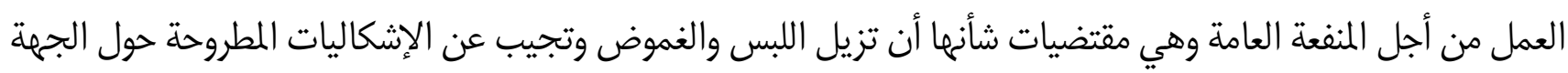

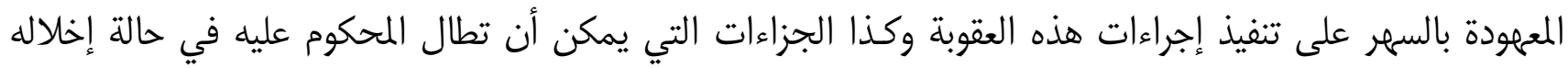

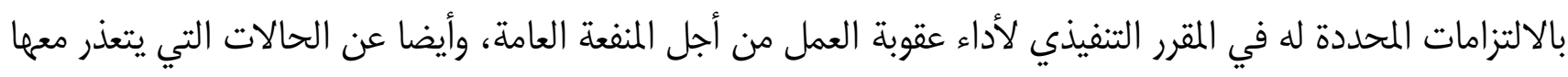

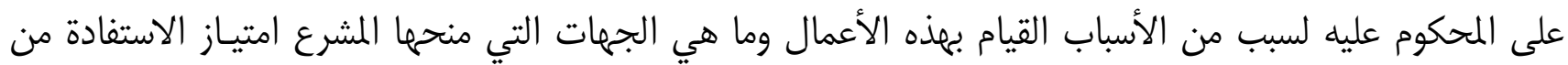
الأعمال المقدمة من قبل المحكوم عليهمه.

435 تنص المادة 755 من مسودة القانون الجنائي على أنه : " ... المدة تتراوح بين 40 و 600 ساعة "، وتعتبر المحكمة في هـذا الإطار موازاة كل يوم من مدة العقوبة الحبسية المنطوق به لساعتين من العمل، مع مراعاة الحد الأقصى لعدد ساعة سلعاعات العمل. 436 عبد الرؤوف حنان : العمل للنفع العام كبديل عن عقوبة الحبس، رسالة ماجستير، جامعة محمد خيضر، الجزائر، السنة الجامعية : 2013 - 2014،

. $61: 0$ 437 مقال تحت عنوان : " العمل لفائدة المنفعة العامة "، مقال منشور بمجلة الشؤون الجنائية، يصدرها مركز الدراسات والأبحاث الجنائية بمديرية الشؤون الجنائية والعفو، وزارة العدل، مطبعة إليت، جمعية نشر المعلومة القانونية والقضائية، العدد الثاني، أكتوبر 2012.

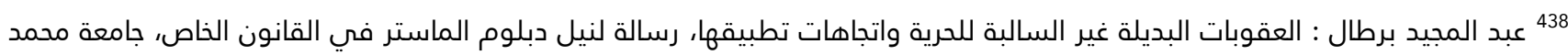
الخامس، كلية العلوم القانونية والاقتصادية والاجتماعية، السويسي - الرباط، السنة الجامعية : 2011 - 2012. ص 89. 
تلكم إشكاليات سوف لن نجد سبيل لإجابة عنها غير التعرض للمواد التي ضمنها المشرع في مسودة مشروع قانون

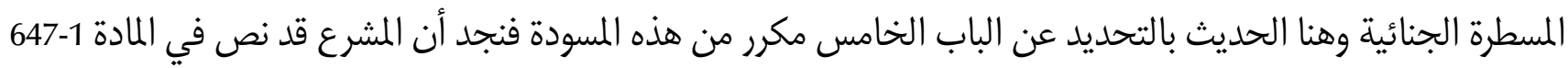

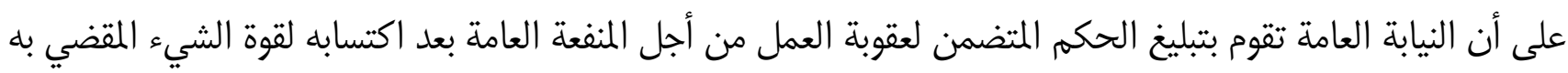
إلى قاضي تطبيق العقوبات الذي يتولى السهر على تنفيذ إجراءات هذه العقوبة.

ويتضح من خلال هذه المادة بما لا يدع مجالا للشك بأن الجهة التي أناط بها المشرع مهمة تنفيذ إجراءات عقوبة الماتية

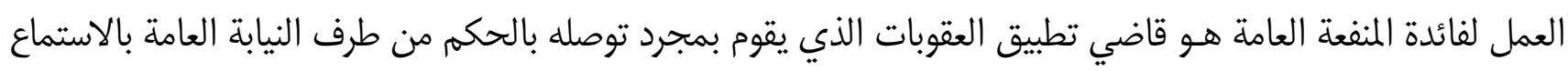

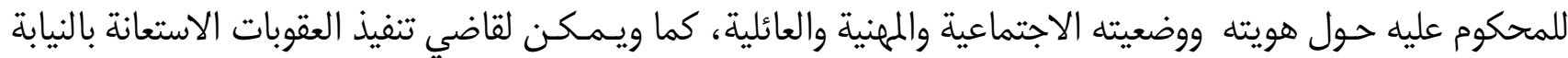

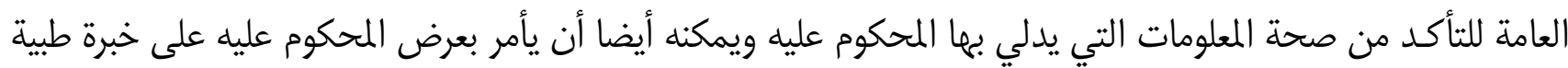

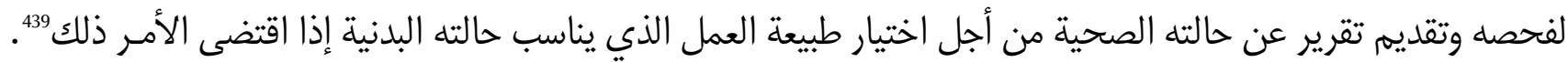

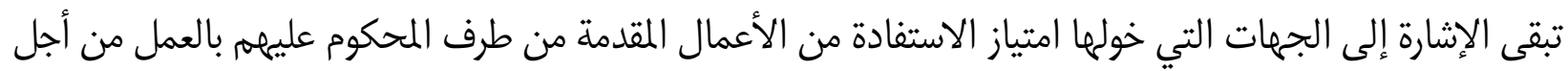

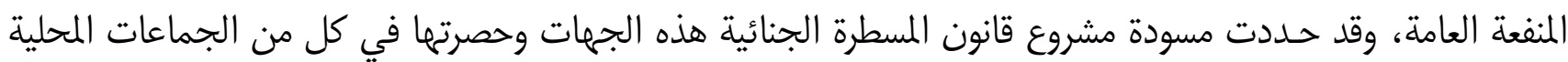

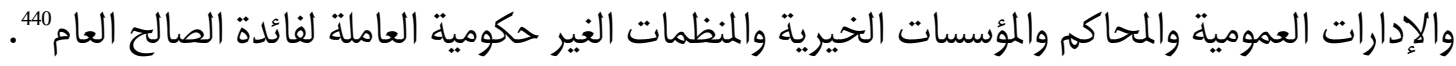

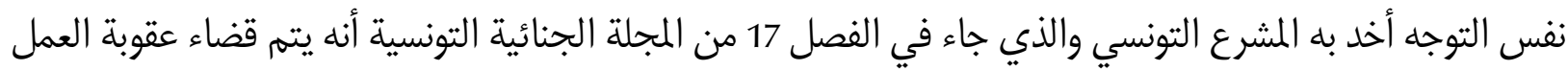

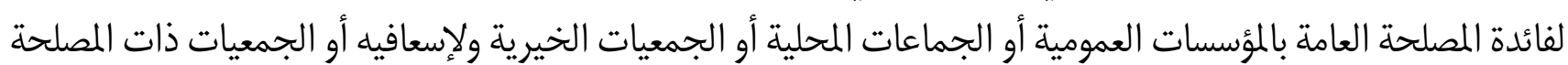

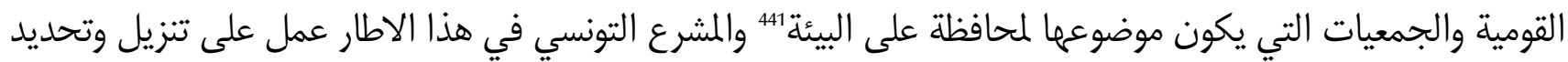
شروط تطبيق العقوبات البدلة المرتبطة بالعمل في أجل المنفعة العامة في إطار الحد من آثار العقوبة السالبة للحرية القعائة القصيرة

وكذا تجدر الإشارة إلى حالة إخلال المحكوم عليه بالالتزامات المحددة له في المقرر التنفيذي لأداء عقوبة العمل من

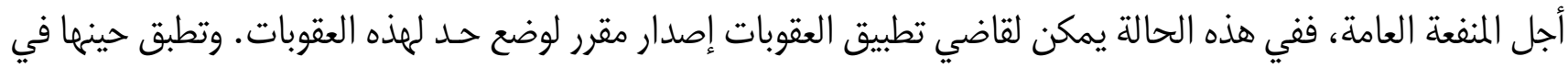

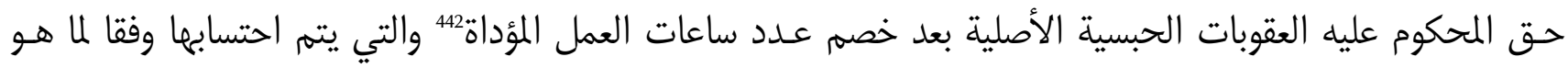

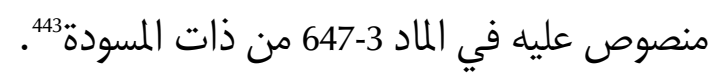

كما هناك نقطة لا تقل أهمية عن سابقاتها لا تفوتنا الإشارة إليها والمتمثلة في كون قاضي يطبق العقوبات يجوز له

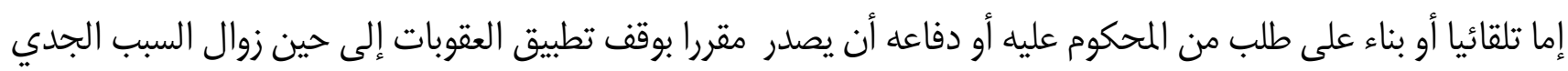

439 المادة 647-2 من مسودة مشروع قانون المسطرة الجنائية.

440 المادة 4-677 من مسودة مشروع قانون المسطرة الجنائية. 441ـــأبو لبابة العثماني النظام القانونية لعقوبة العمل لفائدة المصلحة العامة كبديل عن العقوبة السجنية مقال منشور بمجلة القضاء والتشريع

وزارة العدل التونسية العدد 4 أبريل 2004 ، 202 442 المادة 647-6 من مسودة مشروع قانون المسطرة الجنائية. 443 تخصم مدة الاعتقال المؤقت أو الحبس التي قضاهـا المحكوم عليه بحساب ساعتي عمل عن كل يوم حبس ثم تمد تستبدل المتبقية من عقوبة الحبس الأصلية ليؤديها لنفع عـام. 
متى استدعت ذلك الظروف الاجتماعية أو الصحية أو العائلية أو الدراسية أو المهنية للمحكوم عليه أو إذا تعلقت بظروف المؤسسة التي يقضي بها العقوبة دلت.

وبالرجوع للمقتضيات التي نص عليها المشرع المغربي في هذا الصدد سواء على مستوى مسودة قانون المسطرة الجنائية

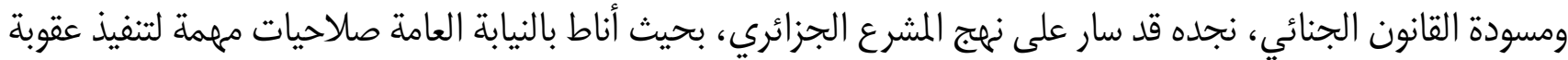

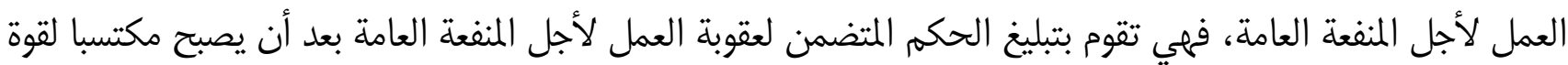
الشيء المقضي به، إلى قاضي تطبق العقوبة، هـذا الأخير الذي يسهر على عملية لمعنية التنفيذ.

ولقد سلك المشرع لبلوغ الهدف المتعلق بتبليغ الحكم بعقوبة المنفعة العامة بطريقتين، فالملف يبلغ لقاضي تطبيق العقوبة

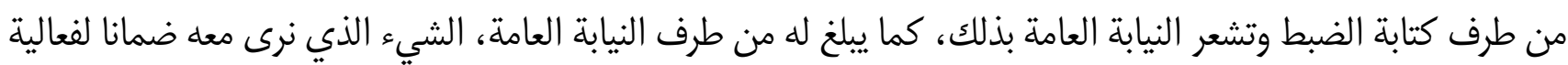

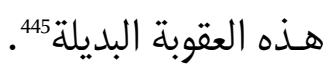

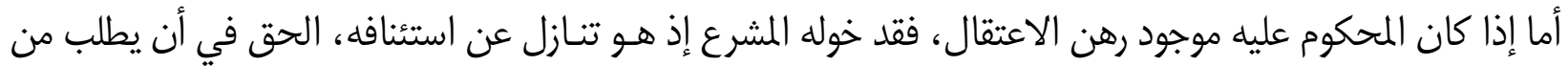

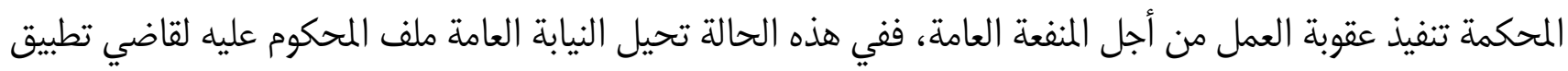
العقوبة لإصدار قرار يقضي بتنفيذ هذه العقوبة البديلة حسب المادة 2-647 من مسودة قانون المسطرة الجنائية. كما خول المشرع للنيابة العامة أيضا صلاحية إبداء وجهة نظرها في البرامج التي يعدها قاضي تطبيق العقوبة والذي

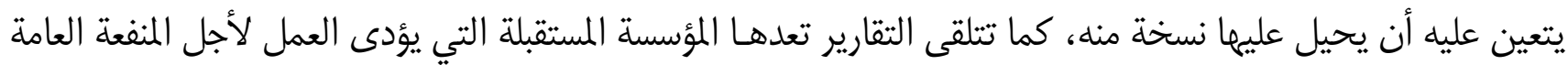

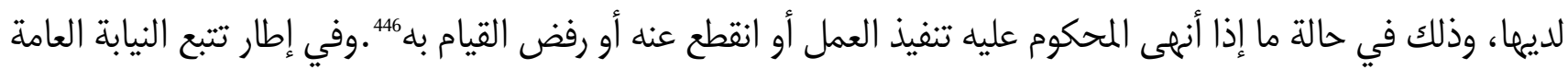

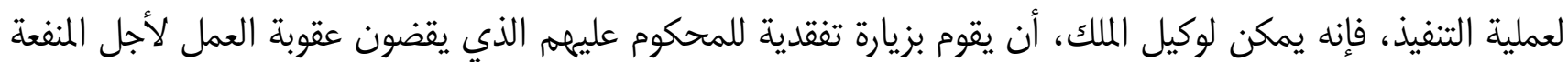

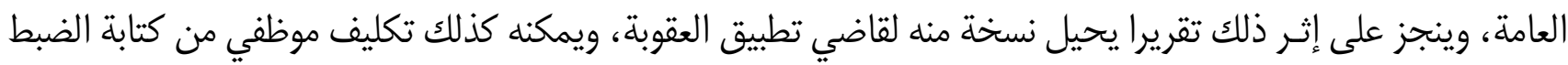

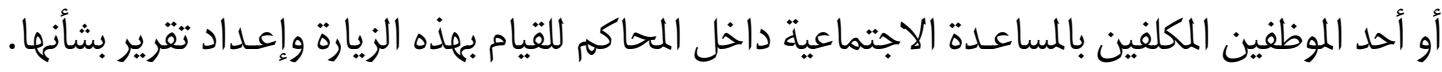
وفي الأخير فإن الاتجاهات المعاصرة للسياسة الجنائية في العقوبة تهدف للتخفيف من أزمة السياسة العقابية و

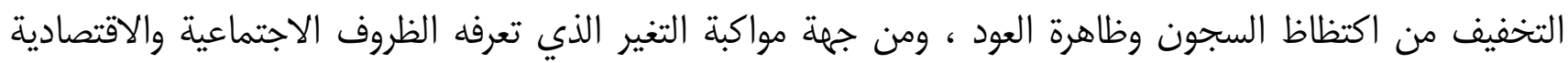

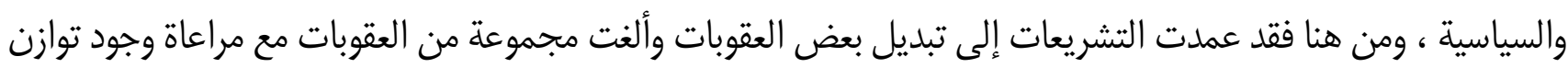

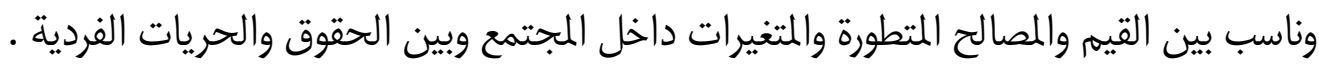

444 المادة $447-7$ من مسودة مشروع قانون المسطرة الجنائية. 445 عبد الفتاح لغزايلي : العقوبات البديلة - العمل لأجل المنفعة العامة نموذجا، دراسة على ضودة ضون بعض مض القوانين المقارنة ومسودة القانون الجنائي، رسالة لنيل دبلوم الماستر في القانون الخاص، جامعة القاضي عياض، كلية العلوم القانونية والاقتصادية والاجتماعية، مراكش، السنة 


\section{تكعين اتفاق التحكيم الداخلي}
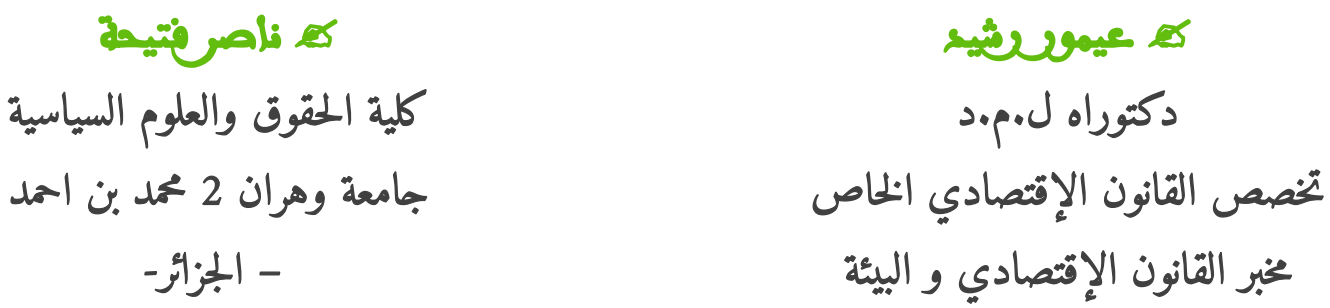

\section{الملخص:}

يتضمن قانون الإجراءات المدنية والإدارية رقم 08-09 الصادر بتاريخ 25 أبريل 2008 الذي ألغى قانون

الإجراءات المدنية بتاريخ 08 جوان 1966 في كتابه الخامس " الطرق البديلة لحل المنازعات من الصلح والوساطة إلى

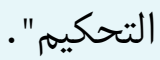

خصص المشرع الباب الثاني من هذا الكتاب الخامس "للتحكيم الداخلي" فتناول في الفصل الأول من هذا الباب "اتفاقيات التحكيه" ابتداء من المادة 1006 إلى المادة 1018.

تعرف المادتين 1007 و1011 اتفاق التحكيم بأنه اتفاق الطرفين لعرض النزاعات التي نشأت أو يمكن أن تتشأ بينهما بشأن عقد على التحكيم.

كما تبين أن اتفاق التحكيم عقد ككل العقود يتكون بشروط عامة وهي الرضاء، المحل، السبب، وشروطا

خاصة وهي كتابة اتفاقية التحكيه، تحديد موضوع النزاع وأهلية الأطراف وإلاّ كان اتفاق التحكيه باطلا بطانانا

مطلقا.

الكلمات المفتاحية:

الإجراءات المدنية والإدارية، التحكيم الداخلي، اتفاقيات التحكيم، عقد على التحكيم، النزاع.

\section{Résumé :}

La loi n ${ }^{\circ} 08-09$ du 25 février 2008 de procédure civile et administrative abrogeant la loi de procédure civile du 08 juin 1966 comporte dans son livre $\mathrm{V}$ « des modes alternatifs de règlement des litiges ».

Le législateur a prévu dans le titre II du livre V « de l'arbitrage » et dans son chapitre I « des conventions d'arbitrage » a partir de l'article 1006 à l'article 1018.

Le chapitre I traite dans la section 1 de « la clause compromissoire » et dans la section 2 « du compromis ». L'articles 1007 et 1011 définissent la « convention d'arbitrage » comme étant la convention par laquelle les parties à un contrat s'engagent à soumettre à l'arbitrage un litige né ou un litige qui pourrait naître à ce contrat.

De même qu'il ressort de ces différents texte que la convention d'arbitrage est un contratr comme tout contrat qui se forme par des conditions générales : consentement, objet et la cause et par des conditions spéciales de validité qui sont : l'écrit de la convention arbitrale et la capacité des parties.

Mots clés :

L'arbitrage, clause compromissoire, convention d'arbitrage, arbitrage interne, litige 


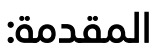

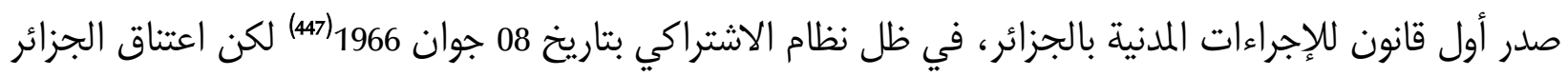

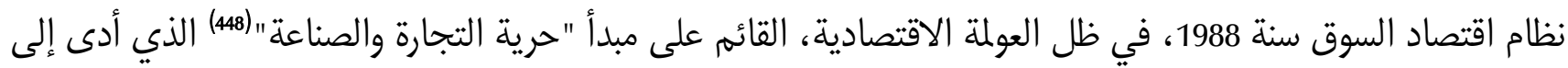

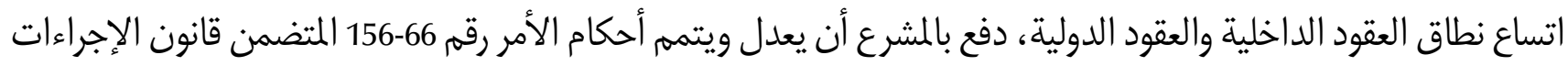

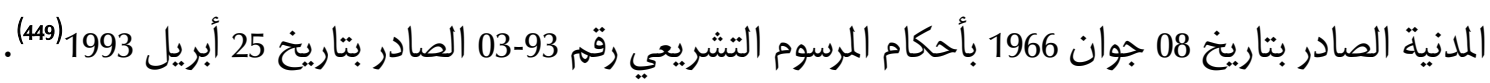
جاء هذا الأخير ليطابق أحكام دستور 1989 الذي يتبين منه الاتجاه الليبيرالي للنظام الاقتصادي الجزائري وانتهاء مرحلة النظام الاشتراكي.

لتتماشى هذه القوانين ومعطيات الواقع الذي نعيشه ومسايرة لدستور سنة 1996 الذي ينص صراحة على أن "حرية

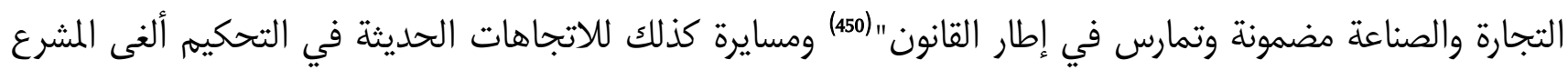

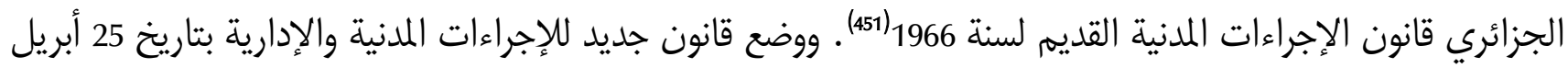

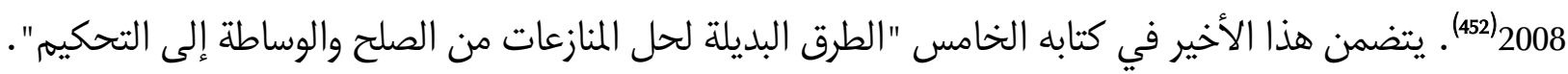
خصص المشرع الجزائري الباب الثاني من الكتاب الخامس "للتحكيم الداخلي". فتناول في فصله الأول "اتفاقيات

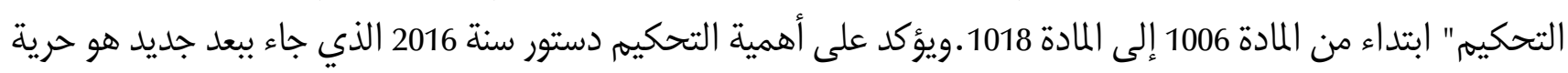
الاستثمار خدمة للتنمية الاقتصادية الوطنية (453).

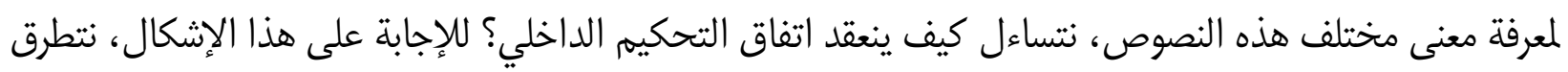

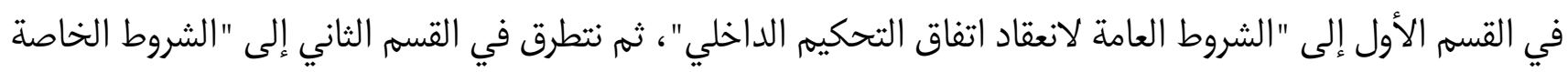
لانعقاد اتفاق التحكيم الداخلي".

\section{|- الشروط العامة لانعقاد اتفاق التحكيم الداخلي}

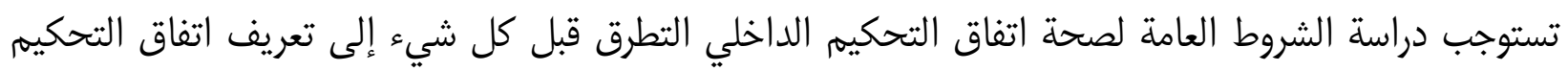

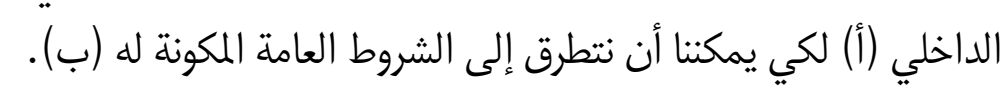

447) الأمر رقم 66-156 المؤرخ في 08 جوان 1966 المعدل والمتمم المتضمن قانون الإجراءات المدنية. الجريدة الرسمية للجمهورية الجزائرية العدد 48. 448) كرس مبدأ حرية التجارة والصناعة صراحة دستور سنة 1996 المعدل والمتمم في مادته 37 التي تنص على أنه: "حرية التجارة والصناعة مضمونة تمارس في إطار القانون" ج ر ج ج العدد 76.

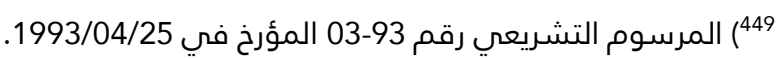

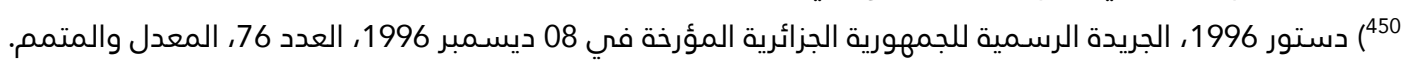
451 452) القانون رقم 09 09 الصادر بتاريخ 25 فبراير سنة 2008 يتضمن قانون الإجراءات المدنية والإدارية، الجريدة الرسمية للجمهورية الجزائرية، العدد 21، ص3. 453) المادة 43 من دستور سنة 2016 الصادر بموجب القانون رقم 16-01 المؤرخ في 06 مارس 2016 ج د ج ج العدد 14 الصادرة بتاريخ 07 مارس 2016 المتضمن بتعديل دستور سنة 1996 الصادر بالمرسوم الرئاسي رقم 96-438، ج رج ج العدد 96. 


\section{أ- تعريف اتفاق التحكيم الداخلي:}

يعرف الفقه والقانون اتفاق التحكيه الداخلي لكن لا يكتمل هذا التعريف إلا بدراسة الطبيعة القانونية التي تستخلص من تعريفه.

\section{1- التعريف الفقهي والقانوني لاتفاق التحكيم:}

حسب ما يتفق عليه جل الفقه التحكيم هو الاتفاق على طرح النزاع على محكم أو أكثر ليفصلوا فيه بحكم ملزم للخصوم، وقد يكون هذا الاتفاق بندا في العقد ويسمى شرط التحكيم (la clause compromissoire)، وقد يكون بعد قيام النزاع بين الخصوم ويسمى اتفاق التحكيم (Ile compromis) (454).

وحسب الفقيه فوشار (Fouchard) اتفاق التحكيم يشمل من جهة شرط التحكيم (Ia clause compromissoire) وهو الشرط المنصوص عليه في العقد لفصل أي نزاع يمكن أن يقع بسبب هذا العقد عن طريق التحكيه، ومن جهة أخرى، اتفاق

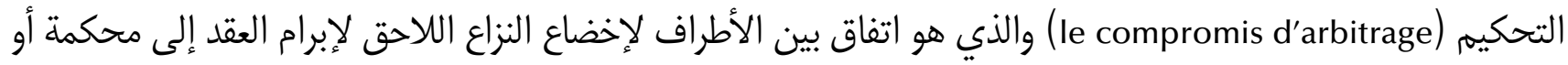
هيئة تحكيمية (455).

يفهم من التعريف الفقهي إن اتفاق التحكيم هو اتفاق الطرفين على تسوية كل أو بعض المنازعات التي نشأت أو يمكن أن تنشأ بينهما من تنفيذ عقد معين عن طريق التحكيم. رجح جل الفقه هذا التعريف لاتفاق التحكيم(456). ويرى الفقه أن شرط التحكيم هو الأكثر استعمالا خاصة في العقود الدولية وأن هذا الشرط هو "حجر الأساس الذي يقوم عليه الصرح التحكيمي" (457). فما هو موقف القانون من تعريف اتفاق التحكيم؟ تعرف بعض القوانين العربية(458) اتفاق التحكيه بأنه اتفاق الطرفين لعرض النزاعات التي نشأت أو يمكن أن تنشأ بينهما بشأن عقد على التحكيم.

454) إشراف عبد العليم الرفاعي، اتفاق التحكيم، دار الفكر الجامعي، الإسكندرية، 2006، ص223 وما بعدها. ${ }^{455}$ ) Ph.Fouchard, l'arbitrage commercial international, Dallos, Paris, 1986, p53.

محمود هاشم، النظرية العامة للتحكيم في المواد المدنية والتجارية، ج الأول، اتفاق التحكيم، دار الفكر العربي، س 1995، ص77. ${ }^{456)}$ En ce sens Berthold Goldman, Arbitrage commercial international, Cd tint Fox 586-1, 1989, p.

- E.Gaillard, arbitrage commercial international, J.CL d tint, 1994, n8, p.

- Ph.Fouchard, E.Gaillard, B.Goldman, Traité de l'arbitrage commercial international, Delta, Paris, 1996, p - أحمد أبو الوفا، التحكيم الاختياري والإجباري، الطبعة الخامسة، منشأة المعارف، الإسكندرية 1988، ص15 وما بعدها. - سامية راشد، التحكيم في العلاقات الدولية الخاصة، الكتاب الأول، اتفاق التحكيم دار النهضة العربية، 1984، ص757 وما بعدها. 457) إشراف عبد العليم الرفاعي، المرجع السابق ذكره، ص225. 458) القانون المصري رقم 27 الصادر بتاريخ 1994، المتعلق بالتحكيم في المواد المدنية والتجارية، المادة 10 منه تنص على أنه: "اتفاق التحكيم هو اتفاق الطرفين على الالتجاء إلى التحكيم لتسوية كل أو بعض المنازعات التي نشأت أو يمكن أن تنشأ بينهما بمناسبة علاقة قانونية معينة عقدية كانت أو غير عقدية. 
له تعرف الكثير من الدول العربية(459) ومن بينها الجزائر اتفاق التحكيم بنص خاص حيث اكتفى المشرع في قانون

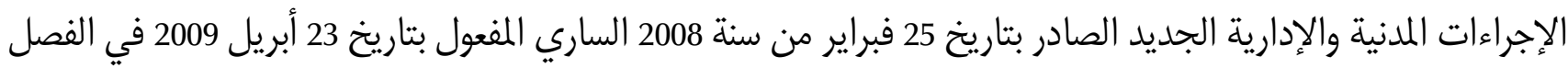

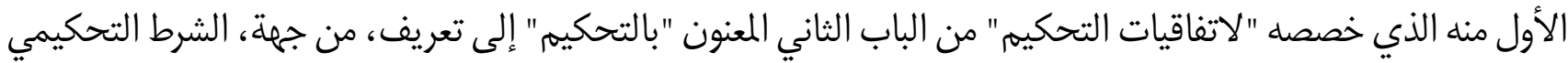

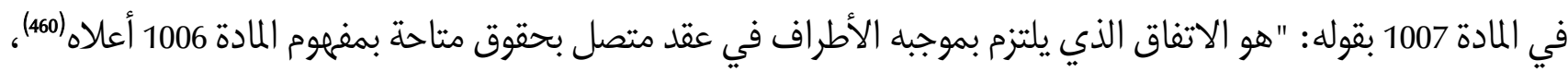

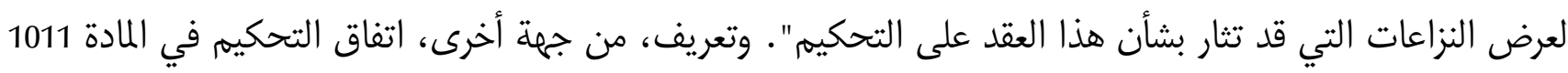

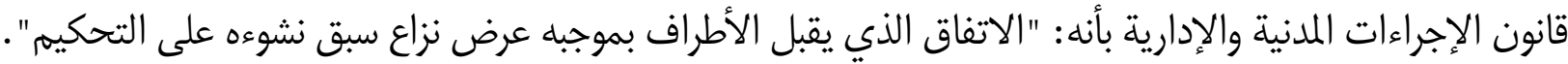
وفي نظرنا بهذين التعريفين اللذين ضمهما المشرع في الفصل الثاني تحت عنوان "اتفاقيات التحكيه" قد عرف اتفاق

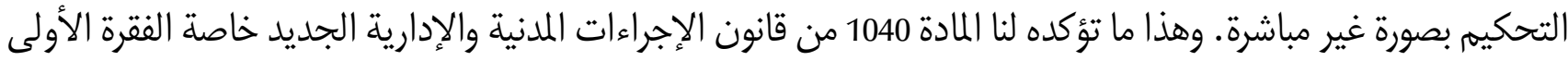
منها التي تتص على أنه "تسري اتفاقية التحكيه على النزاعات القائمة والمستقبلية".

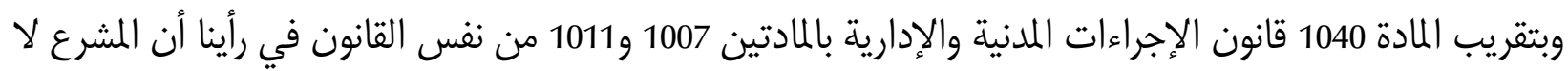

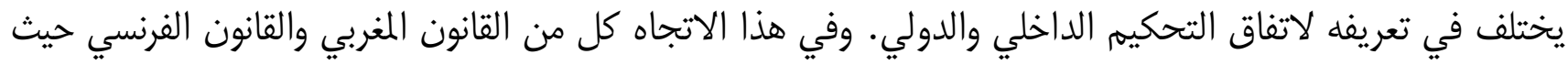

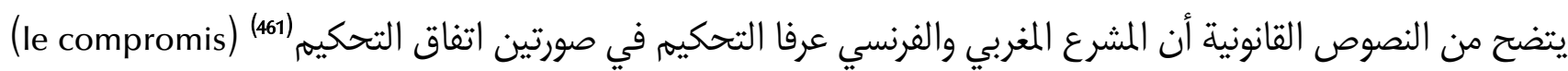

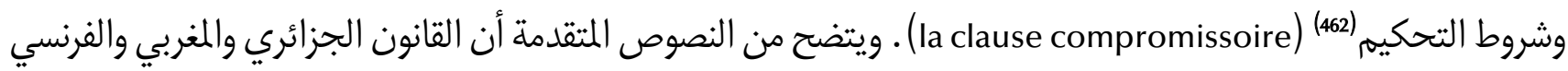
قد اعتمد التمييز بين اتفاق التحكيم وشرط التحكيم وعرّق التحكيم في صورتيه اتفاق التحكيم وشرط التحكيم. كما نلاحظ أن هذه القوانين اتجهت اتجاها حديثا في تعريفها لشرط التحكيم (la clause compromissoire) واتفاق

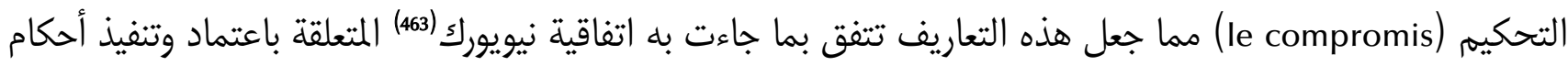
التحكيم الأجنبي في تسميتها لصور اتفاق التحكيم: "شرط التحكيم" و"اتفاق التحكيم" (464).

ــ يجوز أن يكون اتفاق التحكيم سابقا على قيام النزاع سواء قام مستقلا بذاته أو ورد في عقد معين بشأن كل أو بعض المنازعات التي تنشأ.

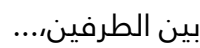

ـ ـ كما يجوز أن يتم اتفاق التدكيم بعد قيام النزاع ولو كانت قد أقيمت في شأنه دعوى أمام جهة قضائية.....".

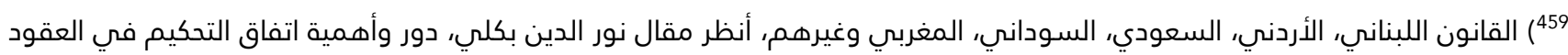

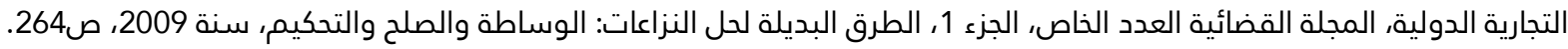
460) تنص المادة 1006 قانون الإجراءات المدنية والإدارية على أنه: يمكن لكل شخص اللجوء إلى التحكيم في الحقوق التي له مطلق التصرف صلئ

ـ لا يجوز التحكيم في المسائل المتعلقة بالنظام العام أو حالة الأشخاص وأمليتهم. - ـ - ولا يجوز للأشخاص المعنوية العامة أن تطلب التحكيم، ما عدا في علاقتها الاقتصادية الدولية أو في إطار الصفقات العمومية.

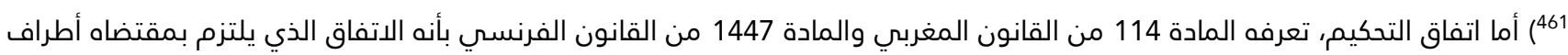

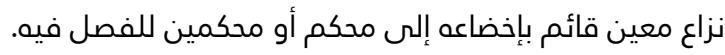
462 فيما يخص الشرط التحكيمي، المادة 316 القانون المغربي والمادة 1442 من قانون المرافعات المدنية اللتان عرفتا الشرط التحكيمي بأنه

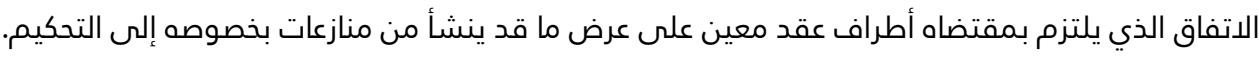

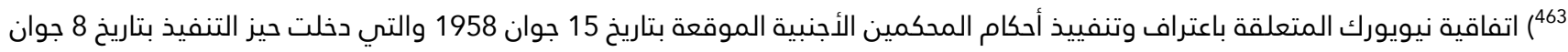

${ }^{464}$ ) Ph.Fouchard, E.Gaillard, B.Goldman, traité de l'arbitrage commercial international, Dallos, Paris, 1986, p290 et s. 


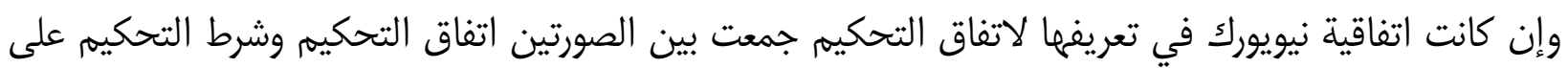

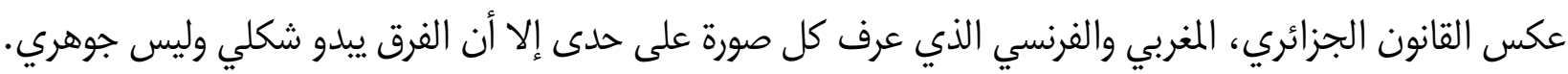
تجرّنا هذه التعاريف الفقهية والقانونية إلى التساؤل عن الطبيعة القانونية لاتفاقية التحكيم؟

\section{2- الطبيعة القانونية لاتفاقية التحكيم}

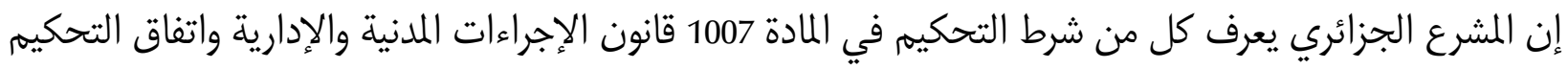
في المادة 1011 قانون الإجراءات المدنية والإدارية بأنهما "اتفاق بين المين في الأطراف" . فما المقصود بهذه العبارة؟

$$
\text { هل هذا معناه إن اتفاق التحكيم عقد ككل العقود؟ }
$$

يرى جانب من الفقه أنه "مستقل عن العقد...لأنه يمتاز بخصائص يفتقدها العقد العادي"(465). يرى الفقه الآخر أن اصطلاح العقد والاتفاق لهما نفس المعنى(466). أي أن اتفاق التحكيم "عقد من العقود أي تصرفا

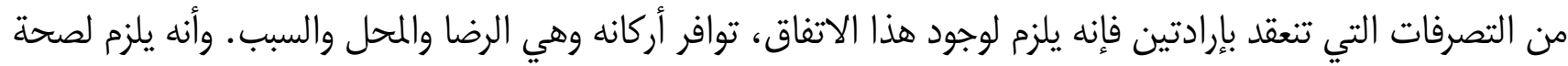

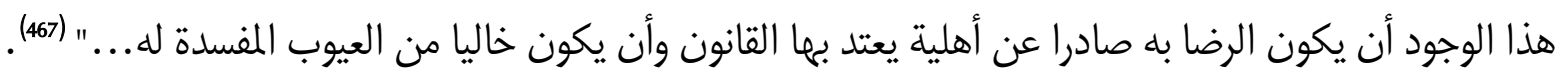
نتفق مع الرأي الثاني لأن برجوعنا إلى الشريعة العامة وبالضبط إلى القانون المدني نجد المشرع يعرف العقد في المادة 54 قانون مدني (468) بأنه "اتفاق بين الأطراف...." أي توافق إرادتين أو أكثر على أحداث أثر أثر قانوني. هذا التعريف ينطبق على "اتفاق التحكيم" لاسيما أن مكونات العقد: الرضاء، المحل، السبب والشكلية هي نفس

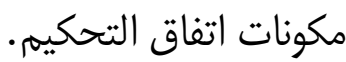

في هذا الصميم المادة 4 من القانون المصري المتعلق بالتحكيم في المواد المدنية والتجارية (469) التي تعرف التحكيه بأنه

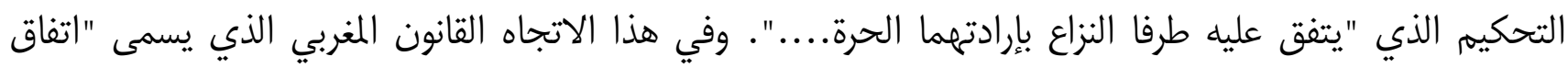
التحكيم" "بعقد التحكيم" في المادة 114 من قانون المسطرة المدنية.

ومما سلف نستنتج أن للعقد والاتفاق مدلولا واحدا وأن اتفاق التحكيم هو عقد ككل العقود له خصائصه تميزه كما

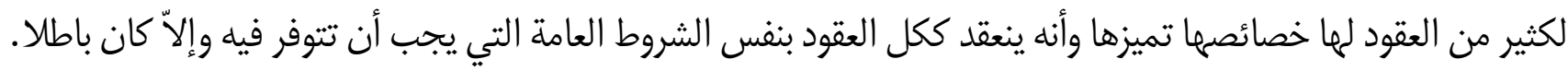

465) نور الدين بكلي، دور وأهمية التحكيم في العقود التجارية الدولية، مقال بمجلة القضاء، عدد خاص، جزء 1، سنة 2009، ص270.

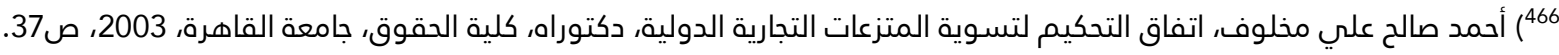

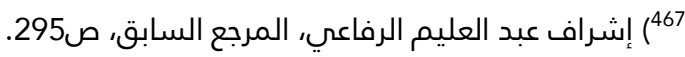

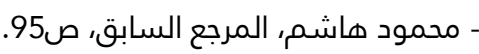
468) القانون رقم 07-07 المؤخ في 13 مايو 2007 المعدل والمتمم للأمر رقم 75-58 المؤرخ في 26 سبتمبر 1975 المتضمن القانون المدني، المعدل والمتمم بالقانون رقم 05-10 المؤرخ في 20 جوان 2005. 469 القانون السالف الذكر. 


\section{بـ الرضا، المحل والسبب شروط عامة لانعقاد اتفاق التحكيم الداخلي:} ينعقد اتفاق التحكيم ككل عقد بشروط عامة، هي الرضاء، المحل والسبب.

1 الرضا (le consentement): رضاء المتعاقدين شرط هام في العقد ويقصد به توافق الإرادين وهذا ما تتص عليه المادة 59 قانون المدني الجزائري

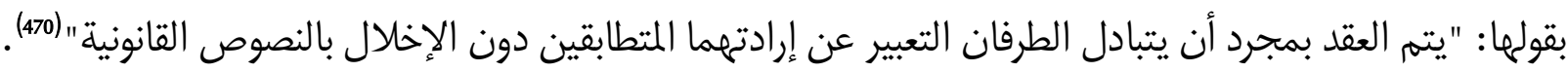
ويقوم اتفاق التحكيم على رضاء الأطراف للجوء إلى التحكيم لحل النزاعات الناشئة أو المستقبلية، وإلا كان اتفاق

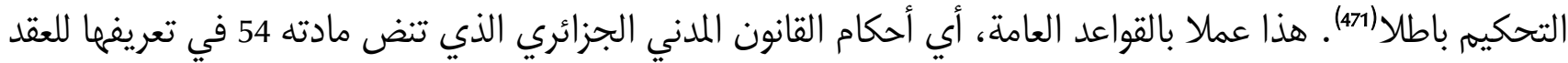

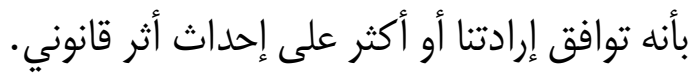
يفمهم من هذه النصوص يجب توافر ركن الرضاء لوجود اتفاق التحكيم وأن يكون صادر عن أهلية يعقد بما القانون(472)، وإلا كان اتفاق التحكيم باطلا بطلانا مطلقا.

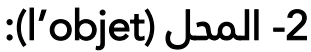

تتص المادة 54 من القانون المدني الجزائري المعدلة بقانون 05-10 المؤرخ في 20 جوان 2005 على أنه: "العقد اتفاق يلتزم

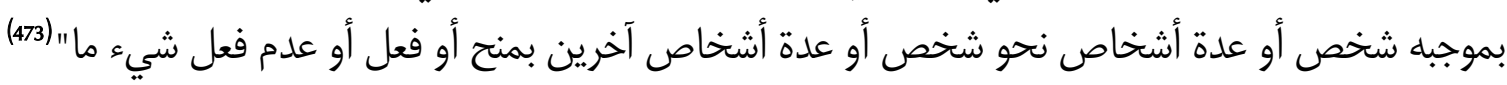

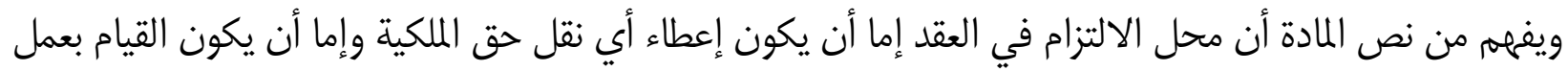

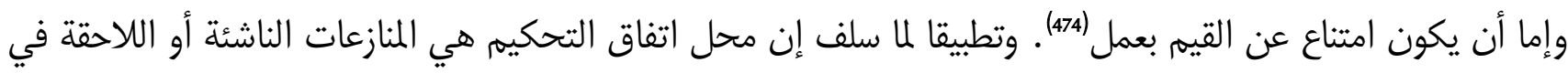
عقد متصل بحقوق يسمح بشأنها القانون (475). وتطبيقا للمادة 1006 من قانون الإجراءات المدنية والإدارية يقصد بعبارة "بحقوق يسمح بشأنها القانون أنه يستطيع كل

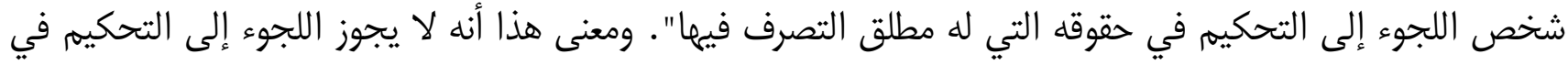
المسائل المتعلقة بالنظام العام والمسائل المتعلقة بحالة الأشخاص أو أهي أهليتهمه.

470 القانون المدني الجزائري مذكورا أعلاه.

- سليمان مرقس، الوافي في شرح القانون المدني، مطبعة السلام، شبرا، ص130. - عبد الرزاق السنهوري، الوسيط في شرح القانون المدني، دار النشر للجامعات المصرية، القاهرة، 1952، ص135. 471) قرار المحكمة العليا رقم 5144 بتاريخ 1978/11/11 قضية (د ب) ضد (ب-ل)، المجلة القضائية الجزائرية، 1990. 472) المادة 40 قانون المدني الجزائري تنص على أنه: "كل شخص بلغ سن الرشد متمتعا بقواه العقلية ولم يحجر عليه، يكون كامل الأهلية لمباشرة حقوقه المدنية. وسن الرشد تسعة عشر (19) سنة كاملة". 473 القانون المدني الجزائري المذكور سالفا.

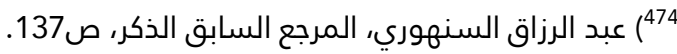
475 تنص المادة 1006 إجراءات المدنية والإدارية الجديدة على أله أنه: " يمكن لكل شخص اللجوء إلى التحكيم في الحقوق التي له مطلق التصرف فيها. لا يجوز التحكيم في المسائل المتعلقة بالنظام العام أو حالة الأشخاص أو أهليتهم. ولا يجوز للأشخاص المعنوية العامة أن تطلب التحكيم ماعدا في...أو في إطار الصفقات العمومية". 
أما الأشخاص المعنوية العامة فلا يجوز لها اللجوء إلى التحكيم لحل نزاعتها إلا في ما تبرمه من عقود اقتصادية دولية أو فيما يتعلق بالصفقات العمومية.

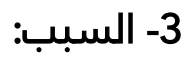
يقصد بالسبب الباعث الدافع للتعاقد (476).

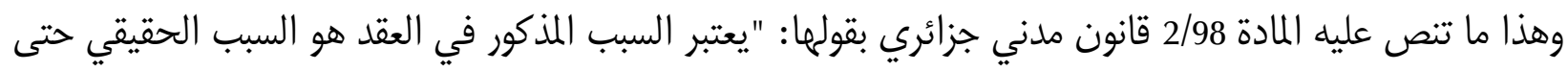

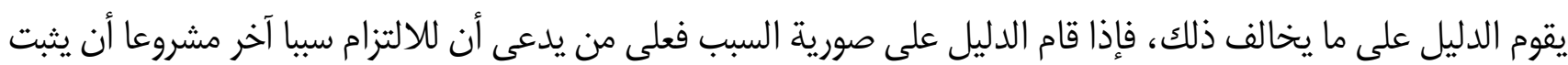

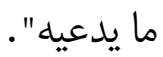

ويفهم من نص المادة أن السبب شرط من شروط انعقاد العقد ويجب أن يكون مشروعا وإلا بطل العقد بطلانا مطلقا. فسبب إبرام اتفاق التحكيم هو اتفاق الأطراف بحسن نية على حل نزاعهم عن طريق التحكيه. ويرى الفقيه "نور الدين بكلي" أن "سبب إبرام اتفاق التحكيم هو اللجوء إلى التحكيم لعدالة خاصة لما فيها من

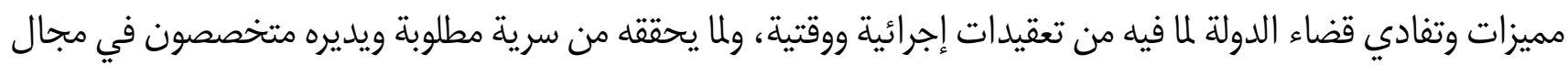
التجارة الدولية، مع فرض حسن النية" (477).

يفهمم مما سلف أن سبب اتفاق التحكيم يجب أن يكون موجودا أو مشروعا وإلا بطل اتفاق التحكيم بطلانا مطلقا. كما يجب، بجانب هذه الشروط العامة، توافر شروط خاصة لانعقاد اتفاق التحكيه.

|ll- الشروط الخاصة لانعقاد اتفاق التحكيم الداخلي:

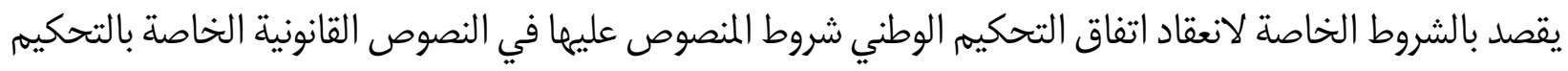

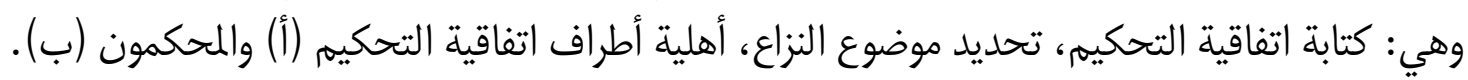

أ- كتابة اتفاقية التحكيم، تحديد موضوع النزاع وأهلية الأطراف:

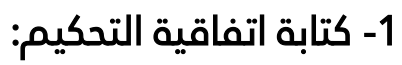

نتساءل: هل الكتابة تعد ركنا لانعقاد اتفاق التحكيم أم هي مجرد وسيلة لإثباته؟

حسب قانون الإجراءات المدنية والإدارية الجزائري الجديد إن اتفاقية التحكيم شكلية أي أن الكتابة شرط لوجودها

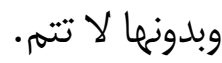

وهذا ما تتص عليه المادة 1008 في شأن شرط التحكيم بقولمها "يثبت شرط التحكيم، تحت طائلة البطلان بالكتابة في الاتفاقية الأصلية أو في الوثيقة التي تستند إليها" .

476 سليمان مرقس، الوافي في شرح القانون المدني، مطبعة السلام، شيرا، ص284 يرى "السبب أنه ركن في إرادة الالتزام".

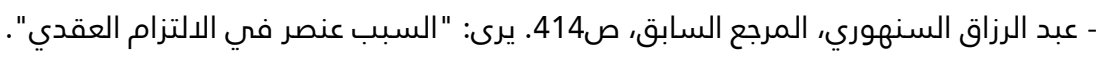
(477) نور الدين بكلي، المرجع السابق، ص274. 
وما تتص عليه المادة 1012 قانون إلإجراءات المدنية والإدارية فقرة الأولى بقولها: "يحصل الاتفاق على التحكيه كتابيا" • ويفهم من النصين أن الكتابة شرط من شروط انعقاد كل من شرط التحكيم واتفاق التحكيم وليس وسيلة للإثبات. ويجب الإشارة إلى أن البطلان الشرط التحكيم لا يؤدي إلى بطلان العقد بل وحده شرط التحكيم هو الذي يعتبره وكأن لم يكن (478)

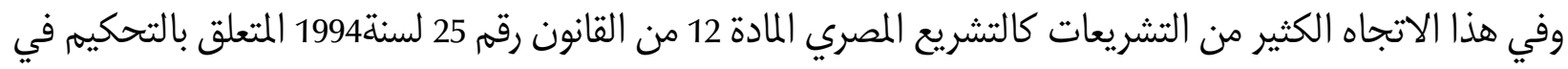

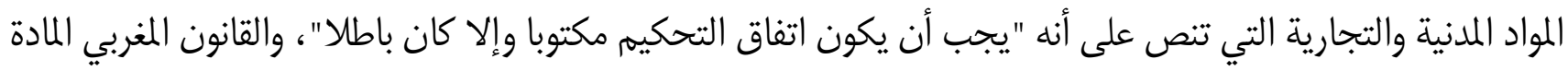

والقانون الفرنسي المادة 1443 من قانون المرفعات التي حسبها يبطل شرط التحكيم إذا لم يكن مكتوبا. ويتضح مما

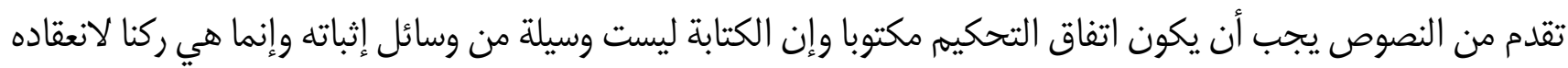

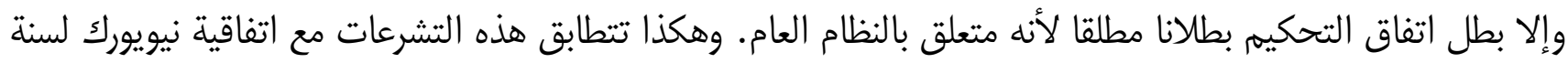

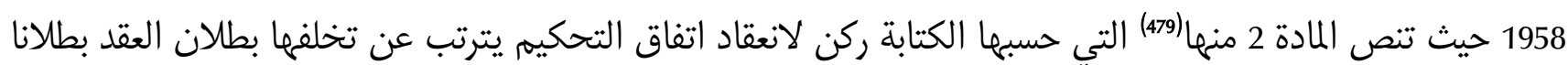
مطلقا ولا يمكن اعتباره وسيلة من وسائل الإثبات.

لكن السؤال الذي يطرح نفسه، ماذا يقصد المشرع بالكتابة؟ هل الكتابة الرسمية أو المحضر الموقع أمام المحكمين أو يقصد بما مجرد الكتابة العرفية؟.

وفي رأينا المشرع لم يشترط للكتابة شكلا خاصا بل ترك المجال واسعا، ومن تم إذا الكتابة يمكن أن تكون بعقد رسمي أو عرفي أو بمحضر يحرر أمام المحكين أو الهيئة التحكيمية المختارة.

وفي هذا الاتجاه جاءت المادة 313 من قانون المسطرة المغربي التي تنص على أنه: "وعملا بما جاءت به المادة 2، الفقرة الثانية من اتفاقية نيويورك قد يكون الاتفاق الكتابي في صورتين : أ- إفراغ اتفاق التحكيم في وثيقة موقع عليها من الأطراف.

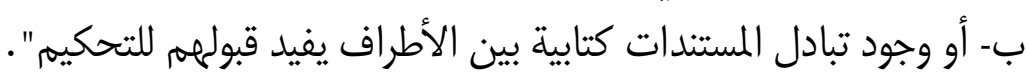

\section{2- تحديد موضوع النزاع في التحكيم الداخلي}

حسب قانون التحكيم الداخلي يجب أن يحدد اتفاق التحكيم موضوع النزاع المقصود عرضه على التحكيم. ويقصد بالنزاع الادعاءات المتبادلة التي يدعيها الخصوم، وهذا ما تتص عليه المادة 1012 قانون الإجراءات المدنية والإدارية فقرة 2 بقولها: "يجب أن يتضمن اتفاق التحكيم، تحت طائلة البطلان، موضوع النزاع....".

478) عبد الباسط محمد الواسع الضراسي، النظام القانوني لاتفاق التحكيم المكتب الجامعي الحديثن الإسكندرية، 2005، ص156. - نور الدين بكلي، المرجع السابق، ص277. 479) اتفاقية نيويورك الخاصة بالاعتراف وتنفيد أحكام المحكمين الأجنبية الموقعة في نيويورك بتاريخ 15 يونيو 1958 والتي دخلت حيز التنفيد بتاريخ 8 يونيو 1959. 
ويفهم من نص المادة أن الامتناع عن تحديد موضوع النزاع يؤدي إلى بطلان اتفاق التحكيه.

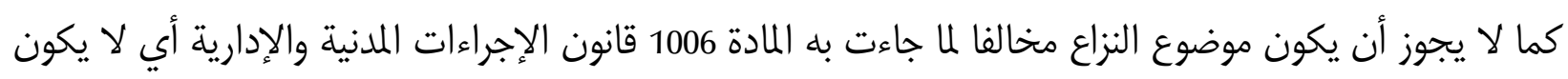

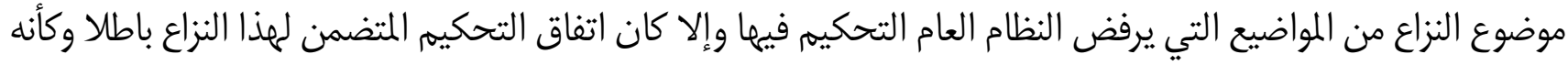

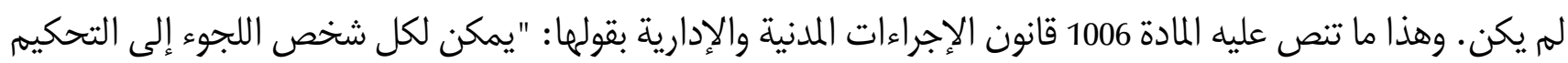
في الحقوق التي له مطلق التصرف فيها. لا يجوز التحكيم في المسائل المتعلقة بالنظام العام أو حالة الأشخاص أو أهليتهم. لا يجوز للأشخاص المعنوية العامة أن تطلب التحكيم، ما عدا...في إطار الصفقات العمومية". كما يفهم أن على المحاكم التحكيمية التقيد بموضوع النزاع المحدد (480 أي أنها لا تتجاوز حدود الوقائع التي يتكون

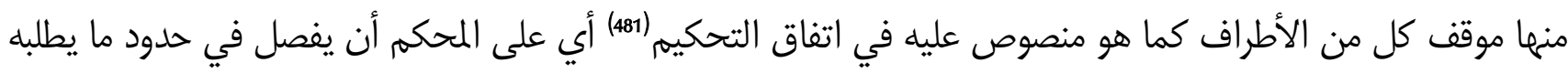

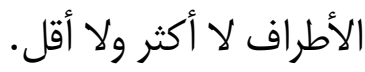
ومن هذا الاتجاه ماجاءت به المادة 1/315 من قانون المسطرة المغربي التي تتص على أنه "يجب أن يتضمن عقد التحكيم تحت طائلة البطلان: "تحديد موضوع النزاع...." (482).

\section{3- الأهلية في التحكيم الداخلي:} تتص المادة 1006 قانون الإجراءات المدنية والإدارية فقرة 1 على أنه "يمكن لكل شخص الده اللجوء إلى التحكيم في الحقوق التي له مطلق التصرف فيها". يفهم من نص المادة أن القانون يشترط أهلية التصرف وهي 19 سنة كاملة حسب ما جاءت به المادة 40 من القانون المدني الجزائري (483) وليس مجرد أهلية التقاضي وإدارة الحقوق. كما أصبحت للأشخاص المعنوية العامة أهلية التحكيم في الصفقات العامة أي الأشغال العامة بحكم المادة 1006 قانون

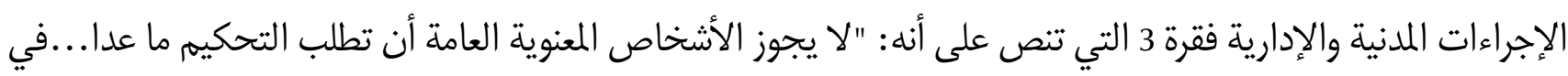
إطار الصفقات العمومية".

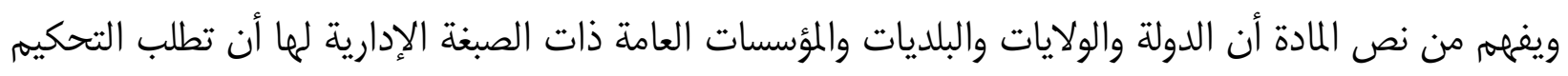
في الأشغال العامة الداخلية التي أصبحت قابلة للتحكيم الداخلي.

${ }^{480}$ - J.Robjert : I'arbitrage, p94.

481 482) عبد الحميد الأحدب، السالف ذكره، ص 56-57 "يبطل موضوع النزاع اتفاق التحكيم إذا ما اختصاص المحاكم القضائية". - Juris-classeur procédure civile, Fasc, p6-7, n¹6 à 24. 


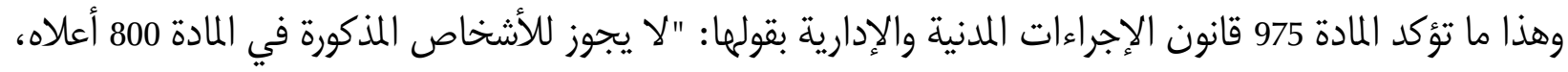

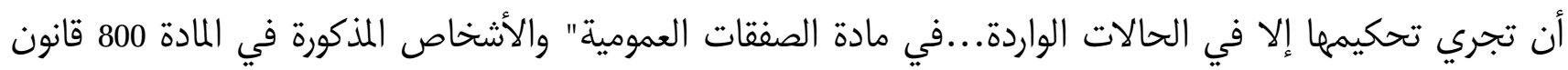
الإجراءات المدنية والإدارية: الدولة، الولاية، البلدية وإحدى المؤسسات العمومية ذات الصبنة الإدارية. وتتص المادة 1010 على أنه: "لا تسند مهمة التحكيم لشخص طبيعي، إلا إذا كان متمتعا بحقوقه المدنية". ويفهم من نص المادة أن الشخص الطبيعي الذي أسند إليه مهمة التحكيم لا تكون له الأهلية إذا كان محجورا عليه

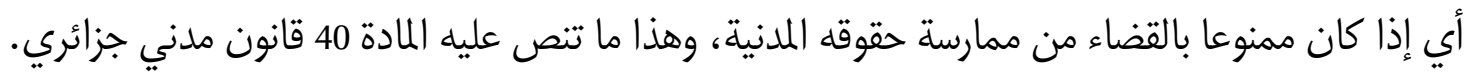
إذن لا يكون المحكم أهلا للتحكيم في ممارسة حقه المخول له بحكم المادة 1014 قانون الإجراءات المدنية والإدارية

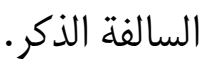

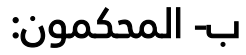

\section{1- تشكيل هيئة التحكيم: تعيينهم وعددهم المئم}

أوجب المشرع الجزائري تعيين المحكم أو المحكمين في اتفاق التحكيم سواء كان شرطا أو اتفاقا واعتبره شرطا أساسيا

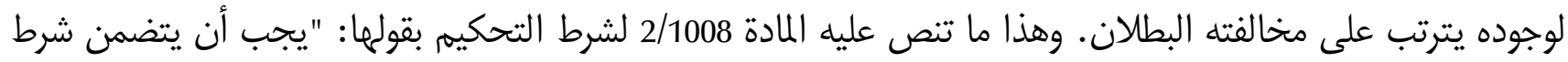

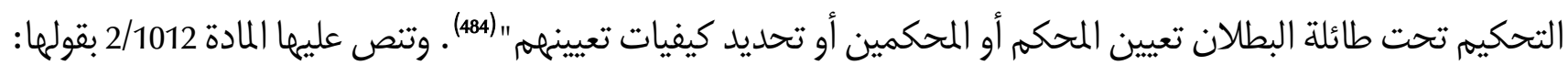

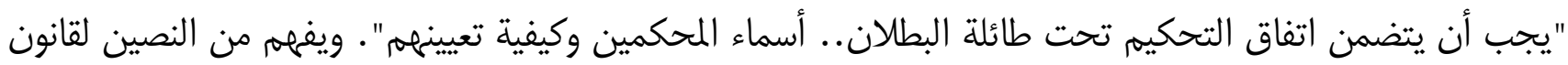
التحكيم الداخلي الجديد أن سلطان الإدارة يعين المحكمين أو يحيل على نظام تحكيمي الميطان تعيين المحكمين. كما يفهم من النصين أن المحكم أو المحكين أو تحديد كيفيات تعيينهم شرط من شروط اتفاقيات التحكيم يترتب

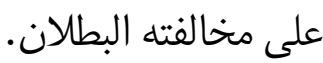

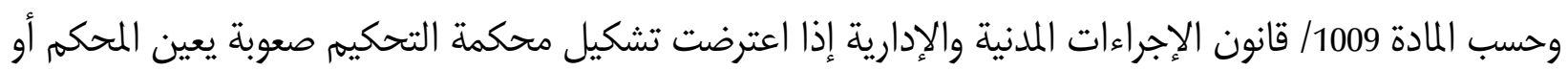

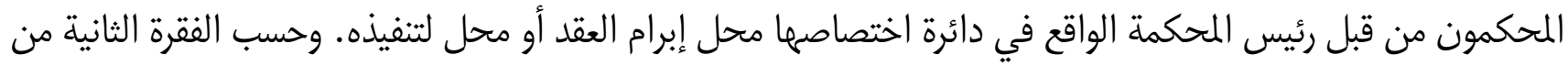

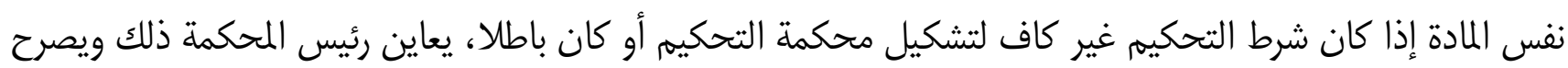

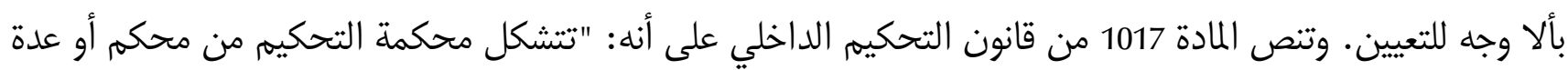

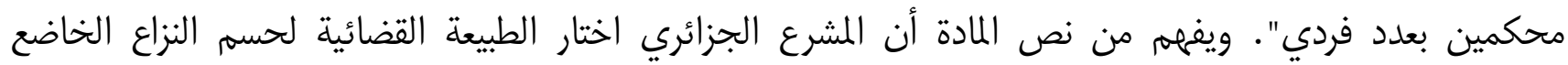
للتحكيم(485).

وحسب المادة 1013 قانون الإجراءات المدنية والإدارية يمكن للأطراف الاتفاق على التحكيم أثناء سريان الخصومة

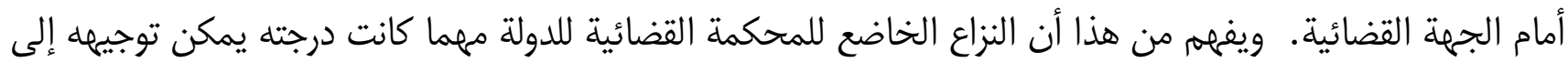

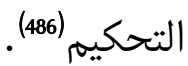

(484) قانون الإجراءات المدنية والإدارية السالف ذكره.

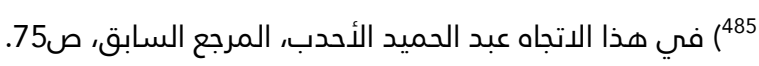
486) عبد الحميد الأحدب، المرجع السالف الذكر، ص56-57. 


\section{2- 2 - 2 المدكم شخص طبيعي أو معنوي}

تتص المادة 1014 فقرة 2 قانون الإجراءات المدنية والإدارية على أنه: "إذا عينت اتفاقية التحكيم شخصا معنويا، تولى إنى

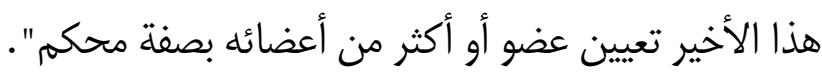
يفهم من النص المادة أن الشخص المعنوي تتحصر مهمته في تسمية محكم أو محكمين من أعضائه. فإذا، حالت اتفاقية التحكيه على الفصل في النزاع مثلا على غرفة التجارة فإن هذه الأخيرة تتحصر مهمتها في تسمية

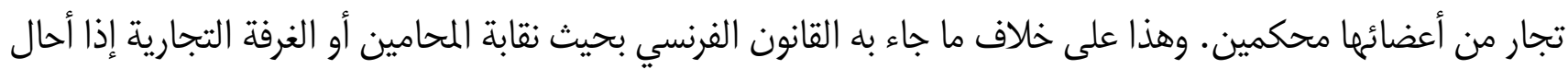

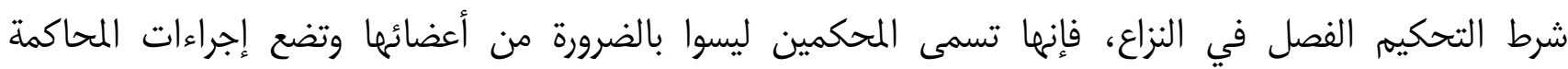
التحكيمية (487).

\section{3- شروط قبول المحكم مهمته:}

تنص المادة 1015 قانون الإجراءات المدنية والإدارية على أنه: "لايعد تشكيل محكمة التحكيم صحيحا، إلا إذا قبل المحكم أو المحكمون بالمرمة المسندة إليعم" .

ويفهم من نص المادة أن رضاء المحكم بقبول المرمة المسندة إليه شرط من شروط صحة تشكيل محكمة التحكيم المحاء

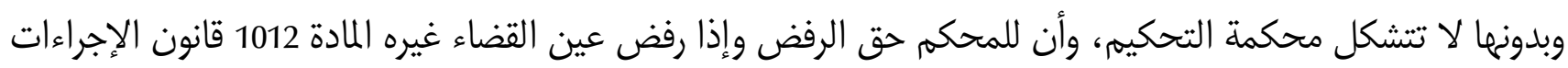
المدنية والإدارية فقرة 3.

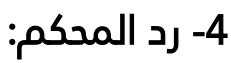

تنص المادة 1015 قانون الإجراءات المدنية والإدارية فقرة 2 على أنه: "إذا علم المحكم أنه قابل للرد يخبر الأطراف بذلك

ولا يجوز له القيام بالمهمة إلا بعد موافقتهم".

فما هي الأسباب التي يمكن أن يرد بمبا المحكم؟؟ (488).

حسب المادة 1016 يمكن رد المحكم للأسباب الآتية:

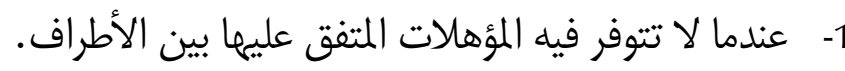

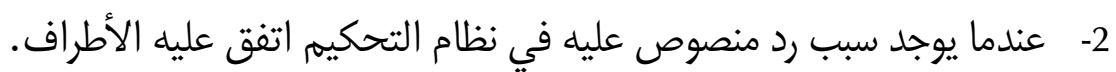

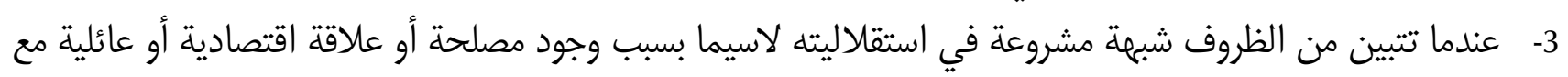
أحد الأطراف مباشرة أو عن طريق وسيط. لا يجوز طلب رد المحكم من الطرف الذي كان قد عينه، أو شارك في تعيينه، إلا لسبب علم به بعد التعيين. وتوجب نفس المادة السالفة الذكر إبلاغ المحكمة التحكيمية والطرف الآخر بسبب الردد (489.) من يفصل في طلب الرد؟. 


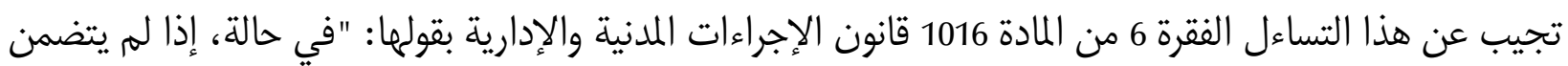

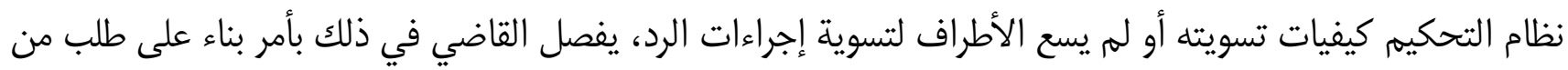

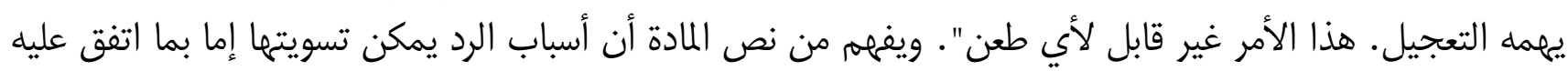

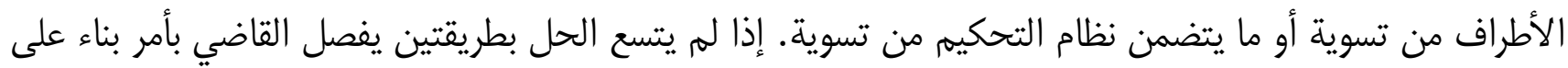

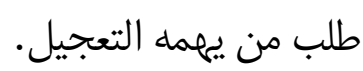
ويستتج مما سبق أن أسباب الرد ليست من النظام العام وأن الأمر الصادر من القاضي لتسوية نزاع الرد لا يمكن للطرف المتضرر أن يطعن فيه.

\section{الخاتمة:}

وفي الختام يمكن القول بأن المشرع الجزائري خطا خطوة جيدة في التشريع الجديد لما حظيت به اتفاقيات التحكيم من اهتمام.

لقد خصص لكل من "شرط التحكيم" و"|تفاق التحكيم" بقسم خاص للا لـما من أهمية في نظام التحكيم. فاعتبر اتفاقيات التحكيم عقد ككل العقود له خصوصياته. يتضح لنا مما درسنا أن اتفاق التحكيم أو اتفاقيات التحكيم كما سماه المشرع الجزائري هو الأساس الذي يبنى عليه نظام التحكيم.

فهي الوسيلة الحديثة البديلة لحل النزاعات بين الأطراف التي تسهل الوصول للحق مراعاة لمصالح الأطراف بأقل

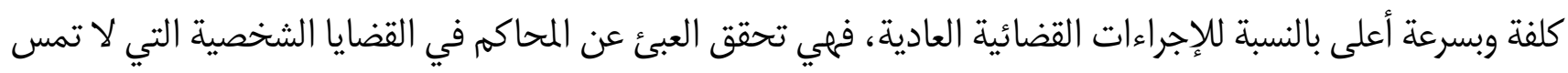

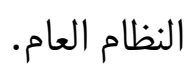




\title{
دراسة في المقتضيات الجديدة الضابطة لعمل البنوك الإسلامية
}

\section{في معريتانيا على ضعء التجربة المغربية}

\author{
dor ex \\ دكتـــــــور في الحقــــــوق
}

\section{مقدمة:}

عرفت موريتانيا البنوك الإسلامية منذ العام 1985 من خلال بنك البركة الإسلامي، بنك الوفاء حاليا، إلا أن الاعتماد

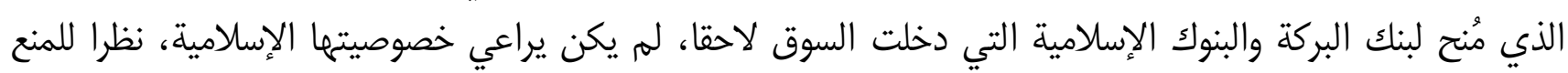

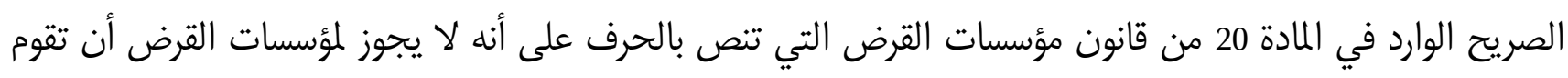

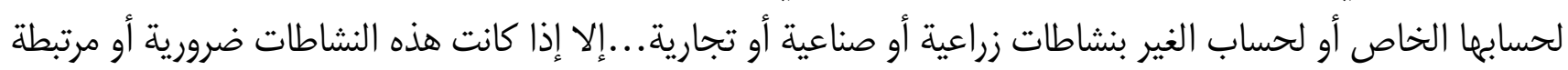
بتحصيل ديونها.

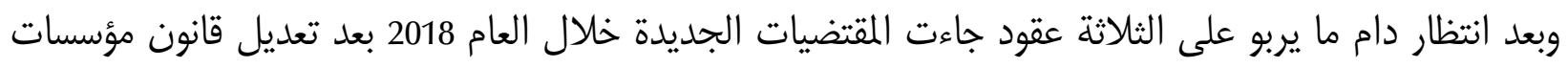

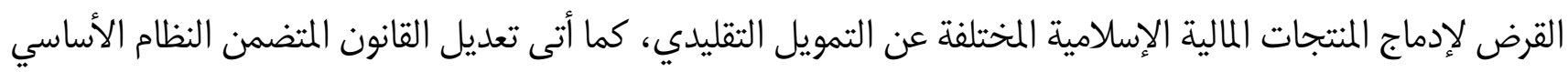

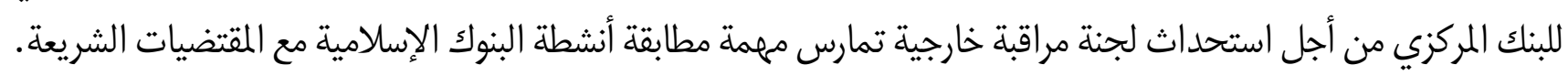
وقد اعتمد المشرع الموريتاني على غرار المغربي مقاربة الإدماج من أجل خلق انسجام داخل الحقل البنكي، وهي ذات

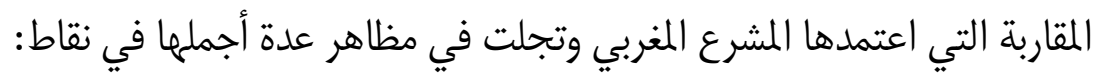
- - إدماج المقتضيات الضابطة لعمل البنوك الإسلامية في صلب القانون البنكي

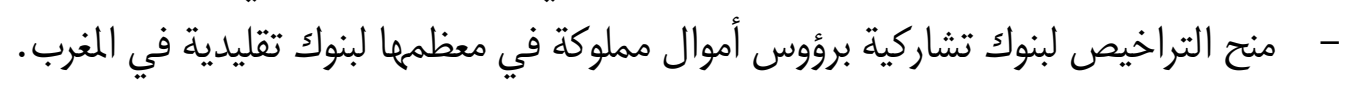

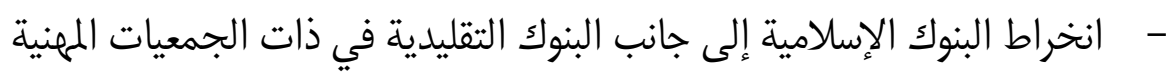

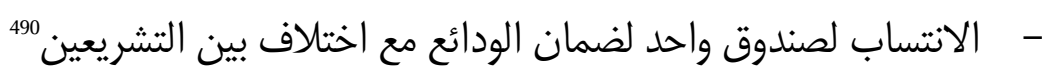
وهي المقاربة التي تخدم التنافسية وتوفر للبنوك الإسلامية جوا يمكنها أن تنموا فيه وتنضج بعيدا عن الضربات الني

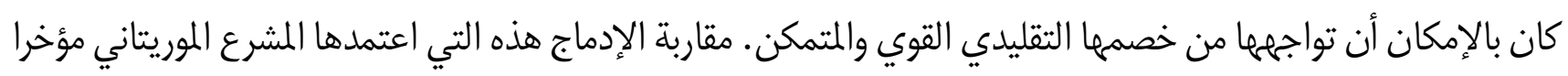

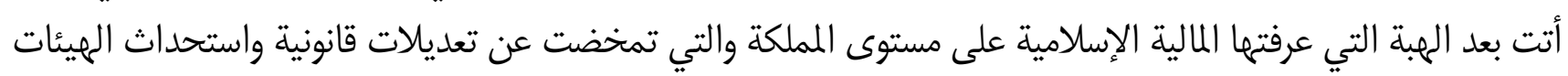

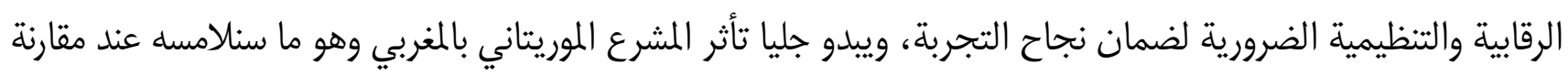
المقتضيات، وهو استمرار لمنهج التأثر الواضح في المدونة التجارية وقانون الالتزامات والعقود الموريتاني.

490490 ــبالإضافة إلى انسجامها في صندوق ضمان ودائع البنوك التشاركية تلزم هذه البنوك بالانضمام للصندوق الجامع المعني بضمان الودائع

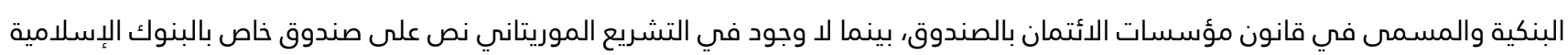
ما يعني الاكتفاء بصندوق واحد تنسجم فيه كافة البنوك العاملة على أرض الجمهورية الإسلامية الموريتانية. 
ونقف هنا على إيجابيات مقاربة الإدماج:

أ. عدم تشتيت المقتضيات المنظمة للمجال البنكي، على اعتبار أن حقبة القطيعة ومناصبة العداء بين النظامين أصبحت متجاوزة، لكونها لا تخدم النظامين وخصوصا البنوك الإسلامية لأنما تدخل على نظام ضارب في القدم

$$
\text { اكتسب قوته ومكانته مع الزمن. }
$$

ولكون البنوك بغض النظر عن طبيعتها تمارس نفس الأنشطة من الناحية الشكلية من قبيل الإيداع وتقديم التمويل

$$
\text { مع اختلاف الآليات المعتمدة. }
$$

فالبنوك التقليدية تعتمد آلية واحدة هي القرض بالفائدة في حين تعتمد البنوك الإسلامية آليات متعددة تصل إلى ست عشرة آلية للتمويل من قبيل المرابحة والإيجار والمشاركة... وقد نص المشرعين المغربي المعروفة. وترك الباب مفتوحا أمام باقي المنتجات مع شرط المطابقة مع المقتضيات الشرعية والمقتضيات المنصوصة في القانون

ب. وحدة الجهرة الوصية على المجال في كلا النظامين وهي البنك المركزي الذي ينهض بمرمة الرقابة والإشراف، من خلال هيئاته مع اختلاف في طبيعة التعامل مع النظامين نظرا للطبيعة المختلفة، وفي إطار الرقابة الشرعية فقد منحها القانون المغربي للمجلس العلمي الأعلى في حين أبقت عليها موريتانيا في دائرة اختصاص البنك إكناص المركزي من خلال لجنة مستحدثة لهذا الغرض.

ومن تجليات الإدماج كذلك الترخيص للبنوك التقليدية بممارسة الصيرفة الإسلامية من خلال فروع أو شبابيك إسلامية نص القانون الموريتاني بهزا الخصوص على مقتضيات ظاهرها المحافظة على أسلمة تلك العمليات واستقلالها استقلالا ماليا تاما عن البنك الأصيل، حيث نصت الفقرة الأخيرة من المادة 40 من قانون مؤسسات القرض الموريتانية على أنه "تمنح الشبابيك الإسلامية مخصصات من رأس المال وتتمتع باستقلالية تمكنها من فصل أنشطتها كليا عن الأنشطة التقليدية

$$
\text { لمؤسسات القرض المعنية". }
$$

وتجسيدا لمسيرة الإدماج أتى النص صراحة على سريان القانون البنكي على البنوك الإسلامية فيما عدا الحالات التي أتى النص عليها في القسم الثالث من قانون مؤسسات الائتمان والهيئات المعتبرة في حكمما بعنوان "البنوك التشاركية"، ويقابلها الباب الثالث من قانون مؤسسات القرض الموريتاني تحت عنوان "المالية الإسلامية".

وفي هذه الورقة أتناول المقتضيات المستحدثة من خلال القانون 034.2018 المعدل للنظام الأساسي للبك المركزي والمنشئ لهيئة المطابقة الشرعية (المحور الأول)، قبل الخوض في المقتضيات الجديدة المدمجة في القانون رقم 036.2018 المنظم لمؤسسات القرض في موريتانيا (المحور الثاني).

491ـ المادة 58 من قانون مؤسسات الائتمان والهيئات المعتبرة في حكمها" يمكن البنوك التشاركية أن تمول العملاء بواسطة المنتجات التالية على الخصوص (عددت المادة المنتجات: المرابحة والإجارة والمشاركة والمضاربة والسلم والاستصناع) 492 المادة رقم 36 من ق م ق" يمكن للبنوك الإسلامية المعتمدة أن تمول زبناءها بواسطة كل المنتجات المطابقة لضوابط الشريعة وخاصة

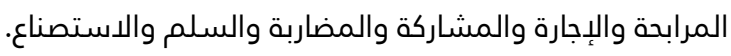




\section{المحور الأول-استحداث هيئة المطابقة مع أحكام الشريعة}

تم سن القانون رقم 034.2018 ويتضمن النظام الأساسي للبنك المركزي الموريتاني، ويهدف حسب المادة الأولمنه إلى

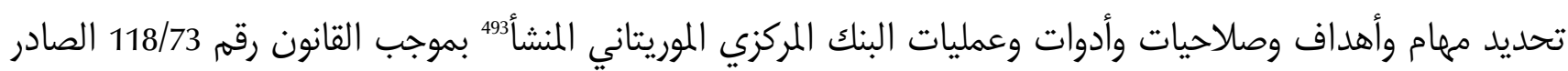
بتاريخ 30 مايو 1973 الذي يلغي ويحل محل القانون رقم 004-2007 الصادر بتاريخ 12 يناير 2007). وقد أتت هذه التعديلات للمواءمة مع قانون مؤسسات القرض الذي تم تعديله مؤخرا من أجل إدخال المتتضيات الضابطة لعمل البنوك الإسلامية ولتكتمل الصورة، حيث يتطلب الاعتراف بالبنوك الإسلامية احترام خصوصيتها الأبرز المتمثلة في استحداث هيئة للمطابقة مع أحكام الشريعة الإسلامية.

وأدرس في هذا المحور تشكيلة هذه الهيئة -أولا-قبل الوقوف على العمل المنوط بها-ثانيا-

\section{أولا-تشكيلة الهيئة:}

نصت المادة الثامنة 494 من هذا القانون على استحداث هيئة سمتها بهيئة المطابقة مع الشريعة الإسلامية، كما نصت على استحداث هيئات أخرى للرقابة والتدقيق.

وهي خطوة هامة أتت بالموازاة مع إصدار القانون البنكي المعروف بقانون مؤسسات القرض والذي تضمن بابا باسم المالية الإسلامية، وهي الخطوة التي تشكل التكامل بين الجوانب التنظيمية والرقابية الأساسية لعمل البنوك الإسلامية. وتعتبر الرقابة الشرعية أمرا ضروريا في إطار الصيرفة الإسلامية وهو ما جعل كل الأنظمة القانونية تتشأ هيئات من هذا

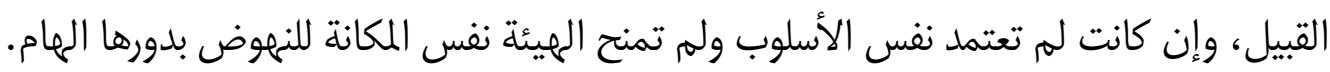

وقد دخلت هذه التعديلات الجديدة من البوابة التي دخلت منها أهم القوانين الموريتانية وهي البوابة الشمالية الغربية وأقصد الشقيقة المغرب،والتي عرفت البنوك الإسلامية مؤخرا باسم مختلف وهو البنوك التشاركية، وقد شكلت لذات الغرض هيئات جديدة من ضمنها هيئة للرقابة الشرعية أسمتها باللجنة الشرعية للمالية التشاركية حسب ما ورد في الفصل الخامس لئس

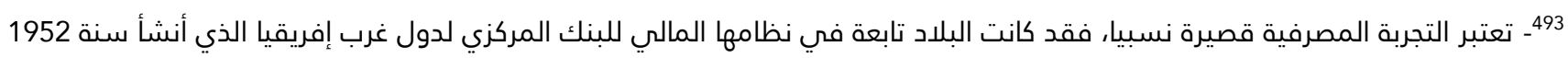
وباشر العمل 1962 يوجد في أفريقيا اتحادين ماليين يرتبطان بعدة مصارف مركزية؛ الأول هو "البنك المركزي لدول غرب أفريقيا (BCEAO) " والثاني هو " بنك دول وسط أفريقيا (BEAC) "تستخدم دول هذين الاتحادين الفرنك الأفريقي في التداولات القانونية. وأول بنك ظهر على أرض الجمهورية الإسلامية الموريتانية كان البنك الموريتاني للتنمية BMD يناير 1973 وتوالى بعد ذالك ظهور البنوك، ولم يظهر البنك المركزي إلا سنة 1973 بعد استقلال البلاد عن النظام النقدي لدول غرب إفريقيا واتخذت موريتانيا من الأوقية عملة لها وكانت عملية الاستقلال النقدي جريئة جدا ومفيدة لتكوين رأس المال القومي الفتي وحمايته وتتم معادلته على أساس سلة عملات تضم الفرنك الفرنسي والليرة الإيطالية ... قديما قبل ظهور العملة الأوربية الموحدة 494-ـ في إطار الفصل الثاني المخصص لهيئات الحكامة في البنك المركزي، حيث نصت المادة على ״تتألف هيئات القرار في البنك المركزي من: 1 ) المحافظ ويساعده محافظا مساعدا 2) (2 3) مجلس السياسة النقدية

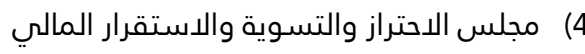
للبنك المركزي كذلك لجنة للمطابقة مع ضوابط الشريعة ولجنة للتدقيق ومراقب ومدقق خارجي. 
من الظهير الشريف الذي أحدثت بموجبه هذه اللجنة 195 التابعة للجنة الإفتاء بالمجلس العلمي الأعلى الذي تم تعديل نظامه الأساسي من أجل إنشاء هذه الميئة.

والاختلاف البارز بين النظامين القانونيين في هذا المجال أن المملكة أوكلت مهمة الرقابة الشرعية -وهو عمل فقهي -

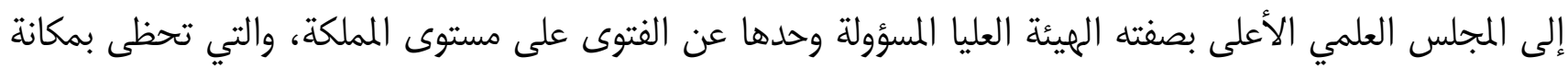
دستورية هامة جدا حيث يترأس الملك هذا المجلس ويضم في عضويته وزير الأوقاف بالإضافة إلى كبار علماء وفقهماء المملكة. وبالتالي فقد أعطوا القوس باريها ومنحوا الرقابة لأصحابها الذين تعودوا إصدار الفتوى، ولكِون المجلس -نظرا لمكانته المعنوية-بمنأى عن التأثر بوسائل الضغط.

أما في موريتانيا فقد بدا الأمر مختلفا حيث تم إلحاق هيئة المطابقة بصفة مباشرة للمجلس العام للبنك المركزي

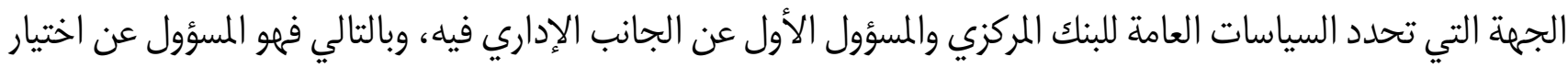

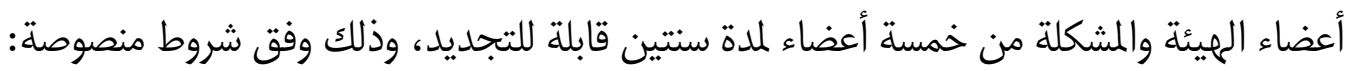

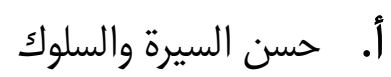
ب. التكوين الأكاديمي وهو ما يعني استبعاد غير الأكاديميين

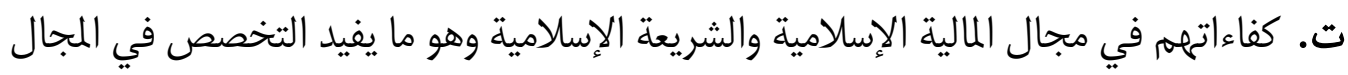
ث. الخبرة الواسعة في المجال ومختلف المجالات ما يعني أن يكون صاحب ثقافة شمولية

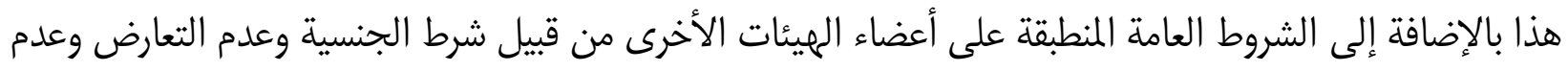

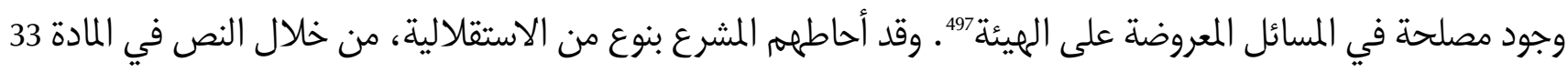

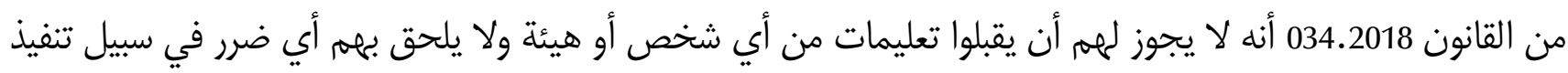
مهامeم.

ولمقارنتها من حيث التشكيلة بنظيرتها المغربية والمسماة بمقتضى القانون المنشئ لها باللجنة الشرعية للمالية التشاركية

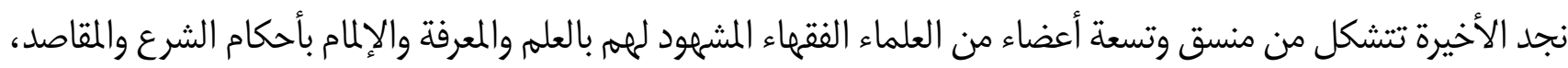

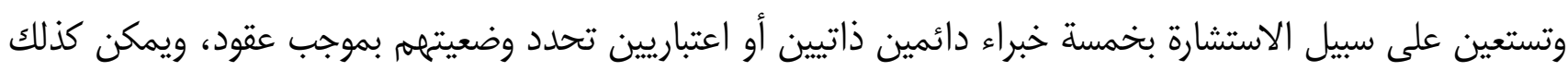

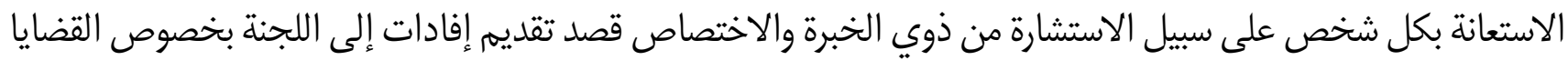
المعروضة.

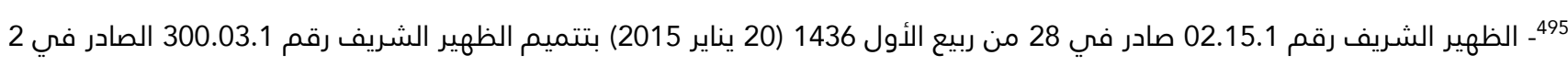
ربيع الأول 1425 (22 أبريل 2004) بإعادة تنظيم المجالس العلمية. 496 تـناوله المشرع من خلال القسم الثالث وحدد من خلال 19 المهام الكبيرة المنوطة به بصفته الأعلى في البنك ويرأسه استحقاقا السيد محافظ البنك المركزي ومساعده بالإضافة لعضوين يقترحهما الوزير الأول والاثنين يقترحهما وزير الاقتصاد والمالية وعضو منتخب من طرف العمال محمي في إطار مهامه كممثل للعمال بمقتضى المواد 125 وما بعدها من مدونة الشغل (المادة 25).

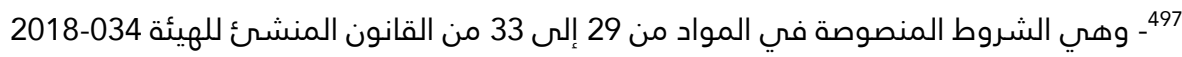
498 المادة 10 المكررة مرتين من الظهير الشريف السالف الذكر 300.30 .1 
وهذه التشكيلة الكبيرة والمتخصصة تجد مبررها في المهام الكبيرة المنوطة باللجنة وهي المنصوصة في المادة 10 المكررة مرتين من القانون 02.15.1، والتي تتجاوز البنوك التشاركية نحو استصدار الصكوك والتأمينات التكافلية، وكل الأقسام المستجدة والمتعلقة بالمالية التشاركية، وهو ما لا نجد له مثيلا في نظيرتها الموريتانية التي فيما يبدو أنها أنشئت حكرا لمطابقة

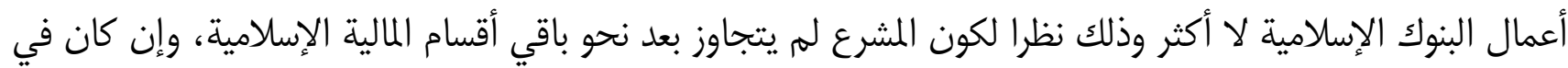
إطار تنظيم عمل هذه البنوك أطلق مسمى المالية الإسلامية على الباب الثالث التي تنضوي تحته تلك المقتضيات كما أتى لتى

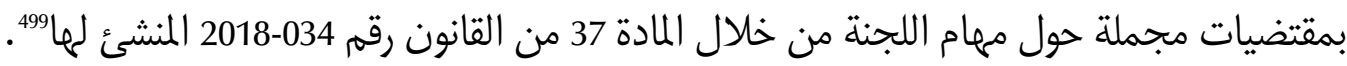

\section{ثانيا-المهام المنوطة بالهيئة}

لأجل المهام المستحدثة لأجلمها تجتمع اللجنة كل شهرين وكلما رأت ضرورة لذلك، ولم يته النص صراحة على إلزامية الاجتماع هذه لكنها واضحة عندما عاد المشرع ليؤكد على إمكانية الاجتماع كلما دعت الضرورة، وهو ما يفيد أن الحالة الأولى إلزامية نظرا لطابع التخيير في الثانية. وفيما يتعلق بالرعدف الذي أنشئت لأجله اللجنة وهو المطابقة مع أحكام الشريعة الإسلامية، نلاحظ أن في الإشارة إلى أحكام الشريعة الإسلامية استمرارا لما انتهجه المشرع الموريتاني في مدونة التجارة التي نصت على أنه يرجع إلى أحكام الشريعة فيما لم يتهم النص عليه في هذا القانون 500

ما يعني أن المشرع حين يتعلق الأمر بالمعاملات المالية ينتهج نهج التوسع وعدم التخندق في مذهب واحد في باب المعاملات، وخلافه في باب الأحوال الشخصية ولعل السب وراء هذا الانفتاح في باب المعاملات هو عامل العالمية التي تتسه بها المعاملات التجارية، والتي تقوم على مبدأ الاستير اد والتصدير والحوالات المصرفية ويتداخل فيها المحلي بالدولي، فمن غير الوارد في هذا الباب مراعاة مذهب بعينه خصوصا حين الحديث عن الحقل البنكي.

499- تختص لجنة المطابقة مع ضوابط الشريعة بالنظر في مطابقة المنتجات والعمليات والأنشطة المصرفية والمالية مع ضوابط الشريعة الإسلامية..." عبارة والمالية التي أضافها المشرع بعد المصرفية في هذه المادة تعتبر نافذة بالإمكان أن تدخل منها كل ما قد يستحدثه البنك المركزي لاحقا من عمليات مالية من قبيل الائتمان التكافلي واستصدار الصكوك بـد 500- المادة 1465ـمن مدونة التجارة الموريتانية تنص على أنه " يرجع إلى أحكام الشريعة الإسلامية في كل ما لم ينص عليه في هذه مذهـ المدونة. وكل غموض في النص الفرنسي يرجع في معناه إلى النص باللغة العربية. 501 أعتقد أن القانون المغربي نص في في إحدى المواد على أن مذهب مالك هو مذهب الدولة إلا أنه ما فتـئ يكرر في القانون المحدث للجنة الشرعية على المطابة مع الشريعة الإسلامية ومقاصد الشريعة (أذكر هنا الحالات التي أثبت المشرع تمسكه بالمقاصد وهل اختلف فئه فيها عن المشرع الموريتانـي) 502- المادة 311 " يرجع في تفسير مدلولات هذه المدونة عند الإشكال إلى مشهور مذهب مالك". كل ما لم ينص عليه في هذه المدونة يرجع فيه إلى مشهور مذهب مالك.

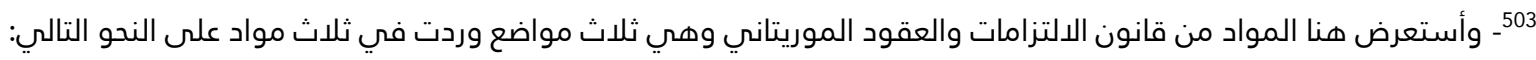
المادة 455 كل ما لم ينص عليه في هذا الفصل يرجع فيه إلى المذهب المالكي. المادة 472 يرجع في تغليظ اليمين بالزمان والمكان والهيئة إلى ما هو مقرر بالمذهب المالـئ الكي. المادة 1179 يرجع إلى مذهب مالك في كل ما لم ينص عليه في هذا الأمر القانوني. وكل غموض في النص الفرنسي يرجع في معناه إلى النص باللغة العربية. 
وهذه الهيئة في إطار المطابقة تبدي الرأي في الأمور المرفوعة إليها من قبل هيئات القرار في البنك المركزي 504 وهو ما

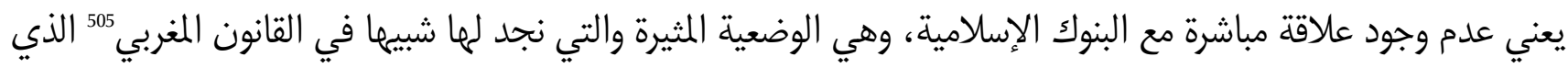

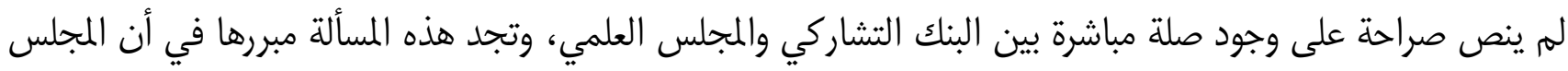

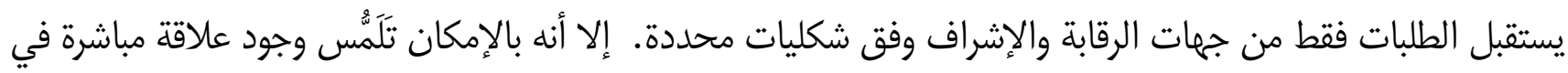

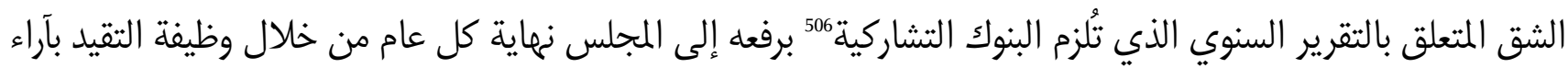
اللجنة.

$$
\text { وقد حددت المادة } 37 \text { من القانون 034-2018 الصلاحيات الممنوحة للهيئة على النحو التالي: }
$$

1- تقوم بإعداد الدراسات وتعطي رأيها: بخصوص الأعمال المتعلقة بالمالية الإسلامية التي ينوي البنك المركزي القيام ب. 2- تقوم بإعداد الدراسات وتعطي رأيها في مسائل تطبيق الشريعة لأنشطة البنك الإسلامي والمؤسسات الأخرى التي

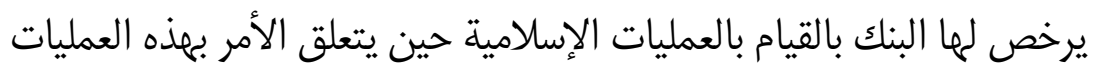
3- وحدها المسؤولة عن إجازة المنتجات المالية الإسلامية لضمان مطابقتها للشريعة الإسلامية الإداية 4- تعطي الرأي بخصوص إجراءات التدخل المتعلقة بأدوات التمويل المرفوعة من طرف مجلس الماتس السياسة النقدية. ولأجل المهام الموكلة إليها تجتمع مرة كل شهرين إلزاما وكلما اقتضت الحاجة، وتكون مداولاتها صحيحة بحضور ثلاثة أعضاء على الأقل. وعند مقارنة هذه الصلاحيات بتلك الممنوحة للجنة المالية التشاركية نجد الأخيرة جاءت محددة للممام بدقة أكبر ومن خلالمبا تحديد للجهات المتدخلة وهي:

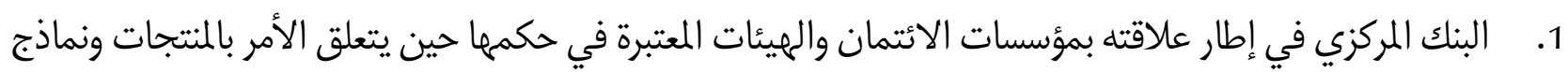

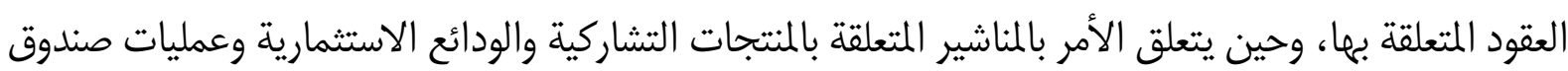

$$
\text { ودائع البنوك التشاركية. }
$$

2. هيئة مراقبة التأمينات في إطار علاقتها بمقاولات التأمين وإعادة التأمين عندما يتعلق الأمر بالتأمين التكافلي

504- في فقرتها الأخيرة أكدت المادة 37 من القانون 034-2018 " تبدي لجنة المطابقة مع ضوابط الشريعة رأيها بناء على طلب من إحدى هيئات القرار في البنك المركزي. 505- المادة 10 المكررة ثلاث مرات: تحال إلى اللجنة الشرعية للمالية التشاركية طلبات إبداء الرأي في الأنشطة والعمليات المشار إليها في المادة الثالثة أعلاه عن طريق: - الثة - بنك المغرب بالنسبة لطلبات إبداء الرأي المقدمة من قبل مؤسسات الائتمان والهيئات المعتبرة في حكمها.

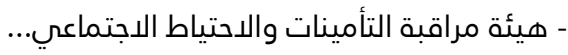
- الهيئة المغربية لسوق الرساميل... 506 المادة 37 من قانون مؤسسات القرض " يجب على البنوك الإسلامية والمؤسسات الأخرى المعتمدة أن ترفع إلى البنك المركزي...تقارير تقييمية حول مطابقة عملياتها وأنشطتها لآراء لجنة المطابقة مع ضوابط الشريعة. المادة 63 من قانون مؤسسات الائتمان المغربي " ترفع البنوك التشاركية إلى المجلس الأعلى المشار إليه في المادة 62 أعلاه عند نهاية كل سنة محاسبية تقريرا تقييميا حول مطابقة عملياتها وأنشطتها للآراء بالمطابقة الصادرة عن المجلس العلمي الأعلى السالف الذكر. 
3. الهيئة المغربية لسوق الرساميل في إطار العلاقة بالجهات المصدرة لشهادات الصكوك كيفما كانت.

$$
\text { وتمارس هذه المرام من خلال طلبات إبداء الرأي المرفوعة للجنة وفق الشكليات المحددة. }
$$

ويبدوا من الجلي أن عمل اللجنة يتجاوز البنوك التشاركية نحو التأمين وسوق الرساميل وهو ما لا نجد له شبيها عند نظيرتها الموريتانية التي يختصر عملها في إطار علاقتها بالبنك المركزي ومن خلاله البنوك الإسلامية، وذلك نظرا لعدم وجود تأمين تكافلي ولا شمادات صكوك إسلامية لا من حيث الواقع ولا من حيث التنظيم القانوني. وتصدر اللجنة آراءها باسم المجلس العلمي الأعلى وبإجماع أعضائما الحاضرين الذين شاركوا في مداولاتمها، وتحدد الإجراءات العملية للتطبيق بواسطة النظام الداخلي للجنة المصادق عليه من طرف المجلس.

\section{المحور الثاني-المقتضيات المنصوصة في القانون رقم 2018/036 المنظم لمؤسسات القرض} لأول مرة وبعد فترة من الإهمال التشريعي الذي عرفه الحقل المصرفي الإسلامي أتى القانون البنكي الجديد المعروف

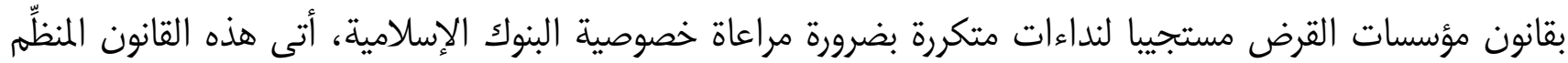
لمؤسسات القرض وهو الضابط لأعمال البنوك والهيئات المعتبرة في حكمها. وقد عمد المشرع إلى تعريف عمليات القرض وأشار إلى أنه لأغراض هذا القانون تعتبر بمثابة عمليات قرض عمليات التمويل الخالية من نسبة الفائدة و/أو تلك المبنية على تقاسم الأرباح والخسائر، في إشارة إلى اعتبار المنتجات المعتمدة في البنوك الإسلامية إنما هي قروض مختلفة عن القروض التقليدية، وهو مسعى منه لضبط المصطلحات ما أمكن وتماشيا مع مقاربة الإدماج والانسجام التي يأتي القانون مجسدا لها، ومن أجل الإتتعاد ما أمكن عن التنافر الذي كان يطبع علاقة مانة البنك الإسلامي بالتقليدي قديما.

وفي هذا المحور أتناول المنتجات المنصوصة كبديل للقرض التقليدي (أولا) قبل تناول أحكام متفرقة (ثانيا) ومستحدثة

$$
\text { في إطار تنظيم البنوك الإسلامية. }
$$

\section{أولا-المنتجات الإسلامية (التشاركية)}

من المعروف أن الآلية الوحيدة للتمويل المعتمدة في البنوك التقليدية هي القرض بفائدة والأمر مختلف في البنوك الإسلامية حيت توجد ستة عشر منتجا بديلا للقرض، وقد نص القانون الموريتاني كما المغربي على الصيغ الست المعروفة، وترك الباب مفتوحا أمام أي منتج آخر بشرط المطابقة مع الشريعة والمقاصد، واعتماد الخصائص الفنية المعتمدة، وهذه الصيغ المنصوصة هي:

أ. المرابحة: وهي بصيغتها الفقهية عملية بيع عادية يصرح فيه البائع بالثمن الأول ويضع عليه ربحا لتنتقل السلعة إلى المشتري بثمنها الأول وزيادة ربح معلوم، وهي المنتج الأهم والذي يكاد يجتاح عمليات البنوك الإسلامية نظرا لبساطتها ودرجة المخاطرة المنخفضة فيها خصوصا في ظل الإلزام بالوعد، وهي النقطة التي أثارت إشكالات شرعية

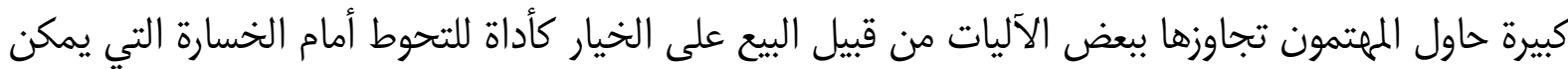
أن تلحق بالبنك فيما لو نكث الزبون عن الشراء، بالإضافة إلى التعويض الملزم للعميل جراء نكوله. 


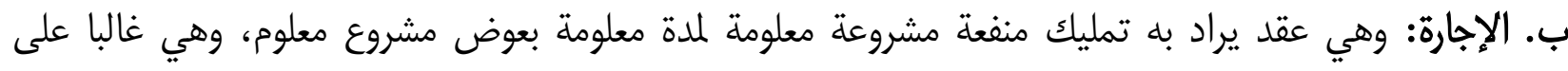

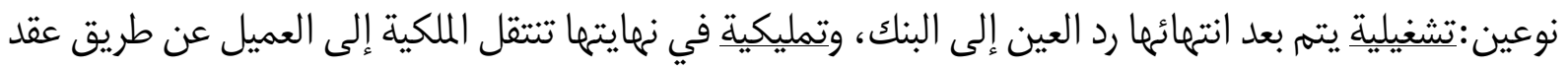

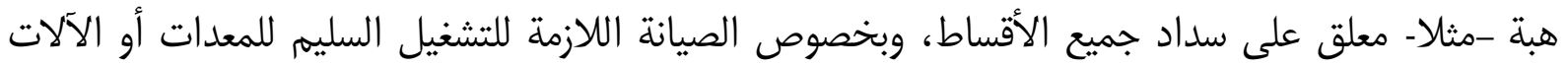

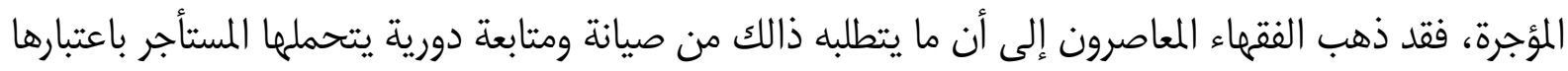

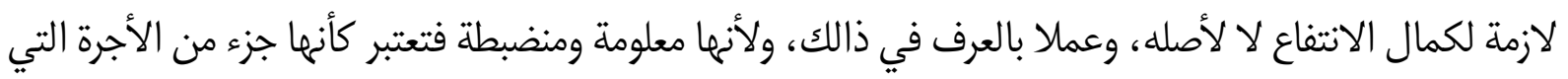

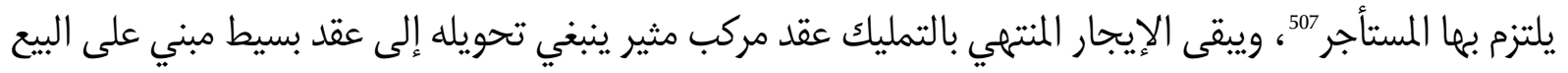
بأجل 508.

ت. المشاركة: وأسلوب المشاركة يعني قيام المصرف الإسلامي بمشاركة غيره بقصد تتمية أحواله بشروط وضوابط يتفق

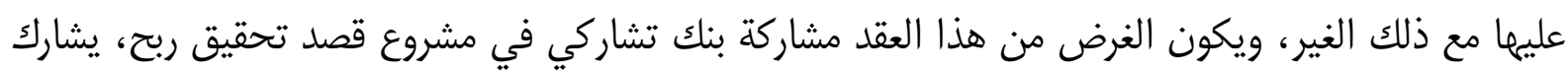

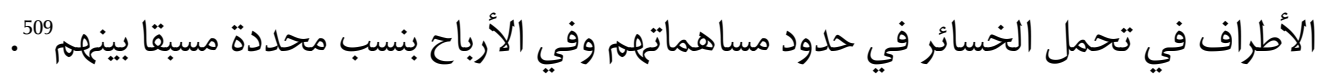
وتتخذ المشاركة شكل المشاركة الثابتة وبمقتضاها يبقى الأطراف شركاء إلى حين انقضاء العقد الرابط بينهم، والمشاركة المتناقصة وبمقتضاها ينسحب البنك تدريجيا من المشروع وفق بنود العقد. ث. المضاربة: وهي عقد على المشاركة بين مالك المال وعامل يقوم بالاستثمار بما لديه من خبرة، ويقتسمون الأرباح

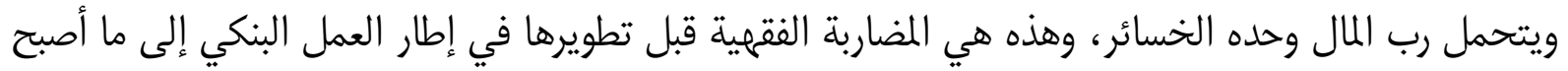

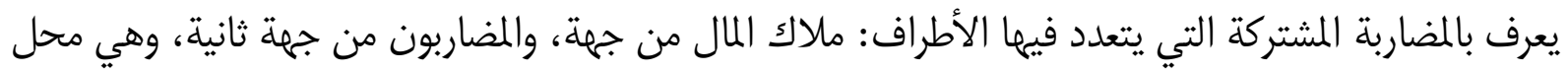

$$
\text { إشكالات شرعية. }
$$

ج. السَّلمُ: يعرفه علماء الشافعية والحنابلة بأنه عقد على موصوف في الذمة مؤجل بثمن مقبوض في مجلس العقد،

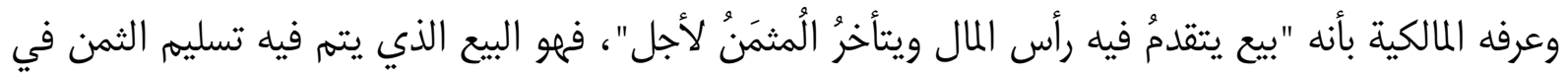
مجلس العقد وتأجيل تسليم السلعة الموصوفة بدقة إلى وقت محدد في المستقبل.

وإذا دخل المسلم إليه في عقد سلهم مستقل مع طرف ثالث على سلعة مواصفاتها مطابقة للسلعة المتعاقد على تسليمها

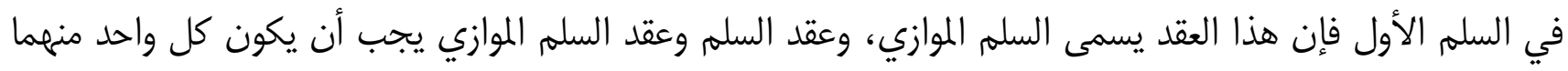

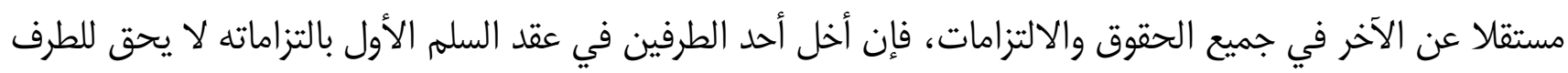

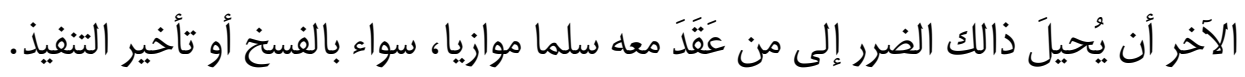

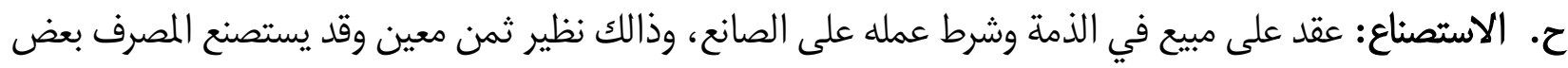

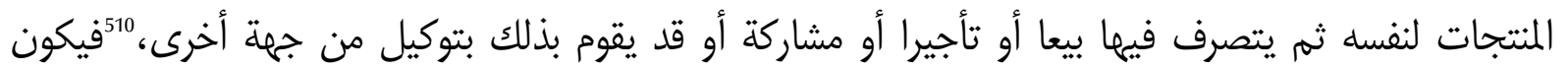

20/1 م507 508- عبد السلام بلاجي، إعادة هيكلة وتمويل منتجات الصيرفة الإسلامية، المؤتمر العالمي الحادي عشر لعلماء الشريعة في المالية الإسلامية، 509- المادة 58 من القانون رقم 16-12 -103 قانون مؤسسات الائتمان والهيئات المعتبرة في حكمها. 510 - هذا الأسلوب يمكن أن يحقق ما يلي: 
مُسْتَصنعاً، وقد يكون صانعا من خلال تلقي طلبات العملاء لتوفير سلع أو منشآت صناعية أو معمارية بمواصفات

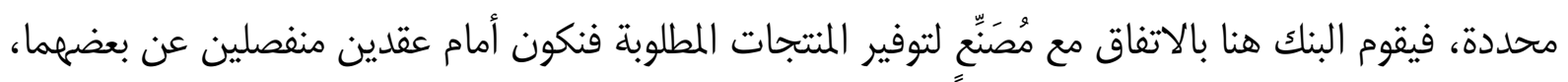

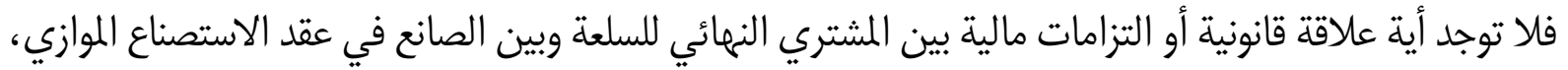

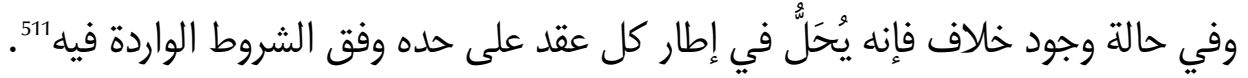

وهذا الأسلوب في تطبيق الاستصناع هو السائد في المصارف الإسلامية لملاءمته لطبيعة العمل المصرفي والمسمى بعقد الاستصناع الموازي.

$$
\text { وقد أردت من استعراض هذه المنتجات توضيح مسائل هي: }
$$

هذه الصيغ تم تغييرها عن صيغتها الفقهية المعروفة لتتلاءم مع متطلبات التمويل والضمانات التي تراها البنوك

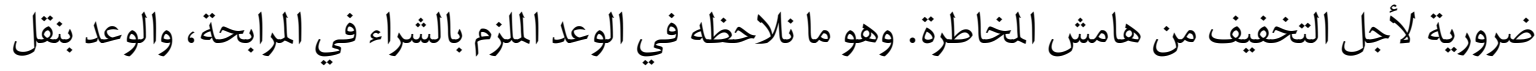

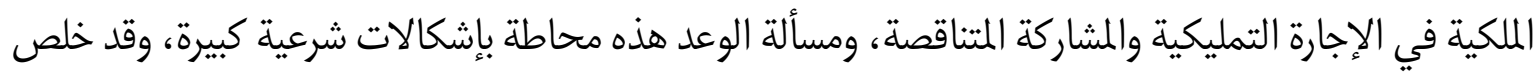
الفقه والقانون إلى اعتبار الوعد ملزما، لكن الإلزام لا يعني إرغام الملتزم على الشراء إلى إنما يعني تحمله لمأل للأضرار التي قد تلحق البنك من جراء نكول العميل. ولضرورة التماشي مع حاجيات الزبناء ولاستغلال المنتجات الشرعية تم تغيير عقد السلم المعروف إلى سلم

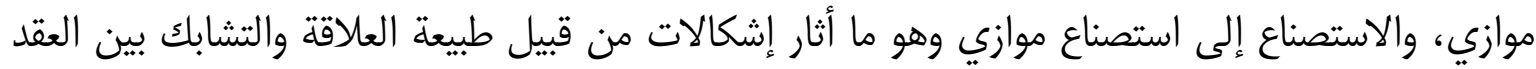

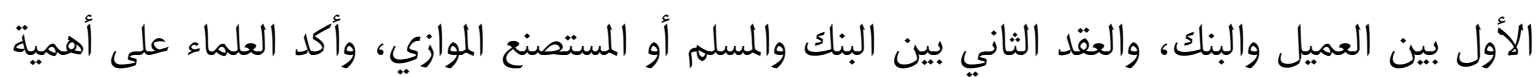

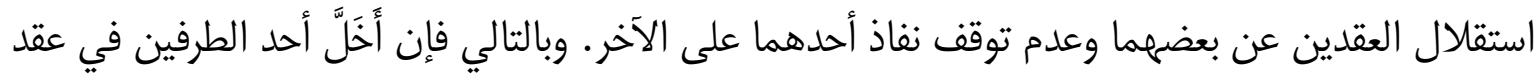

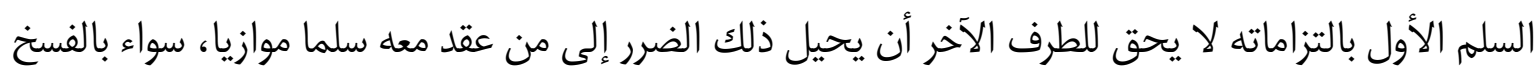
أو تأخير التنفيذ.

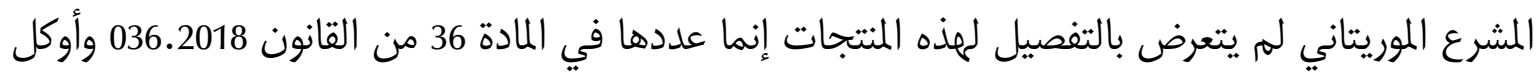

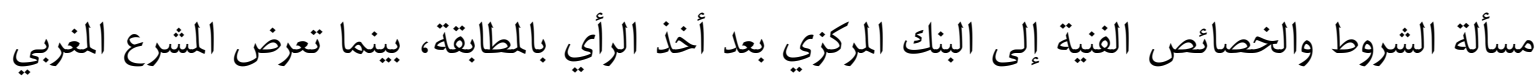

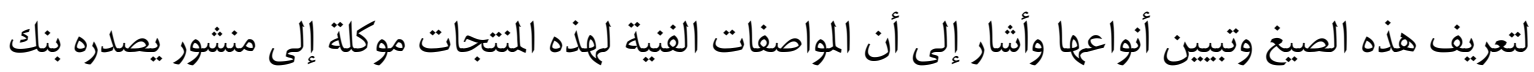

$$
\text { المغرب. }
$$

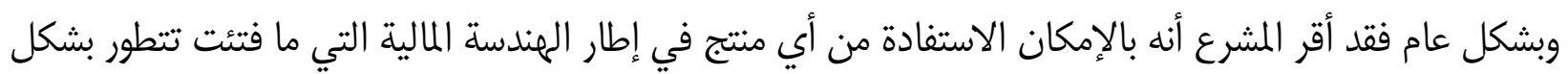

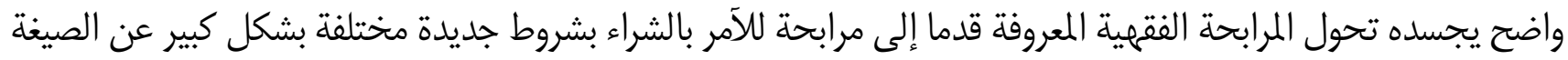

1. قيام المصرف بوظيفتين تمويلية وتجارية من خلال تمويله للمنتجين بشراء منتجاتهم مسبقا 2. توفير السيولة النقدية للمنشآت الصناعية بدل اللجوء إلى القروض الربوية

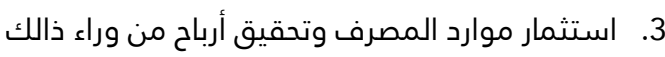
511 - شوقي أحمد دنيا - الجعالة والاستصناع تحليل فقهي واقتصادي - ط2، جدة البنك الإسلامي للتنمية، المعهد الإسلامي للبحوث والتدريب 
المعهودة، ونفس الشيء نلاحظه في السلم والسلم والموازي والاستصناع والاستصناع الموازي، وكذا المضاربة المشتركة في

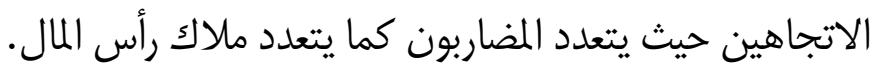

والأمر ينطبق على كافة الصيغ وليس هذا بالأمر المنكر في الشريعة، حيث من المعروف أن الفتوى تختلف باختلاف

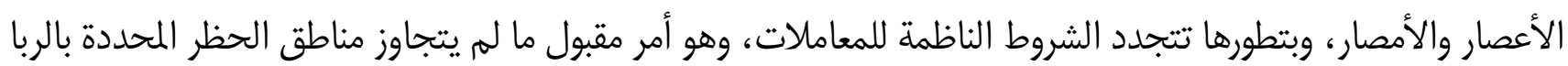

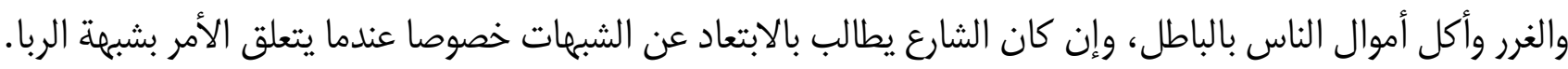

ثانيا: أحكام متفرقة: - ( باء جاء في القانون المنظم للبنوك الإسلامية في موريتانيا كما في المغرب بعض الأحكام المتفرقة أحاول هنا الوقوف عليها بإيجاز:

\section{أ. الشكل الذي يتخذه البنك الإسلامي:}

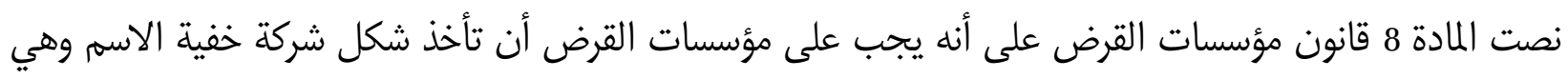

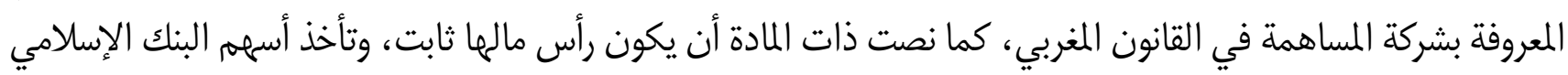
شكلا اسميا ذا قيمة محددة.

ب. ب. الاعتماد: تخضع البنوك الإسلامية للقواعد العامة للاعتماد كما أشارت إلى ذلك المادة 33 وذلك فيما لا يتعارض مع الأحكام

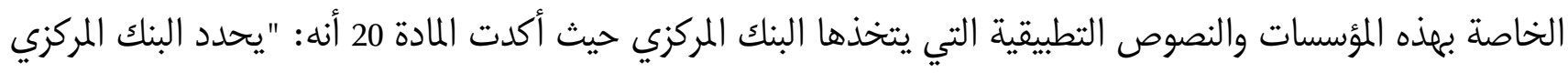

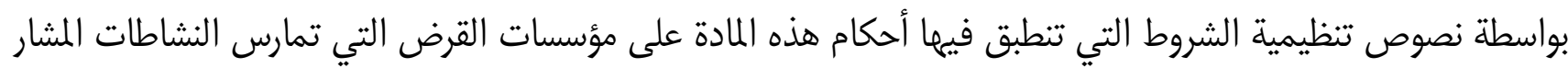

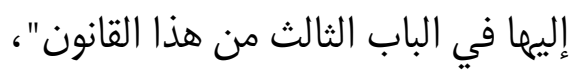

\section{ت. حظر التعامل بالفائدة:}

على غرار التشريعات الضابطة لعمل البنوك الإسلامية حظر المشرع الموريتاني التعامل بالفائدة وليس الأمر بالمستغرب

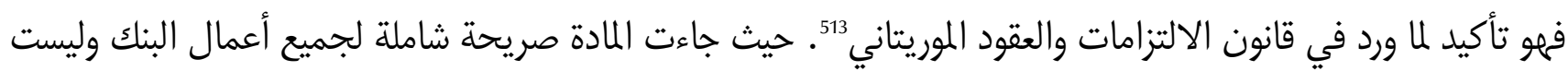

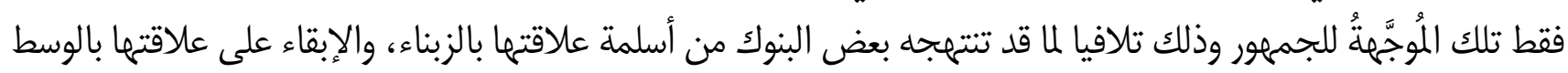
البنكي المحلي والدولي كما هي، فجاءت المادة لقطع الطريق أمام أي تعامل بالفائدة.

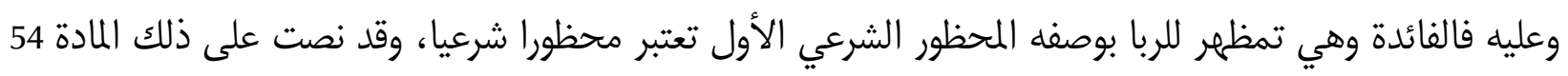

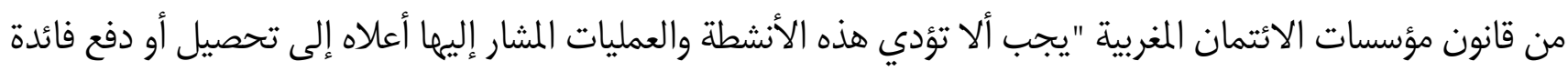
أو هما معا" .

\section{ث. الودائع:}

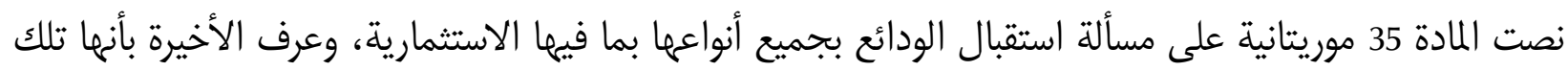

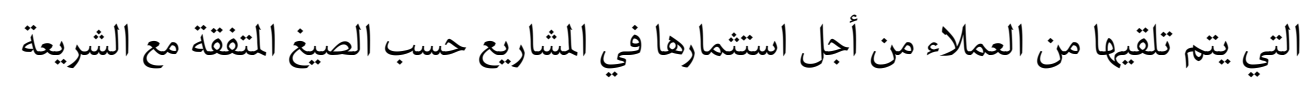

513.ـــ فص في قانون الالتزامات والعقود في ستة مواضع على منع كل ما من شأنه أن يؤدي إلى الربا، وبصيغة السلامة من الربا أحيانا. 
وأقف على ملاحظات:

ـ اختلاف الوديعة الاستثمارية من حيث الأصل عن الوديعة العادية لأن صاحبها يسلمها بدءً للبنك من أجل استثمارها

لا من أجل حفظها.

- يترتب على التمييز كما هو واضح في المادة أنه على البنك استفسار الزبون وأخذ الإذن من أجل استثمار وديعته.

وهو ما يثير مسألة الضمان: لأن المبالغ المسلمة على سبيل الاستثمار غير مضمونة بينما المسلمة كوديعة عادية تكون

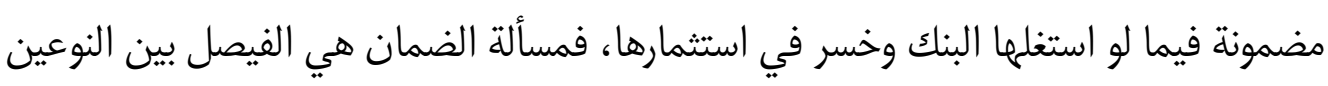
- الوديعة الاستثمارية يمكن استثمارها من خلال صيغ عدة فلم ينص القانون على صيغة واحدة من الضروري الالتزام بما، والأمر متوقف على نصوص تنظيمية بعد أخذ رأي لجنة المطابقة.

\section{ج. التقيد بالآراء بالمطابقة:}

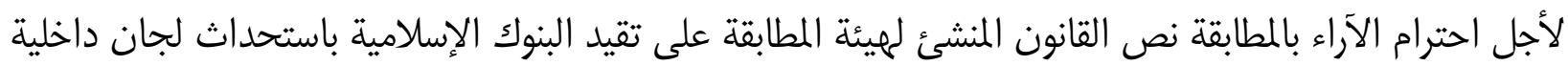

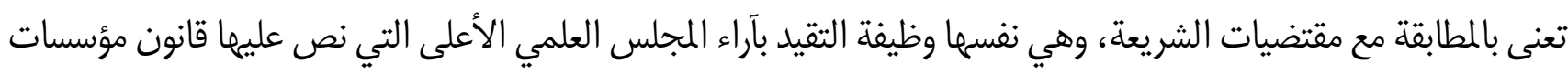

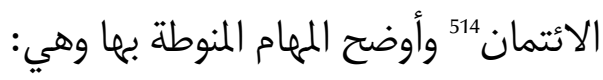
التعرف على مخاطر عدم المطابقة ضمان تتبع وتطبيق الآراء بالمطابقة

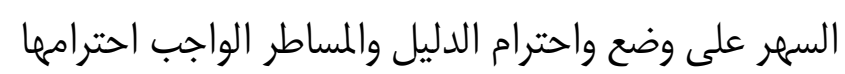

ومن الواضح أن المشرع حين استحداث لجنة المالية التشاركية ارتأى أن عمل هذه اللجنة يحتاج لرقيب داخل المؤسسات

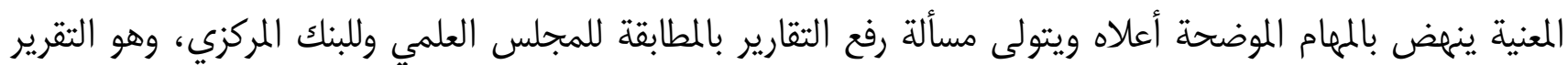

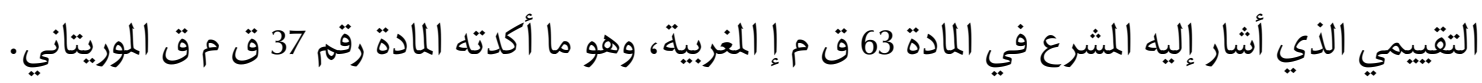
وبالتالي فإن هذه اللجنة كما في التشريع الموريتاني أو الوظيفة كما سماها المشرع المغربي مُلزمَةُ بمراقبة أعمال المطابقة

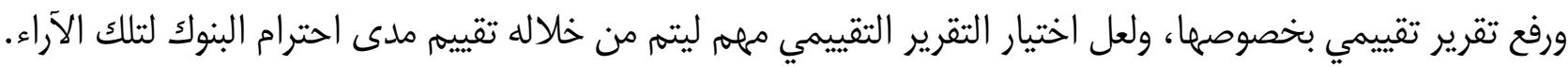

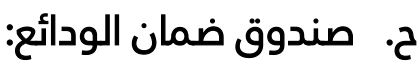

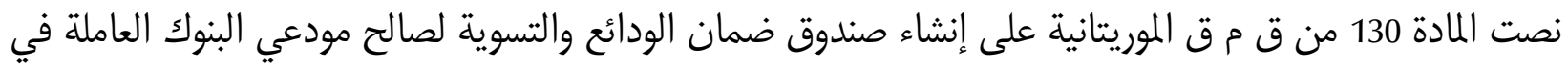

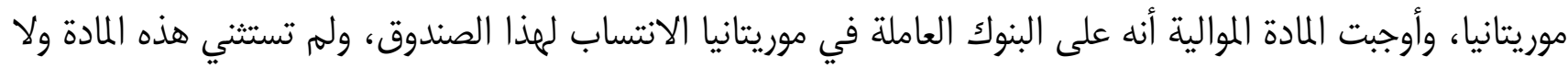

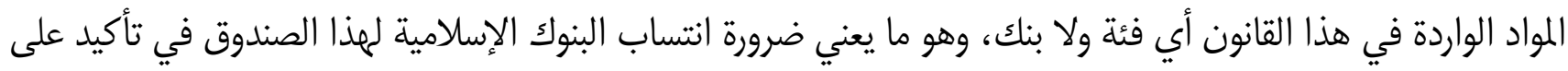

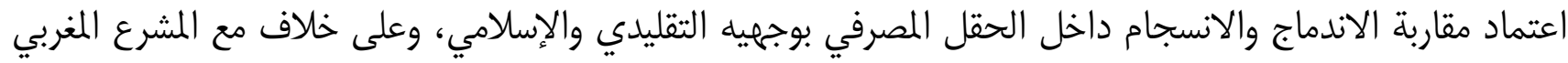

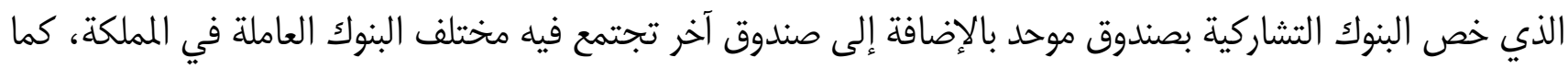


أوكل تسييرها لشركة مساهمة تؤسس لهذا الغرض يعهد إليها بتدبير هذا الصندوق بالإضافة إلى الصندوق المنصوص عليه

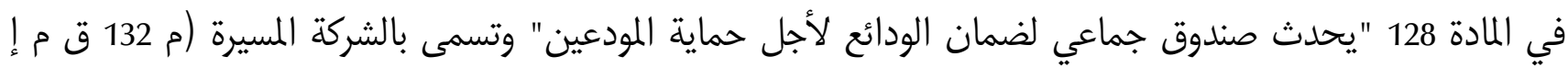

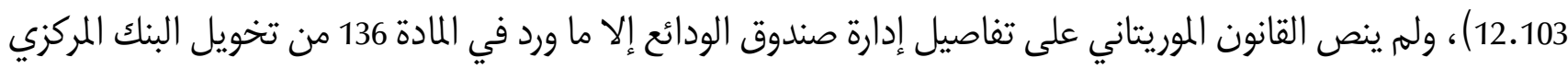
بواسطة نصوص تنظيمية بتحديد إجراءات إدارته وكافة الأمور المتعلق به.

ولعل للتمييز الذي انتهجه المشرع المغربي ما يبرره في ظل الاختلاف الكبير بين ودائع البنوك التشاركية ونظيرتها في

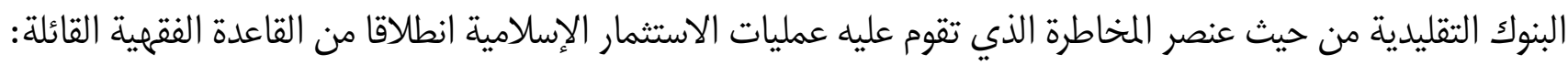
"الغنم بالغنم والخراج بالضمان"، وما دامت الطبيعة تختلف فهذا يعني وجود اختلافات جوهرية كان من الوارد مراعاتها.

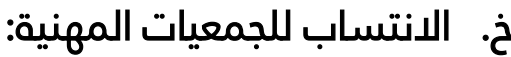
البنوك الإسلامية ملزمة بالانتساب لإحدى هذه الجمعيات حسب الفئة التي تنتمي إليها وهو ما يعني انخراط البنوك الإسلامية إلى جانب التقليدية في جمعية واحدة حسب المادة 145 ق م ق الموريتانية.

ويتهم اعتماد هذه الجمعيات من البنك المركزي وتسهر على مراعاة أعضائها لأحكام القانون وتبلغ البنك المركزي بأي

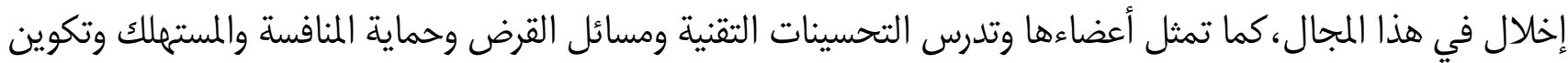
العمال، كما يمكن استفسارها من قبل البنك المركزي، ويمكنها التقاضي دفاعا عن مصالح المهنة (م 147 ق م ق الموريتانية). وقد تم رفع الحظر عن عمل البنوك الإسلامية الذي كانت تقره المادة 20 من ق م ق قبل التعديل حيث كانت تنص على أنه يمنع على مؤسسات القرض الأنشطة الصناعية والتجارية والعقارية والخدماتية.

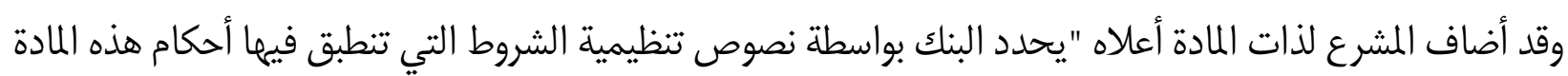

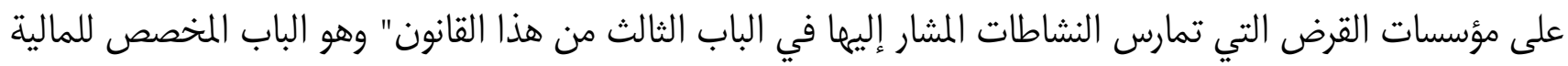

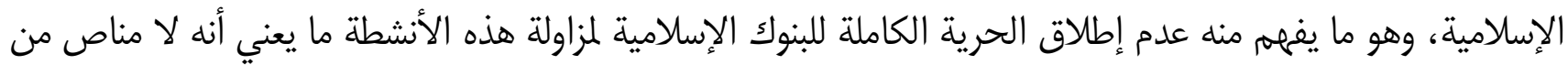

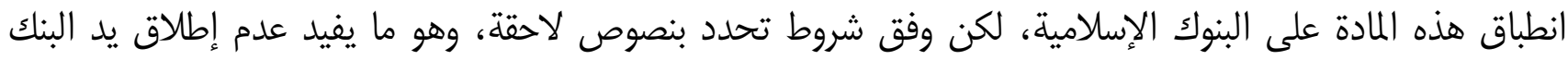

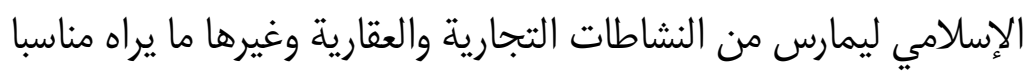

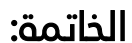

في إطار التسمية المعتمدة مغربيا "البنوك التشاركية" وهي التسمية المعتمدة في تركيا، يبدو أن المشرع أراد التخلي عن

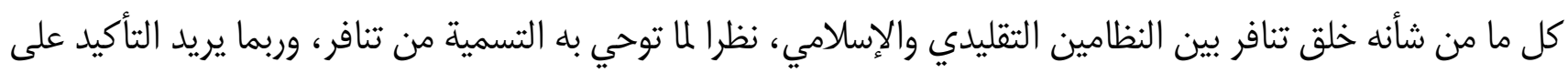

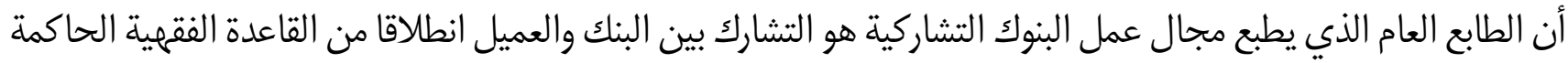

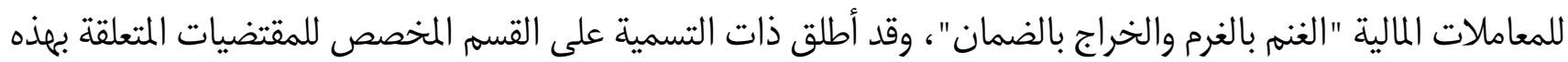

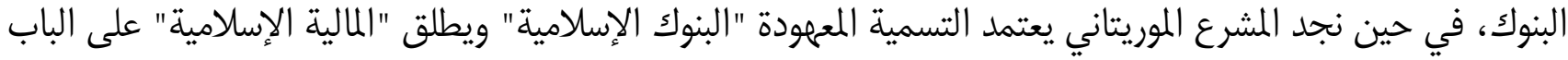

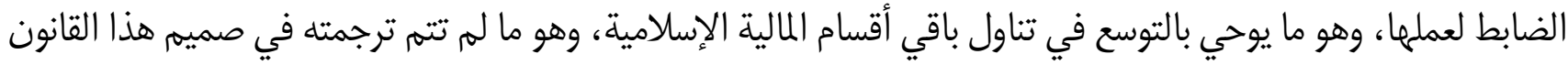
الذي لم يتجاوز البنوك الإسلامية نحو باقي أقسام المالية الإسلامية. 
وفي إطار الرقابة الشرعية لعمل البنوك الإسلامية كان الأحرى بالمشرع الموريتاني الابتعاد بهيئة المطابقة عن وصاية

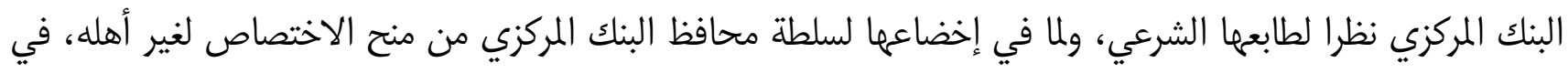

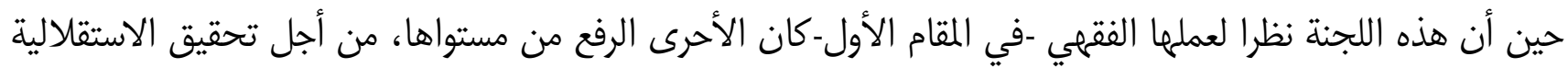

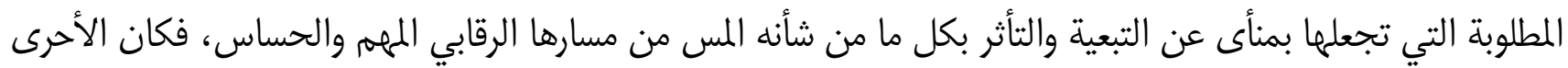

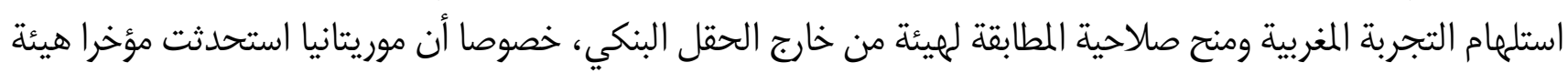

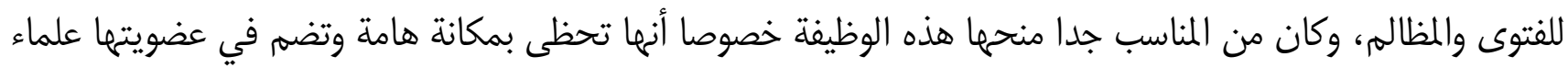
أكفاء تتحقق فييهم شروط الكفاءة المطلوبة. وإكمالا لاستلمام التجربة المغربية كان من المناسب تخصيص صندوق لضمان الودائع خاص بالبنوك الإسلامية يراعي خصوصية هذه الودائع والضمانات في إطار المالية الإسلامية المختلفة عن المنطبقة في مجال عمل المباس البنوك التقليدية.

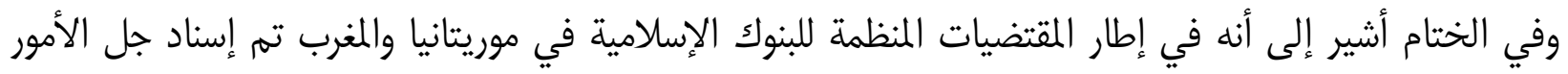

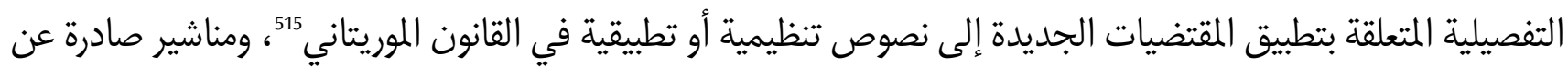

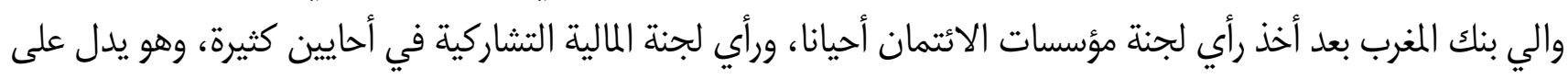

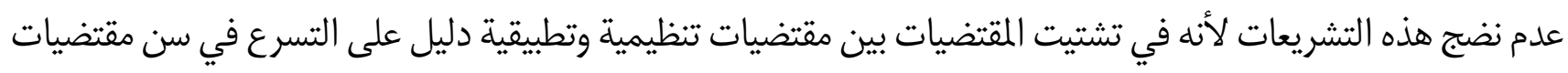

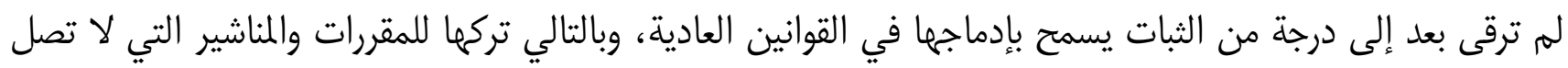

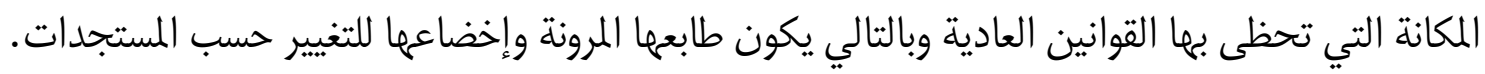

515 نجد كل المواد في الفصل الثاني والثالث مختومة بفقرة: " يحدد البنك المركزي...بواسطة نصوص تنظيمية بعد رأي لجنة المطابقة: وهمي العبارة التي تكررت 8 مرات في الباب الثالث المكون من 9 مواد تتضمن المقتضيات المتعلقة بالمالية الإسلامية. وهو الأمر الملاحظ في قانون مؤسسات الائتمان الذي طالما نص على عبارة من قبيل" تحدد شروط وكيفيات ... بمنشور يصدره والي بنك ملك المغرب بعد استطلاع رأي لجنة مؤسسات الائتمان والرأي بالمطابقة الصادر عن المجلس العلمي الأعلى" المادة 69. 


\section{مسؤولية الصحفي المدنية إثل الاعتداء على الحق \\ في الصورة في القانعن الجزائري}

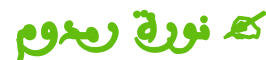

باحثة في القانون كلية الحقوق و العلوم السياسية

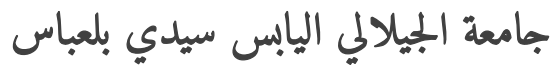

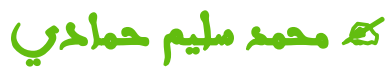

أستاذ بكلية الحقوق و العلوم السياسية

جامعة علي لونيسي البليدة 02

\section{مقدمة:}

لقد استعمل الإنسان الصورة منذ وجوده على الأرض للتعبير عن أغراضه، و ما يجول في ذهنه ويحيط في بيئته ثم

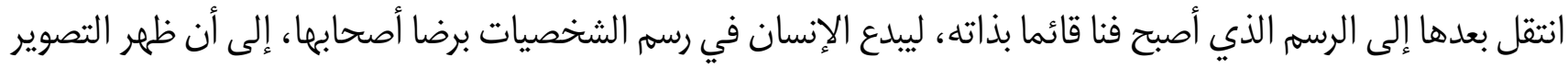

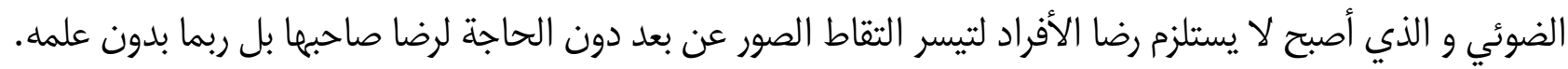
و تعرف الصورة بأنها "كل امتداد ضوئي للجسم البشري، يدل دلالة واضحة على شخصية صاحبها، و يستوي أن يكون هذا ناقلا للصورة على حقيقتها، أو يدل عليها تحريفا بحيث يعطيها منظرا هزليا." والصورة ترتبط ارتباطا وثيقا بالإنسان

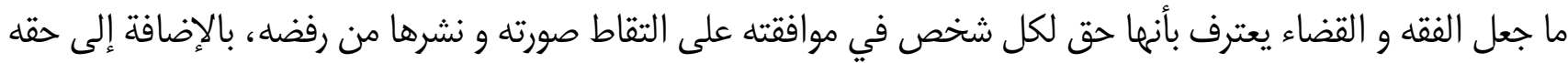
في الاعتراض على المساس بصورته أو تحريفها.

و بظهور وسائل الإعلام أصبحت الصورة أبرز وسائل التعبير الفعالة في العصر الحديث والتي يمكن استخدامها في

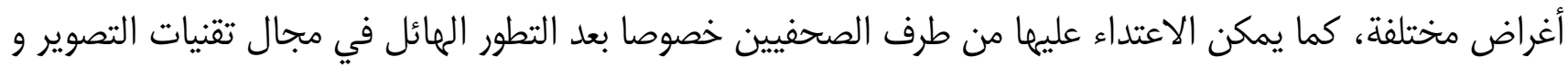

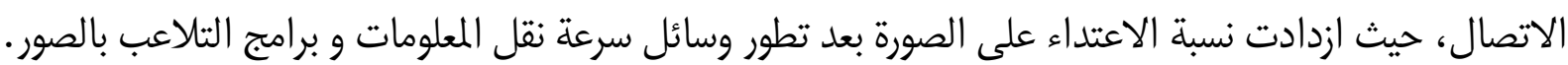
و الملاحظ أن حماية الحق في الصورة في مختلف التشريعات لم يكرس إلا في القوانين الجنائية، ولا يوجد نص

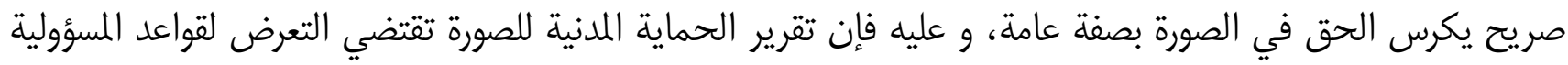

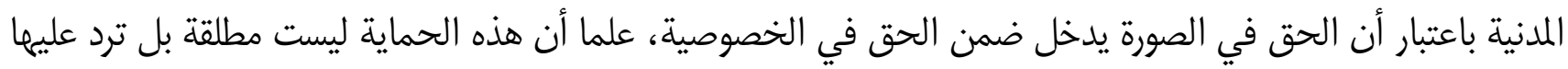

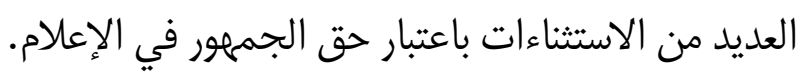

و من هنا نطرح الإشكالية التالية: ما مدى تفعيل قواعد المسؤولية المدنية لحماية صور الأشخاص من الاعتداء سواء

بالتقاطها أو نشرها عبر وسائل الإعلام؟ نطاح الإنية التالية

و على ضوء ما سبق سنتطرق في هذا الموضوع إلى أساس المسؤولية المدنية للصحفي عن نشر الصور و شروط قيامها

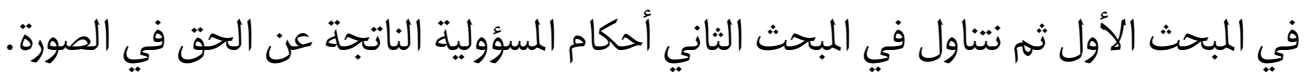




\section{المبحث الأول: أساس المسؤولية المدنية للصحفي عن نشر الصور و شروط قيامها} إن الحديث عن المسؤولية المدنية في حالة الاعتداء على الصور يستوجب البحث في أساس هذه المسؤولية عن هذا الاعتداء، فلا يمكن مساءلة الصحفي ما لم يرتكب فعلا غير مشروع و سبب ضررا للغير، و بالرغم أن الفقه اهتم بضرورة حماية الصورة، إلا أنه لغاية اليوم لا يوجد نص واضح ينظم الحق في الصورة، إضافة للبحث في شروط قيام المسؤولية المدنية للصحفي للمتضرر و استحقاقه للتعويض.

\section{المطلب الأول: أساس المسؤولية المدنية للصحفي عن نشر الصور}

اختلف الفقه في طبيعة الحق في الصورة حيث يرى الاتجاه الأول أنه لا وجود للحق في الصورة لعدم وجود نص تشريعي يقرر حق الإنسان في صورته و كذا انتفاء المصلحة للاعتراف بهذا الحق، فلا يوجد ضرر من تصوير الشخص و نشر صورته.

أما الاتجاه الثاني فيؤيد فكرة وجود الحق في الصورة، و لقد رد على الاتجاه الأول في عدم الاحتجاج بوجود نص تشريعي خاص بالحق في الصورة كمبرر لعدم الاعتراف بهذا الحق القائم بذاته مستوجبا الحماية القانونية، أما بخصوص إنى عدم وجود مصلحة فلا شك أن الاعتداء على الحق يعد مصلحة مشروعة تكفي لقيام المسؤولية. 517

\section{الفرع الأول: فكرة الحياة الخاصة كأساس تقليدي لمسؤولية الصحفي} إن الحديث عن مسؤولية الصحفي في هذا النطاق يقتضي معرفة مفهوم الحياة الخاصة، إذ تعرف بأنها "النطاق المادي

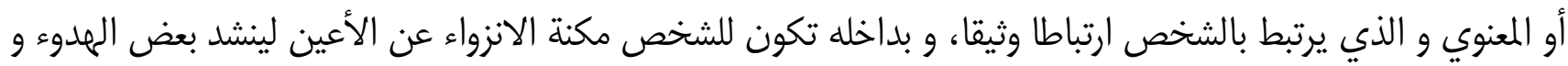
ليحفظ أسرار ذاته." بقصد تحقيق نوع من السكينة و الحفاظ على سرية الحياة الخاصة."

و الحقيقة أن قيام مسؤولية الصحفي تكون عن طريق التعدي على حقه في نشر صور الضحايا عبر وسائل الإعلام المختلفة، و لاعتبار فكرة الحياة الخاصة كأساس لقيام المسؤولية، لابد من دراسة بعض النصوص القانونية في مختلف التشريعات:

في التشريع الفرنسي: جرم المشرع الفرنسي من المادة 1/226 من القانون الجنائي انتهاك الحق في الصورة و ربطها بالحياة الخاصة بقولما "معاقبة كل من يلتقط أو يسجل أو ينشر صورة شخص موجئ جرمد في مكان خاص دون رضائه بالسجن و الغرامة." بامياهاه

516 مها يوسف خصاونة، المسؤولية المدنية للصحفي عن الاعتداء على الحق في الصورة في القانون المدني الأردني، مجلة جامعة الشارقة، العدد 2، 2015، ص ص 175.

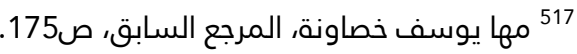
518 مصطفى أحمد عبد الجواد حجازي، المسؤولية المدنية للصحفي عن انتهاك حرمة الحياة الخاصة، دار النهضة العربية، سنة 2004، ص 59. 519 عماد حمدي حجازي، الحق في الخصوصية و مسؤولية الصحفي، دار الفكر الجامعي، سنة 2004، ص 52. ${ }^{520}$ Art 266/1 du code pénal français, dispose que « Est puni d'un an d'emprisonnement et de 45000 euros d'amende le fait, au moyen d'un procédé quelconque de porter atteinte à l'intimité de la vie privée d'autrui : 
أما بالنسبة للقانون المدني فقد نصت المادة 9 منه على "لكل شخص حق في احترام حياته الخاصة و يستطيع القضاة دون المساس بحق المضرور في التعويض أن يأمروا باتخاذ كل الإجراءات كالحراسة و الحجز و أي إجراء آخر يكون من شأنه منع أو وقف الاعتداء على ألفة الحياة الخاصة وهذه الأمور يمكن أن يأمر بها قاضي الأمور الوقتية في حالة الاستعجال. "

في التشريع المصري: أشارت المادة 309 من القانون الجنائي المصري إلى تجريم أفعال الاعتداء على الخصوصية و

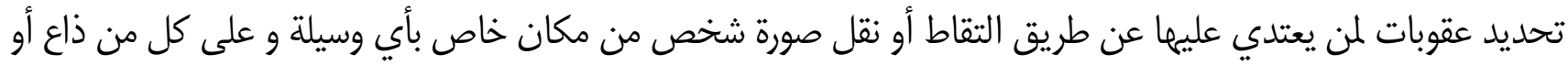
سهل إذاعة أو استعمل الطرق الممنوعة قانونات

أما بالنسبة للقانون المدني فله يرد نص يحمي الحياة الخاصة للأفراد بشكل خاص، ما دفع الفقه المصري بالاستناد إلى المادة 50 من القانون المدني المتعلقة بالحقوق الملازمة للشخصية مثل الحق في الشرف و رد الاعتبار أو الحق في السمعة، و غيرها من الحقوق اللصيقة من أجل الوصول إلى نفس الحماية المقررة بموجب المادة 9 من القانون المدني الفرنسي. في التشريع الجزائري: لابد من الإشارة إلى تأسيس المسؤولية عن انتهاك الحق في الحياة الخاصة موجود في

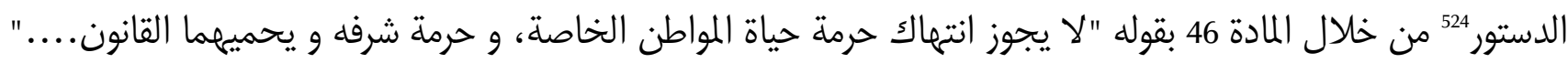
غير أن مصطلح مواطن يثير التساؤلات حول مدى وجود هذه الحماية لغير المواطنين المقيمين في التراب الوطني. و المشرع الجزائري على غرار المشرع المصري فقد أعطى أهمية بالغة من خلال تجريمه لبعض الأفعال كالالتقاط و

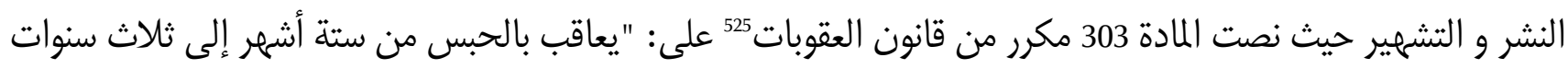

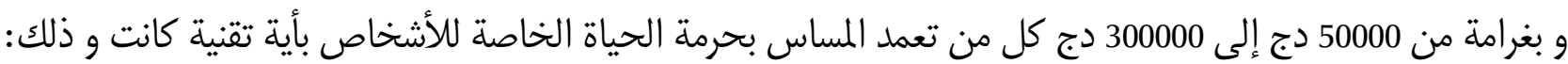

$$
\text { - - - بالتقاط أو تسجيل أو نقل مكالمات أو أحاديث خاصة أو سرية في غير إذن صاحبها أو رضاه }
$$

1- En captant, enregistrantou, sans le consentement de leur auteur, des paroles prononcées à titre privé ou confidentiel

2- En fixant, enregistrant ou, sans le consentement de celle-ci l'image d'une personne se trouvant dans un lieu privé. »

${ }^{521}$ Art 09 du code civil français, dispose que «Chacun a droit au respect de sa vie privée, les juges peuvent, sans préjudice de la réparation du dommage subi, prescrire toutes mesures, telles que séquestre, saisie et autres, propres à empêcher ou faire cesser une atteinte à l'intimité de la vie privée ces mesures peuvent, s'il y a urgence, être ordonnées en référé. "

522 المادة 309 من القانون الجنائي المصري بفقرتيها أ - ب و قد حددت عقوبة الحبس على كل من اعتدى على الحياة الخاصة للأشخاص. 523 جعفر كاظم جبر الموازي، نعيم كاظم جبر الموازي، نحو نظام قانوني لمسؤولية الصحفي المدنية عن عرض صور ضحايا الجريمة، بدون اسم المجلة، العدد 7، سنة 2008، صم 2024. 524 دستور الجزائر المؤرخ في 8 ديسمبر 1996، عدد الجريدة الرسمية 76، المعدل و المتمم بموجب قانون رقم 16-01 المؤرخ في 6 مارس 2016، عدد الجريدة الرسمية 14. 525 الأمر رقم 66-156 المتعلق بقانون العقوبات، المؤرخ في 8 يونيو 1966، المعدل و المتمم بقانون 16-02 المؤرخ في 19 يونيو 2016، الجريدة الرسمية عدد 04. 
كما يعاقب المشرع الجزائري في المادة 303 مكرر كل من نشر خصوصيات الأفراد إذ تنص المادة على "يعاقب بالعقوبات

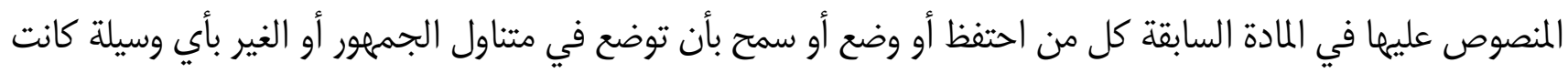

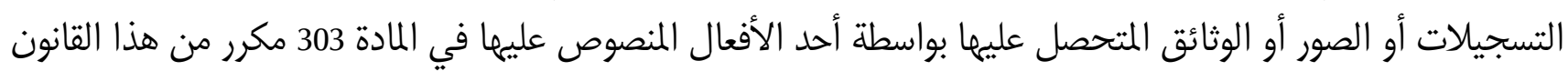

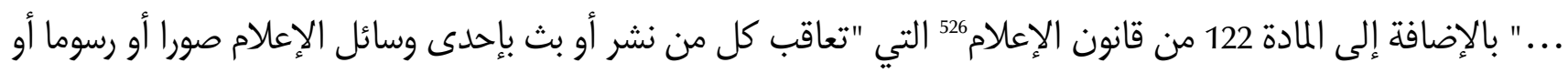

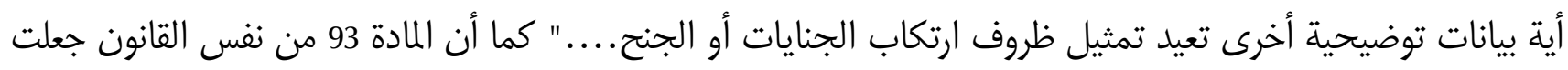
من ضمن أخلاقيات المهنة و آدابها عدم انتهاك الحياة الخاصة للأفراد و شرفهم و اعتبارهمه. و بدوره قانون السمعي البصري اهتم بحرمة الحياة الخاصة من خلال إلزام المؤسسات التي تمارس نشاط السمعي البصري السهر على عدم المساس بالحياة الخاصة للأشخاص.

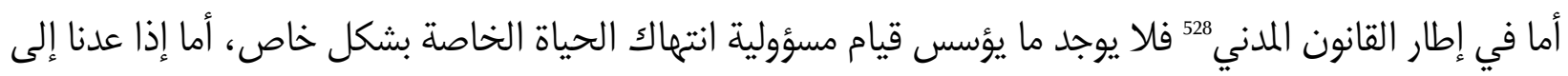

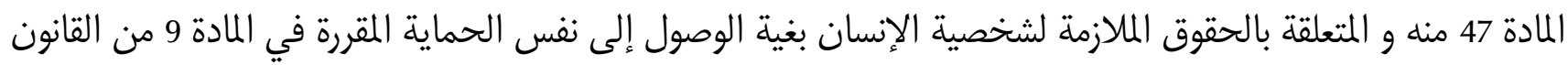

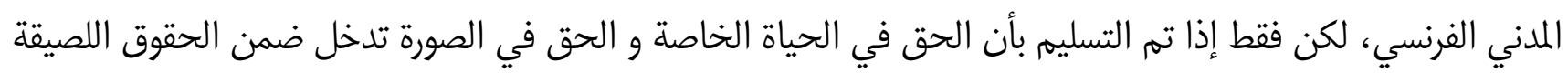
بشصية الإنسان.

\section{الفرع الثاني: فكرة الكرامة الإنسانية كأساس حديث لمسؤولية الصحفي}

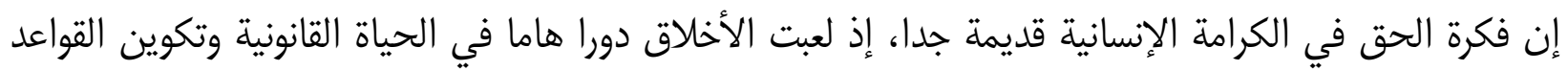

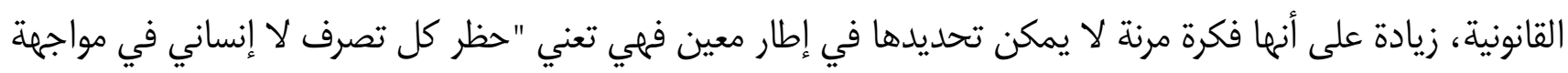

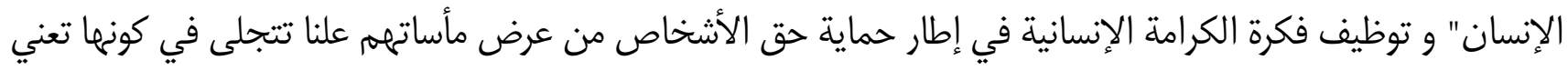

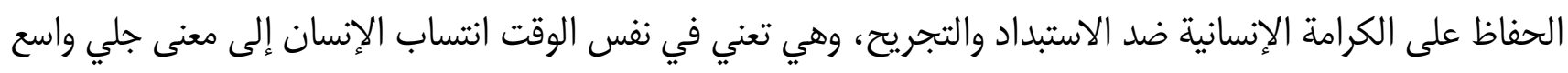
و هو الإنسانية بصفة عامة.

و لقد سعى الفقه الفرنسي لتبرير هذه الفكرة بالاستناد إلى بعض القواعد العامة، منها القاعدة التي تقول أن الكرامة

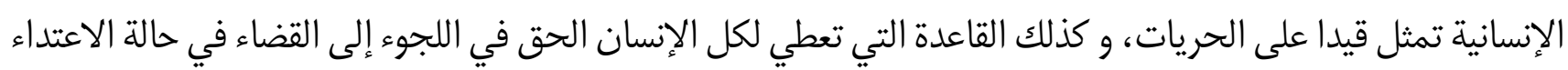
على كرامته الإنسانية حتى مع عدم وجود اعتداء على حق شخصي. و يمكن تأصيل فكرة الكرامة الإنسانية كأساس لقيام المسؤولية المدنية بالرجوع إلى الأديان كمصدر أساس لها، و يعتبر

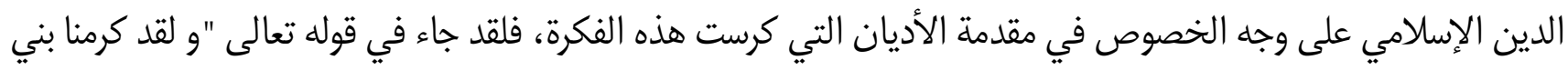
آدم و حملناه في البر و البحر و رزقناهم من الطيبات و فضلناهم على كثير ممن خلقنا تفضيلا."

526 قانون عضوي رقم 12 - 05 المتعلق بقانون الإعلام، المؤرخ في 12 يناير2012، عدد الجريدة الرسمية 02.

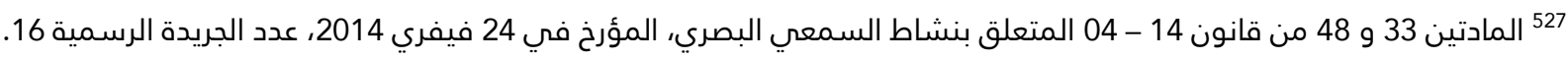
528 الأمر رقم 75-58 المتعلق بالقانون المدني، المؤرخ في 26 سبتمبر 1975، المعدل و المتمم، عدد الجريدة الرسمية78.

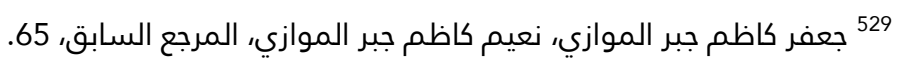
530 
أما على المستوى الدولي فلقد كان لهذه الفكرة صدى كبير على مستوى الاتفاقيات الدولية، و أيضا على مستوى قانون

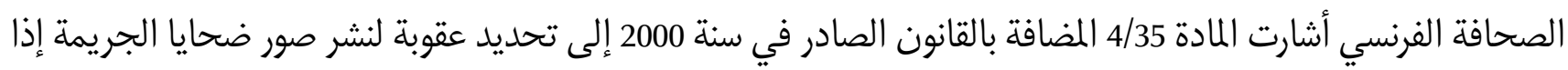
كان النشر اعتداء خطير على كرامة الضحية و أن النشر قد تم دون رضا صاحب الشأن.

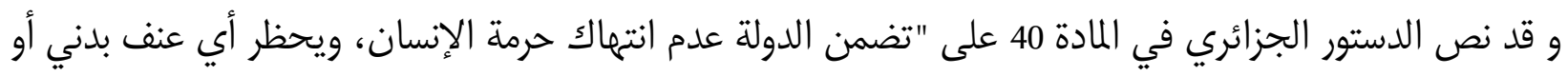

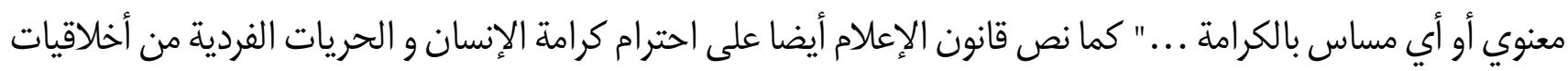

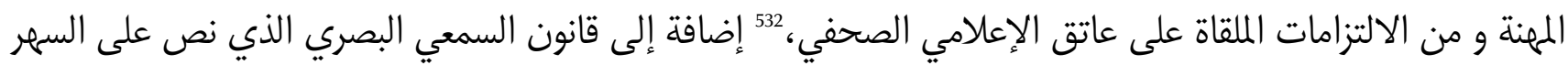
على احترام الكرامة الإنسانية.

\section{المطلب الثاني: شروط قيام مسؤولية الصحفي المدنية عن انتهاك الحق في الصورة} لقيام المسؤولية المدنية للصحفي لابد من توافر ثلاثة شروط هي الخطأ و الضرور و العلاقة السبية المبية و هو ما سيتم معالجته في هذا المطلب.

\section{الفرع الأول: الاعتداء الغير مشروع}

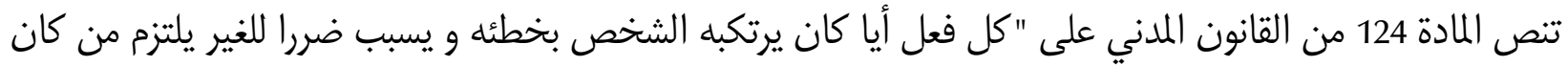

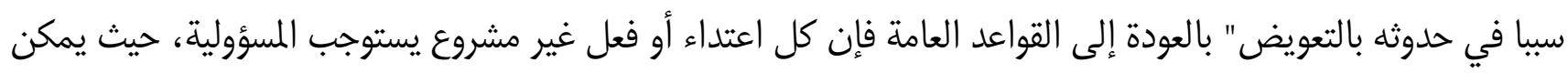

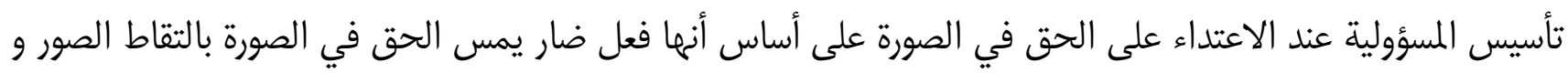

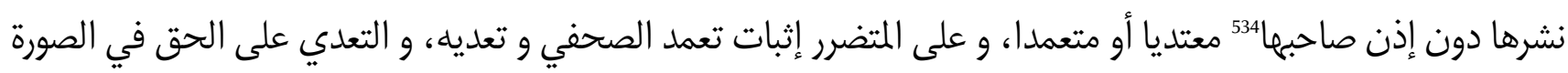

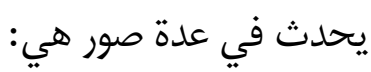

\section{أولا: تشويه صورة الإنسان عن طريق التحريف}

نتيجة للتطور الهائل الذي شهله العالم في مجال العال الكاميرات الرقمية و برامج الحاسوب، أصبح من الممكن إدخال

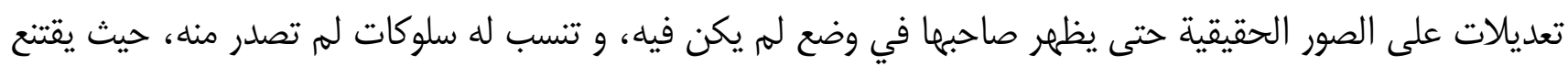

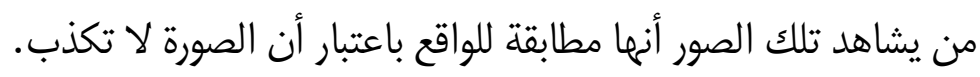

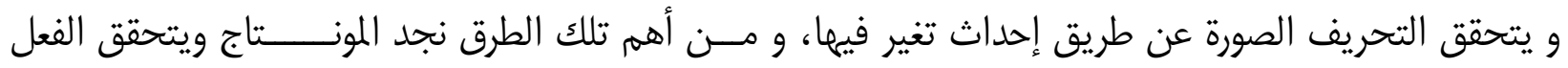

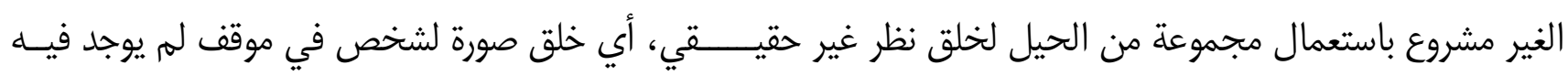

${ }^{531}$ Article 35/4 Créé par Loi 2000-516 du 15 Juin 2000, art. 97, JORF 16 juin 2000 Ordonnance 2000-916 du 19 Septembre 2000, art. 3, JORF 22 septembre 2000, dispose clairement que:" La diffusion, par quelque moyen que ce soit et quel qu'en soit le support, de la reproduction des circonstances d'un crime ou d'un délit, lorsque cette reproduction porte gravement atteinte à la dignité d'une victime et qu'elle est réalisée sans l'accord de cette dernière, est punie de 15000 euros d'amende".

$$
532 \text { المادة } 02 \text { من قانون } 12 \text { - } 05 \text { المادة } 05 \text { المتعلق بقانون الإعلام } 14 \text { من قانون } 04 \text { المتعلق بالسمعي البصري. }
$$

534 بوزيدي سليم و حميطوش الجيدة، الاعتداء على الحق في الصورة في ظل التطورات التكنولوجية الحديثة، مذكرة لنيل شهادة الماستر في الحقوق، كلية الحقوق و العلوم السياسية، جامعة عبد الرحمان ميرة، بجاية، سنة 2016، ص 40. 
في الواقع، كذلك برنامج الفوتوشوب الذي يقوم بإدخال تعديلات على الصورة أو حذفها أو دمجها مع صورة أخرى، بالإضافة

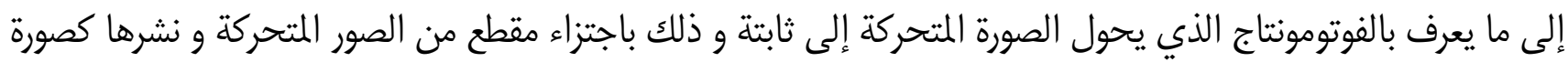

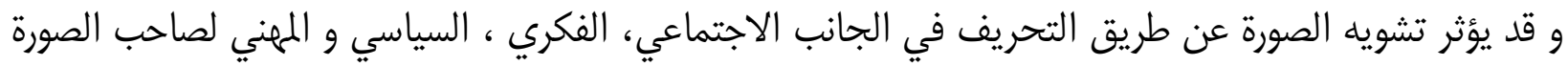
كما يؤدي إلى الخلط بين شخصيتين بشكل يسيء إلى أحدهما أو كليهما،

و من أمثلة ذلك ما عرض على القضاء الفرنسي في قضية جنازة الرئيس الفرنسي السابق "جورج بومبيدو" حيث التقط

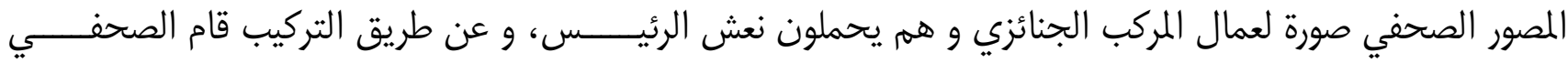

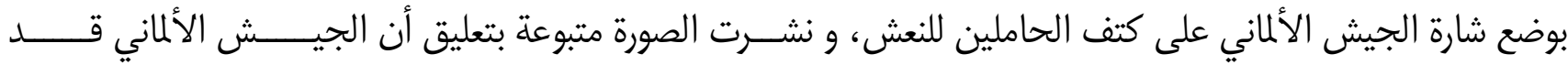

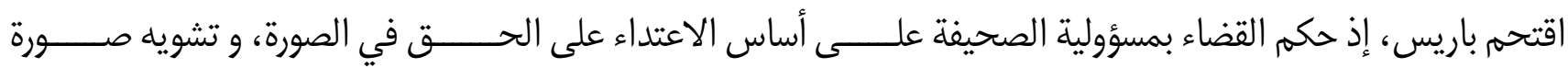

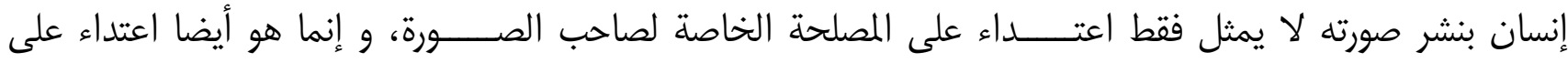
المصلحســة العامة.536

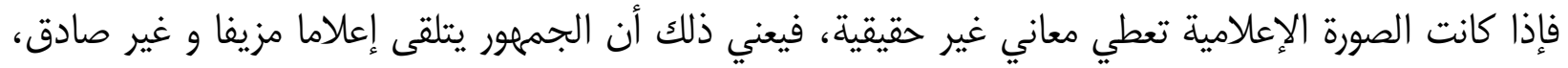

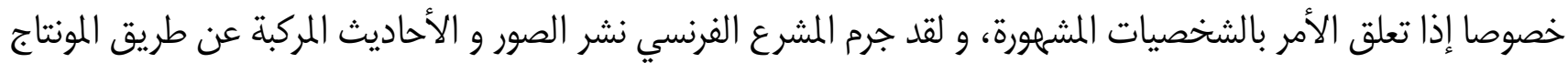
في المادة 8/226 من قانون العقوبات الفرنسي.

ثانيا: تشويه سمعة إنسان بواسطة نشر صوره

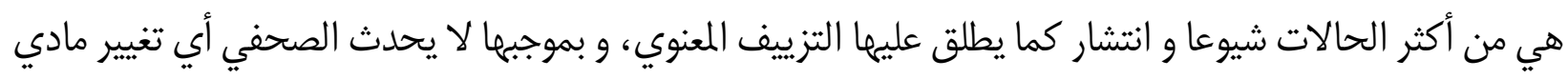

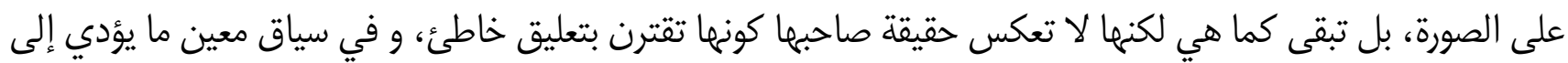

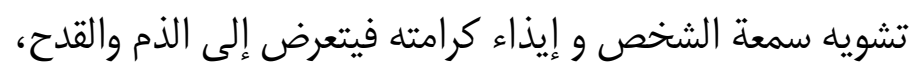
و مثال ذلك أمام القضاء الفرنسي ما نشرته إحدى الصحف حول صورة أم و هي تنادي ابنها، وقد ظهرت في الصورة

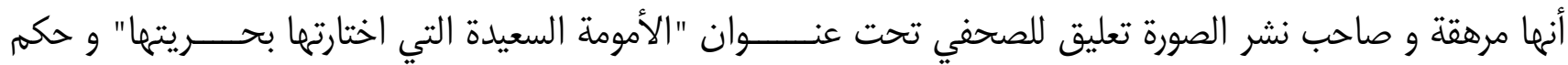

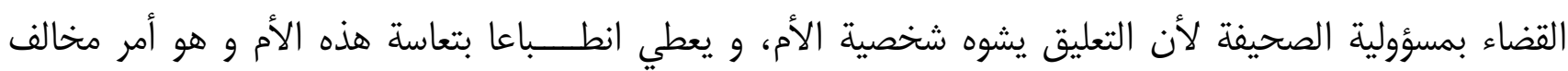
ل ل

535 بوزيدي سليم و حميطوش الجيدة، المرجع السابق، ص 15.

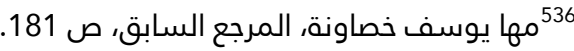

${ }^{537}$ Art 266/8du code pénal français, dispose que«Est puni d'un an d'emprisonnement et de 15000 euros d'amende le fait de publier,par quelque voie que ce soit, le montage réalisé avec les paroles ou l'image d'une personne sans son consentement, s'il n'apparaît pas à l'évidence qu'il s'agit d'un montage ou s'il n'en est pas expressément fait mention . Lorsque le délit prévu par l'alinéa précédent est commis par la voie de la presse écrite ou audiovisuelle, les dispositions particulières des lois qui régissent ces matières sont applicables en ce qui concerne la détermination des personnes responsables »

538 مها يوسف خصاونة، المرجع السابق، ص 182. 
ثالثا: الكاريكاتير

هو رسالة بصرية هزلية تعتمد على الفعل، الحدث، المعنى، و هو وسيلة اتصال جماهرية في الجرائدو المجلات لتتسلل بها إلى الفرد، و هو فن التصوير الساخر من أجل التعليق على حدث ما والنقد من أجل سلوك اجتماعي أو التعبير عن سلوكات اجتماعية و سياسية.

و مبدئيا يعد مشروعا في ظل الديمقراطية و حرية الرأي باعتباره نمط اتصال يقوم على الرسم حاملا مضمونا قصد تحقيق أهداف و أداء رسالة من خلال تصليح الواقع، م39 و على الرغم من تمتع رسام الكاريكاتير بحرية واسعة، فإنه يجب

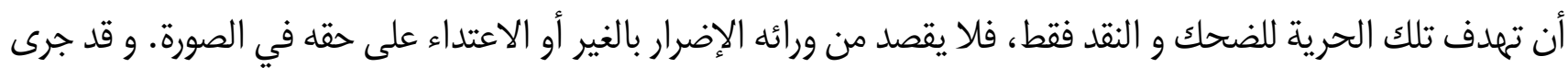
العرف في الدول الديمقراطية على التسامح في الكاريكاتير التي يعتبر من أعمال الصحفي بناءا على حقه في النقد المترتب على الحق في الإعلام، و تبقى الأحكام المتعلقة برسومات الكاريكاتير نادرة، إلا أن الكاريكاتير يبقى مقيدا بعد الاعتداء على سمعة الأفراد و تشويه سمعتهم فإذا تم الاعتداء يصبح الصحفي مسؤولا عنه. لأحد زعماء اليمين المتطرف في فرنسا، و هو يرتدي زي ضابط مظالات يغوص في بانيو مملوءة بالماء، مع تعليق يشير إلى

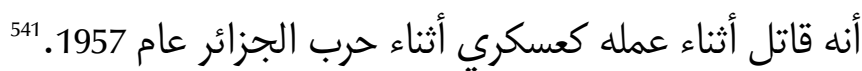

\section{الفرع الثانسي: الضرر}

يعرف الفقه الضرر بأنه "الإخلال بمصلحة محققة، مشروعة للمضرور في ماله أو شخصه. "542 ويعتبر الضرر ركن أساسي من أركان المسؤولية المدنية فإذا أمكن الخطأ في فعل المسؤول فلا يمكن تصور قيام هذه المسؤولية دون وجود ضرر، و ما يميز ركن الضرر هنا هو وقوع الاعتداء على الصور من وسائل الإعلام، و يفترض معه وقوع الضرر بالضحية لأن الاعتداء على هذا الحق يستتبع بالضرورة توافر الضرر، و من ثمة فإن الاعتداء الحق في الصور بالنشر يسبب دائما ضررا حقيقيا يتمثل في تحويل صورهم لمشهرد عام يعرفه الكافة. و الواقع أن الضرر غالبا ما يكون معنويا يتمثل بالاعتداء على الشعور بالحياء من قبل الضحيت من جراء النشر علنا دون إذنه، أما الضرر المادي فيمكن تصوره أحيانا في من خلال استغلال الصور تجاريا أو تفويت فرصة القيام بنشره. لهزا نجد القضاء يقوم بتقدير مبلغ التعويض بما يغطي الضرر المادي و المعنوي معا. 543

\section{الفرع الثالث: العلاقة السببية}

يشترط لقيام المسؤولية المدنية عن الفعل الضار بالإضافة إلى الأركان التي تم ذكرها ركن العلاقة السبيية و يقصد بها أنه يجب أن يكون الفعل الضار هو سبب الضرر، و الذي ما كان ليقع لولا الفعل الضار، و ركن العلاقة السبيية مستقل عن بقية الأركان الأخرى للفعل الضار، و عدم وجودها يعني عدم وجود الفعل الضار

539 بلحاج يوسف، الحماية القانونية للحق في الصورة، مذكرة لنيل شهادة الماجستير تخصص قانون الإعلام، كلية الحقوق والعلوم السياسية،

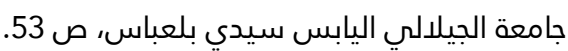

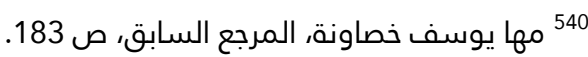
541 بلحاج يوسف، المرجع السابق، ص صوسف 54.

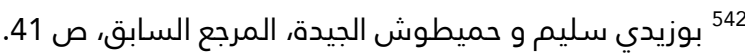

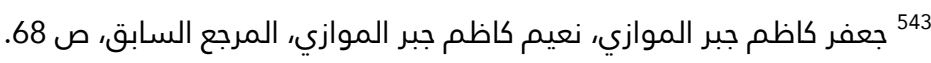
544 مها يوسف خصاونة، المرجع السابق، ص 184. 


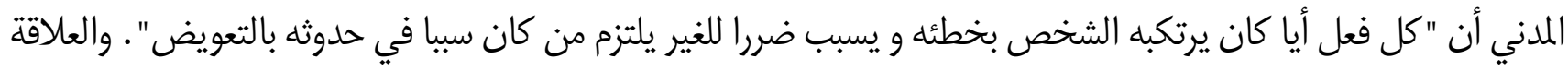

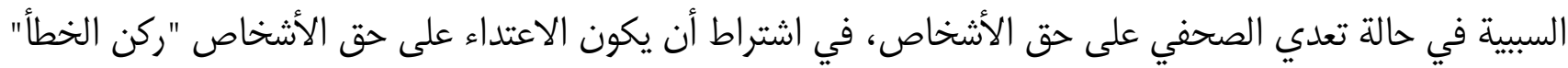

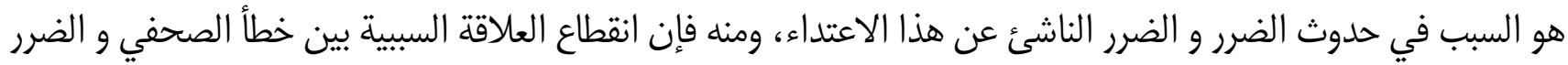

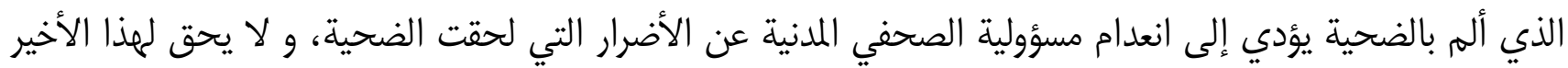

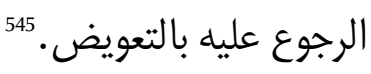

\section{المبحث الثاني: أحكام المسؤولية الناتجة عن الحق في الصورة}

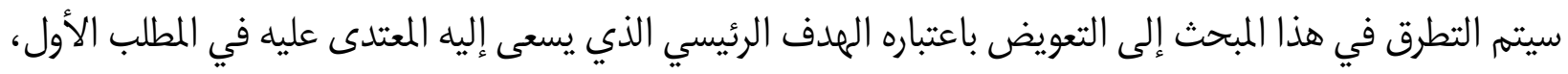

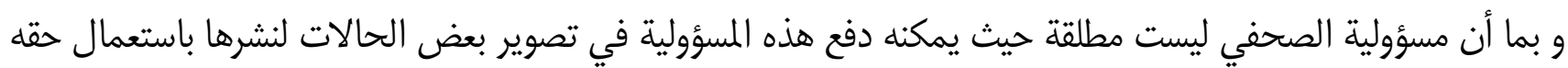
في الإعلام و ذلك في المطلب الثاني.

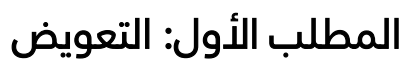

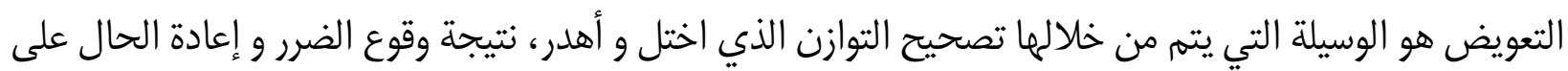

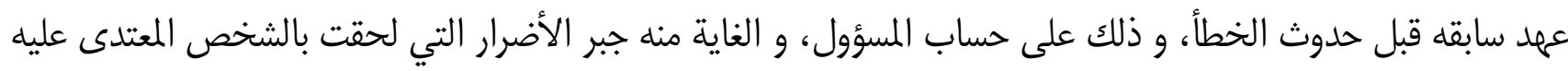
بنشر صورته سواء كانت مادية أو معنوية.

و الملاحظ في مجال تقدير التعويض أنه يقوم على اعتبارات شخصية، فالضرر المعنوي تحدده ضوابط مرنة، و يظهر

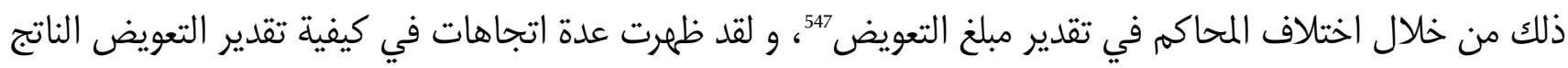

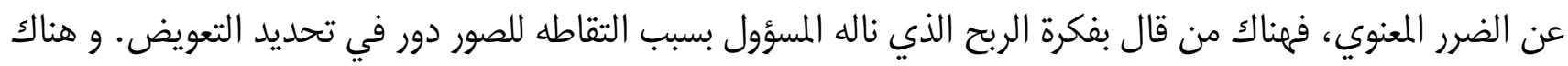

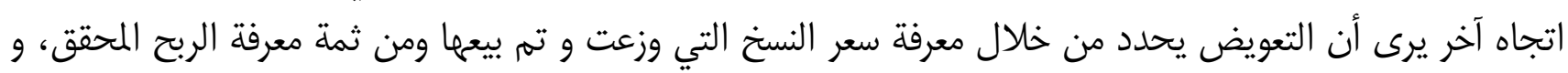

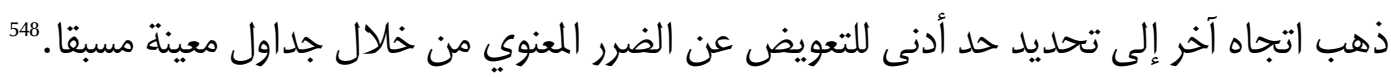

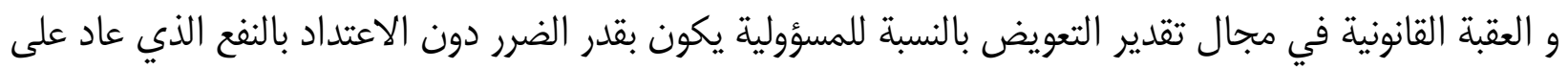

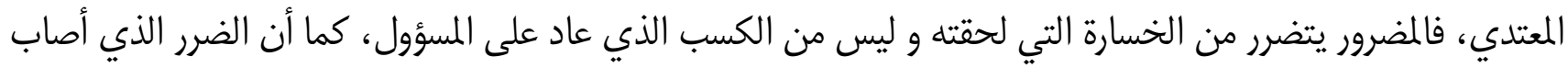

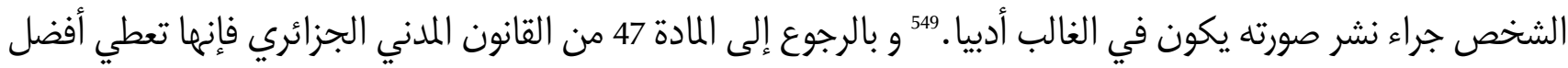
الحلول لجبر الضرر من خلال منح القاضي سلطات أكثر ملائمة.

و يكون التعويض إما عيني أو بمقابل من خلال رد الحال إلى ما كان عيه سابقا و تصحيح المعتدي لما نشره سابقا في

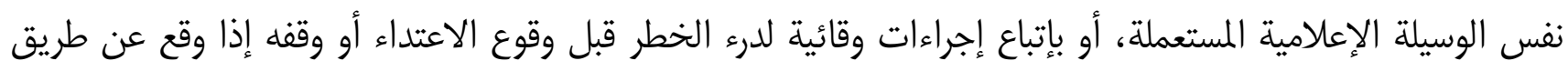

545 جعفر كاظم جبر الموازي، نعيم كاظم جبر الموازي، المرجع السابق، ص 586 546 لعلام محمد مهدي، المسؤولية المدنية للصحفي عن عرض صور ضحايا الجريمة، مجلة الفقه و القانون، العدد 33، سنة 547 رام

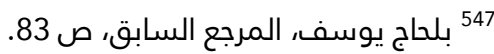
548 جعفر كاظم جبر الموازي، نعيم كاظم جبر الموازي، المرجع السابق، ص 71 بور، 71. 549 بلحاج يوسف، المرجع السابق، ص 83. 
"دعوى وقف الاعتداء" التي تسمح للقاضي بوقف المساس بمصالح الأشخاص، و وقف نشر صورهم و تداولمها و مصادرة و حجز الأجهزة أو الصحيفة طبقا للمادة 47 من القانون المدني الجزائري و المادة 9 من القانون المدني الفرنسي. و في حالة استحالة اللجوء إلى التعويض العيني أو عدم كفايته، يته التعويض بمقابل أي عن طريق النقود و تكون

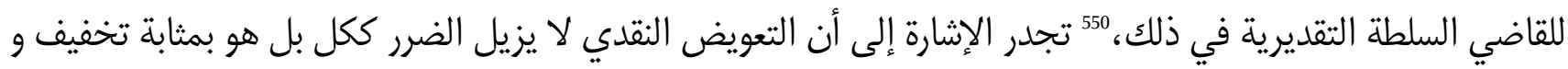

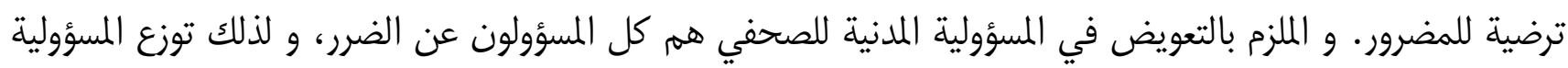
حسب حالة الاعتداء، و هي تأخذ أشكالا متعددة منها: 1- في حالة الاعتداء الصادر من الصحفي المستقل فإن المسؤولية هنا تكون تقصيرية موزعة بالتضامن بين الصحفي و الصحيفة و رئيس التحرير.

2- في حالة الاعتداء من الصحفي التابع لصحيفة فإن الصحفي يسأل على أساس الخطأ الشخصي، أما الصحيفة

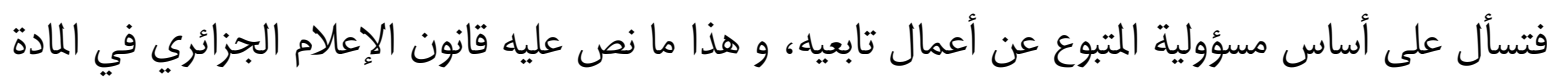

و مادام نشر صورة الضحية من طرف الصحفي يمثل جريمة، فإن المجني عليه يصبح مدعيا مدنيا، حيث يمكن إرفاق

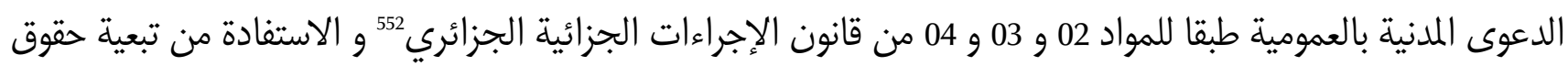

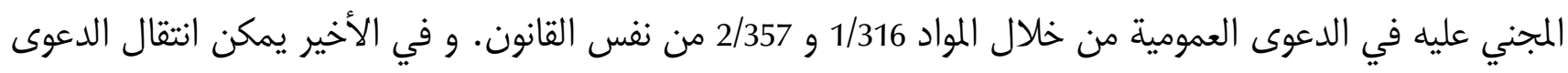
المدنية إلى الورثة في حالة ما إذا تسببت لمهم ضرر شخصي مباشر من جراء الاعتداء على حق مورثهم في الصورة. 553 المطلب الثاني: مدى إمكانية نشر صور الأشخاص بالاعتماد على حق الصحفي في الإعلام "وسائل دفع

المسؤولية" الأصل أنه يمكن للأشخاص في الاعتراض على التقاط صورهم و نشرها من قبل الغير، إلا أنه هناك حالات تسمح للصحفي بنشر الصور دون قيام المسؤولية القانونية.

\section{الفرع الأول: الرضا بالتصوير}

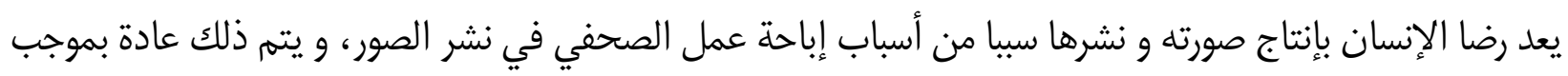
عقد، إذ يوافق صاحب الصورة على استخدام صورته لأغراض محددة في العقد.

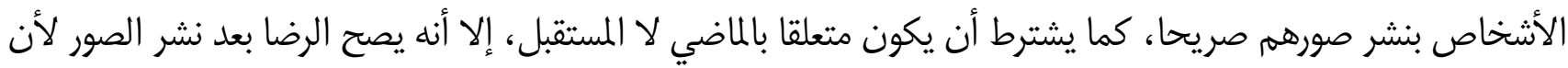

550 لعلام محمد مهدي، المرجع السابق، ص 31. 551 تنص المادة 115 من قانون الإعلام على "يتحمل المدير مسؤول النشرية أو مدير جهاز الصحافة الإلكترونية و كذا صاحب الكتابة أو الرسم مسؤولية كل كتابة أو رسم يتم نشرهما من طرف نشرية دورية أو صحافة إلكترونية ويتحمل مدير الاتصال السمعي البصري أو عبر الأنترنت وصاحب الخبر الذي تم بثه المسؤولية عن الخبر السمعي و/ أو البصري المبث من قبل خدمة الاتصال السمعي البصة فوري أو أو عبر الأنترنت."

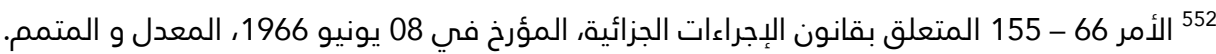

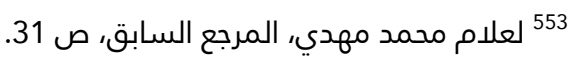
554 مها يوسف خصاونة، المرجع السابق، ص 189. 
الرضا اللاحق بمثابة إذن سابق، كما أن نشر الصور يجب أن يكون بالصيغة المتفق عليها دون تعديل أو تحوير من قبل الصحفي.

فإذا خالف الصحفي ذلك ينشأ له حق التعويض، بالإضافة إلى المسؤولية الجنائية في نشر الصور دون إذن مسبق مما ينفي أسباب الإباحة. 555 و يثار التساؤل فيما إذا يستطيع الصحفي الذي حصل على إذن مسبقا بنشر صورة شخص في إعادة نشر الصورة في تقرير آخر دون الحصول على إذن، هنا استقر القضاء على رأسه محكمة النقض الفرنسية على أن إعادة نشر ما سبق نشره بصورة متفرقة هو أمر محظور متى تم إعادة النشر دون موافقة الشخص، و عليه لا يجوز للصحفي إعادة نشر الصور دون الحصول على إذن جديد.

\section{الفرع الثاني: الحق في الإعلام كسبب لإباحة نشر الصور} يقصد بالحق في الإعلام بأنه حق كل إنسان في تلقي أو نقل المعلومات و الأنباء و الآراء على أي صورة دون تدخل، فللجمهور حق في الاطلاع على كل ما يحدث في المجتمع، الأمر الذي يؤدي إلى تحول الخصوصية إلى العلن و تصبح الأحداث العامة و حياة المشاهير موضوعا للإعلام و الصحافة. و لا يعني الحق في الإعلام التطفل و التعدي على خصوصيات الأفراد، بل يلزم الإعلام بنقل المعلومات في إطار المصلحة العامة، إلا أنه في كثير من الأحيان يتعارض الحق في الإعلام مع خصوصيات الشخصيات العامة و المشاهير، و من هنا كان لابد من إيجاد توازن بينهما لتحقيق المصلحة العامة.

\section{أولا: الوقائع و الحوادث العلنية}

إن ضحايا الجرائم و الحوادث يتمتعون بالحق في حماية صورهم و عدم عرض مأساتهم، لكن هؤلاء يصعب عليهم ممارسة حقهم هذا إذا كانوا ضحايا الحوادث، و الرأي العام الذي له الحق الإعلام. إذ أن الحق في الإعلام يتوسع في

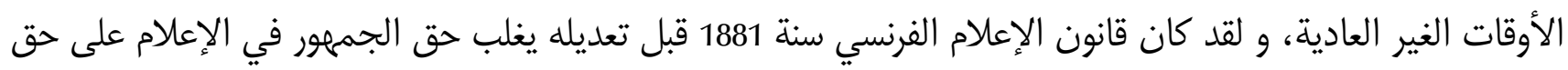

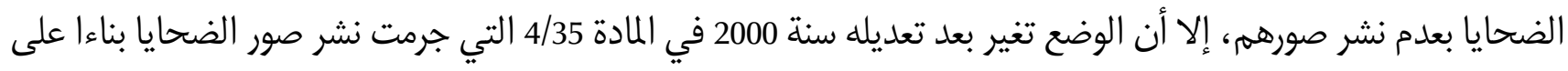
الحق في الكرامة الإنسانية 557، أين لقت صدى أيضا في قانون الإعلام الجزائري باعتبارها مبدأ دستوري منصوص عليه في المادة 40 من الدستور.

و تطبيقا لذلك فقد قضت محكمة النقض الفرنسية إلى القول بجواز نشر صور الأحداث المامة تطبيقا لحق الإعلام شرط احترام الكرامة الإنسانية للضحايا، و يمتد الحق في الكرامة ليشمل حق ضحايا الأموات في عدم تناول صورهم في وسائل الإعلام، و تطبيقا لذلك أدانت محكمة النقض نشر جثمان -PrefetErignac- ليس على أساس الحق في الصورة إنما على أساس الحق في الكرامة الإنسانية. 559 كما أن نشر الصور يكون بناءا على هدف و مغزى، و أن تكون لمها علاقة مباشرة مع الحدث المراد تغطيته.

555 جعفر كاظم جبر الموازي، نعيم كاظم جبر الموازي، المرجع السابق، ص 69.

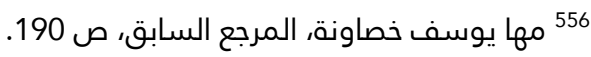
557 لعلام محمد مهدي، المرجع السابق، ص 30. 558 تنص المادة 40 على " تضمن الدولة عدم انتهاك حرمة الإنسان، و يحظر أي عنف بدني أو معنوي أو أي مساس بالكرامة ..." 559 بلحاج يوسف، المرجع السابق، ص 46. 


\section{ثانيا: صور الشخصيات الشهيرة}

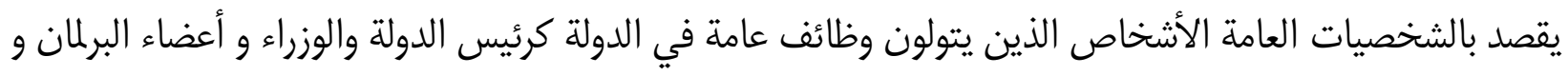
غيرهم، إضافة إلى كل من يقوم بدور بارز في تسيير الأموال العامة في الدولة.

و يباح نشر الصور إذا ارتبطت الصور بممارسة أعمال عامة في حدود المصلحة العامة التي تقتضيها، حيث يحق للجمهرور

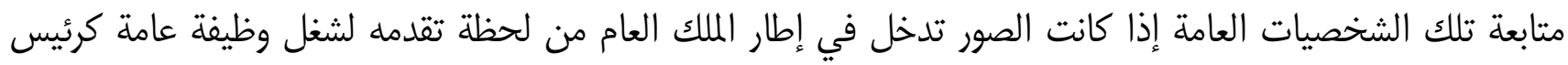

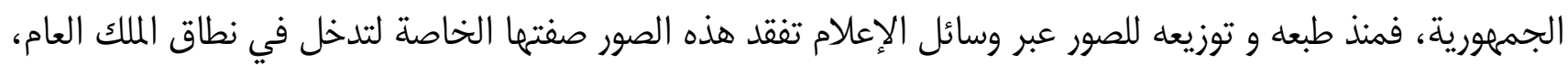

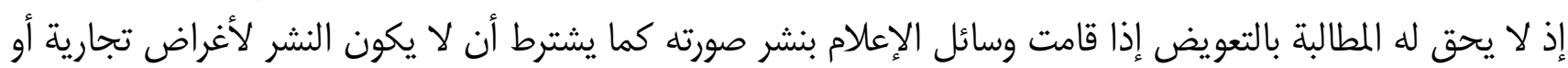

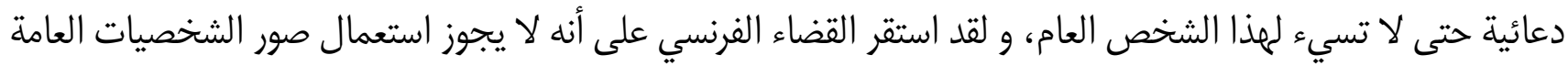

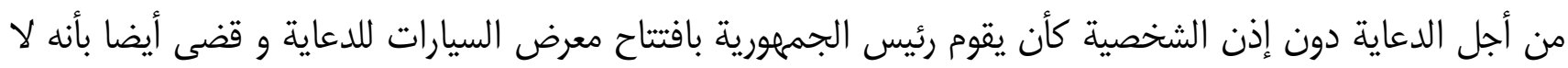
يجوز استخدام صورة إمبراطور النمسا للدعاية لإحدى شركات الإعلام.

الخاتمة:

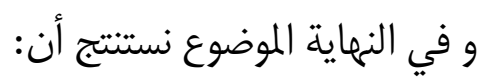

1- أن الحماية المدنية للحق في الصورة جراء الاعتداء الذي يلحقها من طرف الصحفيين عن طريق التقاط الصور

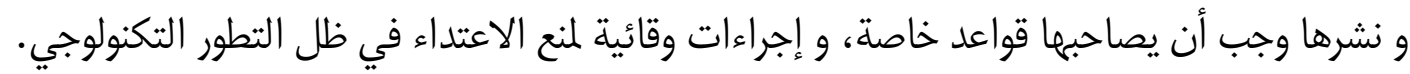

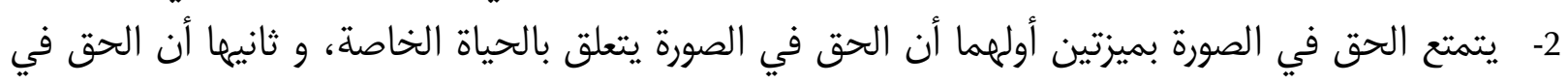
الصورة هو حق ذاتي مستقل عن الحق في الخصوصية.

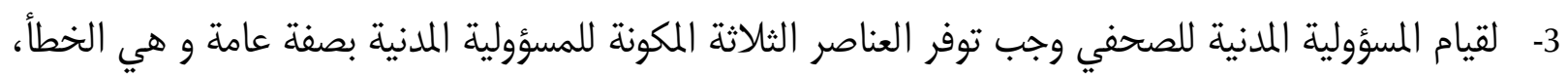
الضرر، العلاقة السبية، و أن التعويض يكون بقدر الضرر. 4- أخيرا فإن الحق في الصورة مقيد إلا أنه قد ترد عليه بعض بلدون الاستثناءات التي تسمح للصحفي بالتصوير و نشر

$$
\text { كما نوصي ب: الصور. }
$$

1- ضرورة زيادة الحماية للحق في الصورة و ذلك من خلال تنظيم مواد خاصة بها في قانون الإعلام و القانون

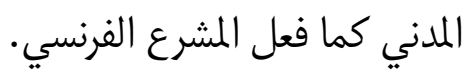
2- حث المشرع الجزائري على تنظيم إجراءات وقائية عند الاعتداء على الحقوق الملازمة للشخصية. 


\section{المعاملات التجارية الالكترونية}

ومسألة إثباتها بين التقييد والحرية وفق التشريع الجذائدي

\section{ن}

أستاذة محاضرة قسم أ بكلية الحقوق و العلوم السياسية

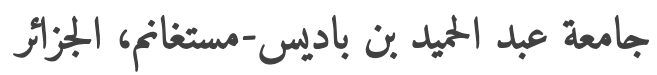

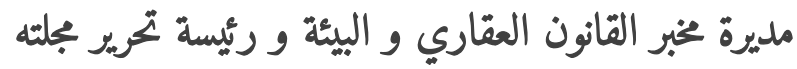

\section{مقدمة:}

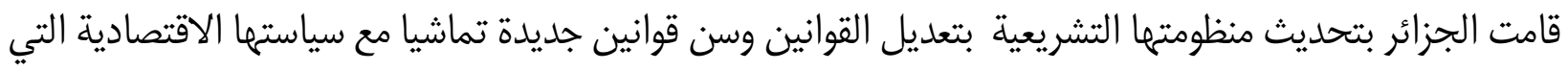

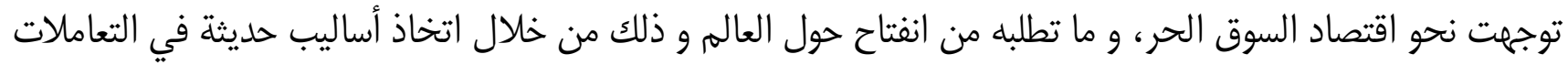

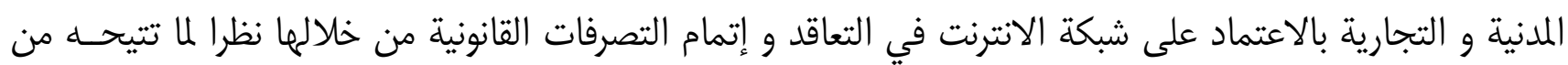

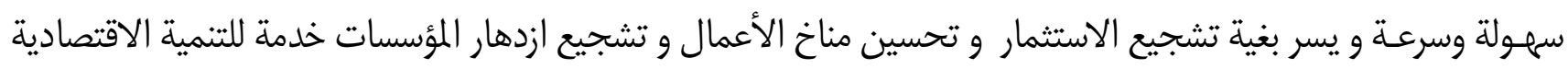

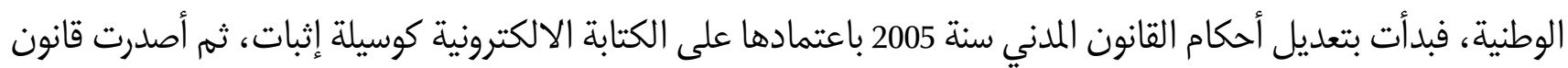

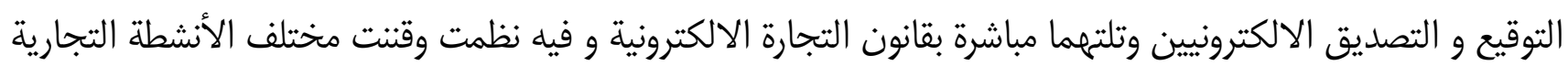
الالكترونية.

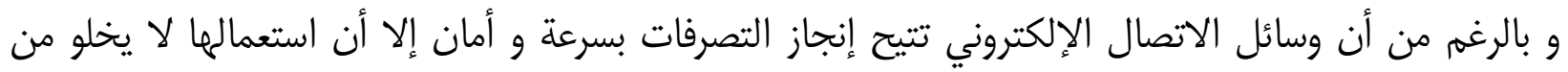

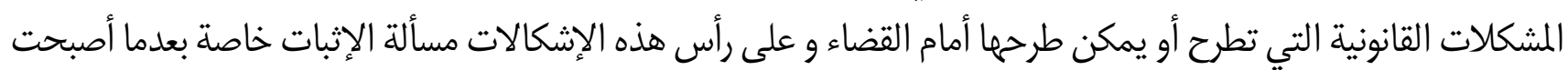

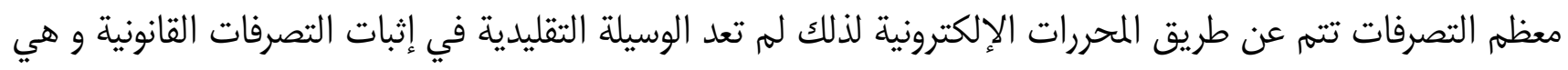

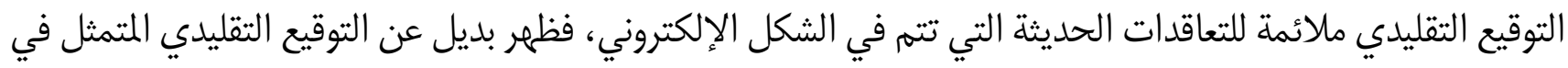
التوقيع الإلكتروني الذي يتوافق و طبيعة التصرفات التي تتم باستخدام الوسائل الإلكترونية.

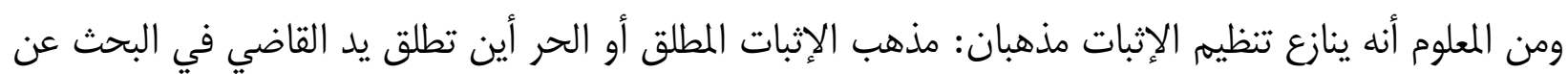

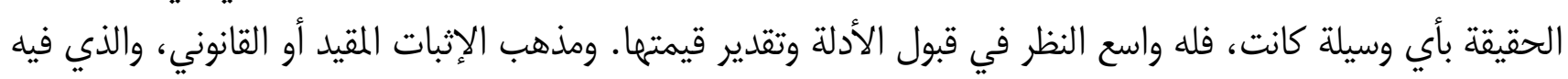

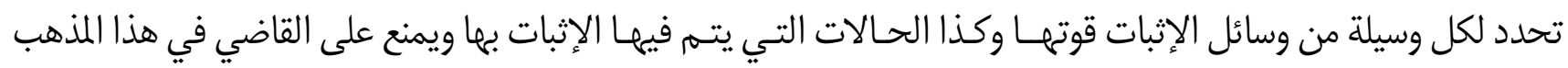

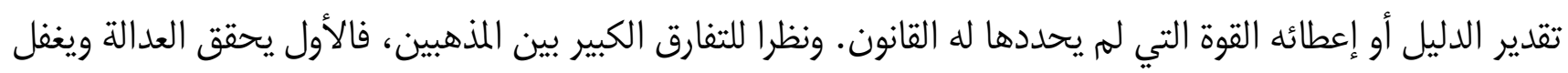

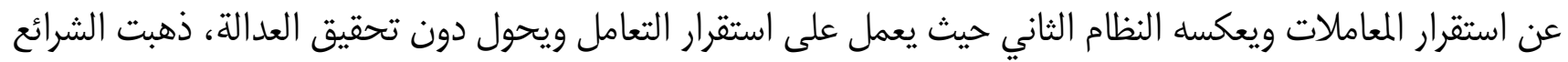

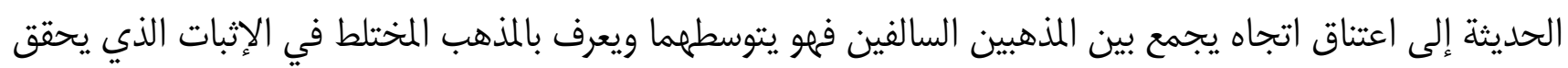

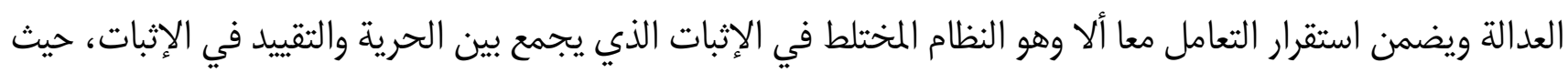
أخذ بحرية الإثبات في المواد الجنائية والتجارية وقيده في المسائل المدنية. 
أما الأولى، فأطلق الإثبات فيها لأنه في المسائل الجنائية كل الأمور تخضع لقناعة القاضي. فكما يُعرف محكمة الجنايات هي محكمة اقتناع لا يخضع فيها القاضي إلا لضميره وللقانون بطبيعة الحال، بالإضافة إلى استحالة تقديم الدليل

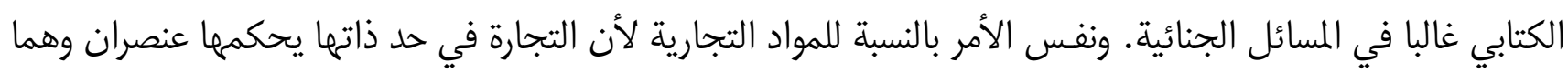
السرعة والائتمان لذا يستحيل تقييد التعاملات بوسائل معينة لإثبات حقوقهم ما عدا مسائل محددة نظرا لأهميتما حدد لها

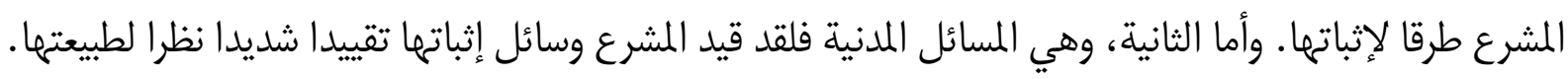
و عليه، كأصل عام يخضع الإثبات قي المسائل التجارية لمبدأ الإثبات المطلق، و لكن وبالنظر إلى أن مصداقية المعلومات التي يتم نقلها و تحويلها عبر شبكة الانترنت و تحديد شخصية طرفي العمليات التعاقدية تتوقف على استعمال التوقيع الإلكتروني الذي تشرف على إصداره هيئة تصديق الكتروني معتمدة من طرف الدول جعل من مسألة المعاماتات التجارية

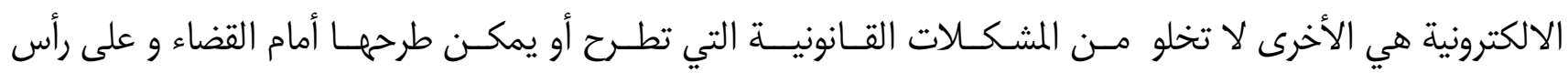

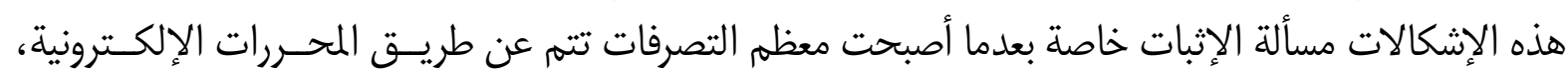
فالسؤال الذي يطرح نفسه هو هل يلزم التجار بإثبات معاملاتهم الالكترونية التجارية بالكتابة لزاما أم لهم مطلق الحرية في إثباتها بأي وسيلة كانت؟ فئ للإجابة على هذه الإشكالية سنقسم بحثنا إلى محورين اثنين، نخصص المحور الأول لدراسة المعاملات التجارية

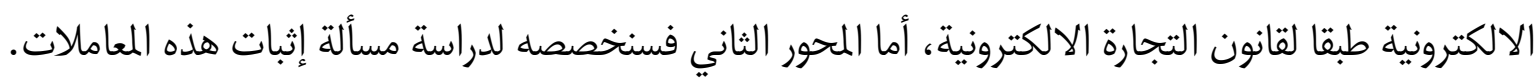

\section{المحور الأول: المعاملات التجارية الالكترونية طبقا لقانون التجارة الالكترونية الجزائري.} نظهم المشرع الجزائري المعاملات الالكترونية في القانون رقم 18-05 المؤرخ في 10-05-2018 المتضمن قانون التجارة الالكترونية 562 الذي بدأ بتحديد مجال تطبيق هذا القانون حيث جعله يطبق على المعاملات الالكترونية التي يكون فيها أحد أطراف العقد الالكتروني متمتعا بالجنسية الجزائرية، أو مقيما إقامة شرعية في الجزائر، أو شخصا معنويا خاضعا للقانون الجزائري أو كان العقد محل ابرامه أو تنفيذه بالجزائر.

وما يلاحظ على هذا القانون، أنه أخرج من محل العقود الالكترونية المعاملات الآتية 563: لعب القمار والرهان واليناصيب، المشروبات الكحولية $564{ }^{264}$ كل سلعة أو خدمة تستوجب إعداد عقد رسمي 565، كل سلعة أو خدمة محظورة بموجب التشريع المعمول به. ولتمام المعاملة التجارية عبر شبكة الانترنت لابد من تتبع بعض الإجراءات الخاصة نص عليها القانون السالف الذكر وفي حالة اتمامها إلا وتترتب عليها بعض الآثار، هذا ما سندرسه تباعا في مايلي.

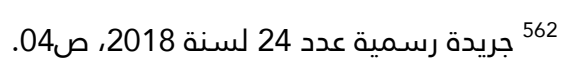
563 المادة 03 من قانون 18-05. 564 حيث يخضع ممارسة هذا النشاط لأحكام خاصة نظمها كل من الأمر 75-26 المؤرخ في في 29-29-04-1975 و قانون الضرائب الغير مباشرة (المواد من 46 إلى 255 منه) الذي تضمنه الأمر رقم 104-10 المؤرخ في -09-12-1976. 565 ذلك لغياب التوثيق الالكترونسي في الجزائر. 


\section{أولا: إجراءات إتمام المعاملة التجارية الالكترونية.}

للقيام بأي معاملة تجاريتة الكترونية لابد من اتباع ثلاث خطوات وهو ما بينته المادة 12 من قانون التجارة الالكترونية والتي تتمثل في الاتي:

كمرحلة أولى، على التاجر وضع الشروط التعاقدية في متناول المسترهلك الالكتروني حتى يكون على دراية تامة بطبيعة العقد وشروطه. ثم يأتي دور المسترلك الالكتروني كمرحلة ثانية وذلك من خلال التحقق من موضوع العقد "الطلبية" لاسيما من حيث الكمية والعدد والثمن، لتأتي المرحلة الثالثة وبها يبرم العقد وتته المعاملة وهي تأكيد الطلبية من طرف المسترهلك. وفي الحقيقة، يعتبر العقد الذي تضمن المعاملة التجارية عقد كالعقود التقليدية إلا أنه يتهم بواسطة دعامة الكترونية ولقد عرفته المادة 03 من القانون 02-04 المؤرخ في 2004/06/23 والمتضمن القواعد المطبقة على الممارسات التجارية 566 المحال

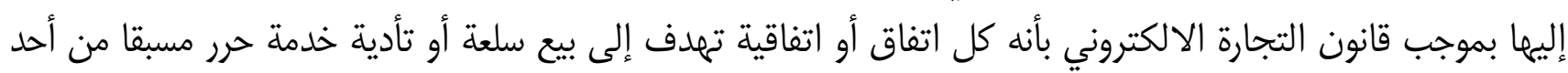
أطراف الاتفاق مع إذعان الطرف الآخر بحيث لا يمكن لهذا الأخير إحداث تغيير حقيقي فيه. وما يميز هذا العقد أنه لا يتم في مجلس واحد وإنما يتم التعاقد عن بعد عن طريق عدة وسائل الكترونية: عن طريق الواب أو عن طريق البريد الالكتروني أو الفاكس أو المباتف الذكي.

و يته بتبادل الايجاب مع القبول، أما الايجاب الالكتروني لا يختلف من حيث المبدأ عن الايجاب التقليدي مادام

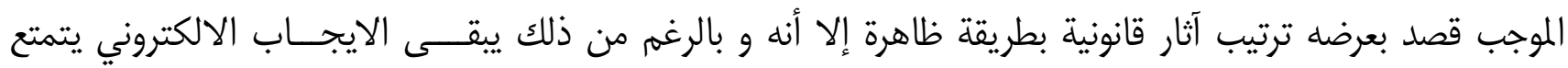

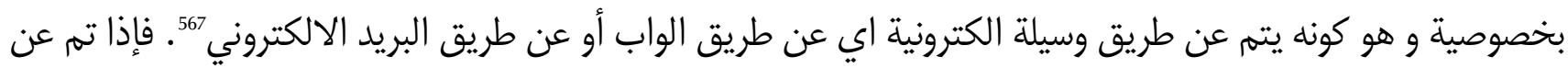
طريق الواب يتخذ شكل قائمة متاحة على الموقع أو المتجر الافتراضي 568. يتهم ارسال العروض التعاقدية عن طريق البريد الالكتروني في شكل رسالة نصية تحتوي على مستندات مرتبطة بها في شكل نصوص أوصوت أو صوت و صورة.569. و لصحة الايجاب لابد من توفره على شروط معينة تتمثل في وجوب كونه كاملا

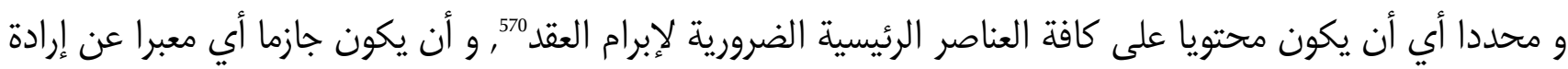
عازمة و حرة على إبرام العقد.

وأما القبول الالكتروني فهو التعبير الثاني عن الإرادة يصدر عن الطرف الثاني يعرب من خلاله موافقته على بنود العقد وهو يتوافق في مضمونه مع ذلك المعنى المشار إليه في القواعد التقليدية فضلا عن خصوصيته المتمثلة في صدوره من خلال وسيط الكتروني ويته عن بعد مع عدم الحضور المادي لأطراف العملية التعاقدية في لحظة تبادل الرضاء. ويتم التعبير عنه

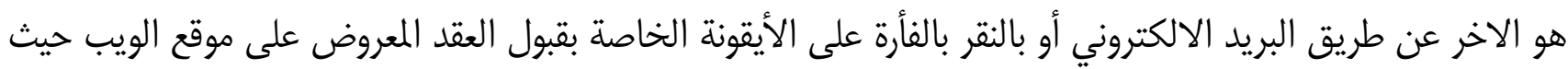

\section{6 الجريدة الرسمية عدد 41 لسنة 2004، ص03.}

567 عبد الله محمد سعيد ربابعة، التعاقد الالكتروني، دراسة فقهية قانونية، مقال، مؤتمر المعاملات الالكترونية، ص 264 وما بعدها.

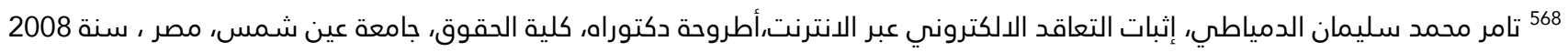


يرسل حاسوب القابل رسالة رقمية إلى حاسوب الخادم (الوسيط مقدم خدمة الواب) الذي يستضيف موقع الانترنت الخاص بالموجب وتعد هذه الحركة تعبيرا عن إرادة القابل أو باستعمال التوقيع الالكتروني حابل.

وبعد مرحلة تطابق الايجاب مع القبول تأتي مرحلة الدفع التي تكون في اغلب الأحوال عبارة عن دفع الكتروني والذي يتخذ عدة صور وان احتوت كلها على ما يضمن مصداقيتها وآمانها التوقيع الالكتروني ونظرا لاعتماد المشرع الجزائري في القانون المدني للتوقيع الالكتروني وباعتباره وسيلة فعالة في الإثبات سنقتصر على دراسة القبول باستخدام التوقيع الالكتروني والذي يأخذ عدة صوركما أسلفنا الذكر.

\section{ثانيا: الأثر المترتب على القيام بالمعاملات التجارية الالكترونية.}

بالرجوع إلى قانون 18-05 المؤرخ في 2018/05/10 والمتضمن قانون التجارة الالكترونية نجده نص على التزامات كل من المتعاقدين، المورد الالكتروني والمسترلك الالكتروني وحدد وقت و طرق دفع الثمن ، فيتهم تنفيذ العقد عن طريق قيام الطرف الأول في العقد بتنفيذ ما التزم به من على شبكة الانترنت بان يسلم السلعة أو يؤدي الخدمة مقابل تنفيذ الطرف الأخر لالتزامه بدفع الثمن. أما موضوع التسليم فهو الشيء المباع ، وقد يكون سلعة ذات كيان مادي ملموس أوكياناً معنوياً أي ليس له وجود مادي ملموس مثل برامج الكمبيوتر وقواعد البيانات فإذا كانت السلع ذات كيان مادي ملموس فعلى المشتري تسليم المبيع بالحالة نفسها التي كان عليها وقت أبرام العقد أو إذا كانت السلعة ذات كيان معنوي (كالمعلومات) فعلى المورد

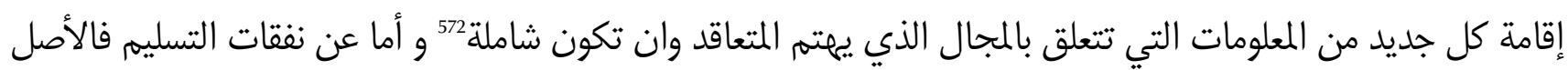
أن تكون على البائع إلا إذا كان هناك اتفاق أو نص بغير ذلك ولكن توجد بعض الصعات الصوبات البريدية والتي تسبب التأخير في تسليهم السلعة أو أداء الخدمة.

ويقابل التسليم أداء المشتري للثمن عن طريق الوفاء الالكتروني الذي يتم عن طريق الدفع الالكتروني بواسطة

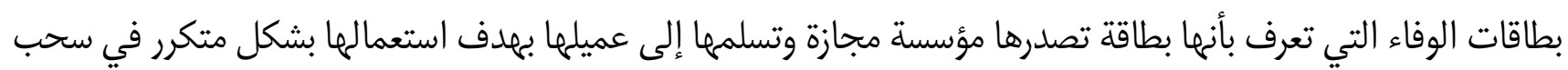

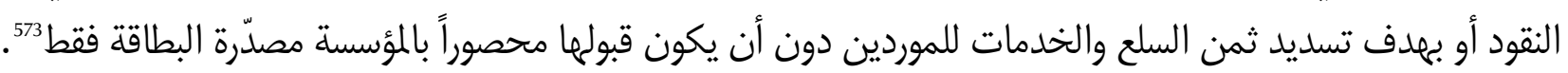
ولقد أقر المشرع الجزائري بمسؤولية المورد الالكتروني العقدية بموجب المادة 18 من قانون التجارة الالكترونية و جعل مسؤوليته قائمة بقوة القانون بمجرد ابرام العقد و لا يمكنه دفع المسؤولية عنه إلا بإثبات السبب الأجنبي من قوة قاهرة أو خطأ المسترهلك الالكتروني.

ويعتبر التوقيـ الالكتروني على العقد الالكتروني من بين أهم النزاعات التي تنشأ عن تنفيذ العقد و ذلك بإهمال

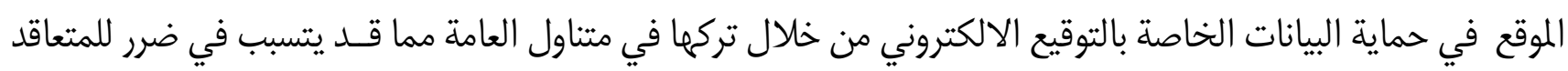
الثاني كما إذا عمد شخص يشتغل لدى تاجر معروف يتمتع بثقـة ماليـة و سمعة طيبة على اختراق البيانات الخاصة بالتوقيع

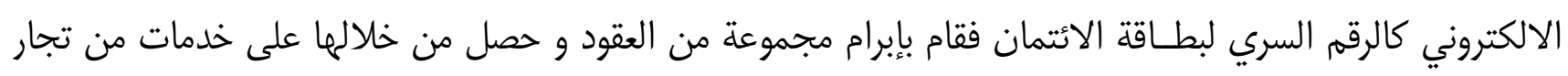

571 تامر محمد سليمان الدمياطي، المرجع السابق، ص 572 572 نزيه محمد الصادق المهدي، انعقاد العقد الالكتروني. مقال، مؤتمر المعاملات الالكترونية، ص 216. 573 احمد السيد لبيب ابراهيم، المرجع السابق، ص 9 و ما بعدها. 


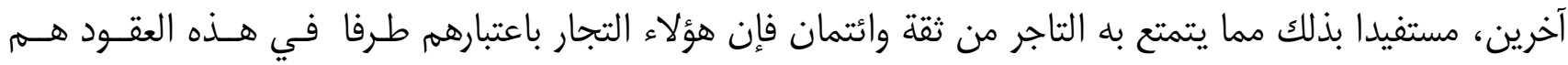

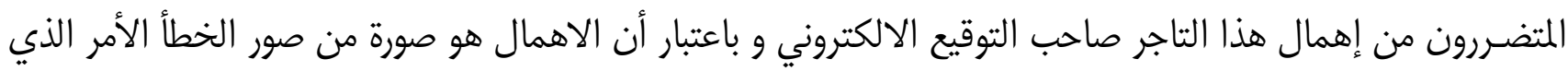
يجعله مسؤولا عن تعويض التجار.

ويكفي للمتضرر إثبات الضرر الذي لحق به نتيجة لتعويله على توقيع الكتروني وفقا لاتفاق عقدي حتى تقوم المسؤولية

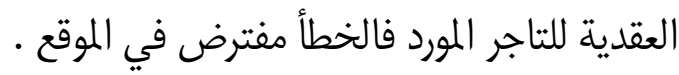

كما يمكن إثارة المسؤولية التقصيرية الالكترونية للتاجر إذا ما تم الاخلال بالتزام غير مستمد من العقد كحالة الاعتداء

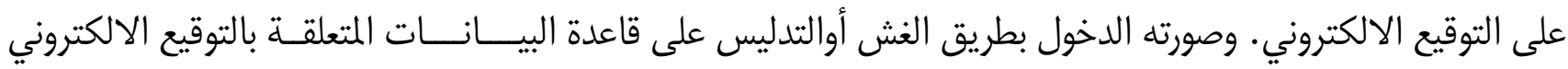

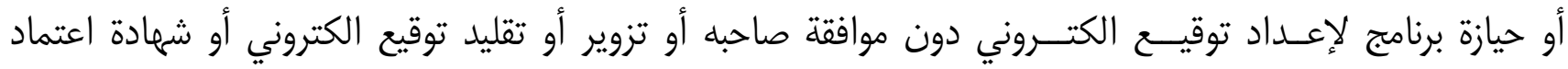

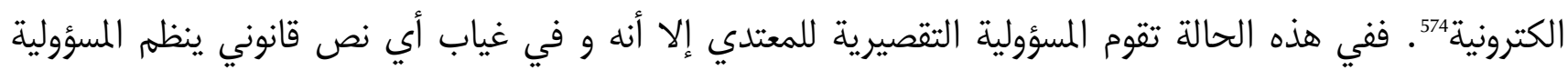

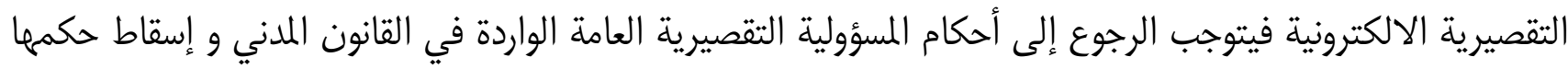

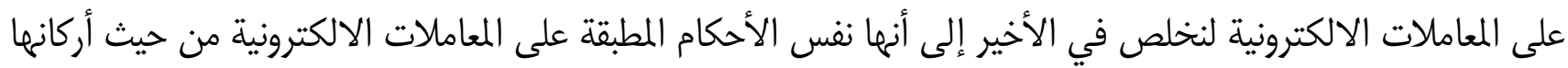

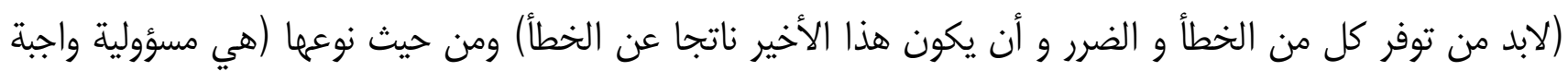

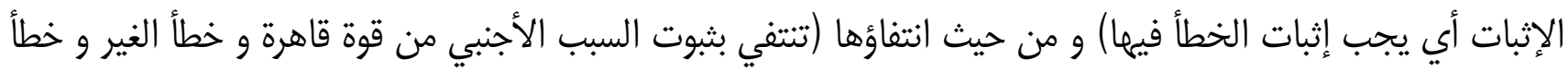

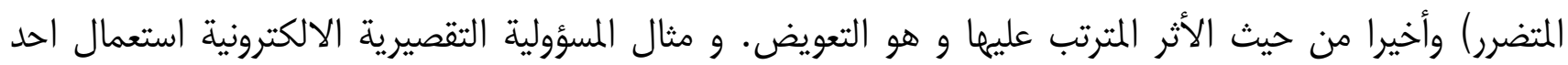

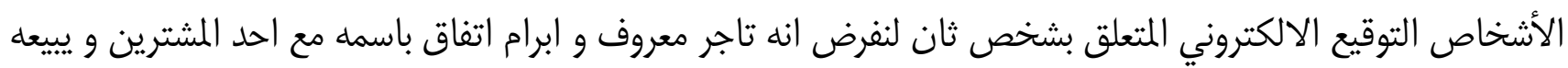

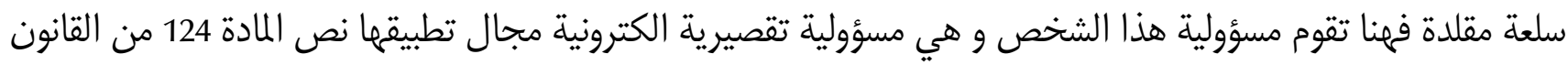
المدني الجزائري تقوم على توفر كل من الخطأ و الضرر و العلاقة السبيية بينهما. أما الخطأ في هذه الحالة مثله مثل الخطأ التقصيري يشتمل على عنصرين واحد مادي و آخر معنوي فالعنصر المادي

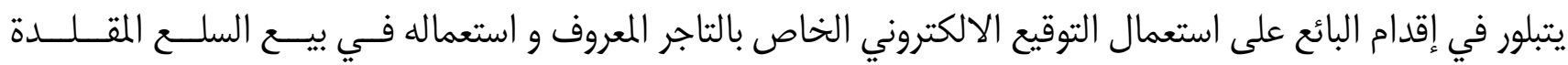

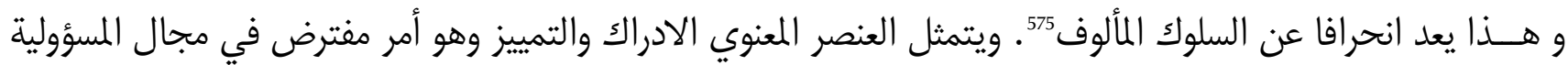

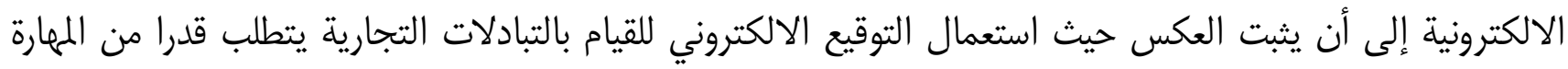

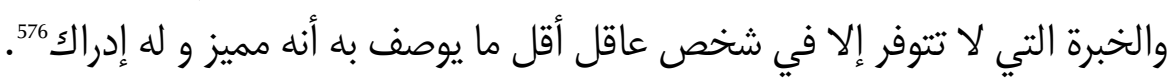

وأما الضرر، فهو أيضا نفسه الضرر في المسؤولية التقصيرية التقليدية حيث يقصد به المساس بمصلحة مشروعة

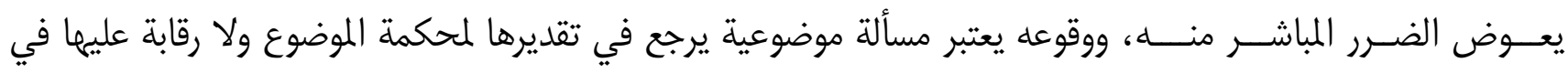
ذلك من المحكمة العليا، و بما أن الضرر يعتبر من قبيل الوقائع المادية فيجوز للمضرور إثباته بكافة وسائل الإثبات.

574 محمد حسين منصور، المسؤولية الالكترونية. منشأة المعارف، الاسكندرية، مصر، سنة 2006، ص152. 575 جمال زكي اسماعيل الجريدلي، المسؤولية المدنية الناشئة عن بيع السلع المقلدة عبر الانترنت. مكتبة الوفاء القانونية، الاسكندرية، مصر، مدورية ط 1 1، سنة 2011، صم 2026 576 جمال زكي اسماعيل الجريدلي، المرجع السابق، ص 203. 
وأخيرا العلاقة السبيية بين الخطأ والضرر أي أن يكون الضرر ناتجا عن الخطأ أي بمفهوم آخر أن يكـــون الخطـأ

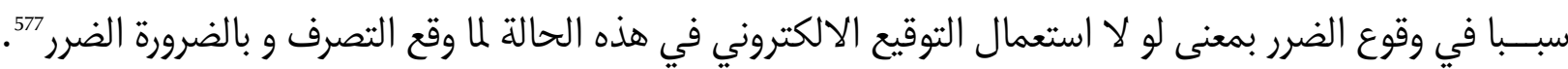
هذا عن قيام المعاملات التجارية الالكترونية والاثار المترتبة عنها بصفة مختصرة، إلا أنه قد تنشأ عن هذه المعاملات

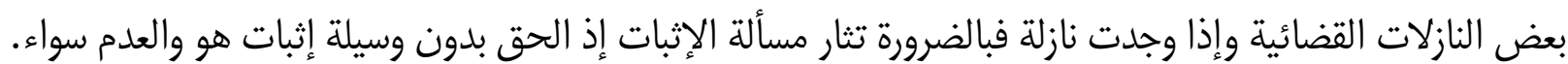

\section{المحور الثاني: إثبات المعاملات التجارية الالكترونية.}

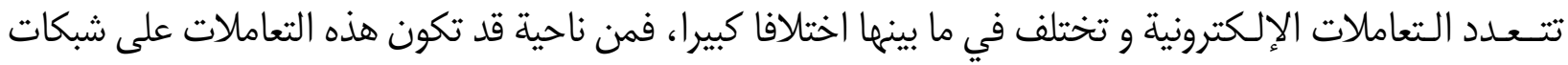

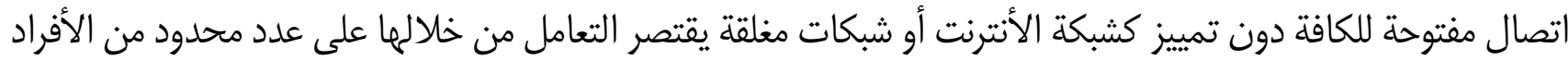

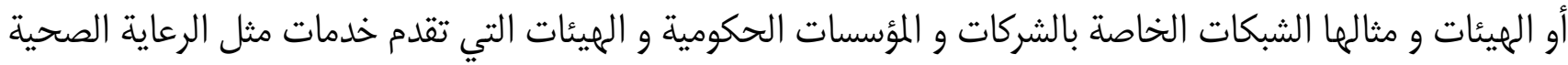
والتأمينية أنمينات

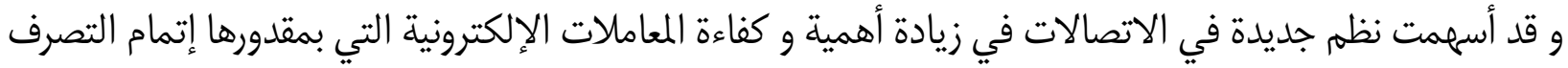
في لحظات معدودة و كذلك وسائل الاتصال عن بعد و نظم التبادل الإلكتروني للبيانات

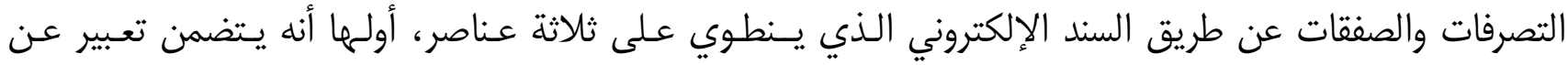

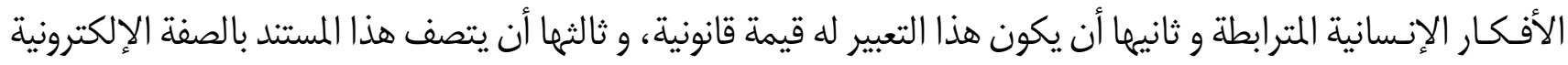
أي أن كتابة المستند و نقله يتم بصورة إلكترونية.

كما تجب الإشارة إلى أن أول نص قانوني تضمن التعامل الالكتروني في القطاع المصرفي هو القانون رقم 03-

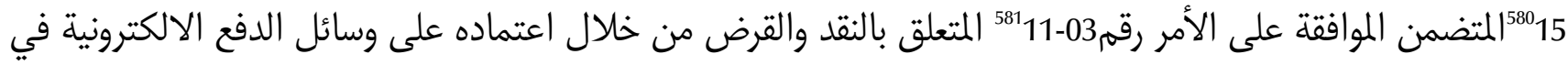

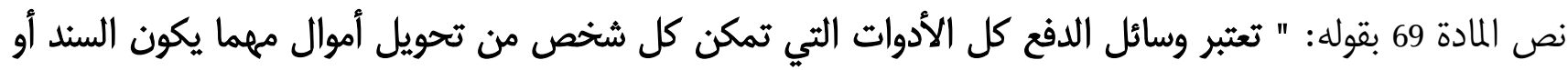

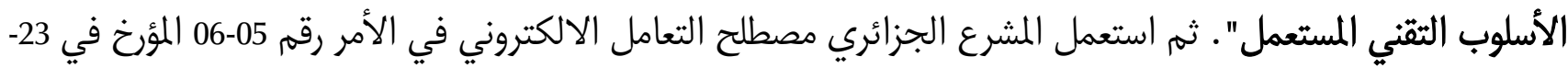

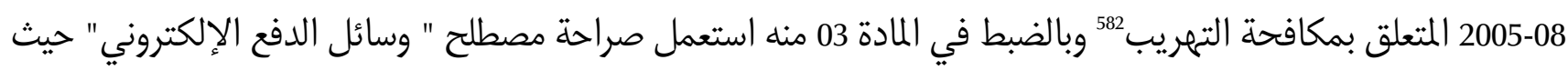

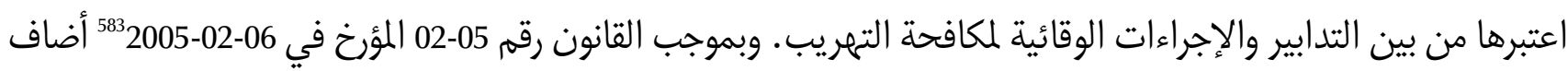

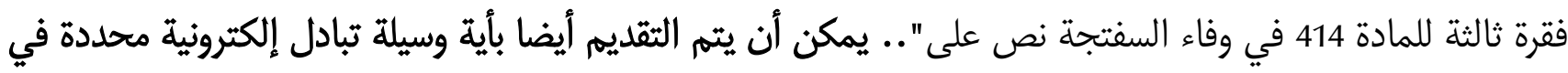

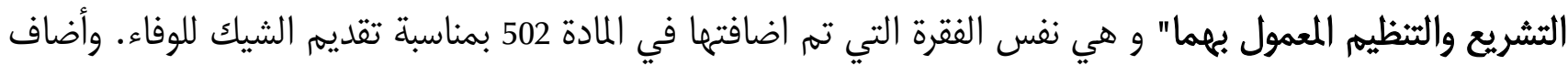

577 احمد السيد لبيب ابراهيم، الدفع بالنقود الالكترونية. دار الجامعة الجديدة، الاسكندرية، مصر، سنة 2009، ص 371 و ما بعدها. 578 عبد الله مسفر الحيان، حسن عبد الله عباس، التوقيع الالكتروني. دراسة نقدية لمشروع وزارة التجارة و الصناعة الكويتية، مجلة العلوم

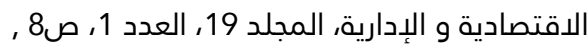
مجلة الموثق، العدد 12، سنة 2005، ص26... 579 Mohamed Fares,le législateur Français crée l'acte authentique électronique 580|الجريدة الرسمية، العدد 52, 581 الجريدة الرسمية، العدد 64. 582 583الأمر المعدل والمتمم للأمر 75-59 لـ 26 سبتمبر 1975 المتضمن القانون التجاري، جريدة رسمية عدد 11. 
المشرع بموجب نفس القانون إلى الكتاب الرابع من القانون التجاري والمعنون بالسندات التجارية، المادة 543 مكرر 23 التي تضمنت بطاقات السحب والدفع.

أما عن الطبيعة القانونية لهذه البطاقات، فلقد اعتبرها المشرع الجزائري أوراق تجارية جديدة إضافة إلى الأوراق التجارية الكلاسيكية وهي السفتجة والشيك والسند لأمر، و بهذا يكون المشرع استحدث نظام الوفاء الإلكتروني في المعاملات التجارية و الذي يكون موضوع دراستنا في ما يلي.

\section{أولا: وسائل الدفع الالكتروني في المعاملات التجارية.}

تتنوع وسائل الدفع الالكتروني وتتخذ عدة صور من بينها الشيكات الالكترونية، بطاقات السحب الالكي و البطاقات الذكية و بطاقات الائتمان.

أما الشيكات الالكترونية، فهي عبارة عـن رسـالة تحـتوي على كافة البيانات التي يحتويها الشيك الورقي العادي من ذكر كلمة شيك في السند نفسه، اسم الشخص الذي يجب عليه الدفع (المسحوب عليه)، المكان الذي يبرم فيه الدفع، تاريخ إنشاء الشيك و مكانه وتوقيع من أصدر الشيك 584 (الساحب) مع العلم أن هذا التوقيع الذي يتضمنه الشيك يكون

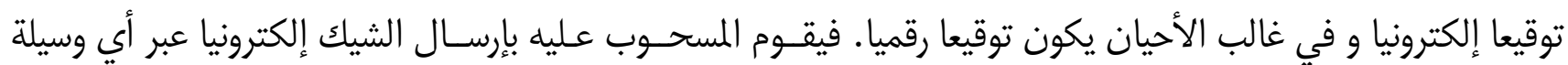
إلكترونية كالفاكس أو البريد الالكتروني في أغلب الأحيان وتتم عملية استخدام الشيك الإلكتروني كوسيلة للدفع كالاتيي:

يقوم المسحوب عليه (المشتري مثلا) بفتح حساب جاري لدى البنك الذي يلعب دور الوسيط والذي يقوم بإجراء عملية

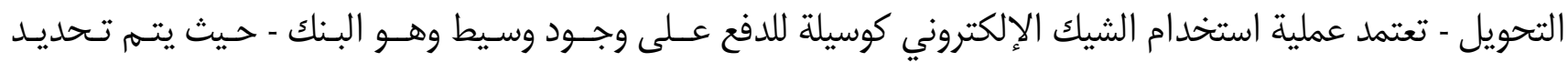
التوقيع الإلكتروني للمسحوب عليه وتسجيله في قاعدة البيانات الخاصة بالبنك شرط أن يكون الساحب (أي البائع مثلا) هو الآخر لديه حساب جاري بنفس البنك و أن يكون توقيعه الإلكتروني محددا و مسجلا بالمثل في قاعدة البيانات الخاصة

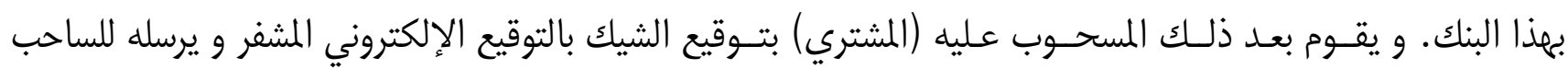
(البائع) عن طريق البريد الإلكتروني و عند استلام هذا الأخير أي الساحب (البائع) الشيك الالكتروني يقوم بالتوقيع عليه كمستفيد بتوقيعه الإلكتروني المشفر و يرسله إلى البنك فيتولى هذا الأخير مراجعة الشيك و التحقق من مدى صحة صلئ الأرصدة

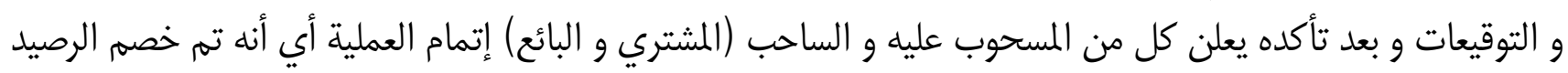
من المشتري و إضافته للبائع

أما بطاقات السحب الآلي و البطاقات الذكية، فأغلب المعاملات البنكية تتم اليوم من خلال أجهزة الصرف الآلي و التي تتم عن طريق إدخــال العميل بطاقة السحب الآلي إلى داخل الجهاز مع الرقم السري و من ثم متابعة العملية من

584 585 قدري عبد الفتاح الشهاوي، قانون التوقيع الالكتروني و لائحته التنفيذية و التجارة الالكترونية في التشريع المصري و العربي و الأجنبي. دار النهضة العربية، القاهرة، ط1، سنة 2005.، ص446.

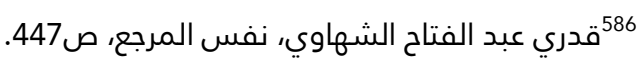




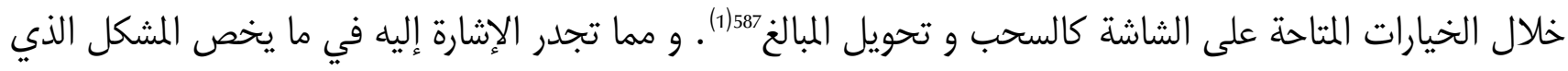

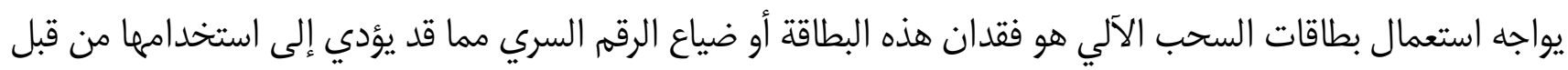

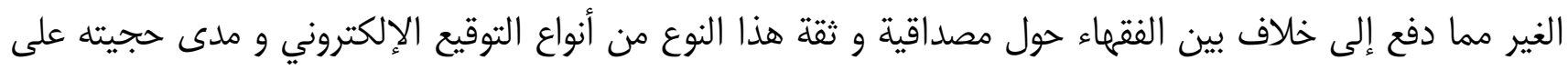
صاحبه و هذا ما سيتم الإشارة إليه لاحقا حين التطرق إلى حجية التوقيع الإلكتروني. ثم ظهر إلى الوجود إلى جانب بطاقات السحب الآلي، البطاقات الذكية فهي تعتبر وسيلة مستقلة للدفع الإلكتروني و

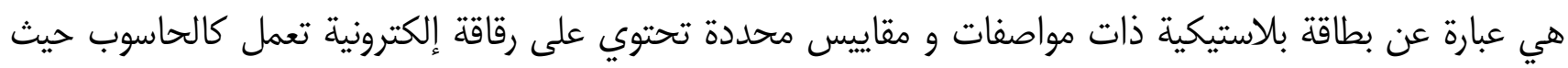

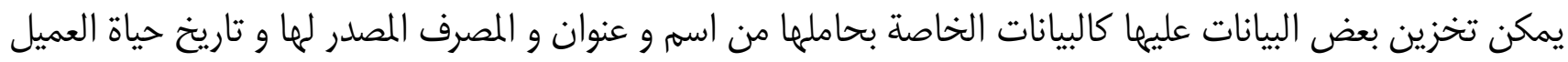

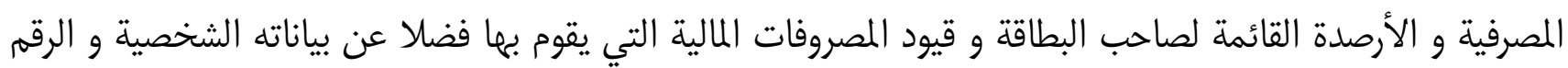
السري - المئ. و أهم ما يميز هذه البطاقات هو الحماية التي توفرها ضد عمليات التزوير و التزييف و سوء الاستخدام من جانب الغير

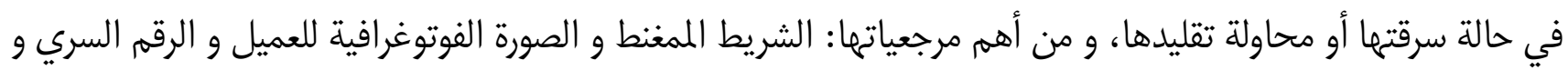

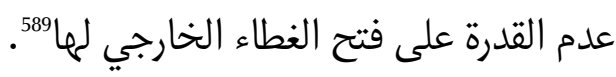

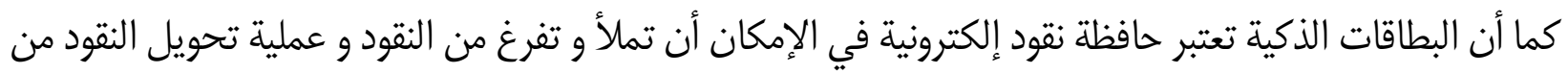

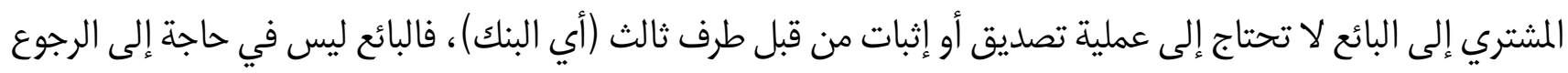

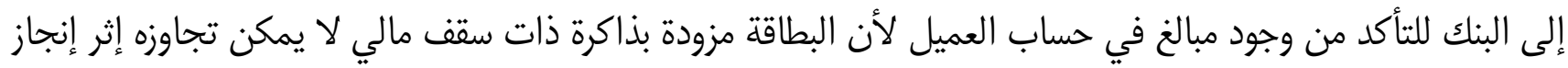

المعاملات

و أخيرا، بطاقات الائتمان التي أصبح استخدامها عبر شبكة الأنترنت منتشرا على نطاق واسع خاصة على مستوى المارى المعاملات التجارية التي تتم بين البائع و المستهلك. ولاستخدات الاتحام بطاقات الائتمان لابد من توافر عاملين هما: 1: فتح حساب خـاص بأحـد البنوك يُعرف باسم الحساب التجاري و لا يعتبر هذا الإجراء سهلا حيث أن معظم البنوك

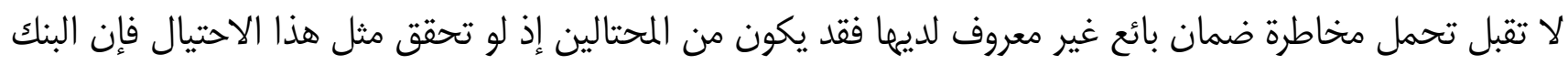

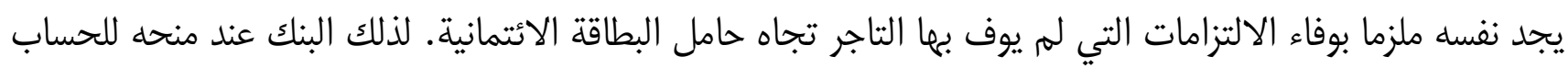

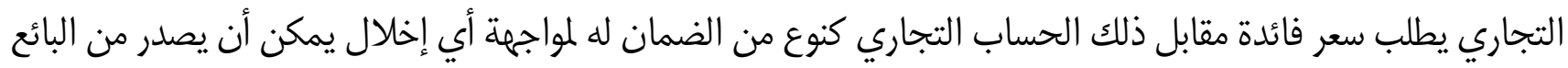
تجاه المشترين حاملي بطاقات الائتمان

2: أن يتوافر ما يسمى مدخل الدفع الآمن حيث يقوم هذا المدخل بعمل السيارة التي تقوم بنقل البيانات الخاصة

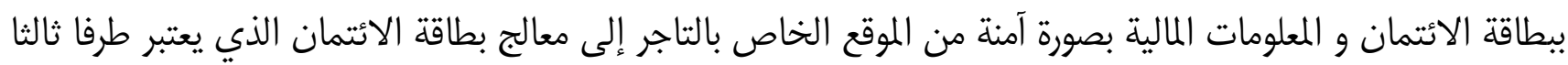

587 عبد الله مسفر الحيان، حسن عبد الله عباس، المرجع السابق، ص17.

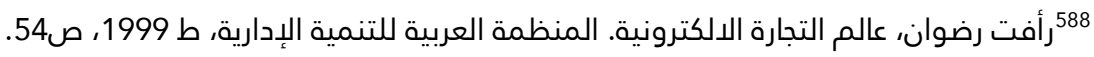
589 رأفت رضوان، المرجع السابق، ص55.

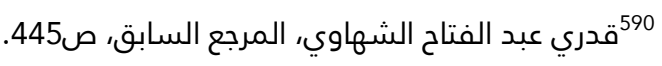

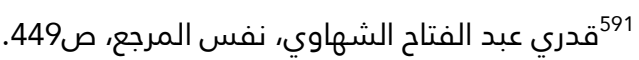


يعمل ما بين شركة الائتمان و البنك الخاص بالتاجر إذ يعمل على الكشف عن حقيقة بطاقة الائتمان و بياناتها و كذا التأكد من صلاحيتها لقيام حاملما بالشراء لإمكانية المصادقة و الموافقة على عملية البيع. ثم يقوم معالج بطاقة الائتمان

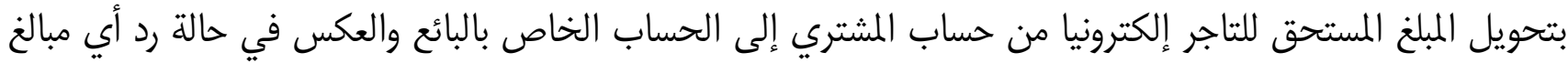

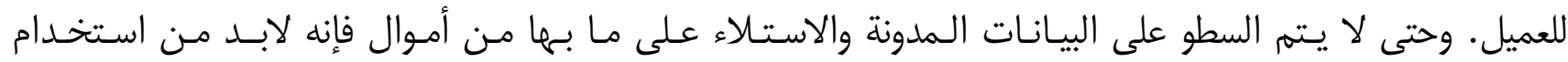

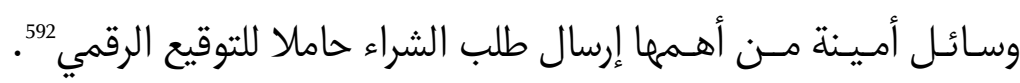

و الملاحظ، أن كل هذه الوسائل تعتمد على ما يطلق عليه التوقيع الالكتروني فكل معاملة تجارية الكترونية إلاو ذيلت بتوقيع الكتروني و هو الذي نظم المشرع حجيته في الإتبات كما سنبينه في الاتي.

\section{ثانيا: حجية التوقيع الالكتروني في الاثبات.}

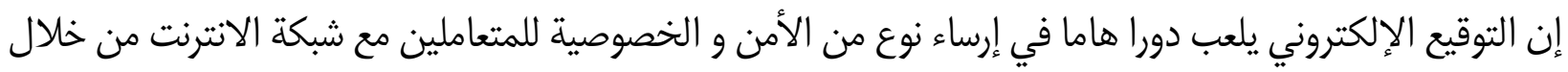

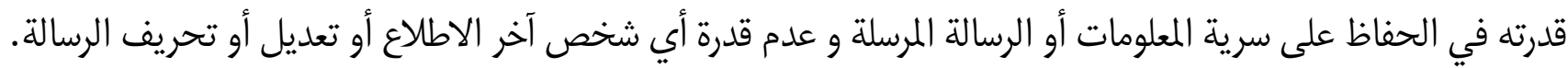

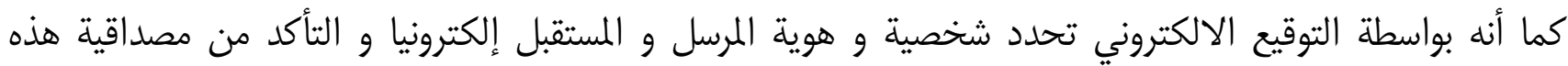
الشخصيات

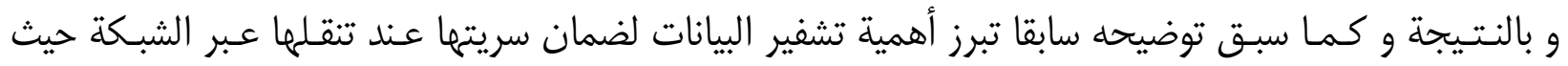

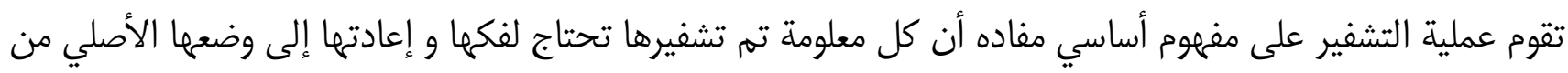
قبل صاحبها و ذلك باستخدام مفاتيح خاصة و بهذا تضمن سلامة المستند المرسل و التأكد من هوية المرسل معا. و التشفير أنواع، فهناك نوع من التشفير يستخدم فيه مفتاح واحد للتشفير و فك التشفير و هناك نوع آخر يستخدم فيه مفتاحين واحد للتشفير و الآخر لفك التشفير إلى جانب أنواع أخرى. نعه، تتعدد أشكـال التوقيع الإلكتروني و أنواعه بحسب الوسيلة أو التقنية التي تستخدم في إنشاء التوقيع و من هذه التها الأشكال أو الصور التوقيع الرقمي، التوقيع البيومتري، التوقيع بالماسح الالكتروني و التوقيع الكودي.

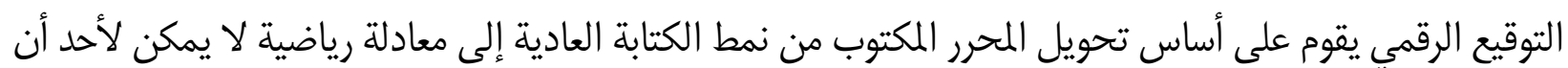

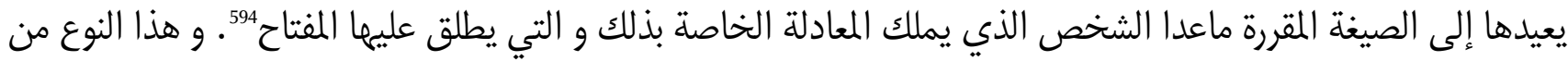

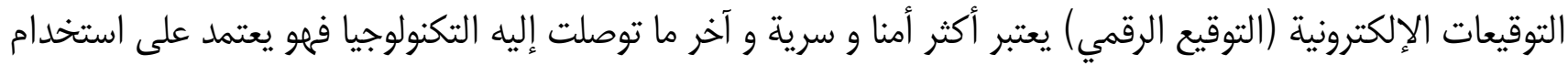

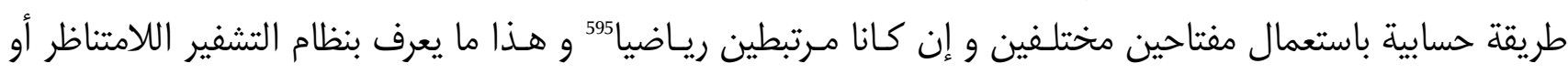

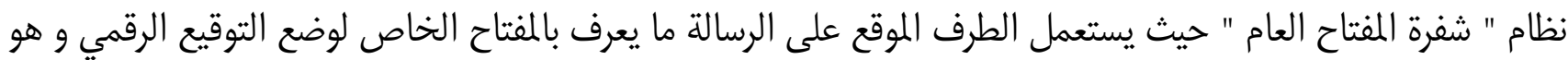

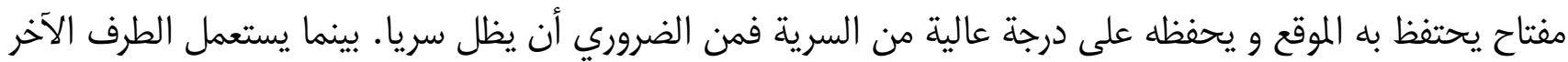

592 قدري عبد الفتاح الشهاوي، نفس المرجع، ص450.

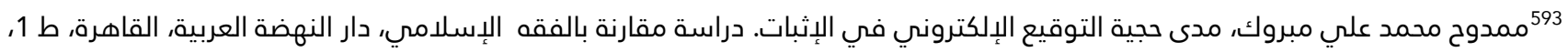
سنة 2005، ص140. 594عبد الله مسفر الحيان، حسن عبد الله عباس، المرجع السابق، ص21, 595 قدري عبد الفتاح الشهاوي، المرجع السابق، صبدئ عبدئ. 
(مستقبل الرسالة) المفتاح العام للتحقق من صحة التوقيع الرقمي الموضوع بواسطة المفتاح الخاص و هو معروف لأكثر من

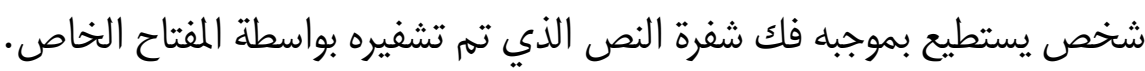

أما التوقيع البيومتري فهو نوع من التوقيعات الإلكترونية التي يعتمد بشكل أساسي على الخصائص الذاتية للإنسان

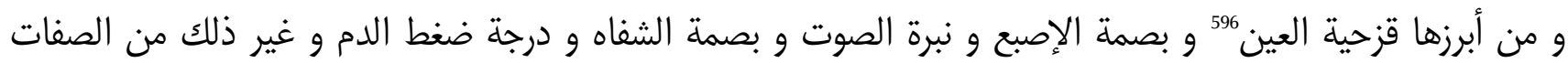

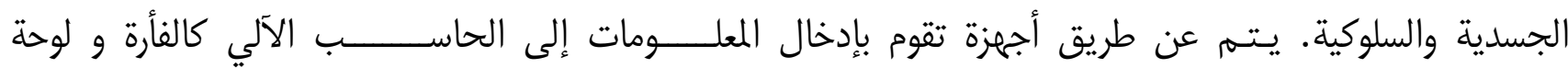

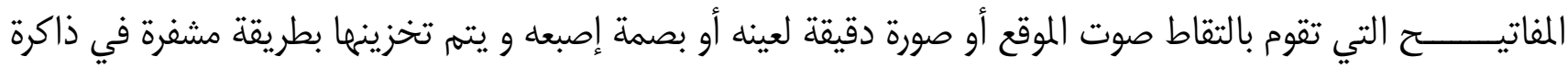

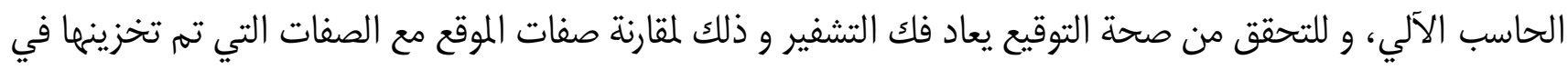
الحاسب الآلي

أما التوقيع بالقلم الإلكتروني فصورته تتمثل في قيام الموقع بكتابة توقيعه الشخصي باستخدام قلم إلكتروني ضوئي

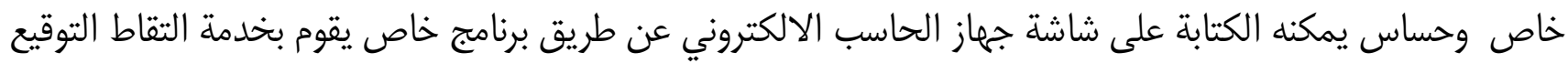

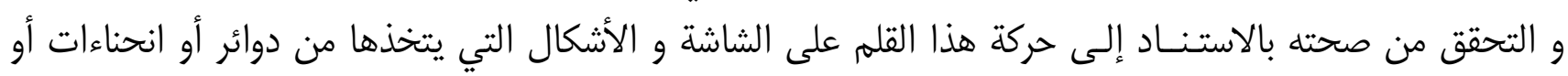

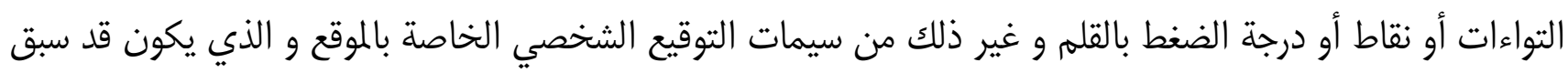

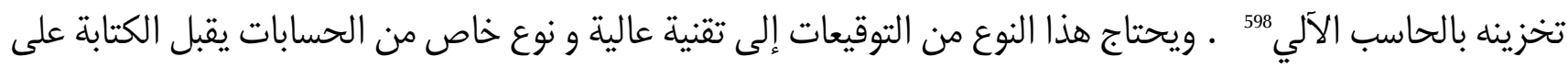
شاشته مباشرة.599. و أخيرا التوقيع الكودي أو السري فيقصد به استخدام مجموعة من الأرقام أو الحروف أو كليهما يختارها صاحب

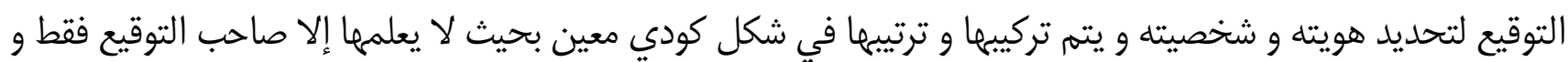
من يبلغه بهها

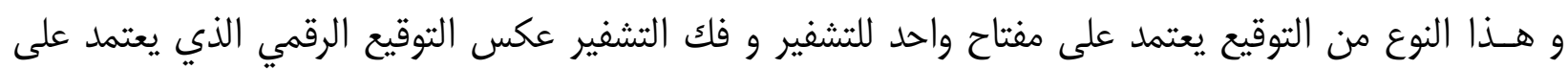

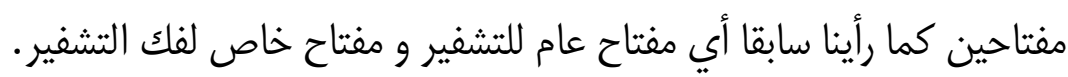
و للحصول عليه نتبع الخطوات التالية:

596 596

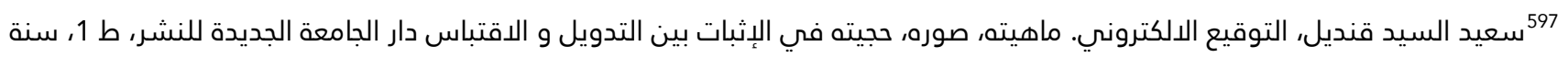
(2004، ص70.  سنة 1998، ص113. 599أيمن سعد سليم، التوقيع الالكتروني.دراسة مقارنة، دار النهضة العربية، بدون سنة طبع، ص 27. و عبد العزيز المرسي حمود مدى حجية

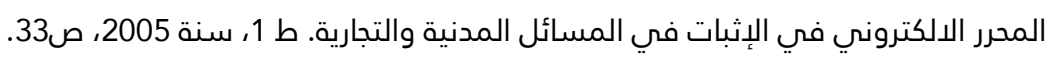
5 ابراهيم الدسوقي أبو الليل، الجوانب القانونية للتعاملات الالكترونية. مجلس النشر العلمي، جامعة الكويت، ط 1، سنة 2003 ص158. ${ }^{601}$ Michel Jaccard, droit de la concurrence et signature numérique. p16. Jaccard@ttv.ch,28/11/2000. 
1: إنق كل حرف من الحروف الأبجدية برقم معين كالتالي:

\begin{tabular}{|c|c|c|c|c|c|c|c|c|c|c|c|c|c|}
\hline ص & ش & س & j & ) & $j$ & د & $\dot{\tau}$ & $\tau$ & ๔ & $ث$ & ث & ب & \\
\hline 14 & 13 & 12 & 11 & 10 & 9 & 8 & 7 & 6 & 5 & 4 & 3 & 2 & 1 \\
\hline ي & 9 & 0 & $\dot{ن}$ & p & J & s & ق & ف & $\dot{\varepsilon}$ & $\varepsilon$ & b & $b$ & ض \\
\hline 28 & 27 & 26 & 25 & 24 & 23 & 22 & 21 & 20 & 19 & 18 & 17 & 16 & 15 \\
\hline
\end{tabular}

2: نقوم بترميز النص و ذلك بإلحاق كل حرف منه بالرقم المرفق و نضيف لكل حرف من أحرف النص، حرف من الكلمة التي تسمى المفتاح و الذي هو بدوره يكون قد رمز برقم مـع الإشارة أن كلمة السر أي المفتاح هي التي يختارها المعني بالأمر و التي ينبني حفظها. ولنضرب مثالا على ذلك: النص هو: "نلتقي على الساعة السادسة" و المفتاح هو كلمة "صباح"، فالتشفير يكون كالآتي: أ- النص الأصلي: " نلتقي على الساعة السادسة".

\begin{tabular}{|c|c|c|c|c|c|c|c|c|c|c|}
\hline س & $J$ & 1 & $\checkmark$ & $J$ & $\varepsilon$ & ي & ق & $\ddot{~}$ & J & $\dot{0}$ \\
\hline \multirow[t]{3}{*}{12} & 23 & 1 & 28 & 23 & 18 & 28 & 21 & 3 & 23 & 25 \\
\hline & $\ddot{0}$ & س & $د$ & 1 & س & $J$ & 1 & $\ddot{0}$ & $\varepsilon$ & 1 \\
\hline & 3 & 12 & 8 & 1 & 12 & 23 & 1 & 3 & 18 & 1 \\
\hline
\end{tabular}

\begin{tabular}{|l|l|l|l|}
\hline \multicolumn{1}{c|}{} & 1 & + & 0 \\
\hline 6 & 1 & 2 & 14 \\
\hline
\end{tabular}

\begin{tabular}{|c|c|c|c|c|c|c|}
\hline J & ع+ب & ي+ص & ق+ & ت & ل ل+ب & $\omega+\dot{v}$ \\
\hline $1+23$ & $2+18$ & $14+28$ & $6+21$ & $1+3$ & $2+23$ & $14+25$ \\
\hline ت+ب & ص+ع & أ+ & س+أ & ل & أ+ص & ي+ح \\
\hline $2+3$ & $14+18$ & $6+1$ & $1+12$ & $2+23$ & $14+1$ & $6+28$ \\
\hline ت+ص & س'ح & د+أ & أ+ب & س+ص & ل & أَ+أ \\
\hline $14+3$ & $6+12$ & $1+8$ & $2+1$ & $14+12$ & $6+23$ & $1+1$ \\
\hline
\end{tabular}

3: لفك تشفـير النــص يكفـــي الحصول على كلمة السر أي المفتاح و القيام بفك التشفير بواسطة عملية الطرح و التي تتم كالآتي: 
أ- يصل النص المشفر إلى المرسل إليه كالتالي: ن+ص=25+14=39 ل لب=23+25، .... ، فنتحصل على:

\begin{tabular}{|c|c|c|c|c|c|c|c|c|c|c|}
\hline \multirow[t]{2}{*}{13} & 25 & 15 & 34 & 24 & 20 & 42 & 27 & 4 & \multicolumn{2}{|l|}{25} \\
\hline & 17 & 18 & 9 & 3 & 26 & 29 & 2 & 5 & 32 & 7 \\
\hline \multicolumn{2}{|l|}{$1-24$} & $2-20$ & \multicolumn{2}{|c|}{$14-42$} & $6-27$ & \multicolumn{2}{|c|}{$1-4$} & $2-25$ & \multicolumn{2}{|c|}{$14-39$} \\
\hline \multicolumn{2}{|l|}{$2-5$} & $14-32$ & \multicolumn{2}{|c|}{$6-7$} & $1-13$ & \multicolumn{2}{|c|}{$2-25$} & $14-15$ & \multicolumn{2}{|c|}{ 6-34 } \\
\hline \multicolumn{2}{|c|}{$14-17$} & $6-18$ & \multicolumn{2}{|c|}{$1-9$} & $2-3$ & \multicolumn{2}{|c|}{$14-26$} & $6-29$ & \multicolumn{2}{|c|}{$1-2$} \\
\hline \multirow[t]{2}{*}{12} & 23 & 1 & 28 & 23 & 18 & 28 & 2 & 3 & 2 & 2 \\
\hline & 3 & 12 & 8 & 1 & 12 & 23 & 1 & 3 & 18 & 1 \\
\hline
\end{tabular}

د- ثم نقوم بإلحاق كل رقم بالحرف الخاص به فنتحصل على النص الأصلي كالآتي:

\begin{tabular}{|c|c|c|c|c|c|c|c|c|c|c|}
\hline 12 & 23 & 1 & 28 & 23 & 18 & 28 & 21 & 3 & 23 & 25 \\
\hline س & J & 1 & ى & J & $\varepsilon$ & ي & ق & ت & J & ن \\
\hline & 3 & 12 & 8 & 1 & 12 & 23 & 1 & 3 & 18 & 1 \\
\hline & 0 & س & د & 1 & س & J & 1 & o & $\varepsilon$ & 1 \\
\hline
\end{tabular}

أي نتحصل على: " نلتقي على الساعة السادسة ".

و تجـب الإشـارة إلى أن التوقيع الكودي أو السري غالبا ما يستخدم في المراسلات و إبرام عقود التجارة الالكترونية

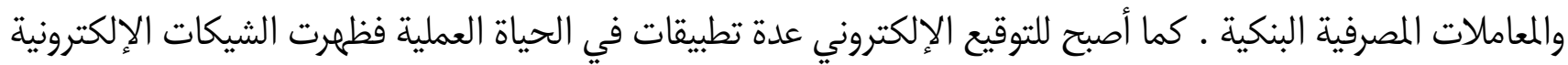
وبطاقات الصرف الآلي و بطاقات الأتتمان و أخيرا التعاقد الالكتروني.

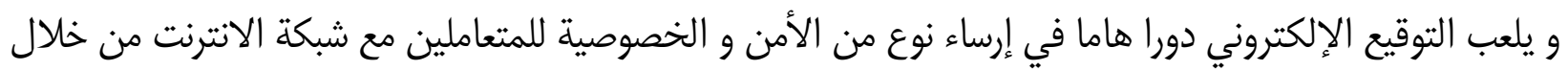

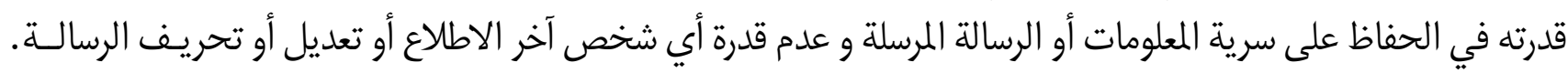

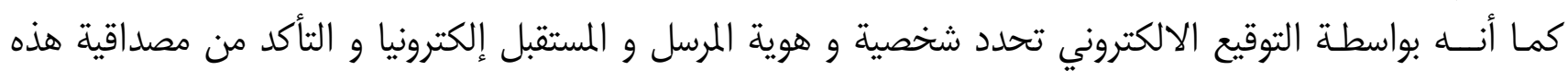
الشخصيات

و تجدر الإشارة إلى أن المشرع نظم التوقيع الالكتروني في القانون المدني بالضبط في نص المادتين 323 مكرر و 327 نالتهات

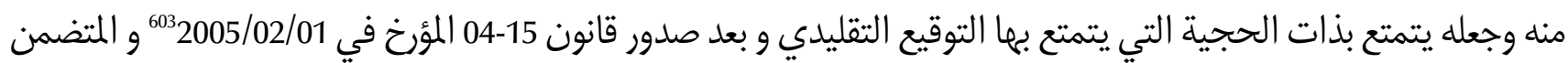

مجلة الموثق، العدد 12، سنة 2005، ص26... جريدة رسمية عدد 06 لسنة 2015، ص06. 
قانون التوقيع و التصديق الالكترونيين أكد على المبدأ و حدد شروط ما يعرف بالتوقيع الالكتروني الموصوف و هو التوقيع

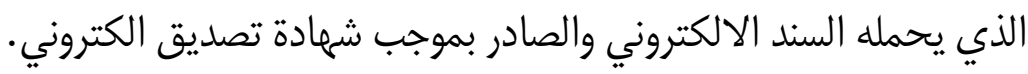

و لقد اتفق الفقه و القضاء على وجوب استفاء الكتابة مجموعة من الشروط حتى تكون لما حجية في الإثبات

\section{1: أن تكون الكتابة مقروءة.}

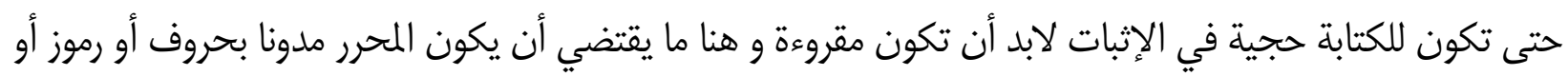

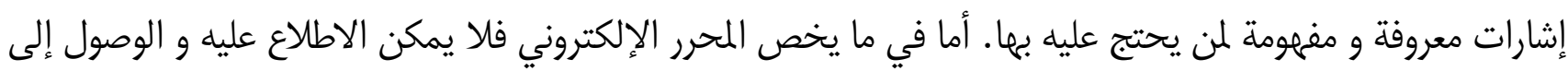

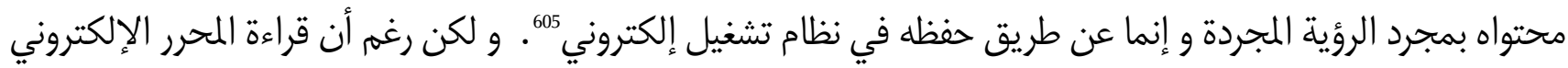

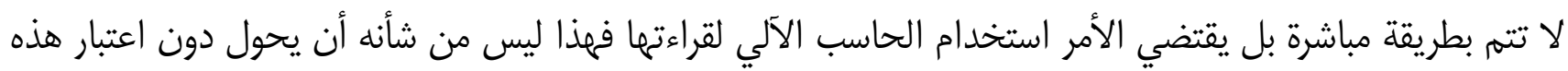

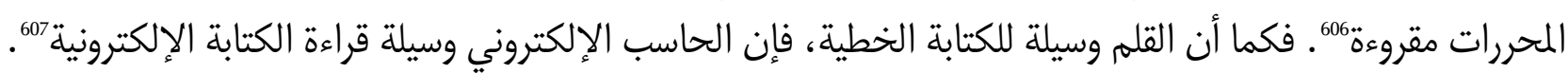

\section{2: أن تكون الكتابة مستمرة.}

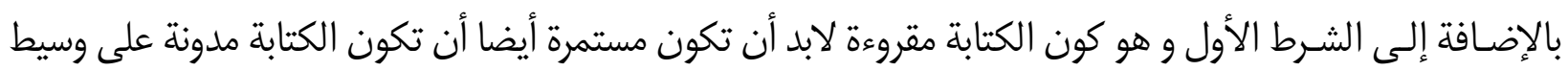

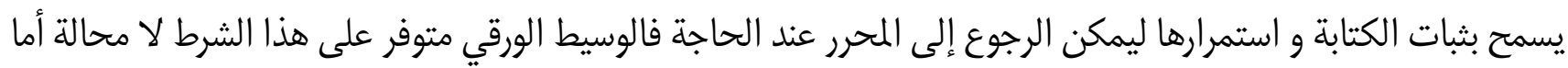
الوسيط الإلكتروني فقد استطاعت التقنية الحديثة من جعله يتصف بالاستمرارية و الديمومة المناته

\section{3: عدم قابلية الكتابة اللتعديل إلا بإتلاف المحرر أو ترك أثر مادي عليه.}

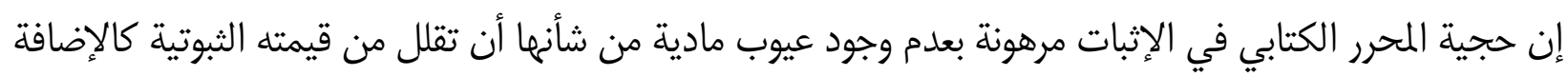

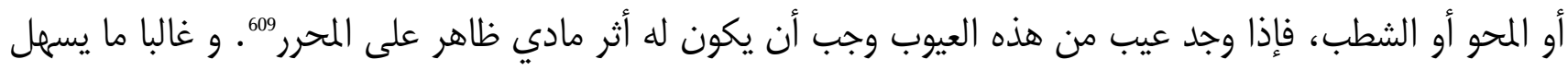

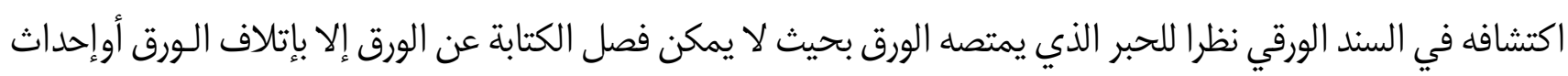

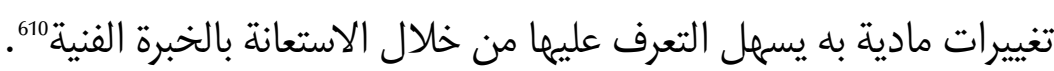

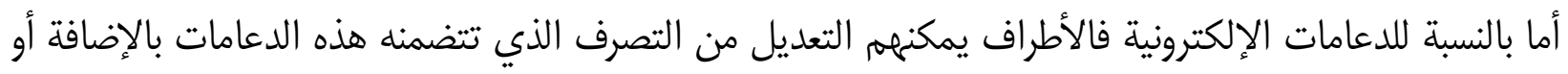

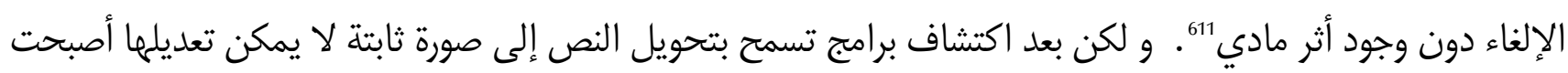

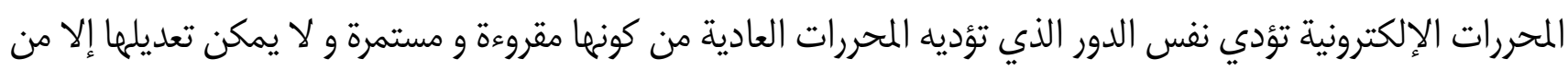

${ }^{604}$ F.Lorentz, rapport du commerce électronique, une nouvelle donnée pour les consommateurs, les entreprises, les citoyens et les pouvoirs publics, Ed Ber 1998,p 5 et s.

605أشرف توفيق شمس الدين، المرجع السابق، ص10. 606 حسن جميعي، إثبات التصرفات القانونية التي يتم إبرامها عن طريق الانترنت. دار النهضة العربية ، ط ط 2000، ص2.

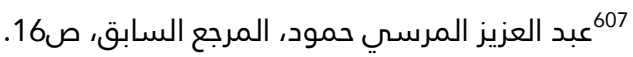

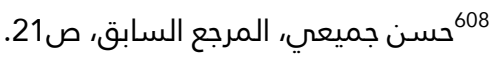

609 عبد العزيز المرسي حمود، المرجع السابق، ص17. ${ }^{610}$ A.Raynoward,la dénaturalisation des titres, étude sur la forme scripturale, thèse, Paris 2, 1998,n65.

611 أسـامة أبو الحسن، خصوصية التعاقد عبر الانترنت. دراسة مقدمة إلى مؤتمر موضوعه " القانون و الكمبيوتر و الانترنت "، جامعة الإمارات العربية، سنة 2000، ص37، منشور على شبكة الانترنت. 
خلال ترك أثر مادي عليها خاصة بعدما أصبح يلجأ إلى حفظ المحررات الإلكترونية في صناديق تكون تحت إشراف جهات

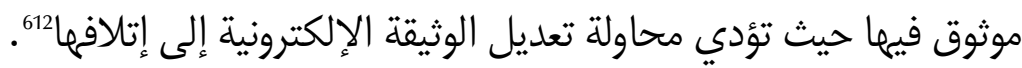
يظهر مما سبق أن المحرر الإلكتروني له نفس حجية المحرر العادي و هذا ما ذهب إليه المشرع الجزائري في نص المادة 323 مكرر1 المذكورة آنفاو التي يستخلص منهر الإكتروني لنتيجتان:

النتيجة الأولى: عدم التمييز بين الكتابة بسبب الوسيط الذي تتم من خلاله. فسواء تمت الكتابة على وسيط ورقي أو

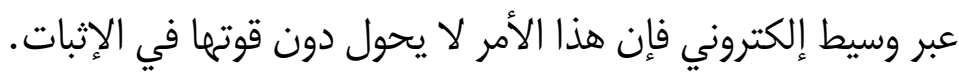
النتيجة الثانية: المساواة الوظيفية بين المحرر الإلكتروني و المحرر التقليدي أي منح نفس الحجية للمحرر الإلكتروني

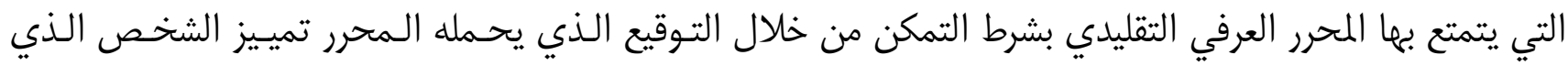

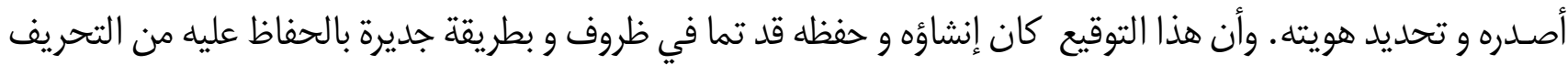

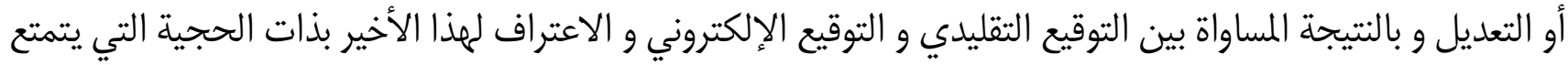
بها التوقيع التقليدي.

و لكن شرط التأكد من إعداد المحرر و حفظه في ظروف تضمن سلامته لا يمكن أن ينفذ و يطبق بشكل دقيق إلا عند

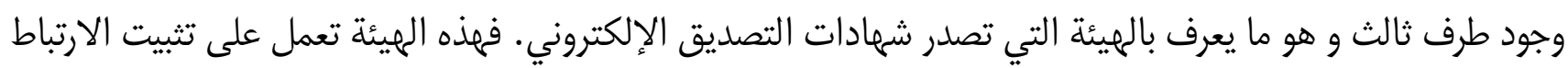

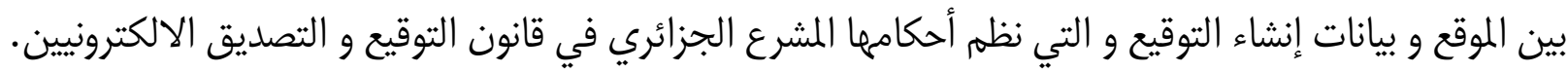
و عليه، و كخلاصة لما سبق يظهر أن المشرع أضفى الحجية على مثل هذه المعاملات بشرط حملها لتوقيع الكتروني

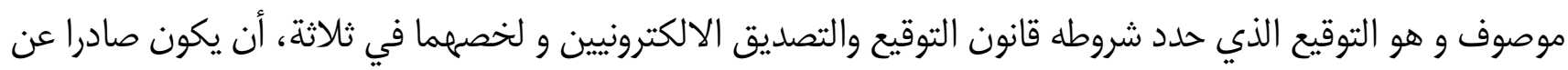

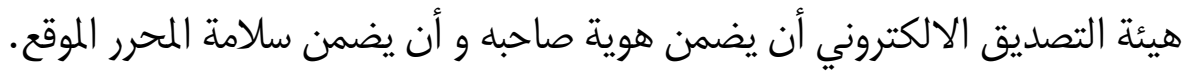

كما أن المشرع الجزائري جعل من وسيلة إثبات المعاملة التجارية الالكترونية تتلخص في الكتابة الالكترونية الحاملة

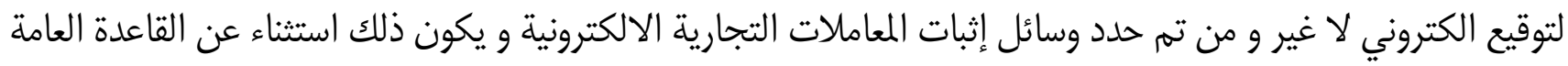

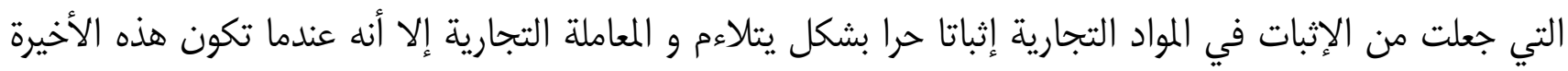

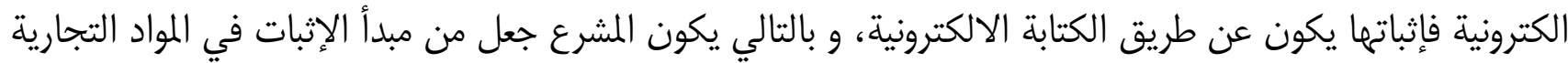

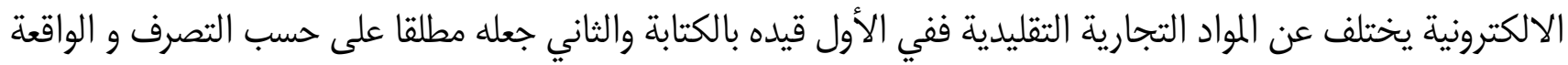

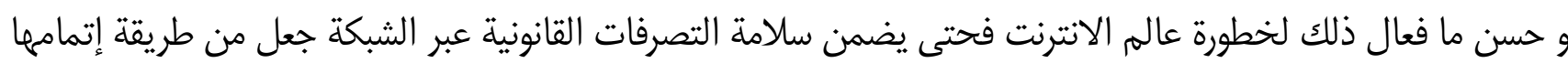
ووسيلة إثباتها محددة بنص القانون.

ق12 محمد حسام الدين لطفي، الإطار القانوني للمعاملات الالكترونية. دراسة قواعد الإثبات في المواد المدنية و التجارية مع إشارة خاصة لبعض قوانين البلدان العربية، القاهرة، ط 2002، ص28. 


\title{
تفاعل المغرب مع الشرعة الدولية لحقوق الإنسان
}

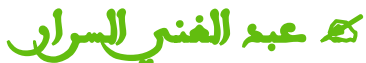 \\ دكتور في القانون العام والعلوم السياسية
}

مقدمة:

يقصد بتعبير الشرعة الدولية لحقوق الإنسان، مجموع العهود والاتفاقيات الدولية التي تعتبر المرجعية الأساسية الصلبة لحقوق الإنسان المعترف بها دوليا، والتي أقرها القانون الدولي لحقوق الإنسان، من خلال هيئة الأمم المتحدة، بهرف تعنير لعزيز حقوق الإنسان وحمايتها من كل انتهاك ${ }^{613}$ وهذه المكانة التي أصبحت تشغلما حقوق الإنسان في النظام الدولي دفعت العديد من الدول إلى العمل على تبني سياسات عامة في مجال حقوق الإنسان، خاصة وأن التشبث بالسيادة الداخلية أضحى من المبررات التي لا تشفع لأي دولة من التنصل بالتزاماتها الدولية تجاه مبادئ حقوق الإنسان وامتثالها لما تتضمنه هذه المواثيق من مبادئ، بل إن هذه المواثيق تتيح لهيئات دولية إمكانية مراقبة مدى امتثال الدول واحترامها لمبادئ

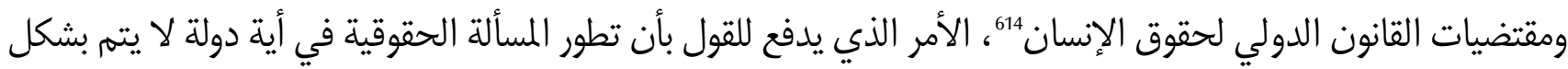
منفصل عن المحيط الدولي الذي تتفاعل معه، بحيث يؤثر في برامجها وسياساتها سلبا وإيجابا.

313. الشرعة الدولية لحقوق الإنسان تدل علي خمس وثائق أساسية وتم استعمال هذا المصطلح لأول مرة، من طرف لجنة حقوق الإنسان في

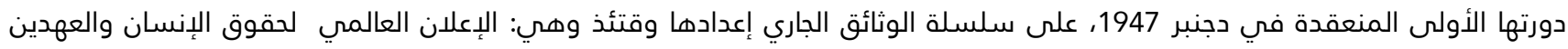

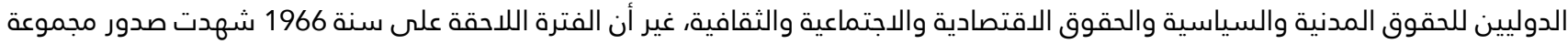
من الوثائق الأخرى ذات الأهمية البالغة في مجال حقوق الإنسان على الصعيدين المحلي والعالمي التي تهتم أساسا بحقوق المرأة وحقوق الطفل وتجريم التعذيب الاختفاء القسري والميز العنصري، .... وتتكون الشرعة الدولية لحقوق الإنسان من: الإنسان 1- الإعلان العالمي لحقوق الإنسان، اعتمد بموجب قرار الجمعية العامة للأمم المتحدة 217 ألف (د-3) المؤرخ في 10 كانون الأول/ ديسمبر

1948

2- العهد الدولي الخاص بالحقوق الاقتصادية والاجتماعية والثقافية، اعتمد وفتح باب التوقيع والتصديق عليه والانضمام إليه بموجب قرار الجمعية العامة للأمم المتحدة 2200 ألف (د-21) المؤرخ في 16 كانون الأول/ ديسمبر 1966، تاريخ بدء النفاذ: 3 كانون الثاني/ يناير 1976، طبقا للمادة

3- العهد الدولي الخاص بالحقوق المدنية والسياسية، اعتمد وفتح باب التوقيع والتصديق عليه والانضمام إليه بموجب قرار الجمعية العامة للأمم لمتحدة 2200 ألف (د-21) المؤرخ في 16 كانون/ ديسمبر 1966 - تاريخ بدء النفاذ: 23 آذار/مارس 1976، طبقاً لأحكام المادة 49 منه؛ 4- البروتوكول الاختياري الأول الملحق بالعهد الدولي الخاص بالحقوق المدنية والسياسية، بشأن تقديم شكاوي من قبل الأفراد - اعتمد وفتح باب التوقيع والتصديق عليه والانضمام إليه بموجب قرار الجمعية العامة للأمم المتحدة 2200 ألف (د-21) المؤرخ في 16 كانون الأول/ النوال ديسمبر

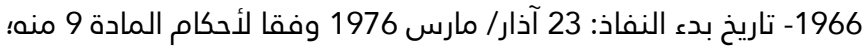
5- البروتوكول الاختياري الثاني الملحق بالعهد الدولي الخاص بالحقوق المدنية والسياسية، ويهدف العمل علي إلغاء عقوبة الإعدام، اعتمد وأعلن رسميا بموجب قرار الجمعية العامة للأمم المتحدة 128/44 المؤرخ في 15 كانون الأول/ ديسمبر المبر المبر 1989. 6146 يوسف البحيري: تأصيل مسؤولية الدولة المغربية في مجال حقوق الإنسان، المكتسب والرهان، وارد ضمن: المواطنة وحقوق الإنسان بالمغرب، أعمال الندوة الوطنية، مراكش 19 و20 مارس 2004. منشورات كلية العلوم القانونية والاقتصادية والاجتماعية مراكش، سلسلة الندوات والأيام الدراسية، العدد 22- المطبعة والوراقة الوطنية مراكش، الطبعة الأولى 2005 ماسك، الصفحة 33. 
في نفس السياق، أصبحت المؤسسات الدولية المانحة"615 والدول العظمى تربط مساعداتها المالية الموجهة للدول لأغراض تنموية بضرورة احترام هذه الأخيرة لمبادئ القانون الدولي لحقوق الإنسان، وهذا الربط بين احترام حقوق الإنسان والمنح المالية تم إعلانه لأول مرة من طرف الولايات المتحدة الأمريكية في فترة حكم الرئيس جيمي كارتر (Jimmy Carter) من خلال خطابه، بتاريخ 20 يناير 1977، الذي صرح فيه بربط أمريكا لمساعداتها المالية بمسألة احترام حقوق الإنسان ودمقرطة الأنظمة السياسية، ومما جاء في هذا الخطاب نجد ما يلي: "إن حسنا الأخلاقي يجعلنا نميل إلى تفضيل المجتمعات التي تثقاسم معنا هاجس احترام حقوق الإنسان"

وهذا التوجه الجديد للسياسة الخارجية الأمريكية أكده في مرحلة لاحقة كاتب الدولة Warren Christopher، في خطابه بتاريخ 13 فبراير 1978، الذي صرح فيه بأن علاقات الولايات المتحدة الأمريكية مع باقي الدول، وخصوصا تلك الراغبة في مساعداتها الاقتصادية والعسكرية يحكمه معطى مدى احترام حقوق الإنسان. ومن جانبه، صوت الكونغرس على حذف المساعدات العسكرية الموجهة إلى دولتي التشيلي والأوروغواي وقرر خفض المساعدات المقدمة لكوريا الجنوبية

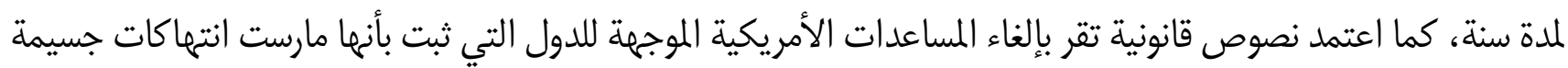
لحقوق الإنسان

615 ـ يعتبر مبدأ اشتراط حقوق الإنسان والديمقراطية معطى ثابت في السياسة الأوربية تجاه دول العالم الثالث، إذ تشير المادة 3 الفقرة 5 من

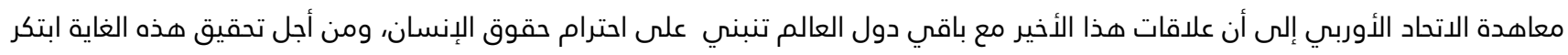

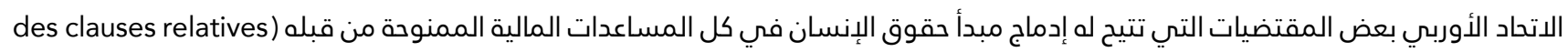
(aux droits de l'homme et à la démocratie dans ses accords internationaux للمساعدات الاقتصادية والمالية. واستخدم هذا الشرط لأول مرة، من قبل الاتحاد الأوربي بمناسبة توقيع اتفاقية لومي الرابعة، بتاريخ 15 دجنبر 1989، بالطوغو بين الاتحاد

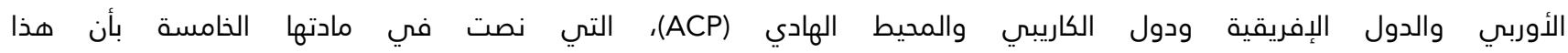
الاتفاق يربط التنمية ربطا وثيقا باحترام حقوق الإنسان والحريات الأساسية، بحيث شكل هذا الشرط ولا زال عنصرا أساسيا أساسيا في جميع الاتفاقات

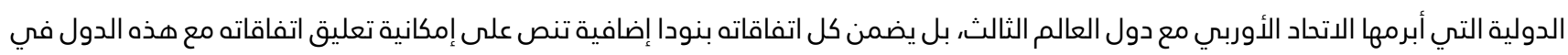
حالة ما تبين بأنها مارست انتهاكات لحقوق الإنسان.

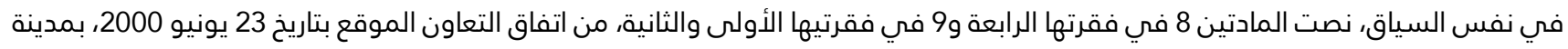
كوتونو بالبينين بين الدول الإفريقية ودول الكاريبي والمديط الهادي (ACP) والمجموعة الأوربية، على أن الطرفان يؤكدان على أن الحوار يرتكز

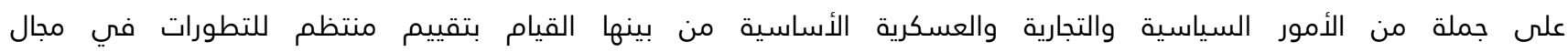
حقوق الإنسان، والمبادئ الديمقراطية وسيادة القانون، واحترام الحقوق والحريات الأساسية والديمقراطية القائمة على دولة الحق والقانون والشفافية باعتبارهما جزءا لا يتجزأ من التنمية المستدامة.

Voir:

Pamphile Sebahara: La coopération politique entre I'UE et les États ACP Bilan des politiques et des pratiques sous les 4 conventions de Lomé (1975-1998), Document de réflexion, ECDPM n 7, Juin 1999, page 8.

616 - Dans son discours inaugural du 20 janvier 1977, Carter a déclaré : «Notre sens moral nous incline à préférer nettement les sociétés qui partagent avec nous le souci constant de respecter les droits de l'Homme...».Voir :Droits de l'Homme en Afrique centrale, Colloque de Yaoundé, 9-11 novembre 1994, sous la direction de Denis Maugenest et Paul- Gérard Pougoué. Pesses de I'UCAC, Paris France- Karthala 1995, page 234.

617 -Droits de I'Homme en Afrique centrale, Colloque de Yaoundé, 9-11 novembre 1994, Op, Cit, page 234. 
ومن جانبها، أكدت فرنسا على لسان رئيسها فرنسوا ميتران في قمة لابول، المنعقدة ما بين 20 و 22 يونيو 1990، بأن المعايير الأساسية لإقامة دولة ديمقراطية، تتمثل أساسا في توسيع هامش الحريات والحقوق وإقامة أنظمة تمثيلية عن طريق انتخابات نزيهلة، وضمان حرية الصحافة واستقلال القضاء ${ }^{6}$ وفي هذا الإطار، أكد فرانسوا ميتران بأن فرنسا ستربط مساعدتمها المالية بالجهود التي تبذلمها الدول لتحقيق مزيد من الحريةة، في مقابل فتورها بالنسبة للأنظمة التي تُسَيَّر بطريقة استبدادية أو ترفض الديمقراطية كمنهج للحكم مبه، خاصة بالنسبة للدول التي ترغب في مساعدات فرنسا المالية،

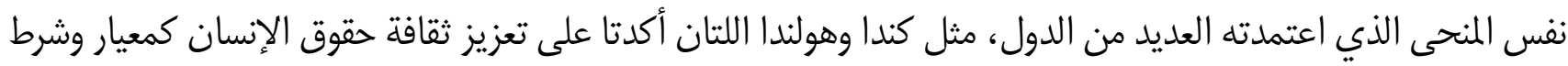
لازم لتقديهم المساعدات المالية للتنمية

وقد تزامن هذا التوجه الدولي المتعلق بربط المنح المالية بالديمقراطية وحقوق الإنسان مع تبني منظمة الأمم المتحدة لقضايا الديمقراطية وحقوق الإنسان، وما حمله ميثاقها من أهداف ومبادئ الفردية والجماعية من أي انتهاك، كما أنه في سنة 1990 أصدر برنامج الأمه المتحدة الإنمائي تقريره الأول عن التنمية البشرية في العالم، حيث تم اعتماد مؤشرات جديدة أكثر شمولية لقياس نسبة التنمية البشرية في العالم، وبموجبه تم

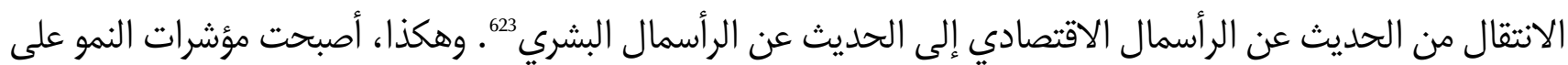

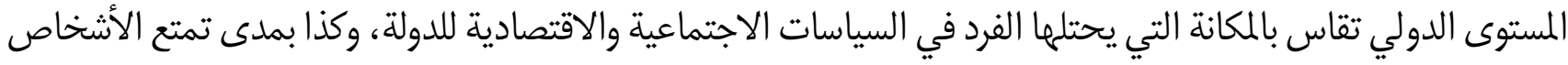

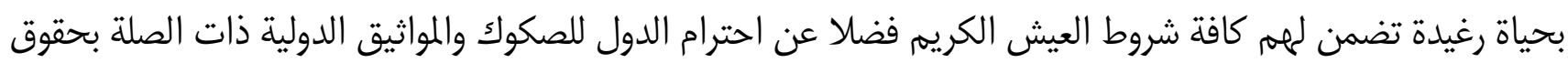

والمغرب بدوره، بحكم علاقاته مع المتتظم الدولي، لا يشكل استثناء عن هذه القاعدة، إذ هو الآخر من بين الدول التي تتفاعل مع النسق الدولي المهتم بحقوق الإنسان، خاصة وأنه انخرط في وقت مبكر في القانون الدولي لحقوق الإنسان

618 -El Hadji Omar Diop :Partis politiques et processus de transition démocratique en Afrique noire, Editions Publibook, Paris France, 2006, pages 479 - 480.

619 " -La France liera tout son effort de contribution aux efforts qui seront accomplis pour aller vers plus de liberté". en fin "I'aide normale de France sera plus tiède envers les régimes qui se comporteraient de façon autoritaire sans accepter l'évolution vers la démocratie, et plus enthousiaste pour ceux qui franchiront le pas avec courage". Extrait de l'allocution prononcée par François Mitterrand président de la république française à l'occasion d'ouverture de la 16 éme conférence des chefs d'état de France et d'Afrique. La Baule, le 20 juin 1990. Citée par Crispin Ngandu Mualaba :République Démocratique du Congo, tout est à refaire - À qui la faute?, Editions Publibook ; Paris 2008, Page 350.

620 - Michel-Ange Tsiba :Pourquoi la violence refuse l'état et la république au Congo Brazzaville, le processus démocratique liquidé, Préface de Alpha Ousmane Diangolo Barry, Editions Publibook, Paris 2009, Page 400.

621- عبد العزيز لعروسـي: التشريع المغربـي والاتفاقيات الدولية لحقوق الإنسان، ملاءمات قانونية ودستورية، منشورات المجلة المغربية للإدارة

المحلية والتنمية، سلسلة مواضيع الساعة العدد 87- 2014، الصفحة 130. 622- حيث نصت المادة الأولى من ميثاق الأمم المتحدة على أن هذه الهيئة تسعى لحفظ السلم والأمن الدوليين، (...)، وإلى تعزيز احترام حقوق الإنسان والحريات الأساسية للناس جميعا (...). 623-ـ والجدير بالذكر أنه منذ 1990 وبرنامج الأمم المتحدة الإنمائي يصدر تقارير عن التنمية البشرية استنادا للأعمال والأبحاث التي قام بها كل من امارتيا صن، اقتصادي هندي حاصل على جائزة نوبل في اقتصاد الرفاه والباكستاني محبوب الحق، الحاصل بدوره على جائزة نوبل في الاقتصاد الحديث، فالتنمية بحسبهما تعني توسيع هامش الحقوق والحريات الفردية والجماعية. 


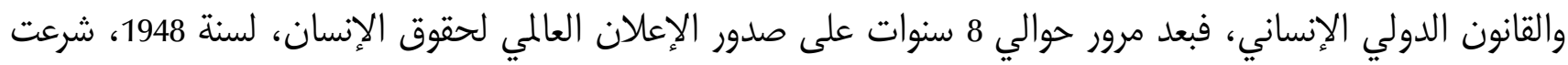

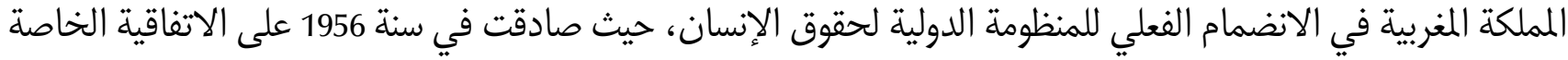

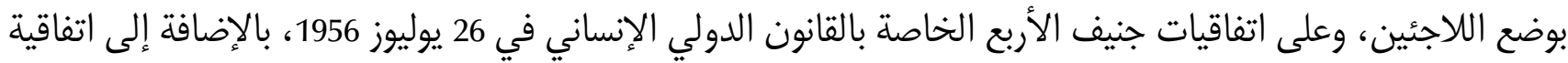

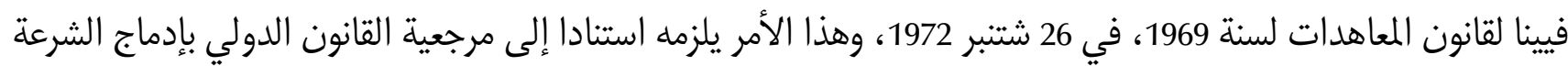

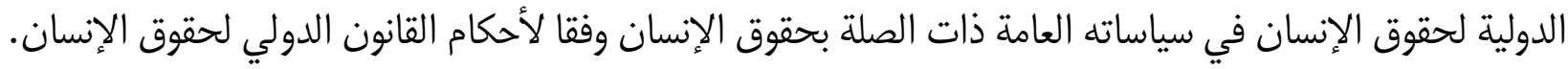
ونتيجة لكل هذه المعطيات السالفة الذكر، وخاصة تلك التي تتعلق بالتوجه الدولي القائم على تعزيز ثقافة حقوق

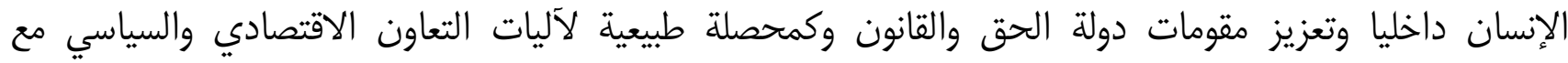

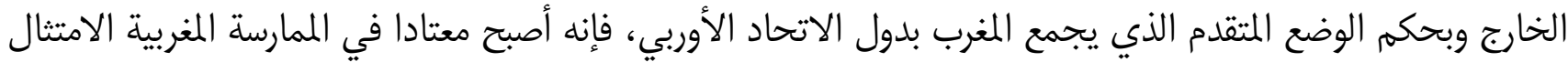

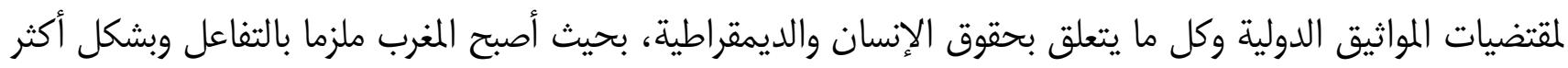

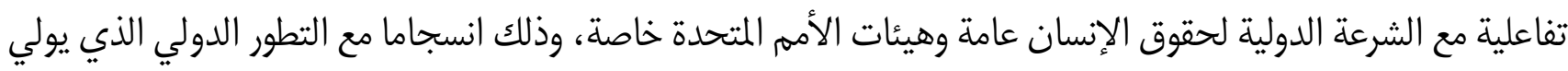
عناية خاصة لحقوق الإنسان وكل الأمور المرتبطة بها.

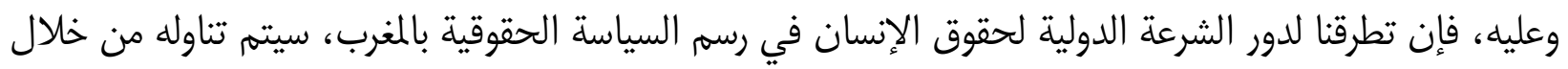

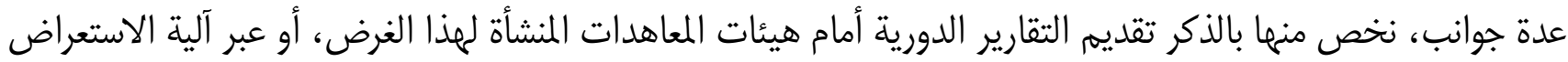

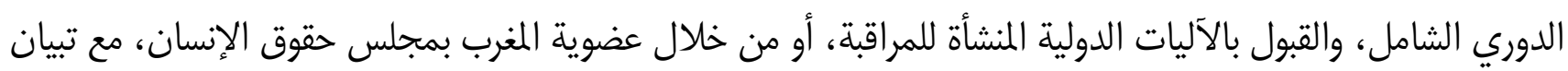
مدى نجاعة إسهامات المغرب بهزه الهيئات الحقوقية، خصوصا بمجلس حقوق الإنسان، وكذا مدى احترامه للمعايير الدولية

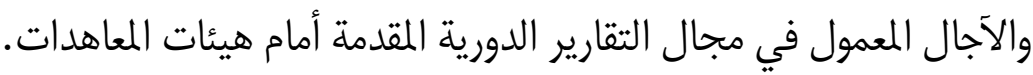

\section{المطلب الأول: تقديم التقارير الدورية لهيئات المعاهدات}

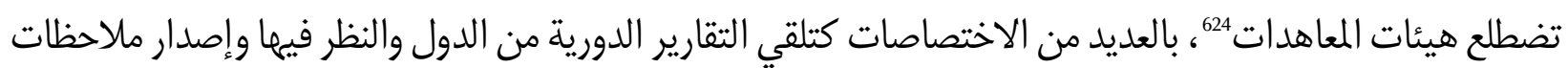

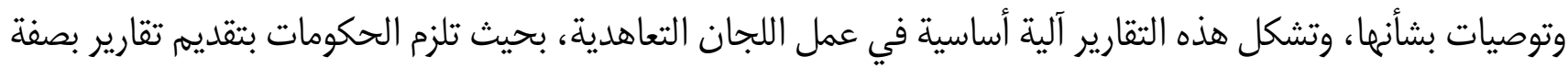

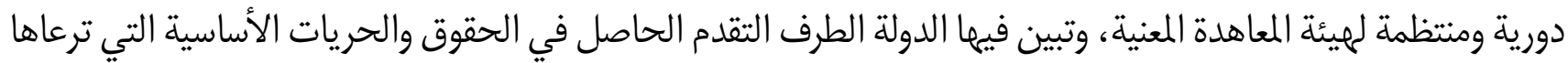

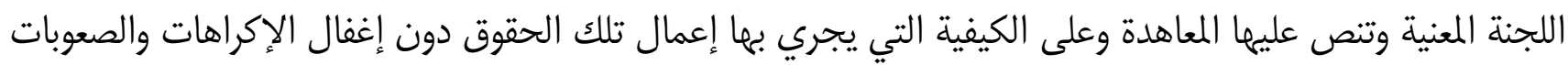

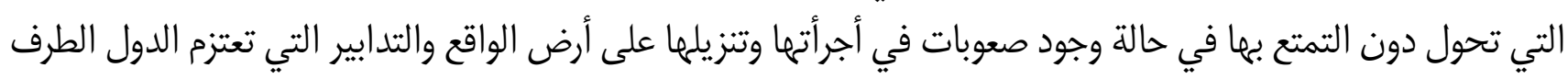
اتخاذها قصد تجاوز هذه الإكراهات.

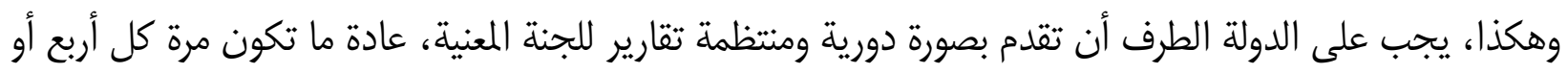
خمس سنوات بحسب ما تتص عليه أحكام كل معاهدة، وتبين الدول في تقاريرها الإجراءات والتدابير القانونية والتشريعية

624 - Il ya 9 organes de traités sur les droits de l'homme qui surveillent la mise en œuvre des principaux traités internationaux sur les droits de l'homme, il s'agit des: 1) Le Comité des droits de l'homme (CCPR) 2) Le Comité des droits économiques, sociaux et culturels (CESCR) 3) Le Comité pour l'élimination de la discrimination raciale (CERD) 4) Le Comité pour l'élimination de la discrimination à l'égard des femmes (CEDAW) 5) Le Comité contre la torture (CAT) et Sous-comité pour la prévention de la torture (SPT) 6) Le Comité des droits de l'enfant (CRC) 7) Le Comité des travailleurs migrants (CMW) 8) Comité des droits des personnes handicapées (CRPD) 9) Comité des disparitions forcées (CED). 
بما في ذلك الشق المتعلق بالسياسات العمومية التي اتخذتها من أجل تنفيذ وإعمال أحكام المعاهدة، علاوة على إشارتها

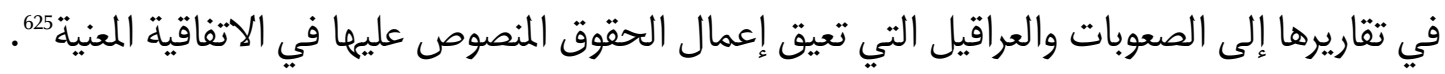
هذا، ولا بد من التأكيد على أن الغرض من إعداد وتقديم التقارير الدورية يشكل للدول الأطراف فرصة سانحة لإجراء

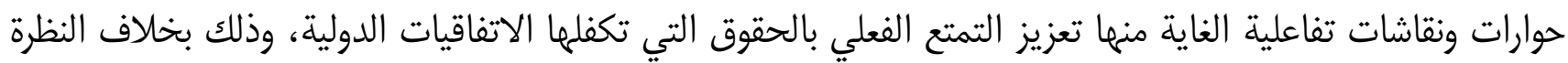

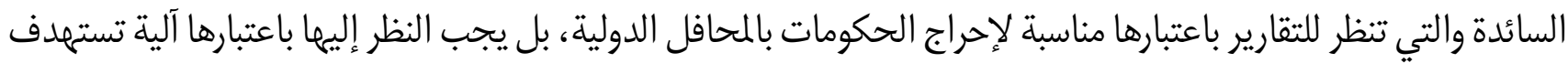

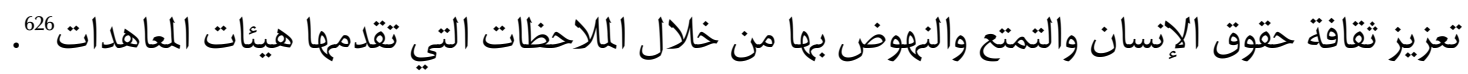
يعتبر المغرب بدوره من الدول التي تلتزم بتقديم تقارير دورية أمام اللجان المعنية برصد تنفيذ مقتضيات الاتفاقيات

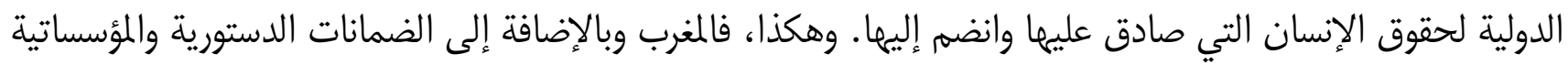

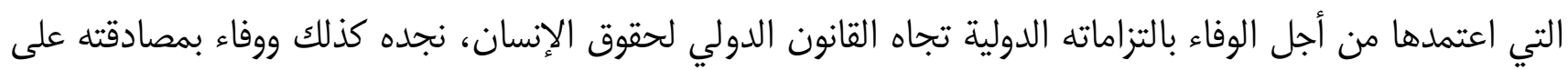

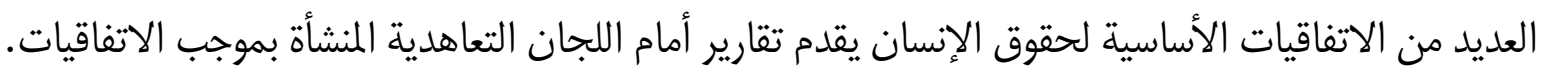

ولكن ما يعاب على المغرب بخصوص التقارير الدورية هو التأخر الحاصل في تقديمها للميئات، بحيث أن العديد منها

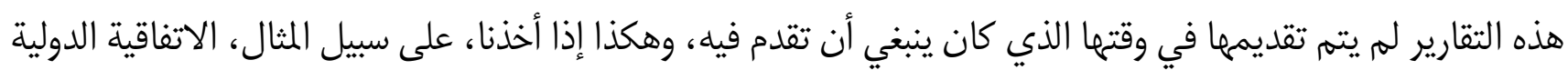

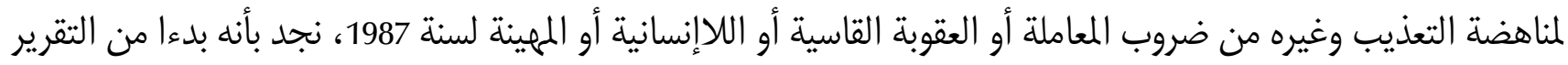

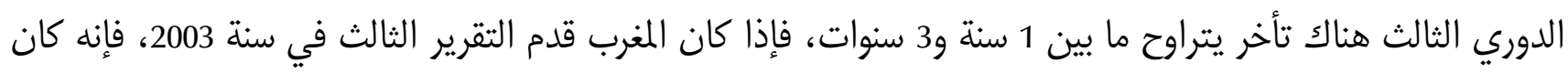

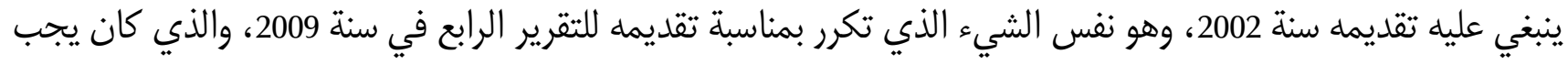

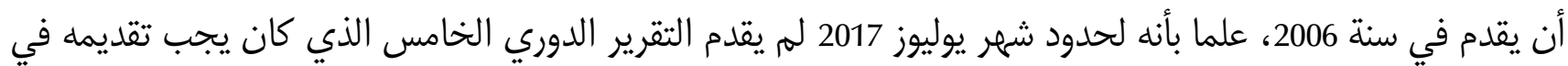
سنة 2015.

ونفس الملاحظة تنطبق أيضا على التقارير الدورية المتعلقة بإعمال مقتضيات العهد الدولي المتعلق بالحقوق المدنية

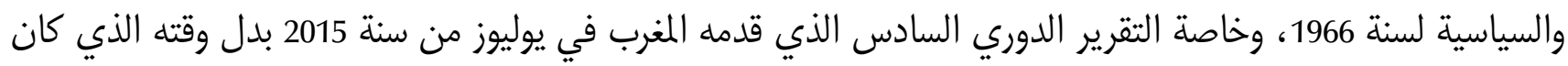

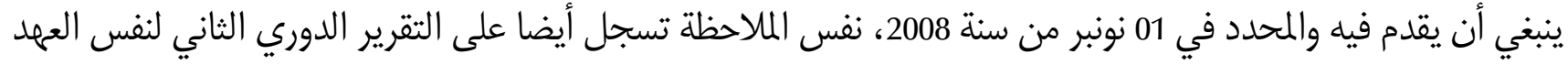

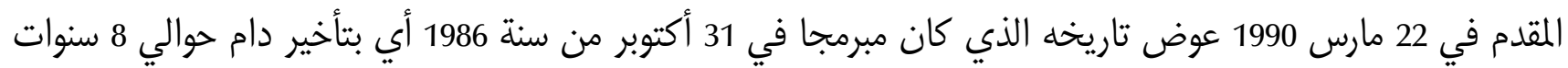
بالنسبة للتقرير السادس وأربع سنوات بالنسبة للتقرير الثاني.

كما أنه كان من المفروض تقديم التقريرين الثالث والرابع من الاتفاقية الدولية لحقوق الطفل واللذين لهم يتم تقديمها

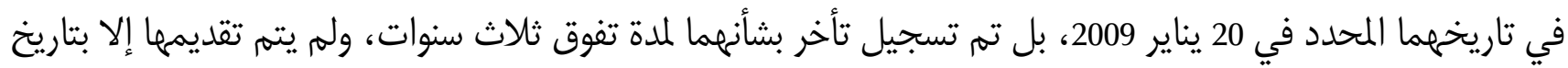
30 ماي 2012، وهو نفس الأمر الذي ينطبق على التقرير الدوري الأول من الاتفاقية الدولية لحماية حقوق جميع العمال

625ـــ عصام الدين محمد حسن: التقارير الحكومية وتقارير الظل، مصر ... والهيئات التعاهدية لحقوق الإنسان، منشورات مركز القاهرة لدراسات

حقوق الإنسان، سلسلة تعليم حقوق الإنسان عدد (19)، سنة 2008، الصفحة 22. 626ـ عصام الدين محمد حسن: التقارير الحكومية وتقارير الظل، مصر ... والهيئات التعاهدية لحقوق الإنسان، مرجع سابق، الصفحة 23. 
المهاجرين وأفراد أسرهم الذي تأخرت الحكومة المغربية في تقديمه بحوالي ثماني سنوات، فقد كان من المفترض تقديمه

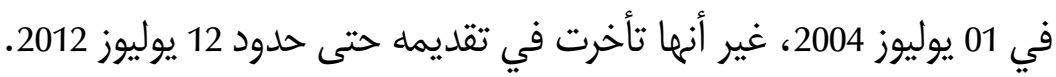

وبتاريخ 24 يناير 2013، قدم المغرب التقرير الدوري الرابع المتعلق بإعمال مقتضيات العهد الدولي الخاص بالحقوق

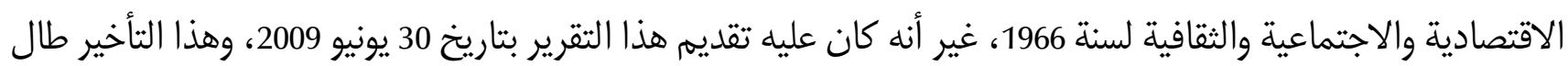

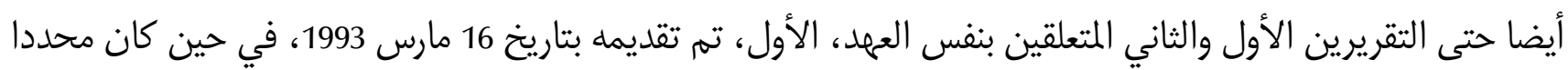

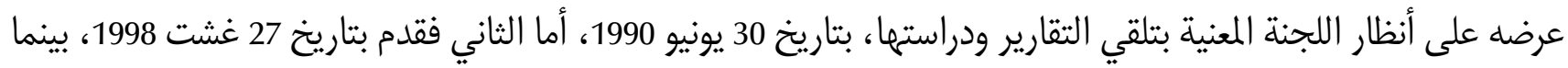
كان ينبغي على الدولة الطرف تقديمه في 30 يونيو 1995.

ويلاحظ كذلك أنه حتى حدود يوليوز من سنة 2017، لم يقم المغرب بتقديم التقارير أرقام 19 و 20 و 21 حول إعمال

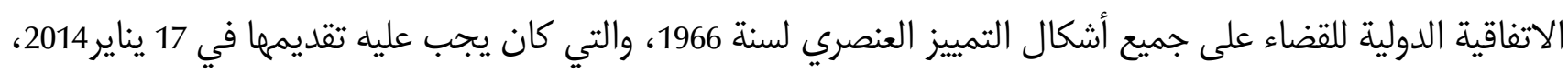

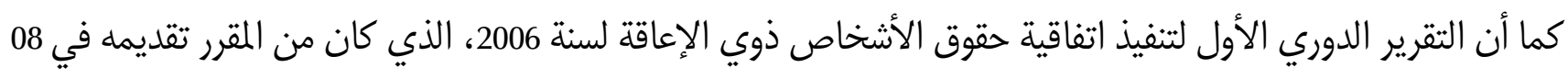

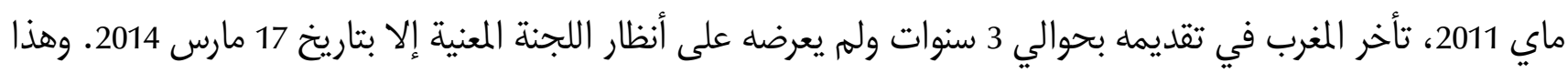

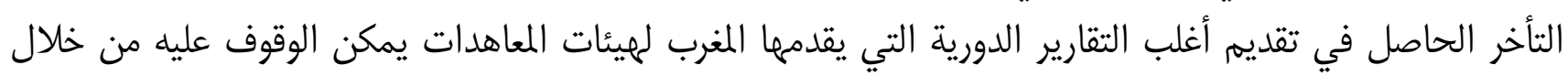
الجدول المبين فيما بعد.

\section{وضعية التقارير الدورية المقدمة لهيئات المعاهدات}

\begin{tabular}{|c|c|c|}
\hline ملاحظات & وضعية التقاريـر & الاتفاقية الدولية \\
\hline \multirow[t]{4}{*}{$\longrightarrow$} & التقرير الأول: تم تقديمه بتاريخ 28 يوليوز & \multirow{9}{*}{ 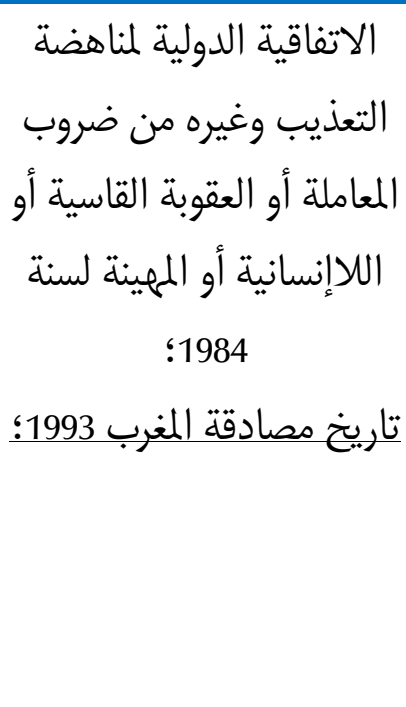 } \\
\hline & 1994 & \\
\hline & التقرير الثاني: تم تقديمه بتاريخ 02 شتببر & \\
\hline & 1998 & \\
\hline \multirow[t]{2}{*}{ كان مقررا تقديمه في 20 يوليوز 2002؛ } & التقرير الثالث: تم تقديمه بتاريخ 24 مارس & \\
\hline & 2003 & \\
\hline \multirow[t]{2}{*}{ كان مقررا تقديمه في 20 يوليوز 2006؛ } & التقرير الرابع، تم تقديمه بتاريخ 27 أبريل & \\
\hline & 2009 & \\
\hline كان مقررا تقديمه في سنة 2015؛ & التقرير الخامس، لم يتم تقديمه بعد & \\
\hline \multirow[t]{2}{*}{ كان مقررا تقديمه في 02 غشت 1980؛ } & التقرير الأول: تم تقديمه بتاريخ 9 & \multirow{5}{*}{ باريخ مصادقة العهد الدولي المتعلق المدنة } \\
\hline & فبراير1981؛ & \\
\hline \multirow[t]{2}{*}{ كان مقررا تقديمه في 31 أكتوبر $1986 ؛$} & التقرير الثاني: تم تقديمه بتاريخ 22 & \\
\hline & مارس1990؛ & \\
\hline كان مقررا تقديمه في 31 دجنبر 1992؛ & التقرير الثالث: تم تقديمه بتاريخ 20 & \\
\hline
\end{tabular}




\begin{tabular}{|c|c|c|}
\hline كان مقررا تقديمه 31 أكتوبر 1996؛ & التقرير الرابع: تم تقديمه بتاريخ 27 يناير 1997؛ & \\
\hline كان مقررا تقديمه في 31 أكتوبر $2003 ؛$ & التقرير الخامس: تم تقديمه بتاريخ 10 & \\
\hline كان مقررا تقديمه 01 نونبر 2008؛ & التقرير السادس: تم تقديمه بتاريخ 07 & \\
\hline كان مقررا تقديمه 14 يونيو 2015؛ & التقرير الأول لم يتم تقديمه بعد & 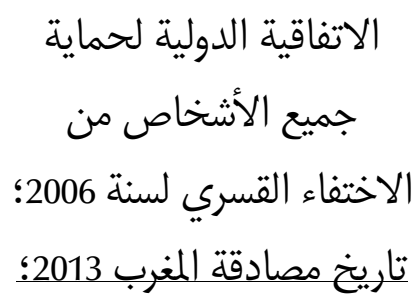 \\
\hline & التقرير الأول: تهم تقديمه بتاريخ 14 شتبر 1994؛ & \multirow{4}{*}{ 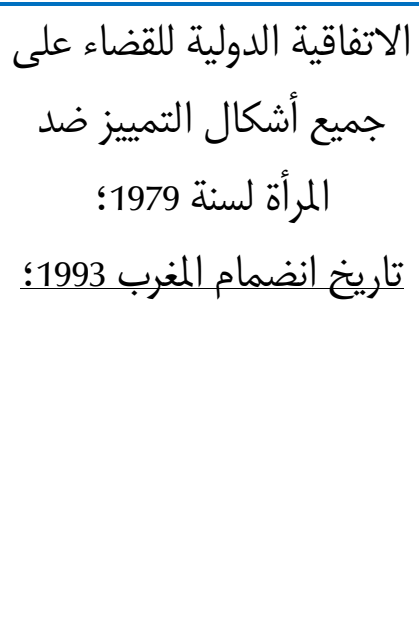 } \\
\hline \multirow[t]{2}{*}{ كان مقررا تقديمه 21 يوليوز 1998؛ } & التقرير الثاني: تم تقديمه بتاريخ 29 فبراير & \\
\hline & التقريرين 4/3: تم تقديمها مجتمعين & \\
\hline \multirow[t]{4}{*}{ كان مقررا تقديمها في 21 يوليوز 2014؛ } & التقريرين الخامس والسادس: له يتهم & \\
\hline & التقرير الأول: تم تقديمه بتاريخ 10يناير & \multirow{5}{*}{ 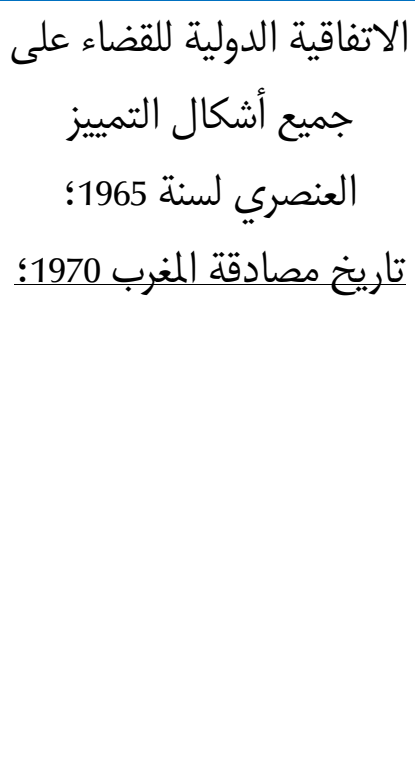 } \\
\hline & التقرير الثاني: تم تقديمه بتاريخ 07 فبراير & \\
\hline & التقرير الثالث: تم تقديمه بتاريخ 09 دجنبر & \\
\hline \multirow[t]{2}{*}{ كان مقررا 17 يناير1978؛ } & التقرير الرابع: تم تقديمه بتاريخ 07 أكتوبر & \\
\hline & التقرير الخامس: تم تقديمه بتاريخ 23يناير & \\
\hline
\end{tabular}




\begin{tabular}{|c|c|c|}
\hline & التقرير السادس: تم تقديمه بتاريخ 29 & \\
\hline & التقرير السابع: تم تقديمه بتاريخ 07 شتنبر & \\
\hline & التقرير الثامن: تم تقديمه بتاريخ 14 يوليوز & \\
\hline كان مقررا تقديمها 1988؛ 1990 و & التقارير أرقام 9 و 10 و11 :تم تقديمها في & \\
\hline كان مقررا تقديمها في 17 يناير 1994 و & التقريرين رقمي 12 و 13: تم تقديمرهما في & \\
\hline كان مقررا تقديمها في 17 يناير1998 و 2000 ثم 2002؛ & في التقارير أرقام 14 و 15 و16: تم تقديمهما & \\
\hline كان مقررا تقديمهما في 17 يناير 2006؛ & التقريرين رقمي 17 و 18: تمم تقديمها & \\
\hline كان مقررا تقديمها في 17 يناير2014؛ & التقارير أرقام 19 و 20 و 21: لم يقدمها & \\
\hline كان مقررا في 30 يونيو 1990؛ & التقرير الأول: تم تقديمه بتاريخ 16 مارس & 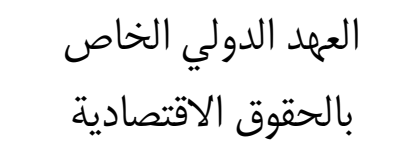 \\
\hline كان مقررا في 30 يونيو 1995؛ & التقرير الثاني: تم تقديمه بتاريخ 27 غشت & والاجتماعية والثقافية لعام \\
\hline & التقرير الثالث: تم تقديمه بتاريخ 27 أكتوبر & تاريخ مصادقة المغرب 1979؛ \\
\hline كان مقررا في 30 يونيو 2009؛ & التقرير الرابع: تم تقديمه بتاريخ 24 يناير & \\
\hline كان مقررا في 01 يوليوز 2004؛ & التقرير الأول: تهم تقديمه بتاريخ 12 يوليوز & حقوق جميع العمالية الدولية لحماية \\
\hline كان مقررا في 13 شتبر $2018 ؛$ & التقرير الثاني: لم يتهم تقديمه بعد؛ & تاريخ مصادقة المغرب 1990؛ ألمراجرين وأفراد أسرهم \\
\hline & التقرير الأول: تم تقديمه بتاريخ 27 يوليوز & اتفاقية حقوق الطفل لسنة \\
\hline
\end{tabular}




\begin{tabular}{|c|c|c|}
\hline & التقرير الثاني: تم تقديمه بتاريخ 4 شتنبر & تاريخ مصادقة المغرب 1993؛ \\
\hline كان مقررا تقديمهما في 20 يناير 2009؛ & التقريرين 4/3: قدما في تقرير واحد 30 ماي 2012؛ & \\
\hline كان مقررا في 08 ماي 2011؛ & التقرير الأول: تم تقديمه بتاريخ 17 مارس & تاريخ مصادقة المغرب الإعاقة لسنة 2006؛ حقوق الأشخاص؛ \\
\hline
\end{tabular}

وجبت الإشارة إلى أن منظمات المجتمع المدني تقدم بدورها تقارير موازية للتقارير الرسمية التي يقدمها المغرب، وهذا

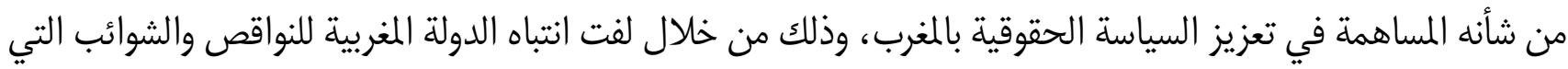

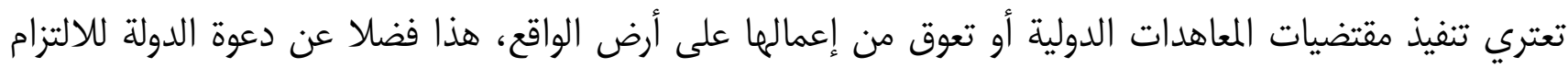

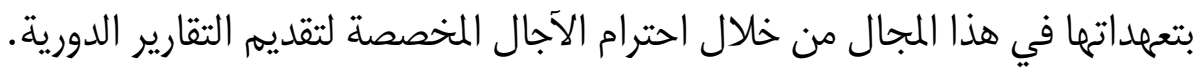

وقد تم فعلا تقديم مجموعة من التقارير الموازية من قبل جمعيات المجتمع المدني التي من الصعب جدا الإحاطة بها

جميعها.

وهكذا، فقد تم تقديم أول تقرير دوري موازي من لدن منظمات المجتمع المدني بمبادرة من المنظمة المغربية لحقوق

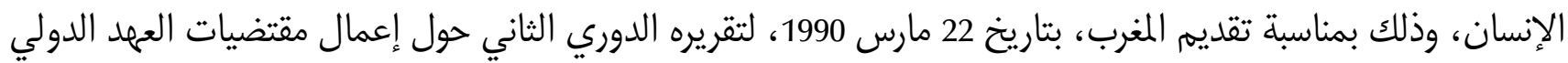

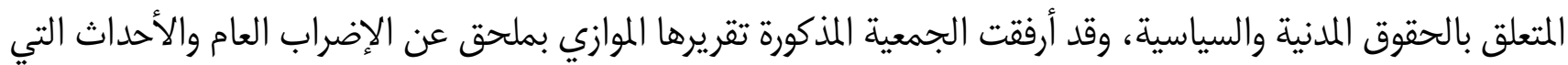

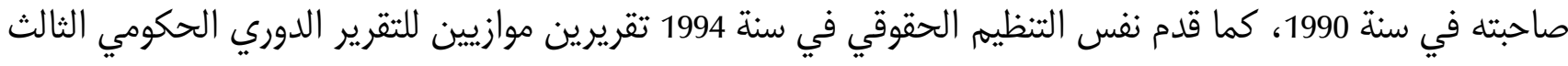

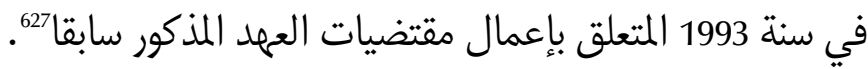

وبمناسبة تقديم المغرب في سنة 2015 لتقريره الدوري السادس حول إعمال مقتضيات العهد الدولي للحقوق المدنية

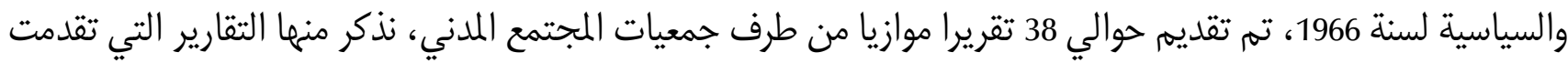

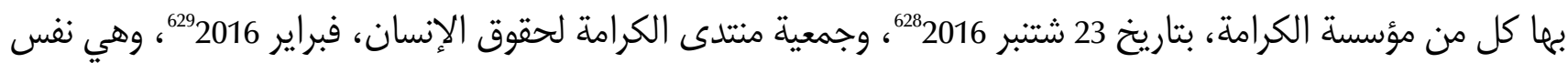

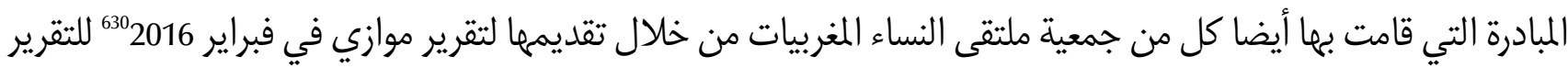

627ـ التقرير السنوي للمجلس الاستشاري لحقوق الإنسان عن وضعية حقوق الإنسان برسم سنة 2009، مرجع سابق، الصفحة 26. 628 - Rapport soumis au Comité des Droits de l'Homme dans le cadre du sixième examen périodique du Maroc par Fondation Alkarama, le 23 septembre 2016.

629 - Rapport alternatif du forum de la dignité, en février 2016, commentaire sur le sixième rapport périodique du gouvernement marocain dans le cadre du Pacte international relatif aux droits civils et politiques.

630 - Rapport parallèle au sixième rapport périodique du gouvernement marocain dans le cadre du Pacte international relatif aux droits civils et politiques, présenté par le forum des femmes marocaines, en février 2016. 
الرسمي الحكومي، وكذا التنسيقية المغاربية لمنظمات حقوق الإنسان عبر تقريرها المقدم للجنة المعنية بحقوق الإنسان في 17 شتنبر 2016 6316، موازاة للتقرير الحكومي.

فإذا أخذنا، على سبيل المثال، التقرير الموازي الذي قدمته جمعية ملتقى النساء المغربيات نجده تطرق بتفصيل للتقدم الذي لحق المشاركة السياسية للمرأة المغربية في الحياة السياسية، وذلك من خلال مجموعة من التدابير التشريعية والقانونية المتخذة من طرف الحكومة المغربية بغية تشجيع تمثيلية النساء داخل المؤسسات المنتخبة 332، دون أن يغفل التقرير التطرق من منياه للإدراهات التي تعترض مشاركة وتمثيلية المرأة في العملية السياسية، وبناء عليما قامت بتقديم مجموعة من التيليه التوصيات والتي ترى بأنها كفيلة بالنهوض بالمشاركة السياسية للمرأة، وذلك من قبيل فئسية

اتخاذ التدابير اللازمة والتي من شأنها تحقيق المناصفة الحقيقية بين تمثيلية الرجل والمرأة داخل المؤسسات المنتخبة وهيئات الحكامة، وذلك على جميع المستويات، سواء المحلية أو الإقليميت والجهويتة وحتى الوطنية؛ بهين العمل بنظام كوطا تدريجي لا يقل عن نسبة 33\% بمناسبة إجراء الاستحقاقات التشريعية لسنة 2016؛ تضمين القوانين التنظيمية المنظمة للمشاركة السياسية للمرأة كافة التدابير التحفيزية قصد تشجيع تقديم النساء

$$
\text { ترشيحاتهم للاستحقاقات الانتخابية؛ }
$$

العمل بمبدأ التمييز الإيجابي وفقا للمقتضيات الدستورية بغية الحد من التفاوت الحاصل بين النساء والرجال في مجال الوصول لمناصب المسؤولية بالوظائف العموميت والمؤسسات العمومية؛

اتخاذ تدابير عاجلة ومؤقتة بهدف تحقيق المساواة الفعلية بين الرجل والمرأة، وفقا لأحكام المادة الرابعة من اتفاقية القضاء على جميع أشكال التمييز ضد المرأة، خاصة وأنها لم تكن موضوع تحفظ من قبل الحكومة المغربية؛ ضمان مشاركة المغاربة المقيمين بالخارج داخل المؤسسات الاستشارية وهيئات الحكامة المنصوص عليها في الوثيقة الدستورية؛ تمتيع المغاربة المقيمين بالخارج بحق التصويت.

631 - Rapport Alternatif de la société civile sur la mise en œuvre du pacte international relatif aux droits civils et politiques. Soumis au Comité des Droits de l'Homme en vue de l'examen du sixième rapport périodique du Maroc, élaboré par la Coordination Maghrébine des Organisations de Droits Humains, le 16 décembre 2015.

632 - Selon le Rapport, (la Page 3), présenté par le forum des femmes marocaines, il ya plusieurs textes et lois organiques ont été adoptés pour encourager la participation des femmes au champ politique notamment: loi organique $n^{\circ} 29-11$ relative aux partis politiques qui stipule que tout parti politique œuvre pour atteindre une proportion d'un tiers de participation des femmes dans ses organes dirigeants aux niveaux national et régional, dans le but de la réalisation, à terme et d'une manière progressive, du principe de la parité entre les hommes et les femmes; loi organique $n^{\circ} 27-11$ relative à la chambre des représentants qui a introduit un mécanisme qui prévoit l'élection de 60 femmes au titre de la circonscription électorale nationale (article 23), et loi organique $n^{\circ}$ 59-11 relative à l'élection des membres des conseils des collectivités territoriales (article 76).

${ }^{633}$ - Voir Rapport parallèle au sixième rapport périodique du gouvernement marocain dans le cadre du Pacte international relatif aux droits civils et politiques, présenté par le forum des femmes marocaines, en février 2016, page 5. 
ومن جهتها، تطرقت جمعية مؤسسة الكرامة في تقريرها الموازي الدي قدمته لكافة الإصلاحات القانونية والتشريعية

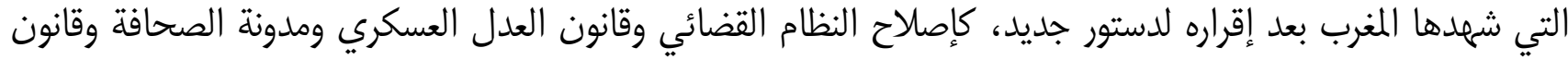

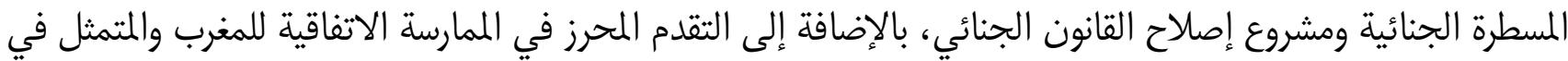

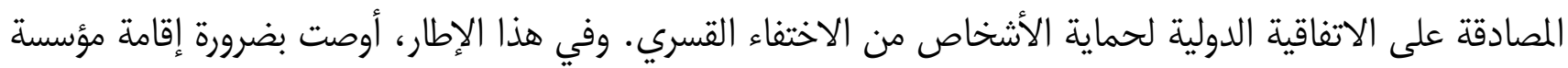

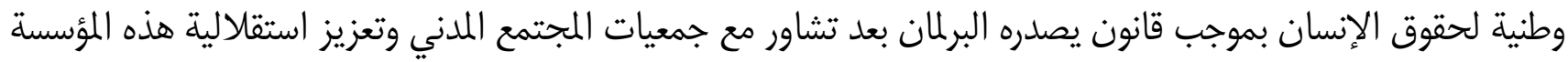
الوطنية وضمان حصانة موظفيهابقان.

وبخصوص ممارسات التعذيب وكل المعاملات الممينة أو اللاإنسانية أوصت المؤسسة المذكورة في تقريرها الموازي

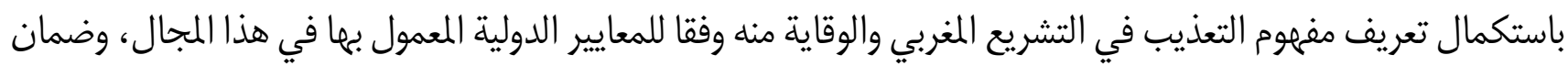

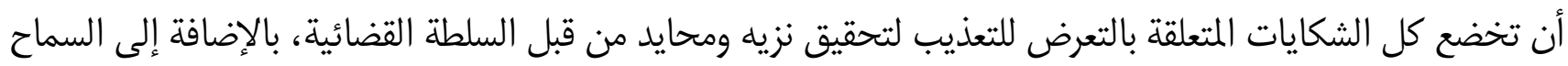

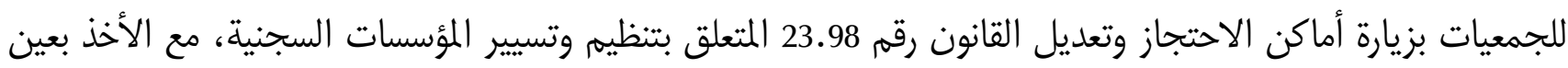

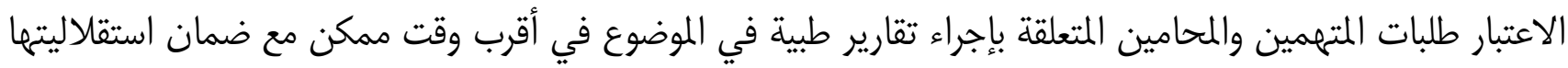

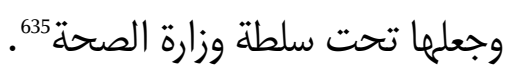
أما فيما يتعلق بالاختفاء القسري، فقد أوصت جمعية مؤسسة الكرامة بالاعتراف باختصاص القاص اللجنة المعنية بحالات

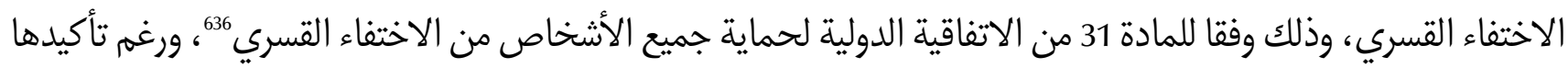

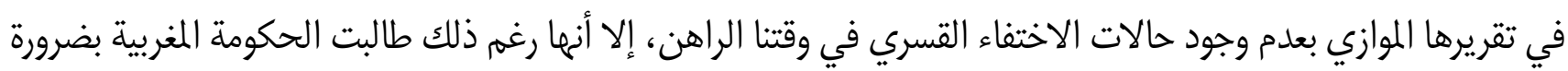

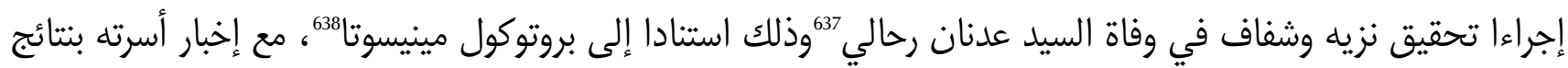

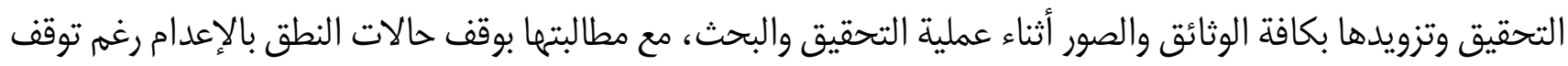

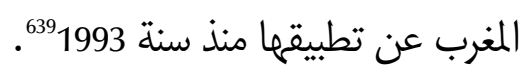

634- Rapport soumis au Comité des Droits de l'Homme dans le cadre du sixième examen périodique du Maroc par Fondation Alkarama le 23 septembre 2016, page 6.

635-Rapport soumis au Comité des Droits de l'Homme dans le cadre du sixième examen périodique du Maroc par Fondation Alkarama, précité, les pages 17-18.

${ }^{636}$ - Qui prévoit ":Tout État partie peut déclarer, au moment de la ratification de la présente Convention ou ultérieurement, qu'il reconnaît la compétence du Comité pour recevoir et examiner des communications présentées par des personnes ou pour le compte de personnes relevant de sa juridiction qui se plaignent d'être victimes d'une violation, par cet État partie, des dispositions de la présente Convention...".

637- Alkarama a relevé que de fait, le phénomène des disparitions forcées est aujourd'hui quasi inexistant dans l'Etat partie, même si en 2015 elle a été saisi par la famille d'un jeune étudiant Adnane Rahali à Agadir de sa disparition, en date du 17 décembre 2015, page 18.

${ }^{638}$ - The Minnesota Protocol on the Investigation of Potentially Unlawful Death. Aims to protect the right to life and advance justice, accountability and the right to a remedy, by promoting the effective investigation of potentially unlawful death or suspected enforced disappearance.

639-Rapport soumis au Comité des Droits de l'Homme dans le cadre du sixième examen périodique du Maroc par Fondation Alkarama, précité, page 19 et 20. 


\section{المطلب الثاني: الاستعراض الدوري الشامل}

يقصد بآلية الاستعراض الدوري الشامل EPU"L'Examen Périodique Universel" قيام جميع الدول الأعضاء في الأمه المتحدة بإجراء استعراض لسجلات حقوق الإنسان، مرة كل أربع سنوات أمام مجلس حقوق الإنسان، وفي إطار هذه

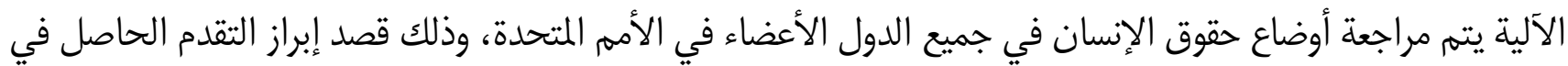
مجالات حقوق الإنسان، وتعتبر هذه الوسيلة من إبداعات مجلس حقوق الإنسان من خلال توفير فرصة لجميع الدول للإففصاح عن سياساتما العامة المتبعة للنهوض بثقافة حقوق الإنسان منان.

أُّشأت هذه التقنية في مارس 2006، وذلك بموجب مقتضيات قرار الجمعية العامة رقم 251/60 والذي أناط بمجلس حقوق الإنسان "إجراء استعراض دوري شامل يستند إلى معلومات موضوعية وموثوق بها لمدى وفاء كل دولة بالتزاماتها وتعهداتها في مجال حقوق الإنسان على نحو يكفل شمولية التطبيق والمساواة في المعاملة بين جميع الدول المها"، وفي يونيو 2007، وافق أعضاء المجلس على بناء مؤسساته التي توفر خريطة طريق ترشد عمله في المستقبل، وكان من بين العناصر الرئيسية التي تم الاتفاق عليها هو الاستعراض الدوري الشامل.

ويمكن القول بأن الرجدف النهائي للاستعراض الدوري الشامل يتمثل أساسا في تحسين ودعم وتوسيع نطاق تعزيز حماية حقوق الإنسان وحمايتها من أي تعسف، ولهزا الغرض يقوم مجلس حقوق الإنسان من خلال لجانه بتقييم سجلات الدول بشأن حقوق الإنسان بحيث يضطلع الفريق المعني بالاستعراض الدوري بتلقي التقارير الوطنية للدول التي يجب ألا

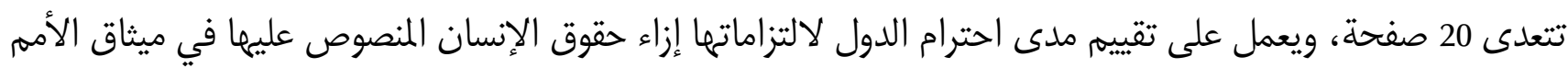
المتحدة والإعلان العالمي لحقوق الإنسان...، وبعد ذلك يقرر في التدابير التي يتعين اتخاذها من طرف حكومات الدول ويصدرها عادة تحت اسم توصيات وملاحظات ختامية الإنسان أن تقدم تقارير موازية للتقرير الوطني الذي تقدمه الدولة المعنية كما يمكن لأي دولة أن تشارك في المناقشات

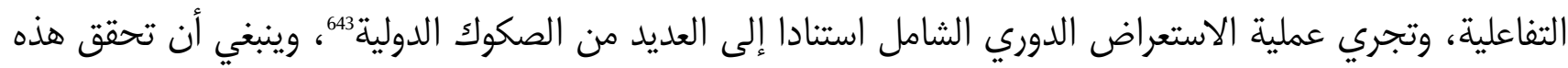
التقنية مجموعة من الأهداف والغايات النبيلة في مجال حقوق الإنسان ${ }^{644}$

640- محمد يعقوب: التقارير المتعلقة بالاستعراض الدوري الشامل، منشورات المركز الوطني لحقوق الإنسان، بدون تاريخ، الصفحة 3 وما بعدها. 641- البند (هـ) الفقرة 5، من القرار رقم 251.60، A/RES/60/251، الصادر عن الجمعية العامة في دورتها 72، بتاريخ 15 مارس 2006. 642 - http://www.cndh.org.

643- خصوصا: ميثاق الأمم المتحدة؛ الإعلان العالمي لحقوق الإنسان؛ صكوك حقوق الإنسان التي تكون الدولة طرفا فيها؛ التعهدات والالتزامات الطوعية من جانب الدول؛ أحكام القانون الإنساني الدولي الواجبة التطبيق، وذلك نظرا لما يتصف به القانون الدولي لحقدي لحقوق الإنسان والقانون الإنساني الدولي من طابع تكاملي ومترابط ومعزز لبعضه البعض. أنظر: المرفق الخاص بمجلس حقوق الإنسان، 1/5 بناء مؤسسات مجلس حقوق الإنسان. أولاً: آلية الاستعراض الدوري الشامل، الدورة الخامسة ما بين 11 و 18 يونيو 2007- إصدارات الجمعية العامة بتاريخ 7 غشت بـإت A/HRC/5/21-2007- الصفحة 4 وما بعدها. 644- من قبيل: تحسين حالة حقوق الإنسان على أرض الواقع؛ الوفاء بالتزامات الدولة وتعهداتها في مجال حقوق الإنسان وتقييم التطورات الإيجابية والتحديات التي تواجهها الدولة؛ النهوض بقدرة الدولة وبالمساعدة الفنية المقدمة إليها، بالتشاور مع الدولة المعنية وبموافقتها؛ تبادل أفضل الممارسات فيما بين الدول وأصحاب المصلحة الآخرين؛ دعم التعاون في مجال تعزيز وحماية حقوق الإنسان؛ تشجيع التعاون والانخراط الكاملين مع المجلس وغيره من هيئات حقوق الإنسان ومع مفوضية الأمم المتحدة السامية لحقوق الإنسان. أنظر: المرفق الخاص بمجلس حقوق الإنسان، 1/5 بناء مؤسسات مجلس حقوق الإنسان. أولاً: آلية الاستعراض الدوري الشامل، مرجع سابق الصفحة 6. 
طبقا لمتضيات القرار رقم 251.60، وفي سياق التعهدات الطوعية للدول بخصوص الاستعراض الدوري الشامل أعربت

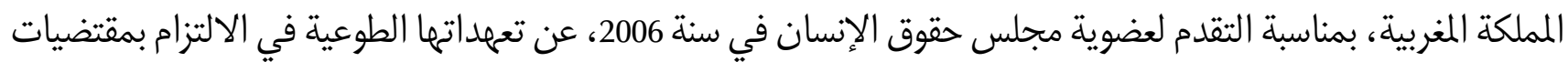

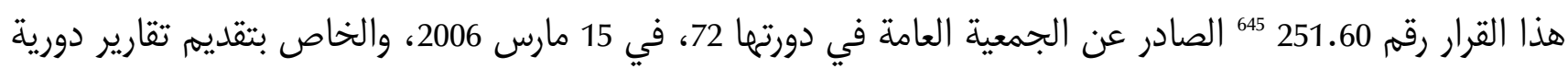

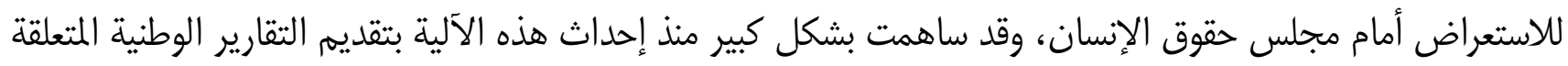

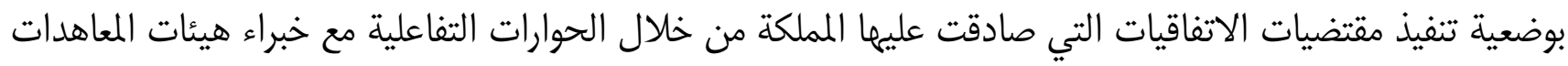

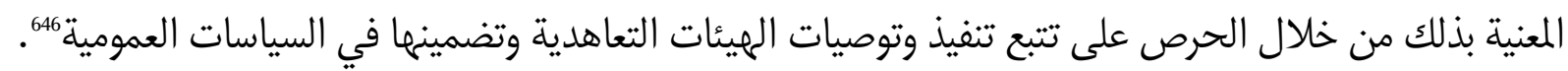

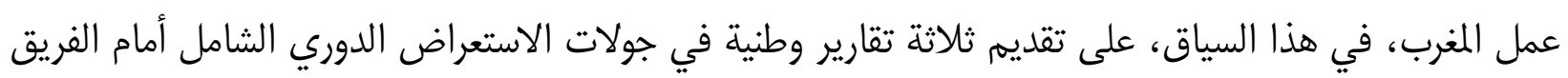

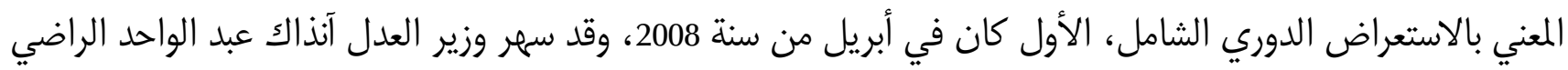

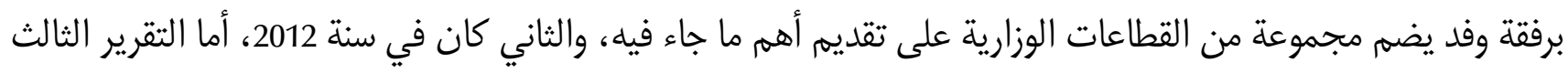

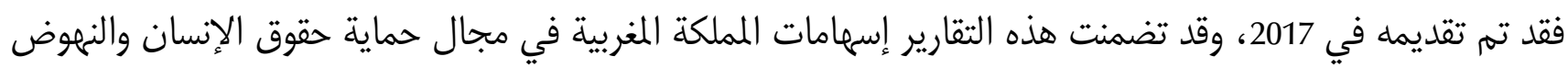

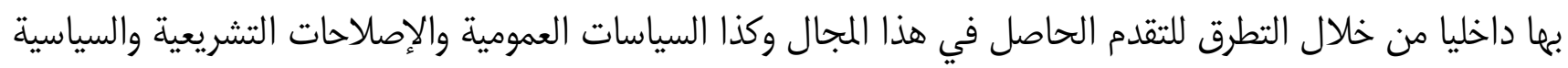

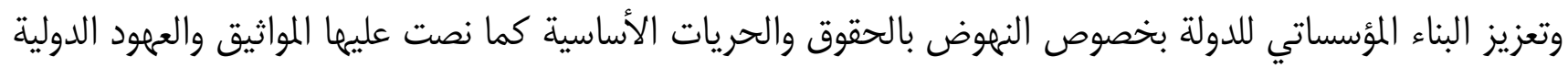
ذات الصلة بحقوق الإنسان.

ومن أجل إعداد التقرير الأول الذي قدمه المغرب في سنة 2008 تم تكوين لجنة مشتركة ما بين مجموعة من القطاعات

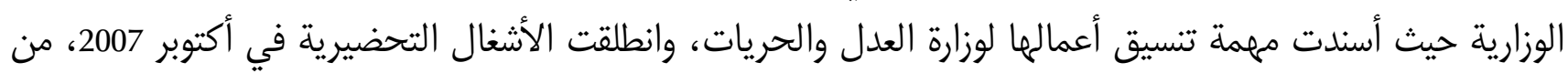

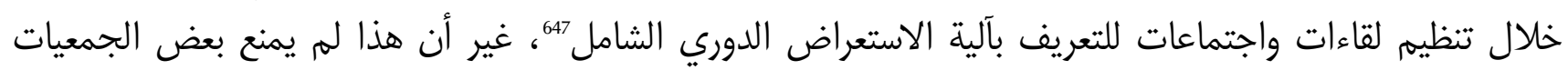

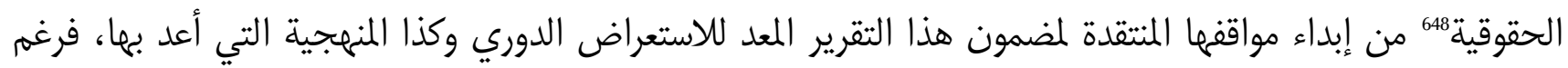

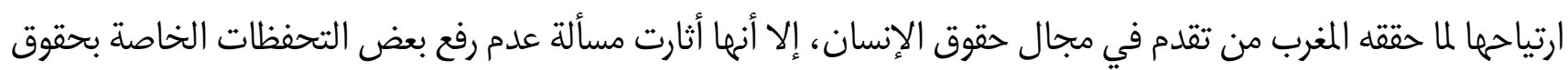

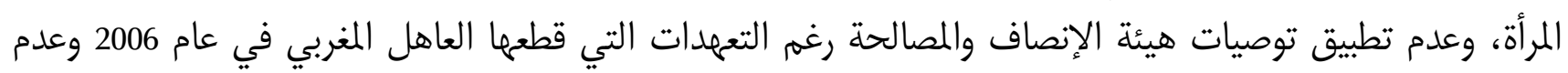
استقلالية القضاء.

وبخصوص التقرير الأول لسنة 2008 فقد تطرق لمجمل الإصلاحات ذات الصلة بحقوق الإنسان وكل الإجراءات التي

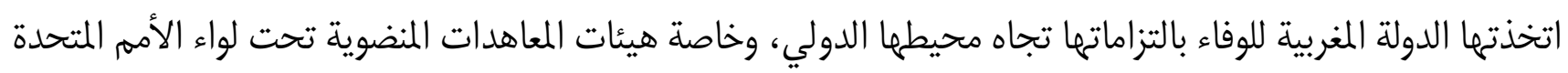
بما في ذلك سياسة التصديق والانضمام إلى المعاهدات الدولية المهتمة بحقوق الإنسان، أو على المستوى القضائي باعتباره

645 - Morocco's voluntary pledges and Commitments in accordance with resolution A/RES/60/251 .The permanent mission of the kingdom of the morocco in united nation, New York 17 April 2006. KM/hi. N0:VN/170/06.

646- وضعية انخراط المملكة المغربية في الاتفاقيات الأساسية في مجال القانون الدولي لحقوق الإنسان والقانون الدولي الإنساني، منشورات المندوبية الوزارية المكلفة بحقوق الإنسان، فبراير 2015، الصفحة 1.

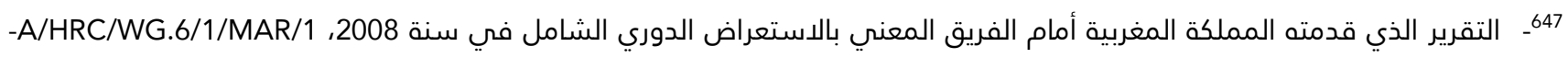
الفقرتين 10-10. 448- كالمنظمة المغربية لحقوق الإنسان، منظمة الكرامة لحقوق الإنسان، المركز المغربي لحقوق الإنسان، العصبة الأمازيغية لحقوق الإنسان، الجمعية الديمقراطية لنساء المغرب، واتحاد العمل النسائي بالمغرب. 
آلية من آليات ضمان ممارسة الحقوق المدنية والسياسية والاقتصادية وغيرها من الحقوق، وفيما يخص هذا التقرير وفي إطار تجميع المعلومات المنجزة من طرف المفوضية السامية لحقوق الإنسان، فقد أشارت هذه الريئة إلى مجموعة من المطالب المعبر عنها في التقارير الموازية التي أعدتها بعض الهيئات الحقوقية الوطنية وكذا الدولية بخصوص الوضعية الحقوقية في المغرب

وفي إطار الجولة الثانية من الاستعراض الدوري الشامل فقد تمت صياغة التقرير الوطني الثاني في سنة 2012 بنفس المنهجية السابقة، بحيث شكلت مناسبة إعداده فرصة لتعزيز مسلسل التشاور الوطني حول موضوع السياسات العامة في مجال حقوق الإنسان وكذا التزامات المملكة المغربية تجاه هيئات الأمم المتحدة، بهذه المناسبة تم تتظيم عدة لقاءات وطنية وجهوية بمشاركة خبراء دوليين ومنظمات دولية كالمفوضية السامية للأمم المتحدة لحقوق الإنسان، اللجنة الدولية للتنسيق بين المؤسسات الوطنية لحماية حقوق الإنسان والنهوض بها، ومنظمات غير حكومية دولية إضافة إلى فاعلين محليين في مجال حقوق الإنسان

ما ميز التقرير الثاني عن التقرير السابق هو كونه جاء بالموازاة مع الدينامية السياسية التي عرفتها البلاد والمتسمة بإقرار المملكة المغربية لعدة إصلاحات دستورية وسياسية شكلت أرضية ملائمة لتبني سياسات مختلفة تجلت أساسا في الشروع في ملاءمة التشريعات الوطنية مع القانون الدولي لحقوق الإنسان، والمصادقة على اتفاقية من أهم الاتفاقيات في مجال حقوق الإنسان ويتعلق الأمر بالاتفاقية الدولية لحماية جميع الأشخاص من الاختفاء القسري، خاصة وأن الدستور المغربي لسنة 2011 أصبح يعاقب لأول مرة على جريمة الاعتقال التعسفي أو السري والاختفاء القسري لإئمئ.

649ـــ مثل: 11/ مطالبة المنظمة المغربية لحقوق الإنسان بإدراج مبدأ المساواة في الدستور ومدونة الأسرة؛ 2/ مطالبة اتحاد العمل النسائي بملاءمة التشريع الوطني مع أحكام اتفاقية القضاء على التمييز ضد المرأة؛ 3/ تشديد كل من المنظمة المغربية لحقوق الإنسان والاتحاد الدولي لحقوق الإنسان على أن بعض المحكوم عليهم بالإعدام لا زالوا مسجونين في في انتظار تنفيذ الحكم؛ 4/ تسجيل المركز المغربي لحقوق الإنسان لمجموعة من حالات الاعتداء الجنسي على الأطفال، ترتبط في بعض الحالات بالسياحة الجنسية المتمثلة أساس في إنتاج أفلام خليعة؛ 5/ أفاد المركز المغربي لحقوق الإنسان أن كثيرا من المؤسسات الإصلاحية تشهد حالة متردية ساهم فيها الاكتظاظ وسوء التغذية وتفشي

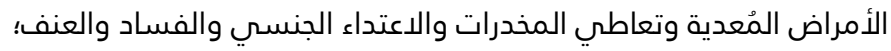

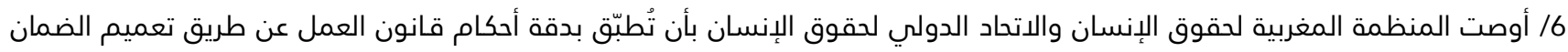
الاجتماعي على جميع العاملين، وحظر التسريح التعسفي للأجراء، ومنح تعويضات مقابل فقدان العمل لأسباب اقتصادية، واحترام شروط الصحة والسلامة المهنية ووضع سياسة عامة لكفالة المساواة بين مأجوري الصناعة والذدمات والزراكراعة. أنظر: تقرير المفوضية السامية لحقوق الإنسان عن الاستعراض الدوري الشامل للمغرب برسم سنة 2008، A/HRC/WG.6/1/MAR/3، 11 مارس 2008. تجدر الإشارة، إلى أن جزءا كبيرا من مطالب الحركة الحقوقية التي تم التعبير عنها بمناسبة تقديم المغرب لتقريره للاستعراض الدوري الشامل

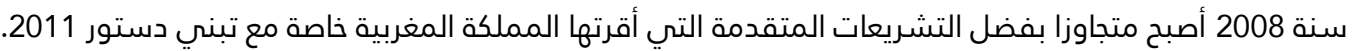

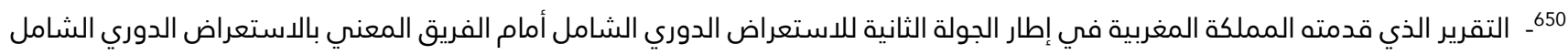

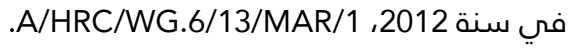
651- الفصل 23 من دستور 2011، كما تم إصداره في الجريدة الرسمية عدد 5964 مكرر بتاريخ 28 شعبان 1432، (30 يوليوز 2011)- الصفحة 
وفي إطار المهام الموكولة إليه في مجال حماية وتعزيز حقوق الإنسان شارك المجلـــــس الوطني لحقوق الإنسان

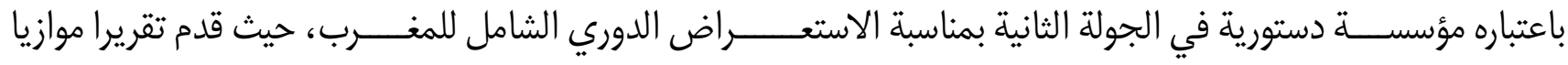
تضمن منجزات المملكة في مجال الحقوق والحريات وتضمن كذلك مجموعة من الملاحظات والتوصيات للحكومة مونة المغربية2652.

التزم المغرب أمام مجلس حقوق الإنسان خلال جلسة المصادقة النهائية على التقرير عن شروع الحكومة المغربية في

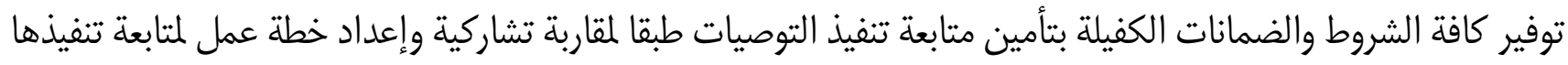

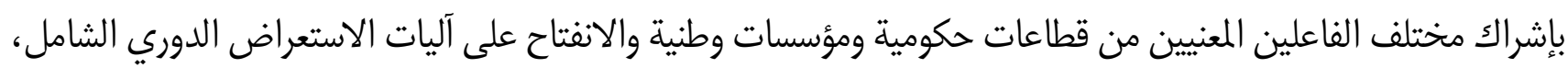

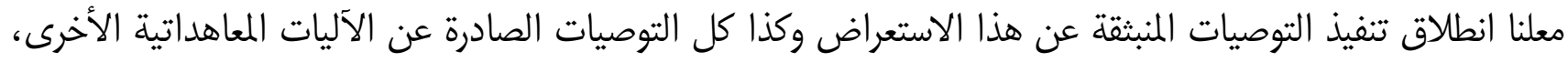

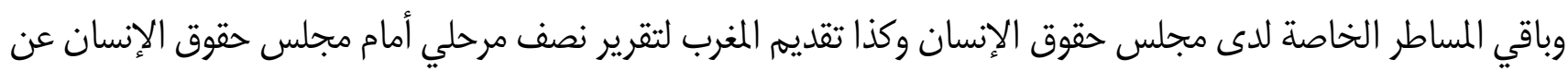
مدى التقدم في تنفيذ التوصيات

وفي ماي 2017، تم تقديم التقرير الوطني الثالث للاستعراض الدوري الشامل أمام الفريق المعني بمجلس حقوق

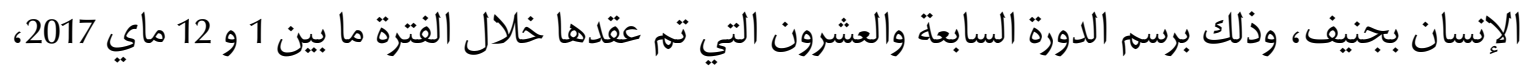

وقد تم إعداد هذا التقرير وفقا لمقاربة يمكن القول بأنها تشاركية ساهمت فيها مختلف الأطراف المعنية بحقوق الإنسان بالمغرب من قطاعات حكومية وبرلمان ومؤسسات وطنية نسقت أعمالمها المندوبية الوزارية المكلفة بحقوق الإنسان فئنان.

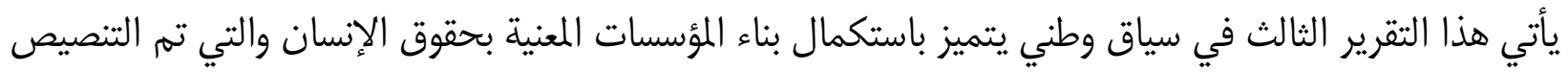
عليها دستوريا، وذلك من خلال إخراج القوانين المتعلقة بإنشاء هذه الميئات الدستورية لحيز الوجود، نذكر منها القانون

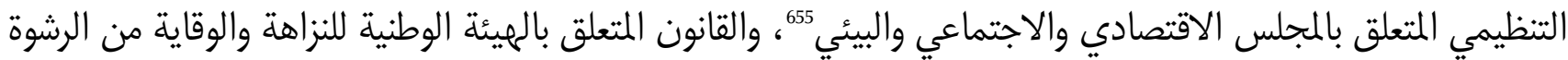

652- مثل:

○ إشراك فعاليات المجتمع المدني في مسار إعداد القوانين المنصوص عليها في الدستور؛ o الاعتماد الرسمي لخطة العمل الوطنية في مجال الديمقراطية وحقوق الإنسان وتنفيذ مقتضيات الأرضية المواطنة للنهوض بثقافة حقوق الإنسان، كما يدعو إلى الإشراك القوي للمجلس الوطني لحقوق الإنسان والمجتمع المدني في تنفيذ وتقييم وتحيين هاتين الآليتين؛ م الدعوة إلى مراجعة شاملة للقوانين المنظمة لقطاع الاتصال والإعلام والمقتضيات الجنائية في مجال حرية التعبير، وذلك طبقا للمقتضيات الدستورية ومبادئ القانون الدولي لحقوق الإنسان مع الحرص على إلغاء العقوبات السالبة للحرية من قانون الصحافة؛ ○ دعوة الحكومة إلى تعزيز ممارستها الاتفاقية مع إحداث الآلية الوطنية التي تنص عليها الاتفاقيات الدولية وفي مقدمتها الآلية الوطنية للوقاية من التعذيب.

أنظر: تقرير المجلس الوطني لحقوق الإنسان برسم الدورة الثانية للاستعراض الدوري الشامل في سنة 2012، الصفحة 2 وما بعدها.

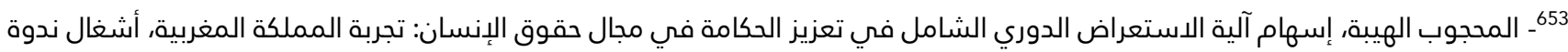
القاهرة حول الحكامة: المسؤولية الاجتماعية في سياق التحولات، الآليات والفاعلون، القاهرة 26 - 29 نونبر 2012. 654ـ التقرير الوطني المقدم وفقا للفقرة ه من مرفق قرار مجلس حقوق الإنسان رقم 21/16 المتعلق باستعراض عمل وأداء مجلس حقوق الإنسان A/HRC/WG.6/27/MAR/1 655 - Loi Organique $n^{\circ} 128-12$ du 31 juillet 2014 relative au Conseil économique, social et environnemental, B.O . N 6284 24 chaoual 1435 (21 août 2014 ), P 3879. 
ومحاربتها ${ }^{656}$ والقانون المتعلق بالمجلس الأعلى للتربية والتكوين والبحث العلمي 657، ثم القانون المتعلق بالمجلس الاستشاري للأسرة والطفولة

هذا علما بأن مشروع القانون المتعلق بالمجلس الوطني لحقوق الإنسان يعطيه صلاحية ممارسة الاختصاصات المرتبطة بالآلية الوقائية من التعذيب.

كما تم إخراج بعض القوانين التي تنظم ممارسة بعض المهن التي لما صلة بحقوق الإنسان لحيز الوجود من خلال نشرها بالجريدة الرسمية، ونخص بالذكر منها القانون المتعلق بالصحفيين المهنيين الأساسي للقضاة ${ }^{661}$ الأعلى للسلطة القضائية363، وغيرها من النصوص التشريعية والتنظيمية الرادفة للنهوض بسير وعمل المؤسسات المعنية بحماية الحقوق والحريات الأساسية المنصوص عليها دستوريا وكذا الدفاع عنها.

أما فيما يتعلق بالقوانين والنصوص التشريعية التي تمكن المواطنين من المشاركة في تدبير الشأن فقد تميزت الفترة التي شملها هذا التقرير بصدور مجموعة من القوانين التنظيمية التي تمكن المواطنات والمواطنين من المشاركة في تدبير الشؤون العامة سواء على المستوى المحلي، كما هو الحال مع القوانين التنظيمية للجماعات الترابية التي مكنت الأفراد من المشاركة في تدبير الشأن المحلي وفق منهجية تشاركية 664 ، أو على المستوى الوطني كما هو الشأن مع القانون التنظيمي

656 - Dahir $n^{\circ} 1-15-65$ du 21 chaabane 1436 (9 juin 2015) portant promulgation de la loi $n^{\circ} 113-12$ relative à l'Instance nationale de la probité, de la prévention et de la lutte contre la corruption. Bulletin officiel N 6388 du 4 kaada 1436 (20 août 2015), P 3357.

657 - Dahir $n^{\circ}$ 1-14-100 du 16 rejeb 1435 (16 mai 2014) portant promulgation de la loi $n^{\circ} 105-12$ relative au Conseil Supérieur de L'Éducation, de la Formation et de la Recherche Scientifique. B.O .N 6284- 24 Chaoual 1435 ( 21 août 2014 ), P 3872. 658 - Loi n ${ }^{\circ} 78-14$ du 20 juillet 2016 relative au Conseil consultatif de la famille et de l'enfance. Bulletin officiel, $N^{\circ} 6496-28$ Kaada 1437 (1-9-2016) P. 1357.

659- التقرير الوطني المقدم وفقا للفقرة ه من مرفق قرار مجلس حقوق الإنسان رقم 21/16 المتعلق باستعراض عمل وأداء مجلس حقوق الإنسان A/HRC/WG.6/27/MAR/1، الفقرة 11. 660 - Loi n 89-13 du 27 avril 2016, relative statut des journalistes professionnelles, Bulletin officiel, N 6506 - 04 moharrem 1438 (06-10-2016), P 1478.

661 - Loi organique $n^{\circ} 106-13$ du 24 mars 2016 portant statut des magistrats, Bulletin Officiel № 6492 du 14 kaada 1437 (18-8-2016), page 1313.

662 - Loi n 90-13 du 10 mars 2016 portant création du conseil national de la presse, Bulletin Officiel N 6506 - 04 moharrem 1438 (06-10-2016) P. 1470.

663 - Loi organique n 100-13 du 24 mars 2016 relative au Conseil Supérieur du Pouvoir Judiciaire, Bulletin Officiel N 6492 du 14 kaada 1437 (18-8- 2016), p 1299.

664 - Notamment, Loi organique $n^{\circ} 111-14$ relative aux régions; Loi organique $\mathrm{n}^{\circ} 112-14$ relative aux préfectures et provinces et Loi organique $n^{\circ} 113-14$ relative aux communes, publiées au Bulletin Officiel Nº 6440 du 09 Joumada I 1437 (18 Février 2016), PP 197- 231-260. 
المتعلق بتحديد شروط وكيفيات ممارسة الحق في تقديم العرائض لدى السلطات العمومية 665 أو القانون التنظيمي المتعلق بتحديد مسطرة وكيفيات ممارسة الحق في تقديم الملتمسات في مجال التشريع

وما يميز الاستعراض الدوري لسنة 2017 هو كونه تتمة للمجهودات السابقة والرادفة إلى تعزيز حقوق الإنسان، بما في ذلك السياسات العمومية والقطاعية المتعلقة بالحقوق الفئــوية ومدى مراعاتها للالتزامات الدولية للمغرب في مجال حقوق الإنسان على أرض الواقع من خلال التركيز على التوصيات الموجهة للمغرب بمناسبـــة فحص التقرير السابق في سنة 2012.

وهكذا، فقد تطرق التقرير الثالث للمجهودات وكل السياسات الحكومية المتعلقة بتعزيز الحقوق المدنية والسياسية كالنهوض بأحوال السجناء والاجتماعية كالحق في الصحة والعمل والتعليم والسكن اللائق ومحاربة الفقر والرشاشة الاجتماعية، وغيرها من المعطيات التي وردت في التقرير.

تطرق هذا التقرير لأهم التطــــــورات التي حقــــــقها المغرب في مجـــــــال حقوق الإنسان، وكـــــــا أهم

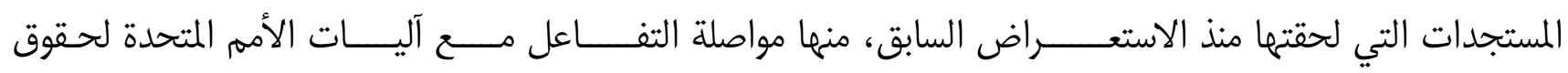

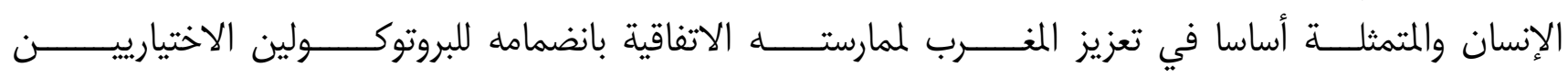

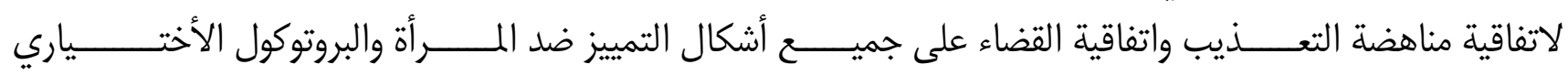
الأول الملحق بالعمد الدولي الخاص بالحقوق المدنية والسياسية، وكذا استعراض هيئات المعاهدات لخمسة تقارير وطنية

665 - Loi organique $n^{\circ} 44-14$ déterminant les conditions et les modalités d'exercice du droit de présenter des pétitions aux pouvoirs publics, B. Officiel № 6492 du 14 kaada 1437 (18 -8- 2016), p 1325.

666 - Loi organique $n^{\circ}$ 64-14 fixant les conditions et les modalités d'exercice du droit de présenter des motions en matière législative, B. Officiel Nº 6492 du 14 kaada 1437 (18-8- 2016), p 1327.

667 بخصوص النهوض بأحوال السجناء، سجل التقرير بأن مشروع القانون الجنائي تضمن أحكاما تعزز العمل بعقوبات بديلة تسمح بتحسين أوضاع

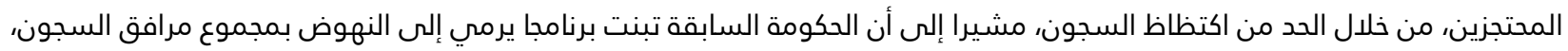
حيث تم فتح 10 مؤسسات سجنية في سنة 2015 بطاقة استيعابية تصل إلى 9000 سرير، ثلاثة منها بدأت عملها منذ يوليوز توجد قيد التشييد. 668ــــ على مستوى حرية التعبير أشار التقرير إلى تكريس القانون الجديد المتعلق بالصحافة والنشر لمجموعة من المستجدات القانونية والمتمثلة

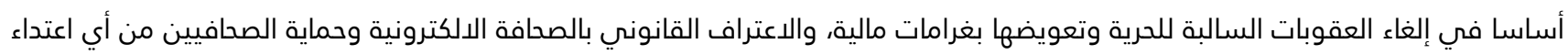
وتعزيز دور القضاء باعتباره الجهة المختصة في حجز المنشورات والمطبوعات وكذا حجب المواقع الإلكترونية.

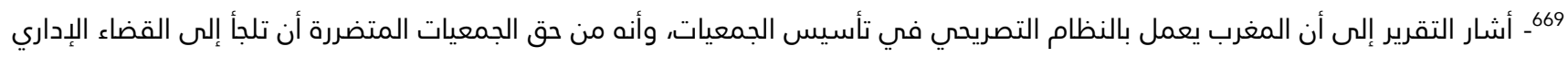

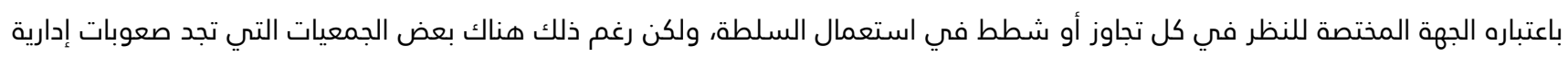
في مسطرة التأسيس أو تجديد مكاتبها المسيرة. 670 - 1) Le sixième rapport périodique sur l'application du Pacte international relatif aux droits civils et politiques, examiné les 24 et 25 octobre 2016; 2) Le quatrième rapport périodique sur l'application du Pacte international relatif aux droits économiques, sociaux et culturels, examiné les 30 septembre et 1er octobre 2015; 3) Les troisième et quatrième rapports périodiques sur l'application de la Convention relative aux droits de l'enfant et le deuxième rapport sur l'application du protocole facultatif concernant la vente d'enfants, la prostitution des enfants et la pornographie mettant en scène des 
فضلا عن زيارة أربعة إجراءات خاصة للمغرب

هذا، بالإضافة إلى الإشارة للإصلاحات الرئيسية التي باشرتها الحكومة المغربية في مجال إصلاح القضاء، وذلك وفقا لأحكام الدستور والمعايير الدولية المتعقلة بإنشاء نظام قضائي مستقل ونزيه يقوم على احترام حقوق الإنسان وسيادة القانون، وهذه الإصلاحات توجت بإصدار ميثاق إصلاح منظومة العدالة في سنة 2013 وإعداد مشروعي قانونين يهدفان إلى ملاءمة قانون المسطرة الجنائية والقانون الجنائي المعمول بهما حاليا مع أحكام القانون الدولي لحقوق الإنسان، مع الإشارة إلى ميلى التزام المغرب بالوقف الاختياري لعقوبة الإعدام منذ سنة 1993، فضلا على أن مشروع القانون الجنائي قيد التحضير عمل على تقليص عدد الجرائم التي يعاقب عليها بالإعدام ومكافحة جميع أشكال التعذيب وسوء المعاملة.

وإذا كان هذا التقرير تضمن مجموعة من الإجراءات والتدابير الايجابية في مجال تعزيز الحقوق المدنية والسياسية

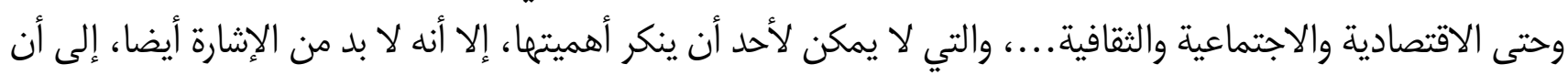
هذا التقرير أتى في سياق يتميز بتنامي وثيرة الحركات الاحتجاجية، خاصة وأن كل الإصلاحات التي شهدها المغرب همت في غالبها الجوانب السياسية أما الجوانب الاقتصادية والاجتماعية فلم تحظ بالقدر الكافي الذي سئي حظيت به مثيلتها على المستوى السياسي، ففي مجال السكن، مثلا، يلاحظ بأن هناك مجموعة من الفئات تجد صعوبة في الحصول على سكن لائق، بحيث يبين واقع الحال بجلاء استمرار ظاهرة سكان الصفيح، هذا علما بأن مشاريع السكن الاجتماعي، وكذا تجربة مدن بدون صفيح لم تؤت النتائج المتوخاة منها رغم الاعتمادات المالية المرصودة لها.

أما في المجال الصحي، فيلاحظ استمرار حالات الوفيات وذلك بسبب الخصاص المسجل في الأطر الطبية وشبه الطبية، حيث أن هناك العديد من الحالات كان بالإمكان تفاديها في حالة تواجد طاقم طبي كاف ومتخصص، علما بأن الولوج إلى الحق في الصحة يتفاوت بحسب المناطق الجغرافية إذ تعرف بعض المناطق عدة إكراهات متعلقة بصعوبة المسالك المؤدية إلى مراكز الاستشفاء، وفي ميدان التشغيل يلاحظ أيضا بأن هناك نقص مسجل فيما يخص توفير مناصب الشغل الشيء الذي ساهم في تتامي ظاهرة البطالة في أوساط النخب المثقفة الحاصلة على الشواهد العليا. وهنا تبدو الحاجة ضرورية للقيام ببعض الإصلاحات الاقتصادية والاجتماعية الموازية التي من شأنها تمكين المواطنين من التمتع بحقوقهمه، بحيث هناك العديد من المواطنين والمواطنات غير قادرين على الحصول على الحد الأدنى من مستويات، التعليم والصحة والشغل والسكن اللائق وهي حقوق نص عليها العهد الدولي المتعلق بالحقوق الاقتصادية والاجتماعية والثقافية لسنة 1966، وهذا ليس نتيجة لانعدام الموارد وإنما يرجع بالأساس لانعدام توفر سياسات عمومية ناجعة وهادفة تأخذ بعين الاعتبار الحاجيات الأساسية للمواطنين.

enfants, présentés en un seul document et examiné le 3 septembre 2014; 4) Le rapport initial sur l'application du Protocole facultatif à la Convention relative aux droits de l'enfant, concernant l'implication d'enfants dans les conflits armés, examiné le 4 septembre 2014; 5) Le rapport initial sur l'application de la Convention internationale sur la protection des droits de tous les travailleurs migrants et des membres de leur famille; examiné les 10 et 11 septembre 2013.

671 - 1) Expert indépendant sur les droits de l'homme et la solidarité internationale (5-19 janvier 2016); 2) Rapporteur spécial sur le droit à l'alimentation (5-12 octobre 2015); 3) Groupe de travail sur la détention arbitraire (09-18 décembre 2013); 4) Rapporteuse spéciale sur la traite des êtres humains, en particulier des femmes et des enfants (17-21 juin 2013). 


\section{المطلب الثالث: عضوية المغرب في مجلس حقوق الإنسان}

يعتبر مجلس حقوق الإنسان هيئة حكومية دولية تابعة للأمم المتحدة، وحل هذا الأخير محل لجنتة الأمم المتحدة لحقوق الإنسان، تتجلى مهمته في تعزيز حقوق الإنسان وحمايتها في جميع أرجاء العالم 672 ورصد كل حالات انتهاك حقوق الإنسان وتقديم توصيات بشأنها فضلا عن تلقي الشكاوى وفحصما، ويتكون هذا الأخير من حوالي 47 دولة تنتخبها الجمعية العامة بالاقتراع السري والمباشر في شهر نونبر كل 3 سنوات لا تتجاوز ولايتين متتاليتين، ويؤخذ بعين الاعتبار في عملية الانتخاب مساهمات الدولة المرشحة في تعزيز حقوق الإنسان وكذا تعهداتها والتزاماتها الطوعية. ويعقد اجتماعاته في مكتب الأمم المتحدة في جنيف ${ }^{673}$ تستند تركيبة المجلس على التوزيع الجغرافي حيث يخصص لكل قارة عدد من المقاعد بناء على مساحتها

ساهمت المغرب بشكل كبير في تطوير نظام الأمم المتحدة لحقوق الإنسان ووضع آلية الاستعراض الدوري الشامل، كما يعد من الدول الأكثر انفتاحا على مجلس حقوق الإنسان، باعتباره هيئة دولية مكلفة بالنهوض بحقوق الإنسان وحمايتها، وذلك وفقا للجهود التي يبذلما المغرب في مجال النهوض بحقوق الإنسان وخاصة فيما يتعلق بتعامله مع هيئات حقوق الإنسان. وفي هذا السياق، اضطلع المغرب خلال ولايتين متتاليتين، منذ سنة 2006، بهذا المجلس بمواصلة التزامه النشط داخل دوراته، وذلك عبر مجموعة من المؤسسات الوطنية المعنية بحقوق الإنسان 675 ، وفي مقدمتها المجلس الوطني لحقوق الإنسان الذي يواصل المغرب من خلاله العمل على تطوير علاقات التعاون مع مختلف الأطراف والفاعلين الدوليين المكلفين بمراقبة حقوق الإنسان بكافة دول المعمور من خلال، التعاون والمشاركة في أشغال هيئات الأمم المتحدة المختصة في حقوق الإنسان وحتى بعض الآليات المنشأة للمراقبة

672ـ أنشأ المجلس بموجب القرار رقم 251/60، A/RES/60/251 الصادر عن الجمعية العامة للأمم المتحدة بتاريخ 15 مارس 2006 وعقد دورته الأولى في الفترة الممتدة من 19 إلى 30 يونيو 2006. 673- دليل عملي حول مجلس حقوق الإنسان، إصدارات المفوضية السامية لحقوق الإنسان والمنظمة الدولية للفرنكفونية، مطبعة فيليار فرنسا،

طبعة 2015، الصفحة 12 إلى 20. 674 - ك وذلك وفق التقسيم التالي: O O

O دول أمريكا اللاتينية ومنطقة البحر الكاريبي: 8 مقاعد؛ O دول أوروبا الغربية ودول أخرى: 7 مقاعد؛ O

أنظر: دليل عملي حول مجلس حقوق الإنسان، إصدارات المفوضية السامية لحقوق الإنسان، المرجع السابق الصفحة 20. 675 - Note $n^{\circ} \mathrm{VN} / 134 / 06$, regarding the decision by the government of the morocco to present its candidature to the human right council in accordance with resolution A/RES/60/251. The Permanent Mission of the Kingdom Morocco in United Nation, New York 17 April 2006. KM/hi. VN/170/06

676- من قبيل:

O التعاون مع المفوضية السامية لحقوق الإنسان؛ O O متابعة أشغال اللجان التعاهدية المكلفة بمراقبة تنفيذ مقتضيات اتفاقيات حقوق الإنسان؛ 
وفي هذا الإطار ، وبمناسبة انعقاد الدورة 19 لمجلس حقوق الإنسان بجنيف قام وفد مغربي بتقديم ترشح المملكة المغربية

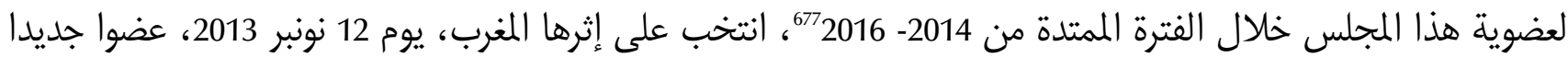

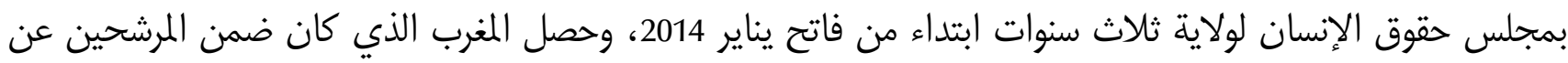

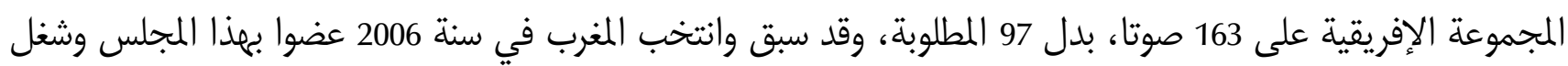

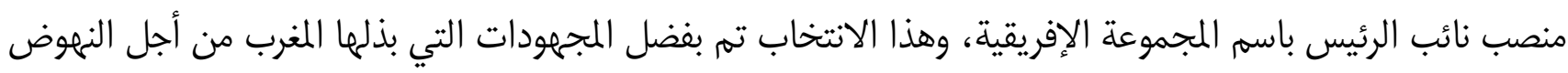
بحقوق الإنسان

يعتبر انتخاب المغرب عضوا بمجلس حقوق الإنسان، الذي يعد أحد أعضائه المؤسسين، اعترافا دوليا بالدور الذي يلعبه

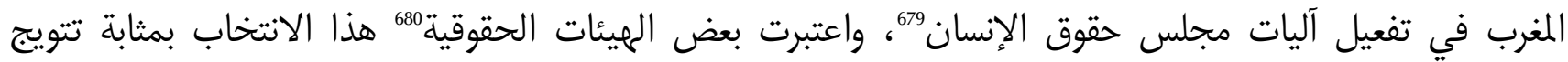

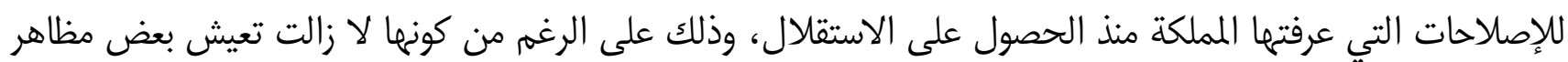

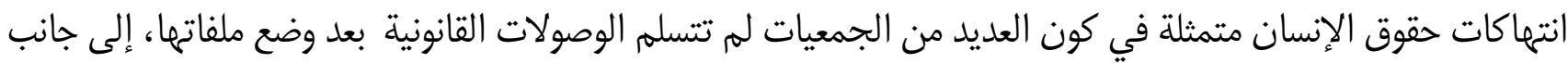

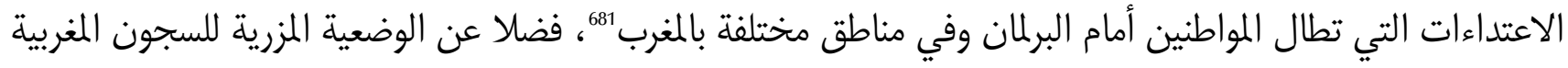

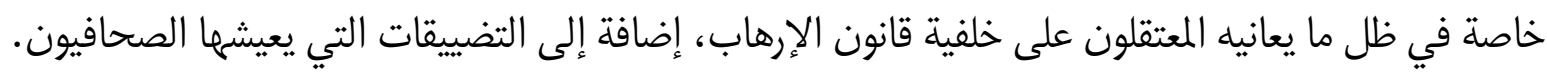
فمنذ حصول المغرب على العضوية بمجلس حقوق الإنسان التابع لهيئة الأمم المتحدة بجنيف، ساهم بشكل إيجابي

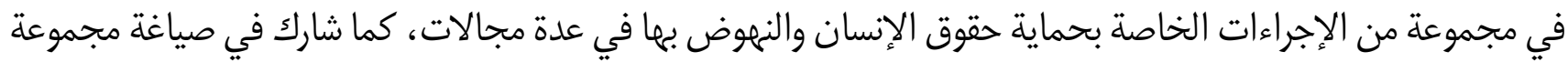

O متابعة أشغال الآليات الأممية غير التعاهدية؛

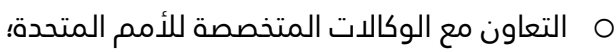
O المشاركة في أنشطة لجنة التنسيق الدولية للمؤسسات الوطنية لحقوق الإنسان؛ O O متابعة أنشطة وتقارير المنظمات الدولية غير الحكومية التي تهم أوضاع حقوق الإنسان في المغرب؛ O ت تيسير التعاون بين هذه المنظمات وبين السلطات الحكومية المغربية؛ O ت تنظيم لقاءات وندوات في مجال حقوق الإنسان بالتعاون مع المنظمات الدولية غير الحكومية؛ O استقبال وفود عن مؤسسات حكومية وغير حكومية أجنبية ومن المجتمع المدني قصد تبادل التجارب وتنمية مشاريع التعاون. http://www.cndh.ma.

677 -See Annex to the note Verbale, dated 6 May 2013.The Permanent Mission of Morocco to the United Nations addressed to the Secretary-General, Regarding Candidature of Morocco to the Human Rights Council, 2014-2016. Publications the General Assembly A/68/83, 16 May 2013.

678- أنظر تقرير المجلس الاستشاري لحقوق الإنسان عن وضعية حقوق الإنسان خلال سنتي 2005 / 2006، منشورات المجلس الاستشاري لحقوق الإنسان- الصفحة 109. 679ـ تأتي عضوية المغرب بهذا المجلس رفقة 13 دولة عن الدول الإفريقية ويتعلق الأمر بالدول التالية: المغرب 2016، الجزائر 2016، 2016، بوتسوانا 2017، الكونغو 2017 ، كوت ديفوار 2015، أثيوبيا 2015، الغابون 2015، غانا 2017، كينيا 2015، ناميبيا 2016 ، نيجيريا 2017، سيراليون 2015،

جنوب أفريقيا 2016. 680- نذكر على سبيل المثال منتدى الكرامة لحقوق الإنسان. 681ـ البيان الصادر عن المكتب التنفيذي للهيئة المغربية لحقوق الإنسان، حول بعض المضرف الأحداث والقضايا الحقوقية وطنيا وإقليميا. الرباط في:31 
من القرارات التي تهدف إلى حماية حقوق الإنسان والتربية عليها في جميع بقاع العالمهان. فبالإضافة، إلى التزامه بمكانيزمات الاستعراض الدوري الشامل مع المفوضية السامة لحقوق الإنسان والمنظمة الدولية للفرنكفونية حول التعريف بآلية الاستعراض الدوري الشامل ومنهجية إعداد التقارير الدورية، نجده يقدم مساعدات مالية وتقنية لفائدة الدول النامية للالتزام بإعداد تقاريرها لدى المجلس | المعني

\section{المطلب الرابع: القبول بالآليات الدولية المنشأة للمراقبة}

أصبح المجتمع الدولي في ظل قواعد القانون الدولي لحقوق الإنسان، وخلافا لما كان عليه الحال سابقا، طرفا أصيلا معنيا بمسألة حقوق الإنسان وصار يقف إزاءها على قدم المساواة مع الدولة المعنية أو تلك التي ينتمي إليها الأفراد الذين

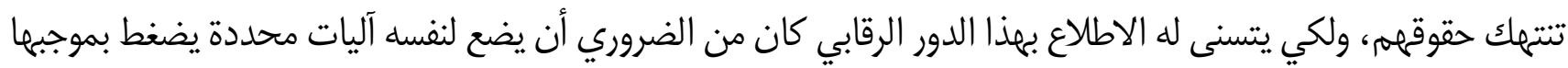
على الدول من أجل حثنها على الإلتزام بالحقوق والحريات الأساسية التي تضمنها المواثيق الدولية للأفراد، فإلى جانب ئب أساليب الضغط المعنوي والأدبي التي تتمثل عادة في اتخاذ قرارات وإصدار تقارير، تمارس بعض المنظمات الدولية سلطة الرقابة تحت إشراف دوليين فيما يتصل بمدى التزام الدول بالقواعد والمعايير الدولية ذات الصلة بحقوق الإنسان أنشأت منظمة الأمم المتحدة ما يسمى بالزيارات القطرية أو الميدانية التي يقوم بها خبراء مكلفون بمراقبة أوضاع حقوق الإنسان 686، حيث يعملد لهم بالقيام بزيارات للتحري عن أحوال حقوق الإنسان بالدول وتقييم الحالة العامة لحقوق الإنسان

682 منذ سنة 2007، ساهم وشارك المغرب في العديد من الإجراءات الملموسة والتي تناولت مختلف الجوانب المتعلقة بتعزيز حقوق الإنسان وحمايتها، وذلك من قبيل: (أ) القرار المنشئ للإجراءات الخاصة لتعزيز الحقيقة والعدالة والجبر وضمانات عدم التكرار، بالتعاون مع الأرجنتين وسويسرا؛ (ب) القرار المتعلق بحالات الاختفاء القسري أو غير الطوعي بشرات القراكة مع فرنسا والأرجنتين؛ (ت) القرار المتعلق بمكافحة التعصب والتمييز والتحريض على العنف أو ممارسته ضد أشخاص معينين بسبب دينهم أو معتقداتهم؛ (ث) أيد المغرب قيام مجلس حقوق الإنسان بإنشاء عدد من الإجراءات الخاصة، مثل الفريق العامل المعني بمسألة التمييز ضد المرأة، والخبير المستقل في مجال الحقوق الثقافية والمقررين الخاصين المعنيين بحق الإنسان في مياه الشرب والمرافق الصدية الصدية والحق في التجمع السلمي

وتكوين الجمعيات؛

(ج) شارك المغرب مع سويسرا، في سنة 2007، في القرار الذي أعلن بموجبه البدء في عملية صياغة إعلان للأمم المتحدة بشأن التثقيف والتدريب في مجال حقوق الإنسان.

683 كنذ إنشاء مجلس حقوق الإنسان، ساهم المغرب بشكل كبير في عملية إنشاء وتعزيز آلية الاستعراض الدوري الشامل. 684 - منذ سنة 2011، ساهم المغرب بمبلغ فاق حوالي 000500 دولار لفائدة الصندوق الطوعي للاستعراض الدوري الشامل المخصص

للمساعدة المالية والتقنية للبلدان النامية، وذلك بهدف تنفيذ التزاماتها المتمثلة في الاستعراض الدوري الشامل. Pour plus d'informations voir, Candidature du Royaume du Maroc au Conseil des Droits de l'Homme 2014 -2016.Adressée au Secrétaire général par la Mission permanente du Maroc auprès de l'Organisation des Nations Unies, A/68/83, 16 mai 2013.

685.ـ لا يخفى على كل متتبع بأن الاهتمام بحقوق الإنسان أضحس يمثل إحدى السمات الأساسية المميزة للنظام الدولي المعاصر الذي أرسيت دعائمه منذ نهاية الحرب العالمية الثانية، فمنذ إنشاء منظمة الأمم المتحدة باتت مسألة حقوق الإنسان وضماناتها الإنات المختلفة تشكل ما يعرف الآن بالقانون الدولي لحقوق الإنسان إلى جانب ما أصطلح على تسميته بالقانون الدولي الإنساني. 686 تم اعتماد اختصاصات الزيارات القطرية عقب الاجتماع السنوي الرابع للمقررين الخاصين (E/CN.4/1998/45) في سنة 1997 بالمجلسئس الاقتصادي والاجتماعي بالأمم المتحدة. 
في بلد معين من خلال عقد لقاءات واجتماعات مع ممثلي الدولة بما في ذلك أعضاء الهيئات القضائية والمجالس النيابية

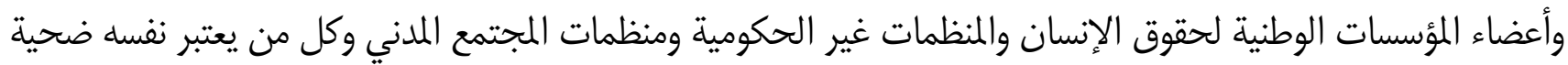

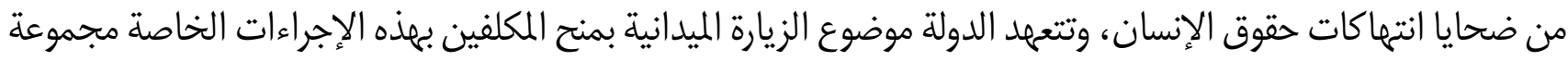

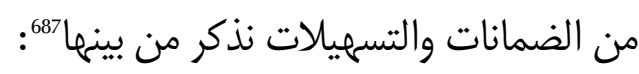
م رية التنقل في البلد بأكمله، بما في ذلك تيسير الانتقال؛ م رية التحقيق، ولا سيما من خلال السماح للهم بـ : النفاذ إلى السجون ومراكز الاحتجاز وغيرها؛ الاتصال بالسلطات المركزية والمحلية التابعة للحكومة؛ الإنان عقد اجتماعات مع ممثلي المنظمات غير الحكومية؛

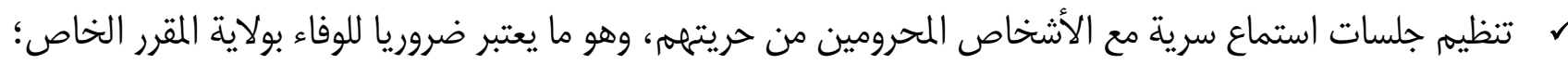
ل ح الاطلاع على التشريع الوطني المتعلق بحقوق الإنسان.

تتعهد حكومة الدولة موضوع الزيارة بأن الأشخاص الذين كانوا على اتصال مع المقرر الخاص سواء كانوا مسؤولين أو أو الخات

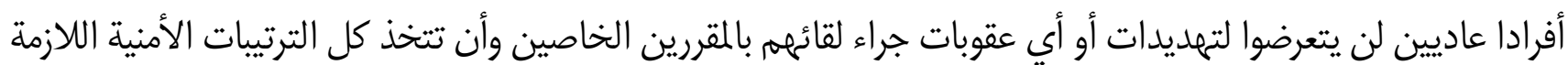

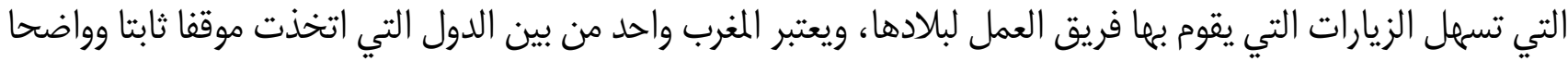

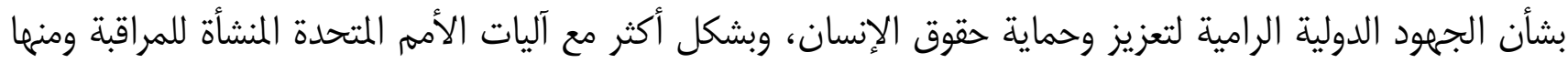

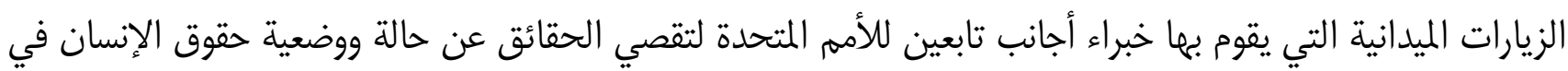

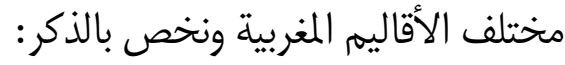

* الزيارة التي قامت بها المقررة الخاصة المعنية بالأشكال المعاصرة للعنصرية والتمييز العنصري وكره الأجانب وما يتصل

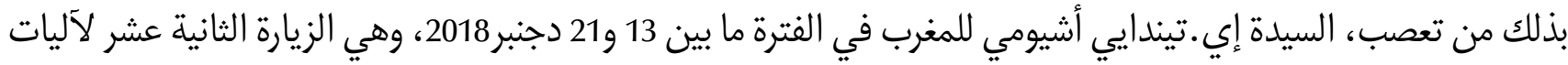

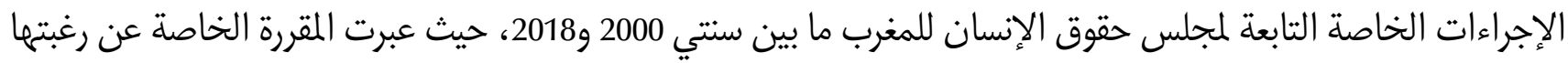

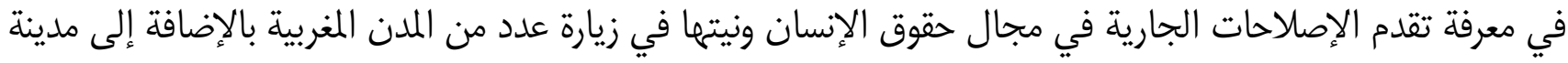

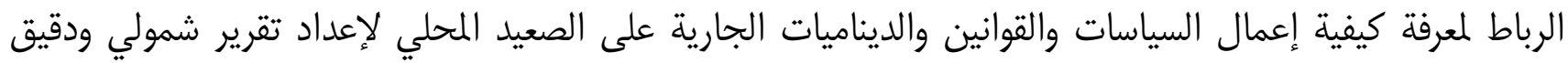

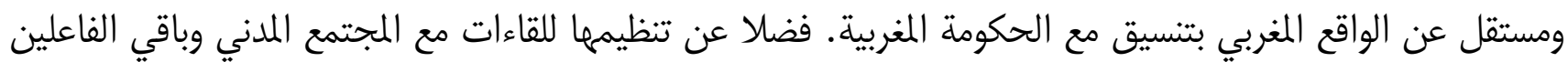

Report of the meeting of special rapporteurs/representatives, Experts and chairpersons of working groups of the special Procedures of the commission on human rights and of the Advisory services programme, Geneva, 20-23 May 1997, Rapporteur: Ms. Fatma-Zhora Ksentini. E/CN.4/1998/45.

687 - http://www.ohchr.org. 
* الزيارة التي قام بها المقرر الخاص بمناهضة التعذيب وسوء المعاملة السيد خوان مانديز للمغرب ما بين 15 و22 شتنبر

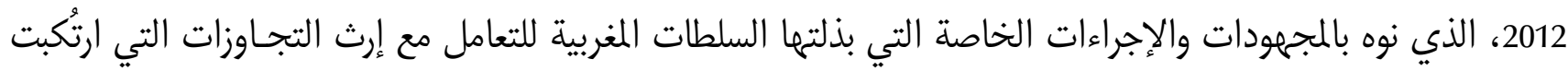
خلال "سنوات الرصاص"، وذلك عن طريق هيئـة الإنصاف والمصالحة، ورحب، بصفة عامة، بظهور ثقافة حقوق الإنسان في المغرب688. وبالمناسبة فقد وجه رئيس المجلس الوطني لحقوق الإنسان من أجل تسهيل هذه الزيارة دعوة إلى العديد من مسؤولي المؤسسات السجنية والأمراض العقلية من أجل التعامل بانفتاح وايجابية مع زيارة مانديز، وذلك للتأكيد على أن الن النيل المغرب قرر بشكل إرادي وطوعي التعامل مع جميع الآليات والمؤسسات الأممية المختصة بمراقبة وتقييم السياسات العمومية في مجال حقوق الإنسان انطالاقا من مصادقته إراديا على عدد من المعاهدات الدولية في هذا المجال

* الزيارة التي قام بها فريق العمل الخاص بالاعتقال التعسفي للمغرب، ما بين 9 و 18 دجنبر 2013 لمدينة العيون، للوقوف على الججهود المبذولة لحماية حقوق الإنسان والنهوض بها، فتلقوا بشكل إيجابي اعتماد المغرب لدستور 2011 وخاصة المادة 23 منه التي تجرم الاعتقال التعسفي

* الزيارة التي قامت بها المقررة الخاصة المعنية باتفاقية الاتجار بالبشر سيما النساء والأطفال لمدينة الداخلة ما بين 17 و21 يونيو 2013، بغية الوقوف على الإجراءات المتخذة من لدن الحكومة المغربية لمكافحة هذه الظاهرة، حيث وجهت عدة توصيات للحكومة المغربية من ضمنها اعتماد إطار قانوني ومؤسساتي للحد من هذه الظاهرة ودعم ومساندة ومواكبة الضحايا

* الزيارة التي قام بها فريق العمل الخاص بالاختفاء القسري من 22 إلى 25 يونيو 2009، حيث نوه الفريق بتجربة المغرب في مجال هيئة الإنصاف والمصالحة معتبرا إياها نموذجا يمكن لدول أخرى الاقتداء به بهاء

خاتمة:

يتضح، من خلال ما سبق، بأن المغرب يبذل جهودا حثيثة لتعزيز انخراطه في الشرعة الدولية لحقوق الإنسان والتفاعل المثمر مع أجهزة رصد المعاهدات، وذلك من خلال تقديم التقارير الوطنية للاستعراض الدوري الشامل، أو عبر آلية التقارير الدورية، فضلا عن إسماماته، عبر مجلس حقوق الإنسان، في مجموعة من الإجراءات والقرارات الدولية التي تهدف إلى تعزيز ثقافة حقوق الإنسان وكذا من خلال توفير بعض المساعدات المالية لبعض الدول قصد وفائما بالتزاماتها في تقديم تقارير الاستعراض الدوري الشامل أمام مجلس حقوق الإنسان.

${ }^{688}$ - Rapport du Rapporteur spécial sur la torture et autres peines ou traitements cruels, inhumains ou dégradants, Mr, Juan E. Méndez, A/HRC/22/53/Add.2, 28 février 2013.

689- وكالة المغرب العربي للأنباء: اليزمي يدعو مسؤولي السجون إلى التعامل بانفتاح مع زيارة المقرر الخاص بالتعذيب بتاريخ 17 يوليوز 2012. 690 -Le Rapport du groupe de Travail sur La Détention Arbitraire , A/Hrc/27/48/Add.5, 4 Août 2014.

691 - Le Rapport de la Rapporteuse spéciale sur la traite des êtres humains, en particulier les femmes et les enfants, Joy Ngozi Ezeilo, A/HRC/26/37/Add.3, 1er avril 2014.

692. Le Rapport du groupe de travail sur les disparitions forcées ou involontaires, A/HRC/13/31/Add.1, 9 février 2010. 
وهكذا، فقد بادر المغرب منذ حصوله على استقلاله السياسي إلى الانخراط الطوعي والتدريجي في الشرعة الدولية

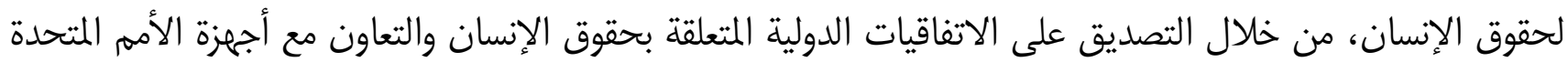

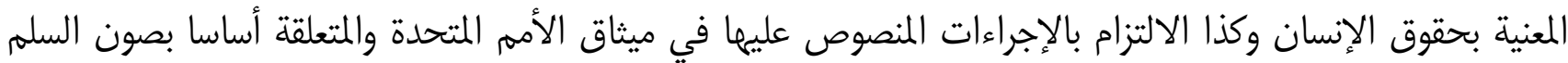

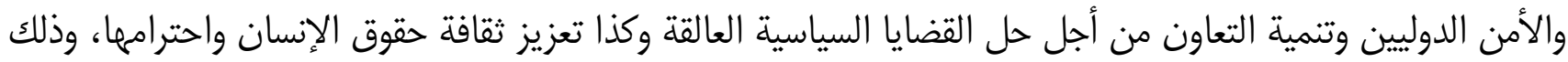
سعيا منه لمسايرة التطور الذي تعرفه قضايا الديمقراطية وحقوق الإنسان.

في نفس السياق، شهدت الممارسة الاتفاقية للمغرب تقدما ملموسا سواء من حيث ارتفاع وتيرة التصديق أو رفع ومراجعة

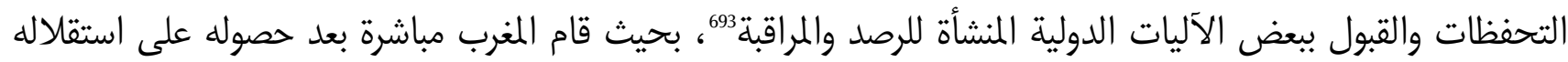

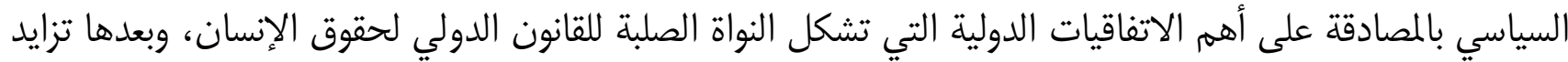

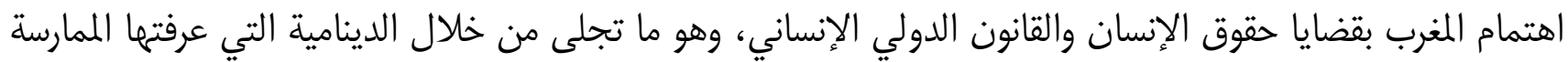

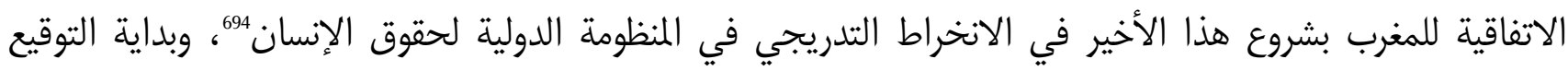

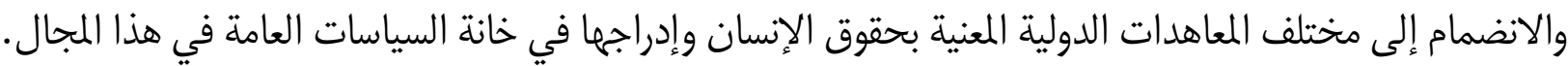
ويمكن القول، بأن المغرب يعد طرفا في جل الاتفاقيات والصكوك الدولية ذات الصلة بحقوق الإنسان، خاصة وأنه

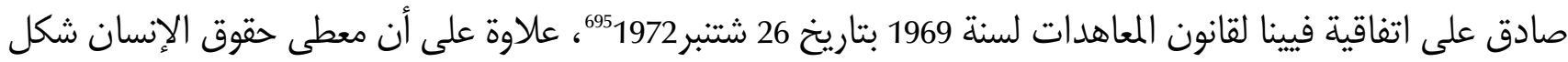

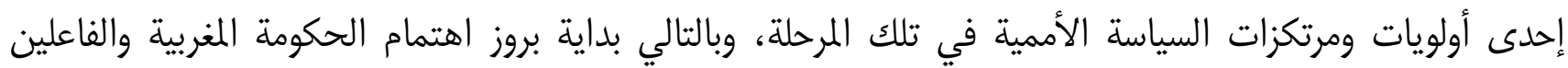

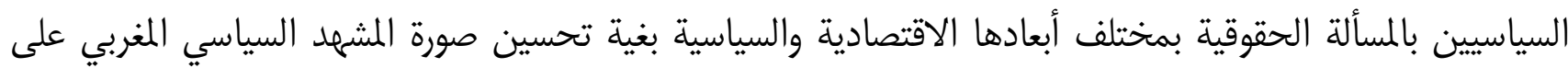

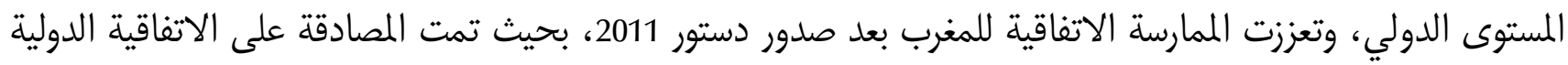

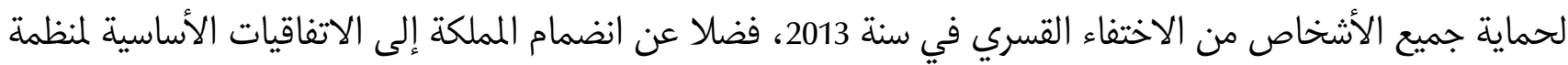
العمل الدولية، منذ سنة 1956، وكذا العديد من البروتوكولات الإضافية والملحقة بالاتفاقيات الدولية المذكورة.

693ـ كقبول المغرب بآلية الاستعراض الدوري الشامل أمام مجلس حقوق الإنسان، وتقديم التقارير الدورية أمام هيئات المعاهدات المعنية

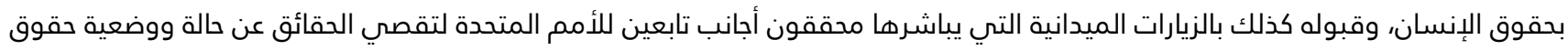
الإنسان في مختلف الأقاليم المغربية، كزيارة المقرر الأممسي الخاص بمناهضة التعذيب وسوء المعاملة السيد خوان مانديز (Juan Mendez) للمغرب خلال الفترة الممتدة ما بين15 و 22 شتنبر 2012.

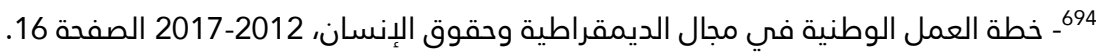
695 الظهير الشريف رقم، 1974)، 1.73.348، بتاريخ 8 رجب 1393 (8 غشت 1973) الجريدة الرسمية عدد 3239، بتاريخ 12 ذو القعدة 1394 (27 نونبر 


\section{مؤسسة المغفض الملكي بالمحاكم الإدارية}

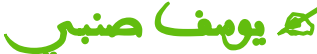

دكتوراه في القانون الخاص

إطار بوزارة إعداد التراب الوطني والتعمير والإسكان وسياسة المدين

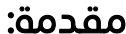

إن الركائز والدعامات الأساسية التي يجب أن تقف عليها دولة الحق والقانون، هو القانون نفسه وخاصة وضع إطار

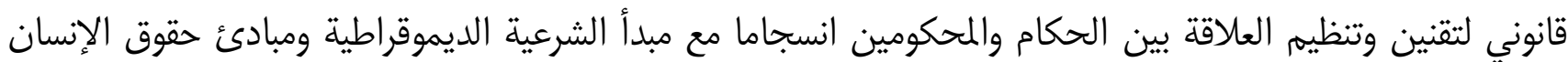
المتعارف عليها دوليا، غير أن هذه العلاقة تفرض وجود طرفين أحدهما ذات صبغة عامة، والدولة باعتبارها واضعة للقانون

وتملك سلطة تنفيذه، يثار التساؤل عما هو القانون الذي تخضع له؟

إن الدولة إما أن تخضع للقانون ذاته الذي يخضع له الأفراد-أو تخضع لقانون خاص يختلف عن الأول حسب ما إذا

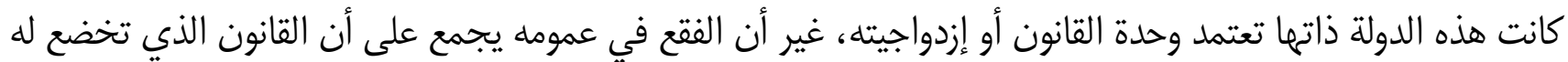

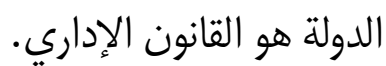

إن تطور وتعدد وتنوع مجالات نشاط الإدارة حسب ما يتطلبه السير اليومي للمرافق العامة ومصالح الرعايا كان من

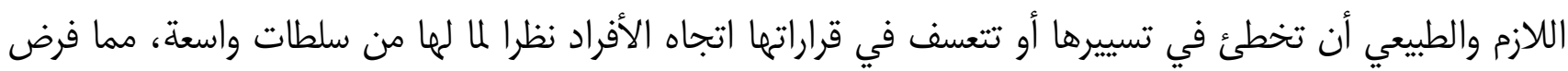

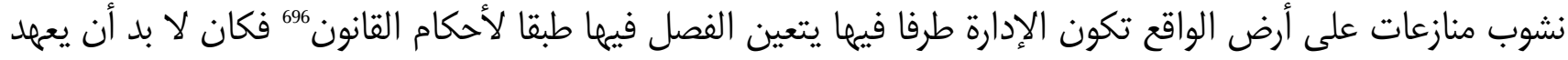
برقابة الإدارة في ممارسة نشاطها إلى جهاز قضائي متخصص، لم يكن سوى القضاء الإداري. وقد عرف القضاء الإداري المغربي تطورا مهما منذ نشأته إلى اليوم حيث لعب القضاء الإداري الفرنسي الدور الأكبر والمام في تطويره، كما مارس تأثير لا يمكن تجاهله.

وهكذا كان المغرب من الدول التي عرف تنظيمها القضائي إصلاحات هامة ومتوالية فرضتها التحولات الإقتصادية

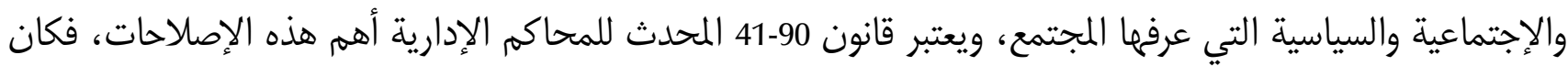

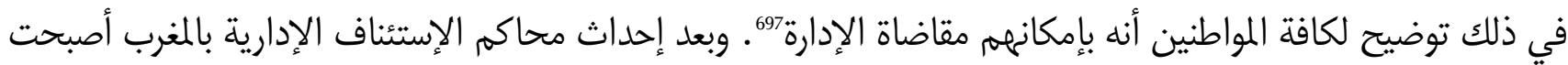

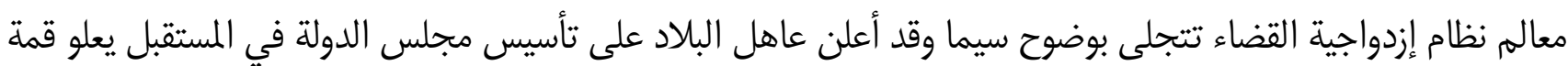

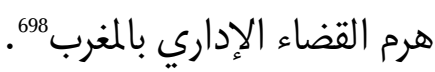

(1) - مبعة 2008 ص 7 696 حسن عثمان محمد عثمان " قانون القضاء الإداري" منشورات 697 الدكتور رشيدي السبايطي: المفوض الملكي للدفاع عن القانون و الحق في المحاكم الإدارية سلسلة مؤلفات و أعمال جامعية. منشورات ريمالد مطبعة دار النشر المغربية 2012. 698 خطاب 1999/12/15 بمناسبة إفتتاح دورة المجلس الأعلى للقضاء 
وعليه فإذا كان إحداث المحاكم الإدارية حدثا جديدا وجديا وفاتحة عهلد حقوقي وقضائي مزدهر، فإنه استحدث معاء

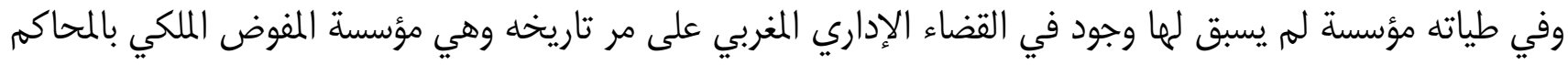

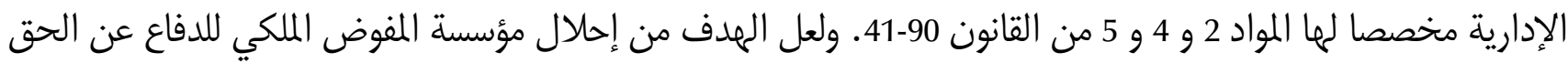

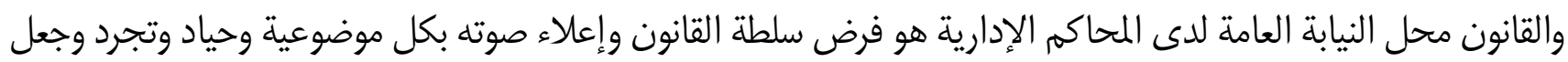
الدولة ذاتها أول الخاضعين لأحكامه.

ونظرا لقصور وقلة النصوص القانونية المنظمة لمؤسسة المفوض الملكي تضعنا أمام عقبات محورية سنحاول الإجابة عنها

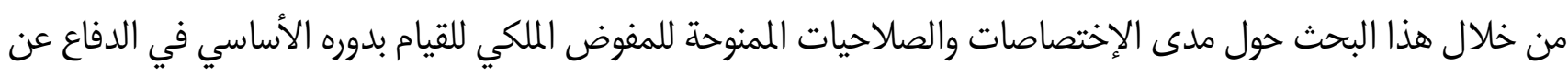
القانون والحق ومدى حصوله على الإستقلال المفروض.

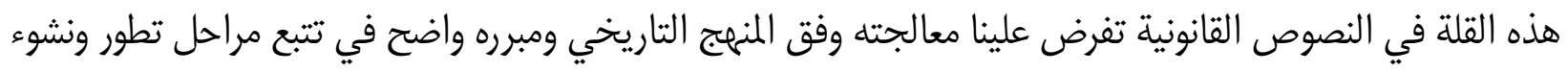

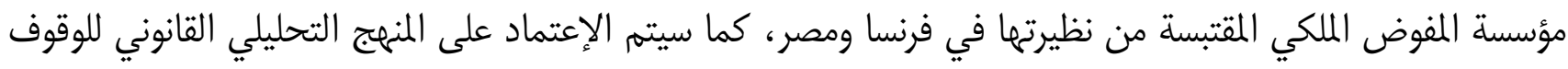
على دوره في الدعوى الإدارية وكذا الإشكاليات المطروحة في الجانب القانوني والعملي على حد المعاء السواء.

وتجدر الإشارة إلى قيامنا بالتركيز على كل من التجربة الفرنسية باعتبارها النموذج والتجربة المصرية للخصوصية العربية والإسلامية المشتركة حتى يتسنى لنا الإستفادة من تجربة هذه الدول الرائدة لدعم المؤسسة فقهما واجتهادادا. كما سنعتمد تقسيم الموضوع إلى قسمين أساسيين سنحاول في الأول التركيز على التجارب المقارنة لفهم طبيعة عمل

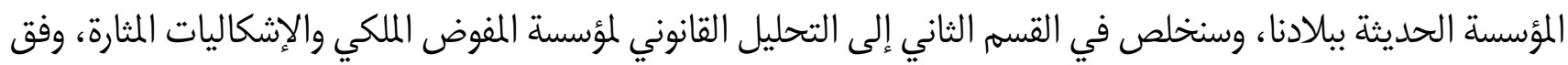
التصميم التالي:

الفصل الأول: المفوض الملكي في القانون المقارن ونشأته بالمغرب المبحث الأول: نظام المفوض الملكي في الأنظمة المقارنة

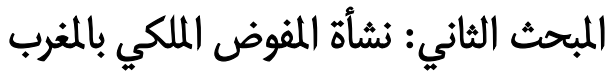
الفصل الثاني: مهام المفوض القضائي وتقييم عمله المبحث الاول: الاختصاصات والمسطرة المبحث الثاني: تقييم نظام المفوض الملكي والمات ولمطاكل المثارة بشأنه.

الفصل الأول: المفوض الملكي في القانون المقارن ونشأته بالمغرب المبحث الأول: نظام المفوض الملكي في الأنظمة المقارنة

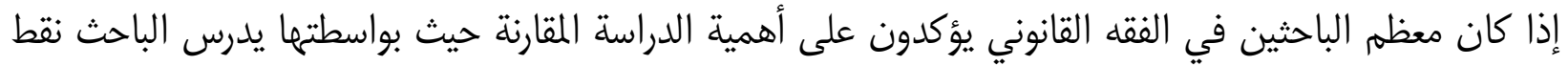

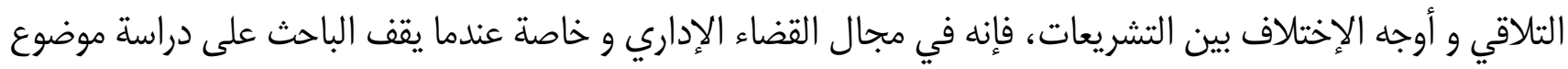

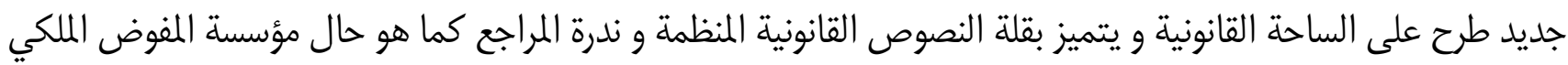
في القانون الإداري المغربي فإن أهمية الدراسات المقارنة تزداد لتصبح مادة خصبة تعطي للموضوع أفقا أرحب و أوسع للدراسة 
و التحليل و تخرجه من إطاره الضيق إلى قضاء أعم يستطيع في خضمه الباحث التعرف على مدى القيمة الفعلية لقانون إحداث المحاكم الإدارية ببلادنا سيما و أن أهمية الدراسات المقارنة أصبحت تحتل الريادة في مجال البحث العلمي و الدراسات القانونية على وجه الخصوص.

وهكذا سنقوم بدراسة موجزة لبنية المفوض في القضاء الإداري المصري لما له من خاصية عالمية متميزة وفريدة مع اعتبار القضاء الإداري الفرنسي مرجعا أساسيا للدراسة والتحليل في هذا الموضوع.

\section{المطلب الأول: النظام النموذج (مفوض الحكومة في فرنسا):}

إن الاتفاق الحاصل في هذا الشأن بين الفقه والقضاء أن القضاء الإداري الفرنسي يعتبر بحق - النظام النموذجي على الساحة العالمية ولم يرق إلى سموه و رفعة مستواه إلا بفضل الجهرود الموفقة التي بذلمبا مفوضو الحكومة والبحوث الفقهية على مر تاريخ فرنسا الحقوقي حيث بزغ هذا النظام - مفوض الحكومة - إلى الوجود سنة 1831 والذي كان يوجب في البداية بأن يتكلف ثلاث نواب من مجلس الدولة بوظيفة النيابة العامة أمام القضاء الإداري، وقد وضع هذا النظام كما بدل عليه إسم المكلفين به " مفوضو الحكومة "للدفاع عن الحكومة أولا وقبل كل شيء، حيث يقوم مفوض الحكومة بدور النيابة العامة كخصم منظم في الدعوى الإدارية، غير أنه يجب التوضيح هنا على أن مفوضو الحكومة ورغم ما يوحي به هذا الإسم لا يمثلون الحكومة ولا اي شخص آخر سوى القانون والدولة .

وقد توفق نظام مفوض الحكومة في فرنسا وبامتياز في أن يشيد لنفسه طريقا خاصا به يخالف بدرجة كبيرة ما تصوره ورسمه له واضعوه في البداية حيث أصبح مفوضو الحكومة في فرنسا لا يعملون لأي جهة عامة أو خاصة أو فردية بل لصالح القانون ولكلمة الحق المجردة المتسمة بالحياد التام والاستقالال البارز في مجال القضاء الإداري، بل في القانون العام بأكمله، وأن من ذاك التشابه في الاختصاص والدور مع النيابة العامة كطرف منظم إلى أن يصير مؤسسة ذات صبغة خاصة

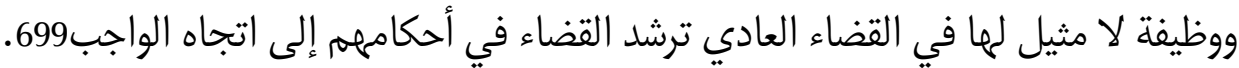

تجدر الإشارة في هذا الباب إلى أن مفوض الحكومة في فرنسا وعلى ما له من حرية واستقلال وعلى ما يتمتع به من

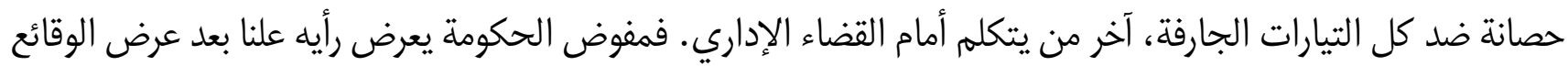
وانتهاء المرافعة700 غير أن البعض يرى بأن القيمة الفقهية التي يتمتع بها آراء المفوض هي التي تجعله يدونها كي يتم نشرها في المجلات والدوريات القانونية.

\section{• الأدوار القضائية لمفوضي الحكومة بالمحاكم الإدارية}

من خلال تطور الأداء القضائي لمفوض الحكومة بالمحاكم الإدارية الفرنسية يمكن إبداء الملاحظات التالية :

يلتزم مفوض الحكومة لدى المحاكم الإدارية وكذلك لدى مجلس الدولة الفرنسي وفقا لما تقتضي به المادة 67 من مرسوم 31 يوليوز لسنة 1945 بإعداد تقرير عن النزاع وإبداء الحل القانوني الذي يراه مناسبا، ومن تم لا يستطيع المفوض أن يسلك

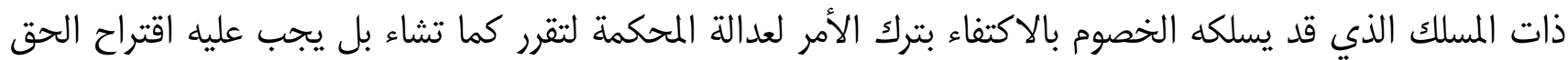

699 محمد زكي النجار "تقويم نظام مفوض الدولة في المنازعة الإدارية" دار النهضة " طبعة أولى 1994 ص 7/6 700 مقال الأستاذ ريموند جليان أورده رشيد السبايطي (مرجع سابق) 


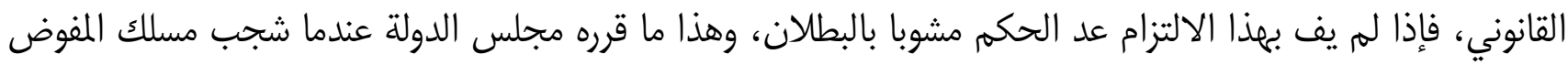

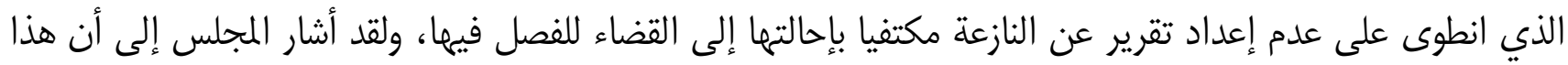
المسلك يمثل انتهاكا للالتزام المنصوص عليه في المادة 167 من قانون المحاكم الإدارية والمادة 46 من قانون 22 يوليو 1889

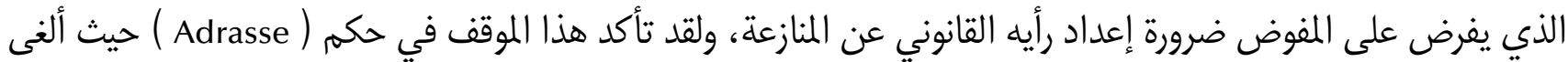

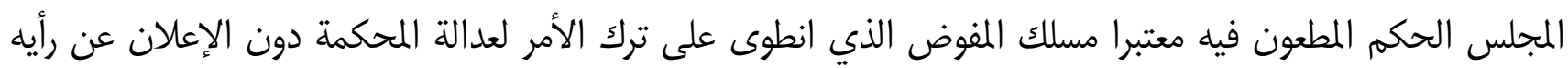

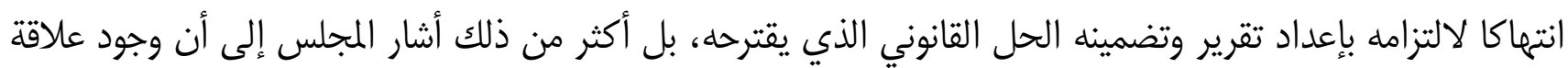
شخصية بين المفوض ورافع الدعوى لا تعفيه من التزامه باقتراح حل للمنازعة وإلا وصف مسلكه بعدم المشروعية .

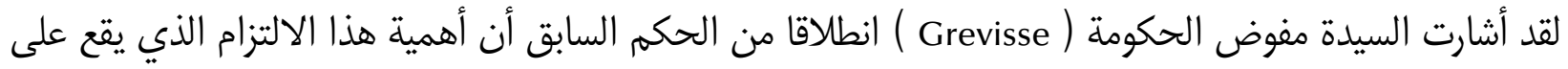

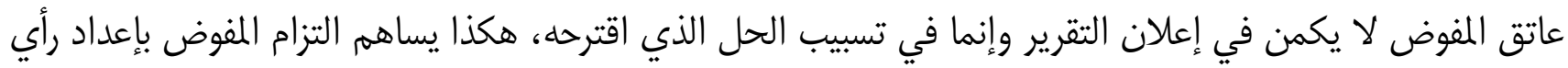

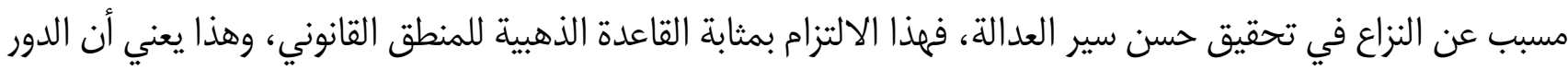

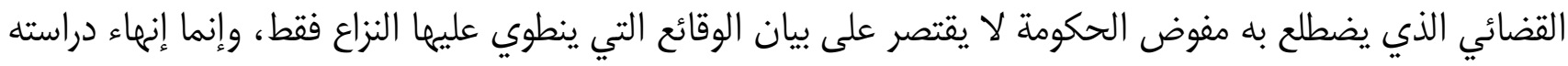

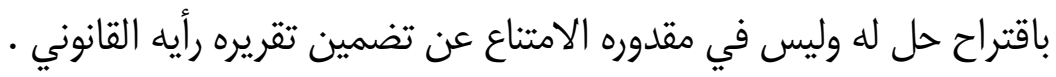
ان مفوض الحكومة لا يستطيع الاستئناف في حكم يرى أنه لا يسند إلى أساس قانوني سليه، وهو ما تم التأكيد عليه

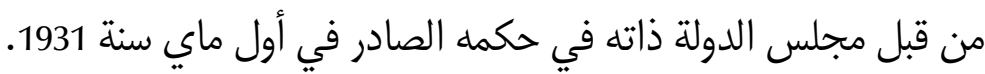

أن مفوض الحكومة يبتدئ دوره من حيث انتهى العضو أو المستشار المقرر، فيستلم مفوض الحكومة ملف الدعوى

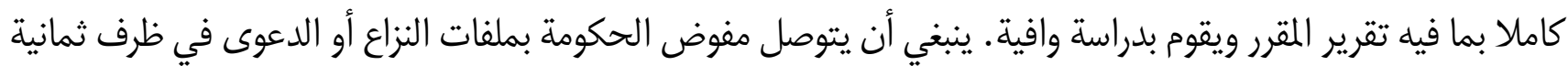

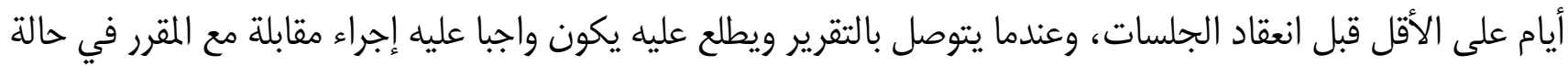

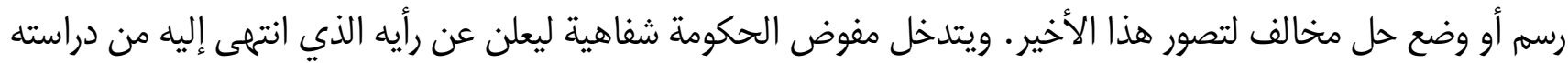
لملف النزاع متمتعا بكامل الحرية والاستقلال

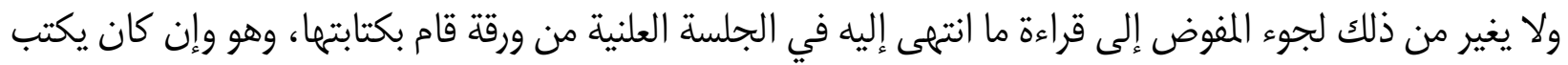

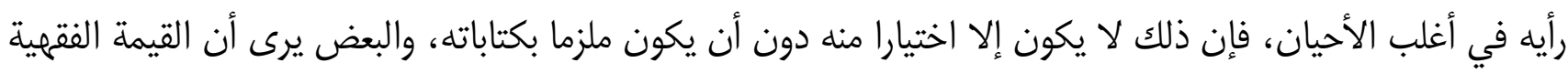

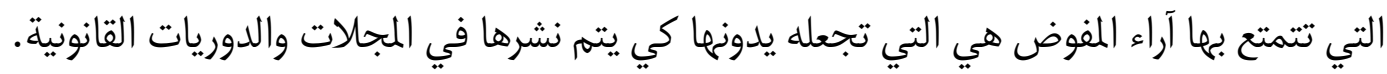
أن مفوض الحكومة لا يتقيد بالقاعدة التي تفرض على القاضي عدم النظر فيما لم يتم إثارته من جانب أطراف

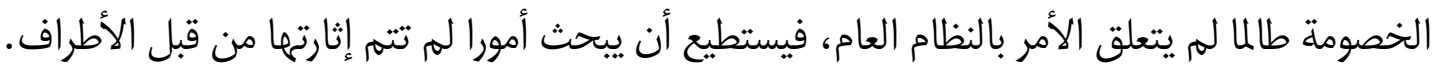

تعتبر مذكرات مفوض الحكومة جزءا لا يتجزأ من إجراءات الدعوى، هذه المذكرات هي التي تعطي للجلسة العلنية

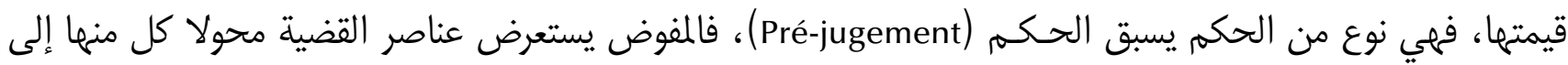

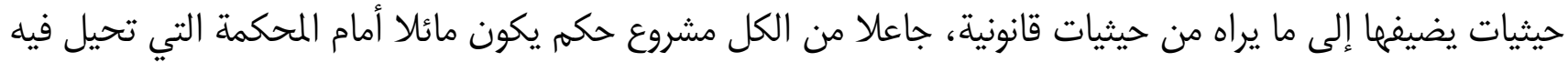

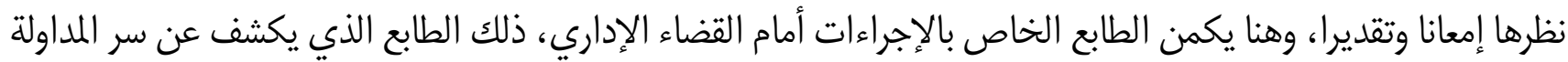

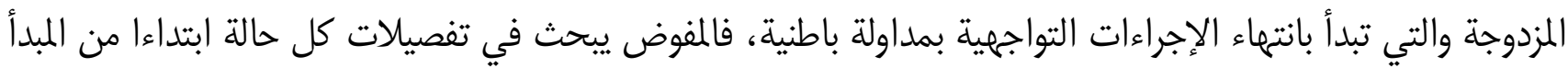


الأساسي إلى أبسط التفاصيل، وبهذا العمل يشترك مع القاضي حيث يقوم بتصنيف القضية وتكييفها من الناحية القانونية،

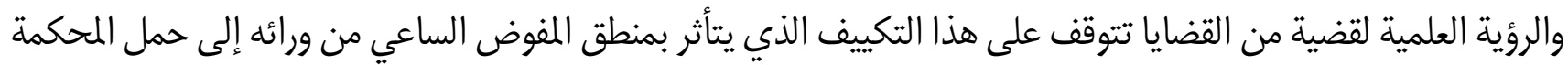
على السير في نفس الاتجاه الذي سار فيه. إن مفوض الحكومة في حقيقة الأمر هو مفوض قانون، ومشروع الحكم الذي يقترحه غالبا ما تتبناه المحاكم الإدارية،

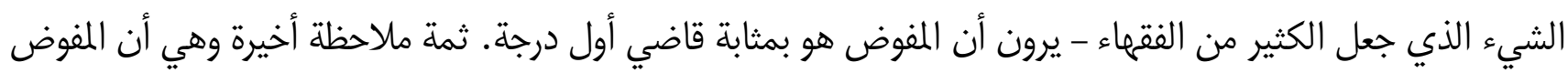

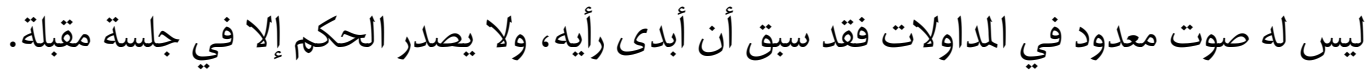
نخلص إذن إلى أن تحضير الدعوى الإدارية في فرنسا يتولاه (المقررle Rapporteur الذي الذي تحال عليه الدعوى من الدي

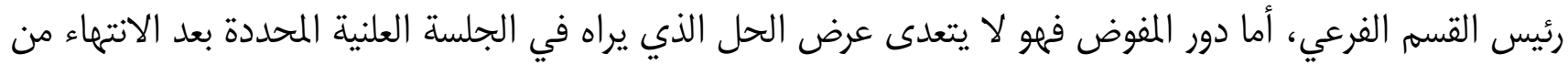

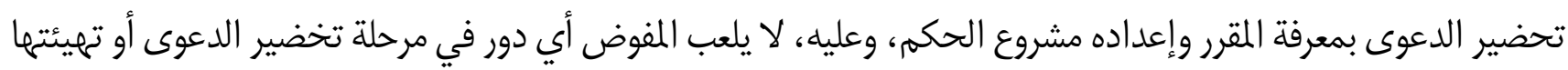

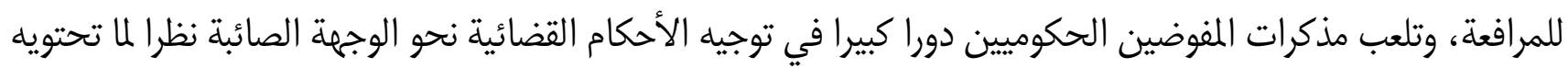

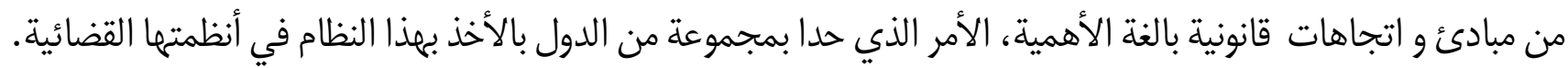

\section{المطلب الثاني: نظام مفوض الدولة بمصر: الخاصية العربية الاسلامية}

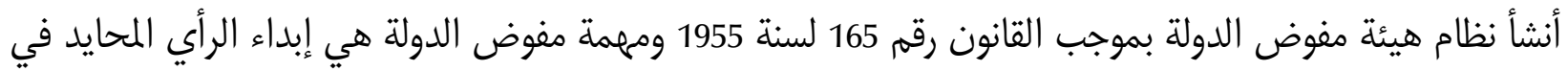
الدعوى الإدارية، وقد بينت المذكرة الإيضاحية للقانون المذكور طبيعة عمل هيئة المفوض بقولهيا:

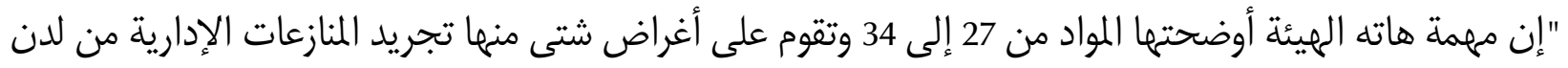

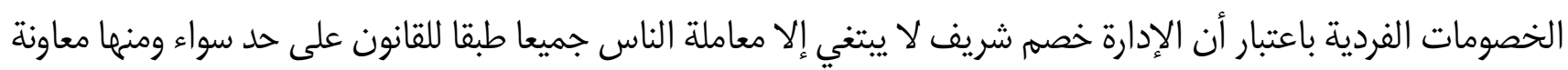

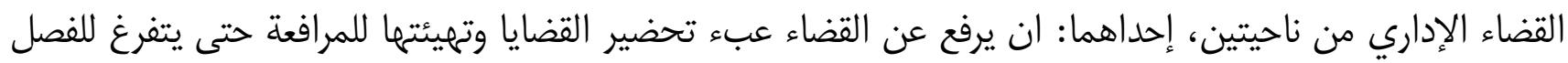

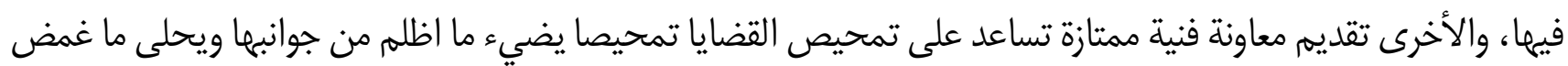

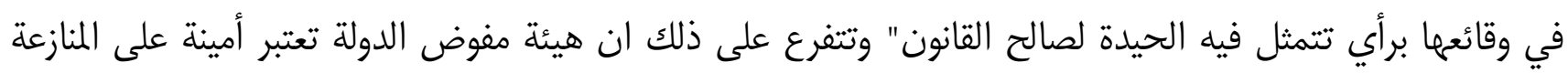

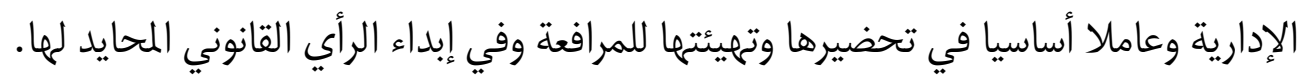

\section{اختصاصات هيئة مفوض الدولة:}

لقد حددت اختصاصات هيئة مفوض الدولة بموجب القانون 165 لسنة 1955 من المواد 27 إلى 34 في المجالات التالية: - النظر في طلبات المساعدة القضائية. - تحضير الدعوى الإدارية حتى تجعلما صالحة للحكم فيها. - تسوية النزاعات الإدارية بين الأطراف وديا على أساس المبادئ القانونية التي استقر عليها فاريا قضاء المحكمة الإدارية

-الطعن في الأحكام أمام المحكمة الإدارية العليا متى رأت وجها لذلك بعد موافقة رئيس هيئة مفوض الدولة. 


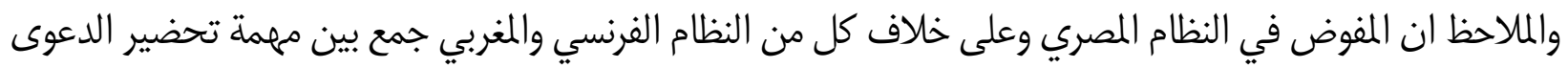

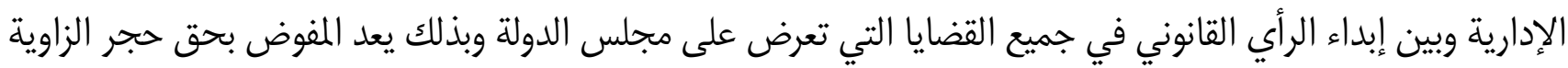

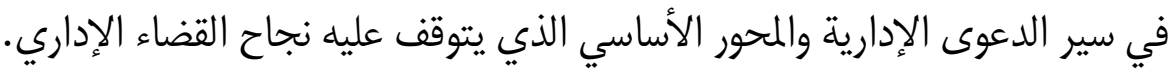
وفي ذلك يقول الدكتور محمد فؤاد مهنا "ولا نخطئ إذا قلنا ان نجاح النظام الجديد لمجلس الدولة كهيئة قضاء إداري أو فشله إنما مرده في الحقيقة إلى نجاح هيئة مفوض الدولة أو فشلها في أداء رسالتها" .

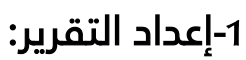

متى إنتهى المفوض من تحضير الدعوى واستكمال أوراقها وتهيئتها للمرافعة قام بإعداد تقرير يحدد فيه وقائع الدعوى

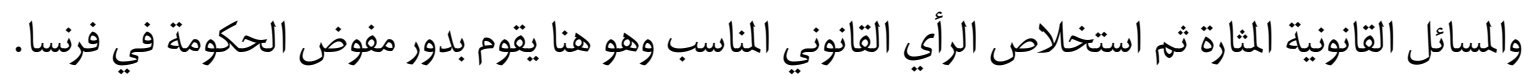

\section{2-تحضير الدعوى الإدارية وتهيئتها للمرافعة:}

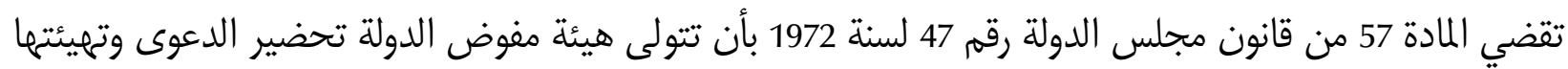

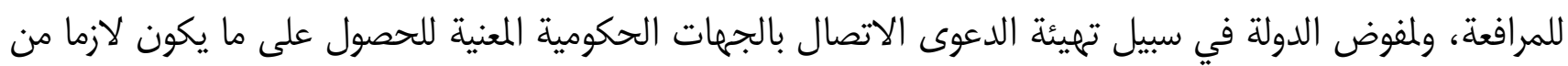

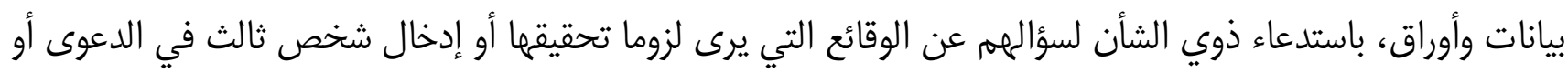

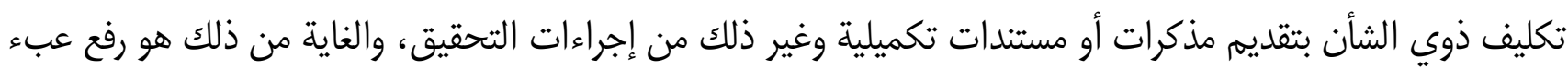

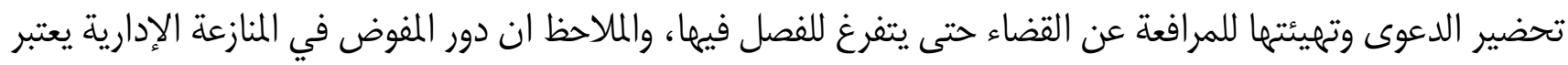
دورا إيجابيا يتمثل في الهيمنة على المنازعة وتوجيهما الوجهة السليمة حتى تصبح صالحة للحكمى فييها.

\section{3-تسوية النزاع وديا بين أطراف الخصومة:}

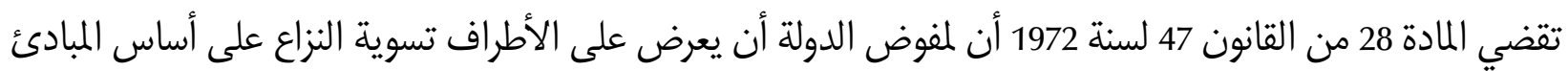

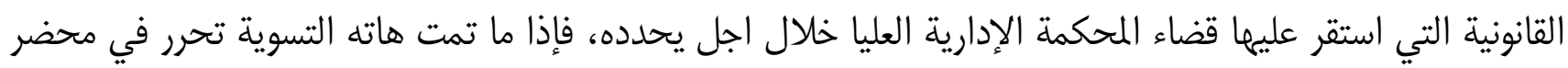

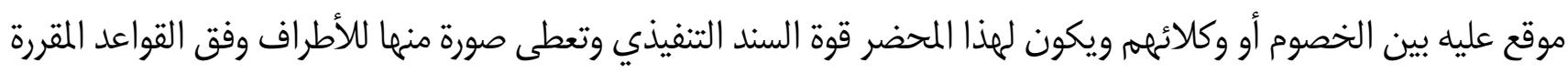
ل إعطاء صور الأحكام.

وحول أهمية نظام مفوض الدولة بمصر يقول د.النجار "ان التنظيم الذي أتى به المشرع المصري لهيئة مفوض الدولة

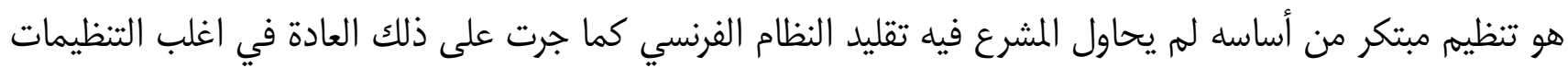

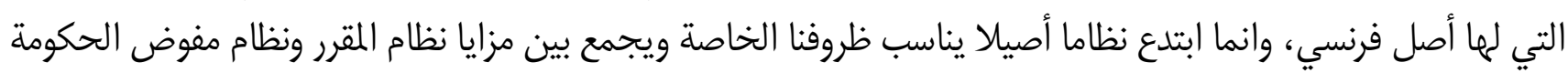
في فرنسا مع سلطات أوسع في سبيل تهيئة الدعوى" .

\section{المبحث الثاني: نشأة المفوض الملكي بالمغرب}

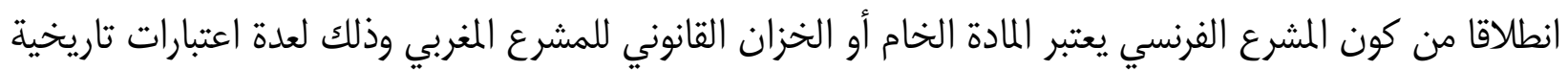

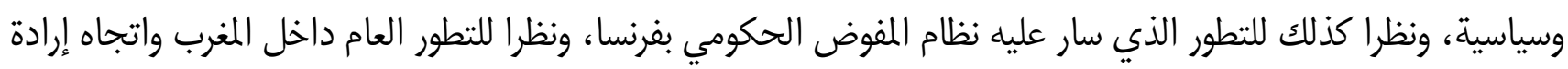


الإدارة السياسية -على حد تعبيرها - إلى القطع مع تسلط وتعسف السلطات الإدارية وحماية المواطنين من التجاوزات التي قد يتعرضون لها في تعاملمهم مع الإدارة.

إضافة الى التطور الملحوظ للقضاء الإداري بالمغرب وكدى نظرا للأسباب الخارجية المتمثلة في هاجس الديمقراطية

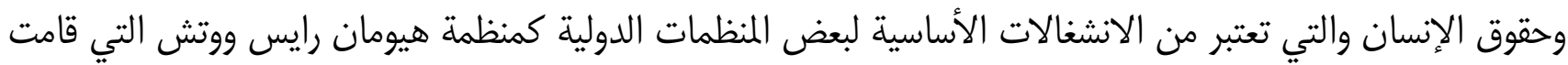

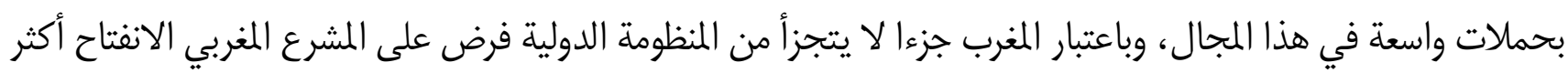

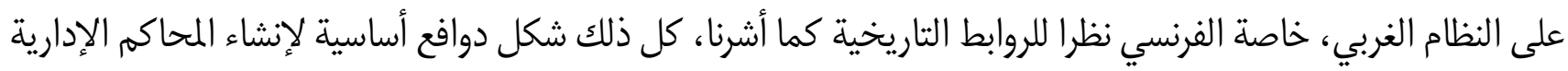

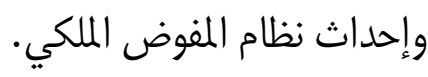
ولدراسة المفوض الملكي بالمغرب لابد من التطرق الى مركزه القانوني (المطلب الاول) والاطلاع عل وضعيته الإدارية

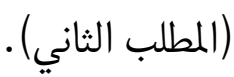

\section{المطلب الأول: المركز القانوني للمفوض الملكي.} إن تبيان المركز القانوني للمفوض الملكي يتطلب اولا قراءة في تسميته (الفقرة الاولى) ثم القيام بمقارنة بينه وبين النظم المشابهة له (الفقر الثانية).

\section{الفقرة الأوله: قراءة في تسمية المفوض الملكي}

إن الهدف المعلن من وراء إنشاء المحاكم الإدارية هو إرساء دولة القانون والحق، واعتبار مؤسسة المفوض الملكي ضمانة حقيقية للمتقاضين في مواجهة الادارة.

إلا انه ما يلفت الانتباه في القانون المحدث للمحاكم الإدارية هو الخروج عن المألوف وعن كافة الأنظمة المقارنة فيما

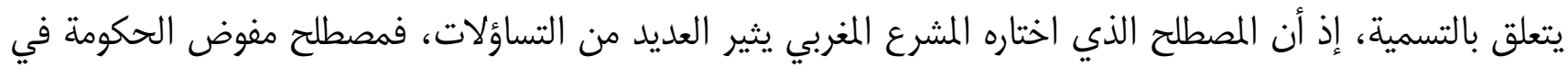

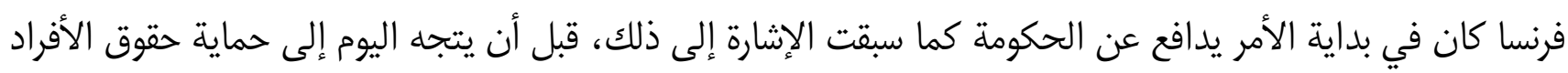
من تعسف الإدارة، ومصطلح مفوض الدولة بمصر يعتبر تفوق رائد للمشرع المصري.

أما مصطلح المفوض الملكي فقد اعتبرها البعض -ونحن مع هذا الاتجاه -تسمية غير موفقة لان استقلال القضاء بشكل

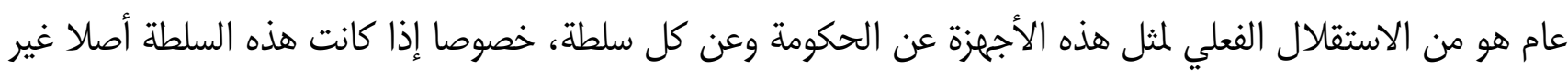

701- المرجع: ماهر الجبوري- مبادئ القانون الاداري- دراسة مقارنة-كلية الحقوق بغداد.المصدر: الدكتور عثمان خليل عثمان.يقول في هذا الصدد

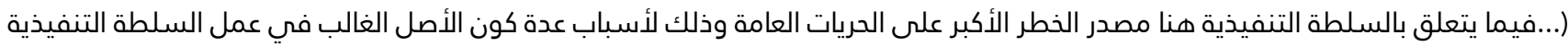
هو مباشرة تنفيذ القانون بقرارات فردية ينقصها حياد القواعد العامة التي تتسامى عن الاعتبارات الفردية ثم أن لدى رجال السلطة التنفيذية من الاختصاصات التقديرية ومن المهام المتعلقة بسلامة الدولة والسيادة والضرورة والتنفيذ المباشر وصيانة الأمن العام والصحة العامة والدفاع والبوليس وغيرها مما يجعل مجال المحاربة والمحاباة أوسع من السلطتين الأخريين ويجعلها أكثر خطراً منها على الحريات وأولى بالرقابة والاحتياط) مؤلف- الاتجاهات الدستورية الحديثة- جامعة بغداد- طبع رونيو- عام 1968- ص196-197 
خاضعة للمساءلة والمحاسبة - حتى وان كنا نتحدث فقط على التسمية -لان هذه التسمية لمها بالغ التأثير في مجرى الدعوى الإدارية وتوحي بالتبعية.

في الواقع لقد تم اختيار مصطلح المفوض الملكي بعد خطاب الملك الذي أكد فيه: "عدم الإبقاء على مؤسسة النيابة

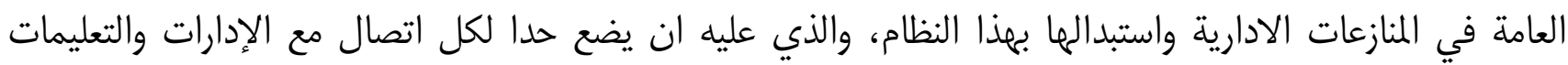

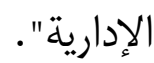

كان بإمكان المشرع الاستفادة من القانون الفرنسي أو المصري ومن اقتراحات أصحاب الاتجاه المتحدث عنه واختيار مصطلح أكثر دقة كمفوض الدولة أو مفوض الشعب. المشرع الاتفادة القان الفرني

\section{الفقرة الثانية: تميزه عن غيره من الانظمة المشابهة}

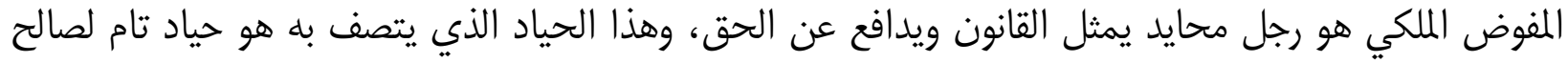

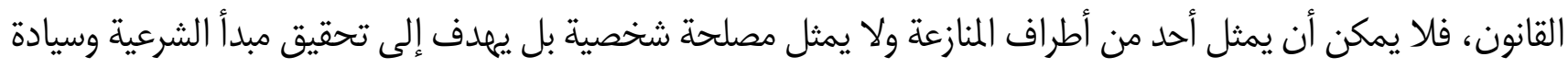

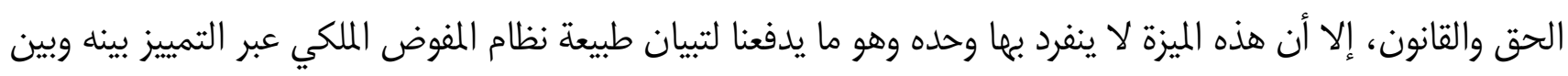

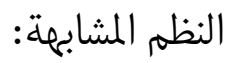

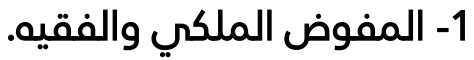

إن مذكرات المفوض الملكي وتقاريره في القضايا تشبه إلى حد كبير المؤلفات الفقهية والتقارير والمذكرات التي تتناول النظريات القانونية والمشكلات العملية في كون كلا هما يعطيان الحلول العلمية لها. وقد كتب الأستاذ جيز702 عن تعاون مجلس الدولة والفقه في استنباط قواعد القانون الإداري الفرنسي إذ اعتبر جيز

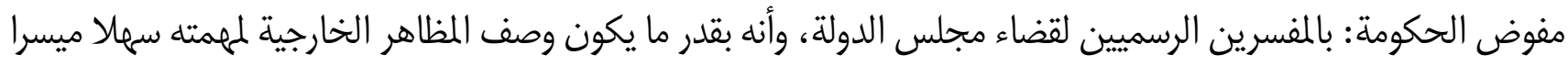

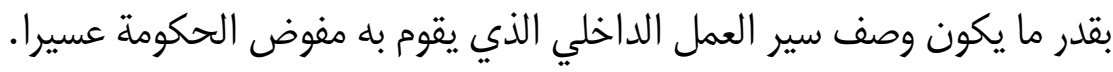
إن هذا التشابه ينبثق من كون المفوض الملكي يراعي منطق التوازن بين المصلحة العامة المتمثلة في حسن سير المرافق

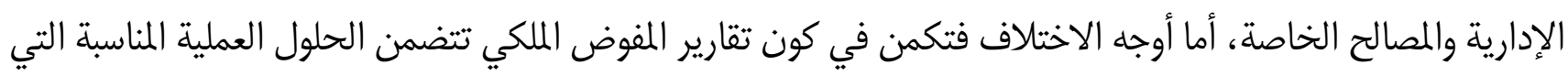

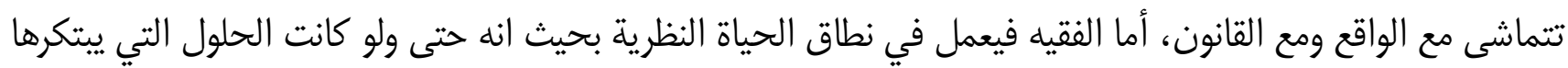

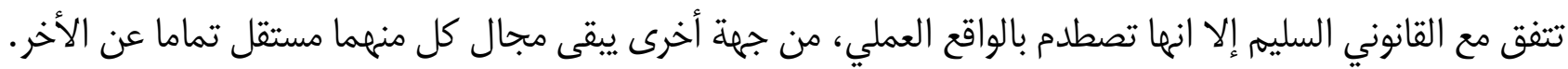

\section{2- 2 المفوض الملكي وقاضي الحكم.}

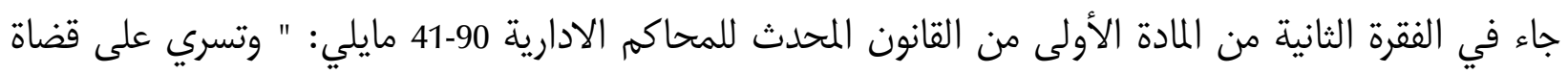

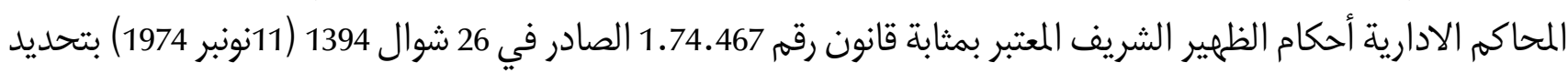

thiqaruni.org/lowthises/2/1 المرجع - .تاريخ الزيارة:2012/12/13 الساعة:13:00 ـالمرجع: ماهر صالح الجبوري- مبادىء القانون الأداري- دراسة مقارنة - كلية القانون جامعة بغدادة.

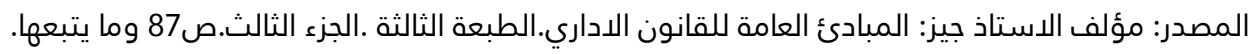


النظام الأساسي للقضاة، مع مراعاة الأحكام الخاصة الواردة فيه باعتبار خصوصية المهام المنوطة بقضاة المحاكم الإدارية

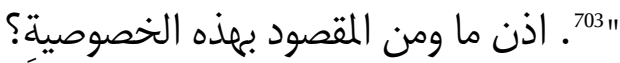

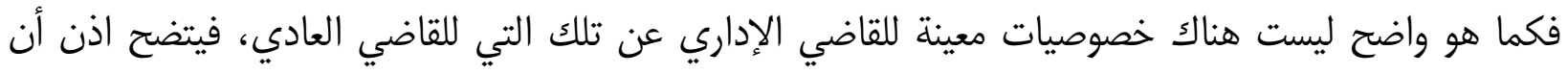
الخصوصية المتحدث عنها تعني المفوض الملكي على اعتبار انه يقوم بدور خاص في الإري عن تلفي المنازعات الإدارية.

$$
\text { ومن أهم الفوارق بين المفوض الملكي وقاضي الحكم ما يلي: }
$$

1-المفوض الملكي لا يعتبر عضو بالميئة المصدرة للحكمم وان كان حضوره وجوبيان، أما القاضي المقرر فهو عضو بالمحكمة - هيئة الحكمم - وله صوت معدود إلى جانب قاضيين آخرين المكونين للمهيئة. 2-قرارات المفوض الملكي لا تعتبر من القرارات الصادرة عن المحكمة مثل قرارات القاضي المقرر. 3-القاضي المقرر لا يبدي رأيه في الدعوى قبل حجزها للمداولة عكس المفوض الملكي الذي يقدم تقارير يضمنها الرأي القانوني الذي يراه مناسبا أثناء الجلسات.

\section{3- المفوض الملكي وممثل النيابة العامة.} يقع الكثير في الخلط بين مؤسسة النيابة العامة والمفوض الملكي إلا أن الاختلاف بينهما شاسع بكافة المقاييس، فالنيابة المابة

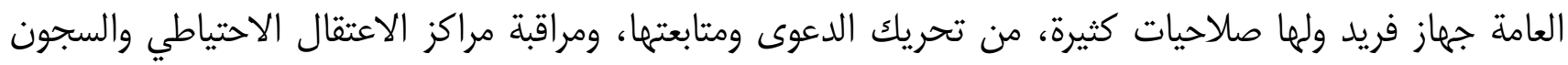

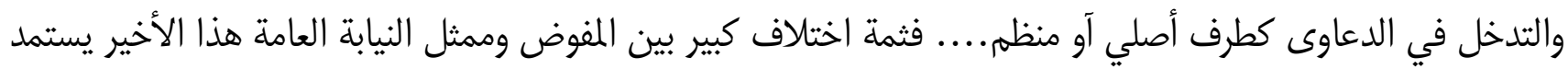

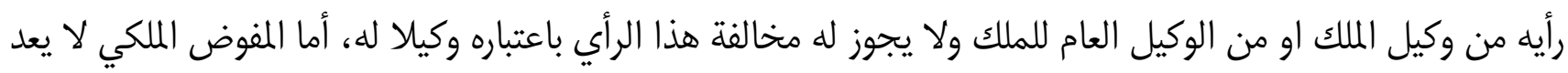

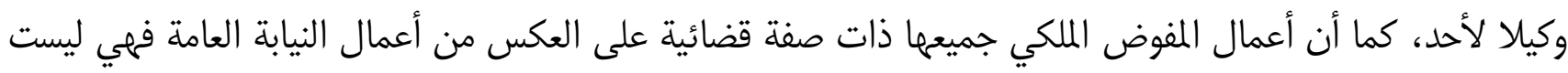

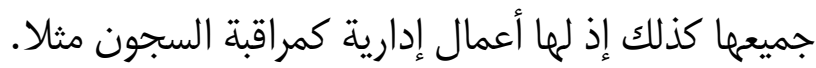
كما أن المفوض الملكي لا يعد طرفا في الدعوى لا أصليا ولا منظما عكس عضو النيابة العامة الذي يعد طرفا في

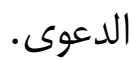
إلا أن الخلط آو التداخل يتجلى أكثر في الغرفة الإدارية بمحكمة النقض، هل ممثل الحق والقانون بها والمشار إليه في الفصل 327 من ق.م.م هل هو المفوض الملكي آو ممثل النيابة العامة.

من جهة أخرى فالنيابة العامة تملك حق الطعن وهو ما لا يملكه المفوض الملكي عكس مفوض الدولة في مصر والذي

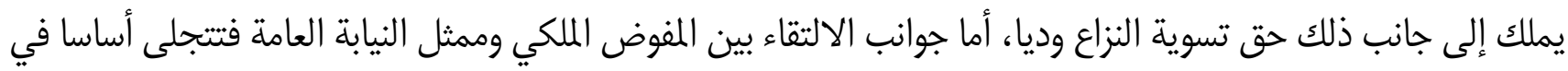

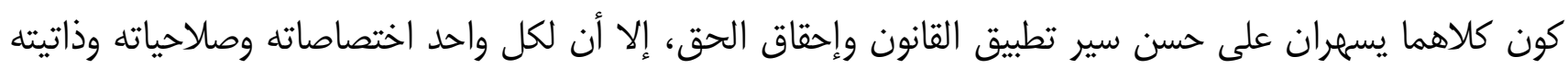

703-احميد واكري ومحمد محجوبـي: المفوض الملكي ومهامه لدى المحكمة الادارية م.س.ص 43 41.90 - 704 705 - ذ.رشيد مشقاقة: وجهة نظر قانونية -الجزء الاول-القسم الثامن -ص 393 -393-394 
المستقلة الخاصة به دون أن تمتد إليه من أي نظام أخر، مما يجعل المفوض الملكي يتمتع بخصوصية ذاتية في مركزه القانوني.

\section{المطلب الثاني الوضع الإداري للمفوض الملكي}

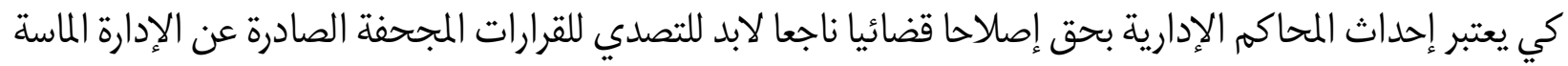

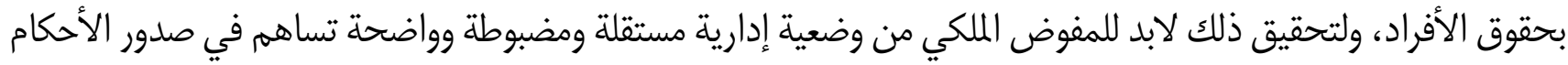

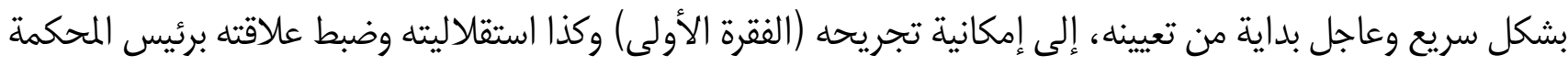

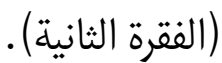

\section{الفقرة الأوله: تعيين وتجريح المفوض القضائي}

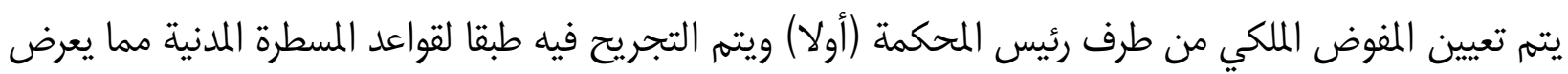
الحكم الذي شارك فيه للبطلان (ثانيا).

\section{أولا) التعيين}

تنص الفقرة الأخيرة من المادة الثانية من قانون احداث المحاكم الإدارية على أن الرئيس يعين من بين القضاة مفوضا ملكيا آو مفوضين ملكيين للدفاع عن القانون والحق باقتراح من الجمعية العمومية لمدة سنتين.

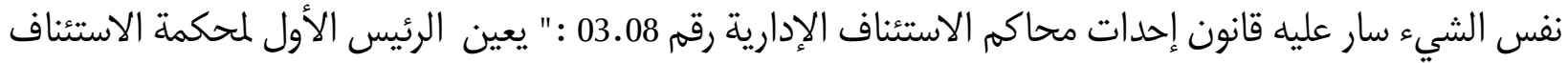

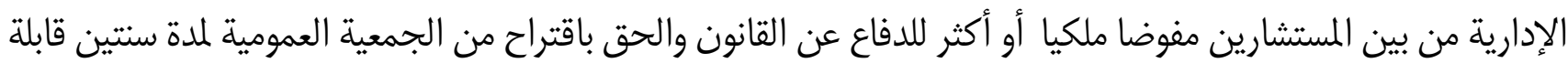

فالمفوض الملكي هو قاضي من بين قضاة المحكمة قبل تعيينه لمهمته تلك، هذا التعيين الذي يته باقتراح من الجمعية

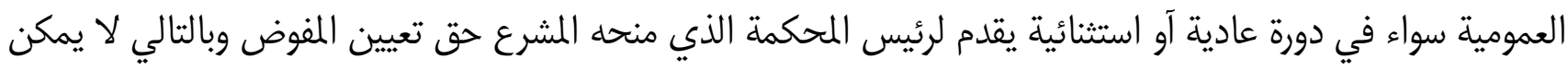
لأي جهة أن تعينه آو أن تعفيه سواء كان وزير العدل أو حتى المجلس الأعلى للسلطة القضائية يقلية. وبما أننا نتحدث عن تجاوز السلطة ماذا لو قام الرئيس بهذا التعيين بشكل فيه تجاوز يعرضه للطعن للشطط في

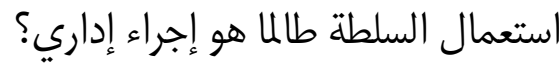
يرى البعض أن ذلك يدخل في إطار التنظيم الداخلي فلا يدخل ضمن القرارات الإدارية المستوفية لجميع شروط ومقومات القرار الإداري 707 القابلة للطعن بالإلغاء لتجاوز السلطة. 
إن تعيين المفوض الملكي يختلف عن تعيين مفوض الحكومة في فرنسا الذي يعين بمرسوم من رئيس الوزراء بناء على

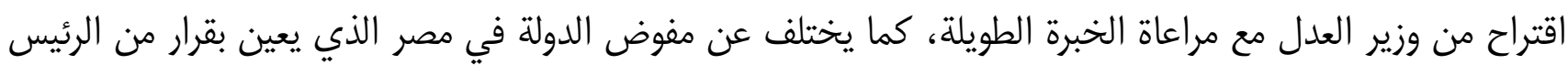
الجمهورية بعد موافقة المجلس الخاص بالشؤون الإدارية لمجلس الدولة. 708

ويمكن تعيين أكثر من مفوض واحد بالمحكمة، وفي هذه الحالة قد تكون هناك ازدواجية الصفة لذا بعض القضاة بحيث قد يكون قاضيا في قضية ومفوض ملكي في أخرى داخل نفس المحكمة مما يعرض القضايا التي يشارك فيها

للتجريح.

\section{ثانيا) التجريح}

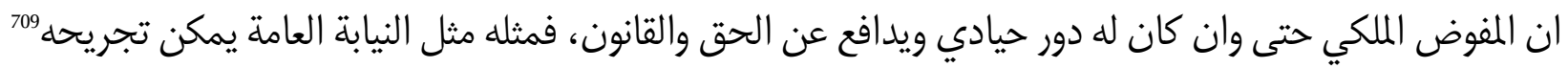

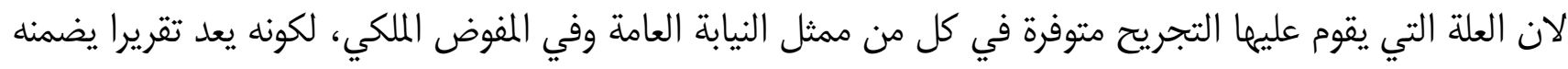

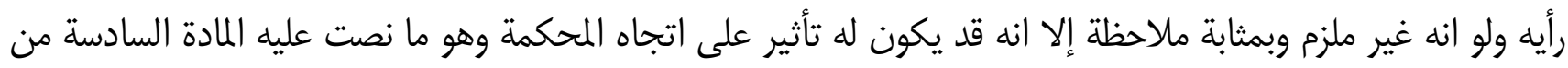

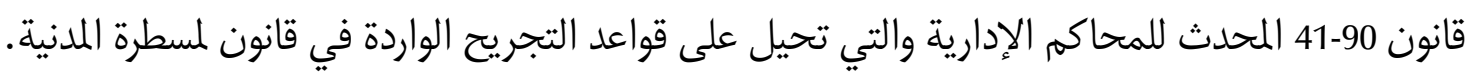

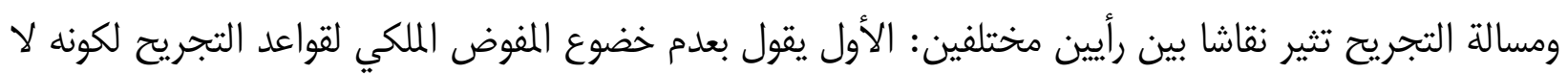

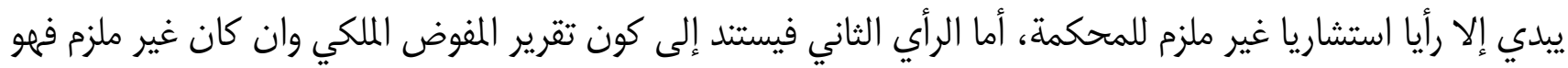
لا شك يؤثر على المحكمة.

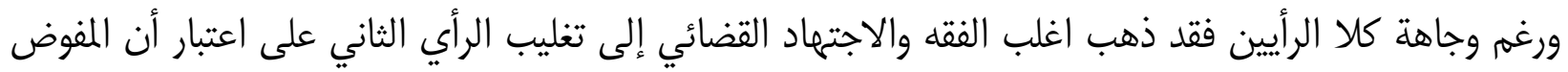

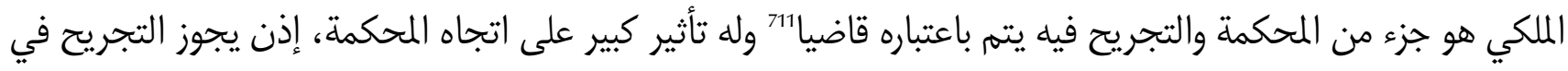

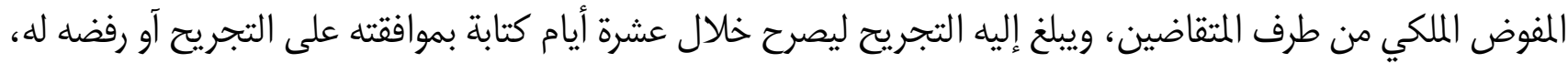

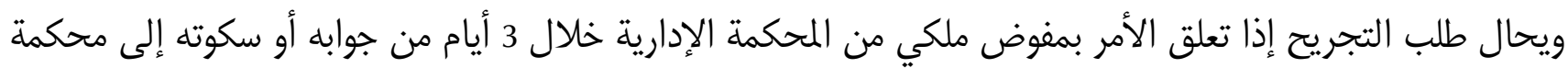

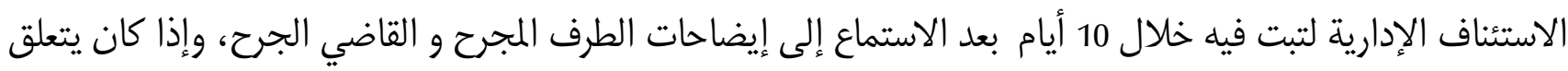

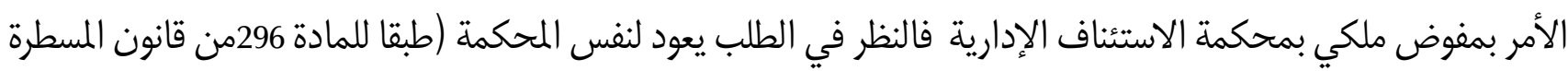
المدنية) .

عموما وطبقا لما هو وارد في قانون المسطرة المدنية يجوز تجريح كل قاض كيفما كان نوع المحكمة والعمل القضائي الذي يقوم به حيث أن كلمة قاضي واردة على إطلاقها.

708 - محمد محجوبي: الوجيز في القضاء الاداري المغربي بعد احداث المحاكم الادارية. دار القلم. طبعة اولى 2002.ص 55

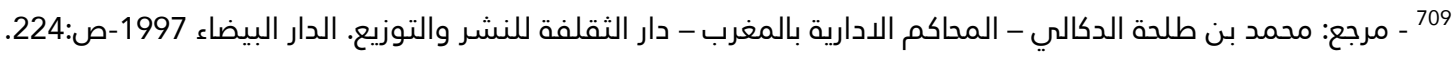
المصدر: د.رشيد مشقاقة " المفوض الملكي وممثل النيابة العامة في ضوء المحاكم الادارية "جريدة العلم -السبت 29 يناير

1994-ص7. 710- ذ. احميد واكري /ذ.محمد محجوبي. مرجع سابق .ص 38 711 -ذ.محمد بن طلحة الدكالي .مرجع سابق ص ذ. 712- ذ.محمد بن طلحة الدكالي. مرجع سابق .ص 63. 


\section{الفقرة الثانية: استقلالية المفوض الملكي}

إن استقلالية القاضي عند ممارسته لمهامه يجد أساسه في دستور البلاد، حيث تم التنصيص على استقلالية القضاء وتم اعتباره سلطة قائمة بذاتها على غرار السلطة التنفيذية والتشريعية، من جانب اخر هذا لا يعني استقلال المحاكم الإدارية عن المحاكم العادية حيث أنهما يخضعان لنفس الهيئة القضائية المتمثلة في مجلس النقض، ويعملون جميعا تحت إشراف الرئيس الأول بالمجلس الأعلى بشكل هرمي بما فيهم المفوض الملكي.

فالقاضي الإداري يخضع لسلطة رئيسه المباشر من الناحية الإدارية، أما من الناحية القضائية أي من خلال نظره في الدعاوي وإبداء أرائه فليست هنا أي تبعية، حيث لا يمكن أن يتلقى أوامر من اجل إصدار نوع معين من الأحكام آو تلقي تعليمات بشأن التعامل مع ملف معين.

وفي إطار الحديث عن استقلالية المفوض الملكي يثار إشكال فيما يتعلق بالعلاقة بينه وبين رئيس المحكمة خصوصا بعد تعديل المادة 19 من النظام الأساسي لرجال القضاء، ففي بحث أجراه الأستاذ محمد القصري لاحظ انه طرأ على المادة المذكورة بعد التعديل تغير تام غير مضمونها، في حين ظل مضمون النص بالفرنسية نفسه، وبذلك كان الرؤساء يمارسون رقابتهم على قضاة الأحكام أصبحوا بعد التعديل يمارسون رقابتهم على قضاة المحاكم حيث تم الخلط بين كلمتي الأحكام والمحاكم ولم يكونا هما موضوع التعديل على ما يبدو، لان النص الفرنسي ظل كما هو وكلا النصين منشور بالجريدة

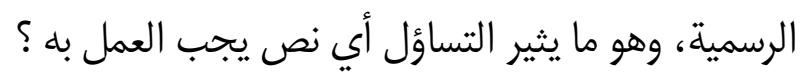

عموما فالمفوض الملكي خارج الدعوى الإدارية يكون مرؤوسا للرئيس وداخل الدعوى الإدارية يعتبر شخصا مستقلا بذاته لا يخضع لآي املاءات.

وستتضح لنا هذه الاستقالية النسبية أكثر من خلال تناول الاختصاصات التي خصه المشرع بها (الفصل الثاني).

\section{الفصل الثاني: مهام المفوض القضائي وتقييم عمله.}

ان معرفة مدى نجاح نضام ما في تحقيق الاهداف التي انشئ من اجلما لا يتأتى الا من خلال الوقوف على ما حققه من نجاح، وذلك يستلزم الالمام أولا بممام المفوض الملكي (المبحث الاول) ومن تم الالملام بمدى الإيجابيات التي حققهيا، وكذلك مدى ما لحقه من سلبيات (المبحث الثاني).

\section{المبحث الاول: الاختصاصات والمسطرة.}

خص المشرع المغربي المفوض الملكي باختصاصات محددة مما ميزه عن دور النيابة العامة سواء بالمحكمة الادارية

$$
\text { (المطلب الاول) او بمحكمة الاستئناف الادارية (محكمة الاستئناف الادارية). }
$$

\section{المطلب الاول: مسطرة عمل المفوض الملكي بالمحكمة الادارية.}

تتجلى مهام المفوض الملكي أولا في الوسائل التي منحها إياه المشرع لمباشرة اختصاصاته بلدا بحضور المفوض الملكي جلسات المحكمة مرورا بعرضه لآرائه المكتوبة والشفهية أي المستنتجات، وصولا إلى الممارسة القضائية أو ازدواجية المهام 


\section{الفقرة الأولى: حضور الفوض الملكي لجلسات المحكمة}

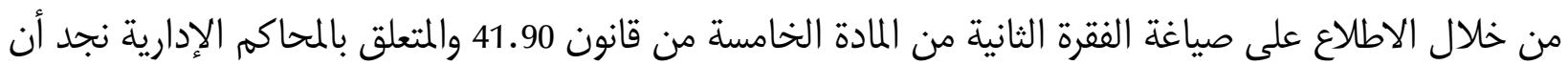
المشرع أكد على إلزامية حضور المفوض الملكي للدفاع عن الحق والقانون جلسات المحكمة الإدارية. كما نصت أيضا على ما يلي "... ويجب أن يحضر الجلسة المفوض الملكي للدفاع عن القانون والحق". لقد استهل المشرع الفقرة الثانية بصفة الوجوب والتأكيد دون التنصيص على البطلان صراحة عند تخلف المفوض الملكي

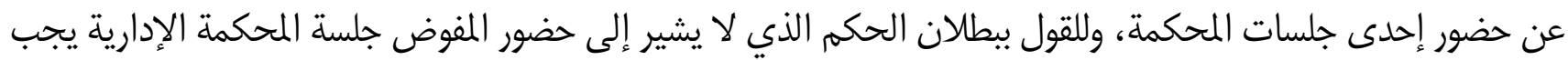
معرفة أية جلسة بالضبط يقصدها المشرع.

فإذا تعلق الأمر بالجلسة التي تكون فيها القضية جاهزة وبالتالي حجزها للمداولة فلا شك أن حضور المفوض الملكي

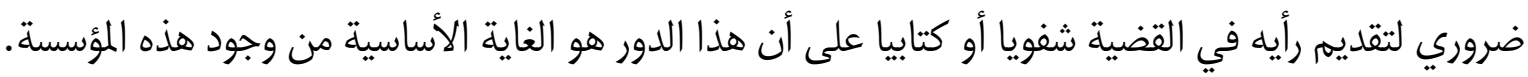

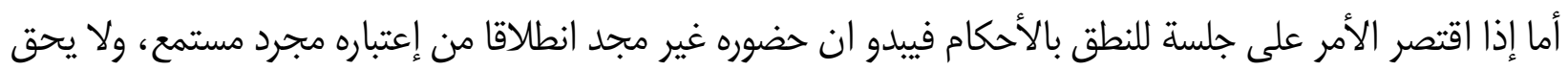

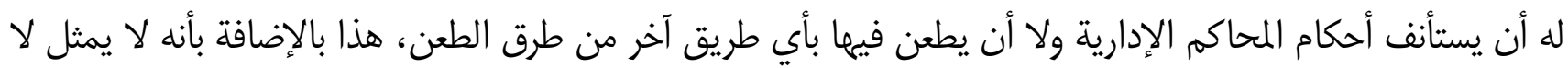

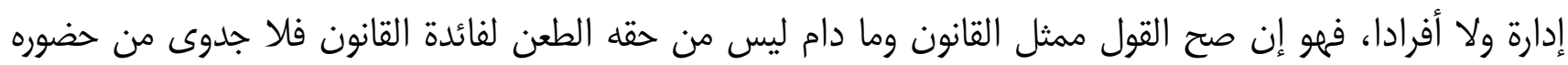

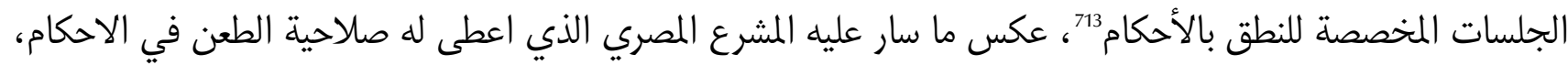
مما قوى دوره وحضوره بجلسات النطق بالحكم ورتب على عدم حضوره البطلان.

\section{الفقرة الثانية: عرض المفوض الملكي لمستنتجاته المكتوبة والشفهية}

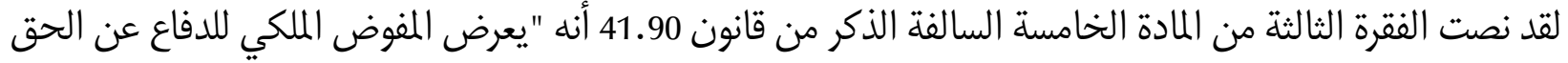

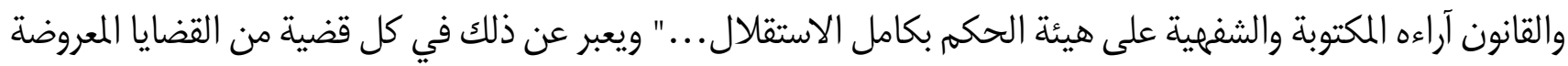

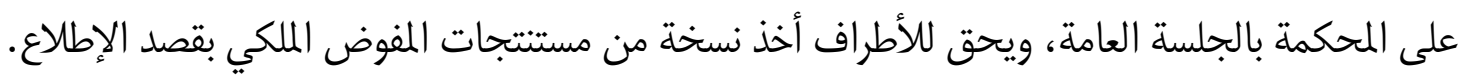
وما يلاحظ على هذه المادة هو استعمالما لمفهومين مختلفين للتعبير عن التقرير الذي يعده المفوض الملكي وهي (آراءه)

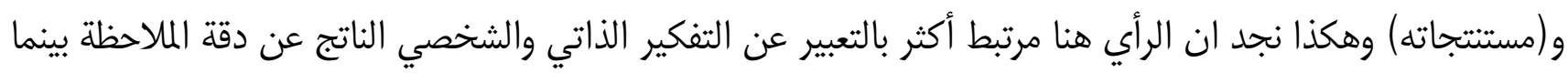

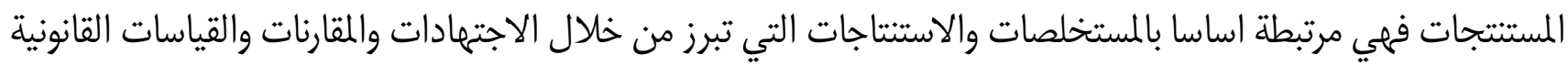
والواقعية.

لكن عندما قررت المادة الخامسة عرض المفوض الملكي لآرائه ومستتجاته المكتوبة والشفهية بكامل الموضوعية على

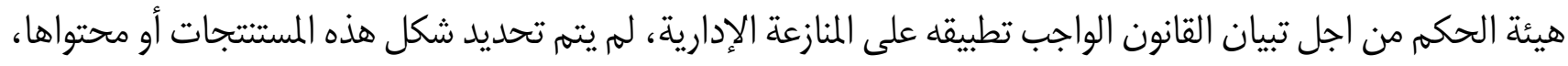

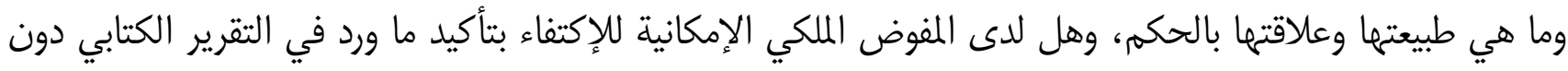
تلاوته، علاوة على ما مدى إمكانية التعقيب من طرف أطراف الدعوى.

713 - ذـ. أحميدو أكري/ ذ محمد محجوبي، مرجع سابق، ص: 69-70. 
ففيما يخص الشكلية التي تجب أن تقوم عليها مستتجات المفوض الملكي، وبالرجوع الى مقتضيات المادة 50 من

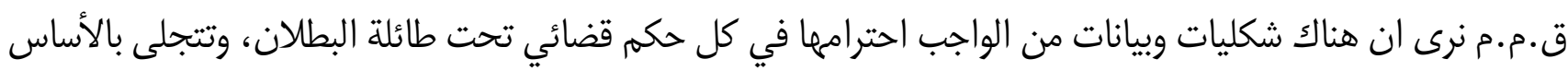

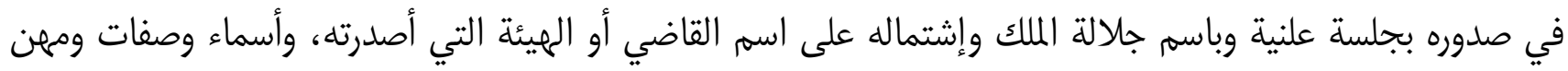

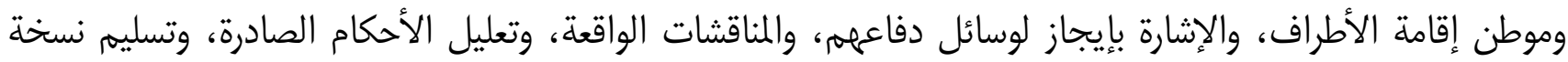

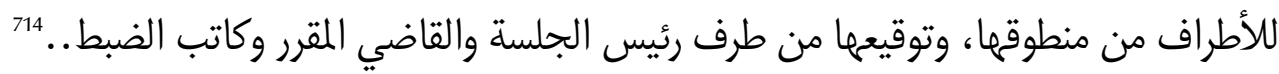
ويرى البعض أن عدم تحديد شكليات المستنتجات أمر إيجابي لمنح حرية أكثر للمفوضين الملكيين حول كيفية صياغة مستتجاتمهم دون التقيد بشكليات معينة.

فقياسا على القواعد اللازم احترامها في الأحكام المنصوص عليها آنفا بالإضافة إلى تطبيق القواعد المقررة في قانون

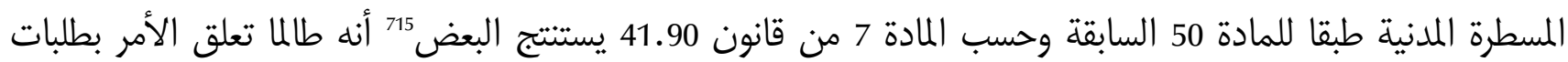

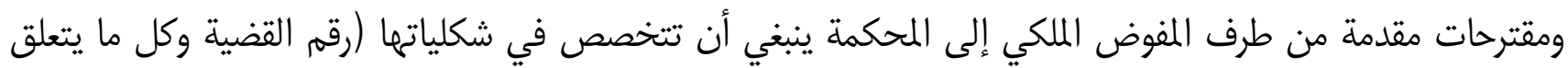

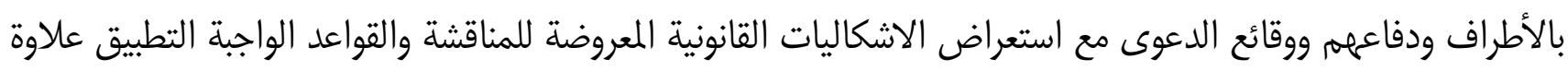
على التعريف بالرأي القانوني المعروض للمناقشةن والقواعد الواجبة التطبيق مع التعريف بالرأي القانوني المعلل). وفيما يخص أيضا مضمون وجوهر هذه المستتتجات فإن المدف من تقديم المفوض الملكي لها هو مساعدة الريئة

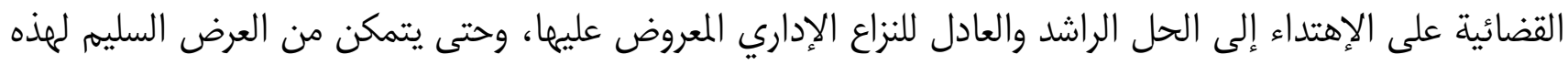

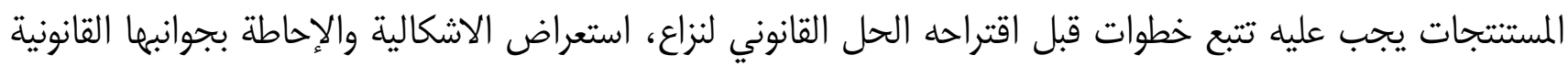

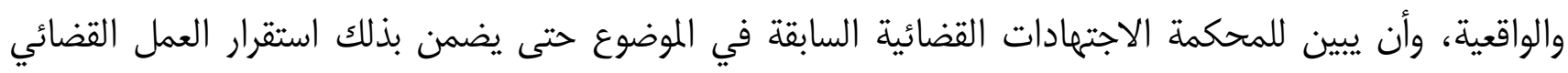
بالمحكة.

بالنسبة لطريقة تقديم المفوض لمستتتجاته: ورد بالمادة الخامسة على أنه يعرض آراءه المكتوبة والشفهية.... أي أنه

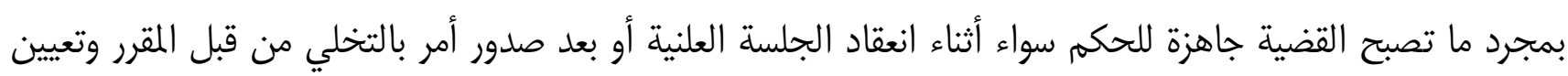
القضية في آخر جلسة علنية تعطى آخر كلمة للمفوض الملكي للتعبير عن وجهة نظره بواه بواسطة مستنتجاته.

وعليه فرغم استعمال المشرع عبارة الآراء الكتابية والشفهية فليس من الضروري أن يدلي المفوض الملكي بآرائه الشفهية في كل ملف، وهو ما يجري عليه العمل بالمحاكم الإدارية المغربية.

وبالنسبة لمسألة إثارة الدفوع: فعلى اعتبار أن الدفوع المتعلقة بالنظام العام واجبة الدفع في كل مراحل الدعوى الإدارية

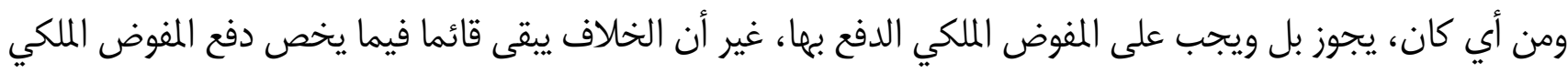
بدفوع لا علاقة بها بالنظام العام. 
وبالنسبة لمسألة تعقيب الخصوم على ملاحظات المفوض الملكي: فالأمر محسوم فقهيا أي لا يحق للهم التعقيب عليها

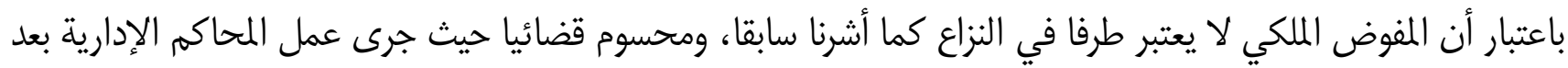

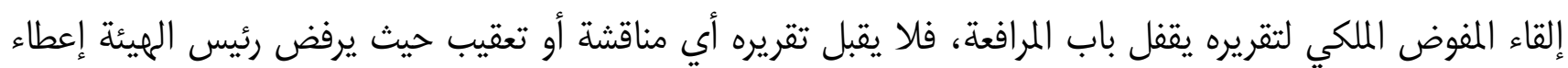
الكلمة للأطراف أو ممثلييهم الذين يرغبون أحيانا في التدخل للتعقيب على آراء المفوض الملكي تلكي. ومن حيث تصرف المفوض الملكي في بسط آرائه، فلا تحتوي المواد على ما يبين إلزامية وقوف المفوض الملكي لبسط

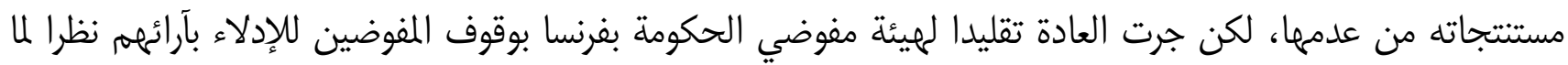
يضفي ذلك من قيمة على علينة الجلسات ولما فيه من تقدير واحترام لهييئة الحكمه. وفيما يخص علاقة المستنتجات بالحكم فحسب منطوق المادة الخامسة فهذه المستنتجات تعتبر جزءا لا يتجزأ من

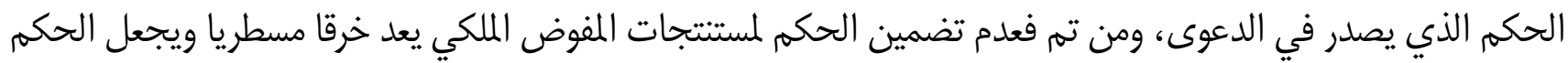

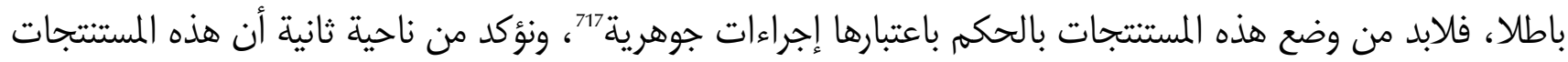

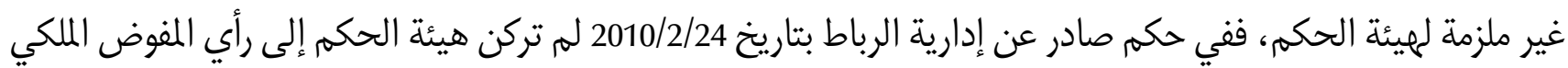

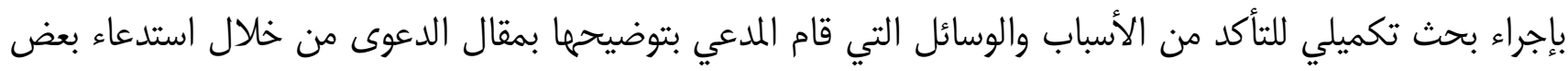

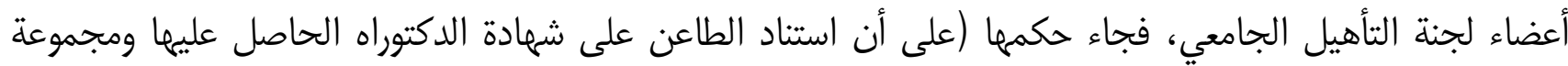

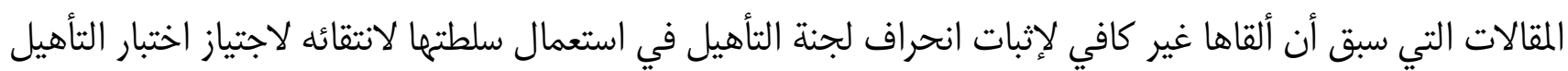
الجامعي خاصة وأنه لم يثبت أن مؤهاله ترشحه أكثر من غيره من الذين تم قبولمهم).

إذن فمستتجات المفوض الملكي هي تعبير عن رأيه القانوني المكتوب والشفوي يعرضه هذا الأخير بكل الاستقلال

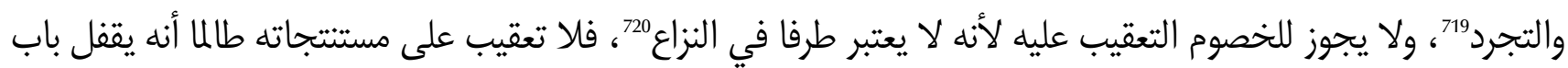

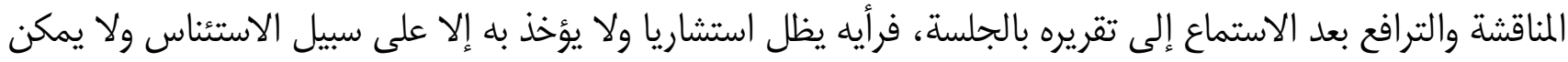
بأي حال أن يلزم الهيئة التئ.

لكن وإن كان دور مستنتجات المفوض الملكي محدودا فإنه في المقابل يمكن أن يكون حاسما في القضايا المستعصية.722 لذلك ينبني أن يعرض المفوض الملكي مستنتجاته عرضا سليما من منطلق المكانة الخاصة التي يمثلما لأنه بحكمم موقعه يملك تنوير هيئة المحكمة استجلاء للحقيقة لتحري الدقة في كل ما يصدر عنه من أقوال وأفعال.

717- ذ. محمد القصري، مرجع سابق، ص: 163. 718- حكم إدارية الرباط رقم 540 بتاريخ 2010/2/24 ملف مقدم رقم 09/12/86. 719- ذ. محمد القصري ، مرجع سابق، ص: 1720

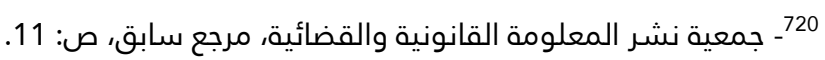
721 - ذ. محمد محجوبي، مرجع سابق، ص:

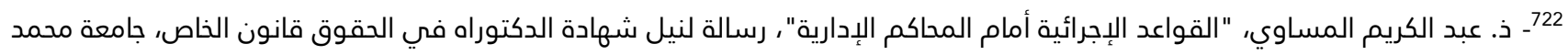
الخامس الرباط، ص: 36. 723- ذ. حسن صحيب، " القضاء الإداري المغربي (دراسة تحليلية للقانون المحدث للمحاكم الإدارية)" ، اطروحة لنيل الدكتوراه في القانون العام، جامعة محمد الخامس، الرباط، ص: 335. 
ان التأملات الفكرية التي يخوضما المفوض الملكي المغربي وأبحاثه في مجالي الاجتهاد القضاء والفقهي سواء بالقانون الوطني والقانون المقارن من شأنها أن تساهم في ترسيخ تخصص الفيات القضاء وارتقاء القضاء الإداري.

ختاما نقول بأن المشرع المغربي خالف نظيره الفرنسي حينما نص هذا الأخير في الفصل 197 من القانون المحدث

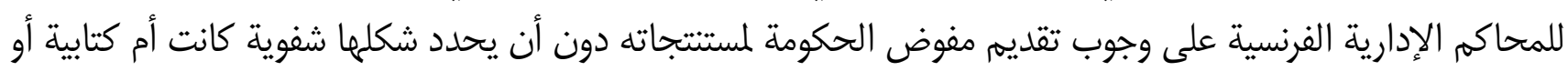

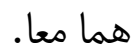

في حين أعطى القانون المصري صلاحيات واسعة في تحضير الدعوى لمفوض الدولة، فلا يتصور أبدا أن يكون تقريره

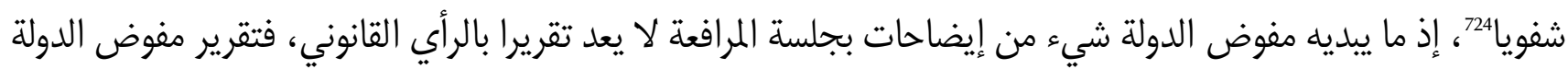
يكون مكتوبا باللغة العربية ليمكن مراقبته من الناحية القانونية.

\section{المطلب الثاني: المفوض الملكي وتعدد درجة التقاضي.}

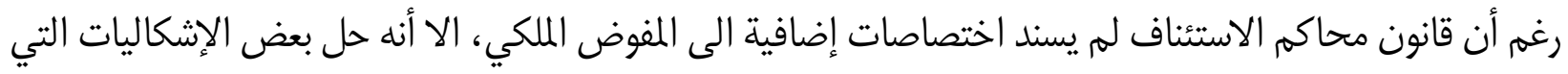

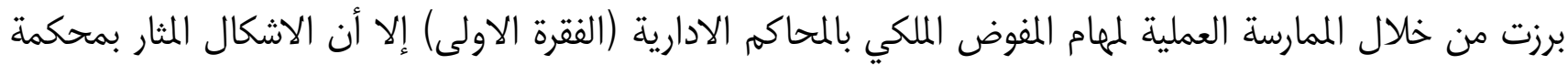
النقض ضل يراوح مكانه (الفقرة الثانية).

\section{الفقرة الاولى: المفوض الملكي على صعيد محكمة الاستئناف الادارية.}

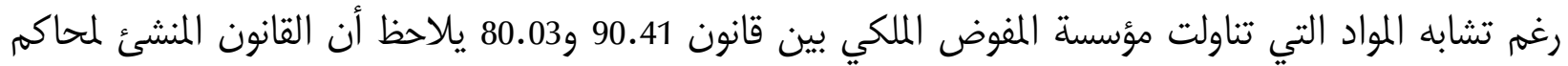
الاستئناف الادارية قد وضع حدا لبعض الاشكاليات التي يمكن ان تطرح على صعيد عمل المفوض الملكي لدى هذه مأه المحكمة.

ومن خلال استقرائنا لنصوص القانون رقم 80.03 المتعلق بإحداث محاكم الاستئناف الادارية يتبين ان المشرع المغربي

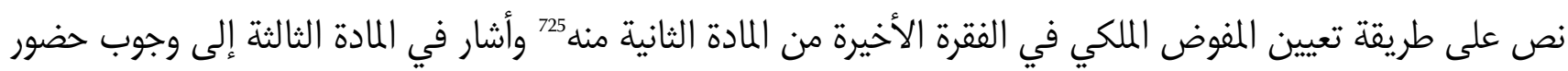

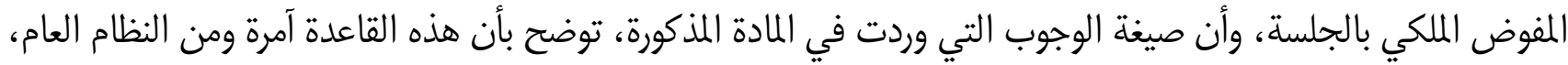
وأن الإخلال بها، يجعل تشكيلة الميئة الحاكمة باطلة والقرارات الصادرة عنها باطلة المئة أيضا. والشيء الجديد الذي أتى به قانون 80-03 هو أن المفوض الملكي بمحكمة الاستئناف الإدارية يدلي بمستنتجاته مكتوبة

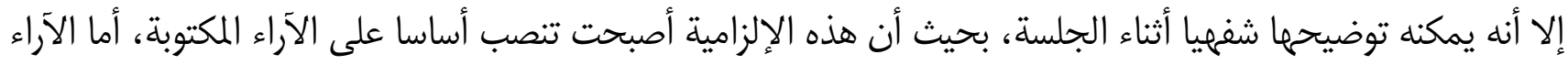

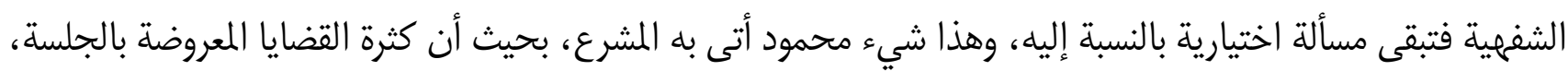

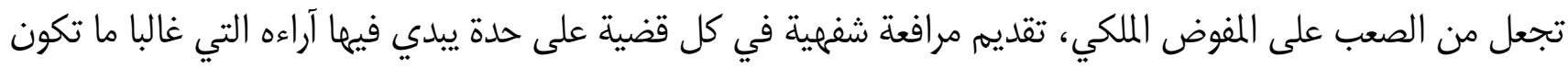
مطابقة لمستتجاته الواردة في تقريره الكتابي.

724ــ حكم المحكمة الإدارية العليا في الطعن رقم 10 لسنة 33 ق.ع بجلسة 1993/11/30، المجلة الحديثة، الجزء 47، ص: 168 ــ 163. 725 ـورد في الفقرة الأخيرة من المادة الثانية من القانون 03 - 80 المحدث لمحاكماكم استئناف إدارية ما يلي : " " يعين الرئيس الأول لمحكمة الاستئناف الإدارية من بين المستشارين مفوضا ملكيا أو أكثر للدفاع عن القانون والحق باقتراح من الجمعية العمومية لمدة سنتين قابلة للتجديد 


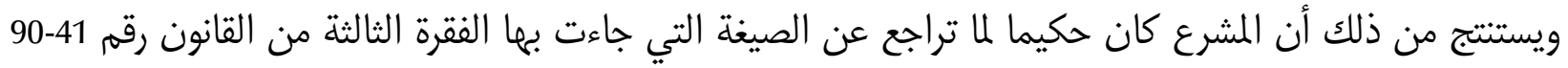

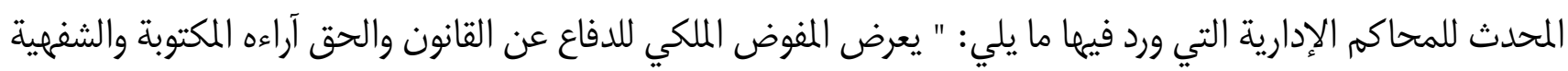

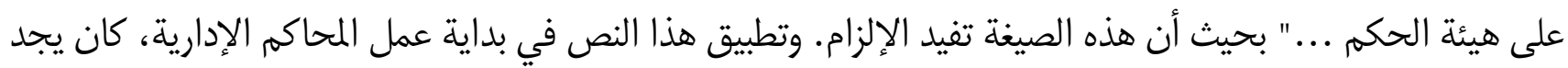

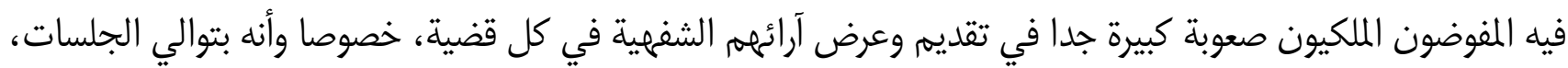

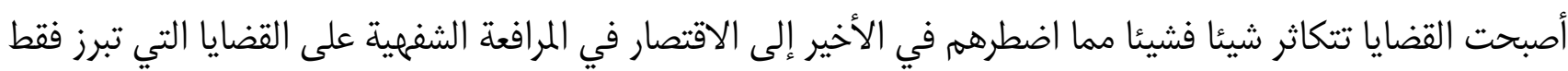

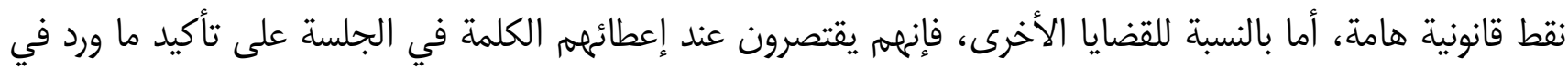
مستتجاتهم الكتابية. كما أن من أهم ما جاء به قانون رقم 80-03 بالنسبة لمؤسسة المفوض الملكي، وهو أنه أورد في الفقرة الأخيرة من المادة

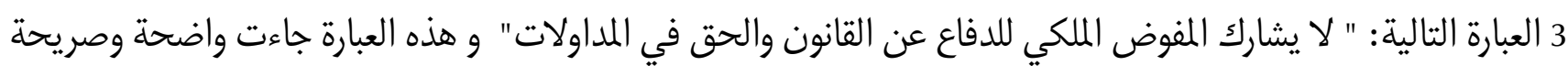

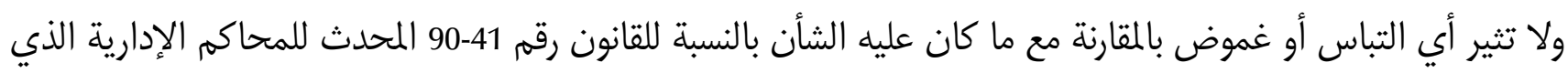

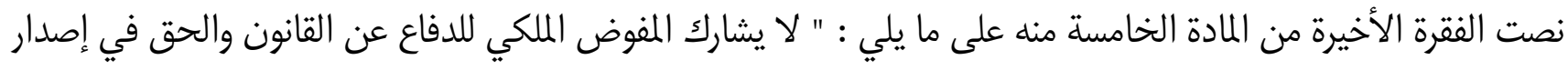

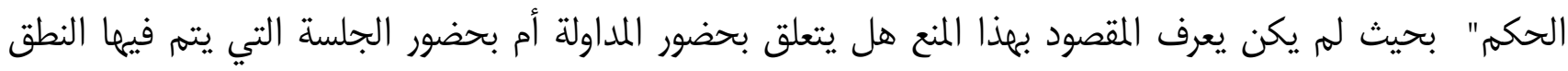
بالأحكام؟

لذا فإن مشرع قانون 80-03 كان حكيما حينما وضح هذه النقطة بشكل جلي أزالت كل التباس في فهم عبارة " إصدار

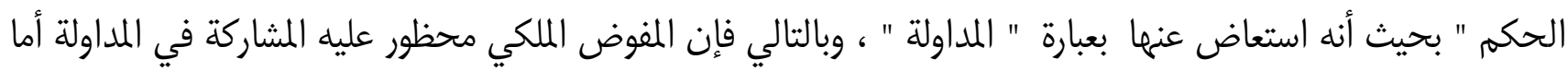

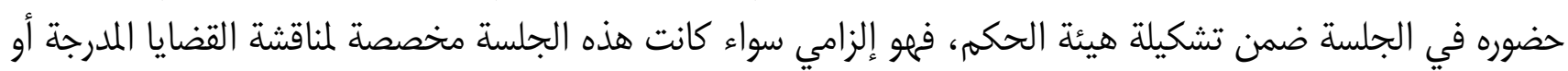

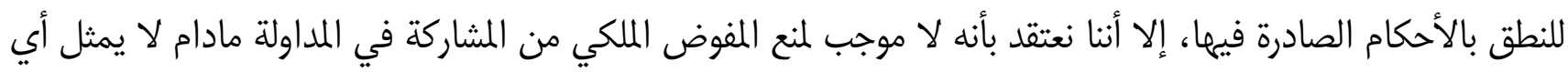

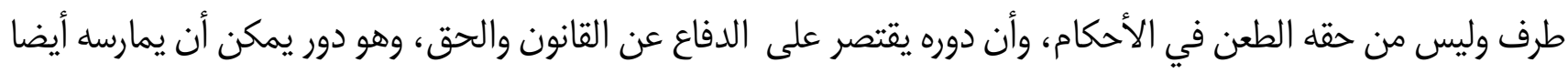

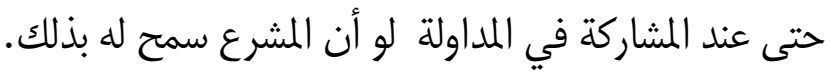

\section{الفقرة الثانية: المفوض الملكي ومحكمة النقض.}

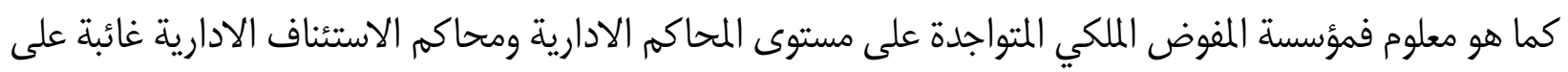

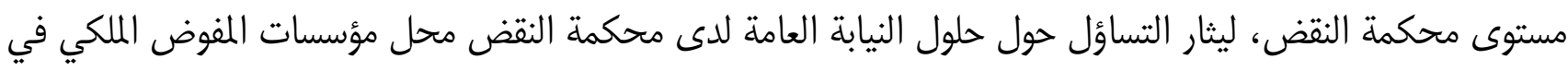
القضايا الادارية.

لقد كان من الراجح والصواب خلق مؤسسات المفوض الملكي على مستوى محكمة النقض لإعطاء دينامية جديدة في

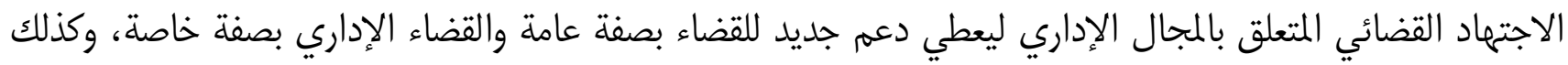
تأكيدا لمبدأ التخصص الذي سار عليه المشرع المغربي بغية تحقيق النجاعة والحرفية.

\section{المبدث الثاني: تقييم نظام المفوض الملكي والمشاكل المثارة بشأنه}

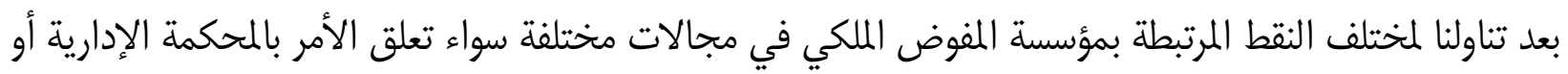

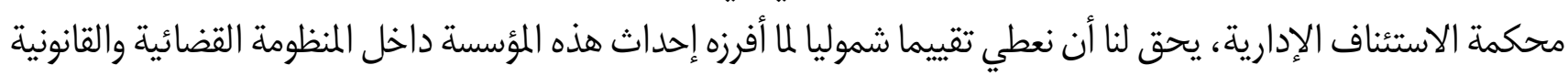


ببلادنا، على أن يشمل التقييم الجانب السلبي والإيجابي لهذه التجربة، دون إغفال إثارة مجموعة من الإشكاليات التي توزعت بين نطاق التسمية، والمجال القانوني والقضائي وأخيرا ما يهمم الجانب العملي والواقعي من خلال الممارسة الفعلية لهزه المؤسسة

\section{المطلب الأول: تقييم تجربة نظام المفوض الملكي. الفقرة الأولى: الجانب الإيجابي.}

إنه بالرغهم من قلة المواد التي تنظهم مؤسسة المفوض الملكي 726، فإن إنشاء هذه المؤسسة يبقى إنجازا مهما وسابقة تاريخية تحسب للمشرع المغربي، على اعتبار أنه كسر القاعدة الثلاثية التقليدية المتمثلة في قضاء الحكم، قضاء النيابة العامة، ثم كتابة الضبط، هذه القاعدة الثلاثية التي تكون عادة هيئة الحكم إذا كان حضور النيابة العامة إلزاميا.

كما يعتبر إحداث مؤسسة المفوض الملكي طفرة نوعية في تاريخ القضاء المغربي، نظرا للخصوصيات التي تتميز بها، وهي تدافع عن القانون والحق، فقد نعتبر المفوض الملكي إلى حد ما فقيها قضائيا من خلال سعيه إلى تجديد قواعد العمل القضائي الإداري، ومساعدة المحكمة وقضاة الحكم، وإرشادهم إلى حلول قانونية، خاصة في بعض القضايا الشائكة، والتي تستمد قوتها من الفقه والقانون المقارن، وكذا من الاجتهادات القضائية سواء تعلق الأمر بالمغرب أو بغيره من الدول الرائدة في هذا المجال، بل هناك من ذهب في إطار حديثنا عن إيجابيات مؤسسة المفوض الملكي إلى القول بأن وضعية هذه

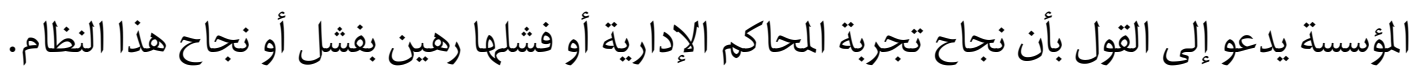

\section{الفقرة الثانية: الجانب السلبي.}

نعتقد أن سلبيات مؤسسة المفوض الملكي قد تستمد عناصرها من المواد المنظمة لها سواء تعلق الأمر بالقانون المحدث للمحاكم الإدارية أو ذلك المحدث لمحاكم الاستئناف الإدارية، وأيضا من الممارسة العملية لهذه المؤسسة، وهكذا فنظئنة لمحدودية الدور الذي تقوم به هذه المؤسسة عكس مثيلاتها في فرنسا ومصر، فقد يذهب الاعتقاد أنها مجرد آلة لعرض المستتتجات ليس إلا، وأن حذفها أو إلغاءها لن يؤثر على الدور الذي يلعبه قضاة الحكم والذين غالبا ما يصدرون الحون أحكاما لا تتماشى مع مضمون المستتتجات، ومن هذه الأحكام مثلا: ما قضت به المحكمة الإدارية بالرباط في حكم صادر لها بتاريخ 2010/04/15 بإيقاف تنفيذ القرار الصادر عن مدير الأكاديمية الجهوية للتربية والتكوين لجهبة دكالة عبدة القاضي بإلغاء

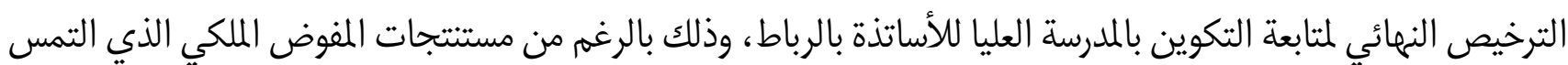
الحكم بعدم الاختصاص لعدم توفر عنصري الاستعجال وجدية الوسائل المثارة.727.

بل وتتجلى سلبيات مؤسسة المفوض الملكي في مضمون المستنتجات التي قد تتسم بالضعف وعدم الإحاطة بالمسائل القانونية والإشكاليات، أو تتناول الإشكالية القانونية بشكل وجيز وغير مدقق، وهكذا فعوض أن تكون هذه المؤسسة بمثابة المساعد والمرشد لقضاة الحكم، فإنها تبعثر أوراق القضية بالشكل الذي لا يساعد هؤلاء القضاة على دراسة الملف ومناقشته وفق ما هو مطلوب.

726- المواد 2-4-5 من القانون رقم 90-41 المحدث للمحاكم الإدارية، والمواد2- 3 من القانون رقم 03-80 المحدث لمحاكم الاستئناف الإدارية. 727- حكم المحكمة الإدارية بالرباط عدد 1102، بتاريخ 2010/04/15 ، رقم الملف 2010/04/09. 
إن هذا المعطى يفضي إلى تعطيل مفعول نظام المفوض الملكي للدفاع عن القانون والحق والغاية من استحداثه، وهاته هي سلبيات نظام المفوض الملكي.

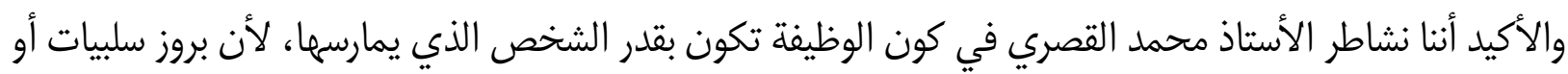

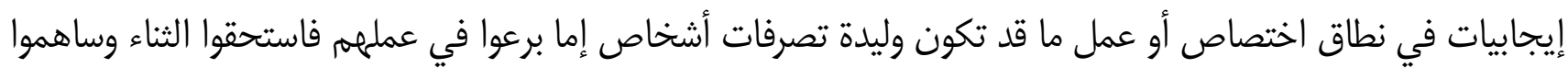

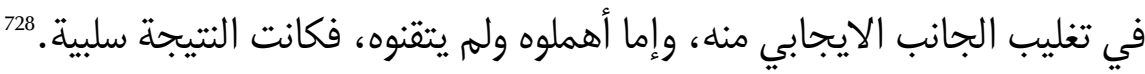

\section{المطلب الثاني: الإشكاليات المثارة بخصوص مؤسسة المفوض الملكي.}

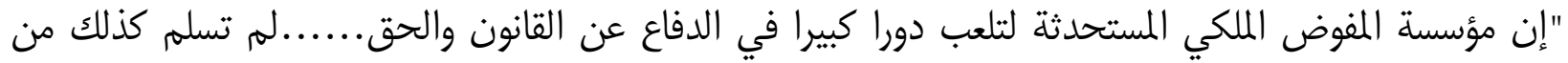

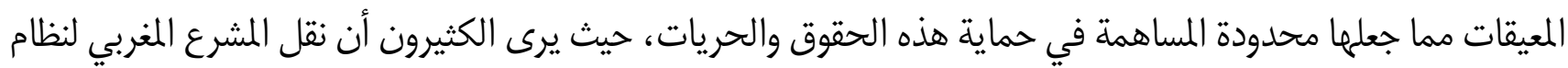

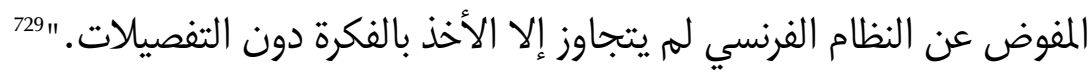
ونتتقد أن عدم الخوض في التفصيلات والغموض الذي يطال النصوص المنظمة لمؤسسة المفوض الملكي هو الذي فتح

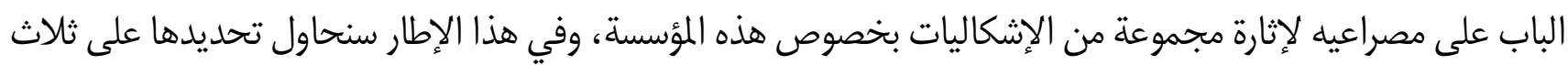

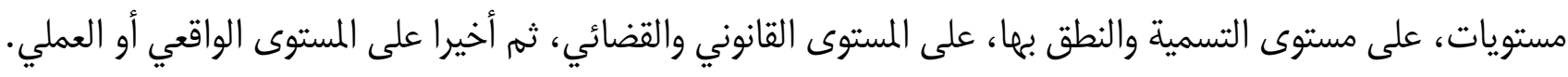

\section{الفقرة الأولى: إشكاليات على مستوى التسمية والنطق بها.}

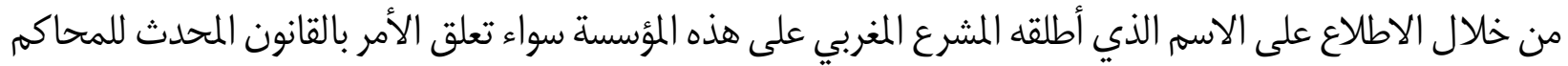

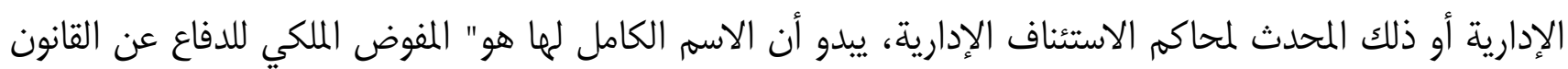

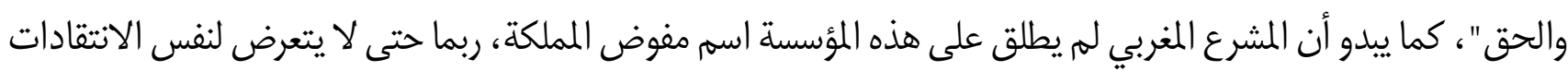
التي طالت اسم المؤسستين في كل من فرنسا ومصر.

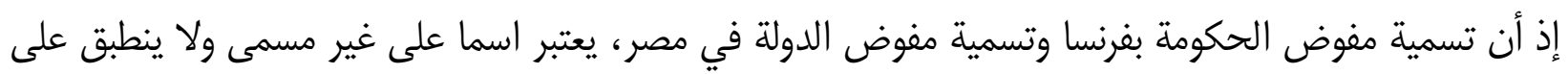

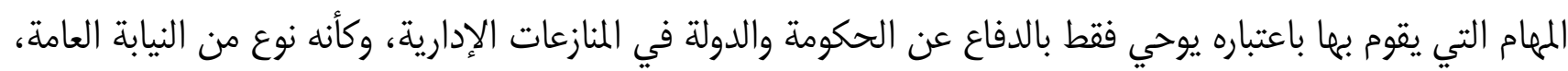

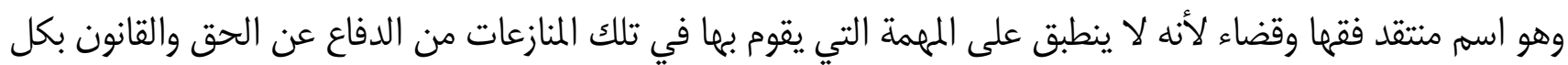
تجرد وحرية.

بل أكثر من ذلك فإن عبارة الدفاع عن القانون والحق التي تجسد قمة العدل والإنصاف، توحي بأنه عندما يمارس

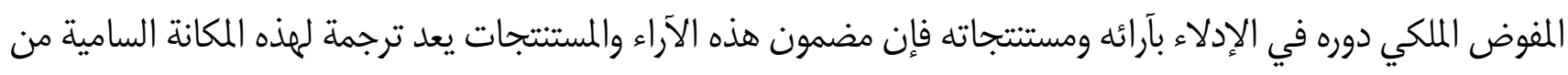

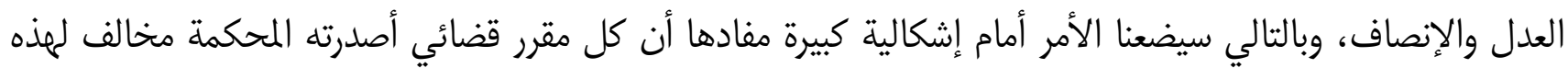
الآراء والمستتجات، يكون بدوره قد خالف تلقائيا مقتضيات العدل والإنصاف.

728 - عرض للأستاذ محمد القصري، منشور بمجلة القضاء والقانون العدد 151 ص:169. 729- رشدي الصبايطي، المفوض الملكي للدفاع عن القانون والحق في المحاكم الإدارية، منشورات المجلة المغربية للإدارة المحلية والتنمية ،

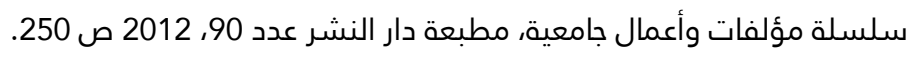
730- عرض الأستاذ محمد القصري، المرجع السابق مؤه 
ومن أجل تفادي هذه التأويلات بخصوص التسمية التي أطلقها المشرع على هذه المؤسسة، فنعتقد أنه من المستحسن إلغاء عبارة للدفاع عن القانون والحق، والإبقاء فقط على تسمية المفوض الملكي.

ومن جهة أخرى فإن كثيرا ما يته النطق بكلمة مفوض (بكسر الواو)، وفي اعتقادنا فإن النطق الصحيح هو مفوض

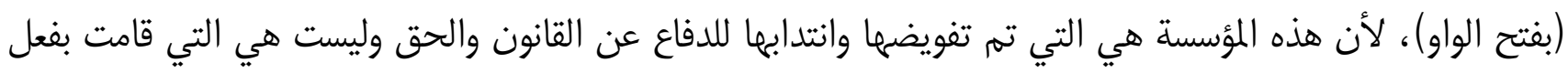

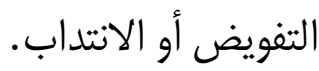

\section{الفقرة الثانية: إشكاليات على الصعيد القانوني والقضائي.}

ننطلق في هذا الإطار من النصوص القانونية التي جاءت محتشمة ولم تتجاوز 3 فصول من أجل تنظيم مؤسسة لا لإنيان زالت تعتبر حديثة العهد بالقضاء المغربي.

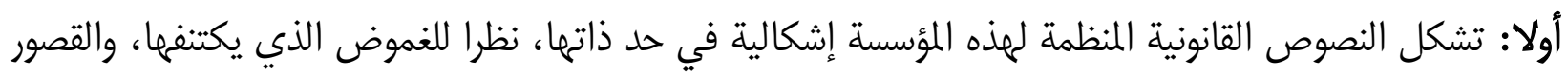

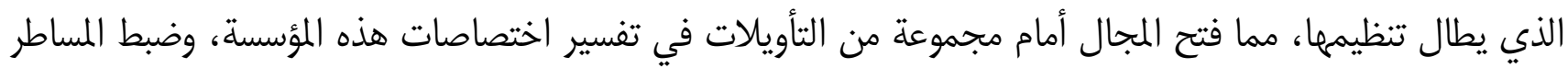

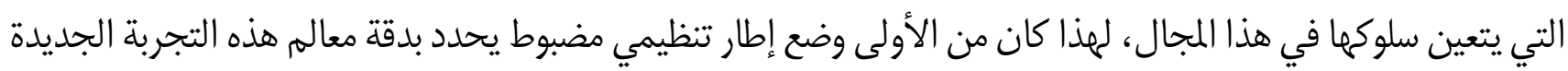
التي عرفها المغرب في المجال الإداري.

ثانيا: لقد منح المشرع المغربي اختصاصات محتشمة للمفوض الملكي 317، مما جعله مغلول اليدين أمام مجموعة من

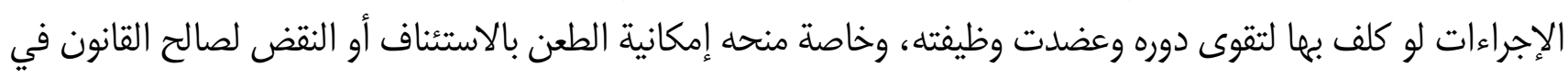

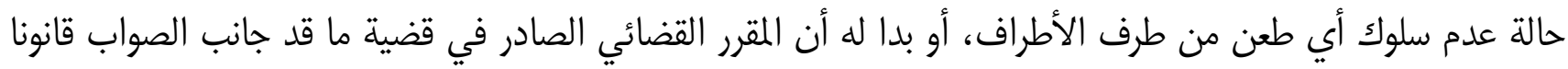

ثالثا: أمام غياب مؤسسة المفوض الملكي أمام محكمة النقض، يطرح تساؤل حول الصفة التي تتقمصها النيابة العامة

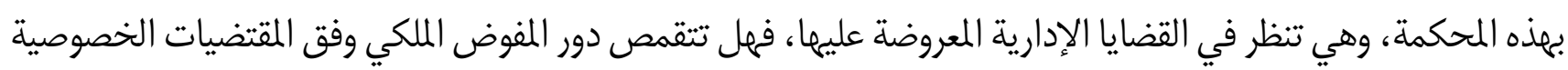

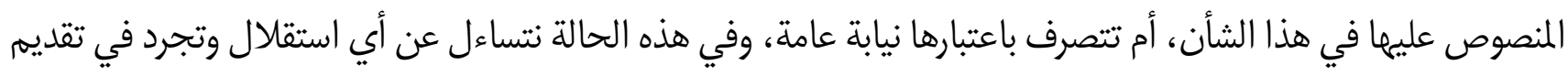

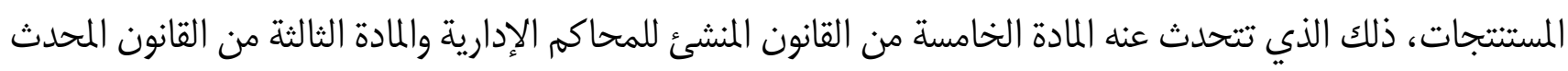
لماكم الاستئناف الإدارية.

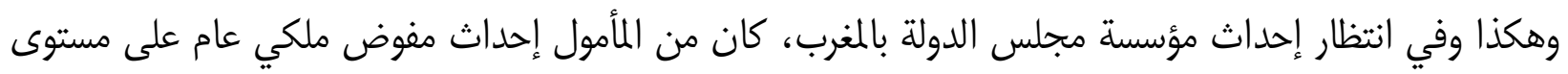

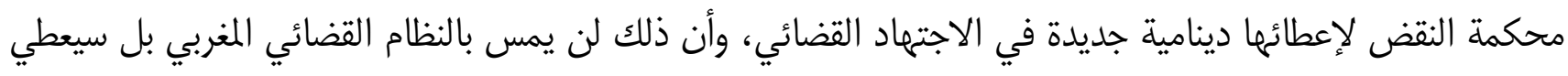
دعامة جديدة لهذا القضاء.

731- المادة 5 من قانون 90- 41 المحدث للمحاكم الإدارية، والمادة 3 من القانون رقم 03-80 المحدث لمحاكم الاستئناف الإدارية. 732- رشدي الصبايطي، المفوض الملكي للدفاع عن القانون والحق في المحاكم الإدارية، منشورات المجلة المغربية للإدارة المحلية والتنمية، سلسلة مؤلفات وأعمال جامعية، مطبعة دار النشر عدد 90، 2012 ص 244. 


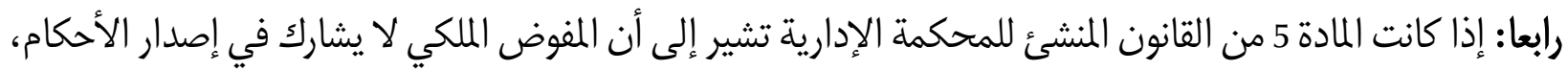

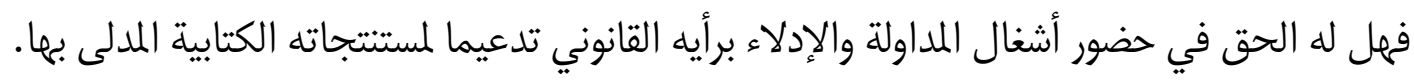

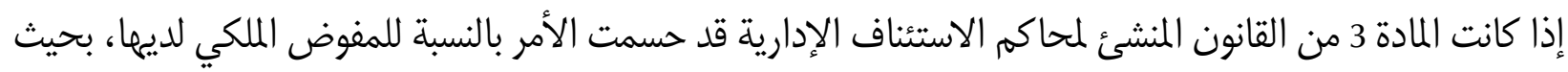

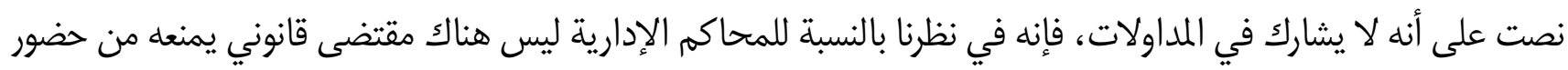

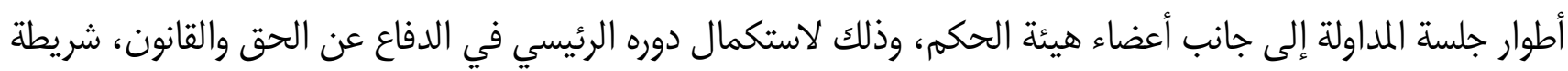
ألا يشارك في عملية التصويت لصالح أو ضد حكم معين.

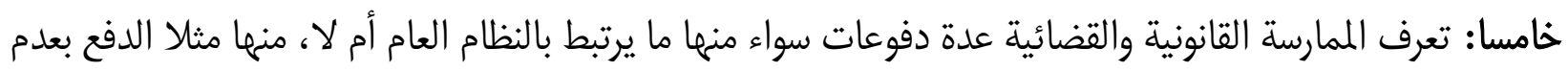

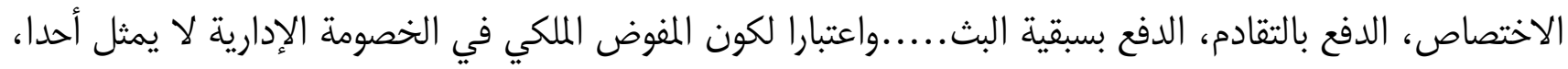

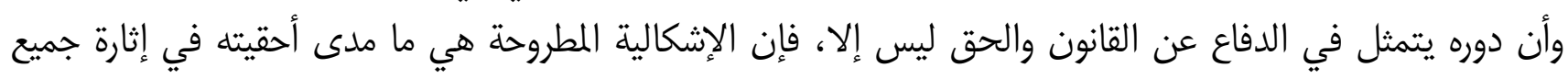

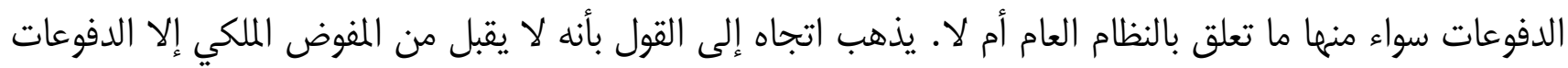

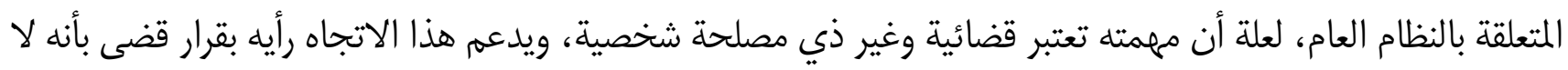
يجوز للمفوض الملكي الدفع بتقادم دعوى التعويض، لأنه دفع بحقوق صاحب الشأن وليس متعلق بالنظام النام العام.

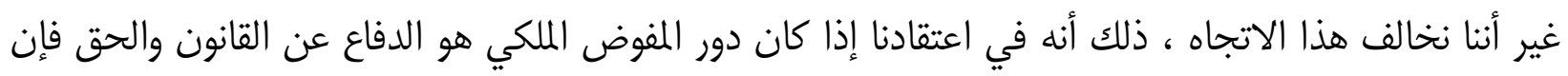

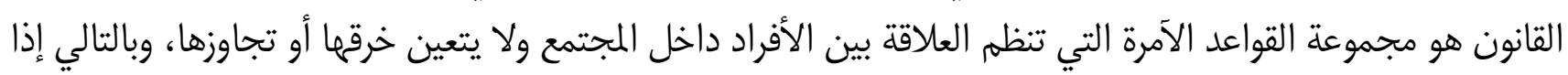

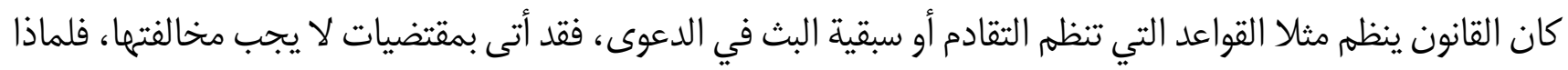

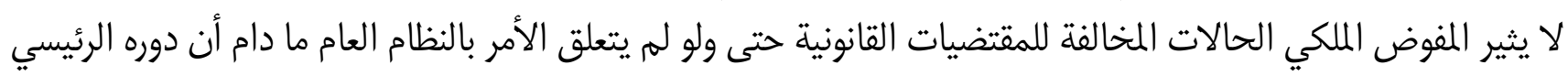
هو الدفاع عن القانون الذي هو أسمى من مصلحة الأفراد الشخصية.

سادسا: إشكالية أخرى تطرحها الطبيعة المزدوجة للمفوض الملكي في الحالة التي تنتهي فيها مهمته بهذه الصفة،

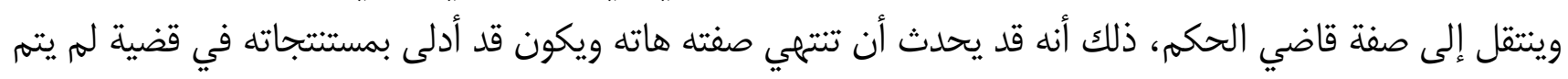

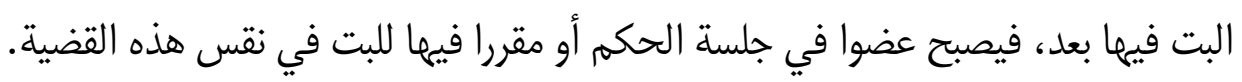
كما تطرح إشكالية إمكانية أن يكون أحد القضاة أو أكثر يحمل صفة قاض مقرر أو مستشار مقرر في بعض القضايا

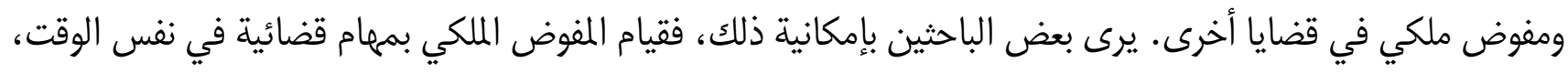

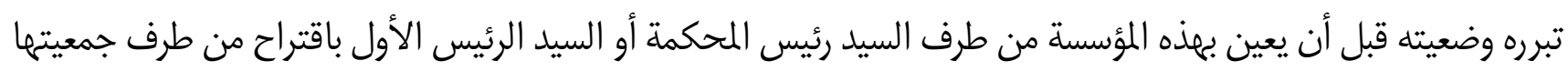

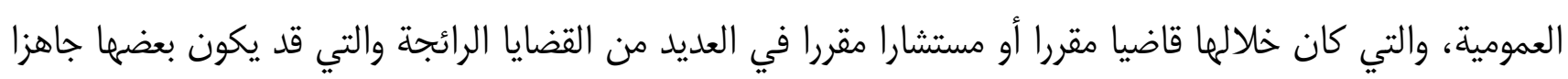
للحكم.

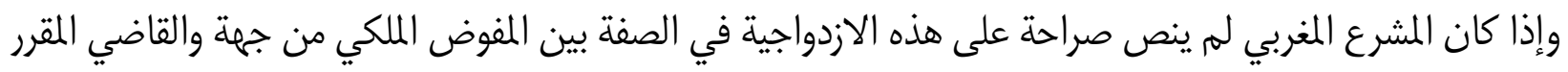

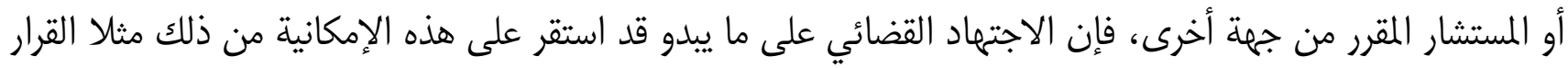

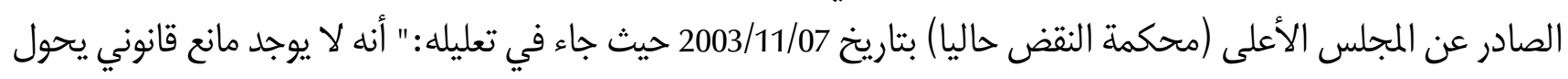


دون تقلد المفوض الملكي لمهام القاضي المقرر في نفس الملف".

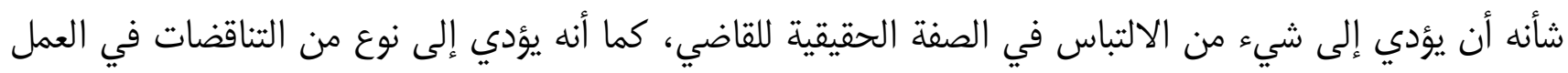
القضائي.

لتفادي هذه الإشكاليات أو للتخفيف من حدتها سواء تعلق الأمر بغياب المفوض الملكي أو بوجود نقص في عدد القضاة

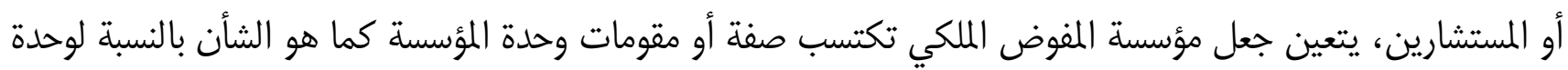

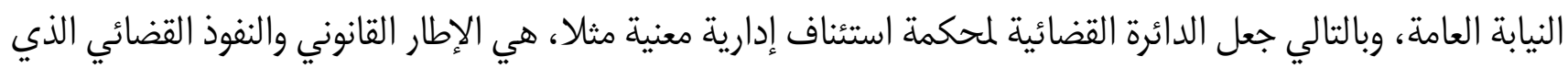

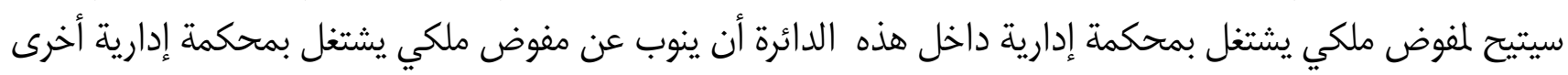

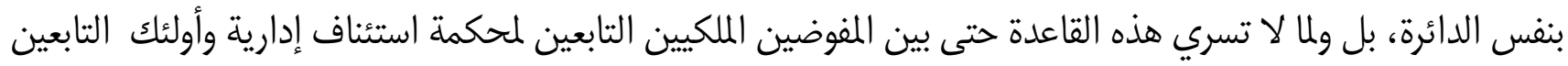
لمكمة إدارية بنفس الدائرة.

\section{الفقرة الثالثة: إشكاليات على الصعيد العملي.}

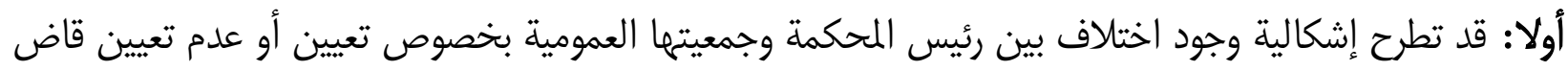

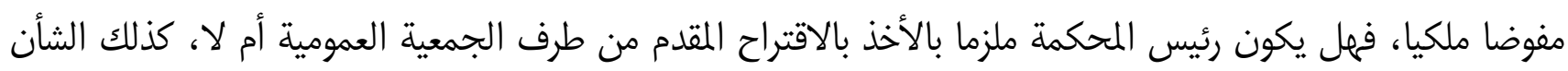
بالنسبة لمحكمة الاستئناف الإدارية.

يذهب اتجاه إلى القول بتبني الرأي المتخذ بالأغلبية، مادام أن رئيس المحكمة أو الرئيس الأول لمحكمة الاستئناف

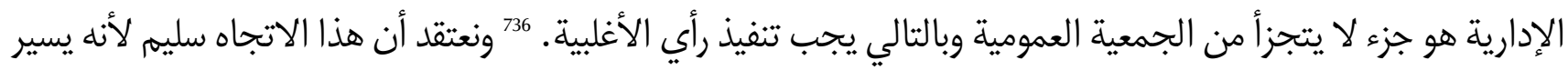

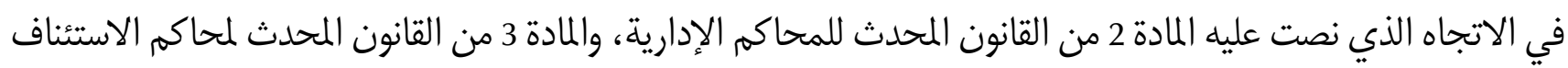

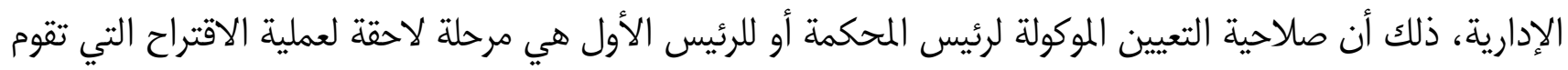

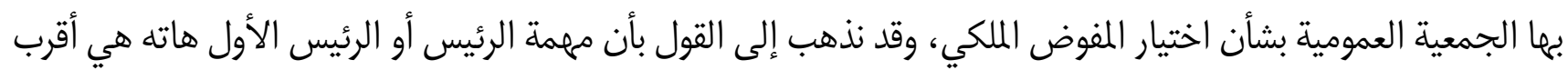
إلى مفهوم تبني الاقتراح منه إلى مفهوم التعيين.

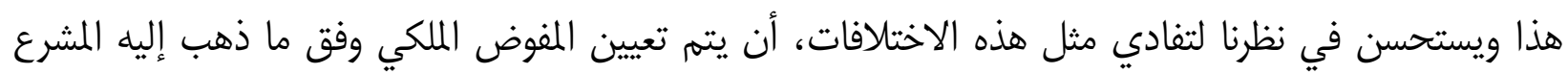

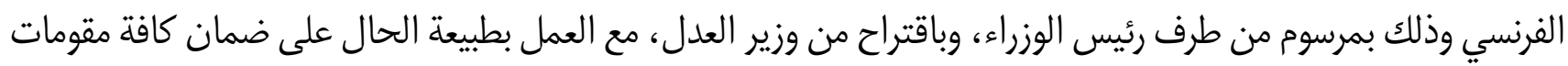
الاستقلالية والتجرد في عمل هذه المؤسسة.

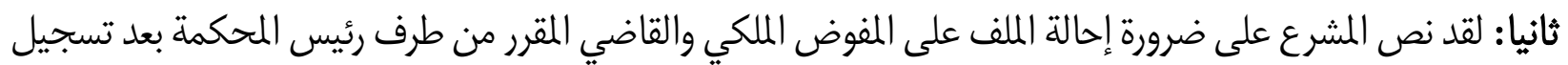

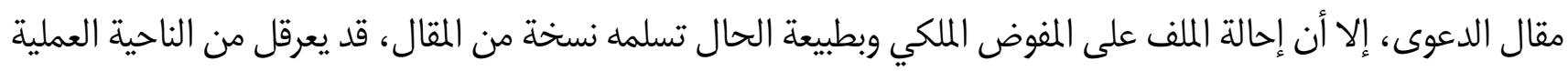

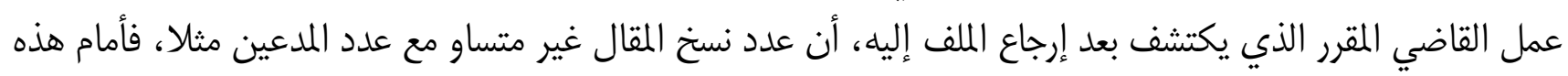

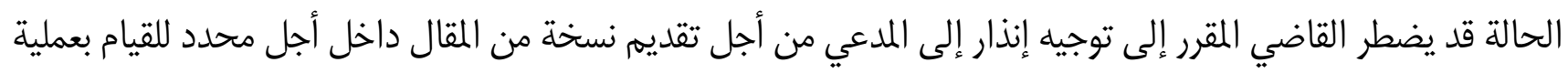

734- قرار عدد 1173 بتاريخ 2003/11/07 في الملف عدد 2002/1071.

735- الأستاذ محمد النجاري، تقويم نظام مفوضي الدولة في المنازعات الإدارية ، ص 51 الع 5134 736ـ رأي الأستاذ محمد النجاري في مقاله" نظرة حول تنظيم المحاكم الإدارية بالمغرب" طبعة سنة 
التبليغ للأطراف، فإذا لم يستجب المدعي لهذا الإنذار وتشبث بكونه أدلى بالنسخ الكافية ، فهل سيكون الجزاء هو الحكم بعدم قبول الدعوى طبقا للفصل 32 من ق م م737 .

في اعتقادنا وحسب مقتضيات القانون المنظم للمحاكم الإدارية، فإن المفوض الملكي ليس طرفا في الدعوى ولا يمثل

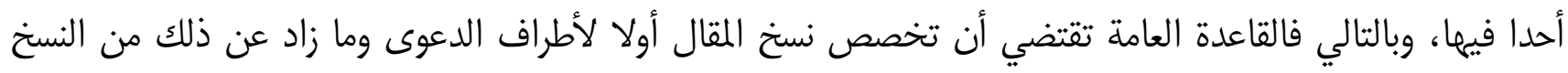

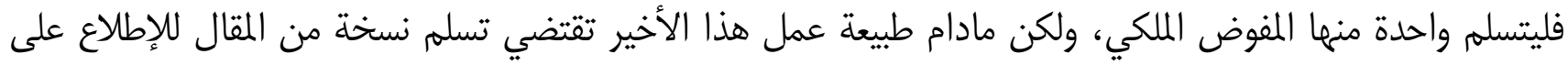

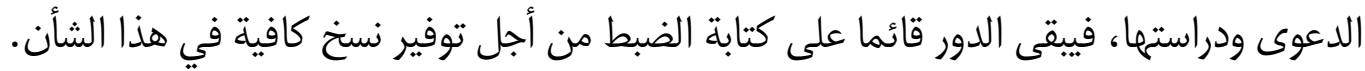
ثالثا: قد يفاجأ أعضاء الميئة يوم الجلسة بتغيب المفوض الملكي لأسباب خارجة عن إرادته، مثل وقوع حادث فجائي،

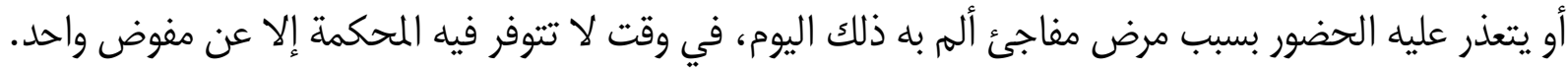
لقد ذهب البعض إلى القول بإمكانية تعيين أحد القضاة أو المستشارين للنيابة عن المفوض الملكي الغائب، ولكن نعتقد

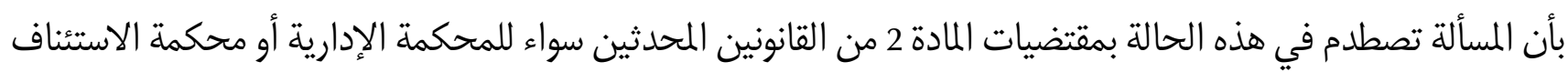
الإدارية، اللتين تشيران إلى أن تعيين المفوض الملكي لا يكون إلا باقتراح من الجمعية العمومية. لتفادي هذا الإشكال فقد اقترح بعض الباحثين استحسان تعيين المفوض الملكي ومن ينوب عنه عند الاقتضاء، وذلك أثناء انعقاد الجمعية العمومية

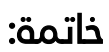

كخالاصة يمكن القول إن للمفوض الملكي دورا مهما ليس لأنه يساعد على تحقيق فعالية العمل الإداري فحسب، بل

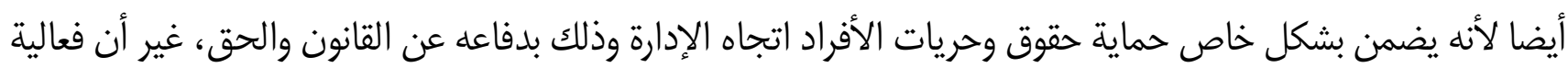

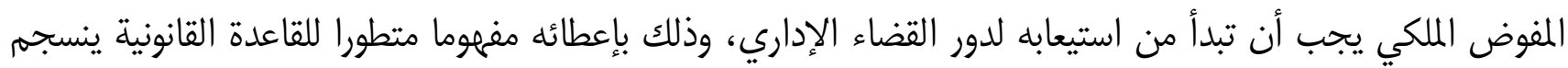

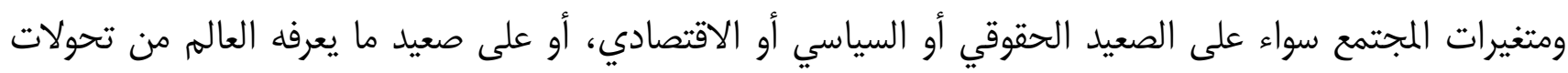

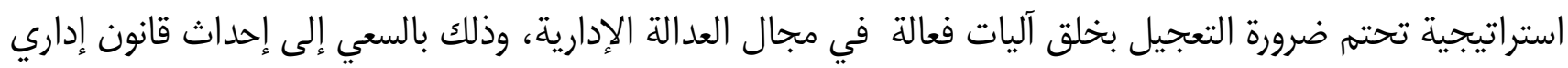

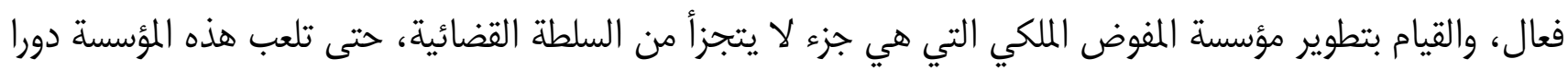

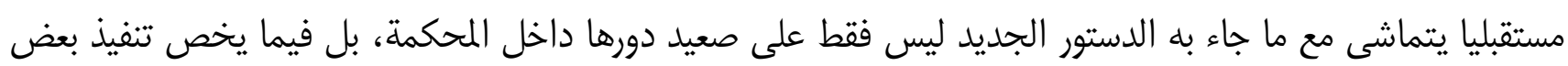

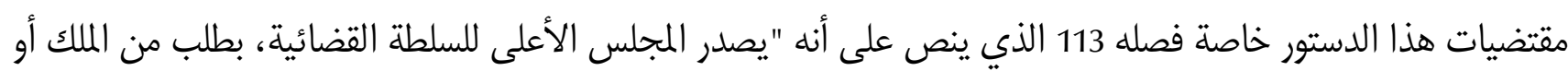

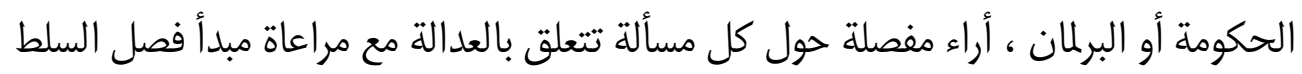




\title{
إشكالية تنفيذ الأحكام ضد الادارة الضريبية
}

بين المقتضيات القانونية والعمل القضائي

\author{
كع المسن المين \\ باحث بسلك الدكتوراه \\ كلية العلوم القانونية والاقتصادية والاجتماعية سطات الدكروه
}

\section{المقدمة}

يعتبر القضاء الإداري من أهم المرتكزات الأساسية التي تدعم مسار التحول الديمقراطي، وهو من الأسس التي تقوم الحما

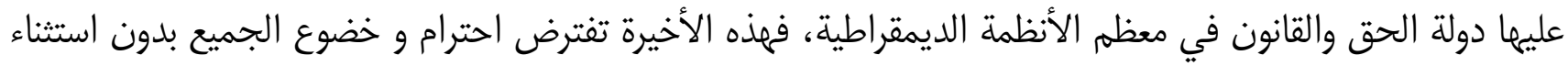

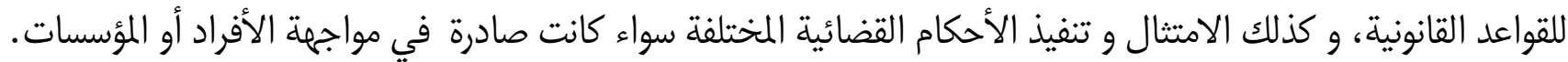

فتنفيذ الأحكام القضائية يحتل أهمية كبرى باعتباره جوهر القضاء والغاية الأسمى منه، حيث لا يمكن تصور سمو

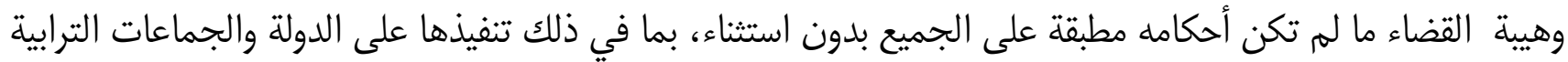

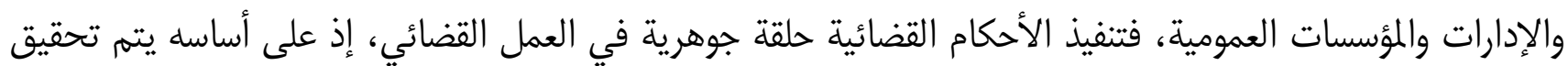
العدل والمساواة أمام القانون

إن ما يتوخاه كل متقاض من دعواه ليس هو فقط صدور حكم لمصلحته، بل أيضا ترجمة منطوق الحكم إلى أرض تلف تلف الواقع وذلك عن طريق تنفيذه وبدون أدنى تباطؤ.

فما من حكم حائز لقوة الشيء المقضي به إلا ويلزم تنفيذه ولو بالجبر والإكراه احتراما لتلك القوة، وهذا ما يجعل

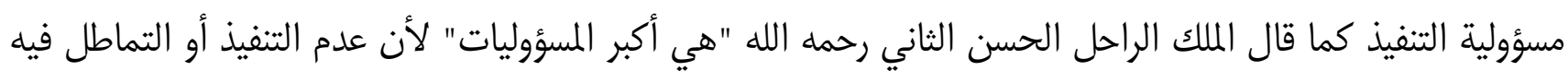

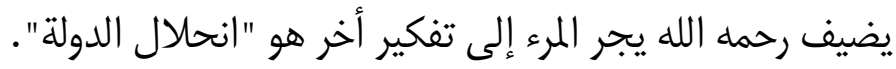

فالتنفيذ هو جواز الشيء

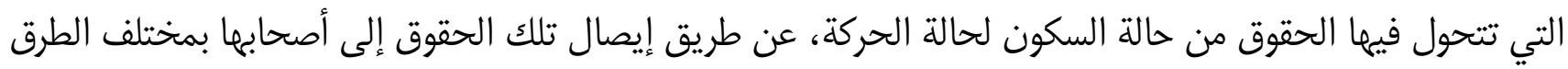

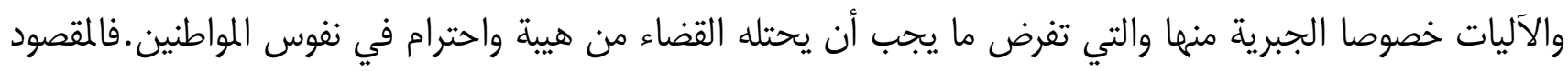

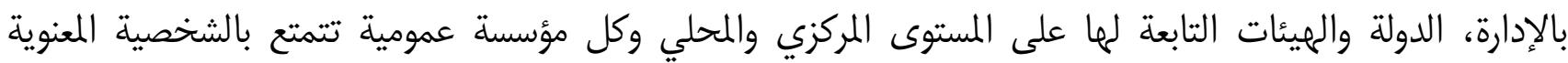

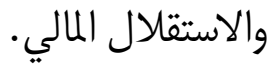

739: عبد القادر باينة: "القضاء الإداري الأسس العامة والتطور التاريخي"، دار توبقال للنشر، الدار البيضاء، الطبعة الأولى، سنة 1987، ص 121.

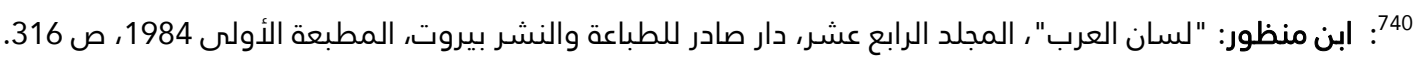
741 - محمد عبد الخالق، "مبادئ عامة للتنفيذ"، دار النهضة العربية، الطبعة الرابعة، سنة 1978، ص 4. 
أما الحكم القضائي فقد اتفق فقهاء اللغة بأن الحكم معناه القضاء وبذلك فإن هذين المصطلحين (الحكم والقضاء)

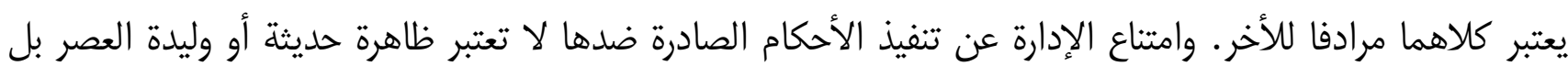

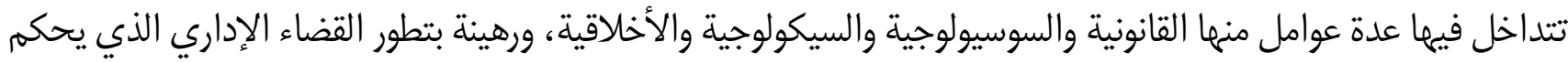
العلاقة بين الدولة والأفراد.

ويمكننا في هذا السياق طرح الإشكالية التالية: ما مدى منح النص القانوني والعمل القضائي لآليات تمكن الإدارة من

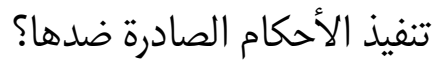

لتناول هذا الموضوع سنقوم بتقسيمه إلى مطلبين نتطرق في (المطلب الأول) إلى أسباب وصور عدم تنفيذ الأحكام ضد الما لفا الإدارة، ثم سنتناول دور القضاء الإداري المغربي في إشكالية تنفيذ الأحكام في ( المطلب الثاني).

\section{المطلب الأول: أسباب وصور عدم تنفيذ الأحكام ضد الإدارة.}

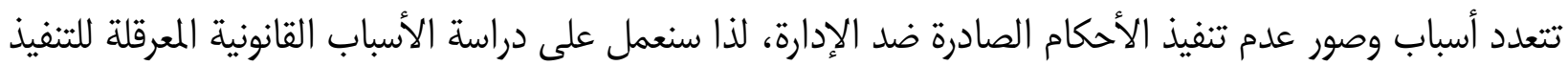
ضد الإدارة(الفقرة الأولى) ثم نتطرق لدراسة صور عدم تنفيذ الأحكام من طرف الإدارة. (الفقرةالثانية).

\section{الفقرة الأولى: الأسباب القانونية المعرقلة لتنفيذ الأحكام.}

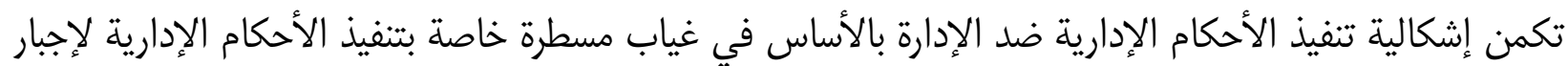

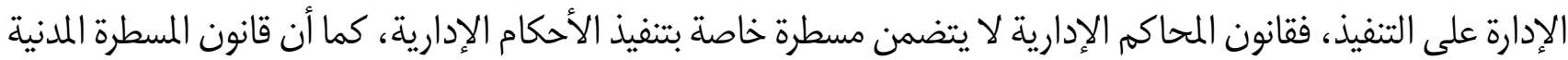

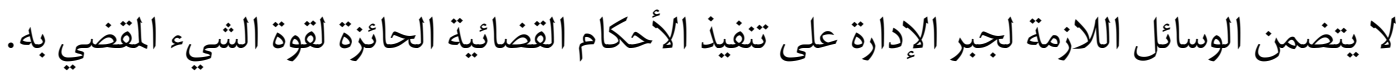

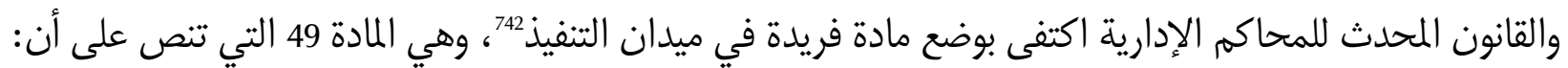

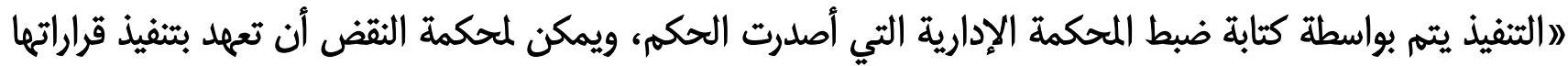
إلى المحكمة الإدارية)، (173.

والمادة 49 لم توضح بشكل مفصل كيفية تنفيذ الأحكام الإدارية، مما جعلما متسمة بالقصور، والأكثر من ذلك أنها

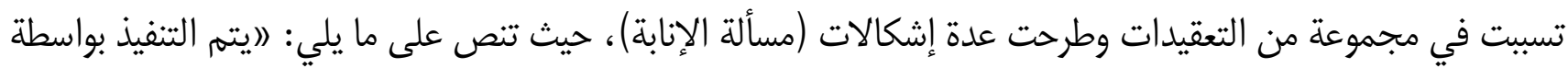

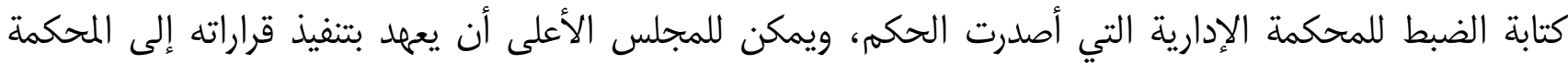

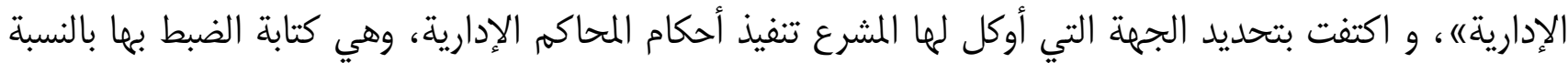

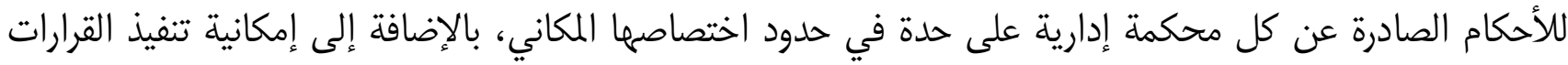
الصادرة عن الغرفة الادارية بمحكمة النقض.

742: تعريف التنفيذ: التنفيذ لغة هو إخراج الشيء من مجال الفكر والتحول إلى مجال العمل فلا يبقى رهين لإحساس والإرادة بل يصبح واقعا معاشا واتصاله بالواقع هو منشأ الصعوبة، منشورات الجمعية المغربية لإنشاء المعرفة القانونية، ودادية المنتدبين القضائيين، 1999.

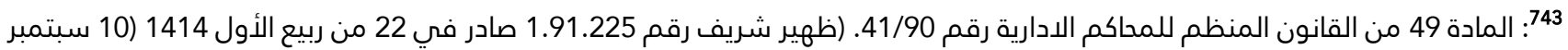
1993) بتنفيذ القانون رقم 41.90 المحدث بموجبه محاكم إدارية ، الجريدة الرسمية عدد 4227 بتاريخ 18 جمادى الأولى 1414 ( 3 نوفمبر 1993)، 
ومقتضيات هذه المادة هي تأكيد لما جاء في الفقرة الثانية من الفصل 429 من قانون المسطرة المدنية التي تنص كذلك

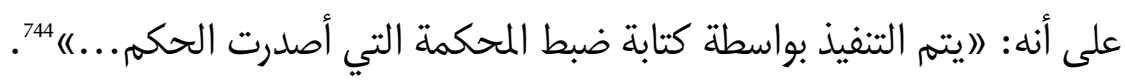

ولهم يحدد القانون رقم 90.41، أي طريقة لإجبار الإدارة على تنفيذ الأحكام الصادرة ضدها، و لهم يرتب أي جزاء على الإدارة في حالة امتناعها عن التنفيذ، و لم يضم صيغة تنفيذية خاصة بالأحكام الصادرة عن المحاكم الإدارية، فهل يعني هذا أن المحاكم الإدارية مدعوة لتذييل أحكامها بالصيغة التنفيذية الواردة في المسطرة المدنية؟ للإجابة عن هدا التساؤلوبالرجوع إلى القانون رقم 90.41، نجد أن المادة السابعة منه تنص على إمكانية تطبيق القواعد المقررة في قانون المسطرة المدنية، وهي المشار إليها في الفصل 433 من قانون المسطرة المدنية الذي ينص على ما يلي: (اوبناء على ذلك يأمر

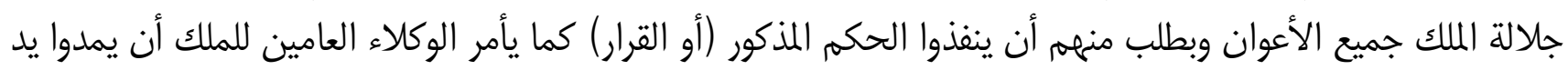
المعونة لجميع أعوان وضباط القوة العمومية وأن يشدوا أزرهم عندما يطلب منهم ذلك قانونيا)،

وقد كانت كتابة الضبط للمحاكم الإدارية تتردد بين اعتماد هذه الصيغة التنفيذية، أو وضع طابع يحمل عبارة "نسخة تنفيذية سلمت طبق الأصل ولأجل التنفيذ"، كما ينص على ذلك الفصل 428 من قانون المسطرة المدنية 746، ويمكن تفسير هذا التردد بعدم تلاءم الصيغة التنفيذية الخاصة بالأحكام المدنية، مع طبيعة الأحكام الإدارية، كما أنها لا تتلاءم مع الجهيلة المطلوبة في التنفيذ، على اعتبار أن التنفيذ ضد الإدارة لا يمكن تصوره عن طريق الاستعانة بالقوة العمومية، ومع ذلك فقد بلد

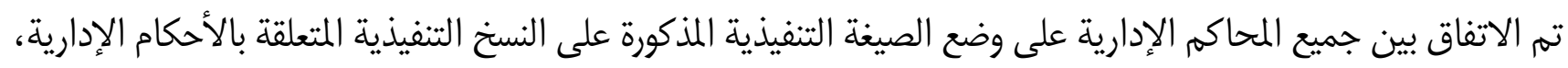
في انتظار تدخل المشرع من أجل وضع صيغة تنفيذية خاصة بالأحكام الإدارية مثل ما هو معمول به في القانون المقارن. كما أن هناك مشكل آخر تسببت فيه المادة 49 من القانون المحدث للمحاكم الإدارية، والمتمثل في مشكل الإنابة القضائية حيث تقضي بأن المحكمة الإدارية هي التي تنفذ الأحكام الصادرة عنها أو الصادرة عن الغرفة الإدارية بمحكمة

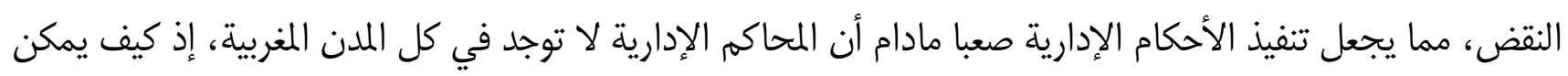
تنفيذ حكم صدر عن المحكمة الإدارية بالرباط في حق الإدارة المحكوم عليها المتواجدة بطنجة التي لا تتوفر على محكمة إدارية، فهذه المدينة تدخل في دائرة نفوذ المحكمة الإدارية بالرباط؟

فحرفية نص المادة 49 تقضي بأن يتوجه عون التنفيذ بالمحكمة الإدارية بالرباط إلى مدينة طنجة ليقوم بإجراء التنفيذ، الأمر الذي يصعب تصوره، وإذا طبقنا المادة السابعة من نفس القانون، سنجد أن المادة 439 من قانون المسطرة المدنية تلمجن،

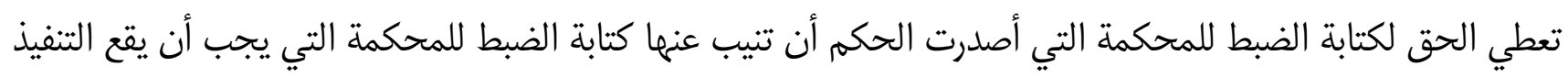
في دائرتها القضائية.

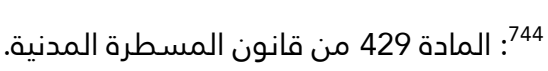

745 الفصل 433 قانون المسطرة المدنية.

466. الفصل 428 من قانون المسطرة المدنية: "تنفذ الأحكام الصادرة من محاكم المملكة في مجموع التراب الوطني بناء على طلب من من من

المستفيد من الحكم أو من ينوب عنه" 747: المادة 439 من قانون المسطرة المدنية: "يتم التنفيذ ضمن الشروط المقررة في الفصلين 433 و 434 غير أنه يمكن لكتابة ضبط المحكمة

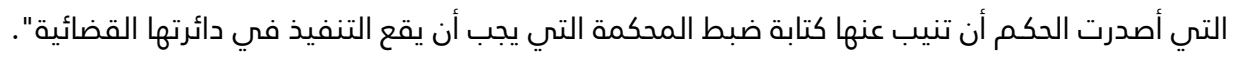


فحسب الفصل 439 منق.م.ميمكن توجيه إنابة قضائية إلى محكمة أخرى، فإذا كان الأمر يتعلق بمحكمة إدارية فلا

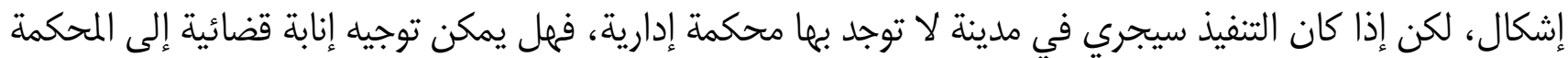
الابتدائية؟

هنا يطرح الإشكال بخصوص طريقة تنفيذ الأحكام الإدارية التي تختلف طبيعتها عن طبيعة الأحكام العادية، كما أن

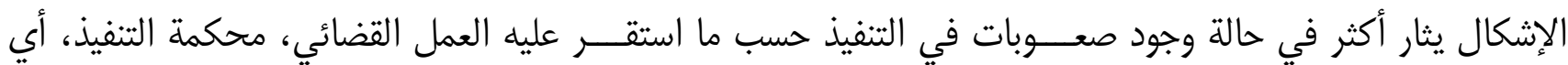

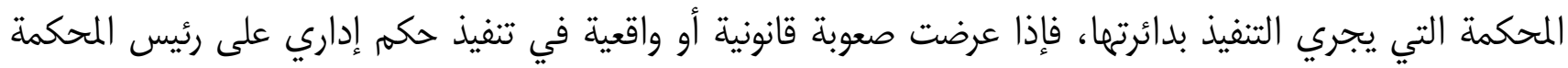

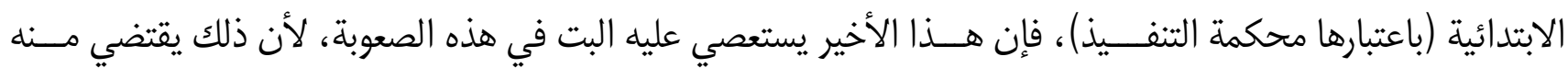

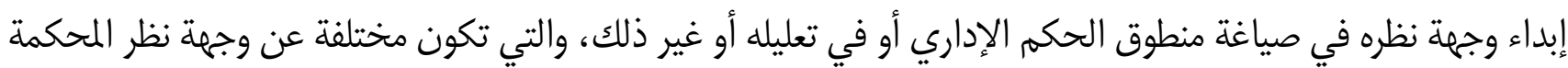

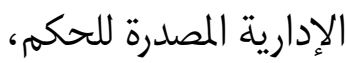

هذا فضلا عن كثرة ملـــفات التنفيذ الموجودة بالمحاكم الابتدائية، ممـا يجعــــلـل عملية تصفيــة الأحكام الإدارية تتأخر. وقد وجدت المحاكم الإدارية حلا لهذا المشكل عن طريق توجيه الملف التنفيذي مباشرة إلى العون القضائي الذي تم

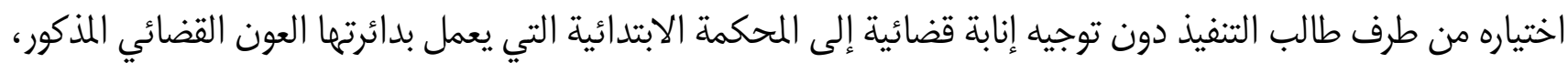

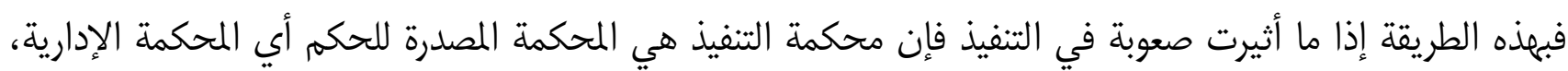

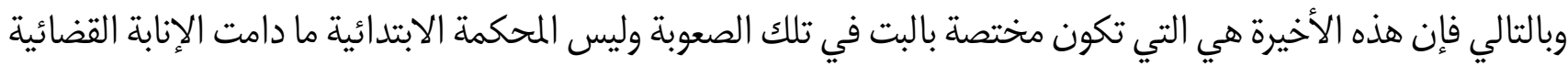
لم توجه إلييها.

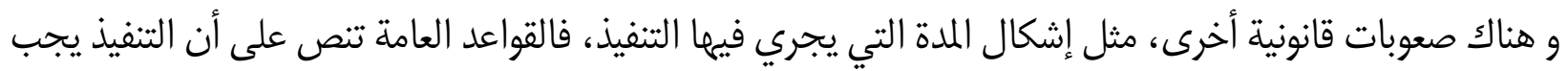

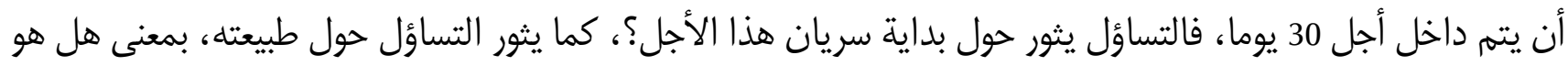

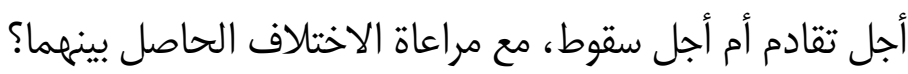
وهناك مشكل أخر، يتمثل في كون النسخة التنفيذية لا تسله إلا مرة واحدة، وذلك على عكس ما كان معمولا به في

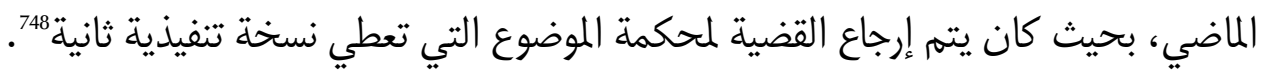

\section{الفقرة الثانية: صورعدم تنفيذ الأحكام.}

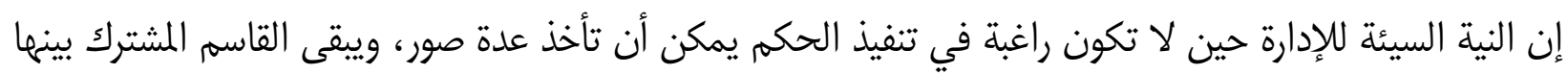

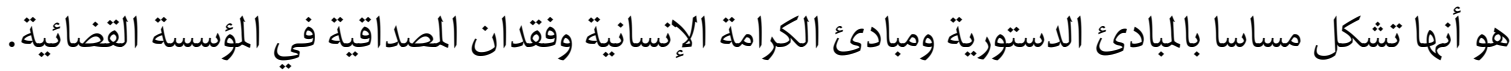
حين تعمد إلى عدم تنفيذ الحكم سواء بطريقة سلبية أو بطريقة سيئة أو سافرة فإنها لا تعدم الوسيلة التي توصلمها إلى إلى

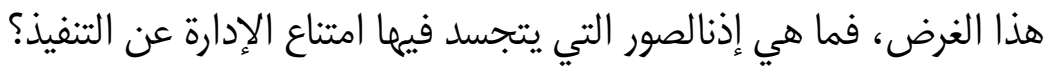

748 : العطشان الحبيب: عدم تنفيد أحكام القضاء الاداري من طرف الادارة، مجلة القضاء والقانون، العدد 156، مطبعة الامنية الرباط، سنة 2009، 


\section{أولا: التراخي في التنفيذ.}

يفترض عند قيام المحكمة بإصدار حكم حائز على قوة الشئ المقضي به أن تبادر الإدارة إلى اتخاذ كافة الإجراءات اللازمة لتنفيذه، ذلك أن التراخي في تنفيذ الحكم، فضلا عما يحمله من تحقير وإضعاف لسلطة القضاء، فإنه يسبب أضرارا لمن صدر الحكم لصالحه ويجعل التنفيذ صعبا على الإدارة، وقد استقرت أحكام القضاء الإداري على أن من واجب الجهية

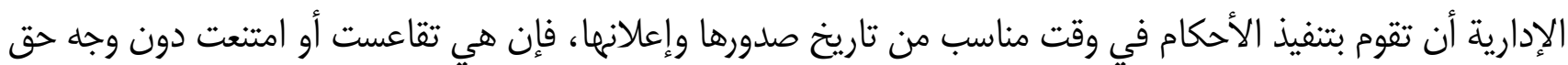
عن التنفيذ في وقت مناسب اعتبر هذا الامتناع بمثابة قرار سلبي مخالف للقانون يوجب لصاحب الشأن التعويض 749. ويلاحظ أن المدة التي تلتزم الإدارة فيها بالانتهاء من تنفيذ الحكم هي في الغالب غير محددة لا من طرف المشرع ولا من طرف القاضي الإداري نفسه الذي أصدر الحكم لكن يجب على الإدارة أن تختار وقت التصرف بعدم التأخر إلى ما لا نهاية، وأن تقرر الإدارة التنفيذ في مواعيد معقولة الإدي نكسة

\section{ثانيا: التنفيذ الناقص.}

تساءلت M. Fayolle في رسالتها ألا تطيعه إلا روحا qu'a l'esprit طالما أنها هي الوحيدة المنوط بها قانونا وفنيا كل ما يتعلق بالتنفيذ؟ بإسي

قد تجيب الإدارة بالإيجاب، ولكن يوجد أيضا المحكوم له وهو صاحب مصلحة أيضا ويضره أن يجد ما قضي له به لا ينفذ، إلا جزئيا أو على غير ما أراد الحكم، فالتعسف يجد ملاذه في عدم التنفيذ. وإذا كانت الإدارة تتمتع بسلطة تقديرية في تنفيذ أحكام الإلغاء بصفة خاصة فإنما مقيدة بطبيعة الحال بالقيد العام على تصرفاتما وهو مراعاة المشروعية، وإلا كان

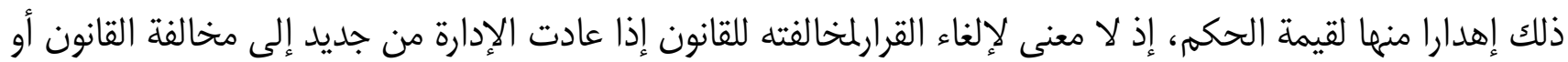
إذا نفذت الحكم تنفيذا صوريا أو مبتورا، وإنما يجب عليها أن تنفذ الحكم تنفيذا صحيحا كاملا مراعية في ذلك ما جاء في

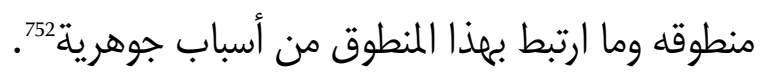

ويتحقق التنفيذ الناقص للحكم الإداري، عندما لا تنفذ الإدارة بعض ما يلزمها به الحكم الإداري الصادر ضدها أو بمعنى آخر عندما لا تراعي بعض الآثار القانونية أو المادية التي يرتبها الحكم عند تنفيذه، فالإدارة وبدلا من الرفض السافر أو التراخي الممل تفضل أن تمكر وتناور لكي تتفادى آثار الشيء المقضي به ضدها وهي للأسف الشديد تتمتع في هذا المجال بخيال خصب توجهرا صعوبات قانونية أو مادية، فإنهم لا ينكرون أن هناك حالات تتخلص فيط فيها الإدارة من التزامها بتنفيذ الأحكام

$749{ }^{749}$ حسني سعد عبد الواحد، تنفيذ الأحكام الإدارية، رسالة دكتوراه،كلية الحقوق، جامعة القاهرة، السنة الجامعية,1984 .ص: 397. 750 : أحمد الصايغ: "إشكالية تنفيذ الأحكام الإدارية"، دراسة تطبيقية الوادية تلفيذ المجلة المغربية لإدارة المحلية والتنمية، العدد 62 سنة 2009، ص: 123. ${ }^{751}$ :Jean Gourdou, «Les nouveaux pouvoirs du juge administratif en matière d'injonction et d'astreinte» revue française de droit administratif. Mars-Avril 1996. p164.

752: كمال الرفاعي، " أصول إجراءات القضاء الإداري"، الكتاب الثاني مكتبة الأنجلو مصرية الطبعة الأولى، 1964، ص: 169.

${ }^{753}$ :Gustave Peiser«Contentieux administratif» Dalloz. Paris 1974. p127.

754 :ODENT RAYMOND «Contentieux administratif»ıInstitut d'Études Politiques de Paris, année 1970-1971,p 1025. 
ثالثا: الرفض الصريح.

إذا ملت الإدارة التباطؤ الرتيب أو عجزت عن المناورة لا يكون أمامها كحصن أخير سوى مجرد الرفض العادي، ومن حسن الحظ أن حالات الرفض الصريح تبقى نادرة بالنسبة للصور الأخرى إلا أنما رغم ذلك خطيرة، والخطورة هنا تبلغ منتماها لأن موقف الإدارة سيؤدي إلى إهدار كل قيمة لأحكام القضاء ${ }^{755 ، ~ و ع ل ى ~ ق د ر ~ ب س ا ط ة ~ ه ذ ه ~ ا ل و س ي ل ة ~ ع ل ى ~ ق د ر ~ م ا ~ ت ت ض م ن ه ~}$ من تحقير صاخخ للأحكام القضائية واستهانة بما لمها من قدسية واحترام، وتفشي هذه الوسيلة من شأنه هدم نظام الرقابة من أساسه وتجريده من كل مميزاته وإضاعة الفائدة منه.

وهناك من الفقهاء من يرى أنه ناذرا ما تلجأ الإدارة المركزيت إلى هذه الوسيلة المكشوفة، وأن غالبية حالات الامتناع التي يكون بهذا الشكل تقع من جانب الريئات المحلية.

ومن الحالات المؤسسة لامتناع الإدارة عن التنفيذ أو الرفض الصريح نجد قضية Fabregue المشهورة، حيث أصدر رئيس بلدية قرار بعزل حارس البلدية السيدفابريك عن عمله بدون وجه قانوني، وتم إلغاء هذا القرار من طرف مجلس الدولة الفرنسي بتاريخ 23 غشت 1909، غير أن رئيس البلدية أعاد إصدار القرار الملغي وتم إلغائه مرة ثانية من طرف مجلس إلس الدولة، وتكرر الإصدار والإلغاء حتى بلغ عشر مرات، وقد انقلبت المسألة - كما بين هوريو - إلى نوع من المبارزة بين المجلس والإدارة

\section{المطلب الثاني: دور القضاء الإداري المغربي في إشكالية تنفيذ الأحكام.} في ظل استفحال ظاهرة عدم تنفيذ الأحكام القضائية الصادرة ضد الإدارة السلبية وعدم فعالية وجدوى الوسائل المستمدة من القانون الإداري، فقد عمل القاضي الإداري على البحث عن وسائل جديدة لجبر الإدارة على التنفيذ، مستندا في ذلك على الإحالة المنصوص عليها بالمادة 7 من قانون المحاكم الإدارية، وقد أقر إمكانية اعتماد الغرامة التهلديدية والحجز الإدئ على الأموال الخاصة للإدارة الممتنعة عن التنفيذئ.

\section{الفقرة الأولى: دور الغرامة التهديدية في حمل الإدارة على تنفيذ الأحكام الصادرة ضدها.} تجد الغرامة التهديدية أساسما القانوني في المادة 7 من القانون رقم 41/90 والفصل 448 من ق.م.م.فما المقصود بالغرامة التهلديدية؟ وما هي خصائصما؟ وما هي شروط الحكم بها؟ وما مدى إمكانية اعتمادها في مواجهة الإدارة الضريبية في حالة امتناعها عن التنفيذ؟

\section{أولا: تعريف الغرامة التهديدية وخصائصها.}

اختلف الفقه والقضاء حول تعريف محدد للغرامة التهلديدية أو الإكراه المالي، إذ يعرفها بعض من الفقه بأنها عقوبة مالية تبعية تحدد بصفة عامة عن كل يوم تأخير، يصدرها القاضي بقصد ضمان حسن تنفيذ حكمه أو حتى بقصد ضمان

755: سليمان الطماوي، "القضاء الإداري الكتاب الثاني قضاء التعويض"، سنة 1977، دار الفكر العربي، ص 153. 756 : حسني سعد عبد الواحد، تنفيذ الأحكام الإدارية، مرجع سابق، ص ص

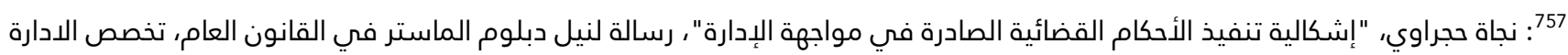
المحلية، كلية العلوم القانونية والاقتصادية والاجتماعية، جامعة الحسن الأول، سطات، سنة 2009-2010، ص 93. 
تنفيذ أي إجراء من إجراءاتهات. وعرفهيا البعض الأخر بأنها وسيلة التي يلزم بها القاضي المدين بتنفيذ التزاماته عينا خلال

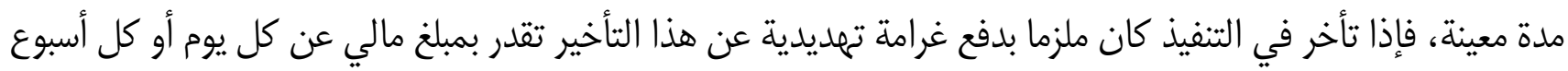

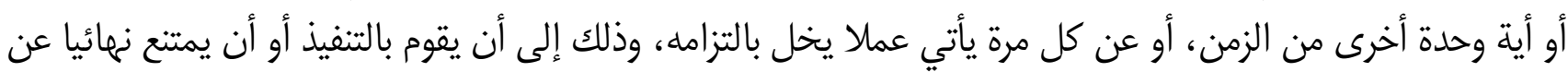
الإخلال بالالتزام

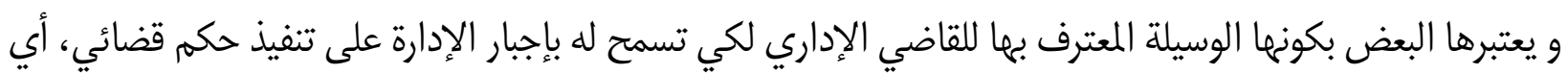

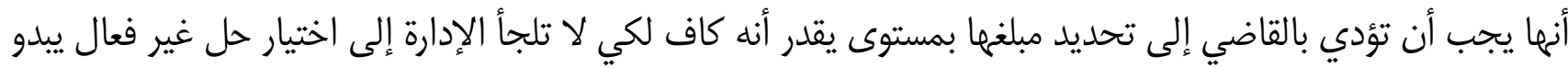

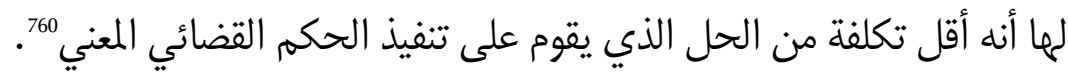
عرفت محكمة النقض الفرنسية الغرامة التهديدية بأنها وسيلة إكراه مختلفة كل الاختلاف عن التعويض، وهي ليست

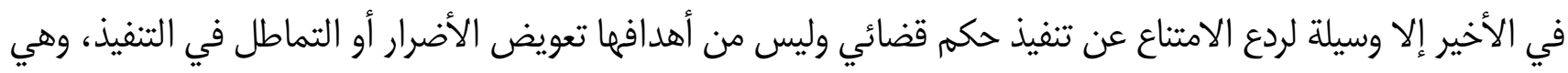

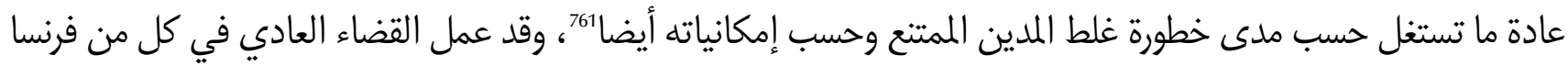
ومصر على وضع قواعد الغرامة التهديدية قبل أن يته تقنينها من قبل المشرع.

و في المغرب فإن الغرامة التهلديدية نظام أقره القانون منذ العمل بالمسطرة المدنية في 1913، إلا أنه لهم يحدد تعريفا

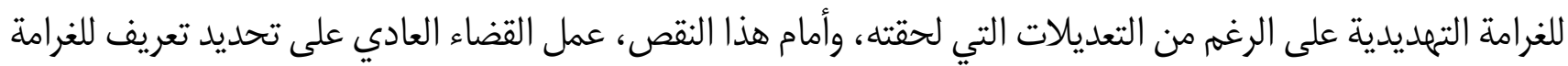

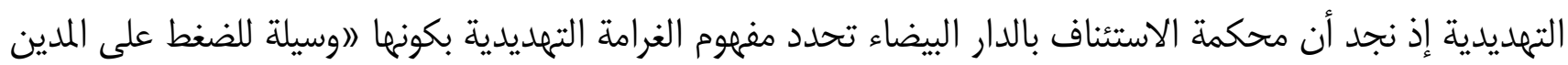

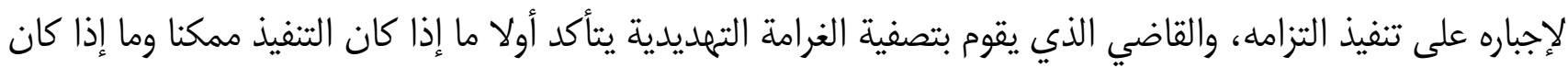

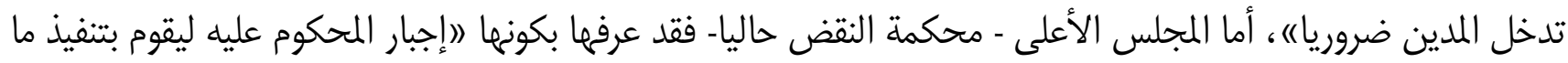

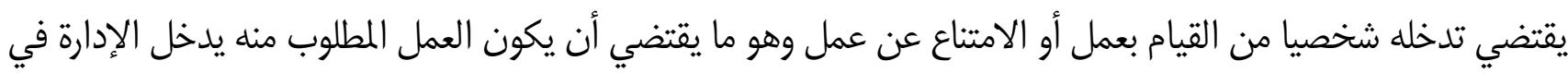

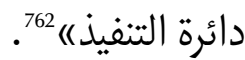

\section{ثانيا: خصائص الغرامة التهديدية.}

- وسيلة لإجبار الإدارة على التنفيذ عن طريق القضاء.

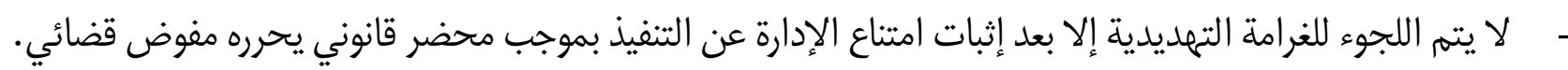

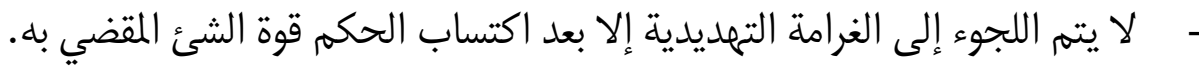

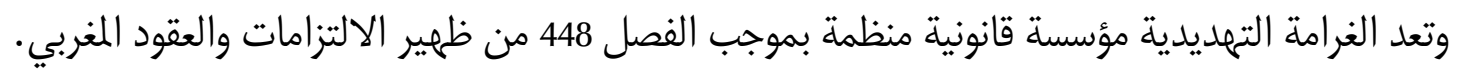

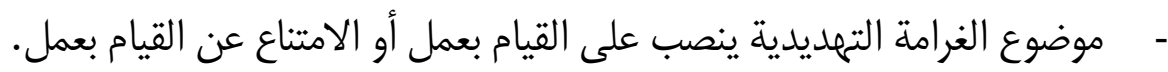

758: أحمد الصايغ، " الغرامة التهديدية كوسيلة لتنفيذ الأحكام القضائية الإدارية" ، مرجع سابق، ص 24. 759: عبد الرزاق أحمد السنهوري، "الوسيط في شرح القانون المدني الجزء الثاني"، دار النهضة العربية القاهرة، الطبعة الثانية، سنة 1967، ص807.

760 :Jean François, «Les grandes décisions de la jurisprudence- droit administratif» - PUF - 1999 p : 555.

761: أدولف ريولط / ترجمة إدريس ملين، "المسطرة المدنية في شروح"، منشورات المعهد الوطني لدراسات القضاء، طبعة 1990، ص 531 : 307. 762: قرار عدد 531 بتاريخ 22 فبراير 1989، منشور بمجلة قضاء المجلس الأعلى، عدد مزدوج 42-43. 40. سنة الطبع 1989،منشورات مركز النشر و 
- تعد الغرامة التهلديدية إجراء وقتي لا تنتهي إلا بتنفيذ المدين أو إنهاء الالتزام.

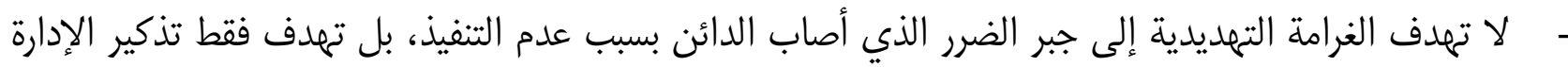
بالتزاماتها الأساسية المتمثلة في احترام مضمون قوة الشيء المقضي به.

\section{الفقرة الثانية: إمكانية الحجز على الممتلكات الخاصة للإدارة لتنفيذ مقتضى الحكم.}

يعتبر الحجز على الأموال صورة من صور التنفيذ الجبري المعمول بها في إطار القانون الخاص، وإذا كان المبدأ العام

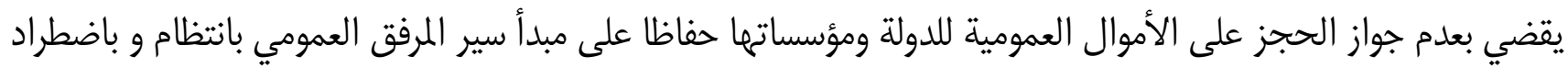
من جهة، ولكون هذه الأموال محاطة بحماية قانونية تمنع التصرف فيها من جهة ثانية. وهذا لم يمنع من بروز اتجاه فقهي واجتماد قضائي يسمح بإمكانية الحجز على أموال الدولة الخاصة بعد فصلما عن

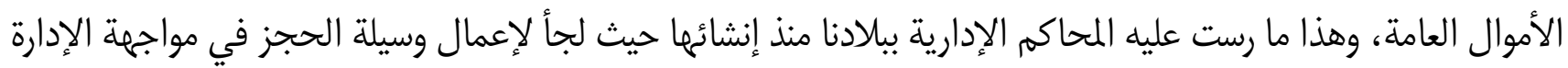
الممتنعة عن التنفيذ لضمان الحقوق والحريات الأفراد ، كما كرس إجراء الحجز التنفيذي اتجاه الإدارة الممتنعة عن التنفيذ، والذي ينصب على المنقولات والعقارات التي تدخل ضمن الأملاك الخاصة المملوكة للإدارة على اعتبار أن هذه الأموال لا تخصص للمنفعة العامة واستعمال الجمهور، وبالتالي فإجراء الحجز عليها لن يعرقل سير المرفق العمومي. ونظم المشرع المغربي الحجز لدى الغير 763 في الباب الثالث من قانون المسطرة المدنية، إذ نص الفصل 488 على أنه: (ايمكن لكل دائن ذاتي أو اعتباري يتوفر على دين ثابت إجراء حجز بين يدي الغير بإذن من القاضي على مبالغ و مستندات لمدينه و التعرض على تسليمها له ها .

والمشرع لم يحدد تعريفا للحجز لدى الغير ${ }^{764}$ بل اكتفى بتنظيم هذا الحجز وتحديد إجراءاته، وترك مهمة تحديد ووضع التعاريف والمصطلحات القانونية والمفاهيم القضائية للفقه والقضاء 765 يقصد بالحجز لدى الغير تلك المسطرة التي ترمي إلى عقل أموال المدين بين يدي هذا الأخير إما بواسطة كتابة الضبط بناء على سند تنفيذي، أو بناء على طلب عند عدم وجود هذا السند، على أن يطالب الحاجز باستخلاص المبالغ المحجوزة مباشرة أو تسليمه نتاج بيع الأشياء المحجوزة لمبكئ. إذا كان الحجز لدى الغير من وسائل التنفيذ الجبرية في القانون الخاص، فإن القاضي الإداري لم يتوانى عن إعمال هذه الوسيلة في مواجهة الإدارة الممتنعة عن تنفيذ الأحكام الصادرة ضدها وخصوصا في مجال التعويض، مستندا في ذلك على إحالة القانون رقم 90/41 على قانون المسطرة المدنية في مجال التنفيذ.

763 : أحمد الصايغ، "إشكالية تنفيذ الأحكام الإدارية بالمغرب"، مرجع سابق، ص 234.

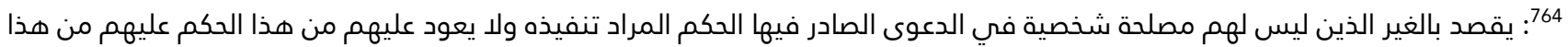
الحكم نفع أو ضرر ولم يكونوا بين في الخصومة بأشخاصهم أو أشخاص غيرهم: للاستزادة انظر مجلة الإشعاع، العدد 28، فبراير 2004، ص

(تحديد الهامش في المتن) 765: عزيز الفرحاني، لحسن المرضي، "مسطرة الحجز لدى الغير في التشريع المغربي"، بحث نهاية تدريب الملحقين القضائيين بالمعهد العالي للقضاء، الفوج 32 سنة 2004، صرير 5. 766: محمد بذيدي، "الحجز لدى الغير"، الندوة الأولى للعمل القضائي والبنكي، منشورات المعهد الوطني للدراسات القضائية والمجموعة البنكية في المغرب - دجنبر 1987، صديد 80. 
ويعد الأمر الصادر عن المحكمة الإدارية بالرباط بتاريخ 23 أبريل 1997 تحت عدد 99 من الأحكام المؤسسة في هذا

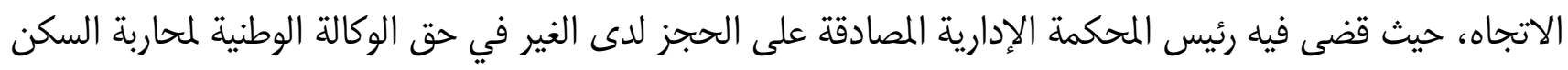

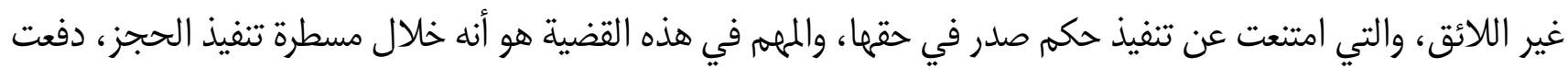

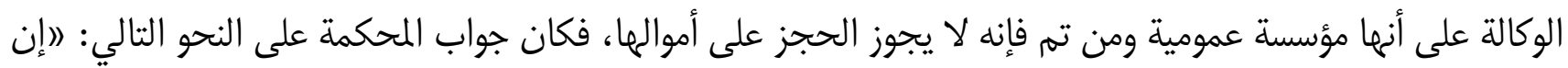

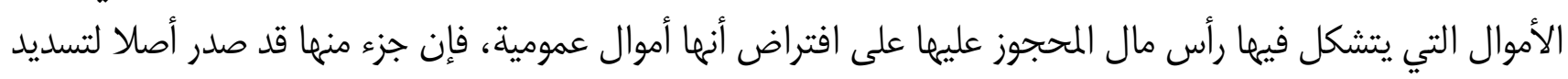

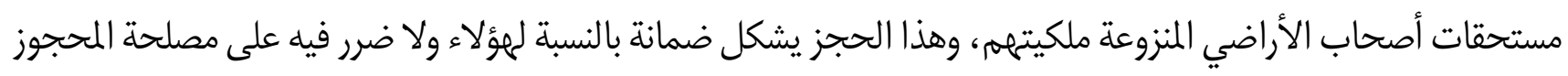
عليهاها. ويمكن اعتبار هذه القاعدة بمثابة إحدى الضمانات التي من شأنها صيانة حقوق أصحاب الأراضي المنزوعة ملكيتهم

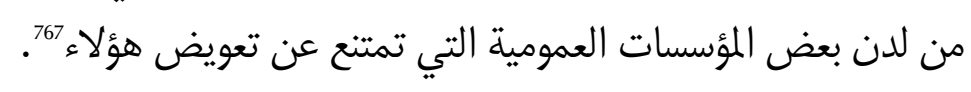

و يلاحظ الأمر القضائي الصادر عن المحكمة الإدارية حصر إمكانية الحجز لدى الغير على أموال نازعي الملكية، إذا

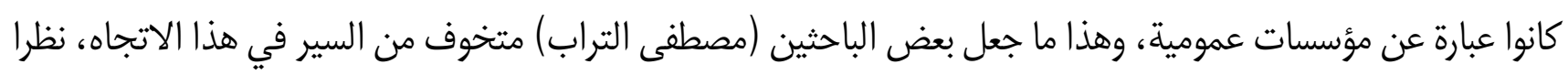

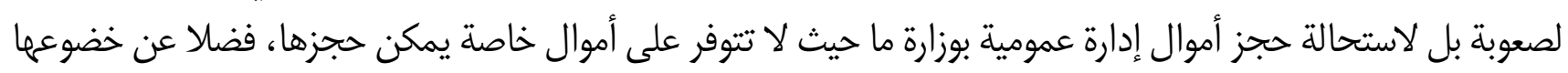
لنظام المراقبة المالية والمحاسبة العمومية.

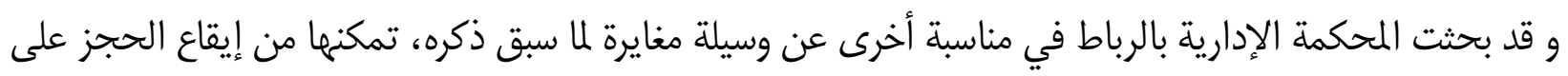

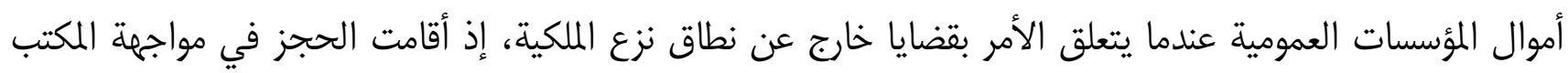

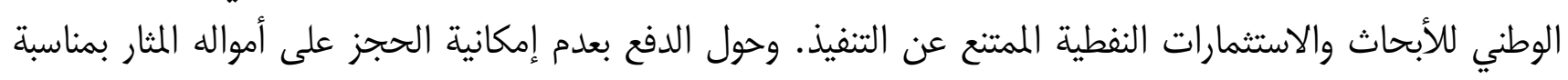

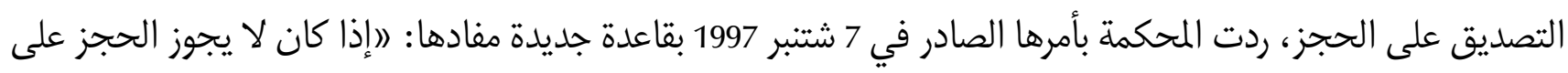

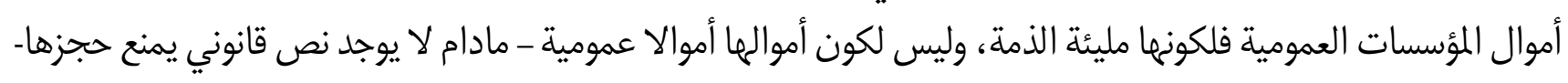

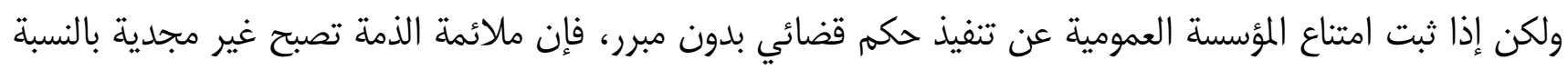

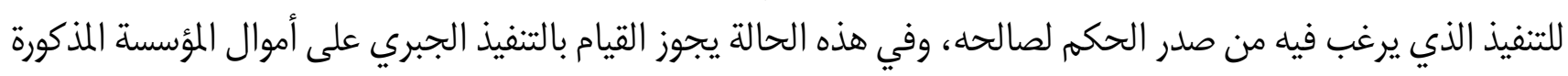

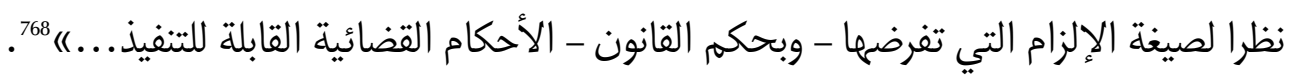

\section{الخاتمة.}

مما سبق يمكن القول أن الإدارة ونظرا للامتيازات التي تتوفر عليها غالبا ما تتهرب من تنفيذ الحكم القضائي الحائز

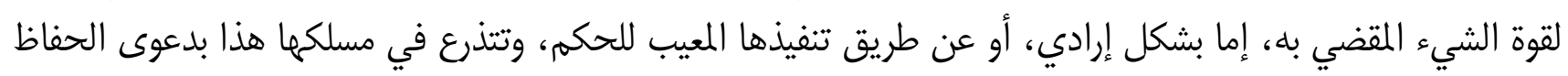

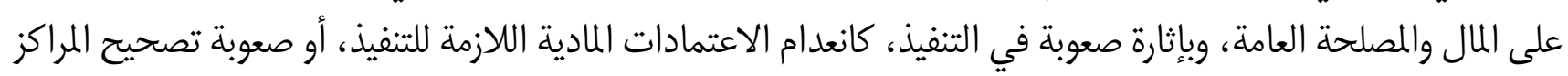
القانونية المتضررة، إلى غير ذلك من الصعوبات التي تعرض على القضاء وتؤدي إلى وقف تنفيذ الأحكام إلى حين البت فيها.

767 : مصطفى التراب، "إشكالية تنفيذ الأحكام الإدارية"، مجلة القصر، العدد 11، ماي 2005، ص 91 و92.

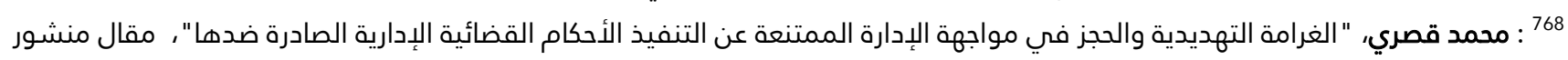

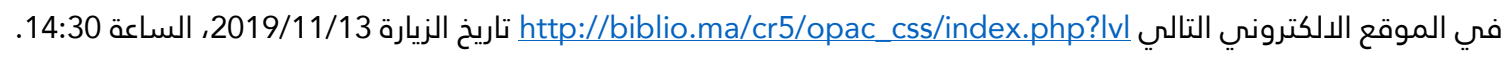


ففي حالة إصرار الإدارة على الامتناع عن التنفيذ نجد أن القاضي الإداري لا يملك أية آلية مادية يستطيع من خلاللها

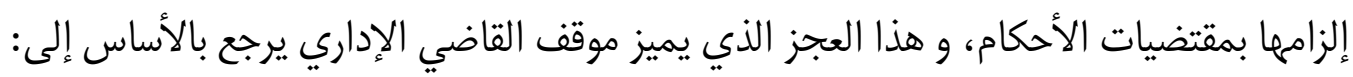
ضعف سلطته القاضي الإداري في توجيه الأوامر للإدارة في حالة مخالفتها لمنطوق حكمه وكذا تبيان الآثار التنفيذية

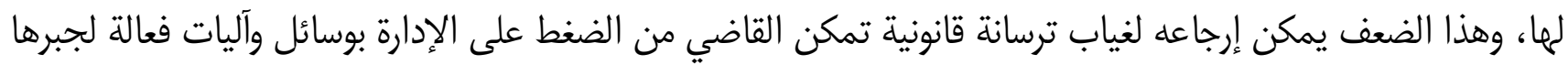

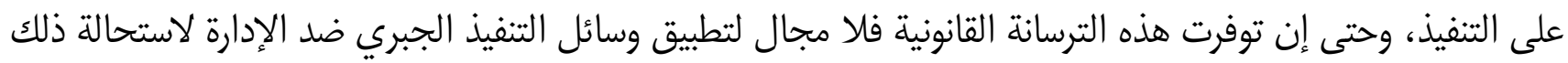
عمليا في بعض الحالات. 


\title{
اختصاص المركز الدولي لتسعية منازعات الاستثمار
}

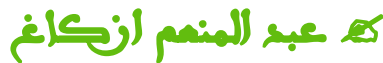 \\ طالب باحث بسلك الدكتوراه بكلية الحقوق السويسي \\ جامعة محمد الخامس الرباط
}

إذا كان المشرع المغربي قد جعل اللجوء إلى مقاولات التشغيل المؤقت من أجل إبرام عقود شغل مؤقتة في حالات محددة على سبيل الحصر حسب مقتضيات المادة 496 من مدونة الشغل المغربية، فإن ذلك لا لإيفيد أن هذه الصفة الإستثنائية

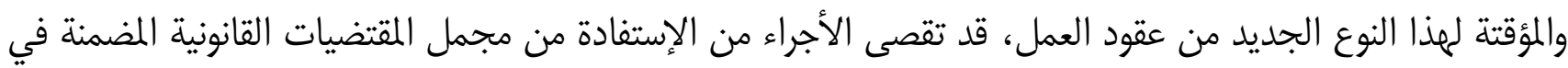

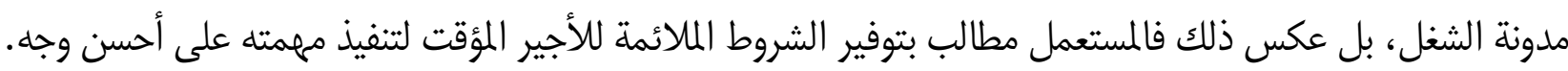
وفي هذا الصدد، وباعتبار عقد الشغل المؤقت عقد مركبا يجمع في طياته عقدين؛ عقد المهمة وعقد الوضع رهن الإشارة،

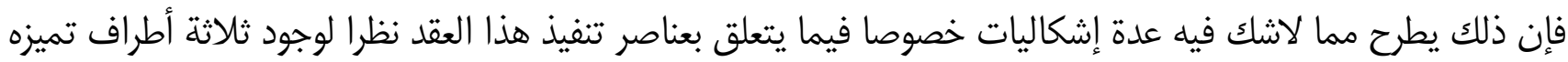

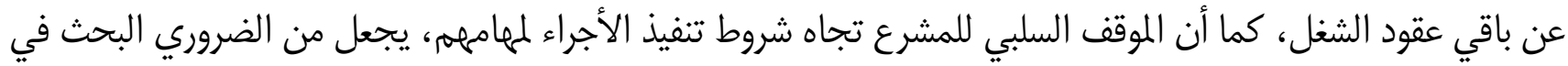

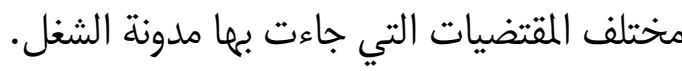

كما أنه لابد من التأكيد على أن تطبيق قانون الشغل، لا يتحقق إلا بمراقبة فعالة تتأرجح غالبا بين السلطتين؛ التاني

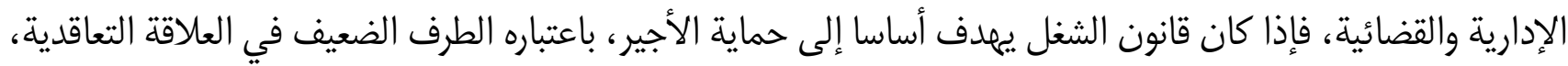

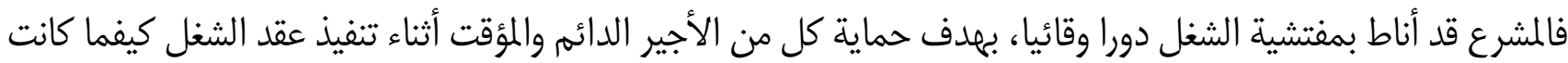

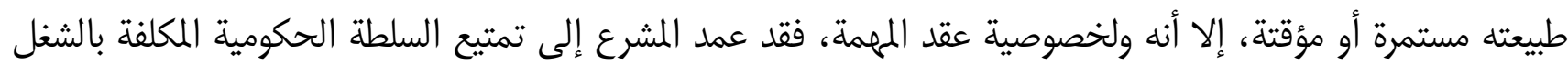

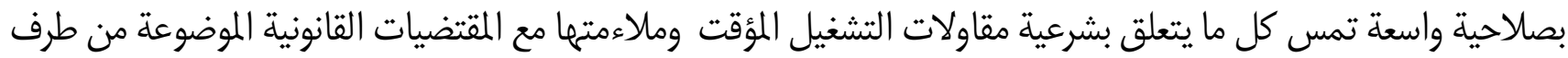

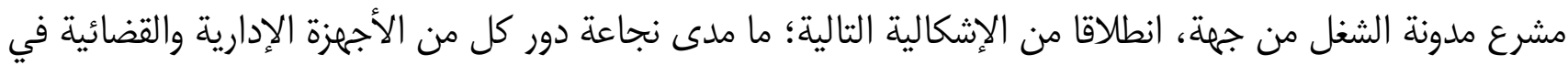
حماية الأجير المؤقت عند انتهاء مهمته؟ من جهو، النطاء للإِجابة عن الإشكالية المطروحة ارتأينا تقسيم خطة بحثنا إلى محورين وفق التصميم التالي: المحور الأول: حماية الأجير المؤقت عن طريق الأجهزة الإدارية المكلفة بسوق الشغل

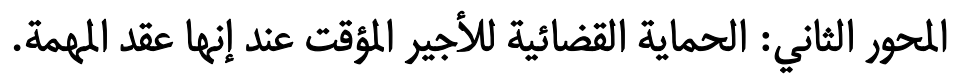

المحور الأول: حماية الأجير المؤقت عن طريق الأجهزة الإدارية المكلفة بمراقبة سوق الشغل إن التطبيق السليم لمتلف المتتضيات الخاصة بعقود الشغل المؤقتة، متوقف على مدى الفعالية والصلاحيات المنوظة

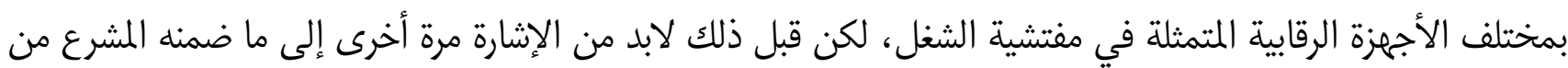
اختصاصات للسلطة الحكومية المكلفة بالشغل. 


\section{المطلب الأول: دور السلطة الحكومية المكلفة بالشغل .}

حسب المادة 10 من الاتفاقية الدولية رقم 181 لسنة 1997 1990 والخاصة بوكالات التشغيل الخصوصية، فالدول المصادقة على هذه الأخير ملزمة بإيجاد آليات وإجراءات ملائمة يشارك فيها عند الاقتضاء المنظمات الأكثر تمثيلا لأصحاب العمل والعمال من أجل التحقيق في الشكاوي والتجاوزات المتعلقة بأنشطة وكالات التشغيل الخاصة. كما أن المادة 14 من نفس الاتفاقية تحث على ضرورة اتخاذ السلطات المختصة لتدابير تصحيحية ملائمة بما في ذلك توقيع العقوبات عند الاقتضاء وتنفيذها تنفيذا فعالا في حالة انتهاك أحكام هذه الاتفاقية.

في هذا الإطار ألزمت المادة 477 من مدونة الشغل الراغب في إنشاء أي نوع من أنواع الوكالات الخصوصية، ومنها بطييعة الحال مقاولات التشغيل المؤقت، ضرورة الحصول على ترخيص مسبق من لدن السلطة الحكومية المكلفة بالشغل ان ما يمكن أن يضمن حقوق الأجراء المؤقتين مبدئيا، هو ما ألزمت به المادة 482 من مدونة الشغل، من وجوب إيداع كفالة مالية لدى صندوق الإيداع والتدبير يساوي مبلغما 50 مرة القيمة الإجمالية السنوية للحد الأدنى للأجر. في هذا الصدد، تقضي المادة 487 على أن السلطة الحكومية المكلفة بالتشغيل بإمكانها سحب الإذن بالممارسة بقرار معلل ودون تعويض، مما يفيد طابع التعقيد الذي يتميز به هذا الإذن، إذ أن هذه المادة أعطت للسلطة الإدارية صلاحيات تمس استمرار نشاط مقاولة التشغيل المؤقت، غير أن عمومية هذه المادة يفهمم منها؛ أن كل مقاولة مستوفية لشروط إنشائهبا، تكون مهردة بسحب الترخيص الممنوح لها والخاص بمزاولة نشاط التشغيل المؤقت؛ في حالة مخالفتها للمقتضيات القانونية التي تكون لا محالة الدافع إلى سحبه أو عدم إعطاءه منذ البداية، هذا الإجراء وباعتباره خاضعا للسلطة التقديرية للسلطات المختصة، إلا أنه في هذه الحالة تبقى إمكانية حق لجوء المقاولة إلى القضاء الإداري في شقه المتعلق بدعاوي الإلغاء إما بسبب نقصان أو انعدام التعليل، وكذلك بسبب الشطط في استعمال السلطة، في إطار القانون رقم 41.90 المحدث للمداء إلماكم الإدارية، دون إغفال المقتضيات القانونية الملزمة في إطار المراقبة المستمرة لنشاط مقاولات التشغيل المؤقت التي جاءت بها المادة 488 من مدونة الشغل.

وفضلا عن ذلك، فقد عزز المشرع الحماية البعدية للأجراء هذه المقاولات، بالزمها بإمساك سجل 771 خاص وفق نموذج محدد من قبل السلطة الحكومية المكلفة بالشغل، قصد إجراء المراقبة الضرورية للتحقق من احترامها للمقتضيات القانونية حسب ما هو منصوص عليه في المادة 486 من المدونة.

769- تجدر الإشارة إلى أن المغرب صادق على هذه الاتفاقية بتاريخ 10 ماي 1999 بظهير شريف رقم 8-89-1 صادر في 2 جمادى الآخرة 1421. 770 770

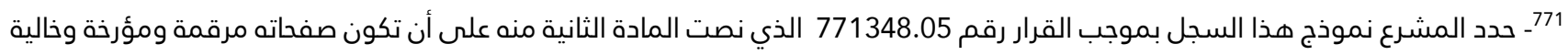
من كل فراغ أو تشطيب ومؤشر عليها من قبل العون المكلف بتفتيش الشغل، وأن تختم صفحاته بخاتم المندوبية المكلفة بالشغل. صادر في 19 من ذي الحجة 1425 (الموافق ل 9 فبراير 2005) بتحديد نموذج السجل الذي تمسكه وكالات التشغيل الخصوصية، منشور بالجريدة الرسمية عدد 3500 بتاريخ 6 صفر 1426 (17 مارس 2005) ص 993. 
بما أن وكالات التشغيل المؤقت لها الحق أيضا في إبرام عقود الشغل للعمل بالخارج فهي تخضع للمادة 489 من مدونة

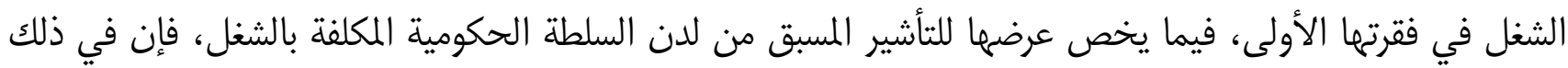
بالتأكيد مراقبة فعالة لحركية اليد العاملة المهاجرة.

وهكذا يتبين أن إدخال السلطة الحكومية المكلفة بالشغل في مراقبة مجال عمل مقاولات التشغيل المؤقت، يشكل أحد

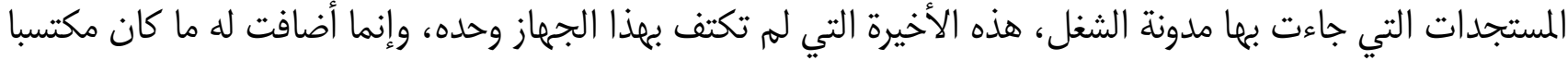
من خلال اختصاص جهاز مفتشية الشغل والذي سيكون محور المطلب الموالي.

\section{المطلب الثاني: دور جهاز مفتشية الشغل.}

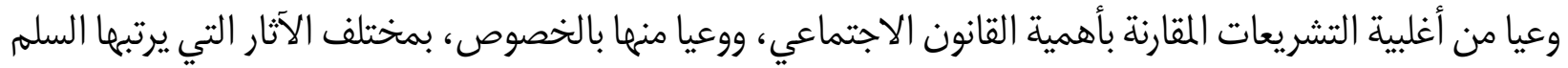

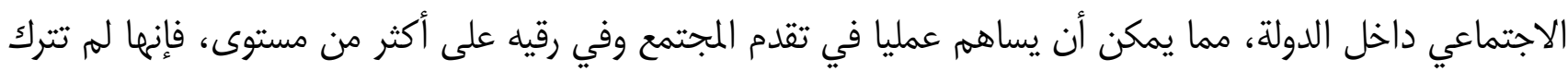

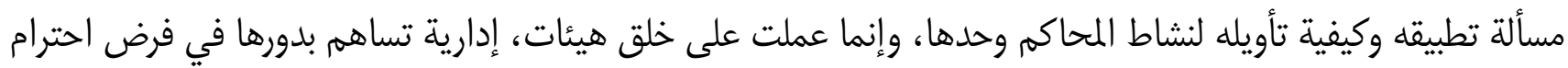

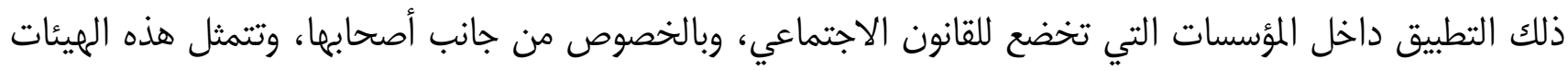

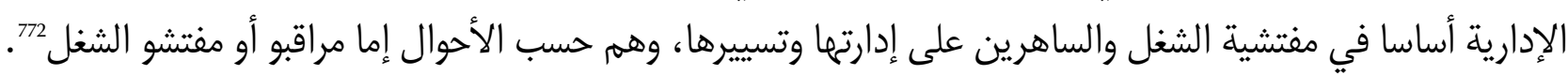
تعد مقتضيات مدونة الشغل بمثابة المصدر الرئيسي لاختصاصات ومهام مفتشي الشغل773، بحيث يضطلعون بمهام

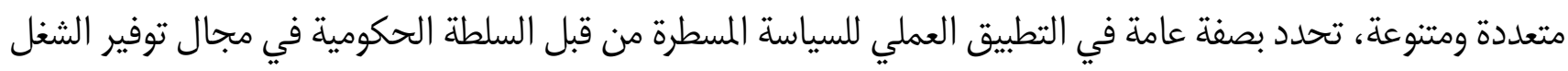

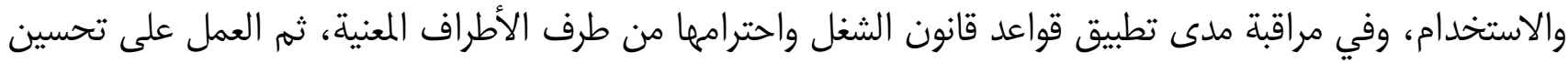

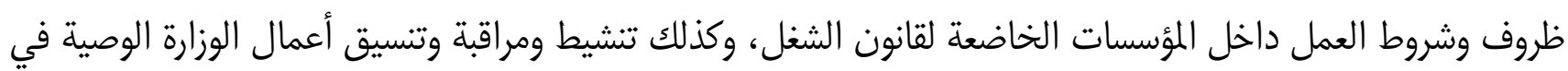

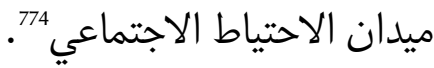

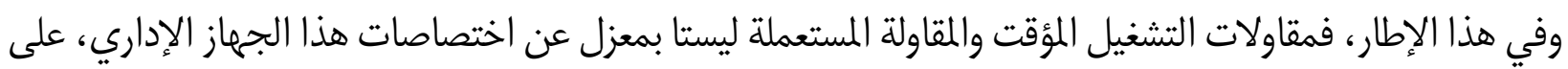

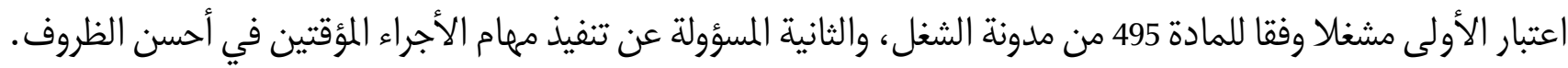

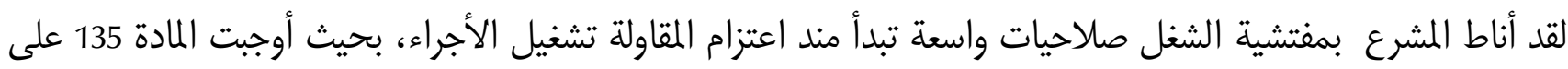
تقديم تصريح بذلك إلى العون المكلف بتفتيش الشغل. كما أن المشغل ملزم بتقديم تصريح مماثل للتصريح الوارد ذكره في المادة 135 في أحوال محددة، منها الحالة التي

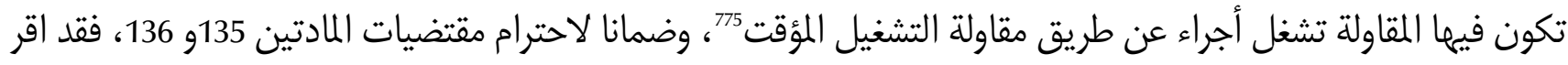
المشرع جزاء في حالة مخالفة أحكامها بغرامة من 2000 إلى 5000 درهم حسب المادة 137 من مدونة الشغل

772- محمد الكشبور: "نظام تفتيش الشغل، الواقع الحالي وآفاق المستقبل"، دار النشر غير مذكور، الطبعة الأولى 1997، ص 11-12. 773- لضمان حسن تطبيق مقتضيات قانون الشغل والنصوص التنظيمية الصادرة لتنفيذه، حددت المواد من 530 إلى 548 من المدونة للأجهزة

المراقبة. 774- عبد اللطيف خالفي: " الوسيط في مدونة الشغل"، الجزء الأول، علاقات الشغل الفردية، المطبعة و الوراقة الوطنية، مراكش، الطبعة

الأولى، ص 135. 775- البند السادس من المادة 136 من مدونة الشغل " 6 - إذا كانت المقاولة تشغل أجراء عن طريق مقاولة التشغيل المؤقت" . (776 - هذه الغرامة في نظرنا هي عقوبات محتشمة. 
أن المادة 506 من مدونة الشغل؛ قد أوجبت على وكالات التشغيل الخصوصية التي كانت تباشر نشاطها قبل صدور مدونة

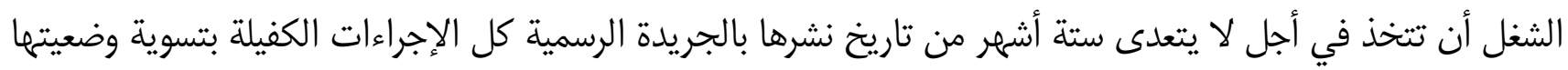

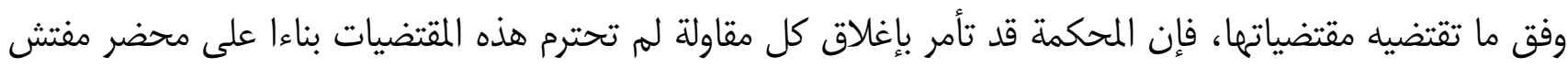
الشغل. وفي هذا الإجراء حماية فعالة من المشرع للأجير المؤقت، وتأكيد على تعامله مع وكالة تشغيل التي تحترم المتتضيات

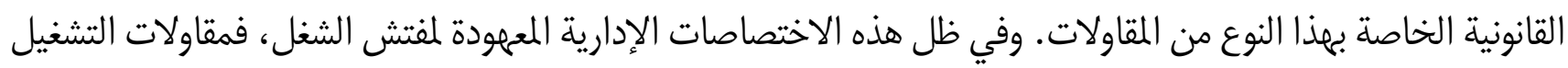

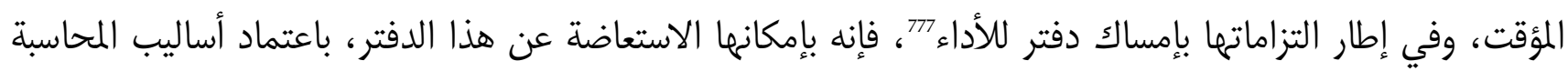

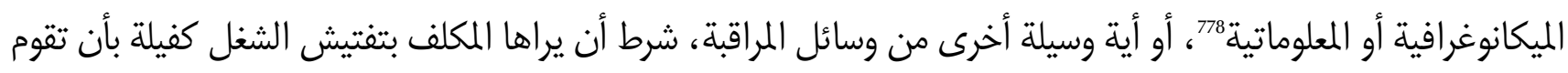
مقام ذلك الدفتر

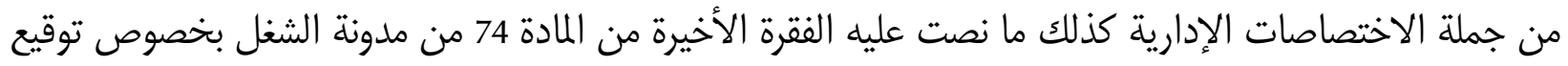

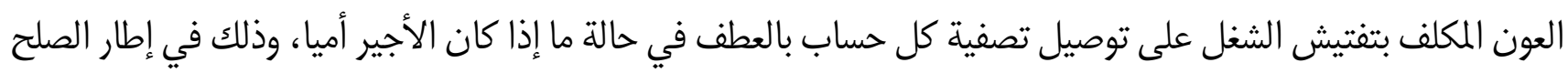
المنصوص عليه في المادة 532 من مدونة الشغل. وإذا كان يجب على مقاولة التشغيل المؤقت باعتبارها المسؤولة عن أداء أجور الأجراء المؤقتين وفق أحكام المادة 396 من المن الماء

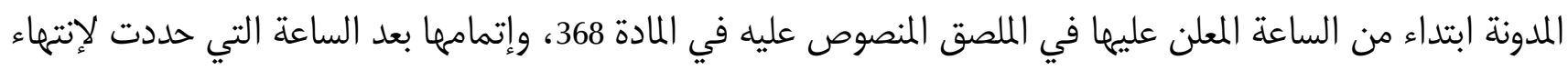

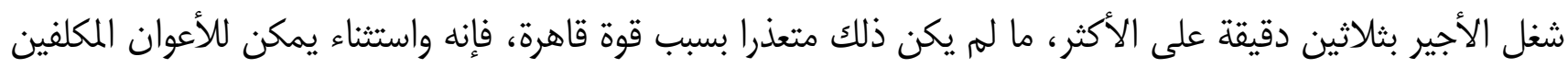

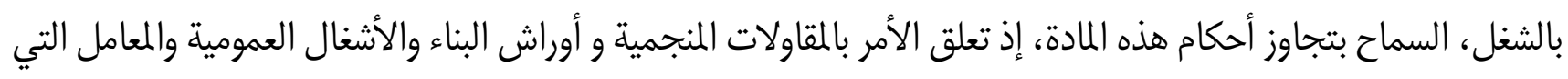
تشتغل باستمرار، وبالمقاولات التي يشتغل فيها أكثر من مائة أجير.

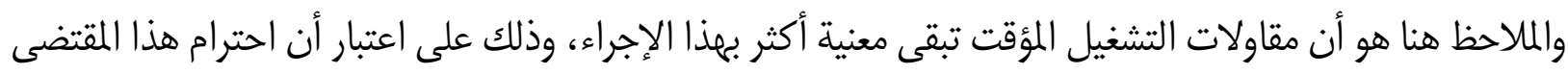

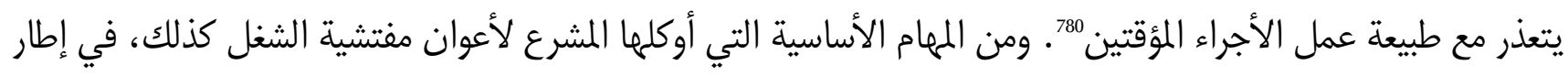

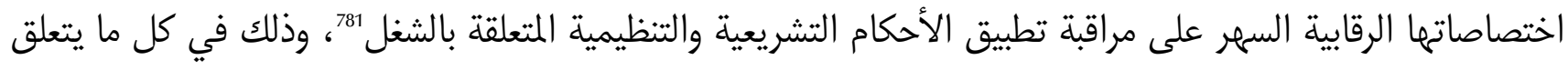

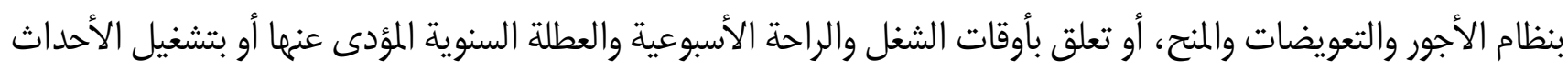

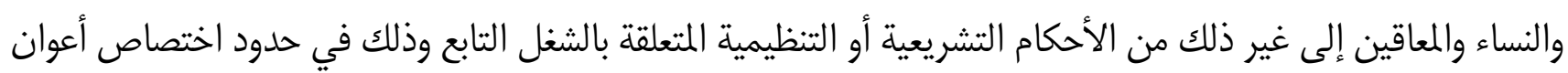
التفتيش

777 - المادة 371 من م، ش، م. -هشام بوتكيوط : "الحماية القانونية للأجراء في عقود الشغل المؤقتة"، رسالة لنيل دبلوم الماستر، كلية العلوم القانونية و الاقتصادية

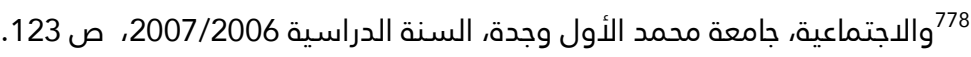

779- المادة 372 من مدونة الشغل المغربية.

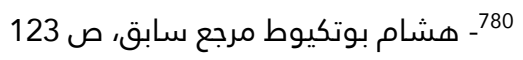
781- الفقرة الأولى من المادة 532 من م ش م" تناط بالأعوان المكلفين بتفتيش الشغل مردو المهام التالية: - السهر على تطبيق الأحكام التشريعية والتنظيمية المتعلقة بالشغل؛..." 782- عبد اللطيف خالفي، الوسيط في مدونة الشغل الجزء الأول، م، س، ص 135. 
وقد ألزمت المادة 532 من المدونة في فقرتها الثانية مفتشي الشغل" بإحاطة السلطة الحكومية المكلفة بالشغل، علما

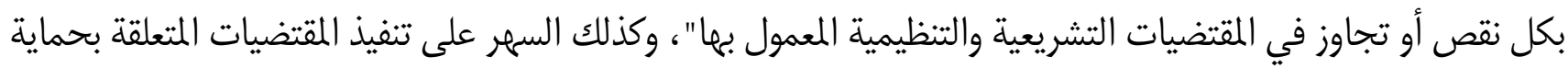
صحة وسلامة الأجراء ووقايتهم من حوادث الشغل والأمراض المهنية، وإعطاء المشغلين والأجراء معلومات ونصائح تقنية حول أنجح الوسائل لمراعاة الأحكام القانونية.783.

من أجل تكريس هذه المتتضيات الموكولة للأعوان التفتيش فلمه أن يدخلوا بحرية ودون سابق إعلام لكل مقاولة

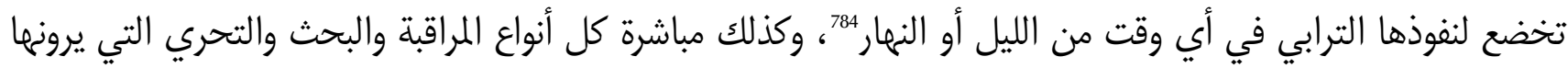

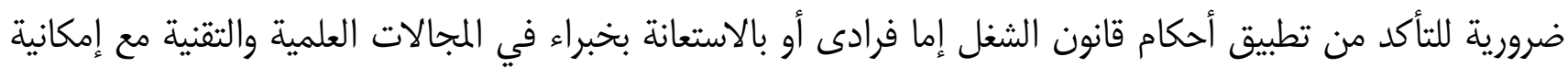

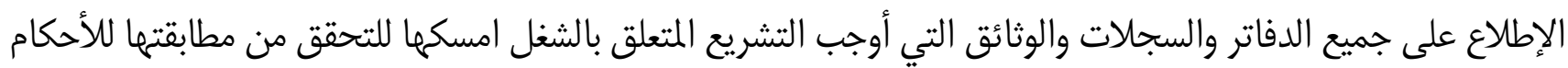

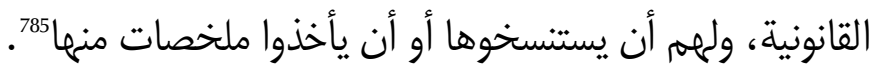

هكذا يمكن القول، أن كل هذه الاختصاصات كانت مسندة إلى هذا الجهاز في إطار التشريع السابق عن المدونة

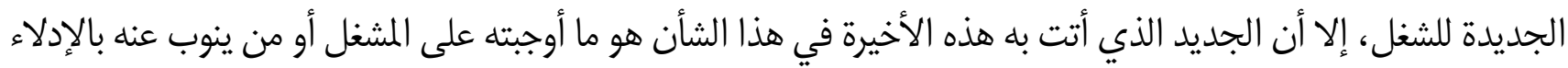

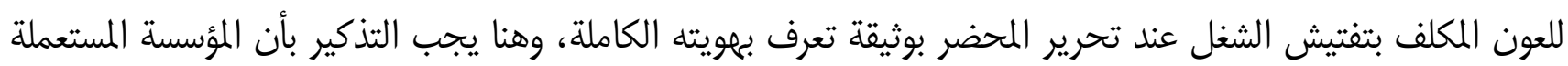

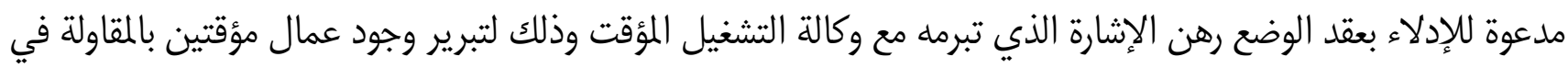
حالة مخالفة المقاولة المستعملة لمتتضيات المدونة.

وتحقيقا لمطالب الفقه المغربي 786، فقد سلك المشرع المغربي مسطرة بسيطة نوعا ما في إطار ضبطه للمخالفات، فإذا

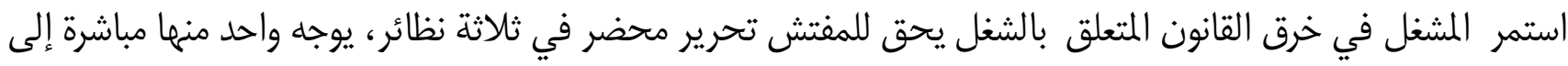

783- الفقرة الثانية من 532 من م ش م"- إعطاء المشغلين والأجراء معلومات ونصائح تقنية حول أنجع الوسائل لمراعاة الأحكام القانونية؛ 784- الفقرة الأولى من المادة 533 من م ش م" يرخص للأعوان المكلفين بتفتيش الشغل، إذا كانوا يحملون الوثائق التي تثبت المهام الموكولة

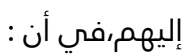

1 - يدخلوا بحرية، ودون سابق إعلام كل مؤسسة تخضع لمراقبة مفتشية الشغل،في أي وقت من ليل أو نهار؛..."

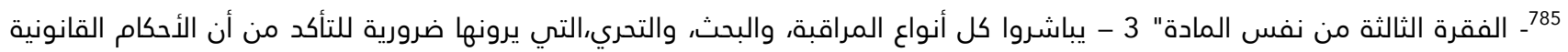
والتنظيمية مطبقة فعلا,إما فرادى، أو بالاستعانة بخبراء في المجالات العلمية والتقنية كالطب والهندسة والكيمياء. ويمكن لهم بصفة خاصة

أ) يستفسروا المشغل أو أجراء المؤسسة، على حدة أو بحضور شهود، حول جميع الشؤون المتعلقة بتطبيق الأحكام القانونية والتنظيمية المتعلقة بالشغل؛ ب) يطلبوا الإطلاع على جميع الدفاتر، والسجلات، والوثائق، التي أوجب التشريع المتعلق بالشغل مسكها، ليتحققوا من مدى مطابقتها للأحكام القانونية، ولهم أن يستنسخوها، أو أن يأخذوا ملخصات منها؛ ج) يأمروا بإلصاق الإعلانات التي توجب الأحكام القانونية عرضها على الأنظار، وبوضع ملصقات تدل على اسم وعنوان العون المكلف بتفتيش الشغل لدى المؤسسة؛ د) يأخذوا معهم وفق الشروط المنصوص عليها في النصوص التنظيمية الجاري بها العمل، عينات من المواد الأولية، ومن المواد التي يستعملها

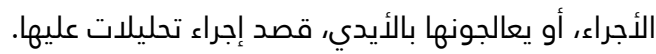
تجرى هذه التحليلات على نفقة المشغل، ويتم إخطاره بنتائج تلك التحليلات. 786 عبد اللطيف خالقي: "الوسيط في مدونة الشغل علاقات الشغل الفردية"، م، س، ص، صدئ 112

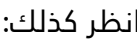


المحكمة المختصة من قبل المندوب الإقليمي المكلف بالشغل، والثاني إلى مديرية الشغل بالمصالح المركزية، ويحتفظ بالثالث في الملف الخاص بالمؤسسة المنصوص عليه في المادة 539 من مدونة الشغل 787.

غير أنه لا يمكن للعون المكلف بتفتيش الشغل أن يحرر محضر ضبط في حال مخالفة قواعد الصحة والسلامة ذات الخطر غير الحال، إلا بعد انصرام الأجل المحددة للمشغل في تنبيه يوجهه إليه مسبقا، والذي لا يمكن بأي حال أن يقل عن أربعة أيام، أما إذا كان في تلك المخالفة ما قد يعرض الأجراء لخطر حال، فيجب على المفتش تنبيه المشغل باتخاذ جميع التدابير اللازمة فورا، وإذا رفض وأهمل هذا الأخير أو من يمثله الامتثال للأوامر فورا، وإذا رفض فالعون المكلف بالتفتيش يوجه فورا لرئيس المحكمة الابتدائية بصفته قاضيا للأمور المستعجلة محضر يثبت فيه امتناع المشغل عن الامتثال لمضمون هذا التنبيه 788، ونتيجة لذلك يأمر رئيس المحكمة الابتدائية بكل التدبير الملائمة لإيقاف الخطر الحال، وله أن يمنح المشغل

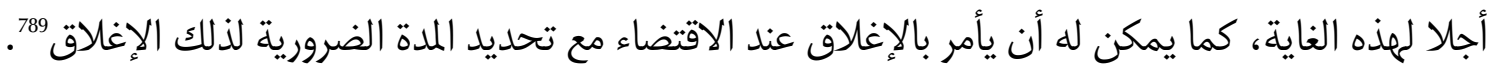

الحقيقة أنه، وفي ظل هذه المقتضيات الخاصة بالحفاظ على سلامة الأجراء من الأخطار الحالة أو غير الحالة التي

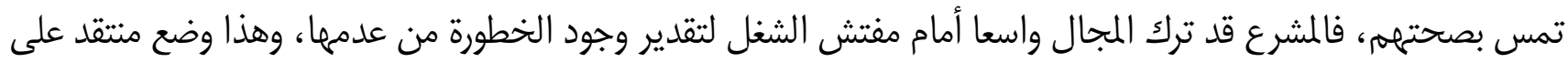
اعتبار أنه كان من الممكن تحديد لائحة تبين القواعد أو الإجراءات التي عند مخالفتها، يمكن تكييفها بأنها تشكل خطورة أم لا، مما يجرنا في مجمل القول كذلك للحديث عن مدى إمكانية تفعيل مفتش الشغل للمادة 497 من المدونة والتي تمنع اللجوء إلى أجراء مقاولة التشغيل المؤقت من أجل إنجاز أشغال تكتسي خطورة خاصة، فالمعول عليه هو جهاز مفتشية الشغل في إطار المادة 542 من المدونة لحماية الأجير المؤقت من ما يمكن أن يهرد صحته في مكان العمل. كما أنه لابد من الإشارة إلى وظيفة المصالحة، التي وإن كانت نابعة من العمل اليومي لمفتش الشغل بفعل احتكاكه بأرباب العمل والأجراء؛ من خلال زيارات التفتيش فإنها تلعب دورا كبيرا في الحفاظ على السلم الاجتماعي، باعتباره الرهدف المتوخى من وراء وضع التشريعات الاجتماعية

- عبد العزيز العتيقي: "محاضرات في القانون الاجتماعي المغربي"، مكتبة المعارف الجامعية، فاس، سنة 1991/ 1992، ص245. - لماني سعيد، دور مفتشية الشغل في تطبيق قانون الشغل، مجلة المرافعة، العدد 2-3 ماي 1993 صـ ص 299.

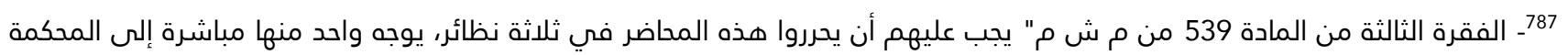
المختصة من قبل المندوب الإقليمي بالشغل، والثاني إلى مديرية الشغل بالمصالح المركزية، ويحتفظ بالنظير الثالث في الملف الخاص 788- المادة 548 من م ش م" يكون مسؤولا جنائيا عن الأفعال المخالفة لمقتضيات هذا القانون، والنصوص التنظيمية الصادرة تطبيقا له، كل مشغل أو مدير أو رئيس طبقا للمادة السابعة أعلاه، يكون له داخل المؤسسة، وبتفويض من المشغل، الاختصاص والسلطة الكافية، لحمل الأجراء الموضوعين تحت إشرافه، على الطاعة الضرورية التي يقتضيها احترام التعليمات القانونية والتنظيمية.

يعتبر المشغل مسؤولا مدنيا عن الأحكام الصادرة على المديرين والمسيرين، والتابعين له بأداء المصاريف، والتعويض عن الضرر. 789- المادة 543 من م ش م" يوجه العون المكلف بتفتيش الشغل الأمر فورا إلى رئيس المحكمة الابتدائية صفته قاضيا للأمور المستعجلة بمقتضى مقال مرفوق بالمحضر المشار إليه في المادة 542 أعلاه. يأمر رئيس المحكمة الابتدائية بكل التدابير التي يراها ملائمة لإيقاف الخطر الحال. وله أن يمنح المشغل أجلا أحلا لهذه الغاية، كما له أن يأمر بالإغلاق عند الاقتضاء، مع تحديد المدة الضرورية لذلك الإغلاق". 790 - هشام بوتكيوط: مرس، ص127 انظر كذلك: 
في هذا الإطار يمكن اعتبار هذه المرام، أنها أيضا من بين المستجدات التي جاءت بها مدونة الشغل مكرسة بذلك الوضع السابق الذي كان يمارسه مفتش الشغل في الواقع، وذلك وفقا للمادة 532 في فقرتها الرابعة التي أناطت بالأعوان المكلفين بتفتيش الشغل مهمة إجراء محاولات التصالح في مجال نزاعات الشغل الفردية.

كتقييم لما سبق، فهذا الجهاز ورغمم أهميته في الحفاظ على المكتسبات سواء منها التشريعية أو الاتفاقية الخاصة بالشغل، إلا أن ما يعاب على المشرع في هذا الصدد هو عدم إيلائه لاهتمام خاص بالأجراء المؤقتين، خصوصا فيما يتعلق بالتطبيق السليم لموانع اللجوء لأجراء مقاولة التشغيل المؤقت في حالة الفصل لأسباب اقتصادية، تكتسي خطورة خاصة 792، ومدى التزام مقاولة التشغيل المؤقت بتسجيل أجراءها في الصندوق الوطني للضمان الاجتماعي إلى غير ذلك من المقتضيات التي قد تؤثر على وضعية الأجراء المؤقتين في حال عدم احترامها.

\section{المحور الثاني: الحماية القضائية للأجير المؤقت عند إنهاء عقد التشغيل المؤقت}

يعرف القانون بأنه مجموعة من القواعد التي تنظه علاقة الأفراد في الجماعة الواحدة وهذه حقيقة لا مراء فيها ولا يكفي وجود هذه القواعد فحسب، لكي يعيش المجتمع في حالة هدوء وأمن، بل لابد من جهاز القضاء الذي يتكفل بتطبيق هذه القواعد القانونية.

فالقضاء هو ملجأ كل مواطن مستضعف هضمت حقوقه أو مست كرامته أو اعتدى على شخصه وربما على حياته لذلك يتعين على القاضي أن يستند إلى الأحكام التي سنها المشرع ويسعى إلى تطبيقها عبر مهمته، في فصل النزاعات الشغلية المعروضة عليه كما أنه مطالب أيضا أمام غموض التشريع أو سكوت المشرع أن يجترهد من أجل التوصل إلى أنسب إنب تأويل للنص ورفع اللبس الذي فيه أو إكمال النقص الذي يعتريه 795، وفي هذا الاجتهاد تتبلور خصوصية الحكم القضائي الذي يصبح عبر تواتره مصدرا من مصادر القانون ومدعما مبادئه.

محمد أسبول: واقع الصلح في المادة الاجتماعية، دراسة نظرية وتطبيقية، رسالة لنيل دبلوم الماستر في القانون الخاص، وحدة التكوين

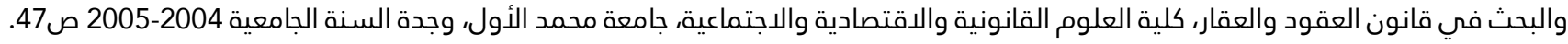

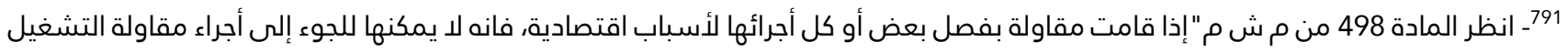
المؤقت خلال السنة الموالية لتاريخ الفصل لمواجهة التزايد المؤقت في نشاط المقاط المقاولة مع مراعاة مقتضيات المادة 508 أدناه.

ينطبق هذا المنع على مناصب الشغل التي شملها إجراء الفصل". 792- تنص المادة 497 من مدونة الشغل على أنه: " لا يمكن اللجوء إلى أجراء مقاولة التشغيل المؤقت من أجل إنجاز أشغال تكتسي خطورة

793ـ المادة 501 من م ش م" يحرر كتابة، العقد الذي يربط مقاولة التشغيل المؤقت بكل أجير من الأجراء الذين تم وضعهم رهن إشارة

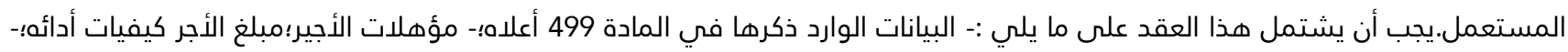

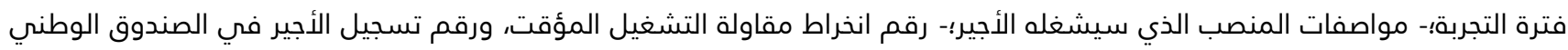
للضمان الاجتماعي؛- شرط إعادة الأجير إلى وطنه من قبل مقاولة التشغيل المؤقت إذا كانت المهمة تنجز خارج المغرب.يجب أمبأ أن ينص العقد على جواز تشغيل الأجير من قبل المقاولة المستعملة بعردة إلعاء التهاء المهمة. 794- إدريس فجر: " دور القضاء في حماية الأجير"، المجلة المغربية للقانون واقتصاد التنمية العدد 22 سنة 1990 ص17 795 النوري مزيد: " القاضي وقانون الشغل، محاولة تحليلية لدور القاضي في النزاعات الشغلية" ، مطبعة 
ولعل أهم ما يميز قانون الشغل هو أنه يحكم علاقات تعاقدية قائمة على عدم التوازن بين طرفيها، نتيجة وجود علاقة تبعيتة بين أجير ضعيف اقتصاديا مقارنة مع المشغل، مما يطرح إشكالية التوافق بين المصالح الاقتصادية للمشغل والاجتماعية لألجير

هذا، وتعد عقود المرمة، من العقود التي طرحت تضاربا قضائيا حول تكييفها ومدى استحقاق أجرائما لمختلف التعويضات أثناء إنهائها من طرف مقاولة التشغيل المؤقت باعتبارها المشغل، لذلك وبهدف دراسة هذا الموضوع لابد من التمييز بين الأجير المؤقت والقار في ظل التشريع السابق عن مدونة الشغل، وهذا ما سنتناوله في المطلب الأول، للنظر بعد ذلك في مدى الحماية التي أضفتها مدونة الشغل للأجراء مقاولة التشغيل المؤقت عند إنهاء العقد في المطلب الثاني.

\section{المطلب الأول: التكييف القضائي لعقد الشغل المؤقت في ظل التشريع السابق.} إن الأجير القار أو الدائم في إطار التشريع السابق، هو الذي يشتغل لمدة غير محددة، وتستخلص صفته إما من الاتفاق الصريح لطرفي العقد، أو الضمني عند عدم وجود ما يفيد ذلك كتابة، أو طبيعة العقد، فالاتفاق إذا كان لا يطابق الواقع القانوني فإن القاضي ملزم، عند النزاع بتطبيق القانون، لا الاعتماد على تأويلات الطرفين. أما الأجير المؤقت، فهو طبقا للفصل الأول من النظام النموذجي المؤخخ في 23 أكتوبر 1948797، والثالث من ظهير 24

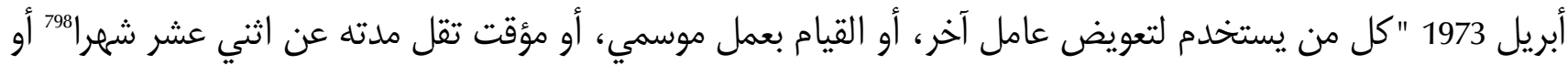

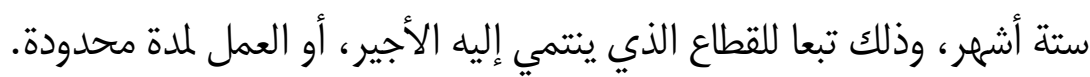
وقد كان لمحكمة النقض (المجلس الأعلى سابقا)799 ومعها محاكم الموضوع، السلطة التقديرية لتكييف العقد بكونه مؤقتا أو مستمرا، وذلك حسب ظروف كل قضيتة، فتكييف عقد الشغل من حيث المدة كان يرجع فيه إلى دفوعات الأطراف

796 محمد سعيد بناني، قانون الشغل بالمغرب، م س، ص 41 797 تنص مقتضيات الفصل الأول من النظام النموذجي المؤرخ في 23 أكتوبر 1948 المتعلق بالأجراء الذين يمارسون مهنة تجارية أو صناعية أو حرة والملغس بمقتضى المادة 586 من مدونة الشغل أنه: يتألف خدمة المدل المذكور من مستخدمين ثابتين ومستخدمين مؤقتين، فالأجراء الثابتون يحتشدون لمدة خدمة غير معين وقتها، والأجراء المؤقتون يحتشدون للقيام بالخدمة عوض الغير، أو بخدمة في فصل معلمهل معلوم أو خدمة مؤقتة أو محدودة الوقت ـ كل أجير يعمل بصفة مستمرة منذ أكثر من اثنى عشر شهرا في العمل يعتبر بمقتضى الحال من جملة المستخدمين الثابتين، إلا إذا نص في عقد الخدمة كتابة على شرط خاص مناف لذلك، ولا تكون الغيبة المضبوطة المنصوص عليها في الفصلين 11 و12 من هذا النظام سببا في إيقاف مدة الخدمة لتطبيق هذه الفقرة، ولا الرخص السنوية المؤذاة عنها أجرتها، ولا مدة الاستراحة حالة النفاس، ولا أيام المدة الواجب استغراقها في التمرين العسكري ولا الإغلاق المؤقت للمحل كله أو بعضه. 798-- ينص الفصل الثالث من ظهير 24 أبريل 1973 الخاص بالتنظيم القانوني لعقد العمل في القطاع الفلاحي أنه:

" يتألف عملة مؤسسة الاستغلال ألفلاحي من: عملة دائمين عملة مؤقتين

ويستخدم العمال الدائمون لمدة غير محددة أو المدة معينة تتجاوز ستة أشهر. ويستخدم العمال المؤقتون لتعويض عمال آخرين أو القيام بعمل موسمي أو مؤقت تقل مدته عن ستة أشهر .

وتعتبر عملة دائمين، العملة المؤقتون الذين استخدموا مدة ستة أشهر متصلة في مؤسسة استغلال واحدة أو عند مشغل واحد..."

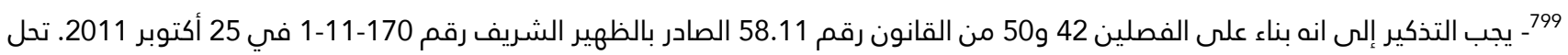
عبارة محكمة النقض محل عبارة المجلس الأعلى في جميع مقتضيات الظهير الشريف رقم 223-57-1. الصادر في 2 ربيع الأول 1337 (27) 


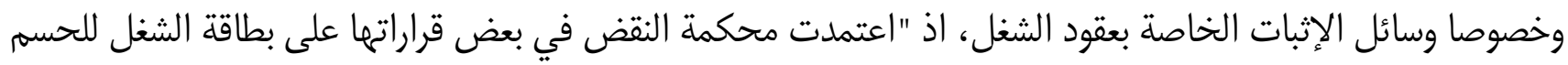

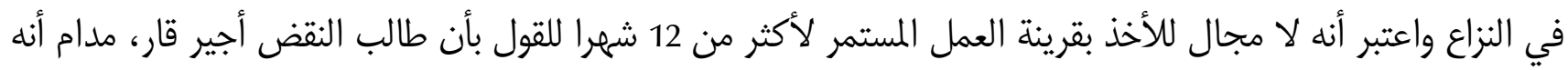

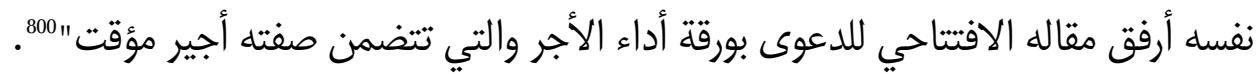

كما جاء في قرار آخر لمحكمة النقض ما يلي: "حيث ثبتت صحة ما عابته الوسيلة على القرار المطعون فيه إن محكمة

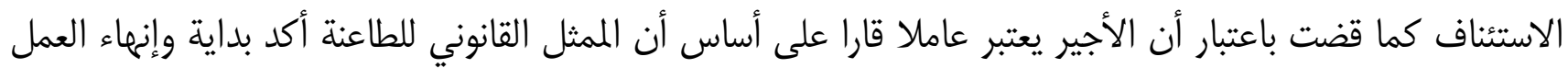

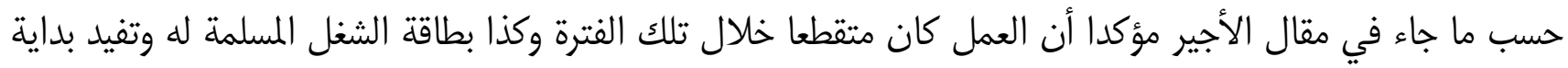

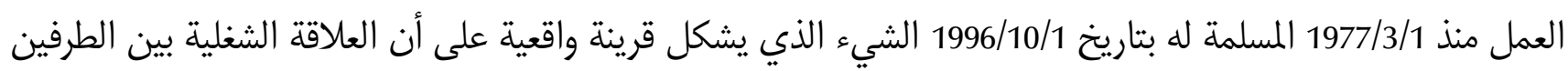

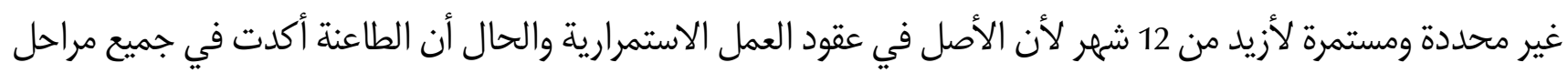

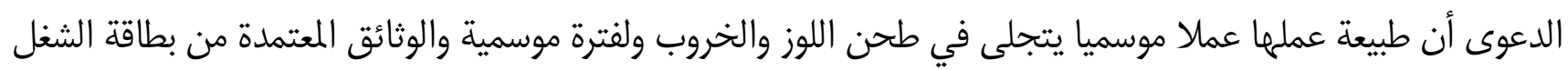

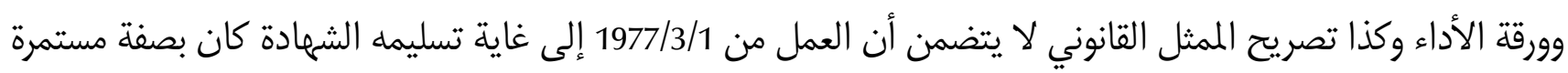

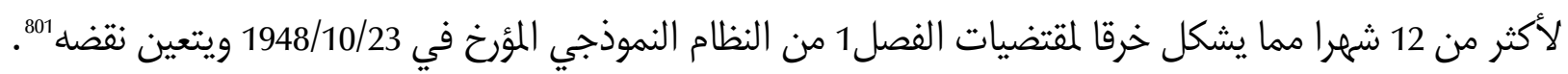
ويتضح لنا جليا أن المجلس الأعلى (محكمة النقض حاليا) لا يثبت صفة الأجير القار إلا العامل الذي يثبت أنه عمل

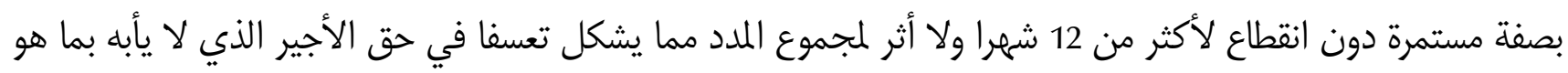

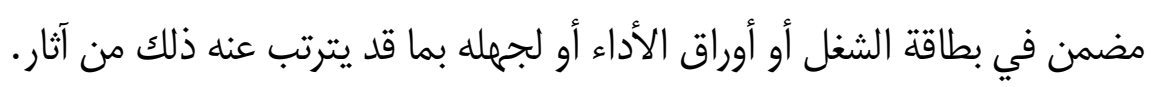

وفي نفس السياق، فقد ذهبت محكمة النقض إلى حد استبعاد شهادة الشهود لعدم توضيح سند العلم واعتماد أوراق

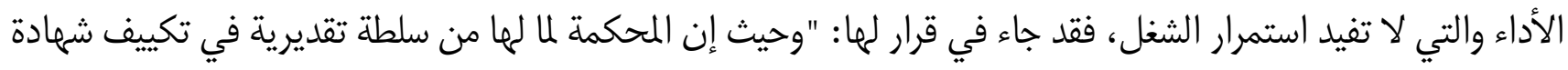

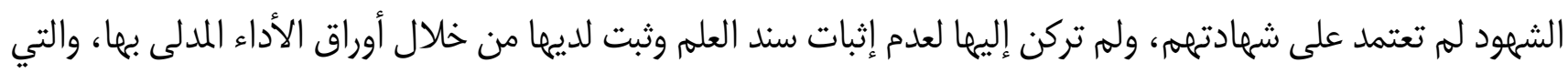

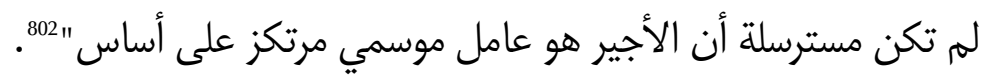

فمحكمة النقض في قرارها هذا لم تنظر إلى طول المدة التي اشتغلما الأجير، وبالتالي اعتباره أجيرا دائما بقدر ما

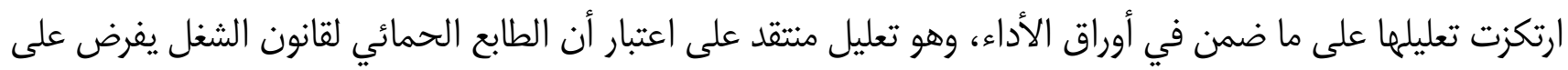

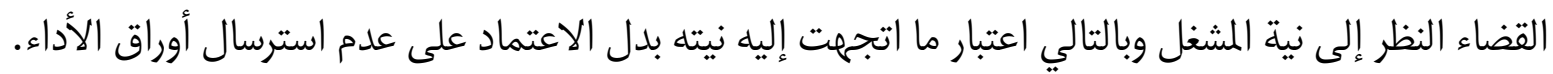

هذا، وقد ذهب نفس المجلس سابقا (محكمة النقض حاليا) إلى أبعد من ذلك، واعتمد بشكل مطلق على منطوق

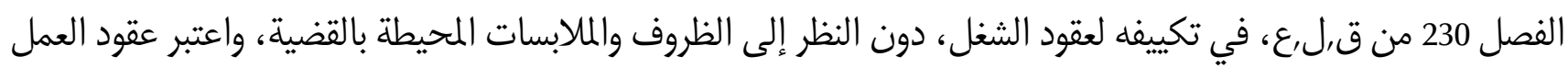

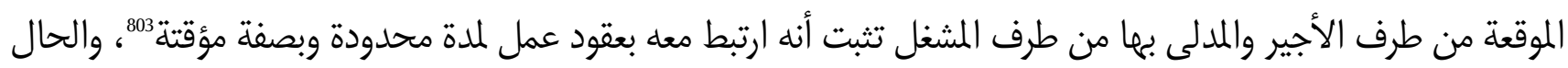

سبتمبر 1957) بشان المجلس الأعلى، كما تم تغييره وتتميمه وكذا في جميع النصوص التشريعية والتنظيمية الجاري بها العمل. الجريدة الرسمية عدد 5989 مكررا.

800- قرار المجلس الأعلى عدد 186 في 2003/2/25، ملف اجتماعي عدد 2002/1/5/737 (غير منشور)

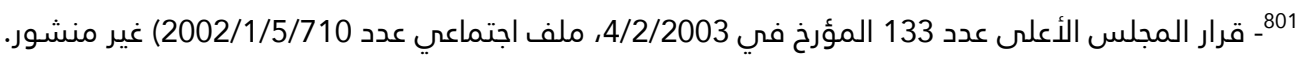

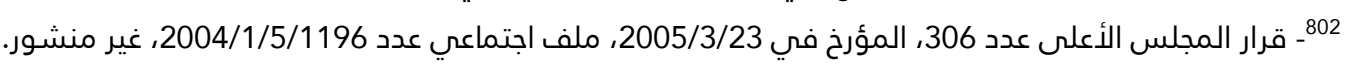
803 قرار المجلس الأعلى عدد 149 المؤرخ في 2003/2/18، ملف اجتماعي عدد 2002/1/5/590 (غير منشور) 
أن استرسال عقود الشغل المحددة المدة لا يمكن أن يفسر إلا لصالح الأجير، وذلك باعتبارها وسيلة للتهرب من آثار عقود الشغل غير محدودة المدة.

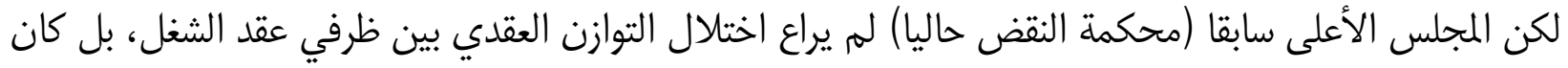

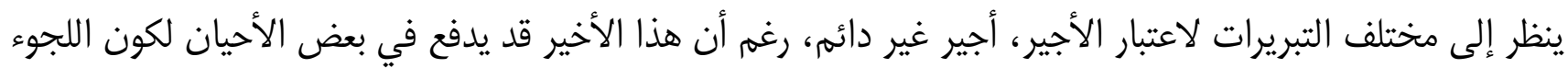

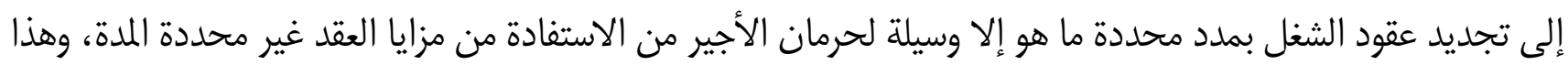

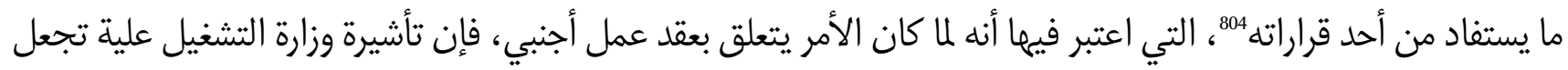

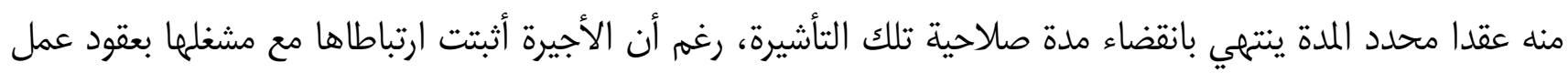

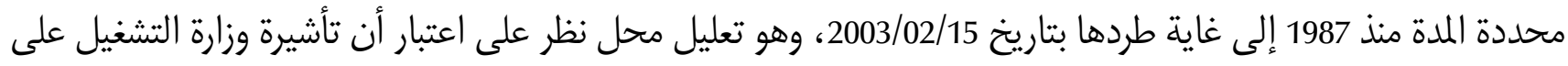

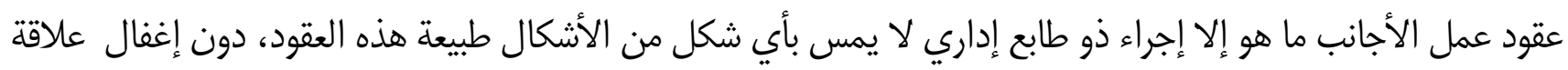
القاضي بهذا الإجراء والاستناد إليه للقول بأن الأجيرة مؤقتن.

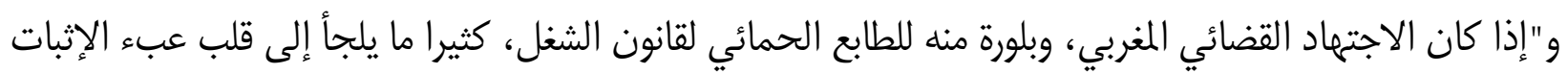

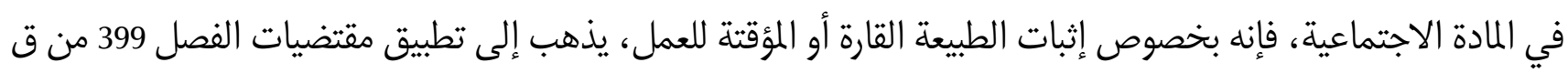
ل ع، وبالتالي يجعل إثبات الاشتغال لمدة تفوق 12 شهرا متصلة على عاتق الأجير. "

بهذا الخصوص جاء في قرار للمجلس الأعلى (محكمة النقض حاليا) ما يلي:" وحيث تعيب الطاعنة على القرار خرق

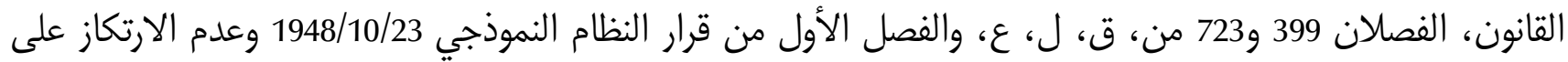

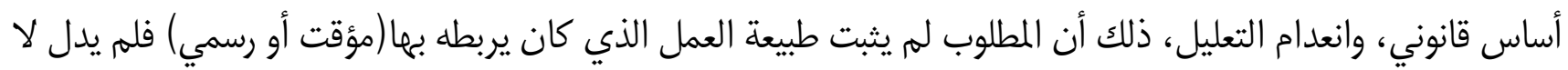

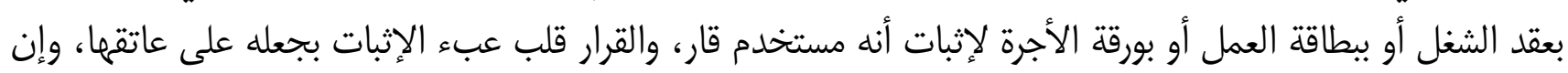

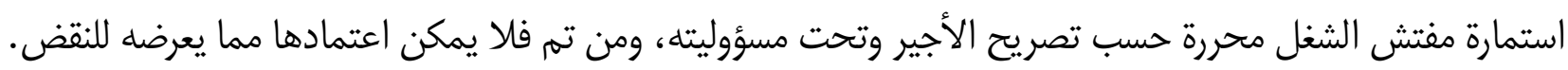

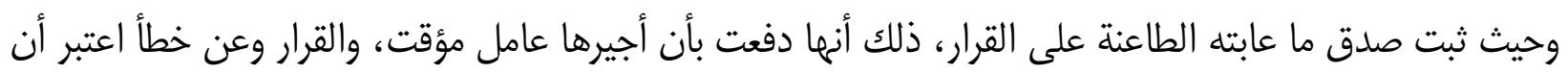

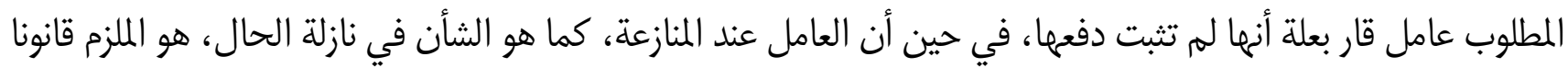

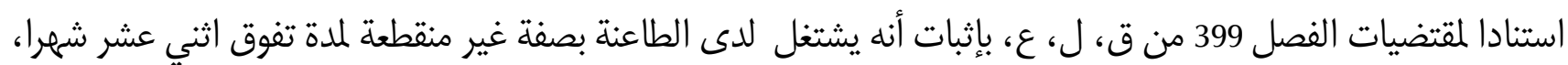

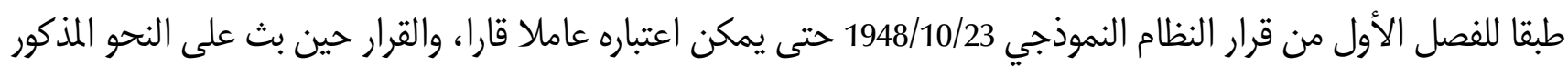

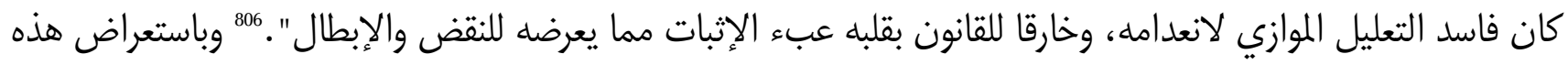

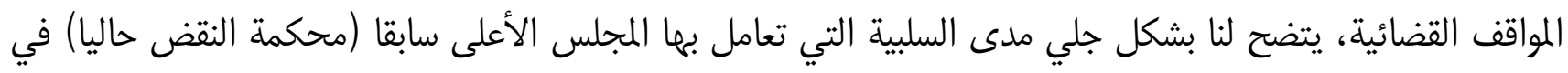
تكييفه لعقود الشغل المؤقتة، مما يدفعنا بالتالي إلى البحث في الحماية التي قررها القضاء لهذه الملية الفئة من الأجراء.

804- قرار المجلس الأعلى عدد 325 المؤرخ في 2005/3/30، ملف اجتماعي عدد 2004/1/5/1205 (غير منشور)

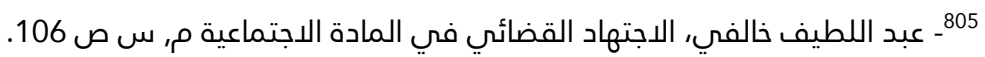

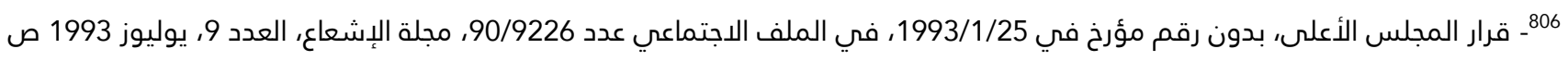




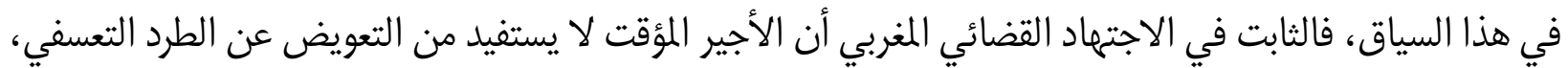
على اعتبار أن استغناء المشغل عن الأجير المؤقت بعد نهاية العقد لا يعتبر طردا تعسفيا.

كما نجد أن محاكم الموضوع هي الأخرى، قد أخذت تتبنى نفس موقف محكمة النقض حاليا، حيث جاء في قرار

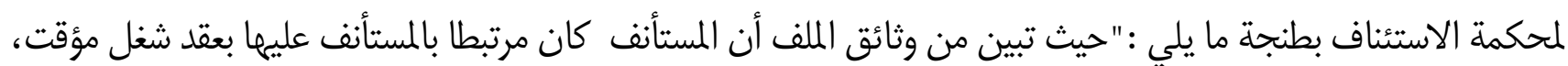

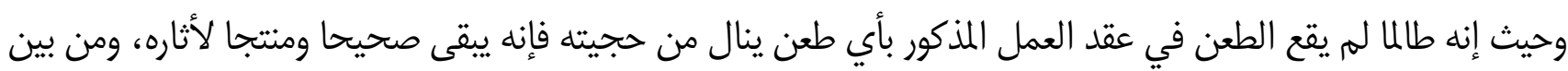

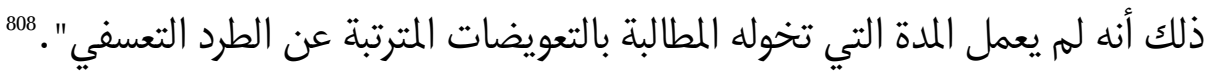

كما أن المحكمة الابتدائية بالرباط رفضت طلب التعويضات، نظرا لأن صفة استمرارية الشغل غير ثابتة، وعللت موقفها

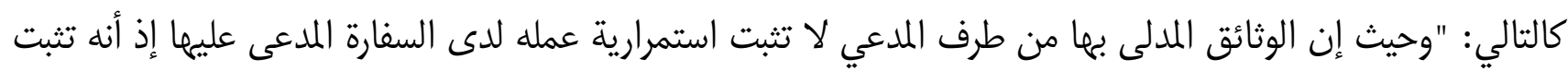

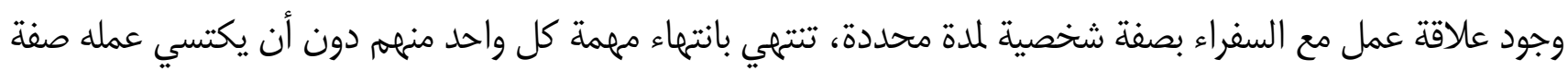

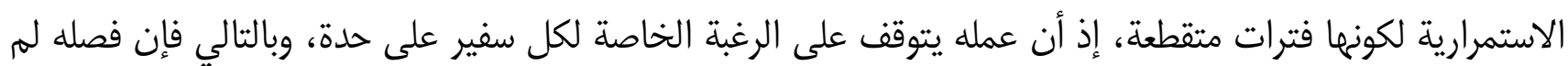

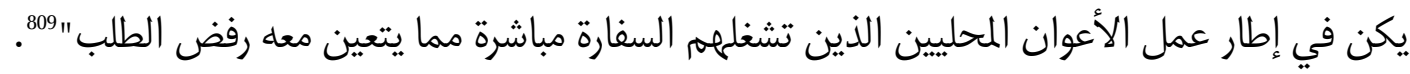
انطلاقا مما أومأنا إليه أعلاه من الأحكام والقرارات القضائية، يتضح بشكل جلي أن القضاء تعامل بشكل سلبي في

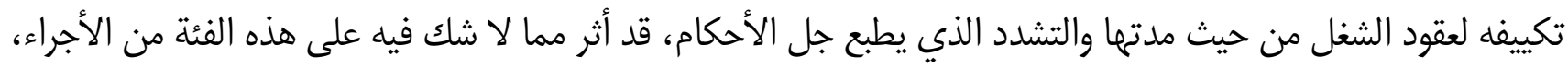

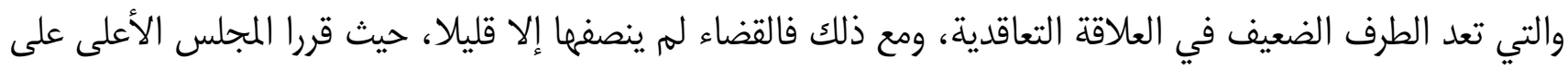

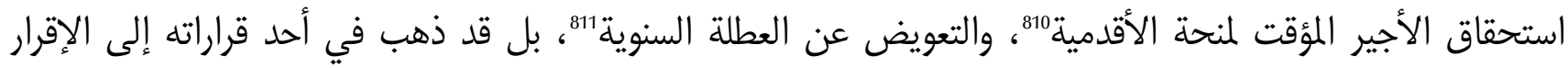

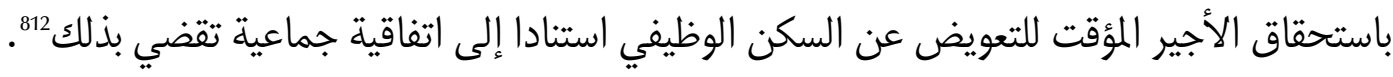
رغم ذلك، فالأجير المؤقت له يكن محميا في ظل التشريع السابق، مما يدفعنا إلى التساؤل عن مدى الحماية التي

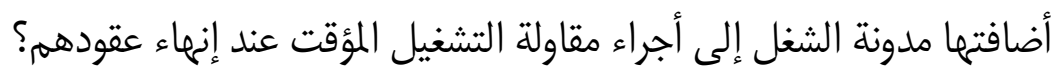

\section{المطلب الثاني: حماية الأجير المؤقت عند إنهاء عقد الشغل المؤقت.}

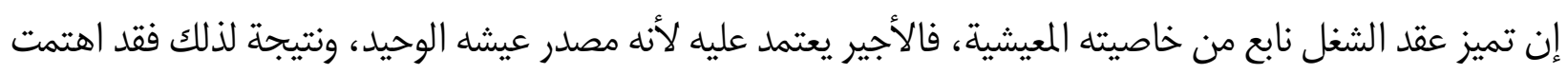

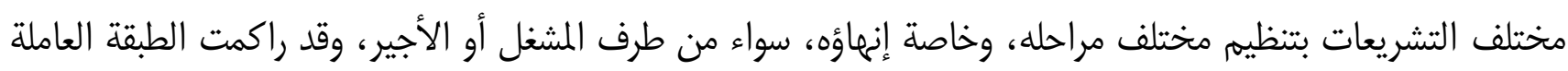

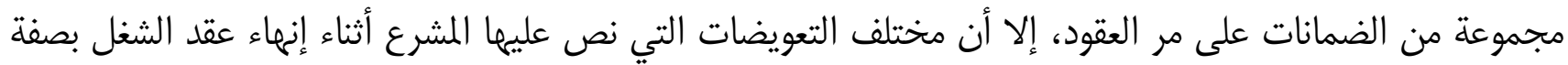

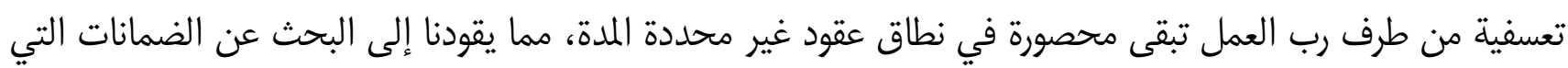

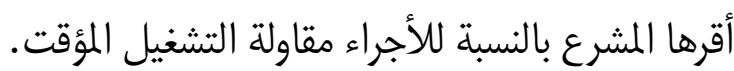

807 قرار المجلس الأعلى، عدد 7/3، المؤرخ في 2005/6/23، ملف اجتماعي عدد 2005/1/5/328، غير منشور.

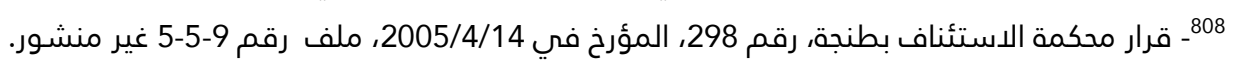

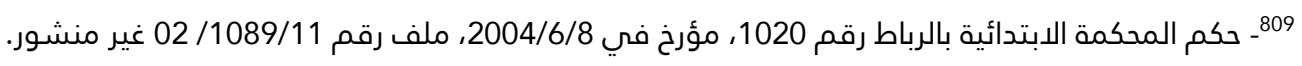

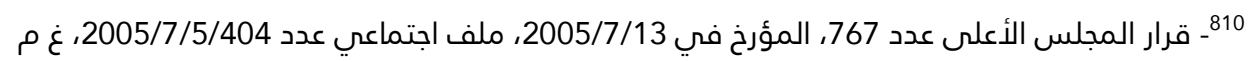

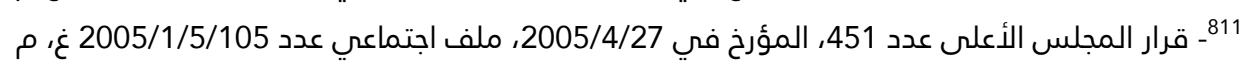

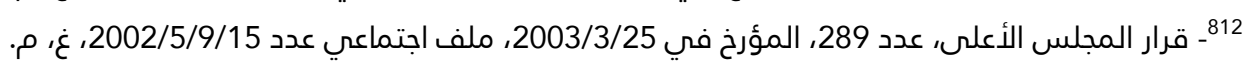




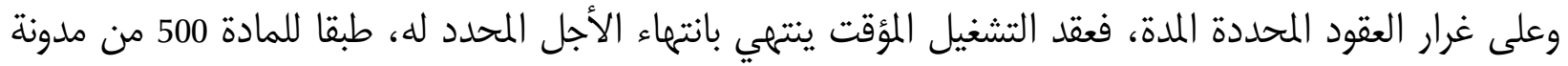

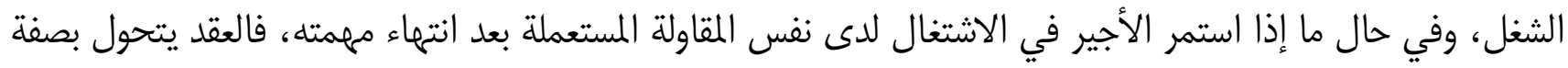

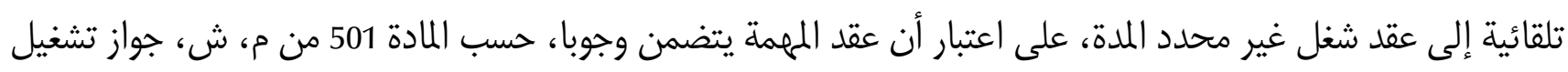
الأجير من قبل المقاولة المستعملة بعد انتهاء المرمة.

هذا، وينتهي عقد الشغل بانتهاء مدة المهمة المحددة في عقد التشغيل المؤقت وفي عقد الوضع رهن إشارة المستعمل،

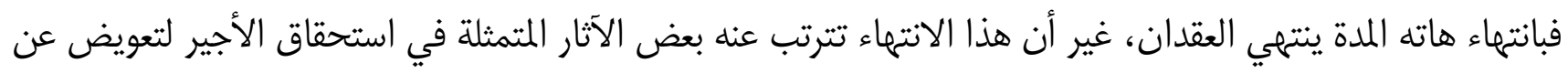

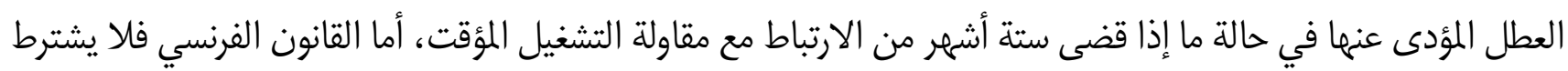

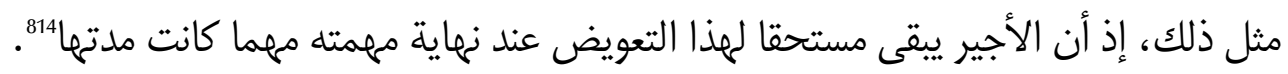

إضافة إلى أن الأجير المؤقت يستحق وجوبا طبقا للقانون الفرنسي بعد انتهاء مهمته تعويضا عن وضعيته المؤقتة، هذا

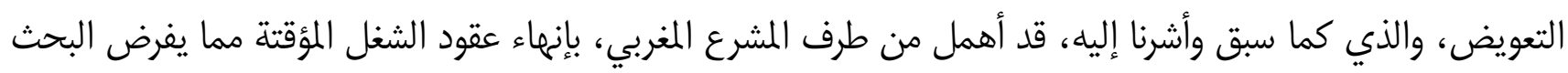
في مدى استحقاق الأجير المؤقت لمختلف التعويضات التي نصت عليها اليها مدونة الشغل. تجدر الإشارة في هذا الصدد إلى أن المادة 502 من مدونة الشغل، نصت على فترة تجربة لا يمكن أن تتعدى يومين

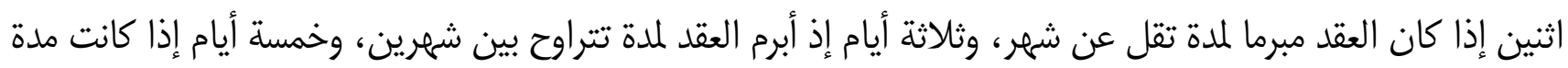
العقد تفوق شهرين.

وارتباطا مع المادة 13 من مدونة الشغل دائما في فقرتها الأولى، فخلال فترة التجربة، يمكن لكال الطرفين إنهاء عقد التها

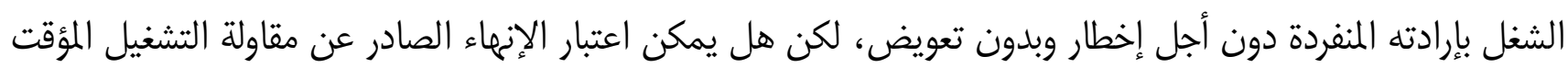

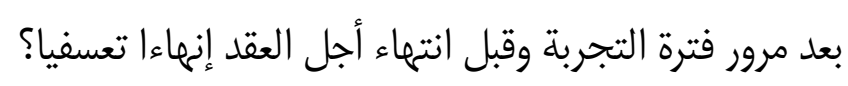

يرى أحد الباحثين

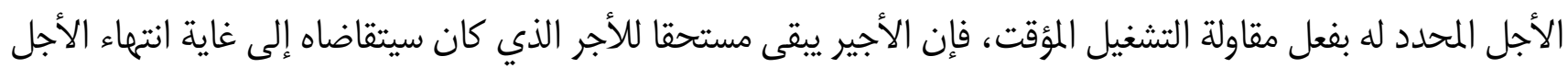
المحدد ما لم يكن الإنهاء لخطأ جسيم ولقوة قاهرة.

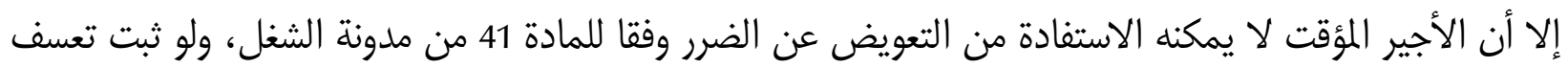

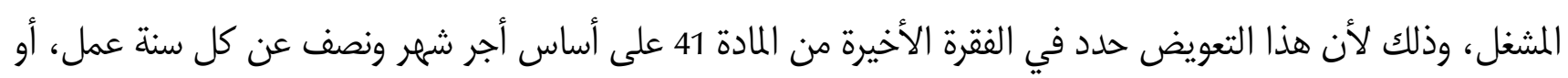

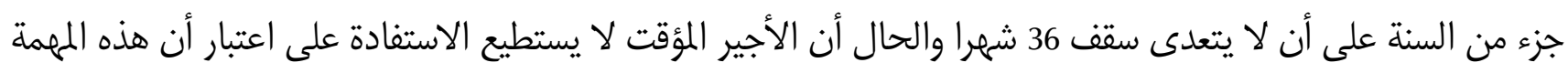

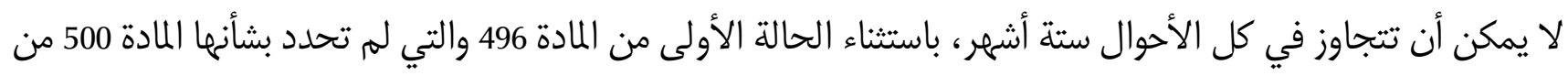
المدونة أي أجل، مما يطرح لاشك عدة إشكاليات، يبقى الاحلى على القضاء الحسم فيها مستقبلا.

813 814 - فاتح كمال، قراءة أولية اعقد التشغيل المؤقت على ضوء مدونة الشغل الجديدة، مجلة الملف العدد6، ماي 2005، ص ص 201.

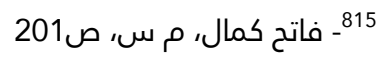


لذلك، فما يعاب على المشرع بالنسبة للتعويض عن الفصل حسب مقتضيات المادة 52 من م، ش أنها صريحة في عدم

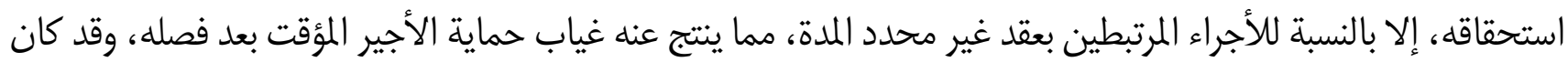
حريا بالمشرع وضع أحكام خاصة بإنهاء عقود الشغل المؤقتة.

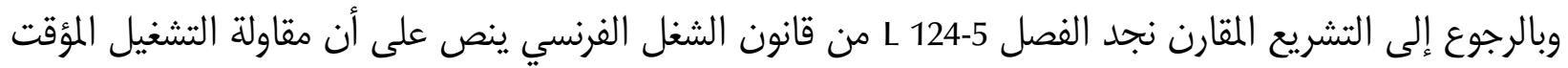

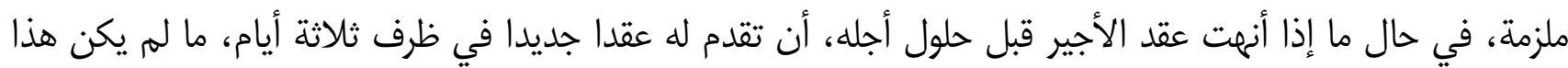
الإنهاء ناتجا عن خطأ جسيم أو قوة قاهرة.

كما نصت الفقرة الثانية من نفس الفصل، على أن العقد الجديد يجب أن لا يمس الحقوق المكتسبة للأجير المؤقت في

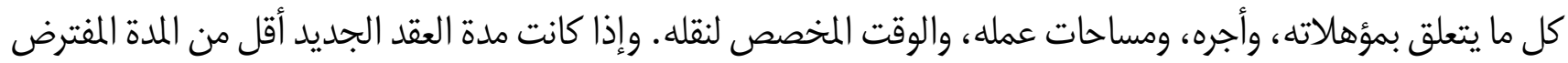

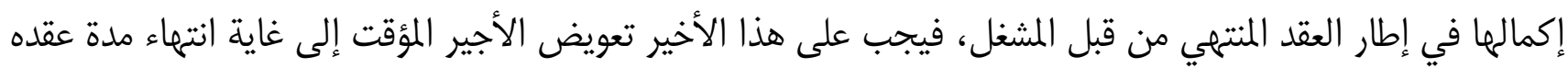

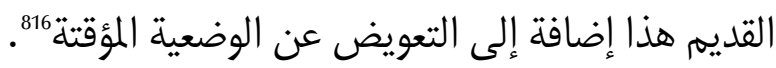

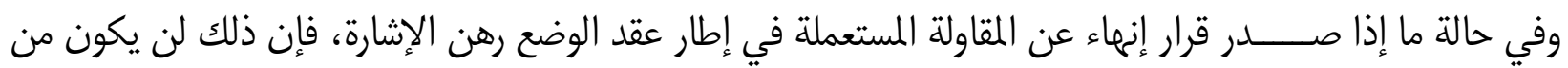

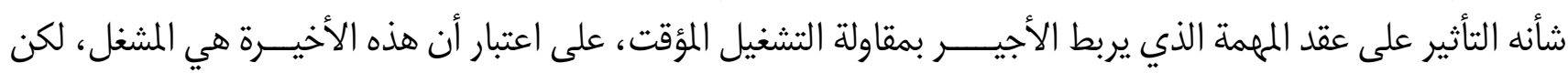

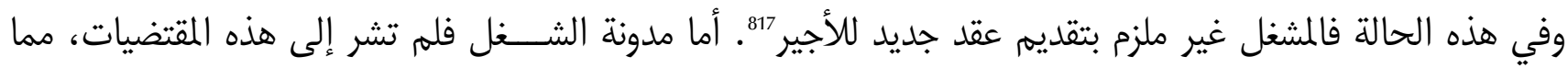

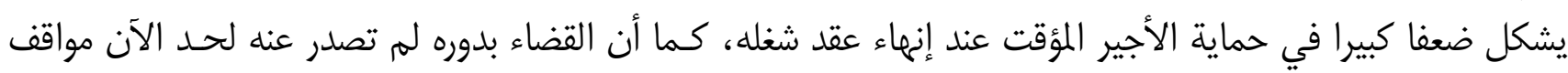
واضحة بهذا الشأن.

وبهذا الخصوص، فقد صدر قرار عن محكمة الاستئناف بطنجة، جاء فيه: "وحيث ثبت المستأنفة الأصلية استئنافها

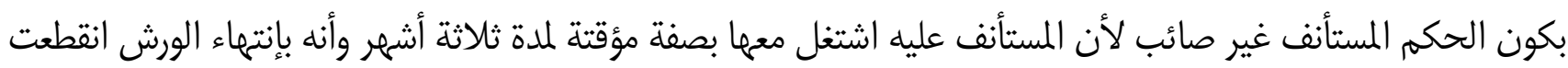

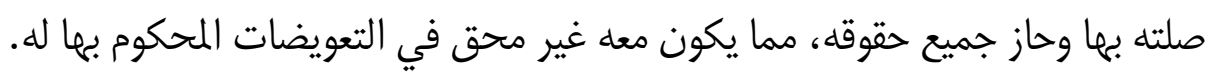
وحيث إن العلاقة الشغلية المستمرة تثبت بجميع وسائل الإثبات حسب المادة 18 من مدونة الشغل، وحيث يتبين من

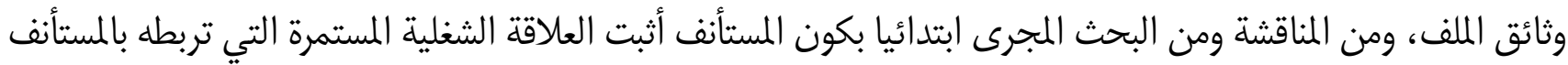

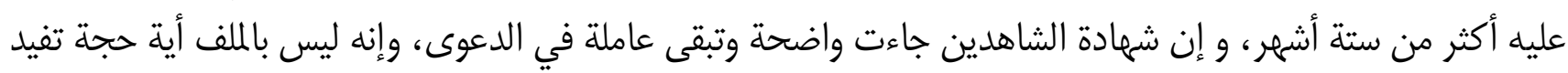

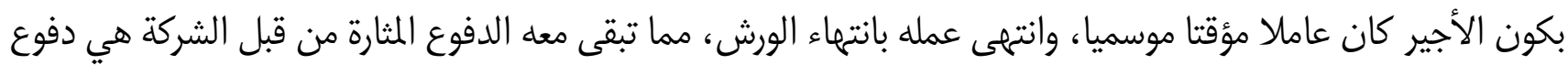

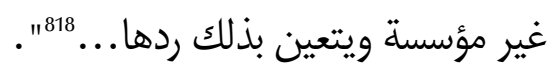

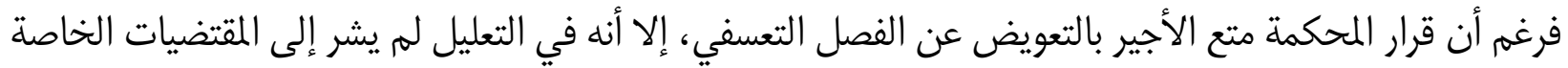

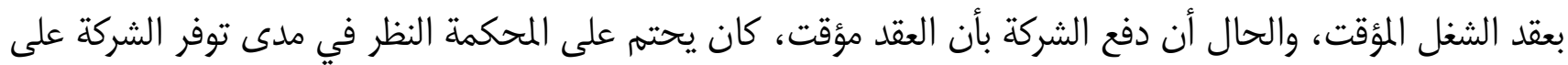

816 - I'article 124-5, paragraphe 3 ; loi n 90-613 du 12 juillet 1990

817 - soc 9 juillet 2003.voir Code du travail ; op .cit, p 268

818 قرار محكمة الاستئناف بطنجة، رقم 643، مؤرخ في 2006/6/8، ملف رقم 127-05-5ير منشور 
عقد الوضع رهن الإشارة وفي غيابه فالدفع يكون بالتالي غير مؤسس، استنادا إلى المادتين 499 و501 من مدونة الشغل

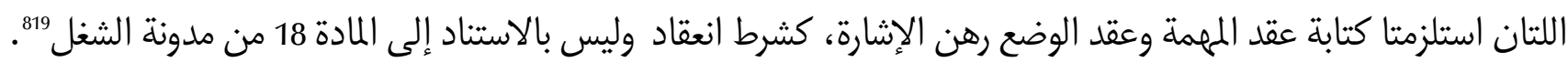
من كل ما أومأنا إليه سابقا نناشد المشرع المغربي بتعديل الأحكام المنظمة لمقاولة التشغيل المؤقت وحدوا ما حداه نظيره

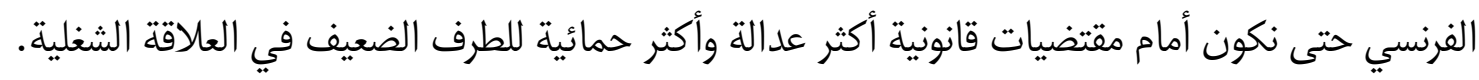

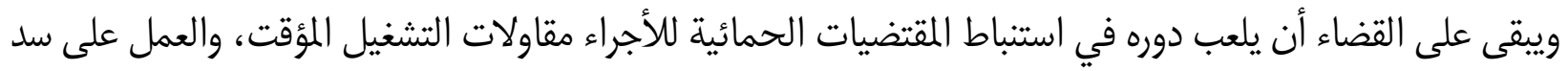

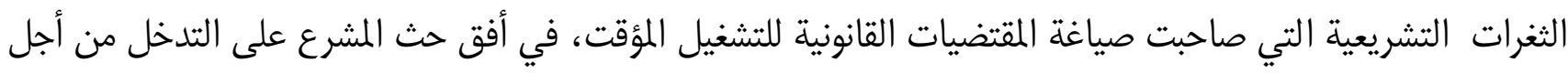

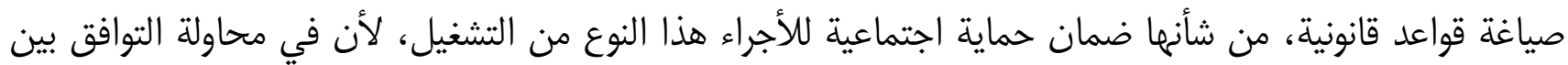

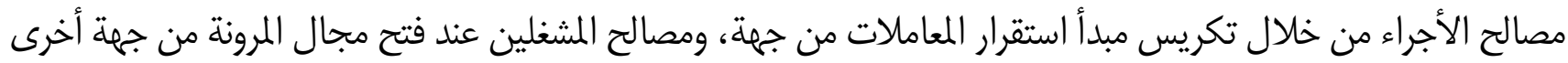

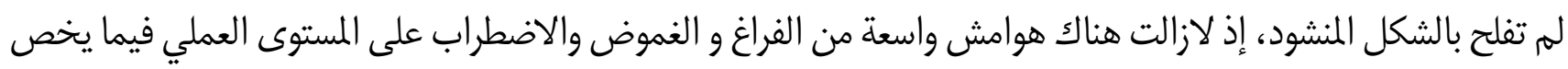

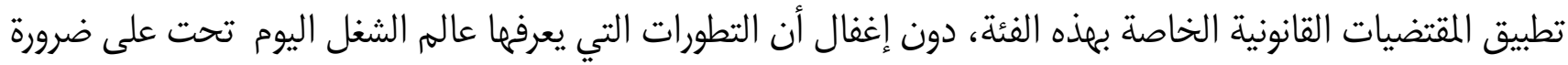

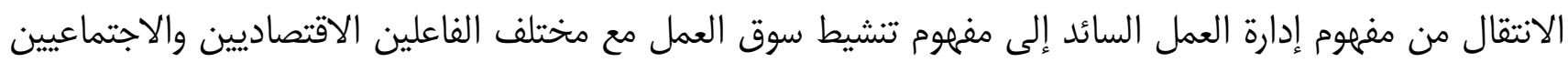

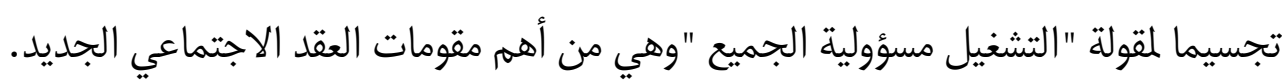




\title{
تعويضات نظام الضمان الاجتماعي المغربيي
}

\author{
(2) \\ طابلة باحثة بسلك الدكتوراه \\ كلية العلوم القانونية والاقتصادية والاجتماعية السويسي بالي \\ جامعة محمد الخامس بالرباط
}

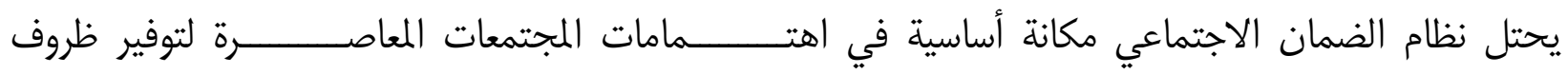

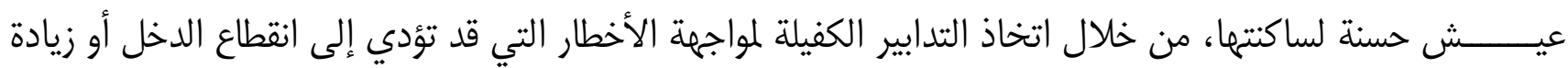
في النفقات.

من هذا المنطلق، ولأجل توفير الحماية اللازمة لأفراد المجتمع من تلك الأخطار، من خلال تعويضمهم عن الدخل

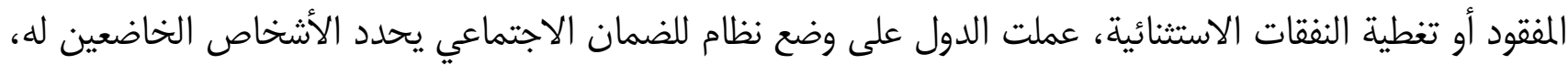

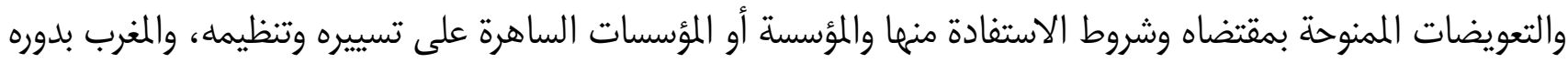

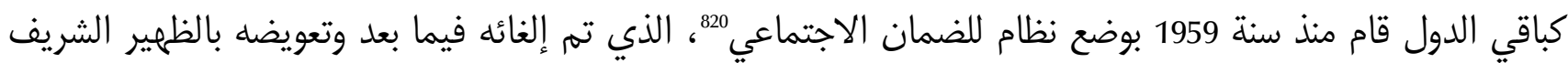
الصادر في 27 يوليوز 1972

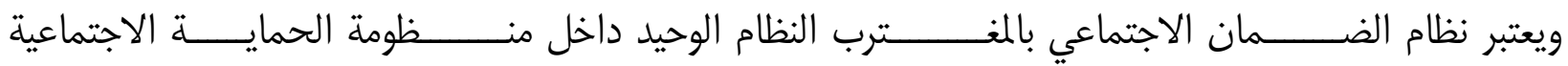

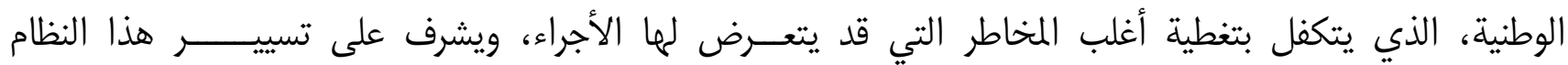

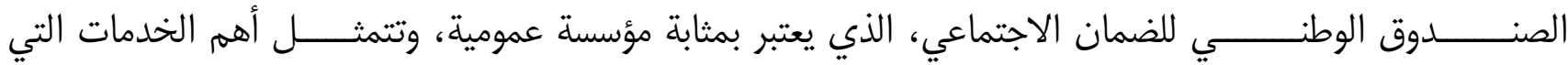

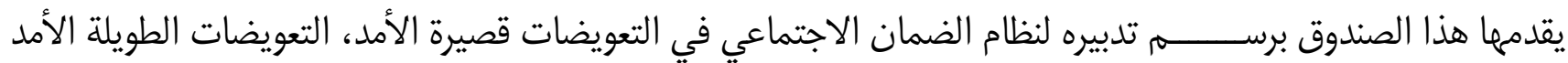
والتعويضات العائلية.

ولإِحاطة أكثر بهذا النظام والمؤسسة الساهرة على تدبيره وأهم الخدمات التي يمنحها سنتناول هذا الموضوع من خلال

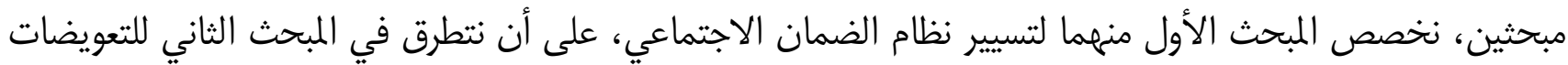

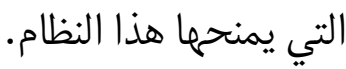

820 - الظهير الشريف رقم 1.59 .148 في إحداث نظام للضمان الاجتماعي، ج ر ع 2465 الصادرة بتاريخ 22 يناير 1960، ص 262.

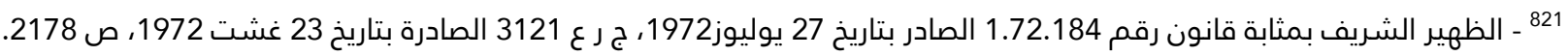




\section{المبحث الأول: تسيير نظام الضمان الاجتماعي}

أناط المشرع المغربي مهمة تسيير نظام الضمان الاجتماعي بمثابة مؤسسة عمومية تتمتع بالشخصية المدنية وبالاستقلال المالي 824 خاضعة لوصاية الوزارة المكلفة بالتشغيل والتكوين المهني 825، وفي إطار تدبيره لنظام الضمان الاجتماعي يقدم هذا الصندوق إعانات اجتماعية مختلفـة، لفائدة أجراء القطاع

822 - طبقا للفصل الثاني من الظهير الشريف بمثابة قانون رقم 1.72 .184 الصادر بتاريخ 15 جمادى الثانية 1392(27 يوليوز 1972) المتعلق بنظام الضمان الاجتماعي كما تم تغييره وتتميمه، فإن نظام الضمان الاجتماعي يجري وجوبا على المتدربين المهنيين والأشخاص المأجورين

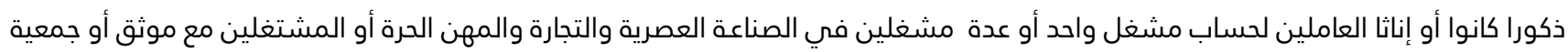

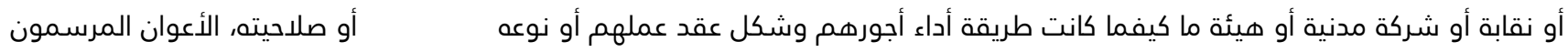

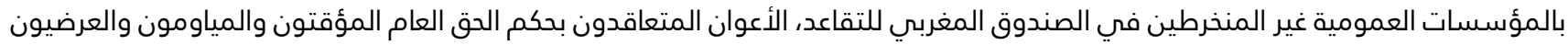
العاملون مع الدولة والجماعات العمومية والمؤسسات العمومية، الأشخاص الذين تشغلهم التعاونيات كيفما كان نوعها، الأشخاص الذين يشغلهم أرباب الأملاك المعدة للسكنى أو التجارة، البحارة الصيادون بالمحاصة، العاملون بمقاولات الصناعة التقليدية، الأجراء العاملون بالمنشآت

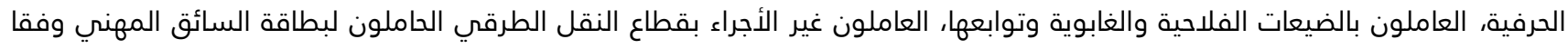
لمقتضيات القانون رقم 52.05 بمثابة مدونة السير ونصوصه التطبيقية والأشخاص العاملون بمصالح عمومية ذات صبغة صناعية وتجارية الذين

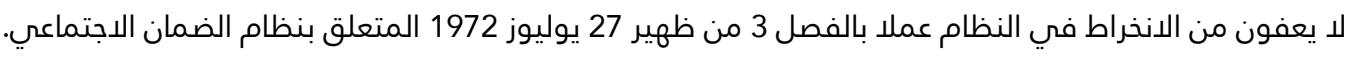

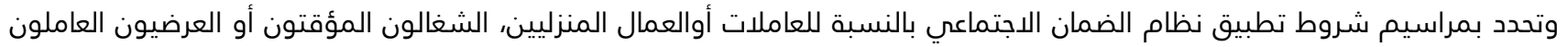

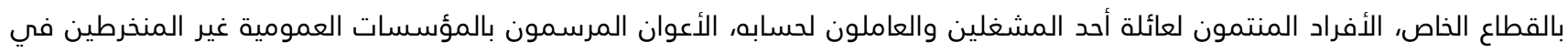
الصندوق المغربي للتقاعد والأعوان المتعاقدون بحكم الحق العام المؤقتون والمياومون والعرضيون العاملون مع الدولة والجماعات العمومية

والمؤسسات العمومية.

وتجدر الملاحظة إلى أن هاتين الفئتين الأخيرتين، وعلى الرغم من عدم صدور مرسوم يحدد شروط استفادتها من نظام الضمان الاجتماعي،

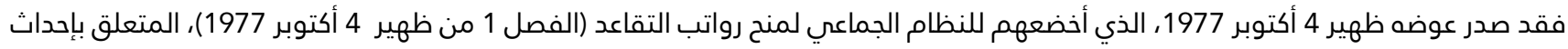

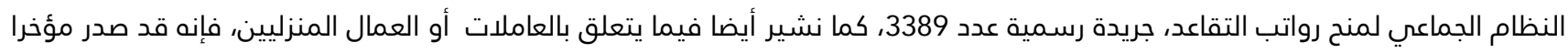

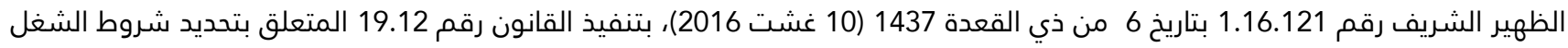

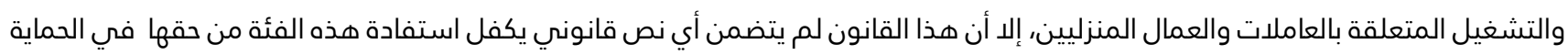
الاجتماعية، وذلك على خلاف الظهير الشريف رقم 190-14-1 الصادر في 6 ربيع الأول 1436 (29 ديسمبر 2014)، بتنفيذ القانون رقم 12- 18 المتعلق بالتعويض عن حوادث الشغل، الذي جعل فئة العمال المنزليين تستفيد من حقها في الحماية الاجتماعية. 27) 823 - انظر بهذا الذصوص الفصل 1 من الظهير الشريف بمثابة قانون رقم 1.72.184 الصادر بتاريخ 15 جمادى الثانية 1392

1972)، المتعلق بنظام الضمان الاجتماعي كما تم تغييره وتتميمه. 824 - الفصل 6 من ظهير 27 يوليوز 1972 المتعلق بنظام الضمان الاجتماعي كما تم تغييره وتتميمه. 825 - خلال الفترة ما بين 1988 و1993 عهد إلى وزير الصحة العمومية بالاختصاصات والصلاحيات المترتبة عن الرقابة الإدارية وفي نفس السياق عهد لوزير المالية بمهمة الرقابة المالية للدولة في القضايا ذات الطابع المالي المحض. 826 - يقدم الصندوق الوطني للضمان الاجتماعي لفائدة أجراء القطاع الخاص، طبقا للفصل الأول من ظهير 27 يوليوز 1972 المتعلق بنظام

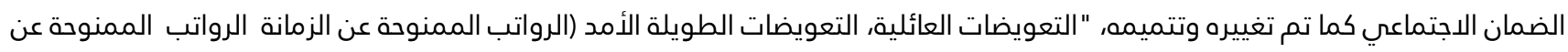
الشيخوخة و الرواتب الممنوحة للمتوفس عنهم) و التعويضات القصيرة الأمد (التعويضات اليومية الممنوحة في حالة مرض أو حادث لا يجري عليه التشريع الخاص بحوادث الشغل والأمراض المهنية، التعويضات اليومية الممنوحة عن الولادة الإعانات الممنوحة عن الوفاة و التعويض عن فقدان الشغل)، كما ترتب أيضا في صنف التعويضات القصيرة الأمد، المبالغ المتعين على الصندوق الوطني للضمان الاجتماعي إرجاعها وفقا للتشريع المعمول به إلى المشغل الذي سبق إلى المأجور الأجرة المطابقة للإجازة الإضافية التي له الحق فيها بمناسبة كل ولادة في بيته، وزيادة على ذلك فإن الصندوق الوطني للضمان الاجتماعي يتيح إمكانية الاكتتاب في " التأمين الاختياري "، حيث يحق لكل مؤمن له الاكتتاب في التأمين 
وكباقي المؤسسات العمومية، يتوفر الصندوق الوطني للضمان الاجتماعي الإع، على مجموعة من الأجهزة التي تسهر

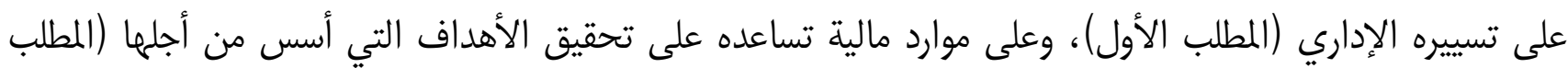

\section{المطلب الأول: التنظيم الإداري للصندوق الوطني للضمان الاجتماعي}

بالرجوع لمقتضيات الفصل السابع وما بعده من ظهير 27 يوليوز 1972 المتعلق بنظام الضمان الاجتماعي كما تم

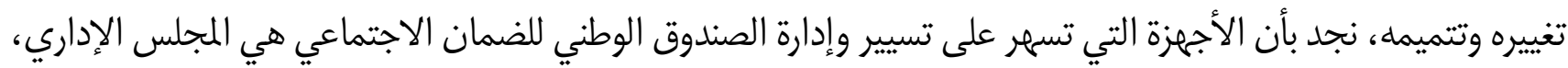
اللجان التابعة لهذا المجلس، المدير العام والموظفين العاملين بهذه المؤسسة.

\section{الفقرة الأولى: المجلس الإداري للصندوق الوطني للضمان الاجتماعي واللجان التابعة له}

يترتب على اعتبار الصندوق الوطني للضمان الاجتماعي مؤسسة عمومية، تمتعه كغيره من المؤسسات بأهلية تمكنه المانه من القيام بمجموعة من التصرفات منات، وكذا ممارسة الاختصاصات الموكولة له، وقصد ممارسة هذه التصرفات والقيام

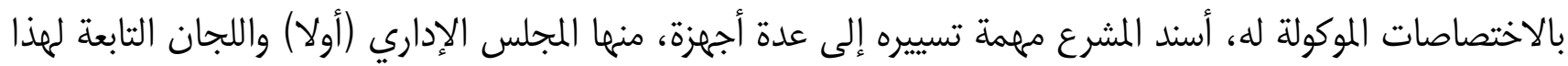

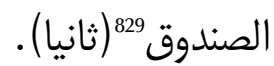

\section{أولا - المجلس الإداري للصندوق الوطني للضمان الاجتماعي}

يسير الصندوق الوطني للضمان الاجتماعي مجلس إداري ثلاثي، يتألف من 24عضوا رسميا يعينون بمرسوم لمدة 3

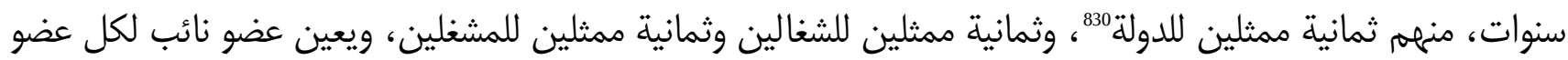

الاختياري إذا استوفس الشروط المحددة في الفصل 5 من ظهير 27 يوليوز 1972 المتعلق بنظام الضمان الاجتماعي كما تم تغييره وتتميمه بالقانون رقم 17.02 الصادر في 4 نونبر 827 - قبل إحداث الصندوق الوطني للضمان الاجتماعي، كان هناك صندوق يسمى صندوق الإعانة الاجتماعية، أنشئ بمقتضى ظهير 22 أبريل 1942، الذي عوض بظهير 25 دجنبر 1957، وقد نسخ هذا الظهير بظهير 31 دجنبر 1959، الذي تم نسخه هو الآخر بمقتضس ظهير 27 يوليوز

828 - حدد في هذا الإطار الفصل 6 من ظهير 27 يوليوز 1972 المتعلق بنظام الضمان الاجتماعي كما تم تغييره وتتميمه، البعض من هذه

التصرفات فيما يلي: “تلقي تسبيقات وإعانات مالية من الدولة أو الجماعات العمومية الأخرى؛ *تلقي الهبات والوصايا؛ *اقتناء بعوض وتفويت جميع المنقولات وكذا جميع العقارات، شريطة التوفر مسبقا على إذن مشترك للوزير المكلف بالتشغيل والوزير المكلف بالمالية ببيع العقارات وذلك بعد موافقة المجلس الإداري؛ * إبرام قروض لدى المؤسسات البنكية بعد موافقة الوزير المكلف بالتشغيل والوزير المكلف بالمالية؛ *إبرام عقود إيجار عقارات تتعلق باحتياجات مصالحه.

829 - محمد بنحساين، شرح قانون الشغل المغربي، طبعة مزيدة ومنقحة، بدون ذكر تاريخ الإصدار، ص 43. 830 - ويكون ذلك على أساس: - مدم:

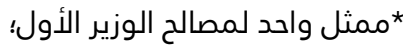

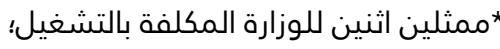
*ممثل واحد لكل من الوزارة المكلفة بالمالية، الصحة، الوظيفة العمومية، الفلاحة، التجارة والصناعة و الصناعة التقليدية. 
رسمي 831، وفي حالة وفاة متصرف أو استقالته أو تجريده من حقوقه، يعين متصرف جديد طبقا لنفس الكيفية في تعيين

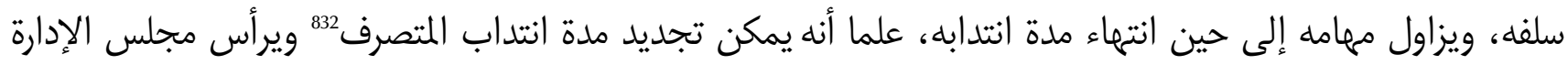

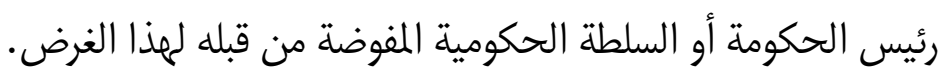

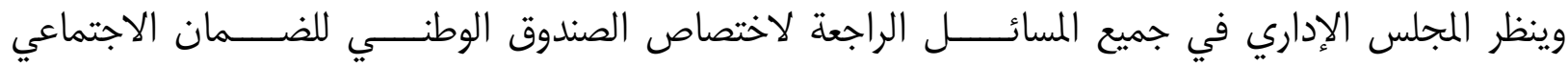

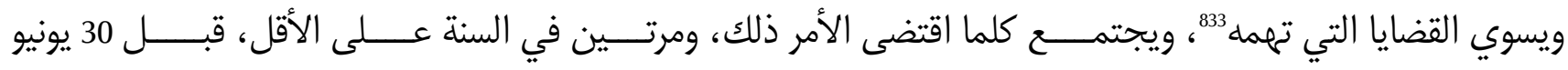

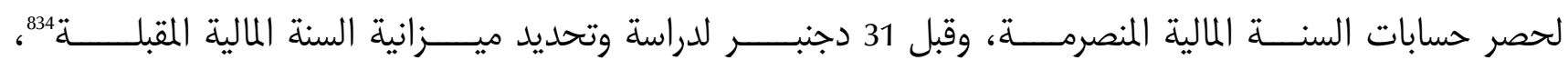

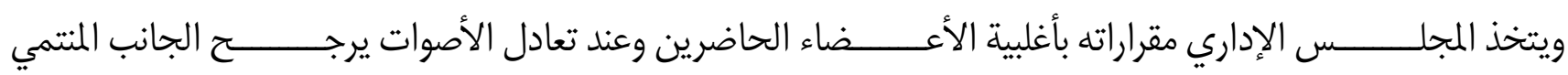

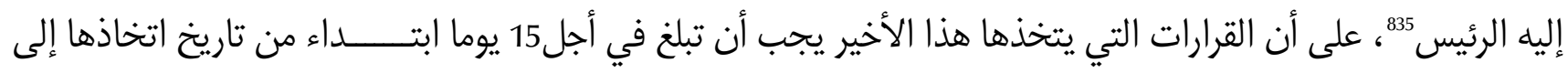
الوزارة الوصية

831 - تجدر الملاحظة إلى أن هناك مشروع وضعته وزارة الصحة بشأن إصلاح نظام الضمان الاجتماعي سنة 1989 - 1990، وقد تضمن هذا المشروع رفع عدد أعضاء المجلس الإداري إلى 30 عضوا، وذلك بنسبة 10 أعضاء ممثلين عن الدولة و10 أعضاء ممثلين عن العمال و10 أعضاء

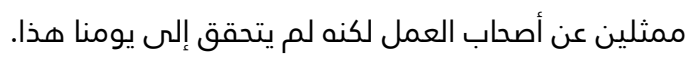

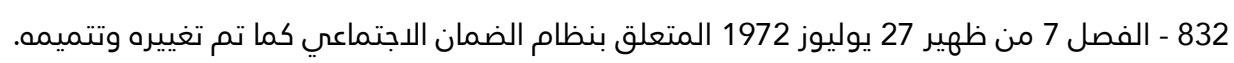

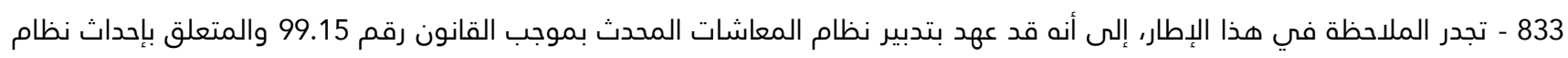

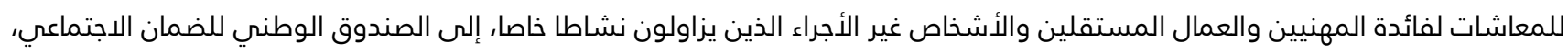

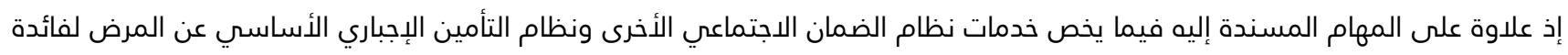

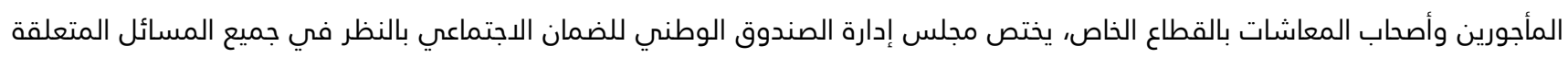

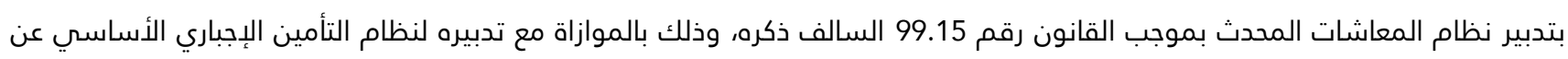

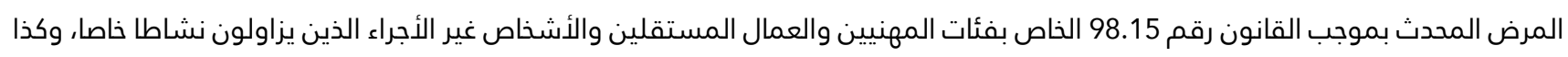
البث في جميع القضايا المرتبطة بهذين النظامين.

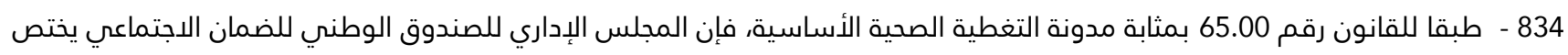

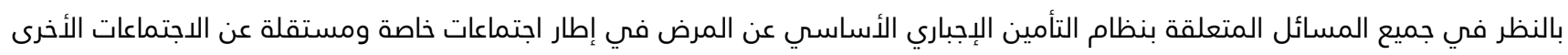

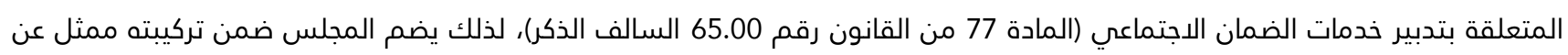
الوكالة الوطنية للتأمين الصحي والذي يعين بنص تنظيمي مع مراعاة التمثيلية الثلاثية المتساوية.

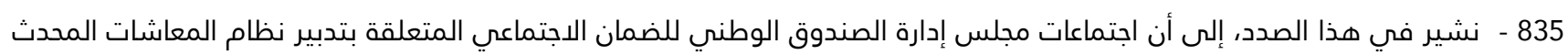

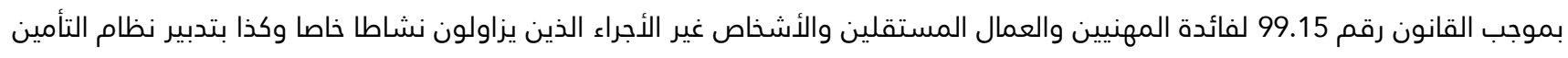

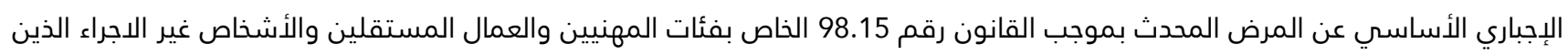

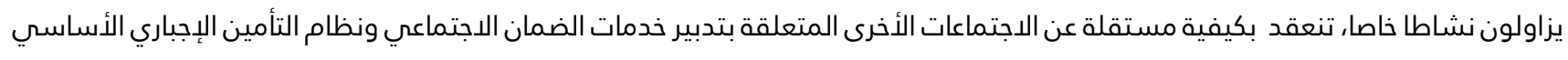

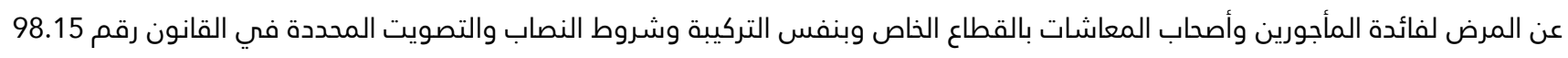

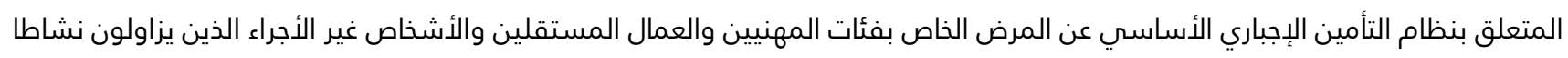

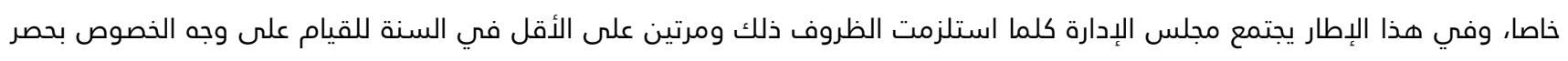

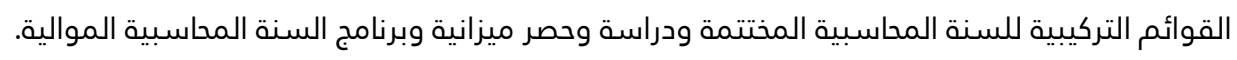

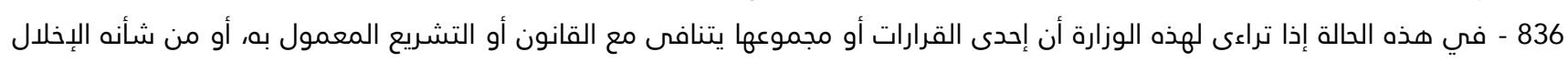

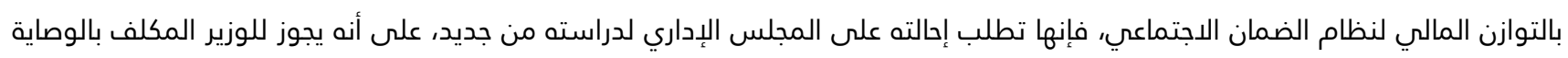

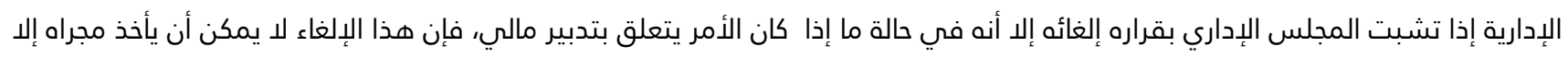
بعد موافقة الوزير المكلف بالمالية، على أنه إذا لم يتخذ أي قرار وزاري في أجل 15 يوما من تاريخ تبليغ القرار الصادر عن المجلس الإداري الماري أصبح

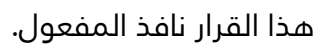




\section{ثانيا - اللجان التابعة للصندوق الوطني للضمان الاجتماعي}

إضافة إلى المجلس الإداري، تسهر على الحكامة الجيدة للصندوق الوطني للضمان الاجتماعي مجموعة من اللجان، ويتعلق الأمر هنا بلجنة التسيير والدراسات 837، ولجنتين مختصتين دائمتين وهما "لجنة الافتحاص والمخاطر" و"لجنة الاستراتيجية والتطوير" "838، هذا إضافة إلى اللجان الخاصة،

\section{1- لجنة التسيير والدراسات}

تختص هذه اللجنة في الفترات الفاصلة بين اجتماعات المجلس الإداري، بتتبع تدبير شؤون الصندوق الوطني للضمان الاجتماعي، والقيام عند الاقتضاء بتسوية جميع المسائل المفوضة إليها من طرف المجلس الإداري المجلس الإداري للصندوق بصفته رئيسا لها أو السلطة الحكومية المفوضة من قبله لهذا الغرض إلهيعة مئه ومن عضو مجلس الإدارة الذي يمثل الوزير المكلف بالتشغيل، وعضو مجلس الإدارة الذي يمثل وزير المالية وثلاثة أعضاء مجلس الإدارة يمثلون العمال وثلاثة عن أرباب العمال، ويتم تعيين ممثلي الشغالين وممثلي المشغلين داخل لجنة التسيير والدراسات من قبل

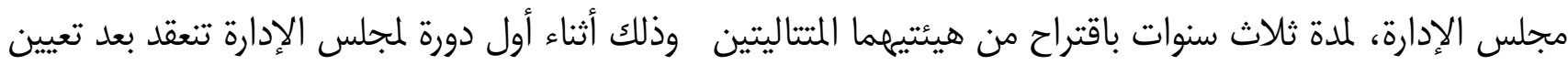

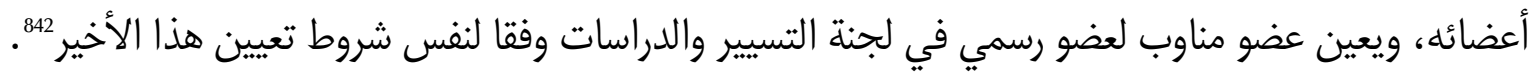

هذا، وتجتمع لجنة التسيير والدراسات بمبادرة من رئيسما، كلما دعت حاجة الصندوق الوطني للضمان الاجتماعي لذلك وعلى الأقل مرة كل ثلاثة أشهر، ولا تكون مداولاتها صحيحة إلا إذا حضرها عضوان عن كل هيئة من هيئاتها

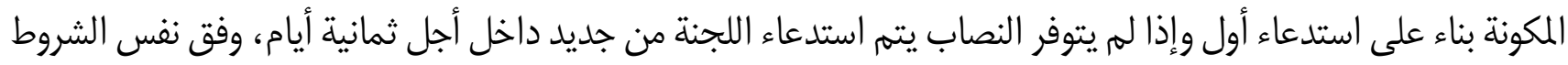
وعلى أساس نفس جدول الأعمال، وعندئذ تتداول اللجنة إذا حضر عضو واحد عن كل هيئة وتتداول لجنة التسيير

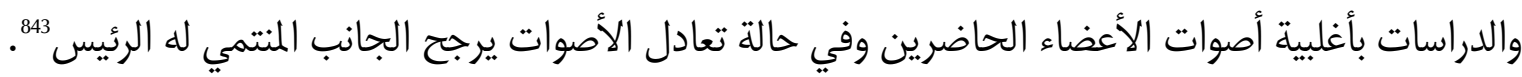

837 - تمت الإشارة إلى هذه اللجنة في الفصل 8 من ظهير27 يوليوز1972 المتعلق بنظام الضمان الاجتماعي كما تم تغييره وتتميمه وكذا في الفصل 10 والفصول التي تليه إلى غاية الفصل 15 من القانون الداخلي للصندوق الوطني للضمان الاجتماعي الملحق بقرار وزير التشغيل والتكوين المهني رقم 1148 الصادر بتاريخ 20 ماي 2013. 838 - انظر بهذا الخصوص الفصل 17 من القانون الداخلي للصندوق الوطني للضمان الاجتماعي الملحق بقرار وزير التشغيل والتكوين المهني رقم 1148 الصادر بتاريخ 20 ماي 2013. 839 - تمت الإشارة إلى هذه اللجان الخاصة في القانون الداخلي للصندوق الوطني للضمان الاجتماعي السالف ذكره، من الفصل 18 إلى غاية الفصل 23 منه. 840 - وذلك باستثناء النقط المدرجة في الفصل 2 من القانون الداخلي للصندوق الوطني للضمان الاجتماعي السالف ذكره، والتي يتعين وجوبا التداول فيها من قبل مجلس الإدارة. 841 - يلاحظ في هذا الإطار، أن رئيس المجلس الإداري هو ذاته يترأس أشغال هذه اللجنة، الشيء الذي يمكن أن يحد من استقلاليتها كجهاز من أجهزة الصندوق قائم بذاته، لذلك كان من الأفضل لو تم انتخاب رئيس اللجنة أو على الأقل تعيينه من طرف وزير التشغيل. 842 - الفصل 11 من القانون الداخلي للصندوق الوطني للضمان الاجتماعي الملحق بقرار وزير التشغيل والتكوين المهني رقم 1148 الصادر بتاريخ 20 ماي 2013. 843 - نشير في هذا الإطار، إلى أنه يتم تدوين مداولات لجنة التسيير والدراسات في محاضر توقع من طرف رئيس اللجنة ومتصرف ممثل للشغالين ومتصرف ممثل للمشغلين، وعند نهاية كل جلسة تسجل القرارات التي تتخذ عقب المداولات بخصوص كل نقطة مدرجة في جدول الأعمال في سجل يوقع عليه جميع أعضاء لجنة التسيير والدراسات الحاضرين، وترسل محاضر مداولات لجنة التسيير والدراسات وكذا نسخ من قراراتها إلى جميع المتصرفين الرسميين والمناوبين خلال 10 أيام الموالية لتاريخ سريان مفعولها. 
يتعلق الأمر هنا بلجنة الافتحاص والمخاطر ولجنة الاستراتيجية والتطوير والمخاطر بلدور استشاري، لاسيما فيما يتعلق بإعداد الحسابات وكل ما يخص مهام المتفحصين ومدققي الحسابات وكذا جهاز المراقبة الداخلية والمخاطر بينما تقوم لجنة الاستراتيجية والتطوير بدور استشاري، في مجالات التوجهات الاستراتيجية

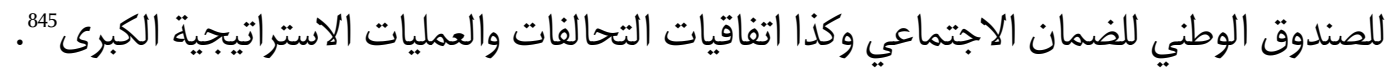

3- الجان الخاصة فضلا عن اللجان السالف ذكرها، يمكن لمجلس الإدارة وللجنة التسيير والدراسات أن يحدثا بداخلمما حسب الاحتياجات لجانا خاصة، يتم تحديد مهامها في محاضر اجتماعات الجهازين المذكورين، وتتكون كل لجنة خاصة على الأقل من متصرف رسمي أو مناوب ممثلا عن كل هيئة من المتصرفين داخل مجلس الإدارة، ويتم تعيين أعضاء اللجان الخاصة من قبل مجلس الإدارة أو من قبل لجنة التسيير والدراسات، باقتراح من كل هيئة من المتصرفين، وتقدم كل لجنة خاصة ملاحظاتما واستنتاجاتما وتوصياتها معللة في تقارير محررة وموقعة من قبل أعضائما، على أن هذه التقارير تقدم بحسب الحالة لمجلس الإدارة أو للجنة التسيير والدراسات قصد دراستها والقيام بما يلزم بشأنها ولنها

هذا، وتجدر الإشارة في هذا السياق، إلى أن ظهير 27 يوليوز1972 المتعلق بنظام الضمان الاجتماعي كما تم تغييره وتتميمه، لم ينص على أي لجنة تختص بتدبير نزاعات الضمان الاجتماعي ضمن الهيكلة الإدارية للصندوق الوطني للضمان الاجتماعي، وهو نفس الأمر بالنسبة للقانون الداخلي للصندوق الوطني للضمان الاجتماعي الحالي، وفي مقابل

844 - فضلا عن هاتين اللجنتين، تنص المادة 11 من القانون رقم 99.15 المتعلق بإحداث نظام للمعاشات لفائدة فئات المهنيين والعمال

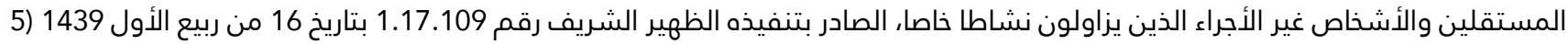
ديسمبر2017) على ما يلي: "... يجوز لمجلس الإدارة أن يحدث كل لجينة أو لجنة متخصصة يحدد تأليفها وطريقة تسييرها، ويجوز له أن يفوض

إليها جزء من سلطه واختصاصاته." 845 - ينص في هذا الإطار الفصل 17 من القانون الداخلي للصندوق الوطني للضمان الاجتماعي على ما يلي: " يتم تهييئ مداولات مجلس الإدارة بالنسبة لبعض المجالات، من قبل لجنتين مختصتين تتكونان من أعضاء يعينهم مجلس الإدارة وبمساعدة أُطراف أخرى إذا أعتبر ذلك لازما.

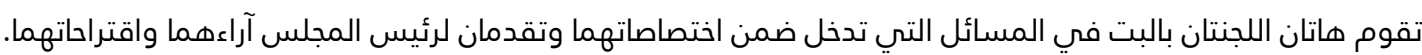
كما يمكنهما أيضا في إطار مزاولة اختصاصاتهما المتتالية، الاستماع إلى المدير العام وطلب إجراء دراسة خارجية على نفقة الصندوق الوطني للضمان الاجتماعي، طبقا للمساطر المعمول بها وبعد موافقة رئيس مجلس الإدارة. تقدم اللجنتان المختصتان تقريرا لرئيس مجلس الإدارة حول المعلومات المحصل عليها والآراء التي تم تجميعها. وهاتان اللجنتان المختصتان الدائمتان هما:

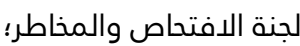
لجنة الاستراتيجية والتطوير.

ينظم تركيب واختصاصات وكيفيات تسيير هاتين اللجنتين، قانون داخلي خاص بكل لجنة يحدده مجلس الإدارة." 846 - يدضر المدير العام ومراقب الدولة بصفة استشارية اجتماعات مجلس الإدارة ولجنة التسيير والدراسات وكذا اجتماعات اللجان المختصة الدائمة واللجان الخاصة، كما يكمن لهذه الأجهزة أيضا الاستعانة بمستشارين مكلفين بتقديم كل الآراء أو الوثائق التقنية المرتبطة بإنجاز دراسات أو أبحاث تعتبرها ضرورية للقيام بمهامها، ويذصص للأجهزة السالف ذكرها من أجل إنجاز مهامها اعتماد من ميزانية تسيير الصندوق الوطني 
ذلك نجد أن النظام الداخلي للصندوق الوطني للضمان الاجتماعي، المصادق عليه بقرار لوزير الشغل والشؤون الاجتماعية سنة 1959، قد أشار في الفصل 11 منه إلى لجنة تسمى " لجنة المنازعات" ، التي كانت تنظر في جميع النزاعات التي قد تثور بسبب تطبيق تشريعات ونظهم الضمان الاجتماعي، وقد كانت هذه اللجنة تتكون من رئيس المجلس الإداري الذي يترأس

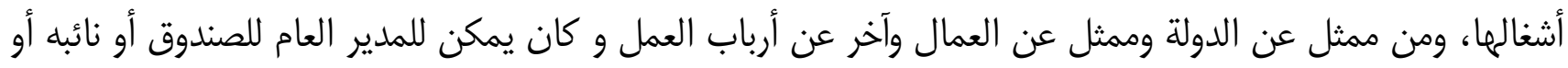
للمراقب المالي للصندوق أن يحضروا اجتماعات هذه اللجنة ولكن بصفة استشاريتة فقط، كما كان يمكن أن يحضر اجتماعاتها كل شخص يتوفر على الكفاءة التي تساعدها على قيامها بمهامياتهرئ.

وعلاقة بنفس الموضوع، نجد أن ظهير 31 دجنبر1959المتعلق بنظام الضمان الاجتماعي - الذي تم نسخه بموجب ظهير 27 يوليوز1972 - كان ينص في الجزء الرابع منه وبالضبط من خلال الفصل 71 على لجان قضائية متكونة من جميع الأطراف المعنية 848 تتولى النظر في النزاعات المرتبطة بنظام الضمان الاجتماعي، وهي نوعان اللجان الابتدائية واللجان العلياتهنئ. وبناء على ذلك، فإن قرارات لجنة المنازعات السالف ذكرها، كانت غير ملزمة ويمكن عرضما على اللجان القضائية المشار إليعا في الفصل 71 من ظهير 1959 المتعلق بنظام الضمان الاجتماعي، ونظرا لعدم اجتماع لجنة المنازعات بسبب كثرة أشغال أعضائما، فقد أحدث المجلس الإداري في ذلك الوقت لجنة أخرى تتولى اختصاصات هذه اللجنة تسمى "لجنة التظلم الإداري" للنظر في الشكاوى المرفوعة ضد الصندوق الوطني للضمان الاجتماعي، حيث كانت تتولى هذه الأخيرة حل خلافات الصندوق مع الأجراء والمؤاجرين.

وبالتالي فإن لجنة المنازعات للأسف لم يتم تفعيلما على أرض الواقع بالطريقة التي كانت مرجوة منها، حيث تم نقل اختصاصاتما إلى لجنة التظلم الإداري، التي يظهر من خلال اسمها أنما لجنة تابعة للصندوق الوطني للضمان الاجتماعي هذا من جهلة، ومن جهة أخرى فإذا كان ظهير 1959 قد نص على وجود لجان ذات طبيعة قضائية ابتدائية واستئنافية، فإن

847 - Article 11 du règlement intérieur de la CNSS (approuvé par une décision du ministre du travail et des affaires sociales en 1959), dispose que : « la commission du contentieux de la caisse est chargée d'examiner tous les recours présentés par les prestataires ou les employeurs contre les décisions de la caisse.

Cette commission, est présidée par le président du conseil d'administration, d'un administrateur représentant l'Etat qu'il aura désigné, comprend un administrateur représentant les travailleurs et un administrateur représentant les employeurs. Le directeur général ou son représentant et le contrôleur financier de la CNSS assistent avec voix consultative, au réunions de la commission qui peut s'adjoindre toutes personnes dont la compétence est jugée utile ».

848 - للاطلاع على ظهير 31 دجنبر1959 المتعلق بنظام الضمان الاجتماعي، أنظر الجريدة الرسمية عدد 2465 الصادرة بتاريخ 23 رجب 1379 (22)

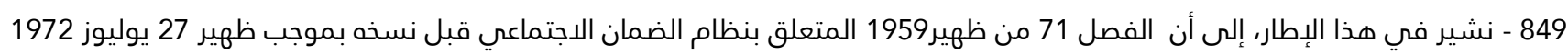
كان ينص على ما يلي: " إن النزاعات التي تنجم عن تطبيق تشريعات ونظم الضمان الاجتماعي، بخصوص المؤمن عليهم والمشغلين والصندوق بله

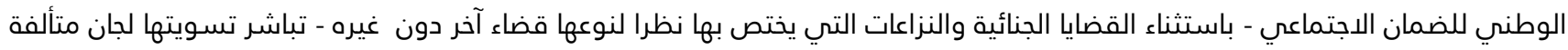
من قاض تابع لمحكمة ابتدائية بصفة رئيس وممثل عن وزارة الشغل والشؤون الاجتماعية وممثل عن العملة وممثل عن المشغلين، وفي حالة تساوي الأصوات يكون صوت الرئيس هو الراجح. وتكون المقررات الصادرة من هذه اللجان قابلة للاستئناف لدى لجنة عليا مؤلفة من قاض تابع لمحكمة الاستئناف بصفة رئيس وممثل عن وزير الشغل والشؤون الاجتماعية وممثل عن العملة وممثل عن المشغلين، وفي حالة تساوي الأصوات يكون صوت الرئيس هو الراجح.

وتكون المقررات الصادرة من اللجان العليا قابلة للطعن فيها بطريق النقض، وتحدد في مرسوم كيفيات تعيين أعضاء هذه اللجان وتسييرها." 
هذه اللجان لم يتم إحداثما أبدا، ولم يصدر أي مرسوم لتحديد دائرة اختصاص كل لجنة كما نصت على ذلك الفقرة الأخيرة من الفصل 71 من ظهير 31 دجنبر 1959 السالف ذكره، وقد ظل الحال على ما هو عليه، إلى غاية نسخ ظهير 31 دجنبر 1959

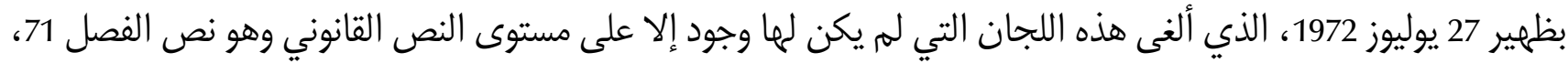

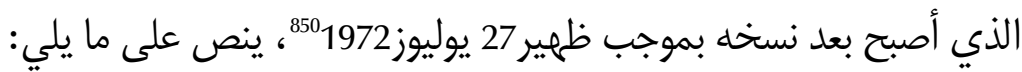

" تنظر المحاكم الاجتماعية في النزاعات المترتبة عن تطبيق مقتضيات ظهيرنا الشريف هذا والنصوص التنظيمية

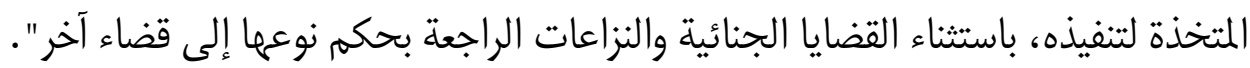

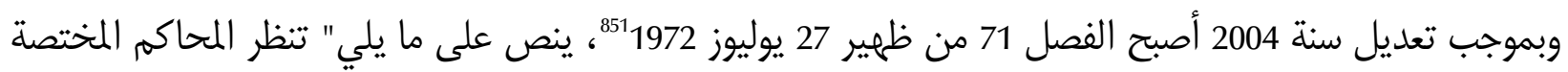
في النزاعات المترتبة عن تطبيق مقتضيات ظهيرنا الشريف هذا والنصوص التنائن التظيمية المتخذة لتنفيذه، باستثناء القضايا الجنائية والنزاعات الراجعة بحكم نوعها إلى قضاء آخر ".

هكذا، وفي ظل غياب لجان مختصة بالبت في نزاعات الضمان الاجتماعي ضمن الهيكلة الإدارية للصندوق الوطني

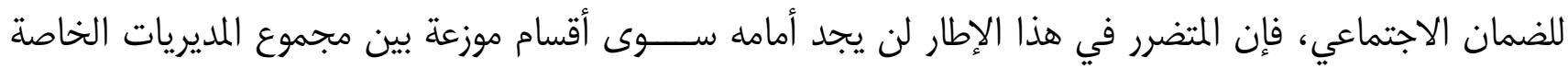

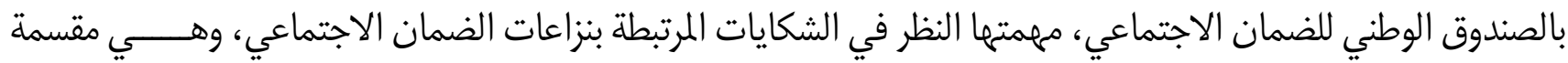

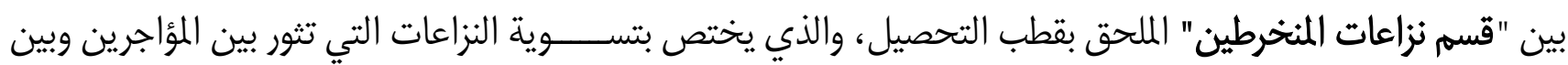

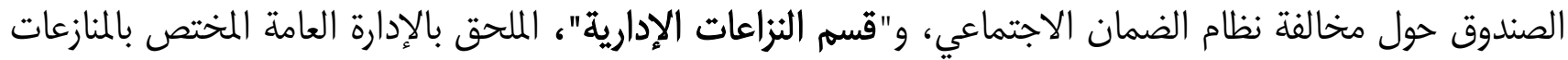

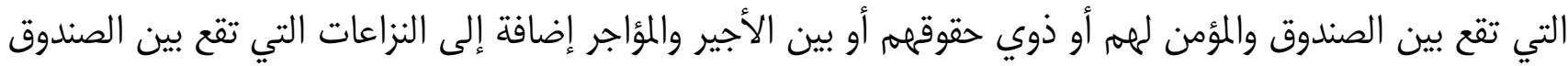
ومستخدميه.

هذا ونسجل في هذا السياق، أن الأقسام السالف ذكرها لا يمكن أن تحقق الآمال المعقودة عليها في تسوية نزاعات

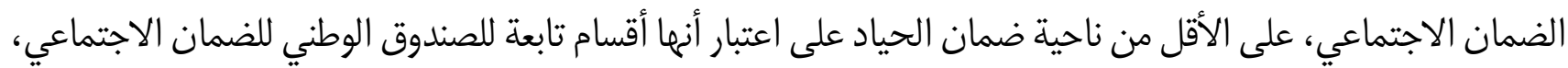

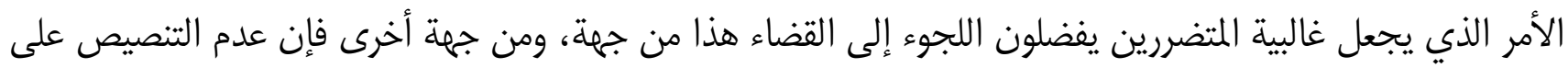

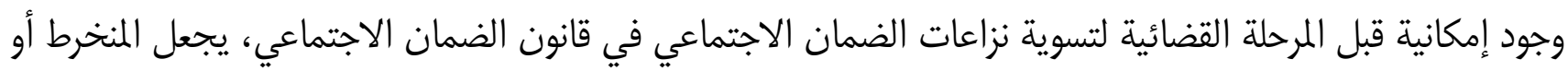

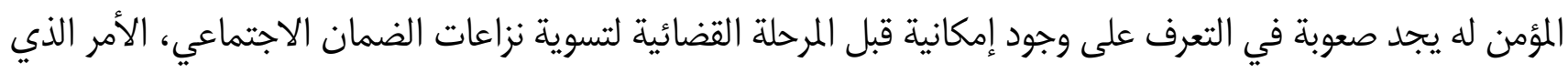
يجعله في غالب الأحيان يطرق باب القضاء مباشرة دون اللجوء إلى الأقسام السالف ذكرها.

وتجدر الإشارة في هذا الإطار، إلى أنه أمام غموض مقتضيات الفصل 71 من ظهيير 27 يوليوز1972 المتعلق بنظام

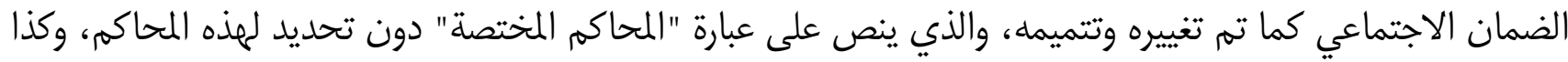

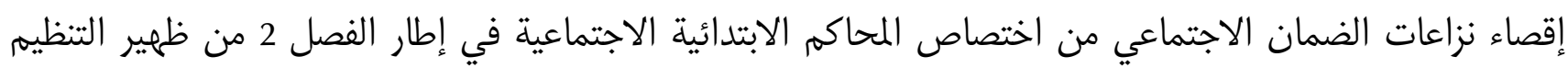

850 - الظهير الشريف بمثابة قانون رقم 1.72 .184 الصادر بتاريخ 15 جمادى الثانية 1392 (27 يوليوز 1972) المتعلق بنظام الضمان الاجتماعي،

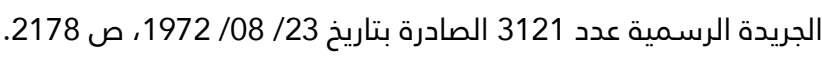
851 - يتعلق الأمر هنا بالظهير الشريف رقم 1.04 .127 الصادر في 21 من رمضان 1425 (4 نونبر 2004)، بتنفيذ القانون رقم 17.02 المغير والمتمم بموجبه الظهير الشريف بمثابة قانون رقم 1.72 .184 الصادر بتاريخ 15 من جمادى الآخرة 1392 (27 يوليوز1972) المتعلق بنظام الضمان الاجتماعي. 
القضائي المعدل سنة 2011 الإدارية ${ }^{853}$

\section{الفقرة الثانية: المدير العام للصندوق الوطني للضمان الاجتماعي والموظفين العاملين به}

من بين الأجهزة الإدارية التي تقوم بلدور أساسي في تسيير الصندوق الوطني للضمان الاجتماعي نجد المدير العام (أولا) والموظفين العاملين بهذا الصندوق (ثانيا).

\section{أولا - المدير العام للصندوق الوطني للضمان الاجتماعي}

يعتبر المدير العام للصندوق الوطني للضمان الاجتماعي، أحد المراكز التنفيذية المرمة بالنسبة للأجراء وممثليهم النقابيين بالمجلس، إذ يعتبر من الموظفين الساميين الذين يته تعيينهم بظهير بعد المداولة في المجلس الوزاري، بناء على بلى اقتراح من رئيس الحكومة وبمبادرة من الوزير المعني ${ }^{856}$ ويتولى المدير العام تنفيذ قرارات المجلس الإداري، وتسيير المصالح التابعة للصندوق وتنسيق أعمالرها، ويمثل الصندوق لدى المحاكم وفي جميع أعمال الحياة المدنية المدير العام بإحدى الوسائل المنصوص عليها في قانون الوظيفة العمومية، منها العزل كعقوبة تأديبية أو الاستقالة كتعبير إرادي يصدر عن الموظف أو الإحالة على التقاعد أو الوفاة كسبب ضمني لإنماء علاقة الموظف بإدارته.

\section{ثانيا - موظفوا الصندوق الوطني للضمان الاجتماعي}

يسند تنفيذ الأعمال اليومية للصندوق الوطني للضمان الاجتماعي، إلى موظفين يتألفون من أعوان دائمين وأعوان

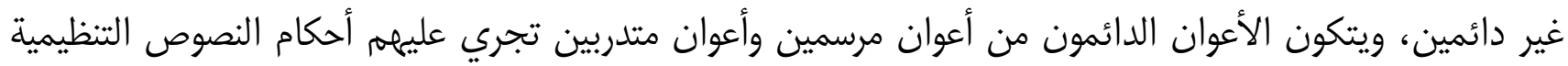
المطبقة على موظفي الدولة، ويخضعون أيضا لنظام أساسية

852 - ينص الفصل 2 من ظهير التنظيم القضائي على ما يلي:

تقسم المحاكم الابتدائية الاجتماعية إلى أقسام قضاء الأسرة وغرف حوادث الشغل والأمراض المهنية وغرف نزاعات الشغل. ... " . . . . 853 - وذلك بموجب القانون رقم 41.90 الصادر بتنفيذه الظهير الشريف رقم 1.91 .225 بتاريخ 10 شتنبر 1993، الجريدة الرسمية عدد 4227 الصادرة بتاريخ 03/ 11/ 1993، ص ص 2168. 854 - وذلك بمقتضى القانون رقم 95-53 الصادر بتنفيذه الظهير الشريف رقم 1.97 .65 بتاريخ 12 فبراير 1997، الجريدة الرسمية عدد 4482

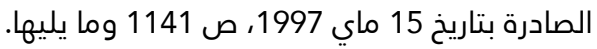
85585 - إذا كان الفصل 20 من قانون المسطرة المدنية، قد أعطى الاختصاص للمحاكم الابتدائية للبت في نزاعات الضمان الاجتماعي فإن مناط

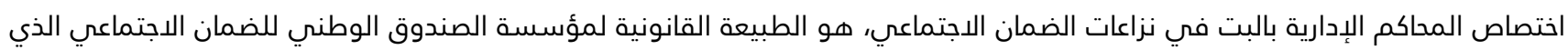
يعتبر مؤسسة عمومية، وبالتالي فإن ديونه تعتبر ديون عمومية تخضع للمساطر المرتبطة بتحصيل الدين العمومي المنصوص عليها في القانون رقم 15.97 بمثابة مدونة تحصيل الديون العمومية، بالإضافة إلى الطبيعة الإدارية للقرارات الصادرة عن الصندوق الوطني للضمان الاجتمانماعي باعتباره مؤسسة عمومية، أما اختصاص المحاكم التجارية بالبت في نزاعات الضمان الاجتماعي فيرجع إلى طبيعة المنخرطين في الصندوق الوطني للضمان الاجتماعي، الذين يعتبرون في جلهم مقاولات تجارية وصناعية، قد تتعرض لصعوبات تستوجب تدخل القضاء التجاري في محاولة منه لتصحيح مسار المقاولة المختلة. 856 - أنظر بهذا الخصوص مقتضيات الفصل 49 من الدستور المغربي الصادر سنة 2011 وكذا مقتضيات المادة 2 من القانون التنظيمي رقم 02.12 المتعلق بالتعيين في المناصب العليا تطبيقا لأحكام الفصلين 49 و92 من الدستور. 857 - الفصل 13 من ظهير 27 يوليوز 1972 المتعلق بنظام الضمان الاجتماعي كما تم تغييره وتتميمه. 858 - الفصل 14 من ظهير 27 يوليوز 1972 المتعلق بنظام الضمان الاجتماعي كما تم تغييره وتتميمه. 
استشارة الوزير المكلف بالمالية وموافقة الوزير المكلف بالوظيفة العموميته من الشروط العامة للتشغيل والأجور المطبقة على أعوان الدولة المياومين والمؤقتين، ومن حق الأسبقية في الترسيهم إذا كانت الفترات التي استخدموا فيها يعادل مجموعما 7 سنوات وكانت تتوافر لديهمم الشروط اللازمة لهزا الغرض العاملون بعقد، فإنه لا يمكن بأي حال من الأحوال أن يستفيدوا من وضعية أحسن من وضعية عون دائم تتوافر لديا نفس لتس

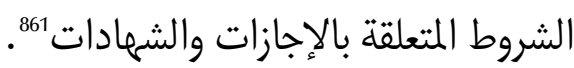

وتختلف مهام موظفي الصندوق الوطني للضمان الاجتماعي باختلاف الوضعية الإدارية أو السلك الذي ينتمون إليهمة، ويتهم تعيينهم بمقرر للمدير العام، أما فيما يتعلق بالشروط العامة لتعيينهم وترقيتهم في الرتبة والدرجة فهي نفس الشروط المطبقة على موظفي الدولة:863.

هذا، ويستفيد أعوان الصندوق الوطني للضمان الاجتماعي في حالة التساوي في الرقم الاستدلالي من نفس المرتبات التي يتقاضاها موظفوا الدولة، ويستفيدون كذلك وطبق نفس الشروط من التعويضات ذات الصبغة الدائمة أو المؤقتة الممنوحة للموظفين المذكورين، كما يمكن أيضا أن تمنح في نهاية السنة مكافأة لبعض الأعوان الدائمين التابعين للصندوق الوطني للضمان الاجتماعي زيادة على التعويضات السالف ذكرها، وذلك وفق الشروط المعمول بها في هذا الإطار

\section{المطلب الثاني: التنظيم المالي للصندوق الوطني للضمان الاجتماعي}

إن الحديث عن التنظيم المالي للصندوق الوطني للضمان الاجتماعي، يتطلب منا التطرق لموارد هذا الصندوق من جهة (الفقرة الأولى)، وللرقابة المفروضة على أمواله من جهة ثانية (الفقرة الثانية).

859 - يتعلق الأمر هنا بالمرسوم رقم 2.79 .725 الصادر بتاريخ 26 من جمادى الثانية 1400 (12 ماي 1980) بشأن النظام الأساسي الخاص بموظفي الصندوق الوطني للضمان الاجتماعي، الجريدة الرسمية عدد 3527 الصادرة بتاريخ 04 يونيو 1980، 1980، ص740.

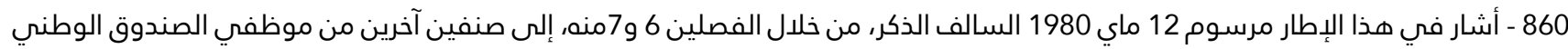
للضمان الاجتماعي، ويتعلق الأمر هنا بموظفي المعمل بمطبعة الصندوق الوطني للضمان الاجتماعي الصاعي، الذين تجري عليهم الأحكام المطبقة

على موظفي المعمل بالمطبعة الرسمية والموظفين الإعلاميين الذين تحدد وضعيتهم بمرسوم. 861 - الفصل 7 من مرسوم 12ماي 12 موطمي 1980 السالف ذكره.

862 - يدرج موظفوا الصندوق الوطني للضمان الاجتماعي المرسمون والمتدربون بالإضافة إلى الأعوان المشار إليهم في الفصلين 5 و و6

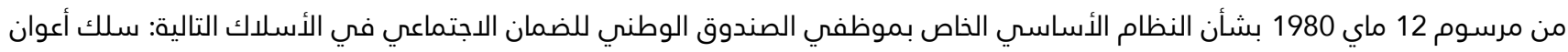
الخدمة، سلك أعوان التنفيذ، سلك الأعوان العموميون، سلك المراقبين، سلك المفتشين المساعدين، سلك المفتشين وسلك المفتشين

الإقليميين.

863 - خلافا لمرسوم 12 ماي 1980 الخاص بالنظام الأساسي لموظفي الصندوق الوطني للضمان الاجتماعي، الذي اكتفى فيما يتعلق بالشروط العامة لتعيين وترقية موظفي هذا الصندوق بالإحالة فقط على الشروط العامة المطبقة على موظفي الدولة الة فإن الاتفاقية الجماعية المنظمة لوضعية مستخدمي الصندوق الوطني للضمان الاجتماعي قد حددت هذه الشروط بشكل دقيق، حيث ميزت بين المستخدمين

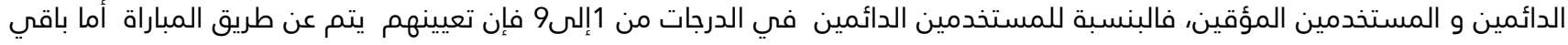
الدرجات فإن تعيينهم يتم من طرف المدير العام للصندوق، طبقا للشروط المحددة في الفصلين 9و 10من الاتفاقية الجماعية المنظمة لوضعية

مستخدمي الصندوق الوطني للضمان الاجتماعي.

864 - أنظر بهذا الخصوص الفصل 31 من مرسوم 12 ماي 1980 بشأن النظام الأساسي الخاص بموظفي الصندوق الضدوق الوطني للضمان

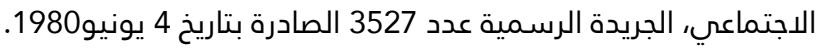




\section{الفقرة الأولى - موارد الصندوق الوطني للضمان الاجتماعي}

لقد حدد الفصل 18 من ظهير 27 يوليوز1972المتعلق بنظام الضمان الاجتماعي كما تم تغييره وتتميمه، موارد

$$
\text { الصندوق الوطني للضمان الاجتماعي فيما يلي: }
$$

*واجبات الاشتراك والزيادات المفروضة في حالة التأخر في أداء الاشتراكات 865؛

* الربات والوصايا؛

*عوائد توظيف أموال الصندوق الوطني للضمان الاجتماعي لدى صندوق الإيداع والتدبير؛ *جميع الموارد الأخرى المخولة للصندوق بموجب تشريع أو نظام خاص.

هذا بالإضافة إلى أموال احتياطية تقنية وأرصدة التأمين، حيث نجد أن الصندوق الوطني للضمان الاجتماعي، قد أسس في الفترة ما بين 1961 و1972 رصيدا واحدا للاحتياط لدى صندوق الإيداع والتدبير، ثم انشطاره فيما بعد ليشمل ثلاثة أرصدة مختلفة بعد إصلاح سنة 1972 وهي كالتالي: *أموال احتياطية لأداء التعويضات العائلية؛ *أموال احتياطية لأداء التعويضات الاجتماعية القصيرة الأمد؛ ألعويفات العاكيه:

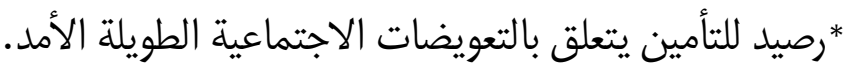

وتتتج هذه الأموال من فائض المبالغ السنوية بالنسبة للموارد الخاصة بكل صنف من التعويضات ${ }^{866 . ~}$

\section{الفقرة الثانية: الرقابة المالية على أموال الصندوق الوطني للضمان الاجتماعي}

يخضع الصندوق الوطني للضمان الاجتماعي للمراقبة المالية، بهدف التأكد من تدبير أمواله بكيفية صحيحة تمكنه من تحقيق السياسة المتبعة في مجال الضمان الاجتماعي الخارجية (ثانيا).

865 - نلاحظ في هذا الصدد، أن المشرع المغربي لم يعطي تعريفا للاشتراكات، رغم أنها تعد المصدر الأساسي والرئيسي لتمويل الصندوق الوطني للضمان الاجتماعي، ويمكن أن نعرفها في هذا الإطار و بشكل مبسط بأنها هي تلك الكان المبالغ المالية المقدمة من طرف كل كل من الأجير والمشغل، بهدف تغطية التزامات الصندوق الوطني للضمان الاجتماعي، وقد حدد المشرع مقدار هذه الاشتراكات في نسب معينة من الأجر، تختلق بحسب كل صنف من أصناف التعويضات المستحقة للأجراء، إذ تحدد نسبة الاشتراك عن التعويضات العائلية في 6 في 6 من من الأجر الكامل ويتحملها المشغل لوحده، في حين تعادل نسبة الاشتراك عن التعويضات قصيرة الأمد \% 1\% في حدود سقف

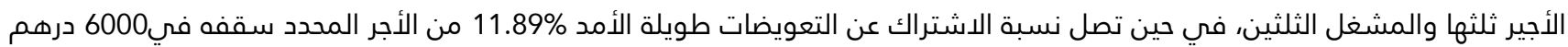

في الشهر يتكفل الأجير بأداء ثلثها والمشغل ثلثيها. وتخضع المهن البحرية لنظام خاص، حيث تصل نسبة المساهمات إلى 4,65 \% من صافي الدخل بالنسبة لسفن الصيد و 6 \% بالنسبة للسفن التي تستعمل تقنية الخيوط الطويلة وسفن صيد السردين، وتحتسب هذه النسب من الدخل الخام لسفن الصيد وتمول كلا من الخدمات قصيرة وطويلة الأمد، وتتم مراجعة نسب الاشتراك بطريقة تسمح بموازنة الموارد بالنفقات السنوية بشكل يمكن من تحقيق فائض يمول صناديق

الاحتياط.

866 - نظام الضمان الاجتماعي بالقطاع الخاص،" تاريخ، تنظيم، إحصائيات"، الطبعة الثانية، منشورات الضمان الاجتماعي 1999)،

867 - عبد الله الحميدي، إشكالية تمويل الصندوق الوطني للضمان الاجتماعي، بحث لنيل دبلوم الماستر في القانون الخاص، تخصص قانون الأعمال والمقاولات، جامعة محمد الخامس، كلية العلوم القانونية والاقتصادية والاجتماعية السويسي الرباط، يوليوز 2012 ص 52. 


\section{أولا - الرقابة الداخلية}

يمارس هذه الرقابة المجلس الإداري للصندوق الوطني للضمان الاجتماعي، باعتباره الهيئة المركزية المكلفة بذلك، غير أنه ونظرا لكثرة المهام التي يقوم بها هذا الأخير، فإنه يخول هذه المرمة إلى أحد المصالح المكلفة بإدارة الضمان الاجتماعي

\section{ثانيا - الرقابة الخارجية}

يخضع تدبير وتسيير أموال الصندوق الوطني للضمان الاجتماعي، لرقابة الدولة التي نظمها ظمير 22أبريل وفي هذا الإطار فإن الصندوق الوطني للضمان الاجتماعي يخضع لرقابة خارجية من طرف وزارة الاقتصاد والمالية، من خلال تعيين مراقب مالي من بين مفتشي المالية أو المدراء، حيث يعملد إليه بتتبع كل العمليات التي تكتسي بشكل مباشر أو غير مباشر صبغة مالية باستثناء العمليات التي تندرج في إطار النظر في تصفية الحقوق التأمينية المتعلقة بالتعويضات لفائدة المستفيدين من خدمات الصندوق الوطني للضمان الاجتماعي

هذا، وفضلا عن رقابة وزارة الاقتصاد والمالية، فإن الصندوق الوطني للضمان الاجتماعي يخضع لرقابة من نوع آخر، من طرف هيئة مراقبة التأمينات والاحتياط الاجتماعي، وذلك تطبيقا لمتتضيات المادة 2 من القانون رقم 12-64 القاضي بإحداث هيئة مراقبة التأمينات والاحتياط الاجتماعي، حيث تمارس هذه المراقبة على عمليات التقاعد الخاضعة لأحكام الظهير الشريف بمثابة قانون رقم 184.72 .184 الصادر بتاريخ 15 من جمادى الآخرة 1392( 27 يوليوز 1972 19: المتعلق بنظينام الضمان الاجتماعي كما تم تغييره وتتميمه

868 - زروال بلعيد، التنظيم الإداري والمالي للصندوق الوطني للضمان الاجتماعي، رسالة لنيل دبلوم الدراسات العليا في القانون الخاص جامعة الحسن الثاني، كلية العلوم القانونية والاقتصادية والاجتماعية الدار البيضاء، السنة الجامعية 1998- 1999، 1969، ص 120. 869- يتعلق هذا الظهير بتنظيم مراقبة الدولة المالية على المكاتب والمؤسسات العمومية والشركات ذات الامتيازات، وكذا الشركات والمنظمات المستفيدة من المساعدة المالية التي تمنحها الدولة أو الجماعات الترابية، حسب ما وقع تغييره بالظهير الشريف رقم 61.402. 1 التوات المؤرخ في 30 يونيو1962. 870- في هذا الإطار تعرض على المراقب المالي، كل الوثائق والقوائم ونظير من الموازنة الشهرية العامة للحسابات، كما يمسك محاسبة خاصة، تمكنه من تقييم مشروع الميزانية العامة السنوية النهائية، وتتبع تطبيقها عن قرب ومن معاينة تقلبات المداخيل، ومن مهامه أيضا معاينة المزايدات والمصادقة على اقتناء المعدات الضرورية وعلى المضاربات وكذا على سندات التحويل والاقتناء، ويتلقى حسابات السنة المالية السابقة والحساب الختامي والحساب التعويضي وناتج السنة الماضية، وبعد دراسة هذه الوثائق يباشر المراقب المالي عملية عرض مجموع النتائج المالية للسنة ويوجه نظيرا منه إلى الوزارة الوصية إلى وزارة المالية وإلى المدير العام. 871- تنص في هذا الإطار المادة 2 من القانون رقم 12-64 القاضي بإحداث هيئة مراقبة التأمينات والاحتياط الاجتماعي على ما يلئي: " تمارس الهيئة مراقبتها على الأشخاص الخاضعين للقانون العام أو الخاص باستثناء الدولة، الذين يقومون بممارسة أو تدبير: 
وتمارس مراقبة الهيئة وفقا للأحكام التشريعية والتنظيمية التي تطبق على هذه العمليات

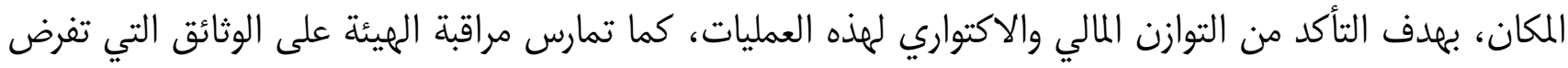
الهيئة الإدلاء بها إذا كانت ضرورية لمهمة المراقبة.

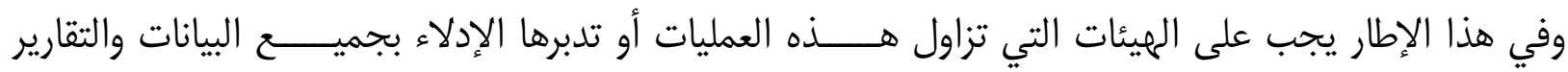

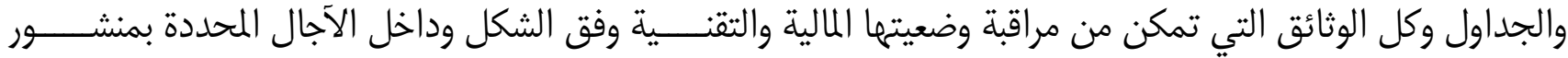

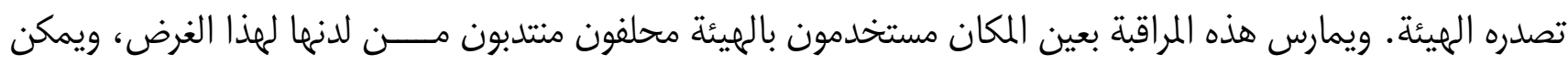

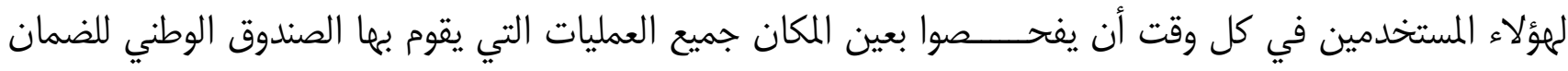

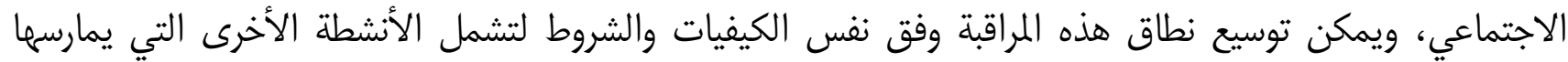
الصندوق.873.

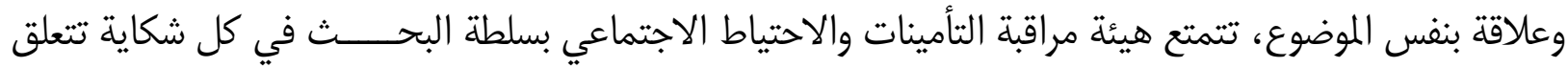

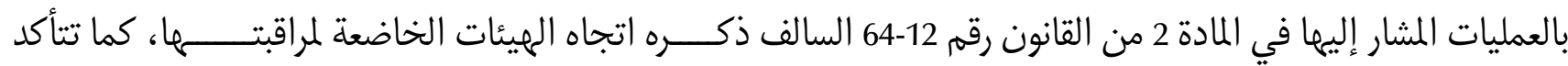

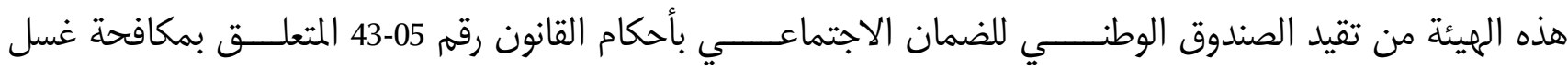

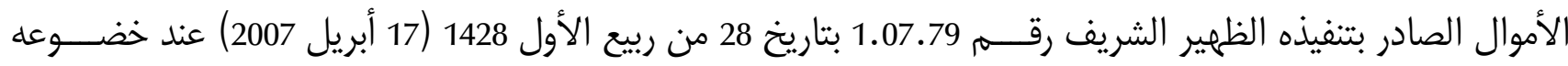

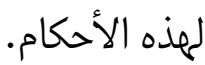

وفضلا عن ذلك، وفي إطار القيام بمهامها تقوم هيئة مراقبة التأمينات والاحتياط الاجتماعي بتوجيه المعطيات

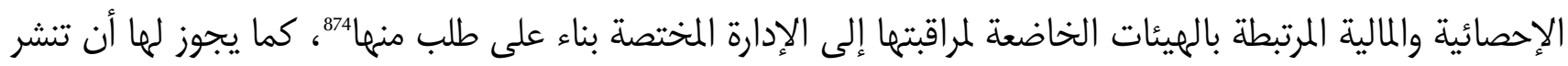

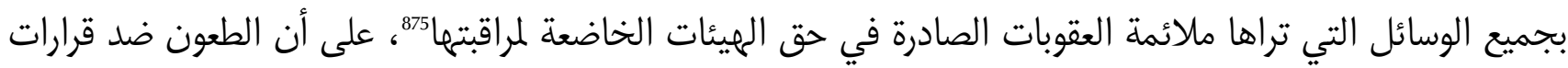

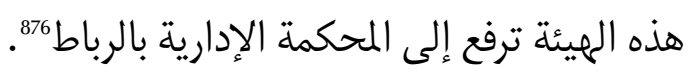

هذا، وتتميما لأحكام المادة 2 من القانون رقم 64.12 القاضي بإحداث هيئة مراقبة التأمينات والاحتياط الاجتماعي،

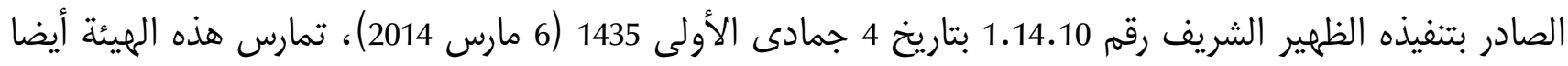

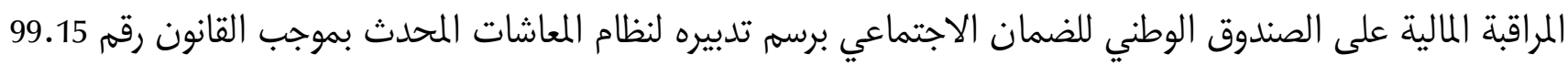

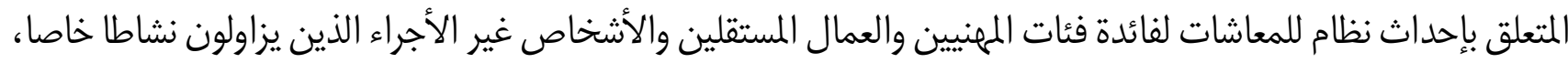

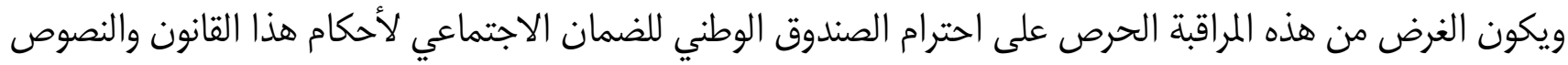

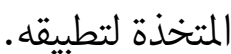

872 - الفقرة الثانية من المادة العاشرة من القانون رقم 12-64 القاضي بإحداث هيئة مراقبة التأمينات والاحتياط الاجتماعي. 873- توجه هيئة مراقبة التأمينات والاحتياط الاجتماعي سنويا إلى رئيس الحكومة تقريرا حول نتائج هذه المراقبة، وذلك تطبيقا لمقتضيات المادة 11 من القانون رقم 12- 64 القاضي بإحداث هيئة مراقبة التأمينات والاحتياط الاجتماعي. 874 - المادة 9 من القانون رقم 12 - 64 القاضي بإحداث هيئة مراقبة التأمينات والاحتياط الاجتماعي. 875 - المادة 50 من القانون رقم 12 - 64 القاضي بإحداث هيئة مراقبة التأمينات والاحتياط الاجتماعي. 876 - المادة 51 من القانون رقم 12 - 64 القاضي بإحداث هيئة مراقبة التأمينات والاحتياط الاجتماعي. 
وفي هذا الإطار، يتعين على الصندوق الوطني للضمان الاجتماعي، أن ينجز افتحاصا اكتواريا لوضعية نظام المعاشات

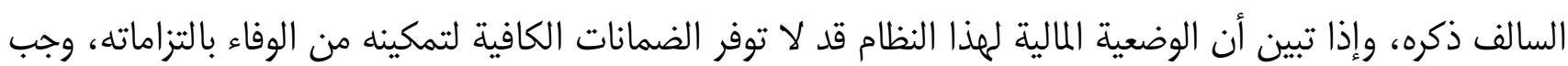
على الصندوق الوطني للضمان الاجتماعي أن يقدم لهيئة مراقبة التأمينات والاحتياط الاجتماعي، مخططا للتصحيح مرفقا بتقرير إكتواري ويجب أن يتضمن هذا المخطط الإجراءات المتعلقة بمحددات الاشتراكات وبقيمة النقطة عند التصفية الكفيلة بتوفير الضمانات الكافية لتمكين النظام من الوفاء بالتزاماته وإذا لهم يقدم الصندوق الوطني للضمان الاجتماعي هذا المخطط أو رفضت هيئة مراقبة التأمينات والاحتياط الاجتماعي مخطط التصحيح الذي قدمه إليها هذا الصندوق أو له يقم هذا الأخير داخل الآجال المحددة بتنفيذ مخطط التصحيح الذي تم قبوله، توجه هيئة مراقبة التأمينات والاحتياط الاجتماعي، إلى رئيس الحكومة تقريرا يعاين هذه الوقائع وتقترح فيه عند الاقتضاء الإجراءات المناسبة لاستعادة توازن نظام المعاشات المذكور

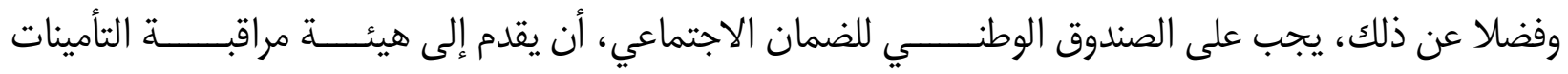

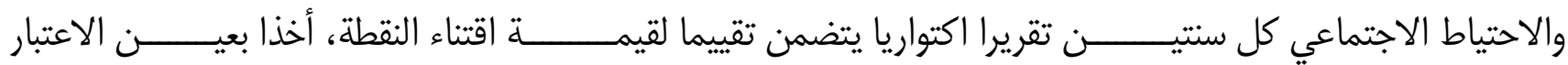

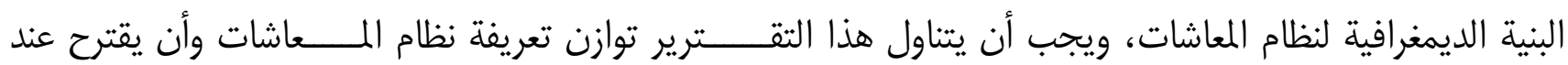

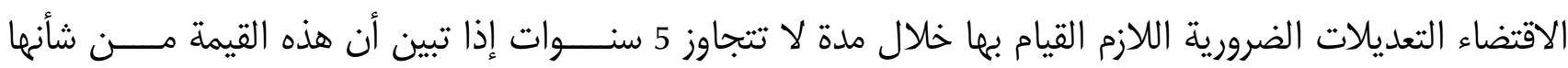
الإخلال بهذا التوازن.

\section{المبحث الثاني: تعويضات نظام الضمان الاجتماعي}

تتجلى أهم نفقات الصندوق الوطني للضمان الاجتماعي لمنترطيه، ذلك أن اشتراكات هؤلاء المنخرطين تعتبر المصدر الرئيسي والأساسي لموارده المالية، وبالتالي فإن المنطق يفرض

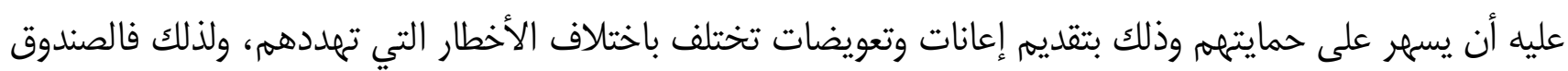
الوطني للضمان الاجتماعي كباقي المؤسسات في مختلف الدول الساهرة على نظام الضمان الاجتماعي، يتولى تسيير

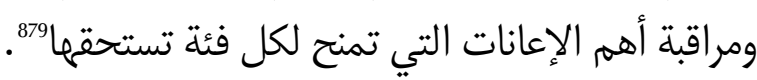

877 ـ توجه هيئة مراقبة التأمينات والاحتياط الاجتماعي إلى رئيس الحكومة تقريرا يعاين الوقائع التالية: *عدم تقديم الصندوق الوطني للضمان الاجتماعي للتقرير الاكتواري المنصوص عليه في المادة 48 من القانون رقم 12 - 64 القاضي بإحداث هيئة مراقبة التأمينات والاحتياط الاجتماعي؛ *رفض الهيئة للتقرير الذي قدمه الصندوق؛ *عدم قيام الصندوق داخل الآجال المحددة بتنفيذ التعديلات المقترحة من طرفهه. وتقترح الهيئة في التقرير المذكور عند الاقتضاء الإجراءات الواجب اتخاذها لاستعادة توازن تعريفة نظام المعاشات. 878 - نشير في إطار حديثنا عن نفقات الصندوق الوطني للضمان الاجتماعي، إلى أن المشرع المغربي قد ألزم الصندوق الوندر الوطني للضمان الاجتماعي بموجب الفصل 30 من الظهير الشريف رقم 1.72 .184 الصادر في 27 يوليوز 1972 المتعلق بنظام الضمان الاجتماعي كما تم تغييره وتتميمه، بإيداع الأموال الاحتياطية المتوفرة لديه غير الأموال اللازمة لتسييره العادي لدى صندوق الإيداع والتدبير. 879 - الحسن كيحل، أنظمة التقاعد في المغرب "الصندوق المغربي للتقاعد والصندوق الوطني للضمان الاجتماعي نموذجا "، رسالة لنيل دبلوم الماستر في العلوم القانونية، تخصص قانون الأعمال ، جامعة محمد الخامس، كلية العلوم القانونية والاقتصادية والاجتماعية أكدال، الرباط السنة الجامعية 2010 - 2011، صبوم 42. 
وفي هذا الإطار، يقدم الصندوق الوطني للضمان الاجتماعي، برسم تدبيره لنظام الضمان الاجتماعي تعويضات مختلفة، يمكن إجمالما في التعويضات العائلية (المطلب الأول) والتعويضات القصيرة الأمد والتعويضات الطويلة الأمد (المطلب الثاني)

\section{المطلب الأول: التعويضات العائلية}

ترتكز التعويضات العائلية على مبدأ المساعدة الاجتماعية الاجتماعي عن الأولاد من أجل رعاية سليمة، وذلك مساعدة للأجير على المصاريف التي يضطر إلى إنفاقها، وهي تعويضات تهلدف إلى حماية الأسرة لأنه ينتج عنها توفير دخل إضافي بالنظر إلى تعدد الأولاد، وهي تتغير حسب السياسة الديمغرافية للدولة ويتحمل المشغل في إطارها وحده مبلغ الاشتراك اعتمادا على اقتطاع من الكتلة الإجمالية للأجور دون تحديد السقف 882. هذا، ويستفيد من التعويضات العائلية الأجراء المزاولون لنشاط مهني، الخاضعون لنظام الحماية الاجتماعية والمقيمون بالمغرب وكذا أصحاب المعاشات الذين لديهم أطفال ولدوا على أبعد تقدير في اليوم الثلاثمائة الموالي للتاريخ الفعلي للمعاش383، وتشمل التعويضات العائلية التي يصرفها الصندوق الوطني للضمان الاجتماعي في الوقت الحالي

880 - تجدر الملاحظة في هذا السياق، إلى أن التعويضات التي يقدمها الصندوق الوطني للضمان الاجتماعي ( التعويضات الطويلة الأمد

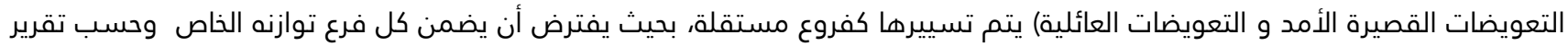

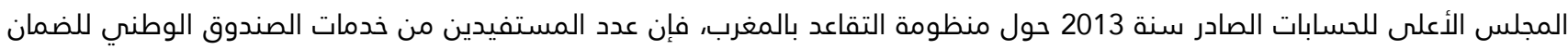
الاجتماعي خلال سنة 2011 قد بلغ 407.810 مستفيد، منها نسبة 79\% استفادت من معاش الشيخوخة ونسبة 19\% استفادت من معاش ذوي الحقوق ونسبة 2 \%استفادت من معاش العجز. وقد حددت المبالغ الموزعة برسم سنة 2011 كالتالي:

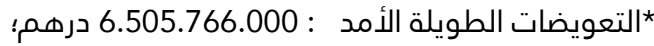

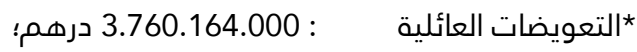
التعويضات القصيرة الأمد : 472.432.000 درهم. 881

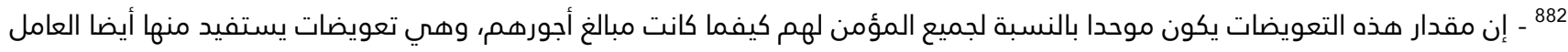

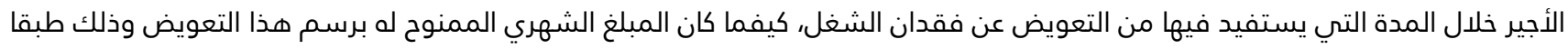
لمقتضيات الفصل 40 من ظهير 27 يوليوز 1972 المتعلق بنظام الضمان الاجتماعي كما تم تغييره وتتميمه بموجب القانون رقم 03.14 الصادر

سنة 2014.

883 - للاستفادة من هذه التعويضات يتعين على الأجير المؤمن له:

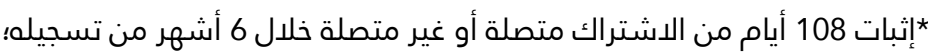

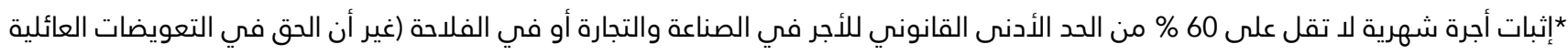
يخول للمؤمن له الذي يمارس نشاطا موسميا ويثبت أنه يتقاضى أجرة شهرية متوسطة هي عبارة عن سدس الأجرة المؤداة عنها الاشتراكات والمقبوضة خلال 6 أشهر المنصرمة بشرط أن تعادل الأجرة الشهرية المتوسطة ما لا يقل عن نسبة 60 \% من الحد الأدنى القانوني للأجر في الصناعة والتجارة أو في الفلاحة). وإضافة إلى الشروط السابقة المتعلقة بالمؤمن له يجب أن لا يتجاوز سن الطفل: * 12 سنة بالنسبة للطفل المتكفل به والمقيم بالمغرب؛ * 18 سنة بالنسبة للطفل المستفيد من تكوين مهني؛ *21 سنة بالنسبة للطفل الحاصل على البكالوريا والذي يتابع دراسته الجامعية بالمغرب أو بالخارج. 
قسطين 884، قسط نقدي وقسط عيني الحصول على التعويضات العائلية وذلك في حدود ثلاثة أولاد الأولون و36 درهما للأطفال الثلاثة الموالين العيني فإنه يمنح في شكل إعانة صحية عائلية بعد تقديه ملف طبي يخول الحق في إرجاع المصاريف، ضمن حدود المقادير

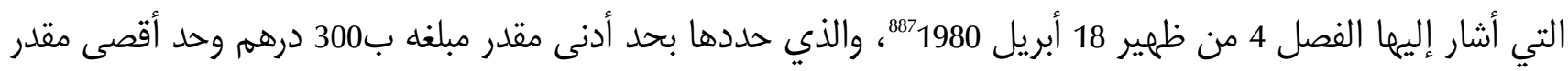
مبلغه ب800 درهم سنويا تينا

وابتداء من شهرماي2007 أصبحت تصرف التعويضات العائلية مباشرة إلى المستفيد 889 ويقوم الصندوق الوطني للضمان الاجتماعي بشكل دوري بمراقبة منح هذه التعويضات للتأكد من استمرار شروط الاستفادة منها (الحياة، التمدرس، التكوين....

ولا يشترط تحديد السن بالنسبة للأطفال في وضعية إعاقة ولا يتوفرون على دخل قار، كما أنه يمكن عدم مراعاة واجب الإقامة المشار إليه في الفقرة الأولى من الفصل 40 من ظهير 27يوليوز 1972 المتعلق بنظام الضمان الاجتماعي كما تم تغييره وتتميمه، وذلك طبق الشروط المدددة

884 - للاطلاع على الوثائق اللازمة للحصول على التعويضات العائلية، انظر الموقع الرسمي للصندوق الوطني للضمان الاجتماعي )www.cnss.ma.(

885 - يجب إيداع طلب الاستفادة من التعويضات العائلية في أجل لا يتعدى 6 أشهر ابتداء من تاريخ ولادة الطفل وفي حالة التأخر في تقديم

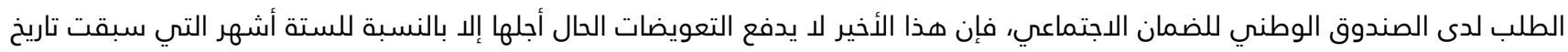

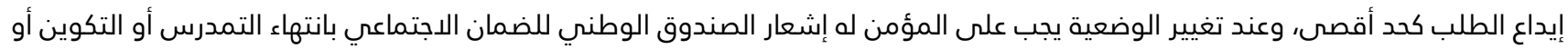
وفاة الأطفال المعنيين. 886 - نشير في هذا الإطار، إلى أنه لا يمكن للمؤمن له أن يتقاضى هذا التعويض إلا عن ستة أولاد على الأكثر، فيما يخص الأولاد المصرح

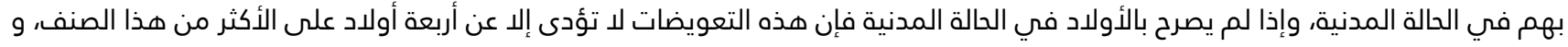

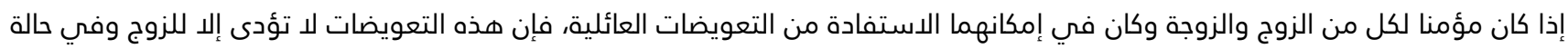
هجران فراش الزوجية أو في حالة انفصام عرى الزوجية، فإن التعويضات العائلية تؤدى في جميع الحالات إلى الشخص المعهود إليه بحضانة الأولاد. وفي جميع الحالات لا يمكن منح تعويضات عائلية مضاعفة بالنسبة لنفس الولد، كما يمكن أن يتوقف الحق في تخويل التعويضات العائلية على

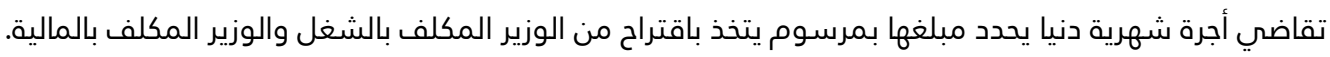

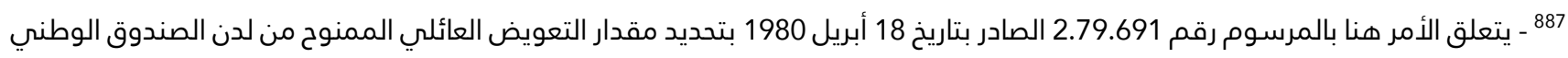
للضمان الاجتماعي. 888 - في إطار المقتضيات المشتركة بين التعويضات التي يمنحها الصندوق الوطني للضمان الإنمان الاتماعي، فإنه يتعين على المستفيد من هذه

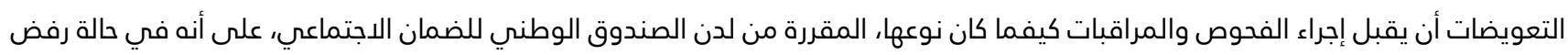
هذه الإجراءات يجوز للصندوق أن يوقف أداء هذه التعويضات أو يخفض منها أو يحذفها وتبين في النظام الداخلي الضمان الضمانات التونات التي ينتفع بها المستفيد من التعويض قبل أن تطبق عليه العقوبات السالفة الذكر. 889

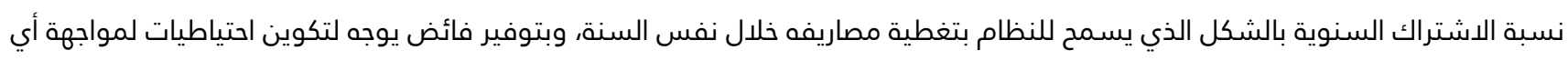
تراجع غير متوقع للموارد أو ارتفاع مفاجئ للنفقات.

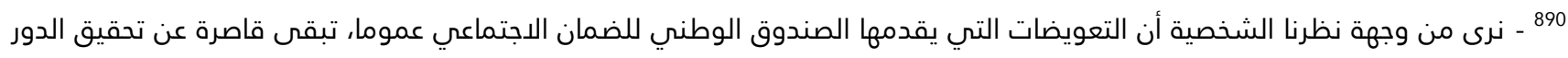

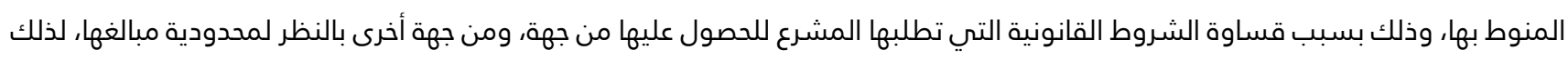
لابد من تبني إصلاحات عميقة للنظام القانوني المؤسس لهذه التعويضات، قصد تحقيق حماية اجتماعية فعالة للمؤمن لهم. 


\section{المطلب الثاني: التعويضات القصيرة والطويلة الأمد}

يمنح الصندوق الوطني للضمان الاجتماعي إضافة إلى التعويضات العائلية تعويضات قصيرة الأمد (الفقرة الأولى)، وتعويضات طويلة الأمد (الفقرة الثانية).

\section{الفقرة الأولى: التعويضات القصيرة الأمد}

يمنح الصندوق الوطني للضمان الاجتماعي تعويضات قصيرة الأمد 891 وهــــذه التعويضات طبقا للفصل الأول من ظهير 27 يوليــــوز 1972 المتعلق بنظام الضمان الاجتماعي كما تم تغييره وتتميمه بمقتضى القانون رقــــم 03.14 الصادر

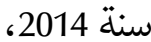

تشمل التعويضات اليومية عن الحوادث والأمراض غير المهنية (أولا)، التعويض اليومي عن الولادة (ثانيا)، التعويض عن الوفاة (ثالثا) والتعويض عن فقدان الشغل (رابعا)، وهذه التعويضات لا تمنح إلا بتوفر شروط محددة فرضمها القانون في هذا الإطار.

$$
\text { وسنتطرق لهذه التعويضات بنوع من التفصيل فيما يلي: }
$$

\section{أولا: التعويضات اليومية عن الحوادث والأمراض غير المهنية}

يستفيد المؤمن له من تعويض يومي عن المرض، في حالة تعرضه لعجز بدني يمنعه من استئناف عمله يكون هذا العجز مثبت من طرف طبيب معين لهذا الغرض أو طبيب معتمد من طرف الصندوق الوطني للضمان الاجتماعي،

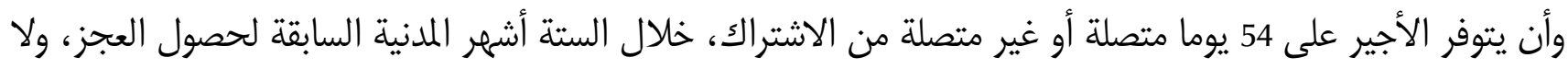
يجوز للمؤمن له بعد العجز الأول أن يطالب من جديد بالتعويض اليومي، إلا بعد أن تنقضي على استئناف العمل مدة لا لا

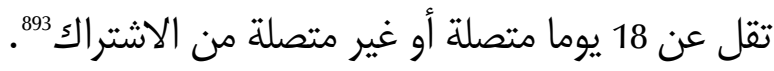

891 - تسمى هذه التعويضات أو الإعانات قصيرة الأمد، لأنها تقدم إما خلال مدة غير معينة ولكن قصيرة نسبيا، ويتعلق الأمر هنا بالتعويضات اليومية في حالة المرض والحادثة، وإما تقدم خلال مدة معينة ومحددة ويتعلق الأمر هنا بالتعويض عن الولادة وعن فقدان الشغل وإما تقدم دفعة واحدة ويتعلق الأمر هنا بمنحة الوفاة. 892 - يتضح من خلال مقتضيات الفصل 32 من الظهير الشريف بمثابة قانون رقم 184.12.184 الصادر بتاريخ 15 جمادى الثانية 1392(27 يوليوز1972)

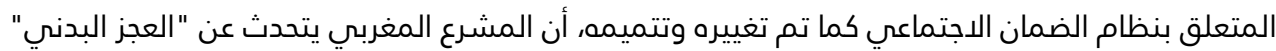
وهو ما يدفعنا إلى التساؤل حول حق الأجير في الحصول على هذا النوع من التعويضات في حالة إصابته "بعجز صحي" ناتج عن مرض نفسي أو عقلي تعرض له هذا الأخير، والواقع بخصوص هذه النقطة أن بعض التشريعات قد أقرت حق الأجير في الحصول على هذا التعويض في مثل هذه الحالات، منها التشريع اللبناني حيث ورد في المادة 25 من قانون الضمان الاجتماعي اللبناني بأن المرض الذي يعوض عنه الأجير هو " كل

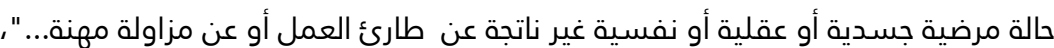
لذلك لا بد من تعديل مقتضيات الفصل 32 السالف ذكره، وذلك بالإشارة إلى المؤمن له المصاب "بعجز صحي" بدل عبارة " العجز البدني". 89383 - نرى في هذا الصدد، أنه لابد من التخفيف من الشروط المتطلبة للحصول على هذا النوع من التعويضات، خاصة الشرط المتمثل في توفر

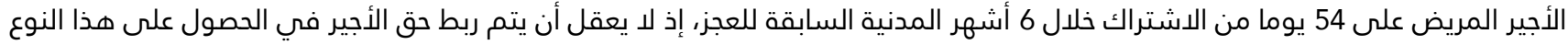
من التعويضات بالتوفر على فترة معينة من الاشتراك، وأن يتم حرمانه من هذا التعويض لأن فترة الاشتراك لم يتم استيفائها، لذلك لابد من إلغاء هذا الشرط. 
وفي حالة وفاة المؤمن له، يؤدى مبلغ التعويضات اليومية عن المرض المستحقة للمؤمن له إلى تاريخ وفاته، لذوي حقوقه

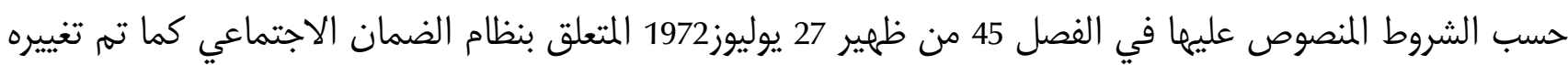
وتتميمه.

هذا، وإذا كان العجز ناتجا عن حادثة غير حادثة الشغل، اعترف للمصاب بالحق في التعويضات اليومية دون مراعاة

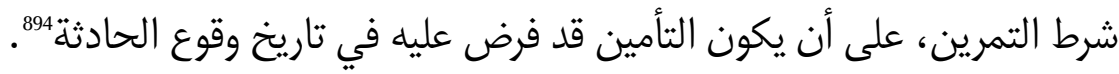

ويصرف التعويض اليومي ابتداء من اليوم الرابع وطوال 52 أسبوعا على الأكثر خلال 24 شهرا المتتابعة التي تلي بداية

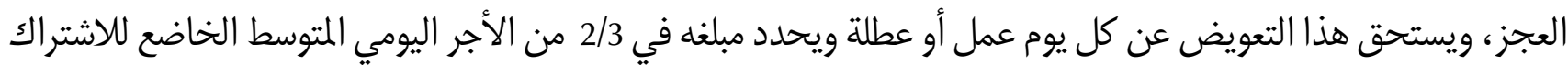
والمقبوض خلال 6 أشهر السابقة لبداية العجز ونز

هذا، وإذا استمر المستفيد من تعويضات يومية في تقاضي أجرة خلال مدة العجز عن العمل فإن التعويض اليومي لا

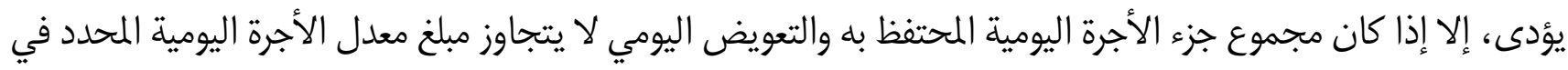
الفصل 35 من ظهير27 يوليوز 1972 المتعلق بنظام الضمان الاجنان الاجتماعي كما تم تغييره وتتميمه.

\section{ثانيا: التعويضات اليومية عن الولادة}

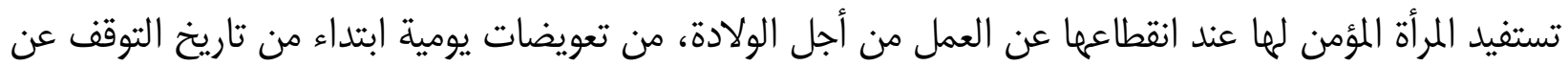

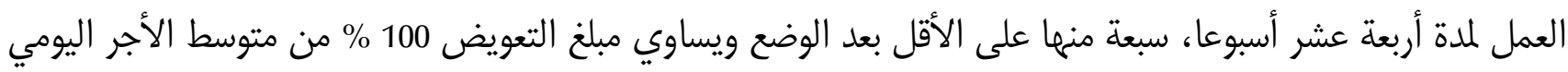

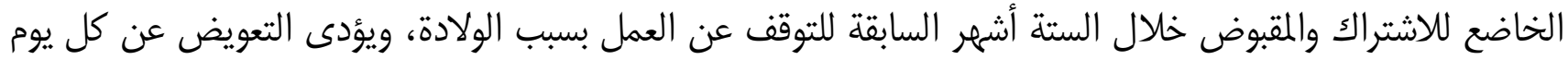

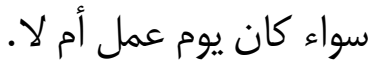

894 - طبقا لمقتضيات الفصل 33 من القانون رقم 17.02 الصادر سنة 2004 والمغير والمتمم بموجبه الظهير الشريف بمثابة قانون رقم 184 الصادر بتاريخ 15 من جمادى الثانية 1392 ( 27 يوليوز 1972) المتعلق بنظام الضمان الاجتماعي، فإنه يجب = = على المؤمن له تحت طائلة إيقاف صرف التعويضات اليومية عن الحوادث والأمراض غير المهنية، أن يوجه خلال الثلاثين يوما التالية لانقطاعه عن العمل أو تمديد التوقف عنه إلى الصندوق الوطني للضمان الاجتماعي ما لم تحل دون ذلك قوة قاهرة إعلاما بانقطاعه عن العمل، يوقعه الطبيب المعالج والمشغل على مطبوع يحدد نموذجه المدير العام للصندوق الوطني للضمان الاجتماعي كما يجب أيضا على المؤمن له تحث طائلة التقادم مالم تحل دون ذلك قوة قاهرة، إيداع طلب التعويضات اليومية عن المرض لدى الصندوق الوطني للضمان الاجتماعي في أجل الستة أشهر الموالية لتاريخ العجز عن العمل. 895

- بالنسبة للطلب الأولي:

* *إشعار بالتوقف عن العمل وطلب التعويضات اليومية عن المرض (المطبوع مرجع 16-1-312) معبأ من طرف المشغل والطبيب المعالج؛ *محضر المعاينة (معد من طرف السلطات المعنية) في حالة حادثة سير، بالإضافة إلى المطبوع مرجع 07-317 الخاص بالحلول محل المعني مي مئي بالأمر!

^نسخة من بطاقة التعريف الوطنية أو جواز السفر أو بطاقة الإقامة (إذا لم يتم الإدلاء بها سابقا للصندوق الوطني للضمان الاجتماعي)؛

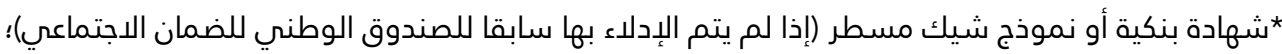
*طي سري للطبيب المعالج (اختياري). - بالنسبة لطلب التمديد طي سري للطبيب المعالج (اختياري). 


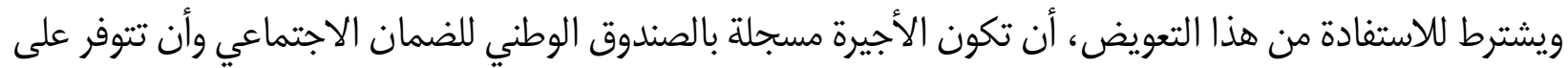

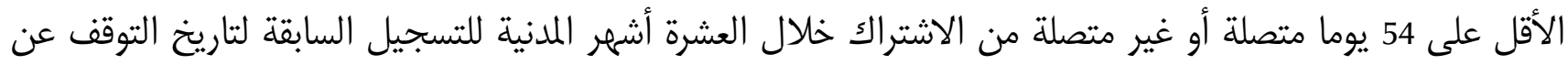

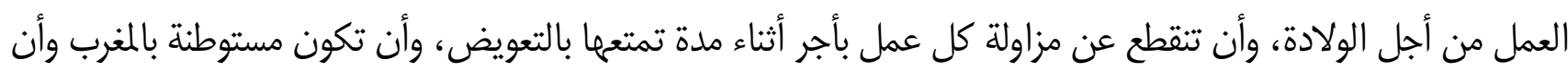

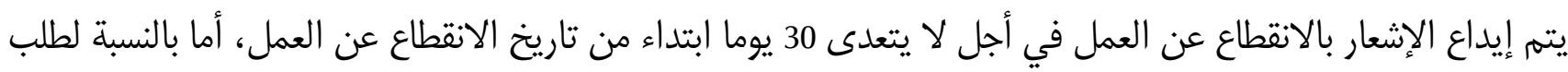

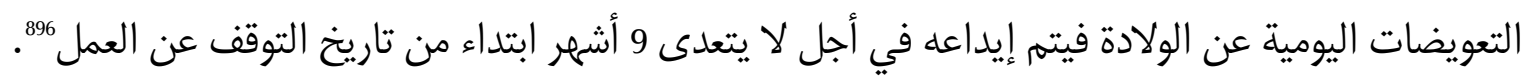

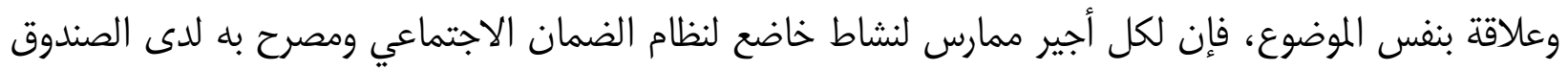

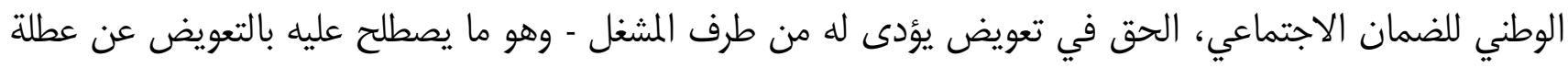

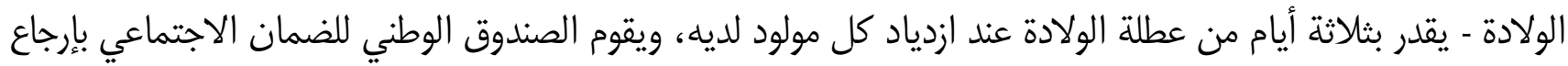

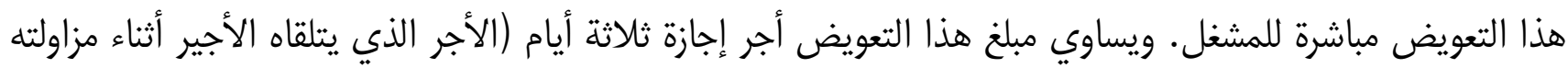

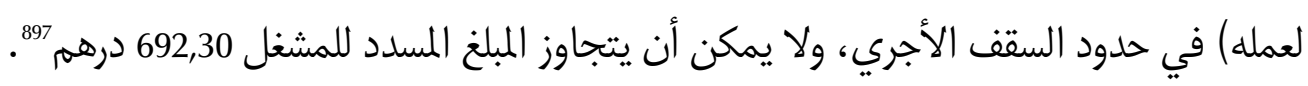

\section{ثالثا: التعويض عن الوفاة}

في حالة وفاة المؤمن له، يستفيد أقرباءه من تعويض مادي يمكنهم من مواجهة المصاريف الأولية المترتبة عن الوفاة،

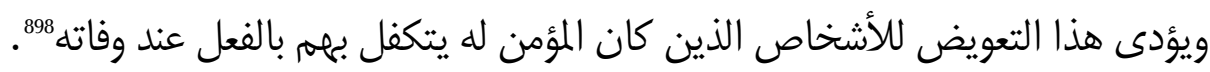

هذا، ويجب أن يودع طلب التعويض عن الوفاة مالم تحل دون ذلك قوة قاهرة، لدى إحدى وكالات الصندوق الوطني

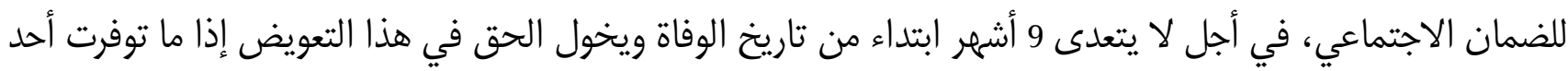
الشروط التالية:

896 - للاستفادة من التعويضات اليومية عن الولادة يتعين الإدلاء بالوثائق التالية: * إشعار بالتوقف عن العمل وطلب التعويضات اليومية عن الولادة (المطبوع مرجع 312-1-16) معبأ من طرف المشغل والطبيب المعالج)؛

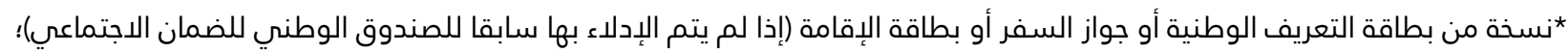
*شهادة بنكية أو نموذج شيك مسطر (إذا لم يتم الإدلاء بها سابقا للصندوق الوطني للضمان الاجتماعي)؛ *عقد الازدياد أو شهادة الولادة مسلمة من طرف الطبيب؛ شهادة الوفاة في حالة وفاة المولود الجديد. 897

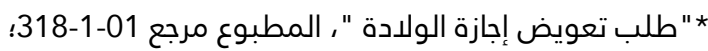
*نسخة من بطاقة التعريف الوطنية أو جواز السفر أو بطاقة الإقامة (إذا لم يتم الإدلاء بها سابقا لمأدة للصندوق الوطني للضمان الاجتماعي)؛ *نسخة من عقد ازدياد الطفل. 898- وذلك حسب الترتيب الآتي: 1- الزوج (ة) المتوفس عنه (عنها) أو الزوجات؛ 2- الفروع عند عدم الزوج (ة) أو الزوجات؛ 3- الأصول عند عدم الفروع؛

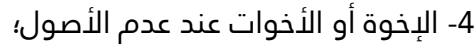
5- الشخص الذي تحمل مصاريف الدفن. وتوزع الإعانة بالتساوي على المستفيدين المرتبين في نفس الدرجة. 


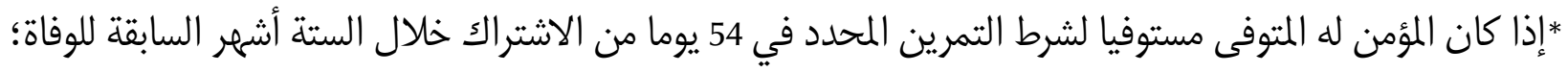

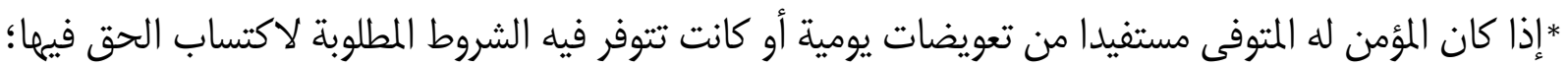

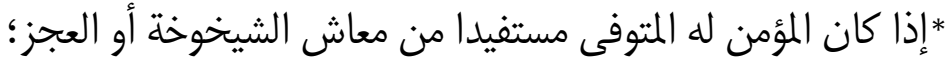

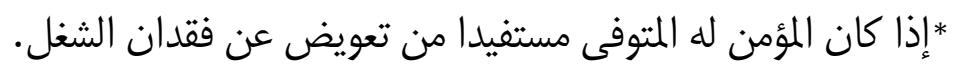
وإذا كانت الوفاة ناتجة عن حادث يعزى إلى الغير وكان المؤمن له المتوفى خاضعا لنظام الضمان الاجتماعي حينه،

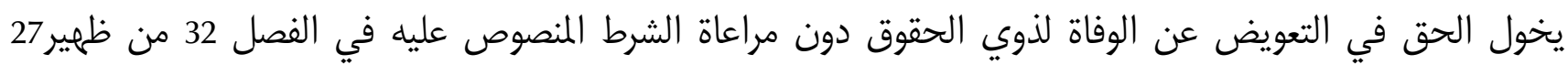
يوليوز1972 المتعلق بنظام الضمان الاجتماعي كما تم تغييره وتتميمه.

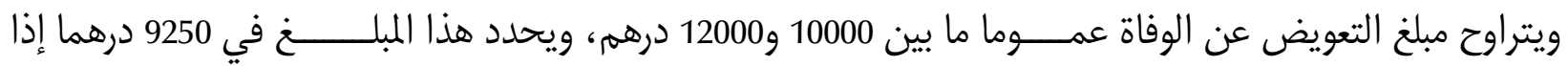
كانت الوفاة نتيجة حادثة شغل ويتراوح هذا المبلغ ما بين 5000 و6000 درهم إذا كان المستفيد شخصا آخر غير قرين إنيب اللمتوفى 299.

\section{رابعا: التعويض عن فقدان الشغل}

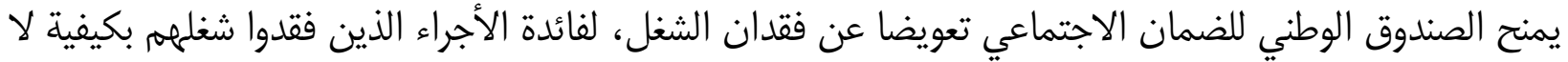

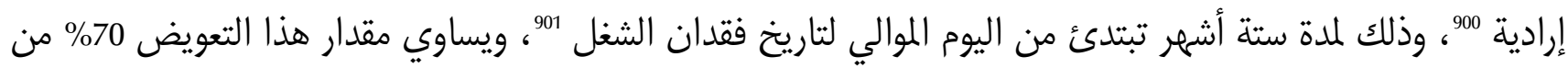

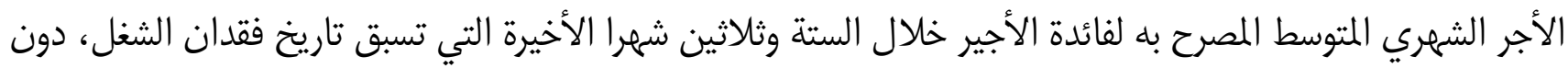

899 ـ للاستفادة من التعويض عن الوفاة يتعين الإدلاء بالوثائق التالية:

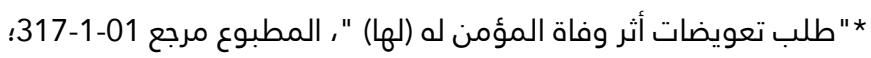

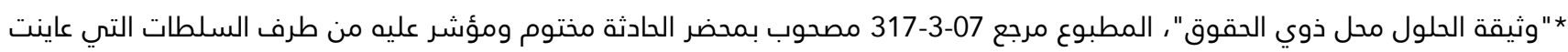

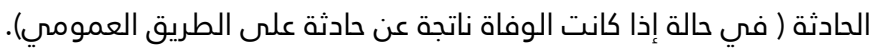
- وثائق خاصة بالمؤمن له (لها) المتوفى(ة): *نسخة من بطاقة التعريف الوطنية أو جواز السفر أو بطاقة الإقامة (إذا لم يتم الإدلاء بها سابقا للصندوق الوطني للضمان الاجتماعي)؛ * شهادة وفاة المؤمن له (لها)؛ *نسخة من عقد الزواج مصادق عليها؛ * شهادة طبية مبينة لسبب الوفاة بالنسبة للمؤمن له (لها) الأجير (ة) أو شهادة الوفاة مسلمة من طرف المصالح المختصة. - وثائق خاصة بصاحب الطلب:

* التزام بإرجاع المبالغ التي تم صرفها بعد وفاة المؤمن له (لها) المستفيد (ة) من معاش (استمارة رقم 22-1-310)؛ *نسخة من بطاقة التعريف الوطنية لصاحب (ة) الطلب (إذا لم يتم الإدلاء بها سابقا للصندوق الوطني للضمان الضمان الاجتماعي)؛

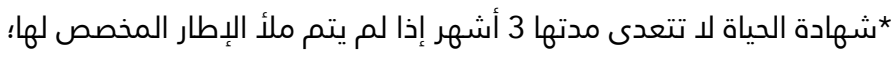

* شهادة بنكية أو نموذج شيك لصاحب الطلب (إذا لم يتم الإدلاء بها سابقا للصندوق الوطني للضمان الاجتماعي). هذا، وللاطلاع على الوثائق المطلوبة للاستفادة من التعويض عن الوفاة والخاصة بوضعية كل مستفيد على حدى، أنظر الموقع الرسمي للصندوق الوطني للضمان الاجتماعي (www.cnss.ma). 900 - تم إقرار التعويض عن فقدان الشغل بمقتضص الظهير الشريف رقم 14.143 1.14.14. الصادر في 25 من شوال 1435 (22 غشت 2014) بتنفيذ القانون رقم 03.14 القاضي بتغيير وتتميم الظهير الشريف بمثابة قانون رقم 1.72 .184 الصادر في 15 من جمادى الثانية 1392 (27 يوليوز 1972) المتعلق بنظام الضمان الاجتماعي.

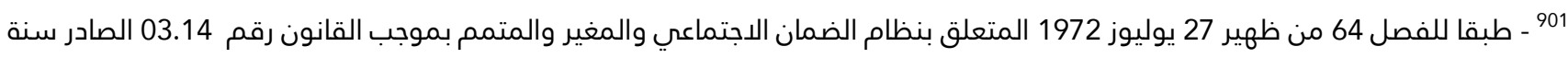
2014، فإن المستفيد من راتب زمانة أو شيخوخة لا يستفيد من التعويضات اليومية و من التعويض عن فقدان الشغل. 


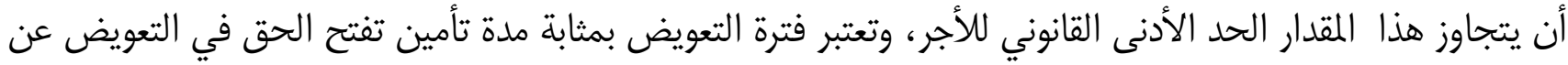

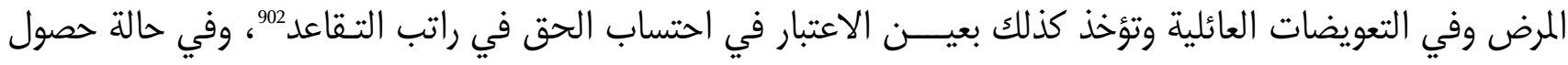

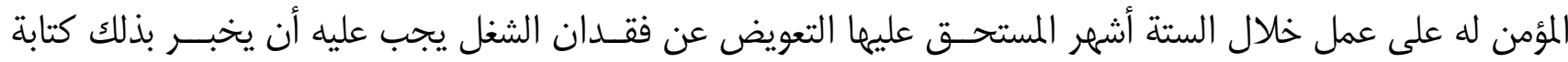

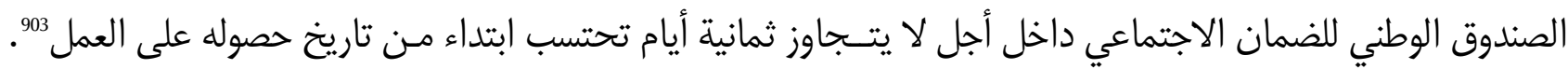
ولاستفادة من التعويض عن فقدان الشغل، فإنه يتعين على الأجير الذي فقد شغله بكيفية لا إرادية، أن يثبت توفره

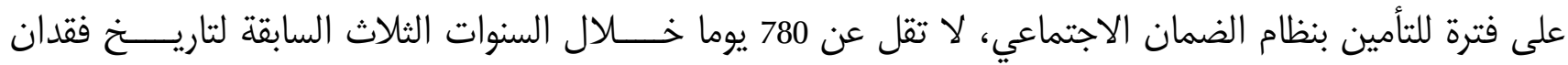

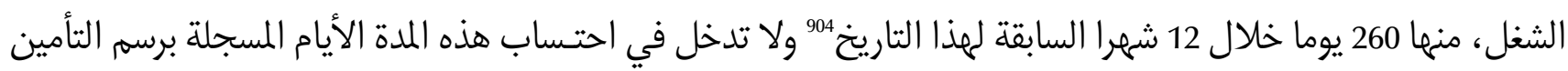

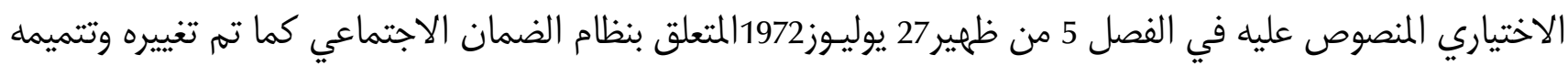

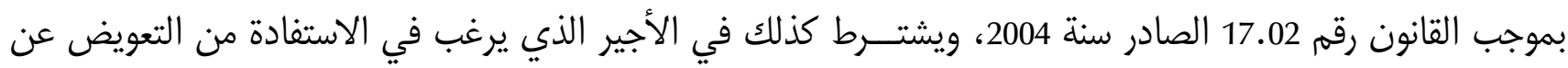

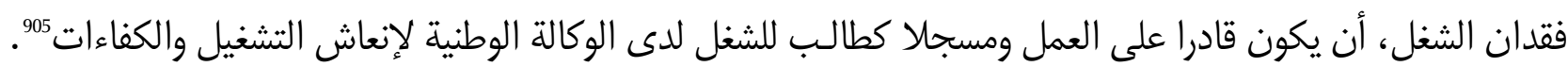
هذا، وفي حالة وفاة مؤمن له مستفيد من التعويض عن فقدان الشغل، يصرف مبلغ التعويض المستحق له غير المدفوع

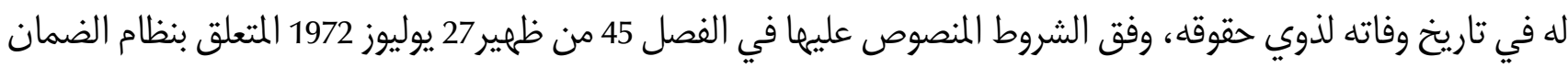
الاجتماعي كما تم تغييره وتتميمه.

\section{الفقرة الثانية: التعويضات الطويلة الأمد}

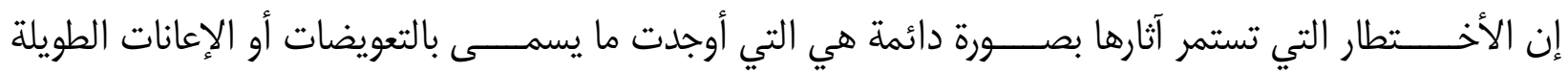

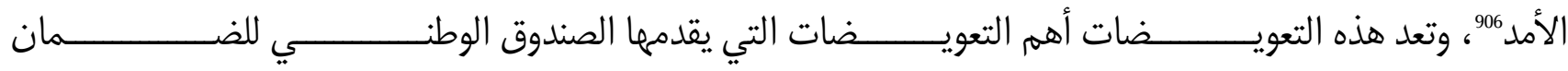

902 - تنص المادة الثانية من المرسوم رقم 2.01 .2723 الصادر في 27 من ذي الحجة 1422 ( 12 مارس 2002) المتعلق بتحديد مقدار واجبات الاشتراك المستحقة للصندوق الوطني للضمان الاجتماعي والمغير بالمرسوم رقم 2.14 .14 الصادر في 17 من صفر 1436 (10ديسمبر2014)

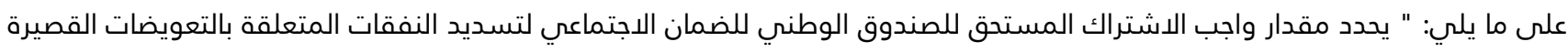
الأمد في نسبة 1,57 \% من أجرة الأجير الإجمالية الشهرية موزعة كالتالي:

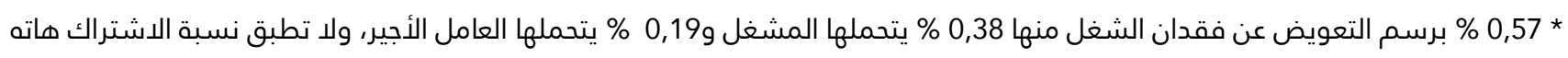
على الشخص المكتتب في التأمين الاختياري المنصوص عليه في الفصل 5 من الظهير الشريف بمثابة قانون رقم

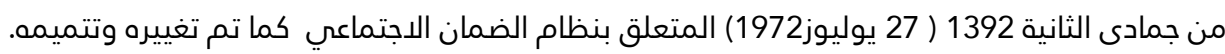
* * 1 \% برسم التعويضات الأخرى القصيرة الأمد، منها 0,67 \% يتحملها المشغل و0,33 \% يتحملها الأجير". 903 904 من أجل تخويل حق الاستفادة من التعويض عن فقدان الشغل الشعل. 905 *طلب التعويض عن فقدان الشغل المطبوع مرجع 26-110-3 معبأ من طرف آخر مشغل، والذي يجب إيداعه لدى إحدى وكالات الصندوق الوطني

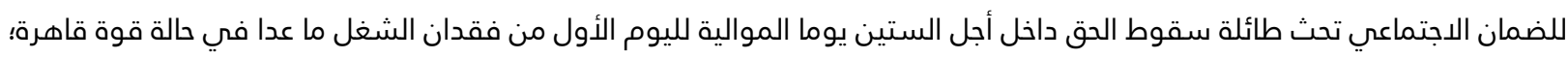

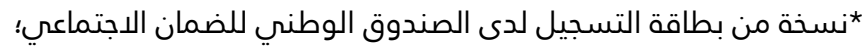

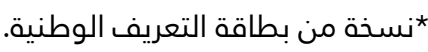

906 - علي عمدي، الصندوق الوطني للضمان الاجتماعي، موارده، خدماته، مدفوعاته، " إشكالية إصلاح مرتقب"، الطبعة الثانية 1998 ص 52. 
الاجتماعي 907، وهي تعويضات يمنحها الصندوق لمدة طويلة مقارنة بباقي التعويضات الأخرى، وبما أن نسبتها هي التي تشكل أكبر نسبة فيما يخص الاشتراكات، فمن الطبيعي أن تكون هي أيضا النوع الذي يستنزف أكبر قدر من محفظة الصندوق والتعويضات الطويلة الأمد تغطي ثلاثة أنواع من المخاطر وهي معاش الشيخوخة (أولا) ومعاش الزمانة (ثانيا)، ومعاش المتوفى عنهم (ثالثا) (009.

\section{أولا: معاش الشيخوخة}

يعتبر معاش الشيخوخة (التقاعد) بمثابة منحة شهرية يمكن أن يستفيد منها المؤمن له مدى الحياة إذا بلغ السن القانوني للإحالة على التقاعد واستوفى الشروط القانونية المطلوبة للاستفادة من هذا المعاش الشيخوخة بالنسبة للمؤمن له الذي يراكم 3240 يوما من العمل 50 \% من معـــــــل الأجور التي تلقاها خلال 96 شهرا الأخيرة من الاشتراك، وتتهم زيادة 1\% على هذا المبلغ بالنسبة لكل مدة من التأميــن تبلغ 216 يوما علاوة على 3240 يوما دون تجاوز نسبة 70\% من الأجر المتوسط ل 96 شهرا الأخيرة من الاشتراك

فإن الصندوق الوطني للضمان الاجتماعي يقوم سنويا بعملية مراقبة المستفيدين من هذا المعاش للتأكد من أنهم مازالوا على قيد الحياة.

907 - توفيق كرداد، تمويل التعويضات الطويلة الأمد في قانون الضمان الاجتماعي المغربي، رسالة لنيل دبلوم الماستر في القانون الخاص، كلية العلوم القانونية والاقتصادية والاجتماعية أكدال، جامعة محمد الخامس بالرباط، السنة الجامعية 2009 - 2010، ص د 12. 908 - الحسن كيدل، م س، ص 43. 909 - الفصل الأول من الظهير الشريف بمثنابة قدابة قانون رقم 1.72 .184 الصادر في 15 من جمادى الثانية 1392 ( 27 يوليوز 1972) المتعلق بنظام الضمان الاجتماعي كما تم تغييره وتتميمه.

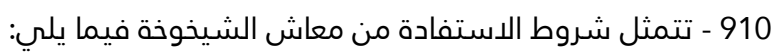

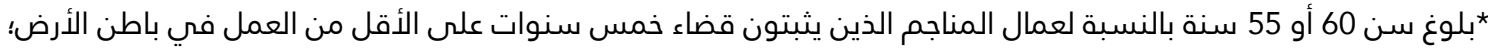
*التوقف عن كل نشاط مؤدى عنه أجرة؛ *التوفر على الأقل على 3240 يوما من الاشتراك.

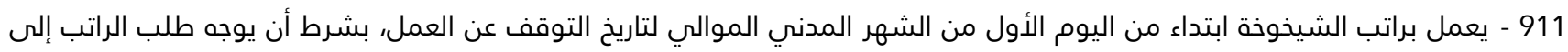

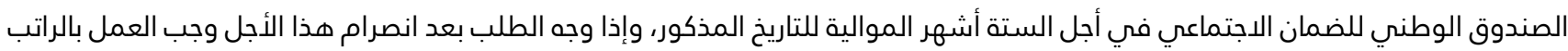
ابتداء من اليوم الأول من الشهر المدني الموالي لاستلام الطلب من طرف الصندوق الوطني للضمان الضان الاجتماعي. 912 - طبقا للفصل 64 من ظهير 27 يوليوز 1972 المتعلق بنظام الضمان الاجتماعي كما تم تغييره وتتميمه، لا يخول المستفيد من راتب زمانة أو شيخوخة الحق في التعويضات اليومية وفي التعويض عن فقدان الشغول من الشغل. 913 - تتمثل الوثائق المطلوبة للاستفادة من معاش الشيخوخة فيما يلي: × طلب راتب الشيخوخة (المطبوع مرجع 04 -1-315)؛

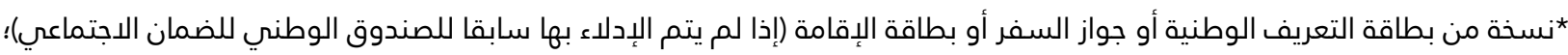

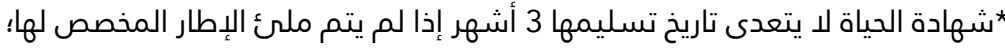

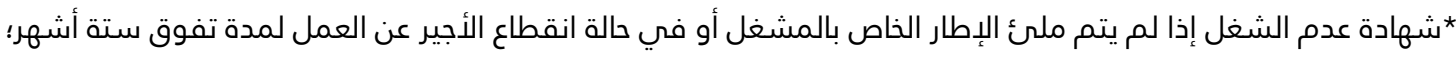
^شهادة بنكية أو نموذج شيك لصاحب (ة) الطلب (إذا لم يتم الإدلاء بها سابقا للصندوق الوطني للضمان الاجتماعي). 
هذا، ويمكن للمؤمن له بناء على طلب منه، أن يستفيد من التقاعد النسبي ابتداء من 55 سنة شريطة أداء منحة معينة دفعة واحدة من طرف المشغل ويتهم تحديد مبلغ هذه المنحة حسب سن المؤمن له ومبلغ المعاش السنوي المحتسب وندئ، ويمكن للمشغل طلب حساب مبلغ المنحة الواجب أداءه بالنسبة للمؤمن لهم المراد استفادتهم من هذا الإجراء، عن طريق التوجه

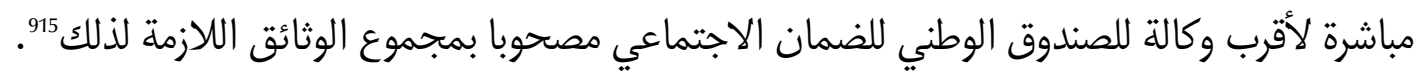

\section{ثانيا: معاش الزمانة}

يخول الحق في معاش الزمانة بالنسبة للمؤمن له الذي يعاني من عجز دائم، ناتج عن حادثة غير حادثة الشغل أو مرض غير مهني، يمنعه من مزاولة أي نشاط مهني مربح 916 ويمنح معاش الزمانة بصفة مؤقتة ويستبدل بمعاش الشيخوخة

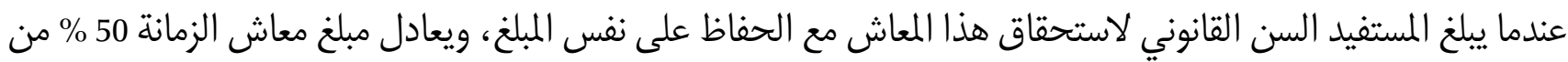

وتضاف إلى هذه الوثائق بالنسبة لعمال المناجم (شهادة العمل في باطن الأرض لمدة 5 سنوات على الأقل)، وبالنسبة للمقيمين خارج المغرب (شهادة الإقامة إذا كان أداء المعاش سيتم خارج المغرب)، وبالنسبة للمشتركين بالتأمين الاختياري نسخة من آخر ورقة أداء الاشتراكات، وبالنسبة الإبة

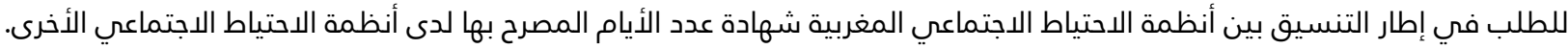

914 - تحدد شروط الاستفادة من التقاعد النسبي فمان يلمين ×أن يكون عمر المستفيد 55 سنة و أكثر دون أن يصل إلى 60 سنة 60 سنة؛

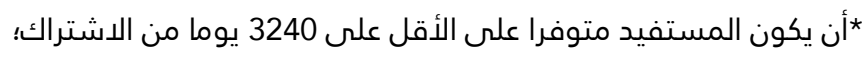
* أن يتوفر المستفيد على 54 يوما من الاشتراك خلال الستة أشهر السابقة لطلب التقاعد النسبي؛ ^夫أن يتوفر المستفيد على موافقة المشغل ( هذا الشرط ليس ضروريا بالنسبة لفئة البحارة الصيادين)؛ ×أن يكون المشغل قد أدى مبلغ المنحة الذي بذمته والمتعلق بالراغب في الاستفادة من التقاعد النسبي. 915 - تتمثل الوثائق التي يتعين على المشغل الإدلاء بها لدى إحدى وكالات الصندوق الوطني للضمان الاجتماعي، قصد احتساب مبلغ المنحة

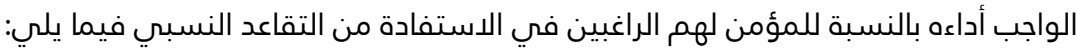

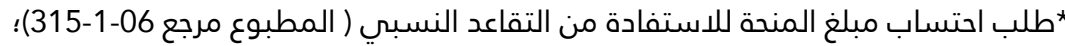

(لائحة المؤمن لهم المعنيين بالطلب (المطبوع مرجع 08-1-315). أما الوثائق التي يتعين على المؤمن لهم الراغبين في الاستفادة من التقاعد النسبي الإدلاء بها فهي كالتالي: *طلب التقاعد النسبي (المطبوع مرجع 07-1-315)؛ *نسخة من بطاقة الصندوق الوطني للضمان الاجتماعي أو كل وثيقة تبين رقم التسجيل؛ *نسخة من بطاقة التعريف الوطنية ( في حالة عدم التصريح برقم التعريف الوطني لدى الصندوق الوطني للضمان الضمان الاجتماعي)؛ ^شهادة الحياة ( لا تتجاوز مدة إصدارها ثلاثة أشهر ) في حالة عدم توفر المعني بالأمر على بطاقة التعريف البيوميترية؛

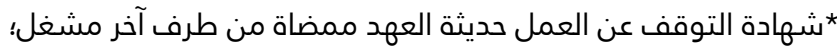
*شهادة الاستفادة من التغطية الصحية ( المطبوع مرجع 25-10-310) في حالة استفادة المؤمن له من نظام آخر للتغطية الصحية؛ *شهادة بنكية تثبت رقم الحساب الشخصي للمعني بالأمر أو نموذج شيك مسطر أو رقم التعريف البنكي بالنسبة للمؤمن لهم القاطنين بالخارج الذين يرغبون في التوصل بالمعاش عبر التحويل البنكي؛ شهادة السكنى ( بالنسبة للمؤمن له القاطن بالخارج)؛ * ^ورقة أداء المنحة المتعلقة بالتقاعد النسبي. 916 - للاستفادة من معاش الزمانة يجب أن تتوفر في المؤمن له الشروط الآتي ذكرها:

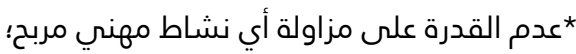

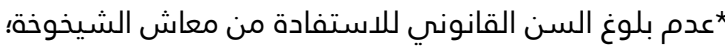
*إثبات شرط التمرين المتمثل في 1080 يوما من الاشتراك منها 108 أيام خلال 12 شهرا السابقة لبداية العجز عن العمل المترتبة عنه الزمانة. وإذا ما كان العجز ناجما عن حادث وكان المؤمن له حينه خاضعا لنظام الضمان الاجتماعي، اعترف له بالحق في راتب العجز دون شرط التمرين. 
معدل الأجر الشهري الخاضع للاشتراك بالنسبة للمؤمن له المتوفر على فترة تأمين تتراوح ما بين 1080 و 3240 يوما دون تجاوز 70 \% ، و إذا كان المصاب بعجز مضطر للاستعانة المستمرة بشخص آخر، تته زيادة مبلغ المعاش بنسبة 10\% من معدل

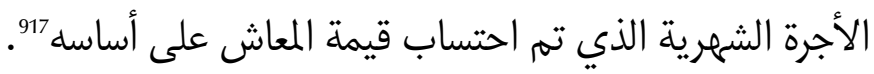
هذا، ويحدد معدل الأجرة الشهرية الذي يتخذ أساسا لاحتساب هذا المعاش باعتباره الجزء الثاني عشر أو الستين من مجموع الأجور المفروض عليها واجب الاشتراك والمقبوضة خلال الاثنى عشر شهرا أو الستين شهرا المصرح بها السابقة لآخر شهر مدني من التأمين قبل بداية العجز عن العمل المترتبة عنه الزمانة 1918، على أن الاستفادة من هذا المعاش تبتندئ من اليوم الأول للعجز إذا تم إيداع طلب المعاش في أجل 6 أشهر الموالية لحدوث العجز، و إذا تم إيداع طلب المعاش بعد انقضاء

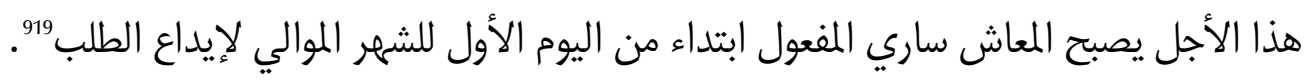

\section{ثالثا: معاش المتوفى عنهم}

يخول الحق في معاش المتوفى عنهم لذوي الحقوق 220، إذا كان المؤمن له قبل الوفاة يستفيد من معاش الشيخوخة أو معاش العجز أو كان يستوفي الشروط المطلوبة للاستفادة من هذين المعاشين، ويعادل مبلغ هذا المعاش بالنسبة للأزواج 50 \% من مبلغ معاش العجز أو الشيخوخة الذي كان للمؤمن له الحق فيه أو كان بإمكانه المطالبة به عند تاريخ وفاته وفي حالة تعدد الزوجات فإن معاش المتوفى عنه يوزع عليهن بالتساوي في حدود المقدار المشار إليه سلفا، ويعادل مبلغ معاش المتوفى بلى بلى

917 - إن الزيادة الخاصة بالاستعانة بشخص آخر، تبقى مكتسبة للمستفيد من راتب الزمانة عندما يبلغ هذا الأخير السن التي تخول له الحق في الحصول على راتب الشيخوخة. 918 - تختار المدة المستند إليها في هذا الصدد اعتبارا لمصلحة المؤمن له، و إذا تم التسجيل - في حالة زمانة مترتبة عن حادثة حسبما هو مقرر

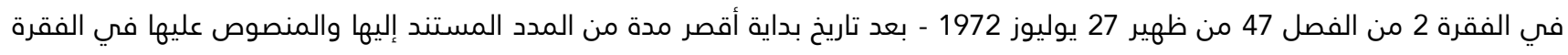
الأولى من الفصل 50 من ظهير 27 يوليوز 1972 المتعلق بنظام الضمان الاجتماعي كما تم تغييره وتتميمه، فإن معدل الأجرة الشهرية يحصل

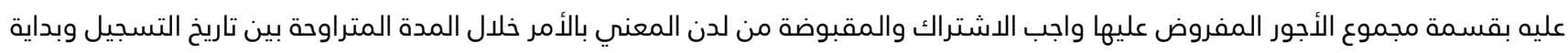

العجز عن العمل المترتبة عنه الزمانة على عدد الأشهر التي تشملها المدة المذكورة ويعتبر بمثابة شهر واحد كل جزء يبقى من ثلاثين يوما.

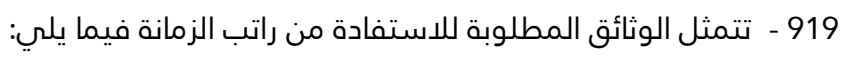

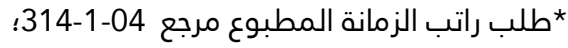

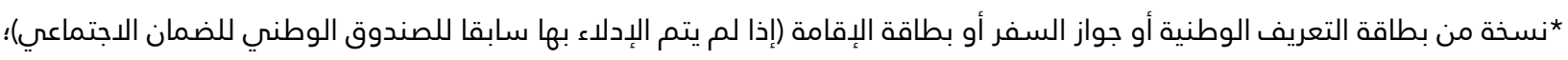

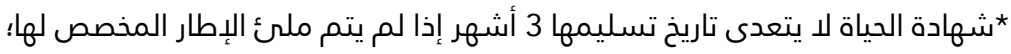

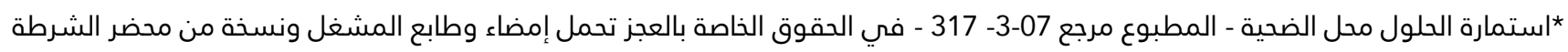

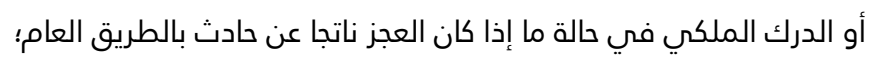

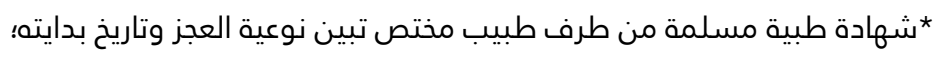

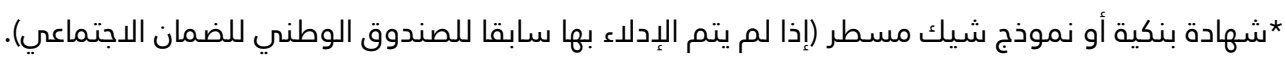

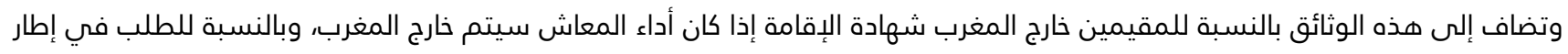

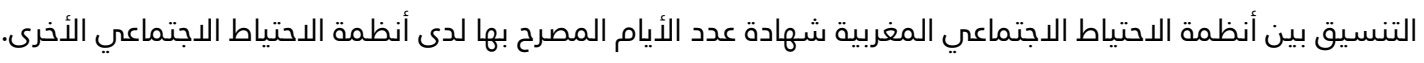

920 - يستفيد من هذا المعاش ذوو حقوق المؤمن له المتوفى وهم:

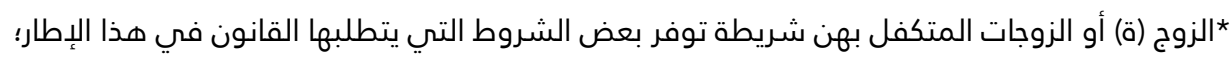

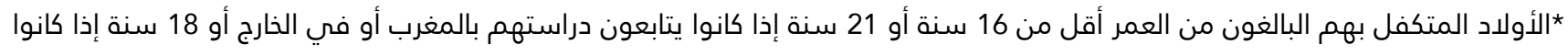

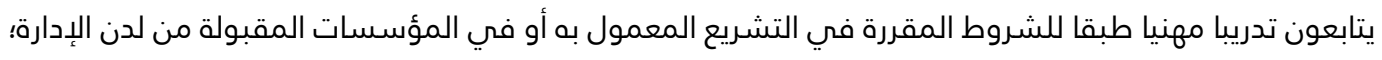

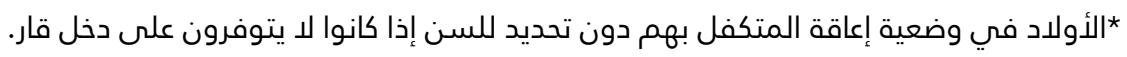


عنهم بالنسبة ليتامى الأبوين 50 \% وبالنسبة ليتيهم الأب أو الأم 25 \% من مبلغ معاش العجز أو الشيخوخة الذي كان للمؤمن

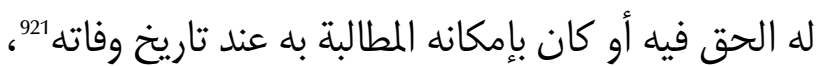

على أن معاش المتوفى عنهم لا يمكن أن يتجاوز مجموع مبلغ معاش العجز أو الشيخوخة الذي كان لصاحبه الحق فيه أو كان في إمكان المؤمن له المطالبة به عند تاريخ وفاته، وإذا تجاوز هذا المقدار وقع تخفيض نسبي من الحصة منس المتعلقة

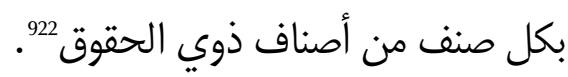

وتبتدئ الاستفادة من معاش المتوفى عنهم ابتداء من اليوم الأول للوفاة، إذا تم إيداع طلب المعاش داخل أجل أقصاه 12 شهرا الموالية للوفاة، أما إذا تم إيداع طلب المعاش بعد انقضاء هذا الأجل، يصبح المعاش ساري المفعول ابتداء من اليوم

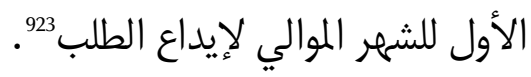

921 - بالنسبة للوثائق المطلوبة للاستفادة من معاش المتوفى عنهم فهي كالتالي:

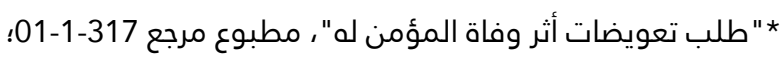

* شهادة وفاة المؤمن له (لها)؛

*نسخة من عقد الزواج مصادق عليها؛

* شهادة طبية مبينة لسبب الوفاة بالنسبة للمومن له (لها) الأجير (ة) أو شهادة الوفاة مسلمة من طرف المصالح المختصة؛ *محضر الشرطة أو الدرك الملكي واستمارة الحلول محل ذوي الحقوق ذات المرجع 317-3-07 (وفاة ناتجة عن حادث الطريق العام)؛ *بالنسبة للأرملة أو الأرمل، شهادة عدم الطلاق أو الكفالة، شهادة الزوجة الوحيدة أو تعدد الزوجات أو نسخة من عقد الاراثة مصادق عليها؛ * بالنسبة للمطلق (ة) المتكفل(ة) بأطفال قاصرين مخول لهم الحق، نسخة مصادق عليها من عقد الطلاق؛

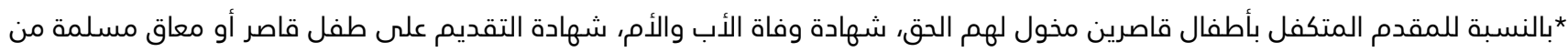

طرف المحكمة، شهادة طبية للطفل المعاق مسلمة من طرف طبيب مختص، عقد ازدياد الأطفال وشهادة حياة الأطفال؛ *بالنسبة للأبناء شهادة مدرسية بالنسبة للأطفال الذين تتراوح أعمارهم بين 16 و 21 سنة، شهادة التكوين المهني بالنسبة للأطفال الذين تتراوح أعمارهم بين 16 و 18 سنة؛ * †النسبة للطفل المريض أو المعاق البالغ من العمر ما فوق 16 سنة وأقل من 21 سنة، شهادة طبية مسلمة من طرف طبيب مختص تثبت عدم القدرة على متابعة الدراسة أو التكوين المهني؛ *بالنسبة للشخص المريض أو المعاق البالغ من العمر أكثر من 21 سنة، شهادة طبية مسلمة من طرف طبئ طبيب مختص مصادق عليها من طرف اللجنة الطبية الإقليمية، نسخة من بطاقة التعريف الوطنية، شهادة الحياة، نسخة من عقد الازدياد أو نسخة من البطاقة الوطنية للتعريف الالكترونية، شهادة ضريبية تثبت دخل صاحب الطلب ودخل الشخص المعاق، شهادة عدم العمل بالنسبة للشخص المعاق. 922 - قصد الاستفادة من معاش المتوفى عنهم لابد من توفر أحد الشروط التالية: *وفاة صاحب معاش العجز أو الشيخوخة؛

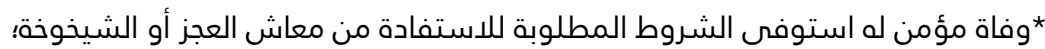
*وفاة مؤمن له يتوفر على 3240 يوما من التأمين على الأقل. وفي حالة ما إذا كانت الوفاة ناتجة عن حادث يعزى إلى الغير وكان المؤمن له المتوفى خاضعا لنظام الضمان الاجتماعي حينه يخول الحق في معاش المتوفى عنهم لذوي الحقوق دون شرط. 923 - يجب أن يوجه طلب الراتب إلى الصندوق الوطني للضمان الضوف الاجتماعي في أجل 12 شهرا الموالية لتاريخ الوفاة ما لم تحل دون ذلك قوة قاهرة، وإذا وجه الطلب بعد انصرام هذا الأجل وجب العمل بالراتب ابتداء من اليوم الأول من الشهر الموالي لاستلام الطلب وذلك طبقا لمقتضيات الفقرة الثانية من الفصل 58 من ظهير 27 يوليوز 1972 المتعلق بنظام الضمان الاجتماعي كما تم تغييره وتتميمه بموجب القانون 
ونشير في ختام حديثنا عن التعويضات الطويلة الأمد 924، أنه يمكن إعادة تقدير رواتب الزمانة والشيخوخة والمتوفى عنهم، بموجب مرسوم يتخذ باقتراح من الوزير المكلف بالشغل وطبق الشروط المحددة في هذا المرسوم، إذا استوجب ذلك الفرق الملاحظ بين مستوى الأجور المصفاة على أساسها الرواتب المذكورة وبين مستوى الأجور المعمول بهرا. هذا، وإضافة إلى التعويضات السالف ذكرها، التي يقدمها الصندوق الوطني للضمان الاجتماعي برسم تدبيره لنظام

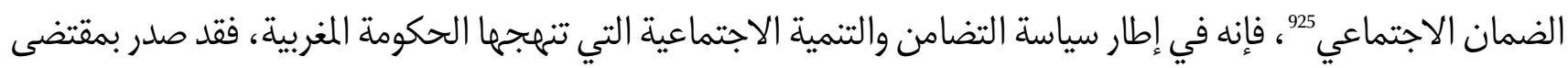
الظهير الشريف رقم 01.02.296 القانون رقم 65.00 بمثابة مدونة التغطية الصحية الأساسية سنة 2002، والذي دخل حيز التطبيق بتاريخ 18 غشت 2005، وقد عهد للصندوق الوطني للضمان الاجتماعي بموجب هذا القانون بالإشراف على تدبير التأمين الإجباري الأساسي عن المرض 926، بالنسبة للأشخاص الخاضعين لنظام الضمان الاجتماعي وذوي حقوقهم وكذا

924

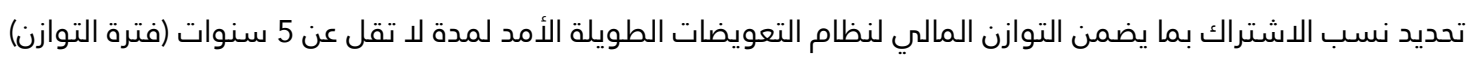

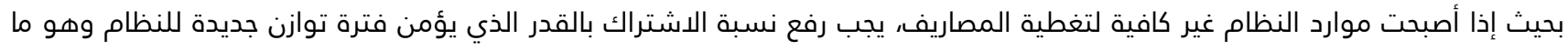

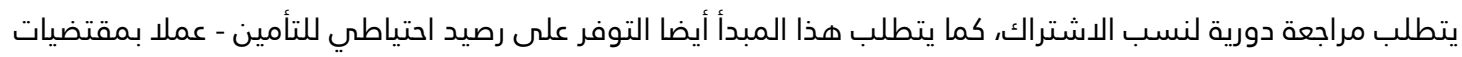

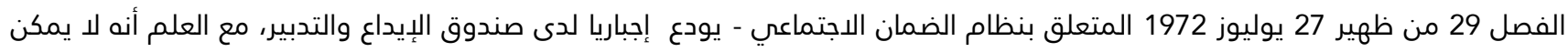

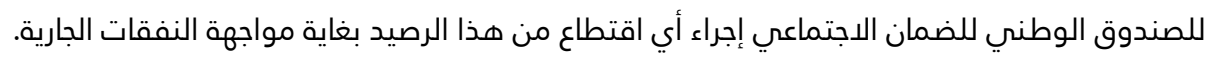

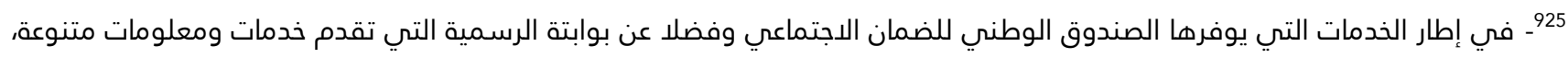
فقد عمل هذا الصندوق في إطار حرصه على تطوير الخدمات التي يقدمها، على إطلاق باقة من الخدمات الإلكترونية لفائدة منخرطيه، وذلك بهدف الحفاظ على التواصل السريع والآني معهم، ونذكر من بين ذلك ما يلي:

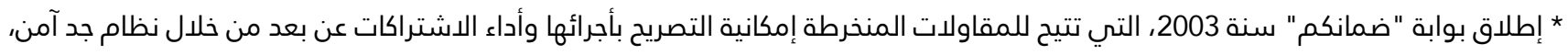

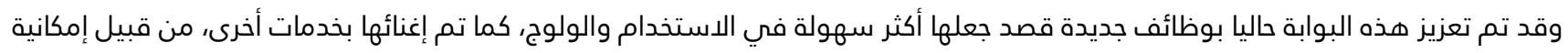
الاطلاع على تفاصيل وضعية المقاولة اتجاه الصندوق الوطني للضمان الاجتماعي، تسجيل الأجراء...

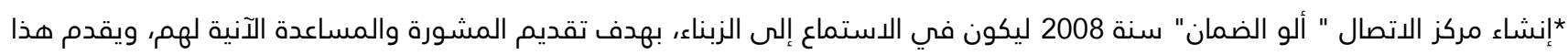

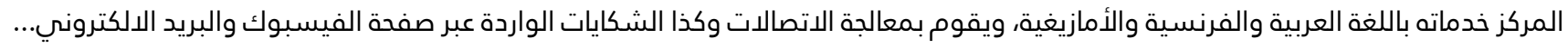
* وضع الصندوق الوطني للضمان الاجتماعي رهن إشارة الزبناء لمجيب آلي متاح على طول الأسبوع، قصد الإجابة على مختلف تساؤلاتهم حول الخدمات الاجتماعية والصحية التي يقدمها الصندوق.

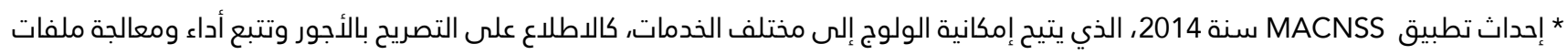

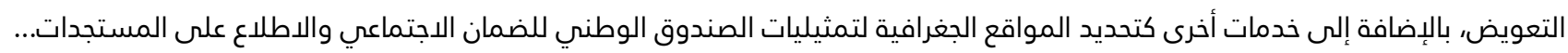

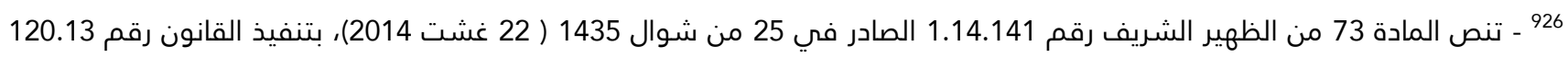
القاضي بتغيير وتتميم القانون رقم 65.00 بمثابة مدونة التغطية الصحية الأساسية على ما ما يلي:

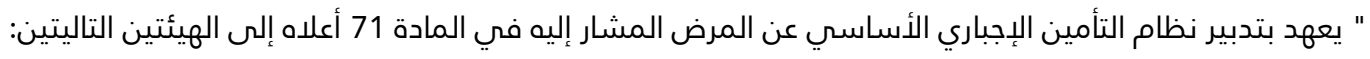

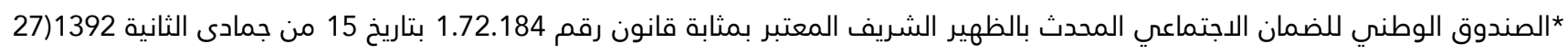
يوليوز1972) بالنسبة إلى الأشخاص الخاضعين لنظام الضمان الاجتماعي وذوي حقوقهم وكذا أصحاب المعاشات بالقطاع الخاص.

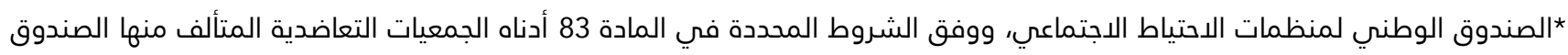

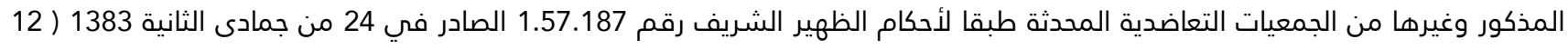

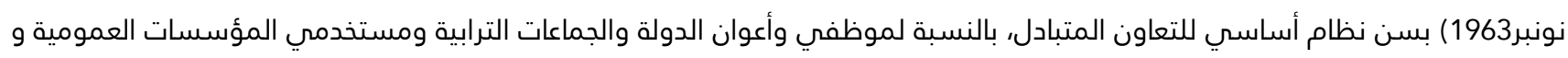
الأشخاص المعنوية الخاضعة للقانون العام وذوي حقوقهم وكذا أصحاب المعاشات بالقطاع العام". 
أصحاب المعاشات بالقطاع الخاص 927. ويعتبر الانخراط في هذا النظام، إجباريا بالنسبة للمقاولات الخاضعة لنظام الضمان الاجتماعي، التي لا تتوفر على أي نظام للتغطية الصحية عند دخول التأمين الإجباري الأساسي عن المرض حيز التطبيق

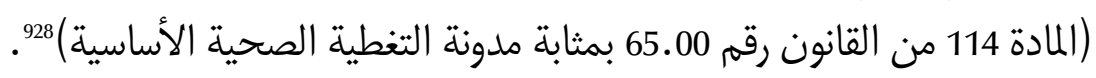

وقد سجل التأمين الإجباري الأساسي عن المرض منذ انطالاقه، تطورا كبيرا ليس فقط على مستوى العلاجات التي يغطيها، بل حتى على مستوى جودة الخدمات التي يوفرها، فبعد أن اقتصر عند انطالاقه على سلة محدودة من العلاجات، فقد تم توسيعه فيما بعد تدريجيا ليشمل أنواعا أخرى من العلاجات وفئات أخرى من المستفيدين فئني

927 - تجدر الإشارة في هذا الإطار، إلى أنه قد تم تحديد نسبة الاشتراك برسم التأمين الإجباري الأساسي عن المرض، عند تاريخ دخوله حيز

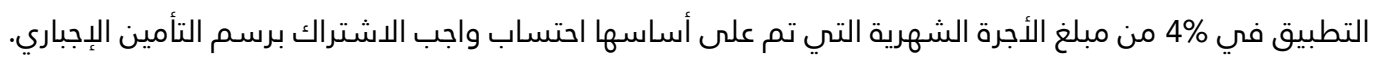

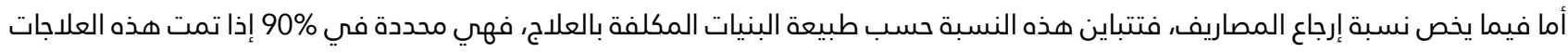
داخل المؤسسات العمومية، بينما تحدد في \% 70 إذا تم العلاج في مؤسسة يشرف عليها القطاع الفاع الخاص، إذ تتحمل الدولة العلاج وإرجاع

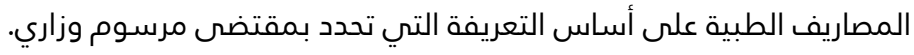
928 - طبقا للمادة 728 الاجتماعي برسم التأمين الإجباري الأساسي عن المرض، تشمل إرجاع لـاع مصاريف العلاجات الطبية والوقائية ومصاريف إعادة التأهيل التي

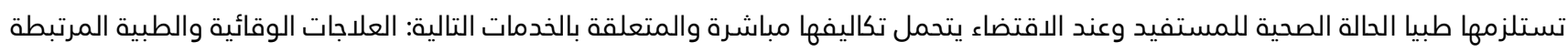

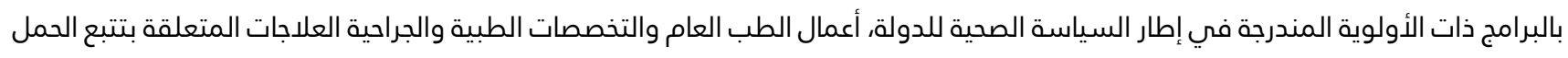

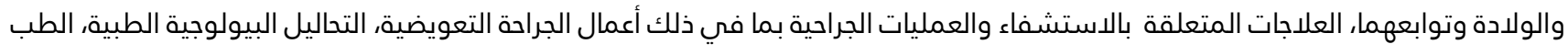

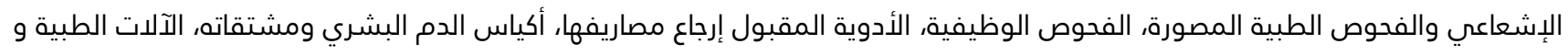

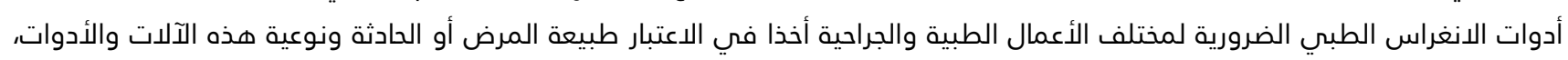

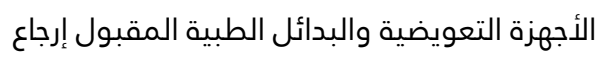
مصاريفها، النظارات الطبية، علاجات الفم والأسنان، تقويم الأسنان بالنسبة للأطفال، أعمال التقويم الوظيفي والترويض التوبئ الطبي والأعمال شبه الطبية. 2029 - نذكر من بين ذلك ما يلي: * * شتنبر2005- مارس 2006 دخول نظام التأمين الإجباري الأساسي عن المرض حيز التطبيق، وانطلاق جمع واجبات الاشتراك؛ *مارس 2006 انطلاق التعويضات والتكفل بالعلاج لصالح المستفيدين؛

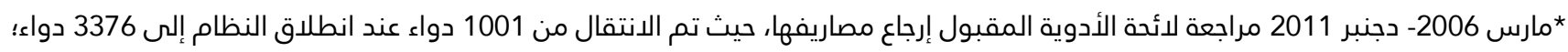

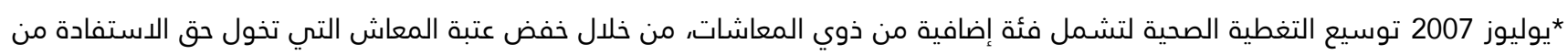
التأمين الإجباري الأساسي عن المرض؛ * يوليوز 2008 - 2009 الإعفاء الجزئي أو الكلي من التذكرة المعدلة بخصوص 108 مرض تمثل 10 من الأمراض المكلفة و 11 من الأمراض الطويلة الأمد؛ * فبراير 2010 توسيع التأمين الإجباري عن المرض ليشمل العلاجات الخارجية؛

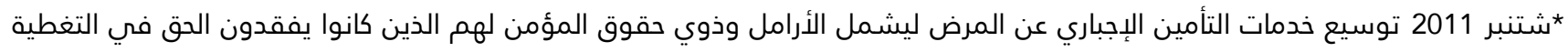
الطبية الأساسية بعد وفاة المؤمن له الرئيسي؛

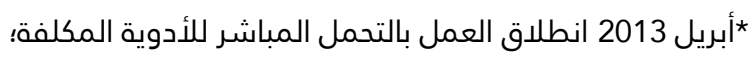

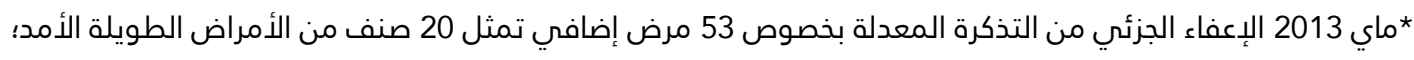
* يناير 2015 توسيع سلة علاجات التأمين الإجباري عن المرض، لتشمل علاجات الفم والأسنان بالنسبة لجميع المستفيدين كيفما كانت أعمارهم. 


\title{
اختصاص المركز الدولي لتسعية منازعات الاستثمار
}

\author{
كأes \\ باحثة في صف الدكتوراه \\ تخصص قانون الأعمال والاستثمار \\ كلية العلوم القانونية والاقتصادية والاجتماعية - جامعة محمد الأول وجدة الاعمال
}

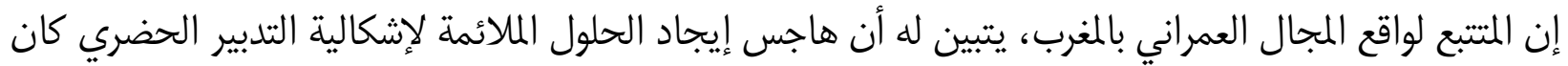

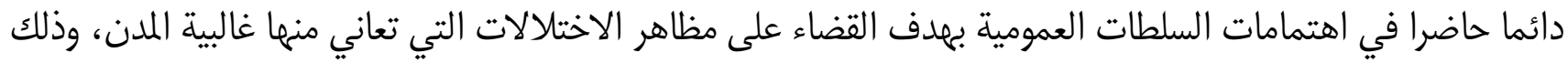

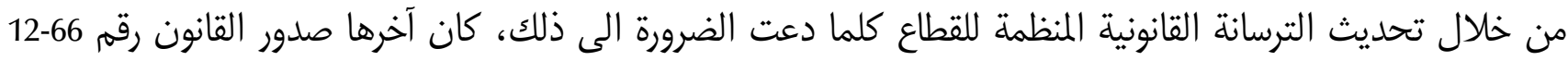

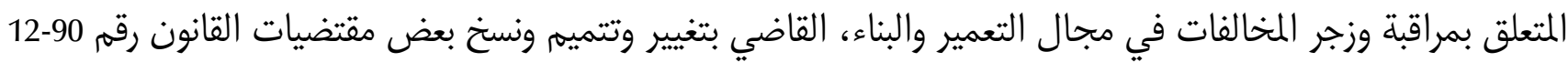
المتعلق بالتعمير والقانون رقم 90 -25 المتعلق بالتجزئات العقارية والمجموعات السكنية وتقسيم العقارات، وكذا الظهير الشريف التهاءيف رقم 063-60-1- بشأن توسيع نطاق العمارات القروية.

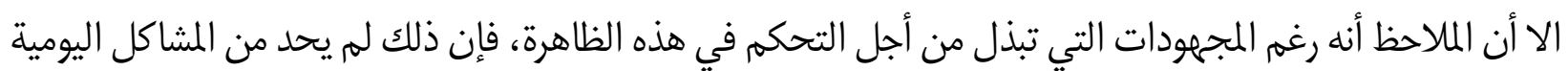

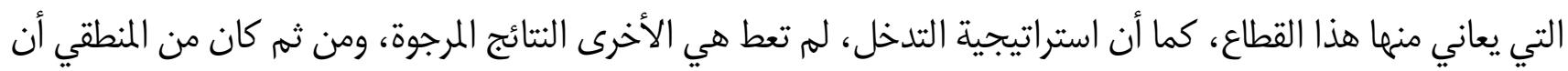

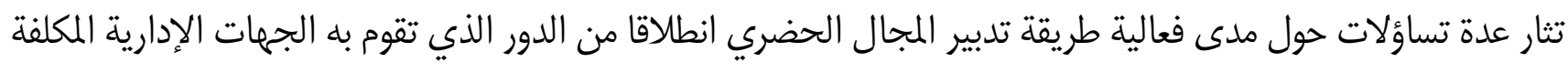

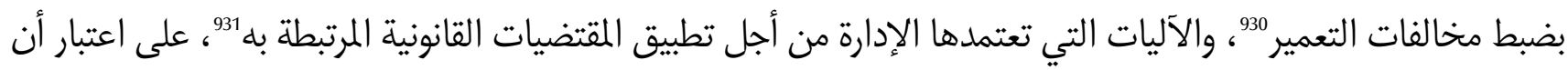

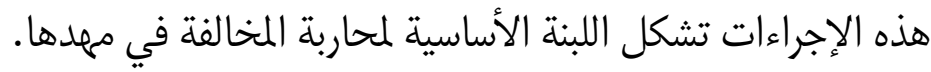
وتأسيسا على هذه الإشكالية، سأحاول معالجة هذا الموضوع من خلال الحديث عن نطاق الرقابة الإدارية على المجال

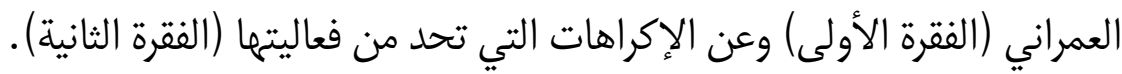

\section{الفقرةالأولى: نطاق الرقابة الإدارية على المجال العمراني}

يواجه الفضاء الحضري تحديات متزايدة ترتبط أساسا بالانفجار العمراني والنمو الديمغرافي المتزايد، وبظاهرة التمدن

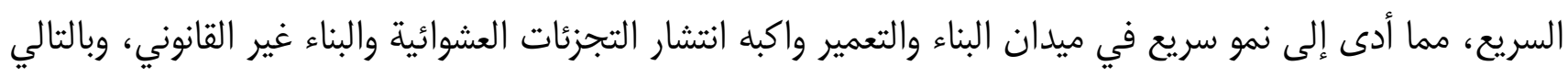

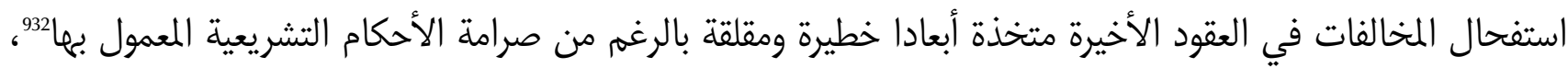

930 تنص المادة 65 من القانون رقم 66-12 على أنه: يقوم بمعاينة المخالفات المشار اليها في المادة 64 أعلاه وتحرير محاضر بشأنها: ضباط الشرطة الإدارية مراقبو التعمير التابعون للوالي أو للعامل أو للإدارة المخولة لهم صفة ضابط الشرطة القضائية.

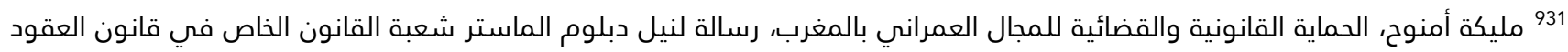
والعقار، جامعة محمد الأول وجدة كلية العلوم القانونية والاقتصادية والاجتماعية السنة 2010-2011، ص 6. الشريف البقالي، رقابة القاضي الإداري على مشروعية القرارات الصادرة في مجال التعمير، مطبعة دار القلم للطباعة والنشر والتوزيع الطبعة الأولى السنة 2016 ص 259.932 
ذلك أن تنفيذ عمليات البناء قد تدفع أصحابها إلى ارتكاب خروقات لقوانين التعمير تتخذ عدة أشكال وتكون لمها آثار سلبية

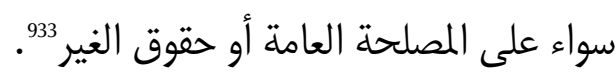

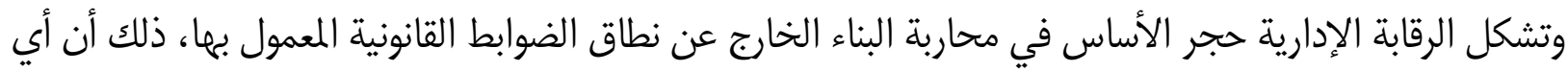

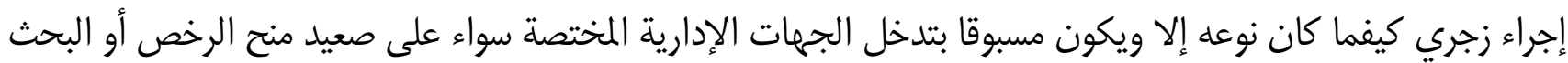
عن المخالفات، تمهيدا لاستكمال الإجراءات المسطرية المعمول بها لإصدار العقوبات في حق المات المخالفين. ويعد تدخل الإدارة في ميدان المراقبة مسلسلا تشترك فيه عدة جهات إدارية تتدخل كل منها في إطار الاختصاص

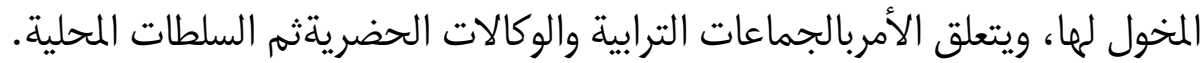
وتتخذ عملية المراقبة شكلين، الشكل الأول، مراقبة الشروط الواجب توفرها في ملفات التجزيء والبناء من أجل

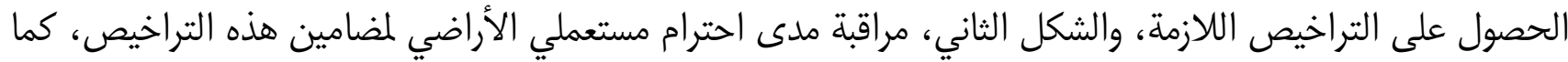
تنصب على نوعين من البنايات، تلك التي تتهم بترخيص والبنايات الفوضوية.

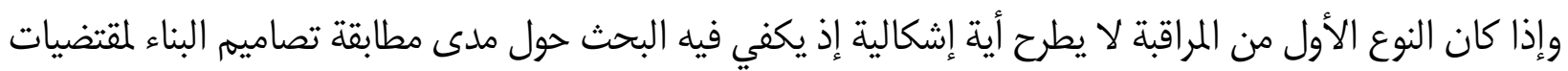

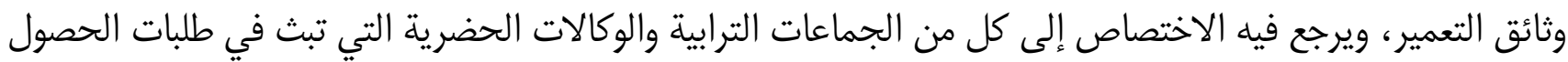

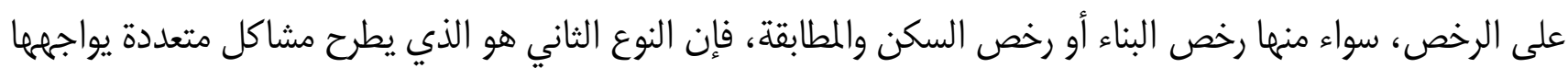
المتدخلين أثناءالمراقبة الميدانية وزجر المخالفات.

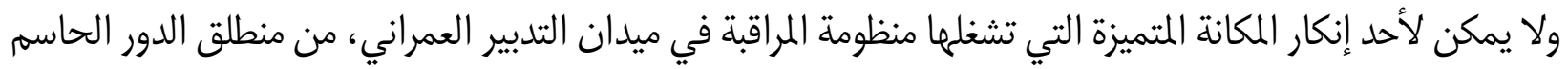

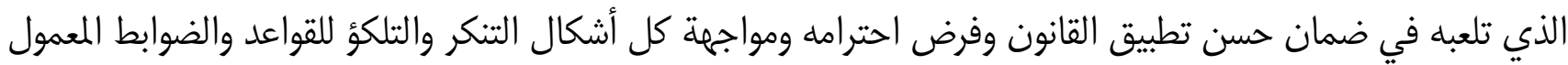

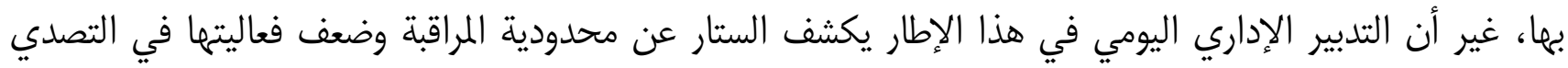

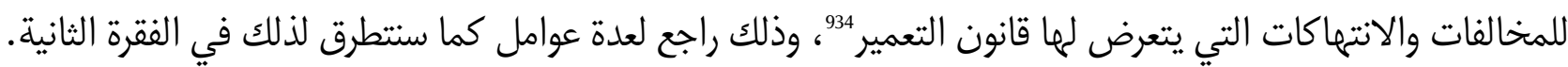

\section{الفقرة الثانية: الاكراهات التي تحد من فعالية الرقابة الإدارية:}

على الرغه من رغبة المشرع في الارتقاء بمنظومة قوانين التعمير وجعلما قادرة على التصدي للاختلال الذي يشهاهد

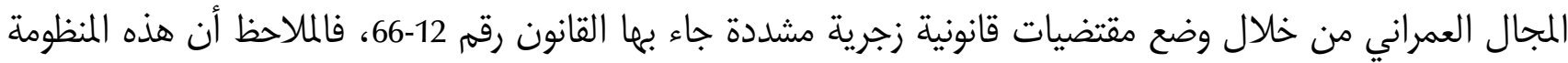

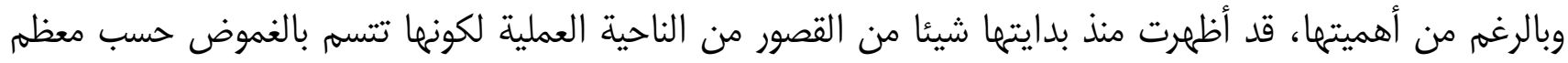

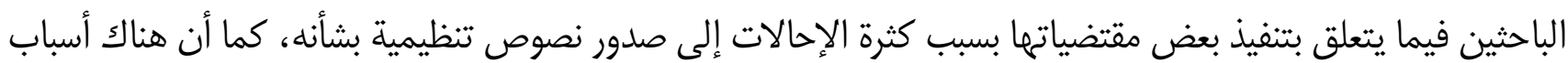
مادية وبشرية تساهم هي الأخرى في صعوبة تنزيلها.

933 Mohamed kharraji, le juge judiciaire et le droit de l'urbanisme, Le censeur, revue de contentieux Administratif et douanier, numéro 1 octobre 2011, page 32 .

934غيتقدكراوي منازعات التعمير بين المحاكم الإدارية والمحاكم العادية، منشورات المجلة المغربية للأنظمة القانونية والسياسية، العدد الخاص

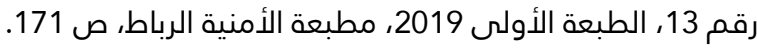


وهذا ما سأحاول معالجته من خلال الحديث عن غموض بعض المقتضيات التشريعية(أولا) وعن ضعف وسائل المراقبة (ثانيا) وثقل وسائل الضبط (ثالثا) وعدم استكمال المساطر الإدارية (رابعا)، حصر العقوبة على إنى مالك الك المبنى (خامسا).

\section{أولا: غموض المقتضيات التشريعية:}

إن القانون رقم 66-12 المتعلق بمستجدات ميدان التعمير والبناء هو قانونا يتعلق بالمراقبة بامتياز على عمليات البناء والتجزيء وتقسيم العقارات

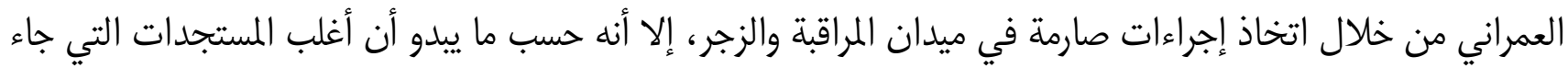

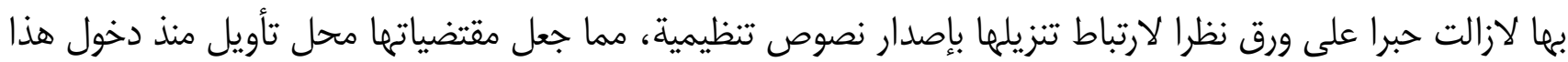
القانون حيز التنفيذ بعد نشره بالجريدة الرسمية عدد 6501 بتاريخ 19 شتنبر 2016. ويتعلق الأمر بالمقتضيات التالية:

-تحديد إجراءات وكيفيات منح رخصة الإصلاح.

- تحديد إجراءات وكيفية منح رخصة الهرم

- تحديد إجراءات وكيفية منح رخصة التسوية.

- تخويل ضابط الشرطة القضائية إلى المراقبين التابعين للوالي أو العاملة العامل أو الإدارة.

- تحديد طرق وكيفيات عمل مراقبي التعمير ونطاق ممارستهم لمهامهام.

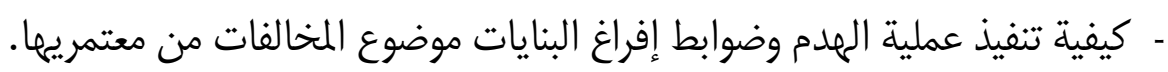

- تكوين لجنة الإشراف على عملية الهبدم.

- تحديد طبيعة وخصائص المشاريح، الخاضعة لمتضيات تنظيم الورش، الواقعة في نطاق العمارات القروية المنطاة

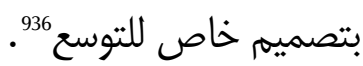

ومن خلال استقراء هذه الإجراءات، يبدو أنها تشكل جوهر وأساس عملية الإصلاح التي شملت منظومة التعمير

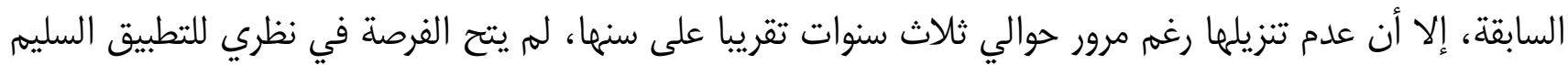

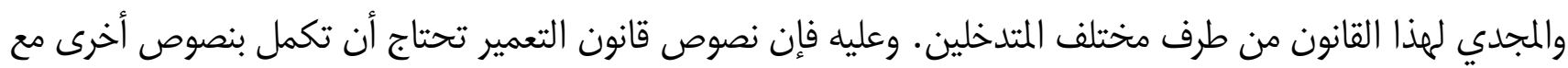
توضيح بعض مقتضياتها لإطلاق دور السلطات الإدارية المختصة لضبط المخالفات التي ما انفكت تنتشر وتزيد من تشويه التعمير والعمران بمددنا7ف․

لذا فإن التعجيل بوضع نصوص تنظيمية واضحة تضع حدا لكل تأويل، تبقى في اعتقادي، ضرورة ملحة لتصحيح الوضعية

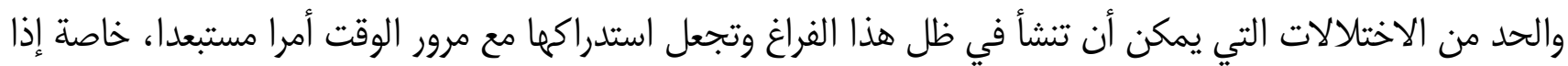

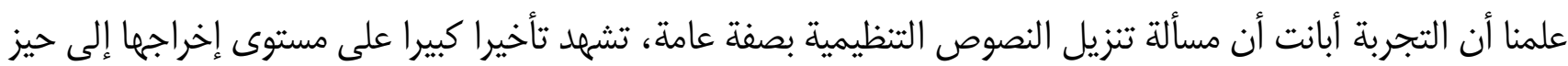

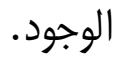
935 يونس أبلاغ، قراءة في القانون رقم 66-12 بشأن المراقبة وزجر المخالفات في ميدان التعمير والبناء، مجلة ملفات عقارية، العدد 6 خاص

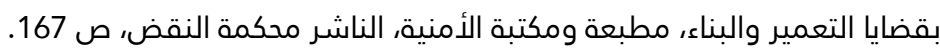
936 الدورية المشتركة رقم 07-17 بشأن تفعيل مقتضيات القانون رقم 66-12 المتعلق بمراقبة وزجر المخالفات في مجال التعمير والبناء،ص 7. 937 الشريف البقالي، رخصة البناء بالوسط القروي نطاق إلزاميتها وشروط منحها، منشورات المجلة المغربية للإدارة المحلية والتنمية، عدد مزدوج 


\section{ثانيا: ضعف وسائل المراقبة:}

إن تدخل الإدارة وهيئاتها في مجال محاربة المخالفات المرتكبة في ميدان التجزيء والبناء، يعد من أصعب ممامها وأكثرها تعقيدا بسبب ديناميكية الظاهرة ولما تحتاجه من وسائل بشرية ولوجستيكية كفيلة للاستجابة بشكل فوري وسريع للقضايا المطروحة. والملاحظ من خلال الواقع العملي، أن الجهات المتدخلة تعاني من نقص حاد إن لم نقل شبه منعدم في الوسائل التي من المفروض أن توضع رهن إشارتها للتصدي لهذه الظاهرة، إذ يقتصر المراقب الذي هو القائد أو الباشا في تدخلاته على سيارة المصلحة الموضوعة رهن إشارته أو بالاعتماد على أعوان السلطة، وهو ما يحول دون توفير الظروف الملائمة التي تضمن نجاعة تدخلاتهم. ويستفاد من ذلك، أن إقصاء المجالس الجماعية من دور المراقبة، قد أثر بشكل سلبي على تدخل الإدارة لما تتوفر عليه هذه الهيئات من وسائل مادية يمكن وضعما خصيصا لهزه الغاية، وهو ما يشكل في نظري تكريسا لأزمه المراقبة والزجر ويحول دون إرساء منظور جديد يتجاوز نقائص الممارسات القديمة.

\section{ثالثا: ثقل إجراءات الضبط الإداري}

مما لا شك فيه أن تدخل الجهات الإدارية قبل بلدء البناء المخالف أو أثنائه قد يحقق النتائج المنتظرة منه، سواء بالنسبة للجهات المكلفة بضبط المخالفات، إذ يمكنها ذلك من وضع حد لها قبل تفاقمها أو بالنسبة لصاحب البناء على اعتبار أنها

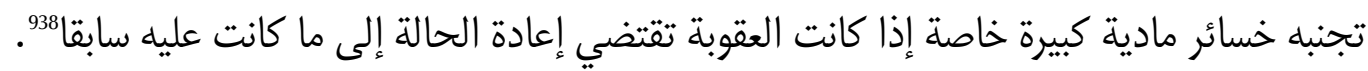
وبطبيعة الحال أن هذا الأمر لن يتأتى إلا إذا توفرت الوسائل البشرية الكافية التي تمكن من الاستجابة بالسرعة المطلوبة لإبطال كل فعل مخالف للقانون في بدايته، وهو الإكراه التي تعاني منه الجهات المتدخلة في ظل القانون الجديد،

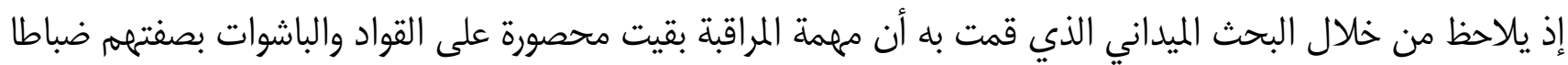
للشرطة الإدارية، مما زاد من تعقيد مسألة السرعة في التغطية والتدخل، بالنظر إلى شساعة الرقعة الجغرافية التي يشرف عليها كل رجل سلطة، وبالنظر كذلك إلى تشعب اختصاصاته التي تفرض عليه التدخل في جميع ميادين الحياة العامة، ويمكن أن نورد كمثال على ذلك النفوذ الترابي لجماعة بركان الممتد على مساحة حوالي 20 كلم مربع، ويضم خمس ملحقات

$$
\text { إدارية أي بمعدل أربعة كلم مربع لكل مراقب لمبن }
$$

لكن التساؤل يبقى مطروحا، حول مدى إمكانية انخراط كل أصناف ضباط الشرطة القضائية في عمليات المراقبة؟ وأقصد بذلك الدرك الملكي والأمن الوطني حسب الاختصاص الترابي لكل جهة على حدة، أو أن الأمر سيبقى كما كان، أي إثقال كاهل السلطة المحلية وإعفاء باقي الأجهزة من أي مسؤولية، خصوصا أن الواقع العملي أثبت بالملموس عدم مساهمة باقي الأجهزة أي الدرك والأمن في محاربة الظاهرة وكأنهم غير معنيين، مع الإشارة أنه من حسنات القانون الجديد تبسيط إجراءات المتابعة في حق المخالفين حيث أصبحت علاقة هؤلاء أي ضباط الشرطة القضائية مباشرة بالنيابة العامة ولن يكونوا مجبرين بالمرور بقناة السياسي المنتخب لتحريك المتابعة

938 نجاة أبريكي، الحماية الجنائية للمجال العمراني الطبعة الأولى 2016، مطبعة دار السلام الرباط، ص 47. 939 إفادة إطار بباشوية بركان بتاريخ 9 أكتوبر 2018.

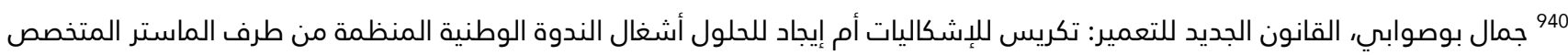
في قانون العقار والتعمير بالكلية المتعددة التخصصات بالناظور أيام 2-3-4 مارس 2017، ص 162. 


\section{رابعا: عدم استكمال المساطر القانونية المتعلقة بالمخالفات}

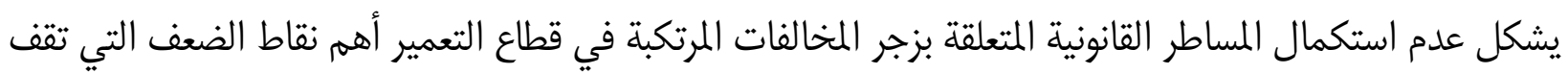
عائقا في وجه التطبيق السليم للعقوبات المقررة في حق المخالفين، ذلك أنه عادة ما يتوقف مسار هذه المساطر عند توجيه محاضر المخالفات إلى النيابة العامة دون استكمال الإجراءات الأخرى التي تليها، والتي من شأنها إنهاء المخالفة، خاصة فيما يتعلق بعمليات حجز المعدات والأدوات وإغلاق الورش ووضع الأختام عليه الحال، مما يساهم في إضعاف العقوبة وجعلما تقتصر على الغرامة دون المس بجوهر المخالفة التي تبقى مستمرة، وهو إجراء ليس له ما يبرره ما دام أنه يتيح فرصة العود إلى ارتكاب المخالفة وإنهاء ما شرع فيه من بناء من طرف المخالفين. ونعتقد أن المشرع كان موفقا عند أقراره للحجز، لأن هذا الإجراء أبان في الواقع العملي، عن فعالية كبرى إثر ممارسته من طرف رجال السلطة في ظل القانون رقم 90-12، حيث كانوا يستندون في ذلك على الفصل 57 من قانون المسطرة الجنائية2942، معتبرين ما يته حجزه يدخل ضمن أدوات ارتكاب الجريمة، أما الآن مع وجود نص صريح، فإن اللجوء لحجز أدوات ومواد البناء سيؤدي لامحالة إلى ردع المخالفين وتحقيق الغاية المرجوة التي لم يتهم تطبيق اجراء إغلاق الورش ووضع الأختام عليه المنصوص عليه في الفقرة الثالثة من المادة 67 إلا مرة واحدة منذ صدور القانون رقم 66-12 سنة 2016. ويبدو في اعتقادي، أن التقصير في استكمال المساطر يعد من أهم الأسباب التي تكمن وراء عدم الشعور بالخوف لدى المخالفين كما يترجم ضعف مساهمة تدخلات الإدارة في التقليص من حجم المخالفات

\section{خامسا: حصر العقوبة على مالك المبنى}

إن عملية البناء هي عملية مشتركة يساهم في تنفيذها العديد من الأشخاص إلى جانب رب العمل، منهم على

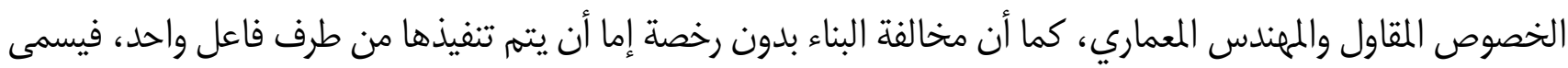

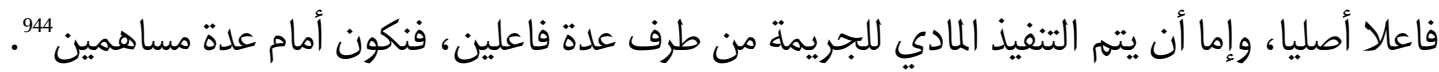

ومن هذا المنطلق فإنهم يعدون شركاء في المخالفات المرتكبة في مجال التعمير ومسؤوليتهم تبقى قائمة لإخلالهم

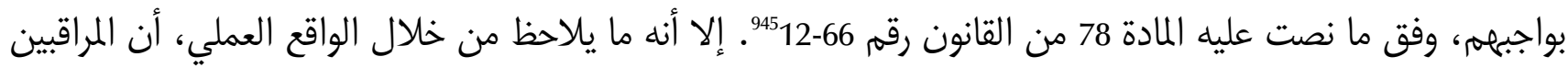

9419نص الفقرة الثانية من المادة 67 من القانون رقم 66-12 على أنه: إذا لم ينفذ المخالف الأمر المبلغ اليه بإيقاف الأشغال في الحال، يمكن للمراقب، حجز المعدات والأدوات ومواد البناء وكذا إغلاق الورش ووضع الأختام عليه ويحرر محضرا تفصيليا بذلك، يوجه المات إلى الى كيل الملك. 942 تنص المادة 57 من قانون المسطرة الجنائية على أنه: يجب على ضابط الشرطة القضائية الذي أشعر بحالة تلبس بجنحة أو جناية أن يخبر بها

النيابة العامة فورا وأن ينتقل في الحال إلى مكان ارتكابه لإجراء المعاينات المفيدة. وعليه أن يحافظ على الأدلة القابلة للاندثار وعلى كل ما يمكن أن يساعد على إظهار الحقيقة وأن يحجز الأسلحة والأدوات التي استعملت في ارتكاب الجريمة أو التي كانت معدة لارتكابها وكذا جميع ما قد يكون ناتجا عن هذه الجريمة.... 943 سعيد الوردي، مراقبة وزجر المخالفات في مجال التعمير والبناء، الطبعة الأولى

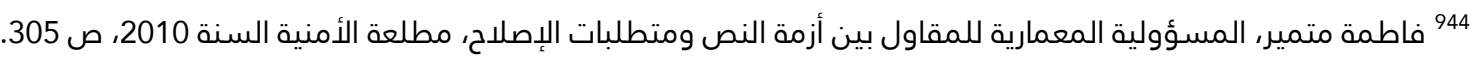

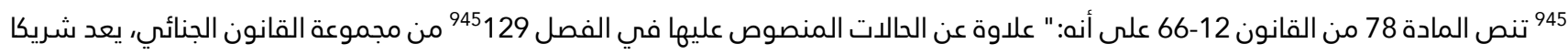

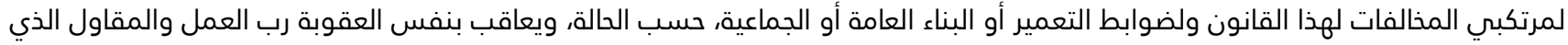
أنجز الأشغال والمهندس المعماري والمهندس المختص والمهندس المساح الطبوغرافي، في حالة عدم تبليغهم عن المخالفة 48 ساعة من علمهم بارتكابها، وكل من صدرت عنهم أوامر نتجت عنها المخالفة والأشخاص الذين سهلوا أو ساهموا في عملية البناء المخالف للقانون. 
يقتصرون في المحاضر التي ينجزونها على مالك المبنى دون غيره، خاصة محترفي مهنة البناء الذين يلعبون دورا مهما يتمثل

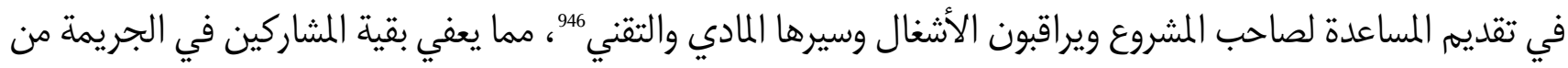

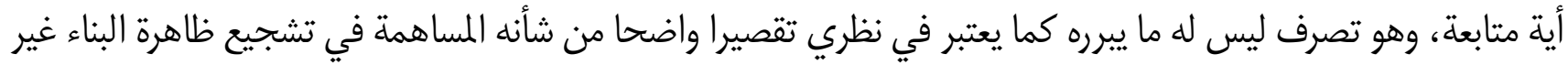

وفي هذا الصدد، لا بد من الإشارة إلى أن كل مخالفة لقوانين التعمير ترتب المسؤولية الجنائية للمخالف، والتي ينتج

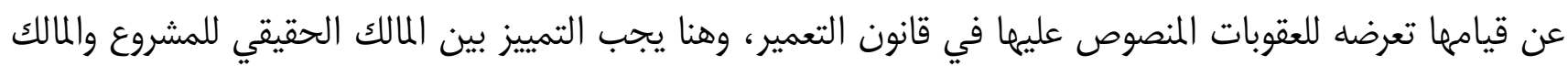

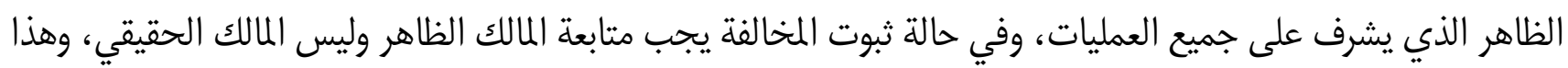

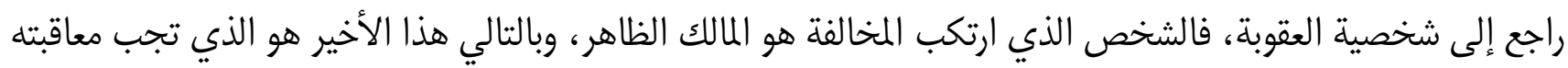

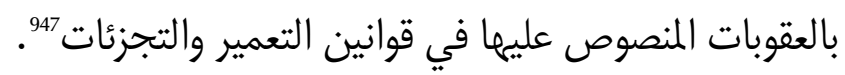
من جهة أخرى، وما دام أن المقاول أو المهندس المعماري يقوم بالتنفيز ولمئ المادي والفعلي لعملية البناء، وقيامه بهذه العملية

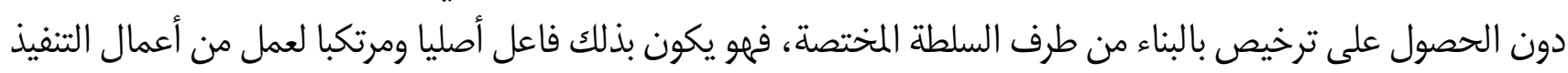

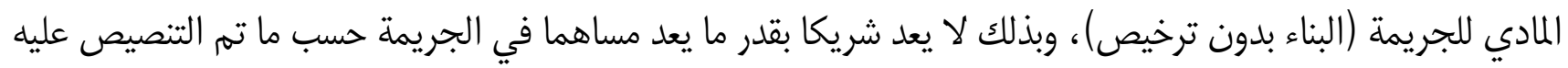

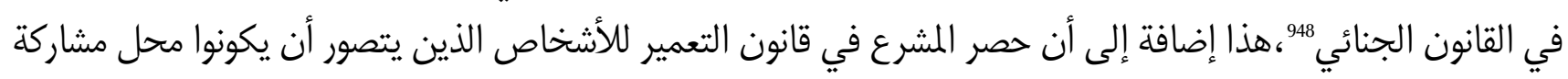

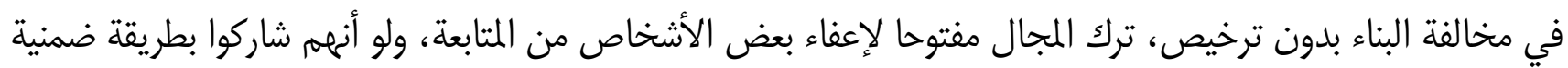

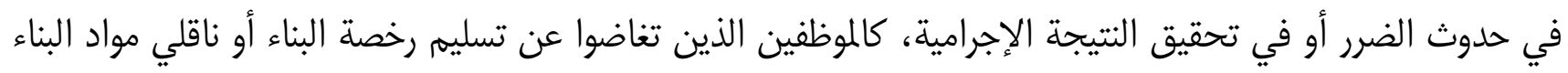

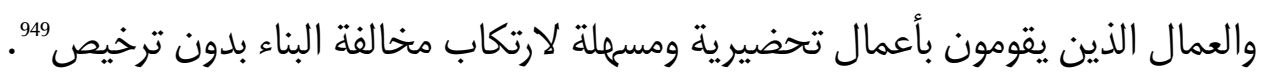

ومن خلال ما سبق، يمكن أن نستتج أن محاربة مخالفات التعمير سواء منها المرتبطة بمخالفة مضمون التراخيص التباء

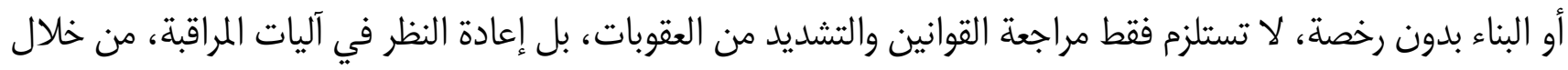

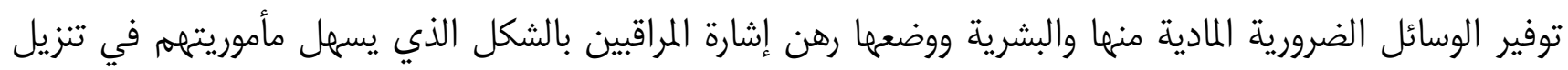

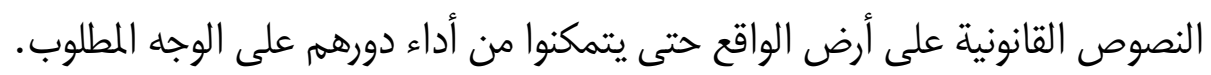

وخلاصة القول أن القوانين والنصوص التنظيمية وإن كانت راقية لا تكفي وحدها لضبط عمليات التوسع العمراني

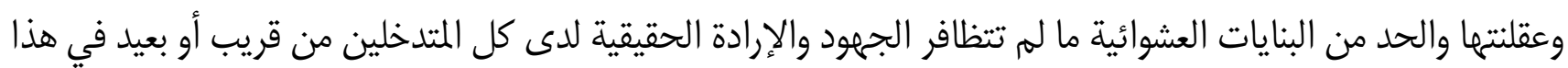
القطاع الحيوي

يعاقب المشاركون المذكورون بالعقوبات المطبقة على الفاعلين الأصليين ما لم يتعلق الأمر بجريمة أشد ". 946 زهور أبو الخير، اختصاص القضاء في حل منازعات التعمير والإسكان، رسالة لنيل دبلوم الدراسات المعمقة في القانون العام، جامعة محمد

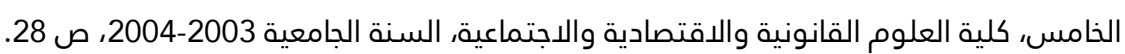
947 غيتة دكراوي منازعات التعمير بين المحاكم الإدارية والمحاكم العادية، مرجع سابق ص 121.

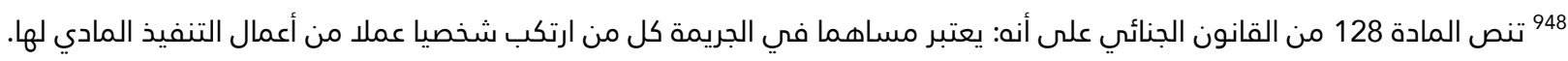

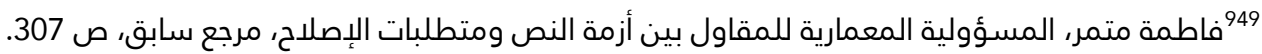
950 أحمد الهرجاني، الإطار القانوني لضبط وزجر التجزئئات العقارية المخالفة لقانون 90-25 المتعلق بالتجزئات العقارية وتقسيم العقارات والمجموعات السكنية التجزئة العقارية والتعمير ص 109. 


\section{رور التوقع في تحديد المسؤولية الجنائية عن الخطأ

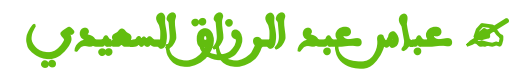 \\ طالب دكتوراه في القانون العام القسم الجنائي \\ في جامعة سوران-كوردستان العراق}

\section{Abstract:}

The Role of Expectation in Determining Involuntary Criminal Liability:

The term "Expectation" in legal contexts can be explained from the linguistic point of view as waiting for what might happen in the future resulting from the normal flow of the case. This means that occurrence of expectation requires three major elements; selecting a sensitive event, the selected event requires a decision, and a possibility for an effect to happen in the future. In other words, a criminal effect is expected to happen arising from the causation resulted from the behavior of the offender. Such behavior comes because of the actual movement linked to the decision. In Arabic language, expectation is not far from the given meaning. Meaning that expectation is a belief about what might happen in the future. In some cases, expectation does not have to do with experience or knowledge. However, expectation has many commons with prediction; they are exchangeable in many situations. Expectation is a process of guessing what might happen in the future, whereas prediction depicts more than that with more accuracy and precision, which might embrace a wider range of possible results. Unintentional act shall not be count for neglecting precautionary measures or breaching its rules only, since law does not impose punishment on the abstract behavior itself, rather, it imposes the punishment based on the results of the behavior that breaks a forbidden effect. From this standpoint, in expectation, the offender expected the occurrence of the crime arising from his/her conducted behavior. Further, s/he is aware that such behavior might or might not lead to a crime. In other words, the offender is not one-hundred percent sure, that such behavior will cause insults that forbidden by law. Thus, associating the cause and effect of such event requires linking points. Whenever such linking point is determined, then the cause becomes questionable and therefore can be examined as intentional cause. Eliminating a questionable linking point shall be justified by the absent of criminal liability. Unintentional act is in fact a psychological condition links the cause, which in this case represented by the offender's behavior, to the effect. Obviously, this association is justified through the willingness of expecting the effect, taking into consideration the capability of determining such expectation alongside with capability to prevent such behavior. 


\section{المقدمة}

الحمد لله الذي جعل الكمال صفة لازمة ملازمة لذاته العليا، وجعل الخطأ والنسيان صفات للإنسان، ليتجلى برحمته

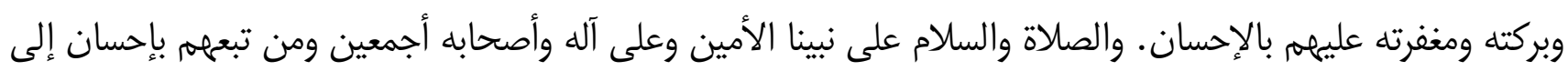

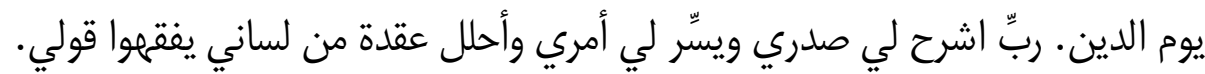

أما بعد:

فالتوقع بالمعنى اللغوي للمصطلح في الفقه الجنائي يعني انتظار ما يمكن حدوثه مستقبلا وفقا للا يجري فيه السير

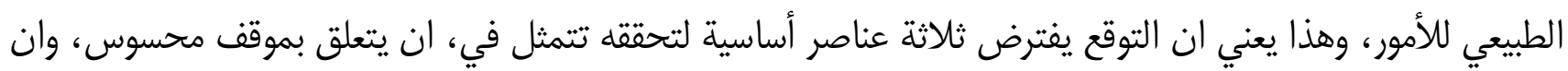

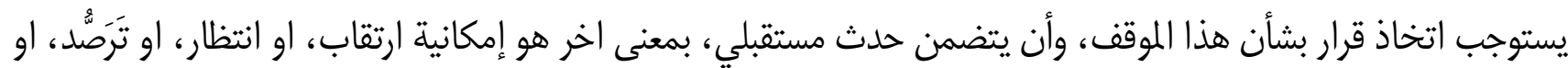

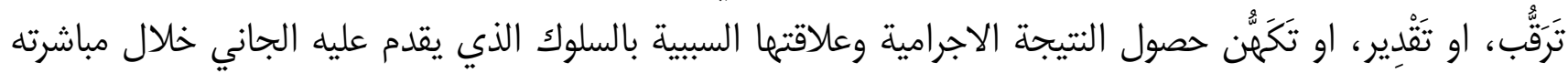

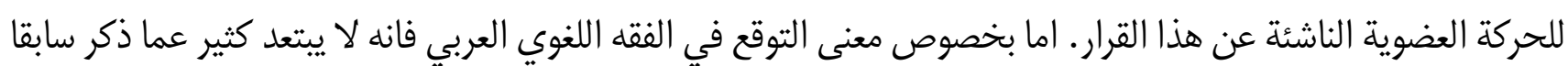

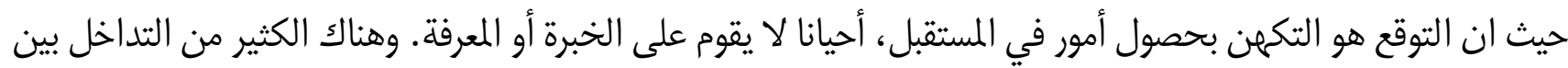

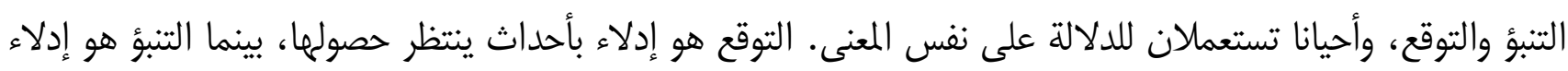
بتوقعات أكثر تحديدا ودقة، ويمكن أن يغطي مجموعة واسعة من النتائج المحتملة.

أولاً -نطاق البحث: حيث ان موضوع التوقع في مجال القانون الجنائي موضوع واسع ومتشعب وانه يدخل أيضا في

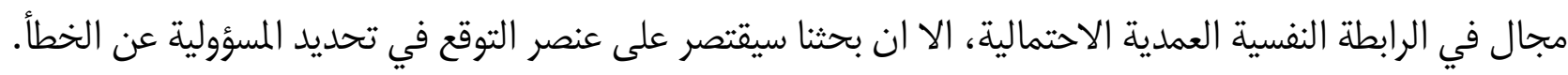
ثانياً -إشكالية اشكالية: تتمثل إشكالية البحث في: 1-إشكالية اشتراك التوقع في العلاقة النفسية في العمد والخطاء. 2-إشكالية كيف يمكن نستطيع حسم مسالة القبول وعدم القبول خاصة في الخطاء الواعي. 3-إشكالية يجب ان تكون الإشكالية الفرق بين الخطاء الواعي والقصد الاحتمالي لكون الاثنين مبنية على التوقع كيف نضع خط فاصل بينهما.

4-الإشكالية الاصطلاحية التي رافقته في صياغة احكام قانون العقوبات من خلال توحيد المصطلحات المستخدمة. ثالثاً -أهمية البحث: تتبع أهمية البحث من أهمية اشكاليته، فمن الضروري إيجاد الية للتمييز بين التوقع في العلاقة

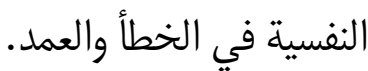

رابعاً -منهجية البحث: يعتمد البحث على منهج مركب: فهو دراسة تحليلية ومقارنة وانتقادية نظرية ووصفية، فهي

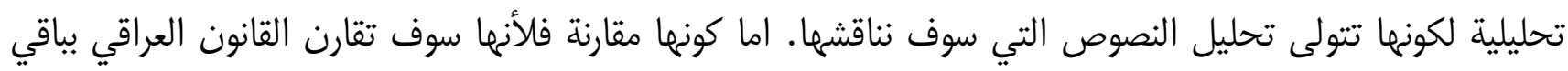

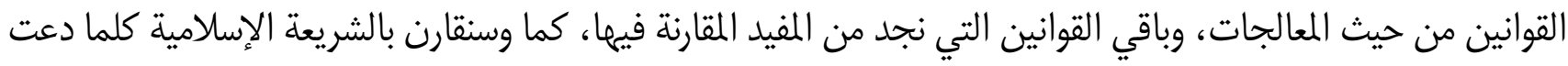


الحاجة الى ذلك. اما كونها انتقادية ونظرية ووصفيه فلكونها تتناول بالانتقاد والوصف النظري للنصوص الجزائية الخاصة في القانون العراقي واقتراح البدائل للمعيبة منها.

خامساً -هيكلية البحث: تناولنا موضوع البحث في مقدمة وثلاث مباحث يتناول المبحث الأول، التوقع جوهر العلاقة النفسية في الخطأ. والمبحث الثاني، وجود علاقة بين الارادة والنتيجة الاجرامية (كعنصر في الخطأ). والمبحث الثالث، الاتجاهات الفقه بشأن دور التوقع أو استطاعته في نظرية الخطأ. ودوننا تفصيل ذلك وينتهي البحث بخاتمة نعرض فيها لأهم النتائج والاستنتاجات والتوصيات التي ترشحت عن البحث.

\section{المبحث الأول: التوقع جوهر العلاقة النفسية في الخطأ}

لا يتحقق الخطأ غير العمدي لمجرد عدم اتخاذ تدابير الحيطة والحذر او الاخلال بها لكون القانون لا يعاقب على السلوك المجرد بذاته ولكن يعاقب على السلوك الذي يصدر من الجاني ويفضي الى نتيجة يجرمها، بمعنى يفترض في التوقع ان يكون الجاني كان ينتظر وقوع الجريمة كأمر ممكن للسلوك الذي ارتكبه قد يحصل وقد لا يحصل، أي ان الجاني لا لاني يكون متأكدا على نحو يقيني ومؤكد ان سلوكه سيقود لحصول النتيجة المتمثلة بالاعتداء على الحق الذي يسبغ القانون الحماية عليه.

وتأسيسا على ذلك، فلا بد من توفر رابطة او صلة تقوم بجمع الإرادة والنتيجة المتحققة بشكل يجعل من الإرادة محلا للمساءلة القانونية وتوسيمها بسمة الإرادة الاجرامية ويترتب على انتفاء تلك الصلة انتفاء المسؤولية الجنائية عن النتيجة المتحققة، لكون الخطأ غير العمدي هو في الحقيقة صلة نفسية تربط بين إرادة الجاني المتمثلة بالسلوك المرتكب من قبله وبين النتيجة المتحققة عن ذلك السلوك، وان هذه الصلة تتراءى من خلال خمول الإرادة عن توقع النتيجة مع قدرتها على بلى ذلك ومنع حصولمبا.

ولأجل التفصيل في ذلك فقد قمنا بتقسيم المطلب الى مطلبين: المطلب الأول، استطاعة التوقع ووجوبه. بينما المطلب الثاني، نظرية الخطأ غير العمدي المتمثل بإمكانية التوقع:

\section{المطلب الأول: استطاعة التوقع ووجوبه}

التوقع يمثل الجانب الإيجابي للآصِرَة التي تربط بين سلوك الجاني والنتيجة المتحققة من جراء سلوكه، وأهمية ذلك تتمثل في ثلاثة حقائق مهمة هي: الأولى، من حيث كونه تكتمل باه مكونات الخطأ وتتحقق به العلاقة النفسية التي تربط بين سلوك الجاني والنتيجة المتحققة عن فعله، حيث ان الخطأ لا يتحقق لمجرد خمول الإرادة عن توقع النتيجة الاجرامية مالم تكن النتيجة متوقعة. والثانية، باستطاعة التوقع يتجلى الخطأ في سلوك الجاني حيث ان النتيجة إذا كانت متوقعة من ين لئن قبل الجاني فيكون بإمكانه الحيلولة دون وقوعما. والثالثة، ان استطاعة التوقع تستقيم به الحدود الفاصلة بين الخطأ وبين

951 د. حميد السعدي، شرح قانون العقوبات الجديد، دراسة تحليلية مقارنة، في الاحكام العامة الجريمة والعقاب والمسؤولية الجنائية، ط2، دار

الحرية للطباعة، بغداد، 1976، ص ص دمبد 261.

952 د. سامح السيد جاد مبادي قانون العقوبات القسم العام، دار الكتاب الجامعي، القاهرة، 1987، ص صداعد، 378. د. محمود نجيب حسني، الخطأ غير العمدي في قانون العقوبات، مصدر سابق، 514. د. احمد عبد اللطيف، الخطأ غير العمدي في القانون الوضعي والشريعة الإسلامية، دار

النهضة العربية، القاهرة، 2004، صدي هون 138. 
الحادث الفجائي، فاذا استحالت عملية توقع النتيجة التي وقعت يترتب على ذلك انتفاء المسؤولية الجنائية وتخرج الحادثة من فضاء الخطأ لتدخل فلك الحادث الفجائي.

أولاً - نظرية قبول الخطر : نظرا لتزايد حالات الجريمة غير العمدية في السنوات الأخيرة بشكل ملحوظ نظرا لتعقيد الحياة بسبب التطورات العلمية والاكتشافات التكنولوجية الحديثة التي شهدها العالم في الآونة الأخيرة، الامر الذي دفع بالفقه الجنائي الى ضرورة البحث عن أساس متين للعقاب لا يقوم على إرادة الجاني ولا على المسؤولية الأخلاقية، وقد وجد العقاب أساسه وفقا لهذه النظرية على السلوك الخطر والحالة الخطرة للجاني مستندة في ذلك الى السياسة الجنائية الواقعية التي تسعى الى مكافحة الاجرام عن طريق المنع والوقاية. وبموجب هذه النظرية فان الجرائم غير العمدية هي بالحقيقة جرائم خطر قوامها قبول الجاني لسلوك خطر اجتماعياً، تماما كما في الجرائم العمدية الذي ترتب على سلوكه خطر اجتماعي، الا أن الاختلاف بينهما يتجسد بدرجة علم كل منهما بحالة الخطر، ففي العمد ان الجاني يعلم حق العلم بان سلوكه خطر ويقبل بذلك، بينما في غير العمد فان الجاني لا يجهل الخطر وانما يحاول اقناع نفسه بغير ذلك ولكن في نهاية المطاف يقبل المخاطرة بذلك، بمعنى ان الجريمة غير العمدية ما هي الا قبول خطر اجتماعي مع رغبته السلبية وتمنيه في تفادي هذا الخطر.

ولم تسلم هذه النظرية من الانتقاد، حيث انها لا توفر الأساس السليم للمسؤولية عن الجرائم غير العمدية من حيث تعارض المبادئ القانونية الحديثة في قوانين العقوبات (خصوصا مبدأ الشرعية الجزائية ومبدأ حرية الاختيار ومبدأ المسؤولية الأخلاقية التي تسري أيضا على هذه النظرية التي تعتبر الجرائم غير العمدية من جرائم الخطر) مع الاعتماد على خطورة الجاني كأساس للعقاب، المتمثلة بقبوله غير العمدي للخطر، بالإضافة الى ان القول بان الخطأ هو قبول الجاني لسلوك خطر اجتماعياً مع امله السلبي في إمكانية التخلص منه، مع القول بان الجاني قبل السلوك الخطر دون قبول النتيجة، فان هذا الكالام يدخلنا في افق القصد الاحتمالي الذي هو صورة من صور العمد، كما ان القول بان الجاني كان يتأمل تجنب حصول النتيجة فان هذا القول يشمل فقط حالات الخطأ الواعي (الخطأ مع التوقع) وانما تخرج حالات الخطأ غير الواعي (الخطأ بلدون توقع) من مجال قانون العقوبات.

كما ان القول بان خطورة الجاني وسلوكه الخطر لا يصلح كأساس للعقاب على الجرائم غير العمدية لكون المشرع لا يعاقب على مجرد السلوك ولا على مجرد الخطأ ما لم تترتب عليهما نتائج ضارة يجرمها. ثانياً -الضرر المحتمل: ابتداءً نقول، أن المقصود بالضرر المحتمل هنا ليس النتيجة التي تحققت بل الضرر الذي قد

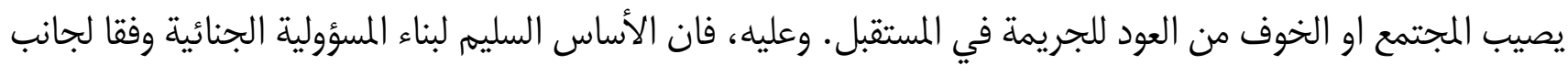

953 د. رمسيس بهنام، الجريمة والمجرم والجزاء، منشأة المعارف، الإسكندرية، 1972، الفقرة رقم 110، ص 546. 954 د. شريف سيد كامل محمد، النظرية العامة للخطأ في القانون الجنائي، دراسة تأصيلية مقارنة للركن المعنوي في الجرائم غير العمدية،

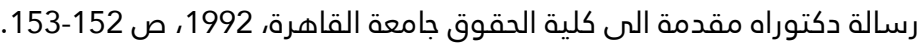
955 د. محمود نجيب حسني، شرح قانون العقوبات القسم العام، ط6، دار النهضة العربية، القاهرة، 1989، 1959، الفقرة رقم 956 د. محمود نجيب حسني، شرح قانون العقوبات القسم العام، مصدر سابق، الفقرة 725، ص 664. 
من الفقه 957، هو الضرر المحتمل وهذا الامر ينطبق على حالة العمد وكذلك على حالة الخطأ، حيث ان الغاية من وضع قانون

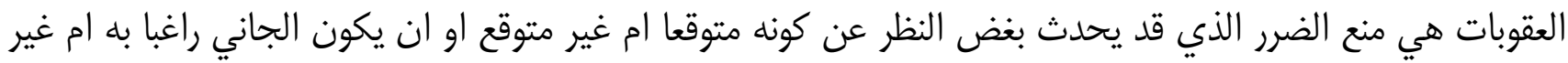

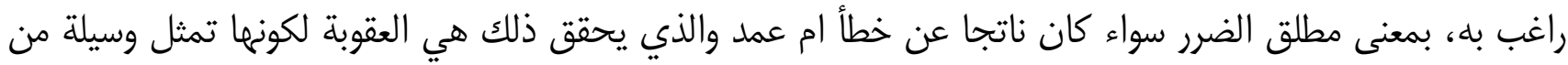

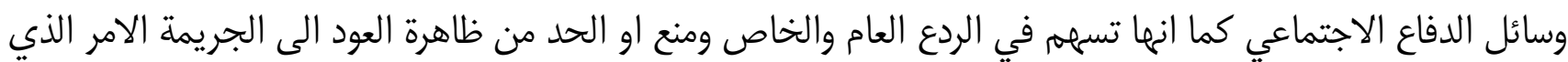

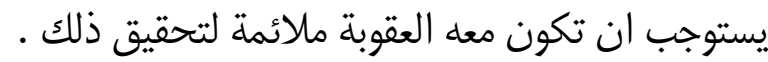

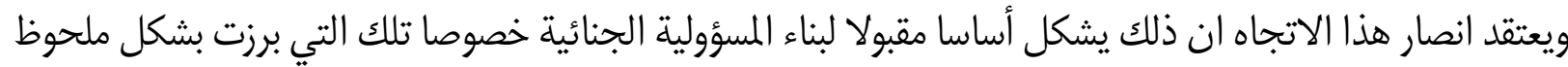

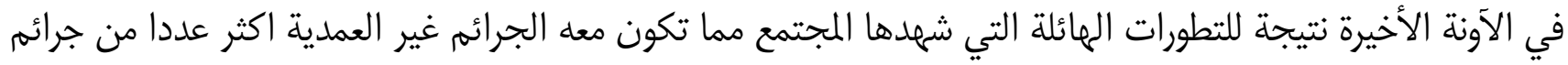

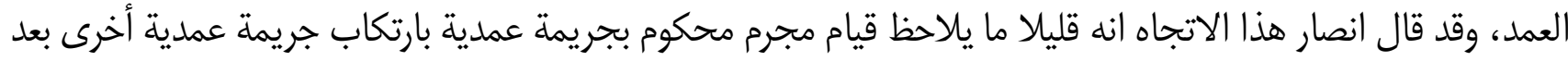

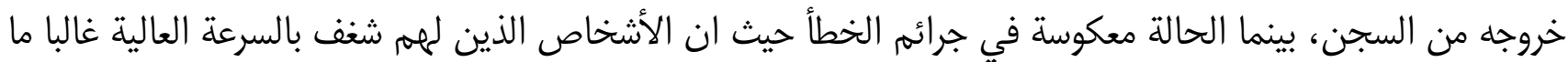

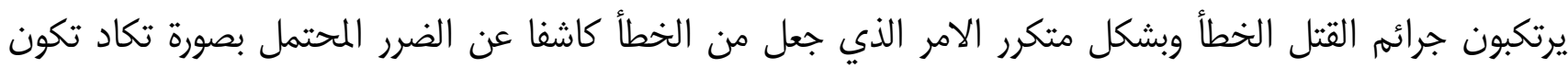
مؤكدة.

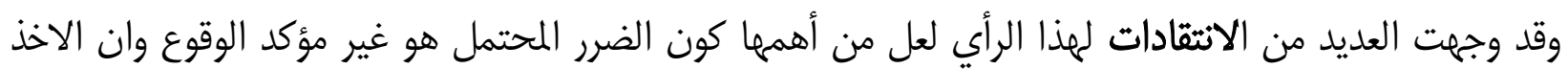

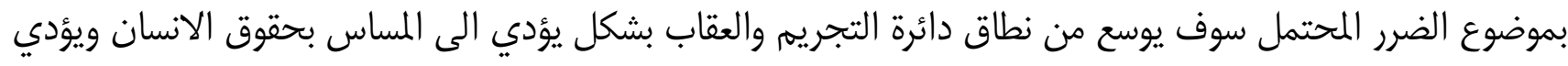

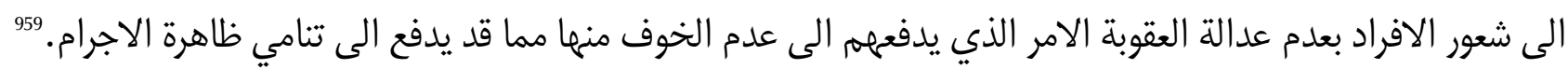

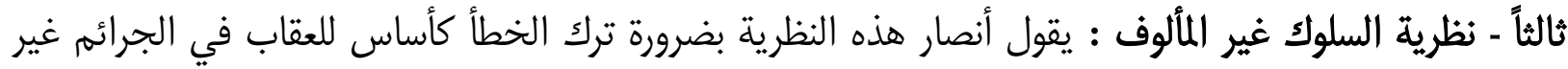

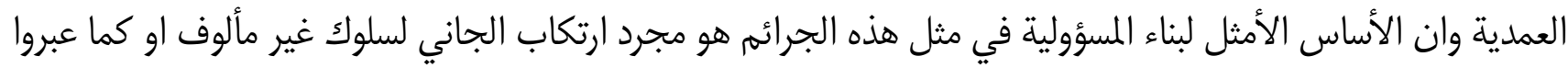

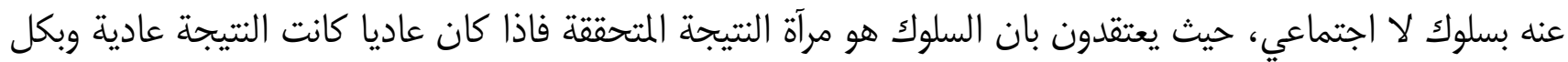

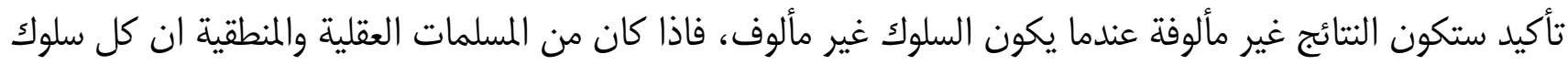
يقود الى نتيجة، لذا يجب ان يتحمل مرتكب السلوك ما يترتب عليه من نتائج، مما يجعل المسؤولية الجنائية عن الجرائم

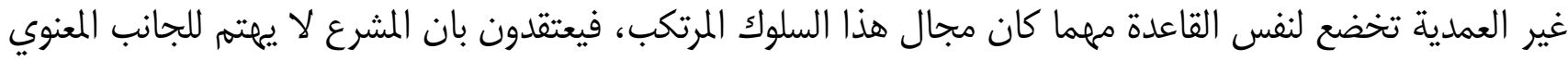

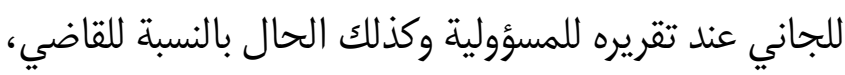

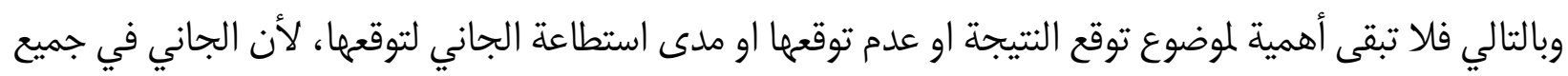

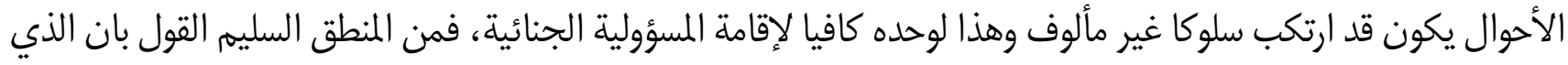

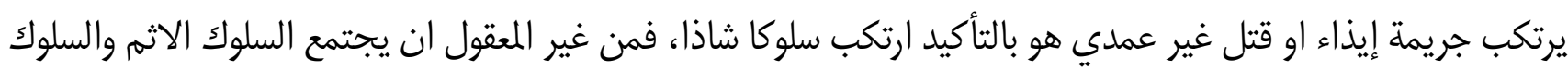
المثالي في تصرف واحد

${ }^{957}$ Givry F., Essai sur le fondement de la responsabilite penale en matiere de delits intentionnale ET de delits dim prudence, Montpellier, 1970.

${ }^{958}$ Givry F., op. cit. p.p.43, 48.

959 د. شريف سيد كامل محمد، النظرية العامة للذطأ في القانون الجنائي، مصدر سابق، ص185-186. ${ }^{960}$ Daskalakis E., La notion dunite ET de pluralite dinfractions ET son role dans le process penal, These, Paris, 1969, p. 107. 


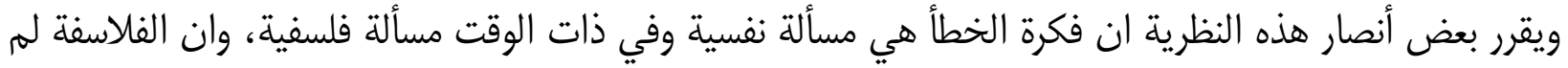

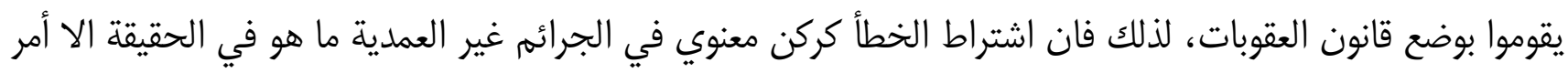

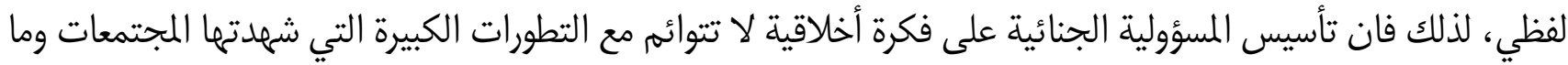

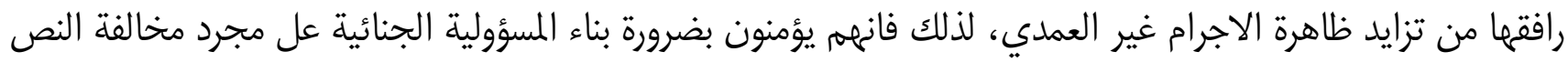

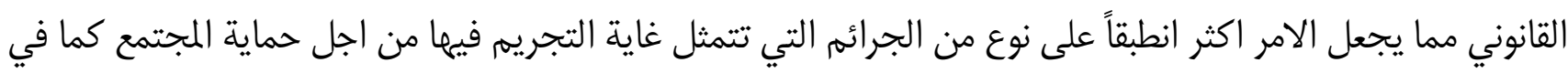

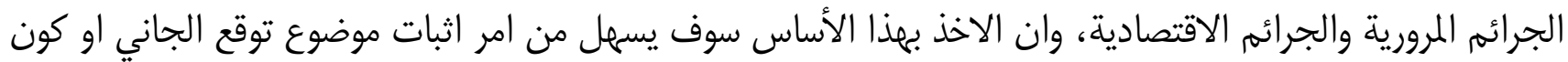

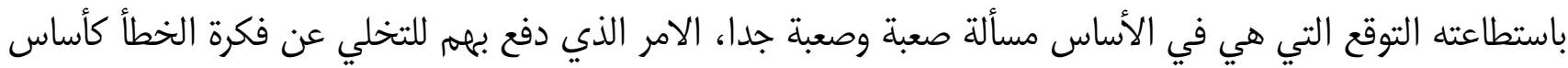
للتجريم في هذا النوع من الجرائم.

وقد طال الانتقاد هذه النظرية أيضا فأهم ما يؤخذ عليها مخالفتها لنصوص القانون التي تعاقب على الجرائم غير

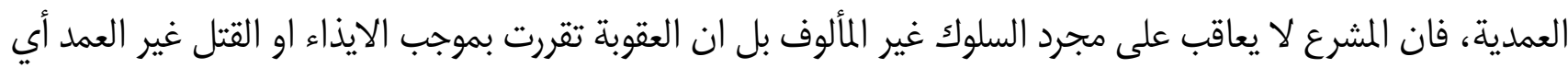

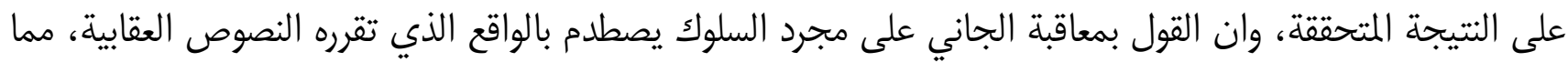

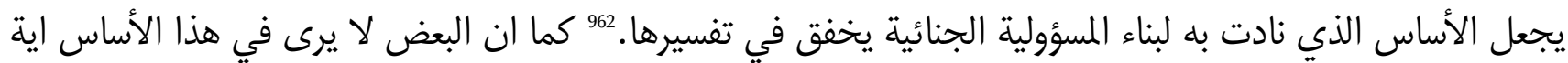

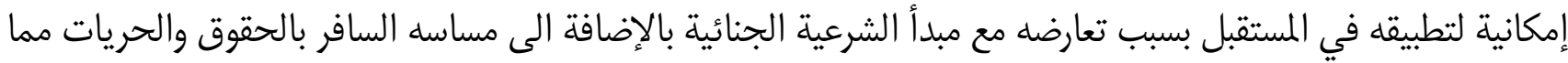
يجعل من الصعب ان لم يكن من المستحيل تحديد حدود المسؤولية الجنائية.

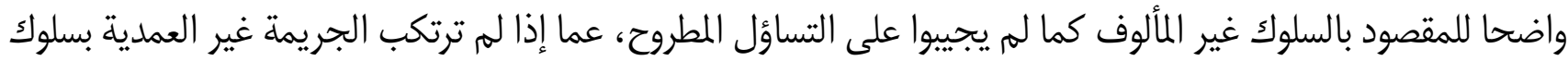
مألوف؟

\section{رابعاً -الخطأ اليسير والخطأ الجسيم/ الاخلال بواجبات الحيطة والحذر كأساس للعقاب في الجرائم غير العمدية:}

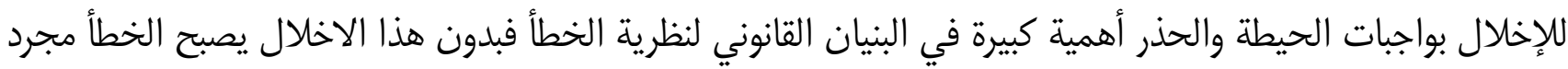

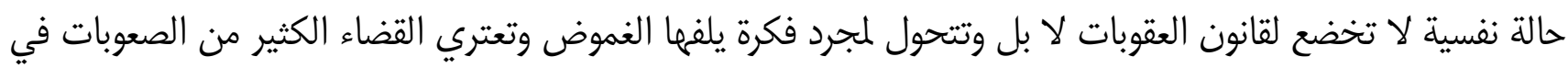

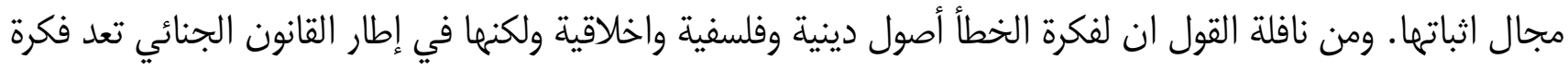

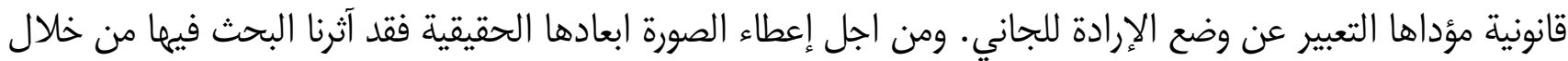
المحاور الثلاثة المبينة في الآتي: 1. مذهب التفرقة بين الخطأ اليسير والخطأ الجسيه: قسم الفقه الجنائي الفرنسي 964 في بادئ الامر الخطأ الى ثلاثة

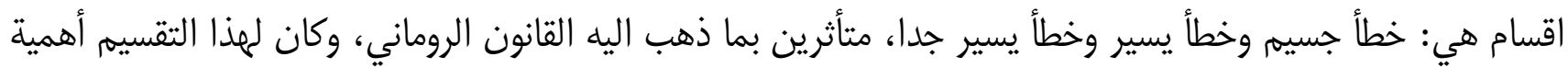

961 Lebbret J., Rapport presente au VIII, eme congress international de droit penal, R.I.D.P., 1961, P.1069.

962 د. محمود نجيب حسني، شرح قانون العقوبات القسم العام، مصدر سابق، الفقرة 725، ص 664. د. السعيد مصطفى السعيد، شرح الاحكام العامة في قانون العقوبات، المطبعة العالمية، القاهرة، 1952، ص 416. د. علي بدوي، الاحكام العامة في القانون الجنائي، ج1، الجريمة،

مطبعة نوري، القاهرة، 1938، ص 373. 963 د. شريف سيد كامل محمد، النظرية العامة للخطأ في القانون الجنائي، مصدر سابق، ص 190. 964 Laingui A., Et Lebigre A., Histoire du droit penal, T.I. cujas, 1985, p. 29. Barberot C., Lhomicide au XVIII, eme, siècle dapres les arrest du parlement de Paris, these, Paris, 1979, pp. 274-275. 
وصدى كبيراً جدا من حيث إقامة المسؤولية بنوعيها المدنية والجنائية، حيث ان الأنواع الثلاثة تصلح لان تكون أساسا للمسؤولية المدنية، بينما المسؤولية الجنائية لا تقوم الا على أساس الخطأ الجسيم وقد اخذ بهذا التهيب التقسيم جانب من فقهاء الجنائي الفرنسي القديم 965، وكذلك جانب من الفقه الجنائي المصري

ويعتقد أصحاب هذا الاتجاه ان أهمية هذا التقسيم تبرز في مجال التمييز بين الخطأ المدني الذي يتوفر مهما كانت درجته وبين الخطأ الجنائي الذي يشترط ان يكون على درجة معينة من الجسامة، وكذلك فان أهمية هذا التقسيم تبرز أيضا في مجال التفريق بين الخطأ الفني الذي يشترط فيه ان يكون على درجة معينة من الجسامة، وبين الخطأ المادي الذي لا يشترط فيه درجة معينه من الجسامة. 967

وقد انتقد هذا التقسيم كونه يتعارض مع النصوص القانونية التي تخص القتل والاصابة الخطأ، حيث ان المشرع لم يستوجب في صياغتها درجة معينة من الجسامة وهذا واضح من صراحة تلك النصوص القانونية. 968 هذا من جهة، ومن جهة أخرى حتى الخطأ اليسير اخذ يتسبب بأضرار بالغة لا يجبرها التعويض المدني كما في الأخطاء الطبية التي اخذت بالتزايد

${ }^{965}$ Chavanne A., Le probleme des delits involontaires R.S.C., 1962, p. 247.

966 د. رؤوف عبيد، في التسيير والتخيير بين الفلسفة العامة وفلسفة القانون، دار الفكر العربي، القاهرة، 1984، ص 379-380. د. احمد امين،

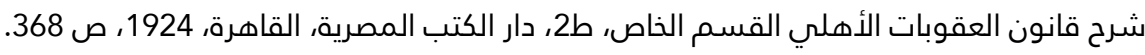
967 د. فوزية عبد الستار، النظرية العامة للخطأ غير العمدي، دار النهضة العربية، القاهرة، 1977 فقرة رقم 25، ص المرال 127.

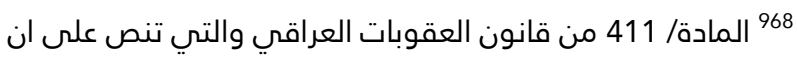
(1-من قتل شخصا خطأ او تسبب في قتله من غير عمد بأن كان ذلك ناشئا عن اهمال او رعونة او عدم انتباه او عدم احتياط او عدم مراعاة القوانين والانظمة والاوامر من ل... 2-وتكون العقوبة ... إذا وقعت الجريمة نتيجة اخلال الجاني اخلالا جسيما بما تفرضه، عليه اصول وظيفته او مهنته او حرفته او كان تحت تأثير مسكر او مخدر وقت ارتكاب الخطأ الذي نجم عنه الحادث او نكل وقت الحادث عن مساعدة من وقعت عليه الجريمة او عن طلب المساعدة له مع تمكنه من ذلك. 3-وتكون العقوبة ... إذا نشأ عن الجريمة موت ثلاثة اشخاص او أكثر....)

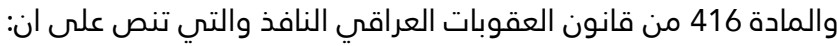
(1-كل من أحدث بخطئه اذى او مرضا بآخر بأن كان ذلك ناشئا عن اهمال او رعونة او عدم انتباه او عدم احتياط او عدم مراعاة القوانين والانظمة والاوامر يعاقب .... - (1) 2- وتكون العقوبة ... إذا نشأ عن الجريمة عاهة مستديمة او وقعت نتيجة اخلال الجاني اخلالا جسيما بما تفرضه عليه اصول وظيفته او مهنته او حرفته او كان تحت تأثير مسكر او مخدر وقت ارتكاب الخطأ الذي نجم عنه الحادث او نكل وقت الحادث عن مساعدة من وقعت عليه الجريمة او

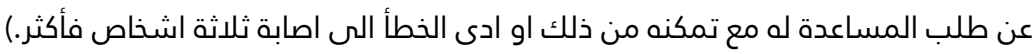
والمادة/ 238 من قانون العقوبات المصري النافذ التي تنص على ان (من تسبب خطأ في موت شخص أخر بأن كان ذلك ناشئًاً عن إهماله أو

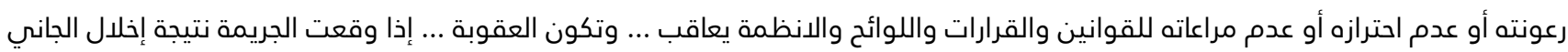
إخلالًً جسميا بما تقرضه عليه أصول وظيفته أو مهنته أو حرفته أو كان متعاطيا مسكرا أو مخدرا عند ارتكابه الخطأ الذي نجم عنه الحادث الذاث أو نكل وقت الحادث عن مساعدة من وقعت عليه الجريمة أو عن طلب المساعدة له مع تمكنه من ذلك. وتكون العقوبة ... إذا نشأ عن الفعل وفاة أكثر

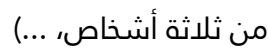
والمادة/ 244 من قانون العقوبات المصري التي تنص على ان (من تسبب خطأ في جرح شخص أو إيذائه بأن كان ذلك ناشئا عن إهماله أو رعونته أو عدم احترازه أو عدم مراعاته للقوانين والقرارات واللوائح والانظمة يعاقب ... وتكون العقوبة ... إذا نشأ عن الإصابة عاهة مستديمة أو إذا إذا وقعت الجريمة نتيجة إخلال الجاني إخلالا جسيما بما تفرضه عليه أصول وظيفته أو مهنته أو حرفته أو كان متعاطيا مسكراً أو مخدراً عند ارتكابه الخطأ الذي نجم عنه الحادث أو نكل وقعت الحادث عن مساعدة من وقعت عليه الجريمة أو عن طلب المساعدة له مع تمكنه من ذلك. وتكأل الجنون العقوبة بالحبس إذا نشأ عن الجريمة إصابة أكثر من ثلاثة أشخاص .........). 
وتتسبب بأضرار كبيرة، مما يستوجب تجريمها مهما كانت درجته حسب رأي جانب من الفقه. 969 بالإضافة الى أنه لا يوجد

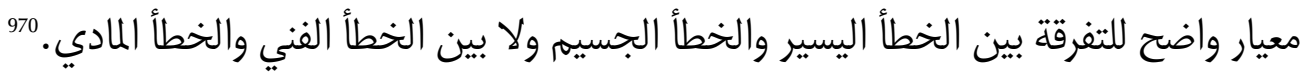

2. مذهب عدم التفرقة بين الخطاً اليسير والخطاً الجسيم: بسبب الانتقادات الجدية التي وجهت الى أصحاب التقسيم التها

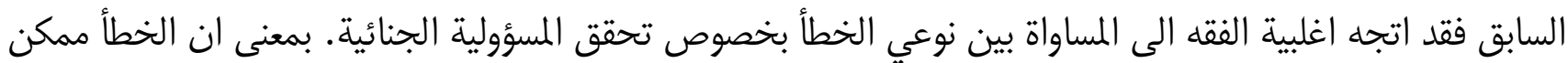

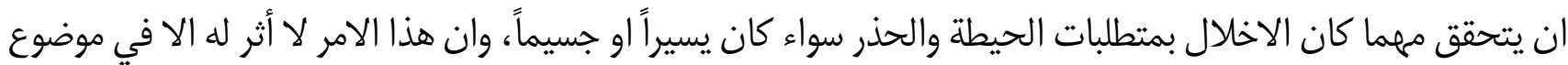

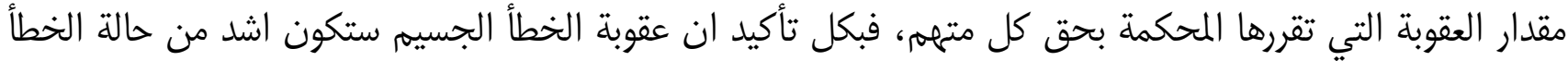

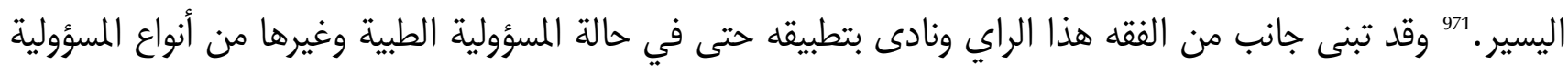
المهنية بحيث تتحقق مسؤولية هؤلاء حتى في حالة الخطأ اليسير.

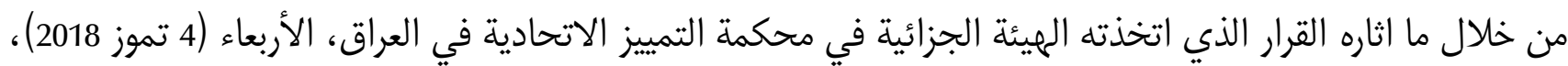

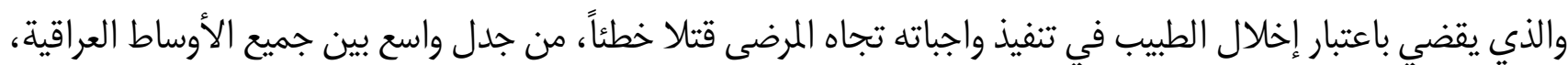

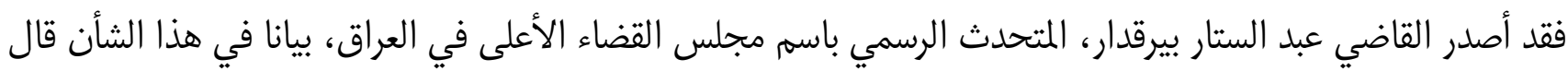

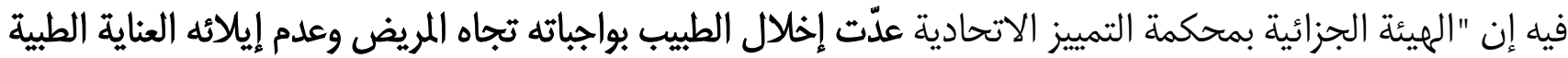

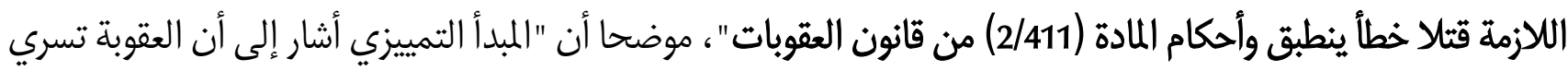

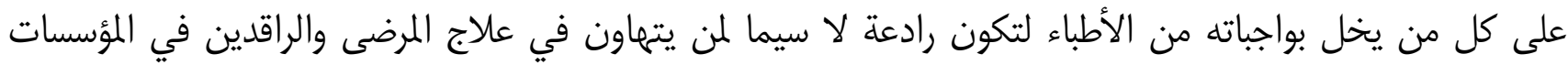
الصحية".

وجاء قرار الهيئة الجزائية في محكمة التمييز الاتحادية، وفق بعض الآراء المعارضة له، التي تعتقد أن القرار يكمل

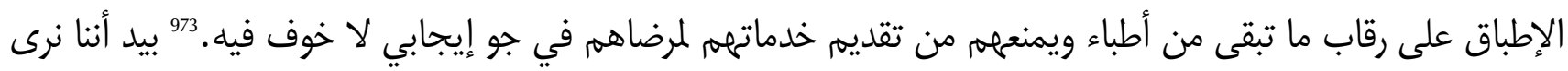

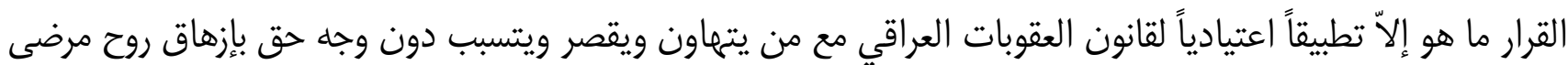

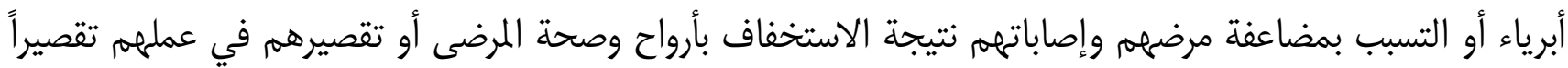
فاضحاً.

969 د. احمد فتحي سرور، أصول قانون العقوبات القسم العام، دار النهضة العربية، القاهرة، 1979، الفقرة رقم 281، ص 489. د. فوزية عبد الستار، النظرية العامة للخطأ غير العمدي، مصدر سابق، الفقرة رقم 78، ص 133. د. عوض محمد، قانون العقوبات القسم العام، مؤسسة الثقافة الجامعية، الإسكندرية، 1983، الفقرة 221، ص 276. د. محمود نجيب حسني، شرح قانون العقوبات القسم العام، مصدر سابق، الفقرة

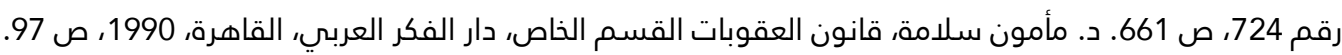
970 د. محمود نجيب حسني، شرح قانون العقوبات القسم العام، مصدر سابق، الفقرة رقم 571، صات

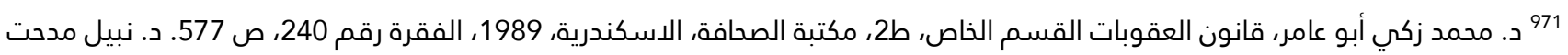

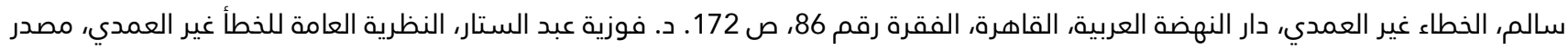
سابق، 63. د. محمود نجيب حسني، شرح قانون العقوبات القسم العام، مصدر سابق، الفقرة 723، ص 159.

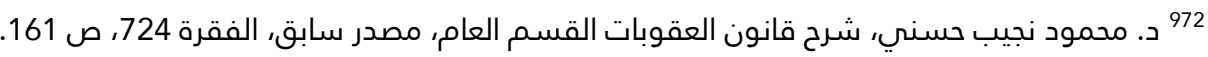

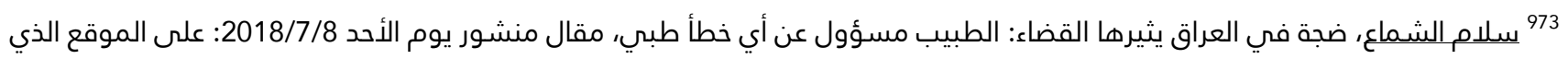
تمت زيارته بتاريخ 2018/12/18: ت :2019/1/4 https://alarab.co.uk 


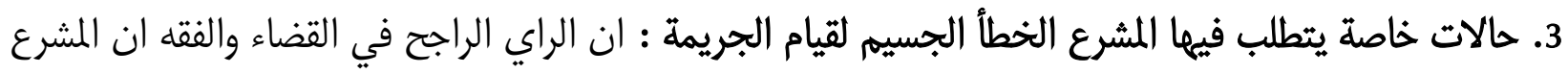

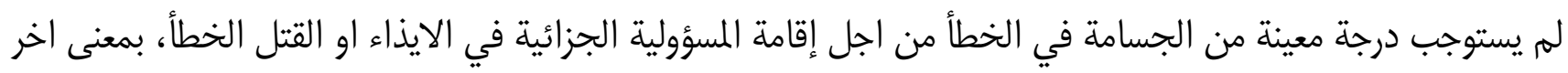

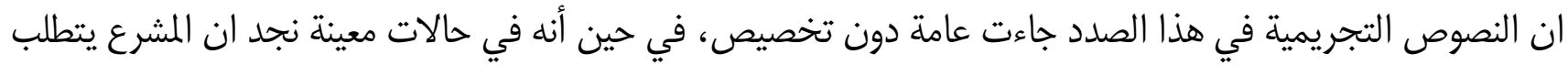

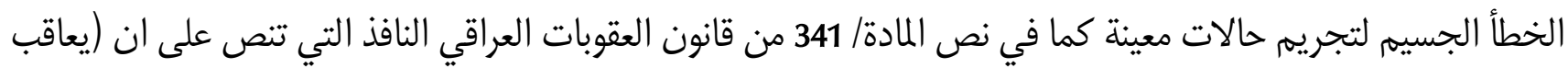

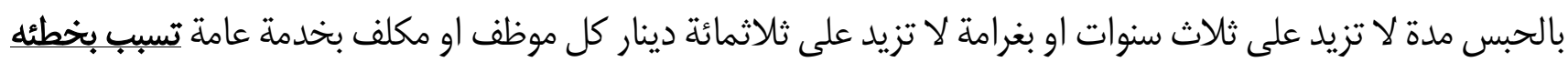

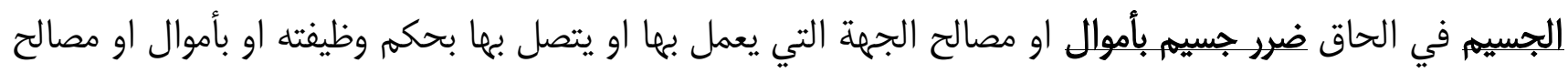

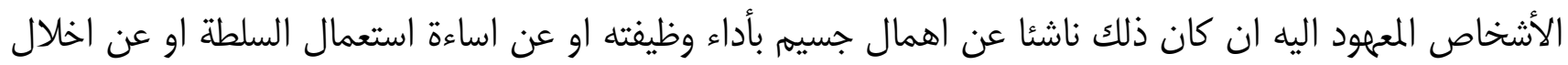

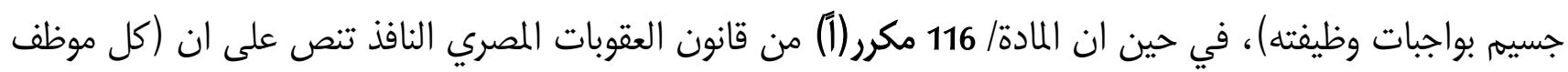

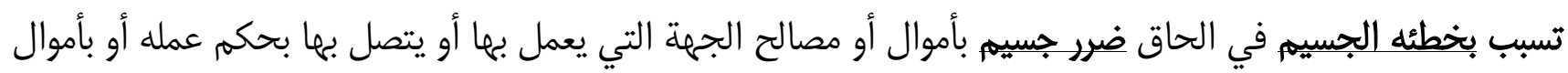

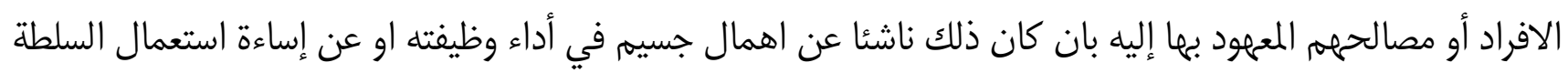

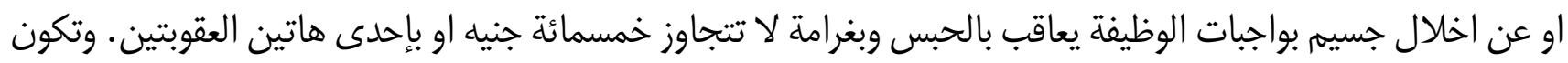

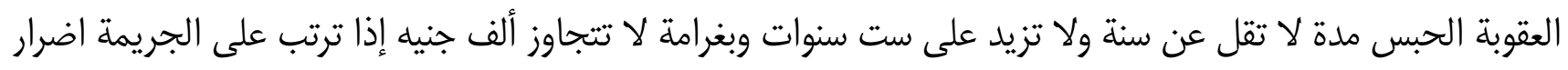
بمركز البلاد الاقتصادي او بمصلحة قومية لها).

ومن خلال تحليل النصين العراقي والمصري يتضح بان المشرعين اشترطا في هذا النوع من الخطأ الجسامة من اجل

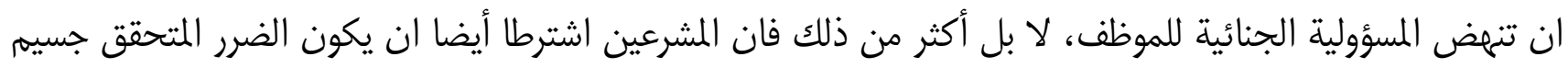

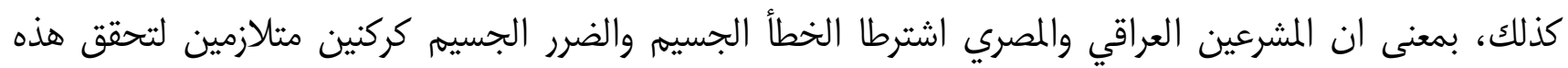

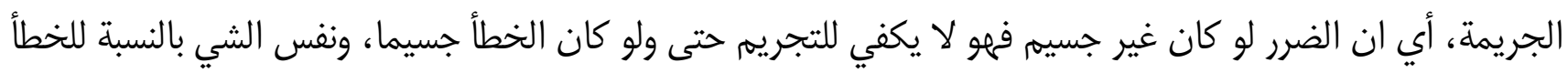
إذا كان غير جسيم فلا يكفي للتجريم حتى ولو كان الضرر جسيما.

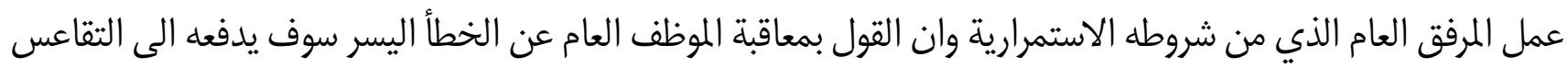

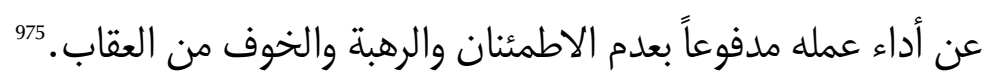

\section{المطلب الثاني: نظرية الذطأ غير العمدي المتمثل بإمكانية التوقع}

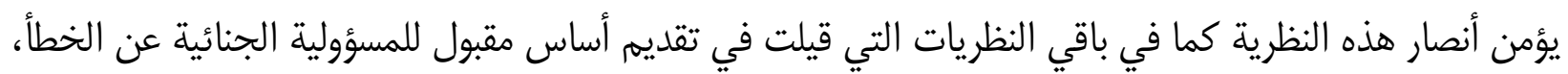

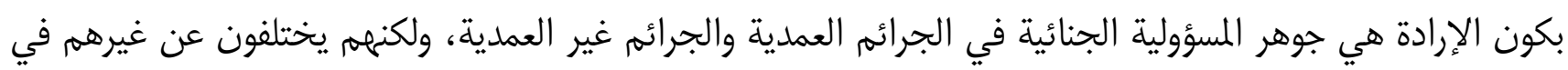
تبرير العقاب على الخطأ وهو ما سنتطرق اليه في بندين أساسيين:

أولاً -مضمون النظرية: يعد الفقيه جارو من مؤسسي هذه النظرية التي يعتمد أساسها في اعتبار استطاعة التوقع أرضية

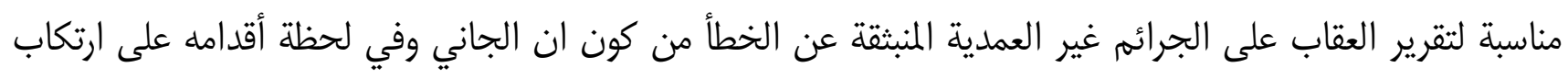

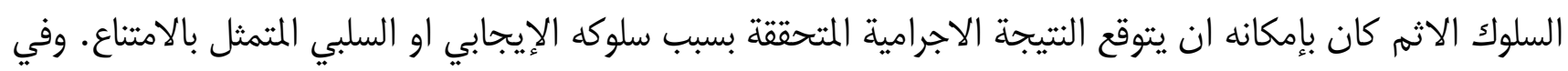

974 د. شريف سيد كامل محمد، مصدر سابق، ص 336.

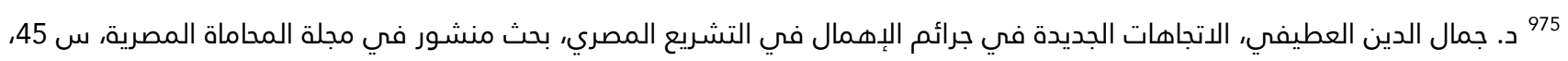

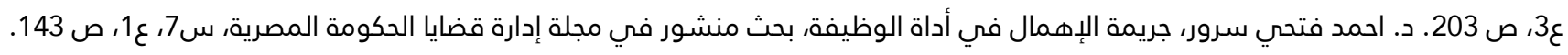


هذا المجال فان هذه النظرية تقترب كثيراً من نظرية خمول الإرادة التي هي الأساس في الخطأ، وتؤمن هذه النظرية بكون

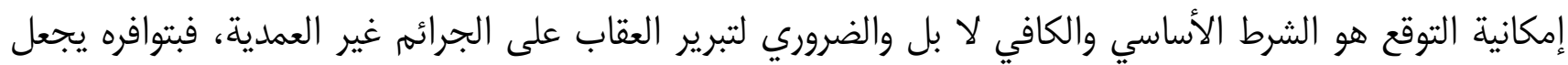

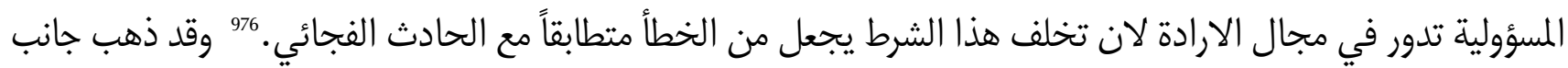

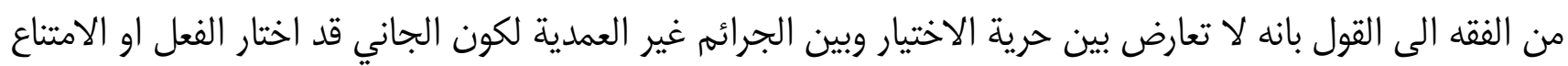

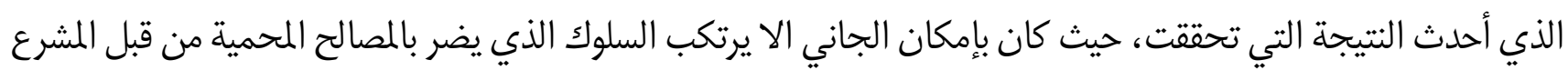

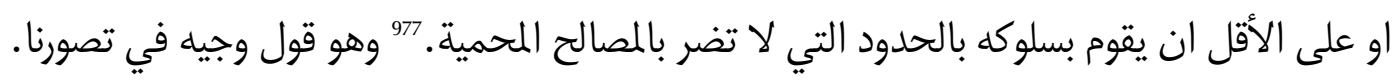
وتقول هذه النظرية، انه من العدالة إيقاع العقوبة على الجاني الذي لهم يقم بمحض ارادته لا بل وكان باستطاعته ومن

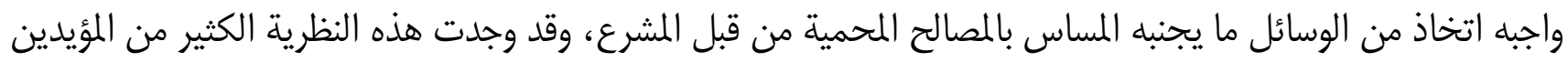

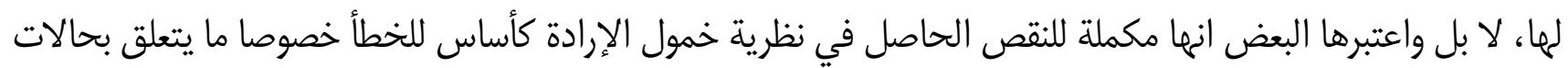

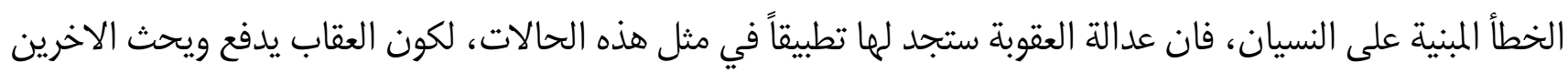

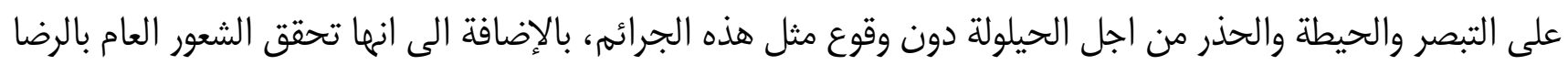
والعدالة من جراء معاقبة الجاني المخطئُ

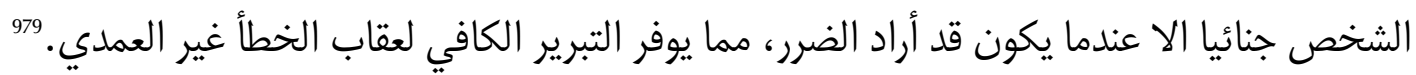
ومما تقدم، ووفقا لمزذه النظرية فلا يسأل جزائيا الجاني الذي ليس لديه القدرة على توقع النتيجة المترتبة على سلوكه

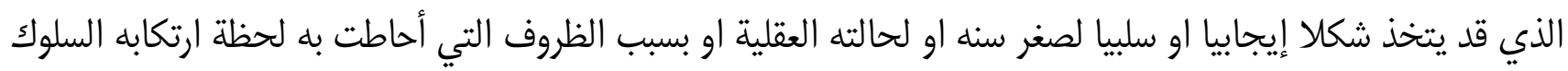

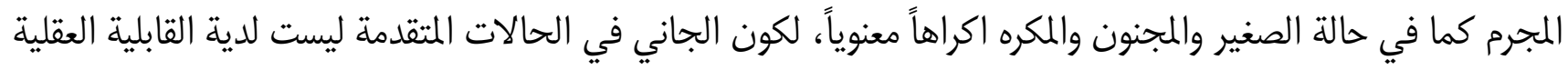

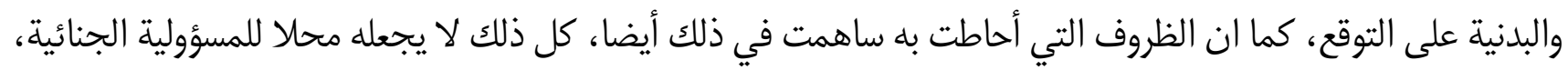

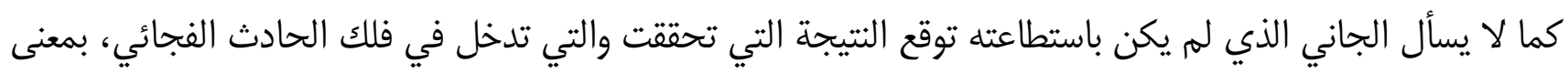

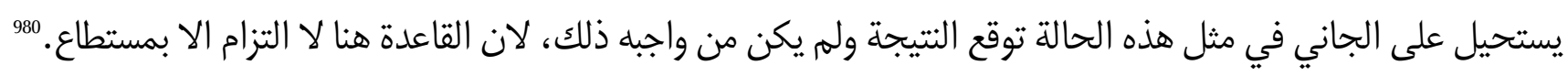

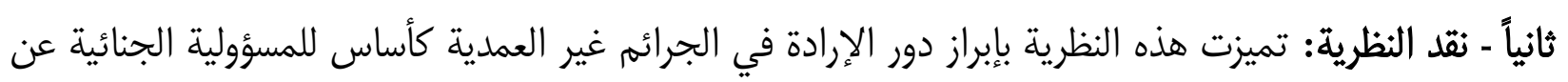

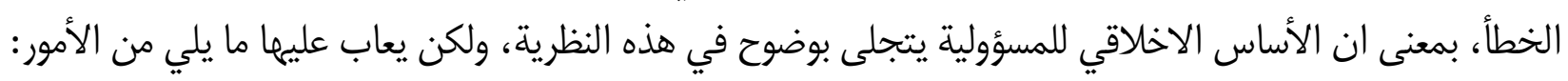
أولها، انها لم تأتي بالأساس المنطقي للعقاب الذي يشمل جميع حالات الجرائم غير العمدية، فهذه الجرائم لا تقتصر

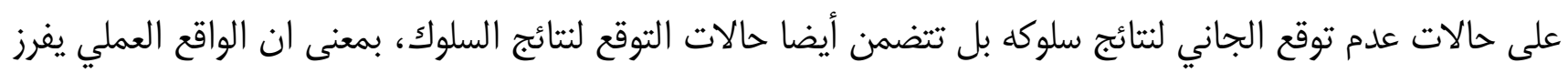

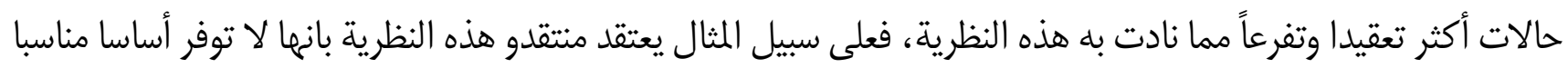

976 Garraud, Traite Theorique ET Pratique du droit penal Francais, op. cit. p.557.

977 د. رؤوف عبيد، في التسيير والتخيير بين الفلسفة العامة وفلسفة القانون مصدر سابق، ص 382. د. مصطفس القللي، في المسؤولية

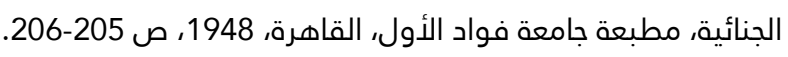
978 د. فوزية عبد الستار، مصدر سابق، الفقرة رقم 11، صو صو 19-21.

979 Garraud, Traite Theorique ET Pratique du droit penal Francais, op. cit. p 586.

980 د. شريف سيد كامل محمد، مصدر سابق، ص 107-108. 
لعقاب حالات توقع النتائج من قبل الجاني مع استطاعته ذلك الا انه لم يتخذ احتياطات الحيطة والحذر التي تضمن عدم حدوثها، او تلك الحالات التي لا يبالى الجاني بالنتائج التي قد تحدث نتيجة لسلوكه لا بل وعدم اكتراثه بحصولما. وثانيها، ان الاعتماد على عدالة ومنفعة العقوبة كأساس لبناء المسؤولية الجنائية امر فيه نظر، لان ذلك من باب تحصيل الحاصل فلولا عدالة ومنفعة العقوبة لما قررها المشرع، هذا من جهة ومن جهة أخرى فان هاتين الصفتين من الخصائص العامة للعقوبة سواء في الجرائم غير العمدية او العمدية.

وثالثها، ان التركيز على إمكانية التوقع وحتميته في الخطأ واستبعاد العقاب عن الحادث الفجائي وعن الشخص الذي لا يملك القابلية البدنية والذهنية على التوقع، فان هاتين الحالتين تمثلان جزءاً من عناصر الخطأ، وليس أساس العقاب على الخطأ.

\section{المبحث الثاني: العلاقة بين الارادة والنتيجة الاجرامية (كعنصر في الخطأ)}

لا شك بأن التمييز وحرية الاختيار هما مفترضان اساسيان للمسؤولية الاجرامية، ومن المبادئ التي أصبحت راسخة في التشريعات الجنائية الحديثة هو عدم كفاية تحقق الركن المادي من اجل قيام المسؤولية الجنائية، لا بل يستوجب أيضا تحقق الرابطة النفسية بين ماديات الجريمة والجاني وهذه الرابطة تسمى بالإرادة الاجرامية والتي هي في الحقيقة جوهر واساس القصد الجنائي مهما كان الرداء الذي يرتديه هذا القصد سواء كان خطا ام عمد لهديه

كما ان الإرادة لوحدها لا يعتد بها ما لم يتوفر لها التمييز والإدراك وحرية الاختيار وهما عنصران باجتماعهما تتحقق الاهلية الجنائية، وعند تخلف أي من هذين الركنين يترتب على ذلك انهيار الركن المعنوي للجريمة لعدم تحقق الإرادة التي تكّون هذا الركن، لذلك فان التمييز والاختيار يمثلان مفترضان للمسؤولية عند قيام الركن المعنوي وليسا عنصران فيه لكون التهني توفرهما لا يعني باي حال من الأحوال تحقق الركن المعنوي بل تحقق المسؤولية الجنائية في حال قيام الركن المعنوي والمادي ، بدليل ان الجرائم المادية التي هي بالأساس تعد استثناءً من القواعد العامة في التجريم والتي لا يتطلب فيها تحقق الركن المعنوي، ومع ذلك فان القضاء والفقه يشترطان ان يتوفر لدى الجاني فيها حرية الاختيار والتمييز.

981 المصدر السابق نفسه، ص 109 982 بدليل ان المادة/33 الفقرة/1 عقوبات عراقي تعرف القصد الجنائي بانه توجيه الفاعل إرادته إلى ارتكاب الفعل المكون للجريمة هادفا إلى

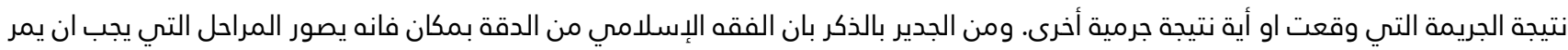
بها القصد حتى يمكن القول بانه قصد جنائي وانه يقررها بخمس مراحل هي: 1-مرحلة الهاجس: وهو ورود صورة الشـيء في الذهن سواء هذا الشيء كانت طاعة أو كانت معصية إذا ما تأكدت الصورة وثبتت.2-مرحلة الخاطر: ذا ما تكلم الإنسان وتردد مع نفسه في الفعل وعدم الفعل هل يقدم على هذا الفعل سواء أكان طاعة أو معصية.3مرحلة حديث النفس: وهو ما يقع فيها من التردّد هل يفعل أو لا. 4-مرحلة الهّم: وهي مرحلة ترجيح قصد الفعل، أي وهو القصد المؤكد وهو أن يصمم الإنسان على فعل هذا الشـيء من هنا يبدأ الحساب بالثواب أو بالعقاب.5-مرحلة العزم: وهي مرحلة عقد القلب على القيام بفعل من من الأفعال. وللمزيد من التفصيل ينظر: الامام جلال الدين عبد الرحمن السيوطي، الاشباه والنظائر في قواعد وفروع فقه الشافعية، دار الكتب العلمية،

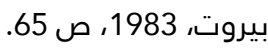
983 د. عبد العظيم مرسي وزير، افتراض الخطأ كأساس للمسئولية الجنائية، دار النهضة العربية، القاهرة، 1988، الفقرة رقم 2، ص 10. د. محمود نجيب حسني، شرح قانون العقوبات القسم العام، مصدر سابق، الفقرتان 542 و543، ص 501-502. د. مأمون سلامة، قانون العقوبات القسم العام، دار الفكر العربي، القاهرة، 1990، ص 186. 
وقد ارتأينا تقسيمه الى مطلبين خصصنا المطلب الأول للإخلال بواجبات الحيطة والحذر (كعنصر مادي في الخطأ لا

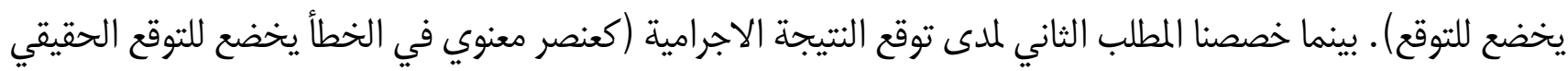
او الافتراضي):

\section{المطلب الأول: الاخلال بواجبات الحيطة والحذر (كعنصر مادي في الخطأ لا يخضع للتوقع)}

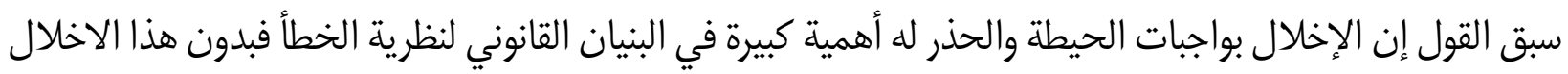

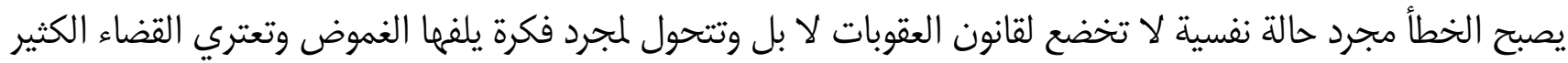

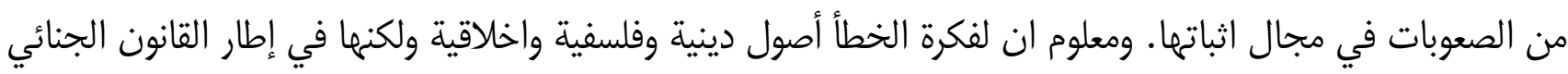

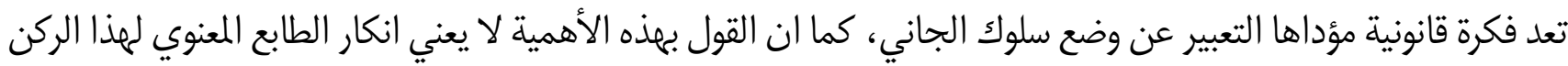

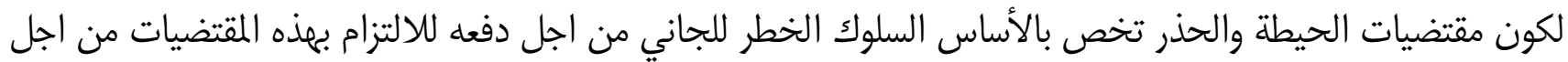

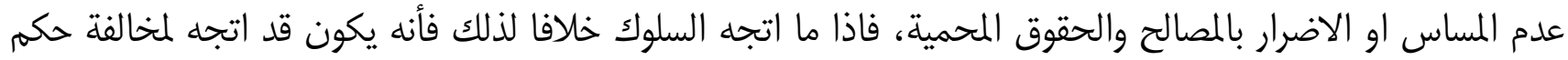
القانون الامر الذي يدفع المشرع الى اسباغ صفة السلوك الاثم عليه، لذلك لا يمكن اعتبار الاخلال بمتطلبات الحيطة

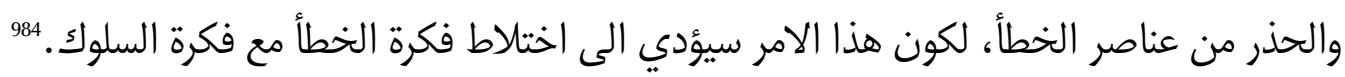

كما ان البعض يعتبر الاخذ بعنصر الاخلال بواجبات الحيطة والحذر، بمثابة تفنيد للآراء التي قيلت حول هجر الخطأ

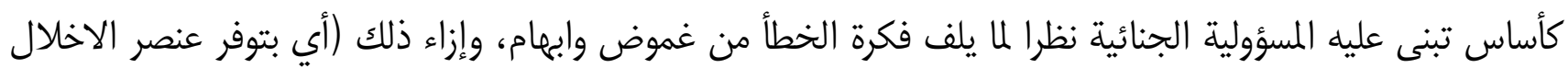

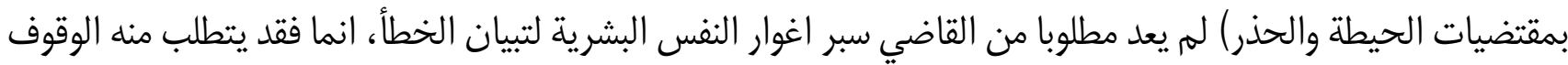

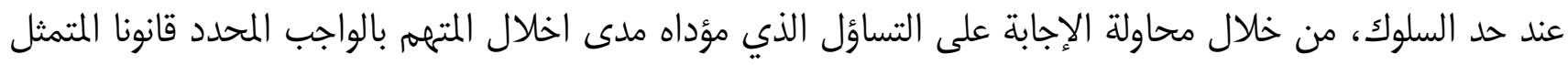

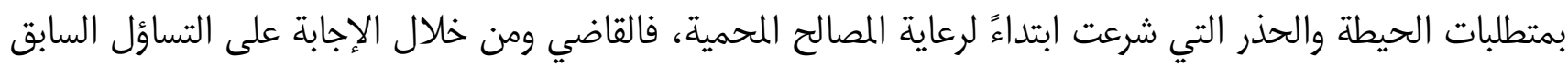

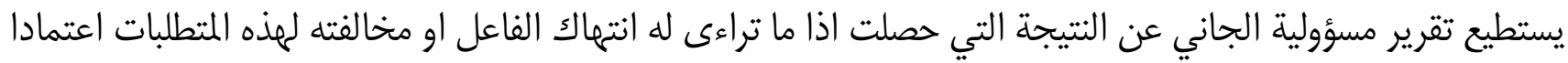
على معيار الرجل المعتاد في مثل ظروف الجاني.

كما ان البعض يقول بان الرابطة النفسية بلدون عنصر الاخلال بمتطلبات الحيطة والحذر غير كافية لبناء نظرية الخطأ

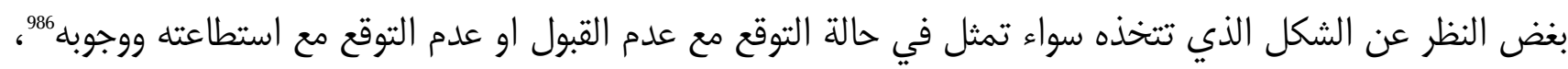

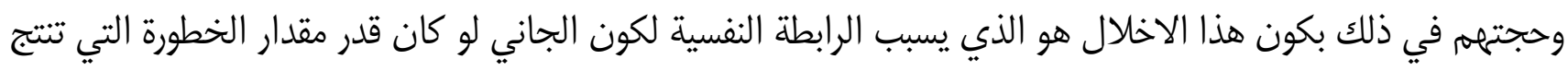

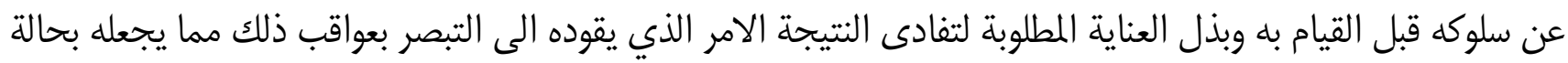

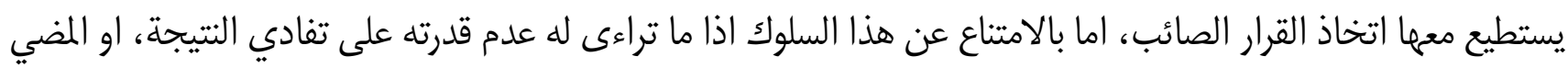

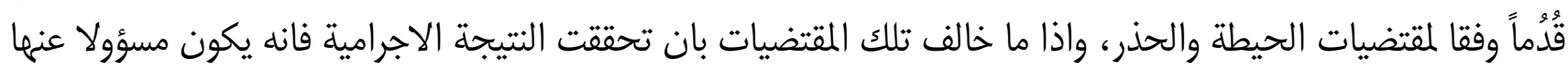
بسبب الاخلال بتلك المقتضيات، هذا من ناحية، ومن ناحية أخرى فان الخطأ قد لا يتحقق ومع ذلك الكقات تقوم الرابطة السبة السبية

984 د. محمود نجيب حسني، شرح قانون العقوبات القسم العام، مصدر سابق، ص638. د. شريف سيد كامل محمد، مصدر سابق، ص 285.

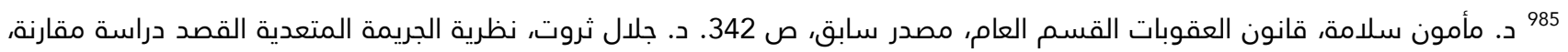

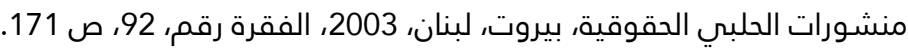
986 د. شريف سيد كامل محمد، مصدر سابق، ص 285-286. 
الا ان الفاعل لا تنهض بحقه المسؤولية الجنائية لكونه استوفى متطلبات الحيطة والحذر .

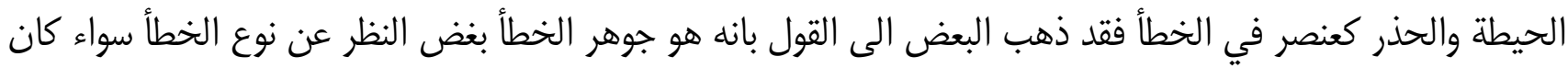
مع التوقع او بدونه.

الا اننا نعتقد بان الفقه عندما يتطرق لموضوع اركان الخطأ يذكر عبارة (عناصر الخطأ) وان الاخلال في الحقيقة هو

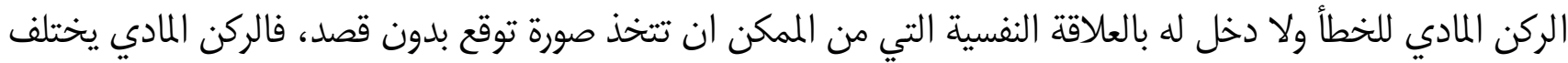

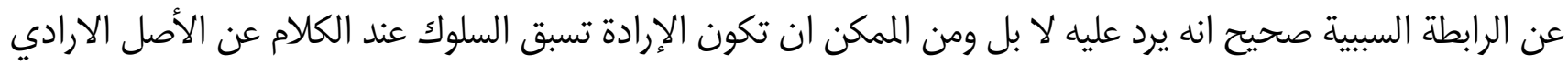

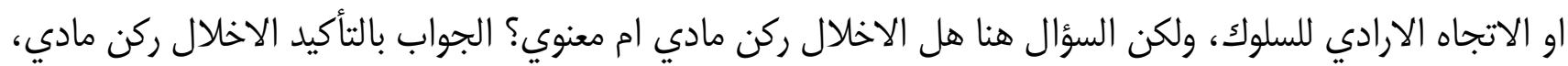

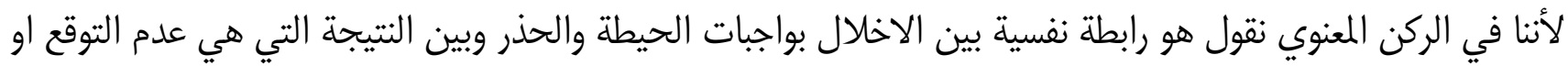

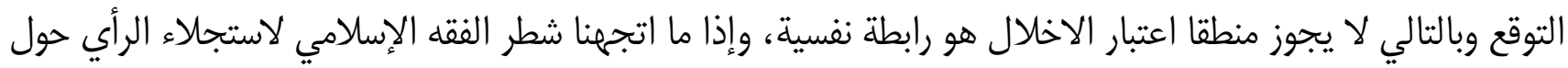

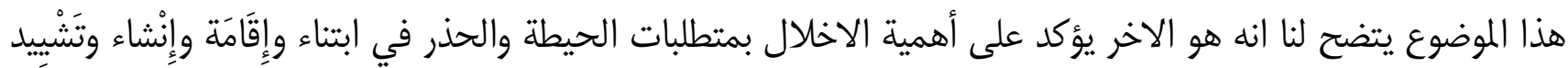

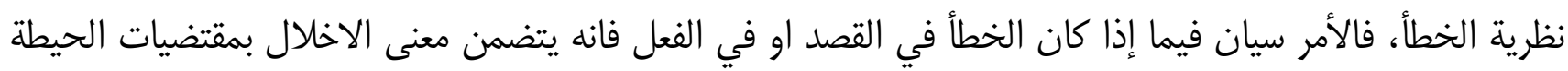

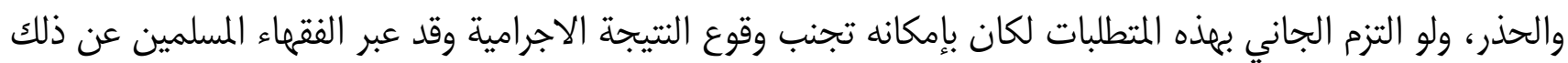
بعبارة مقتضبة بليغة توصل هذا الامر نقتبسها "ان القتل امرٌ عظيم، قلما يبتلى به المرء من غير قصد ما لم يكن بهاه تهاون

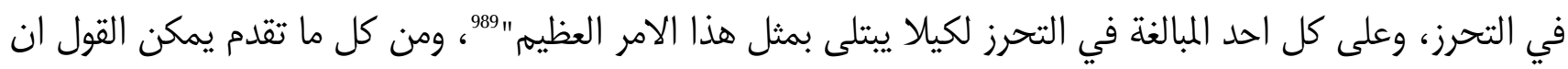

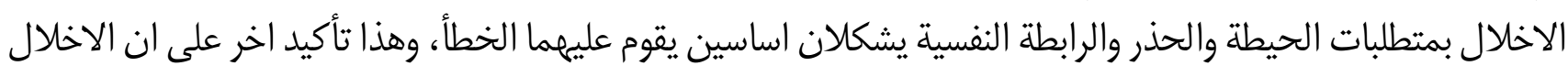

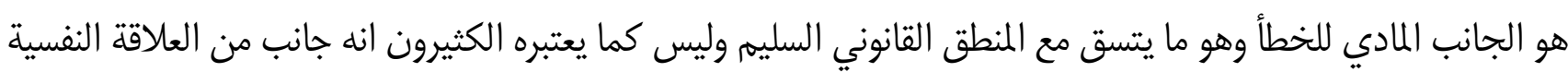
اللخطأ.

وصفوة القول ان الركن المعنوي في الخطأ هو ان المشرع يفترض الحيطة والحذر بالجاني وان هذا الأخير قصّر فيها،

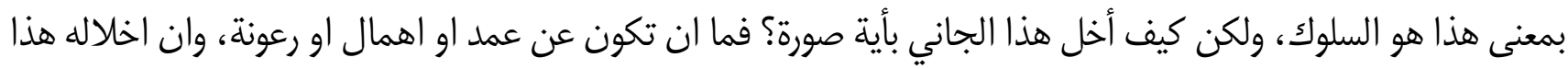

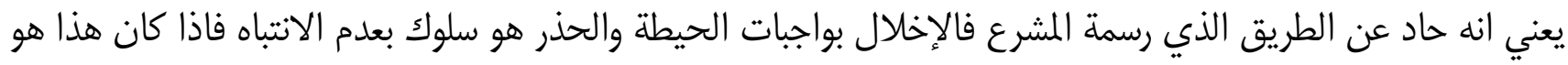

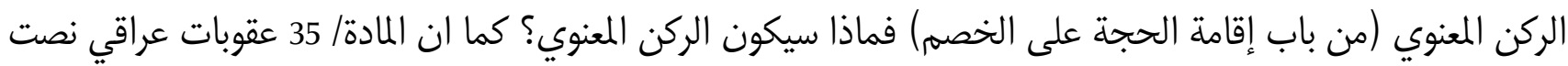

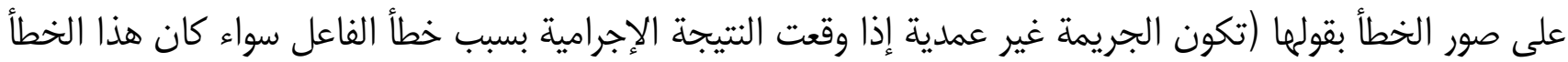

987 د. شريف سيد كامل محمد، مصدر سابق، ص 289. 988 د. محمود نجيب حسني، شرح قانون العقوبات القسم العام، مصدر سابق، الفقرة 705، ص639. د. د. مأمون سلامة، قانون العقوبات القسم العام، مصدر سابق، ص 350 989 شمس الدين بكر محمد بن ابي سهل السرخسي، المبسوط، ط1، ج25، دار الفكر للطباعة والنشر، بيروت، لبنان،2000، ص 67. أبو بكر بن مسعود الكاساني، بدائع الصنائع، ج7، دار الكتب العلمية، القاهرة، 1986، ص 271-272. فخر الدين عثمان بن علي الزيلعي الحنفي، تبين الحقائق شرح كنز الدقائق، ج6 دار الكتاب الاسلامس، القاهرة، 1313هجري، ص 97. الامام محمد أبو زهرة، نظرة الى العقوبة في الإسلام، الفقرة رقم 40، ص 46. الامام محمد أبو زهرة، الجريمة والعقوبة في الفقه الإسلامدي، ج1، الجريمة، دار الفكر العربي، القاهرة، 2006، الفقرة رقم 40، ص46. عبد القادر عودة، التشريع الجنائي الإسلامي مقارنا بالقانون الوضعي، ج1، دار الحديث، القاهرة، 2009، الفقرة رقم 300، ص 433. 
إهمالاً او رعونة او عدم انتباه او عدم احتياط او عدم مراعاة القوانين والأنظمة والاوامر.) التي هي في الحقيقة صور معنوية وان الاخلال كعنصر مادي أي انه السلوك الخاطئ ولكن ان يكون بإهمال او بدون اهمال الهال فتلك صوان صور معنوية.

\section{المطلب الثاني: مدى توقع النتيجة الاجرامية، (كعنصر معنوي في الخطأ يخضع للتوقع الحقيقي او}

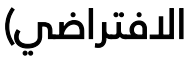

ان البحث في موضوع مدى توقع النتيجة الاجرامية كعنصر معنوي في الخطأ يخضع للتوقع الحقيقي او الافتراضي

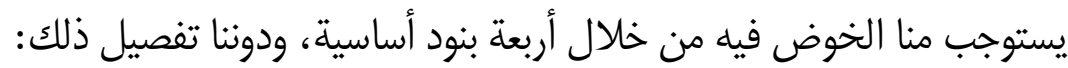

أولاً -صورة عدم توقع النتيجة الاجرامية المصحوب باستطاعة توقعها ووجوبه: المقصود من هذه الصورة ان الجاني عندما

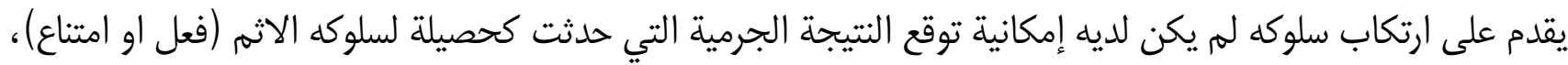

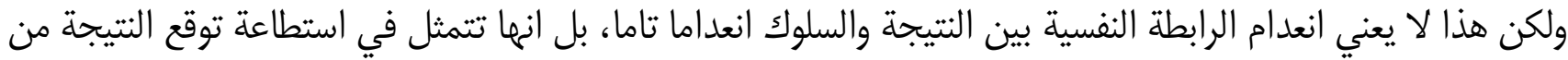

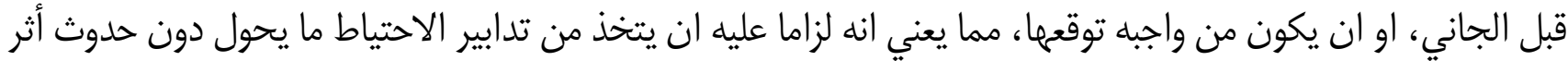

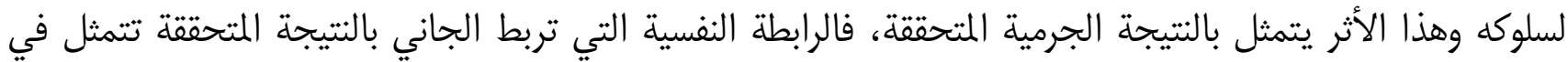

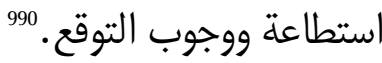

كمن يفرغ سلاحه الشخصي من العتاد ويعبث به ضنا منه انه فارغ فتنطلق رصاصة لتصيب شخص بجواره وتؤدي

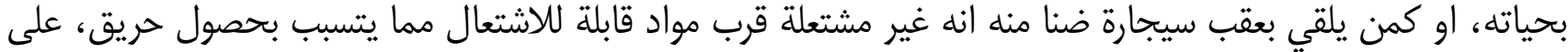

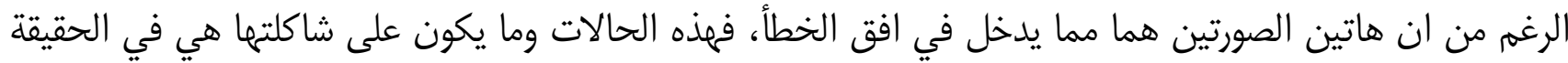

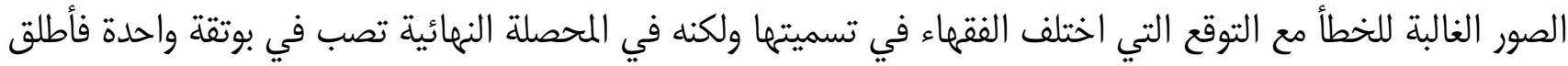

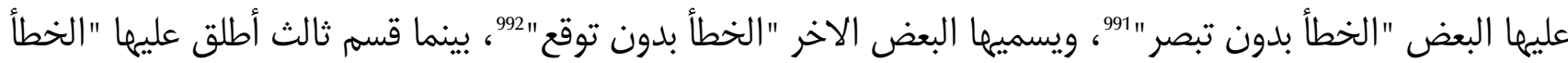

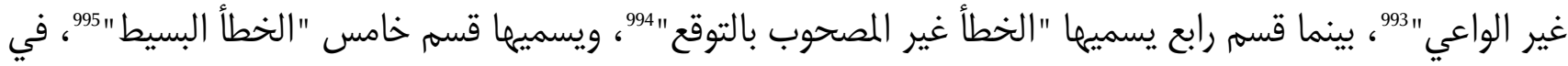

990 د. محمود نجيب حسني، شرح قانون العقوبات القسم العام، مصدر سابق، الفقرة رقم 710، ص 645. د. مأمون سلامة، قانون العقوبات القسم العام، مصدر سابق، ص 330 وص 341. د. حسنين عبيد، جرائم الاعتداء على الأشخاص، ط2، دار النهضة العربية، القاهرة، 1984، مُ الفقرة رقم 85، ص 95. د. عوض محمد، قانون العقوبات، مصدر سابق، الفقرة رقم 190، ص 223-224. د. ادور غالي الذهبي، مشكلات القتل والايذاء

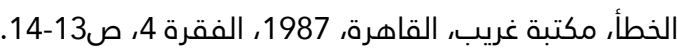
991 د. محمود إبراهيم إسماعيل، شرح الاحكام العامة في قانون العقوبات، دار الفكر العربي، القاهرة، 1959، ص 368.

د. احمد امين، مصدر سابق، ص 368.

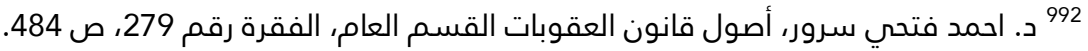
993 د. رمسيس بهنام، النظرية العامة للقانون الجنائي، مصدر سابق، ص 862. د. فوزية عبد الستار، النظرية العامة للخطأ غير العمدي، مصدر

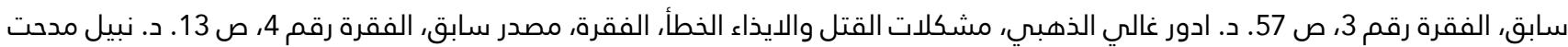

سالم، الخطأ غير العمدي، مصدر سابق، الفقرة رقم 61، ص صدمان 113. 994 د. محمود نجيب حسني، شرح قانون العقوبات القسم العام، مصدر سابق، الفقرة رقم 709، ص644. 995 د. عبد الرؤوف مهدي، شرح القواعد العامة في قانون العقوبات، منشأة المعارف، الإسكندرية، 1983، الفقرة رقدم رقم 180، ص عمر السعيد رمضان، شرح قانون العقوبات القسم الخاص، دار النهضة العربية، 1986، الفقرة رقم 250، ص 276. د. عبد المهيمن بكر، القسم الخاص في قانون العقوبات، جرائم الاعتداء على الأشخاص، دار النهضة العربية، 1986، الفقرة رقم 100، ص 135. د. حسنيين عبيد، جرائم 
حين يعتقد قسما سادسا بإطلاق مصطلح "الخطأ" لوحدة دون إضافات أخرى مستندين في ذلك الى ان عدم توقع النتيجة

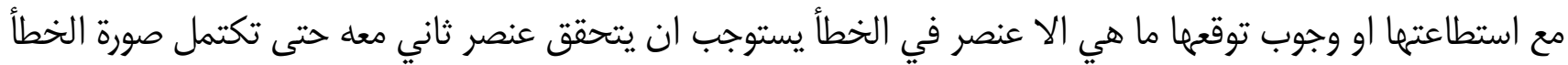

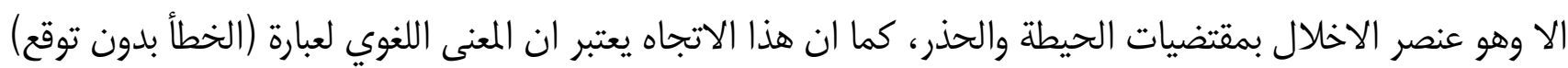

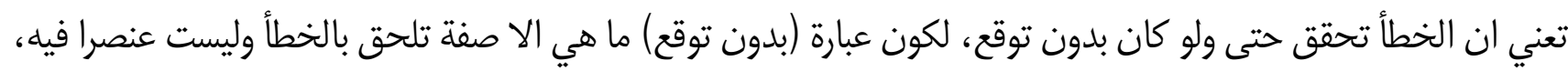

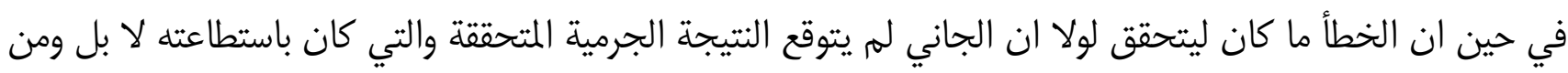
واجبه ان يتوقعها حين ان أخطا.

الا اننا نتقد بان كلام هذا الاتجاه غير دقيق فهذا الاتجاه يخلط بين العنصر المعنوي والمادي للخطأ، فالعنصر المادي

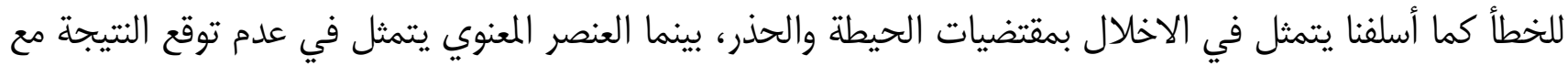

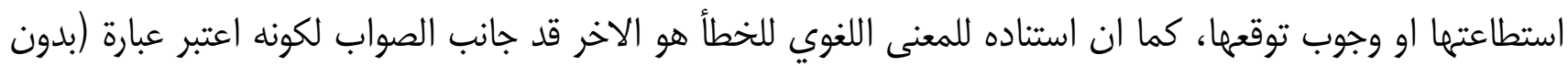
توقع) صفة تلحق في الخطأ في حين انها عنصر في الرابطة المعنوية غير العمدية.

وتقوم صورة عدم توقع النتيجة الاجرامية المصحوبة باستطاعة توقعها ووجوبه على عنصرين أساسيين هما:

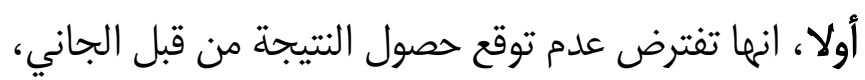

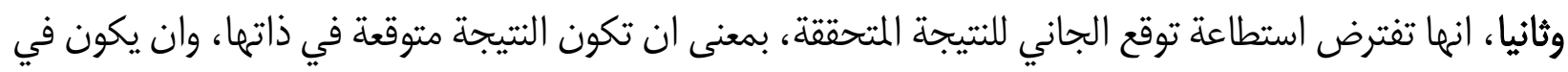

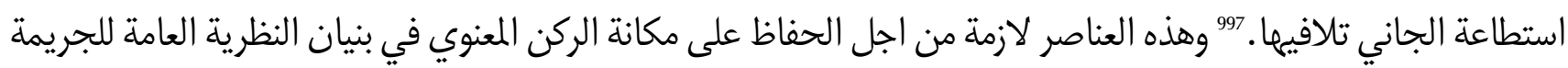

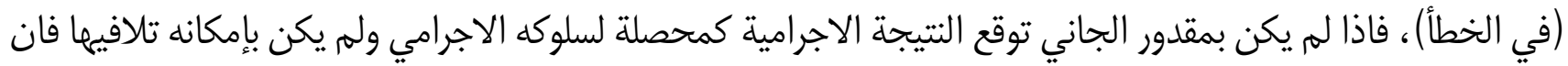

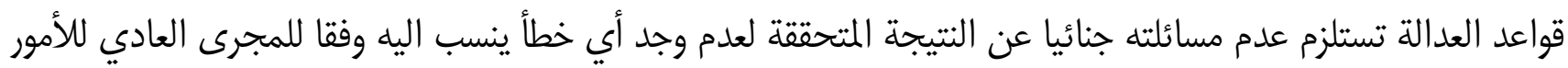

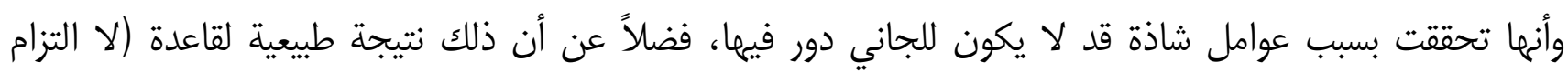
بمستحيل). ولأجل توضيح هذه الصورة نسوق المثال التالي، كما في حالة الممرضة التي تعطي الدواء للمريض مرتين متتاليتين

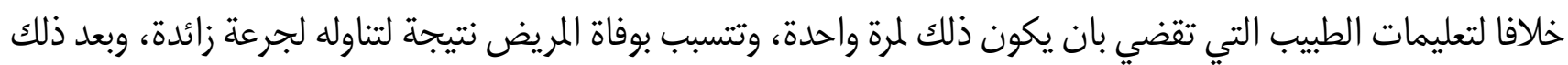

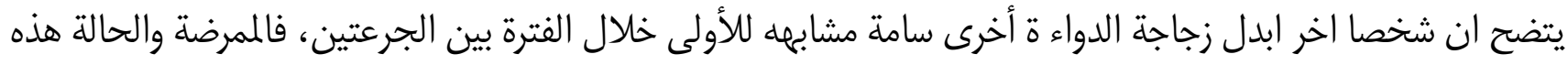

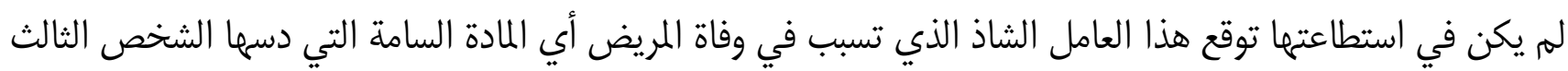

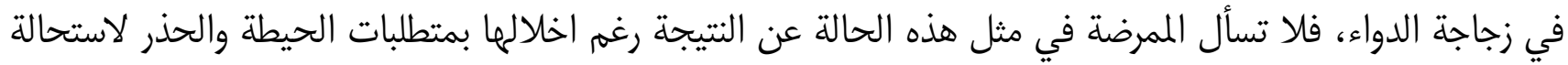

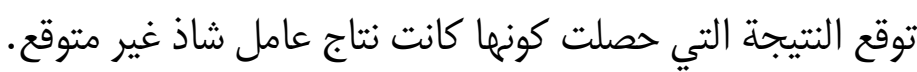

الاعتداء على الأشخاص، دار النهضة العربية، القاهرة، 1984، الفقرة رقم 58، ص 95. د. محمد زكي أبو عامر، قانون العقوبات القسم الخاص، 1989، الفقرة رقم 232، ص ص 2865

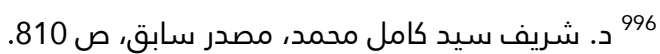
997 د. عبد الرؤوف مهدي، شرح القواعد العامة في قانون العقوبات، مصدر سابق، الفقرة رقم، 180، ص 229. 2010. د. مأمون سلامة، قانون العقوبات القسم العام، مصدر سابق، ص 350. د. محمود نجيب حسني، شرح قانون العقوبات القسم العام، م س، الفقرة رقم

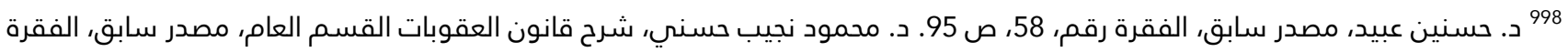


ثانياً - صورة توقع النتيجة الاجرامية المصحوب بعدم قبولمها : المقصود من هذه الصورة ان الجاني عندما أقدم على كلى

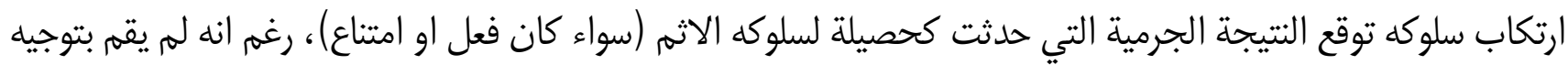

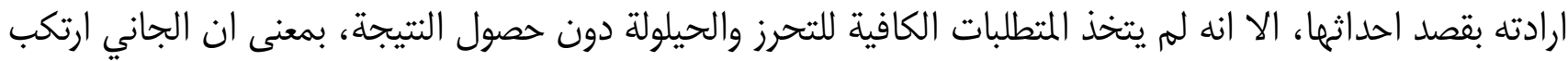

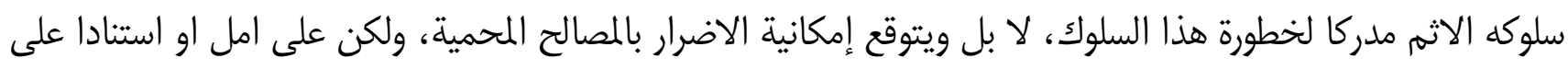

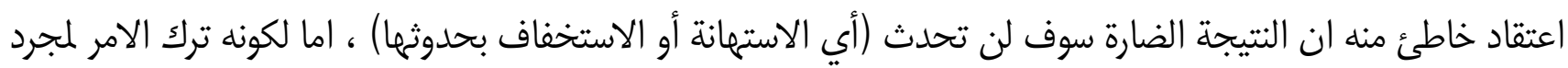

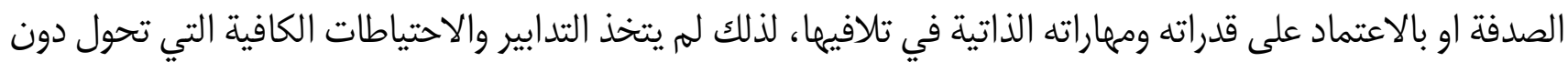

وتقوم صورة توقع النتيجة الاجرامية المصحوب بعدم قبولها على عنصرين أساسيين هما: الأول، عنصر إيجابي يتمثل

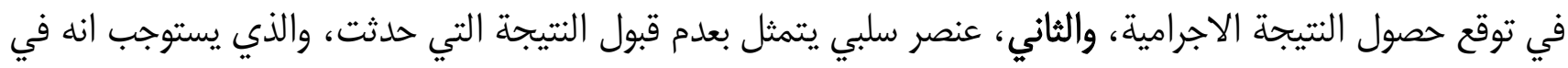

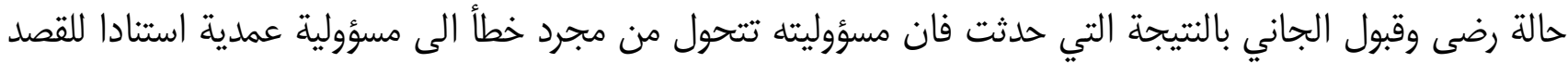

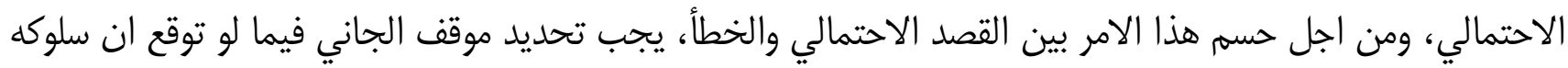

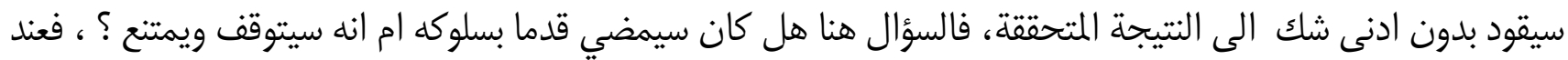

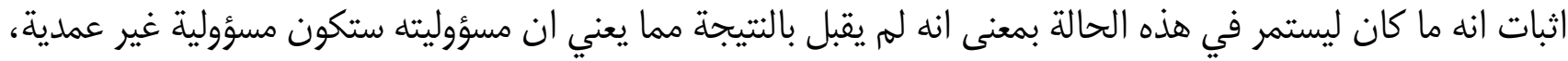

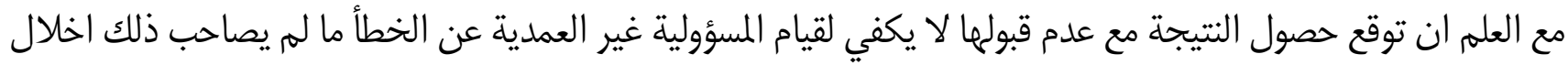
بمقتضيات الحيطة والحذر، فقد يتوقع الجاني حصول النتيجة ومع ذلك لا تتحقق مسؤوليته اذا ما ثبت بانه اتخذ كافة التها

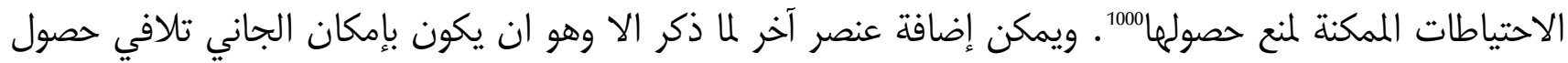
النتيجة المتحققة حتى يمكن القول بتحقق مسؤوليته غير العمدية عن الخطأ.

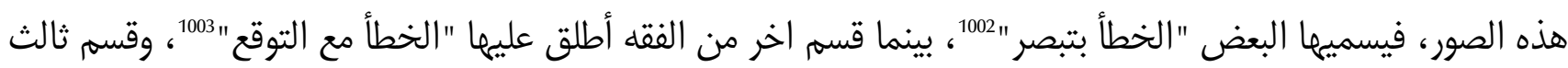

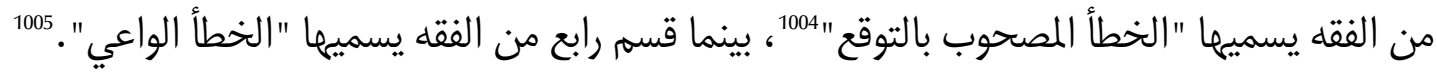

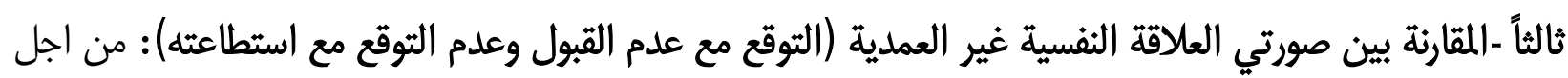

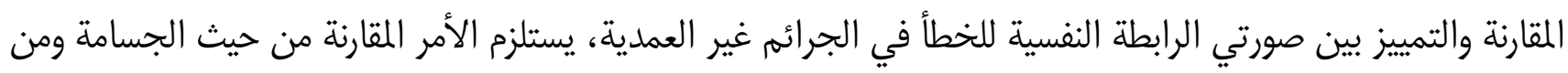

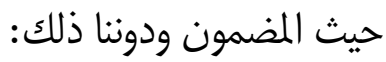

999 د. فوزية عبد الستار، مصدر سابق، الفقرة رقم 31، ص 57.

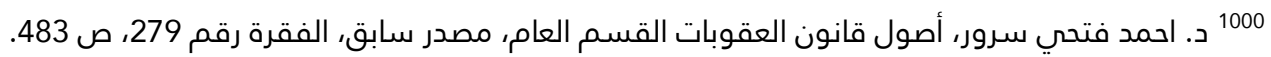
1001 مأمون سلامة، قانون العقوبات القسم العام، مصدر سابق، الفقرة 350، ص ص 150 1002 د. عبد الرؤوف مهدي، شرح القواعد العامة لقانون العقوبات، مصدر سابق، الفقرة رقم 180، ص 229. د. مصطفى القللي، في المسؤولية الجنائية، مصدر سابق، ص 212. د. عوض محمد، جرائم الأشخاص والأموال، دار المطبوعات الجامعية، الإسكندرية،1985، الفقرة رقم 42، ص 99.

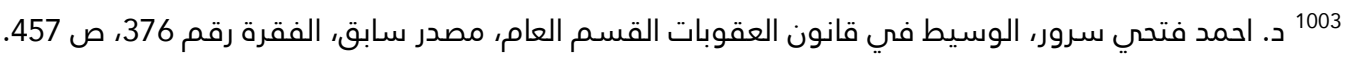
1004 د. محمود نجيب حسني، شرح قانون العقوبات القسم العام، مصدر سابق، الفقرة 709، ص 644. 1005 د. محمد زكي أبو عامر، قانون العقوبات القسم الخاص، مصدر سابق، الفقرة رقم 232، صد55. دمانون. د. عمر السعيد رمضان، شرح قانون العقوبات القسم الخاص، مصدر سابق، الفقرة 250، ص 276. د. مأمون سلامة، قانون العقوبات القسم العام، مصدر سابق، ص350. 
1- من حيث الجسامة: من أجل الإجابة على التساؤل المتعلق بأي من صورتي الخطأ (الخطأ الواعي و الخطأ غي الخأي

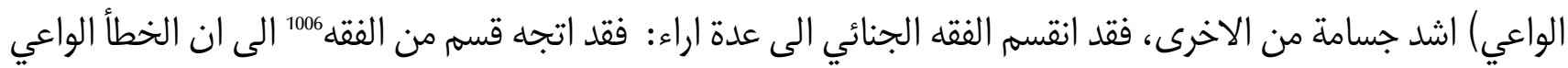

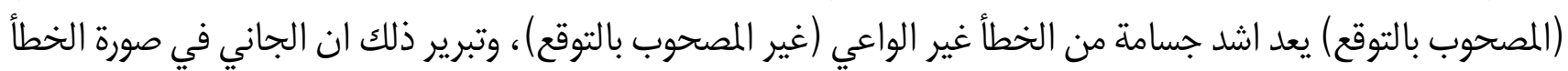

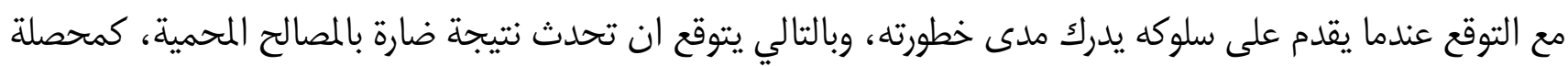

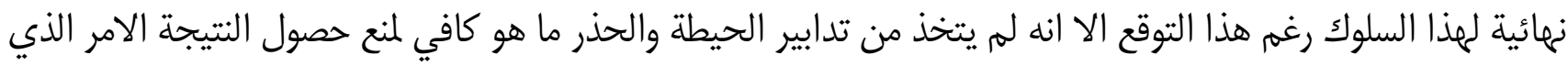
يجعل تصرفه هذا يجاور ويقارب القصد الجنائي الامر الذي يستوجب العقاب المغلظ على الجاني في هذه الصورة ، مقارنة

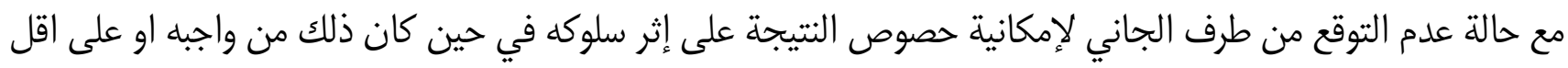

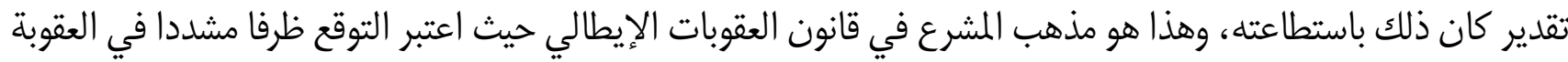
على الجريمة غير العمدية. في حين ساوى قسم اخر من الفقهاء بين صورتي الخطأ من حيث الجسامة دون ان يكون بينهما أي تدرج من حيث الخها

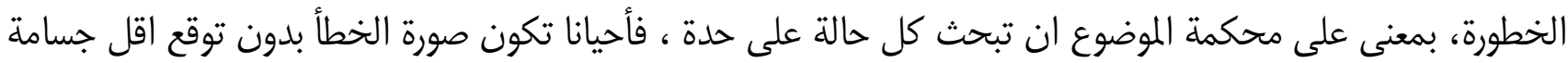

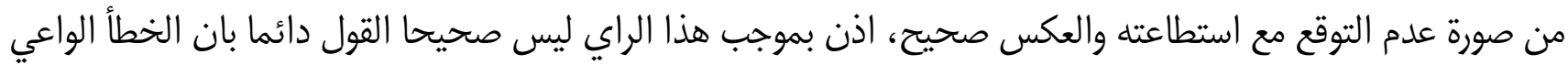

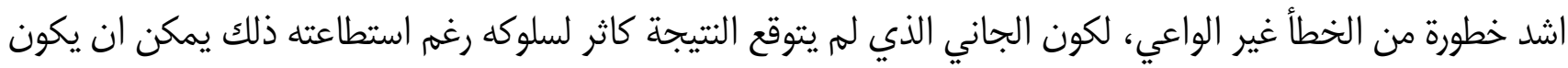

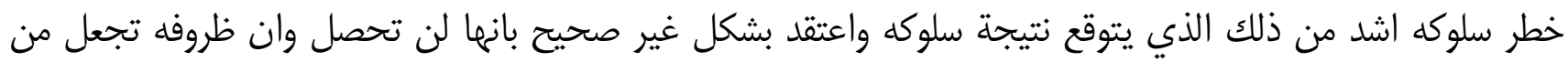

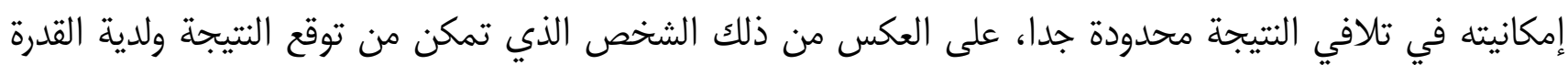

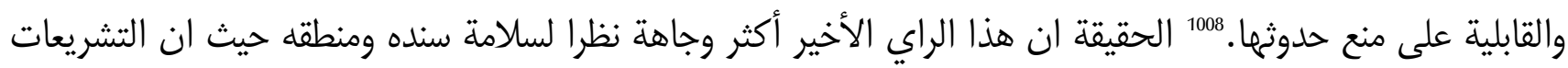

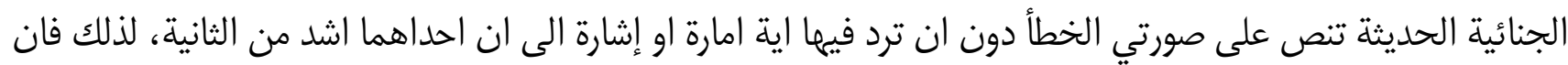

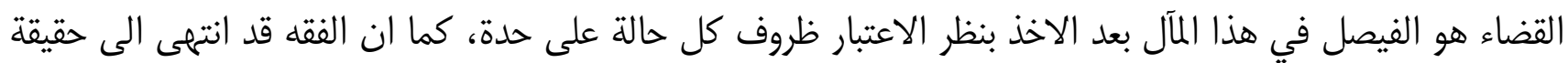
مفادها بعدم وجود فرق جوهري بين نوعي الخطأ من حيث عناصرهما ومضمونهما.

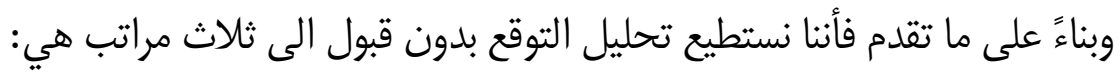

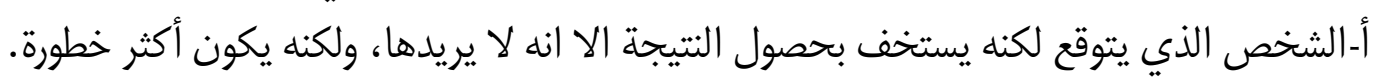

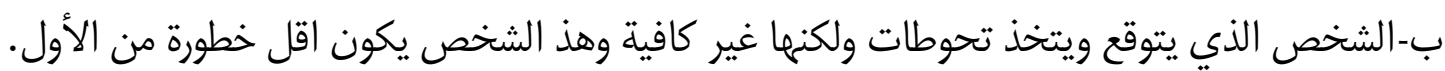

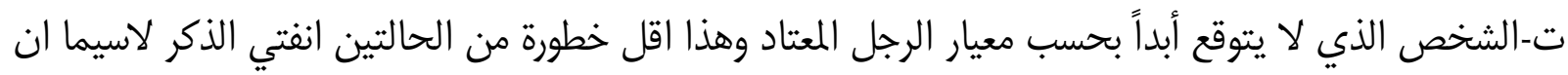
الفقه الانكلوسكسوني اعتبر حالة عدم التوقع مع استطاعته ووجوبه حالة مدنية لا جنائية.

1006 د. علي احمد راشد، مبادئ القانون الجنائي، مطبعة السيد عبد الله، القاهرة، 1970، ص 377. د. رمسيس بهنام، نظرية التجائرة التجريم في القانون

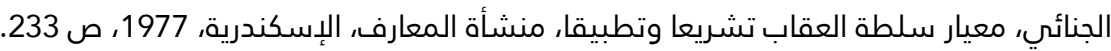

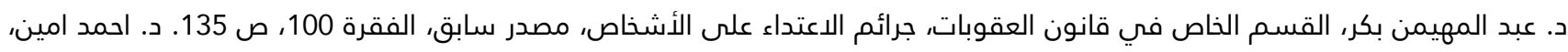
شرح قانون العقوبات الأهلي القسم الخاص، مصدر سابق، ص 369. د. مأمون سلامة، قانون العقوبات القسم العام، مصدر سابق، ص 350. 1007 Delogu T., La culpabilite dans la theorie general, op. cit.P.241.

1008 د. ادور غالي الذهبي، مشكلات القتل والايذاء الخطأ، مصدر سابق، الفقرة رقم 4، ص 15. د. فوزية عبد الستار، النظرية العامة للخطأ غير

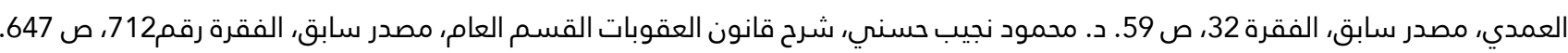
1009 د. شريف سيد كامل محمد، النظرية العامة للخطأ في القانون الجنائي، مصدر سابق، ص صداب 810. 
2- من حيث المضمون: يكاد يكون هناك اجماع فقهي بعدم وجود اختلاف أساسي بين صورتي الرابطة النفسية في

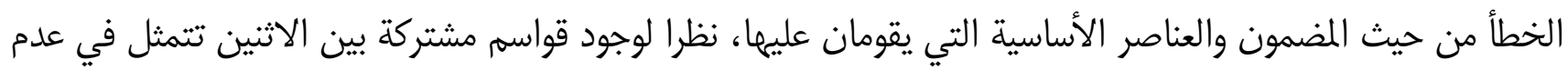

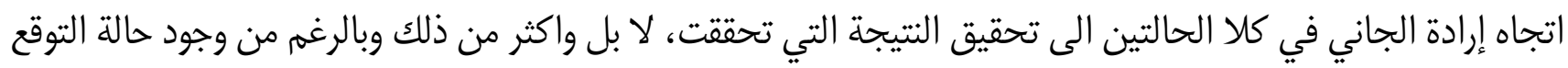

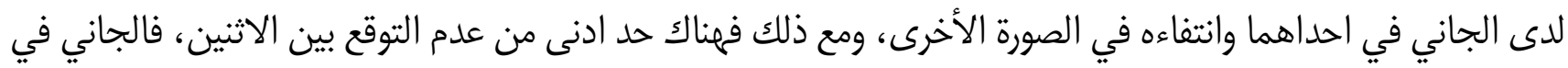

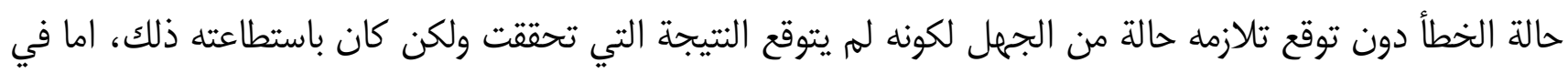

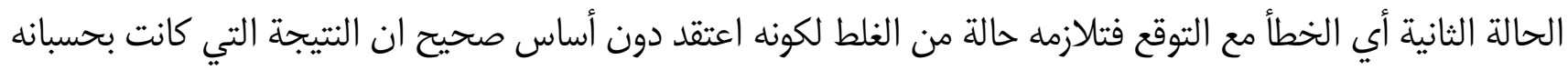

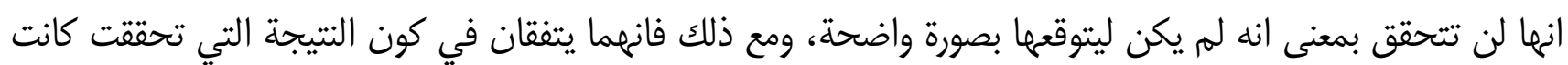

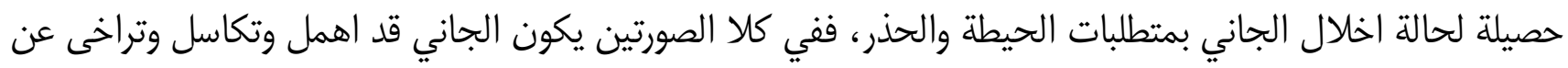
اتخاذ التحوطات اللازمة لمنع حصول النتيجة التي تحققت.

الا ان هناك اتجاه في الفقه يرى بوجود اختلاف بين صورتي الخطأ (الخطأ مع التوقع والخطأ بدون توقع) من حيث الخدان

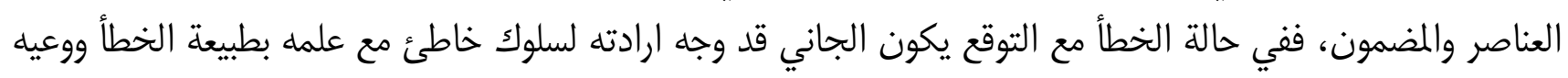

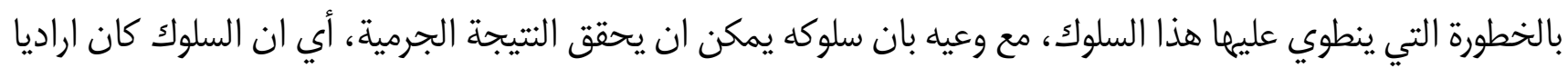

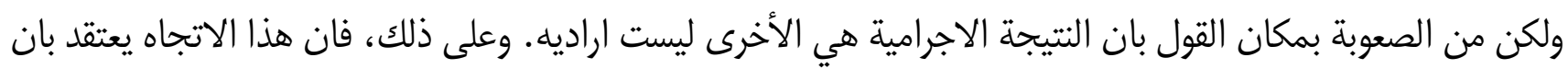

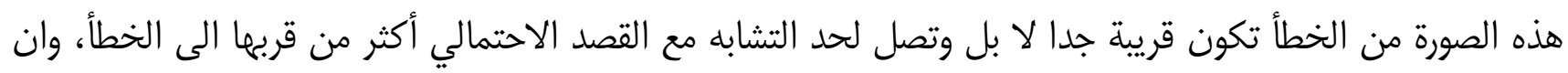

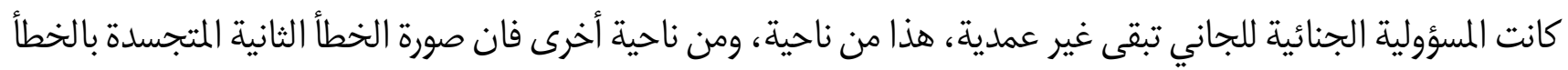

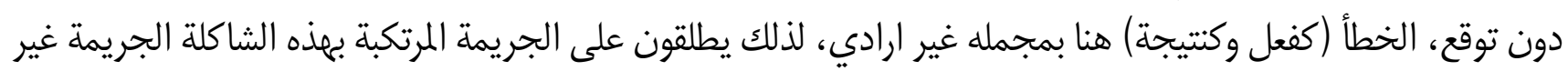

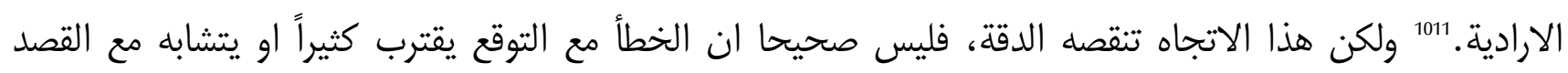

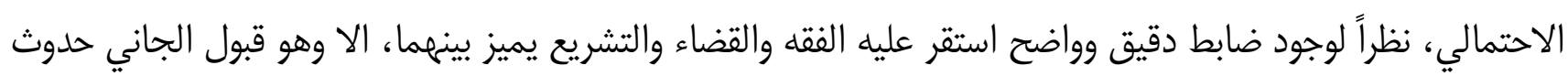

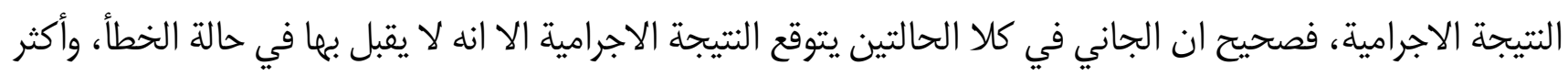

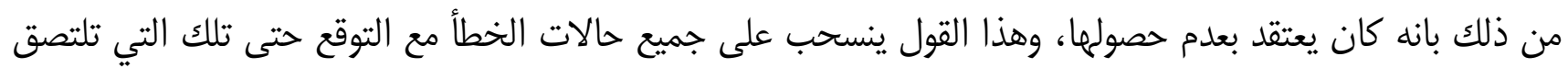

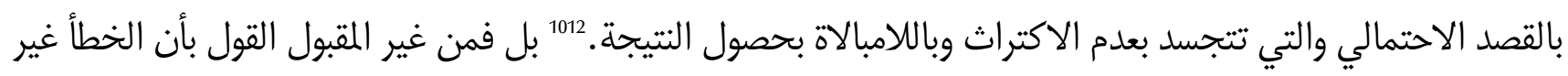

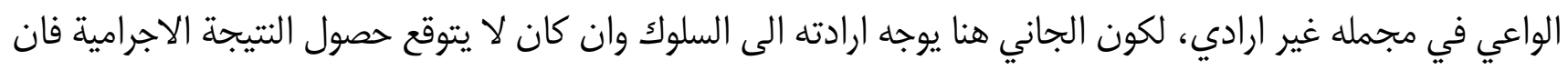

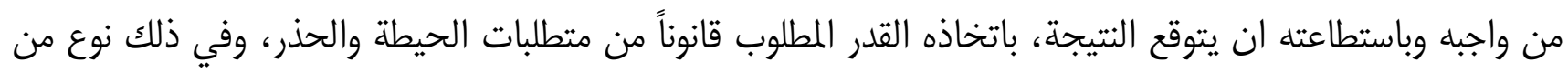

1010 د. نبيل مدحت سالم، الذطأ غير العمدي، مصدر سابق، الفقرة رقم 62، ص116. د. د. فوزية عبد الستار، النظرية العامة للخطأ غير العمدي،

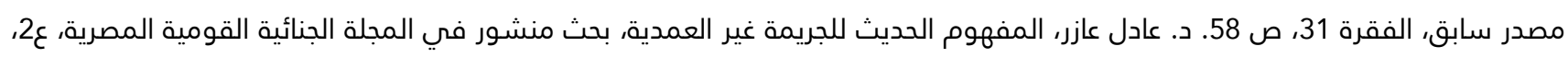

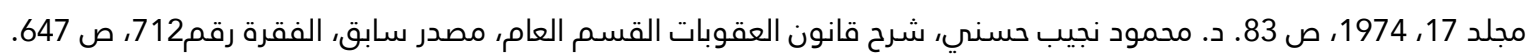
1011 J. Borricand, Droit penal, Masson, 1973, p. 114. P. Bouzat ET J. Pinatel, Traite de droit penal ET de criminolgie, T. 1. Droit penal general par, $2^{\text {eme }}$ Ed, 1970, Paris, Dalloz, p.260. A. Dorsner Dolivet, Contribution a la restauration de la faute, condition des responsabilites civile et penale dans I homicide et les blessures par imprudence, a propos de la chirurgie, These, Paris, 1985, pp.193-194.

1012 د. محمد زكي محمود، اثار الجهل والغلط على المسؤولية الجنائية، رسالة دكتوراه، كلية الحقوق جامعة القاهرة، 1967، الفقرة 486، ص 368. د. محمود نجيب حسني، شرح قانون العقوبات القسم العام، مصدر سابق، الفقرة رقم 114، ص 238. 
التأكيد على توافر نوع من الصلة بين ارادته والنتيجة، فبدون هذا النوع من الصلة يكون من المتعذر محاسبة الجاني، بمعنى

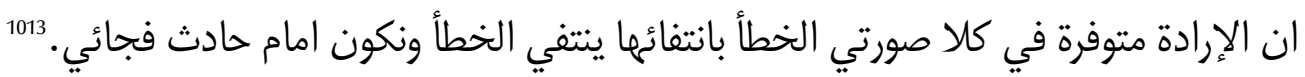

رابعاً - أثر الغلط على التوقع : ابتداءً نقول بأن الغلط هو العلم بأمر معين ولكن هذا العلم اما ان يكون منقوصاً او مخالفاً

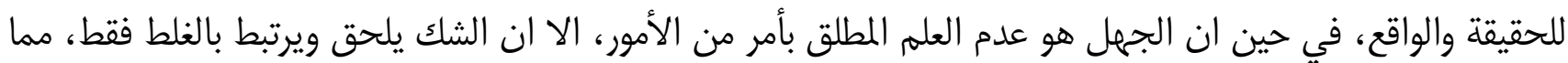

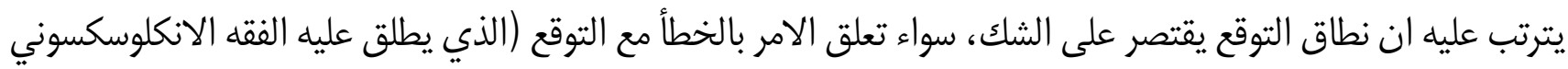
عدم الاكتراث) او تعلق بالقصد الاحتمالي، بخلاف القصد الذي يستوجب العلم الكامل الذي يطابق الواقع، ومن اجل ذلك الك الكاف يكون للغلط الذي يقع فيه الجاني اثر كبير في نفي القصد، فان الغلط في الحقيقة يعد دفعا يمكن للفاعل ان يتمسك بان بهاه

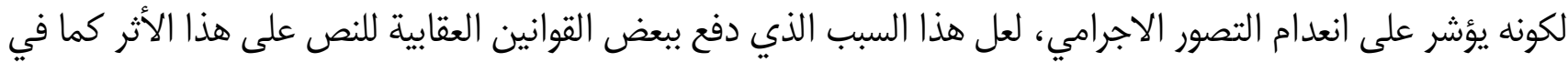

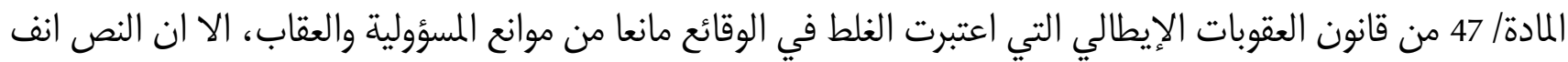

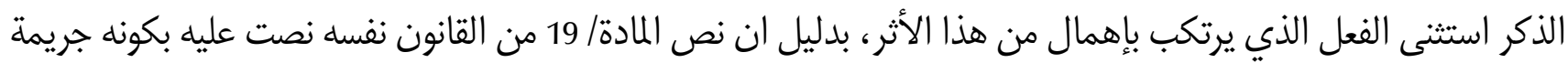

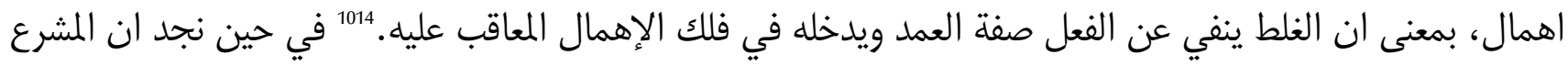

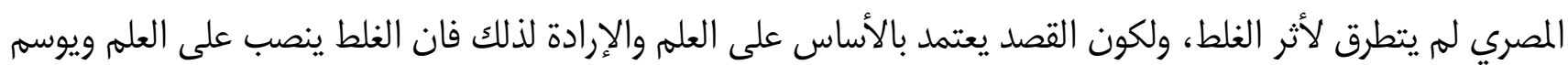

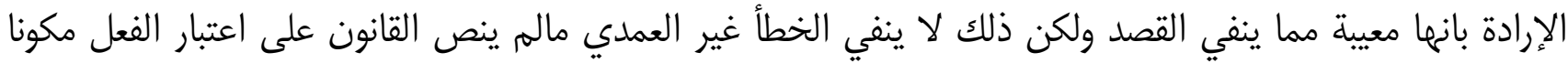
لجريمة عمدية ويرتب بالتالي العقاب عليه.

اما بخصوص موقف المشرع العراقي في قانون العقوبات فانه واضح من خلال نص المادة/37 عقوبات عراقي بتقرير

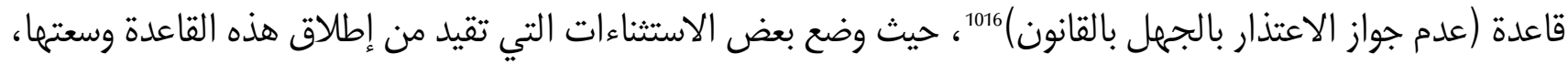

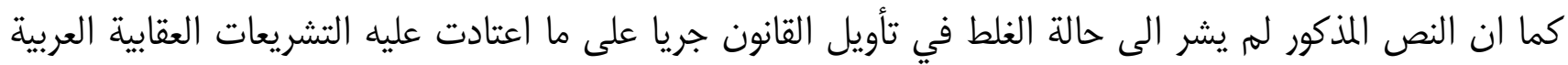

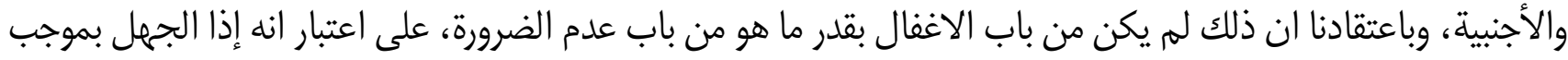

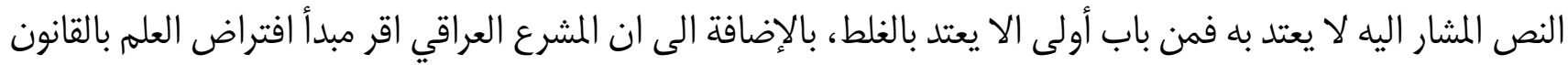

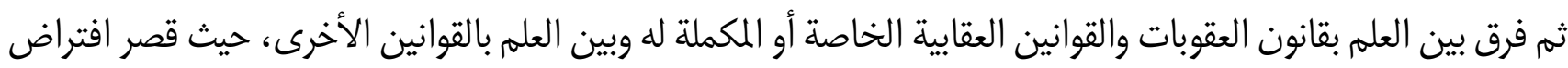
العلم بالقوانين العقابية دون القوانين الأخرى، وقد أورد على افتراض العلم بالقوانين العقابية استثناءين:

$$
\text { أولمها، حين تثبت استحالة العله بالقانون (وتفسيره من باب أولى)، }
$$

وثانيهما خاص بالأجنبي الوافد حديثا الى العراق. ولهم يتطرق المشرع لموضوع الاستثناء الخاص بالجهل بالقانون الجديد

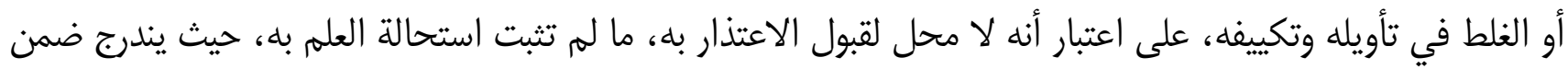
مفهوم الفقرة/1 من المادة المذكورة على اعتبار أن القول بغير ذلك يتناقض لاعلى مع النظام العام، حيث تتص المادة 129 من الدستور

1013 د. محمود نجيب حسني، شرح قانون العقوبات القسم العام، مصدر سابق، الفقرة رقم 710، ص 645.

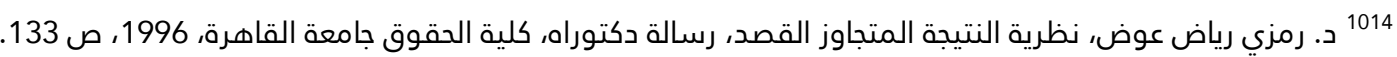

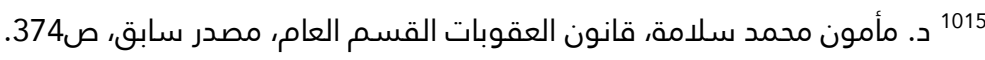
1016 المادة 37 عقوبات عراقي انه (1.ليس لأحد أن يحتج بجهله بأحكام هذا القانون أو أي قانون عقابي آخر مالم يكن قد تعذر علمه بالقانون الذي يعاقب على الجريمة بسبب قوة قاهرة .2. للمحكمة أن تعفو من العقاب الأجنبي الذي يرتكب جريمة خلال سبعة أيام على الأكثر تمضي من تاريخ قدومه الى العراق إذا ثبت جهله بالقانون وكان قانون محل اقامته لا يعاقب عليها). 
العراقي لسنة 2005 على ان (تنشر القوانين في الجريدة الرسمية، ويعمل بها من تاريخ نشرها، مالم ينص على خلاف ذلكاك).

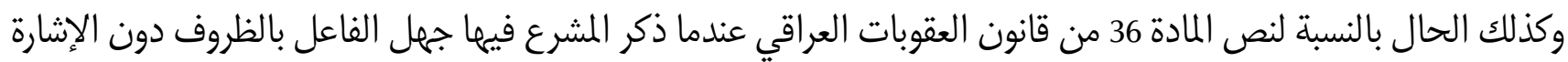
الى غلطه فيها وكلى فهنا نحن نتكلم عن الجعل والغلط بالقانون الذي لا عذر فيه الا ان الامر ليس كذلك فيما يخص الغلط والخطأ في الوقائع. وقدر تعلق الامر بالغلط في الوقائع، فلم يفرد المشرع الجنائي العراقي نصا عاما ينظم حالة الغلط في فهم الوقائع

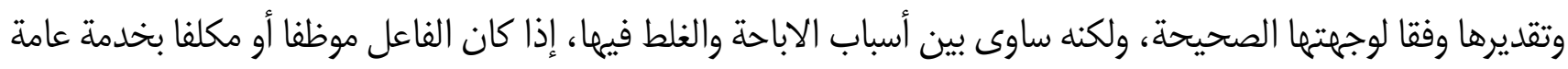

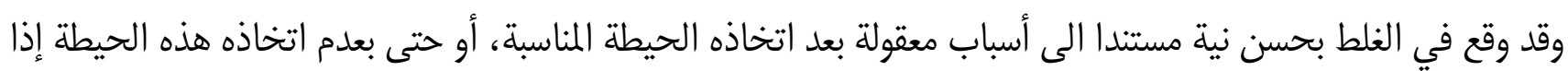

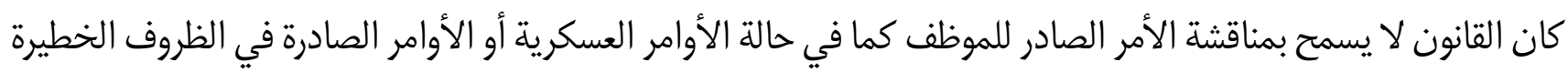

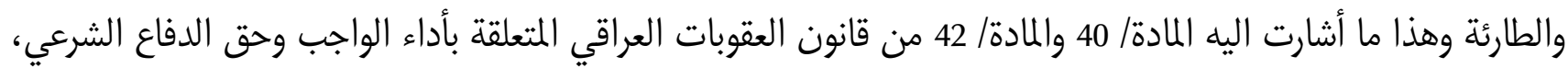

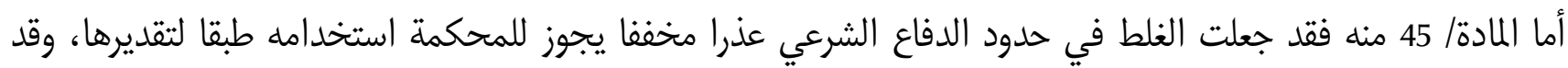

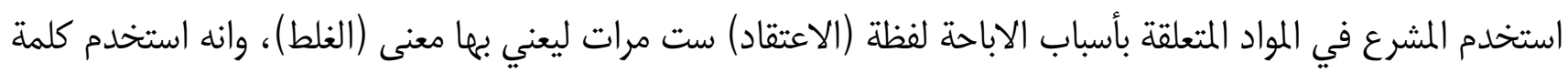

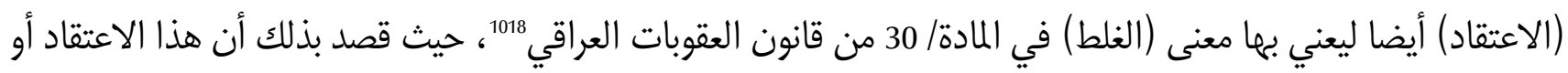

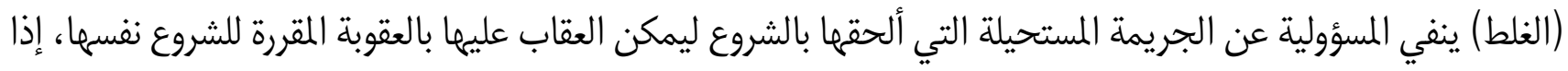

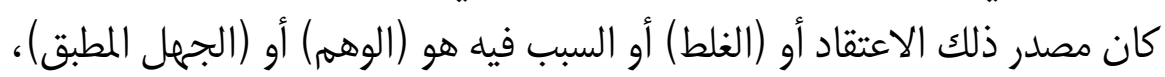

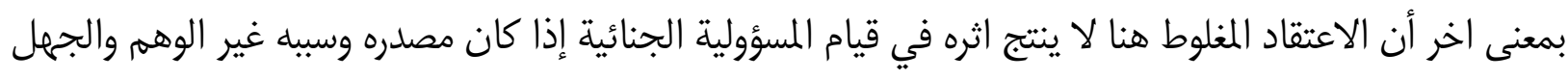

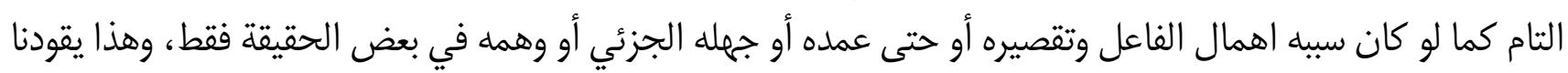

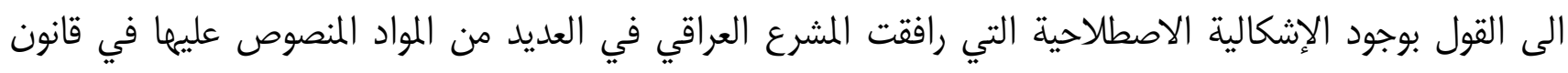

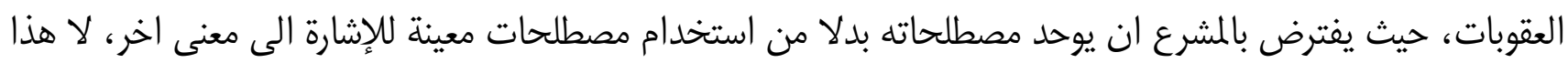
الامر سيقود بكل تأكيد لعدم استقرار القضاء.

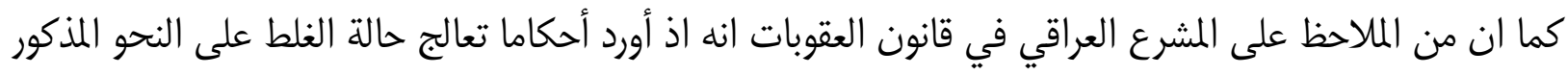

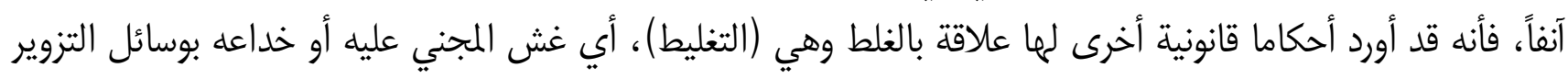

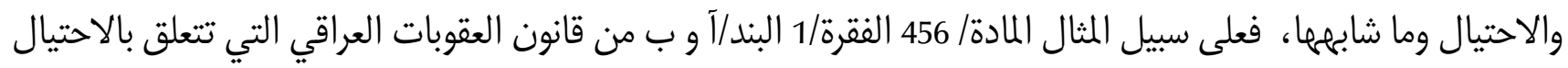

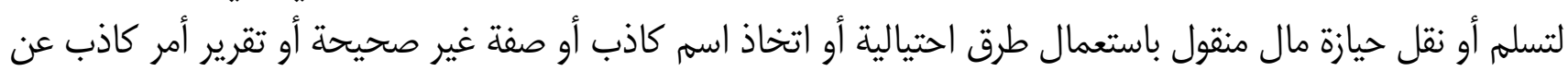

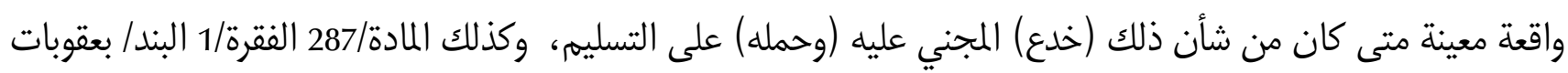

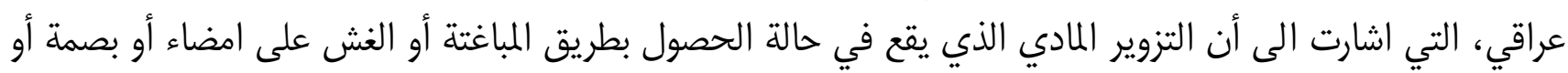

1017 حيث نصت المادة 36 عقوبات عراقي على انه: (إذا جهل الفاعل وجود ظرف مشدد يغير من وصف الجريمة فلا يسأل عنه ولكنه يستفيد من

العذر ولو كان يجهل وجوده). 1018 المادة (30) عقوبات التي نصت على (...ويعتبر شروعا في ارتكاب الجريمة كل فعل صدر بقصد ارتكاب جناية أو جنحة مستحيلة التنفيذ .... مالم يكن اعتقاد الفاعل صلاحية عمله لأحداث النتيجة مبنيا على وهم أو جهل مطبق). 
خته لشخص لا يعلم مضمون المحرر على حقيقته، وكذلك المادة/ 308 عقوبات عراقي المتعلقة بالرشوة والتي جاء فيها لفظ

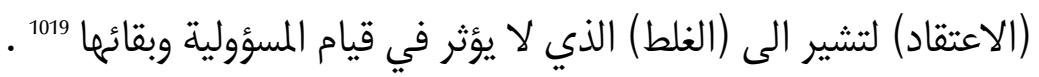

وإذا اتجهنا شطر قانون أصول المحاكمات الجزائية العسكري العراقي رقم 44 لسنة 1941 الملغي بالقانون رقم 22 لسنة 2016، نجد أن المشرع قد استخدم كلمة (الغلط) صراحة، وجعل الغلط في العقوبة مانعا من تنفيذ الحكم الصادر من قبل آمر الضبط01020، بينما عاد المشرع العراقي الجزائي العسكري الى استخدام الفاظ أخرى (كالخطأ) للدلالة على (الغلط)، على

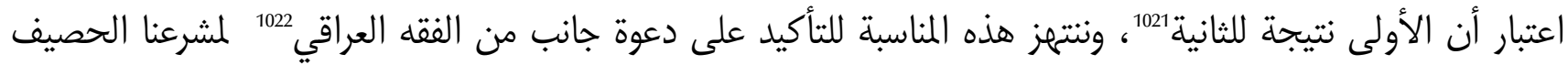

1019 المادة 308 عقوبات عراقي والتي نصت على ان (كل موظف أو مكلف بخدمة عامة طلب أو قبل لنفسه أو لغيره عطية أو منفعة أو ميزة أو

وعدا بشيء من ذلك لأداء عمل أو الامتناع عن عمل لا يدذل في أعمال وظيفته ولكنه زعم ذلك أو اعتقده خطأ يعاقب...).

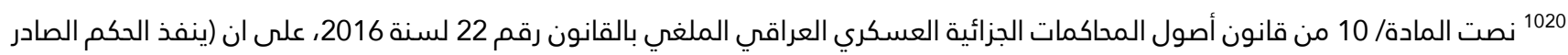

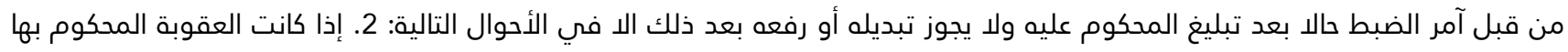

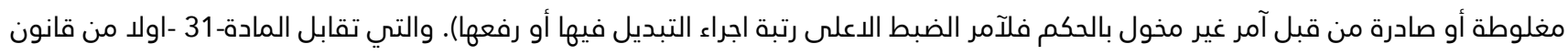

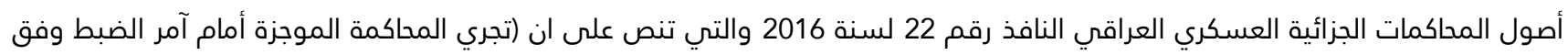

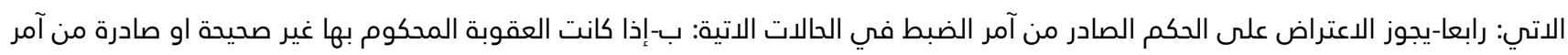

غير مخول بالحكم فلآمر الضبط الاعلى رتبة تبديل العقوبة او رفعها). اصلير وذذا ما نراه في المادة/ 82 قانون أصول المحاكمات الجزائية العسكري العراقي على ان (يجوز للمحكمة العسكرية الى حين النطق بالحكم

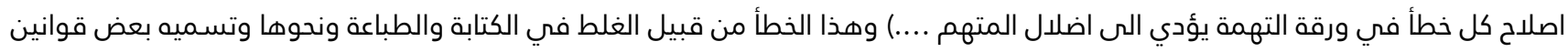

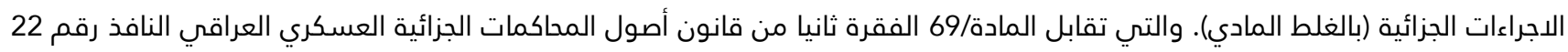

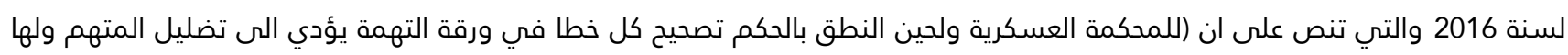

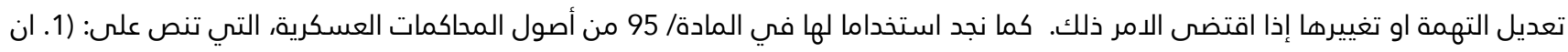

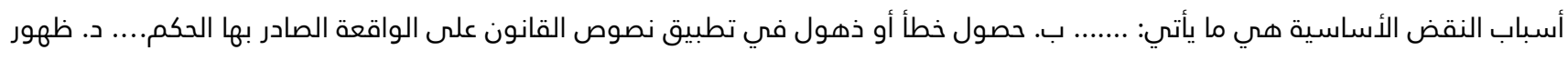

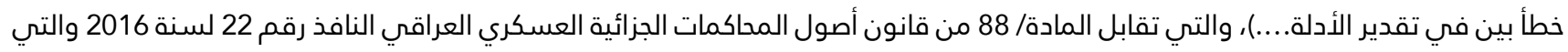

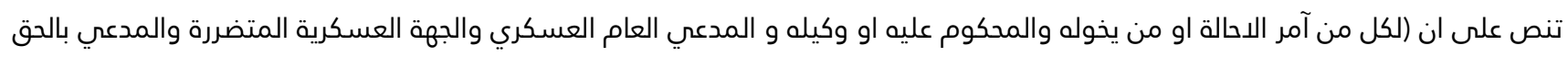
الشخصي او وكيله الطلب من محكمة التمييز الاتحادية تصحيح الذطأ القانوني في الاحكام والقرارات الصادرة من محكمة التمييز العسكرية

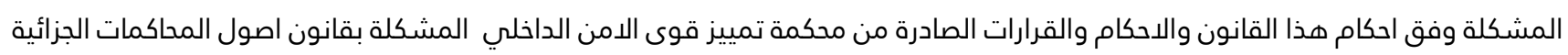

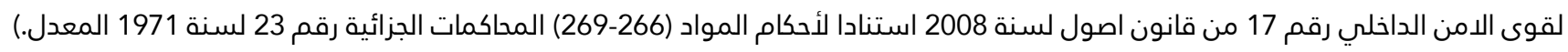

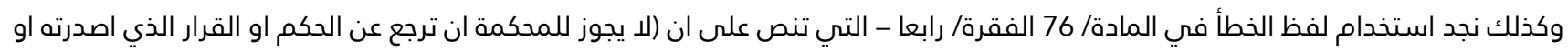

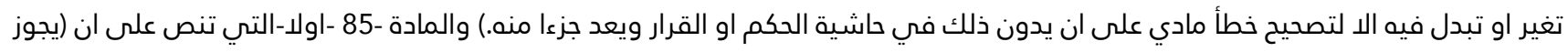
الطعن تمييزا في الاحكام الصادرة من المحكمة العسكرية لاحد الاسباب الاتية: د-ظهور خطأ جوهري بتقدي العدير الادلة. الجزائية العسكري العراقي رقم 22 لسنة 2016 والمنشور في جريدة الوقائع العراقية رقم 4444 في

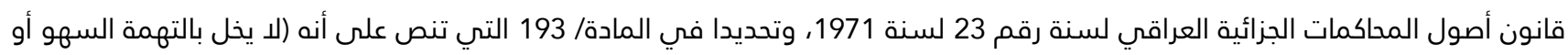

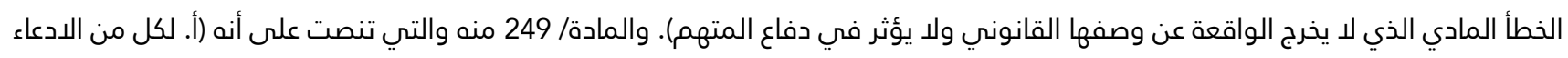

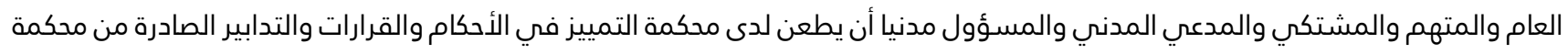

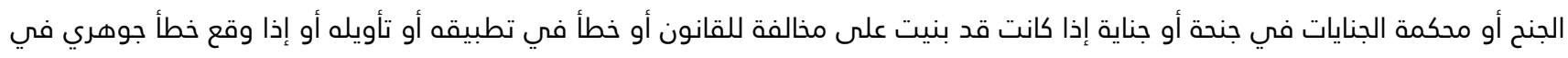

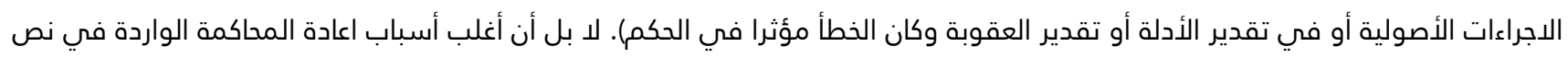

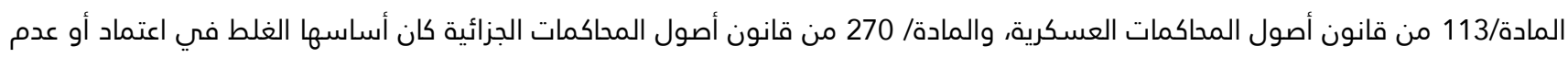

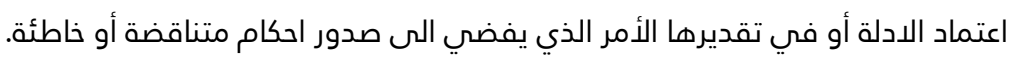

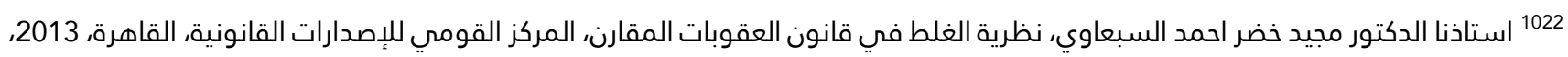




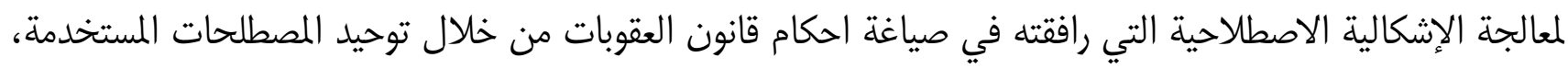

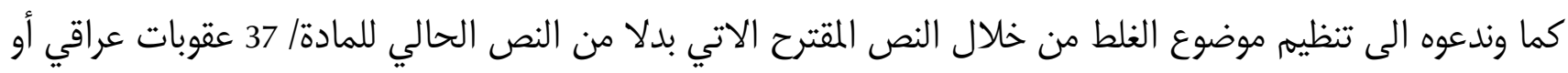

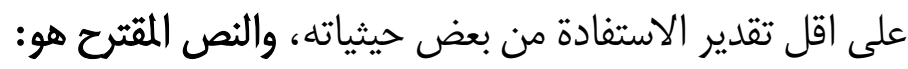
(1. ليس لأحد أن يحتج بجهله بأحكام هذا القانون أو أي قانون عقابي آخر، أو بالغلط في فهمه على الوجه الصحيح.

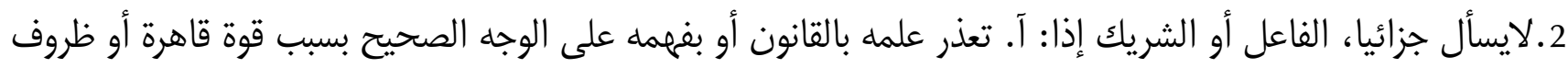

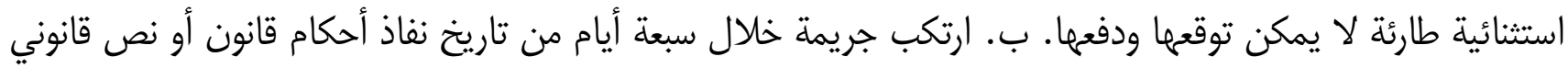

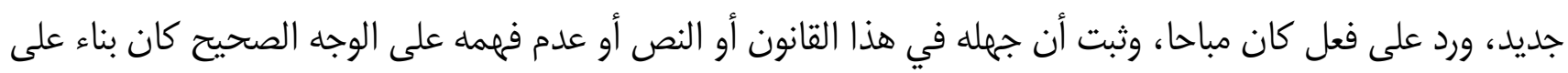

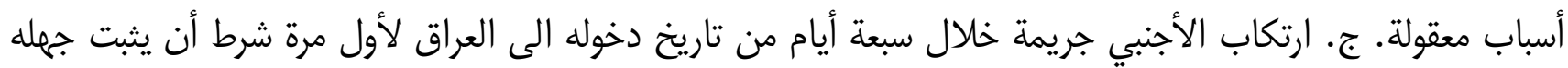

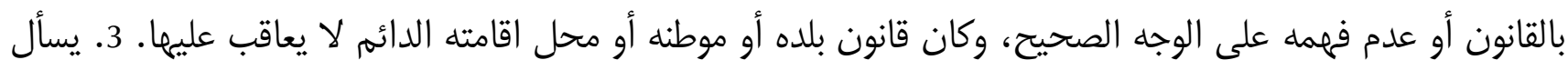

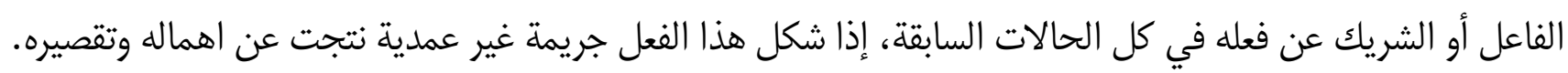

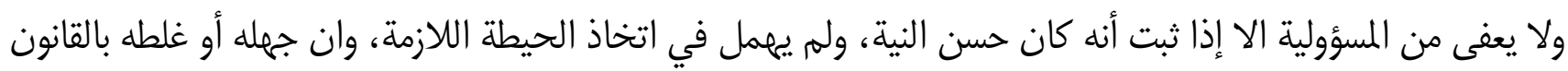
أو بالوقائع كان مبنيا على اسباب كافية ومعقولة).

بقي ان نقول بان للغلط المؤثر ثلاثة شروط يجب ان انت تتوفر من اجل ان ينتج أثره في نفي القصد الجنائي هي: أولا: يجب ان يكون هذا الغلط ناشئا عن اعتقاد صادق بصحة الواقعة. ثانيا: يجب ان يكون معقولا . ثالثا: ان يتعلق

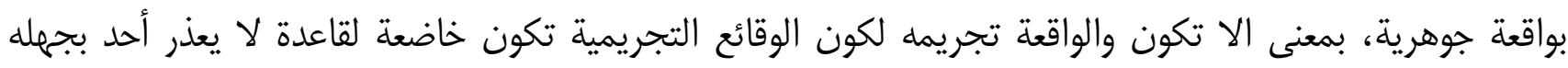
القانون.1023

\section{المبحث الثالث: الاتجاهات الفقهية والدور الصحيح للتوقع أو استطاعته في نظرية الخطأ}

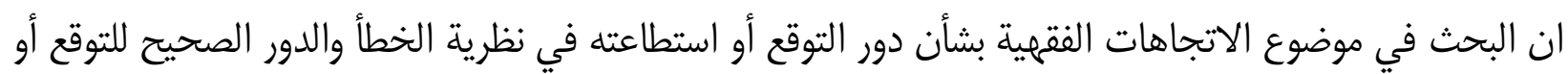

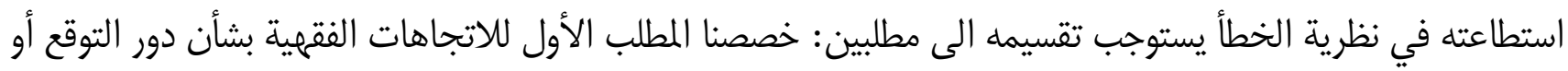

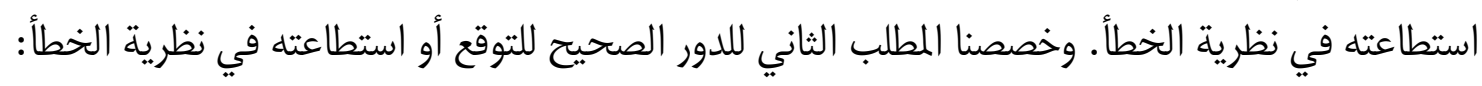

\section{المطلب الأول: الاتجاهات الفقهية بشأن دور التوقع أو استطاعته في نظرية الخطأ}

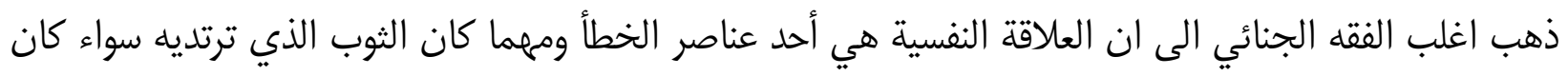

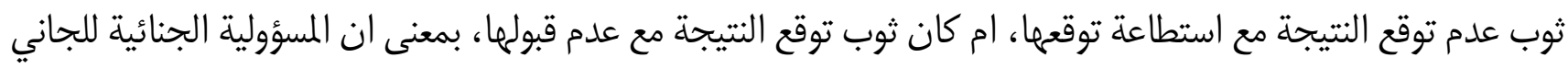

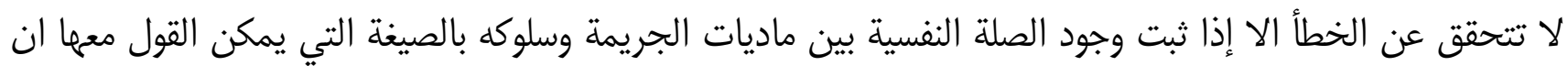

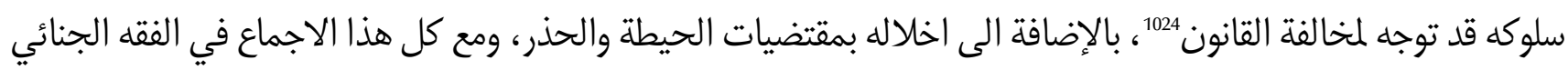

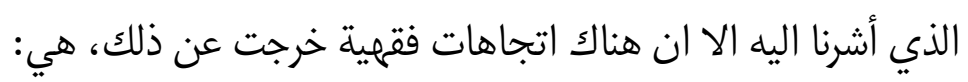

1023 أستاذنا الدكتور مجيد خضر احمد السبعاوي، نظرية الغلط في قانون العقوبات، مصدر سابق، ص66. د. مأمون محمد سلامة، شرح قانون

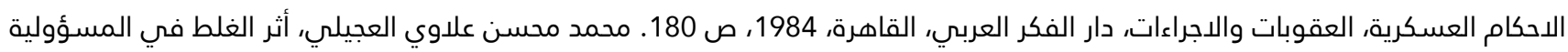
الجنائية، دراسة مقارنة، مكتبة السنهوري، بغداد، 2016، ص103. د. علي محمود علي حمودة، الغلط في القانون ومدى اعتباره مانعا من

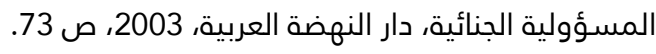
1024 د. محمد زكمي محمود، اثار الجهل والغلط على المسؤولية الجنائية، مصدر سابق، الفقرة 478، ص 363-364. 
الاتجاه الاول -استطاعة التوقع كشرط كاف لقيام الخطأ وتبرير المسؤولية الجنائية عنه: تبنى هذا الاتجاه القول بأن

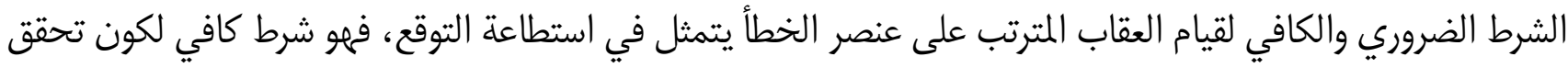
استطاعة التوقع فهذا يعني انها تدور في فلك الإرادة.

اما من حيث اعتبار استطاعة التوقع شرطا ضروريا فهذا متأتي من كون تخلفها يعني ان نكون بصدد الحادث الفجائي، التهاء

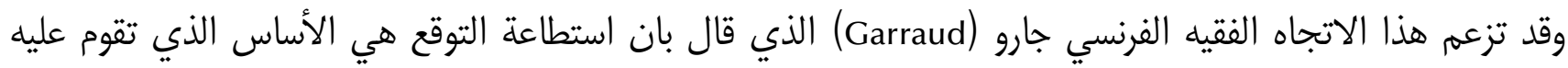

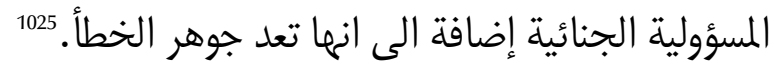

وقد ايد هذا الاتجاه جانب من الفقه الجنائي العربي واعتبر ان جوهر الخطأ هو استطاعة التوقع عند ما عبر عن ذلك الك الكا بالقول "عدم توقع النتيجة الاجرامية مع القدرة عليه"

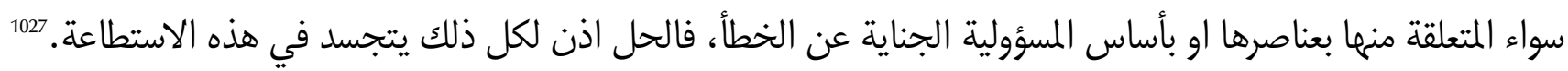

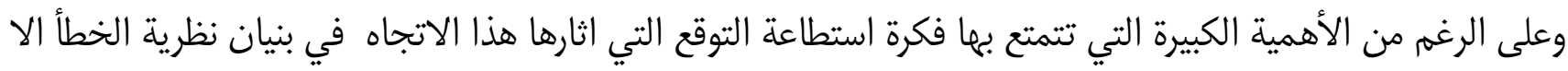

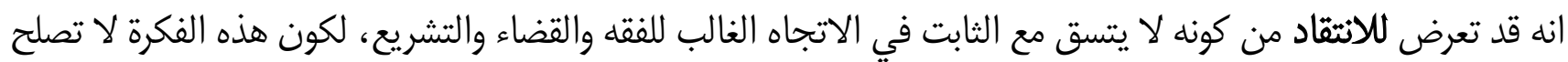

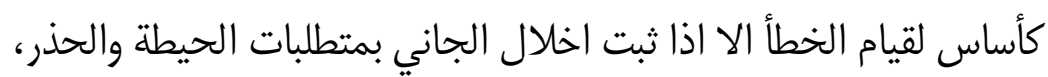

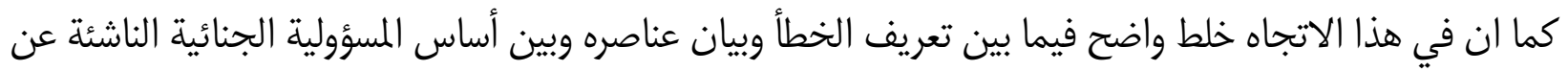

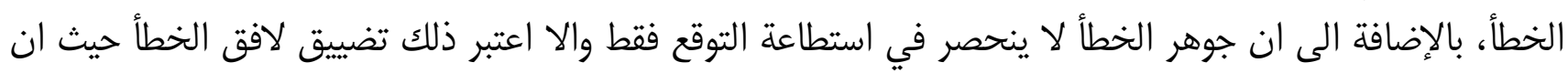

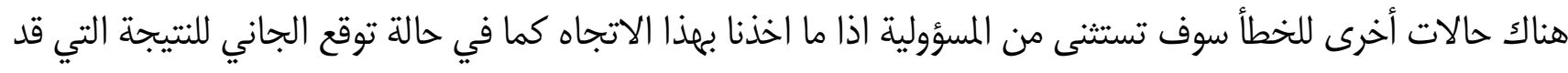
تترتب على سلوكه الا انه اعتقد بانها سوف لن تحصل، لكون مجال الخطأ يبدأ حال انتهاء مجال العمداه وكذلك هناك حالات الخطأ بدون توقع والحد الأدنى من القصد الذي هو القصد الاحتمالي التي تفصل بينهما هوة

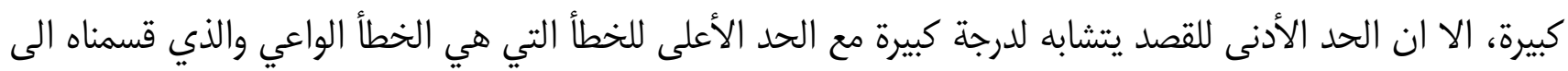

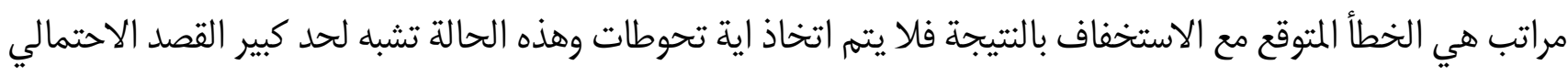

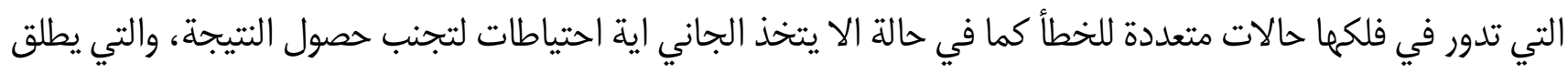

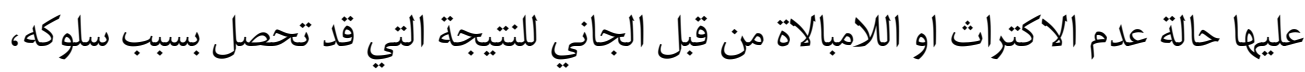

والمرتبة الثانية هي حالة التوقع مع اتخاذ تحوطات الا انها غير كافية

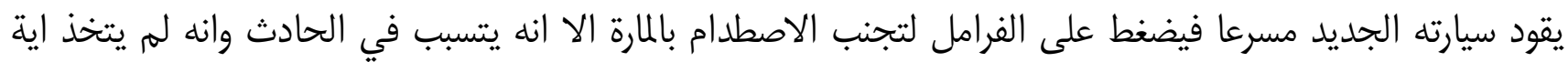
تحوطات على اعتبار ان سيارته جديدة وانه اعتمد على مهارته ولكنها غير كافيه.

${ }^{1025}$ Garraud, Traite Theorique ET Pratique du droit penal Francais, Paris, 1931, T.1, No. 297, p 586.

1026 د. نبيل مدحت سالم، الخطاء غير العمدي، مصدر سابق، ص الفقرة 41، ص 70.

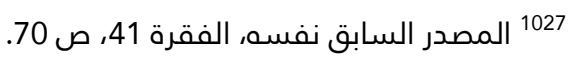
1028 د. شريف سيد كامل محمد، مصدر سابق، ص 831. 


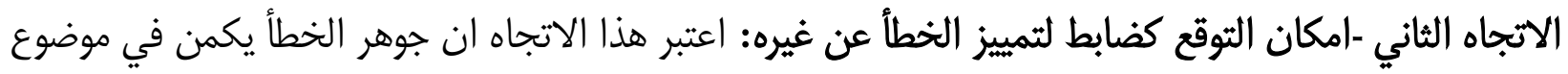

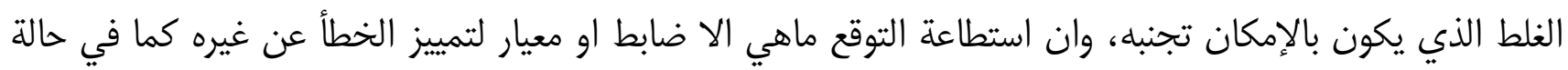
تمييزه عن القوة القاهرة. 1029

وان هذا المعيار او الضابط يصلح لتحديد حالتي الخطأ الواعي وحالة الخطأ غير الواعي، لكون الجاني في حالة الخطأ

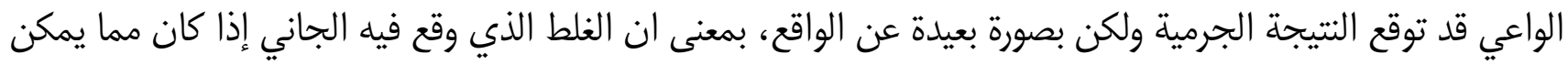

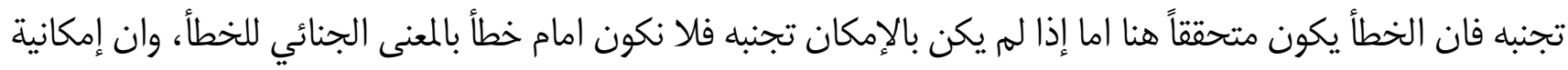

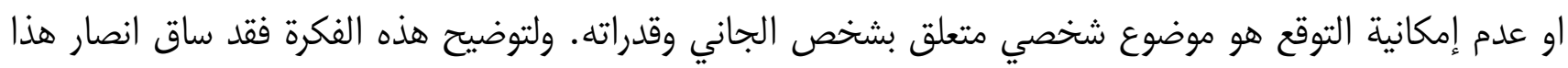

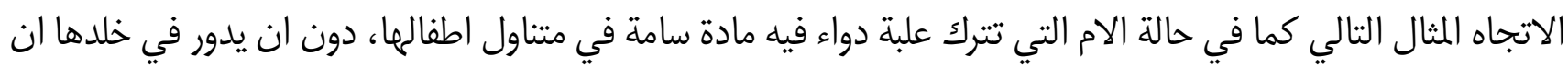

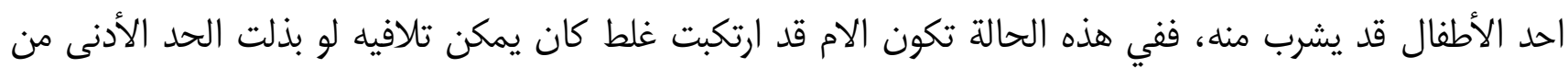

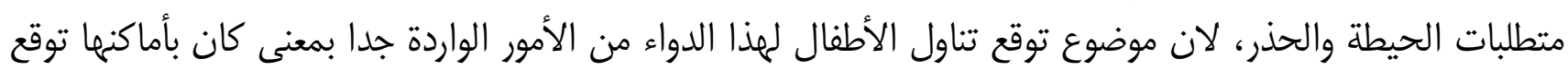

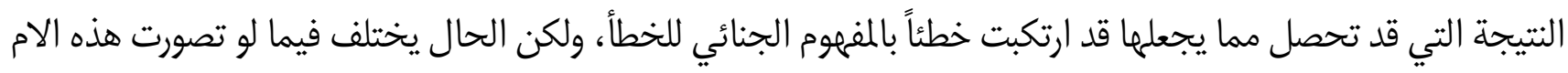

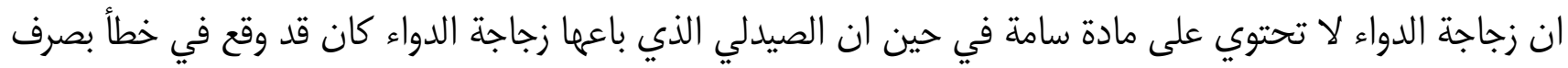

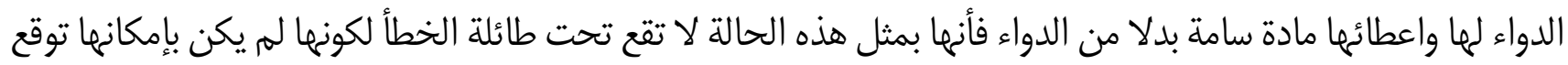

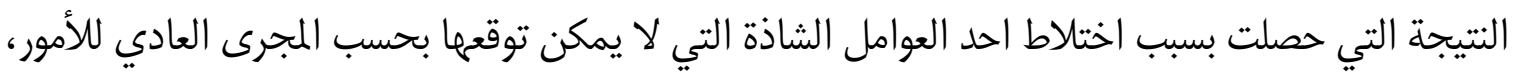
بمعنى نكون والحالة هذه امام حادث فجائي وفقا لهزا الاتجاه الذي يخلص الى القول ان الغلط هو جوهر الخطأ بنوعيه ( مع التوقع او بلون التوقع)، وان امكان التوقع هو الضابط الذي يميزه عن فئ غيرها.

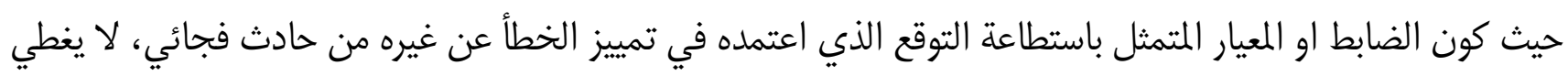

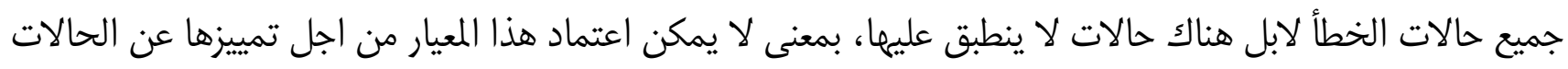

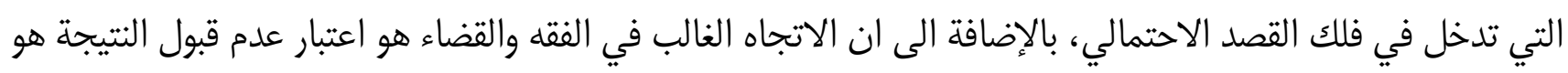

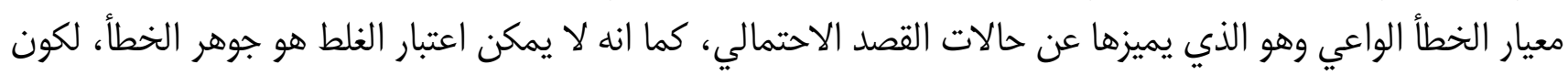

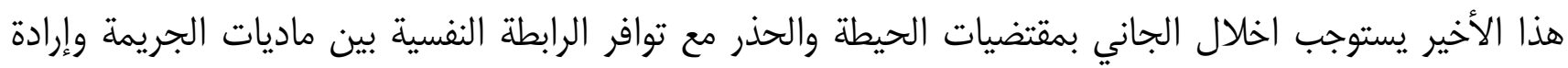
الجاني. الاتجاه الثالث - التوقع كظرف مشدد للعقاب على الخطأ: ويرى هذا الاتجاه ان الخطأ غالبا ما يأخذ صورة عدم مراعاة

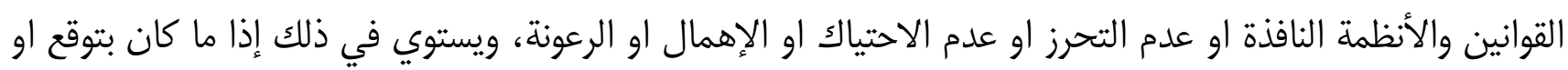

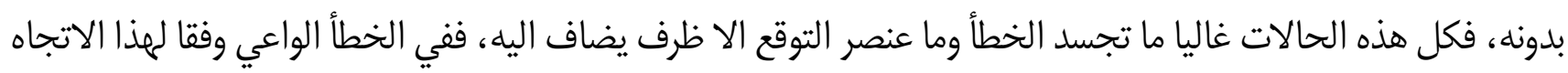

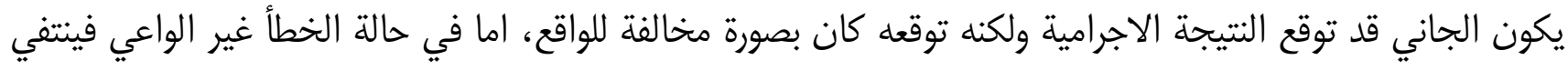
1029 د. علي حسين الخلف و د. سلطان عبد القادر الشاوي، المبادئ العامة في قانون العقوبات، العاتك لصناعة الكتاب-القاهرة والمكتبة القانونية-بغداد، بدون سنة طبع، ص 350. د. رشيد عالي الكيلاني، النظرية العامة في الحقوق الجزائية، مطبعة الأهالي، بغداد، 1922، ص 
التوقع مطلقاً، مما يعني ان التوقع خلافا للواقع وعدم التوقع يكونان في حالة من التعادل لكون الجاني في الحقيقة لهم يكن

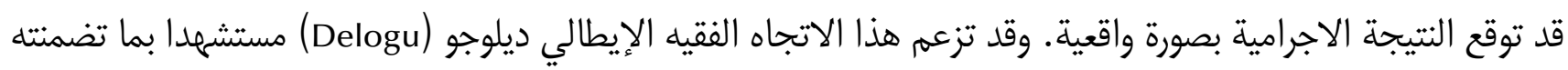

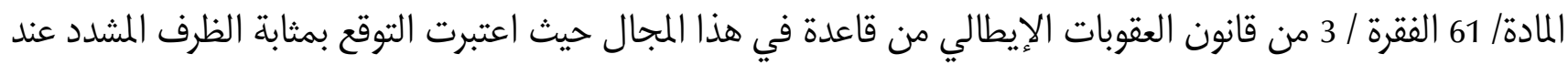

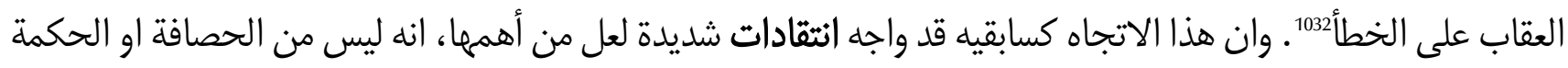

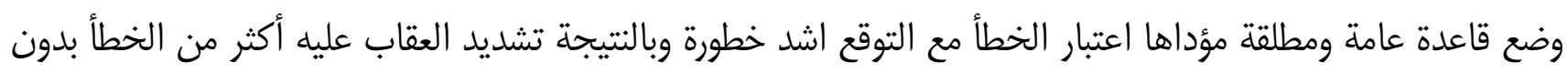

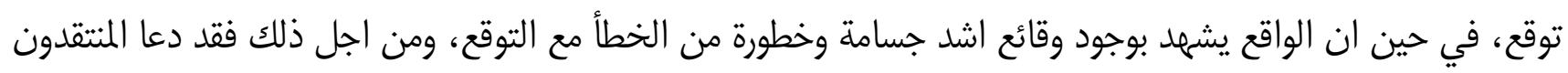

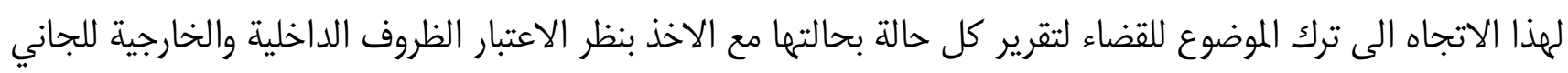
وفقا للسلطة التقديرية الممنوحة للقاضي، بدلا من التقيد بقاعدة جامدة لا تشمل الكثير من الحالات.

الاتجاه الرابع - التوقع كعنصر من عناصر اثبات الخطاً : هذا الاتجاه يقول بان الخطأ هو أحد عنصري الاثبات يستوجبه

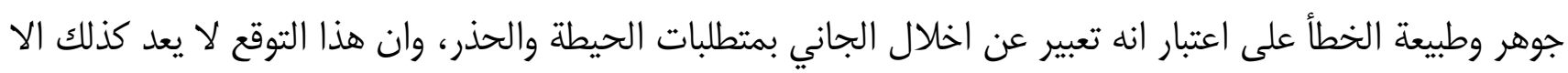

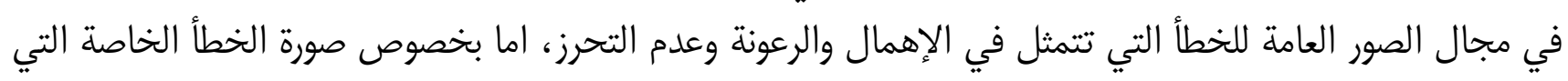

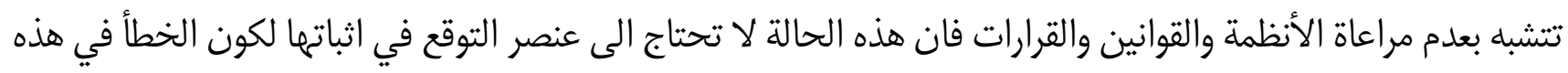

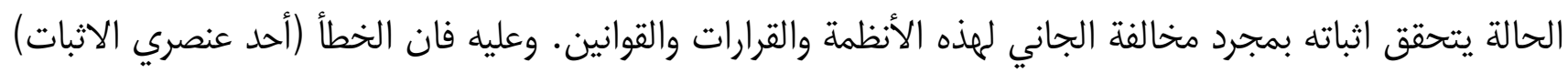

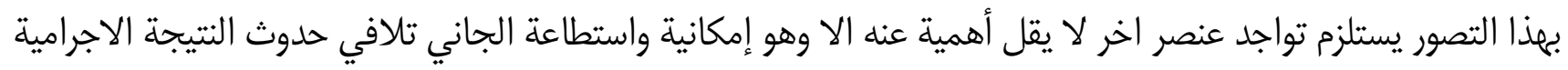

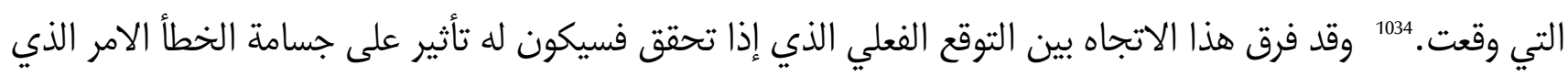

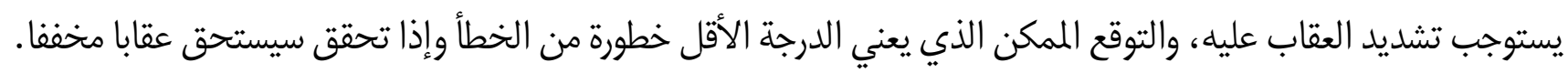

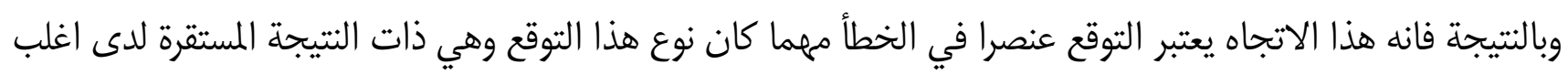

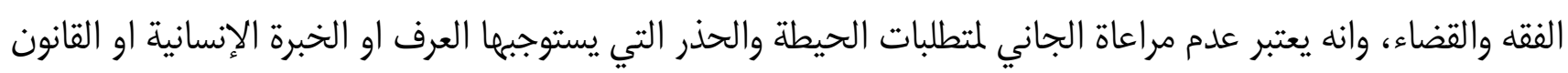

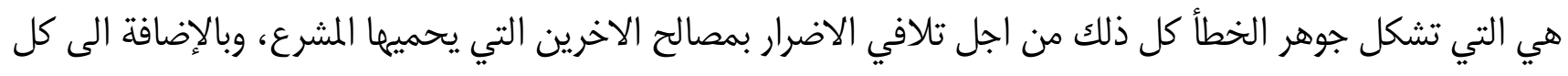

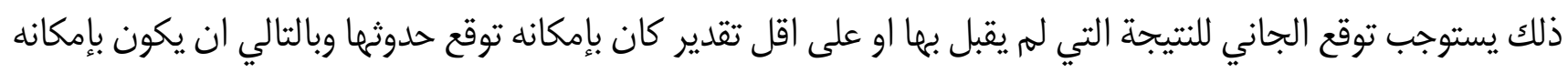

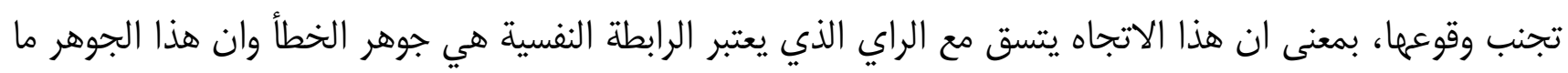
كان ليتحقق لولا هذه الرابطة. وعلى الرغم من اننا نتتقد بان هذا الاتجاه أكثر واقعية لكونه يلتقي مع الاتجاه الغالب في الفقه والقضاء الا اننا نجده ينحى عنه في منحيين هما:

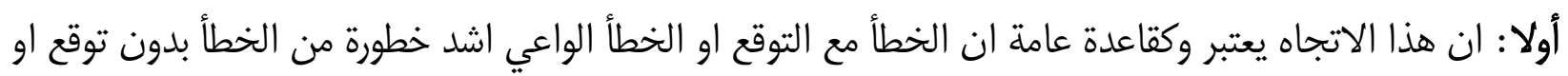

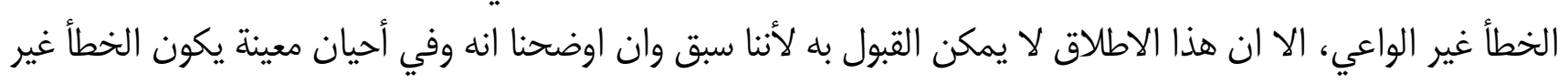

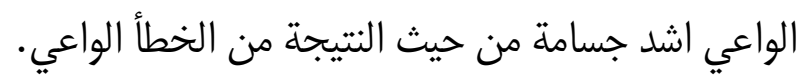

1032 Delogu T, La culpabilite dans la theorie general, Universite du Caire, 1949-1950, p. 640.

1033 د. شريف سيد كامل محمد، مصدر سابق، ص 826.

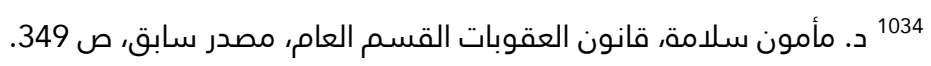
1035 د. شريف سيد كامل محمد، مصدر سابق، ص 835. 
ثانيا: ان عدم مراعاة الأنظمة والقوانين والتي تشكل الصورة الخاصة من الخطأ يكون الاثبات فيها مختلف تماها عن الصورة العامة للخطأ لكونها لا تستوجب التوقع او استطاعته.

ومهما يكن من امر فأننا نتتقد بعدم وجود اختلاف في الخطأ بصورته العامة والخاصة من حيث الاثبات والعناصر

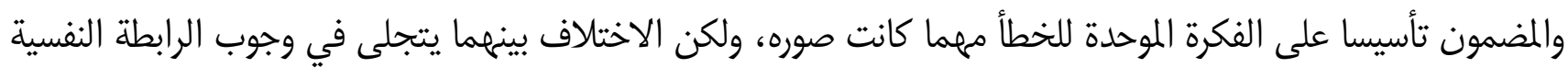

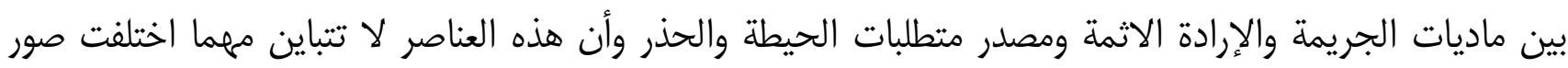
الخطأ.

\section{المطلب الثاني:الدور الصحيح للتوقع أو استطاعته في نظرية الخطأ}

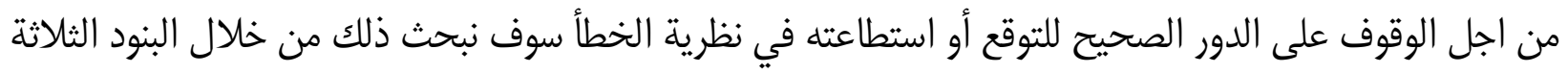
التالية:

أولا -الدور الصحيح للعلاقة النفسية في بنيان الخطأ: يذهب جانب من الفقه -ونؤيده في ذلك-الى ان الدور الصحيح

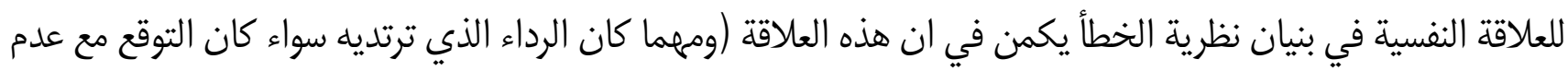

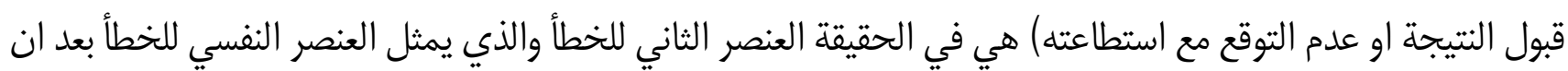

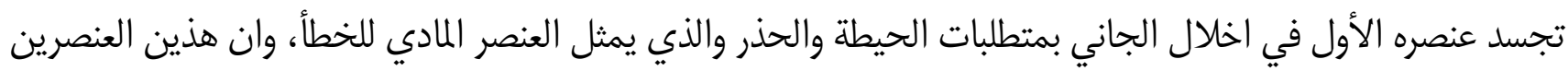

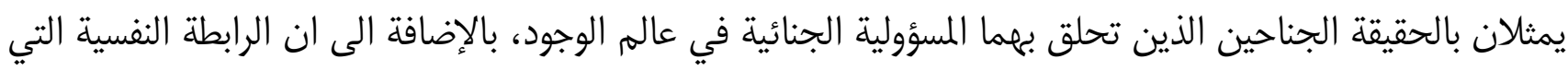

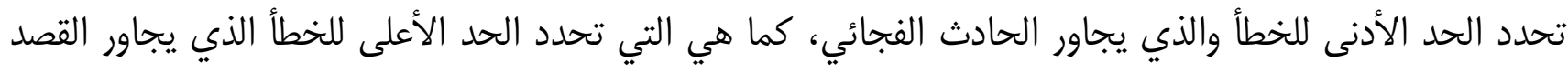

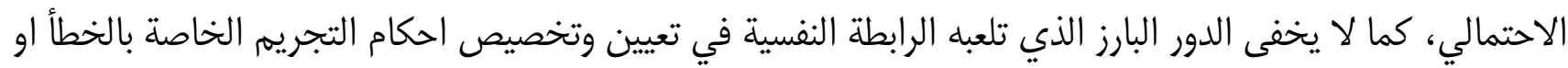

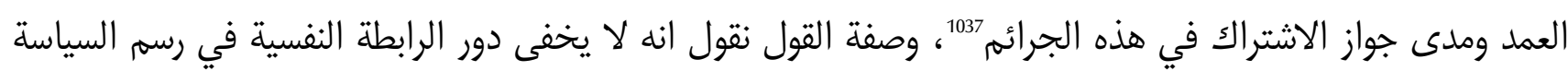

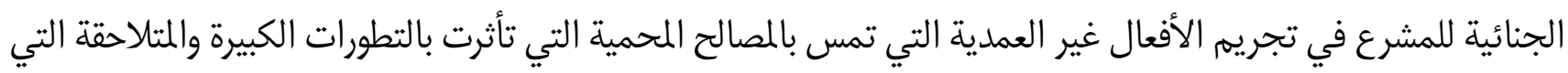
تشهرها المجتمعات.

ثانيا -الصورتان في التشريعات الحديثة والقانون الانكلوسكسوني: سنبحث في دور الرابطة النفسية في بنيان نظرية

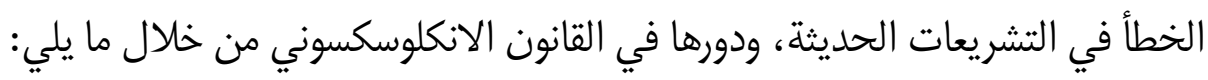
1 ـ دور الرابطة النفسية في بنيان نظرية الخطأ في التشريعات الحديثة: انقسمت الى قسمين هما: القسم الأول - تشريعات تضمنت نصوص واضحة بشأن دور الرابطة النفسية في بنيان نظرية الخطأ: حيث اتجهت

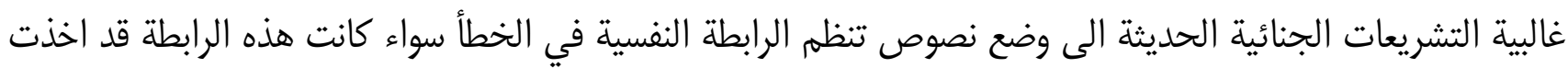

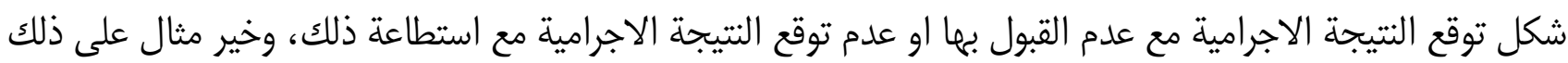

1036 المصدر السابق نفسه، ص 836. 1037 د. محمود نجيب حسنس، شرح قانون العقوبات القسم العام، مصدر سابق، الفقرة رقم 709، ص 644. 1038 د. شريف سيد كامل محمد، مصدر سابق، ص 836. د. محمود نجيب حسني، شرح قانون العقوبات القسم العام، مصدر سابق، الفقرة رقم 713، ص 648. 
المادة/ 43 الفقرة/ 3 من قانون العقوبات الإيطالي لسنة 1930 والتي نصت على ان (الجريمة غير عمدية او مخالفة للقصد عندما لا يريد الجاني الحدث الذي يقع حتى لو كان متوقعا بسبب الإهمال او عدم الحرص او الرعونة او عدم احترام القوانين واللوائح والنظم والاوامر)1039، والمادة/18 الفقرة/3 من قانون العقوبات السويسري لسنة 1938 التي نصت على ان (يعد مرتكبا لجناية او جنحة بإهمال كل من تصرف بعد تبصر آثم دون ان يعني او يضع في اعتباره نتائج فعله. ويكون عدم التبصر آثما إذا كان الفاعل له يتخذ الاحتياطات التي تقتضيها الظروف ووضعه الشخصي)، ومن هذا النص يتضح ان المشرع السويسري قسم الخطأ الى خطأ واعي او خطأ مع التوقع وخطأ غير واعي او خطأ بدون توقع دون الإشارة الى ان أحدهما اشد جسامة من الاخر. العقابية العربية المادة/191 من قانون العقوبات اللبناني لسنة 1943 والتي تنص على ان (تكون الجريمة غير مقصودة سواء لم يتوقع الفاعل نتيجة فعله او عدم فعله المخطئين وكان في استطاعته او من واجبه ان يتوقعها وسواء توقعها فحسب ان بإمكانه اجتنابها)، والمادة/ 190 من قانون العقوبات السوري لسنة 1949 والتي تنص على ان (تكون الجريمة غير مقصودة سواء لم يتوقع الفاعل نتيجة فعله أو عدم فعله المخطئين وكان في استطاعته أو من واجبه أن يتوقعها فحسب أن بإنهان إمكانه اجتنابه.). (1042

\section{القسم الثاني -تشريعات اغفلت النص على دور الرابطة النفسية في بنيان نظرية الخطأ: اغفلت التشريعات التي تبنت} هذا الاتجاه وضع نص يتضمن تعريف للخطأ غير العمدي في القسم العام من قوانينها العقابية، في حين جرمت حالات من

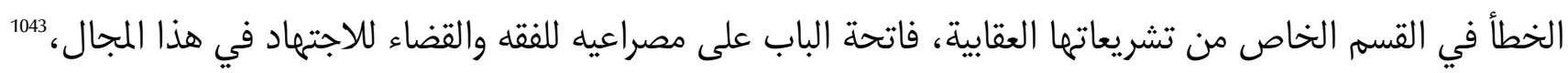

1039 د. محمد محمد طلعت محمد حسن، تطور مضمون نظرية الذطأ غير العمدي في القانون الجنائي، رسالة دكتوراه، كلية الحقوق جامعة عين شمس، 2015، ص ص200 1040 لاحظ نص قانون العقوبات السويسري لسنة 1937 باللغة الانكليزية والمنشور على الرابط الالكتروني التالي والذي كانت زيارته بتاريخ:

:2019/1/21

\section{https://wipolex.wipo.int/ar/legislation/details/17169}

1041 فعلى سبيل المثال المادة/7 من قانون العقوبات اليوغسلافي (السابق) لسنة 1961، وكذلك المادة/ 28 من قانون العقوبات اليوناني لسنة 1950، والمادة/ 14 الفقرة/ 2 من قانون العقوبات البولوني لسنة 1960، 1932، والمادة/ 9 من من قانون العقوبات السوفياتي (السابق) لسنة 1960، والمادة/ 5 من قانون العقوبات التشيكوسلوفاكي لسنة 1961، والمادة/ 18 من قانون العقوبات لجمهورية المانيا لسنة 1960، 1960، والمادة/ 19 من قانون عقوبات جمهورية رومانيا الاشتراكية لسنة 1986. د. محمد محمد طلعت محمد حسن، مصدر سابق، ص 77. د. د. فوزية عبد الستار، النظرية العامة للخطأ غير العمدي، مصدر سابق، الفقرة رقم 8، ص ص 10. 1042

1957، ص 169-168. 1043 ومن أبرز الأمثلة على هذه التشريعات المادة/ 319 و المادة/ 320 من قانون العقوبات الفرنسي القديم لسنة 1810 والذي تضمن فقط الفوا

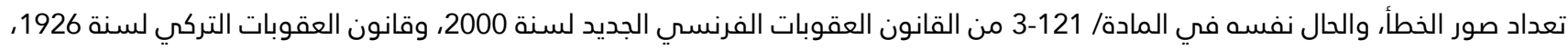
والسويدي لسنة 1962، والفنلندي لسنة 1889، والنرويجي لسنة 1902، وكذلك الحال بالنسبة للعديد من التشريعات العقابية= =العربية ومنها قانون العقوبات المصري لسنة 1937، والسوداني لسنة 1925، والجزائري لسنة 1966، والمغربي لسنة 1963، والقطري لسنة 1971، وقانون العقوبات العراقي رقم111 لسنة 1969 في المادة/ 35 والتي نصت على ان (تكون الجريمة غير عمدية إذا وقعت النتيجة الإجرامية بسبب خطأ

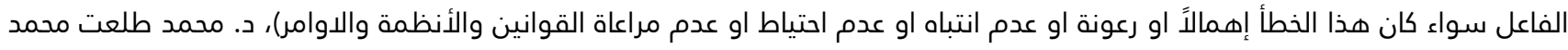
حسن، تطور مضمون نظرية الخطأ غير العمدي في القانون الجنائي، مصدر سابق، ص 76. 
وعلى الرغم من ان هذه التشريعات لم تتطرق لصورتي الخطأ في الرابطة النفسية الا الفقه يرى بضرورة تحقق أحد صورتي الرابطة النفسية من اجل تحقق الخطأ. 1044

2 ـ في القانون الانكلوسكسوني: ومن أبرز الدول التي اخذت بهذا النظام هي إنكلترا والولايات المتحدة الامريكية

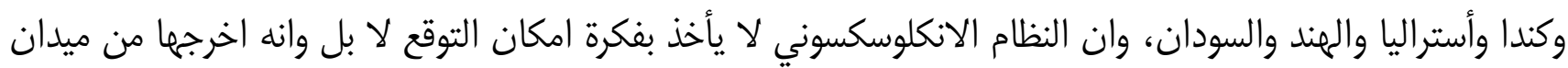

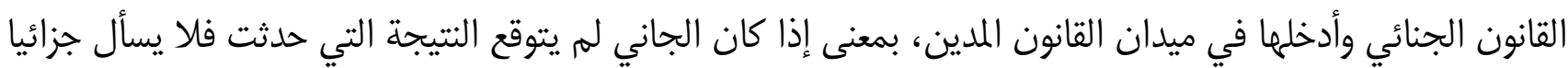

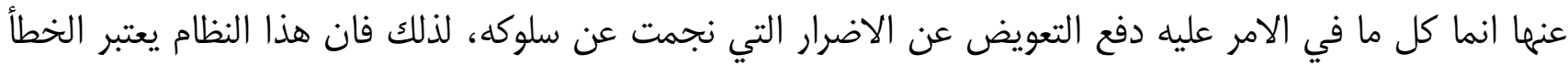

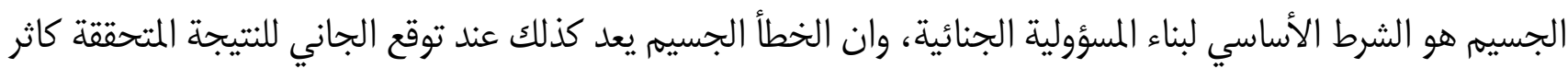
لسلوكه الآثم 1045.

ويفرق هذا القانون بين حالة اللامبالاة التي تتحقق عند ارتكاب الجاني سلوك خطير ويتوقع معه حصول النتيجة

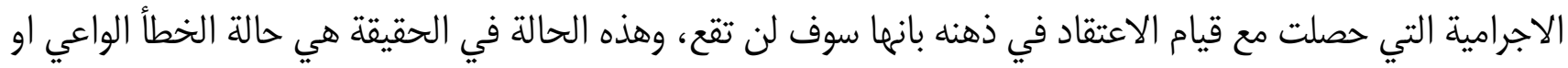

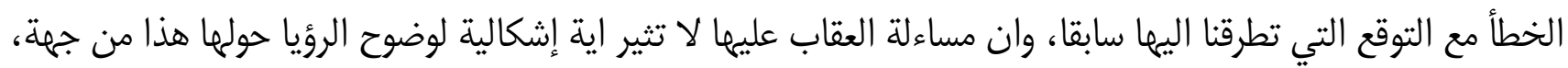

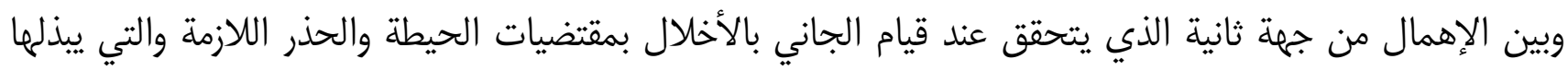

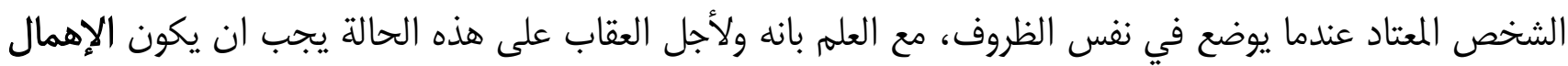

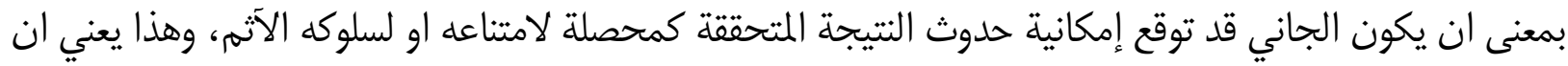

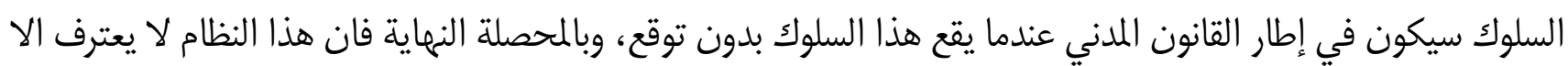

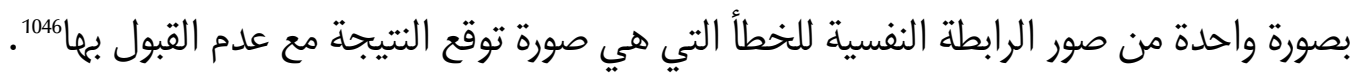

\section{وتبرير هذا الموقف يستند الى ركيزتين أساسيتين،}

الاولى: ان الخطأ بدون توقع لا يظهر ولا يكشف عن خطورة إجرامية ناشئة عن إرادة إجرامية من اجل بناء المسؤولية

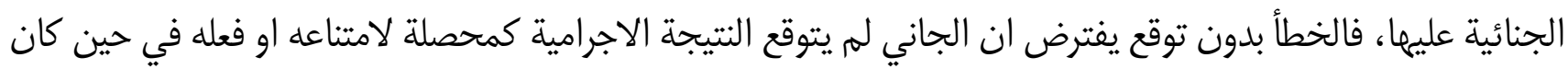

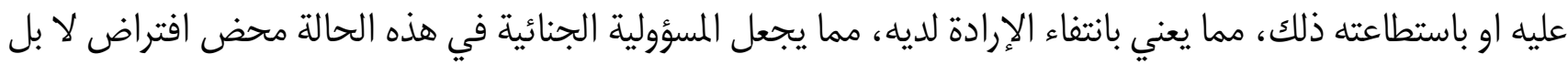

1044 د. شريف سيد كامل محمد، مصدر سابق، ص 841.

1045 د. رمزي رياض عوض، الاحكام العامة في القانون الأنجلو امريكي، دار النهضة العربية، القاهرة، 2007، ص صد 111. د. محمد محي الدين عوض، المبادئ الأساسية التي يقوم عليها القانون الجنائي الأنجلوامريكي، بحث منشور في مجلة القانون والاقتصاد

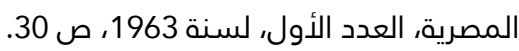

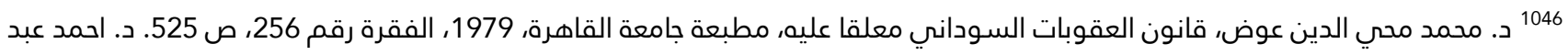
العزيز الالفي، شرح قانون العقوبات الليبي، ط2، المكتب المصري الحديث، القاهرة، 1979، الفقرة رقم 307، ص 321. د. د. محمد محسي الدين عوض، المبادئ الأساسية التي يقوم عليها القانون الجنائي الأنجلوامريكي، مصدر سابق، ص 29. د. محمد إبراهيم زيد، قانون العقوبات المقارن، القسم الخاص، دراسة تحليلية مقارنة للنظم اللاتينية والنظم الأنجلو سكسونية والتشريعات العربية ومشروعات القوانين العربية الجديدة، منشأة المعارف، الإسكندرية، 1974، الفقرة رقم 92، ص 130. 
ونوع من أنواع المسؤولية المادية الامر الذي لا يمكن التسليم به في القوانين العقابية الحديثة، لكون المبدأ العام ان لا جريمة

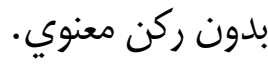

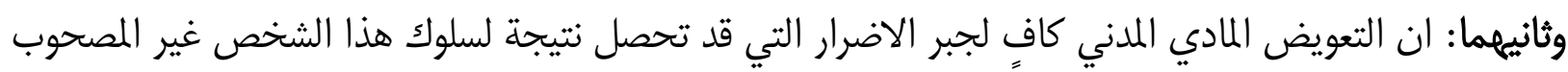

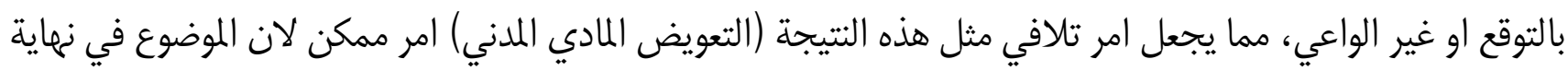
المطاف ما هو الا مبلغ نقدي قابل للاسترداد عند عدم تحقق مسؤولية من حكم به.

\section{وقد تعرض هذا الموقف من الفقه الانكلوسكسوني لانتقادات نتطرق لأبرزها،}

أولها: انكار المتتقدين لهزا النظام ان الخطأ غير الواعي لا يتضمن ارادة إجرامية كما انكروا ان طبيعة المسؤولية

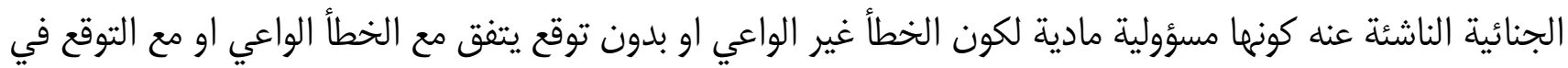

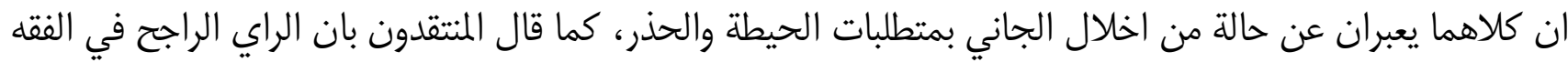

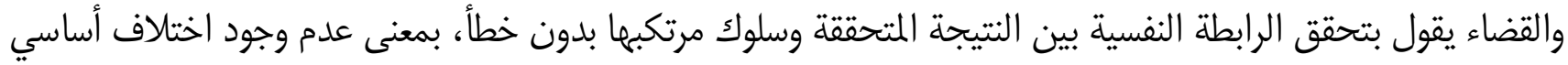

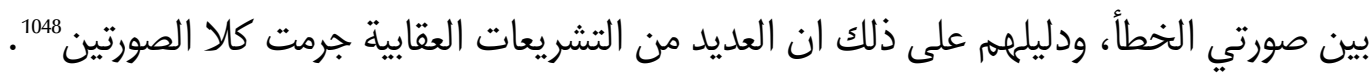

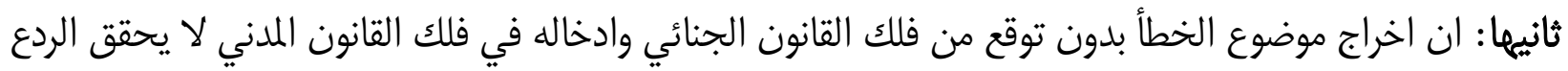

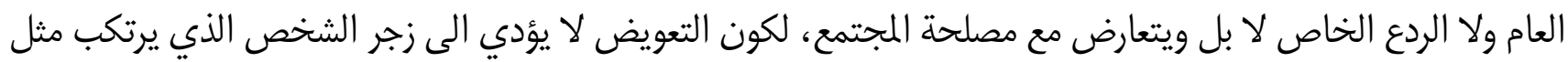

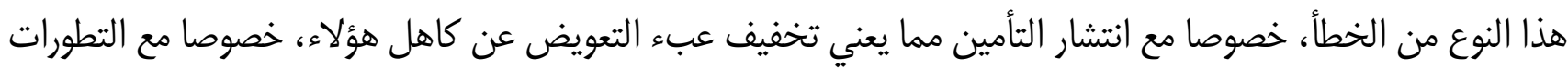

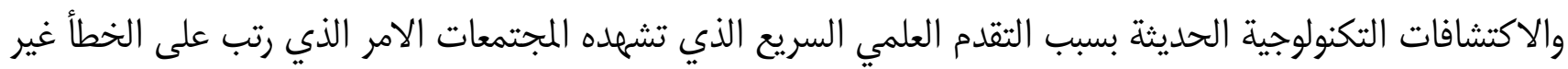
الواعي اضرار اجتماعية جسيمة تكون احيانا اشد جسامة من السلوك المتعمد. 1049

وباعتقادنا، وبالرغه من كل الانتقادات التي وجهت لموقف الفقه الانكلوسكسوني انف الذكر، الا أننا نجد فيه الكثير

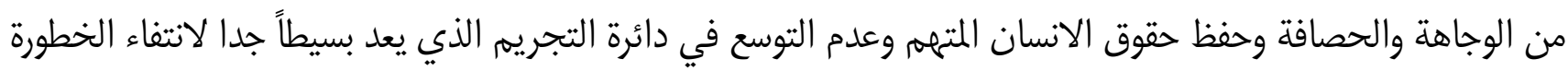

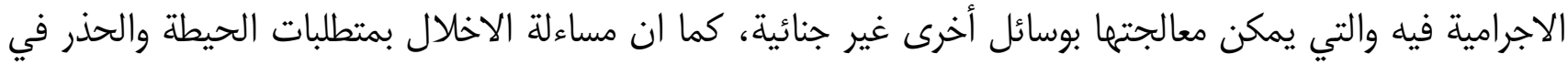

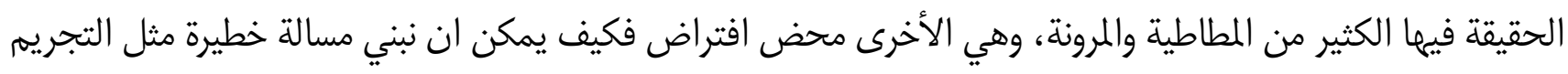

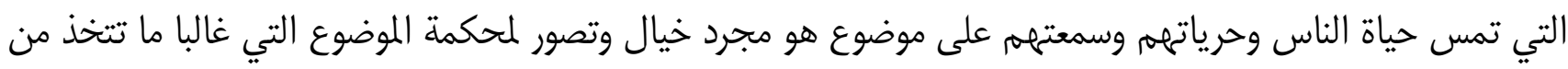

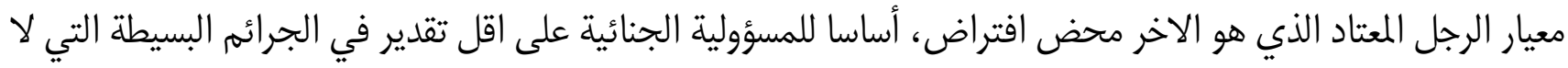

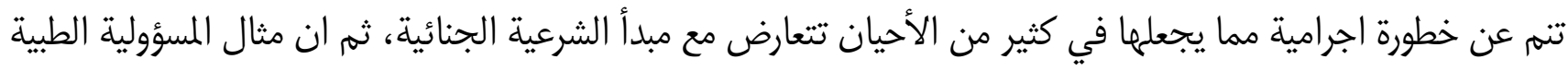

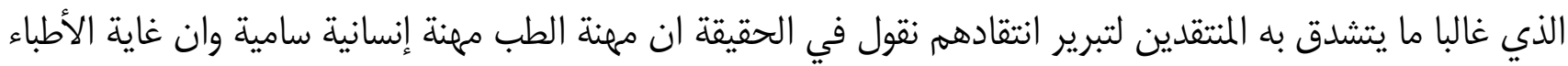

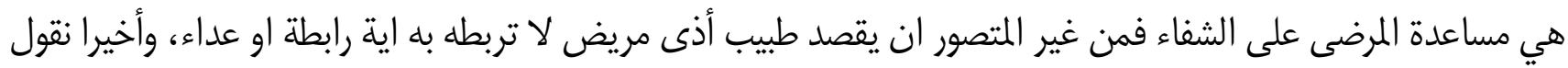

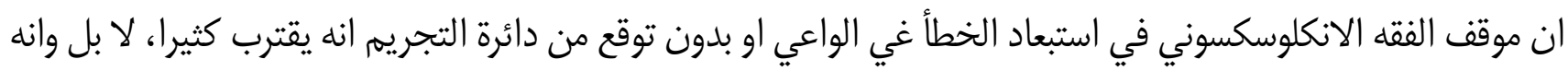

1047 د. محمد محي الدين عوض، مصدر سابق، ص 29. 1048 د. محمود نجيب حسني، شرح قانون العقوبات القسم العام، مصدر سابق، الفقرة رقم 1049 ردم

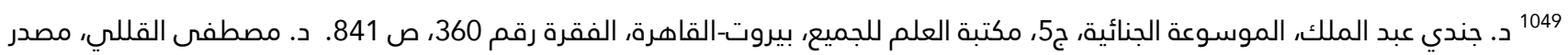

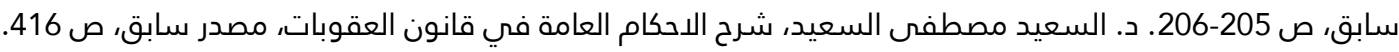


مستمد بطريقة وبأخرى من اراء فقهاءنا المسلمين الاجلاء اللذين ناقشوا باستفاضة مسألة معالجة الحالات المبنية على نوعين

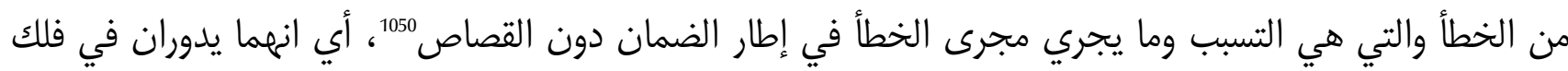
التعويض والدية وهو في الحقيقة موقف غاية في الروعة والدقة ومستنبط من حديث الرسول الأعظم محمد صلى الله عليه

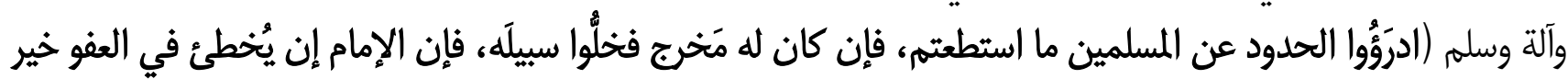
من أن يُخطئ في العقوبة)

كما وان هذا مبدأ غايت في الإنسانية والروعة وتقرير لحقوق الانسان مما يستوجب ان يكون من المبادئ الجنائية الحديثة في معالجة موضوع الخطأ والتي يجب على المشرع ان يقرره بصورة نص في قانون العقوبات.

ثالثا -انتفاء الخطاً إذا استحال على الفاعل توقع النتيجة الاجرامية كأثر لسلوكه: إذا كان من المستحيل على الجاني توقع النتيجة التي وقعت، فان الخطأ لا يكون متحققا في هذه الحالة لانعدام هذه الامكانية او تلك الاستطاعة ويترتب على ذلك استحالة تفاديها. وتأكيدا على هذه الحقيقة فقد استقر قضاء محكمة التمييز العراقية في العديد من قراراتها على ذلك فقد قضت "لا يسال المتهم جنائيا عن الضرر الحاصل جراء التصادم إذا كان متسببا عن خطأ المشتكي نفسه. "ـ1052، وقضت في قرار اخر لها "الأذى الذي أصاب المجني عليه نتيجة سيره على خط القطار لا يسال عنه سائق القطار الذي له يصدر عنه اهمال وتقصير."

وفي قرار اخر لها "لا يسأل المتهم عن الحادث الذي وقع بخطأ المجني عليه وحده دون ان يساهم المتهم فيه." إنمان، وفي قرار اخر لها "لا يسأل المتهمه عن القتل الناتج من الاصطدام إذا كان الحداث واقعا بخطأ المجني عليه." اخر لها "إذا حاول المجني عليه اخذ بندقية المتهم جبرا فثارت طلقة منها في اثناء المجاذبة اصابت المجني عليه فيكون الخطأ صادرا من المجني عليه ولا مسؤولية على المترم. "

1050 سنبحث فيها مفصلا في الباب الثاني من هذه الاطروحة.

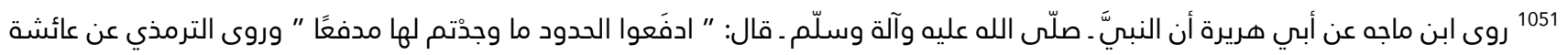

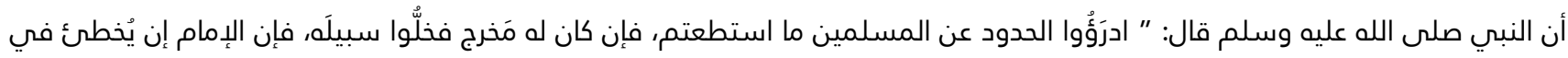

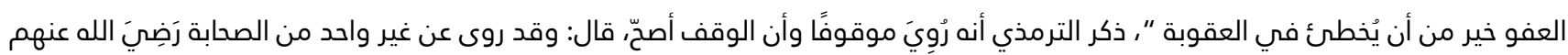
أنهم قالوا مثل ذلك. يقول الشوكاني في كتابه " نيل الأوطار" : حديث ابن ماجه ضعيف، وحديث الترمذي الترّي عن عائشة في إسناده راو ضعيف،

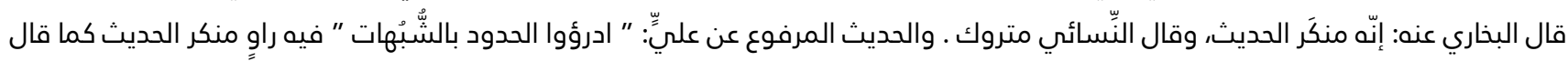

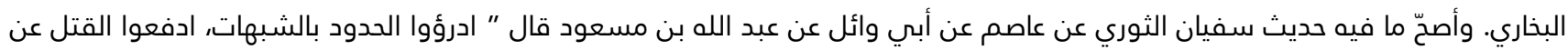

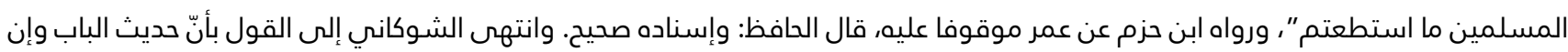

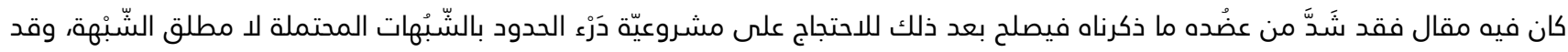

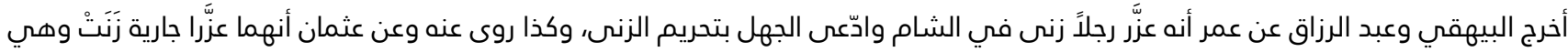
أعجميّة وادّعت أنها لم تعلم التحريم.

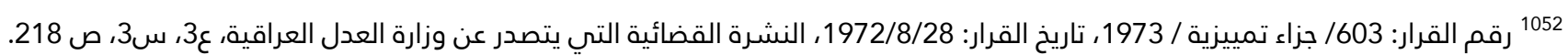

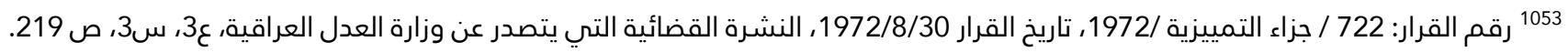

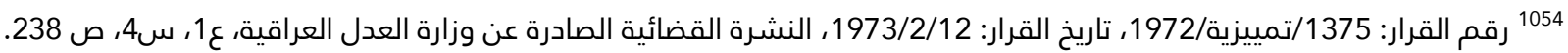

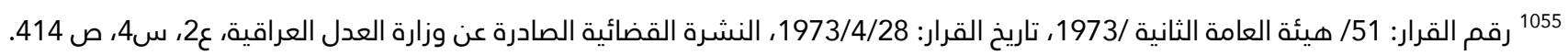
1056 رقم القرار: 1973/1924، 1974/3/18، 1974، النشرة القضائية القرارية الصادرة عن وزارة العدل العراقية، ع1، س5، ص 404. 
وفي قرار اخر لها "لا يكون السائق قد ارتكب خطاً سبب دهس الطفلة عليها بمؤخرة السيارة عند تحركها إذا كانت المجني عليها قد خرجت من داخل دارها التي تقف السيارة امامه واصطدمت بالسيارة وكان الشارع خاليا عند بدء السيارة بالحركة." ب057، وفي قرار اخر لها "إذا كان المتهم يقود سيارته بسرعة معتدلة وقد عبر من امامه فجأة طفل فاصطدم بالسيارة لعدم اتخاذه الحيطة عند العبور فلا يكون المتهمم قد ارتكب خطأ سبب الدهس ويعتبر الحادث واقعا نتيجة خطأ المجني عليه وحده." "1058، وفي قرار اخر لها "إذا عبر المجني عليه الشارع في الوقت الذي اقتربت فيه السيارة المتههم من المجني عليه اقترابا تعذر معه تلافي الاصطدام فلا يمكن نسبة خطأ للمترهم يستوجب مساءلته عن الحادث."1059، وفي قرار اخر لها "إذا كان انقاب عربة التراكتور التي سببت إصابة المجني عليه وبالتالي وفانة قد حصلت قضاء وقدر وليس بسبب خطأ السائق فلا يجوز ادانته عن الحادث لان قيادته لتراكتور تمت دون إجازة.".

كما ان محكة النقض المصرية قد قضت بانه " متى كان الحكم إذا قضى ببراءة المتهمم بالقتل الخطأ ورفض الدعوى المدنية قد عول في ذلك على اقوال الشاهد من ان الترام كان يسير سيرا عاديا وكان المتهم يستعمل جهاز التنبيه طوال الطريق وقت حصول الحادث وانه لم يكن في استطاعته ان يتفاداه لان المصاب قد ظهر فجأة على بعد ثلاث أمتار .... وانه مما يتنافى مع طبائع الأشياء ان يتوقع ان كل من ينزل من الرصيف يريد عبور الشارع من جهة أخرى وان من حقه ان

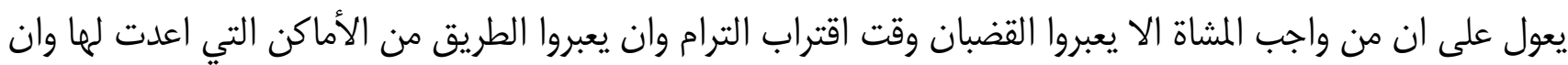
يتبصروا مواقع اقدامهم عند عبورهم ومتى كان ذلك فان ما قاله الحكم سائغ في العقل والقانون" . 1061 كما وقضت في حكم اخر لها "لما كانت الوقائع كما أوردها الحكم تدل على ان العيار الذي انطلق لم يكن ليصيب أحدا لولا انفجار ماسورة السلاح وان إصابة المجني علية حدثت من شظايا الماسورة المتفجرة بسبب عيب في صناعتها بما لم يكن للمتهه يد فيه ولم يكن في استطاعته ان يتوقعه .... فان الحكم يكون صحيحا فيما انتهى اليه من اعتبار الرابطة السبيية غير متوفرة بين خطأ المتهم واصابة المجني علية والقضاء ببراءة المتهم من تهمة القتل ينت الخطأ ".

ونظرا لأهمية هذا المبدأ الوارد في القرار اعلاه، فقد ذهب جانب من الفقه المصري الى القول بان اتجاه محكمة النقض بانتفاء الرابطة السبيية بين سلوك المتهم والنتيجة الجرمية المتحققة، (رغم ان انتفاء الخطأ لدى المتهم لا يكاد يثير اي

1057 رقم القرار: 1884/جزاء أولى - تمييزية /1980، تاريخ القرار: 1981/12/6، مجموعة الاحكام العدلية التي تصدر عن وزارة العدل العراقية، ع4،

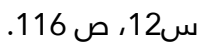
1058 رقم القرار: 195/جزاء أولى -تمييزية/1982، تاريخ القرار: 1982/6/5، مجموعة الاحكام العدلية التي تصدر عن وزارة العدل العراقية، ع1، س 12 ر059 رقم القرار: 12، صن 1982/485/جزاء اولى/تاريخ القرار: 1982/6/6، مجموعة الاحكام العدلية التي تصدر عن وزارة العدل العراقية، ع4، س . 92 1060 رقم القرار: 1662، صنائايات أولى/986-985، تاريخ القرار: 1986/7/16، المبادئ القانونية في قضاء محكمة التمييز القسم الجنائي، اعداد القاضي إبراهيم المشاهدي، مطبعة الجاحظ، بغداد، 1990، ص 156. 1061 قرار محكمة النقض المصرية 5/ ابريل/1954 والمنشور في مجلة المحاماة المصرية، س35، رقم655، 1352 1062 نقض 23 يونية سنة 1963، مجموعة احكام النقض المصرية، س14، رقم 102، ص 530. 
اشكال) بسبب كون المتهم لهم يكن باستطاعته توقع النتيجة الاجرامية أي ان محكمة النقض أعطت للرابطة السببية طابعا معنويا، وجعلت استطاعة التوقع عنصرا مشتركا بين الخطأ وعلاقة السبيية.

الان وبعد ان انتهينا من بحث موضوع التوقع وأصبح واضحا للعيان بوجود صلة بينه وبين التسبب على أساس من ان

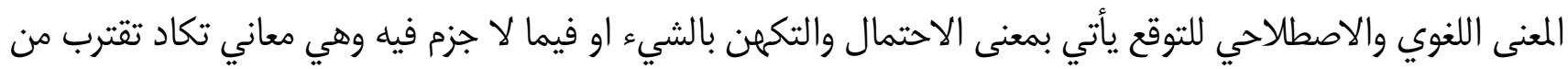

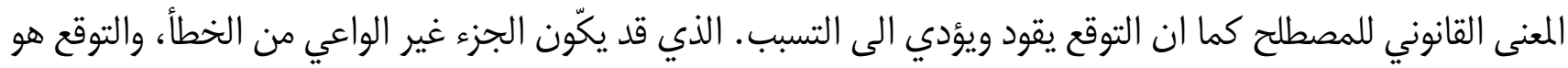

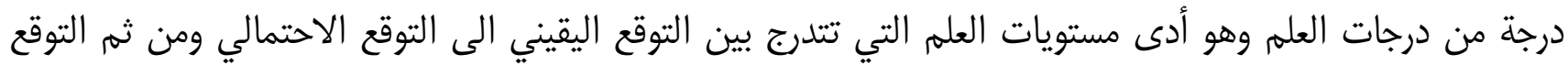

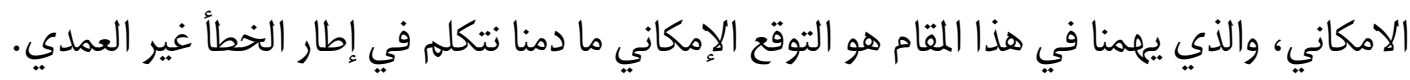
وهنا تتضح أولى الصلات بين التوقع والتسبب. وان مصدر هذه الصلة تتبع بالإضافة الى ما ترشح من المعنى اللغوي

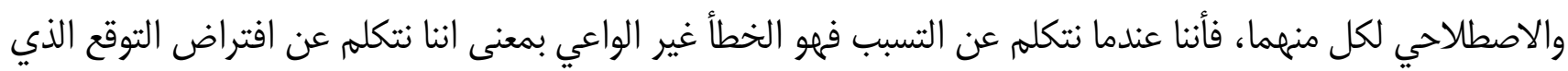

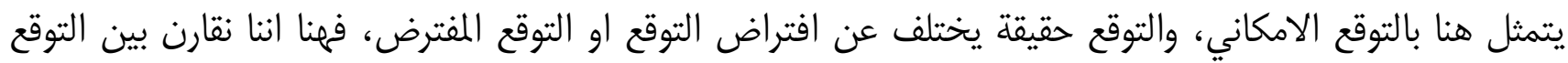

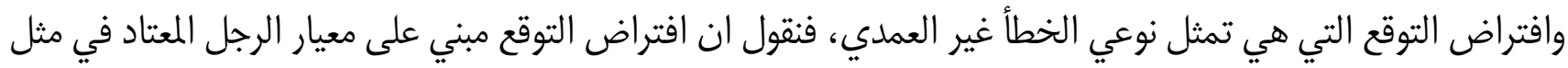

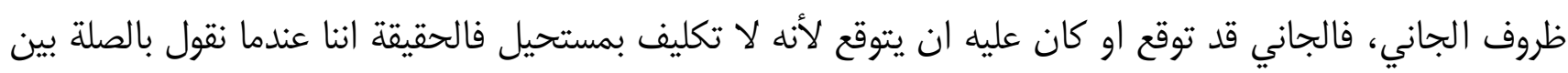

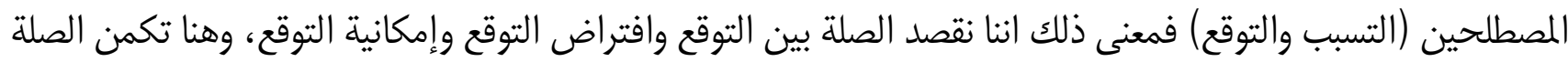

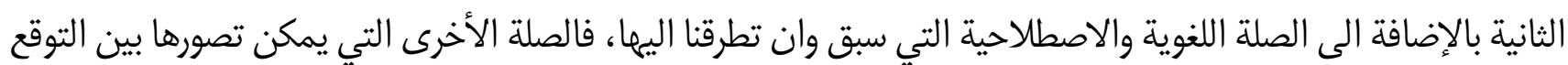

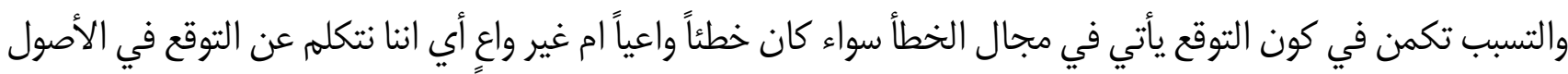

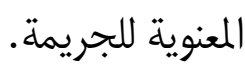

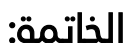

بعد ان أنهينا البحث في هذا الموضوع فقد كان لنا عدد من النتائج والاستتتاجات والمقترحات نوردها فيما يلي:

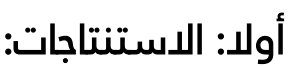

1-عدم صلاحية خطورة الجاني وسلوكه الخطر كأساس للعقاب على الجرائم غير العمدية لكون المشرع لا يعاقب على المانى

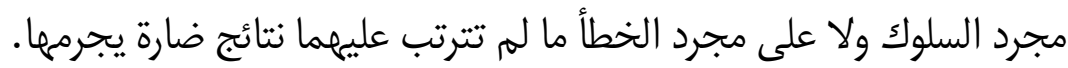

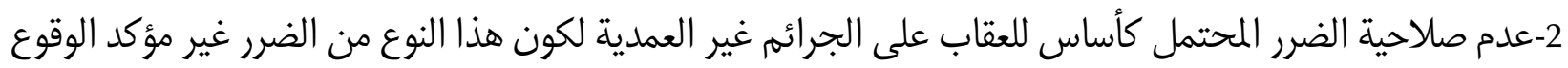

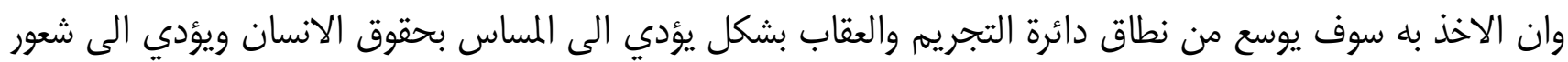
الافراد بعدم عدالة العقوبة الامر الذي يدفعهم الى عدم الخوف منها مما قد يدفع الى تنامي ظاهرة الاجرام. 3-ان تأسيس المسؤولية الجنائية على فكرة أخلاقية لا تتوائم مع التطورات الكبيرة التي شهلتمها المجتمعات وما رافقها

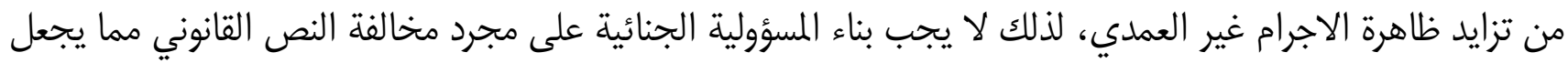

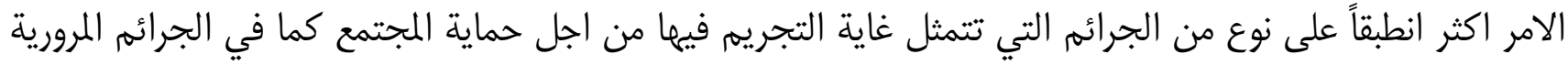

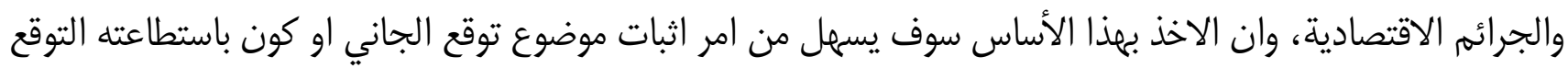


التي هي في الأساس مسألة صعبة وصعبة جدا، الامر الذي دفع بهم للتخلي عن فكرة الخطأ كأساس للتجريم في هذا

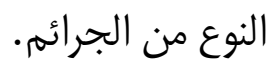

4-ان الركن المعنوي في الخطأ هو ان المشرع يفترض الحيطة والحذر بالجاني وان هذا الأخير قصّر فيها، بمعنى هذا

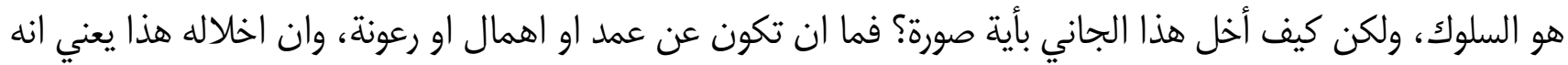

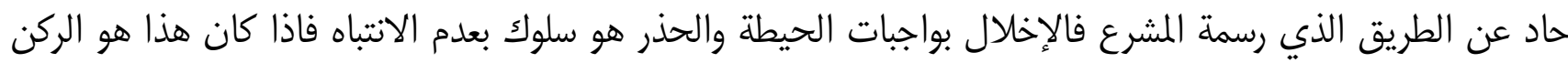

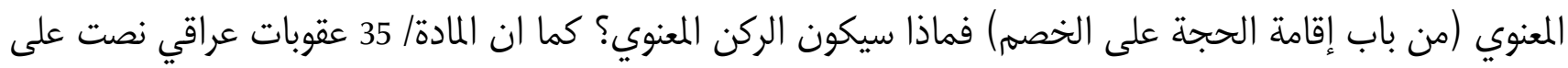

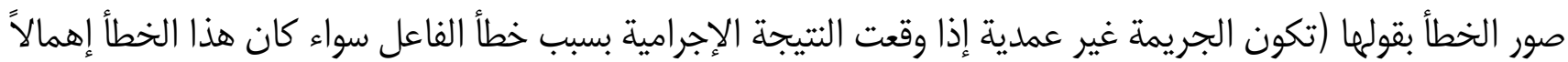

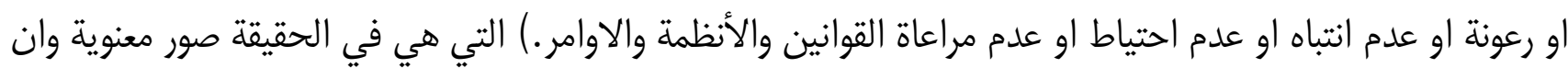

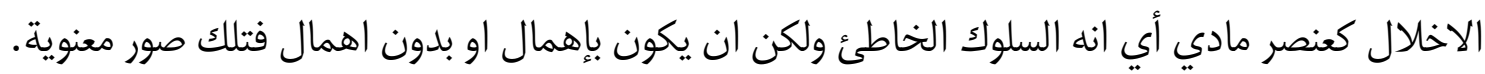
5-هناك خلط بين العنصر المعنوي والمادي للخطأ، فالعنصر المادي للخطأ يتمثل في الاخلال بمقتضيات الحيطة والحذر ،

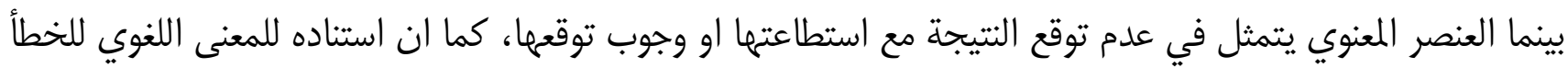

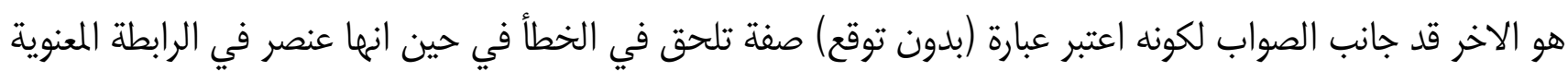

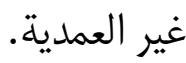

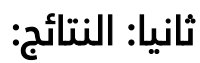

1-لم يفرد المشرع الجنائي العراقي نصا عاما ينظه حالة الغلط في فهم الوقائع وتقديرها وفقا لوجهتها الصحيحة، ولكنه

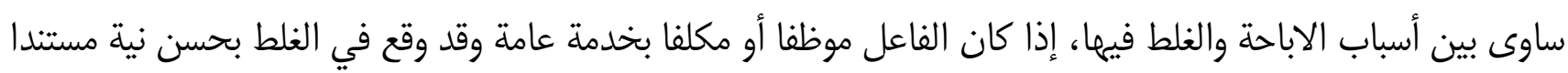

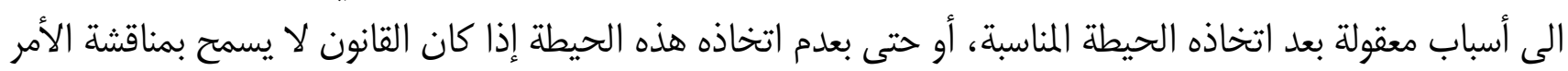

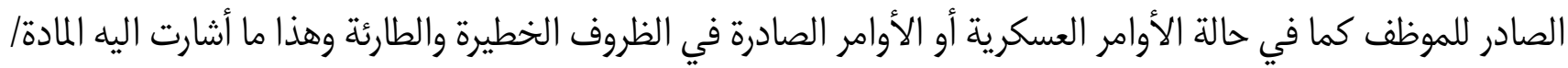

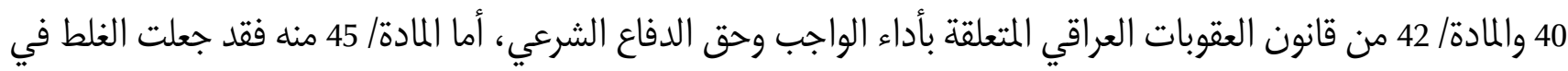

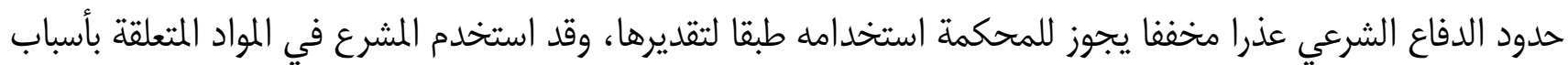

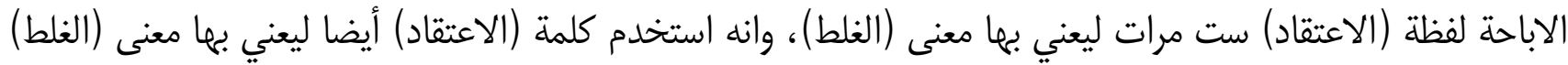

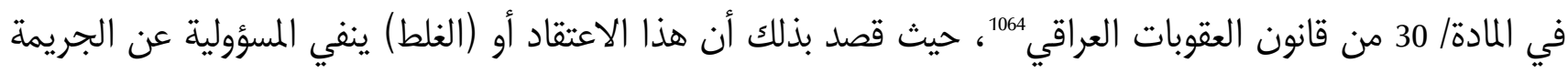

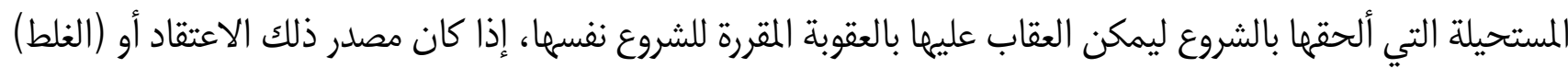

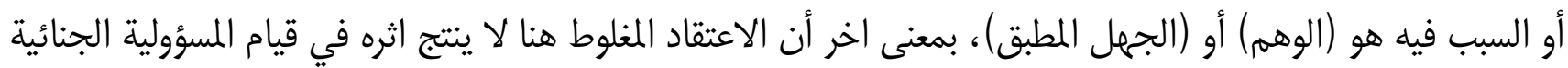

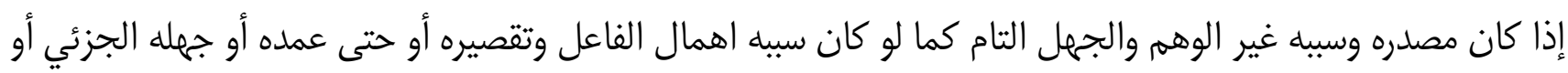

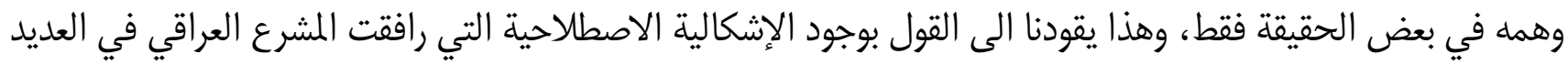

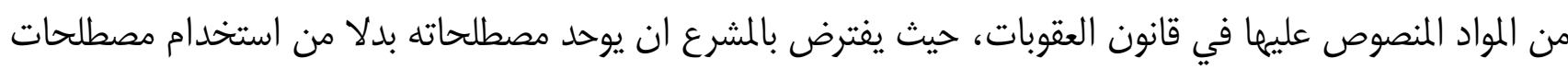
معينة للإشارة الى معنى اخر، لا هذا الامر سيقود بكل تأكيد لعدم استقرار القضاء.

مالم 1064 المادة (30) عقوبات التي نصت على (...ويعتبر شروعا في ارتكاب الجريمة كل فعل صدر بقصد ارتكاب جناية أو جنحة مستحيلة التنفيذ .... مالم يكن اعتقاد الفاعل صلاحية عمله لأحداث النتيجة مبنيا على وهم أو جهل مطبق). 


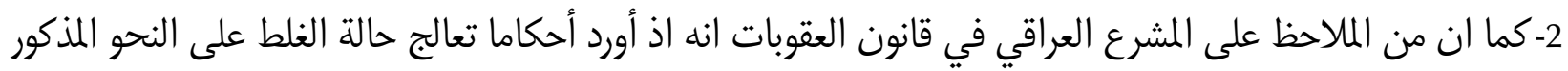

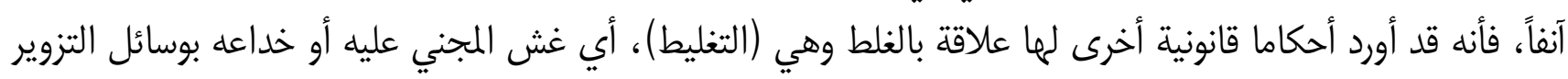

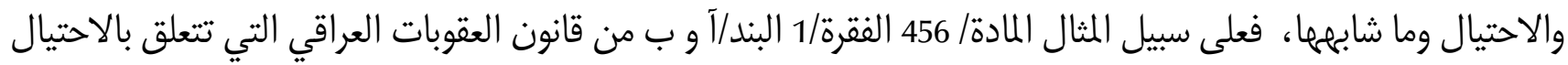

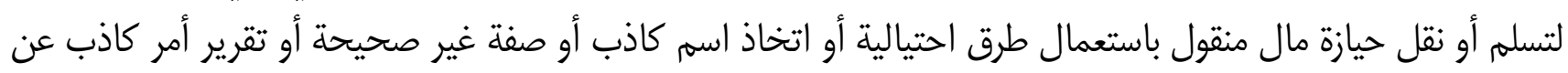

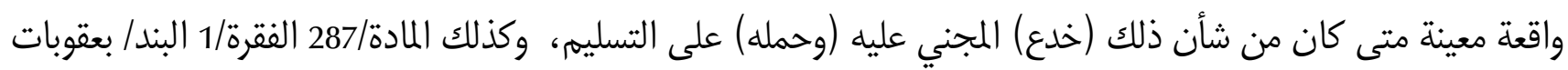

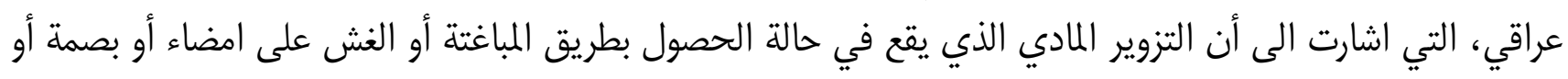

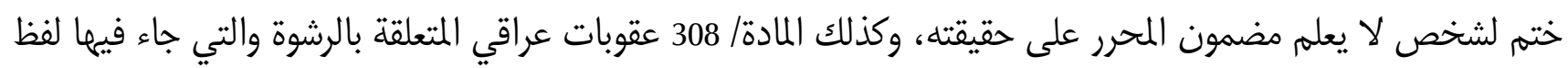
(الاعتقاد) لتشير الى (الغلط) الذي لا يؤثر في قيام المسؤولية وبقائما.

9- وبالرغم من كل الانتقادات التي وجهت لموقف الفقه الانكلوسكسوني الذي لا يأخذ بفكرة امكان التوقع لا بل وانه

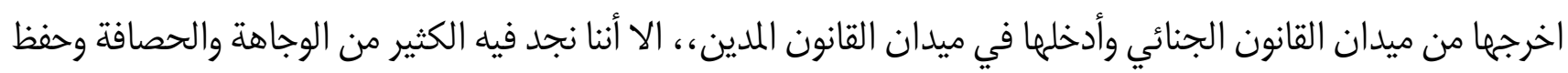

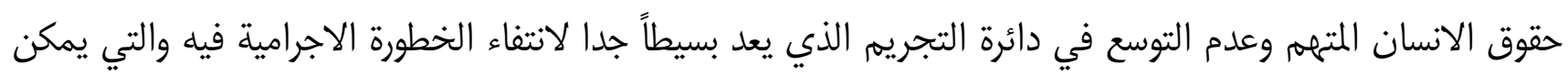

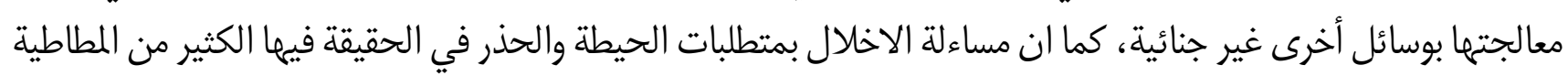

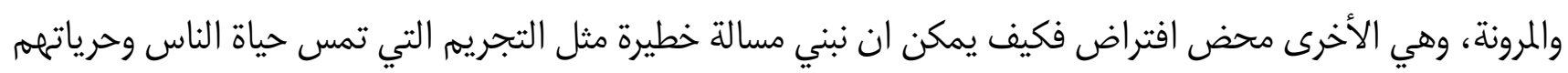

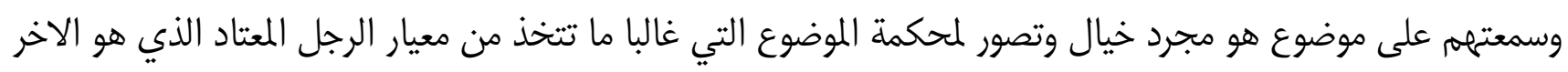

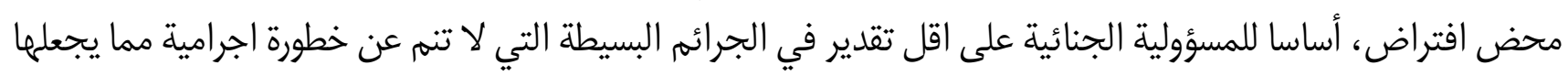

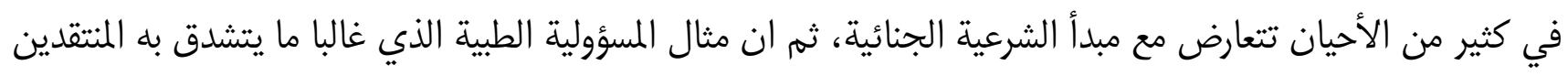

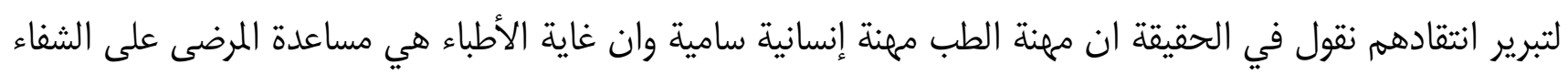

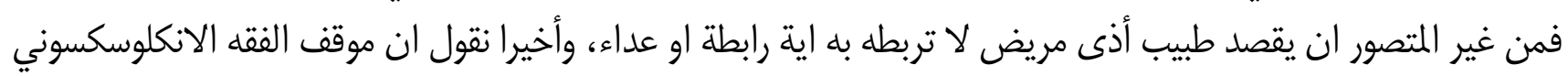

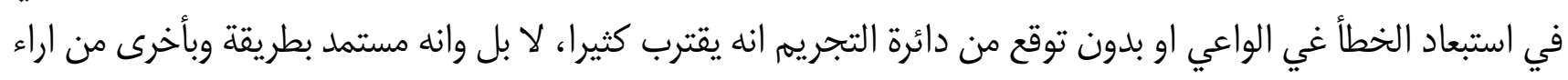

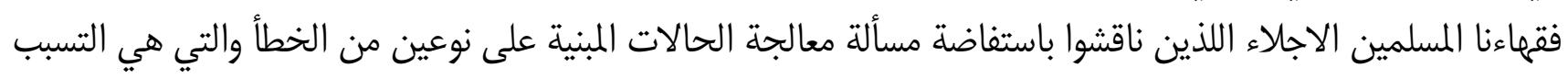

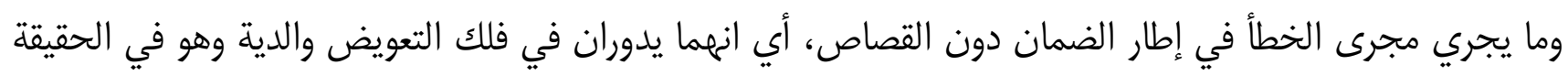

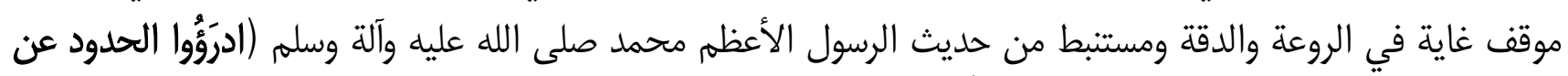

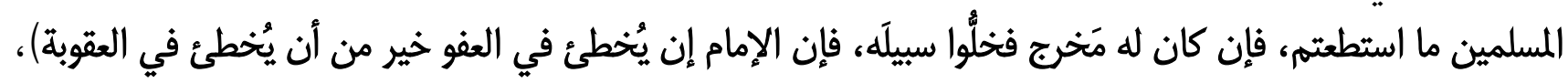

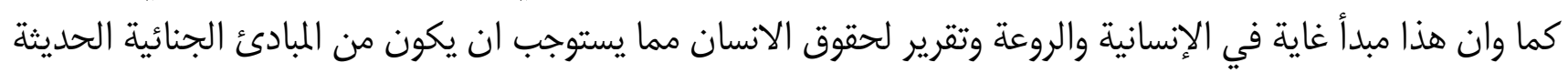

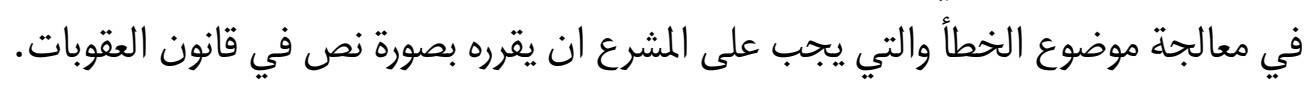

10-وجود صلة بين التوقع وبين التسبب على أساس من ان المعنى اللغوي والاصطلاحي للتوقع يأتي بمعنى الاحتمال

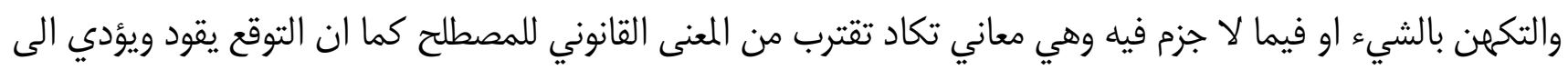

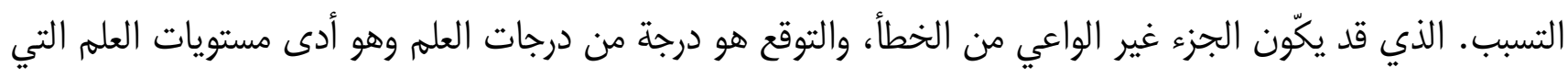

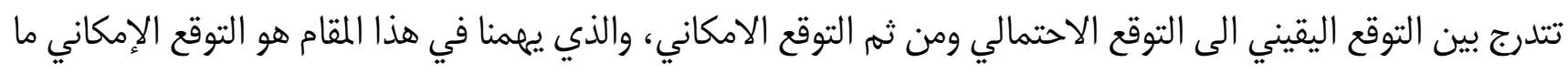

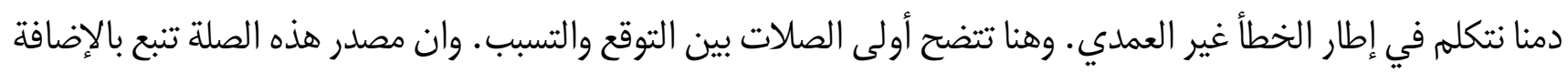


الى ما ترشح من المعنى اللغوي والاصطلاحي لكل منهما، فأننا عندما نتكلم عن التسبب فهو الخطأ غير الواعي بمعنى اننا

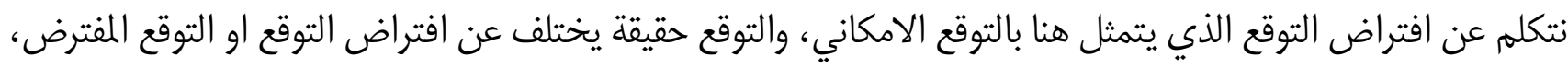

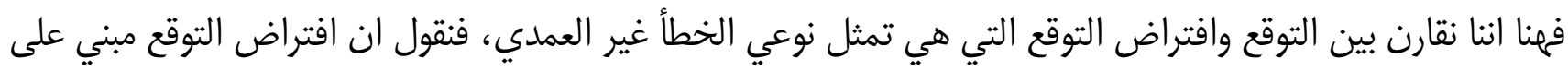

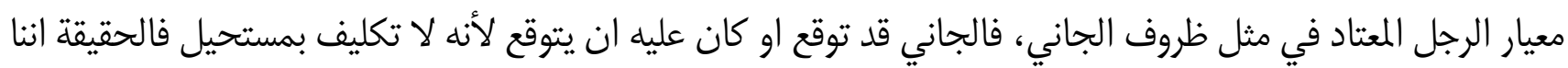

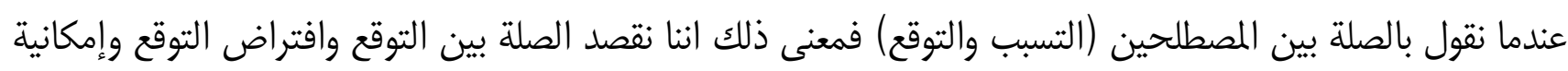

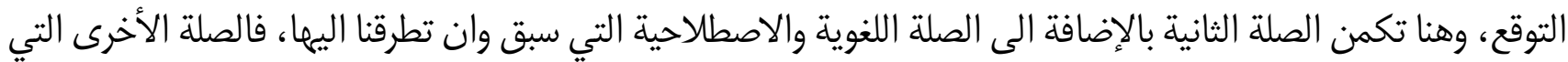

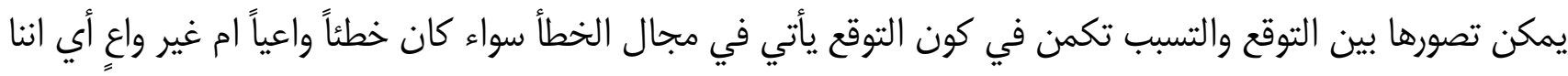
نتكلم عن التوقع في الأصول المعنوية للجريمة.

\section{المقترحات:}

1-ندعو مشرعنا الحصيف لمعالجة الإشكالية الاصطلاحية التي رافقته في صياغة احكام قانون العقوبات من خلال

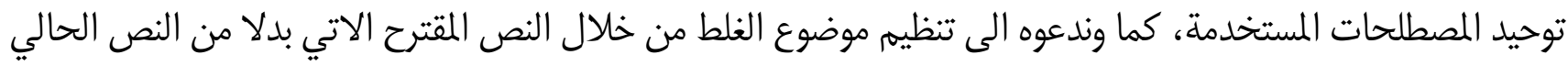

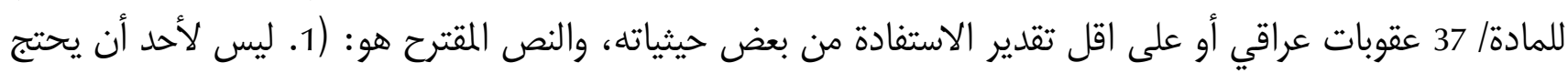

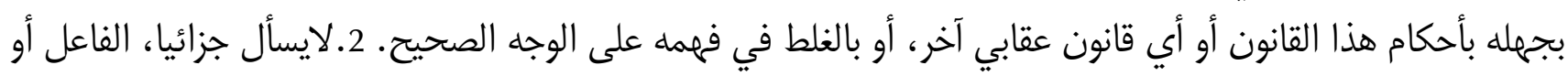

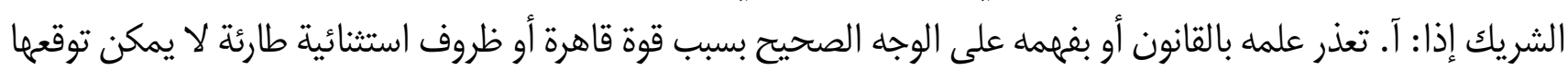

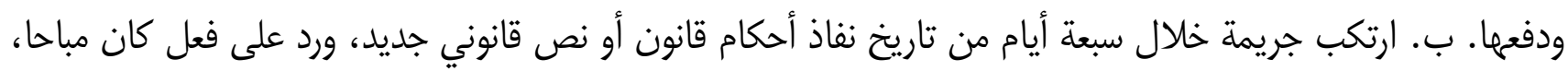

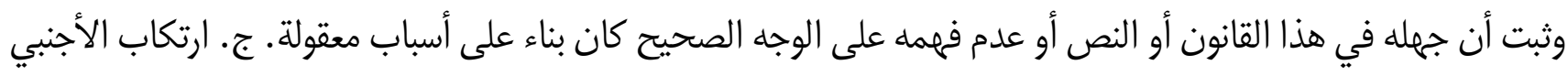

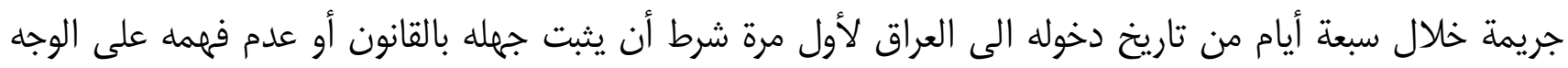

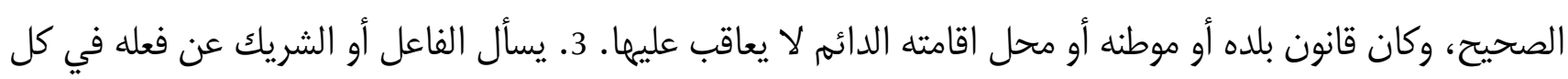

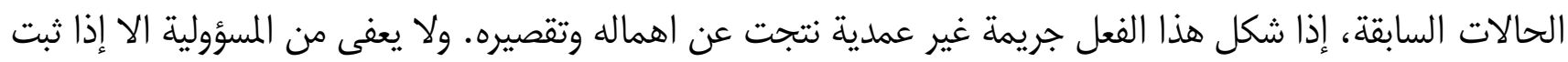

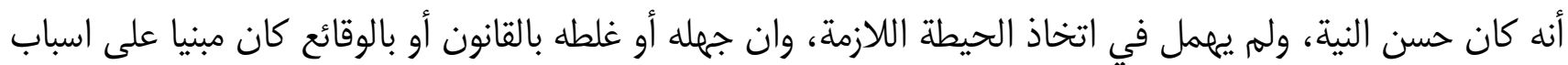
كافية ومعقولة). 


\title{
الغش في مرحلة تنفيذ عقد البيع
}

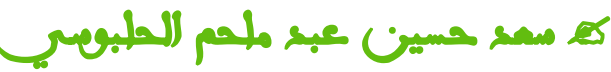 \\ تحت اشراف الأستاذ الدكتور}

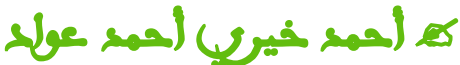 \\ طالب باحث
}

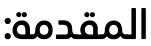

قد تتم مرحلة المفاوضات على عقد البيع وإبرامه بشكل سليم وبما يتطابق مع ما يستوجبه مبدأ حسن النية في التعامل,

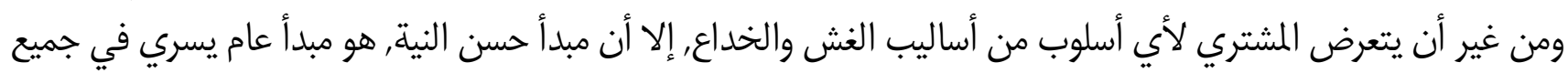

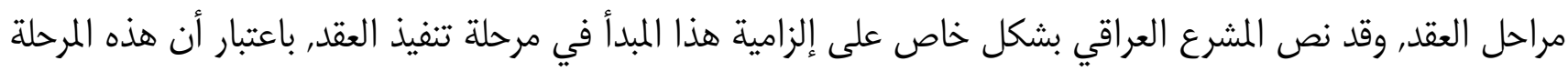

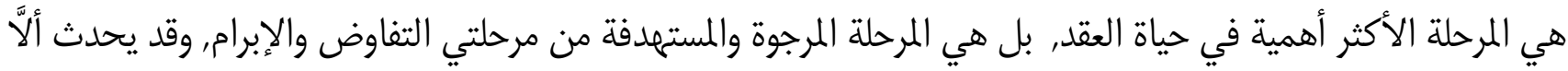

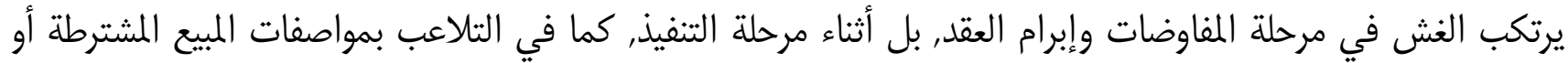

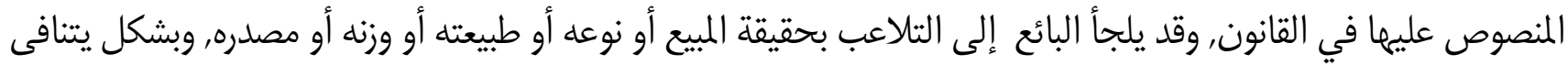

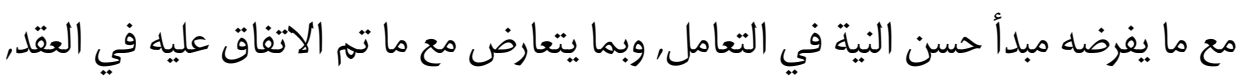

إلا أن المشرع ورغبةً منه في حماية المشتري ولكي يحقق العقد الغرض المقصود منه, فقد جعل البائع بموقف الضامن

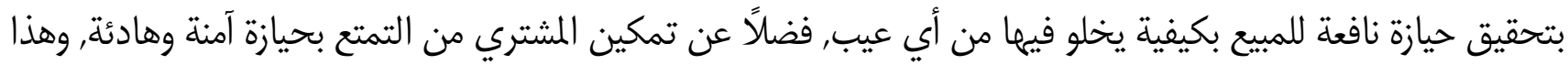

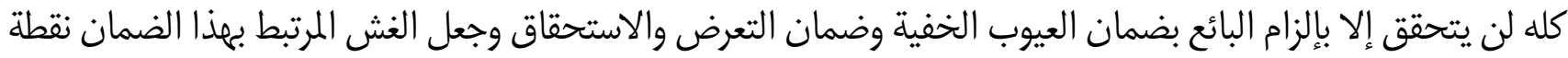

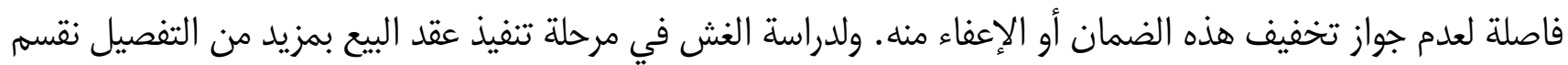

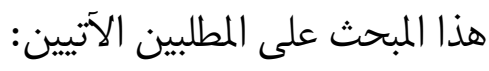

\section{المطلب الأول: عدم التنفيذ بحسن نية} المطلب الثاني: الغش المرتبط بضمان البائع

\section{المطلب الأول: عدم التنفيذ بحسن نية}

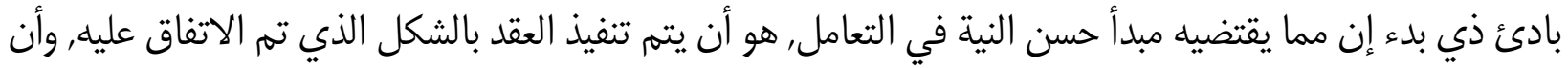

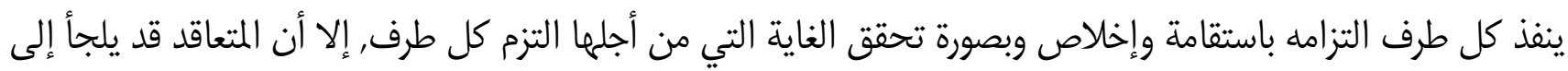

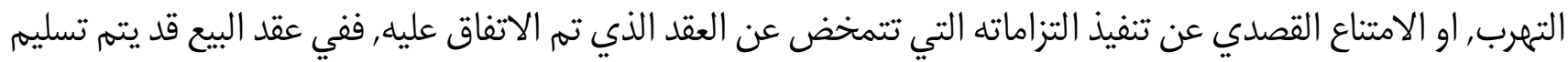

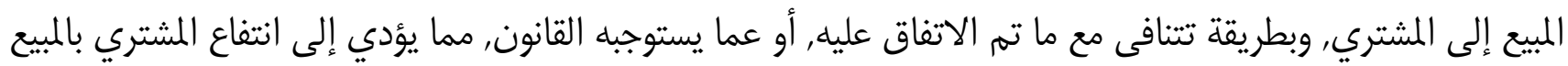

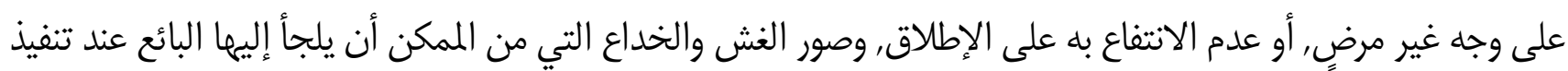

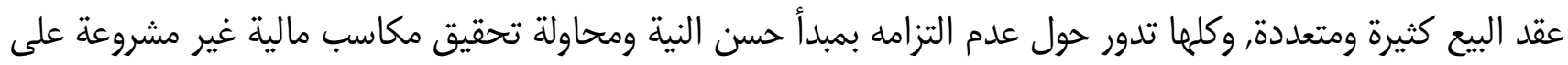

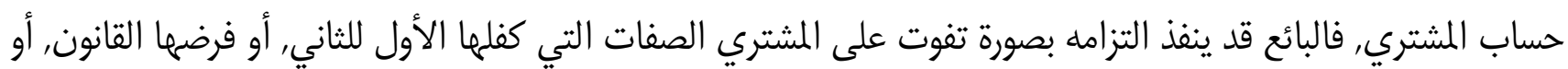

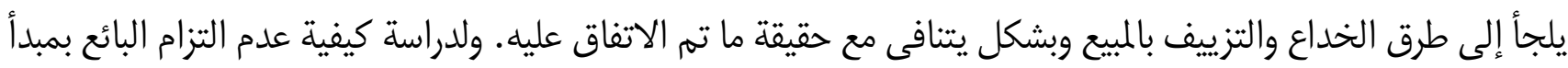
حسن النية عند تنفيذه عقد البيع, نقسم هذا المطلب على الفرعين الآتيين: 


\section{الفرع الأول: عدم الالتزام بتسليم مبيع مطابق للمواصفات. الفرع الثاني: الخداع والتزييف في المبيع.}

\section{الفرع الأول: عدم الالتزام بتسليم مبيع مطابق للمواصفات}

قد يسعى البائع باستعمال أساليب الغش والخداع إلى عدم الالتزام بمطابقة السلع والخدمات التي يقدمبا للمواصفات المتفق عليها, أو المواصفات القياسية المحلية والدولية, بهرف تحقيق ربح مادي غير مشروع على حساب صحة وأمن ومصالح

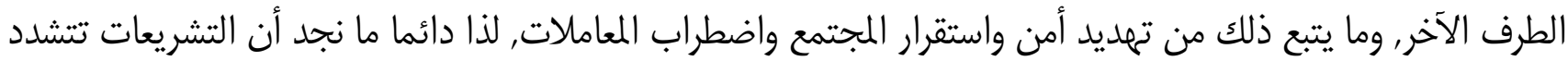
في التعامل مع السلع والخدمات المغشوشة والتي لا تنطبق مع المواصفات المعتمدة لها في سبيل المحافظة على صحة و أمن ومصالح الأفراد. ولدراسة دور الغش في مخالفة المواصفات الاتفاقية و القياسية في عقد البيع بمزيد من التفصيل نقسم هذا الفرع على المقصدين الآتيين:

\section{المقصد الأول: عدم الالتزام بالمواصفات الاتفاقية}

من المعلوم أن للمتعاقد استنادًا لقاعدة العقد شريعة المتعاقدين, أن يحدد بعض المواصفات للسلعة التي يرى أن إشباع

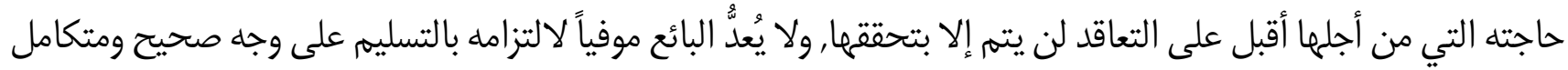
إلا بتحقق هذه المواصفات في السلعة عند التسليم, رغم خلوها في هذا الفرض من العيوب ورغم اتخاذ البائع من إجراءات تصير معها مأمونةً في حيازتها واستعمالمها (1065).

وإن الالتزام بوجود صفات معينة في المبيع قد ينشئ عن تعهد صريح من البائع, أو عن اشتراط المشتري وجودها في المبيع, كما قد ينشأ هذا الالتزام عن العرف التجاري (1066). ويُعدٌّ تخلف الصفة التي كفل البائع وجودها في المبيع كافيًا بحد ذاته لقيام مسؤوليته أيًا كانت هذه الصفة, لأن أهمية الصفة تتحدد بالنظر إلى شخصية المشتري الذي اشترط وجودها في المبيع, فلا يعتد بتحديدها بالعنصر الموضوعي, لذا فإن شرط التأثير غير مطلوب في هذه الصورة, فاشتراط المشتري وجود صفة في المبيع يدل على أن إرادته قد اتجهت إلى أن لها أهمية, ولا يستطيع البائع أن يتهرب من المسؤولية بإثبات أن الصفة التي كفلمها وتخلفت لا تنقص من قيمة المبيع أو من نفعه (1067). وبطبيعة الحال فإن المنتج أو البائع يهدفان من وراء خلو المبيع من الصفات المشروطة أو المكفولة باستخدام أساليب الغش والخداع إلى تحقيق الربح عن طريق تسليم سلع ذات مستوى أدنى من المتفق عليه, أو إدخال عناصر أقل جودة فيها,

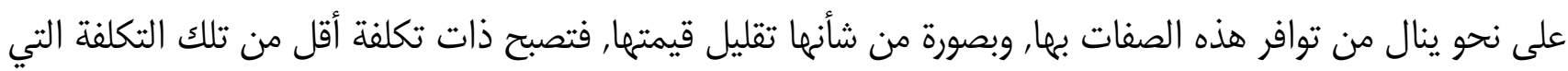
يلتزمان بموجبها متى تحققت هذه الصفات, لذا فإن عدم تحقق المواصفات المتفق عليها في المبيع على هذا النحو يعد من هن من من قبيل الغش والخداع (1068).

(1065) د. جعفر الفضلي, الوجيز في القانون المدني, ط2,المكتبة القانونية, بغداد, بلا سنة طبع, ص 130؛ د. عمر محمد عبد الباقي, الحماية

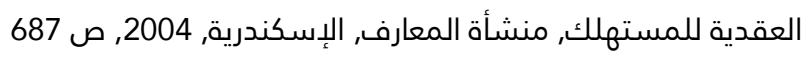

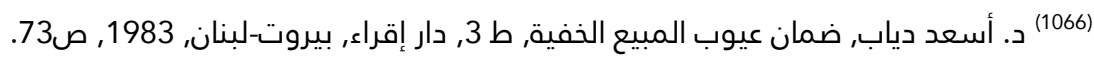

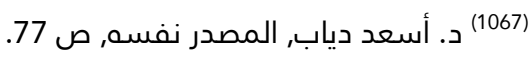

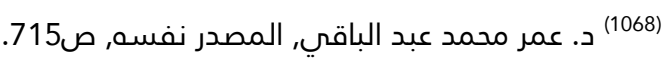




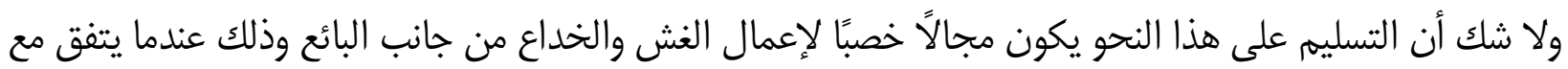

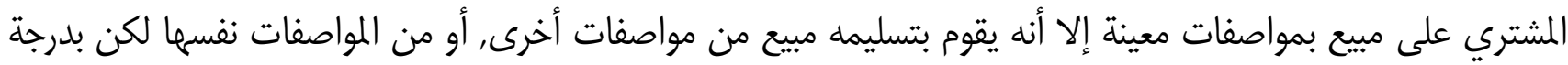

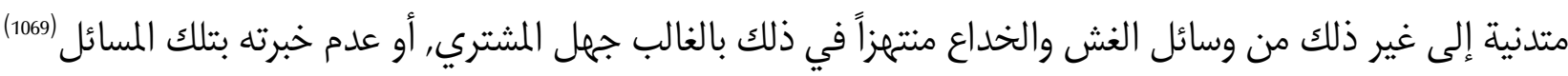
ومن خلال ملاحظة الأحكام التي أوردها المشرع العراقي بخصوص العيوب الخفية, يلاحظ أن المشرع العراقي لم

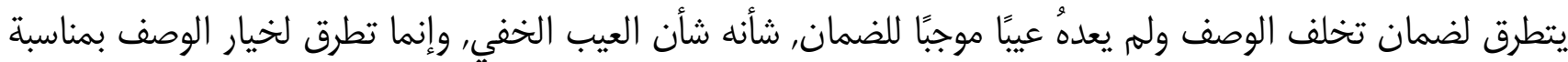

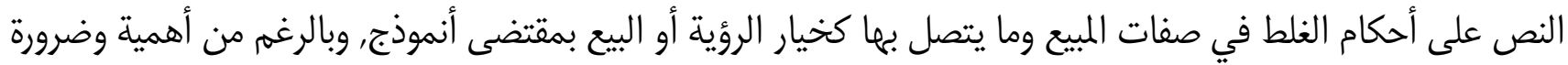

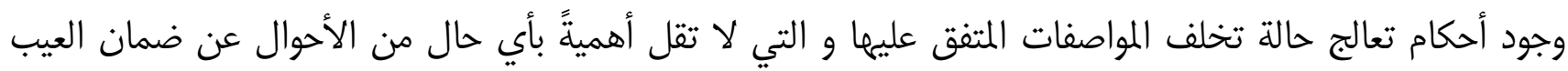

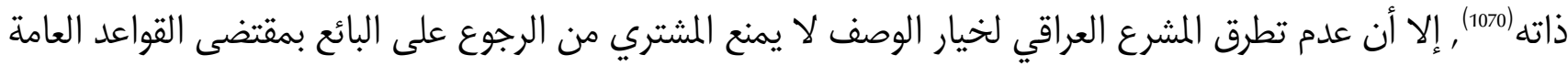

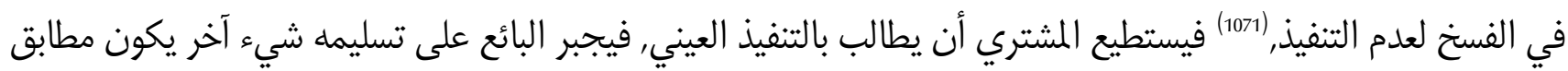

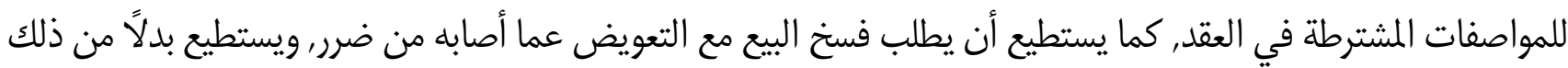

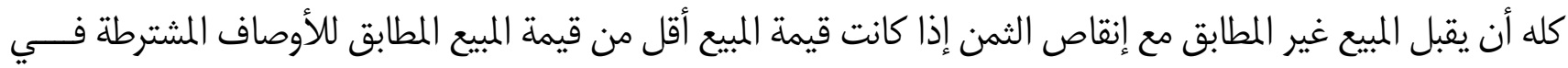
العقد (1072.).

أما المشرع المصري فقد نص بشكل واضح على أن البائع يكوم ملزمًا بالضمان إذا لم تتوافر في المبيع وقت التسليم

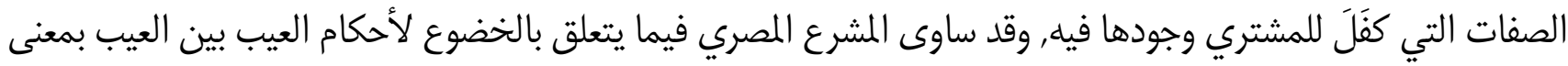

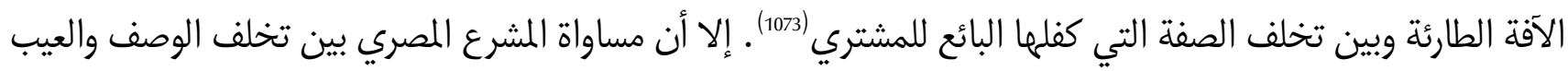

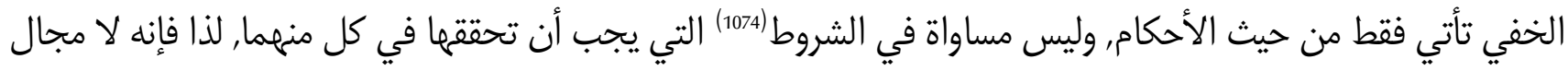

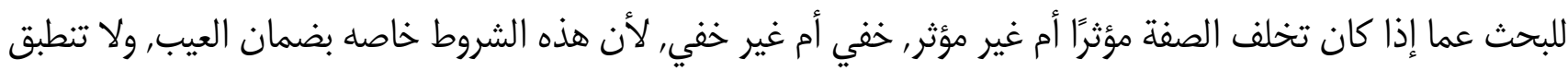

(1069) د. هلدير أسعد أحمد, نظرية الغش في العقد, ط2, دار الكتب العالمية, بيروت-لبنان, 2013, ص375.

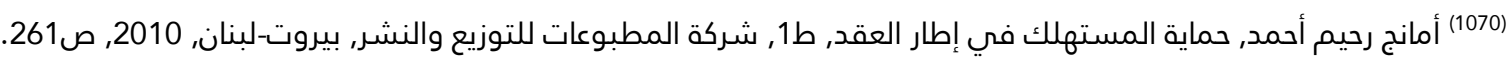
(1071) إلا أن المشرع العراقي خرج عن القواعد العامة هذه في البيع بمقتضى نموذجة, والذي نص عليه في المادة(518) من القانون المدني, فإذا ثبت أن المبيع لا تتحقق فيه مواصفات النموذج الذي اشترى على مقتضاه, فإن المشتري مخيراً بين فسخ عقد البيع, أو قبول المبيع بالثمن

المسمى, دون أن يكون له في هذه الحالة الأخيرة الحق بالتعويض عن فوات الوصف المتفق عليه بمقتضى النموذج. (1072) د. جعفر الفضلي, مصدر سابق, 130 ؛ د. عبد الرزاق السنهوري, الوسيط في شرح القانون المدني, ج 4 ، دار إحياء التراث العربي, بيروت-

لبنان, بلا سنة طبع, ص237. (1073) إذ نصت المادة (447) من القانون المدني المصري علدئ على أنه (( يكون البائع ملزمًا بالضمان إذا لم يتوافر في المبيع الصفات التي كفل للمشتري وجودها.......) في حين أن المشرع العراقي لم يشير إلى حالة تخلف الوصف بل اكتفى بالتطرق الى العيب بمعنى الأفة الطارئة.

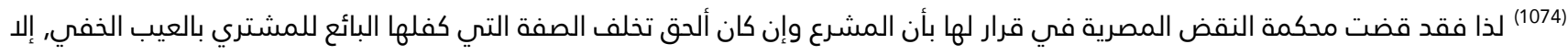
أنه لم يشترط في حالة فوات الصفة ما اشترطه في العيب الذي يضمنه البائع من وجوب كونه مؤثرًا وخفيًا, بل إنه جعل مجرد تخلف الصفة وقت التسليم موجبًا لضمان البائع متى قام المشتري بإخطاره, سواء كان المشتري يعلم بتخلفها وقت البيع, أم كان لا يعلم وسواء كان يستطيع أن يتبن فواتها, أم كان لا يستطيع، ولما كان الحكم المطعون فيه لم يعرض لأمر تحقق الصفة في الحدود السالف ذكرها, وجرى على أن عدم توافر

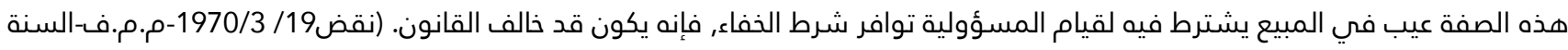
21- مدني ص 475) أشار إليه المستشار أنور العمروسي, دعوى الضمان في القانون المدني, منشأة المعارف, الإسكندرية, 2014, ص131. 
على حالة تخلف الوصف (1075). فالعيب هو آفة طارئة أو تلف أو عطب يؤثر على حسن أداء الشيء لوظيفتها, أو يؤثر في متانته,

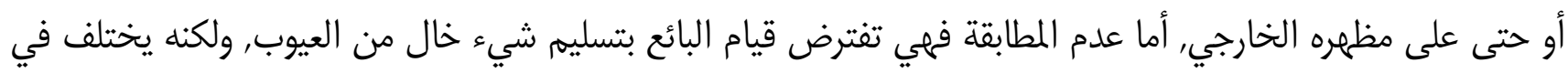

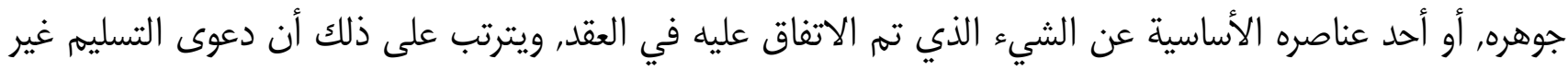

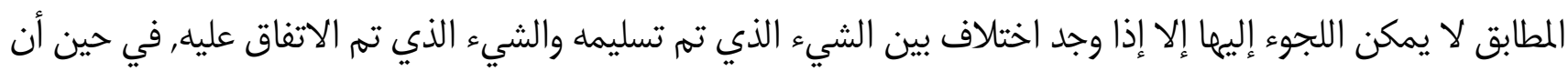

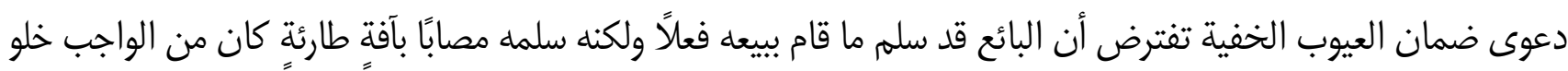

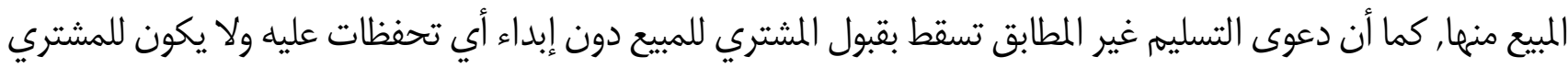

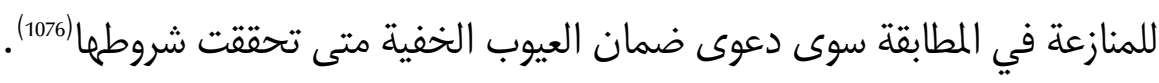

ويذهب القضاء الفرنسي إلى عد مطابقة المبيع للمواصفات شرطًا من شروط التسليه, فلا يكفي أن يقوم البائع بتسليم

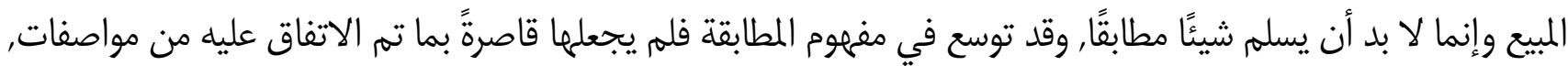

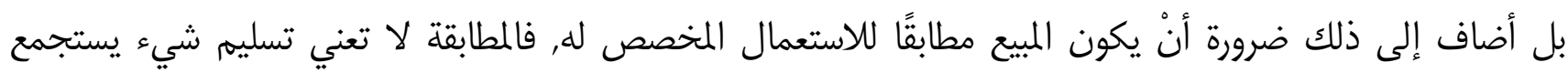

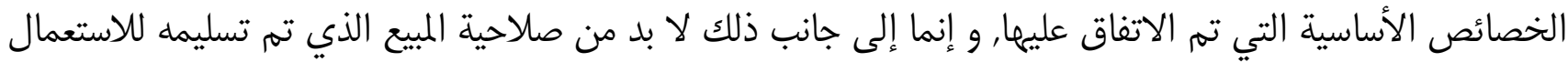

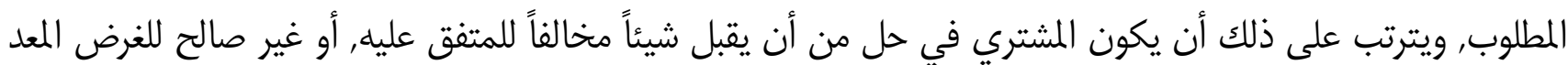
.${ }^{(1077)} d$

ولا بد من الإثارة إلى أن التزام البائع بتسليم مبيع مطابق للمواصفات المتفق عليها, هو التزام بتحقيق نتيجة وليس

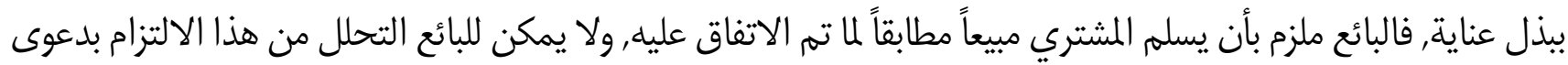

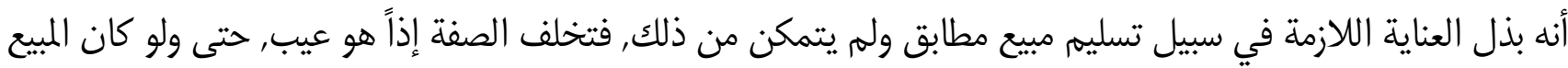
خاليًا من آفة طارئة (1078).

\section{المقصد الثاني: عدم الالتزام بالمواصفات القياسية}

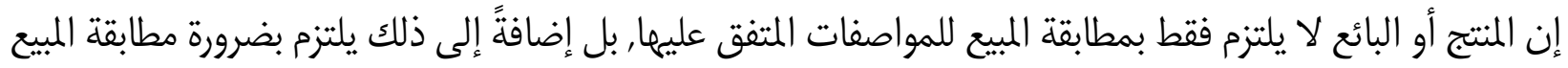

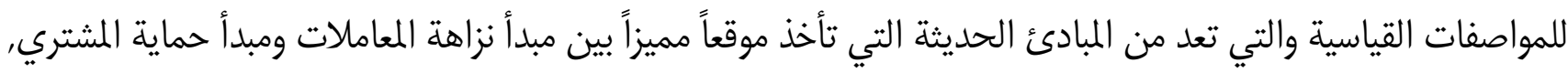

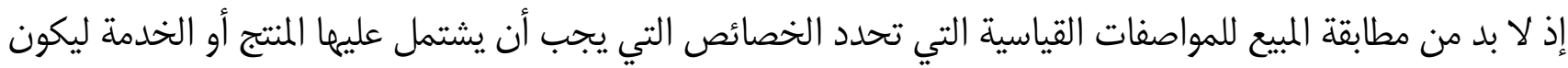
صالحاً لاستعماله في الغرض المعد له (1079).

(1075) أنور العمروسي, المصدر أعلاه, ص1989؛ د. حسام الدين كامل الاهواني, عقد البيع في القانون الكويتي, مطبوعات جامعة الكويت,

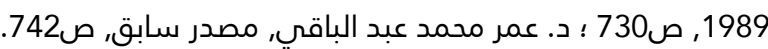

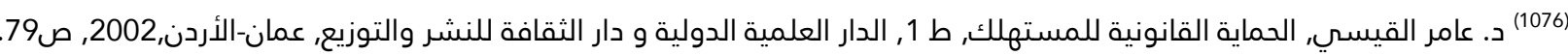
Cass. 1 ch.,civ., 22 nov. 1978, j.c.p.,1979-2-191391, cass. 1 ch civ., 1 dec. 1987 bull.civ., In 324. (1077) الباقي, مصدر سابق, صان 721؛ د. عامر قاسم أحمد القيسي, الحماية القانونية للمستهلك, ط1, الدار العلمية الدولية ودار الثقافة للنشر والتوزيع,

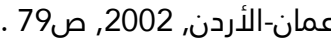

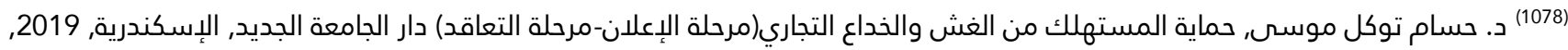
ص 342 ؛ حسام الدين كامل الأهواني, مصدر سابق, صكابة (1079) د. روسم عطيه موسى دسم نو, الحماية الجنائية للمستهلك من الغش في المعاملات التجارية, دار المطبوعات الجامعية, الإسكندرية, 2014, 
وتُعرف الموصفات القياسية على أنها الوثيقة المعتمدة التي يته إعدادها بإتباع أساليب التقييس في مجال ما, وتشمل مجموعة الاشتراطات التي يجب توافرها في السلعة أو المادة(1080).

وقد ألزم المشرع العراقي كل من المجهز والبائع بضرورة الالتزام بالمواصفات القياسية العراقية, أو العالمية لتحديد جودة الماتية

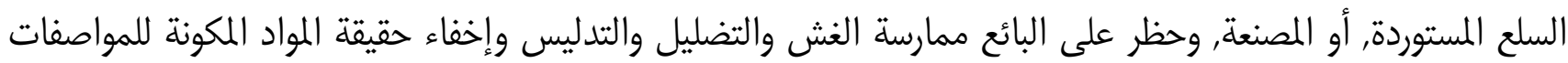

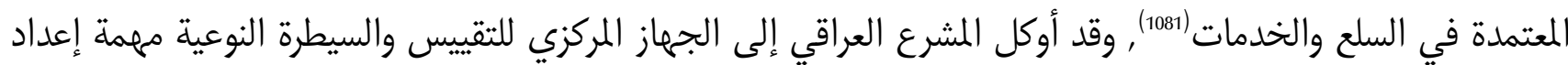

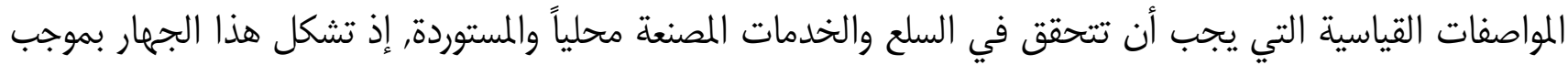

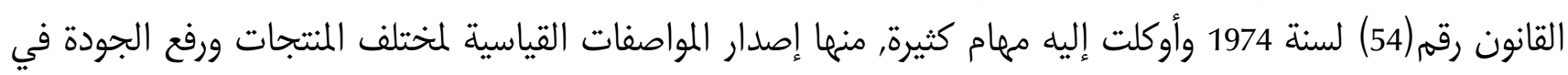

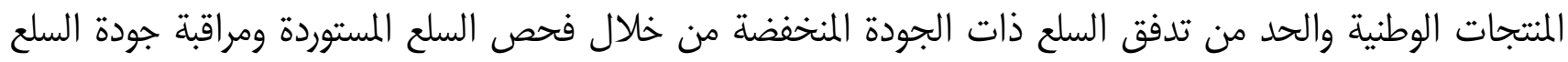

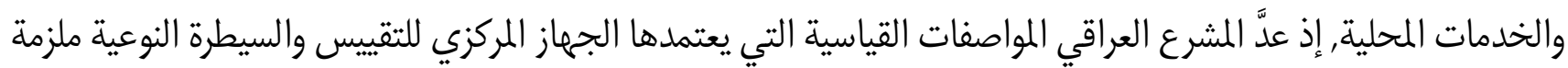

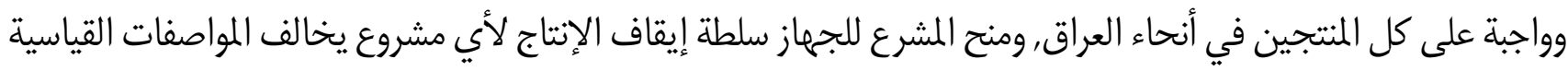
العراقية (1082).

وبالاتجاه نفسه أكد المشرع المصري على إلزام المورد, أو البائع بقواعد الصحة والسلامة ومعايير الجودة وضمانها

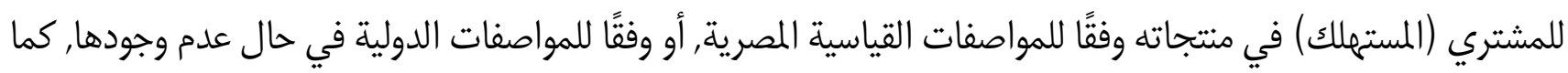

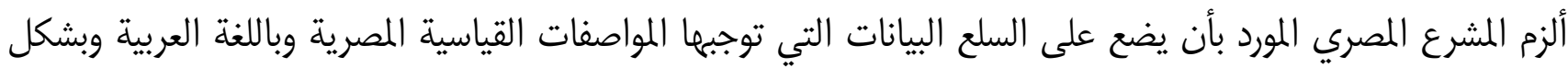

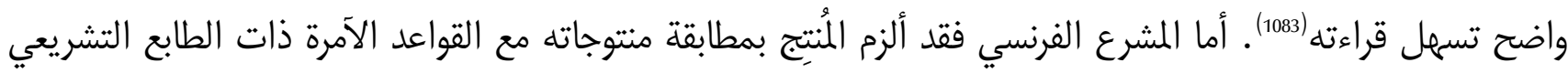

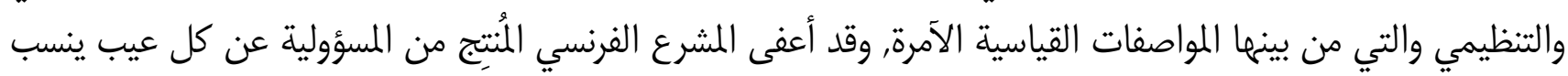
الى المُتَّج في حالة التزامه بالقواعد والموصفات القياسية (1084).

والمواصفات القياسية دائمًا ما تعبر عن الحدود الأساسية للجودة, سواء فيما يتعلق بطبيعة السلعة وصنعها وصنفها

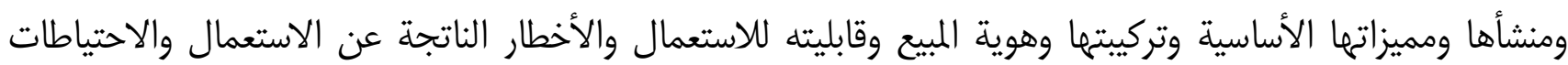

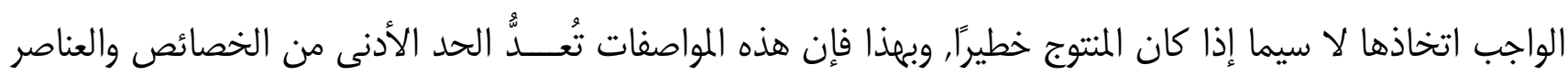

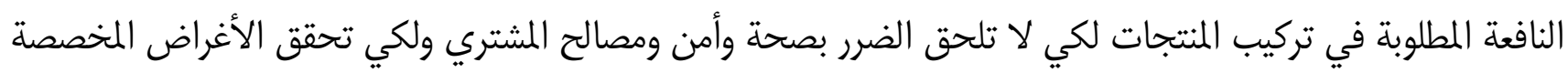

وتقسم الموصفات القياسية من حيث عنصر الإجبار بالتقيد بها الى نوعين, مواصفات قياسية إجبارية وهي المواصفات

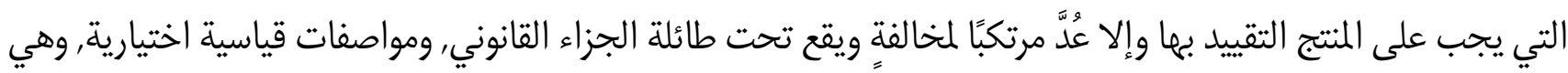

(1080) د. عبد المنعم موسى إبراهيم, حماية المستهلك, ط1, منشورات الحلبي الحقوقية, بيروت-لبنان, 2007, ص139. (1081) المادة (7/ثانياً)والمادة(19/ أولاً) من قانون حماية المستهلك العراقي رقم 1 لسنة 2010.

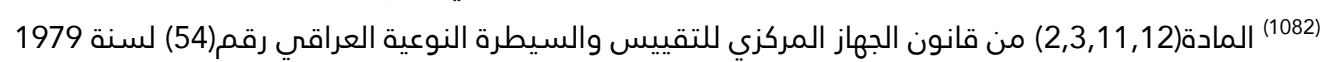
(1083) المادة (3,6) من قانون حماية المستهلك المصري لسنة رقم 181 لسنة 2018. (1084) المادة (1245-10) من قانون العقود الفرنسي الجديد لسنة 2016. (1085) جليل أمال, تأثير قانون حماية المستهلك على عقد البيع, رسالة ماجستير مقدمة إلى كلية الحقوق والعلوم السياسية-جامعة وهران, الجزائر, ص87 ؛ كالم حبيبه, حماية المستهلك, رسالة ماجستير مقدمة إلة كلية الحقوق والعلوم الإدارية, جامعة الجزائر, الجزائر، 2005,ص 40. 
المواصفات التي يتاح للمنتج حرية التقييد بها, ولا يقع تحت طائلة الجزاء القانوني فيما إذا لهم يتقيد بها, وضابط التفرقة بين

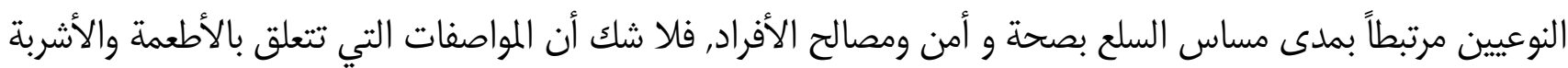

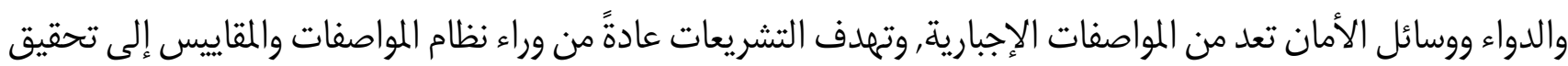

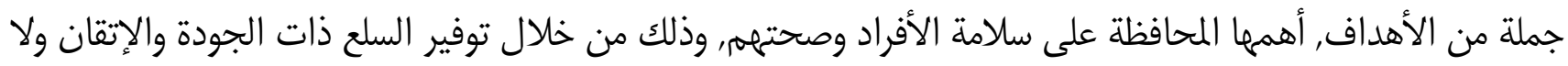
سيما في مجال الطعام والدواء, وتحقيق الاستقرار في التعامل ونشر الثقة بين المتعاملين (1086). لذا يُعلُّ غشًا عرض المنتجات بصورة تخفي حقيقتها, أو صفاتها الجوهرية, أو معدل العناصر المفيدة الداخلة بها وبما

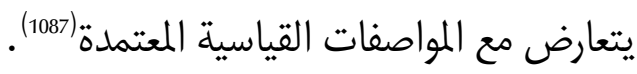

\section{الفرع الثاني: الخداع والتزييف في المبيع}

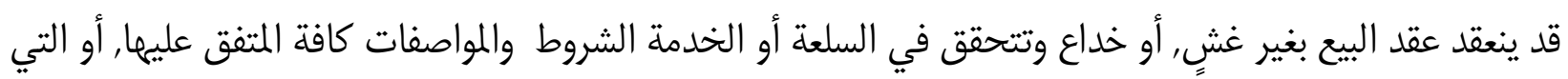

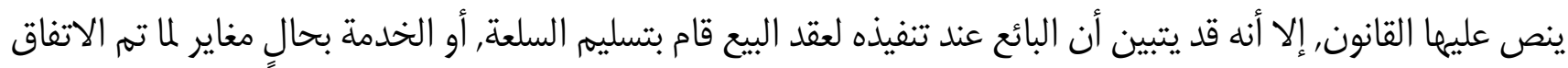

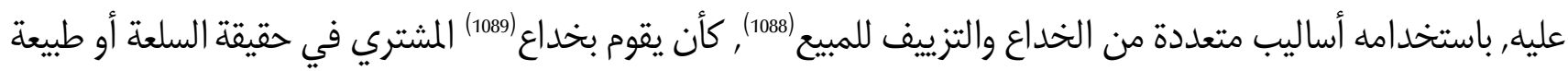

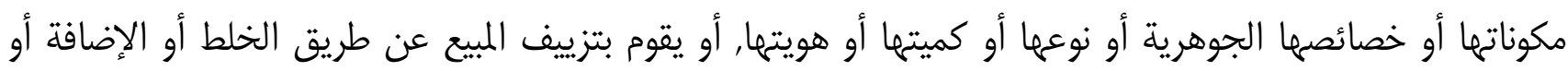
الإنقاص (1090).

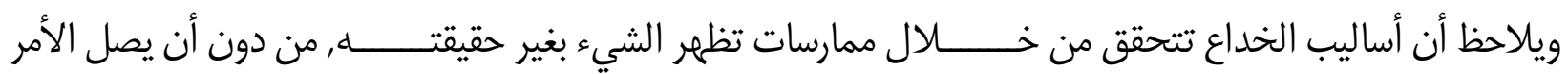

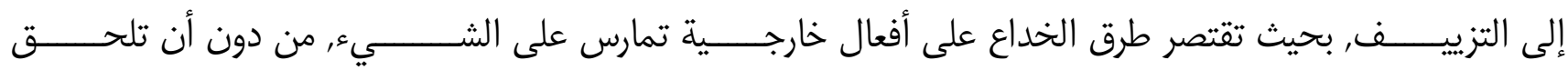

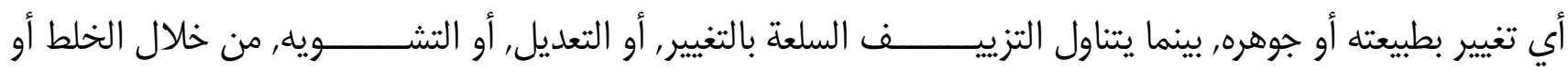

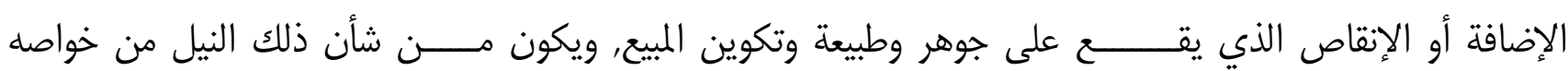
الأساسية (1091). ولدارسة أساليب الخداع والتزييف في المبيع بمزيد من التفصيل نقسم هذا الفرع على المقصدين الآتيين: جرش (1086) د. محمود البخيت, المواصفات القياسية الأُردنية أهميتها وأحكامها في الشريعة الإسلامية وقانون المواصفات والمقاييس الأُردني, مجلة جرش للبحوث والدراسات, المجلد الخامس, العدد الأول, 2000, صدات

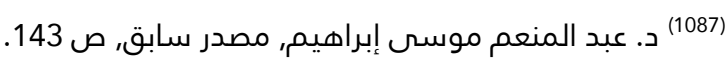

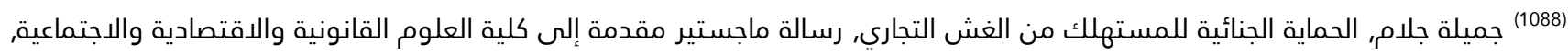
جامعة القاضي عياض, مراكش, 2011, ص357).

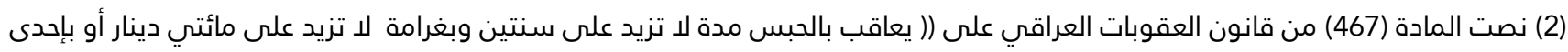

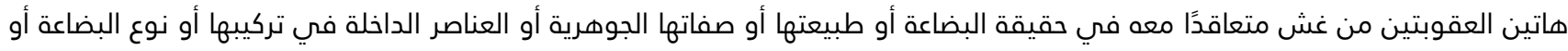

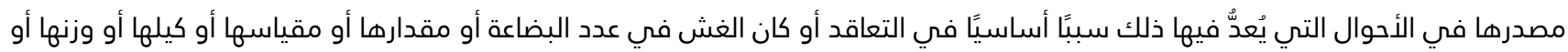
طاقتها أو كان في ذاتية البضاعة إذا كان ما سلم منها غير ما تم التعاقد عليه)). (1090) د. إبراهيم أحمد البسطويسي, المسؤولية عن الغش في السلع, دار الكتب القانونية, القاهرة, 2011, ص55 ؛ ؛ د. عبد الفضيل محمد أحمد, جريمة الذداع التجاري في نظام مكافحة الغش التجاري السعودي, بحث منشور في مجلة الحقوق, السنة الثامنة عشر, العدد الرابع, الكويت 1994, 


\section{المقصد الأول: الخداع في المبيع}

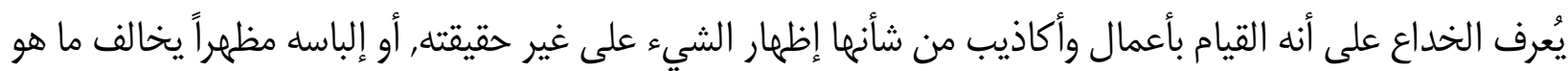
عليه في الحقيقة والواقع (1092).

فقد يعمد البائع إلى القيام ببعض الأعمال والأكاذيب, أو الحيل التي من شأنها إظهار السلعة على نحو مخالف لحقيقتها عند التسليم, كأن يسلم للمشتري شيئًا أخر يختلف عما تم الاتفاق عليه سواء من حيث المصدر أو النوع, أم من حيث ليثيا الخصائص الجوهرية . (1093), فالخداع المكون للغش أمر مادي لا يكفي فيه مجرد الكتمان أو الكذب, بل يتحقق من خلال أعمال تقع على السلعة و إن صاحب ذلك كتمان وكذب ليحدث الغلط المطلوب في فكر المشتري من خلال إظهار الشيء بغير حقيقته (1094).

فقد يعمد البائع إلى القيام بعدة ممارسات بقصد خداع المشتري بطبيعة السلعة أو مقدارها أو مقاسها أو كيلما أو وزنها أو طاقتها أو عيارها, أو يخدع المشتري بذاتية السلعة وذلك من خلال تسليهم سلعة أخرى غير التي تم التعاقد عليها, أو يعمد

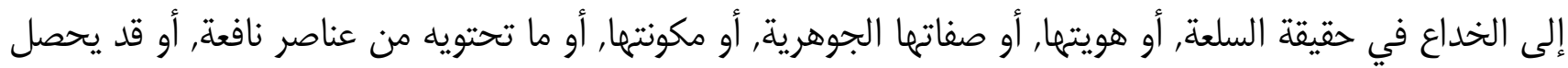

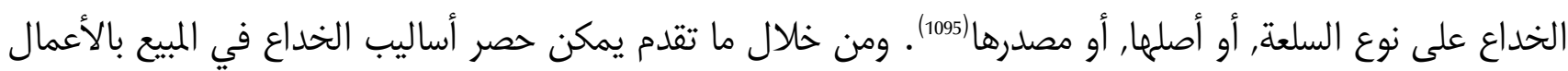
والطرق الآتية:

أولاً: الخداع في طبيعة أو حقيقة المبيع: يقصد بطبيعة أو حقيقة المبيع مجموعة العناصر المميزة للمبيع و التي كانت دافعًا للإقبال عليه, ويكون هناك خداع بشأن طبيعة, أو حقيقته المبيع, إذا كان هناك تغيير جسيم في خصائص المبيع محل الخداع,

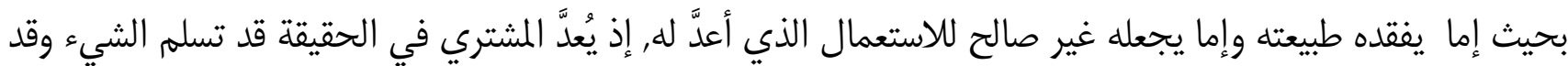
تحول إلى شيء آخر غير المتفق عليه, كأن يتعاقد المشتري مع البائع على شراء صابون مصنوع من زيت الزيتون في حين يتسلم صابونًا خاليًا من زيت الزيتون والخداع في طبيعة, أو حقيقة المبيع لا يكفي لتحققه أن يحصل التغيير في صفة من صفات الشيء, بل يجب أن يقع التغيير في صفة من الصفات الأساسية, مما يشوه طبيعة المبيع, أو يجعله غير صالح للغرض الذي أعدَّه له المشتري (1097). وقد يتحقق الغش في طبيعة المبيع من خلال خداع المشتري بحقيقة المبيع الذي اتجهت إليه إرادته, فالتشابه الكبير

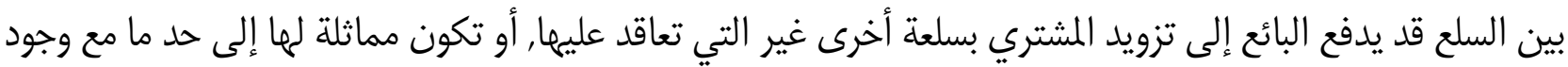

(1092) د. حسني الجندي, شرح قانون قمع التدليس والغش المصري, ط 3, دار النهضة العربية, القاهرة, ص 29.

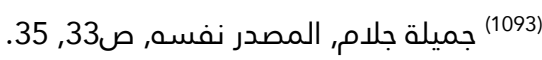
(1094) كالم حبيبه, مصدر سابق, ص 102.

(1095) د. السيد محمد السيد عمران, حماية المستهلك أثناء تكوين العقد, منشأة المعارف, الإسكندرية, بلا سنة طبع, ص51. (1096) د. عبد الفضيل محمد أحمد, جريمة الخداع التجاري في نظام مكافحة الغش التجاري السعودي, بحث منشور في مجلة الحقوق, السنة الثامنة

عشر, العدد الرابع, الكويت, 1994,صبد138. (1097) د. روسم عطية موسى نو, الحماية الجنائية للمستهلك من الغش في المعاملات التجارية, دار المطبوعات الجامعية, الإسكندرية, 2014 
ثانياً: الخداع في كمية المبيع: وتتحقق هذه الصورة من الخداع باستعمال البائع موازين, أو مقاييس, أو مكاييل زائفة, وبكل طريقة ترمي خداعاً إلى رفع الوزن و الكيل عند تسليمه للمبيع, ويدعم البائع أفعاله هذه غالبًا باستخدام طرق احتيالية يلجأ إليها لإيهام المشتري بسلامة المبيع سواء في العدد, أم الوزن, أم الكيل (1099).

والغش في الكمية قد يتحقق في فرضين, أولرما: أن تكون كمية المبيع محددة بموجب الاتفاق إلا أن البائع قام بتسليم المشتري المبيع, وهو أقل مما تم الاتفاق عليه, وثانيهما: أن تكون كمية المبيع محددة بموجب البيانات و المعلومات التي يحتويها المبيع ويقوم البائع بالتاعب بالكمية من أجل الاستفادة في الحالتين بفارق الوزن والكمية على حساب المشتري

فالبائع لا سيما المحترف قد يستغل جهل المشتري بموضوع المعاملة فيعمد إلى عدم تحديد مقدار المبيع على وجه الدقة, لذا فالاتجاه الراجح في الفقه يرى بضرورة تطبيق العرف التجاري في حالة المطابقة الكميت, فإذا عين مقدار المبيع كان البائع مسؤولًا عن النقص في هذا القدر بحسب العرف التجاري, وترتيبًا على ذلك فإنه إذا كان البائع ملتزمًا بتسليم المبيع بالقدر المتفق عليه , فإنه يجب أن يراعى ما يسمح به العرف التجاري من نقص في الكمية المسلمة (1101).

ثالثاً: الخداع في نوع المبيع: يقصد بنوع المبيع المزايا والخصائص التي توجد فيه, أو مجموعة العناصر التي تميز مبيعًا

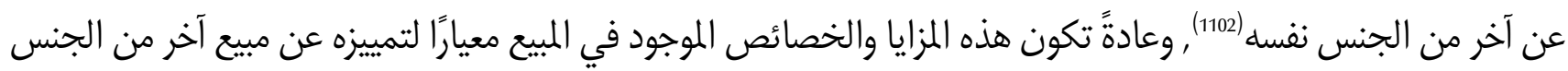
نفسه (1103). وحقيقةً أن السلع قد تتشابه من ناحية الشكل والمظهر ولكنها تختلف فيما بينها بحسب النوع, مما يترتب عليه تغير في قيمتها لدى المتعاقدين, فتسليه البائع للمشتري سلعةً مشابهةً للسلعة التي تعاقد عليها ولكنها مختلفة في النوع يعد غشًا وخداعًا (1104).

وقد يخدع البائع المشتري عن طريق تسليمه سلعة من نوع مشابه للسلعة الأصلية, ولكنها مختلفة عنها في النوع, مع وضع بيانات السلعة الأصلية على السلعة التي تسلمها المشتري, مما يؤدي إلى خداع المشتري كأن تكون السلعة المتعاقد عليها زيتًا خاليًا من الكولسترول إلا أن البائع يسلم المشتري زيتًا يحتوي على الكولسترول مع وضع البيانات التي تؤكد الخلو من الكولسترول عليه (1105).

(1098) د. سالم محمد عبود و م.م. رشا كيلان شاكر, الحماية القانونبة للمستهلك من الغش التجاري, بحث منشور في مجلة الحقوق, كلية القانون-

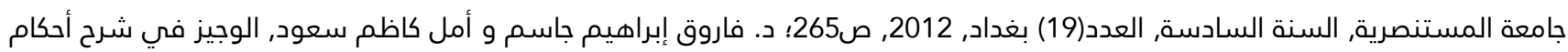
قانون حماية المستهلك رقم 1 لسنة 2010, دار السنهوري, بيروت-لبنان, 2016, ص 55.

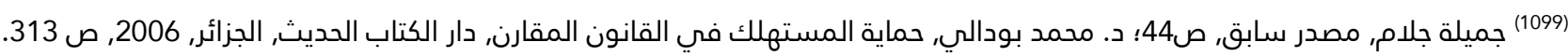

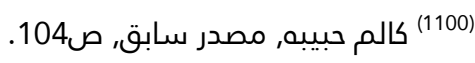
(1101) د. عمر عبد الباقي, مصدر سابق, ص مصدر 697.

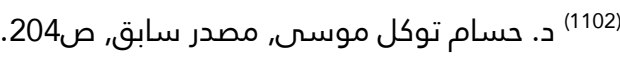
(1103) بصائر علي محمد البياتي, جريمة الغش التجاري في السلع, رسالة ماجستير مقدمة الى كلية القانون-جامعة بغداد,1998,ص

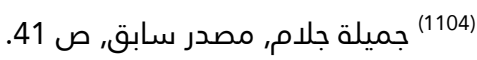
(1105) د. إبراهيم أحمد السيوطيلة جلام، مصدر سابق, ص71144. 


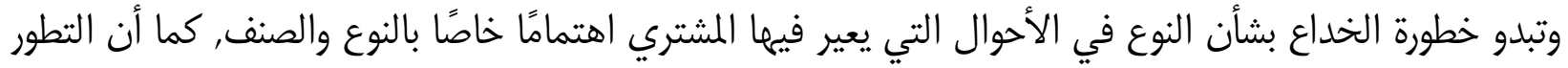

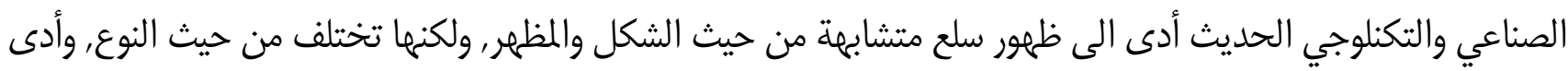

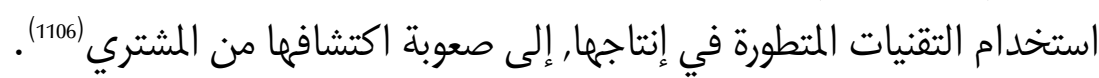

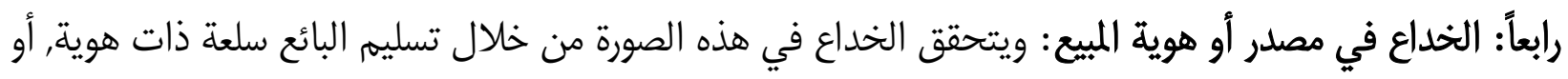

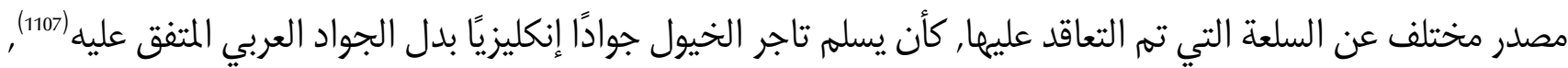

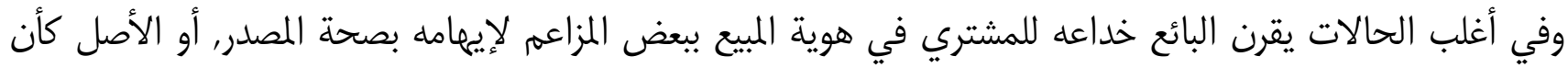

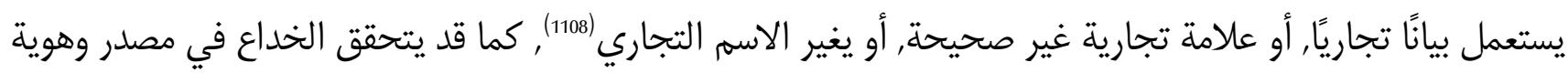

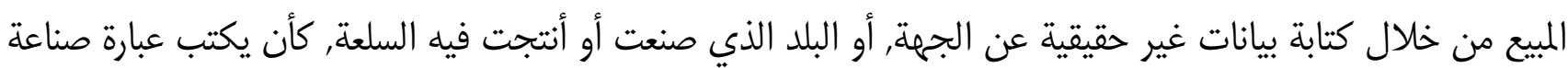

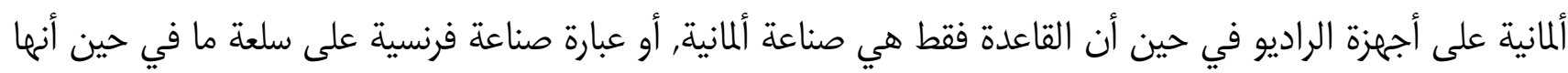

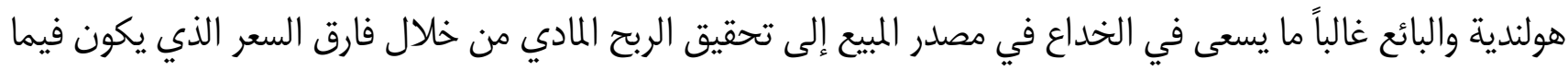

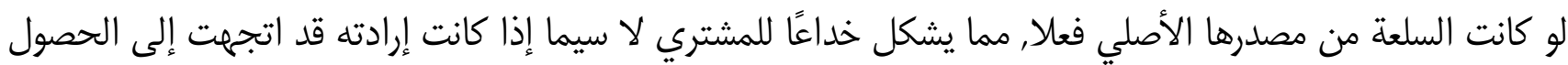
على السلعة من منشأ أو مصدر محدد (1109).

\section{المقصد الثاني: التزييف في المبيع}

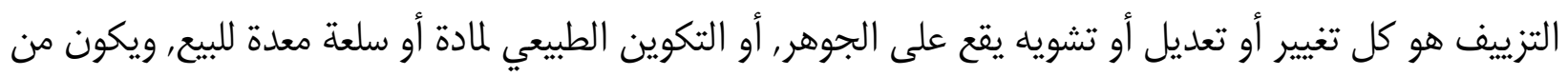

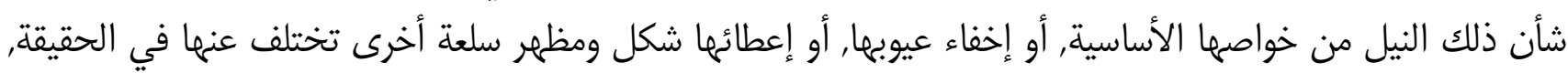

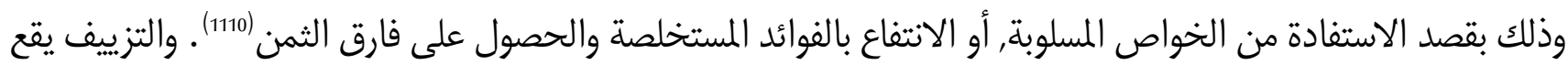

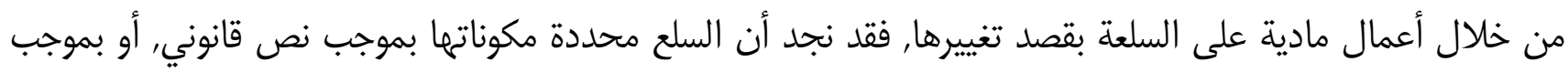

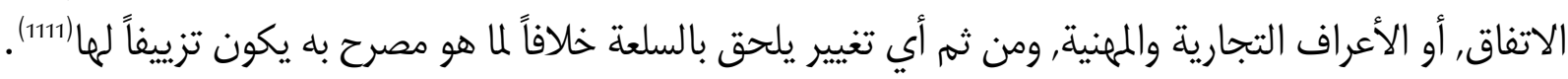

$$
\text { ومن خلال ما تقدم يتبين لنا أن حالات التزييف في المبيع هي: }
$$

أولاً: التزييف عن طريق الخلط أو الإضافة تُعلُّه هذه الطريقة من طرق التزييف من أشهر وأقدم الطرق التي يستخدميها

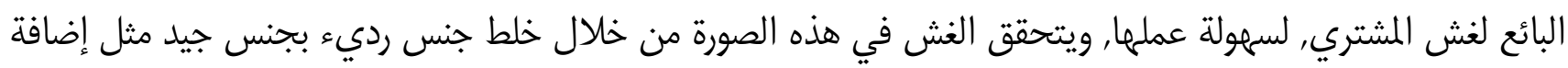

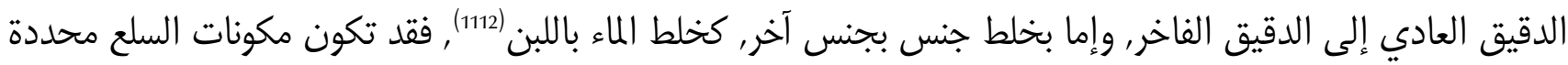

(1106) أفين كاكه زياد, الترويج الجرمي للسلع الاستهلاكية المغشوشة بطرق الإعلان,ط1, مكتبة زين الحقوقية, بيروت-لبنان, 2015 ص41 ؛ د. عبد الفضيل محمد أحمد, مصدر سابق, ص142) (1107) كالم حبيبه, مصدر سابق, ص 106.

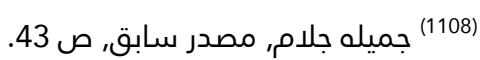

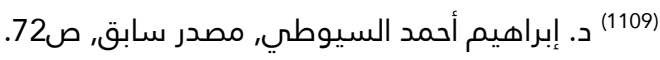
(1110) حسني الجندي, مصدر سابق, ص45. (1111) كالم حبيبه, مصدر سابق, ص 106. (1112) د. عبد الله بن ناصر السلمسي, الغش في العقود, ج11, ط1, دار كنوز اشبيلية للنشر والتوزيع, الرياض, 2004, ص 49. 
بمقتضى القانون, أو الاتفاق, أو العرف وبنسب معينة, فأي إضافة أو خلط لمكونات السلعة بما يتعارض مع النسب المصرح بها يعد غشاً من البائع (1113).

والبائع غالباً ما يهاف من الغش بالخلط, أو الإضافة إلى زرع الاعتقاد بأن السلعة خالصة, أو بإظهارها ذات مواصفات,

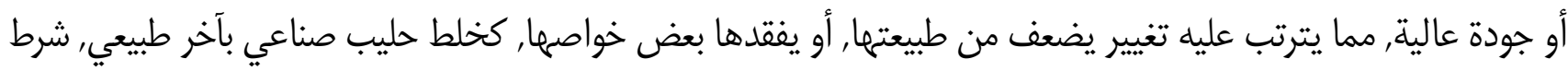

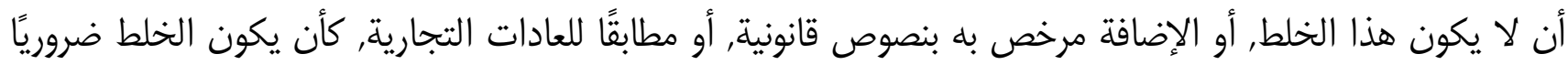

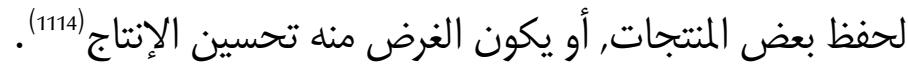
ثانياً: التزييف عن طريق الإنقاص: ويتم الغش في هذا النوع من التزييف عن طريق إنقاص جزء من العناصر التي

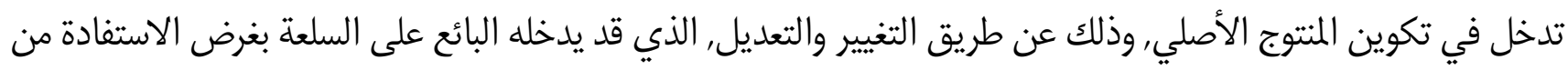

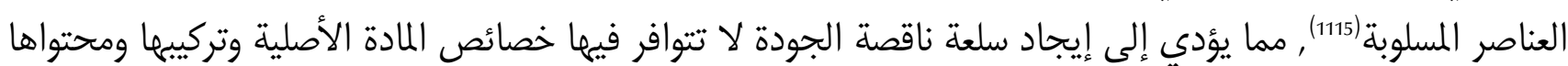
من العناصر المفيدة (1116).

وغالبًا ما يسعى البائع الغاش عند إنقاصه السلعة إلى أن يترك للسلعة المظهر الخارجي الذي يوحي بأنها السلعة الأصلية

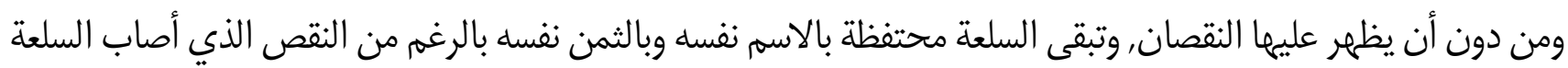

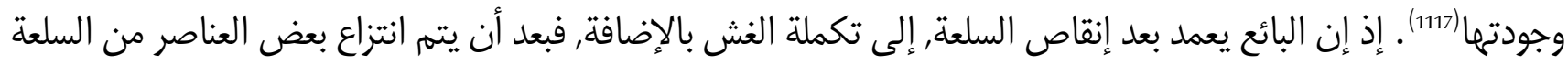

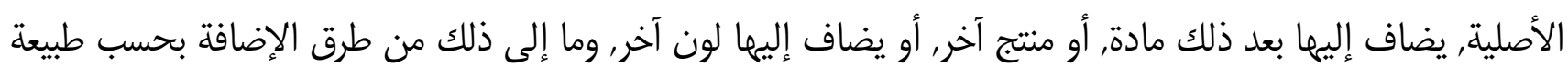

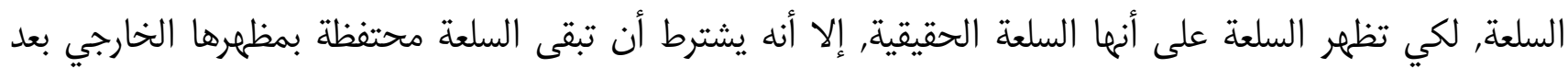

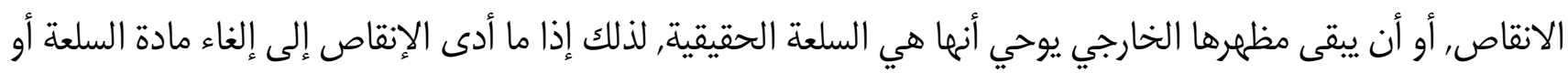
أعدمها أو أفقدها مظهرها الحقيقي, فإن هذا الفي مهار الفعل لا يعد انتقاصًا (1118).

\section{المطلب الثاني: الغش المرتبط بالتزام البائع بالضمان}

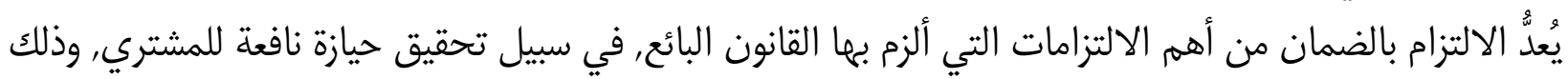

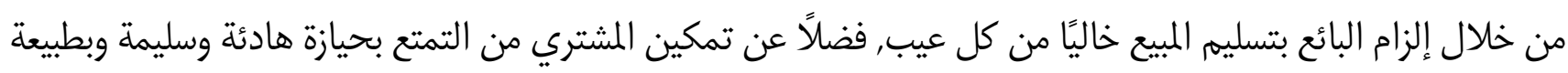

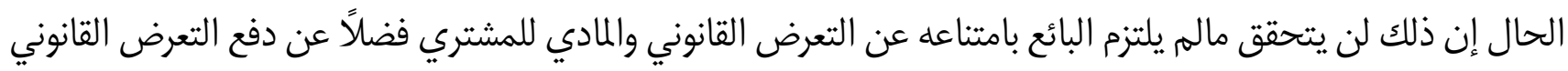

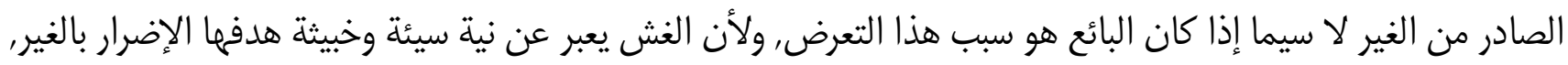

(1113) د. أحمد البسطويسي, مصدر سابق, ص 59. (1114) د. حسام توكل, حماية المستهلك من الغش والخداع التجاري(مرحلة الإعلان-مرحلة التعاقد) دار الجامعة الجديد, الاسكندرية, 2019 ص155 ؛ د. علي حمودة, الحماية الجنائية للتصنيع الغذائي في ضوء التشريعات المطبقة, ط 1, دار النهضة العربية, القاهرة, 2002, ص 47 ؛ مبروك

سامي, مصدر سابق, ص 29.

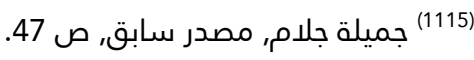

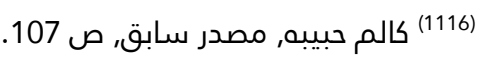

(1117) د. محمد بودالي, مصدر سابق, ص صد 321 ؛ د. محمد مختار القاضي, الغش التجاري, الدار الجامعية الجديدة, الإسكندرية, 2014 ص 17. (1118) د. إبراهيم أحمد البسطويسي, مصدر سابق, ص62 ؛ د. د. حسام توكل موسى, مصدر سابق, ص 156 ؛ د. علي حمودة, مصدر سابق, ص مص 
فإنه لا مجال أمام البائع لعقد أي اتفاق على التخفيف أو الإعفاء من ضمانه للمبيع, فيعد باطلاً وبحكم القانون كل اتفاق يهلدف إلى إنقاص ضمان البائع للمبيع, أو إعفائه. ولدراسة دور الغش وتأثيره على ضمان البائع, نقسم هذا المطلب على الفرعيين الآتيين:

\section{الفرع الأول: الغش المرتبط بضمان العيوب الخفية. الفرع الثاني: الغش المرتبط بضمان التعرض والاستحقاق.}

\section{الفرع الأول: الغش المرتبط بضمان العيوب الخفية}

نص المشرع العراقي في النصوص الخاصة بعقد البيع في القانون المدني, على ضمان البائع لعيوب المبيع الخفية والتي

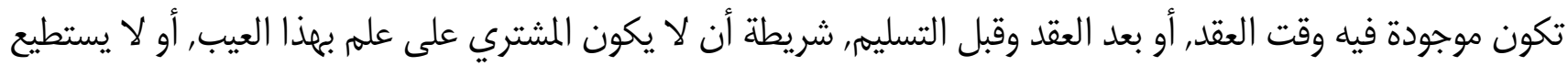
أن يتبينه لو أنه فحص المبيع بما ينبني من العناية (1119), ويشترط في العيب الموجب للضمان أن يكون خفيًا وقديمًا ومؤثرًا وأن يكون غير معلوم للمشتري (1120).

ويلاحظ أن شرط الخفاء وعدم علم المشتري بالعيب يعد وثيق الصلة بمسألة تحقق الغش لدى البائع, فالبائع قد يعلم

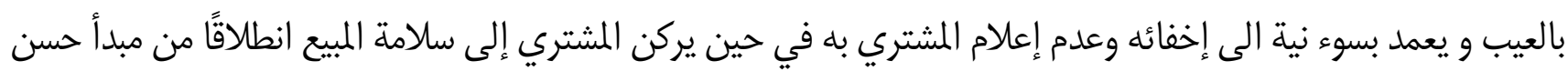

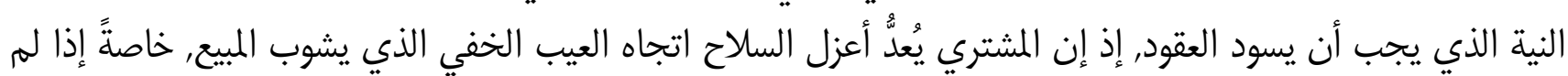

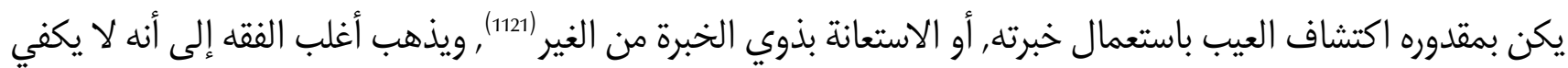

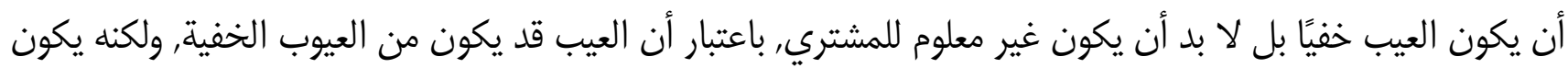
في الوقت نفسه معلومًا وقت العقد, أو وقت التسليم, ففي مثل هذه الفرض يعد العيب الخفي الذي يعلم به المشتري في حكم العيب الظاهر الذي لا يضمنه البائع, إذ إنه في الغالب قد وضعت مسألة وجود العيب في الحسبان عند تحديد الثمن (1122).

وفي حقيقة الأمر أن اشتراط الخفاء وعدم علم المشتري بالعيب كشرط لتحقق ضمان البائع, جاء في سبيل تحقيق استقرار المعاملات, وصيانةً لحقوق البائع, إلا أنه في الوقت نفسه فإن البائع غير جدير بهلذه الحماية ويضمن العيب ولو كان

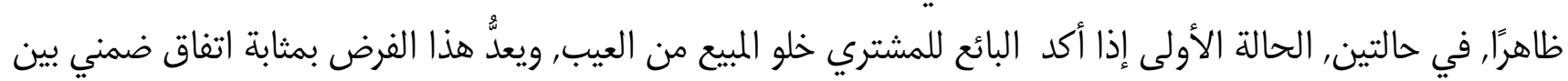
البائع والمشتري على أن البائع يضمن بالذات هذا العيب إذا ظهر بالمبيع, ولا تثريب على المشتري في هذه الحالة إذ إنه قد

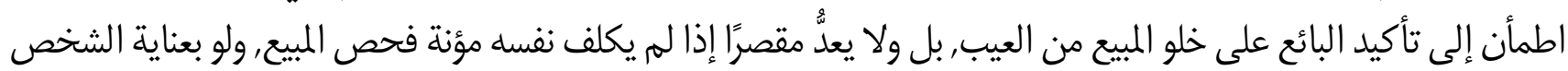

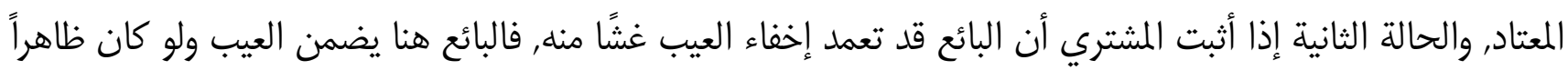
للمشتري, إذا كان يستطيع أن يكتشفه بنفسه, أو بواسطة الاستعانة بذوي الخبرة من الغير إذ أن البائع هنا يضمن العيب؛

(1119) المواد (558) (559) مدني عراقي وتقابلها المادة (447) (448) (449) مدني مصري والمادة (1641) (1642) مدني فرنسي.

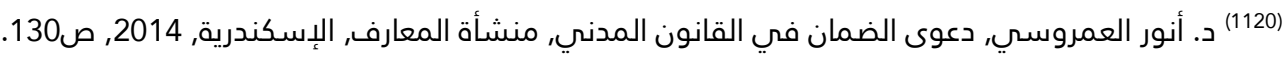
(1121) د. أسعد دياب, انو ص ؛ د. د. محمد كامل مرسي باشا, شرح القانون المدني, العقود المسماة, منشأة المعارف الإسكندرية, 2005, ص

(11222) د. أسعد دياب, المصدر أعلاه, ص 86؛ د. عبد الرسول عبد الرضا محمد, الالتزام بضمان العيوب الخفية, دار حراء, القاهرة, 1974, ص 89. 
لأن خطأه كان مستغرقًا لخطأ المشتري, ولأن خطأ البائع خطأ عمدي بقصد الغش, وخطأ المشتري هو مجرد إهمال أو تقصير في فحص المبيع (1123), لذا فقد قضت محكمة النقض المصرية بأنه مع كون الأصل أن البائع لا يضمن العيب إلا إذا كان

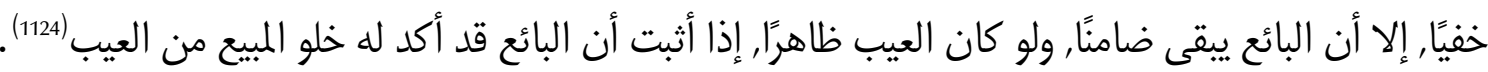
علمًا أن البائع يضمن العيب الخفي ســــــواء كان عالمًا به أم لهم يعله (1125), إلا أن علم البائع بالعيب ورغم ذلك أخفاه

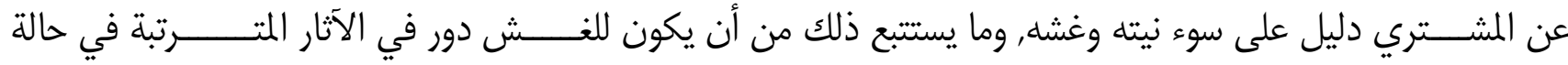

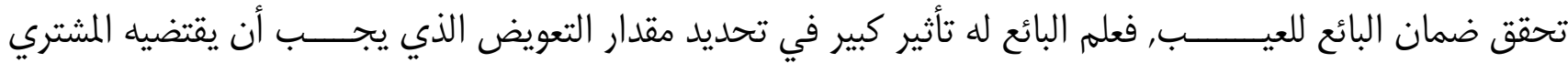

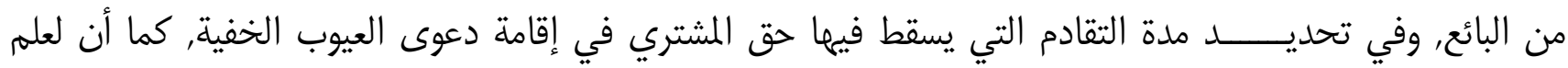

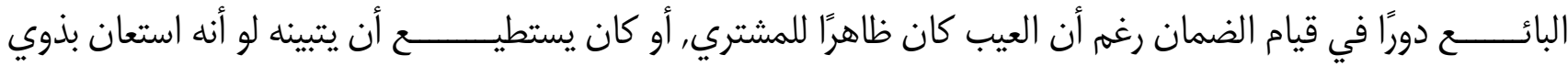

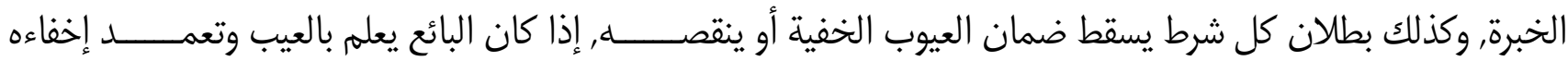
عن المشتري غشًا به (1126).

فالبائع إذا كان يعلم بوجود العيب في المبيع وعمد بسوء نية إلى إخفائه عن المشتري غشًا به, فإنه يُسأل عن تعويض

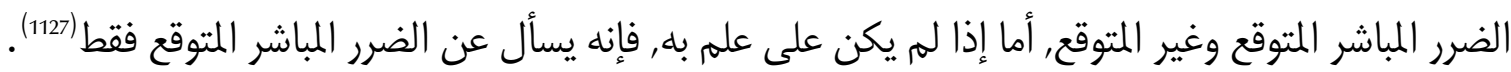

كما أن للغش دورًا في تحديد مدة التقادم التي يسقط فيها حق المشتري في إقامة دعوى ضمان العيوب الخفية, إذ إنه و إن كان الأصل في القانون المدني العراقي أن هذه الدعوى لا تسمع بعد انقضاء ستة أشهر من وقت تسليم المبيع, إلا

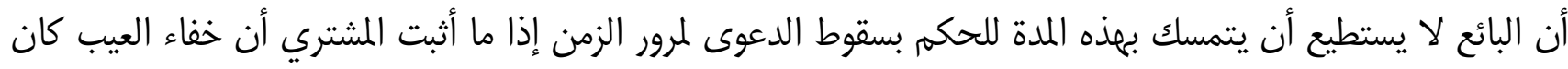

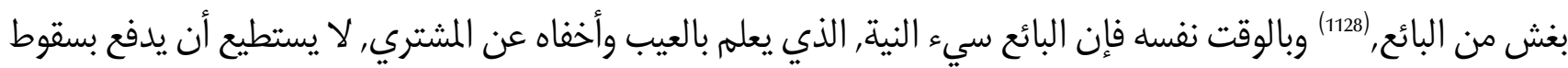

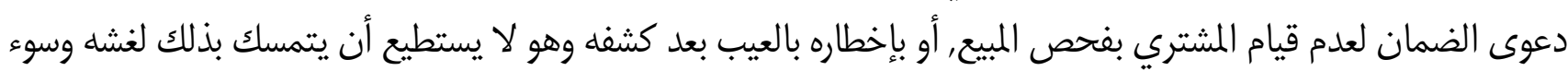

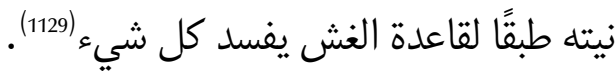

كما أنه وإن كان الأصل أن للمتعاقدين أن يتفقا على إسقاط ضمان العيب الخفي, أو إنقاصه إلا أنه إذا كان البائع يعلم بالعيب الخفي وتعمد إخفاءه عن المشتري, فإنه يقع باطلاً كل اتفاق يسقط الضمان, أو ينقصه نتيجةً للغش (1130).

(1123). عبد الرزاق السنهوري, الوسيط في شرح القانون المدني, ج 4, مصدر سابق, ص 726 ؛ د. عمر محمد عبد الباقي, مصدر سابق, ص 538 ؛ د. كمال ثروت الوندي, شرح أحكام عقد البيع, ط 12, مطبعة دار السلام, بغداد, 1972, ص221.

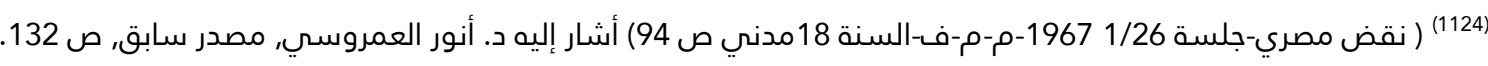

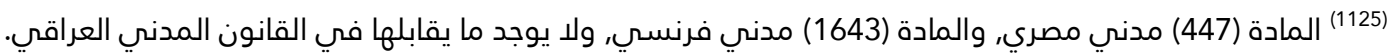

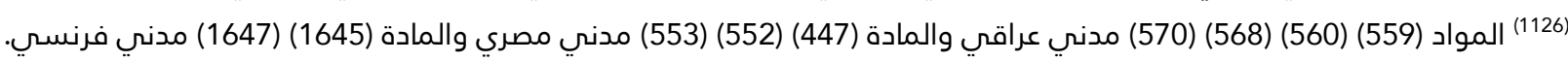

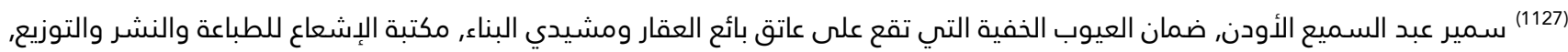

الإسكندرية, 2000, ص 13؛ د. عمر محمد عبد الباقي, مصدر سابق, 560.

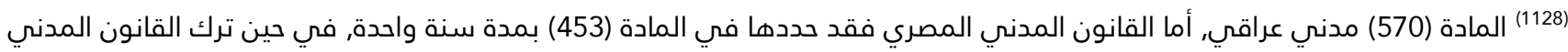
الفرنسي وحسب نص المادة (1684) للقاضي تحديد هذه المدة التي أكد على أنها يجب أن تكون قصيرة. نقلاً عن د. عمر محمد عبد الباقي, مصدر سابق, ص Cass. Com., 25 fev .1981, d.,1981, somm.p. $445^{(1129)}$ (1130) المادة ( 568 ) مدني عراقي والمادة(453) مدني مصري والمادة (1643) مدني فرنسي. 
ونتيجةً للنتائج المترتبة على علم البائع بالعيب الخفي والمذكورة أعلاه, ورغبة من القضاء الفرنسي في تحقيق حماية أكبر

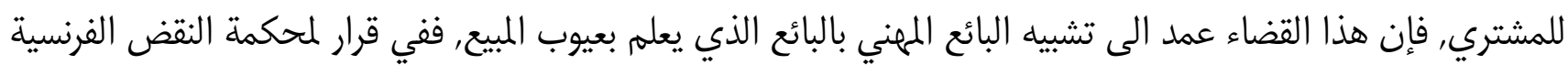

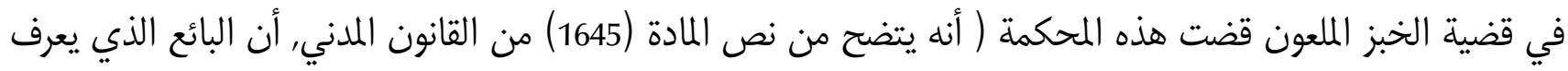

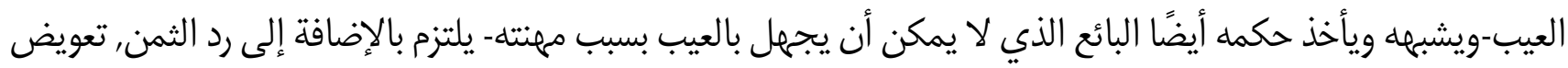
المشتري عن الأضرار كافة التي لحقت به) (1131).

وقد أقام القضاء الفرنسي حكمه في تشبيه البائع المحترف بالبائع الذي يعلم بالعيب الخفي, على أساس أن البائع

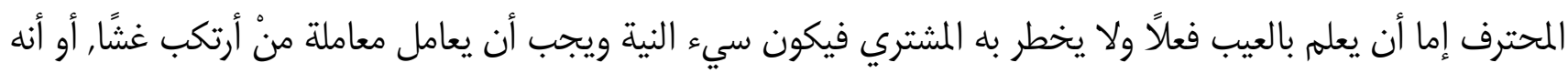

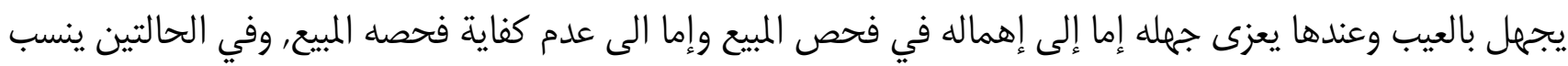

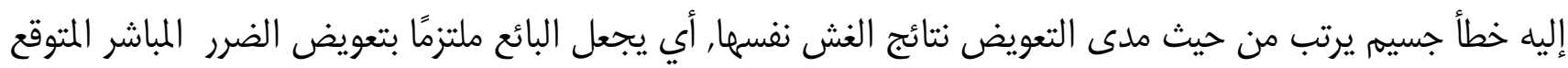

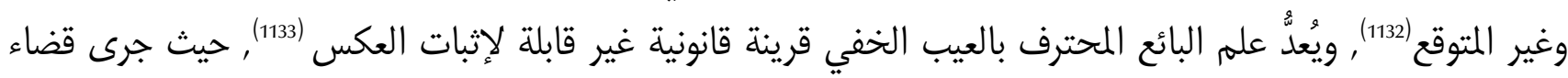

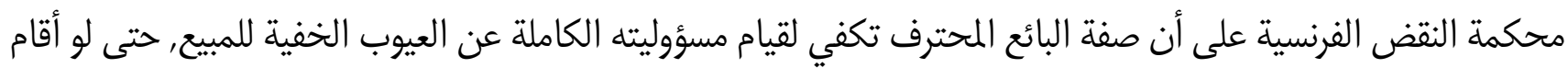

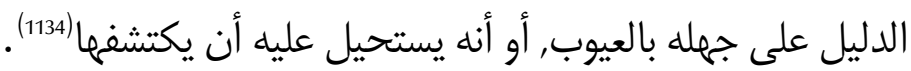

\section{الفرع الثاني: الغش المرتبط بضمان التعرض والاستحقاق}

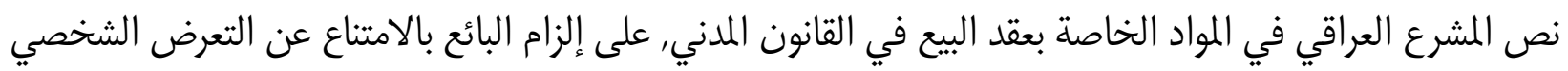

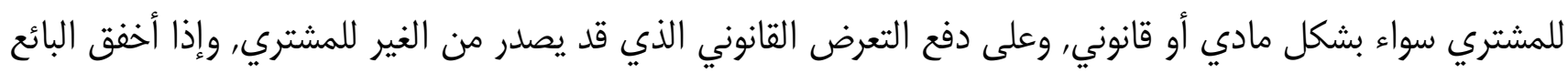

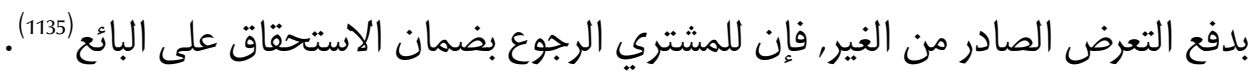

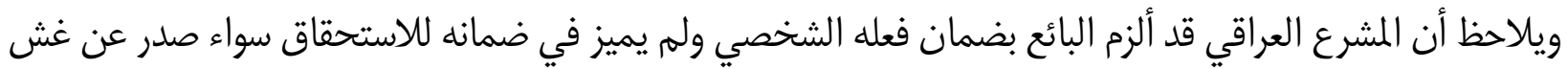

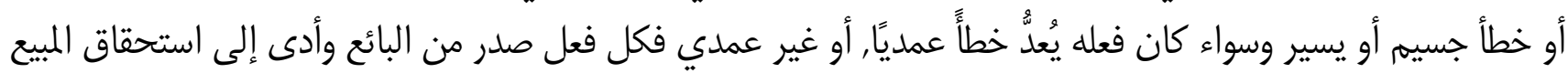

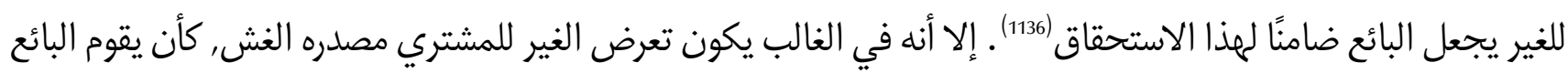

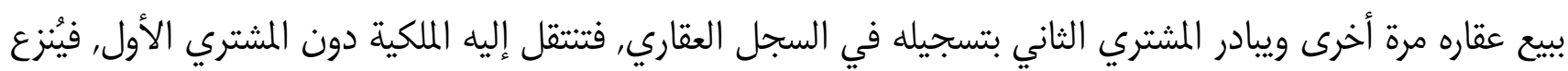

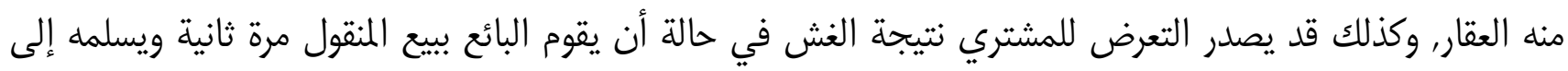

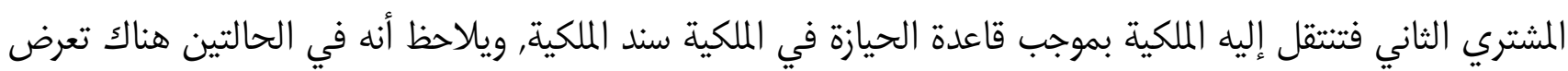

(1131) أشار إليه د. عمر محمد عبد الباقي, مصدر سابق, ص 567.

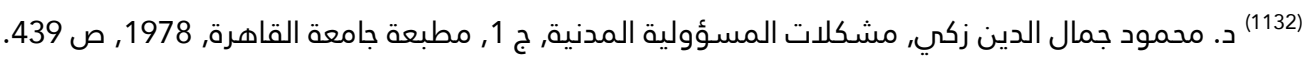

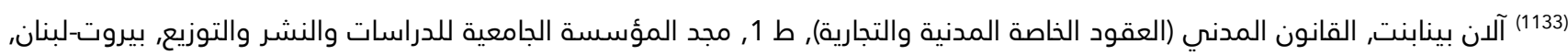
أشار إليه د. فتحي عبد الرحيم عبد الله, دراسات في المسؤولية التقصيرية(نحو Com, 27 nov. 1972, bull. Civ. Lv, no, 266 p 282. (1134)

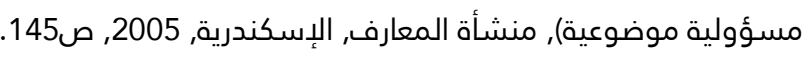

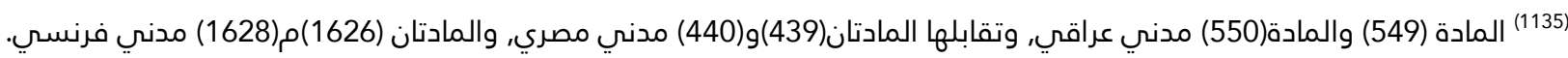

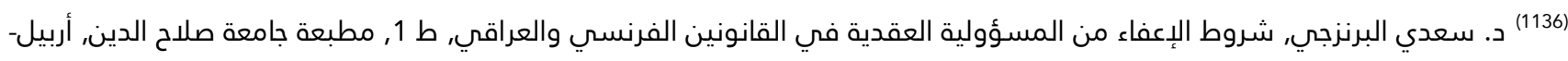
العراق, 2003, ص47. 
للمشتري من الغير والبائع في الوقت نفسه, وأن تعرض الغير للبائع سببه غش البائع البان . فالحالة الأبرز لغش البائع هو عندما

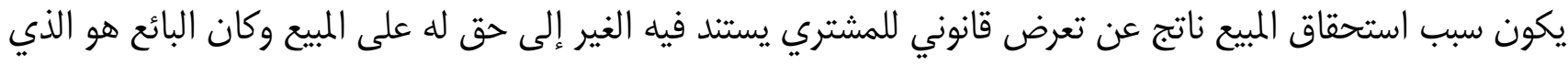

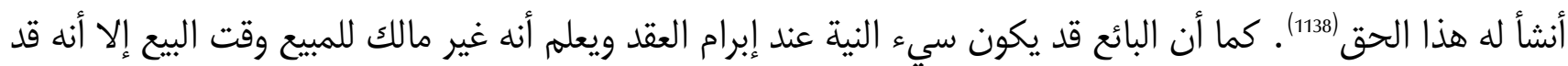

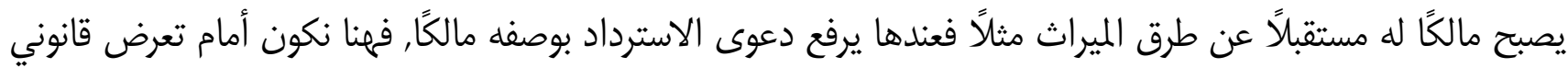

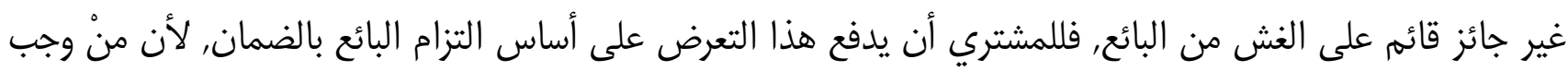
عليه الضمان أمتنع عليه التعرض (1139).

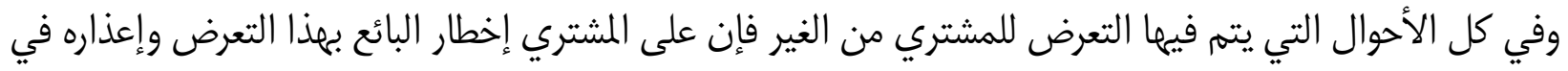

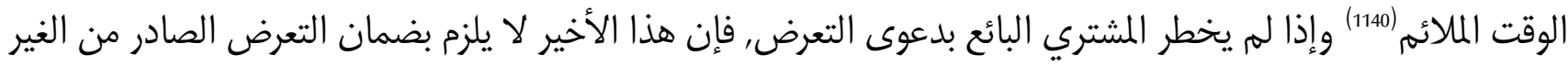

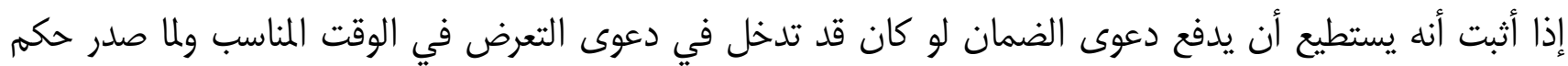

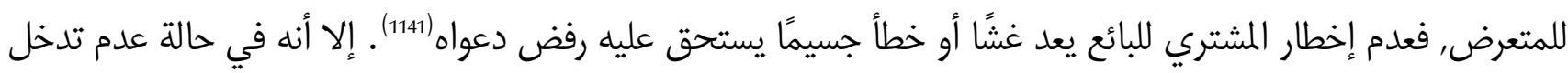

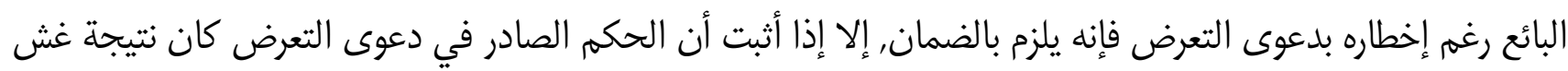

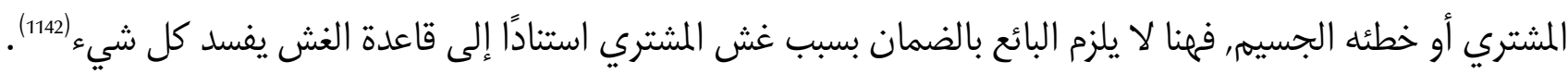
وللغش دورُ كبير في تحديد مقدار ما يدفعه البائع للمشتري في حالة استحقاق المبيع, فإذا أستُحق المبيع من المشتري

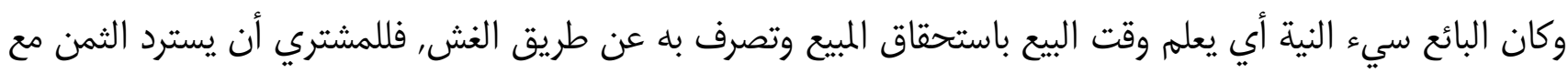

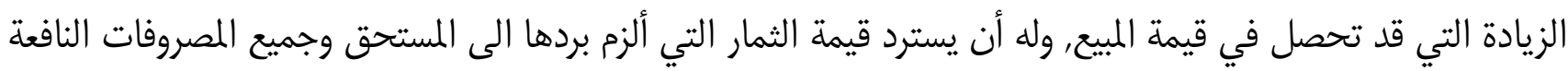

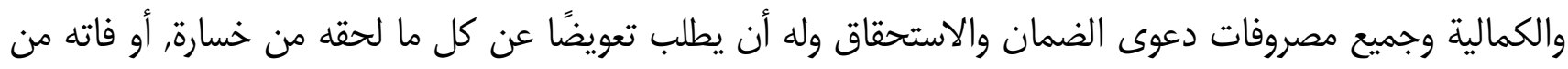

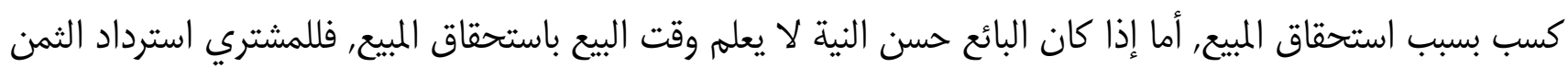

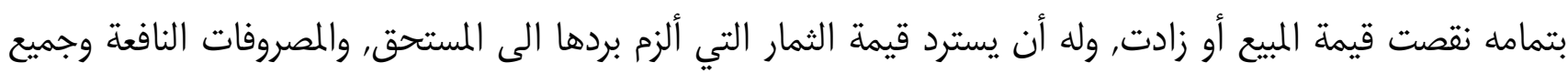

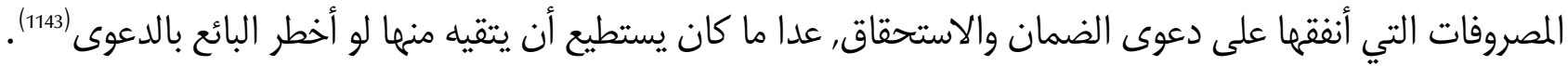
ولا بد من ملاحظة أن الأحكام المتعلقة بضمان التعرض والاستحقاق لا تعد ذات طابع إلزامي, وهي مقررة لحماية

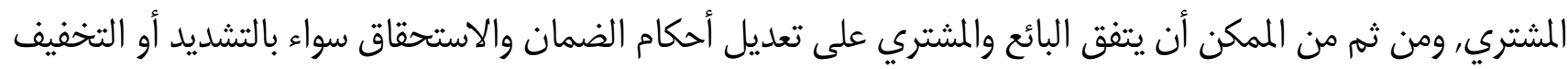

(1137) د. سمير عبد السيد تناغو, عقد البيع, ط 1, مكتبة الوفاء القانونية, الإسكندرية, 2009, 248 ؛ ؛ د. عبد الرزاق السنهوي, الوسيط في

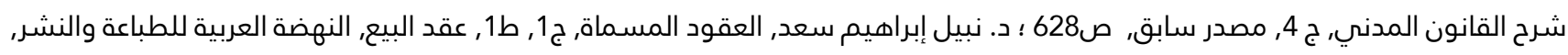

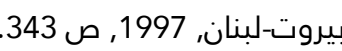
(1138) أنور العمروسي, مصدر سابق, 15؛ د. د. جعفر الفضلي, مصدر سابق, ص 109.

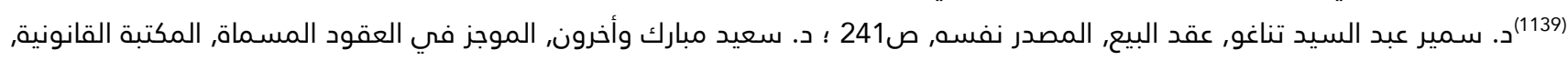

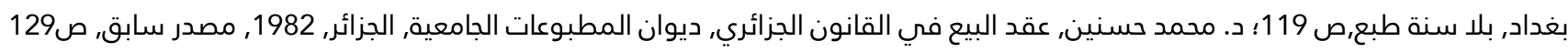
؛ د. نبيل إبراهيم سعد, مصدر سابق, ص343.

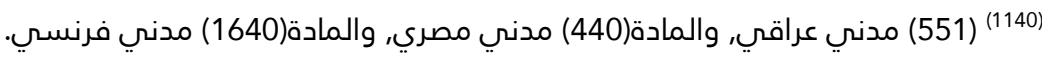

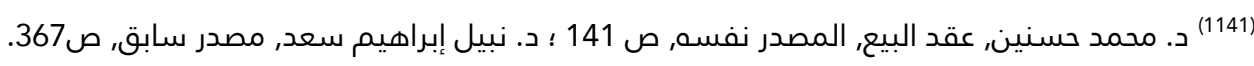

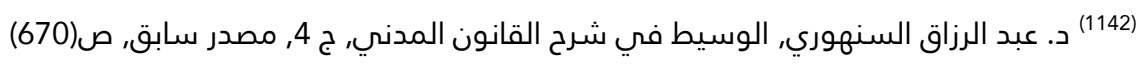
(1143) المادة(554) مدني عراقي, والمادة (543) مدني مصري, والمادة(1635) مدني فرنسي. 
أو الإعفاء, إلا أنه يشترط لسريان مفعول هذه الاتفاقات عدم تعمد البائع إخفاء حق المستحق؛ لأن ذلك يعد غشًا منه (1144).

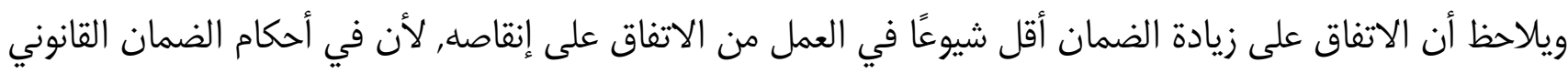

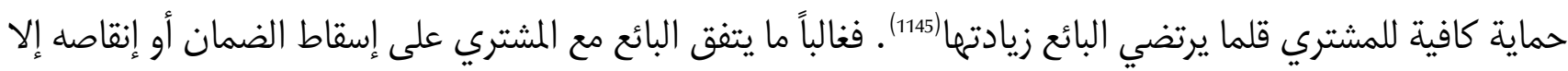

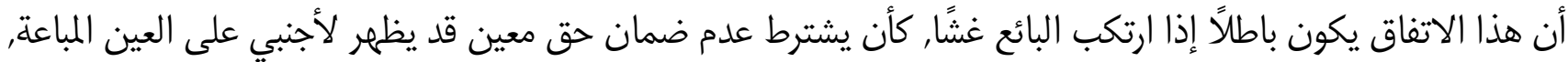

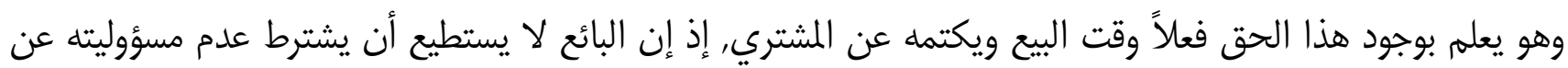

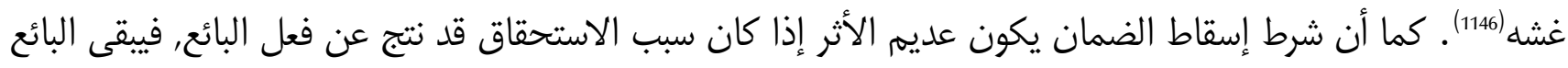

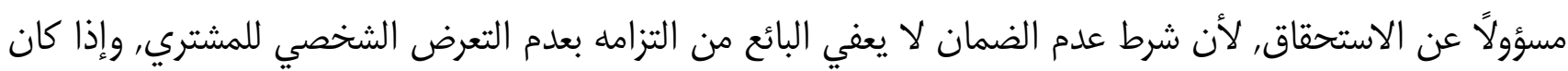

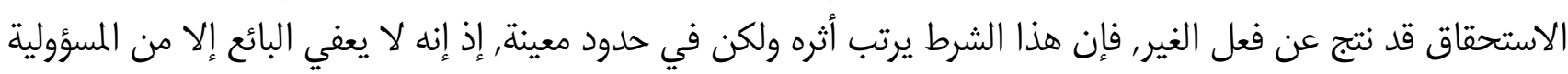
عن التعويض وبالتالي يبقى مسؤولاً عن رد قيمة المبيع وقت الاستحقاق (1147).

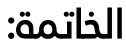

إن الغش في مرحلة تنفيذ عقد البيع, يتهم من خلال إما التلاعب بالمواصفات التي تم الاتفاق عليها بين البائع والمشتري,

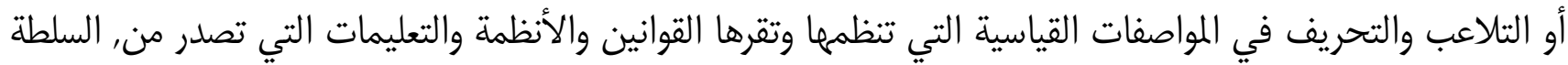

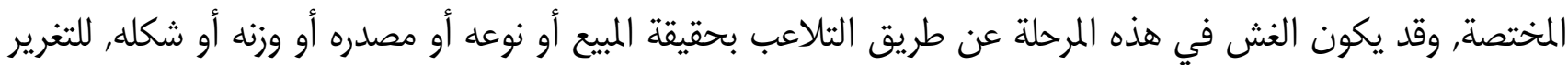

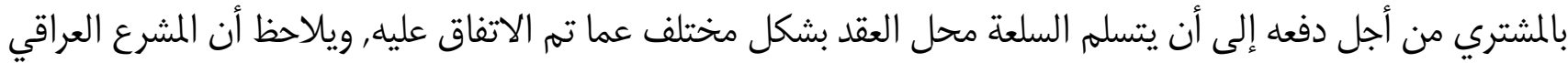

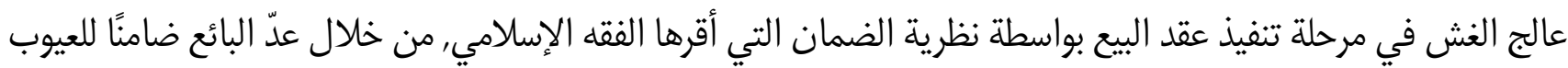

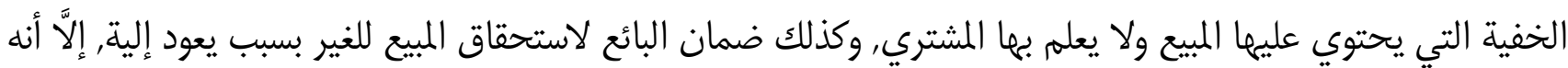

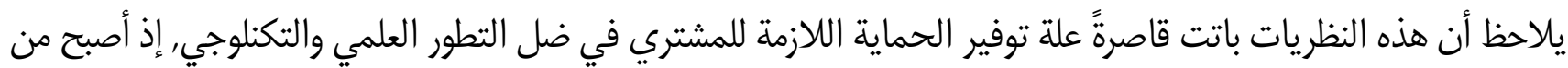

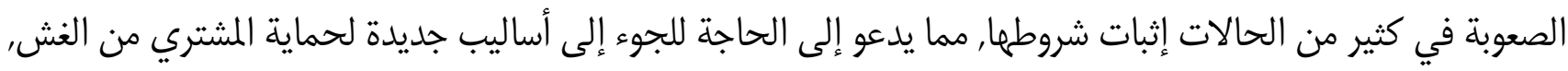

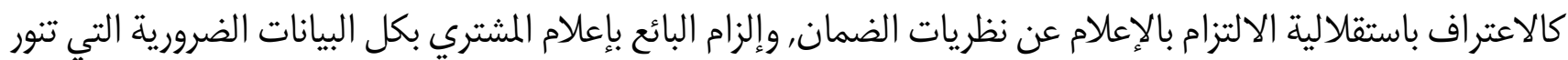

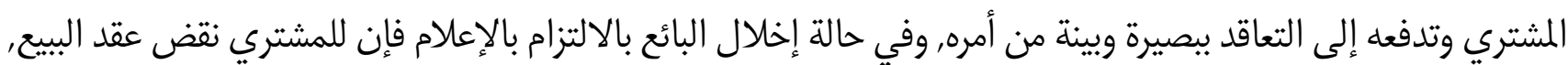
أو الإبقاء عليه مع حقه بالتعويض في كلا الحالتين.

(1144) المادة(556) مدني عراقي والمادتان(545) و(546) مدني مصري, والمادتان(1627)و(1628) مدني فرنسي. (1145) د. محمد حسنين, مصدر سابق,صني (149).

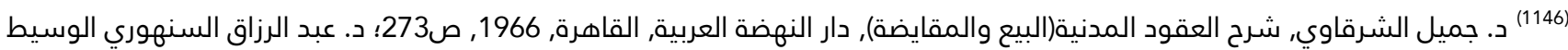

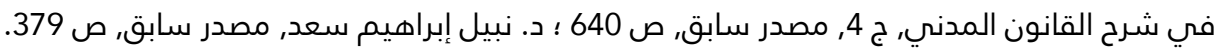
(1147) د. سمير عبد السيد تناغو, عقد البيع, مصدر سابق, ص287. 
النذاعات العقارية الجماعية : الإجراعات والاختصاص

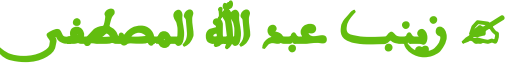 \\ باحثة بصف الدكتوراه - مدرسة الدكتوراه

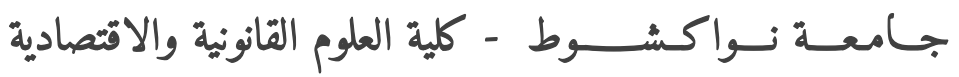

\title{
مقدمة
}

إن المحلل للوضعية العقارية في موريتانيا يرى أن السمة الأبرز لها هي كثرة النزاعات العقارية، إذ تحتل مرتبة كبيرة بين النزاعات الأخرى، سواء المعروض منها أمام القضاء أوالإدارة.

وتعتبر الملكية العقارية الجماعية (1148) أحد مجالات هذه النزاعات، وذلك لكونها ملتقى حقوق عدة أشخاص، وما قد يستتبع ذلك من تعارض قد يؤدي في أحيان كثيرة إلى نشوب نزاعات عقارية جماعية.ويثير مفهوم الجماعية إشكالات كثيرة حيث تختلف أحيانا مواقف القضاة والإداريين منه (1149).

1148) يقول جيزيفاستيفان أنه "منذ العهود التاريخية القديمة نجد الهيكل الاجتماعي لافريقيا الشمالية كان قبليا ، وكانت النتيجة الطبيعة لهذا الهيكل هي الملكية الجماعية. انظر سعاد عاشور، حجية التسجيل وفق نظام التحفيظ المغربي 1997 -ص : 20 1149) فأحيانا تدفع اللجان العقارية في المقاطعات بكون النزاع ليس جماعيا فيطعن الأطراف أو أحدهم في القرار أمام الغرفة الإدارية بالمحكمة العليا فتعتبر النزاع جماعيا تبت فيه لجنة المقاطعة ويطعن فيه أمام لجنة الولاية من ذلك مثلا القرار رقم 2016/35 بتاريخ 2016/05/02 والذي جاء فيه "مما سبق يتضح بجلاء أن التكييف الواردة في المحضر المطعون فيه والذي اعتبر النزاع القائم بين طرفي الخصومة نزاعا فرديا جانب الصواب، وهو ما نصت عليه الفقرة الرابعة من نفس المادة بقبولها: أو في حالة فشل هذه المحاولة ( محاولة حل النزاع صلحا) يمكن اللجنة أن تعتبر ، إما أن النزاع ذو طابع جماعي" المقصود في المادة 7 من الأمر القانوني 83 - 127 بتاريخ 06 يونيو 1983 وفي هذه الحالة تواصل تحرياتها وجهودها بغية التوصل إلى حل تصالحي للنزاع أو إلى قرار التحكيم". هذا النص هو الذي يتعين على اللجنة أن تأخذ به وتعمل بمقتضاه لكون النزاع جماعيا بشكل لا غبار عليه ، حيث ينطبق عليه مدلول المادة 103 السابقة تمام الانطباق، اما وصفه بأنه فردي ، وخلع حلية " الجماعية" عنه فلا يخلو من تعسف وتجاهل النصوص وتغيير للوقائع، وهو ما يترتب عليه بطلان التكييف الذي اعتمدته اللجنة وأصدرت على أساس قرارها باعتبار النزاع فرديا ، مما يتعين معه إلغاؤه باعتباره نزاعا جماعيا طبقا للمان ولمادة 7 من الأمر القانوني 83 - 127 والمادة 103 المرسوم 2010 - 080 المطبق له ، وتختص لجنة الوقاية وتحكيم النزاعات الجماعية العقارية

بمقاطعة بوامديد بالنظر والتصدي له طبقا لنص المادة 104 من نفس المرسوم السابق. وفي بعض الحالات الأخرى تبت لجنة المقاطعة في نزاع خصوصي على أنه نزاع جماعي وتصدر فيه قرارا وبعد طعن أحد الأطراف أمام الغرفة الإدارية بالمحكمة العليا تقضي بخصوصية النزاع ، من ذلك مثلا القرار رقم: 09/59 بتاريخ 2009/06/11 والذي جاء فيه "حيث أن النزاع الجماعي عرفه النص السالف الذكر بأنه ذلك النزاع الذي ينشأ بين جماعتين أي قبيلتين أو تجمع حضري ، أما النزاع الذي تتناوله محضر اللجنة العقارية محل النزاع قد سبق أن أصدرت فيه أحكام قضائية (الحكم رقم 2002/30 الصادر بتاريخ 2002/02/17 (الصلح الصادر بتاريخ 1985/09/20) وبالتالي يكون محل النزاع خصوصي.حيث إن المادة 102 من المرسوم رقم 2000/089 تحدد النزاع الجماعي بأنه النزاع الذي تكون مجموعة تقليدية أي قبيلة على الأقل طرفا فيه وهذا النزاع زعم أنه تم تخصيص القطعة الأرضية موضوع النزاع عن طريق أحكام قضائية سبق ذكرها فهو نزاع حسب ما أورد الحاكم في مذكرته بين أسرتين وبالتالي لم يكن من اختصاص اللجان الإدارية المنصوص عليها في المادة 103 من المرسوم رقم 
مما ينشأ عنه تنازع سلبي في الاختصاص يذهب ضحيته أطراف النزاع ، مما يدعونا للتساؤل ما هي النزاعات العقارية

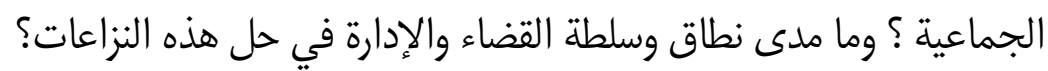

ولإجابة على هذه التساؤلات سنعالج الموضوع من خلال تحديد النزاعات العقارية الجماعية ( مطلب أول) ثم بيان الاختصاص والإجراءات في هذه النزاعات (مطلب ثاني).

\section{المطلب الأول:النزاعات العقارية الجماعية}

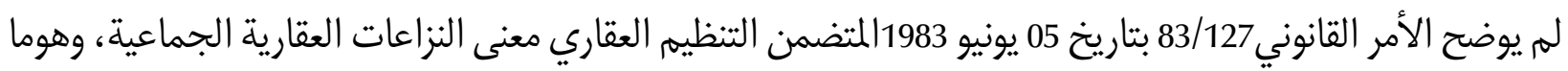

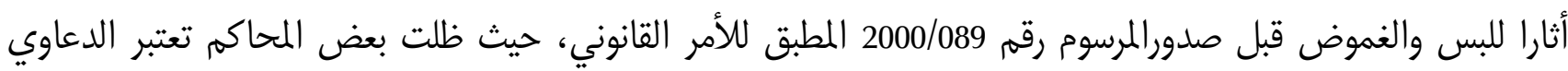
المرفوعة من جماعة لمجرد كونها جماعة نوعا من الدعاوي الجماعية (1150).

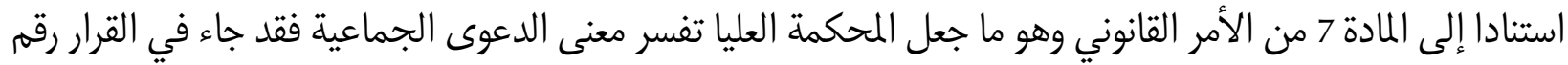

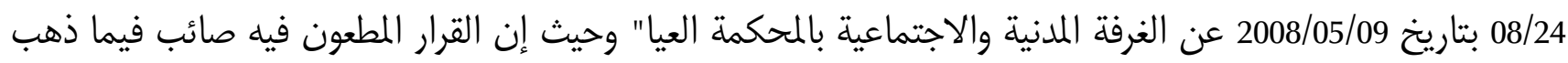

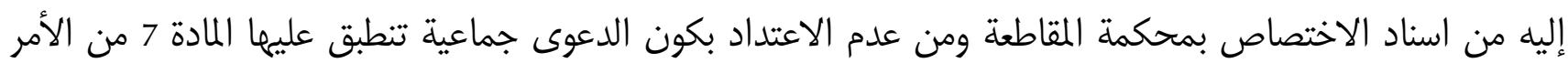

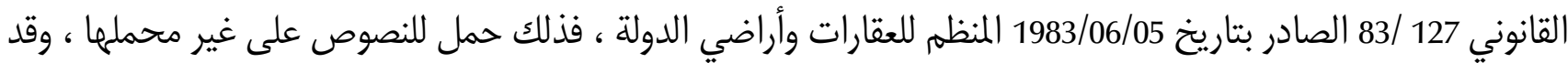

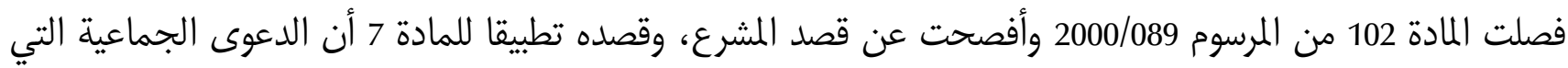

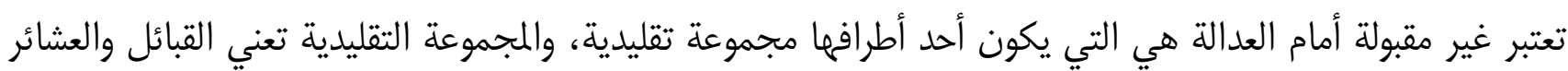

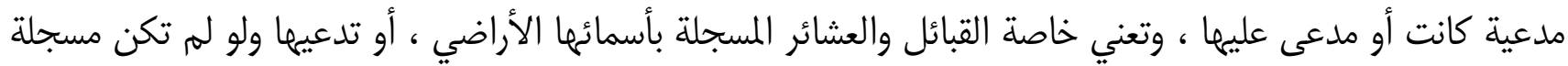

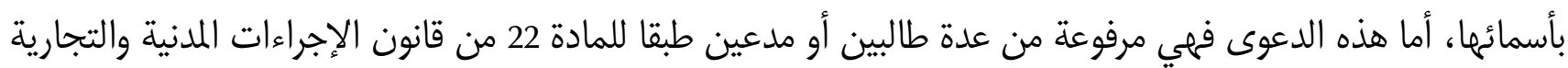

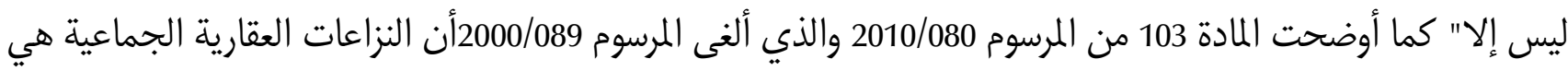

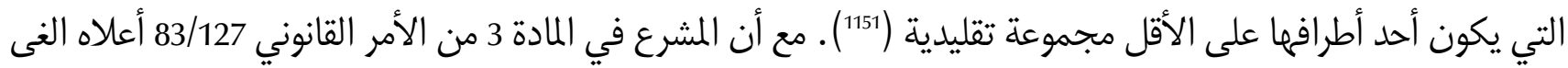

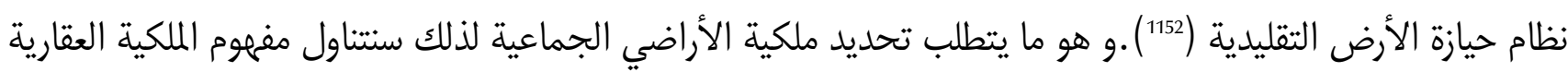

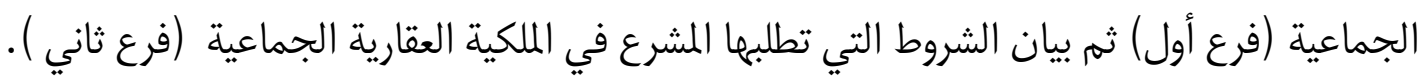

\section{الفرع الأول: مفهوم الملكية الجماعية}

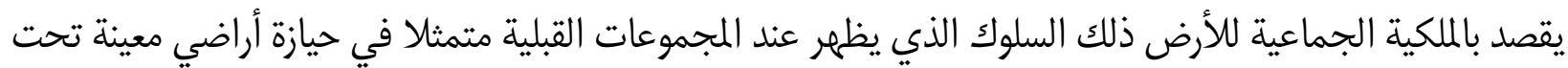

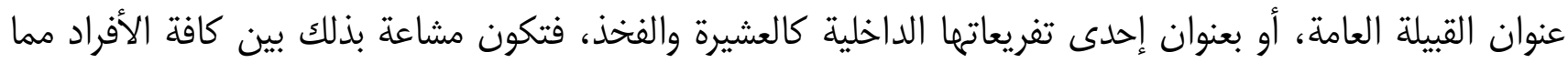
يخولمم الانتفاع ولو بشكل رمزي (153).

1150) الحكم رقم 08/10 بتاريخ 2008/02/18 عن محكمة مقاطعة الطينطان

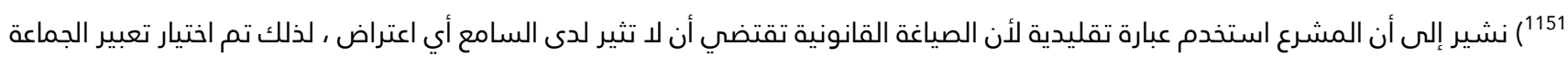

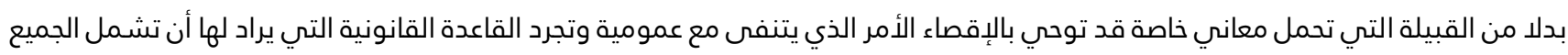


كما يمكن تعريفها بأنها الأراضي التي ترجع ملكيتها إلى جماعات على شكل قبائل أو عشائر تربط بينهم روابط عرفية

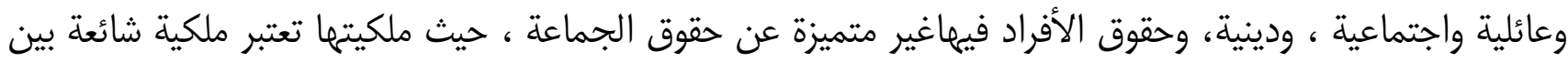
جميع الأفراد مع إمكانية توزيع حق الاتتفاع فيما بينهم (1544). يتبين من خلال هذه التعريفات أن الملكية الجماعية للأرض هي ذلك النوع من الملكية الذي تشترك فيه جماعات قد

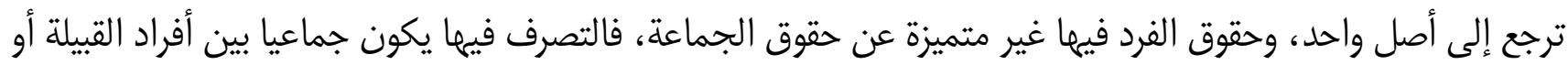

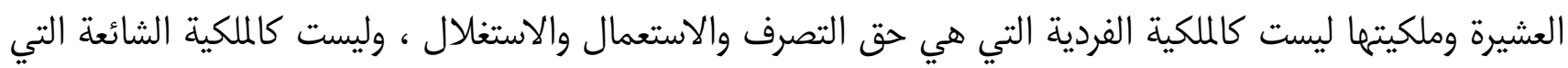

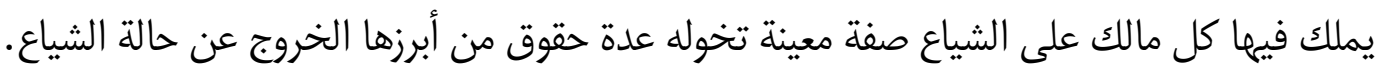
ويخضع هذا النوع من الملكية للأعراف والتقاليد التي تشكل عموما إحدى السمات الأساسية التي ترى فيها القبائل الإطار الذي يضمن حياتها ويحافظ على هويتها وذلك لتحقيق بعض الأهداف التي يمكن تلخيصما في النقاط التالية. المحافظة على وحدة القبيلة من خلال جعل مصالحها مشتركة ومترابطة لما يمكن أن ينجر عن ذلك من تدعيم لعلاقة التراخي والترابط من بين أعضاء القبيلة (1155). - الرفع من شأن القبيلة وإظهار هذا الشأن في عيون الآخرين نظرا لما يمكن أن يمنحه هذا النوع من الملكية من قيمة معنوية ذات شان. الحفاظ على الأرضبغض النظر عن استثمارها من عدمه، نظرا لسهولة حيازتها كلما كانت جماعية وبساطة الحفاظ عليها لتهيب مجموعات أخرى من الصدام معما أو الخصام. ويتم تحقيق الأهداف أعلاه من خلال آليتين اثنتين: 1- أحادية التداول: وتعني هذه العبارة أن الملك الجماعي القبلي يفرض أن يكون المستفيد من الأرض معروفا سلفا ، يلزم أن يكون من أبناء القبيلة لا يخرج عنهم إلى سواهم (1156).

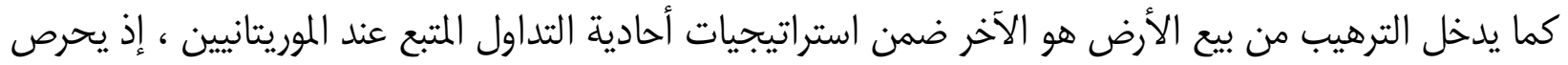

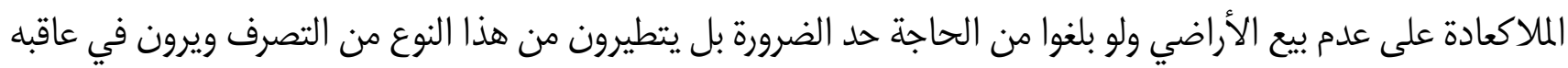
الخسارة والشؤم (1157).

1154) عبد الكريم بزاع، أراضي الجموع محاولة لدراسة بنيتها السياسية ودورها في التنمية الطبعة الأولى 1998 مطبعة النجاح الجديدة الدار البيضاء ص: 5. 1155) القبيلة ككيان تقليدي وسياسي محكم التنظيم تتكون بفعل عوامل متعددة منها القرابي والنسبي ، والولاء، والعصب ، ويتمدد أفقيا

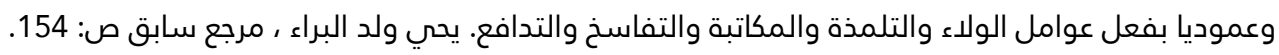

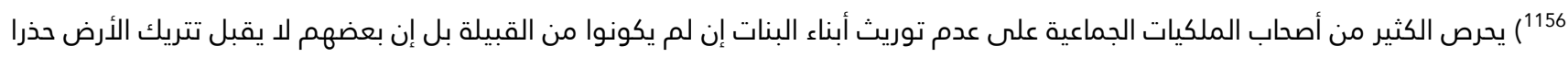

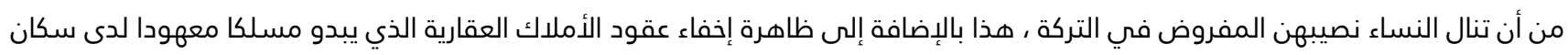
الواحات والمدن القديمة ، فكثرة تعاقد الأجيال عليها من نفس العشيرة يؤدي في الغالب إلى تشتت هذه الملكية وانتقالها بالإرث والهبة

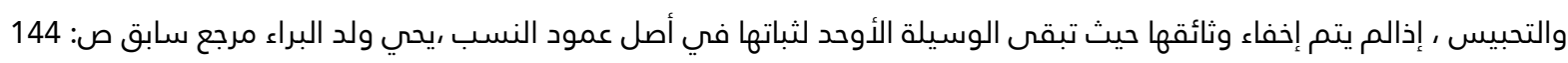

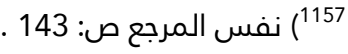




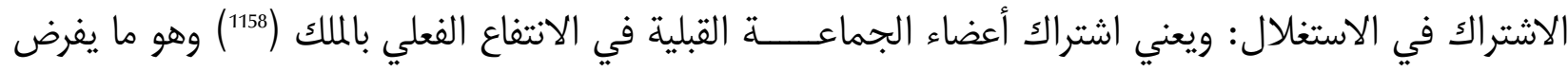

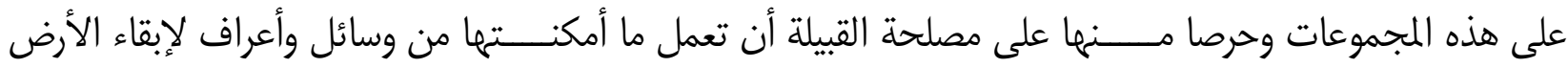

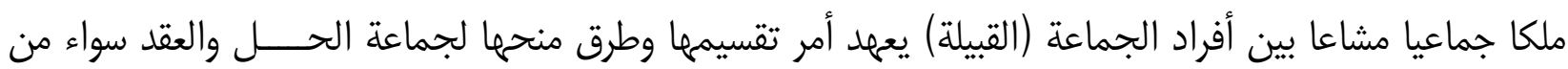

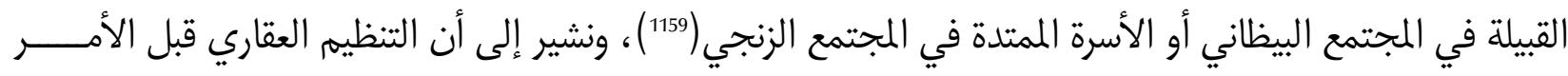

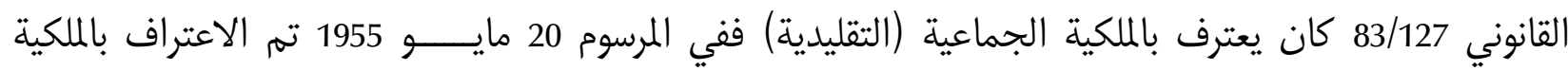

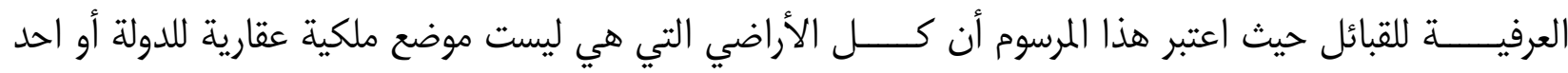

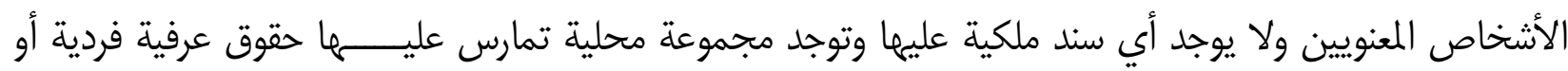

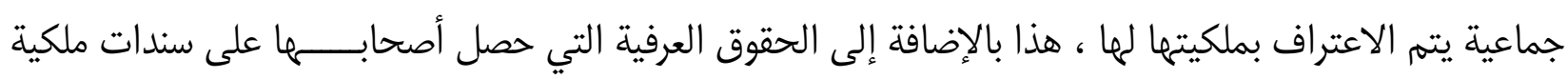
قبل سريان مرسوم 1955 (1160).

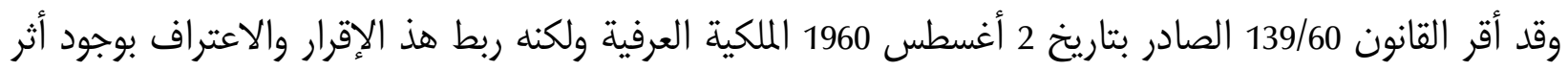

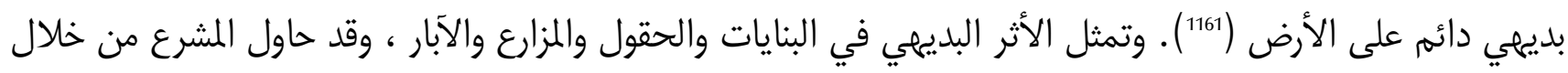

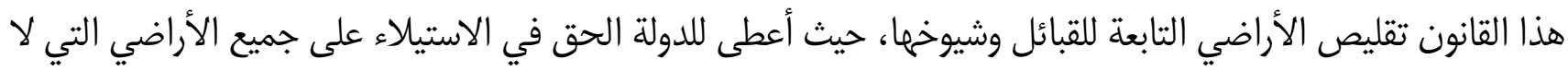

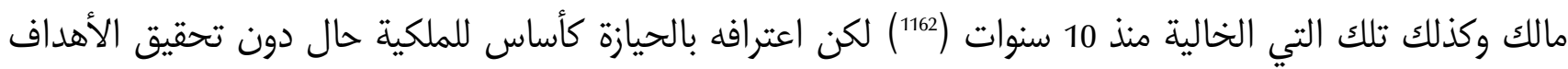
الأخرى.

ومع تطبيق الأمر القانوني 83/127 لم تعد الحيازة التقليدية معترفا بها (1163). حيث أكد في المادة 5 على أن التسجيلات

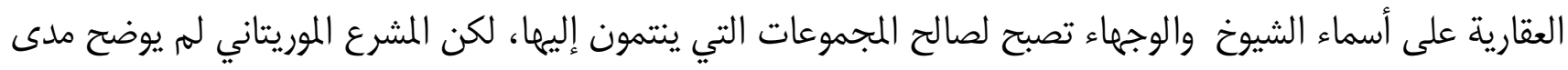

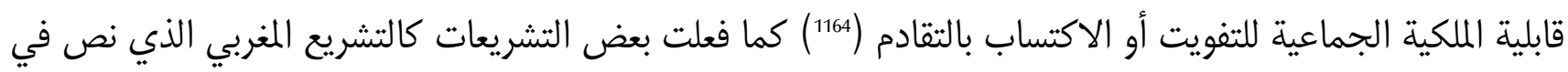

(1158) ويأخذ هذا الاشتراك الفعلي عدة أنواع :

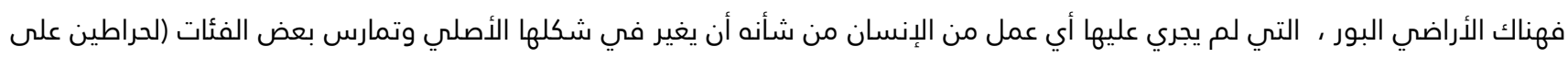

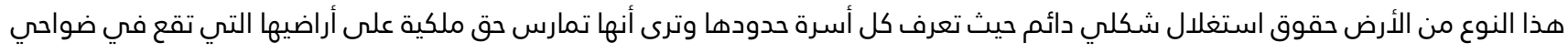

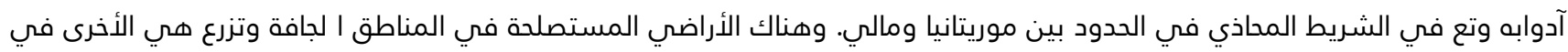
نفس الفئات خلف سدود أنشأت بوسائل بدائية ويطلبون الإذن دائما من الأسر المتحكمة وتقع هذه المناطق في أفل وآفطوط. الأراضي

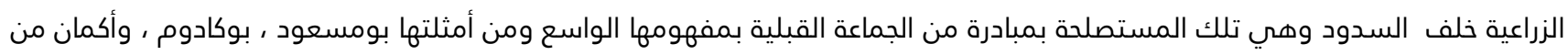

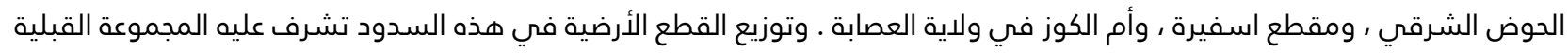

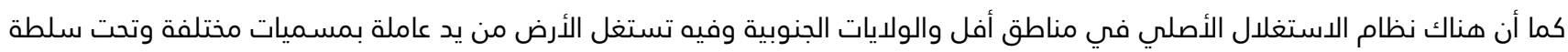

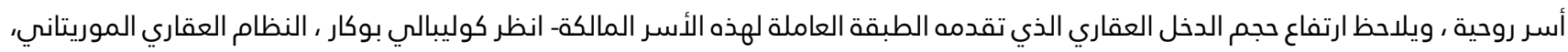
مداخلات في ملتقيات للسلطات الإدارية لسنة 2000 ترجمة إدارة الترجمة بوزارة الدارة الدارية. 147 1159) الدكتور يحي ولد البراء مرجع سلتان 1460

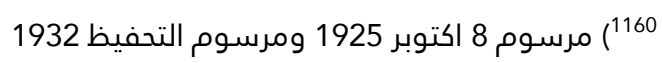

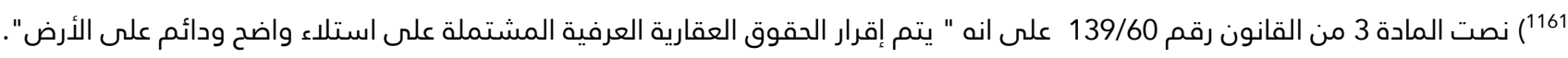
60/139 1162 (1162 المادة 7 من القان (1163 1163 نص المادة 3 على أن نظام حيازة الأرض التقليدية أصبح لاغيا. 1164) لم نجد نص في التشريع العقاري الموريتاني يحدد مدى قابلية الملكية الجماعية للتفويت أو التقادم المان 
الفصل الرابع من ظهير 1919/04/27 على أن "الأراضي الجماعية غير قابلة للتقادم ولا للتفويت أو الحجز" (1165) ونرى بأن ما كان من هذه الأراضي محفظا لا يمكن أن يطاله التقادم وذلك بمقتضى المادة 4 والمادة 10 من المرسوم 2010/080 (1166). أما الأراضي التي لم تكن موضع تسجيل عقاري أو لم تكن محياة من طرف أصحابها أي لهم يبق لإحياءها آثار بديهيية فيمكن ادعاء انتهاء ملكيتها بالاندراس (1167).

\section{الفرع الثاني:شروط الملكية الجماعية}

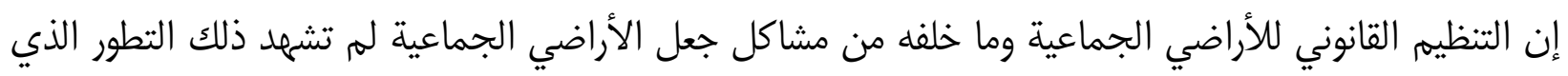

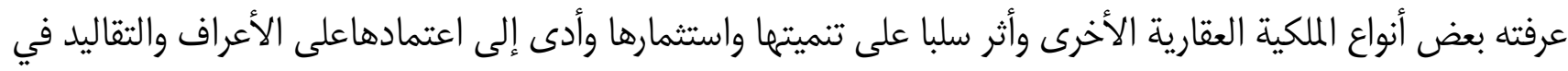

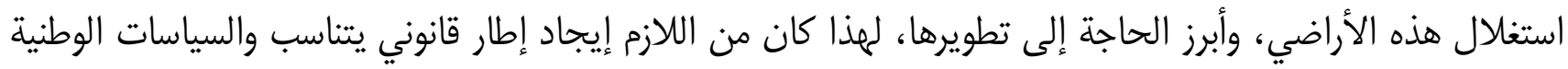

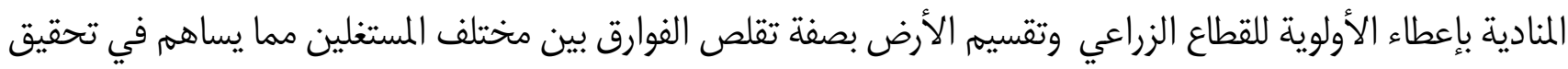

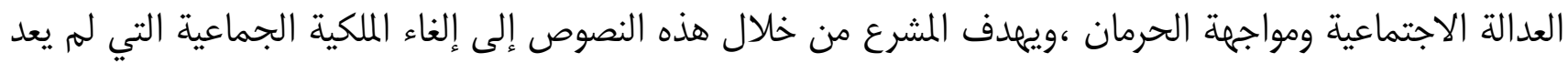

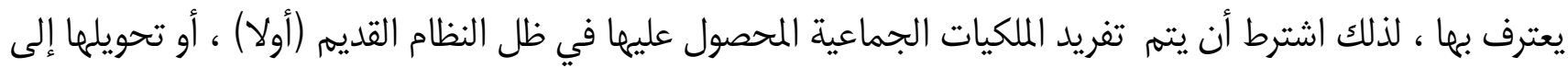

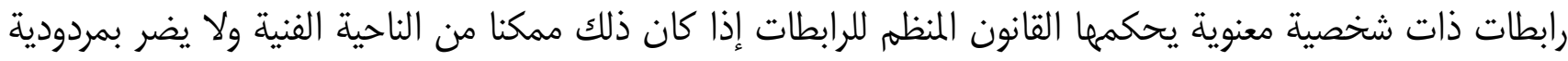
الأرض (ثانيا).

\section{أولا: التفريـد}

التفريد هو إجراء قانوني يقصد منه تصفية صيغة من التملك لم تعلد موجودة قانونا ، أو هو عبارة عن تقسيم ملكية جماعية إلى عدة ملكيات فردية،ويتم بموجب محضر ويتوج بإصدار شهادة ملكية (168) . أما مجال تطبيق التفريد فهو: - الأراضي التي كانت مملوكة قبل 1983 للقبائل أو العشائر أو من تجمعهم عصبية معينة .

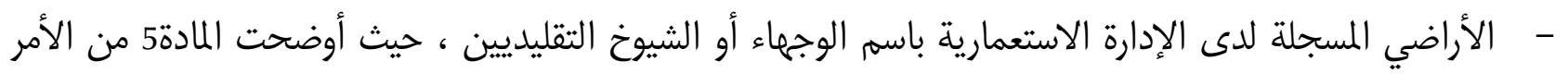

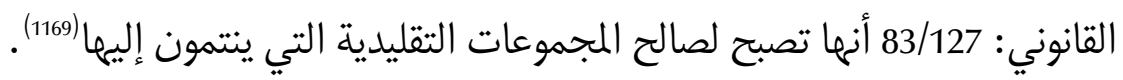

1165) د / محمد مومن ، معيقات الاستثمار في أراضي الجموع مقال منشور في مجلة الحقوق المغربية العدد الأول سنة 2010 ص:108 صدأ 1166) نصت المادة 4 على أنه "يمكن ادعاء فوات حق الملكية بالإندراس على كل مالك لم يسجل أرضه طبقا للمسطرة المعمول بها كما نصت المادة 10 "... ويحصن التسجيل ضد فوات حق الملكية بالإندراس كما يشكل دليلا قاطعا على الملكية" 1168) حمادي ولد اميمو مقال مقدم في اليوم العلمي المنظم من طرف المحكمة العليا حول الأمن العقاري في موريتانيا 24-25 نوفمبر 2016

1169) وقد أوضحت (المادة 6) الأشخاص الذين يحق لهم الاستفادة من التفريد حيث نصت على أن الحقوق الجماعية المكتسبة شرعا حسب النظام السابق والخاصة بالأراضي الزراعية يجب أن تعود لفائدة الذين ساهموا في الاستصلاح الأصلي لتلك الأرض ، وكذلك الذين ساهموا في لـإي استمرارية قابليتها للاستغلال ، كما نصت نفس المادة على إجبارية فردية الملكية ، وأنه في حالة ما إذا وقع نزاع على التوزيع أو تطلب النظام الاجتماعي ذلك فإن الإدارة تتدخل للإشراف على عملية التوزيع ، ويتضح من نص هذه المادة أن المشرع أراد حماية حقوق الأشخاص الذين ساهموا في الاستصلاح الأصلي للأرض وكذلك الذين ساهموا في استمرارية قابليتها للاستغلال ، وذلك راجع لما تسبب فيه هذا النمط من 
وقد نصت المادة 36 من المرسوم 2010/080 على أن الملكية الزراعية المكتسبة قبل سريان القانون 60/139 المنظم للعقارات

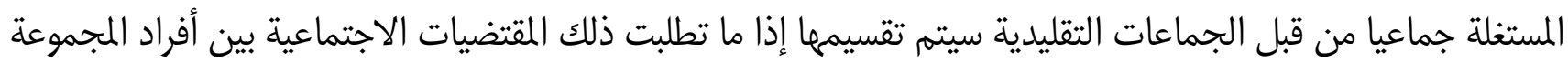

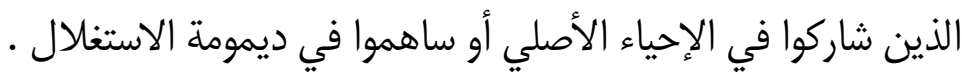

وأوضحت المادة 37 أنه يستفيد من تقسيم الأراضي الجماعية ضمن الشروط المحددة في المادة 36 أعلاه الأشخاص

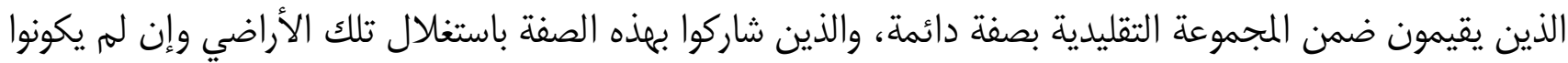
مسجلين إداريا ضمن المجموعة المذكورة .

ونشير إلى أن الأشخاص المستفيدين من التفريد سواء كانوا مشاركين في الإحياء الأصلي أو مساهمين في استمراره ينتقل حقهم إلى ورثتهم وتكون حصة كل فرد متناسبة طردا مع ما بذله من مجهود مادي أو عضلي في عملية الإحياء واستمراره

وأضافت المادة أن الأشخاص الذين قاموا بمبادرتهم الخاصة أو بموافقة مجموعة ببناء منشآت لحجز المياه أو بترميمها

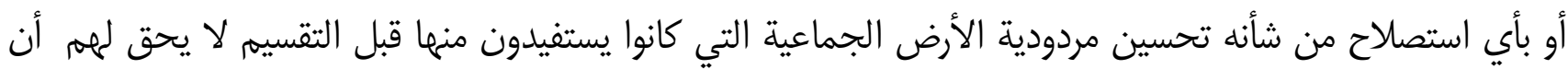
يتمتعوا بمناسبة ذلك التقسيه بأي ميزة إضافية على جميع المستفيدين الآخرين. ويته القيام بعملية التفريد إذا حصل أحد الشروط التالية: - - اقتضاها الوضع الاجتماعي بحيث أصبحت العلاقات بين أفراد المجموعة متوترة أو بطلب من بعض الأفراد أو باتفاق

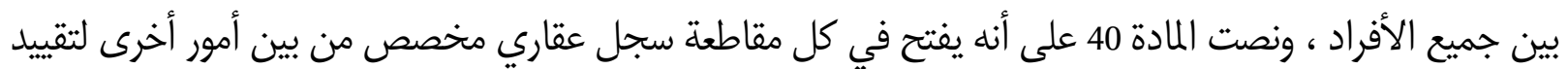

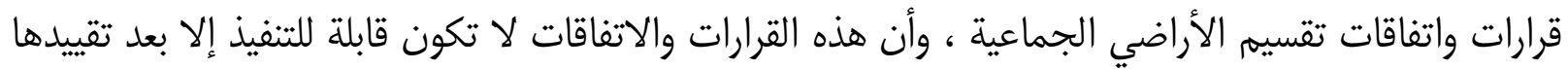

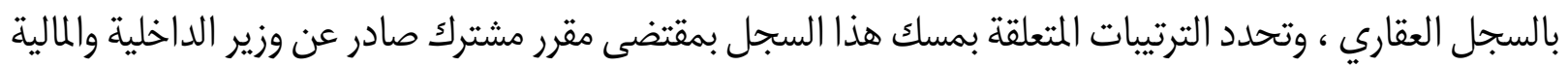
والتنمية الريفية والبيئة .

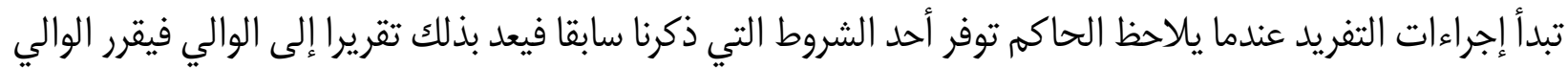

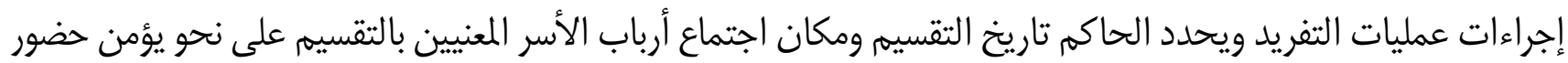

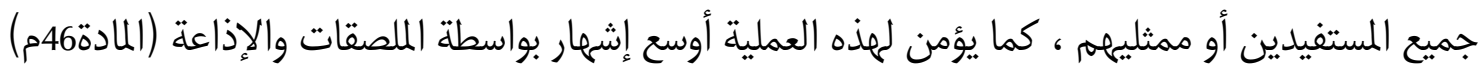

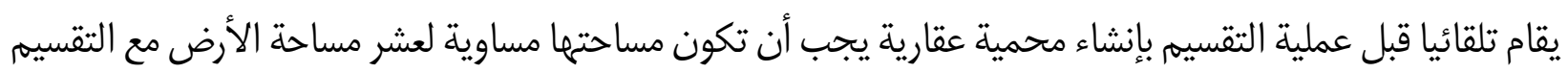

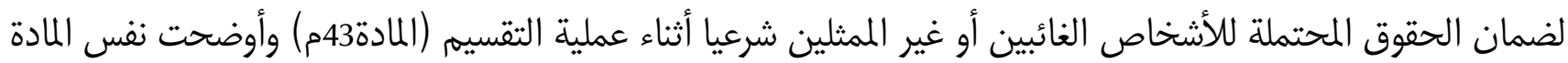

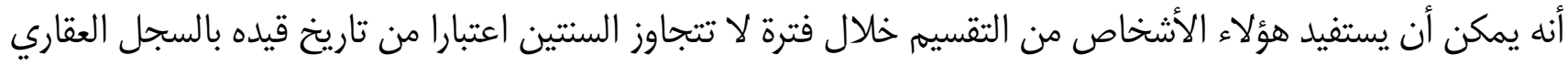

الملكيات من تعطيل الكثير من المناطق الزراعية عن الاستغلال والاستثمار وتسخير أعداد كبيرة من بعض فئات المجتمع لاستصلاحها بشكل لا

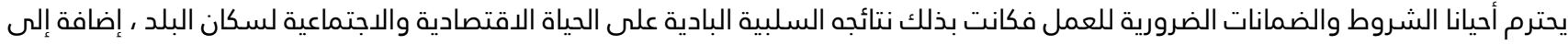
دور التملك التقليدي في الإبقاء بشكل صارم على ثبات واستمرار المواقع الجهوية لأبناء هذا المجتمع ، تلك المواقع التي ظلت حاجزا حصينا أمام مبتغي التحديث مما شكل ضرورة ملحة لوجود حماية قانونية لهذه الحقوق الفردية. 
كما هو منصوص في المادة45وأوضحت ذات المادة أن قرار التوزيع يكون من اختصاص الوزير المكلف بالداخلية بعد الاطالاع على تقرير مفصل من الوالي وعلى رأي لجنة الوقاية وتحكيم النزاعات العقارية الجماعية للمقاطعة (1170.) وبعد انتراء إجراءات التفريد يعد الحاكم محضرا بختم عمليات التفريد وعلى إثر ذلك تسجل القطع الأرضية باسم ملاكما الفرديين وتسلم لكل واحد منهم شهادة ملكية للقطعة التي حصل عليها(1171).

\section{ثانيا: تحويل المجموعات إلى رابطات ذات شخصية معنوية} أكد الأمر القانوني 83/127 على أن كل حق ملكية لا يرتبط بشخصية قانونية يعتبر غير موجود في الوقت الذي حرمت فيه النصوص المجموعات التقليدية من الشخصية القانونية. فمن خلال الأمر القانون يتضح أن على المجموعات التقليدية الإنتظام في شكل شخصيات معنوية تتشكل طبقا للقانون ويتهم استصدار شهادة الملكية باسم الشخصية المعنوية الجديدة وقيدها في السجل العقاري ويخته على مقلوب إفادة الملكية خته يحوي على عبارة كل المستفيدين (1172). ومع أن تطبيق فكرة الرابطات وفقا لشروط مضبوطة سيشكل حافزا لسكان الأراضي الجماعية لاستغلالمها بشكل أكثر

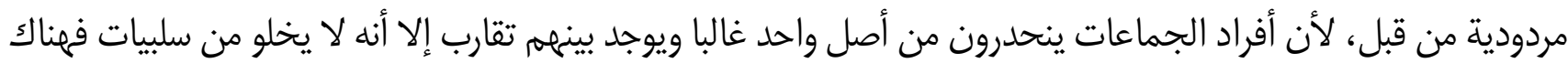
بعض المجموعات التي تحولت فعلا إلى رابطات ولكن العلاقات الاجتماعية الطبقية ظلت باقية ، وإن كانت قد تقمصت شكلا جديدا ، فا الوجيه التقليدي هو رئيس الرابطة، وبنو عمه الأقربون هم مكتبها والباقون هم بقية أعضاء الرابطة (1173). وهو ما قد يزيد من تعقيد مشكل الأراضي الجماعية سواء على الصعيد الاجتماعي أو الاقتصادي وهو ما يستدعي إيجاد بدائل ملائمة لتطوير الملكيات الجماعية.

\section{المطلب الثاني: الاختصاص والإجراءات}

إذا كانت معظم التشريعات والقوانين تخول من تتعرض ملكيته للتشويش أو الاعتداء أن يلجأ إلى القضاء لعرض نزاعه

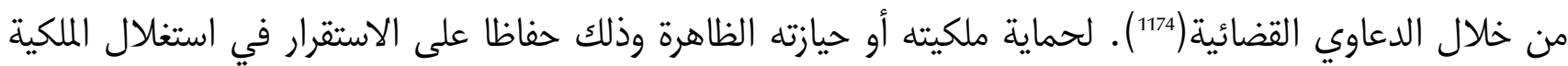

1170) لكن مع ذلك هنالك معوقات عملية تحول دون تطبيق التفريد، من هذه المعوقات عدم تحديد بعض المفاهيم كالمساهمة في استمرار الاحياء الذي يعتبر مفهوما عائما إذ يشمل اعتبارات مادية ومعنوية يصعب تقويمها ومنها كذلك صعوبة توزيع الأراضي بحيث يستفيد كل فرد من قطعة تتوفر على نفس الامتيازات فالعملية تقوم على تقسيم قطع أرضية تتناقص يوميا بفعل التصدر على أفراد يشكلون مجموعة في ازدياد مستمر لذلك لم يتم تفريد الملكيات الجماعية منذ ربع قرن إلا مرتين فقط، واحدة في بلدة (فيد افيد) في ضواحي بحيرة ألاك والثانية في قرية لهبيلة التابعة لكيعة التيدومة في مقاطعة تامشكط.،انظر حماد ولد اميمو مرجع سابق ، صـ43 1171 - إن رغبة تملك الأرض قوية جدا في نفوس المزارعين والتقسيم بقصد الاستغلال الدائم سيلبي هذه الرغبة وسيقضى على الجمود الذي يسيطر على أفراد الجماعات الذي لا يريدون إصلاح أرض ليس لهم فيها سوى حق الانتفاع المؤقت. - إن التقسيم سيخفف من النزاعات القائمة على الرغم من أنه سيتطلب مجهودا كبيرا من طرف السلطات الإدارية المشرفة. - إن هذا التقسيم سيشجع الجماعات على استثمار أراضيها بطرق عصرية جد منتجة وسيمكنه من مباشرة استصلاح الأراضي الزراعية. 2010/080 1172 المادة 49 من المرسوم

1173 1173 محمد فال ولد عبد اللطيف مرجع سابق ص: 1174. 1174) ومنها التشريع الموريتاني الذي خول لصاحب الحق الالتجاء إلى القضاء لتقرير حقه وحمايته، وذلك من خلال دعوى الاستحقاق العقارية والتي تطالب باسناد ملكية العقار المحفظ ونزعه من يد حائزه. وأيضا هنالك دعوى الحيازة التي تناولتها المادة 441 في مدون الإجراءات من م أ م ت أ 
والاستفادة منها، وحماية النظام العام في المعاملات، إلا أن المشرع الموريتاني بمقتضى المادة 7 من الأمر القانوني 83/127 استثنى النزاعات العقارية الجماعية من هذه القاعدة وجعل المحاكم غير مختصة بالنظر في هذه النزاعات. وأسند البت في تلك الدعاوي للإدارة وفق مسطرة تحكيم إداري تبدأ بلجان محلية وجهوية وتنتهي بقراراللجنة الوطنية على مستوى وزارة

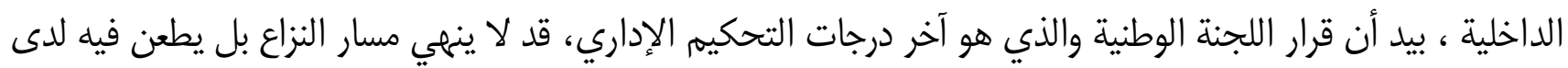
قضاء الإلغاء الإداري بالمحكمة العليا حيث تحكم الغرفة الإدارية ابتدائيا ونهائيا فيه، الأمر الذي يتطلب منا تناول مسطرة التحكيم الإداري (فرع أول) ثم مسطرة الطعن القضائي (فرع ثاني).

\section{الفرع الأول: مسطرة التحكيم الإداري}

بمقتضى المادة 7 من الأمر القانوني 83/127 يعتبر القانون قد قلص نسبيا لصالح الإدارة من الاختصاص الطبيعي للقضاء، وذلك بمنع القضاء من النظر في الدعاوي العقارية الجماعية وشطب المعروض منها أمامه بقرارات وأحكام غير قابلة للطعن (1175) وإسناد الاختصاص في تلك الدعاوي لإددارة من خلال مسطرة تحكيم ادارية تبدأ بالمقاطعة والتي يطعن في قراراتها أمام لجنة الولاية ثم ، اللجنة الوطنية على مستوى وزارة الداخلية والتي يعتبرقرارها نهائيا في مسطرة التحكيم.

\section{أولا: التحكيم الإداري على مستوى المقاطعة والولاية}

- اللجنة العقارية في المقاطعة:

يدخل تسيير النزاعات العقارية الجماعية ضمن اختصاص لجنة الوقاية وتحكيم النزاعات العقارية في المقاطعة (1176). يمكن للجنة الوقاية وتحكيم النزاعات العقارية الجماعية في المقاطعة:

أن تعين ضمنها لجنة فرعية برئاسة العمدة المختص ترابيا وتضم مفتش التنمية الريفية وقائد فرقة الدرك(1177). تعد هذه اللجنة الفرعية تقريرا وتعرضه على لجنة المقاطعة التي يجب عليها استدعاء ممثلي الأطراف لمحاولة التوصل إلى حل النزاع صلحا وفي حالة فشل هذه المحاولة يمكن للجنة أن تعتبر:

"توصف "بدعوى حوزية" القضية التي خول القانون القيام بها لحائز عقار أو حق عيني على عقار ، وذلك بقصد استرجاع حيازته أو استبقائها أو تعطيل أشغال". 1175) نصت المادة 7 على انه لا تقبل الدعاوي العقارية الجماعية لدى العدالة ، وتشطب المحاكم من مداولاتها على كل الدعاوي التي تكتسي

نفس الطابع والمعروضة أمامها حاليا " كل مالمادة 23 من قانون 075 /2014 "تكلف اللجنة العقارية بالمقاطعة بوقاية وتحكيم النزاعات العقارية الجماعية. لذلك فهي معنية بدارسة

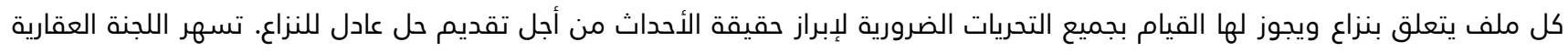

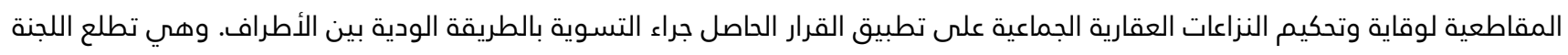

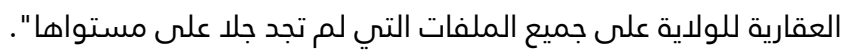
1177) المادة 24 جديدة من نفس المرسوم " تضم اللجنة العقارية المقاطعية كل من - حاكم المقاطعة رئيسا - عمدة البلدية المركزية - مفتش وزارة التنمية الريفية في المقاطعة - ممثل المديرية العامة للعقارات وأملاك الدولة - رئيس مصلحة الزراعة في المقاطعة - مائمة ـ رئيس مصلحة المياه في المقاطعة - ممثل مصلحة البيئة في المقاطعة - ممثل المزارعين والمنمين - الشخصين أثنين مشهود لهما بالاسلاستقامة المراكة الخلقية يعينان من طرف الوالي بناء على اقتراح من الحاكم" 
إما أن النزاع ذو طابع جماعي بالمعنى المقصود في المادة 7 من الأمرالقانونى وفي هذه الحالة تواصل تحرياتها وجهودها

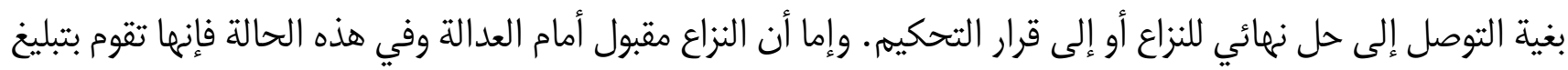
الأطراف بأنمها تعتبر نفسما غير مختصة مع دعوتهم إذا رغبوا في ذلك إلى إلى اللجوء إلى العدالة (1178).

وفي حالة ما إذا كانت الأرض موضوع النزاع قد عرفت بداية استغلال متثبت منه من قبل اللجنة الفرعية المذكورة سابقا

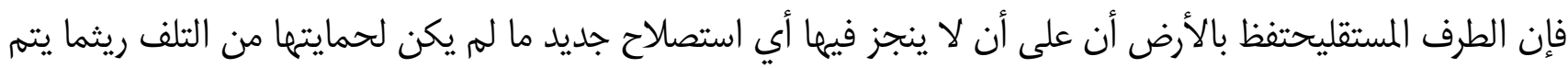

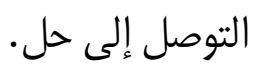

لا تراعي قيمة المصاريف المستثمرة في الأرض أثناء فترة عرض النزاع بشأنها على الهيئات التحكيمية أو القضائية إذا كان قد تم دعوى من يحتلونها إلا في حالة الطرف المحكوم له (1779). تدرس اللجنة العقارية للمقاطعة بنفسما ملف النزاع ، كما تقوم باقتراح حل على الأطراف، لكنها في حال فشل مساعي

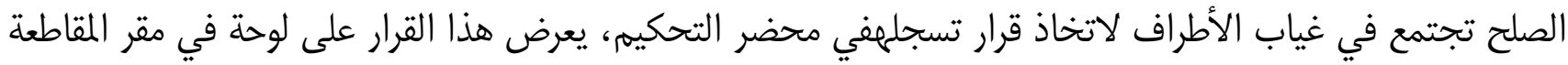

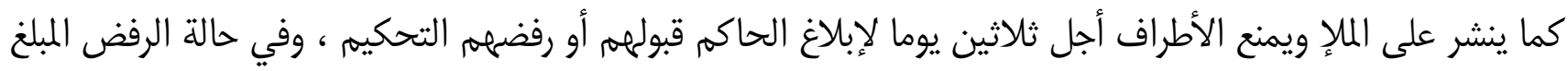

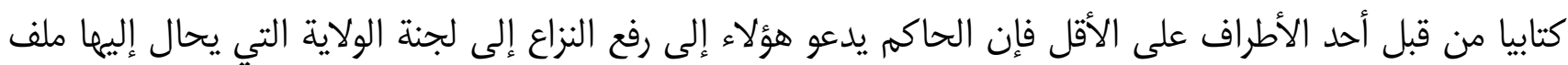
القضية سبعة أيام بعد تبليغ الرفض ويرفق الحاكم ملف النزاع بتقرير مفصل. اللجنة العقارية في الولاية: تملك الولاية هي الأخرى نفس الاختصاص حيث تقوم هذه اللجنة برئاسة الوالي وعضوية

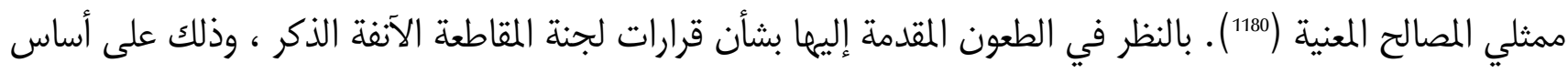

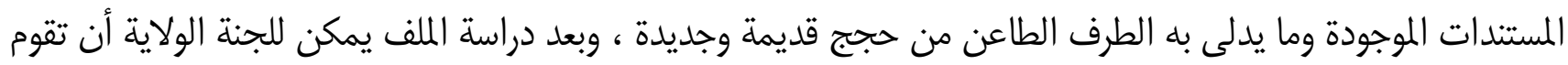

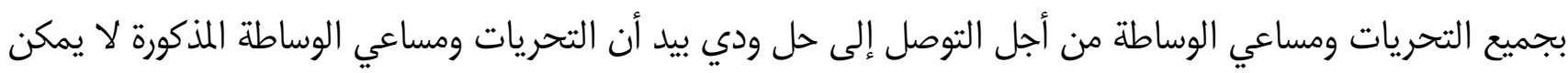

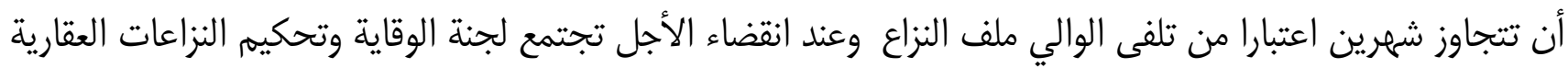

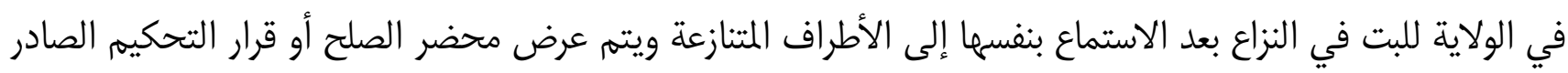

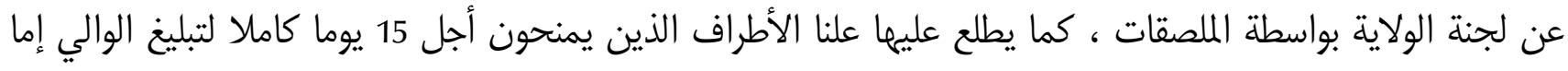

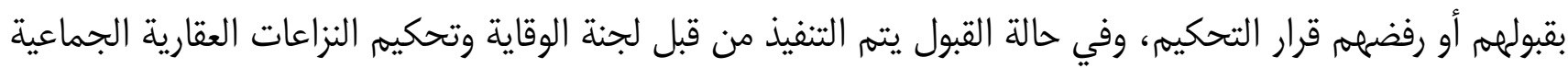

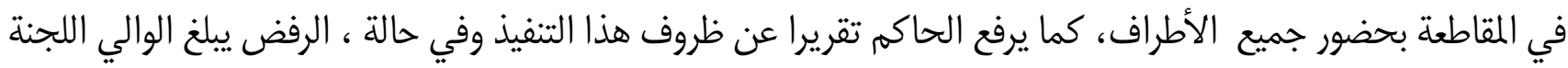
الوطنية أ. م كما يرفع إلى وزير الداخلية ملف النزاع مرفقا بتقرير مفصل (1811).

2010/080 1178 المادة 104 من المرسوم

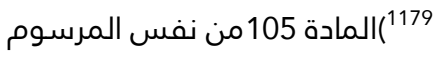
1180) المادة 22 من مرسوم 2014/075 تشكل اللجنة العقارية للولاية كما يلي :- الوالي رئيسا - المندوب الجهوي لوزارة التنمية الريفية المندوب الجهوي لوزارة البيئة - المندوب الجهوي لوزارة المياه - الممثل الجهوي للمديرية العامة للعقارات وأملاك الدولة - المندوب الجهوي للوزارة المكلفة بالعمران الاستصلاح الترابي - ممثلان إثنان عن المزارعين والمنمين يعينان في مقرر من الوالي- شخصيتان مشهود لهما بالاستقامة الخلية يعينان من طرف وزير الداخلية بناء على اقتراح من الوالي. 1181) المادة 109 م 2010/080. 


\section{التحكيم, على مستوى اللجنة الوطنية}

تتمثل مهمة اللجنة الوطنية المكلفة بوقاية وتحكيه النزاعات العقارية الجماعية في معالجة النزاعات العقارية الجماعية. تبلغ اللجنة الوطنية المكلفة بوقاية وتحكيم النزاعات العقارية الجماعية من طرف وزير الداخلية وعندها تكون مخولة في القيام بكل ما تراه ضروريا لتتمكن من اقتراح حل عادل للنزاع.

ولا تعالج اللجنة الوطنية المكلفة بوقاية وتحكيم النزاعات العقارية الجماعية لغير النزاعات التي سبقت معالجتها على مستوى الولاية والمقاطعة على التوالى.

تبدى اللجنة الوطنية المكلفة بوقاية وتحكيم النزاعات العقارية الجماعية رأيا مبررا حول كل ملف يعرض عليها(1182) ولا يمكن لهزه اللجنة أن تتجاوز تحرياتها ثلاثة أشهر ، وتجتمع لاقتراح حل على وزير الداخلية (1183). يحيل الوزير قرار تحكيمه إلى الوالي الذي يبلغه إلى الأطراف المتنازعة ولا يمكن لأية لجنة أن تحل محل أخرى، ويكتسي قرار تحكيم الوزير صبغة النفاذ الفوري ، ويتهم تنفيذه من قبل الوالي بحضور الأطراف، وفي الأيام الثمانية الموالية للتنفيذ يرفع الوالي إلى الوزير تقريرا عن ظروف تنفيذ قرار اللجنة المكلفة بوقاية وتحكيم النزاعات العقارية الجماعية ولا يمكن تعليق أو تأجيل التنفيذ(1184).

ولضمان استقلالية التحكيم الإداري نص المشرع على أنه لا يجوز للجنة الوطنية أن تحل محل اللجنة الجهوية في

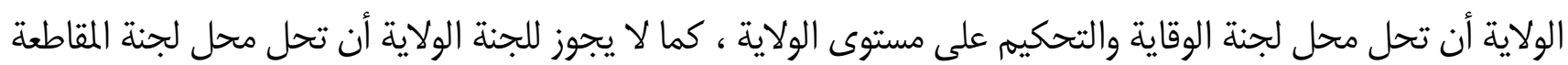
حتى وإن حل الوالي محل الحاكم لسبب ما (1185).

كما أن المشرع حاول أن يحد من بطء الإجراءات التي تتبعها هذه اللجان في حل النزاعات. من خلال تحديده إلزامية أن تبت لجنة التحكيم على مستوى الولاية في كل نزاع تم وصوله إليها من لجنة المقاطعة وذلك في ظرف شهرهي شهرين على الأكثر اعتبارا من تلقي الوالي ملف النزاع (المادة 109 من المرسوم 2010/080).

\section{الفرع الثاني: مسطرة الطعن القضائي}

من المعلوم أن دور القضاء الإداري ذا أهمية قصوى في الموازنة بين مصلحـــــــة الإدارة التي ينبغي أن تكون دائما

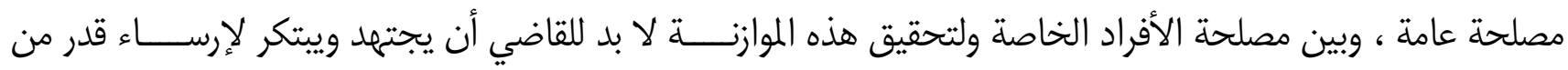

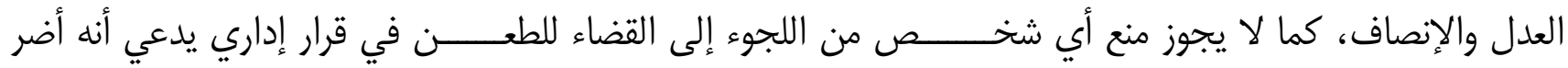

1182) المادة 20 " تتألف اللجنة الوطنية المكلفة بوقاية وتحكيم النزاعات العقارية الجماعية كما يلي: ممثل عن الوزارة المكلفة بالمالية -ثلاثة ممثلين عن الوزارة المكلف بالعمران - ممثل عن الوزارة المكلفة بالبيئة - ممثل عن الوزارة المكلفة بالعدل - ممثلون عن المزارعين والمنمين والمنظمات الغير حكومية الناشطة في مجال البيئة، تحدد إجراءات تعينهم بمقرر مشترك من وزراء الداخلية التنمية الريفية والبيئة".

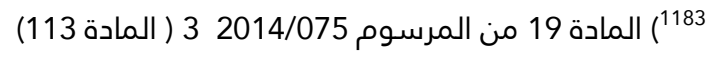
2010/080 1184 المادة 104 و المادة 108 من المرسوم المرسوم 1985 1185 المادة 114من نفس المرسوم 


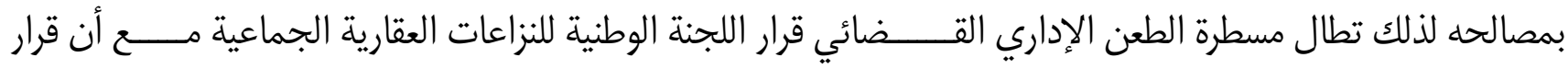

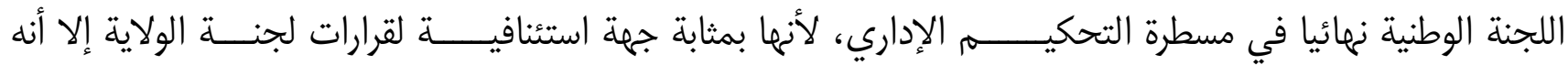

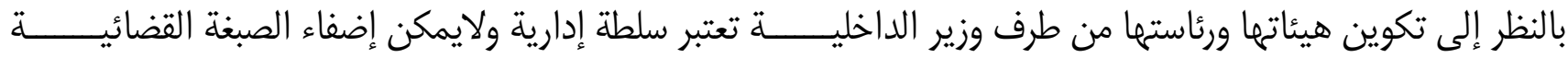

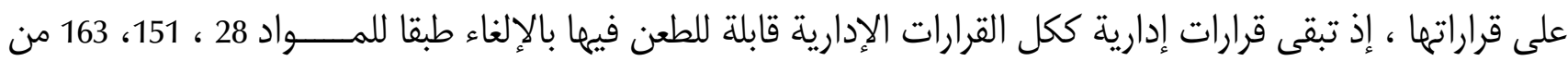

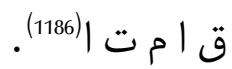

ويختلف موقف التشريع الموريتاني مع بعض التشريعات الأخرى التي لا تقبل الطعن في هذه القرارات (1187)

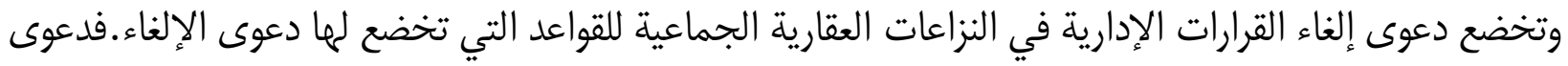

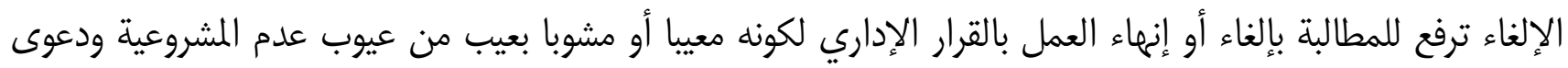

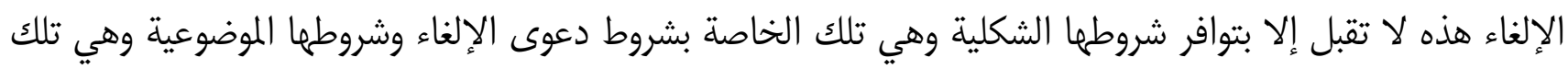
المتعلقة بالعيوب التي تشوب موضوع القرار الإداري فتخول الحق في طلب الإلغاء لإل (188).

1186) نشير الى أن هذا الاختصاص مثار إشكال واختلاف كبير بين القضاة و الإداريين فيرى معظم الإداريين أن قرار اللجنة الوطنية قرار نهائي لا

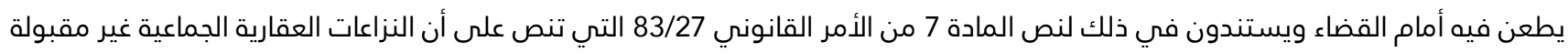
أمام العدالة وأن المشرع عزل القضاء عن هذه النزاعات لأنها محدودة في الزمان والمان والمكان وقائمة على صيغة من التملك لم يعد القانون يقرها (الملكية التقليدية) فكان من المناسب تصفيتها بالسرعة التي تتناسب مع ضرورة القضاء عليها نهائيا وأن نص المادة 7 نص خاص يقيد النص العام الوارد في مدونة

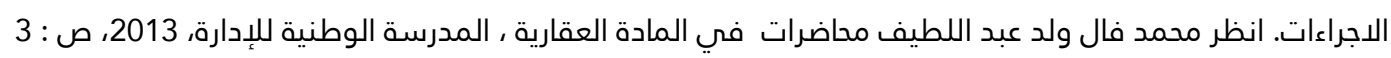

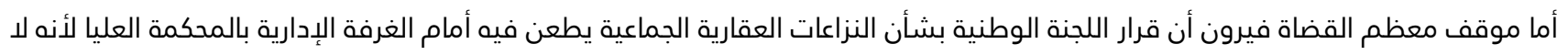
يوجد نص في التشريع الموريتاني ينص على عدم قابليته للطعن ، ولأن الغرفة الإدارية تختص بالبت فيه ليس كنزاع عقاري جماعي وإنما كقرار إداري يطاله الطعن بالالغاء ككل القرارات الإدارية ، انظر القاضي محمد عبد الرحمن ولد عبدي، الملكية العقارية الخاصة وتطبيقاتها في قرارات المحكمة العليا والمذهب المالكي، رسالة لنيل

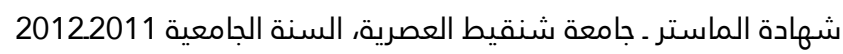
والذي نرى أنه يطعن فعلا في القرار الصادر عن اللجنة الوطنية ليس بوصفه نزاعا عقاريا جماعيا وانما باعتباره قرارا اداريا مستوفيا لجميع شروط الترائ

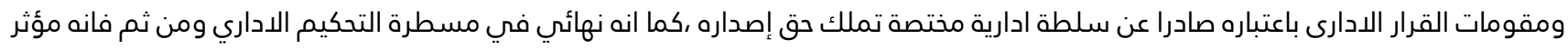

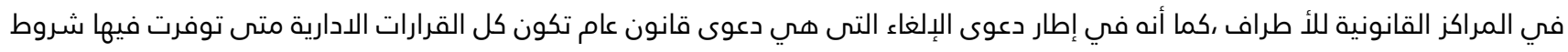

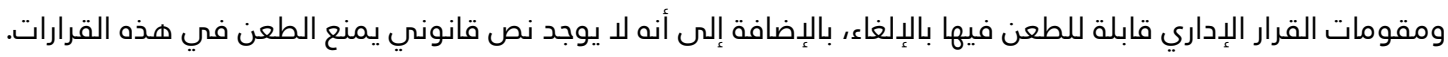

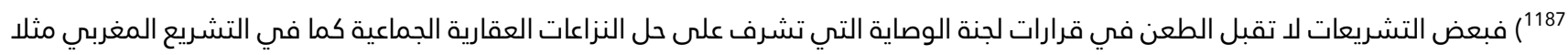

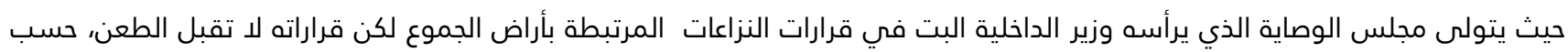
الفصل 12 من ظهير 27 إبريل 1919 " تحرر المقررات من طرف النائب ويوقع عليها من جميع أعضاء المجلس وتكون المقررات غير مدعمة بالأسباب وغير قابلة للطعن" ويلاحظ ان

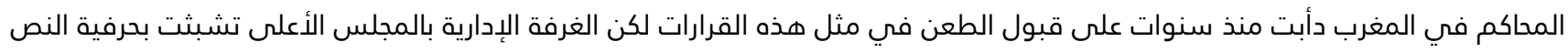

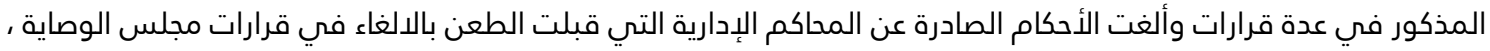

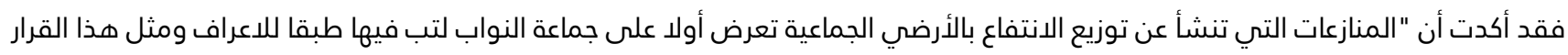
لا يقبل الطعن أمام أية جهة أخرى غير مجلس الوصاية التي تعتبر مقرراته غير قابلة للطعن فيها أمام المحاكم الإدارية مادامت تدخل في إطار

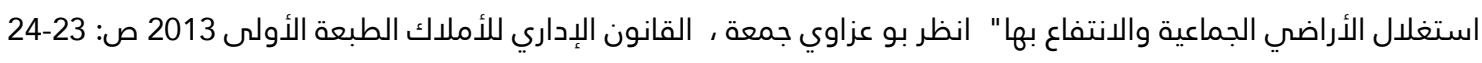
1188) د/ ملكية الصروخ القانون الإداري / دراسة مقارنة ، الطبعة السابعة مع آخر المستجدات 2010 ص: 508 
ويرجع الاختصاص في دعوى الإلغاء بالملكية العليا ، حيث تنظر غرفتها الإدارية ابتدائيا ونهائيا في الطعون التي يقام

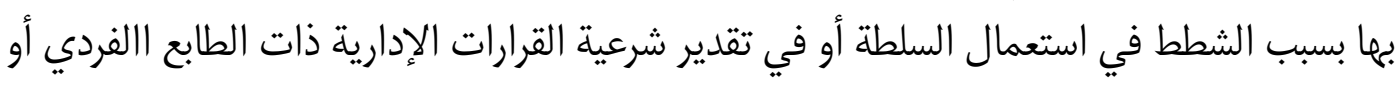
التنظيمي (1899) ولا يجوز أن تتعهد المحكمة في القضايا الإدارية إلا عن طريق عريضة ضد قرار إداري صريح أو ولا تكون العريضة الفاتحة للدعوى مقبولة إلا من خلال أجل شهرين يسرى من تاريخ إبلاغ القرار المطعون فيه (190). ونشير إلى أن قرار الغرفة الإدارية بالمحكمة العليا يكون إما بإلغاء القرار المطعون فيه وإما بتأكيده.

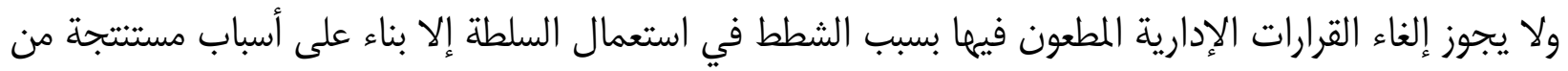

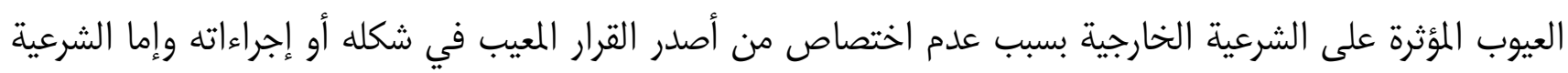

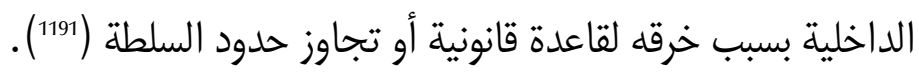

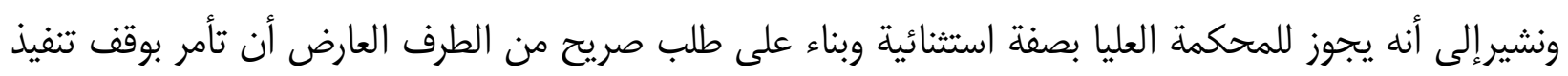
القرارات التي قدم ضدها الطعن بالالغاء. لكن لا يجوز أن يمنح وقف التنفيذ إلا إذا كانت الأسباب المثارة تبدو جدية وكان الضرر الذي سيلحق بالعارض غير قابل للإصلاح (1929). 


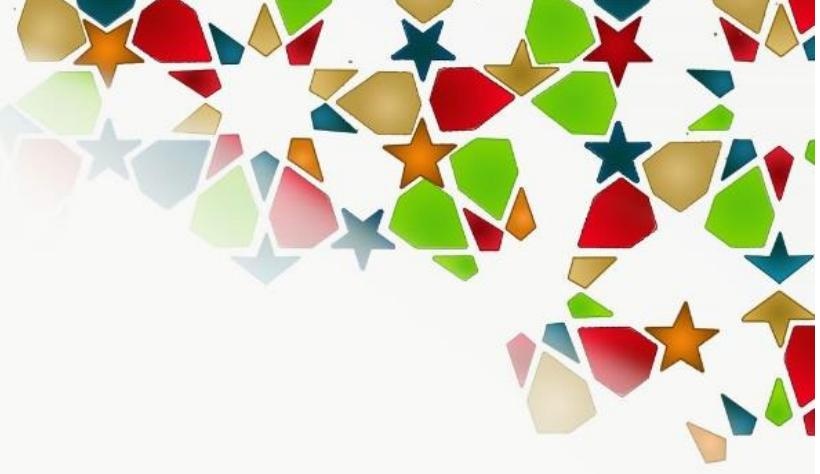

مجلتّ القانون والأعمال الدوليتة

Revue internationale du droit des affaires
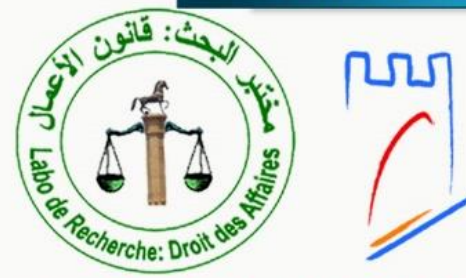

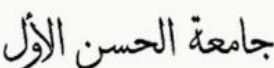
UNIVERSITÉ HASSAN $1^{\text {Do }}$

www.Droitetentreprise.com

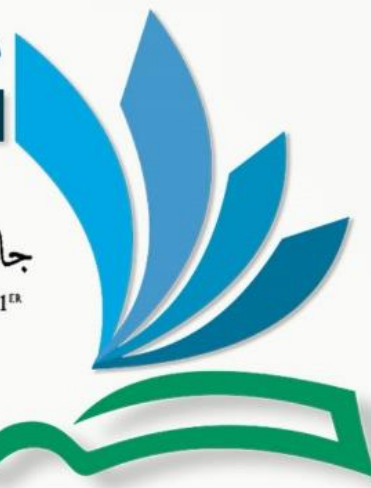

محور الدراسات والأبحاث باللغة الفرنسيت

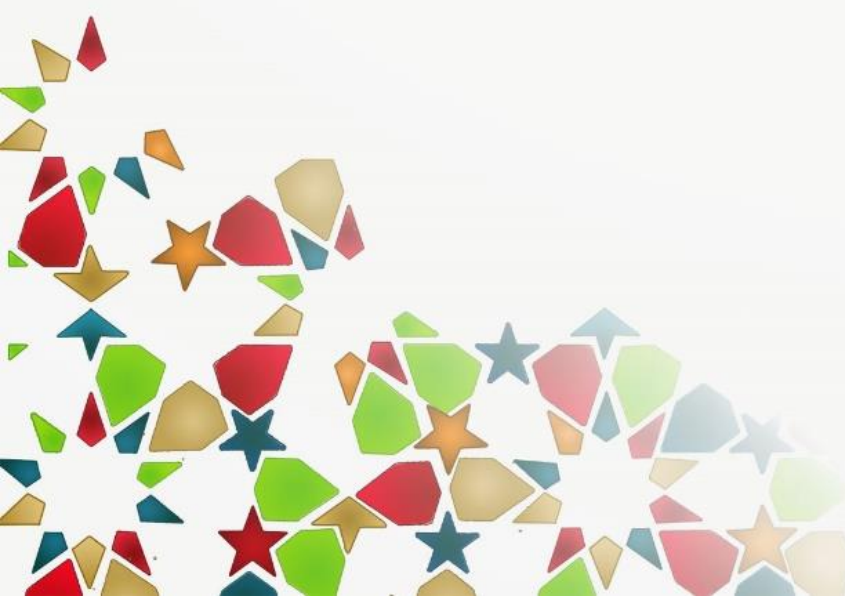




\title{
Péripéties historiques de l'arbitrage
}

\author{
es Elkbir MESHALI \\ Doctorant au Laboratoire Droit des Affaires \\ FSJES Settat université Hassan 1er
}

De nos jours, nous ressentons avec force cette mondialisation féroce qui a bouleversé le cours du monde, à plusieurs égards, et notamment au niveau de la scène politique, de la sphère économique et financière et de la norme juridique et judiciaire des pays formant notre globe ${ }^{1193}$.

Ainsi, la croissance technologique, conjuguée à l'autonomisation industrielle des pays, a permis de créer un scénario mondial caractérisé par de nombreuses transactions très rapides. Il est naturel, au milieu de cette commercialisation intense à l'échelle mondiale, qu'il y ait des frictions tant dans les sphères publique que privée, amenant le conflit à recourir à une forme de résolution du différend.

Ainsi, à la lumière des caractéristiques commerciales actuelles, les parties sont censées rechercher le moyen le plus équitable et le plus rapide de régler leur différend, la décision par défaut ou injuste de ce dernier pouvant représenter un préjudice économique important pour l'une des parties ou les deux.

L'institut d'arbitrage a été qualifié de forme de résolution de conflit très bien adaptée aux exigences internationales, car il présente des avantages tels que la neutralité territoriale, en ce qui concerne le tribunal à utiliser ; le secret quant à la matière ; la possibilité de choisir des arbitres expérimentés et techniques dans un domaine donné ; des coûts inférieurs à ceux d'une procédure judiciaire ; plus rapide que la voie judiciaire. Il est entendu que chaque État a sa souveraineté et son autonomie, étant gouverné sur son territoire par son propre ordre juridique.

Ainsi, au niveau international, il est difficile de mettre en place un tribunal unique qui ait la légitimité nécessaire pour juger des différents conflits entre pays. Compte tenu de cette situation, l'arbitrage international - parce qu'il s'agit d'une forme de résolution de conflit dans laquelle intervient une ou plusieurs personnes choisies par les parties intéressées et dans lequel la procédure d'arbitrage est déterminée par les parties en vue de générer la sentence arbitrale - plus impartiale à la flexibilité que réclament des conflits de cette ampleur.

Cependant, grâce à cette flexibilité, il est possible d'identifier, au cours de l'arbitrage international, l'incidence des systèmes juridiques de différentes nations, les normes des conventions et traités internationaux, les règles stipulées par les tribunaux arbitraux déjà constitués ou même, de règles établies par les parties ou d'un ensemble de règles choisies par celles-ci, ce qui entraîne par conséquent une incertitude quant à leur validité devant l'ordre juridique national, puisque la sentence arbitrale générée par l'arbitrage international doit être déclarée reconnue et exécutoire. Au Maroc c'est par le président de la juridiction commerciale dans le ressort de laquelle la sentence arbitrale a été rendue, ou par le président de la juridiction commerciale du lieu d'exécution si le siège de l'arbitrage est situé à l'étranger, observant, au cours de cette analyse, le respect de certaines

1193 M. TAMOURO, "Droit de l'arbitrage interne et international, Droit et pratique de l'arbitrage international au Maroc ", UIR, 20152016, p.4. 
exigences. En outre, la communauté internationale comprend que la sentence arbitrale est valable entre les parties concernées et peut donc être efficace de différentes manières dans chaque Etat.

Pourquoi l'arbitrage a-t-il si prospéré dans le domaine des relations commerciales internationales?

Étant donné les qualités et les difficultés de l'arbitrage international, cet article entend clarifier le concept et les types d'arbitrage et, parallèlement, aborder la loi 08/05 1194 chaque fois utile, avec son règlement sur l'arbitrage international, permettant finalement, un point de vue sur la résolution des conflits dans le commerce international avec le recours à l'arbitrage, est ce pour bien le décanter des incertitudes et des insécurités qui surgissent naturellement lorsqu'une partie domiciliée dans un pays conclut un accord avec un autre domicilié dans un autre pays?

\section{A. Concept et types d'arbitrage}

Donner une définition précise à l'arbitrage ${ }^{1195}$ est une gageure, compte tenu de la diversité et de l'immense richesse du concept.

\section{1) Concept}

Il existe plusieurs concepts sur ce que serait un arbitrage, mais il peut être défini comme suit :

L'arbitrage, traditionnellement dénommé " arbitrage commercial », mais dont le domaine excède désormais assez largement celui du droit commercial, est un mode alternatif de règlement des litiges ; il est " alternatif » dans le sens où il propose le traitement d'un litige en dehors du cadre judiciaire d'un recours aux tribunaux étatiques. II n'en est pas moins un mode de règlement juridictionnel du litige, et c'est pourquoi on le distingue des autres modes alternatifs de règlement des litiges, également conventionnels dans leur source, mais non juridictionnels dans leur régime ${ }^{1196}$.

C'est un règlement des litiges rapide, équitable et de qualité qui contribue à la stabilisation des relations économiques et à l'amélioration du climat des affaires. De même doit-on se garder d'exagérer et de croire la justice arbitrale nécessairement moins coûteuse que la justice étatique. Sous ces réserves, on peut admettre que "speed, convenience and économy» sont trois vertus maîtresses de l'arbitrage. ${ }^{1197}$

Vieille comme le monde, l'institution arbitrale a fait, et continue à faire, l'objet de tant de commentaires et d'analyses qu'il semble aussi impossible que superflu d'y ajouter quelque chose. On est tenté de citer ici La Bruyère et de remarquer que, sur l'arbitrage, «tout est dit et l'on vient trop tard » et que l'«on ne fait que glaner après les Anciens et les habiles d'entre les Modernes»!1198

L'arbitrage a pour objet de faire trancher un litige par un tribunal arbitral qui reçoit des parties la mission de juger en vertu d'une convention d'arbitrage ${ }^{1199}$.

Le tribunal arbitral est un organe non gouvernemental constitué de personnes choisies par les parties ou désignées conformément à la procédure établie par la loi en vue de régler le différend.

\footnotetext{
${ }^{1194}$ Loi n08-05 abrogeant et remplaçant le chapitre VIII du Code de procédure Civile a été promulguée par le dahir n 1-07-169 du 30 novembre 2007 et publiée au bulletin Officiel n 5584 du Jeudi 6 Décembre 2007.

1195 Vient du mot arbitre, Etymologie : du latin arbiter, tri=témoin (qui assiste à une chose), juge ; dérivé, le verbe : arbitror, are=observer, épier, penser.

${ }^{1196}$ Dominique Vidal, « Droit français de l'arbitrage interne et international », Gualino éditeur, Lextenso éditions, $2012 . p .14$.

1197 Johnson, «Arbitration in English and International Law» (1956) 41, Transactions of the Grotius Society, p. 96, cité par E. J. Conn, "The Rules of Arbitration of the I.C.C.», International and Comparative Law Quarterly, January 1965, p. 132.

1198 Jean de La Bruyère, "Les Caractères, Des ouvrages de l'esprit, I ", éd.1696.

1199 Article 306 de la loi 08/05.
} 
Dans le contexte du droit international privé au sens large l'arbitrage commercial international 1200 est probablement le domaine par excellence de l'autonomie des parties, ainsi que celui où le recul de l'Etat est le plus marqué. En effet, au cours des cinquante dernières années l'arbitrage n'a pas cessé de gagner de liberté par rapport aux systèmes juridiques des Etats en même temps qu'il continuait à gagner d'importance comme instrument alternatif aux juridictions étatiques pour le règlement des litiges dans les rapports commerciaux internationaux.

Souvent considéré comme un succédané de la justice étatique, l'arbitrage consiste, on le sait, dans le règlement des litiges par de simples particuliers choisis par les parties, soit directement, soit, tout au moins, selon des mécanismes convenus ou acceptés par elles. Que ce soit en matière interne ou en matière internationale, qu'il s'agisse de relations privées ou de relations interétatiques, l'essence de l'institution est la même : fondée sur un accord, elle tend à obtenir le règlement d'un litige par une décision émanant d'une ou plusieurs personnes choisies par les parties . . . « par des juges de leur choix ", comme dit la Convention de La Haye de 1907 sur le règlement pacifique des différends entre Etats. ${ }^{1201}$

Aux termes de la loi 08/05, "les parties intéressées peuvent soumettre le règlement de leurs différends au tribunal arbitral au moyen d'une convention d'arbitrage, ainsi entendant le compromis et la clause d'arbitrage"1202. Avec cela, les parties, exerçant le principe de l'autonomie de la volonté, déterminent de manière consensuelle la procédure d'arbitrage ; l'objet de l'arbitrage ; le lieu de l'arbitrage ; le nombre d'arbitres ; la loi qui sera appliquée au litige ou à la résolution en équité.

Comme indiqué précédemment, le compromis d'arbitrage et la clause d'arbitrage sont des points essentiels d'un arbitrage, car elles représentent un accord entre les parties, d'un différend actuel ou futur, qui définit le règlement du différend par l'arbitrage. En ce qui concerne la définition des deux formes de convention d'arbitrage, le compromis d'arbitrage est défini par l'accord consensuel des parties qui établit le règlement du conflit actuel entre elles par voie d'arbitrage. En revanche, une clause d'arbitrage ${ }^{1203}$ est un type de convention d'arbitrage, insérée dans un contrat ou un document séparé qui la mentionne, par laquelle les parties établissent que les litiges qui pourraient naître relativement à ce contrat seront réglés par des arbitres. Ainsi, la divergence générale entre les deux formes de convention d'arbitrage est que le compromis d'arbitrage est un différend en cours ${ }^{1204}$ et que la clause d'arbitrage fait référence à un différend futur ${ }^{1205}$.

\section{2) Types d'arbitrage}

Il existe deux formes de procédure d'arbitrage : l'arbitrage ad hoc et l'arbitrage institutionnel. Un arbitrage ad hoc est un arbitrage dans lequel les parties par convention (le compromis ou la clause d'arbitrage) décident de la manière dont l'arbitrage se déroulera par rapport à leur objet ; arbitre (s) ; règles ; local ; procédures. En d'autres termes, les parties sont responsables de l'ensemble de l'administration de l'arbitrage et doivent respecter les règles du droit de l'arbitrage et des autres lois

\footnotetext{
1200 Par ce terme on se réfère ici à l'arbitrage entre personnes privées (ou entre personnes privées et entités étatiques étrangères) portant sur des litiges commerciaux et présentant des rattachements à plusieurs Etats. Pour plus de détails, aussi au sujet des particularités de cette terminologie dans les conventions internationales et les droits nationaux, voir Ph. Fouchard, E. Gaillard et B. Goldman, On International Commercial Arbitration, La Haye, Boston, Londres, 1999 (ci-après Fouchard-Gaillard-Goldman), pp. 9 ss. ; J.-F. Poudret et S. Besson, Droit comparé de l'arbitrage international, Bruxelles, Paris, Zurich, 2002 (Poudret-Besson), pp. 23 ss. ; J. D. M. Lew, L. A. Mistelis et S. M. Kröll, Comparative International Commercial Arbitration, La Haye, Londres, New York, 2003 (Lew-MistelisKröll), pp. 49 ss.

${ }^{1201}$ Article 37 de la Convention de La Haye de 1907.

1202 Article 307 de la loi 08/05.

1203 La clause d'arbitrage n'est valable qu'entre commerçants.

1204 Article 314 de la loi 08/05.

1205 Article 316 de la loi 08/05.
} 
en la matière afin de parvenir à un consensus sur l'ensemble de la procédure d'arbitrage. Ce type d'arbitrage est guidé par le principe de l'autonomie des parties, puisque la procédure d'arbitrage est établie selon leur volonté.

Entre-temps, l'arbitrage institutionnel est un processus dans lequel les parties, par consensus, choisissent une institution d'arbitrage qui administrera l'arbitrage, en désignant les arbitres ; les règles ; la législation ; l'emplacement ; les délais ; langue ; mener le procès ; entre autres questions liées à l'arbitrage conformément à son règlement. Ce type est caractérisé par des questions de procédure d'arbitrage par les parties, préservant un comportement d'éthique et de secret. Les institutions d'arbitrage représentent généralement une sécurité et une agilité pour les parties, dans la mesure où elles suivent des règles de fonctionnement interne, selon la loi 08/05 dans son article 319 , alinéa 3 "...seront respectées les règles relatives aux droits de la défense ", en plus ils ont des arbitres avec des connaissances techniques et spécialisées dans plusieurs domaines, constituant une véritable structure pour l'exécution de l'arbitrage.

Au niveau international, l'arbitrage institutionnel est très efficace, considérant qu'il s'agit d'une relation entre entreprises, individus et États-nations avec des lois, des langues et des cultures différentes, représentant un éventail de décisions à prendre pour un arbitrage équitable, et avec l'institution intermédiaire, tout devient une responsabilité de la même manière, générant moins d'usure entre les parties et assurant une relation plus saine entre elles.

\section{Le contrat est conclu sous les formes suivantes :}

1) La convention est incluse dans le texte du contrat économique extérieur (le compromis d'arbitrage).

Conformément à la législation marocaine en vigueur, le compromis d'arbitrage contenu dans le texte du contrat est toujours traité comme une transaction distincte et indépendante du contrat principal, la transaction. Ainsi, la reconnaissance d'un accord de commerce extérieur invalide n'invalidera pas la clause d'arbitrage et le différend sera examiné ${ }^{1206}$.

La solution admise (l'arrêt Gosset ${ }^{1207}$, l'arrêt Impex ${ }^{1208}$, l'arrêt Toulouzy ${ }^{1209}$ en France et l'arrêt Prima Paint ${ }^{1210}$ au Etats-Unis) a été reprise au point qu'il apparaît, à raison de sa conformité à l'attente des parties et aux intérêts du commerce international, qu'elle devient un élément des " principes généraux de l'arbitrage auxquels les arbitres du commerce international se réfèrent volontiers quel que soit le lieu où ils siègent ${ }^{1211}$. Ce principe est également énoncé à l'article $16 \$ 1$ de la loi type de la CNUDCl ainsi qu'à l'article $6 \S 9$ du règlement d'arbitrage de la $\mathrm{CCl}$.

2) Une clause d'arbitrage distincte. A cet effet l'article 308 de la loi 08/05 dispose que " la clause d'arbitrage est réputée être une convention indépendante des autres clauses du contrat. La nullité,

\footnotetext{
1206 Une décision rendue par la Cour de Commerce de Casablanca a rendu un arrêt par lequel elle reconnait une sentence arbitrale internationale et en donne l'exequatur à l'encontre d'une société n'ayant pas signé la clause compromissoire et n'ayant pas été partie au contrat contredisant alors le Jugement de Première Instance avait accordé l'exequatur, mais partiellement et à l'encontre d'une seule partie au litige (la partie contractante). La sentence arbitrale dont il s'agit, en application du Droit Suisse, avait étendu les effets de l'arbitrage à des sociétés du Groupe n'ayant pas signé de clause compromissoire ni souscrit à la convention objet du litige. Le dossier impliquant la Société Ynna Holding en 2015.

1207 Cass.civ.1 ${ }^{\text {ere }}, 7$ mai 1963, Gousset.

1208 Cass.civ. $1^{\text {ere }}, 18$ mai 1971.Impex.

1209 Cass.com, 9 avril 2002.Toulouzy.

1210 Cour suprême des Etats-Unis, 12 juin 1967.Prima Paint.

1211 Fouchard, Gaillard et Goldman, n 392 et 406 ; cf. Paris, 7 juin 2001, Hellfrance, Rev. Arb. 2001.616 :l'autonomie de la clause compromissoire par rapport au contrat principal est un principe général de droit de l'arbitrage commercial international.
} 
la résiliation ou la cessation du contrat n'entraine aucun effet sur la clause d'arbitrage comprise avec ledit contrat lorsque celle-ci est valable en soi ».

Conformément à la Convention de New York de 1958, la législation de la plupart des pays, y compris la Maroc, une convention d'arbitrage est requise pour se conformer à la forme écrite ${ }^{1212}$. Ainsi l'exigence d'une forme écrite d'un accord d'arbitrage, permet sa conclusion sous toute autre forme ${ }^{1213}$, étant donné qu'il existe des États dans lesquels aucune loi n'impose de forme écrite pour un accord d'arbitrage. L'arbitre ne peut pas représenter les intérêts des parties dans les procédures d'arbitrage. L'une des tâches principales des arbitres est la confidentialité des différends examinés par l'instance d'arbitrage ${ }^{1214}$.

- Dans I'application de l'arbitrage institutionnel (l'arbitre est nommé par la Cour internationale d'arbitrage de la Chambre de commerce internationale) ${ }^{1215}$.

- Lorsqu'elles forment un groupe spécial d'arbitrage, les parties choisissent indépendamment un arbitre individuel (à moins que les parties n'aient convenu qu'un arbitre sera nommé, trois arbitres seront nommés, chaque partie désignant un arbitre, deux arbitres nommés par les parties, choisissent le troisième arbitre, qui est un arbitre (le responsable de l'arbitrage ad hoc).

Aussi un arbitre ne peut être récusé que si des circonstances soulèvent des doutes raisonnables quant à son impartialité ou à son indépendance, ou s'il ne dispose pas des qualifications requises par l'accord des parties ${ }^{1216}$. Une partie ne peut contester un arbitre qu'elle a désigné ou pour lequel elle a été partie que pour des raisons qui lui sont connues après sa nomination ${ }^{1217}$. Son révocation ne peut avoir lieu qu'à la suite du consentement unanime des parties ${ }^{1218}$.Dans sa forme, la révocation est normalement expresse, et résultera, soit par un procès-verbal en cours d'arbitrage ou d'une lettre adressée par les parties aux arbitres ${ }^{1219}$.

\footnotetext{
1212 Article 313 : « La convention d'arbitrage doit toujours être établie par écrit, soit par acte authentique ou sous seing-privé, soit par procès-verbal dressé devant le tribunal arbitral choisi. La convention d'arbitrage est réputée établie par écrit lorsqu'elle est consignée dans un document signé par les parties ou dans un échange de lettres, de communications télex, de télégrammes ou de tout autre moyen de télécommunication considéré comme convention et qui en atteste l'existence, ou encore dans l'échange de conclusions en demande ou de conclusions en défense, dans lesquelles l'existence d'une telle convention est alléguée par une partie et n'est pas contestée par l'autre... ».

1213 La souplesse de ces dispositions relatives à l'établissement de la preuve de la convention d'arbitrage a mis fin la rigidité des dispositions de l'ancien article 309 (alinéa 2) du code de procédure civile de 1974 qui disposait que « les parties peuvent, lorsque le contrat concerne un acte de commerce, désigner à l'avance dans la convention même, le ou les arbitres. Dans ce cas, la clause doit être écrite à la main et spécialement approuvée par les parties, à peine de nullité ». Abdallah KHIAL, "L'arbitrage en droit marocain », sur : https://cimeda.org/larbitrage-en-droit-marocain-par-mr-abdallah-khial/. visité le 27/08/2019 à 14 h37.

1214 Article 326 de la loi 08/05.

1215 La cour marocaine d'arbitrage (CMA) est la principale institution nationale de règlement des différends commerciaux internationaux. CASABLANCA TECHNOPARK, route de Nouaceur, Casablanca - Maroc.

1216 L'article 327-3 de la loi 08/05 vise l'un des cas de mise en jeu de la responsabilité des arbitres.

1217 Article 322 de la loi 08/05.

L'article 323 énumère les motifs de la récusation d'un arbitre quand :

1 - il a fait l'objet d'une condamnation définitive pour l'un des faits énumérés à l'article 320 ci-dessus ;

2 - il a ou son conjoint ou ses ascendants ou descendants un intérêt personnel direct ou indirect à la contestation ;

3 - il y a parenté ou alliance entre l'arbitre ou son conjoint et l'une des parties jusqu'au degré de cousin germain inclusivement ;

4 - il y a procès en cours ou quand il y a eu procès terminé depuis moins de deux ans entre l'une des parties et l'arbitre ou son conjoint ou leurs ascendants ou descendants;

5 - il est créancier ou débiteur de l'une des parties ;

6 - il a précédemment plaidé ou postulé ou déposé comme témoin sur le différend ;

7 - il a dû agir comme représentant légal de l'une des parties ;

8 - il existe un lien de subordination entre l'arbitre ou son conjoint ou ses ascendants ou descendants et l'une des parties ou son conjoint ou ses ascendants ou descendants.

9 - il y a amitié ou inimitié notoire entre l'arbitre et l'une des parties.

1218 Article 324 de la loi 08/05.

1219 JEAN, Robert. , « L'arbitrage : droit interne, droit international privé ». Paris : Édition Dalloz 6e édition. P.93.
} 
L'arbitre a le droit de se déclarer lui-même pour les motifs suivants :

- une déclaration aux parties (l'arbitre dans ce cas peut lui-même refuser de participer à la procédure qu'avec l'accord des parties);

- en cas de perte de confiance des parties et de l'arbitre ou lorsqu'un fait nouvel essentiel intervenant après l'acceptation par l'arbitre dénature le compromis ou la mission de l'arbitre ${ }^{1220}$.

\section{B. L'arbitrage international dans la sphère commerciale}

L'originalité essentielle de l'arbitrage commerciale international provient du fait que ses règles prennent fortement en compte les usages du commerce international ou plus précisément la lex mercatoria comme étant une règle juridique dans les règlements du litige confié aux arbitres.

\section{1) Lex Mercatoria en tant que source d'arbitrage international}

Les sources de l'arbitrage international sont : les lois, les traités internationaux, les coutumes et pratiques, la jurisprudence arbitrale, la doctrine, les principes généraux du droit et la lex mercatoria. Comme les lois, les traités internationaux, les coutumes et les pratiques, la jurisprudence arbitrale, la doctrine et les principes généraux du droit sont des instituts récurrents communs aux autres branches du droit, nous soulignerons la lex mercatoria, qui est la source différentielle appliquée dans l'arbitrage international.

Appelée également "droit des marchands" ou encore "droit des praticiens", la Lex mercatoria est constitué de règles professionnelles propres sans référence à un droit déterminé. C'est à dire qu'elle s'appuie sur des usages et des principes largement reconnus et respectés, sur des usages observés entre commerçants, sur des contrats-types et des principes consacrés par les sentences arbitrales rendues en matière de commerce international.

On y trouve plus particulièrement :

- des dispositions qualifiées de "sources spontanées" car elles ont leur origine première dans les pratiques et usages du commerce international : Les Incoterms

- le droit conventionnel qui inclut à la fois les conventions inter-étatiques bilatérales, et les conventions multilatérales. ${ }^{1221}$

C'est une théorie qui part du principe que les sous-traitants ont l'intention d'unifier le régime juridique des ventes internationales et des opérations complémentaires par le biais de contrats.

Pour Emily Kadens: La lex mercatoria historique n'était pas un système juridique unique, uniforme et essentiellement privé, mais un lus mercatorum, le droit des commerçants : ensembles de privilèges et de pratiques privés, statuts publics et coutumes privées régis par le droit des marchands avec un certain type de commerce supra-local et les personnes qui l'exercent. Certaines normes coutumières étaient similaires dans de grandes zones; beaucoup étaient locales ou régionales, voire spécifiques à certains groupes professionnels. En outre, il ne s'agissait pas d'un régime indépendant purement coutumier de lois et de tribunaux locaux, mais d'une création hybride reposant sur un échafaudage de lois étroitement lié aux règlements et aux alliances locales. ${ }^{1222}$

1220 BOUDAHRAIN, Abdellah, « L'arbitrage Commercial Interne Et International Au Regard Du Maroc ». Casablanca : Édition Al Madariss .p.67.

1221 https://www.glossaire-international.com/pages/tous-les-termes/lex mercatoria.html\#iYBxjTzribgjvmuV.99. visité le 22 aout 2019 à $17 \mathrm{~h} 55$.

1222 KADENS, Emily. " Ordre dans le droit, variété avec coutume : le caractère du droit des marchands médiéval ", Chicago Journal de droit international, Chicago, v. 5, n. 1, p. 42, 2004. 
Malgré tout, il est certain que Lex Mercatoria avait pour prédécesseur le Lex Rhodia de Jactu, ce qui, selon les mots de Trakman, était "un ensemble de lois maritimes utilisées par les Grecs et les Romains entre le troisième et le deuxième siècle avant notre ère"1223

Lex mercatoria consiste en un ensemble de règles de droit, connues et utilisées, non liées à un système juridique spécifique, fondées sur les coutumes et pratiques de cette localité, ainsi que par l'adoption répétée de clauses types et de contrats et pratiques standard reconnus acceptées internationalement par des associations professionnelles, des organisations supranationales et des entités similaires.

L'institut utilise les principes généraux du droit, englobe les us et coutumes et forme un ensemble de normes. Ainsi, il est possible que les problèmes puissent être résolus grâce à une pratique inscrite dans le droit international, dans la mesure où il s'agit d'un ensemble de solutions déjà trouvées dans le scénario du commerce international.

Caractérisée comme nationale, la nouvelle lex mercatoria, qui n'est liée à aucun ordre juridique étatique, évolue vers un droit transnational construit au sein de l'ordre juridique international. Et sur l'effectivité de la fonction normative de la lex mercatoria dans l'arbitrage commerciale international que L'article 29-4 de la loi type de la CNUDI ${ }^{1224}$ (commission des Nations Unis pour le Droit commercial International) par exemple impose aux tribunaux arbitraux de juger dans les cas conformément aux stipulations du contrat et de tenir compte aux obligations des règles d'usages du commerce applicable à la transaction ${ }^{1225}$.

\section{2) L'arbitrage commercial international ${ }^{\mathbf{1 2 2 6}}$}

L'arbitrage commercial est présent dans le monde depuis longtemps, car l'être humain a toujours recherché, en tant que nécessité inhérente de sa personnalité, la relation avec les autres êtres humains. C'est ainsi que sont apparues les coutumes de l'achat et de la vente. L'échange d'objets, d'aliments et de services à la recherche de la satisfaction de certains besoins matériels et biologiques. Comme le début de l'arbitrage commercial, nous avons connu la période au cours de laquelle les relations commerciales étaient réglementées par la Lex Mercatoria, en vigueur au Moyen-âge et présentant des divergences dans certaines localités, mais généralement suivies par plusieurs peuples.

Avec l'évolution humaine, d'une part, nous avons consolidé les États-nations, obligeant la "Lex Mercatoria" à laisser la place aux traités internationaux et aux lois mises en œuvre de manière interne par les pays respectifs. D'autre part, l'évolution technologique et la mondialisation qui rapprochent de plus en plus les pays et accroissent le nombre de relations commerciales. En conséquence, de plus en plus de conflits apparaissent entre ces négociations internationales et les pays se trouvent dans une situation qui mérite une forme de résolution de conflit plus appropriée, chaque pays ayant son ordre juridique et sa souveraineté, empêchant les différends sont généralement réglés sans influence judiciaire impartiale.

\footnotetext{
1223 TRAKMAN, Léon E. « L'évolution Le marchand de loi : notre patrimoine commercial ». Partie I. n. 12. Journal de droit maritime et du commerce. Philadelphie : JMLC, 1980.

1224 Dans le même sens cf. convention euro de GENEVE sur l'arbitrage com. interna : article33RAC.N.U.D.I. pp172.

1225 Transaction com. interna : l'évolution 1985.

1226 la formation d'un contrat appelé convention d'arbitrage est définie à l'article 7 (1) de la Loi-type de la CNUDCI sur l'arbitrage commercial international comme étant « une convention par laquelle les parties décident de soumettre à l'arbitrage tous les différends ou certains des différends qui se sont élevés ou pourraient s'élever entre elles au sujet d'un rapport de droit déterminé, contractuel ou non contractuel ». La même disposition précise qu' « une convention d'arbitrage peut prendre la forme d'une clause compromissoire dans un contrat ou faire l'objet d'une convention séparée ».
} 
Le commerce international est défini par l'échange de biens et de services entre personnes physiques ou morales de pays différents ou comportant des éléments juridiques ou matériels de caractère international. Toutefois, dans le cas de l'arbitrage international, le droit marocain de l'arbitrage a pour critère l'article 327-46 de la territorialité, c'est-à-dire que si la sentence arbitrale est rendue en dehors du Maroc, elle sera considérée comme étrangère. La décision du tribunal arbitral est assortie de l'exécution provisoire, l'exercice du recours en annulation ne suspend pas, ipso facto, l'exécution de la sentence arbitrale internationale ${ }^{1227}$.

Parmi les avantages de l'arbitrage dans la résolution des conflits commerciaux internationaux, on peut citer la flexibilité de son processus, qui permet aux parties de disposer d'une autonomie dans le choix de l'arbitre, du lieu et des règles, par exemple. De plus, les parties bénéficient de la rapidité et du secret, qui sont deux autres grands avantages, car en matière de commerce, le temps est un facteur important de profit et de secret, car il est entendu que la divulgation des affaires litigieuses peut entraîner des pertes d'entreprise.

Il est également important de souligner que, sur la scène internationale, la résistance au respect des décisions rendues par des arbitres n'est pas très récurrente, car les relations commerciales sont, en règle générale, continues et ramifiées, c'est-à-dire celles qui ne respectent pas leurs obligations ; il devient une cible de discrimination au sein de la communauté commerciale internationale car il ne garantit pas la sécurité de leurs relations.

En plus le Maroc a promulgué la Convention sur la reconnaissance et l'exécution des sentences arbitrales étrangères, plus simplement appelée "Convention de New York», ratifiée en vertu du Dahir du 19 février 1960. Pour le moment, il est important de souligner que la Convention de New York est un document extrêmement utile pour permettre l'arbitrage international. Bien que l'ancien code de la procédure civile, du 12 août 1913, a réservé un chapitre 15 du titre IV (articles 527 à 543) à l'arbitrage. Ce texte constituait le régime commun en la matière et ne fut remplacé que bien plus tard, par celui du 28 septembre 1974, en l'occurrence par son chapitre 8 du titre V (articles 306 à 327). La loi $n^{\circ} 08 / 05$ quant à elle contienne déjà des préceptes assurant de manière satisfaisante la reconnaissance et l'exécution des sentences arbitrales étrangères au Maroc, c'est l'adhésion à la Convention de New York qui confère la confiance des partenaires internationaux et la certitude que les sentences arbitrales seront reconnu et appliquées dans les pays qui subordonnent l'application de la Convention de New York à la réciprocité.

Par conséquent, depuis l'adhésion à la Convention de New York, le Maroc est pleinement intronisé dans le monde de l'arbitrage international, un fait qui contribuera certainement énormément à la croissance de ses activités à l'étranger. L'arbitrage entre les parties marocaines et étrangères sera plus fréquent et important. Il doit se dérouler dans la langue et la localisation d'un autre pays, dans lequel une loi étrangère ou même des règles de droit non nationales pour le règlement du mérite seront appliquées et des procédures établies seront adoptées par des institutions d'arbitrage internationales, loin de notre code de procédure civile. Ces faits impliquent un défi important pour les avocats marocains, un défi qui se pose lorsque notre environnement juridique s'efforce toujours d'absorber pleinement une véritable culture de l'arbitrage. Les avocats marocains doivent se préparer à voyager avec aisance dans le monde de l'arbitrage international, plaider devant des collègues étrangers, déjà familiarisés avec les subtilités et les complexités de cet univers.

1227 Mohamed Chakib Kanouni Hassani « La Justice étatique face à la sentence arbitrale en droit marocain : étude critique de l'office du juge », Droit. Université Bourgogne Franche-Comté, 2018. P.284. 


\section{Conclusion}

L'arbitrage représente une forme alternative et extrajudiciaire dans une résolution de conflit, dans laquelle un ou plusieurs arbitres constituent la "sentence arbitrale". Chaque partie jouit d'une autonomie dans la manifestation de sa volonté, établissant ainsi, de manière consensuelle, l'intégralité de la procédure d'arbitrage. Les parties peuvent choisir entre un arbitrage ad hoc ou un arbitrage institutionnel. Les caractéristiques de secret, de célérité, de souplesse, de spécialité des arbitres font de ce système extrajudiciaire un choix très avantageux, en particulier pour les questions de la sphère internationale, dans lesquelles on a le choc des cultures et la souveraineté de chaque État-nation.

En raison de tous ces facteurs, l'institut d'arbitrage a de plus en plus attiré les justiciables, car il s'agit d'une méthode de résolution des conflits véritablement efficace, rapide et confidentielle sur le plan contractuel et commercial, national ou international. Outre ces avantages, l'expertise, la qualité professionnelle et la profondeur technique des arbitres dans l'affaire en litige dépassent souvent le niveau technique de la justice de l'État.

Ces caractéristiques sont les principaux facteurs qui poussent les parties à recourir à l'arbitrage national ou international et montrent en quoi cette méthode de résolution des conflits peut constituer une excellente alternative aux principaux besoins des entreprises lors du règlement de leurs différends commerciaux.

La loi sur l'arbitrage 08/05 établit, avec d'autres traités internationaux tels que la convention d'arbitrage de New York de 1958 et la loi type de la CNUDCl, d'importants règlements concernant l'exécution de l'arbitrage et la validité de la sentence arbitrale, contribuent de plus en plus au développement d'un système qui répond très bien aux demandes internationales.

Dans le domaine commercial, l'arbitrage international a été mis en place grâce à l'élargissement des organismes de réglementation et des tribunaux arbitraux internationaux, garantissant ainsi un système plus adéquat de résolution des conflits en matière de commerce, ainsi que les avantages offerts par ce système extrajudiciaire alternatif.

Dans de telles circonstances, seul l'arbitrage est en mesure de garantir qu'aucune des parties ne risque de voir un tribunal du pays de la partie adverse opposé à un éventuel litige concernant les activités contractées. La convention d'arbitrage, en vertu de ses effets négatifs et positifs, a le pouvoir de supprimer la juridiction de la justice d'État des deux côtés du pays.

De plus, en arbitrage, le consensus des parties prévaut sur les diktats de l'État. Ce sont les parties qui choisissent d'un commun accord le juge ou le critère de nomination du juge; le processus à adopter lors du procès et les règles de droit à appliquer pour résoudre le fond du conflit. Ils ne risquent donc pas de voir leurs litiges réglés par le pouvoir judiciaire d'un pays étranger, conformément aux lois, règles de procédure et pratiques judiciaires plus familières à la partie adverse. Ils ont également toute latitude pour choisir la langue à utiliser dans la procédure arbitrale et le lieu où le jugement sera rendu.

L'arbitrage commercial international a aujourd'hui un véritable appareil transnational composé de conventions internationales, de lois nationales, de réglementations sur les procédures d'arbitrage, de coutumes et pratiques dûment établies, d'institutions d'arbitrage saines et respectables, d'une communauté de professionnels spécialisés composée d'arbitres, de juristes experts. Universitaires, jurisprudence, congrès, séminaires, conférences, revues, etc. 


\title{
Douane et commerce électronique
}

\author{
Elfaique Amine \\ Etudiant-Doctorant \\ «Equipe de recherche " Gouvernance Douanière \\ Faculté de Droit - Casablanca
}

\section{Introduction :}

Le commerce électronique n'est pas un nouveau phénomène, " les entreprises n'ont pas attendu la disponibilité d'internet pour réaliser les transactions électroniques ${ }^{1228}$, les échanges électroniques existaient depuis la fin des années quarante principalement sous la forme des EDI (Electronic Data Inter change).

L'avènement de l'internet a marqué un changement essentiel dans l'histoire de l'économie mondiale, la naissance de cette technologie a engendré notamment trois phénomènes, l'accélération et l'internalisation des échanges commerciaux et leur dématérialisation.

La naissance du Web a changé toutes les données et a marqué alors l'histoire du commerce électronique, à partir des années quatre-vingt-dix, et grâce à cette technologie convivial et axé sur la présentation graphique et qui facilite la communication et la recherche de l'information, les beaux jours de l'e-commerce vont commencer...

Dans ce cadre, " les véritables débuts commerciaux d'Amazon, Cisco ou Dell datent de 1995 et ce n'est qu'en 1998 que sont apparues les premières formes du commerce électronique alimentaire en France ${ }^{1229}$ (Télémarket, suite à une expérience antérieure en télématique sur Minitel).

Le commerce électronique n'a pas fait l'objet d'une définition commune et universelle, en raison notamment du nombre important des acteurs sur le marché e-commerce et la complexité et l'évolution rapide des rapports entre ces acteurs.

Le comité technique permanent de l'organisation mondiale des douanes (CTOMD) le définit comme " un moyen de gérer les affaires en utilisant l'informatique et les télécommunications afin de faire circuler les donnes entre les systèmes informatique propres aux organisations en présence pour effectuer une transaction commerciale ${ }^{1230}$.

Le CTOMD adopte une conception matérielle large de la notion du e-commerce, donc, la définition proposée met en lumière les échanges de données dans le contexte des opérations fondamentales réalisées par la douane.

L'histoire du commerce électronique a commencé au début des années 90, " en 1991, il y avait moins de 3 millions d'internautes dans le monde, et l'application d'internet au commerce

\footnotetext{
1228 : Henri Isaac et Pierre Volle, E-COMMERCE: De La Stratégie A La Mise En CEuvre Opérationnelle, PEARSON Education, Paris, 2008, P.11.

1229 : Gilles Marouseau, A la recherche d'un modèle logistique pour les cybermarchés, Université du Maine, p.3.

1230: Alioune Dione, Le droit douanier, le commerce électronique et la dématérialisation, L'Harmattan, Paris, 2012 , p.17.
} 
électronique était quasiment inexistante, près d'une décennie plus tard, en 1999, on estimait que 300 millions de personnes avaient accès à internet et que le quart environ effectuaient des achats en ligne pour une valeur avoisinant 110 milliards de dollars ${ }^{1231}$, il s'agit alors d'un marché en pleine croissance...

Le sondage de Louis-Harris réalisé pour Enjeux Les Echos et France Info en 1995 a souligné que 9 $\%$ des entreprises françaises seulement étaient connectées à internet, selon les prévisions, le chiffre d'affaires du commerce sur internet en France ne dépassera pas 457 millions d'euros en $2000 . .$.

Après cinq années, "la réalité était tout autre, avec un chiffre d'affaires de 2,2 milliards d'euros sur le marché français (42 milliards au niveau mondial), en vingt ans, l'e-commerce a connu un développement exponentiel, il s'est élevé en 2014 à 57 milliards d'euros en France, 423,8 milliards en Europe et 1,462 milliards dans le monde ${ }^{1232}$, alors, on peut parler d'une croissance à une vitesse vertigineuse !

Selon le rapport 2015 sur l'économie de l'information de la CNUCED, 1,1 milliard de personnes, soit environ $41 \%$ des internautes au niveau mondial, ont réalisé au moins une opération d'achat en ligne au cours de 2013, dans le même cadre, et d'après eMarketer, "le nombre des acheteurs en ligne devrait dépasser en 2018 le chiffre de 1,6 milliard de personnes dans le monde, soit une croissance de $50 \% »^{1233}$ par rapport à l'année 2013.

La Chine occupe en 2015 la première place mondiale sur le marché e-commerce, avec un chiffre d'affaires qui a dépassé 691 milliards euros, suivie par les Etats-Unis avec plus de 537 milliards euros selon les chiffres clés 2016 de la Fevad.

Les estimations présentées par eMarketer pour les années 2014 à 2017, " laissent entrevoir une hausse du commerce électronique de $122 \%$ dans le monde ${ }^{1234}$, ce qui montre le rythme avec lequel évolue ce marché...

Le commerce sur internet devrait poursuivre sa croissance exponentielle, participer au développement des micro-, petites et moyennes entreprises, et jouer donc son rôle comme l'un des moteurs clés de la croissance économique mondiale... Le développement du commerce en ligne permet d'accroître sensiblement l'efficience des économies, hausser leur compétitivité, améliorer l'affectation des ressources et accélérer la croissance à long terme.

En Belgique, " 23,1 \% du chiffre d'affaires total du transport et 17,9\% du chiffre d'affaires du commerce en 2011 , ont été réalisé grâce à ce type de commerce, en moyenne, l'industrie belge a réalisé $10,4 \%$ de son chiffre d'affaires ॥ $^{1235}$ à travers des activités liées à l'e-commerce.

L'e-commerce a favorisé " la création de nouveaux marchés et constitué les bases de plusieurs milliers d'entreprises nouvelles $"{ }^{1236}$, au niveau de I'UE, plus de $20 \%$ de la croissance du PIB est liée à l'économie internet ${ }^{1237}$ au cours de la période 2007-2012.

\footnotetext{
1231 : OMC, Le commerce électronique dans les pays en développement : Possibilités offertes aux petites et moyennes entreprises et difficultés rencontrées, Genève, 2013, p.3.

1232 : Les Echos, le : 15/07/15, Internet a bousculé le commerce mondial.

1233 : CNUCED, La cyberlégislation et réglementation comme moyen de renforcer le commerce électronique: études de cas et enseignements tirés de l'expérience, Genève, mars 2015, p.6.

1234 : Desjardins, Etudes économiques, Volume 24 / Mars 2014.

1235 : SPF Economie, L'e-commerce : un atout pour la durabilité de votre entreprise ?, Bruxelles, 2016.

1236 : Kenneth Laudon et Jane Laudon, Management des systèmes d'information, Pearson Education, Paris, 2010, p.98.

1237 : Antonio Tajani, Les opportunités qu'internet et le Marché Intérieur Digital offrent aux PME, Bruxelles, 2012, p.2.
} 
L'Economie internet représente en France 5,2\% du PIB et environ 900.000 des emplois (3,7\% du total) dans les 100.000 entreprises de 10 salariés ou plus en $2013^{1238}$, en France toujours, le développement des TIC a participé à la création de 700000 emplois en 15 ans, entre 2012 et 2015, 450000 emplois supplémentaires ont été créés ${ }^{1239}$ sur l'ensemble de l'économie du pays.

L'e-commerce permet d'employer en Chine 2,5 millions de personnes, en plus de 18 millions dans des services liés à ce type de commerce en $2014^{1240}$, comme le transport par exemple. Une étude du Boston Consulting Group en $2013^{1241}$ confirme que les PME disposant d'un projet e-commerce organisé et développé, ont connu une amélioration de leurs chiffres d'affaires de $22 \%$ de plus par rapport aux autres PME.

Cette évolution du commerce sur internet représente une opportunité sérieuse pour l'économie, les entreprises et les consommateurs pour réaliser des gains de productivité considérables, or, la croissance du commerce électronique constitue parallèlement, une manne providentielle pour les criminels...

Le commerce électronique se caractérise notamment par « l'anonymat, le sentiment d'impunité, la transformation permanente des sites (dénomination, adresse web, pays d'hébergement...), et bien sûr l'extrême morcellement des envois ${ }^{1242}$, ces spécificités permettent de faciliter la fraude sur internet.

Les informations transmises dans le cadre du e-commerce sont bien moins précises qu'en commerce traditionnel, en fret postal, les obligations déclaratives sont minimales et invérifiables, et les envois ne font pas l'objet d'une procédure informatisée de contrôle, mais d'un " tri visuel " reposant sur la provenance ou l'aspect du colis ${ }^{1243}$, ce qui complique encore la mission des autorités chargées du contrôle...

Le rythme de croissance, les avantages et les spécificités du commerce sur internet nécessitent alors une adaptation des outils et méthodes de contrôle de la douane, pour pouvoir faciliter les transactions électroniques qui créent une valeur ajoutée pour l'économie nationale, et renforcer l'efficacité du contrôle en matière de lutte contre les marchandises illicites. Le commerce électronique présente donc de grandes possibilités de développement pour les e-marchands et pour le secteur économique de manière globale, or, ces gains de productivité s'accompagnent aussi de difficultés...

Quels sont alors ces risques et ces difficultés sur le plan économique, financier et aussi sécuritaire ? et comment les autorités douanières peuvent s'adapter à ces évolutions ?

\section{Section 1 - E-commerce : risques économiques et financiers}

L'e-commerce peut être considéré comme un vecteur essentiel des fraudes et trafics, la montée en puissance des canaux de vente sur internet est perçue comme une opportunité par les fraudeurs de bénéficier des points faibles des systèmes de paiement électroniques et des transactions en ligne.

\footnotetext{
1238 : Groupe de travail interministériel sur la lutte contre la cybercriminalité, Protéger les Internautes : Rapport sur la cybercriminalité, Février 2014, p.7.

1239 : Premier Ministre, France numérique 2012-2020 : bilan et perspectives, Novembre 2011, p.2.

1240 : Les Echos, le 24/06/15, Olivier Verot, L'e-commerce, un phénomène de société en Chine.

1241 : Banque de développement du Canada, Planifier votre croissance cinq tendances de consommation qui changent la donne, 2013,

p.7.

1242 : SÉNAT, Les douanes face au commerce en ligne : une fraude fiscale importante et ignorée, Rapport d'information $n^{\circ} 93$ (20132014), déposé le 23 octobre 2013, p.8.

1243 : Cour des comptes, L'action de la douane dans la lutte contre les fraudes et trafics, Janvier 2015, p.25.
} 
Les risques économiques et financiers liés au commerce électronique proviennent notamment des évolutions rapides de technologies, ces évolutions devancent dans la majorité des cas l'adaptation des pouvoirs publics.

Le développement des ventes en ligne pourrait représenter alors des nouvelles opportunités de fraude financières importantes, en raison notamment de la difficulté de réaliser des opérations de contrôle efficaces sur des transactions virtuelles qui n'ont pas un établissement stable dans le pays.

Autrement dit, l'internet est en train de changer les pratiques du commerce, dans ce cadre, l'émergence des NTIC a facilité le développement de nouveaux types de fraudes financiers sur internet et l'émergence d'un nouveau modèle économique pour les trafiquants...

\section{Commerce en ligne : nouveau modèle économique pour les faussaires...}

L'e-commerce constitue le secteur préféré des faussaires compte tenu des gains et avantages qu'ils tirent, les fraudes, dans ce cas, ont une forme dématérialisée et elles sont réalisées dans le cyberespace, contrairement aux crimes traditionnels commis dans le monde physique.

Avec l'avènement d'internet et le développement des NTIC, le crime financier a évolué et a pris de nouvelles formes, la criminalité financière peut être alors considérée comme la nouvelle menace du 21 ème siècle...

Les caractéristiques du commerce électronique permettent d'offrir des facilités aux cybercriminels, contrairement à la criminalité traditionnelle, le crime financier peut être commis en dehors des frontières à des milliers de kilomètres...

\section{A- Transactions électroniques : vecteur essentiel de la criminalité financière}

Le commerce sur internet présente plusieurs avantages, mais de l'autre côté, il encourage et renforce la criminalité financière, " aujourd'hui, on perçoit cette évolution criminelle, d'une part au caractère nouveau des actes, et d'autre part, à la fréquence des actes commis ${ }^{1244}$, l'e-commerce est devenu alors I'un des vecteurs essentiels de criminalité financière.

D'après le GAFI (2001), les trois caractéristiques principales de l'internet qui peuvent aggraver certains risques de criminalité financière sont: la facilité d'accès, la dématérialisation du contact entre le client et le fournisseur, et enfin la rapidité des transactions électroniques.

Ces caractéristiques rendent difficiles l'identification du client et le suivi des comptes et des transactions par les institutions financières ${ }^{1245}$, notamment lorsque l'ouverture des comptes peut se faire sans contact direct avec le client ni lien à un compte traditionnel existant.

A titre d'exemple, " aux Etats-Unis, la fraude pour les transactions de commerce électronique était 20 fois supérieure aux transactions hors ligne (1,92\% en 2000 et 1,8\% en 2002) ${ }^{1246}$, en plus, $50 \%$ des contestations aux Etats-Unis dans la même période se rapportaient aux transactions électroniques, alors que ces transactions ne constituaient qu'entre 1 à $2 \%$ du chiffre d'affaires ${ }^{1247}$, donc, plus cette part augmente, plus les risques seront plus importants...

\footnotetext{
1244 : Abbas Jaber, Les infractions commises sur Internet, L'Harmattan, Paris, 2009, p.13.

1245 : Jean-Christian Lambelet, Séminaire d'économie nationale, Le blanchiment d'argent en Suisse, Université de Lausanne, Ecole des HEC, Mars 2003, p.25.

1246 : Mostafa Hashem Sherif, Paiements électroniques sécurisés, Presses Polytechniques et Universitaires Romandes, Collection technique et scientifique des télécommunications, Lausanne, 2007, p.9.

1247 : Ibid, p.10.
} 
Le commerce électronique se caractérise aussi par la mise en place de nouveaux modes de paiement adaptés aux besoins des e-acheteurs, dans le cadre de ces nouveaux modes de paiement, la figure suivante montre le nombre des e-acheteurs victimes de débit frauduleux et montant de la fraude à la carte bancaire.

Figure $\mathrm{N}^{\circ} 01$ : E-acheteurs victimes de débit frauduleux et montant de la fraude à la carte bancaire

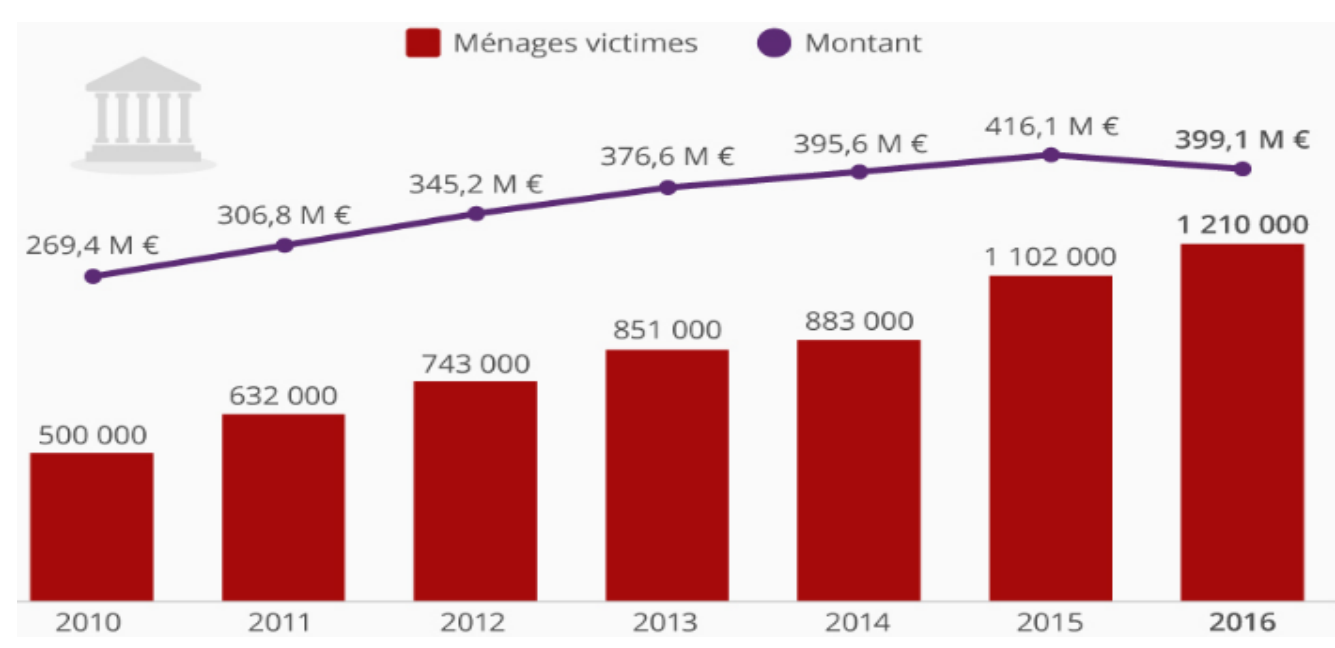

Source : Banque de France, Ministère de l'intérieur, Interstats.

Selon les résultats présentés par cette figure, le nombre de ménages victimes de débit frauduleux s'est élevé à 1210000 en 2016 contre 500000 en 2010, soit plus du double, le montant de la fraude a dépassé 416 millions euros en 2015 et 399 millions euros en 2016.

Enfin, en Italie, et d'après les statistiques publiées par l'agence des douanes italienne, " sur un échantillon de 54000 colis contrôlés, la différence constatée entre le montant déclaré et celui constaté était de $17 \%$, contre $2 \%$ à $3 \%$ sur le fret classique, sur ces seuls 54000 colis, près de 600 000 euros de droits et taxes ont été redressés ${ }^{1248}$, ce qui peut confirmer alors les chiffres déjà cités dans ce cadre.

\section{B- Cout de la contrefaçon sur internet}

L'e-commerce a permis de passer vers une relation directe entre le producteur et le consommateur " en supprimant les intermédiaires classiques, notamment les distributeurs, cependant, nous assistons à une "réintermédiation" dans le contexte de la contrefaçon »"1249, car, les véritables distributeurs des produits contrefaits ne peuvent pas être suivis.

L'internet est devenu l'un des leviers essentiels du marché mondial de la contrefaçon, les contrefacteurs ont bénéficié de la multiplication des sites de vente en ligne et du développement de ce nouveau modèle économique pour encore élargir leurs marchés... La contrefaçon " est devenue depuis des dizaines d'années un sujet de réflexion majeur ${ }^{1250}$, dans son ouvrage, M. Moisés Naím confirme que 25 milliards de dollars de contrefaçons sont commercialisés chaque année sur

\footnotetext{
1248 : SÉNAT, Commission des finances, L'e-commerce : propositions pour une tva payée à la source, Rapport II, 2015, p.31.

1249 : Eric Przyswa, Cybercriminalité et contrefaçon, FYP Editions, Collection Présence / essai, Paris, 2010, p.50.

1250 : Papa Gueye, Criminalité organisée, terrorisme et cybercriminalité : réponses de politiques criminelles, Editions HarmattanSénégal, Dakar, 2018, p.24.
} 
internet ${ }^{1251}$, les caractéristiques du commerce électronique permettent donc de faciliter l'industrie du faux.

Selon une étude réalisée par le cabinet DLA Piper, la vente de marchandises contrefaites sur les sites d'enchères représente chaque année 800 millions de livres (plus d'1 milliard d'euros) au Royaume Uni ${ }^{1252}$, l'étude prévoit que ce chiffre aurait doublé en 3 ans. Dans le même cadre, en France, on peut citer l'exemple d'une opération coup de poing réalisée dans le centre douanier postal de Chilly-Mazarin au cours du mois de juillet 2011.

Le centre douanier postal de Chilly-Mazarin traite chaque jour 5000 colis à l'import et 7000 à l'export ${ }^{1253}$, dans cette opération, les agents douaniers ont contrôlé pendant cinq jours $100 \%$ des colis qui arrivent d'un certain nombre de pays ciblés.

Parmi les principaux résultats de cette opération, on peut citer notamment, $4 \%$ des marchandises contenaient des contrefaçons, (1600 marchandises au total), les douaniers ont saisi en moyenne 22 faux produits par envoi, et enfin la saisie de 580 types de médicaments qui n'ont pas une autorisation de mise sur le marché.

Au niveau des pertes des entreprises internationales, en 2013 à titre d'exemple, la contrefaçon en ligne a fait perdre plus de 350 milliards de dollars aux marques ${ }^{1254}$, ce qui montre l'enjeu que représentent les DPI pour les grandes multinationales.

La contrefaçon sur internet constitue « une menace de niveau élevé de dangerosité, qui entraine des dysfonctionnements, des dégâts et des couts ${ }^{1255}$, les risques liés à ce phénomène évoluent alors de façon permanente et continue...

\section{Vente en ligne : Multiplication des risques financiers et économiques}

L'émergence du commerce électronique a conduit vers l'apparition de nouveaux types de fraudes et le développement des fraudes déjà existantes...

Les risques sont alors plus importants au niveau des ventes en ligne par rapport au commerce traditionnel, les fraudes sur internet se sont multipliées parallèlement au développement des transactions électroniques.

L'apparition et la diffusion d'internet peuvent être considérées donc comme l'un des piliers essentiels du développement des fraudes économiques et financières, les TIC et notamment l'internet ouvrent à ce type de fraudes l'opportunité de se jouer des frontières...

\section{A- Fraudes sur les paiements en ligne}

L'e-commerce est souvent présenté de manière très positive, mais les gains que ce type de commerce peut engendrer s'accompagnent aussi de difficultés, à la tête de ces difficultés, on peut citer notamment les risques sur les paiements en ligne...

\footnotetext{
1251 : Unifab, L'impact de la contrefaçon vu par les entreprises en France, Avril 2010, p.64.

1252 : Ibid, p.65.

1253 : Le Figaro, le : 01/08/11, Christophe Cornevin, Explosion des saisies douanières dans les colis.

1254 : MarkMonitor, Livre blanc : la protection des marques dans le monde numérique, 2014, p.3.

1255 : Solange Ghernaouti-Hélie, La cybercriminalité: le visible et l'invisible, Presses polytechniques et universitaires romandes, Collection le savoir suisse, Lausanne, 2009, p.20.
} 
Selon le groupe international d'assurances spécialisées Hiscox, en 2012, 48\% des cyber-attaques ont concerné les sites de vente sur internet ${ }^{1256}$, ils cherchent principalement les coordonnées postales et bancaires des e-consommateurs.

Les données bancaires volées ou piratées s'échangent par millions dans le monde de l'internet, le prix de ces données volées varient selon plusieurs critères, on peut citer essentiellement la nationalité de la carte, sa date de validité et son niveau.

Le développement des transactions électroniques a permis l'émergence de nouveaux types de risques, dans ce cadre, " la fraude à la carte bancaire a littéralement explosé» ${ }^{1257}$, les chiffres et les statistiques permettent de confirmer ces données...

A titre d'exemple, en 2011, "Sony a été victime d'une attaque de grande ampleur, le vol de 250 millions d'adresses de joueurs en ligne ${ }^{1258}$, cette attaque a visé notamment les données bancaires de ces clients.

En 2015, la France a connu une forte croissance de la fraude sur les paiements par carte bancaire, on parle de 522,7 millions d'euros, soit une augmentation de 4,4\% par rapport à 2014 , sachant que l'augmentation du montant total des transactions était de $1,8 \%{ }^{1259}$, donc toujours la fraude évolue plus vite que le commerce...

Les avantages de l'e-commerce ne sont pas donc automatiques, ce type de vente peut poser aussi des risques à certains acteurs du marché, c'est le cas des cybermarchands par exemple.

Une étude de la société spécialisée dans la sécurité du e-commerce FIA-NET réalisée en 2002 montre que les tentatives de fraude en ligne représentent environ 3\% des 26 millions de transactions effectuées sur internet en France, soit 1,7 milliard d'euros, sachant que le chiffre d'affaires réalisé par le commerce électronique dans le pays sur la même période s'est élevé à 45 milliards d'euros ${ }^{1260}$, à titre de comparaison, les tentatives de fraude ont représenté 245,2 millions d'euros en $2002^{1261}$, donc le montant a doublé 7 fois en 10 ans.

Figure N02 : La fraude à l'échelle du e-commerce français 2013 (en millions d'euros)
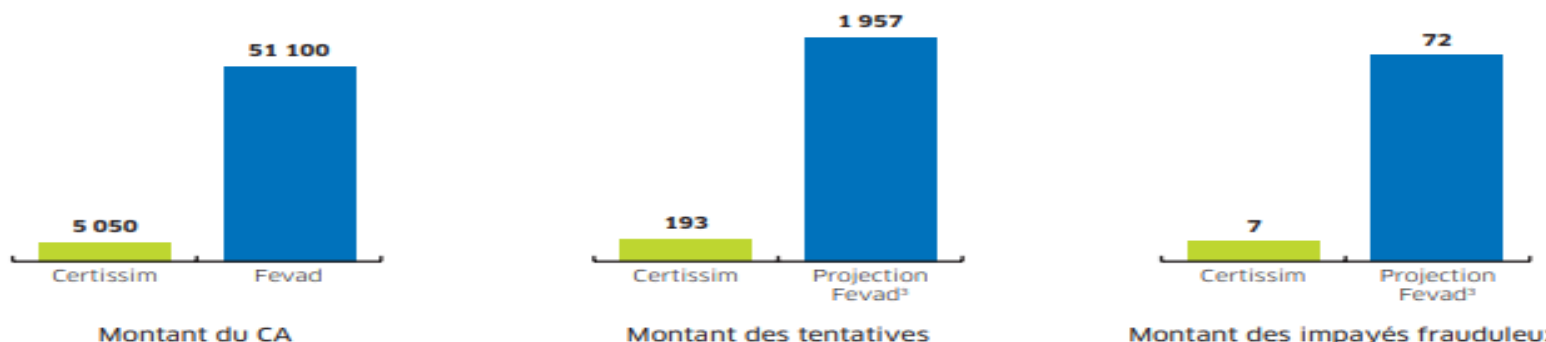

Montant des impayés frauduleux

Transactions des 900 sites marchands partenaires de Certissim

2- Données Fevad (Fédération du E-commerce et de la Vente à Distance), janvier 2014

3-Projection sur la base des taux Certissim. Ces taux sont plus élevés pour les e-marchands nayant pas de politique de lutte contre la 3raude.

Source : Certissim, Livre Blanc : La fraude dans le e-commerce, 12e Édition, Paris, Juin 2014, p7.

1256 : HISCOX, e-commerce : Gérer le risque de la cybercriminalité, p.3.

1257 : Pascal Colombani, Fraudes à la carte bancaire, Editions Carnot, Chatou, 2004, p.19.

1258 : Challenges, le : 14/09/13, Delphine Dechaux, La vérité sur les fraudes à la carte bancaire.

1259 : OSCP, Rapport annuel de l'Observatoire de la sécurité des cartes de paiement 2015, p.18.

1260 : L'expansion L'express, le : 12/04/2013, Samuel Baudoui, La fraude à la carte bancaire passe à l'échelle industrielle.

1261 : Pascal Colombani, Op.Cit, p.36. 
En 2013, le montant total des tentatives de fraudes en France a enregistré une hausse de 11\%, ce qui représente 1.96 milliard d'euros, le montant des impayés frauduleux a atteint dans la même année 72 millions $d^{\prime}$ euros $^{1262}$ selon les chiffres présentés par Certissim.

Dans ce cadre, il sera nécessaire pour les e-marchands de prévenir l'ensemble des risques précédemment cités par des stratégies adaptées à ces risques au lieu de suivre uniquement les résultats et les conséquences...

\section{B- Pertes de recettes fiscales difficiles à chiffrer...}

Le commerce électronique connaît une croissance très rapide du volume des transactions en ligne, mais dans plusieurs pays, ni droits ni taxes ne sont collectés sur ces échanges électroniques, ce qui représente une perte potentielle de recettes pour les Etats.

En France à titre d'exemple, et selon un rapport du SENAT en 2010, la perte de recettes fiscales est estimée à 450 millions d'euros ${ }^{1263}$ dans le secteur du commerce électronique.

Une autre étude réalisée en 2009 par le cabinet Greenwich consulting avait évalué cette perte en France à 300 millions d'euros en 2008, et plus de 600 millions d'euros en $2014^{1264}$, soit une évolution de $100 \%$ en 6 ans...

Les nouveaux chiffres du SENAT publiés en 2018 parlent d'un manque à gagner de 20 milliards d'euros par an ${ }^{1265}$, notamment au niveau de la TVA, ces chiffres montrent clairement qu'il n'y a pas de raison de laisser passer cette forme de travail au noir ${ }^{1266}$, les statistiques présentées par les autres pays leaders du e-commerce peuvent confirmer ces résultats...

Aux États-Unis à titre d'exemple, et selon une estimation publiée en 2010, les pertes des taxes de vente non perçues sur les achats liés au commerce sur internet s'élèvent à 3,9 milliards de dollars par année ${ }^{1267}$, ces pertes peuvent atteindre des montants beaucoup plus importants...

Le manque à gagner s'élève à 1,2 milliard d'euros au Royaume-Uni et à 603 millions d'euros en Allemagne ${ }^{1268}$ à la fin de l'année 2008 selon les chiffres publiés par le journal La Tribune.

Enfin, le tableau suivant présente une étude réalisée par Greenwich Consulting, l'étude cite le cas d'Amazon Europe, cette dernière réalise un CA de 930 millions d'euros en France, alors que la filiale française ne déclare qu'un CA de 25 millions d'euros, le reste est enregistré sous la forme de prestations de services logistiques, rémunérées par la filiale à Luxembourg, la même remarque peut être observée au niveau des autres pays européens.

\footnotetext{
1262 : Français Guillaume, E-commerce, Ecole de Commerce de Lyon, 2015, p.31.

1263 : SENAT, Rapport d'information n 398 (2009-2010) de M. Philippe MARINI, fait au nom de la commission des finances, déposé le 7 avril 2010, p.21.

1264 : SÉNAT, M. Philippe MARINI, Rapport d'information fait au nom de la commission des finances sur la fiscalité numérique, juin 2012 , p.23.

1265 : Le Parisien, le : 25/07/2018, Daniel Rosenweg, Nouvelles règles fiscales en vue pour les ventes en ligne.

1266 : Olivier de Wasseige, E-Commerce, e-Marketing, E-Bay: 3 Leviers de croissance pour les entreprises, Editions des CCI SA, Liège, 2007, p.358.

1267 : Institut économique de Montréal, Mathieu Bédard, Le dilemme des taxes de vente sur les achats en ligne, Novembre 2015 , p.1.

1268 : 20minutes, le : 07/04/10, Elsa Meyer, Le commerce en ligne spécialiste de l'évasion fiscale.
} 
Tableau N01 : Impôt sur les sociétés (IS) et cas d'Amazon Europe : répartition du volume d'activité et du CA déclaré par pays (En millions d'euros)

\begin{tabular}{|c|c|c|c|}
\hline & $\begin{array}{l}\text { Volume } \\
\text { d'activité }\end{array}$ & CA déclaré & Emplois (ETP) \\
\hline Luxembourg & & $3801 \mathrm{M} \in$ & $\begin{array}{c}\text { Non } \\
\text { communiqué }\end{array}$ \\
\hline France & $930 \mathrm{M} \in$ & $25 \mathrm{M} \in$ & 318 \\
\hline Royaume-Uni & $820 \mathrm{M} \in$ & $105 \mathrm{M} \in$ & 1695 \\
\hline Allemagne & $1794 \mathrm{ME}$ & $67 \mathrm{M} \in$ & 1810 \\
\hline Irlande & $90 \mathrm{M} \in$ & $35 \mathrm{M} \in$ & 50 \\
\hline Autres & - & 3,5 M€ & - \\
\hline TOTAL & $4038 \mathrm{M} \in$ & $4038 \mathrm{M} \in$ & - \\
\hline
\end{tabular}

Source : SENAT, Rapport d'information nº 398 (2009-2010) de M. Philippe MARINI, Op.Cit, p.18.

On parle alors d'une perte de recettes de TVA de l'ordre de 100 millions d'euros ${ }^{1269}$ dans ce cas.

Dans le même cadre, ce type de fraude fiscale " privilégie les entreprises en ligne au détriment des magasins traditionnels ${ }^{1270}$ qui payent régulièrement les droits et taxes, sans oublier que la fraude dans ce cas " désavantagent aussi de manière significative les détaillants nationaux " ${ }^{1271}$ qui payent les impôts et les taxes contrairement à une grande partie des e-commerçants exerçant à l'étranger.

Cette situation peut sérieusement « remettre en cause le principe de neutralité technologique de la politique douanière ${ }^{1272}$, et donc fausser le jeu de la concurrence sur le marché.

Le développement de l'e-commerce représente alors un défi majeur pour les organisations chargées du contrôle fiscale, ces dernières doivent donc essayer de s'adapter aux risques et enjeux liés à ce nouveau type de commerce...

\section{Section 2 - Développement des transactions électroniques : risques sécuritaires}

Le développement et la diffusion du réseau internet n'a pas échappé aux réseaux terroristes, les organisations criminelles vont essayer alors d'utiliser les possibilités offertes par cette évolution pour multiplier leurs modes de financement.

La dématérialisation des processus permet aux groupes criminels de réaliser des gains importants et de développer de manière continue leur chiffre d'affaires.

Le développement des TIC et l'émergence du e-commerce ont encouragé la croissance de la cybercriminalité, les infractions commises dépassent souvent les frontières, cette situation peut engendrer des couts importants sur le plan social et économique...

\footnotetext{
1269 : Idem.

1270 : Mostafa Hashem Sherif, Op.Cit, p.487.

1271 : OMD, Ana B. Hinojosa, Le concept de commerce électronique, p.4.

1272 : Laurent Gille, Les dilemmes de l'économie numérique: la transformation des économies sous l'influence de l'innovation, Collection Innovation, Limoges, 2009, p.131.
} 
La croissance des ventes en ligne s'est accompagnée aussi d'un développement du trafic illicite sur internet, ce type de commerce illicite se trouve facilité par l'évolution technologique et principalement l'émergence et la diffusion de l'internet.

Les principales marchandises illicites proposées à la vente en ligne sont notamment la drogue, les produits stupéfiants, les produits contrefaits, les faux médicaments et les produits liés au piratage informatique, autrement dit, on parle principalement des produits interdits, volés ou non conformes.

\section{E-commerce : vers une meilleure réalisation de l’action frauduleuse...}

Le développement des transactions électroniques peut être considéré comme un levier essentiel de réalisation de l'action frauduleuse sur internet...

L'anonymat offert par internet conduit vers l'apparition et le renforcement de plusieurs types de fraudes en ligne, et participe dans ce cas à la diversification des sources de financement des groupes criminels. Le commerce en ligne peut être donc utilisé par les organisations terroristes pour financer leurs activités, mais il peut être aussi utilisé par les cybercriminels pour générer des profits exceptionnels... La croissance des transactions électroniques peut conduire alors vers une augmentation des menaces contre la sécurité et un développement de l'activité criminelle.

\section{A- Commerce électronique et évolution de la criminalité internationale}

L'utilisation des TIC et principalement internet " a ouvert un nouvel espace que l'on appelle “cyberespace" " $^{1273}$, ce dernier permet aux organisations criminelles de bénéficier d'une " technologie à moindre cout et d'agir depuis l'étranger sans risque d'être poursuivi » ${ }^{1274}$, autrement dit, les cybercriminels peuvent faire mieux, avec moins... Les activités criminelles et terroristes (trafics illicites, stupéfiants, espèces protégés, produits pharmaceutiques, propriété industrielle et intellectuelle, blanchiment d'argent...) sont alors facilitées par l'émergence des nouvelles technologies électroniques ${ }^{1275}$, et notamment la diffusion d'internet et l'émergence du ecommerce. Le cyberespace est très grand, on y retrouve le Web visible mais aussi le Darknet accessible uniquement à travers le réseau Tor.

En France par exemple, et comme le montre la figure $\mathrm{N}^{\circ} 03$, un pic d'utilisation de Tor a été enregistré en septembre 2013 avec 350000 utilisateurs directs quotidiens, ce nombre a atteint plus de 300000 utilisateurs directs quotidiens de Tor en 2018.

Figure N03 : Pic d'utilisation du réseau Tor en France entre septembre 2013 et décembre 2017

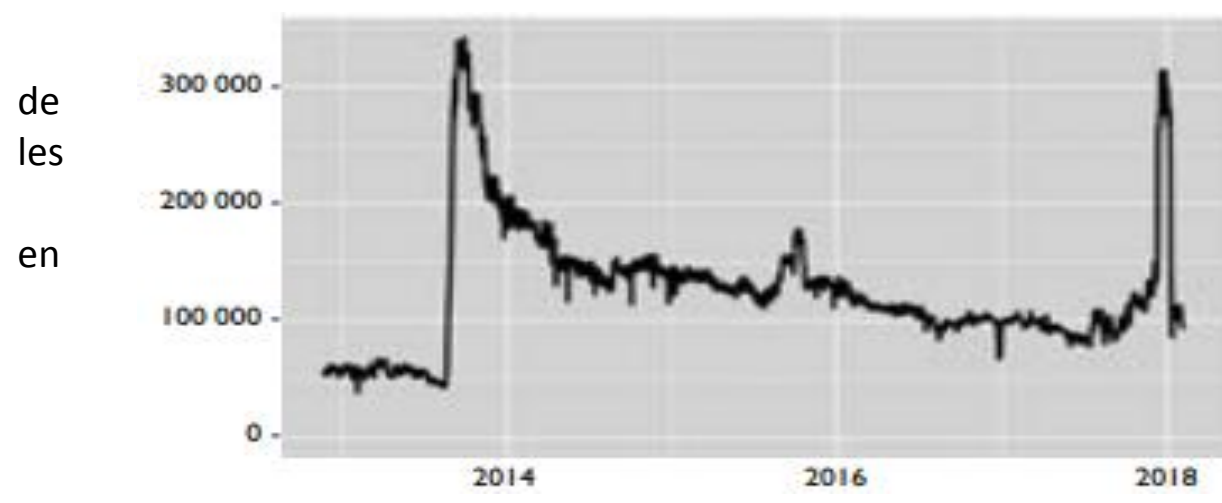

Source : Délégation ministérielle aux industries sécurité et à la lutte contre cybermenaces, État de la menace liée au numérique 2018, Rapport $\mathrm{n}^{\circ}$ 2, Mai 2018, p.16.

1273 : Papa Gueye, Op.Cit, p.29.

1274 : Daniel Ventre, Cyberespace et acteurs du cyberconflit, Lavoisier Librairie, Paris, 2011, p.156.

1275 : Florian Bedet, Essai sur la définition d'un statut juridique de la procédure de dédouanement des envois postaux, Université ParisSaclay, 2016, pp.85 et 86 . 
Toujours en France, la DGDDI a enregistré en 2012 en fret postal et express « 2,8 tonnes de stupéfiants (+ $86 \%$ par rapport à 2011), 29,5 tonnes de tabacs et cigarettes de contrebande (- $18 \%$ par rapport à 2011) et 1,4 million d'articles de contrefaçons (stable par rapport à 2011) ${ }^{1276}$, dans les saisies on trouve notamment des armes, des médicaments contrefaits et aussi des espèces protégées.

L'e-commerce permet aussi aux terroristes de réaliser des transactions financières sans laisser aucune trace, les autorités chargées du contrôle ne peuvent pas dans plusieurs cas déterminer l'origine des transactions, les systèmes de paiement anonymes sur internet peuvent représentés alors un outil efficace pour financer des activités terroristes sans prendre de risques...

Les organisations terroristes peuvent gérer parfois " jusqu'à 50000 sites de vente en ligne illégaux ${ }^{1277}$, plusieurs exemples peuvent être cités dans ce cadre.

Ces groupes terroristes « détiendraient donc une part du trafic illicite sur internet qui servirait à financer leurs opérations, Irish Republican Army (IRA), Euskadi Ta Askatasuna (ETA), Hezbollah et Kurdistan Workers' Party (PKK) ${ }^{1278}$ peuvent être des exemples qui montrent comment ces groupes exploitent des sites e-commerce illicites pour financer leurs activités.

\section{B- Cybercriminalité : évolution et cout économique}

Les spécificités du canal internet favorisent le développement de la cybercriminalité " (anonymat, faibles barrières à l'entrée, difficultés d'application de la loi à des juridictions multiples) ${ }^{1279}$, les risques sur internet sont plus faibles et les couts sont beaucoup moins élevés.

La Figure suivante présente une étude sur les prix de vente de produits illégaux sur le darknet français, autrement dit, une image sur l'économie souterraine de la cybercriminalité française.

Figure $N^{\circ} 04$ : L'économie souterraine de la cybercriminalité française : prix de vente de produits illégaux sur le darknet français

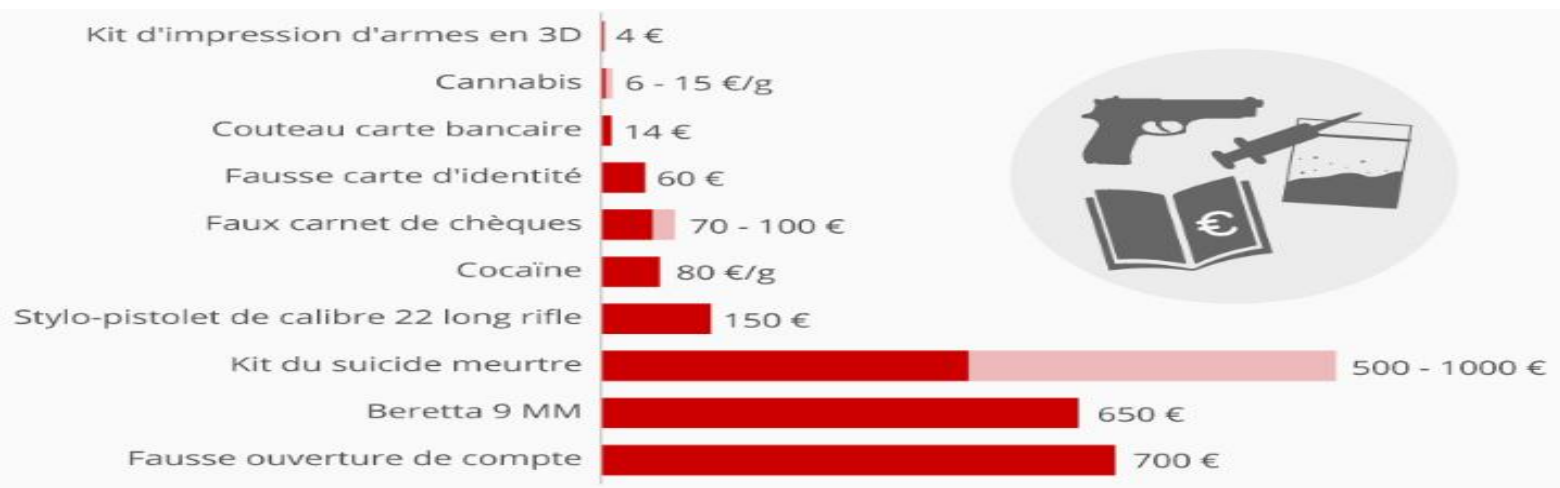

Source : La Tribune, le : 15/09/16, Sylvain Rolland, Cybercriminalité : qui sont les escrocs du darknet français ?

Les cybercriminels proposent donc une liste très variée de produits illicites, « on y trouve des armes discrètes vendues entre 10 et 150 euros, des armes lourdes vendues entre 650 et 1.800 euros, ainsi que des kits d'impression d'armes en 3D, que l'on peut acquérir pour une poignée d'euros, le

\footnotetext{
1276 : SÉNAT, Les douanes face au commerce en ligne : une fraude fiscale importante et ignorée, Op.Cit., p.32.

1277 : Global Security Mag, janvier 2018, Emmanuelle Lamandé, Darknets et Darknautes : les dessous du commerce illicite sur les réseaux virtuels.

1278 : David Décary-Hétu, Vincent Mousseau et Ikrame Rguioui, Le trafic illicite de tabac sur les cryptomarchés une nouvelle frontière?, Université de Montréal, Juin 2017, p.14.

1279 : EL Azzouzi Ali, La Cybercriminalité au Maroc, Editions Bishops Solutions, Casablanca, 2010, p.2.
} 
cannabis se vend entre 6 et 15 euros le gramme, mais on trouve aussi de la cocaïne, de I'héroïne... ${ }^{1280}$, ces produits illégaux sont présentés à des prix très compétitifs par rapport au commerce traditionnel.

Les réseaux sociaux, notamment Facebook, Twitter et Instagram peuvent être considérés aussi comme des leviers essentiels de l'activité frauduleuse, ces réseaux contiennent par exemple des liens renvoyant vers des sites e-commerce de faux.

En France, Symantec estimait en 2011 à plus de 10 millions les Français victimes de la cybercriminalité, soit une facture totale estimée à 2,5 milliards d'euros, en hausse de $38 \%{ }^{1281}$ par rapport à l'année précédente.

D’après un expert en cybersécurité de Symantec, « la cybercriminalité a encore crû en 2014 avec 317 millions de nouveaux programmes malveillants créés au niveau mondial, soit près de 1 million par jour ${ }^{1282}$, on peut parler alors d'un marché en pleine expansion...

Selon une présentation en 2008 de l'éditeur McAfee au Forum économique mondial de Davos, la cybercriminalité a coûté 1000 milliards de dollars au niveau mondial ${ }^{1283}$, le continent africain est l'une des régions les plus touchées par ce phénomène...

Sans oublier enfin, qu'on doit prendre en considération dans le calcul du coût global de la cybercriminalité, les coûts indirects, il s'agit notamment de la perte de confiance dans les services bancaires sur internet, et aussi les coûts liés à la défense, à la détection et à la répression.

\section{Transactions sur internet et évolution de l'activité de la criminalité organisée}

Les fraudes et trafics liés à l'exploitation d'internet sont multiples et diversifiés et leur ampleur se développe plus rapidement que prévu...

L'internet a modernisé la criminalité organisée, dans ce sens, l'émergence et le développement du darknet ont favorisé la croissance des trafics illicites sur internet, cette nouvelle technologie permet de vendre, acheter et commercialiser les produits illicites anonymement et en toute sécurité, la tâche des autorités chargées du contrôle se complique alors de plus en plus.

Dans ce cadre, le fret postal et le fret express sont de plus en plus utilisés aujourd'hui pour l'acheminement des marchandises illicites vendues sur internet...

\section{A- Marchés virtuels et évolution des trafics illicites}

Le déplacement des trafics illicites vers l'internet n'est pas quelque chose de nouveau, depuis l'émergence des NTIC, les cybercriminels ont utilisé les forums de discussion et les chatrooms pour acheter et vendre des produits illicites, ces cybercriminels sont actifs principalement dans le secteur du piratage informatique et les secteurs liés aux différents types de fraude financière.

L'émergence et la diffusion des TIC a bouleversé l'ordre des choses ${ }^{1284}$, dans ce cadre, internet devient un outil essentiel du commerce mondial de marchandises illicites, il représenterait d'ores et

\footnotetext{
1280 : La Tribune, le : 15/09/16, Sylvain Rolland, Cybercriminalité : qui sont les escrocs du darknet français ?

1281 : Institut national des hautes études de la sécurité et de la justice, Enjeux et difficultés de la lutte contre la cybercriminalité, Paris, juillet 2015, Op.Cit, p.6.

1282 : Idem.

1283 : EL Azzouzi Ali, Op.Cit, p.18.

1284 : Papa Gueye, Op.Cit, p.27.
} 
déjà $10 \%$ du commerce illicite, avec une progression de 20 ou $25 \%$ par an ${ }^{1285}$, on peut parler alors d'un marché avec un potentiel de croissance important.

Au niveau de l'Union Européenne par exemple, 1/3 des produits contrefaisants saisis sont en relation avec des réseaux de distribution sur internet ${ }^{1286}$ selon les chiffres publiés par l'Unifab.

Les cybercriminels utilisent aussi les médias sociaux et les sites de petites annonces pour commercialiser leurs produits, les pertes liées au trafic illicite sur internet sont difficiles à chiffrer, mais les études réalisées parlent de plusieurs millions de dollars...

Aux Etats-Unis, le chiffre d'affaires du Silk Road (fermé par le FBI à la fin de 2013) est estimé par le FBI à 1,2 milliard de dollars (880 millions d'euros) ${ }^{1287}$, ce chiffre était réalisé seulement pendant deux ans et demi d'ouverture du site.

Les cybercriminels utilisent le darknet et les cryptomonnaies pour vendre anonymement des armes, " on peut acheter ou louer des moyens d'attaques, des compétences, quand elles ne sont pas disponibles en interne ${ }^{1288}$, la figure suivante analyse la répartition des ventes mondiales d'armes sur le darknet par pays en 2017.

Figure N05 : Répartition des ventes mondiales d'armes sur le darknet par pays en 2017

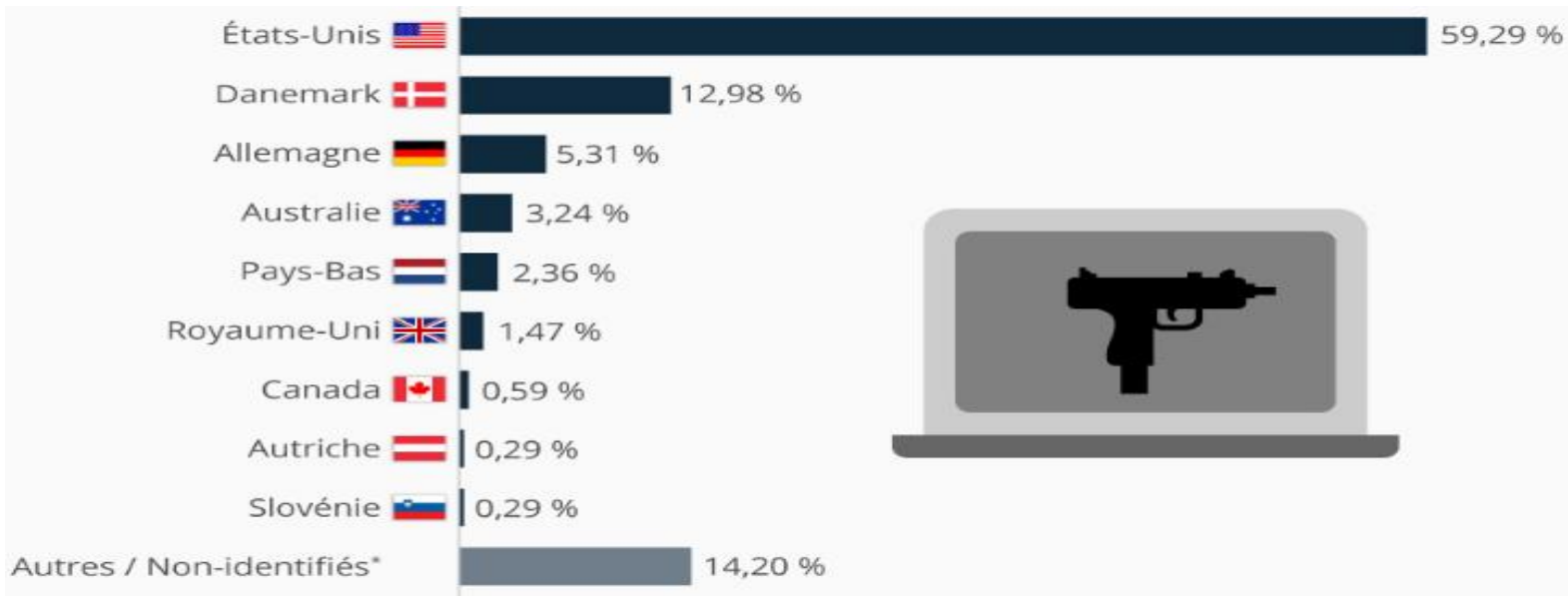

Source : Centre d'analyse RAND Corporation.

Selon les résultats de cette figure, le marché des armes sur le darknet aux Etats-Unis occupe la première place avec plus de $59 \%$ des ventes mondiales, on trouve ensuite le Danemark avec environ $13 \%$ et l'Allemagne avec $5 \%$ de ces ventes, ces chiffres montrent une autre fois l'importance du marché américain du commerce illicite sur internet.

Enfin, et d'après un rapport de la Commission justice pour la faune sauvage (WJC) publié en 2015 sur le trafic illicite d'espèces sauvages, une valeur minimale de 445.356 dollars ont été échangées à travers l'internet, notamment sur Facebook ${ }^{1289}$, ce qui montre le rôle que les NTIC peuvent jouer dans le développement du trafic de produits de la faune sauvage...

1285 : Centre d'Étude et de Prospective Stratégique, Les liaisons dangereuses du commerce illicite : Terrorisme et criminalité organisée, Avril 2018, p.3.

1286 : Unifab, Combattre le commerce illicite en ligne, 2019, p.5.

1287 : Unifab, Contrefaçon et terrorisme, 2016, p.25.

1288 : Daniel Ventre, Op.Cit, p.189.

1289 : L'autre quotidien, le : 12/02/19, Maina Waruru, Le trafic illicite d'espèces sauvages prospère sur internet. 
Les cybercriminels spécialisés dans le commerce illicite d'espèces sauvages utilisent donc de plus en plus l'internet pour commercialiser leurs produits en ligne et réaliser des gains considérables...

\section{B- Développement des risques sanitaires en matière de fret express et postal}

La contrefaçon liée aux produits pharmaceutiques en ligne représente un choix de prédilection pour les cybercriminels pour deux raisons essentielles, la popularité et les prix élevés de ces produits.

Ce type de commerce présente aux trafiquants de médicaments contrefaits plusieurs avantages, notamment la possibilité d'écouler leurs marchandises à grande échelle, à moindre coût et en toute sécurité...

Dans ce sens, l'OMS a estimé qu'en 2010, la contrefaçon de médicaments a généré 75 milliards de dollars en revenus ${ }^{1290}$ pour les cybercriminels spécialisés dans ce domaine.

Selon des études, ce type de trafic

" serait ainsi 25 fois plus rentable que le commerce de l'héroïne et 5 fois plus que celui des cigarettes ${ }^{1291}$, le trafic de faux médicaments permet de gagner beaucoup d'argent sans prendre de risques...

D'après l'OMD, le trafic de contrefaçon de médicaments aurait augmenté de $300 \%$ entre 2007 et 2008 au niveau mondial ${ }^{1292}$, ce qui montre le rythme avec lequel évolue ce fléau...

L'OMS ajoute que les faux médicaments constituent $10 \%$ de marché pharmaceutique mondial, ce taux s'élève à $50 \%$ dans certains pays ${ }^{1293}$, notamment sur le continent africain.

Selon une autre étude de l'OMS, le taux de médicaments contrefaits en Afrique dépasse 60\%, l'étude cite par exemple, 30\% pour le Kenya et notamment $70 \%$ pour l'Angola ${ }^{1294}$, ce qui montre la dynamique que connait ce marché.

L'utilisation des faux médicaments comporte des risques importants pour la santé des econsommateurs, certains de ces médicaments contrefaits s'avèrent seulement inefficaces, mais d'autres peuvent avoir des effets dangereux sur la santé.

Statistiquement parlant, entre 100000 et 1 million de personnes par an sont victimes de la contrefaçon de médicaments ${ }^{1295}$, selon une étude menée par l'OMS.

La Figure suivante présente les résultats d'une étude de I'IRACM publiée en 2013 sur l'organisation du trafic mondial de la contrefaçon de médicaments.

\footnotetext{
1290 : Claudia Thériault, La contrebande de médicaments contrefaits commercialisés sur internet : Réflexions sociopolitiques pour améliorer la lutte contre ce crime transnational, École supérieure d'affaires publiques et internationales, Université d'Ottawa, 2014, p.22.

1291 : Rocher Lauraine, Thèse : La contrefaçon des médicaments dans le monde : situation actuelle et perspectives, Université Claude Bernard- Lyon 1, Faculté de Pharmacie, 2014, p.53.

1292 : Idem.

1293 : Claudia Thériault, Op.Cit, p.22.

1294 : Rocher Lauraine, Op.Cit, p.62.

1295 : SANOFI, Lutte contre la contrefaçon des médicaments, Novembre 2015, p.5.
} 
Figure $\mathrm{N}^{\circ} 06$ : Organisation du trafic mondial de la contrefaçon de médicaments

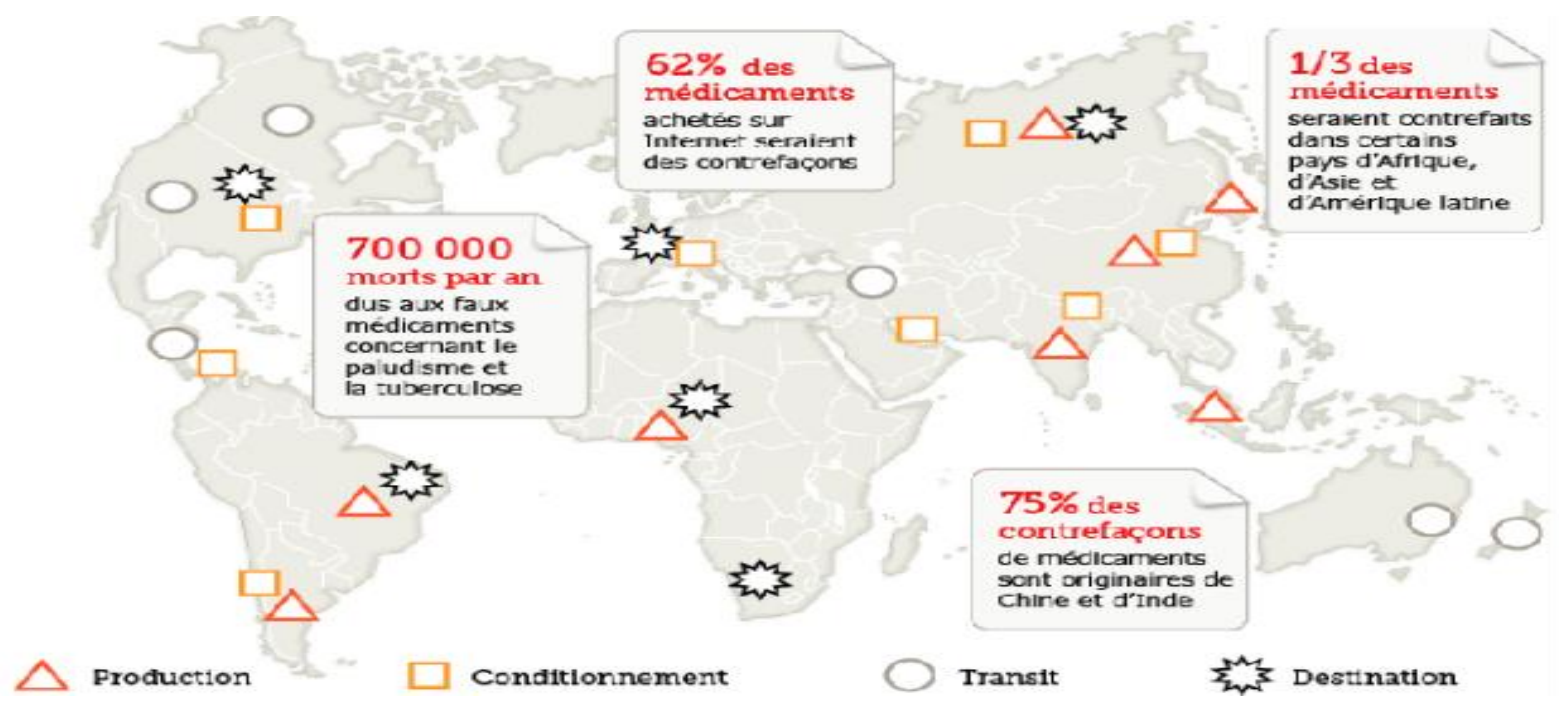

Source : Le Figaro, le : 25/09/13, Thomas Féat, Les médicaments contrefaits tuent 700.000 personnes par an.

Selon cette étude, les faux médicaments tuent 700.000 personnes chaque année ${ }^{1296}$, l'étude de I'IRACM souligne aussi le rôle croissant du commerce en ligne dans ce cadre...

\section{Section 3 - Explosion du commerce électronique : le salut de l'analyse des risques...}

Le commerce électronique est devenu aujourd'hui un canal préféré par les malfaiteurs pour commercialiser massivement leurs produits illicites, la croissance des ventes en ligne apporte des risques majeurs de fraude pour les autorités chargées du contrôle, ces risques sont de plus en plus importants...

Le développement de l'e-commerce représente un défi majeur pour les administrations des douanes, ces dernières doivent donc essayer de s'adapter aux risques et enjeux liés à ce nouveau type de commerce...

Parmi ces enjeux essentiels, on peut citer notamment, la facilitation des échanges, la réduction des délais de dédouanement, la mise en place d'un contrôle efficace pour lutter contre la fraude commerciale et la sécurité de la chaîne logistique.

Face à l'évolution continue des flux de marchandises et des techniques de fraude, la douane devrait mettre en place des systèmes de contrôles intelligents basé sur l'analyse des risques, pour pouvoir trouver un équilibre entre la nécessité de faciliter et l'obligation de contrôler...

\section{Gestion des risques : concept, évolution et valeur ajoutée}

Les administrations des douanes doivent faire face à l'évolution constante et continue des risques liés à l'émergence des transactions électronique, sachant qu'elles disposent de ressources de plus en plus rares, alors pour pouvoir utiliser ces ressources avec le maximum d'efficacité, ces administrations cherchent à appliquer des techniques de ciblage et de gestion des risques. 
La finalité de la démarche d'analyse des risques est double, cette démarche permet d'assurer des contrôles efficaces et de mettre en place parallèlement des procédures de dédouanement simplifiées qui participent à la croissance économique du pays.

Autrement dit, cette démarche permet grâce à un ciblage performant des opérations commerciales, d'offrir de grandes facilités tout en assurant un contrôle efficace aux opérations susceptibles de présenter des risques élevés...

\section{A- Concept et évolution de la gestion des risques}

Les administrations douanières sont placées aujourd'hui sous une pression croissante pour contrôler l'évolution de la criminalité organisée et des risques liés au développement du commerce électronique tout en répondant à la nécessité de faciliter les opérations de commerce extérieur, il $s^{\prime}$ agit donc de trouver un équilibre entre la facilitation et le contrôle, autrement dit, passer vers des techniques modernes de contrôle et d'analyse des risques...

L'OMD définit l'analyse des risques comme : " l'utilisation systématique des informations disponibles afin de déterminer la fréquence d'occurrence de certains risques et l'ampleur de leurs conséquences probables ${ }^{1297}$, elle présente alors l'analyse des risques comme un rapport entre la probabilité d'un événement et son incidence prévisible.

Dans le même sens, la gestion des risques est défini par l'OMD comme : " des activités coordonnées des administrations visant à orienter et à contrôler les risques ${ }^{1298}$, pour arriver à comparer et classer par ordre de priorité ces risques.

L'analyse des risques peut être considérée alors comme la mise en place d'un ensemble de procédures qui permettent d'identifier, analyser, évaluer, traiter et contrôler les risques douaniers.

Ce processus permet « d'axer les activités de contrôle douanier sur les risques plutôt que sur des éléments ou des déclarations sélectionnés de manière aléatoire ${ }^{1299}$, ce qui permet de contrôler mieux avec moins de ressources...

La gestion des risques s'attache aux événements identifiables et quantifiables, la figure suivante présente le champ d'application de l'analyse des risques.

Figure $N^{\circ} 07$ : Gestion des risques : champ d'application

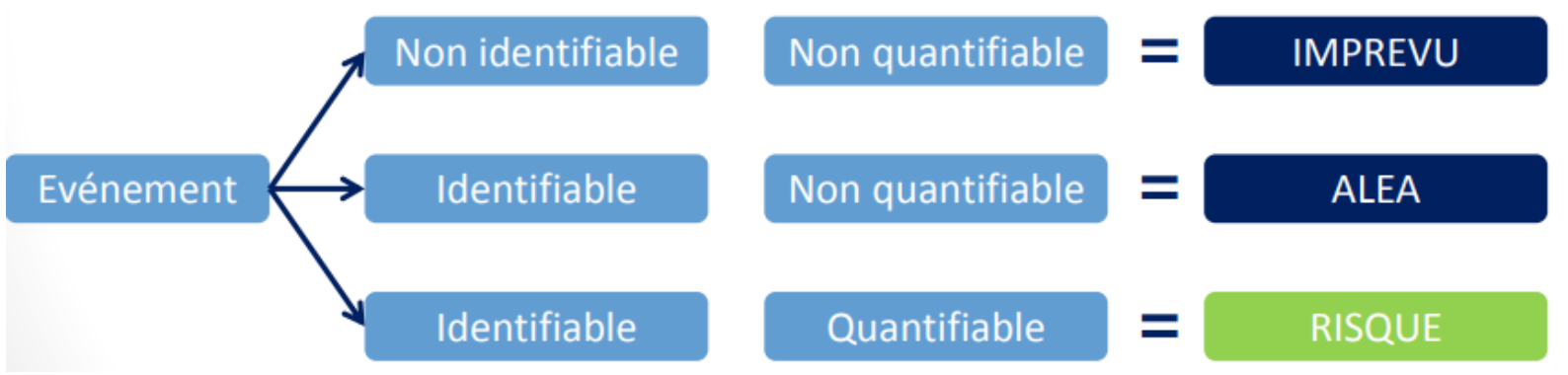

Source : Clémence Duray \& Gatien Braeckman, Gestion des risques, Groupe Jolimont.

1297 : OMD, Recueil de l'OMD sur la gestion des risques en matière douanière.

1298 : Idem.

1299 : Commission Européenne, Opérateurs Economiques Agréés : le modèle compact OEA, Bruxelles, juin 2006, p.2. 
L'analyse des risques permet donc de trouver le meilleur équilibre possible entre la sécurisation et la facilitation des transactions électroniques, puisqu'elle permet à la douane d'axer ses ressources sur les échanges présentant un risque élevé ${ }^{1300}, c^{\prime}$ est dans ce cadre qu'on peut lire le rôle de la gestion des risques pour les administrations douanières...

\section{B- Analyse des risques douaniers : Valeur ajoutée et gains de productivité...}

Le travail des administrations douanières se caractérise par la nécessité de traiter de gros volumes d'échanges liés au développement du commerce sur internet, ces volumes évoluent constamment, il sera alors impossible pour la douane de vérifier tous...

Dans ce cadre, la gestion des risques « constitue, pour les administrations des douanes, une manière efficace et effective de traiter de gros volumes d'échanges lorsque les ressources sont limitées ${ }^{1301}$, sachant que les risques évoluent aussi de manière continue...

Une approche basée sur les risques permet à la douane de cibler plus efficacement les risques, d'orienter les ressources qui sont de plus en plus rares vers les domaines prioritaires, et de trouver un meilleur équilibre entre contrôle et facilitation.

Selon I'OMD, cette approche permet notamment :

$\checkmark \quad$ "Meilleure utilisation des ressources existantes, ou capacité à travailler avec des ressources inférieures ;

$\checkmark$ Utilisation des ressources pour les domaines présentant le plus de risques ;

$\checkmark$ Et amélioration de la facilitation et de la circulation des marchandises et augmentation des investissements étrangers $॥ .{ }^{1302}$

Statistiquement parlant, la figure suivante montre la transition dans le volume des principaux services et le nombre de fonctionnaires au niveau de la douane japonaise.

Figure $\mathrm{N}^{\circ} 08$ : Administration douanière japonaise: étude sur le temps nécessaire à la mainlevée

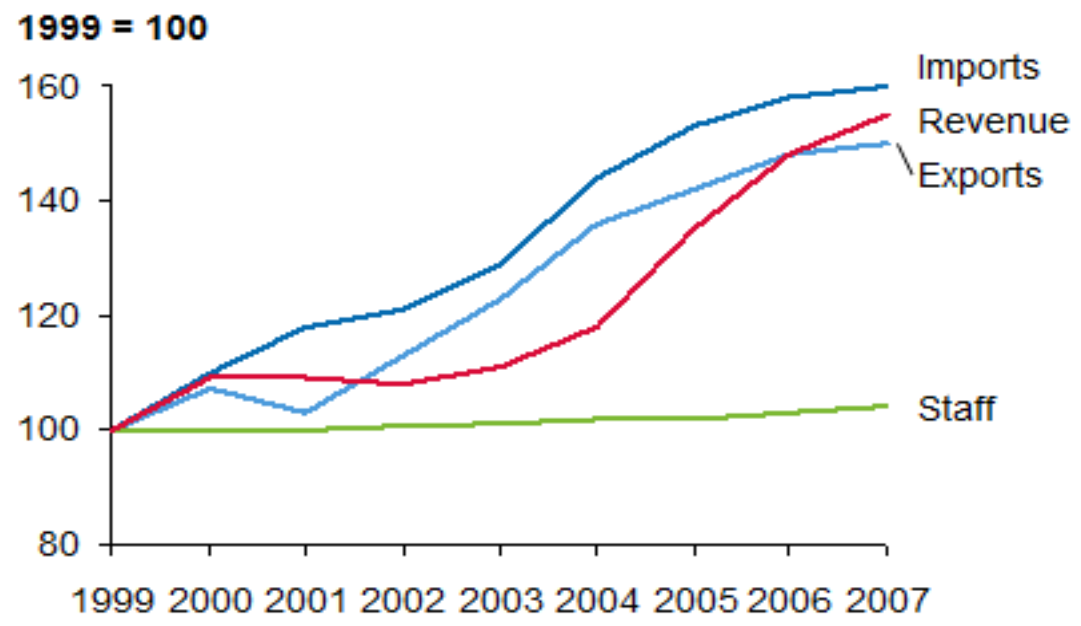

Source : ministère des finances du Japon.

\footnotetext{
1300 : OMC, Étude de cas sur la mise en œuvre de la facilitation des échanges : Gestion des risques, L'expérience de la Nouvelle-Zélande, p.11.

1301 : Idem.

1302 : OMD, Guide sur la Gestion des Risques, 2003, p.5.
} 
Selon les résultats présentés par cette figure, la mise en place d'une démarche basée sur les risques a permis à la douane japonaise de travailler depuis 1999 avec un effectif quasiment inchangé, alors que les Déclarations d'importation ont évolué d'environ 60\% en 2007 et les Déclarations d'exportation ont augmenté de près de $50 \%$ dans la même année, sachant que les recettes douanières ont évolué aussi de manière significative...

L'application des techniques de gestion des risques permis donc aux administrations des douanes de " libérer la grande majorité des cargaisons (jusqu'à 80-90 \% de toutes les importations dans la plupart des pays) ${ }^{1303}$ et d'orienter les contrôles uniquement vers les importations correspondant à des profils à risque déterminés.

\section{Processus de gestion des risques douaniers}

Le processus d'analyse des risques consiste à identifier, analyser, évaluer et traiter les risques, ce processus doit être aussi contrôlé, évalué et documenté pour pouvoir décrire l'ensemble du processus.

L'analyse des risques permet notamment de quantifier les risques à travers un examen des sources des risques, et une évaluation des conséquences de ces évenements pour arriver enfin à les hiérarchiser et mettre en place des stratégies de réduction de ces risques.

Le processus de gestion des risques consiste alors à établir d'abord le contexte de la gestion des risques, identifier ensuite les risques, les analyser, les évaluer et enfin les traiter en ordre de priorité.

\section{A- Identifier, pondérer et comparer les risques douaniers :}

Les risques douaniers ne peuvent pas être analysés et traités avant d'être d'abord recenser et identifiés de manière précise.

Pour identifier les risques douaniers, il suffit principalement de répondre à deux questions :

«Qu'est-ce qui risque d'arriver?

Comment et pourquoi cela risque-t-il d'arriver $»$ ? $^{1304}$

Le résultat de la démarche d'identification des risques est « un registre qui documente les risques et garantit que la totalité de l'éventail des risques est prise en compte ${ }^{1305}$, ces risques seront ensuite analysés et évalués...

L'analyse et l'évaluation des risques permettent d'identifier la probabilité que les risques surviennent et les conséquences liées à ces risques.

Il s'agit comme le montre la figure $N^{\circ} 09$ d'évaluer les risques, en :

« Estimant la fréquence des risques;

Estimant la gravité potentielle des risques (faible, moyenne ou élevée) ». ${ }^{1306}$

\footnotetext{
1303 : CNUCED et OMD, Note Technique No. 5, Audit a posteriori, Janvier 2011.

1304 : Département du commerce international, Banque mondiale, Gestion du respect de la loi basée sur les risques : Guide des administrations douanières, p.11.

1305 : OMD, Recueil de l'OMD sur la gestion des risques en matière douanière, p.15.

1306 : OMD, Guide sur la cartographie des risques en matière de corruption, juin 2015, p.15.
} 
Figure N09 : Grille d'évaluation des risques

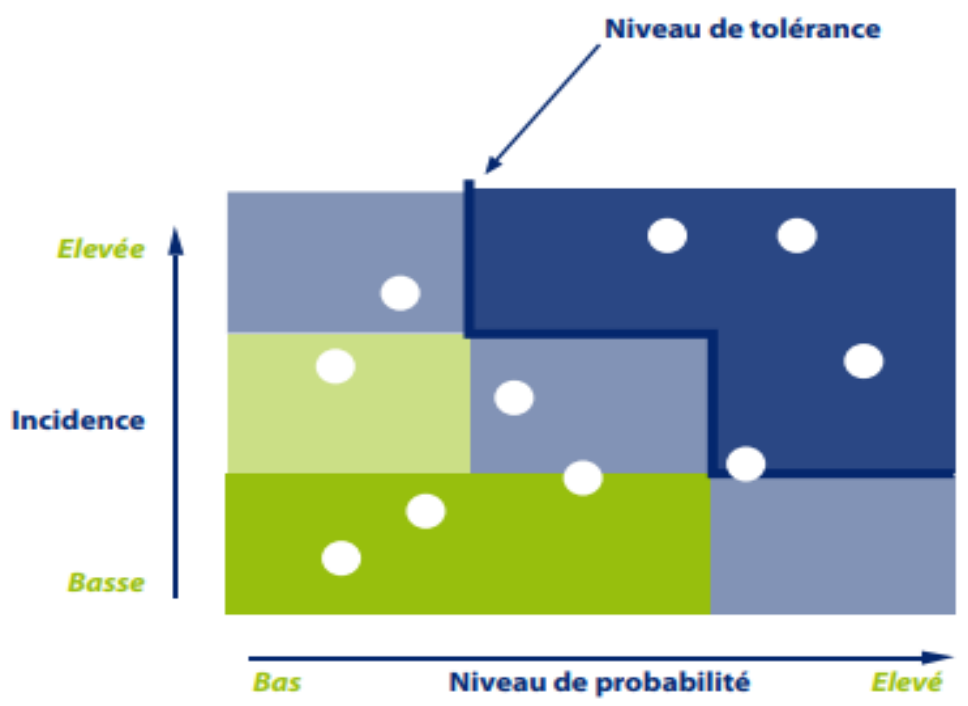

Source : OMD, 2012.

Ces risques doivent être aussi hiérarchisés, cette étape permet de compare les niveaux de risques estimés avec les critères préalablement établis, pour pouvoir hiérarchiser les risques et dégager des priorités de gestion.

\section{B- Traitement, contrôle et documentation des risques :}

Les responsables chargés de la gestion des risques doivent " distinguer trois catégories de situation: soit ils n'ont aucun contrôle sur le déroulement des évènements, soit ils ont un contrôle direct, soit enfin ils ont un contrôle indirect ${ }^{1307}$ sur ces évènements.

Le traitement des risques douaniers fait référence à l'ensemble des mesures prises par la douane face à un risque déterminé, quatre types génériques de réactions peuvent être appliquées ${ }^{1308}$, elles sont dénommées les quatre $\mathrm{T}$ :

II] tolérer : risques acceptables.

III traiter : réduire la probabilité ou la conséquence des risques.

[I] transférer : transférer un risque à un tiers.

[I] terminer : éviter un risque en décidant d'abandonner une activité.

La figure suivante résume les différentes stratégies de réduction des risques, la prévention qui permet de diminuer la probabilité de survenance de l'événement, la suppression, autrement dit, abandonner une activité pour éviter un risque identifié, et enfin, la protection pour réduire la gravité du risque. 
Figure $N^{\circ} 10$ : Stratégies de réduction des risques

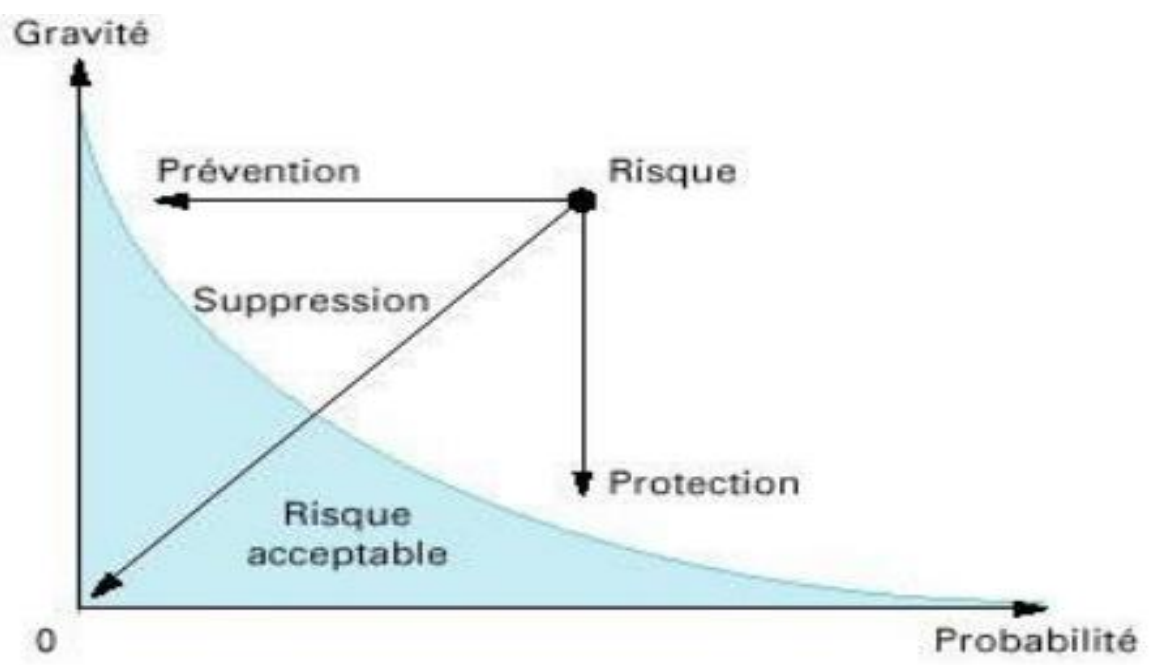

Source : Clémence Duray \& Gatien Braeckman, Gestion des risques, Groupe Jolimont.

Après le traitement des risques, l'étape suivante consiste à " surveiller et à examiner la performance du système de gestion des risques, y compris les changements qui pourraient l'affecter ${ }^{1309}$, il s'agit alors de contrôler et examiner l'évolution des risques traités.

Enfin, la documentation, cette étape permet de tenir des fichiers des risques, en d'autres termes, disposer d'une trace écrite permettant de décrire l'ensemble du processus de gestion des risques.

\section{Conclusion :}

Le développement des transactions électroniques a eu certainement un impact positif sur la croissance économique, notamment grâce à la stimulation de la consommation et la création d'emplois, mais de l'autre côté, ce développement pose sérieusement un certain nombre de défis sur le plan économique, financier et sécuritaire...

Ces risques et défis sont liés principalement au commerce électronique transfrontalier de marchandises de faible valeur B2C (Business to Consumer) et C2C (Consumer to Consumer).

Les caractéristiques du commerce sur internet « (anonymat, mobilité des sites et des hébergeurs et morcellement des envois) ne favorisent pas les contrôles ${ }^{1310}$, ce type de commerce peut alors donner lieu à des infractions graves, on peut citer parmi d'autres, la cybercriminalité, la contrebande de marchandises, la contrefaçon de médicaments et le trafic de stupéfiants.

Les fraudes et trafics liés aux échanges électroniques sont de plus en plus divers, complexes, mondialisés et exploitent toutes les opportunités possibles et tous les vecteurs de transport, aérien, maritime, routier et ferroviaire, et notamment le fret postal et express qui gagne du terrain ces dernières années...

La mission des autorités douanières est devenue de plus en plus complexe, " ces dernières ont dû prendre en compte la dématérialisation inévitable des moyens de communication et du

1309 : OMC, Étude de cas sur la mise en œuvre de la facilitation des échanges, Op.Cit, p.8.

1310 : Assemblée Nationale, Gaby Charroux et Éric Woerth Députés, Rapport d'information sur l'évaluation de l'action de la douane dans la lutte contre les fraudes et trafics, Juin 2015, p.17. 
développement exponentiel du commerce électronique ${ }^{1311}$, ce type de commerce constitue désormais un vecteur essentiel des fraudes et trafics.

Dans ce contexte, l'adaptation sera alors une nécessité pour l'administration des douanes qui devra suivre les évolutions du commerce.

La grande partie des marchandises déclarées à la douane étaient jusqu'à la seconde moitié du 20éme siècle contrôlées par les agents des douanes, cependant, le rôle des administrations douanières est aujourd'hui en constante évolution ${ }^{1312}$, notamment avec la mondialisation des échanges et l'évolution constante et continue des transactions électroniques.

Cette situation a obligé les administrations des douanes « dans le monde entier à repenser leurs structures, procédures, politiques et pratiques existantes ${ }^{1313}$, pour pouvoir faire face à l'ensemble des défis déjà cités et soutenir le développement économique.

Les dirigeants et les cadres supérieurs des administrations des douanes sont obligés aujourd'hui de chercher les meilleurs résultats, sur le plan des recettes douanières, et sur le plan aussi de facilitation et contrôle douanier, avec des ressources de plus en plus rares...

Dans ce cadre, les stratégies et « les méthodes traditionnelles de contrôle douanier, comprenant une intervention à $100 \%$ ou la sélection de pourcentages élevés d'importations ou des critères de sélection purement aléatoire, ne constituent pas les meilleurs modèles en matière de gestion des frontières ${ }^{1314}$, ces méthodes ne permettent pas de répondre aux enjeux de facilitation et de sécurisation fixés par la douane

Les agents des douanes ne peuvent pas vérifier « toutes les déclarations du fait de l'insuffisance des capacités par rapport à la charge de travail, même s'il le pouvait encore, cela ne serait ni nécessaire, ni souhaitable ${ }^{1315}{ }^{131}$, la douane sera obligé alors d'améliorer la stratégie de contrôle appliquée...

Autrement dit, il n'est ni acceptable ni inutile ni possible d'inspecter toutes les déclarations ${ }^{1316}$, dans ce sens, les administrations des douanes modernisées utilisent aujourd'hui des démarches scientifiques de ciblage pour analyser et gérer les risques et cibler de manière précise les risques prioritaires.

Le document sur la douane au 21ème siècle, approuvé par le Conseil de l'OMD lors de la session de juin 2008 à Bruxelles, a signalé la nécessité de mettre en place une démarche positive et dynamique de gestion douanière.

Le troisième élément constitutif de la douane au 21ème siècle considère l'analyse des risques comme la composante clé d'une stratégie douanière orientée vers l'avenir.

Dans le même cadre, les Normes contenues dans le Chapitre 6 de l'Annexe Générale de la Convention de Kyoto révisée peuvent représenter la base légale pour la mise en place de l'analyse des risques.

\footnotetext{
1311 : Florian Bedet, Op.Cit, p.14.

1312 : Commission Européenne, Opérateurs Economiques Agréés : le modèle compact OEA, Op.Cit, p.2.

1313 : Direction des contributions de Maurice, Département des douanes, S.S. Purmah, Mise en œuvre de la facilitation des échanges en République de Maurice, octobre 2011.

1314 : OMD, Renforcement des capacités 2012, p.10.

1315 : Commission Européenne, Opérateurs Economiques Agréés : le modèle compact OEA, Op.Cit, p.2.

1316 : OMD, Cadre de normes SAFE de l'OMD, Juin 2015, p.1.
} 
Alors, il sera nécessaire dans ce contexte de " mettre en œuvre un système de "contrôles intelligents" dans lequel les risques seront évalués et les ressources adéquates débloquées en conséquence ${ }^{1317}$ pour pouvoir utiliser efficacement ces ressources de plus en plus rares.

Ce système de contrôles intelligents basé sur une stratégie de travail ciblée et planifiée, remplace donc le contrôle aléatoire de documents et de marchandises.

L'objectif de la politique d'analyse des risques « est alors d'identifier les opérateurs ou les personnes fiables ainsi que les envois et les transactions à faible risque ${ }^{1318}$, qui peuvent bénéficier d'une politique de facilitation des procédures douanières, et identifier parallèlement les transactions à risque élevé qui nécessitent un contrôle rigoureux.

L'enjeu pour la douane est de trouver le meilleur équilibre possible entre la facilitation et le contrôle, l'analyse des risques est alors indispensable pour les administrations douanières pour moins contrôler et mieux contrôler... 


\title{
La récente loi nº 73-17 : un dispositif pro-débiteur mis à l'épreuve ?
}

\author{
es Oussama CHEKAUD \\ étudiant chercheur en Droit des Affaires, \\ lauréat du Master " Juriste d'affaires » de la FSJES de Fès.
}

Sans doute, avec l'avènement de la récente loi $n^{\circ} 73-17^{1319}$ modifiant et complétant le livre $V$ du code marocain du commerce, entrée partiellement ${ }^{1320}$ en vigueur en avril 2018, la scène juridique marocaine est redynamisée, et la doctrine divisée entre scepticisme et enthousiasme, pourtant et de premier regard, le gain à compenser est colossal car notre droit des entreprises en difficulté étais qualifié souvent comme " un droit de faillite, en faillite. "

Cette faillite est une réalité liée à la défaillance économique (avant de celle juridique et judiciaire) matérialisée par le nombre important des mise en liquidation quasi-systématique des entreprises malades, en fait à travers les statistiques du ministère de justice un pourcentage s'élevant à peu près de $90 \%{ }^{1321}$ de celles-ci finissent et sombrent à travers la procédure de liquidation. C'est à dire une disparition anticipée et imprévisible de ces acteurs économiques incontournables du tissu économique national.

La loi susmentionnée est donc conçue comme une bouée de sauvetage, instituant surtout et pour la première fois au Maroc une nouvelle procédure de " sauvetage " des entreprises en crise, appelée " procédure de sauvegarde ${ }^{1322}$ ".

La lecture rapide des dispositions encadrant cette procédure fait apparaître une ressemblance par rapport à sa sœur aînée introduite en France par la loi nº 2005-845 du 26 juillet $2005^{1323}$ de sauvegarde des entreprises.

Ainsi le nouveau droit marocain des entreprises en difficulté est désormais remodelé et réaménagé pour recevoir ce nouveau-né , qui certainement suscitera l'intérêt de la doctrine en premier lieu en tant que nouveau mécanisme hybride nécessitant une analyse plus approfondie pour l'appréhension de ses finalités et ses retombées pratiques, ensuite cette procédure est censée mobiliser les dirigeants des entreprises car l'une des principales caractéristiques de cette dernière est le maintien de ces dirigeants à la tête de leurs entreprises, sans omettre que le législateur soucieux de garantir sa réussite l'a corréler à un volontarisme sans précédent en laissant exclusivement à ces derniers la faculté et le droit de demander l'ouverture de ladite procédure..

Autre point à préciser, la nouvelle loi est venue combler plusieurs insuffisances et zones d'ombres caractérisant sa prédécesseur, sans être exhaustif, je donnerai l'exemple de la définition apportée

\footnotetext{
${ }^{1319}$ Loi n 73-17 modifiant et complétant le livre V de la loi 15-95 formant code de commerce, publiée en B.O n 6667 le 23 avril 2018. ${ }^{1320}$ Article 798 de la loi $n^{\circ} 73-17$ :

«Dans l'attente de l'institution de juridictions compétentes pour le règlement des différends intervenus entre commerçants ou pour l'application de la présente loi, il sera statué sur lesdits différends conformément à la législation en vigueur. "

${ }^{1321}$ Saida BACHLOUCH, "La prévention et le réglement amiable des difficultés des entreprises en droit compare franco-marocain " THÈSE de doctorat en Droit de l'Université Paris-Est Créteil, Soutenue le 1er octobre 2012, p.232.

1322 La procédure de sauvegarde régie, principalement, par le Titre III du livre V relatif à la procédure des difficultés de l'entreprise (Art 560 au 574) de la loi $n^{\circ} 73-17$.

${ }^{1323}$ La loi n² 2005-845 du 26 juillet 2005 de sauvegarde des entreprises en France.
} 
par ce nouveau texte à la notion de la cessation de paiement ${ }^{1324}$, actuellement mise à jour et mettant terme au renvoi systématique à la jurisprudence, aussi l'institution des procédures internationales d'insolvabilité, disposition totalement novatrice de cette loi...

Aujourd'hui aussi, avec l'avènement de la loi $n^{\circ} 73-17$, rien n'a changé par rapport aux finalités du livre $V$, au contraire, le dispositif réinventé, a consacré enfin, une disposition qui énonce ses finalités ${ }^{1325}$.Cette situation qui a suscité le débat, partant, Professeur A. CHMIA ${ }^{1326}$, a tiré l'attention particulière autour de l'insertion de cette disposition dans la partie relative à la procédure de sauvegarde, tandis que selon le même auteur, il fallait consacrer cette disposition dans la partie dédiée aux dispositions générales, cet aménagement qui écartera toutes nuances éventuelles quant au champ d'application de ces finalités.

D'une façon générale, le législateur en adoptant ce texte avait une double contrainte, d'une part le bilan très décevant des diapositives préventives et curatives du livre $V$, et d'autre part la nécessité d'une refonte de son droit d'insolvabilité capable de l'harmoniser avec les standards internationaux en la matière.

Donc, dans quelle mesure peut-on avancer que cette loi, constitue elle un dispositif prodébiteur, et si au contraire, quelle sont les limites qui font d'elle une simple prolongation de l'ancien livre $\mathrm{V}$ ?

Pour approcher cette problématique, il s'avère opportun de préciser les nouvelles mesures avantageuses, introduite par la récente loi, accordées au débiteur et ensuite dresser un constat autour des dysfonctions et éventuelles entraves, altérants la position du débiteur, qui subsisteront malgré ladite réforme du livre $\mathrm{V}$.

\section{I- Les Mesures « pro-débiteur » circulées par la loi n73-17}

Commençant tout logiquement par l'examen des apports de cette loi qui sont en faveur du débiteur en difficultés, ces apports qui se manifestent, surtout, dans l'introduction pour la première fois de la procédure de sauvegarde (2) mais avant, il faut pointer le doigt la rénovation de l'ancien règlement amiable par l'adoption d'une procédure de conciliation (1) et enfin les nouvelles dispositions très favorables aux cautions personnes physiques (3), souvent des chefs d'entreprises en difficultés.

\section{(1) La procédure de conciliation : maintien de l’approche préventive}

La procédure de conciliation succède à l'ancien dispositif de prévention des difficultés de l'entreprise, le règlement amiable. Institué par la loi du 1er mars 1984 en France, et la loi du 1er aout

${ }^{1324} C^{\prime}$ est d'ailleurs l'une des avancées de la loi $n^{\circ} 73-17$, qui a enfin donné une définition claire à cet état qualifiée de " cessation de paiement ", désormais selon le 2ème alinéa de l'article 575 :

"La cessation de paiement est établie dès lors que l'entreprise est dans l'impossibilité de faire face au passif exigible avec son actif disponible. ".

1325 L'article 560 du livre V, dispose que : " La procédure de sauvegarde a pour objet de permettre à l'entreprise de surmonter ses difficultés afin de garantir la poursuite de son activité, le maintien de l'emploi et l'apurement du passif. ".

1326الدكتور عبد الرحيم شميعة شرح أحكام نظام مساطر معالجة صعوبات المقاولة في ضوء القانون73- 17 ، دار الافاق المغربية، طبعة 2018

ص,19,

و إذ نأسف عن عدم تحلي المشرع المغربي حتى مع القانون 73.17 الذي عمل خلافا للقانون القديم إلى تخصيص المادتين 545 و 546 إلى تحديد المراحل والمفاهيم الخاصة بهذا القانون، وسيتم الإعلان عن أهدافه في المادة 560 م.ت المنظمة لمسطرة الإنقاذ، والحال أنه كان يتعين القيام بذلك في أول مادة من هذا القانون بالشجاعة عن الكشف عن أهداف و غايات الكتاب الخامس من مدونة التجارة، فإنه يجب أن لا يلتبس الأمر لدى أي باحث فيما يخص أهداف الكتاب الخامس، والتي لا تختلف في شيء عن ذات الأهداف عن القانون الأصل الذي أخذ عنه مشرعنا ونقصد به القانون الفرنسي. 
1996 au Maroc, ce dernier qui avait pour objectif « le traitement prophylactique ${ }^{1327}$ des entreprises, ne remplissant pas totalement la mission qui lui avait été assignée, il devait être rénové par la loi $n^{\circ}$ 73-17 par une procédure plus attractive et surtout plus efficace. Le règlement amiable prendra alors avec cette loi le nom de conciliation.

Le président tribunal de commerce ${ }^{1328}$ dans cette procédure joue le rôle d'un amiable compositeur entre les intérêts conflictuels du débiteur et ceux des créanciers. Ce qui signifie que c'est au chef d'entreprise qu'incombe la responsabilité de recourir à ce mécanisme de prévention.

Cette procédure qui reste l'une des première opportunités offertes aux débiteur (après la prévention interne et le mandataire spécial), n'étant pas encore en état de cessation de paiement, de jouir d'une protection judiciaire ( suspension provisoire de poursuite) et d'une large gamme de prérogatives incitatives ( nature confidentielle des démarches judiciaires et conventionnelle de l'accord avec les créanciers ).

(2) La procédure de sauvegarde : renforcement de la position du débiteur

L'innovation de la loi de sauvegarde au Maroc résidait dans la création d'une nouvelle procédure collective, un redressement judiciaire anticipé : la sauvegarde qui implique que l'entreprise ne soit pas encore en cessation de paiements, et que ses difficultés aient été aperçues et analysées et qu'il soit encore possible de trouver avec les créanciers une solution.

La sauvegarde est à la fois une procédure préventive qui doit intervenir avant que les difficultés de l'entreprise ne soient telles que celle-ci se trouve en cessation des paiements. Mais c'est en même temps une procédure curative, dans la mesure où les mécanismes mis en œuvre s'inspirent assez largement de la procédure de redressement judiciaire ${ }^{1329}$.

Cette procédure de sauvegarde, contrairement à celle de redressement judiciaire ne dessaisit pas le chef d'entreprise de la direction de celle-ci : celui-ci poursuit en effet la gestion de son entreprise avec l'aide du syndic. Si l'entreprise n'est pas en cessation des paiements, le débiteur ne court pas le risque de sanction à titre personnel tels que la faillite personnelle ou l'interdiction de gérer, ou encore une condamnation sur ses biens personnels en comblement pour insuffisance d'actif.

Cependant, en cas de fraude de gestion, il est susceptible d'être poursuivi sur ses biens personnels.

Favorable au débiteur par les avantages qu'elle lui procure, notamment de ne pas être exproprié à l'issue de la procédure, favorable aux dirigeants de la personne morale débitrice ou au débiteur personne physique, en c'est qu'elle est incompatible avec les sanctions qui trouvent leur justification dans le préjudice collectif causé par la cessation des paiements et en ce qu'elle accorde aux cautions personnes physiques les conditions d'apurement du passif accordées au débiteur, elle n'a de sens et d'intérêt qu'utilisée avec un réel sens de l'anticipation ${ }^{1330}$.

\footnotetext{
1327 C. SAINTE-ALARY-HOUIN, La procédure de conciliation et la loi de sauvegarde des entreprises : de nouvelles procédures pour de nouvelles stratégies, RPC, 2007, p.13.

$13283^{\text {ème }}$ alinéa de l'article Article 546 de la loi $n^{\circ} 73-17$ :

« On entend par président du tribunal au sens du présent livre, le président du tribunal de commerce ou son suppléant. »

1329 Gerard BLANC, "la nouvelle loi de sauvegarde des entreprises du 26 juillet 2005 ", actes du Colloque organisé par la Faculté de Droit et de Science Politique d'Aix- Marseille, presses universitaires d'Aix Marseille, 2006, p.64.

1330 Veronique MARTINEAU-BOURGINAUD, "la loi de sauvegarde des entreprises : quelles procédures ? Quelles responsabilités ? " Colloque du vendredi 24 février 2006, Lexis Nexis, Paris, p.3.
} 
(3) Les avantages accordés aux cautions "personnes physiques "

Le législateur a déterminé la qualité des cautions qui peuvent bénéficier de l'ensemble des mesures favorables issues de la loi $n^{\circ} 73-17$, qualifiée de pro-débiteur, en précisant que seuls les cautions personnes physiques, solidaires ou non, pourront y intégrées.

Dans leur ensemble, les nouvelles dispositions relatives aux cautions personnes physiques, sont une étape dans laquelle le législateur Marocain, accordent un très grand confort à ces dernières, cette protection qui se manifeste à travers l'étendue des bénéfices que ce législateur a pu réintégrer dans le nouveau dispositif issue de la récente loi $n^{\circ} 73-17$. Ainsi, et durant la procédure de conciliation, les cautions sont mieux placées, dans la mesure où elles bénéficieront désormais de la suspension provisoire des actions et procédures ${ }^{1331}$ durant cette procédure amiable.

Pour sa part, la nouvelle procédure de sauvegarde, s'avère très bénéfique aux cautions, puisque ces dernières seront parfaitement placées à travers l'étendue des mesures protectrices de l'entreprise, n'étant pas encore arrivé au stade ultime de la cessation de paiement, ainsi et à travers l'article 572, ses cautions, personnes physiques, profiteront principalement des dispositions du plan de sauvegarde et aussi de l'arrêt du cours des intérêts mais aussi de la suspension provisoire des poursuites..

Cette position du législateur s'inscrit dans le renforcement de cette procédure et dans l'amélioration de son attractivité, puisque cette protection des cautions n'est pas une fin en soi mais une mesure incitative des chefs d'entreprises au recours à cette procédure, sachant bien, que dans une grande partie, ce sont ces mêmes chefs d'entreprises qui sont cautions de leurs entreprises.

\section{II- Quelques situations juridiques « défavorables » au débiteur, incarnées par la loi n73-17 :}

La loi $n^{\circ} 73-17$, étant donné qu'elle prévoit des mesures favorables au débiteur, présente également des situations juridiques défavorables pour ce même débiteur, à titre non exhaustif, la nouvelle procédure de déclaration de créances (1), le rôle maintenu des organes judicaires dans la concrétisation des solutions adaptées par le tribunal (3), mais surtout l'interventionnisme du tribunal en phase curative (2).

(1) Les retombées négatives de la nouvelle procédure de déclaration de créances sur le débiteur

II ressort de la nouvelle procédure de déclaration de créances que le législateur a essayé de corriger les lacunes de cette phase critique de détermination du passif de l'entreprise en crise, en mettant en avant les droits des créanciers par un assouplissement de démarches, ce qui va aller automatiquement, à l'encontre des intérêts du débiteur.

Ceci dit, on note que le législateur a œuvré pour un élargissement des créanciers concernés par l'avertissement du syndic, en disposant que ce dernier doit avertir en plus des créanciers titulaires d'une sûreté ayant fait l'objet d'une publication ou d'un contrat de crédit-bail publié, tous les créanciers connus par lui ${ }^{1332}$.

Aussi, pour chaque procédure, un registre spécial coté et paraphé par le juge-commissaire doit être tenu par le syndic qui y inscrit les déclarations de créances selon l'ordre chronologique de leur réception. 
Il découle de cette nouvelle procédure de déclaration de créances, que les créanciers seront mieux informés, voire personnellement informés, et avertis en cas de passage de leur entreprise débitrice en phase de traitement de difficulté.

Mais la contrepartie de cette protection des créanciers, n'est que l'altération des intérêts du débiteur qui doit, désormais, subir l'impact négatif de l'élargissement du cercle d'avertissement de ses créanciers.

\section{(2) l'interventionnisme du tribunal en phase curative}

La loi ne précise pas que seul le créancier dont la créance est en souffrance peut initier la demande d'ouverture de la procédure ${ }^{1333}$, le tribunal reste aussi à travers la récente loi, un acteur incontournable, ainsi et pour une veille juridique sur le respect et la bonne marche des procédures de traitement, des difficultés de l'entrepris, le tribunal a gardé son rôle de déclencheur de procédure et de correcteur parfois.

Tout d'abord en matière de déclenchement, le tribunal peut s'auto-saisir pour déclencher l'ouverture de procédures curatives en cas de :

\section{- Redressement judiciaire :}

Ainsi, la procédure peut être ouverte sur l'assignation d'un créancier quelle que soit la nature de sa créance. Mais Le tribunal peut aussi se saisir d'office ou sur requête du ministère public ou du président du tribunal dans la limite de ses attributions en matière de prévention externe ${ }^{1334}$.

\section{- Liquidation judiciaire :}

Dans ce cas, Le tribunal prononce, d'office ou à la demande du chef de l'entreprise, d'un créancier ou du ministère public, l'ouverture de la procédure de liquidation judiciaire lorsqu'il lui apparaît que la situation de l'entreprise est irrémédiablement compromise ${ }^{1335}$.

Ensuite, cet interventionnisme se manifeste par la possibilité donnée au tribunal de convertir la procédure de sauvegarde en redressement ou en liquidation, en cas de non réunion des conditions préalables requises ${ }^{1336}$.

\section{(3) le rôle " gênant " des organes de procédure dans la concrétisation du sort de} l'entreprise défaillante

À côté du tribunal, d'autres organes judiciaires vont s'immiscer dans les affaires de l'entreprise en difficultés, cette intervention qui reste, pourtant, mal digérée par les chefs d'entreprise, ces derniers qui vont perdre le contrôle de leurs unités de production.

Ainsi, le syndic, véritable chef d'orchestre est chargé de mener les opérations de redressement et de liquidation judiciaires à partir du jugement d'ouverture jusqu'à la clôture de la procédure ${ }^{1337}$.

Aussi, convient-il de souligner qu'hormis l'hypothèse où le chef de l'entreprise est écarté de la gestion de celle-ci, le syndic n'est pas le représentant légal de l'entreprise en difficulté ${ }^{1338}$.

\footnotetext{
${ }^{1333}$ Abdeljalil HAMMOUMI, Droit des difficultés de l'entreprise : la prévention des difficultés, le redressement judiciaire, la liquidation judiciaire, 3ème édition, LIBRAIRIE DAR ASSALAM, 2008. p. 58.

1334 Art. 578 de la loi ${ }^{\circ}{ }^{\circ} 73-17$

1335 Art. 651 de la loi n³-17

1336 Art. 573 de la loi n73-17

1337 Abdeljalil HAMMOUMI, op.cit. p.68.

1338 محمد العبدوني، دور السنديك في إدارة المقاولة الخاضعة لمسطرة التسوية القضائية، المجلة المغربية لقانون الأعمال والمقاولة، " سلسلة

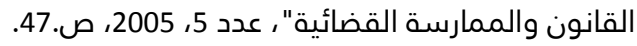


Le juge commissaire est chargé de veiller au déroulement rapide de la procédure et à la protection des intérêts en présence ${ }^{1339}$, contrairement au syndic dont l'étendue de la mission est précisée par le tribunal, ce dernier n'a aucun pouvoir de moduler la tâche du juge commissaire. En effet, bien qu'il constitue un prolongement du tribunal qui l'a nommé, cet organe tient son pouvoir par la loi. Le tribunal conserve néanmoins le pouvoir d'intervenir lorsque des questions importantes concernant la procédure sont posées ${ }^{1340}$.

La polyvalence des attributions offertes au ministère public consolide et conforte sa situation de défenseur de l'ordre public économique, dès qu'il constate le non dépôt des comptes sociaux, il lui est impérativement sollicité :

- La régularisation, voire l'engagement des poursuites

- veiller à ce que des créanciers n'instrumentalisent pas le droit des entreprises en difficulté et si la constatation de la cessation des paiements a été déjà établie, il doit veiller au traitement égalitaire entre les créanciers.

- Il doit veiller au respect de l'ordre public.

- Il doit également remplir convenablement son rôle d'interlocuteur naturel des salariés, lorsque ces derniers n'arrivent pas à obtenir le paiement de leurs salaires.

En guise de conclusion, il est très opportun de faire le point sur les grandes avancées que la loi $n^{\circ}$ 73-17 a pu apporter aux " procédures collectives », dans la mesure où le législateur a renforcer remarquablement le volet préventif de ces procédures, en maintenant l'essentiel des démarches préventives contenues dans la version précédente du livre $V$, d'une part, et d'autre part pas les nombreuses amendements qu'il a administrer dans ce même volet, pour ne pas citer que la fameuse procédure de sauvegarde..

Ce constat, ne doit pas laisser croire que la justice commerciale est à l'épargne de toutes critiques, à l'image du livre $V$, car certains points restent cependant tributaires à une révision prochaine de ce même dispositif.

Le débiteur censé être mieux protégé par cette nouvelle loi, s'est vu attribué un attribut, celui de sauver son entreprise à travers la nouvelle procédure de "sauvetage ", mais qui se trouve dans certaines situation dépourvu de moyens pour la réalisation de cet objectif.

\footnotetext{
1339 Yves GUYON, Droit des affaires tome 2, Entreprises en difficultés, redressement judiciaire, faillite : nouvelle édition 2012 .p.177. ${ }_{1340}$ Abla CHRAIBI, le redressement des entreprises en difficulté au Maroc : état actuel et perspectives de réformes à la lumière du droit français, thèse pour l'obtention du doctorat en droit privé, USMBA, FSJES Fès soutenue le 23-avril-2018. p.234.
} 


\title{
La démocrature politico-économique : Stratégie endogène du développement de l'Empire du Milieu
}

\author{
es NOUR Mohammed Rida \\ Professeur habilité en droit public \\ à la Faculté des sciences juridiques, économiques et sociales de Fès \\ Président du Centre marocain des études africaines et du développement durable
}

Conception particulière et assez originale, la démocrature n'est d'autre que la contraction de " démocratie " et "dictature ", qui fait référence aux régimes politiques hybrides dotés d'une démocratie de façade et dont les mécanismes " démocratiques " sont dévoués au profit du maintien artificiel au pouvoir d'un dictateur ou d'une oligarchie. Comme le précise MERCHET Jean-Dominique, "Les archéologues du vocabulaire considèrent que la première occurrence du mot remonte à 1987, avec la parution du livre du sociologue Gérard MERMET justement intitulé Démocrature : comment les médias transforment la démocratie. Si le mot est forgé depuis trente ans, ce n'est que plus récemment qu'il est utilisé dans son sens actuel, comme le fait abondamment l'essayiste Nicolas Baverez. Le mot s'est imposé dans le dictionnaire et il existe dans de nombreuses langues $"{ }^{1341}$. Néanmoins, ce système hybride

\section{Partie I - La démocrature sociopolitique}

Pendant que la majorité des spécialistes affirmaient qu'il ne peut y avoir de développement sans démocratisation de la société, les pouvoirs politiques chinois, fidèles à des traditions ancestrales, ont préféré maintenir un système politico-social hybride.

\section{Sous partie I- La démocrature politique}

Dans ce sens, la Chine est certainement l'un des États qui répond le mieux aux caractéristiques de cette description. Dans son long chemin vers le développement, l'empire du Milieu a su adopter une stratégie assez originale où démocratie et dictature cohabitent à la fois sur les plans sociopolitiques que dans le domaine économique et monétaire, à travers un dirigisme étatique quasi inimitable. Une stratégie qui, malgré ses déficiences, recueille la bénédiction d'une grande majorité du peuple chinois, puisqu'elle est constante de la philosophie politique chinoise depuis plus 4000 ans.

En effet, pour les Chinois, celui qui sauve la nation d'un grand danger (invasion militaire, des inondations ou la famine, etc.) reçoit automatiquement le " mandat du ciel » c'est-à-dire un pouvoir qu'il conservera à vie tant qu'il ne démérite pas. Alors que, toujours selon la tradition chinoise, un dirigeant impuissant et incapable de défendre les intérêts de la nation, est un Homme stérile qui ne mérite pas son statut et par conséquent, il est dépourvu du " mandat du ciel ". C'est la raison pour laquelle, d'ailleurs, que les Chinois conçoivent assez mal le modèle occidental où le mandat est octroyé par les électeurs, mais sans possibilité de le reprendre lorsque l'élu s'en montre indigne.

Dans ce sens, certains spécialistes de la Chine estiment que, contrairement à ce qui est perçu en Occident, le gouvernement n'est pas une dictature pure et dure. Certes le régime politique chinois est toujours dominé par un parti unique (PCC), mais l'État reste, plus ou moins, à l'écoute de la

1341 MERCHET Jean-Dominique, «Démocrature, dégagisme, ubériser, selfie, climatosceptique : cinq mots qui ont déboulé dans notre vie », 05 juin 2018, (en ligne), disponible sur : www.lopinion.fr. 
population sur plusieurs dossiers et registres. Ainsi, comme le précise Baverez, "Trop souvent la Chine est assimilée à un régime dictatorial ", pourtant il existe des " débats très vifs entre camps opposés bien loin de l'image monolithique faussement perçue en Occident " et cela "révèle une forme de démocratie interne ${ }^{1342}$. Pour lui, parfois on a même tendance à assimiler le pays à une véritable démocratie, tant la force du débat est importante, surtout que depuis quelques années on assiste, bel et bien, à l'émergence d'une opinion publique qui contraint les dirigeants à écouter de plus en plus le peuple. Une nouvelle « mode » due à l'explosion d'internet et des réseaux sociaux dans en Chine. "Sur internet, ce sont 700 millions de personnes qui dénoncent quotidiennement les travers de la société " et qui sont " analysés par des experts, puis débattus en interne au sein du Parti communiste, qui y voit l'occasion de réformer un système conçu comme un être vivant, donc susceptible d'évoluer à tout moment ${ }^{1343}$. Paradoxalement, selon Baverez, ce régime écouterait même plus " son peuple que la France par exemple ", car le gouvernement sait que " sa légitimité il la tient avant tout de son efficacité $»^{1344}$.

Toutefois, il n'en reste pas moins que lorsqu'on désire procéder à de grandes réformes socioéconomiques et politiques on ne consulte pas la population, à l'image d'ailleurs de ce qui ce passe dans la plupart des pays occidentaux dotés d'une démocratie élective et où la prise de décision demeure un champ exclusif de la classe politique professionnelle. Alors que, dans la plupart du temps, le peuple se trouve dépossédé de sa souveraineté de principe, vu qu'il est dépourvu de la jouissance directe de ses pouvoirs politico-économiques, sauf lors de certains rendez-vous électoraux épisodiques (soit à travers les élections, soit à l'occasion de quelques rares consultations populaires " référendums »), lorsque ces derniers ne sont pas truqués ou biaisés.

Politiquement incorrect, en Chine la population n'a pas non plus son mot à dire sur orientations adoptées pour le pouvoir afin de développer l'Empire. Néanmoins, cette stratégie inspirée par un système politique hybride conciliant hard et soft Powers a permis à la Chine de réaliser des avancées extraordinaires dans des secteurs où elle était, économiquement et socialement, faible.

D'ailleurs, l'État chinois n'hésite pas à assumer et faire l'apologie de sa démocrature politique qui lui a permis de réaliser des réformes économiques sans précédent, à une époque où les spécialistes du développement occidentaux affirmaient que le préalable indispensable au développement d'une société, quelle qu'elle soit sa nature, sa taille et son orientation, c'était sa démocratisation. Or Pékin prouve depuis plus de cinquante ans que l'inverse est possible et réalisable. Et c'est d'ailleurs la raison pour laquelle les Chinois soutiennent, en grande partie, l'ensemble des projets du gouvernement.

Donc, ce régime politique hybride a réussi pour l'instant son défi de développement, même si certaines couches sociales continuent de souffrir, à l'image des millions de personnes qui n'arrivent toujours pas à profiter de cette ascension, tel que les Míngōng, considérés par plusieurs spécialistes comme étant les plus grands perdants du miracle chinois.

\section{Sous partie II- Le système du Hukou}

Malgré l'expansion économique actuelle de l'Empire, certains Chinois n'arrivent toujours pas à nourrir correctement leur famille. Le miracle chinois ne profite pas à toutes les composantes de la

\footnotetext{
1342 David Baverez, " Paris-Pékin express : La nouvelle Chine racontée au futur Président », Paris, Bourin Francois Eds, 2017, p. 68. 1343 Le petit journal, " Chine - Quelle évolution pour cette nouvelle "démocrature" ?, 04/04/2017, (En ligne), disponible sur : www.lepetitjournal.com

1344 David Baverez, Ibid.
} 
société à cause, entre autres, de l'adoption par les pouvoirs publics de ce qu'on appelle le " système du Hukou ${ }^{1345}$ qui limite les déplacements de population en Chine.

En effet, en Chine « chaque citoyen n'est libre de travailler, sauf exception, que dans sa province de résidence et uniquement à la campagne s'il est né dans une zone rurale. Le parti annonçait rituellement la fin du Hukou mais il ne l'a pas fait cette fois-ci, car ce système est pour lui une bénédiction ${ }^{1346}$. Le Hukou crée à l'intérieur de la Chine une classe sous-prolétaire dépourvue de droits, représentée par ce qu'on appelle les Míngōng, c'est-à-dire des citoyens chinois migrants ${ }^{1347}$, issus des zones rurales et agricoles et qui, par manque d'opportunité et d'offres de travail, sont contraints de quitter, sans autorisation, leurs villages pour " migrer " vers les villes à la recherche d'un emploi dans les entreprises et chantiers des villes et zones périurbaines et qui représentent « une main-d'œuvre taillable et corvéable à merci. C'est quand même ça la clé du système chinois! $»^{1348}$.

Ce mouvement d'exode de ces ruraux Chinois qui migrant vers les grandes métropoles pour chercher une vie meilleure, a été entamé en 1979, " lors de l'ouverture de la Chine à l'économie mondialisée sous l'impulsion de Deng Xiaoping. Bâtisseurs, ouvriers, balayeurs : ils sont depuis quarante ans les petites mains de la croissance chinoise ${ }^{1349}$.

Dès le milieu des années 1990, profitant de l'assouplissement du hukou, des dizaines de millions de paysans sont ainsi montées à la ville pour trouver du travail. « Bao Jian, dans le Quotidien du peuple de Pékin, rappelait que ces "immigrés de l'intérieur » ou travailleurs migrants réussissaient pour une partie d'entre eux à s'intégrer progressivement. Et c'est précisément cette migration qui a permis l'extraordinaire explosion des villes Chinoises parfois qualifiée de "big bang urbain " dès le début des années 2000 (Westendorff, 2001). Toutefois, ce boom urbain a provoqué une autre vague de migrants en situation précaire à la périphérie des mégapoles de Beijing, Shanghai, Canton. Ces populations mouvantes, sous-payées, ont servi et servent de main-d'œuvre à bon marché pour l'expansion de l'immobilier et la construction de nombreux équipements, comme pour la préparation des Jeux olympiques de $2008 »{ }^{1350}$. En 2012, le nombre de ses migrants a atteint 250 millions, alors qu'en 2016 " on estime cette population flottante à 300 millions de personnes " ${ }^{1351}$ selon le gouvernement chinois. Un chiffre qui dépasse le nombre des travailleurs migrants internationaux recensés par I'ONU1352.

Donc, ces Míngōngs représentent une aubaine pour les entreprises chinoises qui, faute d'autorisation de travail délivrée par les autorités administratives, ils les obligent à accepter des salaires précaires par rapport aux travailleurs chinois légaux. Une situation d'autant plus favorable

\footnotetext{
${ }^{1345}$ Système d'enregistrement des ménages appliqué en République populaire de Chine.

1346 HOLZMAN Marie, " Où va la Chine de Xi Jinping ? », In., " Monde chinois », 2017/2 N 50, p. 42.

1347 Carburant humain de l'avancée économique, ces travailleurs migrants internes sont les grands oubliés du rêve chinois. On les appelle les Míngōng, un nom composé de " mín », " gens du commun / peuple » et " gōng ", " travailleurs / ouvriers », et qui se traduit par « travailleurs migrants ». Cf., Wikipédia.

1348 Idem.

1349 ESPARGILIERE Loup et MONNET Théau, « La deuxième génération des mingong », In., le monde diplomatique, Novembre 2016, p. 16.

1350 QUITTE Jean-Marc et MAIRE Richard, "Chine-Inde : course au développement et impacts socio-environnementaux », In., Chine : regard croisé, 253-254 | Janvier-Juin 2011, p. 16.

${ }^{1351}$ GAY Christophe et LANDRIEVE Sylvie, " Le casse-tête chinois : urbanisation, mobilité et développement durable », Paris, Association Population \& Avenir, In., « Population \& Avenir » 2018/3 n 738, p. 15.

1352 Pour avoir une idée détaillée sur les migrants chinois, voir ROCCA Jean-Louis, " Marchandisation et précarisation des ouvriers chinois ", In., " La condition chinoise. La mise au travail capitaliste à l'âge des réformes (1978-2004) », Paris, Karthala, 2006.
} 
aux gérants des entreprises urbaines que le travail effectué est souvent temporaire et dépend largement des commandes à un moment donné de la saison.

Conséquence, il n'existe quasiment jamais une rémunération des heures supplémentaires et les congés sont rarement payés. Alors qu'en cas d'accident du travail, il est pratiquement impossible d'être indemnisé. Travaillant, généralement, plus de 12 heures par jour, sans congés, ils ne bénéficient que d'une petite pause de quelques minutes pour avaler un repas rudimentaire. Malgré cela, ils considèrent souvent cette existence et leurs maigres salaires préférables à la vie en campagne et à l'incertitude de la production agricole.

Dans de telles conditions propices pour les entreprises chinoises et faute d'une forte idéologie syndicaliste, l'économie chinoise a pu en profiter pour diminuer encore et encore le cout de travail, mais au détriment de la santé psychique des ouvriers ${ }^{1353}$. Ainsi par exemple, le groupe industriel taïwanais Foxconn Technology, le plus grand fabricant d'électronique contractuelle au monde spécialisé dans la fabrication de produits électroniques pour le compte des grandes multinationales telles que Apple, Nokia, BlackBerry ou PlayStation 3 et 4, a compté 18 suicides parmi ses employés en 2010 et plusieurs autres tentatives de suicide en 2017 et 2018, par des personnes qui ont traité l'entreprise de "camp de concentration " et de " cauchemar " à cause de la pression mise sur les ouvriers et des conditions très strictes de travail ${ }^{1354}$.

Il est certain que ce groupe industriel n'est qu'un exemple parmi d'autres de l'exploitation de ces ouvriers, en général, et des migrants chinois clandestins, en particulier, dans la majorité des grandes entreprises en Chine, mais les autorités estiment qu'ils sont indispensables pour le boom économique. Surtout que dans plusieurs cas, les travailleurs, opprimés, mais motivés, continuent de remplir le rôle d'ouvrier jusqu'à ce qu'ils économisent suffisamment d'argent et acquièrent une bonne expérience et compétence pour devenir entrepreneur.

Une situation qui arrange les autorités du pays puisque la Chine bénéficie de tous les avantages de l'immigration - un afflux considérable de pauvres agriculteurs ambitieux, prêts à tout faire pour améliorer ses conditions, ce qui accroît la productivité dans les zones urbaines, sans pour autant amplifier le niveau de xénophobie, bien qu'indubitablement les émigrés ruraux nouvellement arrivés subissent plusieurs préjugés.

Ceci dit, ces dernières années, ce phénomène a été limité, surtout avec l'essor des mouvements ouvriers menés surtout par les migrants internes, la Fédération nationale des syndicats de Chine a été contrainte, surtout depuis 2008, à prendre des mesures plus strictes pour lutter contre l'exploitation des migrants internes. Alors que d'habitude cette Fédération est avant tout un instrument de l'État piloté par le Parti communiste chinois et dont la majorité des responsables syndicaux sont désignés par le gouvernement.

Conséquence, dans son dernier rapport de 2018, l'ONG China Labour Bulletin, basée à Hongkong, analyse près de 7000 mouvements de protestation entre 2015 et 2017. Ainsi, « les nouvelles

\footnotetext{
1353 Pour plus d'informations sur le sujet, Cf., MOU Jin ; CHENG Jinquan ; GRIFFITHS Sian M. ; WONG Samuel ; HILLIER Sheila ; ZHANG,Dan, "Internal migration and depressive symptoms among migrant factory workers in Shenzhen, China ", Journal of Community Psychology, vol. 39, n², March 2011, pp. 212-230.

1354 Cf. NGAl, Pun ; CHAN, Jenny, "Global capital, the State, and Chinese workers : the Foxconn experience ", Modern China, vol. 38, $\mathrm{n}^{\circ}$ 4, July 2012, pp. 383-410.
} 
technologies ont (...) permis aux travailleurs de mieux s'organiser et d'obtenir « une négociation plus rationnelle et ordonnée $»$, relève l'ONG. Fini les grèves sauvages sans lendemain ${ }^{1355}$.

De même, en 2010, plus de 2000 ouvriers de la société Honda à Foshan, ont organisé une manifestation réussie qui a duré presque trois semaines afin d'exiger l'augmentation des salaires et une réforme des syndicats. Une manifestation qui a été bénéfique pour les salariés de Honda, mais qui a provoqué, en parallèle, des protestations partout dans le sud de la Chine. De plus, la manifestation de Foshan a mis au jour une nouvelle génération d'ouvriers migrants qui se distingue des générations précédentes en étant de plus en plus revendicative et beaucoup moins tolérante.

Donc, " le Hukou crée à l'intérieur de la Chine un sous-prolétariat sans droit, ces mingong, ces " travailleurs migrants ", qui viennent à la ville sans autorisation, qui représente une main-d'œuvre taillable et corvéable à merci $»^{1356}$. C'est la raison pour laquelle les autorités chinoises ont tenté de résoudre ce problème à travers une révision de la législation du travail afin d'assurer la viabilité de ce type de salariat.

Ainsi, une modification importante de la loi sur le contrat de travail a été adoptée en 2012. Elle concerne la mise à disposition de personnel ou ce que beaucoup appellent les relations triangulaires de travail, en mettant l'accent sur le perfectionnement des conventions collectives. En outre, inspiré du droit français, la Chine a contraint les entreprises fournir plus de garanties financières, avant de bénéficier d'une autorisation de l'Administration du travail, tout en imposant un seuil maximal relatif au nombre des salariés qui exécutent des travaux temporaires au sein des entreprises et qui ne peut dépasser $10 \%$, sans oublier le perfectionnement de la loi sur la sécurité sociale de 2010 qui a affermi un ensemble de normes adoptées depuis les années 1990.

Par ces mesures, "La loi a renforcé a donc la responsabilité des entreprises et alourdi les sanctions en cas de violation de ces dispositions. Elle a aussi institué le principe "à travail égal, salaire égal". Enfin, son règlement d'application a donné aux entreprises un délai pour s'adapter ${ }^{1357}$.

Cette stratégie s'inscrit dans le projet d'édification de politiques socialement inclusives qui profitent aux salariés de toutes catégories. Néanmoins, cette nouvelle stratégie, malgré les magnifiques progrès réalisés dans le domaine du droit de travail, reste toujours limitée par l'héritage socialiste d'un État marqué par la démocrature, ce qui fait toujours le bonheur des entreprises (publiques et privées) chinoises qui profitent toujours d'une main-d'œuvre abondante et à un prix dérisoire.

\section{Partie II - La démocrature économique et monétaire}

Selon François Bougon, " le marxisme droit dans ses bottes doit réussir sa synthèse avec la tradition chinoise illustrée par Confucius ou Mencius, mais aussi par Han Fei (mort en 233 avant J.C.). Cette réhabilitation de la pensée du philosophe favori de Xi Jinping, concepteur du légisme, qui prône la primauté de la peur, de la force et du contrôle pour servir l'autorité, fait dire à certains que I'on assiste à l'avènement d'un " nouveau totalitarisme de marché ", un totalitarisme adapté au XXle siècle - le prix à payer pour le rêve chinois $»^{1358}$.

\footnotetext{
1355 BOUGON François, « En Chine, les conflits sociaux étendent leur périmètre », In., Le monde, 13.08.2018 (en ligne), consulté le 1210-2018.

${ }^{1356}$ HOLZMAN Marie, « Où va la chine de XI JINPING ? » (Entretien), In., « Monde chinois », Paris, Nouvelle Asie, 2017/2 N 50, p. 42.

1357 TRIOMPHE Claude Emmanuel et ZHENG Aiqing, « Chine : le droit du travail s'éveille, les conflits aussi ! », 04 Août 2016, (en ligne), consulté le 06-11-2018.

1358 BOUGON François, « Dans la tête de Xi Jinping (résumé de 4e de couverture) », Arles, Solin/Actes Sud, 2017, p.65.
} 
Un rêve dont le secret se résume dans un socialisme du marché épaulé par un fort étatisme monétaire.

\section{Sous partie I- l'économie socialiste de marché}

Le concept d'« économie socialiste de marché ${ }^{1359}$, dont l'approche est susceptible de révéler un véritable paradoxe, illustre réalité chinoise assez originale, puisque dans ce système, les moyens de production sont détenus par l'État mais les entreprises demeurent libres quant aux choix de leurs orientations et la prise de décisions. Ceci dit, les prix sont déterminés, empiriquement, par une autorité étatique, mais en cas d'augmentation de la production, les prix baissent en respectant les lois de l'offre et de la demande.

Conséquence, deux systèmes cohabitent dans cette stratégie chinoise. D'un côté, un l'État propriétaire des moyens de production et qui profite de l'efficience des outils rationnels du marché et de l'autre côté, une gérance effectuée par des entreprises indépendantes qui cherchent, comme dans le capitalisme libéral, le profit et la rentabilité et ne subissent aucune régulation. Sauf que dans ce système, les prix sont déterminés, positivement, par les acteurs publics. Donc, il s'agit bien d'un libéralisme original, appliqué selon des méthodes et des stratégies à la Chinoise.

Rappelons à cet effet qu'entre 1978 et 1989, le gouvernement chinois a réformé en profondeur l'économie du pays, la transformant d'une économie planifiée à l'image de ce qui se passait au sein de l'ex-URSS à un " socialisme de marché ", une formule inventée par Deng Xiaoping, dirigeant issu du courant pragmatique, pour désigner un système économique original caractérisé par un libéralisme économique d'un côté, et un contrôle politique autoritaire de l'autre.

Cette stratégie se distingue par quelques critères particuliers :

- Le secteur économique s'accoude sur un contrôle permanent des Institutions par l'État et plus particulièrement par le PCC ;

- Contrairement à certains pays qui avaient tenté d'appliquer la même philosophie économique, en Chine le secteur public garde une place assez importante et centrale dans le paysage économique ;

- Conséquence, la théorie d'Adam Smith de la main invisible n'a pas de place dans cette architecture. Le marché reste régulé par le gouvernement. Il est libéré à l'intérieur, mais très surveillé par l'État.

Donc, la Chine a inventé son propre modèle de développement basé sur un boom de l'entrepreneuriat, facilité par un capitalisme de copinage, corrompu, en dehors de toute conformité à la règle de droit, ce qui a offert et offre encore une voie de réussite et croissance plus rapide et plus courte que celle des États-Unis. Résultat, aujourd'hui, alors que le monde entrepreneurial souffre dans plusieurs Régions du monde, surtout en Europe et aux États-Unis, l'esprit d'entreprise s'épanouit dans tous les secteurs en Chine pour la transformer en véritable " atelier du monde ", surtout que l'empire du Milieu n'a pas adopté les stratégies financières et bancaires occidentales, et encore moins américaines.

En effet, contrairement aux États-Unis où on considère que l'intervention de l'État dans l'économie entrave le développement du pays, et par conséquent il faudrait accorder une liberté illimitée au monde des finances, surtout les banques, les Chinois n'ont pas laissé leur système

1359 Pour avoir une idée générale sur les économies socialistes du marché qui ont été adoptées dans plusieurs pays, Cf. BALCEROWICZ Leszek, "À PROPOS DE L'ÉCONOMIE SOCIALISTE DE MARCHÉ », Paris, Gallimard. In., "Le Débat », 1990/5 n 62, pages 125 à 129. Et Pour avoir une idée générale sur les économies socialistes du marché qui ont été adoptées dans plusieurs pays, Cf. BALCEROWICZ Leszek, "A propos de l'économie socialiste de marché », Paris, Gallimard. In., " Le Débat », 1990/5 n 62, pages 125 à 129. 
bancaire prendre le dessus sur l'économie productive. Les banques chinoises opèrent -pour le peuple -et non pas le contraire, comme on a pu le constater lors de la crise des subprimes en $2008^{1360}$. Et contrairement au monde occidental dominé et apprivoisé par les bourses et économie virtuelle, tout en ayant des conséquences fâcheuses sur le quotidien réel des citoyens, la Chine demeure la seule grande économie où il n'existe pas de véritable déconnexion entre le secteur financier / banquier et le monde ordinaire réel. Grâce à la façon dont le gouvernement a géré ses banques, les deux mondes sont en plein essor. D'ailleurs au moment où les banques occidentales ont du mal à prêter de l'argent aux ménages et entreprises dans leurs pays respectifs, le crédit en Chine coule librement et les banques chinoises continuent à prêter à la population et à leurs entreprises en nombre record. Mieux que ça, pendant que la plupart des États souffraient d'une carence de crédits après la crise des subprimes, les banques publiques chinoises avaient massivement augmenté le prêt.

Ainsi, pendant cette période la Banque populaire de Chine avait prêté pour le premier semestre de 2009 la somme de 1,08 trillion de dollars, ce qui représentait $50 \%$ de plus que le montant des prêts des banques chinoises émis pendant toute l'année 2008. Certains diront que la Réserve fédérale américaine avait également participé à des niveaux record de prêts, mais ce n'était pas pour le même objectif puisque ces prêts sont allés principalement pour renflouer et sauver le secteur financier luimême, alors qu'il été le premier responsable de la crise. Une attitude qui poussé plusieurs politiciens, sociologue et économistes à considérer une telle attitude de la part des gouvernements occidentaux d'injuste et même de criminelle, en accusant le monde politique d'être au service de la dictature financière mondiale. La même dictature que les responsables occidentaux regrettent et critiquent en Chine dans tous ses aspects, y compris l'aspect monétaire.

\section{Sous partie II- Le dumping monétaire}

Dans une économie administrée, la valeur de la « monnaie du peuple » ou yuan est délimitée par l'État. Dès 1994, les responsables du PCC ont instauré un taux de change unique avec le dollar pour le yuan convertible. En effet, un facteur primordial a permis de faire la différence. II s'agit de la politique monétaire suivie par la Banque Centrale chinoise.

Depuis 1995, les Chinois ont appliqué une stratégie volontaire de dévaluation de leur monnaie. Une sorte de dumping monétaire très complexe. Ils ont fustigé le système monétaire international à son propre jeu. À la Chinoise. En effet, les autorités avaient accepté de modifier le système de change avec une réévaluation de $20 \%$ du yuan, mais en réalité, il ne s'agissait que d'un libéralisme de façade. Depuis, la Chine a eu une croissance très importante basée sur l'augmentation des exportations, encouragées par la faiblesse de la valeur de leur monnaie, sans pour autant qu'il ne s'apprécie face au dollar ou l'euro.

En temps normal, une fois que les exportations d'un pays augmentent, la valeur de sa monnaie s'apprécie, car elle devient plus demandée sur le marché des changes international. Mais, en parallèle, une monnaie devenant plus forte, condamne à la baisse la compétitivité des entreprises et diminue le rythme des exportations à cause de l'augmentation des prix. Mais, depuis 1995 la Banque Centrale chinoise, a artificiellement maintenu le Yuan à un cours fixe face au dollar.

Cette " arme » du plongeon volontaire et prémédité de la devise chinoise a toujours été utilisée pour acquérir de nouveaux marchés, surtout les marchés des pays occidentaux.

Ainsi, dans sa guerre engagée contre les États-Unis, et surtout après l'avènement de Donald Trump, la devise de la République populaire de Chine a perdu près de $10 \%$ face au dollar en 2018, ce

1360 Pour plus de détails sur ce point, voir notre article, "La Face Cachée De La Crise Des Subprimes ». In., Revue " Tribune juridique », Casablanca, 2016. 
qui reflète une action volontaire des autorités chinoises, et cela afin de compenser l'impact de l'imposition de droits de douane américains, et ainsi préserver la compétitivité des entreprises du pays. Cette stratégie a permis aux produits chinois d'être exportés vers les États-Unis avec un gain et un avantage considérable en termes de compétitivité, ce qui a généré, pour la Chine, l'équivalent de 1,5 point de PIB.

D'un autre côté et comme nous l'avons mentionné dans la partie réservée à l'analyse de la nature du système économique chinois (le socialisme du marché), la Chine n'a pas opté, dans le cadre de l'organisation de ses marchés financiers, aux produits financiers dérivés. Alors que ceux lancés par les Américains ont engendré une crise sans précédent dans les marchés internationaux, à travers la titrisation, ce qui avait provoqué l'éclatement de la crise financière internationale de $2008^{1361}$, la Chine n'en est pas à cette échelle. En effet, jusqu'à nos jours, les responsables de la surveillance du marché spéculent sur des produits de structure simple, que les autorités peuvent facilement contrôler et réguler, tout en répartissant les risques entre les banques et leurs clients.

Alors que les produits dérivés en occident sont devenus si embrouillés et obscurs que même les investisseurs sont ruinés et perdus. En réalité, aux États-Unis et en Europe, on assiste à une privatisation des profits (la plus grande part est réservée aux banques et au monde des finances, alors que le peuple n'y voit que des miettes) et une socialisation des pertes (après l'éclatement de la crise de 2008 , on a voulu faire endosser la responsabilité de la gestion criminelle des produits financiers aux citoyens en contraignant les gouvernements des pays occidentaux à injecter des centaines de milliards de dollars dans les fonds des banques privées afin de les sauver).

Pour éviter de subir le même sort que les banques occidentales après la crise des subprimes, les autorités chinoises ont tenté de garder le contrôle du degré d'innovation et préviennent les risques tout en s'assurant de la transparence.

Néanmoins, face aux pressions, surtout américaines, et pour s'adapter au contexte international, les autorités chinoises étaient contraintes de procéder à certaines réformes monétaires affectant le Yuan, " notamment en laissant s'apprécier le renminbi à partir de 2005 sous la pression des partenaires commerciaux, puis en aménageant son flottement géré selon les circonstances ${ }^{1362}$.

Ainsi, la Banque populaire de Chine qui n'avait pour objectif, depuis sa création en 1984, que d'exercer les fonctions d'une banque centrale et la conduite de la politique monétaire était obligée de se moderniser et de se perfectionner.

Aujourd'hui, on est passé d'un système planifié par les autorités publiques à un régime davantage inspiré du marché, qui fait de la croissance monétaire le principal objectif intermédiaire. "Dans le cadre de cette transition, les taux d'intérêt ont été libéralisés, ce qui les a rendus plus réactifs aux signaux du marché, et les outils de la politique monétaire ont été modernisés. Le système bancaire a aussi été largement réformé et l'économie est devenue beaucoup plus sensible aux mesures utilisant les mécanismes du marché ${ }^{1363}$.

En réalité, même si l'empire du Milieu est le premier exportateur mondial, il a toujours une monnaie encore peu utilisée dans les transactions commerciales multilatérales. C'est la raison pour laquelle les autorités ont décidé, depuis 2005, de procéder à un « démantèlement progressif des

\footnotetext{
1361 Pour plus d'informations sur le sujet, consultez notre article : La Crise Des Subprimes : Autopsie D’une Frénésie Financière Internationale. In., Revue de finance et de prévisions économiques », Édition L’Harmattan, 2018.

1362 Idem.

1363 OCDE, «Chapitre 2. Poursuivre la réforme de la politique monétaire », In., " études économiques de l'OCDE », Paris, Editions de I'OCDE, 2010/6 $n^{\circ}$ 6, p. 56.
} 
contrôles sur les mouvements de capitaux mis en œuvre sur les dernières années témoigne de la volonté du gouvernement chinois d'internationaliser sa monnaie. L'assouplissement du contrôle de la banque centrale sur le marché des changes relève aussi de cette logique ${ }^{1364}$. Cette réforme financière a reçu une nouvelle impulsion en 2012, surtout avec l'entrée en fonction de la nouvelle Administration, dirigée par Xi JINPING. C'est ainsi que lors de la troisième assemblée du PCC en novembre 2013, les autorités chinoises ont formellement décidé de mettre le projet de libéralisation financière au centre de leurs préoccupations. "Ce message a été interprété comme une annonce de la libéralisation des taux d'intérêt, du libre flottement du RMB et de la libération totale du compte de capital à cette date ${ }^{1365}$.

Ceci dit, il serait hasardeux de considérer que le taux de change du Yuan et la dévaluation de la monnaie sont les moteurs, exclusifs, de la montée en puissance chinoise. Cette politique n'aurait engendré et produit ses effets s'il n'était pas conjugué à d'autres éléments et d'autres facteurs qui ont contribué au dessin de la politique générale de développement chinois, et pour cause : entre 2005 et 2013, même après l'appréciation du Yuan, les entreprises chinoises ont continué leur croissance fulgurante. Il est vrai que même après les différents ajustements des autorités, le Yuan demeure toujours sous-évalué, mais ce n'est pas un facteur essentiel. " En outre, si la dévaluation du yuan peut constituer un avantage en termes d'exportation, c'est loin d'être le cas en termes de production ${ }^{1366}$.

\section{Conclusion}

La Chine a réalisé depuis 1980 une trajectoire assourdissante. Les particularités du pays (Système politique, démographie, territoire, taille du PIB et réserves de change, monnaie, puissance militaire, etc.) sont en train de former un nouvel acteur global. Dans ce sens, trois points doivent être retenus. D'abord, comme nous l'avons expliqué, la Chine est un pays de contrastes, peu de choses sont ou toutes blanches ou toutes noires. Donc, il ne faut pas voir dans l'examen d'une situation seulement le versant ensoleillé de la montagne ou au contraire son seul versant à l'ombre.

Ensuite, il faut aussi relever les trois transformations majeures actuellement en cours dans le pays :

a) La normalisation du cadre juridique qui accompagne le retour au premier plan de l'économie mondiale ;

b) Le passage d'une économie purement industrielle à une économie laissant de plus en plus de place à l'innovation technologique ;

c) une volonté tous les jours plus affirmée des entreprises à sortir de la Chine ${ }^{1367}$.

Ceci dit, la Chine devrait relever les multiples défis qui menacent la guette dans le domaine social, mais aussi et surtout dans le domaine militaire s'elle souhaite détrôner l'Oncle Sam.

\footnotetext{
${ }^{1364}$ COUDERT Virginie « La politique de change chinoise et la place du renminbi dans le système monétaire international », In., « Revue d'économie financière ", Paris, Association d'Économie Financière, 2015/3 n 119, p. 70.

${ }^{1365}$ HERRERO Alicia Garcia, "Internationaliser la monnaie tout en s'endettant massivement : le cas de la Chine ", In., " Revue d'économie financière ", Association d'économie financière, 2015/3 n 119, p. 122-123.

1366 CARTON Malo, JAZAERLY Samy, LEVY Michel, TESTARD Hubert, " Jusqu'où ira la montée en gamme des entreprises chinoises ? » In., « Le journal de l'école de Paris du management », Paris, Association des amis de l'Ecole de Paris, 2015/4 N 114, p. 24.

1367 Cf., JOLLY Dominique, « Ces entreprises qui font la Chine », Editions d'Organisation, Paris, 2011, p. 240.
} 


\title{
La hausse de la dette publique marocaine: Causes et solutions en comparaison avec les économies avancées
}

\author{
es ATTAHIR Oussama \\ Docteur en Economie - Gestion de la FSJES Agadir. Université Ibn Zohr.
}

Mots clés : la dette publique, règles fiscales, économies avancées, causes, solutions.

\section{Introduction}

Le processus d'endettement public au Maroc a commencé depuis les années soixante, et a été intensifier au milieu des années soixante-dix en conséquence à la flambée phosphatière, il a suivi depuis une trajectoire généralement à la hausse. Elle se rapproche maintenant des niveaux jamais atteints et devrait continuer à augmenter considérablement au cours de la prochaine décennie (note du 9 juillet 2019 par le Haut-commissariat au plan (HCP)).

Ceci est en grande partie le résultat d'une expansion séculaire des dépenses gouvernementales - en particulier des programmes de dépenses obligatoires tels que la masse salariale et l'infrastructure, avec des recettes fiscales qui n'augmentant pas aussi rapidement. Le montant global des investissements publics, couvrant les budgets de l'Etat, des Etablissements, des Entreprises Publics et des Collectivités Territoriales, a enregistré un accroissement de 16,5\% entre 2011 et 2019, en passant à 195 milliards de dirhams (MMDH), selon la Direction du Budget, relevant du ministère de l'Economie et des Finances.

Le Maroc n'est pas seul. Les économies avancées en tant que groupe ont connu une augmentation à long terme de la dette publique par rapport au PIB, avec la France et I'Allemagne cités à titre d'exemple dans la figure 1.

L'augmentation de la dette publique dans la plupart de ces pays est également le résultat du fait que les recettes fiscales ne suivent pas l'accroissement des dépenses publiques. Par exemple, entre 1972 et 2016, les recettes fiscales du gouvernement central en pourcentage du PIB ont augmenté en France, en Allemagne et, plus largement, dans les pays de l'Organisation de coopération et de développement économiques (d'après les données de la Banque mondiale) ${ }^{1368}$. 
Figure 1 : la dette publique dans les économies avancées ${ }^{1369}$

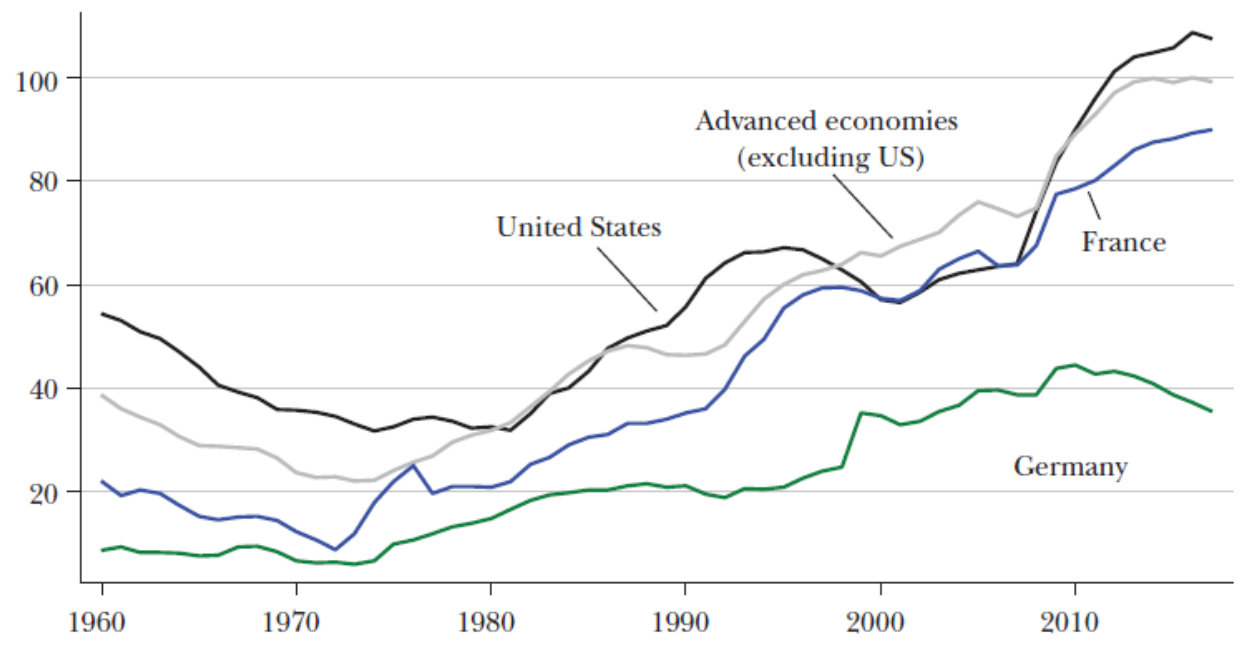

L'accumulation importante de dettes peut éventuellement entraîner une diminution de l'activité économique, soit en évinçant les investissements de capitaux privés, soit en imposant une augmentation des taxes générant des distorsions ou par une réduction des investissements publics, pour faciliter le remboursement. En outre, un gouvernement lourdement endetté peut être contraint de faire face à de futures catastrophes, telles que des crises financières, des catastrophes naturelles ou des guerres ${ }^{1370}$. Dans les cas extrêmes, le résultat est une défaillance résultant d'une répudiation explicite de la dette ou d'une inflation. Il existe de nombreux cas historiques de défaillances dans les économies avancées. Les coûts des défaillances incluent une pression accrue sur les institutions financières, un financement international inférieur pour les entreprises nationales et un accès réduit aux marchés d'exportation ${ }^{1371}$.

L'augmentation de la dette publique marocaine au cours des deux dernières décennies a-t-elle servi un objectif socialement bénéfique qui permettrait de compenser les risques liés au fardeau de la dette supplémentaire ? Dans la première partie de cet article, on passe en revue les théories macroéconomiques normatives dans lesquelles la dette publique remplit trois fonctions possibles: elle peut faciliter l'assouplissement des impôts, constituer un actif sûr ou maintenir l'efficacité dynamique. Tandis que l'augmentation de la dette au cours de certaines périodes peut avoir constitué une réponse optimale à des chocs macroéconomiques spécifiques. La tendance générale à long terme de l'accumulation de la dette semble aller à l'encontre de ces théories de la politique optimale de dette publique.

On passe ensuite en revue les théories d'économie politique de la dette publique, où nous analysons le fait qu'une polarisation politique croissante et une incertitude électorale croissante peuvent expliquer la tendance à long terme de la dette publique dans les économies avancées. L'incohérence dans le temps de la politique gouvernementale est un thème récurrent dans ces

1369 Reinhart, Carmen M., Vincent Reinhart, and Kenneth Rogoff. 2012. “Public Debt Overhangs: Advanced-Economy Episodes since 1800." Journal of Economic Perspectives 26(3): 69-86.

1370 Romer, Christina D., and David H. Romer. 2018. "Why Some Times Are Different: Macroeconomic Policy and the Aftermath of Financial Crises." Economica 85(337): 1-40.

1371 Hébert, Benjamin, and Jesse Schreger. 2017. "The Costs of Sovereign Default: Evidence from Argentina." American Economic Review 107(10): 3119-45. 
théories d'économie politique. Les gouvernements actuels veulent être fiscalement irresponsables, tout en espérant que les futurs gouvernements seront fiscalement responsables.

Ainsi, les gouvernements autour du monde ont adopté des règles fiscales, telles que le déficit, les dépenses ou les limites de revenus prescrits, afin de limiter les futures augmentations de la dette publique. Les règles fiscales ou budgétaires doivent équilibrer entre l'engagement de ne pas trop dépenser, et la flexibilité pour réagir aux chocs. Dans la dernière partie de cet article, on décrit des recherches récentes sur la conception optimale des règles fiscales et budgétaires, en élucidant le compromis engagement / flexibilité en théorie et en pratique ${ }^{1372}$.

\section{Politique optimale de dette publique}

Derrière toute théorie optimale de la dette publique se cache la proposition d'équivalence Ricardienne (Barro 1974) ${ }^{1373}$. Cette proposition indique que le niveau de la dette publique n'est pas pertinent et n'a pas d'effet sur l'activité économique réelle car les emprunts publics peuvent être réversibles par des acteurs privés. Par exemple, si le gouvernement réduit les impôts et emprunte aujourd'hui, le secteur privé prévoit une augmentation future des impôts du gouvernement qui doit rembourser la dette. En conséquence, le secteur privé utilise la réduction d'impôt d'aujourd'hui pour économiser grâce à des obligations d'État afin de financer une charge fiscale future plus lourde, et la décision du gouvernement d'emprunter davantage n'a aucune incidence sur les décisions en matière de consommation, de main-d'œuvre et d'investissement.

L'équivalence Ricardienne nécessite trois conditions fortes qui ne tiennent pas dans la pratique. Premièrement, il suppose que l'augmentation des recettes fiscales n'entraîne aucune perte sèche, raison pour laquelle le moment choisi pour l'augmentation de ces recettes ne déforme pas directement les décisions en matière de consommation, de main-d'œuvre ou d'investissements. Deuxièmement, les ménages et les entreprises sont supposés être sans contraintes financièrement et peuvent donc emprunter et prêter librement aux mêmes conditions que le gouvernement. Enfin, les ménages et les entreprises se soucient du niveau des taxes loin dans le futur. On aborde maintenant les théories de la dette publique optimale qui assouplissent chacune de ces trois conditions et déterminent si l'une d'elles peut justifier la tendance générale à la hausse de la dette publique.

\section{1. Tax Smoothing : besoins budgétaires imprévus et anticipés}

L'argument du "Tax Smoothing » est la théorie la plus largement utilisée de la dette publique optimale. Si les taxes forfaitaires sont exclues, de sorte que la hausse des recettes fiscales déforme les décisions économiques, contrairement à la vente d'obligations d'État, la dette publique permet au gouvernement de compenser la perte sèche résultant de la hausse des recettes fiscales au fil du temps. Cependant, la logique de cet argument se déroule différemment si les besoins financiers sont non anticipés par rapport aux anticipés. Parlons des deux cas.

L'argument du "Tax Smoothing " suggère qu'un gouvernement confronté à des besoins de dépenses temporaires et imprévus devrait réagir de manière optimale en augmentant sa dette. La logique est que le financement de ces besoins par l'augmentation immédiate de recettes serait plus coûteux pour l'économie à court terme, il est donc préférable d'émettre une dette pour répartir ces coûts dans le futur, lorsque les besoins fiscales sont moindres.

\footnotetext{
1372 Lledó, Victor, Sungwook Yoon, Xiangming Fang, Smaba Mbaye, and Young Kim. 2017. "Fiscal Rules at a Glance." March. International Monetary Fund Background Paper.

https://www.imf.org/external/datamapper/fiscalrules/Fiscal\%20Rules\%20at\%20a\%20Glance\%20-\%20Background\%20Paper.pdf.

1373 Barro, Robert J. 1974. “Are Government Bonds Net Wealth?” Journal of Political Economy, 82(6): 1095-1117.
} 
Il est assez facile de penser à plusieurs besoins fiscales temporaires imprévus qui ont entraîné une augmentation de la dette publique dans les économies avancées. La crise financière mondiale, qui a débuté en 2007, a exercé une pression à la baisse sur les recettes des administrations publiques et à la hausse sur les avantages potentiels des mesures de relance fiscale. Aux États-Unis, la dette brute des administrations centrales exprimée en fraction du PIB est passée de $64 \%$ en 2007 à $90 \%$ en 2010. Pendant la même période, la dette publique par rapport au PIB dans la zone euro a également augmenté, non seulement dans des pays fortement touchés par la crise, tels que la Grèce, I'Irlande, I'Italie, le Portugal et l'Espagne, mais également dans des pays moins touchés tels que l'Allemagne et la France ${ }^{1374}$. Avant la crise financière mondiale, les guerres imprévues en Afghanistan (de 2001 à aujourd'hui) et en Irak (de 2003 à 2011) ont contribué à l'augmentation de la dette du gouvernement des États-Unis. Les dépenses militaires des États-Unis en tant que fraction du PIB sont passées de 2,9\% en 2000 à 3,8\% en 2007 (selon les données de la Banque mondiale).

Toutefois, si des besoins fiscales temporaires imprévus résultant de la crise financière mondiale et de la guerre peuvent expliquer en partie l'augmentation de la dette américaine, ils ne peuvent expliquer ni la tendance à long terme de la dette publique depuis le milieu des années 1970 dans les économies avancées, ni l'augmentation des dépenses prévue dans le futur.

Une combinaison de la théorie du "Tax Smoothing » et des besoins fiscaux anticipés peut-elle expliquer la tendance à long terme de la dette publique ? Le problème ici est que, selon la théorie de "Tax Smoothing ", un gouvernement confronté à des pressions fiscales futures croissantes devrait rembourser une plus grande partie de la dette dans le présent afin d'atténuer les tensions fiscales prévues. Dans les économies avancées, la réduction des taux de fertilité et l'allongement de la durée de vie ont augmentés le nombre de personnes âgées, ce qui a entraîné une augmentation à long terme des pressions fiscales ${ }^{1375}$.

Face à ces changements démographiques bien anticipés, la théorie du " Tax Smoothing » aurait imposé une décumulation générale - et non une accumulation - de la dette publique au cours des dernières décennies. De plus, la théorie du "Tax Smoothing " aurait prédit une accumulation moins importante de la dette dans les pays anticipant des tensions accrues dues au vieillissement de la population. Néanmoins, les données montrent le contraire : les pays qui connaissent une augmentation plus importante du vieillissement de la population, comme le Japon, ont accumulé plus de dette en pourcentage du PIB que ceux qui subissent une pression démographique moindre, comme le Canada. En résumé, la tendance séculaire à long terme de l'accumulation de la dette publique dans les économies avancées ne peut refléter une réponse politique optimale aux besoins fiscaux imprévus ou anticipés.

\section{2. Disposition d'actifs sûrs}

Une deuxième théorie de la dette publique optimale considère le rôle de la dette publique lorsque le secteur privé ne peut ni emprunter ni prêter librement aux mêmes conditions que le gouvernement ${ }^{1376}$. Cette théorie repose sur le fait que les gouvernements peuvent emprunter à moindre coût que le secteur privé. En conséquence, lorsque le gouvernement émet des obligations, il assouplit les contraintes financières des emprunteurs qui reçoivent maintenant des ressources supplémentaires du gouvernement (par le biais de réductions d'impôts ou de prêts

\footnotetext{
${ }^{1374}$ Reinhart, Carmen M. and Kenneth S. Rogoff. 2011. “From Financial Crash to Debt Crisis.” American Economic Review 101(5): 16761706.

1375 Lojsch, Dagmar Hartwig, Marta Rodríguez-Vives, and Michal Slavík. 2011. "The Size and Composition of Government Debt in the Euro Area." ECB Occasional Paper 132, European Central Bank.

${ }^{1376}$ Azzimonti, Marina, and Pierre Yared. Forthcoming. "The Optimal Public and Private Provision of Safe Assets." Journal of Monetary Economics.
} 
gouvernementaux). En outre, la théorie de la disposition d'actifs sûrs suggère que, si les contraintes financières deviennent plus strictes, une réponse politique optimale augmente la dette publique pour contrer la contraction de l'offre d'actifs sûrs pour les créanciers, tout en fournissant davantage de liquidités à des emprunteurs de plus en plus limités. Le rôle d'actif sûr de la dette optimale se présente dans divers contextes : au lendemain de la crise financière mondiale, lors de la déréglementation financière, face à l'évolution du risque de revenu et lors de la hausse des flux de capitaux transfrontaliers.

Du point de vue de la théorie de la disposition d'actifs sûrs, la réponse politique optimale à une mondialisation et à un afflux de capitaux plus importants est ambiguë. Ces phénomènes devraient réduire le coût de l'emprunt public pour deux raisons : 1 ) une augmentation de la demande d'actifs d'étrangers réduit les taux d'intérêt et le coût de l'émission de dette publique; et 2) la mondialisation élargit le marché des actifs sûrs, réduisant ainsi la réaction des taux d'intérêt marginaux à l'émission de dette publique supplémentaire. D'un autre côté, les emprunts supplémentaires du secteur privé national (en réponse à la baisse des taux d'intérêt) signifient que les emprunteurs nationaux souffrent davantage des augmentations marginales des taux d'intérêt induites par l'augmentation de la dette publique ${ }^{1377}$.

\section{3. Efficacité Dynamique}

Une dernière théorie, moins explorée dans les travaux de recherche, considère le rôle de la dette publique lorsque le secteur privé n'internalise pas les effets de la politique fiscale loin dans le future $^{1378}$. Dans un tel environnement, les ménages âgés ne sont pas confrontés au coût fiscal futur de l'émission de dette publique, car tous les impôts seront remboursés par les générations futures. En conséquence, une augmentation de la dette publique modifie le profil de consommation à long terme vers les générations plus âgées, tout en augmentant les taux d'intérêt et en évitant les investissements en capital. Dans certaines conditions, la dette publique peut se transformer en bulle. Une génération est disposée à détenir une dette publique simplement parce que les générations futures devraient également le faire.

De ce point de vue, si une économie est dynamiquement inefficace et a accumulé trop de capital, l'accroissement de la dette publique peut être optimal. Une suraccumulation inefficace de capital peut apparaître à l'équilibre lorsque les agents ont des horizons finis, auquel cas une bulle de la dette publique peut améliorer le confort sociale. Cependant, rien n'indique qu'il y ait eu suraccumulation de capital dans les économies avancées après la Seconde Guerre mondiale ${ }^{1379}$.

\section{Les forces de l'économie politique derrière la hausse de la dette publique}

L'absence d'une raison normative claire de la tendance de la dette publique dans les économies avancées suggère que les forces politiques sont à l'origine de ce modèle. Dans cette section, nous passons en revue les théories d'économie politique de la dette publique, en mettant l'accent sur les théories rationnelles fondées sur l'intérêt personnel. Au cours des quatre dernières décennies, l'évolution de facteurs politiques spécifiques peut expliquer la trajectoire à long terme de la dette publique ${ }^{1380}$.

\footnotetext{
1377 Azzimonti, Marina, and Pierre Yared. 2017. "A Note on Optimal Fiscal Policy in an Economy with Private Borrowing Limits." Economics Letters 151: 62-65.

1378 Blanchard, Olivier J. 1985. "Debt, Deficits, and Finite Horizons." Journal of Political Economy 93(2):

223-47.

1379 Abel, Andrew B., N. Gregory Mankiw, Lawrence H. Summers, and Richard J. Zeckhauser. 1989. “Assessing Dynamic Efficiency: Theory and Evidence." Review of Economic Studies 56(1): 1-20.

1380 Buchanan, James M., and Richard E. Wagner. 1977. Democracy in Deficit: The Political Legacy of Lord Keynes. New York: Academic Press.
} 
En politique fiscale, tout facteur politique qui amplifie le biais actuel entraîne des déficits plus importants (augmentation des dépenses ou baisse des impôts) et modifie la tendance à long terme de la dette publique. En outre, un gouvernement avec ce genre de biais actuel, reconnaîtra qu'il souhaite être plus patient à l'avenir, mais sera probablement incapable de le faire, et sera donc intéressé par la mise en œuvre de règles fiscales en tant que dispositif d'engagement ${ }^{1381}$.

\section{1.Vieillissement et hétérogénéité des taux}

Les ménages diffèrent dans la mesure où ils pèsent le présent par rapport à l'avenir. Ces différences peuvent être dues à la démographie, les ménages plus âgés se souciant moins de l'avenir que les ménages plus jeunes. Ceci est cohérent avec les résultats d'enquête sur les différences intergénérationnelles dans les préférences politiques, les ménages plus jeunes accordant une plus grande importance à la responsabilité financière que les ménages plus âgés (Parker 2012. Wolter, Hansen, Campbell et Ansolabehere 2013) ${ }^{1382}$. Dans un environnement politique dans lequel la politique est choisie de manière séquentielle sans engagement, comme cela est courant dans une démocratie représentative qui ne s'est pas imposée de règles fiscales à long terme, cette hétérogénéité implique un biais actuel associé à des préférences incohérentes dynamiques pour le gouvernement.

Conceptuellement, l'hétérogénéité des taux d'actualisation signifie que les ménages impatients exercent une influence disproportionnée dans l'élaboration des politiques de la période actuelle. Si l'engagement était possible, les ménages impatients conviendraient à l'avance de permettre aux ménages patients d'exercer davantage d'influence politique à l'avenir, car ces derniers accordent plus d'importance à l'avenir. Cependant, rien ne peut empêcher les ménages impatients de décider eux aussi d'influencer la politique lorsque les périodes ultérieures deviennent le présent. Jackson et Yariv $(2014,2015)^{13831384}$ formalisent cette idée et montrent que, quelle que soit I'hétérogénéité des préférences, toute méthode d'agrégation non dictatoriale respectant l'unanimité doit être incohérente dans le temps; de plus, toute méthode de ce type séparable dans le temps doit conduire à un biais actuel. Cette théorie suggère que plus les vieux ménages impatients sont nombreux par rapport aux ménages jeunes patients, plus le gouvernement manque de perspicacité, plus les déficits publics sont importants et plus l'accumulation de la dette publique est rapide.

\section{2.Tragédie des communes}

L'élaboration de politiques en manque de perspicacité peut également résulter d'une version de la tragédie des communes dans laquelle les partis politiques agissant de manière indépendante engagent des dépenses gouvernementales excessives et ciblées, du fait qu'ils n'internalisent pas les coûts de financement partagés de la dette publique. Weingast, Shepsle et Johnsen (1981) ${ }^{1385}$ abordent cette approche dans un cadre fiscal statique, tandis que Velasco $(2000)^{1386}$ offre un exemple de cette approche dans un cadre dynamique.

\footnotetext{
${ }^{1381}$ Aguiar, Mark, and Manuel Amador. 2011. "Growth in the Shadow of Expropriation.” Quarterly Journal of Economics 126(2): 65197.

1382 Wolter, Kirk, Mark Hansen, Andrea Campbell, and Stephen Ansolabehere. 2013. "2012 NORC Presidential Election Study: Americans' Views on Entitlement Reform and Health Care." http://www.norc.org/PDFs/NORC_Inauguration\%20Report-FINAL.pdf.

1383 Jackson, Matthew O., and Leeat Yariv. 2014. "Present Bias and Collective Dynamic Choice in the Lab." American Economic Review 104(12): 4184-04.

1384 Jackson, Matthew O., and Leeat Yariv. 2015. "Collective Dynamic Choice: The Necessity of Time Inconsistency." American Economic Journal: Microeconomics 7(4): 159-178.

1385 Weingast, Barry R., Kenneth A. Shepsle, and Christopher Johnsen. 1981. "The Political Economy of Benefits and Costs: A Neoclassical Approach to Distributive Politics." Journal of Political Economy 89(4): 642-64.

${ }^{1386}$ Velasco, Andrés. 2000. “Debts and Deficits with Fragmented Fiscal Policymaking.” Journal of Public Economics 76(1): 105-25.
} 
Même en l'absence de désaccord politique intérieur, un problème de coordination associé peut surgir d'un pays à l'autre, en particulier si ces pays sont fortement intégrés financièrement, comme dans la zone euro. Certains pays peuvent ne pas internaliser l'impact de leurs décisions d'emprunt sur les taux d'intérêt partagés, les taux d'inflation ou la probabilité de contagion financière. Azzimonti, de Francisco et Quadrini (2014) ${ }^{1387}$ traitent des emprunts excessifs dans le contexte de taux d'intérêt partagés, comme le fait Halac et Yared (2018a) ${ }^{1388}$, tandis que Beetsma et Uhlig $(1999)^{1389}$, Chari et Kehoe (2007) ${ }^{1390}$ et Aguiar, Amador, Farhi et Gopinath (2015) $)^{1391}$ le font dans le contexte de taux d'inflation partagés. Dans les deux cas, l'accumulation de la dette publique dans les pays est inefficace. Ces mécanismes s'appliquent également aux gouvernements sous-nationaux qui peuvent émettre leur propre dette (Dovis et Kirpalani 2017) ${ }^{1392}$.

La tragédie des communes prédit que les pays ayant un grand nombre de circonscriptions ou des désaccords profonds en matière de priorités fiscales entre les circonscriptions accumuleront des déficits publics plus importants, ce qui entraînera une accumulation plus rapide de la dette publique. Cette prévision est conforme aux travaux empiriques qui ont montré que des déficits plus importants sont associés à des pays avec plus de ministres, à une polarisation idéologique accrue au sein de l'exécutif et à un système électoral proportionnel (par opposition à majoritaire) (pour preuve, voir Woo 2003 ${ }^{1393}$; Persson et Tabellini 2004 ${ }^{1394}$; Crivelli, Gupta, Mulas-Granados et Correa-Caro 2016 ${ }^{1395}$ ). À travers le prisme de cette théorie, la tendance à long terme de la dette publique dans les économies avancées résulte de la polarisation et de la fragmentation politique croissante dans ces économies.

\section{3. Renouvellement politique}

Une littérature abondante se concentre sur le renouvellement politique comme explication de la hausse de la dette publique; Les premiers exemples sont Persson et Svensson (1989) ${ }^{1396}$ et Alesina et Tabellini (1990) $)^{1397}$, tandis que des exemples plus récents incluent Battaglini et Coate $(2008)^{1398}$ et Yared $(2010)^{1399}$. Dans ce cas, le biais actuel résulte de l'interaction de deux facteurs: 1) la concentration temporaire de l'autorité politique au sein d'un même parti politique, qui tire des avantages supplémentaires des dépenses consenties au pouvoir en renforçant sa popularité, concentrer les ressources du gouvernement sur les initiatives préférées ou augmenter les rentes

\footnotetext{
${ }^{1387}$ Azzimonti, Marina, Eva de Francisco, and Vincenzo Quadrini. 2014. "Financial Globalization, Inequality, and the Rising Public Debt." American Economic Review 104(8): 2267-2302.

1388 Halac, Marina, and Pierre Yared. 2018a. "Fiscal Rules and Discretion in a World Economy." American Economic Review 108(8): 2305-34.

1389 Beetsma, Roel, and Harald Uhlig. 1999. "An Analysis of the Stability and Growth Pact." Economic Journal 109(458): 546-71.

1390 Chari, V. V., and Patrick J. Kehoe. 2007. “On the Need for Fiscal Constraints in a Monetary Union." Journal of Monetary Economics 54(8): 2399-2408.

${ }^{1391}$ Aguiar, Mark, Manuel Amador, Emmanuel Farhi, and Gita Gopinath. 2015. "Coordination and Crisis in Monetary Unions." Quarterly Journal of Economics 130(4): 1727-79.

1392 Dovis, Alessandro, and Rishabh Kirpalani. 2017. "Fiscal Rules, Bailouts, and Reputation in Federal Governments." NBER Working Paper 23942.

1393 Woo, Jaejoon. 2003. "Economic, Political, and Institutional Determinants of Public Deficits." Journal of Public Economics 87(3-4): 387-426.

1394 Persson, Torsten, and Guido Tabellini. 2004. "Constitutional Rules and Fiscal Policy Outcomes." American Economic Review 94(1): 25-45.

1395 Crivelli, Ernesto, Sanjeev Gupta, Carlos Mulas-Granados, and Carolina Correa-Caro. 2016. "Fragmented Politics and Public Debt." IMF Working Paper 16-190.

1396 Persson, Torsten, and Lars E.O. Svensson. 1989. "Why a Stubborn Conservative Would Run a Deficit: Policy with Time-Inconsistent Preferences." Quarterly Journal of Economics 104(2): 325-45.

${ }^{1397}$ Alesina, Alberto, and Guido Tabellini. 1990. "A Positive Theory of Fiscal Deficits and Government Debt." Review of Economic Studies 57(3): 403-414.

1398 Battaglini, Marco, and Stephen Coate. 2008. "A Dynamic Theory of Public Spending, Taxation, and Debt." American Economic Review 98(1): 201-236.

1399 Yared, Pierre. 2010. “Politicians, Taxes and Debt.” Review of Economic Studies 77(2): 806-840.
} 
inutiles; et 2) l'incapacité des parties à prendre des engagements contraignants (intertemporels) les uns envers les autres.

Sur le plan conceptuel, la réalisation (ou la menace) d'un renouvellement politique rend le gouvernement actuel impatient, car le parti au pouvoir reconnaît qu'il n'aura peut-être pas la possibilité de bénéficier de dépenses dans le futur. Ce biais actuel est encore plus grave si les avantages temporaires liés aux dépenses et à la recherche de rente pendant le mandat sont importants, s'il ya plus de partis en concurrence pour le pouvoir, si seul un sous-ensemble de partis peut prendre des décisions à tout moment (comme dans Battaglini et Coate 2008), ou s'il y a plus de risque politique. En plus de surestimer le présent par rapport à l'avenir, les préférences du gouvernement sont incompatibles de manière dynamique; c'est-à-dire que le parti au pouvoir préférerait que les futurs gouvernements soient responsables sur le plan financier, mais les gouvernements futurs ne peuvent pas s'engager dans une politique future. En ce sens, la combinaison du manque d'engagement et du risque politique amène le gouvernement à être " biaisé par le présent " et " incompatible avec le temps ». Aguiar et Amador (2011) ${ }^{1400}$ proposent une analyse formelle dans ce sens.

Cette théorie prédit que les pays avec plus de recherche de rente, une fragmentation politique ou un risque politique encourront un déficit public plus important, ce qui entraînera une accumulation plus rapide de la dette publique. Ces prévisions concordent avec les études empiriques inter-pays sur les déterminants des déficits publics (par exemple, Drazen 20001401; Alt et Lassen $2016^{1402}$ ).

\section{Des règles fiscales pour limiter la hausse de la dette}

Chaque explication politique de la hausse de la dette évoquée dans la section précédente est basée sur une incohérence temporelle dans les préférences du gouvernement. Les gouvernements actuels veulent être irresponsables sur le plan fiscal, tout en espérant que les futurs gouvernements soient responsables sur le plan fiscal. Ainsi, les gouvernements du monde entier ont cherché à adopter des règles budgétaires - telles que le déficit obligatoire, les dépenses ou les limites de revenus - afin de limiter la future politique fiscale et de limiter l'augmentation de la dette publique. La figure 2 illustre le nombre croissant de pays qui ont imposé des règles budgétaires.

Figure 2 : nombre des pays avec des règles fiscales ${ }^{1403}$

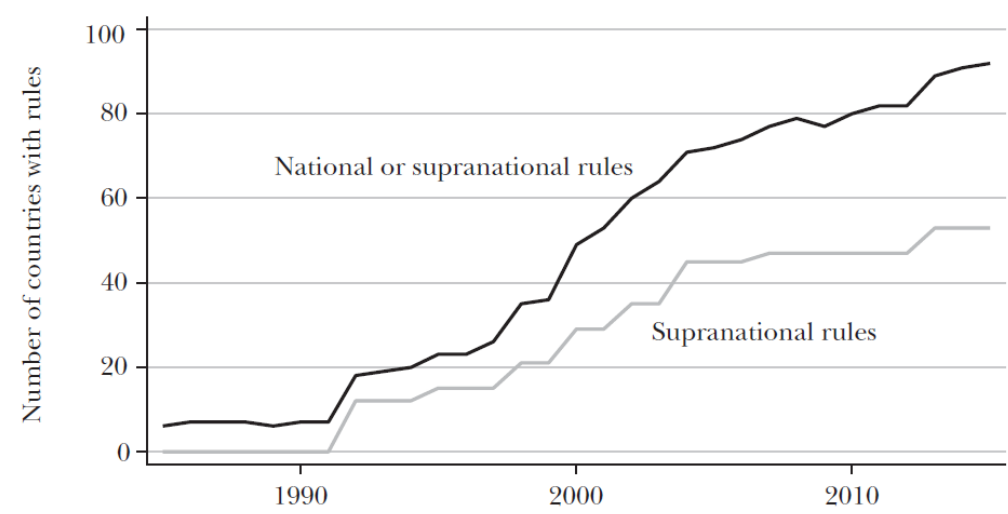

Des règles fiscales ont été adoptées aux niveaux sousnational, national et supranational. Dans certains pays, ces règles ont été efficaces. Par exemple, en Suisse, le ratio dette publique / PIB est passé de $13 \%$ en 1990 à $29 \%$ en 2003, mais après l'adoption d'une règle budgétaire cette année, le rapport dette / PIB de la Suisse est revenu à 20\% du PIB en 2016

\footnotetext{
1400 Aguiar, Mark, and Manuel Amador. 2011. "Growth in the Shadow of Expropriation." Quarterly Journal of Economics 126(2): 65197.

1401 Drazen, Allan. 2000. "The Political Business Cycle after 25 Years." NBER Macroeconomics Annual 15: 75-117.

1402 Alt, James E., and David Dreyer Lassen. 2006. "Transparency, Political Polarization, and Political Budget Cycles in OECD Countries." American Journal of Political Science 50(3): 530-50.

1403 Fond Monétaire International
} 
(d'après les données de la Banque mondiale; voir Pfeil et Feld 2016 ${ }^{1404}$ ). Dans cette section, on décrit la recherche sur la conception optimale des règles fiscales. On commence par le compromis fondamental des règles fiscales entre engagement et flexibilité. En abordant ensuite la manière dont les règles fiscales devraient être subordonnées à l'information du public, à la manière dont elles devraient être appliquées, à la manière dont elles devraient être appliquées à un niveau supranational.

\section{1.Engagement par rapport à la flexibilité}

Les règles fiscales impliquent un compromis fondamental. D'une part, les règles fournissent un engagement à contrecarrer le biais actuel dans l'élaboration des politiques; d'autre part, la flexibilité réduite à un coût, car les règles fiscales ne peuvent pas énoncer les prescriptions d'une politique pour chaque choc ou éventualité possible, de sorte qu'un pouvoir discrétionnaire peut être optimal. Ce compromis entre engagement et flexibilité est bien connu en macroéconomie. Par exemple, il se pose également lors de discussions sur les règles de politique monétaire, et il se pose également dans la théorie d'agent principal dans l'étude de la délégation ${ }^{1405}$.

II existe deux approches pour l'analyse théorique de ce compromis. Une approche qui limite la structure d'une règle fiscale à un formulaire utilisé dans la pratique, tel qu'une limite de déficit, et évalue la rigueur d'une règle optimale. L'autre approche ne restreint pas la structure d'une règle fiscale et utilise une conception de mécanisme pour caractériser simultanément la structure et la rigueur d'une règle optimale. Cette deuxième approche distingue les informations pertinentes sur le plan fiscal sur lesquelles une règle fiscale peut explicitement dépendre - telles que le niveau de la dette publique ou du PIB - et les informations pertinentes sur lesquelles une règle fiscale ne peut pas explicitement dépendre - telles que la profondeur d'une crise financière ou les besoins de l'armée en temps de guerre ${ }^{1406}$.

L'avantage de la première approche est qu'elle peut être utilisée pour évaluer les règles du monde réel et évaluer les coûts et les avantages d'une réforme partielle dans un cadre intégrant un riche ensemble de forces macroéconomiques et politiques. L'avantage de la seconde approche est qu'elle peut être utilisée pour évaluer les coûts et les avantages d'une réforme globale, par opposition à une réforme partielle. Cette deuxième approche explique également comment d'autres considérations, en plus des informations privées et des biais actuels, peuvent contribuer à la détermination d'une règle optimale. Ces deux approches se complètent et fournissent des enseignements utiles pour la conception optimale des règles fiscales.

\section{2. Conditionner sur l'information}

Une règle fiscale optimale repose sur des informations fiscales pertinentes, observables et contractables, telles que le niveau de la dette et le PIB. Comme toutes les informations fiscales pertinentes ne peuvent pas être facilement observées et vérifiées, cette règle peut permettre une certaine discrétion. Amador, Werning et Angeletos $(2006)^{1407}$ montrent que, sous certaines hypothèses sur la diffusion d'informations privées et les préférences du gouvernement, la règle optimale prend une forme de seuil simple, telle que le déficit, les dépenses ou les limites de revenus observées dans la pratique. (Sans ces hypothèses, une règle optimale est plus complexe et peut

\footnotetext{
1404 Pfeil, Christian F., and Lars P. Feld. 2016. "Does the Swiss Debt Brake Induce Sound Federal Finances? A Synthetic Control Analysis." CESIFO Working Paper 6044. https://www.cesifo-group.de/DocDL/cesifo1_wp6044.pdf.

1405 Amador, Manuel, and Kyle Bagwell. 2013. "The Theory of Optimal Delegation with an Application to Tariff Caps." Econometrica 81(4): 1541-99.

1406 Piguillem, Facundo, and Anderson Schneider. 2016. "Coordination, Efficiency and Policy Discretion." ElEF Working Papers Series 1306, Einaudi Institute of Economics and Finance.

${ }^{1407}$ Amador, Manuel, Iván Werning, and George-Marios Angeletos. 2006. “Commitment vs. Flexibility.” Econometrica 74(2): 365-96.
} 
impliquer plusieurs seuils de politique.) En général, le seuil optimal est plus étroit, plus la volatilité des informations privées du gouvernement est faible et plus le biais actuel du gouvernement est grave, comme dans les deux cas. Dans certains cas, la valeur de l'engagement augmente par rapport à la valeur de la flexibilité.

L'établissement de seuils fiscaux optimaux est un défi. Premièrement, il y a des questions pratiques concernant la mise en œuvre. Des recherches récentes ont été consacrées à l'examen des mesures macroéconomiques à utiliser pour fixer un seuil, à la manière de mesurer l'importance relative de ces mesures et aux objectifs chiffrés de manière à offrir une flexibilité suffisante tout en empêchant une croissance excessive de la dette. Par exemple, Azzimonti, Battaglini et Coate $(2016)^{1408}$ analysent les coûts et les avantages à court et à long terme de l'adoption d'un amendement d'équilibre budgétaire aux États-Unis. Alfaro et Kanczuk (2016) ${ }^{1409}$ comparent la performance d'un plafond de déficit indépendant de la dette à un plafond de dette pure pour le Brésil. Eyraud, Baum, Hodge, Jarmuzek, Kim, Mbaye et Türe (2018) ${ }^{1410}$ proposent une discussion générale sur les défis posés par le calibrage des règles budgétaires.

Deuxièmement, la détermination dynamique des règles fiscales optimales soulève des questions lorsque certaines informations fiscales pertinentes ne sont pas contractuelles. Halac et Yared $(2014)^{1411}$ montrent que si les informations privées du gouvernement sont persistantes dans le temps, une règle fiscale optimale devrait conditionner le degré de concordance des politiques antérieures avec les objectifs fiscales, même si cette mesure n'est pas pertinente pour la détermination optimale des politiques. Cela implique des seuils fiscaux qui changent en réponse à des décisions politiques antérieures, contrairement aux seuils qui seraient optimaux lorsque les informations privées du gouvernement sont indépendantes au fil du temps. Comment intégrer de telles considérations dans les règles fiscales du monde réel de manière pratique est un domaine intéressant pour les recherches futures.

\section{3. Implémentation}

Selon le Fonds monétaire international, les gouvernements ne respectent leurs règles fiscales que dans la moitié des cas (Eyraud, Debrun, Hodge, Lledó et Pattillo 2018) ${ }^{1412}$. La violation des règles fiscales peut déclencher un mécanisme d'implémentation formel ou informel. Par exemple, dans I'Union européenne, une procédure de déficit excessif - une suite d'ajustements fiscales coûteux et de sanctions potentielles - est mise en branle lorsqu'une règle est enfreinte (comme décrit dans Lledó et al. 2017, p. 81) $)^{1413}$.

Plusieurs facteurs doivent être pris en compte lors de l'évaluation des sanctions pour infraction aux règles fiscales. Premièrement, il peut être difficile de dire si les règles ont été enfreintes ou non. Il existe de nombreux exemples montrant comment les gouvernements peuvent utiliser une

\footnotetext{
1408 Azzimonti, Marina, Marco Battaglini, and Stephen Coate. 2016. "The Costs and Benefits of Balanced Budget Rules: Lessons from a Political Economy Model of Fiscal Policy." Journal of Public Economics 136: 45-61.

${ }^{1409}$ Alfaro, Laura, and Fabio Kanczuk. 2016. "Fiscal Rules and Sovereign Default." NBER Working Paper 23370.

${ }^{1410}$ Eyraud, Luc, Anja Baum, Andrew Hodge, Mariusz Jarmuzek, Young Kim, Samba Mbaye, and Elif Türe. 2018. "How to Calibrate Fiscal Rules: A Primer." How-To Notes, March. Fiscal Affairs Department, International Monetary Fund.

1411 Halac, Marina, and Pierre Yared. 2014. "Fiscal Rules and Discretion under Persistent Shocks." Econometrica 82(5): 1557-1614.

1412 Eyraud, Luc, Xavier Debrun, Andrew Hodge, Victor Lledó, and Catherine Pattillo. 2018. "Second-Generation Fiscal Rules: Balancing Simplicity, Flexibility, and Enforceability." International Monetary Fund Staff Discussion Note 18-04.

1413 Lledó, Victor, Sungwook Yoon, Xiangming Fang, Smaba Mbaye, and Young Kim. 2017. "Fiscal Rules at a Glance." March. International Monetary Bund Background https://www.imf.org/external/datamapper/fiscalrules/Fiscal\%20Rules\%20at\%20a\%20Glance\%20-\%20Background\%20Paper.pdf.
} 
comptabilité créative pour contourner les règles. Frankel et Schreger (2013) ${ }^{1414}$ décrivent comment les gouvernements de la zone euro utilisent des prévisions de croissance optimistes pour se conformer aux règles fiscales. De nombreux États américains indemnisent les employés du gouvernement avec des retraites futures, ce qui augmente les engagements hors bilan non soumis à des règles fiscales (Bouton, Lizzeri et Persico 2016) ${ }^{1415}$. En 2016, la présidente brésilienne Dilma Rousseff a été mise en accusation pour avoir utilisé illégalement des banques gérées par l'État afin de payer les dépenses du gouvernement et contourner la loi sur la responsabilité fiscale (Leahy 2016) ${ }^{1416}$. Face à ce problème de transparence, de nombreux pays ont mis en place des conseils budgétaires indépendants pour évaluer et contrôler le respect des règles fiscales (Debrun et al. 2013) $)^{1417}$.

Une deuxième question à considérer est la crédibilité des sanctions. Par exemple, la procédure concernant les déficits excessifs à l'encontre de la France et de l'Allemagne en 2003 a été bloquée par un désaccord entre la Commission européenne et le Conseil européen; par conséquent, les déficits français et allemands ont persisté sans pénalité (comme discuté dans Gros, Mayer et Ubide $2004)^{1418}$.

Un troisième problème est la réaction du secteur privé à la violation des règles, qui peut également servir de forme de sanction. Eyraud, Debrun, Hodge, Lledó et Pattillo (2018), par exemple, constatent que la violation des règles budgétaires est associée à une augmentation significative des écarts de taux d'intérêt pour les emprunts souverains. Une telle augmentation des coûts de financement pénalise immédiatement un gouvernement qui enfreint une règle. Cette idée peut être formalisée dans un modèle de dette et de défaut de gouvernement présentant des équilibres multiples résultant des attentes du marché qui se réalise (comme dans Calvo, 1988) ${ }^{1419}$.

\section{Conclusion}

Au cours des dernières décennies, la dette publique en tant que fraction du PIB a connu une trajectoire ascendante dans les économies avancées et le ratio dette publique / PIB du Maroc approche des niveaux non atteints depuis l'indépendance. Ce document soutient que les théories d'économie politique peuvent expliquer cette tendance à long terme comme résultant du vieillissement de la population, d'une polarisation politique croissante et d'une incertitude électorale croissante.

De nombreux pays ont adopté des règles fiscales pour limiter la dette croissante. La plupart de ces règles ont été introduites récemment, et le temps nous dira si elles conduiront à des finances publiques viables et à un renversement de cette tendance vieille de plusieurs décennies. Leur succès dépend en partie de la question de savoir s'ils équilibrent de manière appropriée le compromis entre l'engagement et la flexibilité qui sous-tendent ces règles, et s'ils répondent à d'autres défis qu'on a soulignés, tels que l'implémentation.

\footnotetext{
${ }^{1414}$ Frankel, Jeffrey, and Jesse Schreger. 2013. “Over-Optimistic Official Forecasts and Fiscal Rules in the Eurozone." Review of World Economics 149(2): 247-72.

1415 Bouton, Laurent, Alessandro Lizzeri, and Nicola Persico. 2016. "The Political Economy of Debt and Entitlements." NBER Working Paper 22570.

1416 Leahy, Joe. 2016. “What Is Brazil's President Dilma Rousseff Accused Of?” Financial Times, May 12.

1417 Debrun, Xavier, Tidiane Kinda, Teresa Curristine, Luc Eyraud, Jason Harris, and Johann Seiwald. 2013. "The Functions and Impact of Fiscal Councils." IMF Policy Paper, July 16.

1418 Gros, Daniel, Thomas Mayer, and Angel Ubide. 2004. "The Nine Lives of the Stability and Growth Pact: A Special Report of the CEPS Macroeconomic Policy Group." Centre for European Policy Studies Paperpacks. https://www.ceps.eu/publications/nine-lives-stabilitypact.

${ }^{1419}$ Calvo, Guillermo A. 1998. "Servicing the Public Debt: Role of Expectations." American Economic Review 78(4): 647-61.
} 
تقريد حعل ندوة "رور العدالة في تحسين مناخ الاعمال"

\section{تحت إشراف: الدكتور سمير الستاوي}

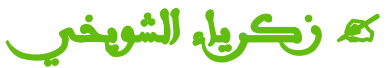 \\ باحـث في القانون الخاص}

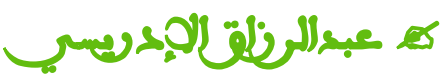

باحثث في القانون الخاص

بسم اللا الرحمر. الرحيم والصحة و والسحم علم أشرف المرسلير سبكنل معمه وعلم آله وصعبه ومر. تبعه بلإحسلن إلى يوم اللكير.

\section{الإطار عام للندوة}

تلعب مؤسسة العدل دورا أساسيا في جميع الدول الديمقراطية نظرا لما تمتلكه من مميزات وخصائص تنعكس بشكل

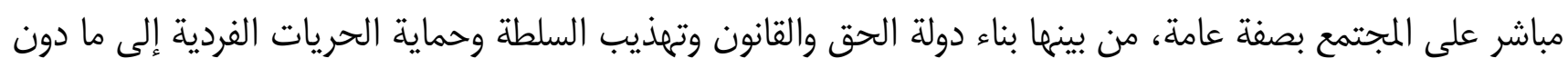

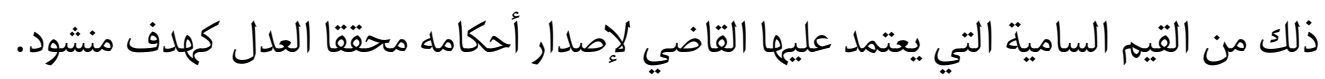
ولا شك أن دور العدالة من هذا المنظور يؤسس إلى مفهوم أساسي وهو الأمن القضائي الذي يتقاطع قطعا مع الأمن

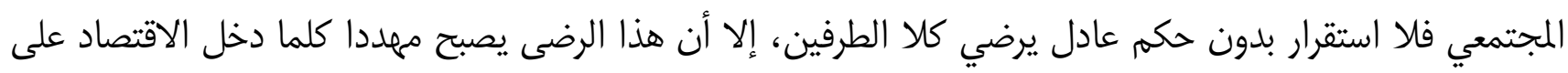

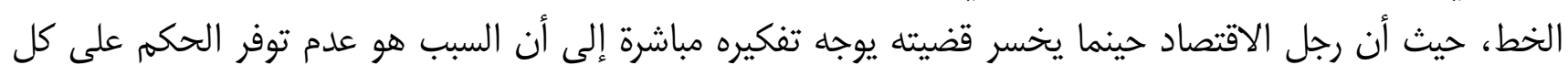
مقومات العدالة والمصداقية.

وسبب هذا الاعتقاد بالنسبة لرجال الاقتصاد يرجع بالأساس لتصورهم حول القضاء وهنا أركز حديثي عن القضاء المغربي

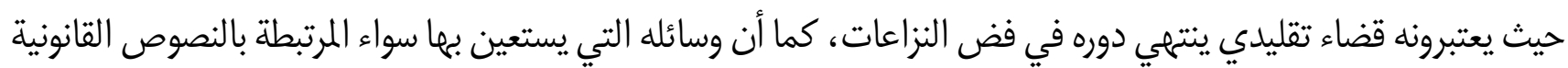

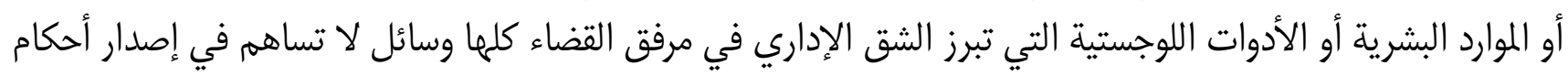
بالجودة المطلوبة، مما ينعكس بالسلب على صورة الاقتصاد الوطني بشكل عام في الإدي أعين المستثمرين. لماذا؟ لأن المستثمر جبان بطبعه فهو لن يضع أمواله في بلد لا يتوفر على شرطين أساسين دائما ما يضعما بعين الاعتبار:

$$
\text { • الشرط الأول: الأمن والاستقرار؛ }
$$

• الشرط الثاني: التمتع بقضاء نزيه مستقل يحمي حقوقهم بمناسبة معاملاتهم الاقتصادية سواء فيما بينهم أو في تعاملهم مع الدولة. 
وبخصوص المغرب إن كان الشرط الأول متوفرا والحمد لله فإن توفر الشرط الثاني يبقى ضروريا لكونه حامل مشعل التنمية الاقتصادية سواء على المستوى المحلي أو الدولي.

وبالتالي فإن تفشي سمعة سيئة أو تسويق صورة مشوهة في الوقت الراهن عن القضاء المغربي أصبح أمرا غير مقبول

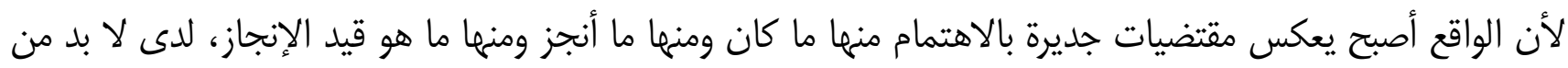
التنويه بها وتشجيعها بعيدا عن الاتباع بشأنها سياسة التبخيس. لاهنيس. وانطلاقا مما سبق تأتي هذه الندوة في إطار التحسيس بالدور الذي أصبحت العدالة تلعبه لتحسين مناخ الأعمال ببلادنا، على جميع المستويات سواء من خلال:

• • بالدور التشريعي لوزارة العدل وما أفرزته من قوانين ومشاريع قوانين تصب في اتجاه مراعاة مركز المستثمر، أو دورها

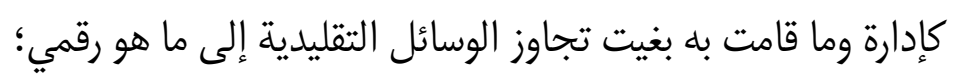

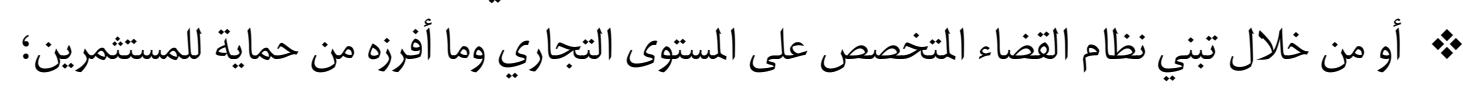

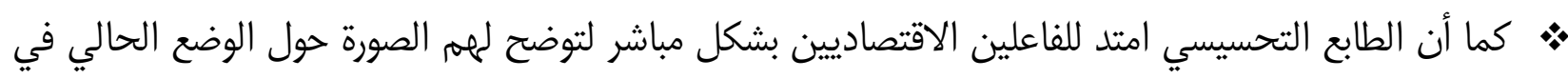
إطار من الشفافية والصدقية الرامية لتحفيزهمه.

وقد افتتحت هذه الندوة بكلمة شكر في حق المحتفى به السيد "عبد الواحد الراضي" ، من قبل شخصيات بارزة داخل

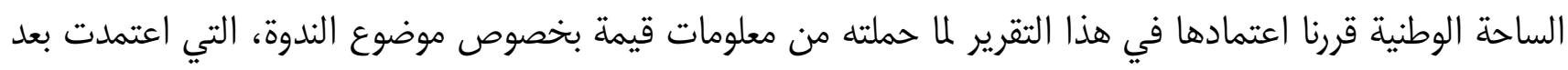
ذلك على ثلاث محاور كبرى تضمنت خمسة مداخلات جاءت موزعة على النحو التالي:

\section{المحور الأول: دور وزارة العدل في النهوض بمناخ الأعمال}

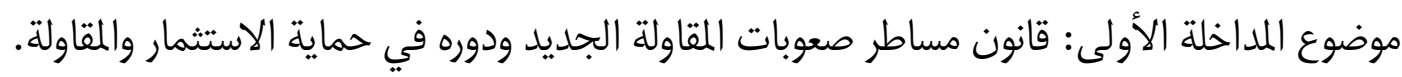
موضوع المداخلة الثانية: الرفع من مستوى خدمات الإدارة القضائية ودوره في تحسين مناخ الأعمال.

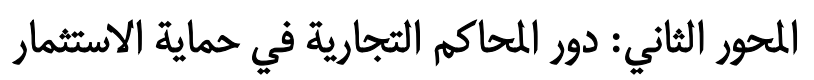
موضوع المداخلة: تجربة المحاكم التجارية في مجال حماية الاستثمار.

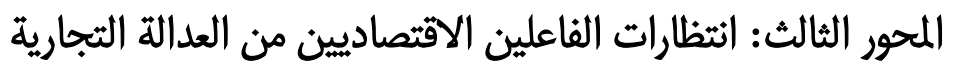
موضوع المداخلة الأولى: نجاعة قضاء الأعمال من منظور المقاولة.

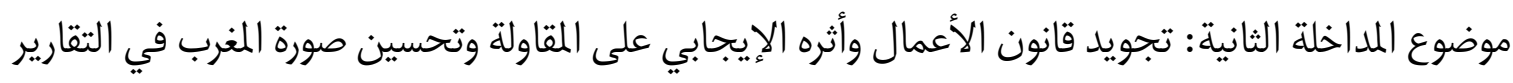
الدولية. 


\section{الكلمات الافتتاحية للندوة}

\section{• ملخص لكلمة السيد وزير العدل "محمد أوجار"}

أتقدم بداية بالشكر للأستاذ الكبير السيد عبد الواحد الراضي والرئيس المنتدب للمجلس الأعلى للسلطة القضائية السيد

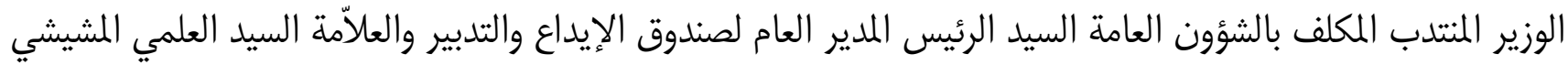

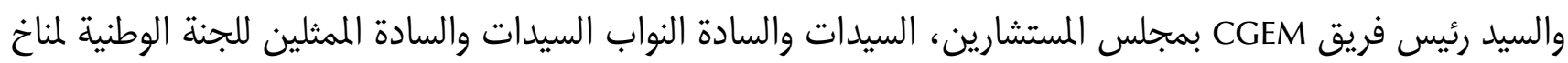
الأعمال السيد رئيس جمعيات وهيئات المحامين بالمغرب السادة النقباء والمحامون السيدات والسادة الباحثون وممثلو المنابر

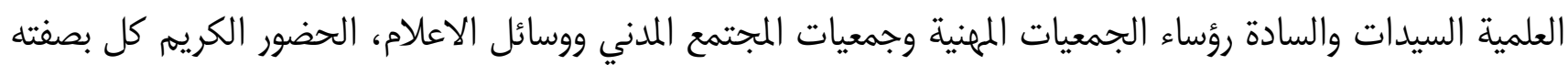
وباسمه السادة المسؤولون القضائيون.

إنه لشرف كبير لي أن أفتتح أشغال هذه الندوة العلمية المهامة التي تنظمها وزارة العدل احتفاء برجل من رجالات الدولة

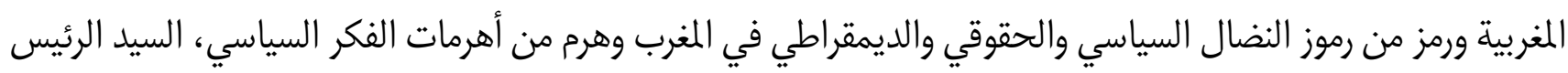
والوزير والقائد والنائب والباحث ووزير العدل الأسبق الأستاذ سيدي عبد الواحد الراضي الفي أطال الله في عمره.

إسمحولي حضرات السيدات والسادة في مستهل هذه الكلمة أن أرحب بكم جميعا في رحاب المعهد العالي للقضاء

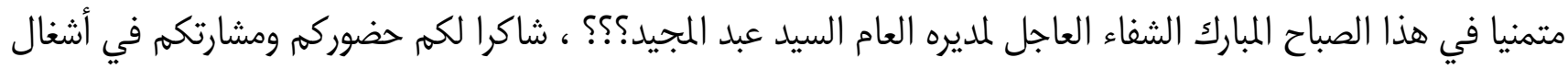

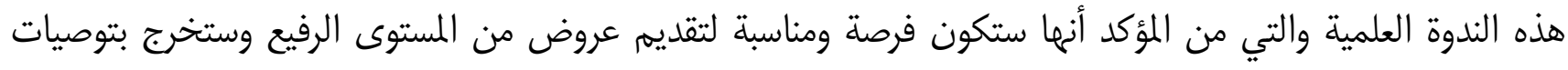

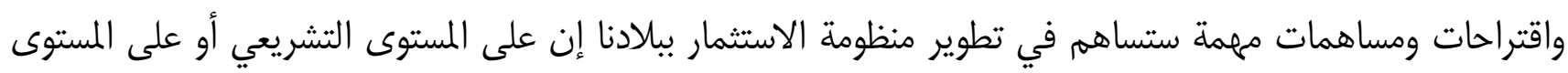

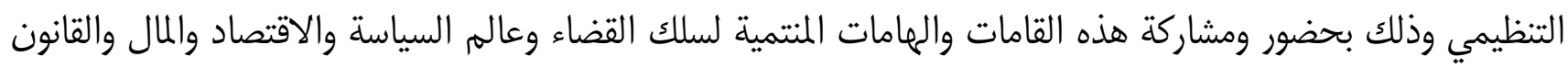
والذين زينت بهم رحاب هذه القاعة ويشكل حضورهم فيها قيمة مضافة لهذه الندوة ويضفي عليها مزيدا من التميز والأهمية.

حضرات السيدات والسادة إن تنظيم هذه الندوة يأتي في سياق التحولات المهامة التي يعرفها مجال الاقتصاد بالمملكة

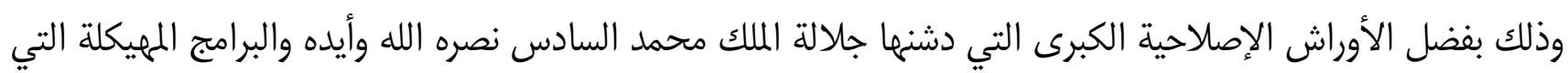

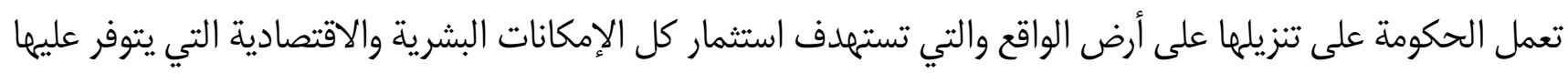

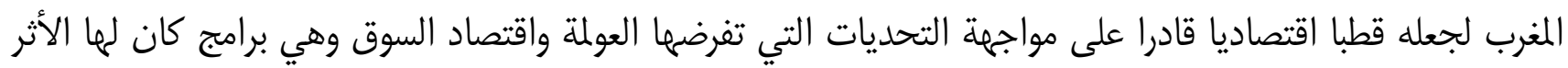

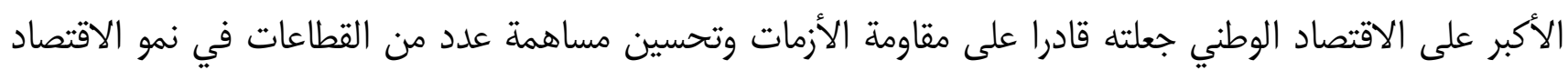

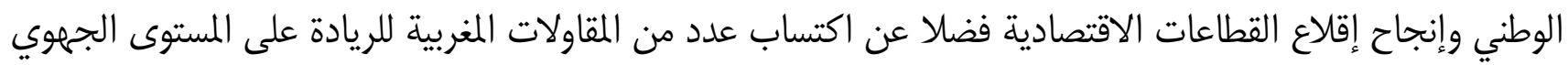

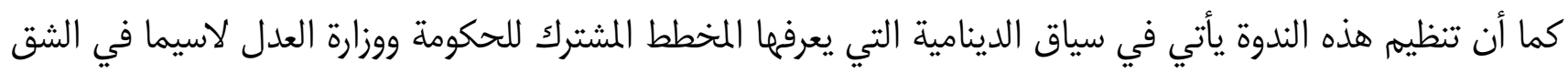

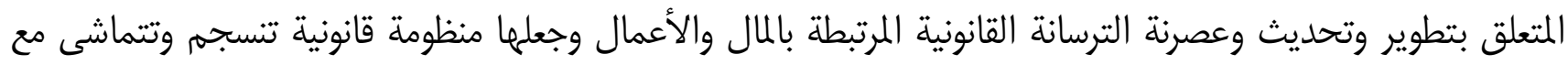

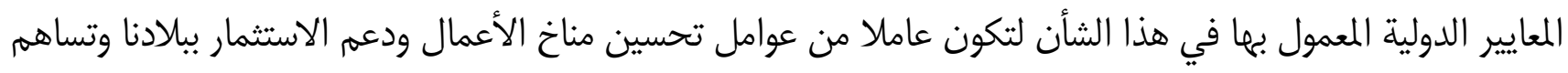

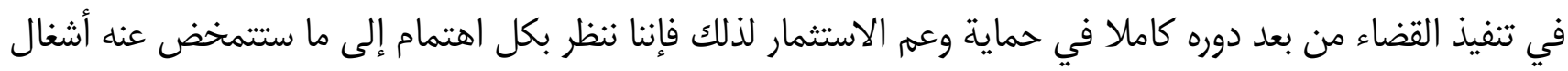


هذه الندوة من توصيات ومخرجات يمكن أن تكون ان شاء الله أساسا لمبادرات تشريعية نتقدم بها مستقبلا من أجل تطوير وتحديث المنظومة القانونية الوطنية في مجال المال والأعمال.

حضرات السيدات والسادة كما لا يخفى عليكم أنه في ظل مناخ الاقتصاد الدولي المتسم بالمنافسة الشديدة أصبح التركيز على الاستثمار كبيرا لتنشيط الدورة الاقتصادية وخلق فرص الشغل ودعم التنمية المستدامة وذلك من خلال التالت تبسيط

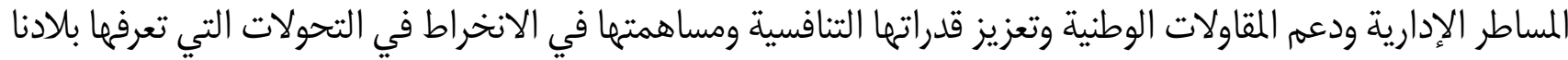
فضلا عن حمايتها من المخاطر لتكون قاطرة للتنمية الاقتصادية والاجتماعية.

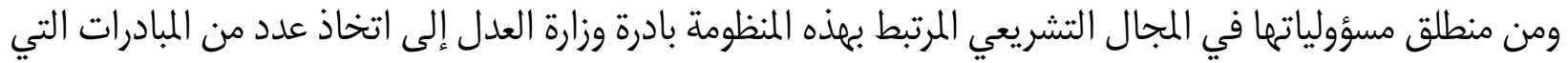

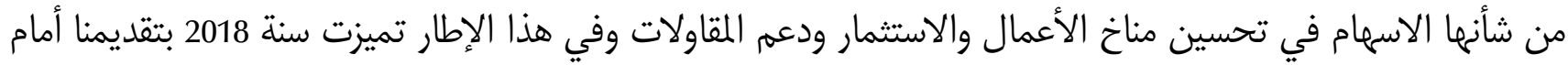
البرلمان لمشروع قانون رقم 17.73 المتعلق بنسخ وتعويض الكتاب الخامس من القانون 15.95 المتعلق بمدونة التجارة فيما

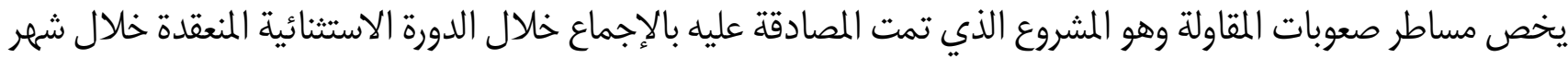

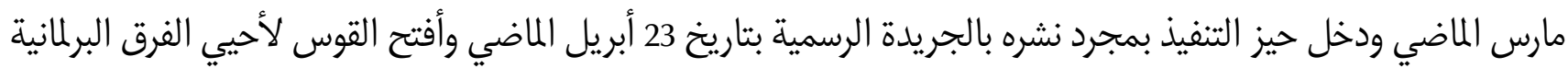

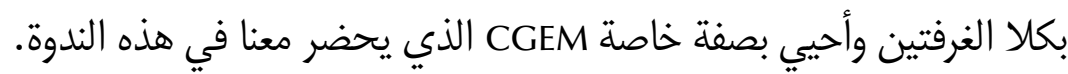

لقد كان الهدف الأساسي من إعداد هذا النص القانوني هو تعزيز قدرة المقاولة المغربية على التنافسية والمساهمة في

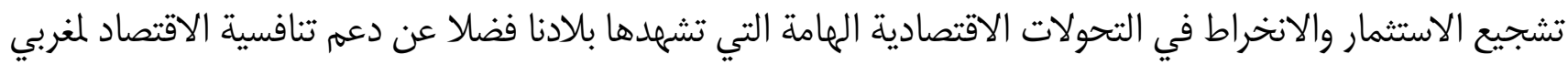

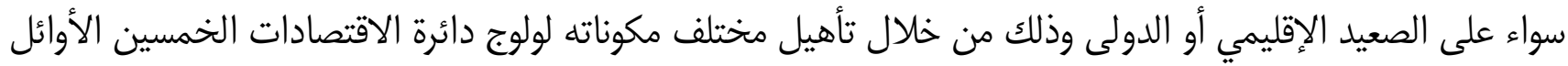
في مؤشر " دوين بيزنيس " لسنة الصعيد الإيمي أل 2021 إن شاء الله.

لقد تضمن القانون الجديد عددا من المستجدات التي تهم أساسا تطوير آليات الرصد المبكر للصعوبات التي قد تعترض

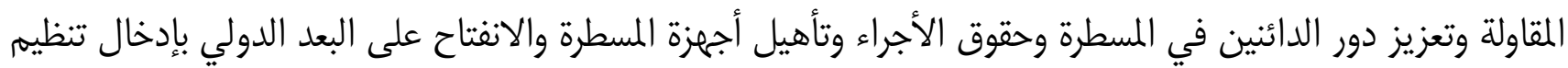

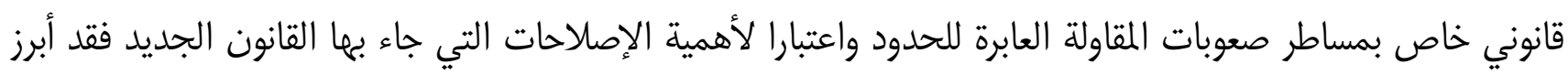

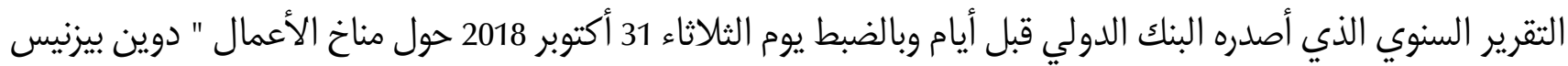

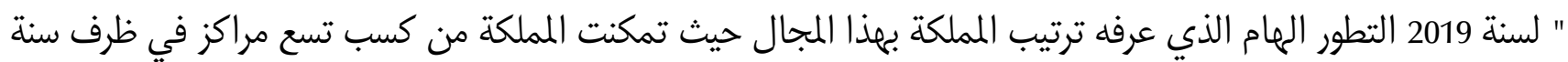

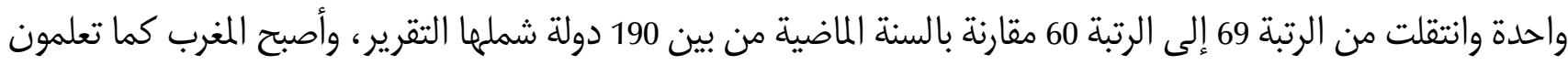

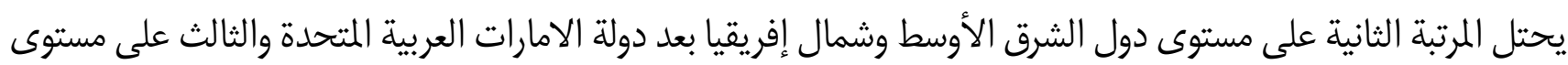

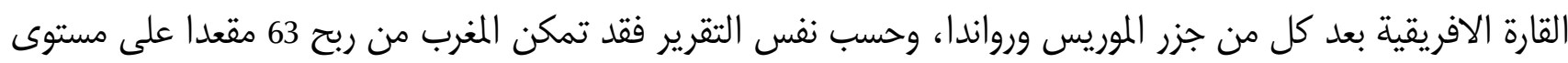

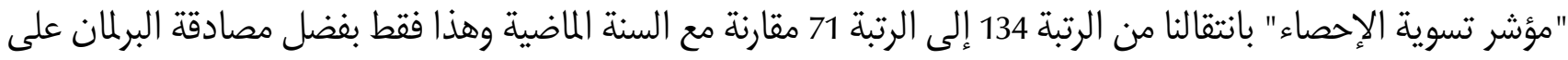

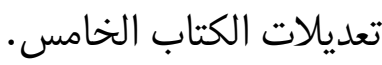

إن تحسين ترتيب المغرب في مؤشر مناخ الأعمال بهذه الوتيرة السريعة بقدر ما يشعرنا بالاعتزاز فهو يجعلنا نستشعر

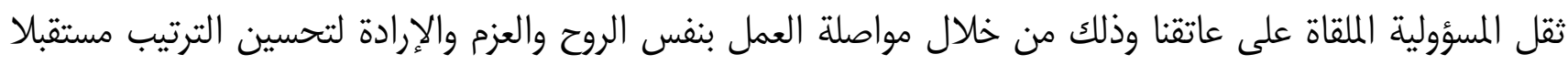

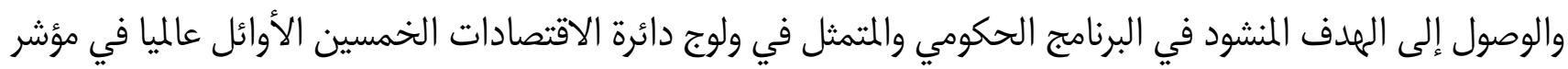




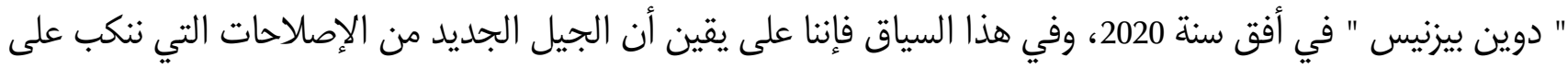

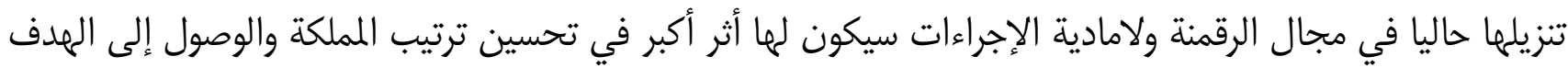

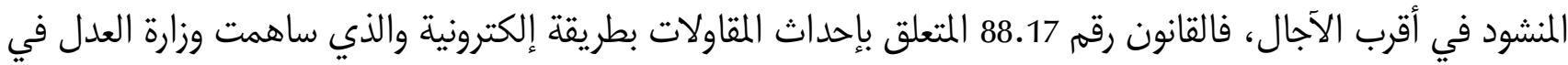

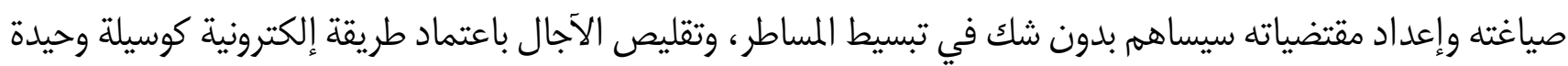

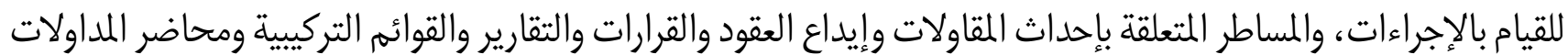
والوثائق والمقررات القضائية على المنصة الالكترونية، مع إمكانية مباشرة الإجراءات القانونية من خلال المنصة إما عبر المراكز

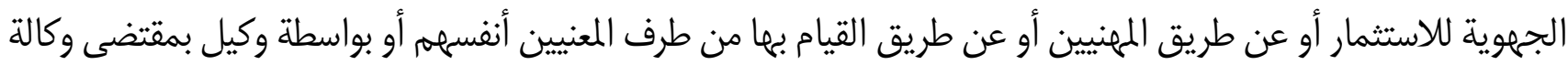
خاصة.

وبمقتضى هذا المشروع الذي أنجز بتشاور كافة الأطراف المعنية فإن الاختصاصات المخولة للمحاكم في مجال السجل

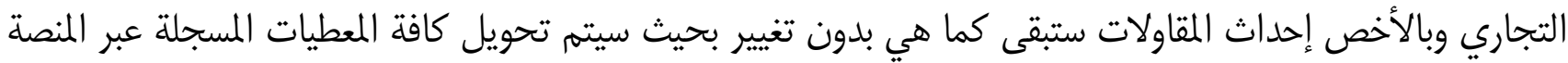

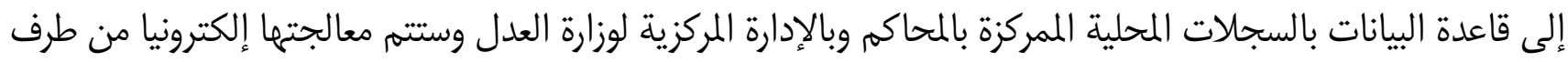

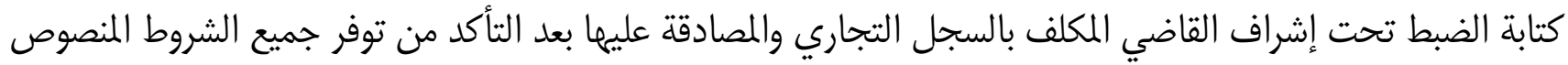

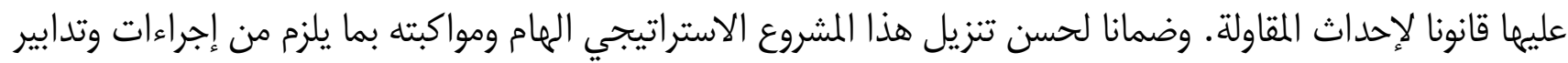

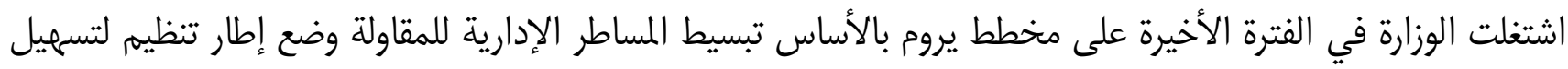

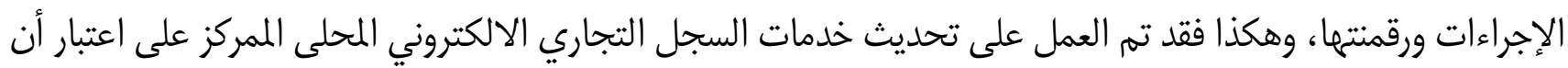

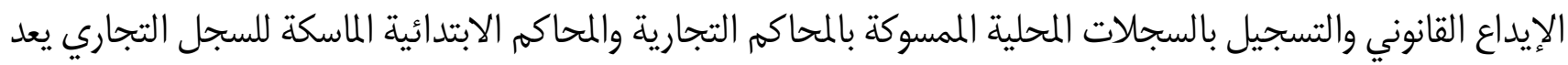

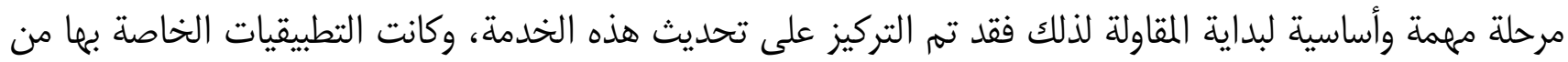

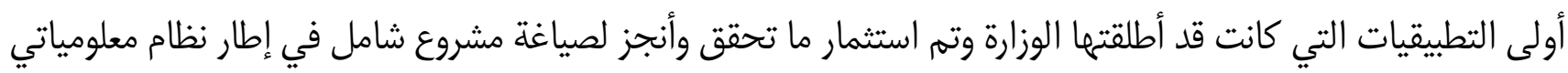
مندمج وممركز يعد أرضية للتواصل مع مشروع منصة تأسيس المقاولات الرقمية وهكذا فقد تم:

تنزيل وتعميم نسخة متقدمة من البرنامج المعلومياتي لتدبير السجل التجارية على مستوى جميع المحاكم التجارية

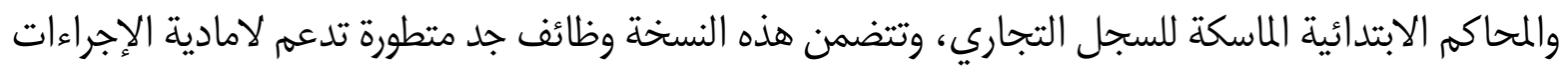

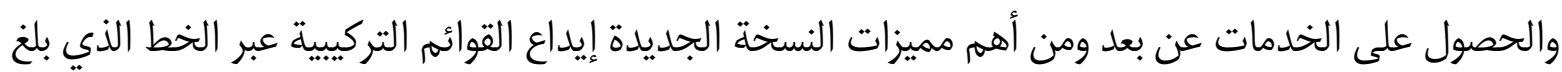
15600 خمسة عشر آلف وستة مائة إيداع قانوني؛ على تحديث هذه الخدمة، وكانت التطبيقيات الخاصة بها من أولى التطبيقيات التي كانت قد أطلقتها الوزارة وتم

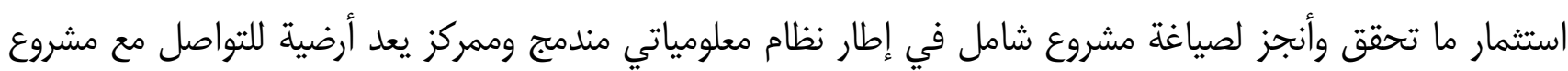

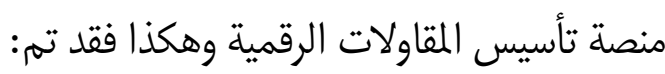

تنزيل وتعميم نسخة متقدمة من البرنامج المعلومياتي لتديير السجل التجارية على مستوى جميع المحاكم التجارية

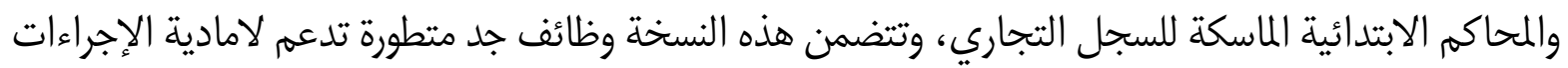

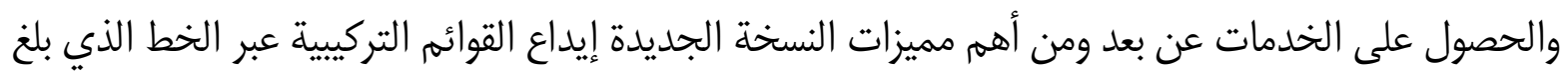
15600 خمسة عشر آلف وستة مائة إيداع قانوني؛ 


\section{أداء الرسوم إلكترونيا؛}

الربط الالكتروني مع نص تأسيس المقاولات عبر الخط؛

تغطية جميع التقييدات اللاحقة والتشطيبات والعقود الخاضعة للإشهار بالسجل التجاري؛

تدبير إجراءات الحصول على مستخرج السجل التجاري والموقع إلكترونيا وباقي الشواهد الأخرى المرتبطة بالسجل التجاري التي أصبحت تدخل إلى الراغبين فيها عبر بريد إلكتروني لا تتجاوز الساعة في أوقات العمل العادية وذلك في أفق أن يتهم بطريقة أوتوماتيكية دون تدخل بشري؛ إصى

الربط الالكتروني المؤمن مع مختلف الأجهزة في عملية التقييد في السجل التجاري، فقد بلغ مجموع شواهد السجل التجاري عبر الخط إلى اليوم 6700 طلب.

ومن بين الإجراءات الأخرى التي ستدعم مناخ الأعمال والتي تندرج ضمن مجال تبسيط الإجراءات لفائدة المقاولة المغربية يتم العمل حاليا على إحداث سجل وطني للرهون ودعم شفافية تدبير مساطر البيوعات بالمحاكم ومشروع اعتماد

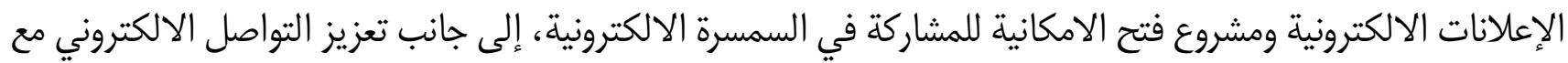
المرنيين خاصة مع الموثقين من خلال تبادل المعطيات القانونية فيما يتعلق بالولوج الالكتروني للسجل التجاري من قبل الموثقين والخبراء المحاسبتين وهذه كلما مشاريع قيد الدرس الآن.

حضرات السيدات والسادة يعد القضاء ركنا أساسيا لإنجاح أس مخطط إصلاحي وعنصرا محوريا في مخططات التنمية الاقتصادية التي نتشدها وبها تتحقق الطمأنينة التي يقوم عليها أمن المجتمع، ولا يمكن الحديث عن الاستثمار دون أن يكون القضاء مستقل ونزيه الضامن لاستمراره فالمستثمر حذر بطبعه لا يجازف في بيئة لا توفر له الأمن القانوني والقضائي وتضمن له سيادة القانون في كافة الأحوال ولاسيما أمام التعقيدات التي تشهرها المعاملات المالية والتجارية بفعل العولمة والتطورات وهو ما يقتضي منا جميعا العمل يدا في يد من أجل توفير قضاء متخصص وعلى قدر كبير من الكفاءة المرنية والخبرة الميدانية والمعرفة الأكاديمية وتهيء الوسائل والظروف الكفيلة لتحقيق عدالة سريعة تراعي متطلبات العصر وتستجيب لشروط المحاكمة العادلة.

ومما لاشك فيه أن تجربة القضاء الإداري المتخصص التي دخلها المغرب منذ سنة 1998 قد أبانت عن نضج كبير ونجاعة مهنية عالية وكفاءة كبيرة في تدبير المنازعات المرتبطة بمجال الأعمال والمال، كما إن إسمامات المحاكم المغربية بمختلف لمابل أصنافها ودرجاتها بالمجهود المبذول لعم الاستثمار والمقاولات قد أضحت ظاهرة للعيان وذلك من خلال الاجتهادات القضائية المتميزة المتواترة سواء تلك الصادرة عن المحاكمة المتعلقة بنزاعات الشغل والمنازعات العقارية أو تلك الصادرة عن المحاكم التجارية المرتبطة بالمعاملات التجارية وفي مجالات الملكية الصناعية والعقود التجارية والنقل البحري وصعوبات المقاولة أو تلك الصادرة عن المحاكم الإدارية في النزاعات التي تكون فيها الدولة أو مؤسساتها طرفا في المنازعة الضريبية أو المنازعات المتعلقة بالصفقات العمومية أو بقانون التعمير إلى غير ذلك من أشكال الخصومة. وهو ما يؤكد بدون شك أن القضاء أصبح فاعلا محوريا في منظومة الاستثمار ودوره لا يقل أهمية عن دور الجهات الأخرى المسؤولة عن هذا الملف إن له يكن أكبر من كل هذه الأدوار. 
تحديث هذه الخدمة، وكانت التطبيقيات الخاصة بها من أولى التطبيقيات التي كانت قد أطلقتها الوزارة وتم استثمار

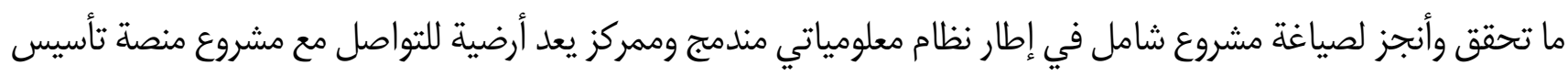

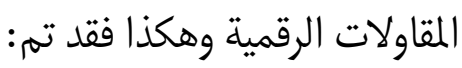

تنزيل وتعميم نسخة متقدمة من البرنامج المعلومياتي لتدبير السجل التجارية على مستوى جميع المحاكم التجارية

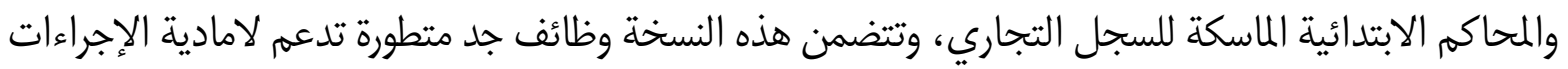

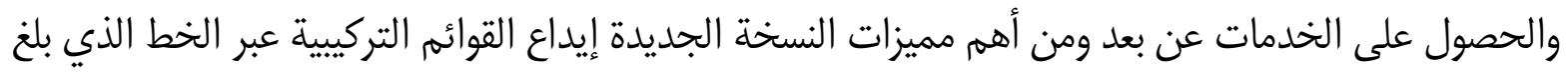

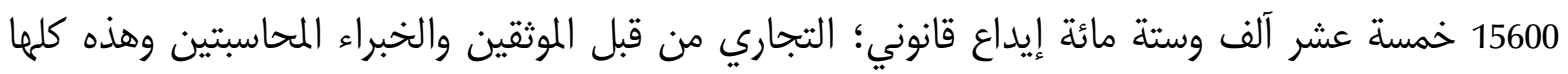

$$
\text { مشاريع قيد الدرس الآن. }
$$

إنني لأغتنم هذه المناسبة لأوجه أسمى عبارات الشكر والتقدير لقضاتنا الأجلاء بمختلف محاكم المملكة وإلى السيد

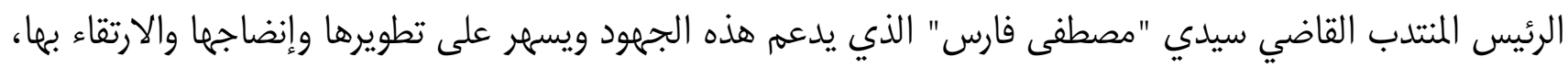

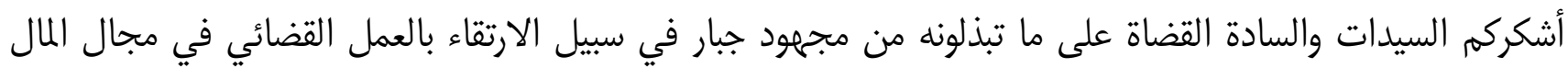

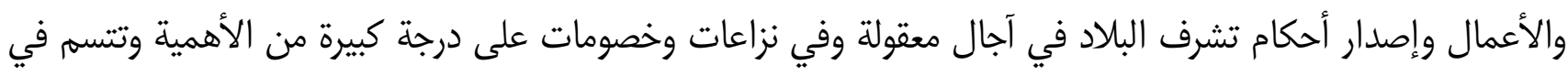
كثير من الحالات بالتعقيد والصعوبة وتتقاطع كلما بمصالح شتى.

ختاما أجدد لكم جميعا شكري الخاص وشكر أطر وزارة العدل على حضوركم وتشريفكم لنا في هذه الندوة العلمية

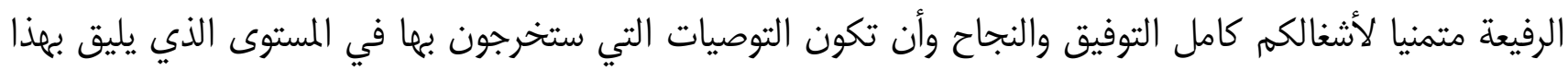

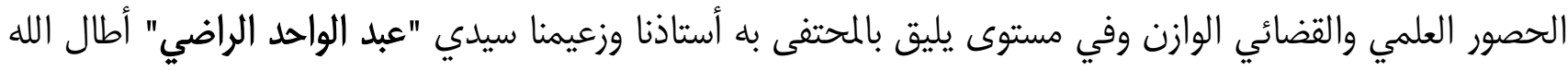

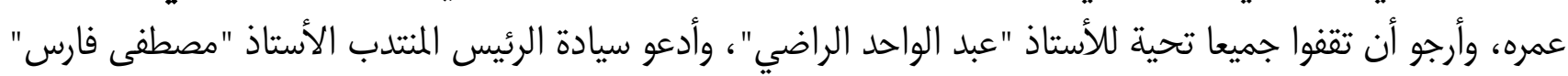
لإلقاء الكلمة.

\section{• ملخص لكلمة السيد الرئيس المنتدب لدى المجلس الأعلى للسلطة القضائية "مصطفى فارس"}

بسم الله الرحمان الرحيم والصلاة والسلام على سيد المرسلين وعلى آله وصحبه أجمعين، الحضور الكريم كل باسمه

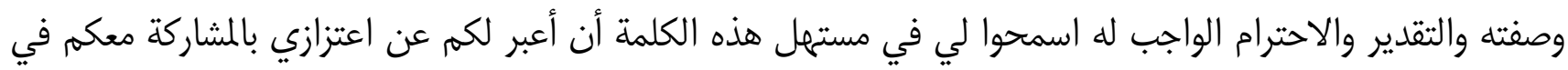

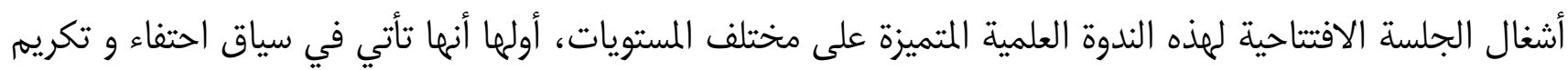

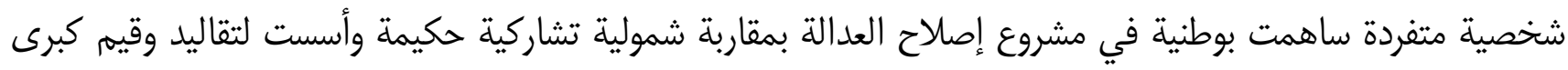

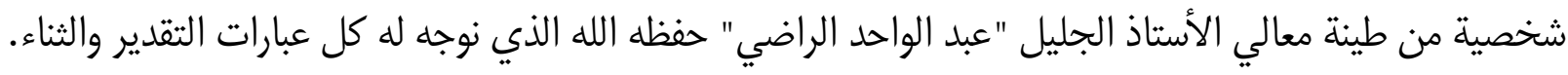
كما أن هذه الندوة تتناول موضوعا ذي راهنية كبرى يحمل مضامين دستورية واقتصادية واجتماعية مختلفة ويكتسي

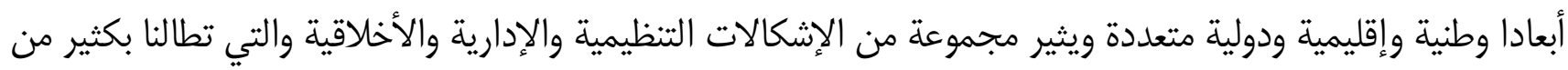
الحكمة والجرأة والمواطنة. 
اسمحو لي أن أغتنم هذه المناسبة أن أنوه بكل من ساهم بهذه المبادرة القيمة التي تبرز أهمية الانفتاح على كافة

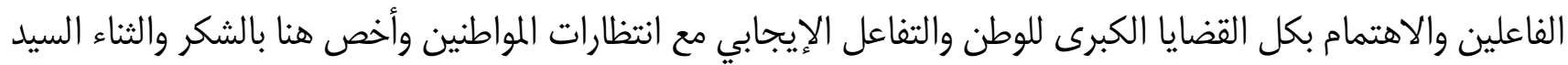

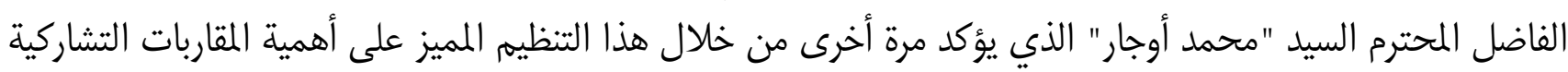

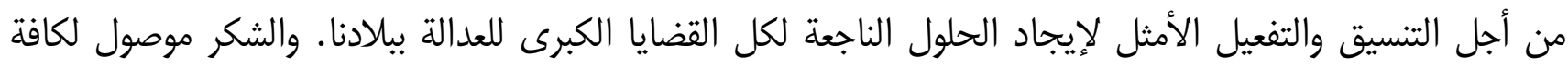

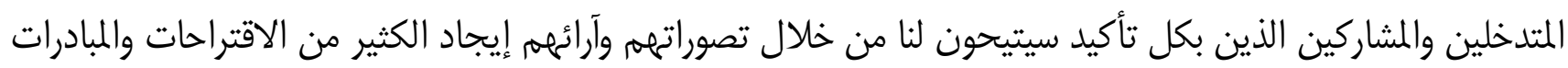

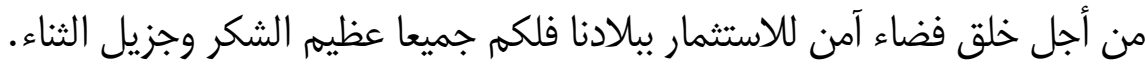

الحضور الكريم لا يخفى على كريم عنايتكم أن السلطة القضائية ملزمة دستوريا وقانونيا وأخلاقيا بحماية الحقوق

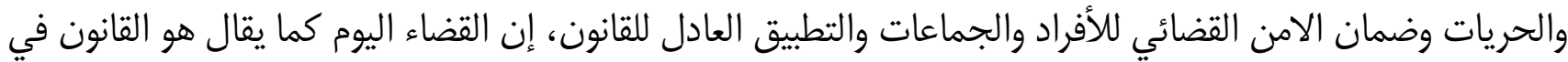

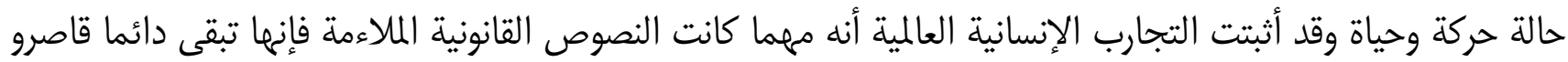

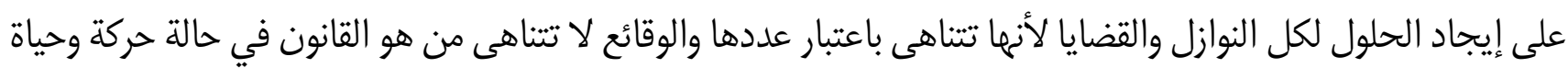

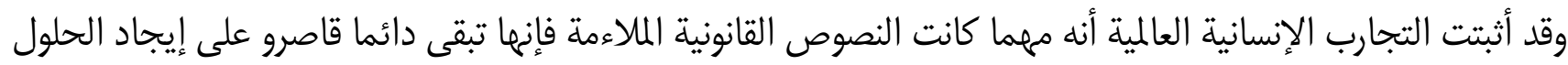

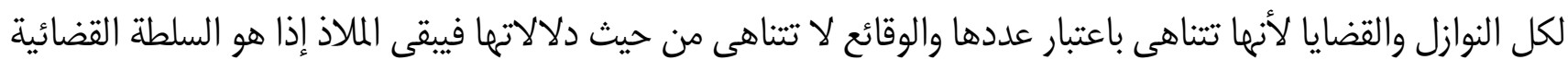

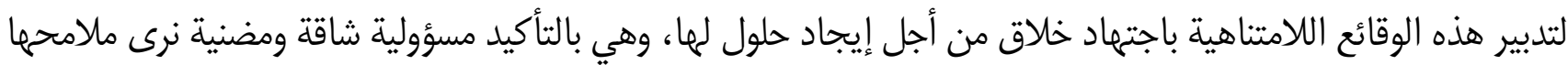

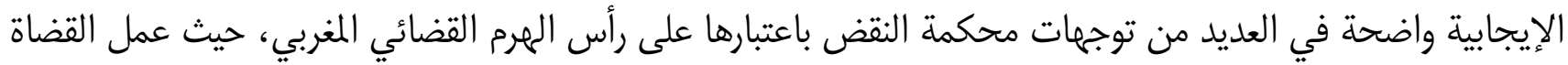

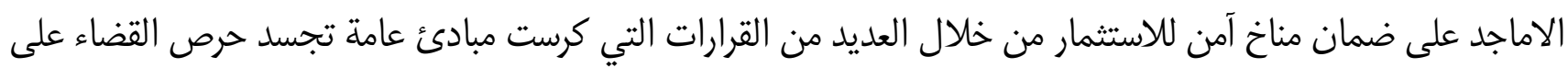
إيجاد التوازن وضبط العلاقات التجارية وتخويلها المرونة والشفافية والفعالية اللازمة وأذكر منها :

$$
\begin{aligned}
& \text { الحرص على عدم تبديد أموال الشركاء؛ } \\
& \text { إقرار حماية الدائن المرتهن؛ - (إك } \\
& \text { ضمان سلامة ومرونة الإجراءات المسطرية في مجال الأعمال؛ } \\
& \text { تشجيع الوسائل البديلة لحل المنازعات؛ }
\end{aligned}
$$$$
\text { السمر على احترام الأنظمة الداخلية للمقاولات؛ }
$$$$
\text { إعمال الاتفاقيات الدولية المتعلقة بحقوق الأجراء؛ }
$$

ضمان عدالة ضريبية من خلال تكريس المسطرة التواجهية عند فرض وتصحيح الضرائب؛ تخليق مجال التوثيق وتطويره وغيرها من المبادئ والقرارات المبدئية المنشورة بمختلف الإصدارات والكتب

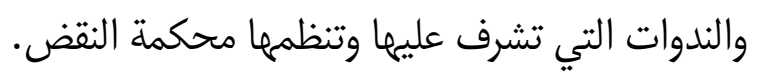

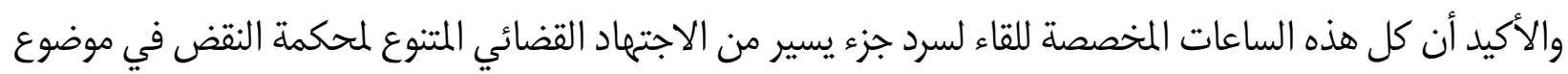

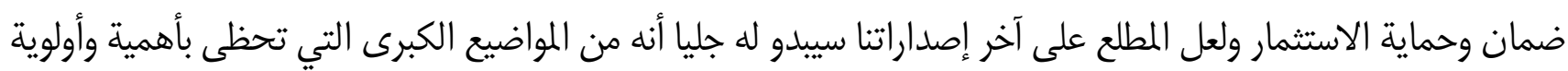




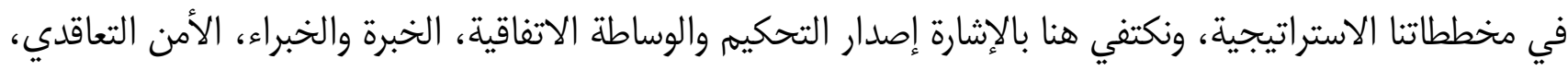

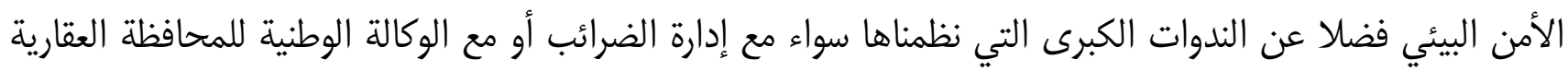

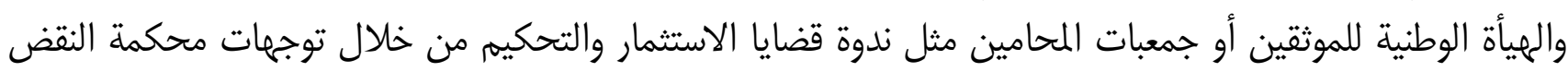

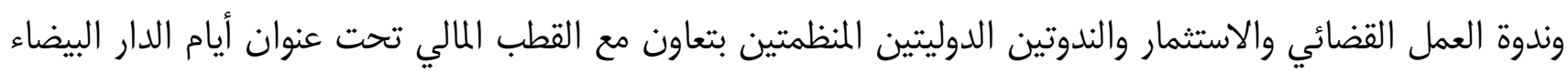

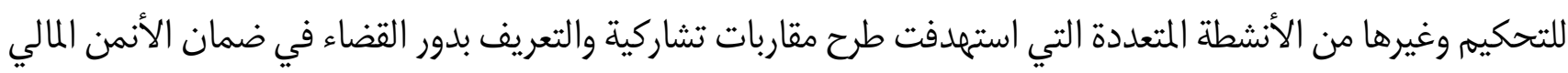
وتكريس الثقة الاستثمارية.

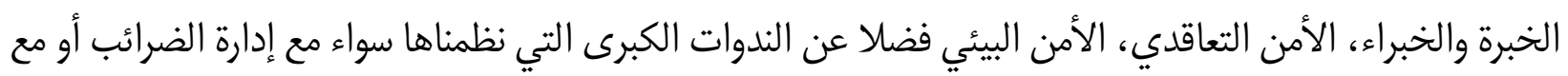

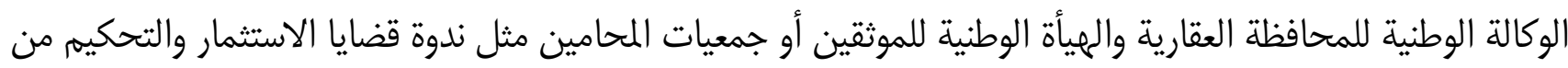

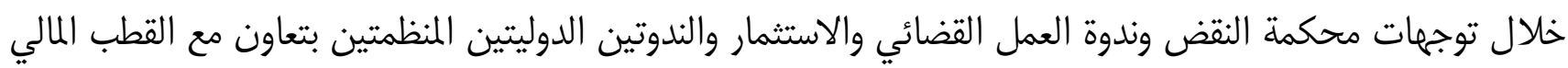

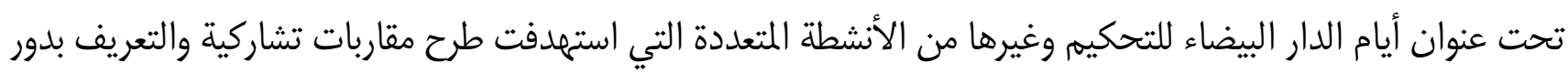
القضاء في ضمان الأمن المالي وتكريس الثقة الاستثمارية.

إنه من الصعب حصر وتفصيل كل ما نقوم به على مستوى محكمة النقض والسلطة القضائية في هذا الحيز الزمني الضيق لكن يمكن الاطالع على كل ما رصدناه من أجل التعريف بهذه الأخيرة الغنية التي نعمل جادئ مادين على تطولى تطويرها وإغنائها.

وأغتنم هذه المناسبة لأدعو الجميع كل من موقعل إلى اقتراح تدابير عملية تساهم معنا في نشر المعلومة القانونية

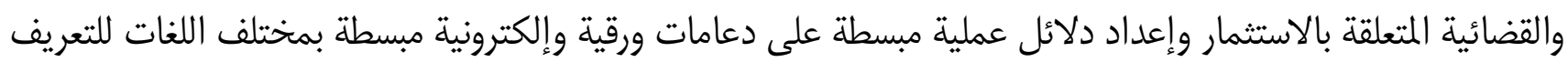
بهذا الرأس المال اللامادي واستثماره بكل مواطنة ووطنية

الحضور الكريم إن اهتمامنا بجودة الاحكام والقرارات القضائية على مستوى محكمة النقض واكبه عمل جاد من أجل

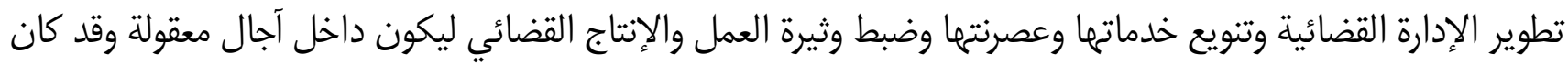

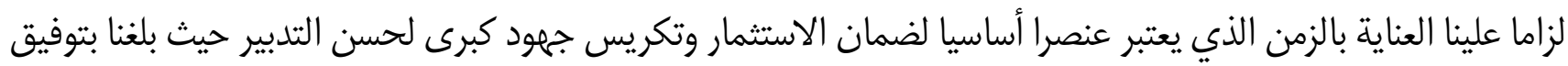

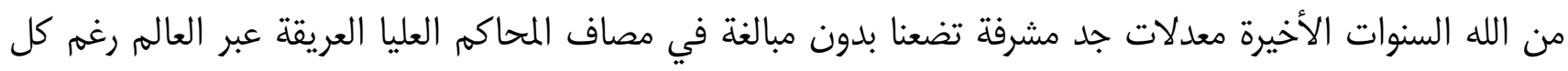

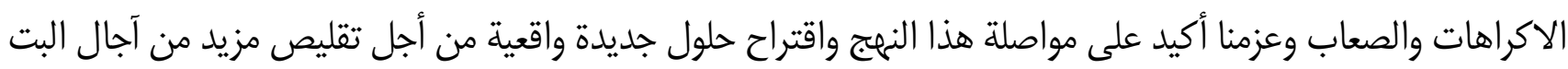

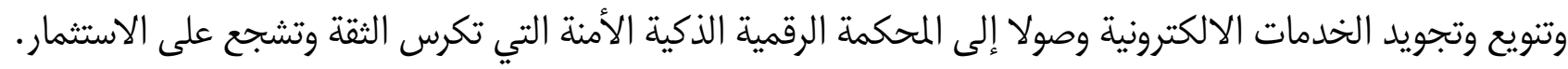
الحضور الكريم لقد وجه صاحب الجلالة نصره الله وأيده رسالة سامية بمناسبة أشغال المنتدى البرلماني الدولي الثالث

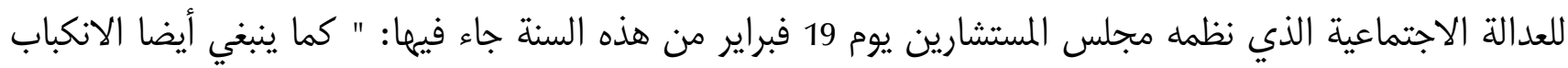

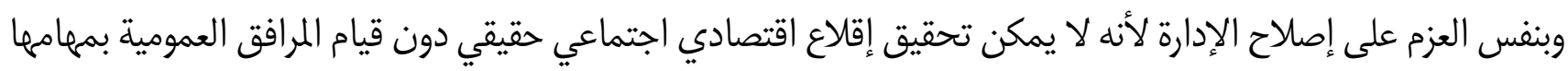

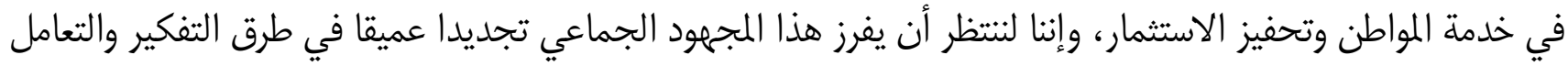

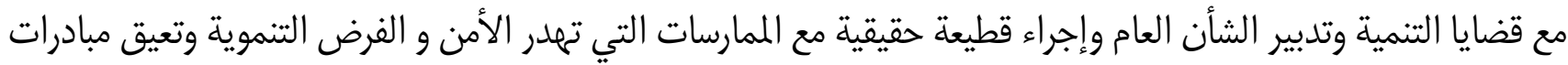
الإصلاح وتكبل روح الابداع والتفكير." 
الثالث للعدالة الاجتماعية الذي نظمه مجلس المستشارين يوم 19 فبراير من هذه السنة جاء فيها: " كما ينبغي أيضا

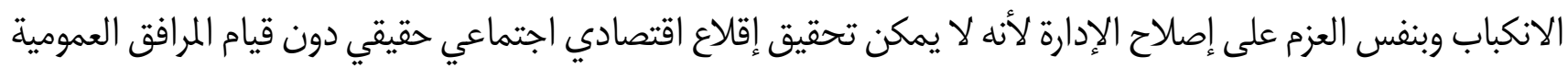

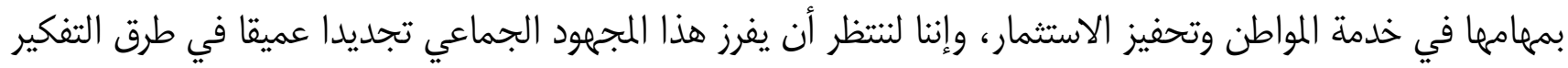

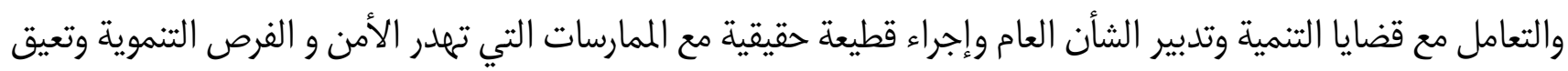
مبادرات الإصلاح وتكبل روح الابداع والتفكير. "

إننا إذن أمام خارطة طريق واضحة الرؤية والآليات حول كيفية تدبير قضايا الشأن العام حيث يجب تجاوز مرحلة

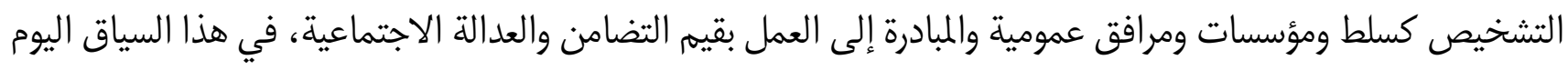

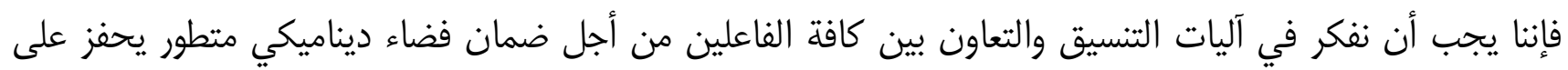

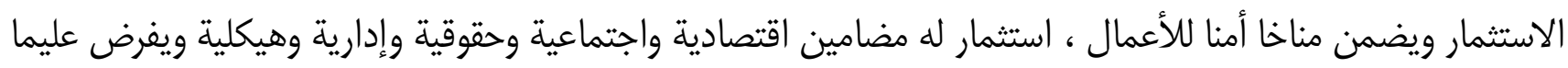

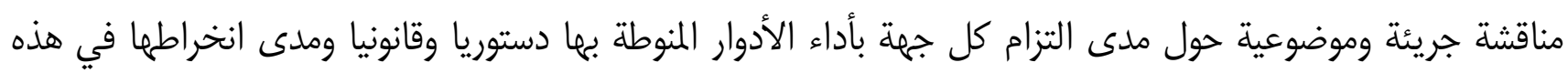

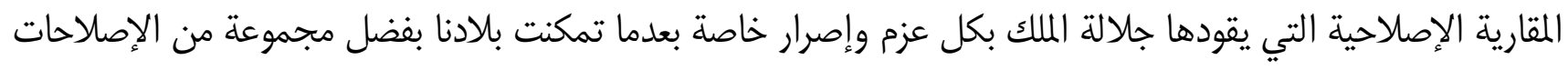

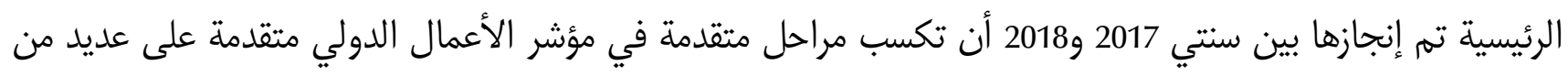
الدول والتجارب العالمية.

واليوم نحن أمام التزام بالمسؤولية والمحاسبة الذي يقتضي منا ونحن نناقش السبل الكفيلة بخلق فضاء آمن للأعمال

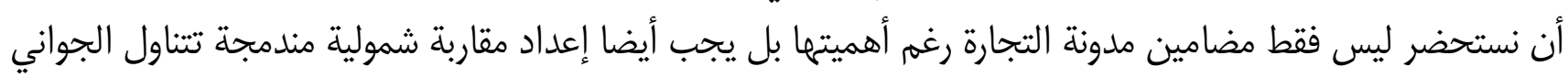

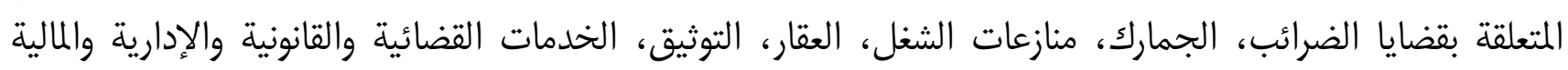

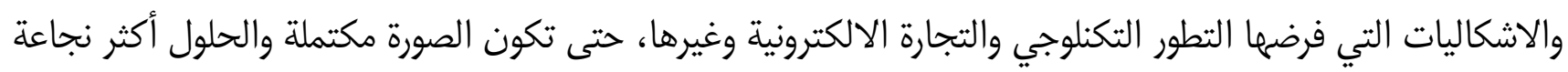

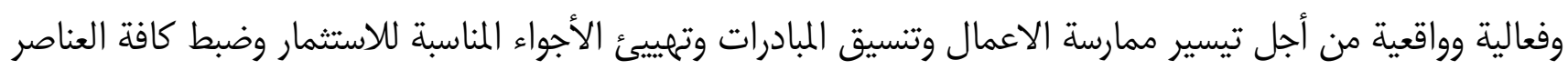

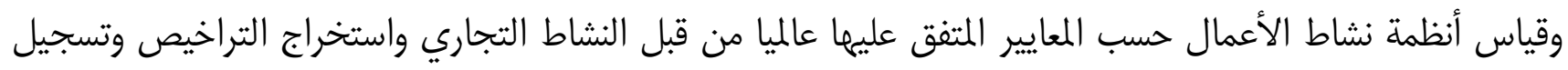

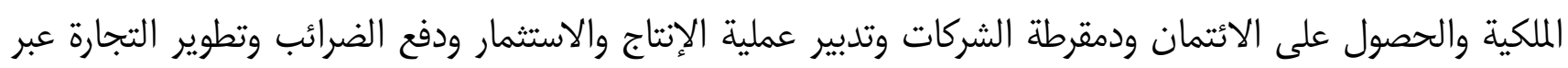
الحدود، وغيرها وهي كلها محاور يجب على الجميع الانكباب عليها بكل جدية فلانية فعالية.

الأجواء المناسبة للاستثمار وضبط كافة العناصر وقياس أنظمة نشاط الأعمال حسب المعايير المتفق عليها عالميا من قبل النشاط التجاري واستخراج التراخيص وتسجيل الملكية والحصول على الائتمان ودمقرطة الشركات وتدبير عملية الإلية الإنتاج

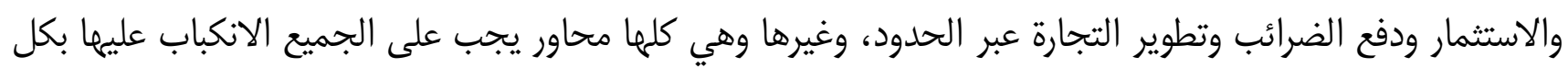
جدية فعالية.

السيدات والسادة الأفاضل، رهانات كبرى أمامنا اليوم من أجل إنجاح المشروع الإصلاحي الكبير الذي يقوده صاحب

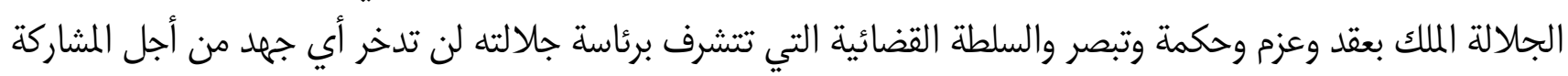

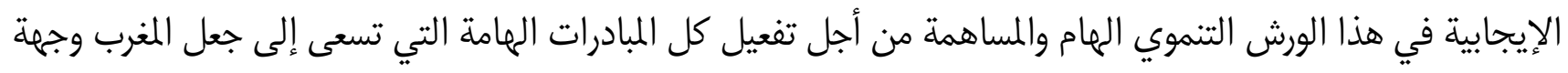

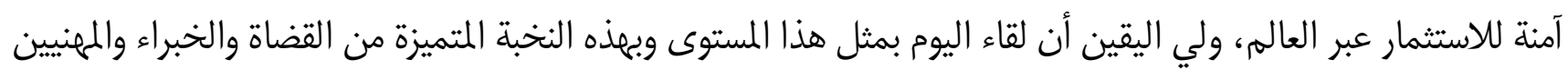


سيكون فرصة ملائمة لإعطاء مؤشرات ثقة لتأكيد وجود الإرادة الجادة من أجل الاستثمار ويكرس التنمية ويضمن حقوق الأجيال القادمة.

كل الدعاء الصادق لكم. بالتوفيق والنجاح لأشغالكم بالسداد والفلاح وشكرا لكم.

• ملخص كلمة باسم الاتحاد العام لمقاولات المغرب ونيابة عن رئيسه السيد "صلاح الدين مزوار" ألقاها السيد المستشار البرلماني ورئيس فريق الاتحاد بالغرفة الثانية

"عبد الالاه حفيظي"

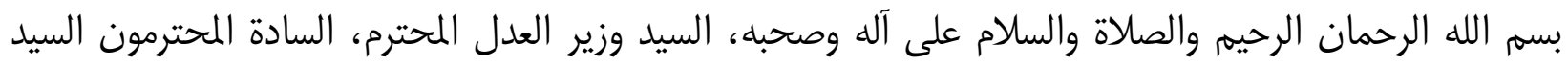

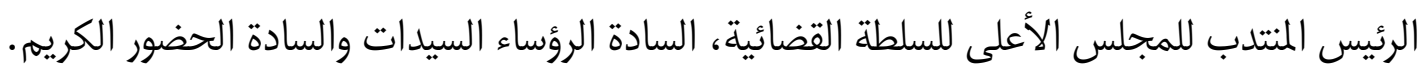

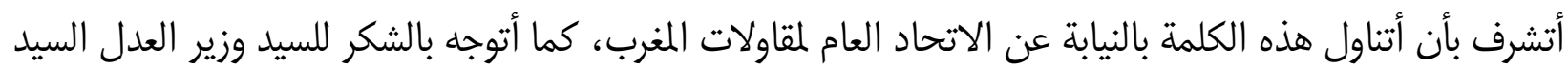

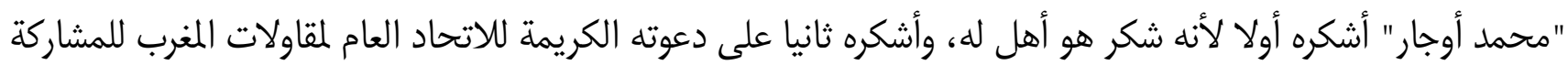

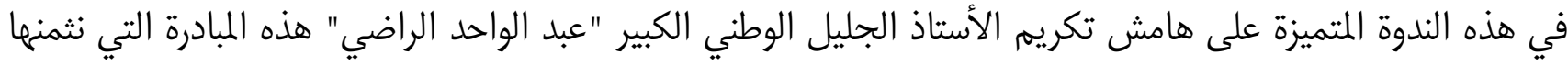

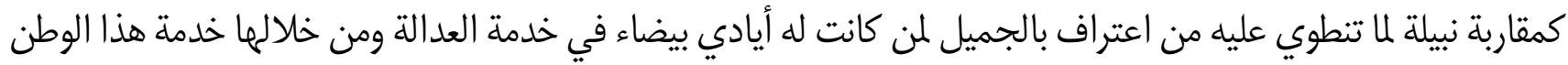

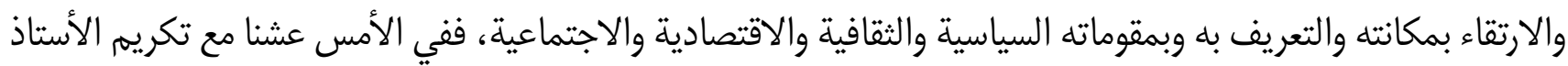

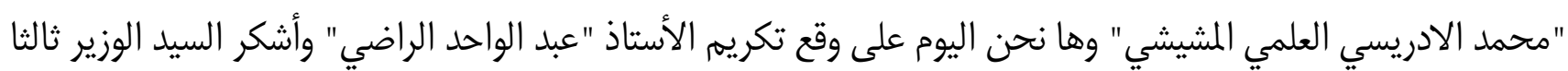

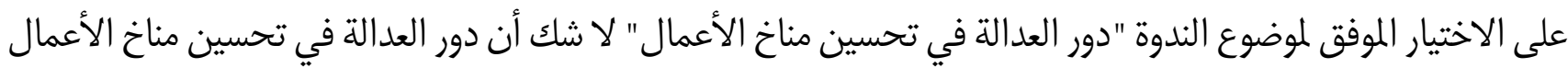

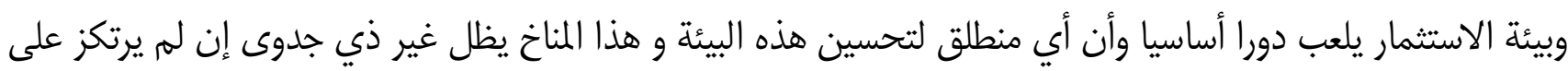
إصلاح منظومة القضاء.

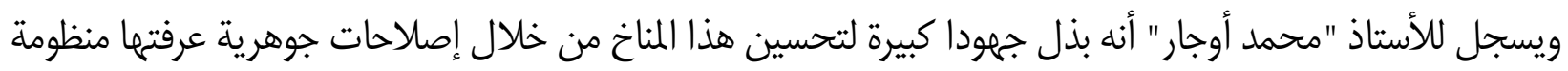

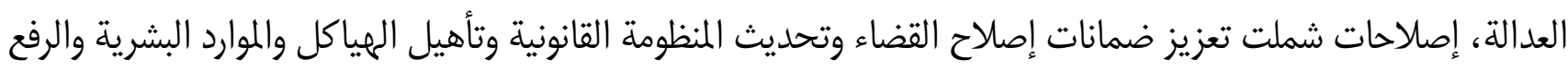

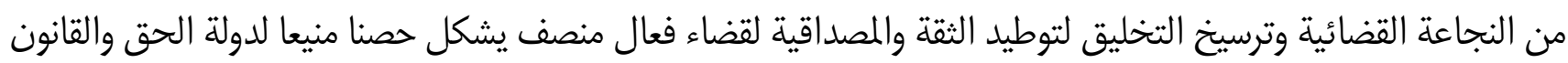

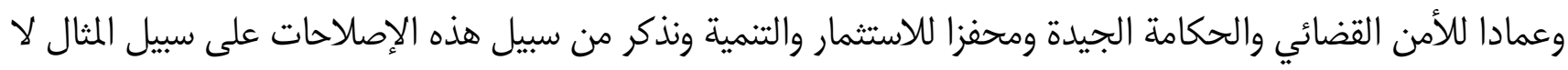
الحصر وقد ذكر بعضما الاخوان الذين سبقوني:

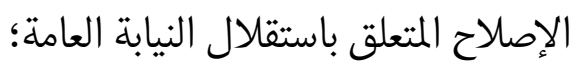

مواصلة تبسيط ورقمنة مجموعة من المساطر الإدارية ذات الصلة بحياة المقاولة؛

الإصلاح الذي شمل الكتاب الخامس المتعلق بمدونة التجارة؛

خلق المقاولات بصفة إلكترونية؛ 
وهذا لا يحجب عن أعينتا بطبيعة الحال الإصلاحات التي قام بها المجلس الأعلى للسلطة القضائية والقانون التنظيمي المتعلق بالقانون الأساسي للقضاة.

وبفضل هذه الإصلاحات التي كانت كان لها الوقع الإيجابي على تحسين مناخ الاعمال لقد تمكن المغرب من التقدم على سلم التصنيف العالمي الجديد ليصبح في الرتبة 60 من بين 190 دولة وفق تقرير السنوي لمجموعة البنك الدولي حول ممارسة الأعمال برسم سنت 2019، وأصبح المغرب كما تعلمون يحتل المرتبة الثانية على مستوى دول الشرق الأوسط وشمال إفريقيا بعد دولة الامارات العربية المتحدة والثالث على مستوى القارة الافريقية.

بصفتي نائب رئيس لجنة العدل والتشريع والحريات العامة بمجلس المستشارين أثمن بكل واقعية وصدق جهود الأستاذ "أوجار" التي تصب كلما في إطار تحسين مناخ الأعمال وتكريس المغرب وجهرة مفضلة للاستثمار وتشجيع المقاولة التي كانت ولا تزال ترى ان تحسي فرص جاذبية الاستثمار لا يتم فقط بواسطة تدابير اقتصادية ومؤسساتية بل يتم أساسا كذلك من خلال توفير مناخ قضائي ملائم لنشاطها. وبالعودة لموضوع الحفل الذي تنعقد على هامشه هذه الندوة العلمية وهو تكريم الأستاذ "عبد الواحد الراضي"، فإنني أجد صعوبة في إيجاد الكلمات التي تناسب هذا المقام وتفي بما يستحقه هذا الرجل الفذ والوطني الكبير من تقدير وثناء، لقد عرفنا السيد "عبد الواحد الراضي" وطنيا كبيرا بكل المقاييس منذ عرفناه وهو يتفانى في خذمة وطنه على أكثر من واجههة، عندما تصافحه فيه الكبرياء بدون تكبر والصرامة بلا تجبر ، مع اشتماله على خيرة من الفضائل وأسماها قادته إلى النجاح في كل مساراته الأكاديمية والسياسية والجماعية المحلية والنيابية وأمدته بطاقة خارقة للعمل والعطاء ساعدته على تجاوز الصعاب بشحنات طموح لامتناهية. إنه رجل حليم بدون ضعف، شامخ في غير تجبر ولا كبرياء، تشعر وأنت في حضوره أنك في حضور مجموعة من الرجال في رجل واحد الرجل الشاب الطالب المناضل، الرجل الجمعوي الفاضل، والرجل السياسي الفريد بمعارضته باعتدال ونصرة للحق نادرة المثال، رئيس جماعة ترابية غزير الخبرة، برلماني طويل التجربة تجربة أبراية أفاد بها وطنه داخليا كما أفاده خارجيا في عمقه الافريقي وامتداده المتوسطي وأصالته وانتمائه العربي والإسلامي. خارقة للعمل والعطاء ساعدته على تجاوز الصعاب بشحنات طموح لامتناهية. إنه رجل حليم بدون ضعف، شامخ في

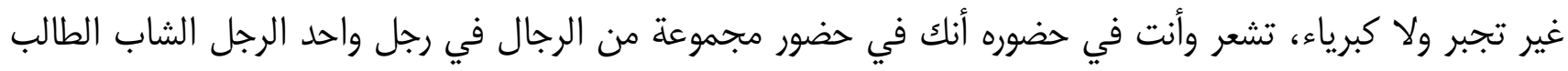
المناضل، الرجل الجمعوي الفاضل، والرجل السياسي الفريد بمعارضته باعتدال ونصرة للحق نادرة المثال، رئيس جماعة ترابية غزير الخبرة، برلماني طويل التجربة تجربة أفاد بها وطنه داخليا كما أفاده خارجيا في عمقه الافريقي وامتداده

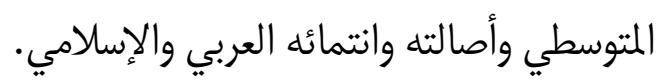

هكذا أعطى السيد "عبد الواحد الراضي" بسخاء بلدا من نشاطه وهو طالب بجامعة "السوربون" ومساهمته في تأسيس العديد من الجمعيات وتحمله المسؤولية القيادية فيها أبرزها الاتحاد الوطني لطلبة المغرب، وفيدراليته بباريس أواخر

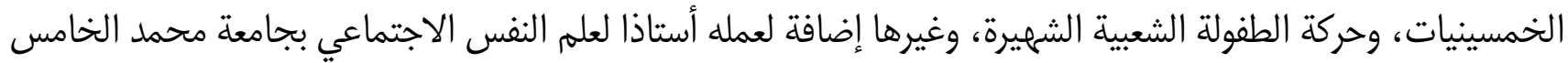
بالرباط وترأس شعبة الفلسفة وعلم النفس بكلية العلوم الإنسانية، وبهذه الصفة التربوية قد الكثير للعمل العلمي والنقابي وهو يتولى الكتابة العامة للنقابة الوطنية للتعليم العالي. 
لقد شهات مسيرة السيد "عبد الواحد الراضي" في الستينيات بداية طفرة عطاء واسع على المستوى السياسي في الماري

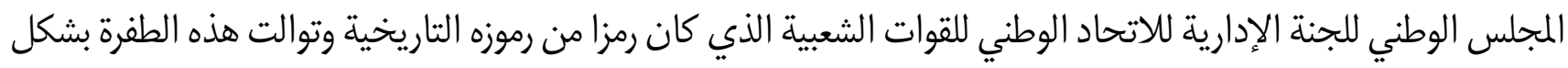

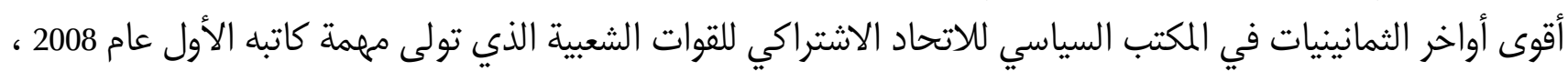

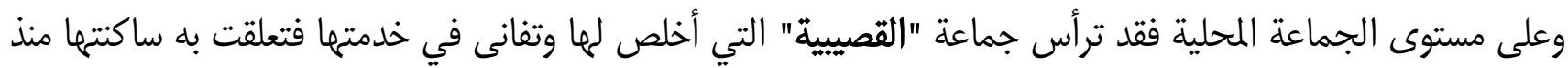
1983 كما سبق وترأس المجلس الإقليمي للقنيطرة ومجلس جهة المجاعة الغرب شراردة بني حسن. أما عطاء السيد "عبد الواحد الراضي" على المستوى البرلماني فحدث ولا حرج لدرجة أصبح معها رمزا برلمانيا بذاته وعطائه

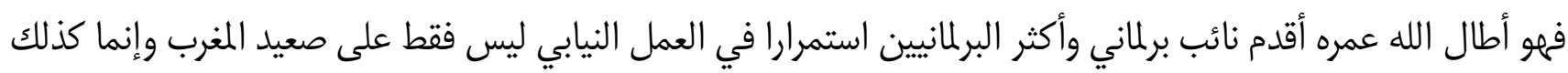

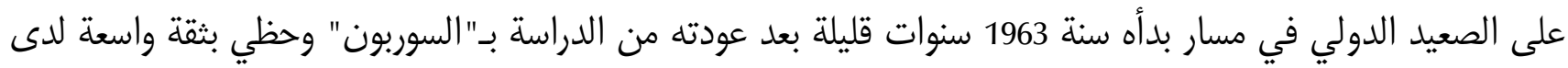

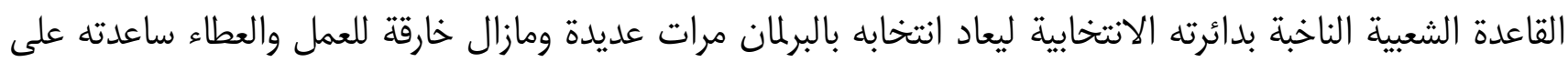

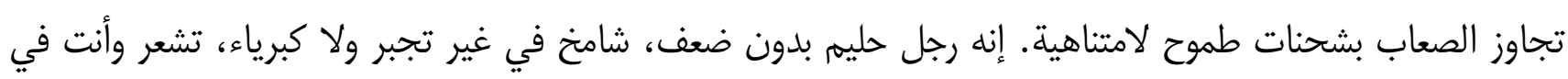

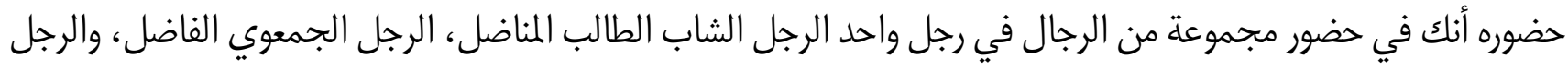

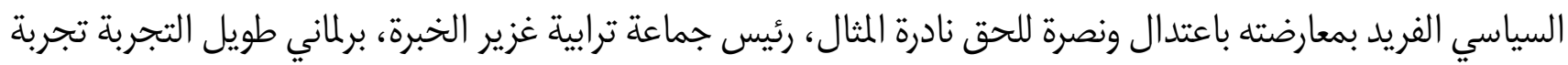
أفاد بها وطنه داخليا كما أفاده خارجيا في عمقه الافريقي وامتداده المتوسطي وأصالته وانتمائه العربي والإسلامي. بماني. يتحمل هذه المسؤولية بما آتاه الله من كفاءة وحكمة وخلال سنوات رئاسته لمجلس النواب لولايتين منذ سنة 1997 لسنة 2007 بصم على مواقف ولحظات بصرامة شديدة وجدية فريدة يذكرها له المغاربة جميعا بكل استحسان وتقدير . وعلى المستوى السياسي دائما كان السيد "عبد الواحد الراضي" أول اشتراكي معارض يعين وزيرا قبل مرحلة التناوب التب

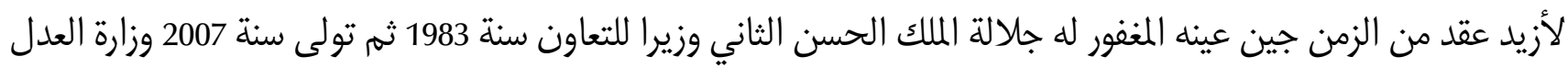

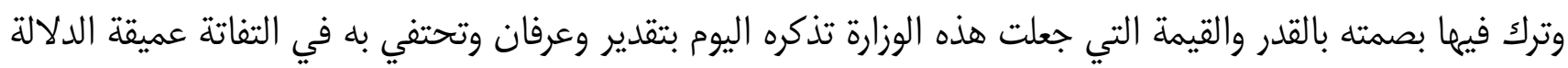
يسجلما التاريخ اليوم بفضل السيد الوزير "محمد أوجار" . وكما كان السيد عبد الواحد رائدا في خدمة وطنه داخليا من خلال ما تولى من مهام ومسؤوليات وخارجيا بنفس الصفات

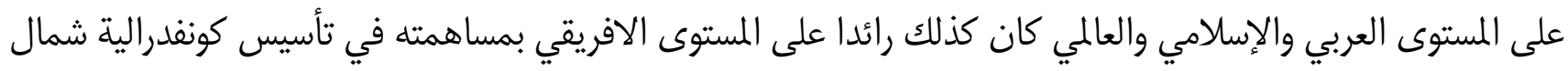

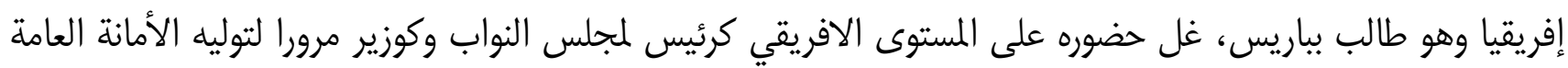
للاتحاد العربي الافريقي سنة 1984. وبنفس الروح الوطنية والإصرار نحت له ولبلاده في شخصه مكانة متميزة حين تقلد الرئاسة المشتركة لمتندى البرلمان

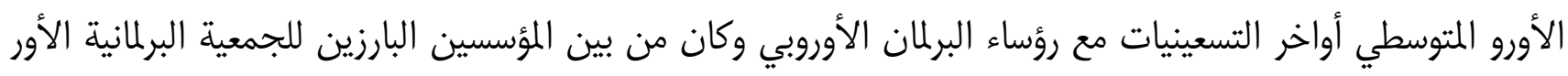
والمتوسطية.

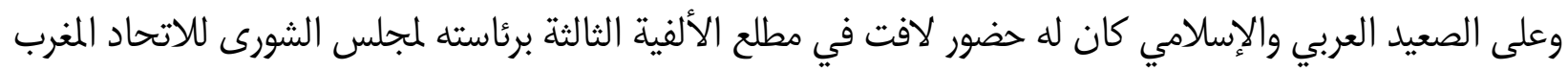

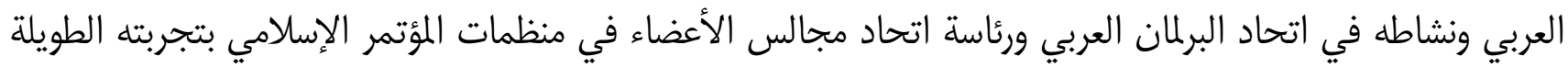

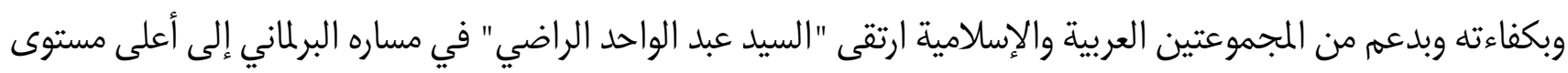




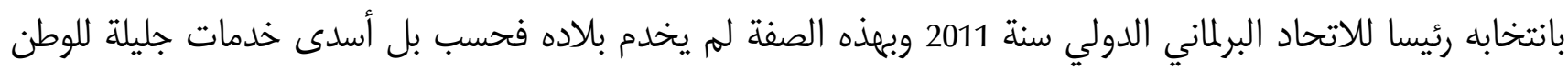

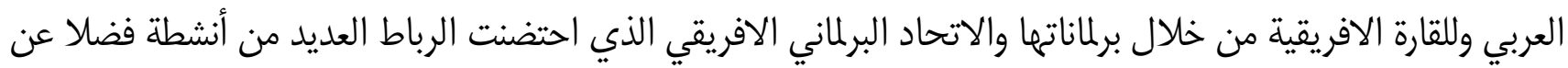

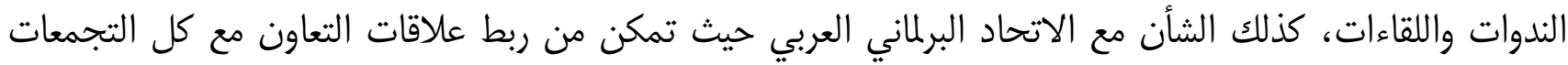

$$
\text { البرلمانية عبر العالم. }
$$

هذا هو السيد "عبد الواحد الراضي" كما عرفناه وكما عرفه المغارية والأشقاء بإفريقيا والعالمين العربي والإسلامي

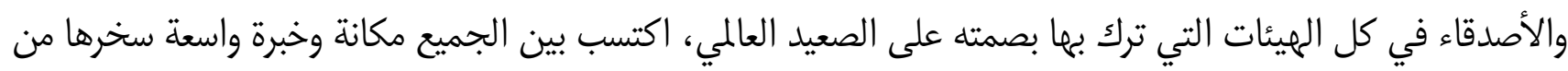

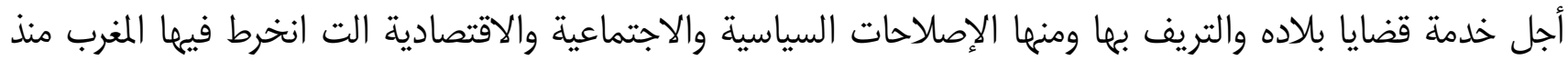

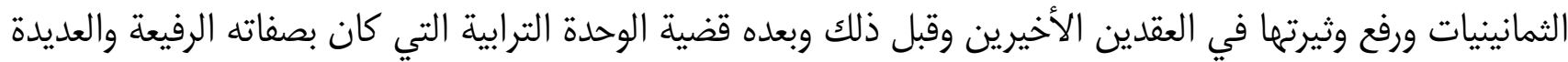

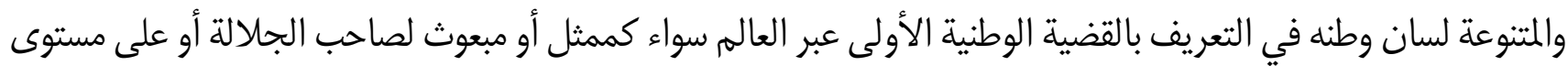

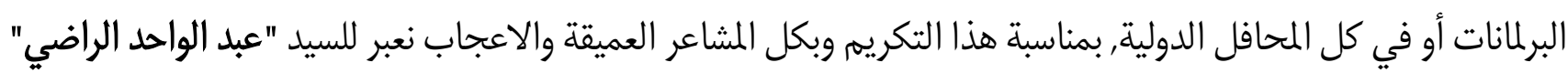

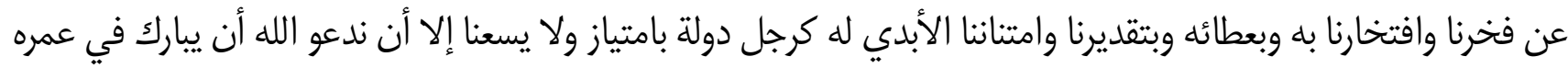

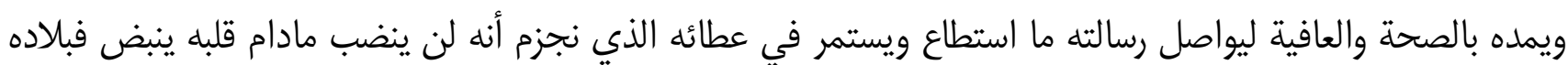

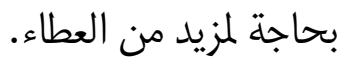

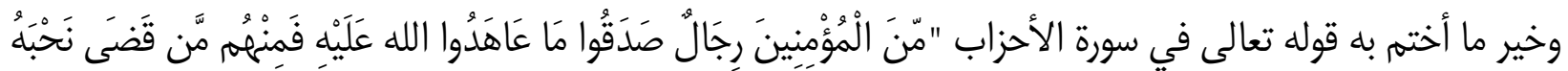

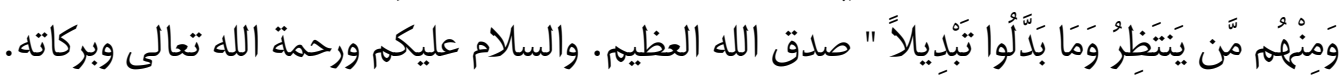

\section{• ملخص لكلمة الأستاذ المحتفس به في حفل تكريمه "عبد الواحد الراضي"}

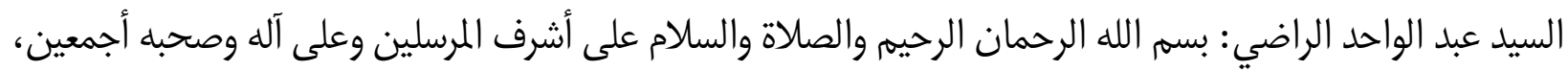

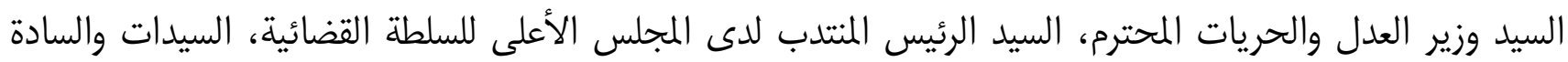

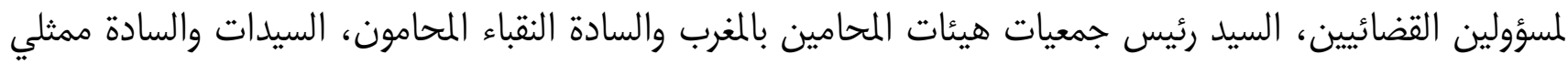
المؤسسات الوطنية والدولية، السيد نائب رئيس الاتحاد العام لمقاولات المغرب، حضرات السيدات والسات المادة كل بلات باسمه وبصفته

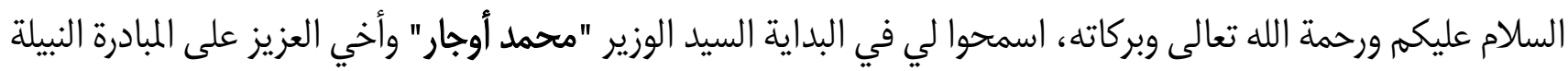

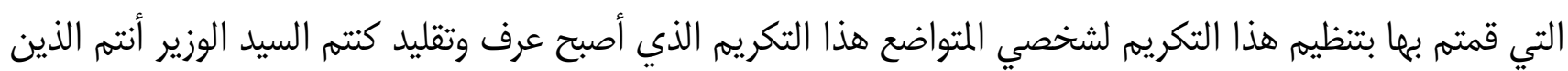
خلقتموه وأنتم الذين ترعونه.

هذا التقليد هو تكريم وزراء العدل السابقين وأريد بهذه المناسبة أخي العزيز أن أتقدم بالشكر الجزيل على تلك الكلمات

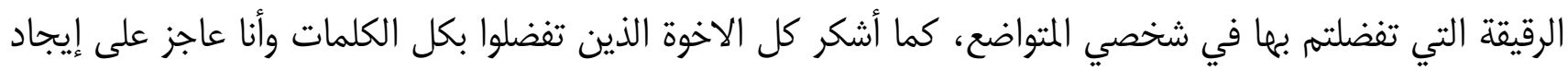

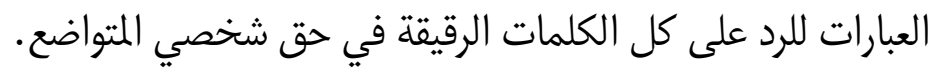

أريد كذلك أن أشكركم أنتم السيدات والسادة المدعوين على حضوركم معنا اليوم في هذه المناسبة وأعتبر حضوركم بمثابة تشريف لي، مرة أخرى شكرا لكم على حضوركم معنا. 
لقد هيئة كلمة بهذه المناسبة سأقدمها غدا ان شاء الله في الأمسية التكريمية وأريد اليوم أن أخصص كلمتي للشكر

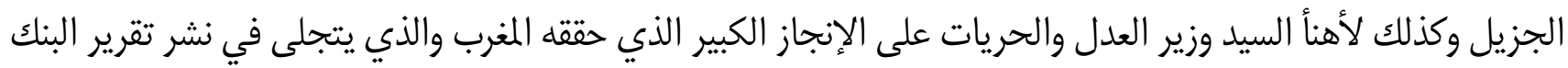

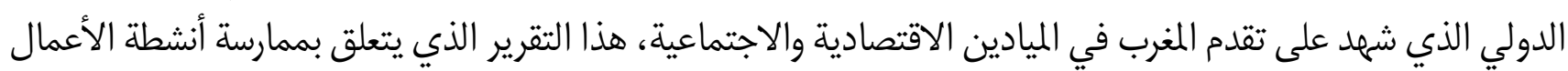

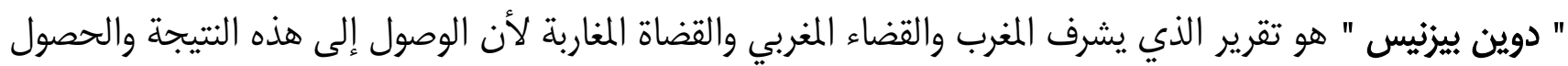

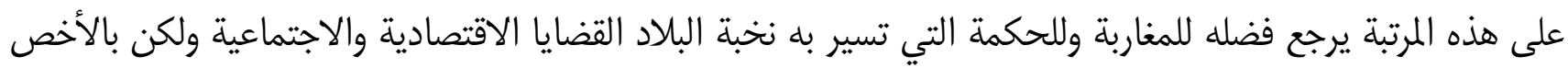

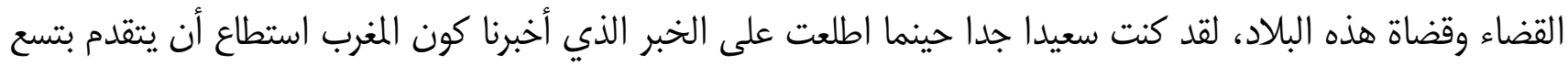
درجات في التقرير وأصبح في المرتبة 60 من بين 190 دولة.

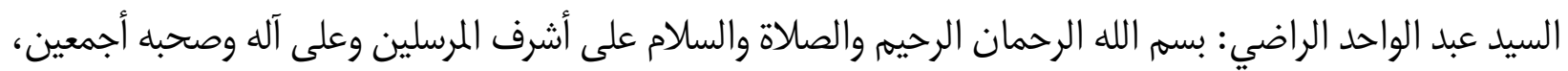

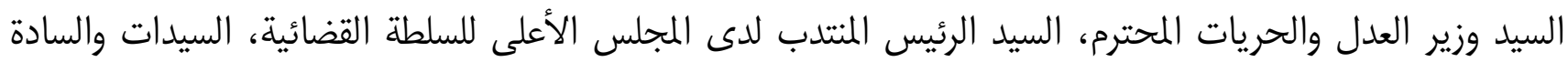

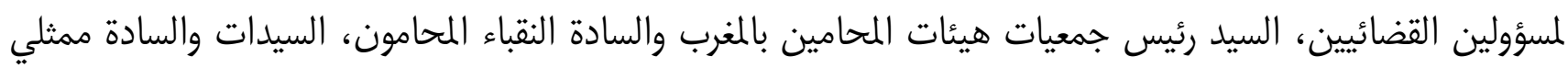

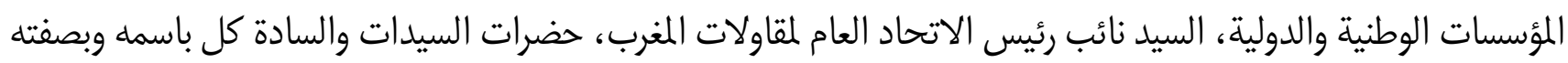

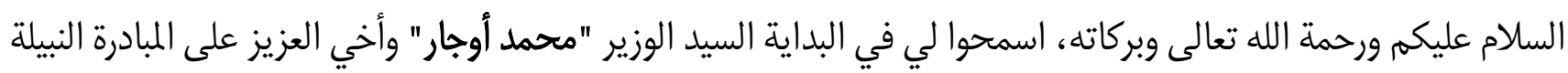

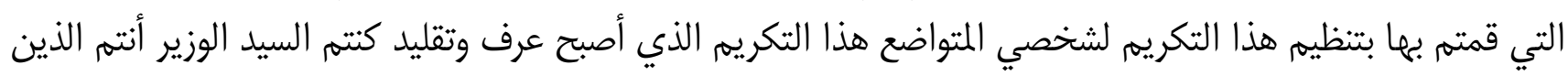
خلقتموه وأنتم الذين ترعونه.

هذا التقليد هو تكريم وزراء العدل السابقين وأريد بهذه المناسبة أخي العزيز أن أتقدم بالشكر الجزيل على تلك الكلمات

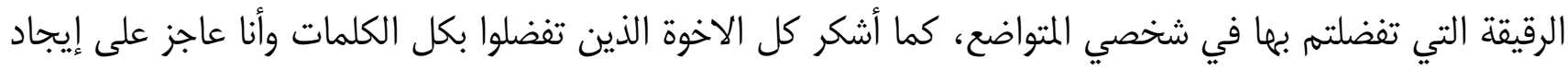

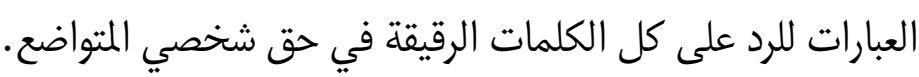
أريد كذلك أن أشكركم أنته السيدات والسادة المدعوين على حضوركم معنا اليوم في هذه المناسبة وأعتبر حضوركم بمثابة تشريف لي، مرة أخرى شكرا لكم على حضوركم معنا.

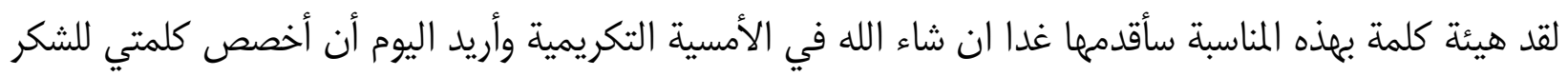

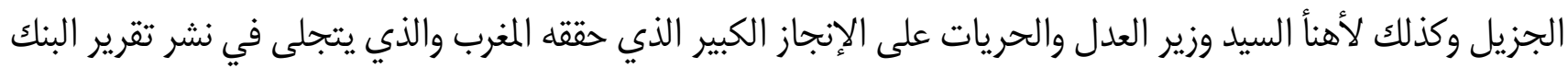

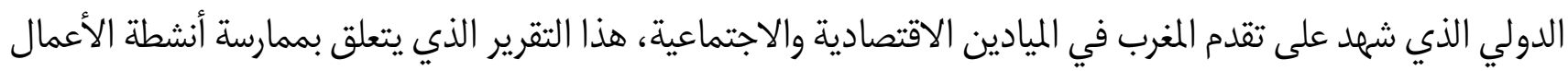

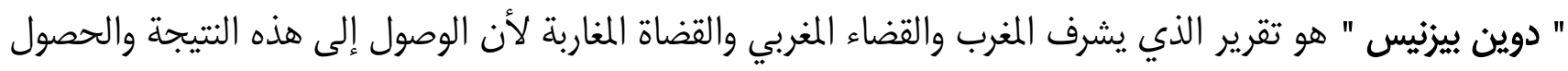

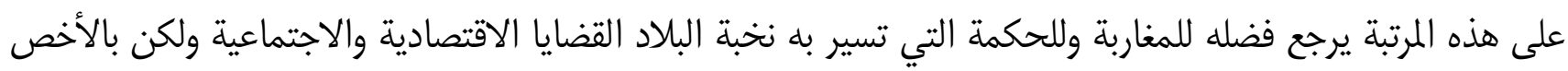

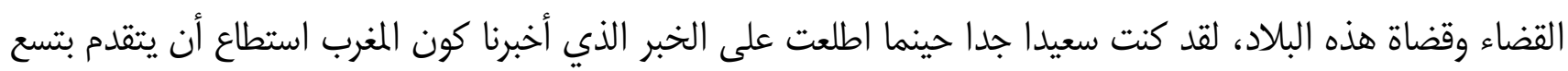

$$
\text { درجات في التقرير وأصبح في المرتبة } 60 \text { من بين } 190 \text { دولة. }
$$

الاقتصادية والاجتماعية ولكن بالأخص القضاء وقضاة هذه البلاد، لقد كنت سعيدا جدا حينما اطلعت على الخبر الذي

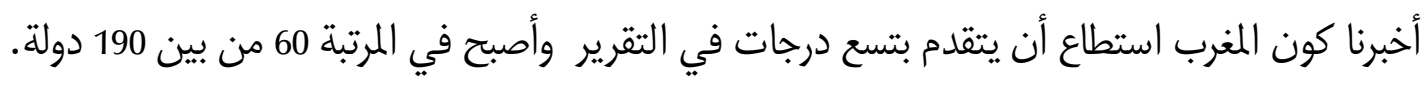


هذا الإنجاز أصبح ممكنا بفضل الجو الذي نعيشه في بلادنا بحول الله جو الاطمئنان وجو السلم الاجتماعي، جو الحمد

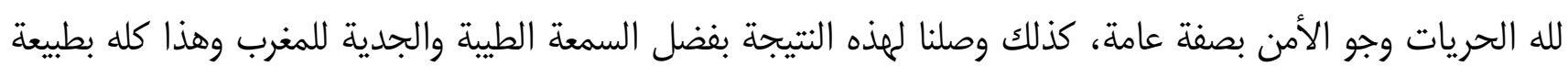

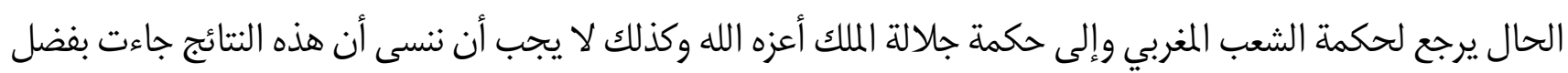

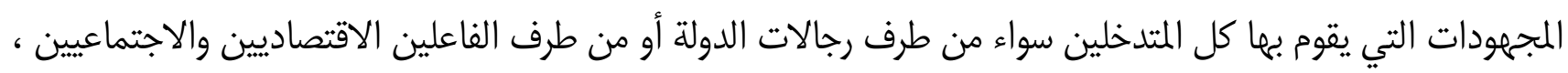

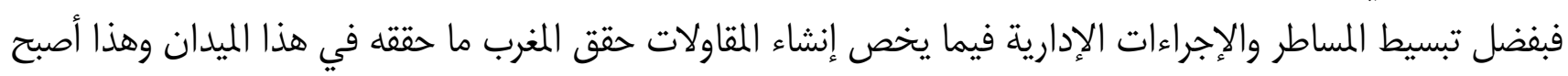

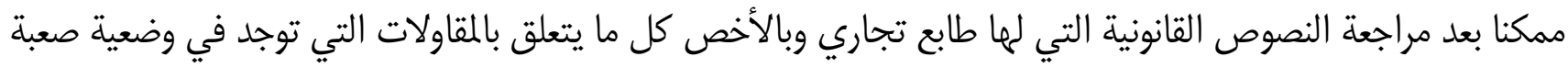

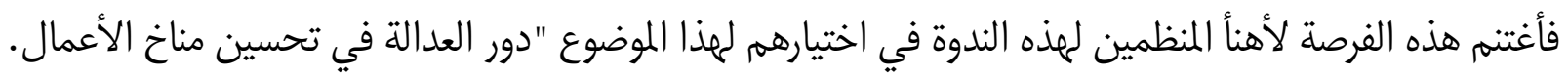
أيها السيدات والسادة دور العدالة أصبح اليوم دورا أساسيا في الميدان الاقتصادي بصفة عامة وفي ميدان المقاولات بصفة خاصة، فالكل يعلم بأن المستثمر الخارجي يأخذ بعين الاعتبار عاملين اثنين: العامل الأول: الاستقرار السياسي والاجتماعي لأي بلد وفي أي دولة. العامل الثاني: هو جودة القضاء وأحكام القضاء.

ولله الحمد هذه الشروط في بلادنا هي متوفرة فهي آمنة ومستقرة إضافة إلى أن قضائنا نزيه، وكما تعلمون أيها السيدات

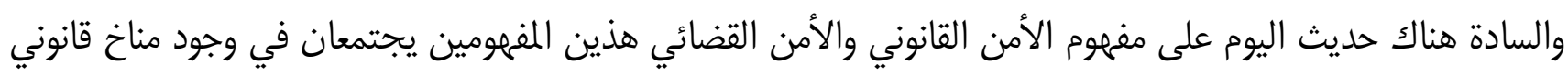
ملاءم في صالح المقاولات بصفة خاصة والاقتصاد الوطني بصفة عامة. كما أن هذين المفهومين يعنيان بالنسبة لي وجود دولة القانون، ودولة القانون معناها هي سمو القانون ودولة القانون

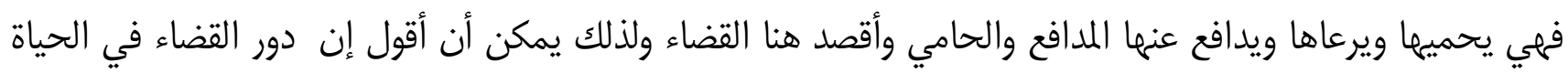

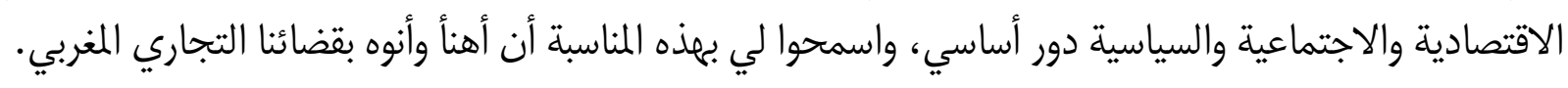
أيها السيدات والسادة أتمنى لهذه الندوة العلمية كل النجاح والتوفيق وأتمنى كذلك أن تخرج هذه الندوة بتوصيات

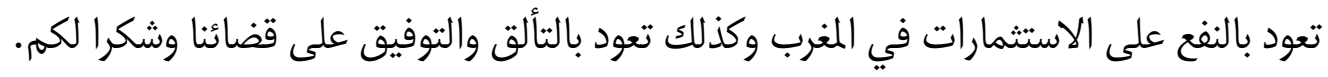




\section{محاور الندوة}

المحور الأول: دور وزارة العدل في النهوض بمناخ الأعمال

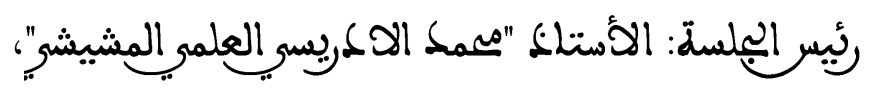

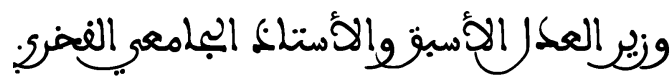

• الكلمة الافتتاحية للسيد رئيس الجلسة:

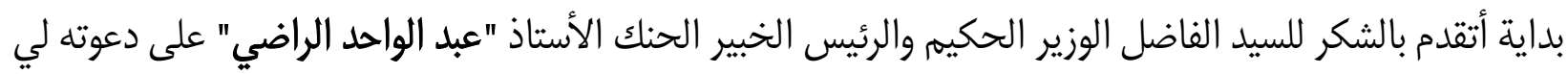

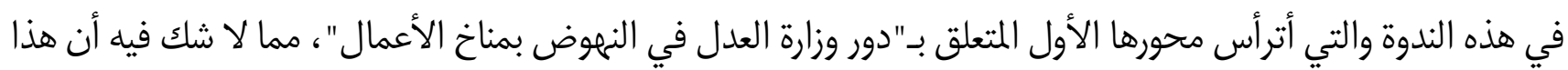

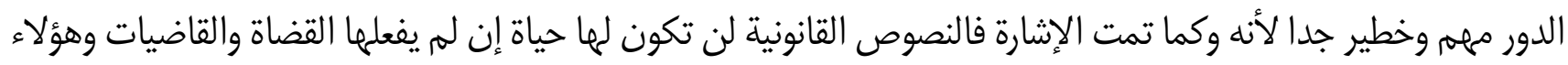

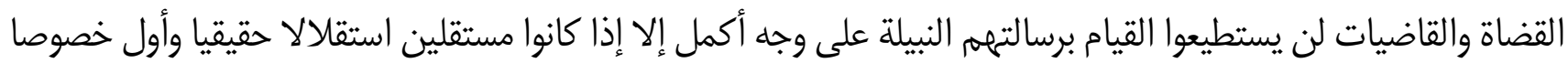
أمام الإدارة والسياسة.

ومن المؤثرات الخطيرة التي تواجه القضاء بصفة عامة في كل دول العالم نجد العلاقة بالاقتصاد، فرجال الاقتصاد

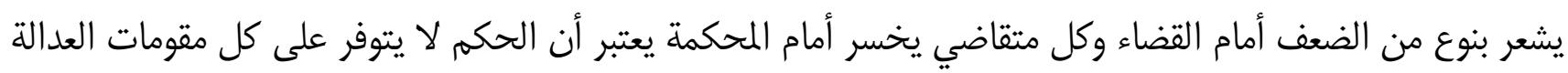

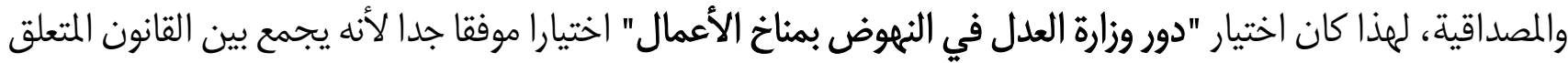

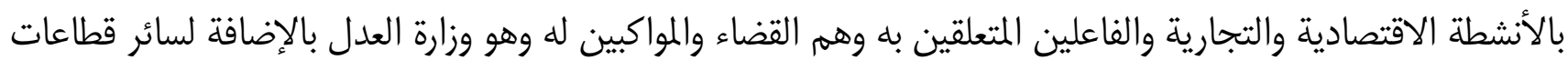
الحكومة والمؤسسات.

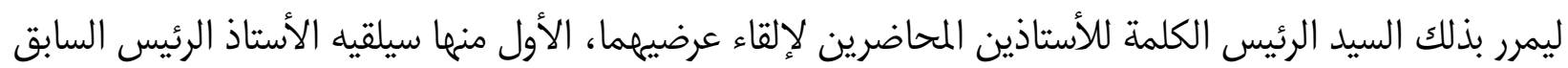

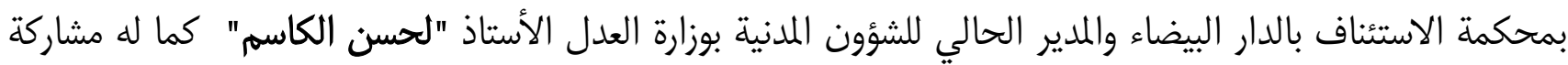

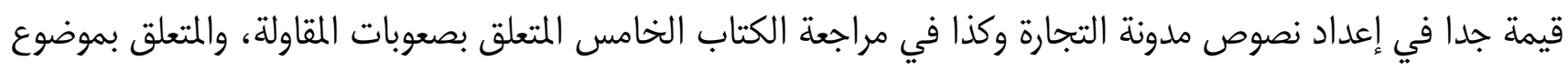

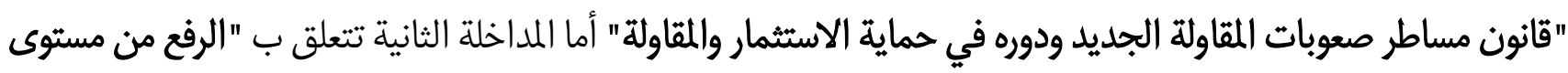

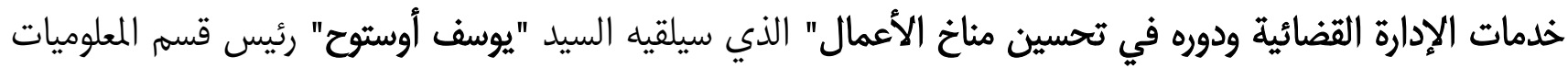

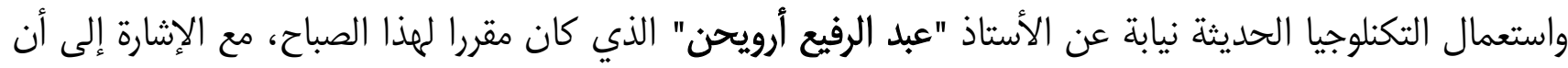

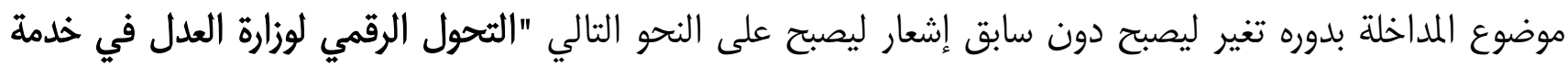

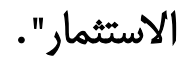




\section{موضوع المداخلة الأولى:}

قانون مساطر صعوبات المقاولة الجديد ودوره في حماية الاستثمار والمقاولة.

المتحخل: إلأستلنه "إيعس. اللكلمر"، كمكير الشؤوني المكنية بوناة الهكل.

\section{مقدمة عامة:}

تعتبر المقاولة النواة الأساسية لكل بناء اقتصادي حر يعتمد على مبدأ المنافسة والمبادرة الفردية. والمغرب كغيره من البلدان التي اعتمدت نظام السوق، قد اختار دعم المقاولة كخيار استراتيجي، وذلك عبر وضع الأساس لسياسات عمومية محفزة ولممارسات داعمة للاستثمار، باعتبار هذا الأخير أداة أساسية لخلق الثروة وتوفير مناصب الشغل وتحقيق ظروف التنمية

ومن منطلق وعي وزارة العدل بالدور الذي تلعبه المقاولة في إطار النسيج الاقتصادي المغربي، وإيمانا منها بأهمية توفير إطار قانوني مرن وشفاف يسهل اندماجها في اقتصاد السوق ويرفع من مناعتها الاقتصادية ويحمي الاستثمار بوجه عام، فقد انخرطت مبكرا في ورش إصلاح المنظومة القانونية المرتبطة بمجال الأعمال باعتباره هدفا محوريا من شأنه الرفع من من مأن الجاذبية الاقتصادية بالمغرب. وفي هذا الإطار يعتبر القانون 73.17 المتعلق بنسخ وتعويض الكتاب الخامس من مدونة التجارة فيما يتعلق بمساطر صعوبات المقاولة نموذجا يجسد هذه الرؤية، ويعبر عن توجه يهدف إلى حماية المقاولة من الأخطار التي تهلدد نشاطها

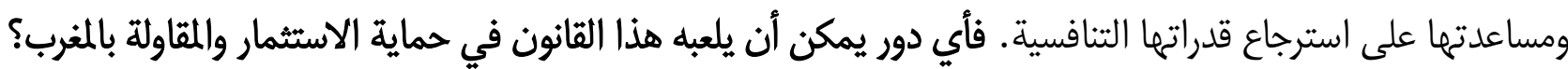
ولإججابة على هذا التساؤل، لابد من التطرق إليه من زاويتين اثنتين: العامل الأول: الاستقرار بصفة خاصة، فالكل يعلم بأن المستثمر الخارجي يأخذ بعين الاعتبار عاملين اثنين: أولا: من زاوية دور هذا القانون في تدعيم موقع المغرب كبلد يتوفر على ترسانة قانونية عصرية تستجيب

$$
\text { للمعايير الدولية؛ }
$$

ثانيا: من زاوية المقومات الذاتية التي يتمتع بها هذا القانون فيما يخص حماية المقاولة.

أولا: تدعيم موقع المغرب كبلد يتوفر على ترسانة قانونية عصرية:

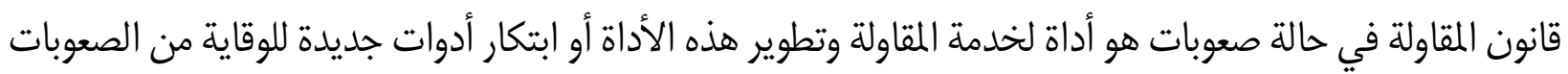
أو معالجتها وأثار ذلك اقتصاديا واجتماعيا لا يمكن إلا أن يكون محمودا. وفي ظل العولمة، فإن تنظيم طرق الوقاية من الصعوبات أو معالجتها أصبح من معايير تقييم هذا النظام أو ذاك وقدرته على المساهمة في المحافظة على المقاولات وتطويرها بما يتميز به من فعالية وجاذبية وتنافسية.

وفي هذا السياق، فإن عدم مسايرة مساطر صعوبات المقاولة المعمول بها سابقا للتحول التي عرفته ظروف المنافسة وواقع المقاولة المغربية وكذا تطور المعايير الدولية، فرض إعادة النظر فيها بالشكل الذي يؤهلما للقيام بدورها في حماية المقاولة. 
وانطلاقا من هذا المعطى، فقد تم إعداد نص القانون رقم 73.17 وفق منهجية ترمي إلى الرفع من مستوى نجاعة هذه المساطر من خلال:

إعادة النظر في المساطر المطبقة بتنقيحما وتجويدها؛ (استحداث آليات جديدة؛

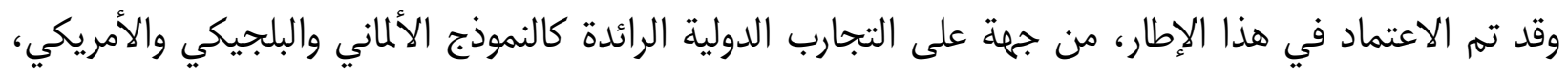
والممارسات الفضلى؛ ومن جهة ثانية على ما توصل إليه الفقه والاجتهاد القضائي المغربي.

وهو ما جعل المغرب يرتقي بنموذجه في مجال حماية المقاولة إلى ما تتطلبه المعايير الدولية من حيث جودة الإطار

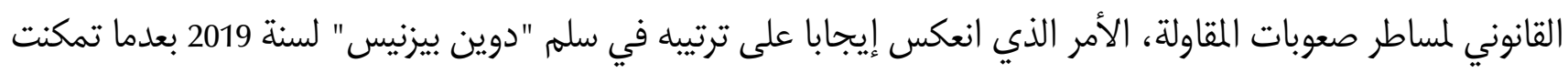

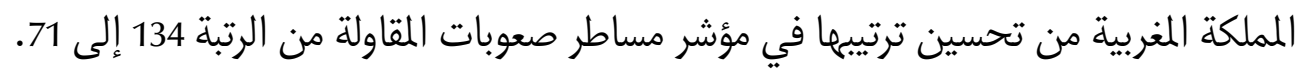
هذه الوضعية الجديدة ساهمت بشكل كبير في تحسين الترتيب العام للمغرب حيث انتقل من 69 في الترتيب الدولي

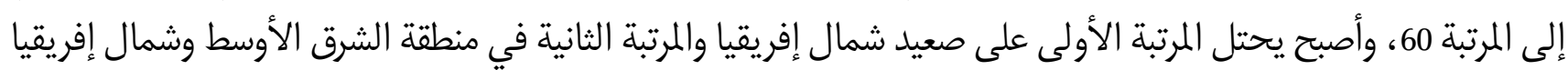
بعد دولة الامارات العربية المتحدة، والمرتبة الثالثة على مستوى القارة الافريقية المرية. لكن، إذا كان هذا الترتيب يعكس جودة الإطار القانوني لمساطر صعوبات المقاولة، فإن نجاح هذا الإصلاح يتطلب ثورة

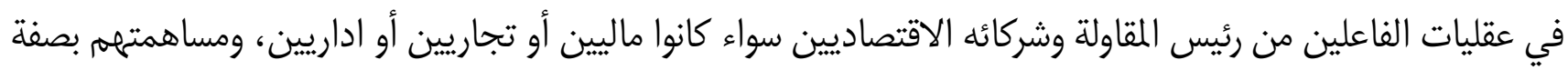

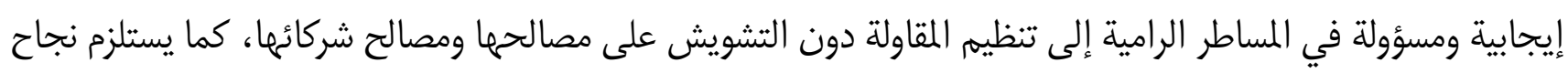
الإصلاح مساهمة مسيري المقاولة ومستشاريها والقضاء في إبداع الحلول.

\section{ثانيا: المقومات التي يتميز بها القانون رقم 73.17}

يمكن القول بأن القانون رقم 73.17 يعتبر إطارا نموذجيا لحماية المقاولة والاستثمار لاستناده إلى مقومين أساسيين، وهما:

التمسك بخيار إنقاذ المقاولة عبر توفير مجموعة من المساطر القانونية يمكن استعمالما حسب حاجيات المقاولة.

إعادة التوازن بين حقوق الدائنين والمقاولة باعتبارهم جميعا شركاء في اختيار الحل الكفيل بإنقاذ المقاولة.

\section{1. التمسك بخيار انقاذ المقاولة}

لقد أفرد هذا القانون مقتضيات هامة تهدف إلى حماية المقاولة من خلال مساطر الوقاية من الصعوبات التي تعترض

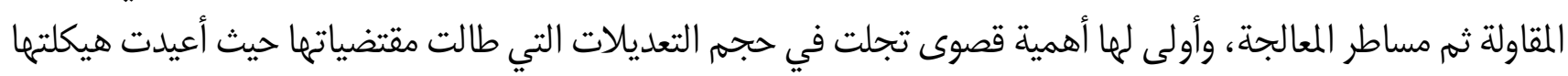
برؤية جديدة تهدف إلى تعزيز التشخيص المبكر للصعوبات، وإلى ضمان فعالية ونجاعة الإجراءات. 


\section{أ- تعزيز آليات الرصد المبكر للصعوبات التي قد تعترض المقاولة}

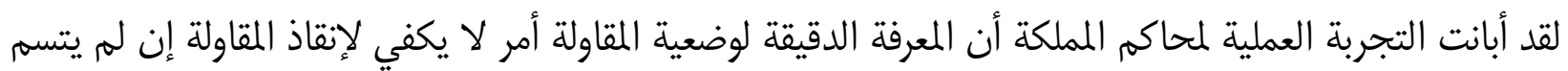
تدخل المحكمة بالاستعجال وفي وقت تكون فيه وضعية المقاولة قابلة لتصحيح. من هذا المنطلق، فإن القانون الجديد اعتمد في منهجيته على التدخل الاستباقي عبر تقوية مساطر الوقاية الخارجية وإحداث مسطرة الإنقاذ.

\section{ب- تقوية مساطر الوقاية الخارجية}

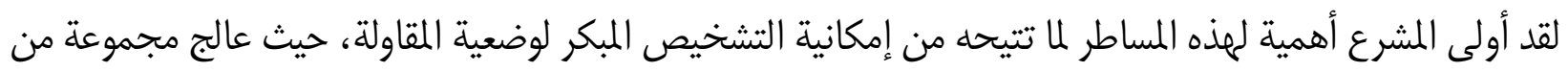

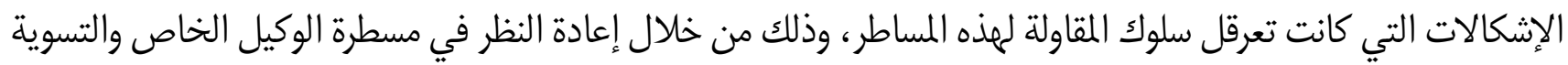

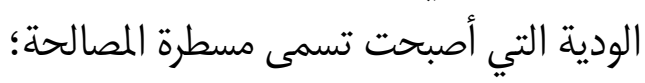

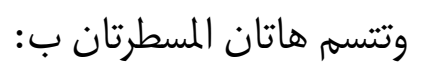

> الوقائية: يمكن مباشرتها بمجرد ظهور أعراض اختلالات مالية أو اقتصادية أو اجتماعية؛

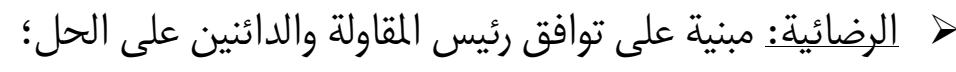

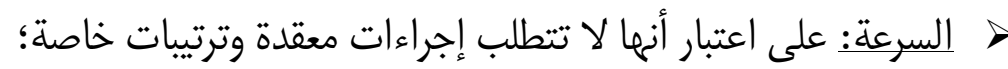

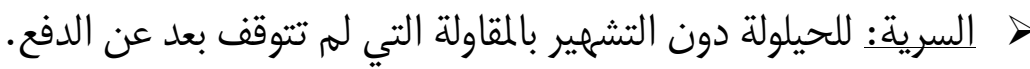

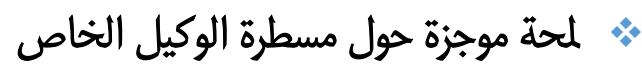

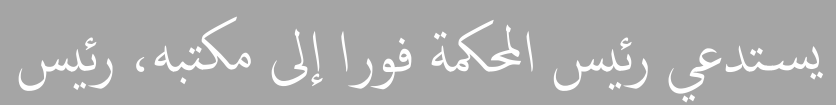

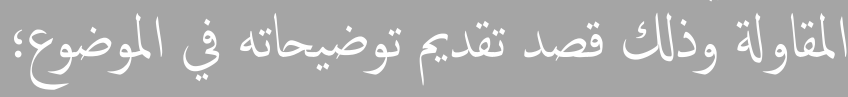

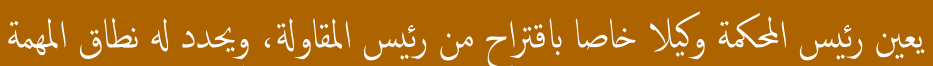

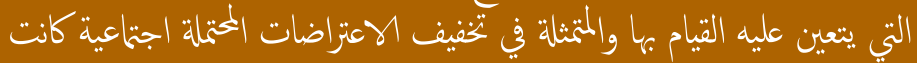

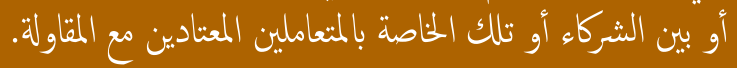

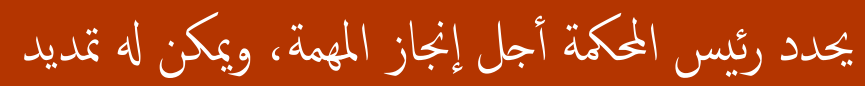

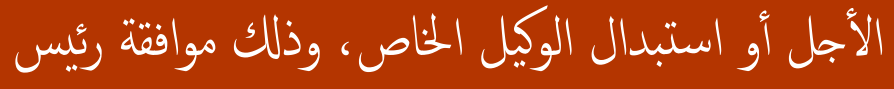

المقاولة. 


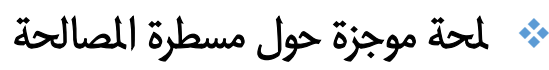

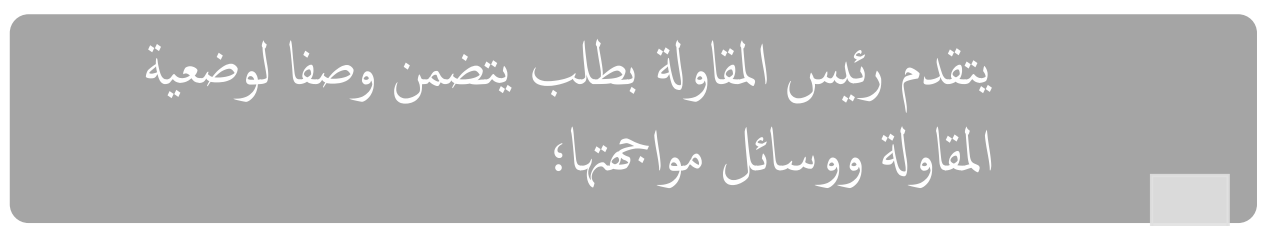

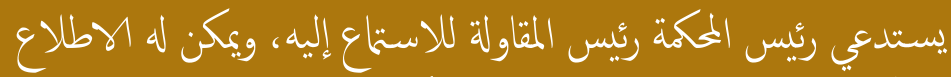

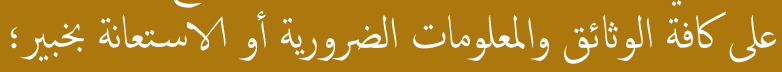

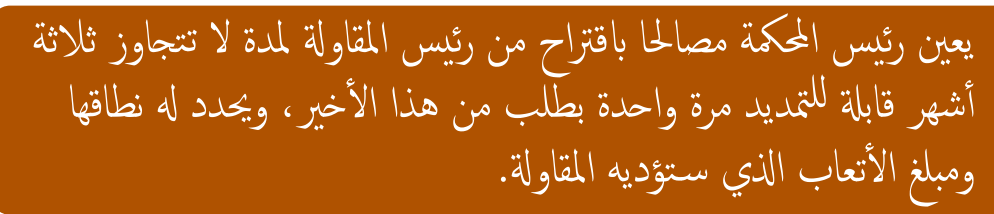

\section{يعمل المصاح على إبرام اتفاق ودي مع دائي المقاولة وعرضه على المكلى رئيس المكمة للمصادقة.}

ولتشجيع المقاولات على سلوك هذه المساطر والرفع من جاذييتها، فإن المشرع أدخل تعديلات مهمة عليها، نذكر منها خاصة:

$$
\text { تخويل الحق لرئيس المقاولة في اقتراح من سيتولى مهمة القيام بدور وكيل الخاص أو المصالح؛ }
$$

إقرار مبدا شمول كفاء المقاولة بوقف المتابعات الفردية بالنسبة للديون موضوع الاتفاق المبرم مع الدائين في إطار مسطرة المصالحة؛

تسهيل تمويل المقاولة من قبل الأغيار من خلال إضفاء حق الأفضلية على الديون الناشئة بعد فتح مسطرة المصالحة؛ تيسير إجراءات فسخ الاتفاق الودي المبرم في إطار مسطرة المصالحة بين رئيس المقاولة والدائنين في حالة عدم تنفيذ

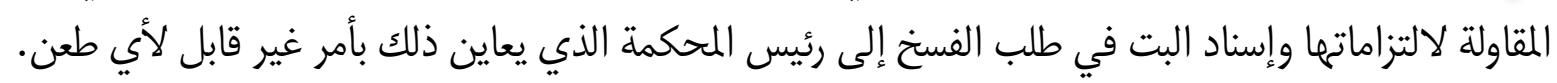

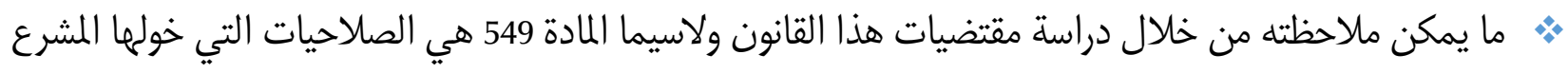

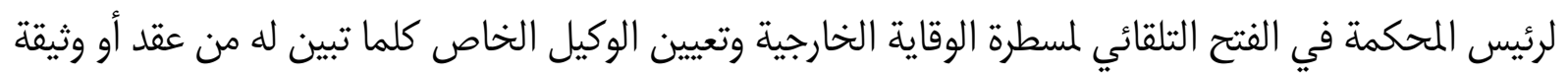

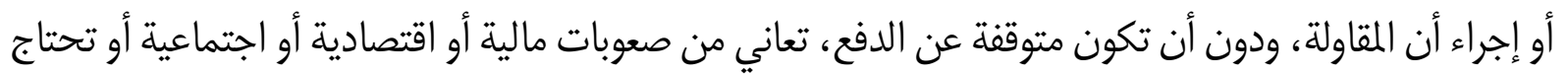
لتمويل لا يتناسب وقدراتها. إن تنزيل هذا المقتضى يستدعي توفر رئيس المحكمة على قاعدة بيانات تمكنه من الرصد المبكر والإستباقي لكل

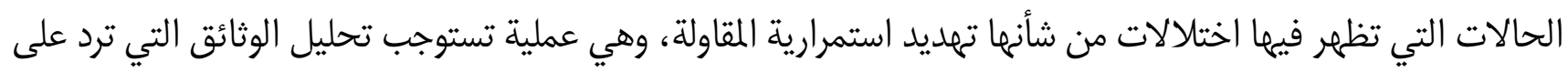


المحاكم التجارية كالوثائق المحاسبية والأحكام القضائية والأوامر بالأداء والأوامر بالحجوز التحفظية وغيرها التي تصدر ضد

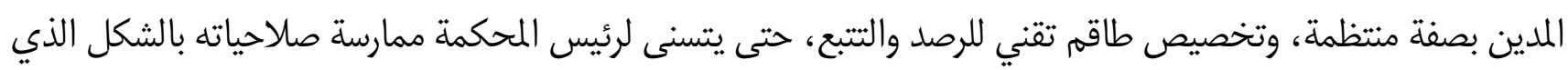
يحقق الأهداف المنتظرة من هذه المسطرة.

ولا يمكن، وأنا أجزم أن يقوم رئيس المحاكم برهذه المهام إن لم يستعينوا بعدد كافي من السادة القضاة للقيام بهذه

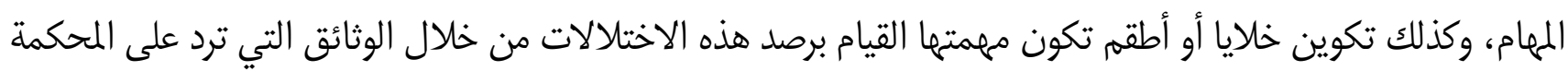

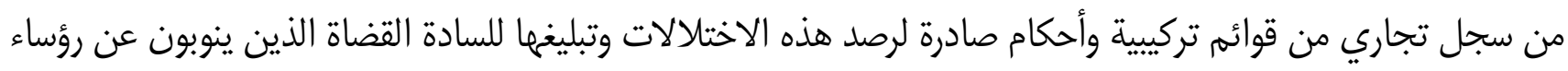

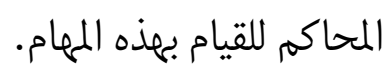

\section{ت- إحداث مسطرة الإنقاذ كآلية إضافية للكشف المبكر عن الصعوبات التي تعترض المقاولة:}

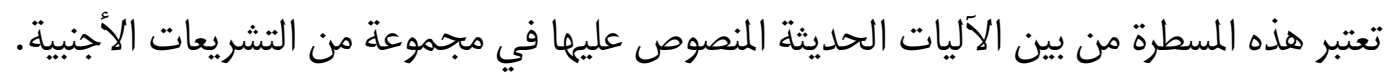
وتمتاز هذه المسطرة عن مسطرة التسوية القضائية بكونا لا تشترط توفر عنصر التوقف عن الدفع لفتحها، بل يكفي

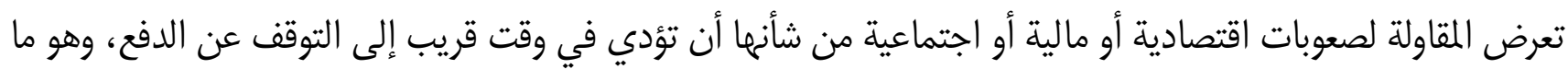

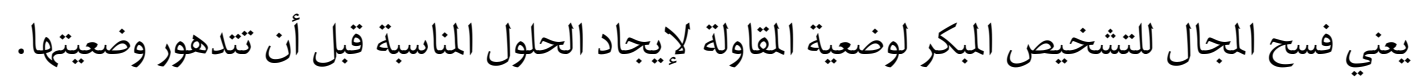
وهذه المسطرة هي تجمع بين مساطر الوقاية ومساطر المعالجة، حيث تقتبس من مساطر الوقاية خاصة الوقاية الخارجية مقتضياتما ومن مسطرة التسوية القضائية بعض مقتضياتها دون أن تكون المقاولة بطبيعة الحال متوقفة عن الدفع. ولتحفيز مسيري المقاولات على مباشرة هذه المسطرة والاستفادة من مزاياها، فقد تم تقرير بعض القواعد كالتالي: التصيص على الهدف من مسطرة الإنقاذ هو ضمان استمرارية نشاط المقاولة، الحفاظ على مناصب

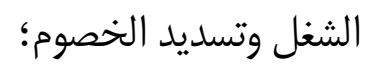

إضفاء الصبغة الارادية على هذه المسطرة بحيث لا يمكن فتحها إلا بطلب من رئيس المقاولة؛ تعزيز دور رئيس المقاولة في المسطرة عبر تخويله الحق في إعداد مشروع الإنقاذ وعرضه على المحكمة؛

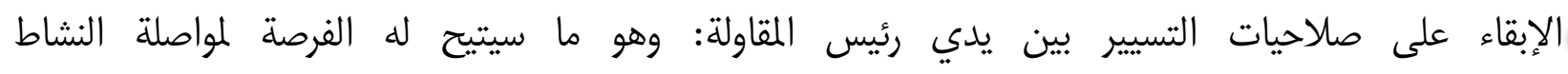

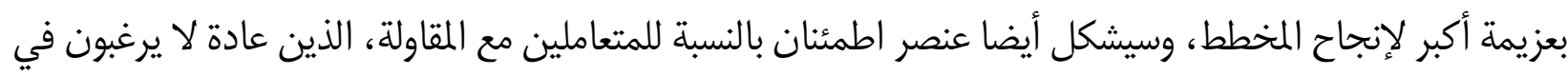
تغيير طاقم التسيير لما قد يترتب عنه من مخاطر متصلة بتغيير التوجهات العامة للمقاولة وطريقة تدبير المعاملات مع شركائمها الاقتصاديين.

تسهيل تمويل المقاولة خلال فترة إعداد الحل عبر التنصيص على حق الأفضلية بالنسبة للديون المتعلقة بنشاط المقاولة خلال هذه الفترة؛ تلمعال تمتيع كفلاء المقاولة الأشخاص الطبيعيون من مقتضيات مخطط الإنقاذ ومن منع وقف سريان الفوائد. 
قبل أن أنتقل لهذه النقطة لابد من الإشارة إلى أن تحفيز المقاولات على اللجوء لمسطرة الإنقاذ لأنها تبينت أن الوضعية

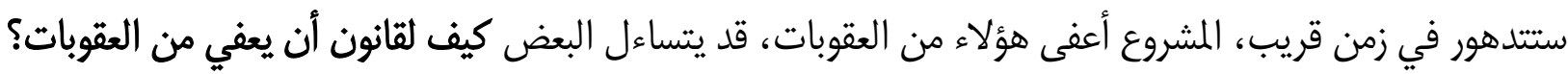
العقوبات التي يمكن أن يتعرض لمها مسيرو المقاولات هي عقوبات مالية تتمثل في تحميل المسيرين النقص الحاصل

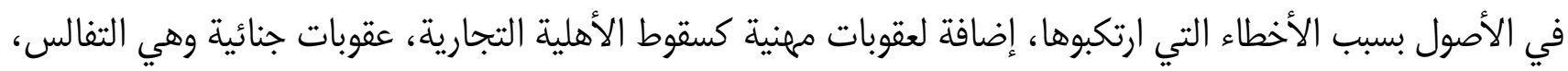

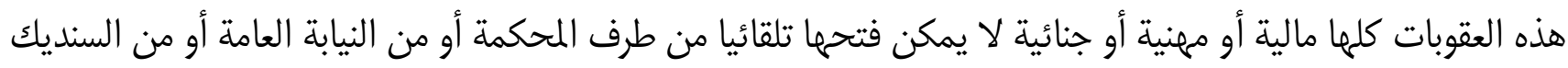
إلا في حالتين فقط: الأولى: حالة صدور حكم بفتح مسطرة التسوية القضائية الثانية: صدور حكم بالتصفية القضائية

إلا أنه لا يمكن إصدار هاته الأحكام سواء بالتسوية أو التصفية القضائية إلا إذا كانت المقاولة متوقفة عن الدفع والحال

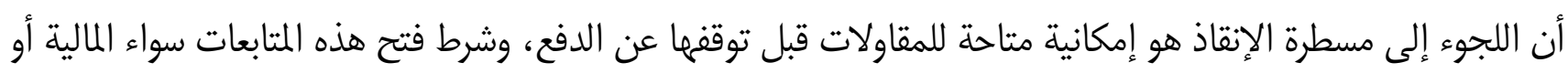
المهنية أو الجنائية فتحت في وجهمها مسطرة التسوية أو التصفية القضائية.

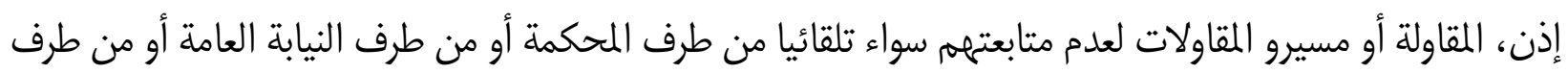

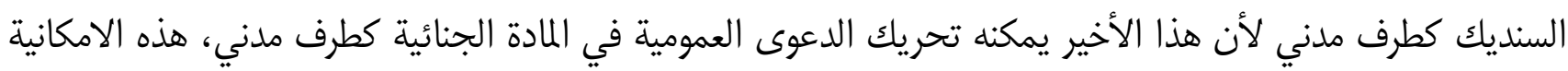

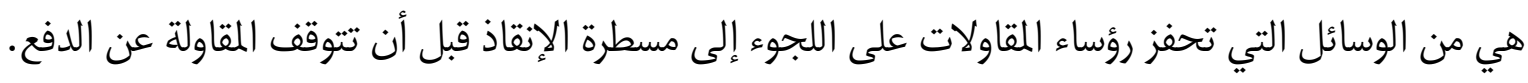

\section{ث- ضمان فعالية ونجاعة مسطرة التسوية القضائية} إن حرص المشرع على ضمان استمرارية المقاولة، وتعزيز وسائل الاستثمار فرض عليه الإبقاء على مسطرة التسوية القضائي كأداة ضرورية لمعالجة المقاولات المتوقفة عن الدفع.

لكن، كان من اللازم إعادة النظر في هذه المسطرة بالشكل الذي يحقق الأهداف المتتظرة منها. ومن هذا المنطلق، فقد تمت مراجعة العديد من المقتضيات التي كانت تثير إشكالات قانونية وواقعية تثني المستثمرين

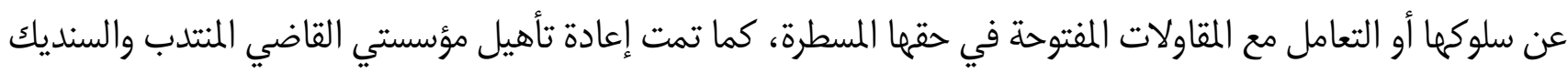
ليضطلع لدورهما.

2. إعادة التوازن بين حقوق الدائنين والمقاولة باعتبارهم جميعا شركاء في اتخاذ الحل الكفيل بإنقاذ المقاولة. من خلال تشخيص الوضع السابق لوضعية الدائنين يتبين بأن هذه الفئة لم تكن تحظى بالحماية القانونية الكافية التي يفرضما موقعها في مجال الاستثمار وخلق الثروة، كما أنما كانت مقصية من اتخاذ القرارات المتعلقة بسير المسطرة. والحال أن غالبية الدائنين تتشكل من الموردين ومؤسسات الائتمان، المعتبرين الرافد الرئيسي لتمويل الاقتصاد وعاملا مهما في تحقيق التنمية.

الجديد في القانون هو أنه أحدث جمعية للدائنين من أجل مأسسة دورهم عبر إشراكمهم بصورة فاعلة ومسؤولة في: 


$$
\begin{aligned}
& \text { ه اختيار الحل؛ } \\
& \text { ه اتخاذ القارات المرمة_1420؛ }
\end{aligned}
$$

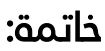

إن التقدم الذي وصل إليه المغرب من حيث جودة الإطار القانوني يستوجب مواصلة ورش الإصلاحات اللازمة لتنزيل

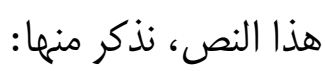

هـ إخراج النصين التنظيمين المتعلقين بالسنديك ورقمنة الإجراءات، إذ نصت المادة الأولى على ضرورة أن

تكون جميع الإجراءات المتعلقة بهذه المسطرة إلكترونية؛

$$
\text { تعزيز قدرات المتدخلين في المسطرة عبر تنظيم دورات تكوينية؛ }
$$

ه خلق خلية على صعيد كل محكمة تجارية لمساعدة رئيس المحكمة أو من ينوب عنه لرصد الاختلالات

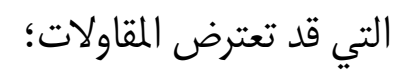

تكليف عدد من القضاة للنيابة عن رؤساء المحاكمة التجارية حسب أهمية النشاط الاقتصادي بدائرة كل

واحدة منها للتفرغ قصد الاضطلاع بالمهام ذات الصلة بمساطر صعوبات المقاولة.

وشكرا 


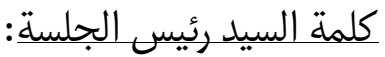

بعل نهاية السيد "لحسن الجاسم" شكر السيد الرئيس الأستاذ المحاضر على هذا العرض الذي جمع ما بين جانب

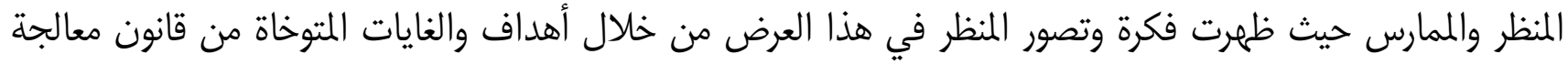
صعوبات المقاولة، وظهرت كذلك وجهة نظر الممارس.

وأضاف السيد الرئيس بهذا الخصوص مسألة كنت تشكل بالنسبة إليه هاجسا قانونيا تتجلى في جانبين وهما:

$$
\text { ه تحميل الكفيل متاعب مع أن المدين، والتي تجاوزها القانون الجديد 73.17. }
$$

ثم أعجبت بفكرة إنشاء آلية للرصد، ففي رأيي المتواضع هذه الآلية هي التي من شأنها أن تحسن مردودية هذا

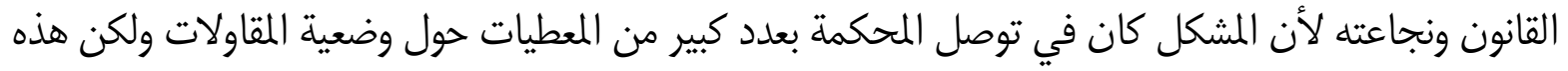

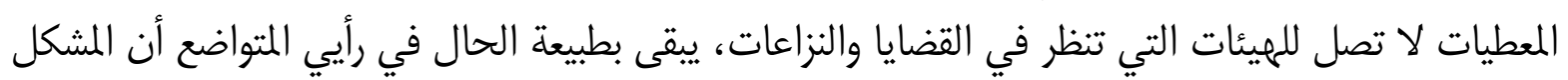

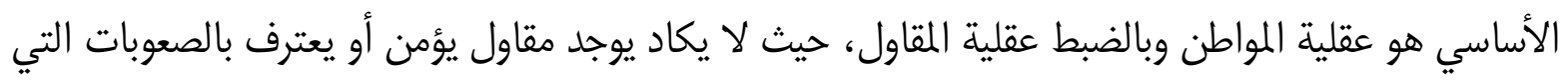

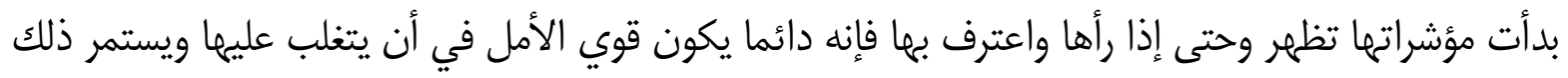
إلى أن يفوت الأوان وتصبح مساطر المعالجة قليلة المردودية إلى أبعد.

لدى ربما كانت فكرة إحداث آلية لرصد الصعوبات تكون أكمل وأنجع إذا واكبتها مساطر وآليات لتحسيس المقاولين بدور هذه الآلية كلما ظهرت مؤشرات حول الصعوبات التي تعترض المقاولة.

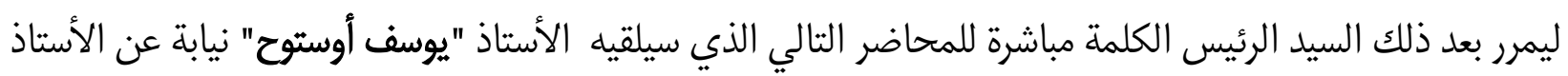

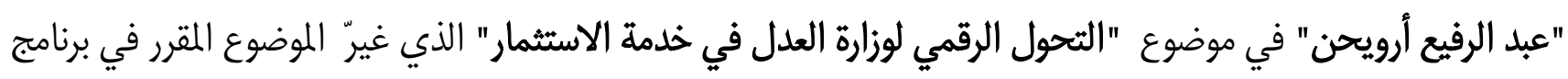

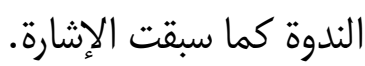


موضوع المداخلة الثانية: التحول الرقمي لوزارة العدل في خدمة الاستثمار.

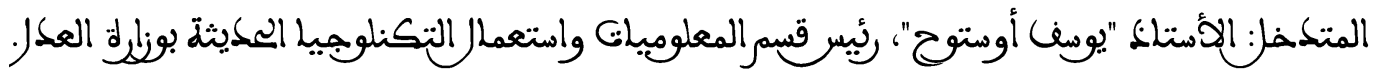

مقدمة عامة:

كما تعلمون وتماشيا مع الخطابات المولوية السامية "فإن اللحاق بركب الدول الصاعدة لن يتم إلا بمواصلة تحسين

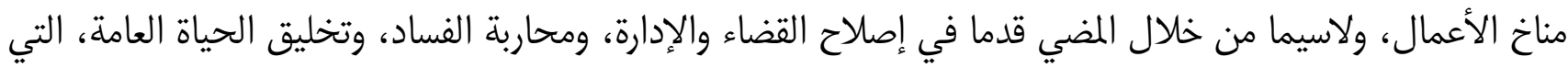

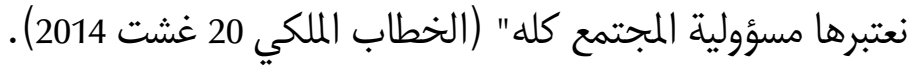

وتماشيا كذلك مع البرنامج الحكومي الذي تمثل في بلوغ الحكومة الرقمية هدف أساسيا يتجلى في "الرفع من تنافسية

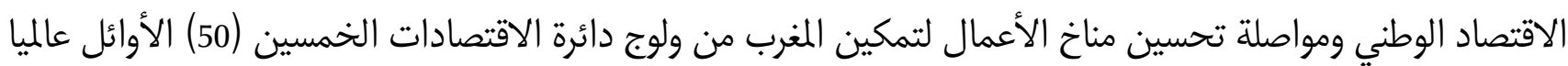
في مؤشر الأعمال Doing Business في أفق 2021" (البرنامج الحكومي 2016-2021).

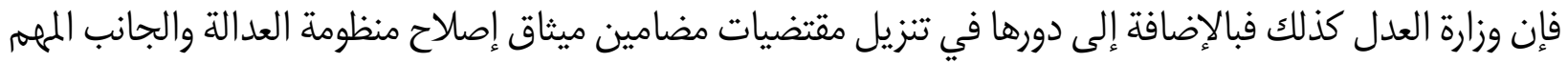

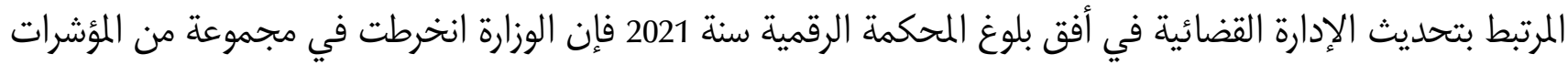

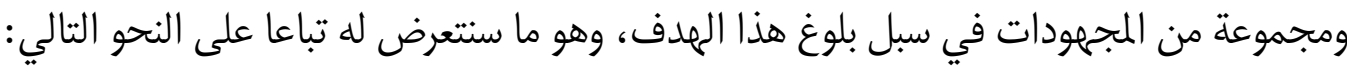

المحاور التي تبني عليها وزارة العدل بخصوص استراتيجية التحول الرقمي.

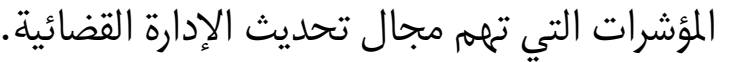

أولا: المحاور المعتمدة بخصوص استراتيجية التحول الرقمي

إن التصور الشامل للوزارة في استراتيجية التحول الرقمي ينبني على أربعة محاور رئيسية هي كالآتي:

1. تبسيط الإجراءات والمساطر الداخلية وحوسبتها وتوفير البرمجيات اللازمة لتدبير العمل اليومي على مستوى المحاكم:

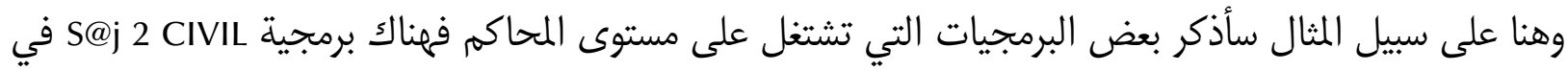

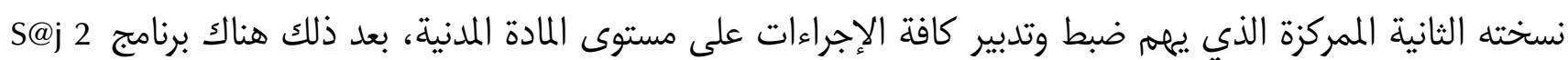

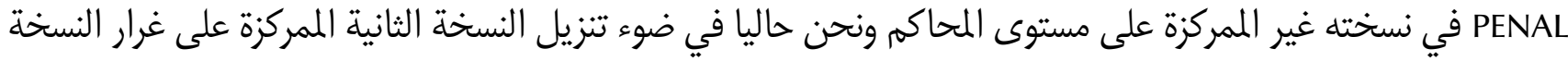

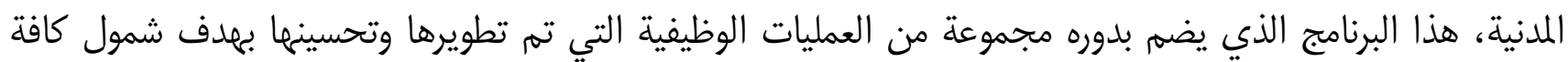

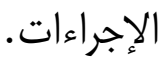

ثم لدينا جانب أخر مهم نشتغل عليه الذي يرهم هذه الندوة وهي البرامج المرتبطة والخاصة بتدبير السجل التجاري

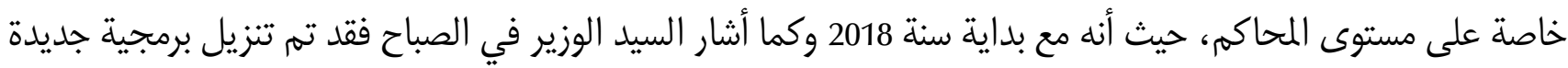

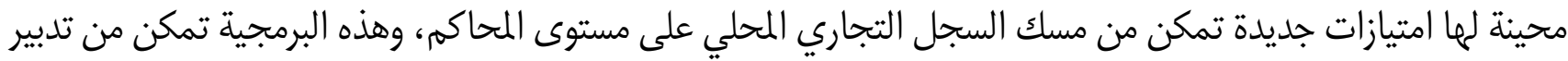

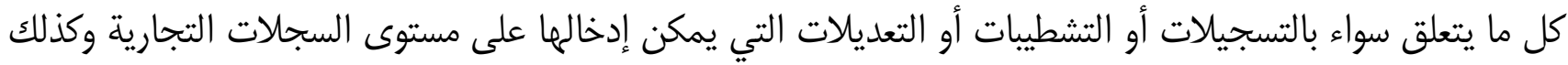

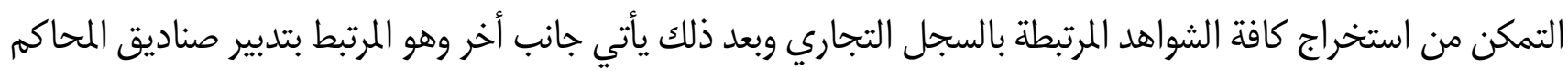




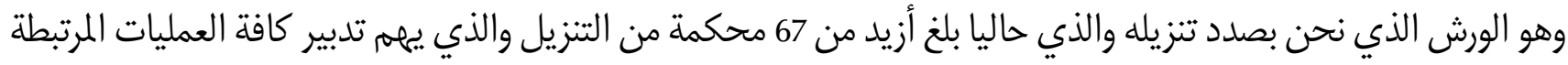

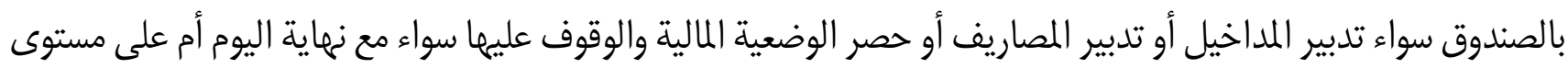
ن مهاية الشهر.

$$
\text { إذن هذا فيما يتعلق بالنسبة للمحور الأول المرتبط بحوسبة الإجراءات ثم نمر للمحور الثاني. }
$$

2. التبادل الالكتروني للمعلومات والوثائق مع كافة شركاء العدالة: منصة المحامي للتبادل الالكتروني.

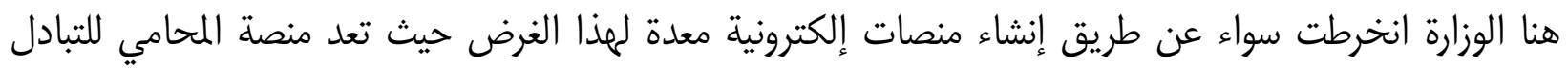

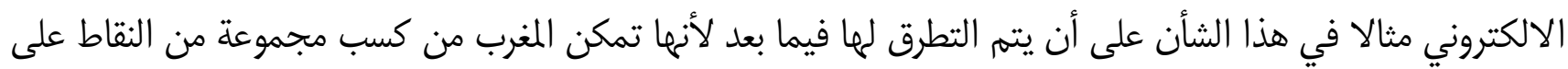

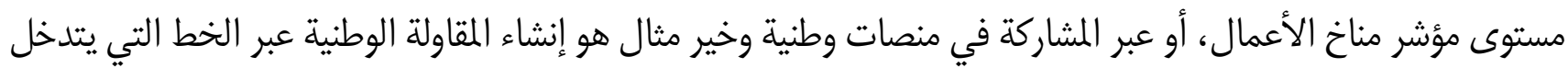

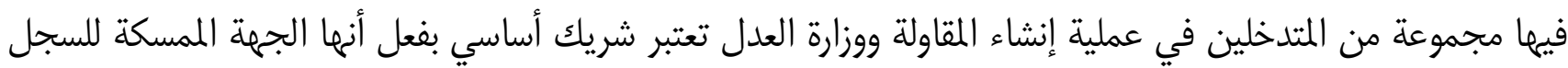

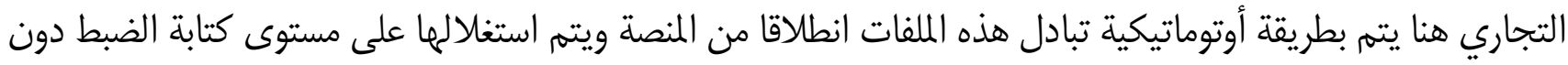

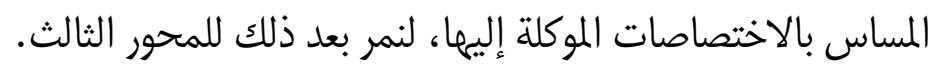

3. توفير خدمات عبر الخط للمتقاضين وعموم المواطنين باعتماد تقنيات حديثة كالتوقيع الالكتروني والأداء

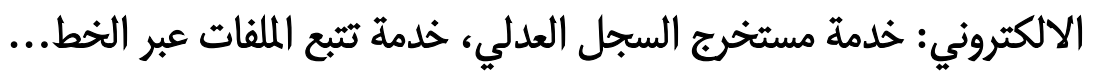

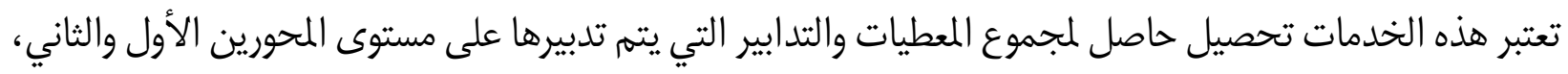

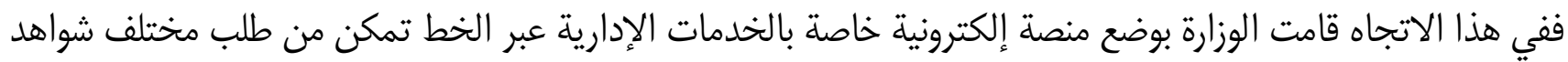

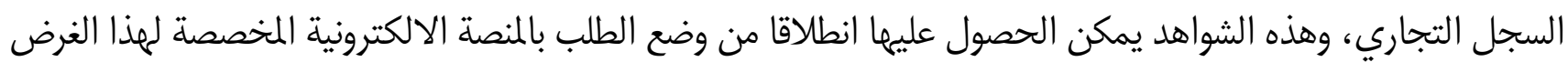

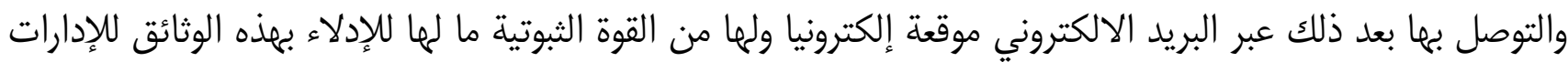

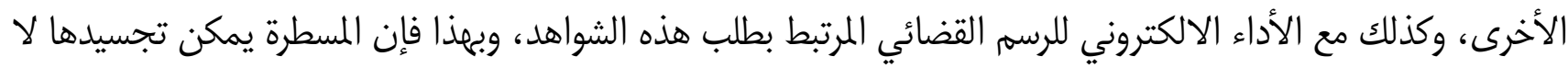
ماديا كاملة دون عناء التنقل إلى المحكمة. كذلك هناك منصة إلكترونية خاصة بإيداع القوائم التركيبية وهذه المنصة مكنت في أول تجربة لهذه السنة على إيداع

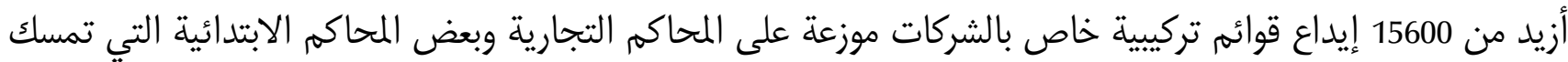

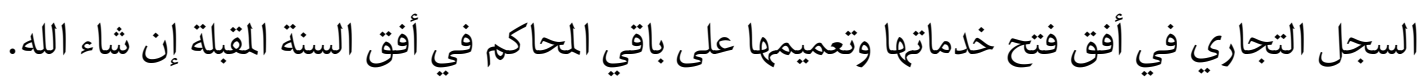

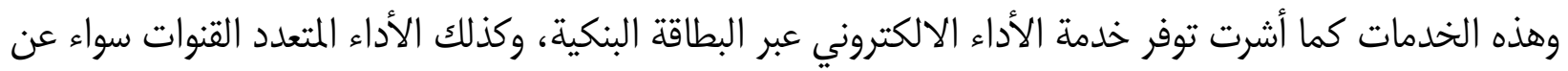

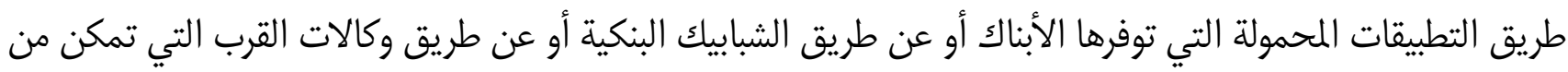
إدخال الرقم المرجعي للطلب من أداء هذه الرسوم القضائية.

لنتنقل للمحور الرابع الذي تنبني عليه كل هذه المجهودات والذي يمكن أنه لا يظهر للعموم يتمثل في: 4. تعزيز البنية التحتية المعلوماتية لاستيعاب جل هذه المشاريع.

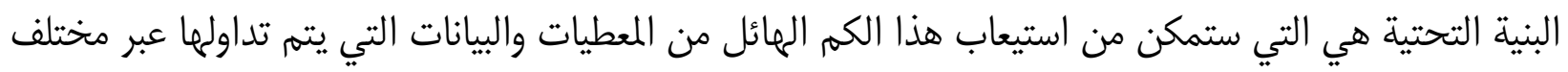

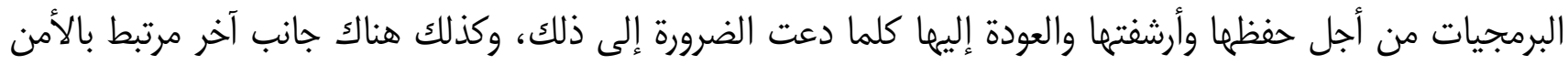




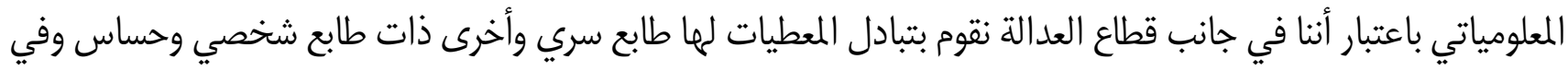

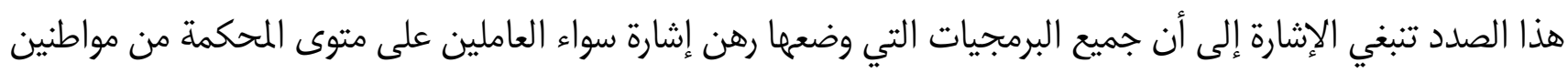

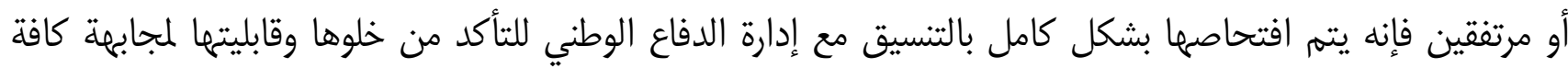

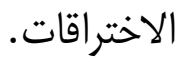

\section{ثانيا: المؤشرات التي تهم مجال تحديث الإدارة القضائية.}

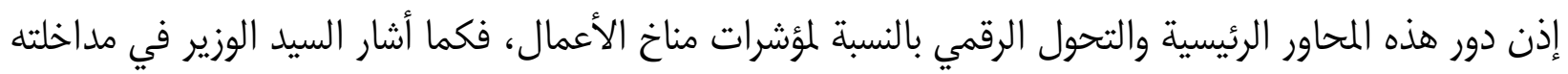

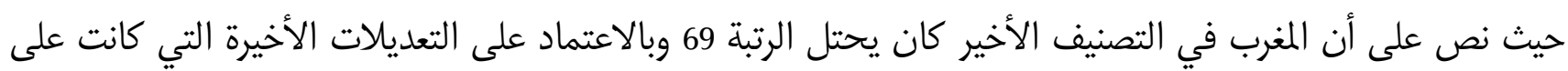

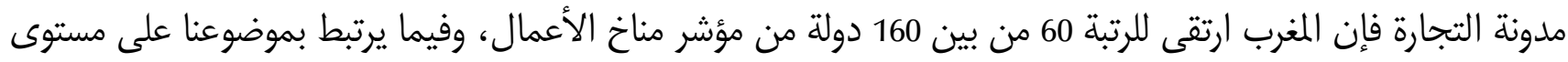

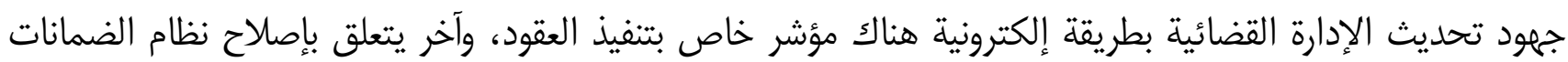
المنقولة وإحداث السجل الوطني للضمانات المنقولة.

1. المؤشر المتعلق بتنفيذ العقود. يمكن المؤشر الخاص بتنفيذ العقود من:

تحسين نجاعة المنظومة القضائية؛

تقليص الآجال والتكاليف المرتبطة بحل النزاعات التجارية؛ وكذا الرفع من جودة الإجراءات القضائية في الميدان التجاري.

وفي هذا الصدد المغرب يحتل حاليا الرتبة 68 في هذا المؤشر، وبتفعيل مجموعة من الآليات التي سنعرضها تباعا سيتمكن المغرب من الحصول على 6 نقاط: • النقطة الأولى: الإيداع الالكتروني للدعاوى والمقالات: وهي العملية الوظيفية المتاحة للمنصة للتبادل الالكتروني مع المحامي بحيث يمكن للمحامي انطلاقا من مكتبه إيداع المقالات مرفقة بالمذكرات ومختلق المرافقات بطريقة إلكترونية على مستوى المحكمة. • النقطة الثانية: التبليغ الالكتروني للمقالات للمدعي: حيث يمكن لكل محامي منخرط في هذه المنصة التوصل بكافة التبليغات وكافة الاشعارات وأخر الاجراءات التي يتم

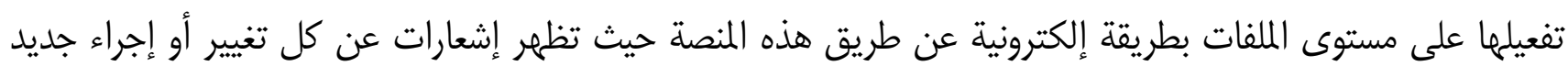
يظهر في هذا الملف.

\section{• • النقطة الثالثة: الأداء الالكتروني للرسوم القضائية:}

فمع تفعيل إمكانية الأداء الالكتروني أصبح كذلك يمكن وضع المقال على مستوى المحكمة مع صفر تنقل، بمعنى المقاء وضع المقال في المنصة ثم توقيعه إلكترونيا ثم إرفاق كافة المرفقات وبعدها أداء الرسم الإني القضائي. 


\section{• النقطة الرابعة: الاطلاع على الأحكام عن طريق النشر عبر الانترنيت:}

http://justice.gov.ma وهذه العملية تساهم في تعزيز الأمن القضائي وفي هذا الإطار فقد تم إحداث موقع إلكتروني والذي يمكن من نشر مجموعة من الاحكام في المادة التجارية ويضمى حاليا أحكام خاصة بالمحكمة التجارية بالدار البيضاء ومحكمة الاستئناف التجارية بالدار البيضاء وقرارات محكمة النقض في المادة التجارية، طبعا بعد معالجة هذه الأحكام والقرارات وحجب المعلومات الشخصية والمعطيات ذات الطابع الشخصي التي تمكن من التعرف على الأطراف.

\section{• النقطة الخامسة: التوزيع التلقائي والالكي للملفات على القضاة المقررين:}

وهذه النقطة كانت من الميثاق الوطني لإصلاح منظومة العدالة وقد تم تفعيلها حاليا بالتنسيق مع بعض المسؤولين القضائيين على مستوى مجموعة من المحاكم منها المحكمة التجارية بالدار البيضاء محكمة الاستئناف والمحكمة الابتدائية الاجتماعية وكذلك على مستوى المحكمة الابتدائية بمراكش. وهذه الخدمة تمكن من الاعداد المسبق وتوزيع القضاة حسب أنواع القضايا التي يبتون فيها كما تمكن البرمجية من تعيين القضاة المقررين والمستشارين المقررين في هذه الملفات بطريقة تلقائية تضمن التوزيع العادل والمتساوي لهذه الملفات على مختلف القضاة.

\section{• النقطة السادسة: إعداد تقارير دورية لتتبع نجاعة أداء المحاكم:}

في هذا الصدد فإن الوزارة تقوم بنشر نشاط مختلف المحاكم على مستوى الموقع الرسمي وثم كذلك في هذا الصدد إنشاء برمجية مساعدة على اتخاذ القرار تعتمد على تقنية ذكاء الاعمال ووضعت رهن إشارة المسؤولين على مستوى المحاكم تمكن من استخراج مجموعة من الاحصائيات والاطلاع على مجموعة من المؤشرات التي تساعد في تتبع العمل اليومي للمحكمة.

إذن مع تفعيل مجموع هذه الإجراءات والمصادقة عليها فسوف يتمكن المغرب من الحصول على 6 نقاط على مستوى 6+ مؤشر تنفيذ العقود.

\section{2. المؤشر المتعلق بإصلاح نظام الضمانات المنقولة وإحداث السجل الوطني للضمانات المنقولة} المؤشر الثاني الذي يرهم مجال تحديث الإدارة القضائية هو مؤشر إصلاح نظام الضمانات المنقولة وإحداث السجل الوطني للضمانات المنقولة، يهدف هذا المؤشر إلى:

تسهيل ولوج المقاولات الصغرى والمتوسطة للتمويل؛

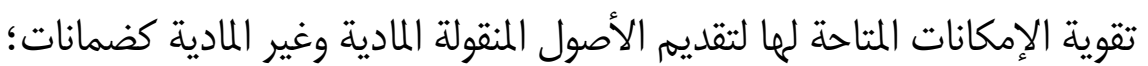
تسجيل وإشهار الضمانات المنقولة عبر الخط للوقت والججهد وتعزيزا للشفافية؛ توفير قاعدة بيانات ممركزة حول وضعية الضمانات المنقولة؛ 
والمغرب حاليا يحتل الرتبة 112 عالميا في ترتيب هذا المؤشر، وفقط للتذكير فإن تنزيل هذا المشروع أوكلته رئاسة الحكومة

لوزارة العدل التي ستقوم بمسك هذا السجل الوطني للضمانات المنقولة.

\section{خاتمة:}

إذن وانطلاقا مما سبق فإنه بالنسبة لمؤشر" تنفيذ العقود" مع تفعيل الآليات المشار لمها سابقا فالمغرب سيتمكن من كسب المباء

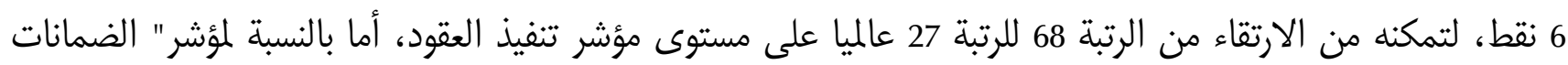
المنقولة" فإن التقدم سيكون من الرتبة 112 إلى الرتبة 36 عالميا.

وهذين المؤشرين سيمكنان لا محالة من رفع الترتيب العام لمناخ الأعمال بالمغرب وذلك ببلوغ المرتبة 41 من خلال

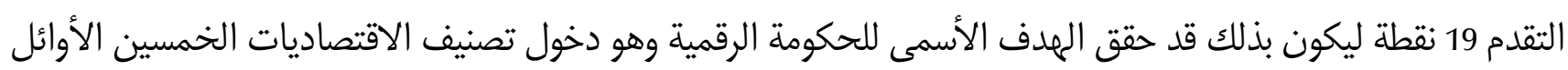
على مستوى العالم.

إذن يبقى فعلا هذا الظهور في هذه المراتب المتقدمة عامل إيبابي ومحفز بالنسبة لكافة المتدخلين في قطاع العدالة إلا

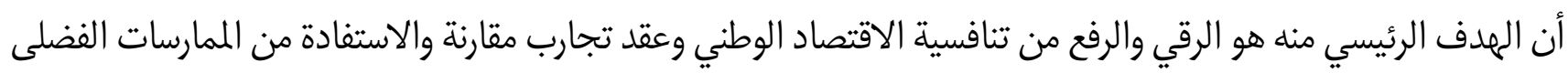

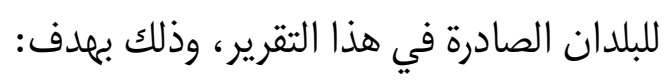
ه جلب الاستثمارات الأجنبية الجديدة؛

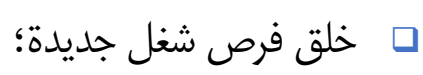

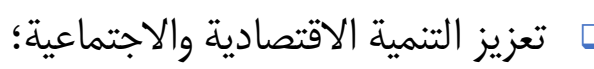

إذن يبقى الهيدف الأسمى من جميع أوراش الإصلاح هو تقديم خدمات إلكترونية لفائدة مرتفقي قطاع العدالة

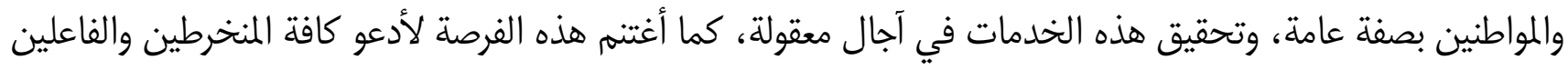

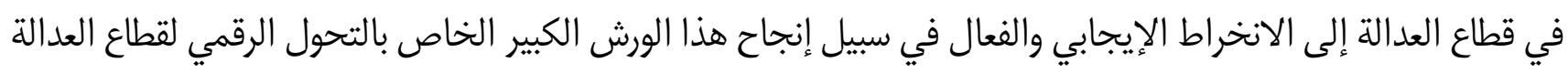
على مستوى المغرب والمضي قدما كذلك في تحسين مناخ الأعمال على مستوى بلادنا. وشكرا لكم على تتبعكم. 
كلمة السيد رئيس الجلسة: بعد انتهاء المحاضر تقدم السيد الرئيس بشكره على العرض الذي اعتبره مركزا تم من خلاله شرح وتبسيط المحاور التي يسير عليها الرفع من الخدمات القضائية. كما شدد السيد الرئيس في هذا الإطار على ضرورة الاعتراف بأن كل المحاور من تبسيط وحوسبة والسجل التجاري

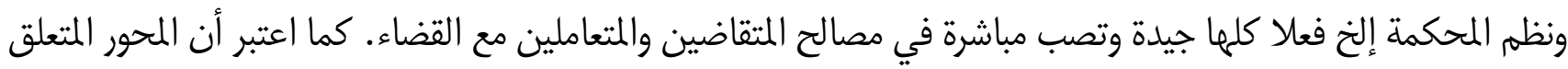

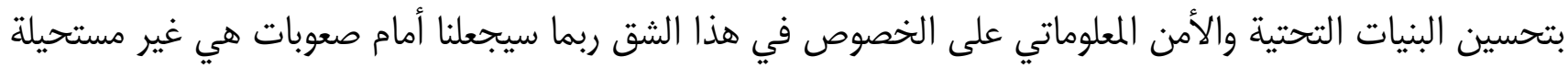

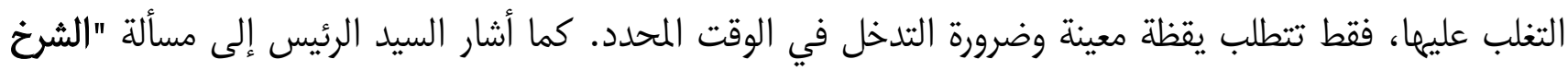

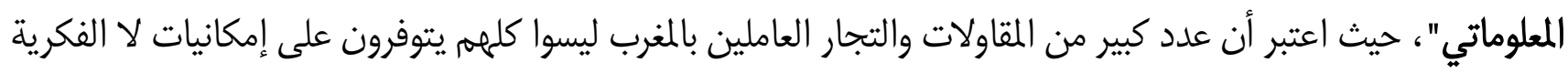
ولا المادية للاستفادة من هذا النوع من الرقمنة.

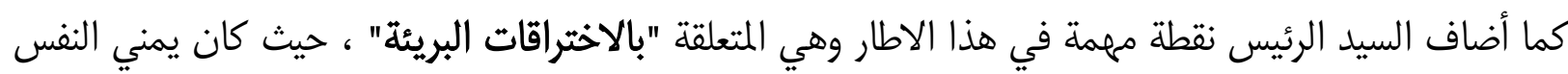

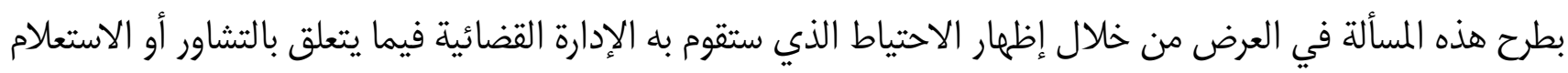

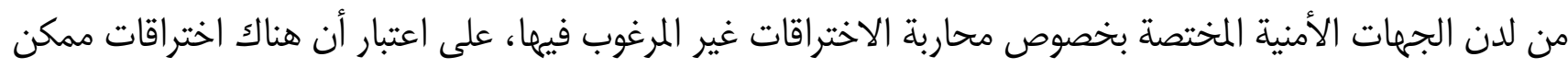

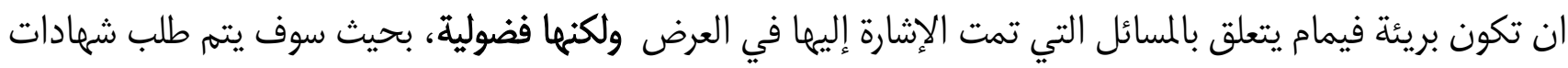

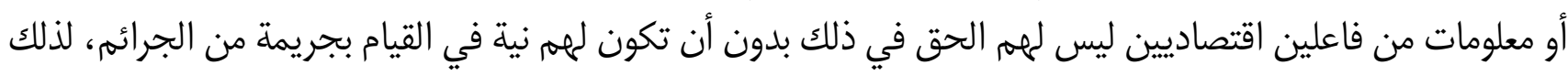
لكان ربما واجب كذلك الاهتمام بهذا الجانب.

ليختتم السيد الرئيس كلمته بالقول أن هذا النحول الرقمي يتطلب شيئا من الوقت وكذلك شيئا من الصبر.

\section{المحور الثاني: دور المحاكم التجارية في حماية الاستثمار}

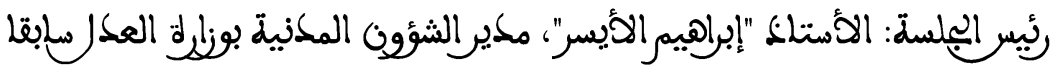

الكلمة الافتتاحية للسيد رئيس الجلسة: افتتح الأستاذ "ابراهيم الأيسر" الكلمة بالترحيب بالسيدات والسادة الحضور

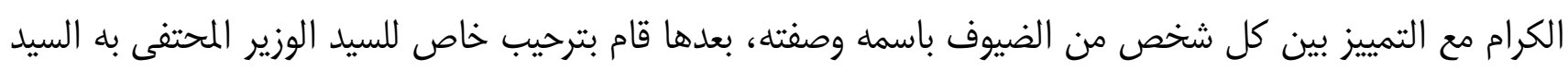

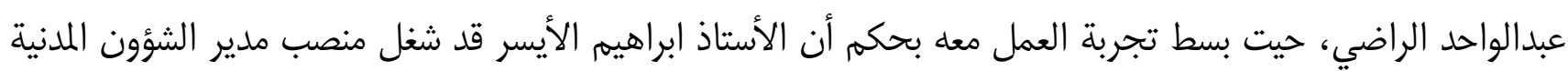

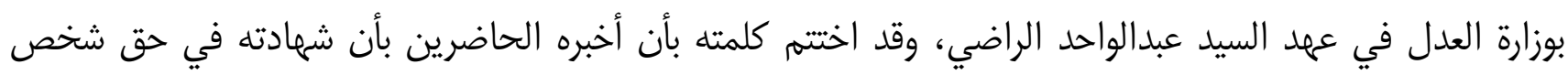

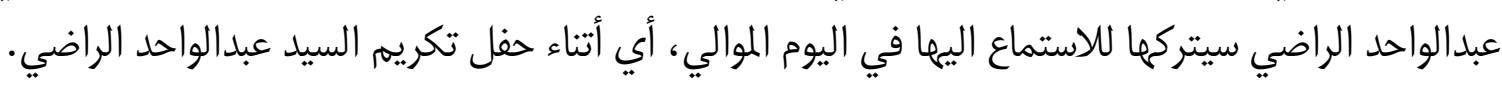

بعد ذلك مهلد رئيس الجلسة لكلمة المتدخل الأستاذ "عبد الرزاق العمراني" وأبرز عنوانها أهميتها في هذه الظرفية

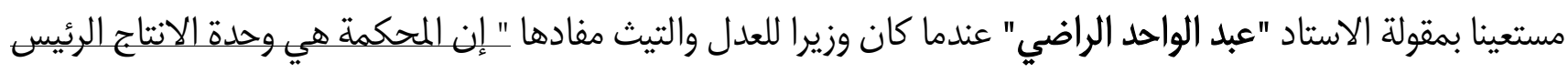

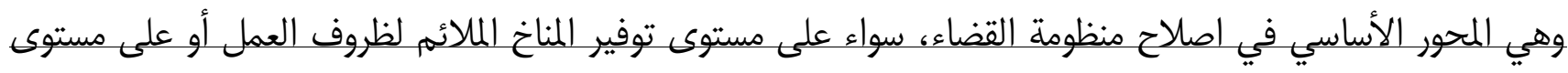

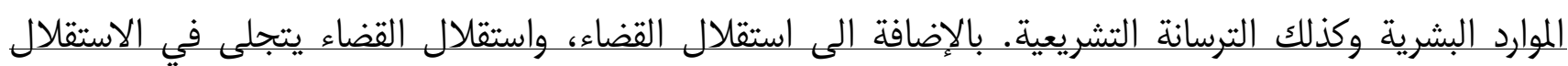

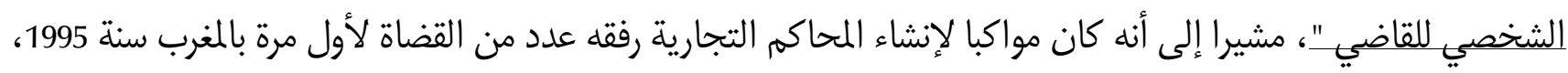

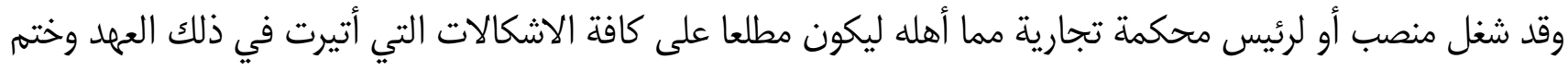
تمهيده بأن مرر الكلمة للسيد "عبدالرزاق العمراني" حتى يباشر مداخلته. 
موضوع المداخلة: تجربة المحاكم التجارية في مجال حماية الاستثمار

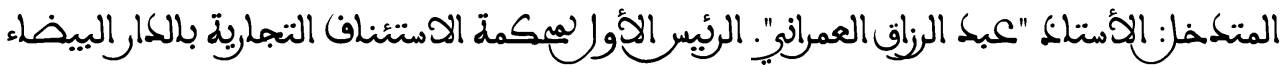

افتتح الأستاذ "عبد الرزاق العمراني" كلمته بشكر رئيس الجلسة وبالترحيب بالسادة الحضور الكرام كل باسمه وصفته والاحترام الواجب لشخصه، كما عبر فرحه وسروره بالتواجد في الندوة وحفل التكريم باعتباره متدخل مطالبا بإبراز دور المحاكم التجارية في حماية الاستثمار، مبرزا النقط التالية:

\section{مقدمة عامة:}

إن الحديث عن تجربة إحدات القضاء التجاري بالمغرب وما راكمه من تجربة ومكاسب، وكذلك ما تم توجيهله إليها من انتقادات بعد مرور عشرين سنة على انشائما، يرتبط بالضرورة بتطور المجال الاقتصادي والتجاري ببلادنا الذي يعرف تحولات مستمرة ومتسارعة وقد جاء انشاء القضاء التجاري ليستجيب دون شك لعدة حاجيات فرضما المناخ الاقتصادي العام الذي عرفه المغرب منذ بداية الثمانينيات، و أدى إلى الشروع في إصدار القوانين وتنقيحها الخاصة بمجال المال والأعمال والتجارة مما يليق بالمجال وتحسينه في هدا المقام، مع تكريس البعد القضائي للاهتمام المتزايد للبلاد بهذا المجال ، وتوجيه اشارة قوية للفاعلين الاقتصاديين مفادها ، أن الدولة تتكفل اساسا بإيجاد البنية المناسبة لتطبيق هذه القوانين تطبيقاليقا يكرسه قضاء متخصص دو كفاءة وجودة للبرهنة على اهتمام البلاد بالتنمية الاقتصادية وتشجيع تدفق الاستثمار واشاعة الاطمئنان وضمان الاستقرار المالي، لكن الظروف والغايات التي أدت الى انشاء هذه المحاكم قد تغير الكثير منها بحكم التطورات المتسارعة كما أسلفت ، التي يعرفها أولا الاقتصاد العالمي وكذلك الاقتصاد المغربي، مما أدى الى تدخل المشرع بين الفينة والأخرى وعدة مرات لتعديل القوانين المطبقة أمام هذه المحاكم : مثلا تعديل الاختصاص القيمي لهذه المحاكم سنة 2002 وتعديل مساطر الأمر بالأداء سنة 2014 تعديل الكتاب الخامس مؤخرا من مدونة التجارة في 23 أبريل 2018 ، وقد واكب تأسيس هذه المحاكم المتخصصة الكثير من النقاش مند لحظة الانشاء الى لحظة الوصول الى محطة الحوار الوطني لإصلاح منظومة العدالة وانبثاق سلطة قضائية مستقلة. حول مدى فعالية هذه المحاكم في المساهمة في تحسين مناخ الأعمال وتشجيع الاستثمار، لكن التساؤل الذي يطرح هو:

\section{ما هي علاقة الاستثمار بالقضاء؟}

فالاستثمار هو توظيف واستخدام لرؤوس الأموال الثابتة والمتغيرة التي تملكما جهة معينة تسعى إلى خلق أو تنشيط مشاريع لإنتاج أو توفير السلع والخدمات وبطبيعة الحال لن أدخل في شرح المفهوم الواسع للاستثمار لكن رجال الاقتصاد متفقون على أن الرعدف المباشر من الاستثمار في المجال الاقتصادي يكمن على الخصوص في الزيادة في رأس المال والربح بخلق مزيد من الثروة مع ما يدفع ذلك من اهداف أخرى ذات أهمية قصوى سواء على النسيج الاقتصادي نفسه أو على ملى مجالات أخرى كتوسع نشاط الصادرات وجلب العملة الصعبة ونقل التكنلوجيا المتطورة وتشجيع وتطوير البحت العلمي، وعلى لئى المجال الاجتماعي على مستوى توفير مناصب الشغل مما يحقق نهضة في سائر المجالات، ولهذا تهتم الدول بأعداد البيئة أو المناخ الملائم لتشجيع الاستثمار وجعله من الأولويات بشتى الوسائل وعلى رأسها الوسائل القانونية والإجرائية في إطار منافسة دولية محتدمة حتى يكون الاستثمار دعامة ورافعة للتنمية الاقتصادية انطلاقا من اصدار القوانين التي تنضم الاستثمار كالقانون الاطار بمثابة ميثاق الاستثمار تحت رقم 18-95 الصادر في 29 نونبر 1995 مرورا عبر اصدار مختلف 


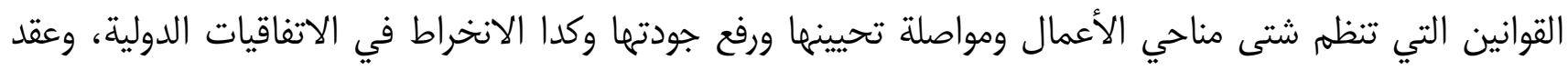

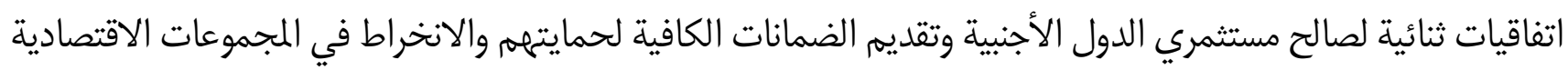

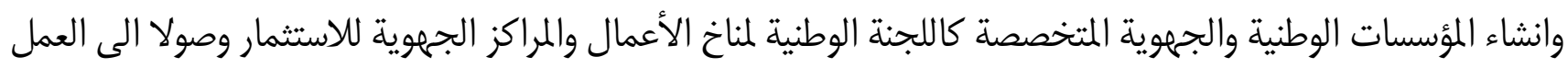

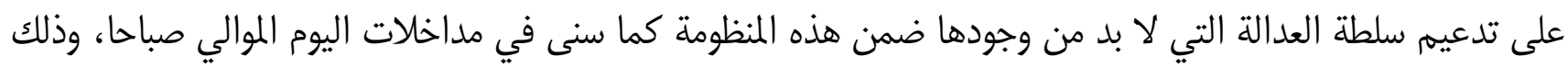

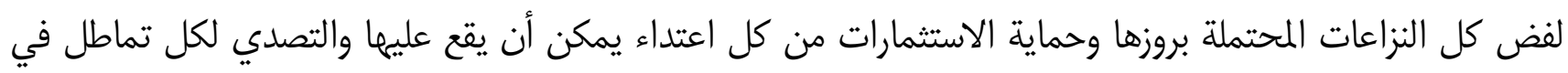

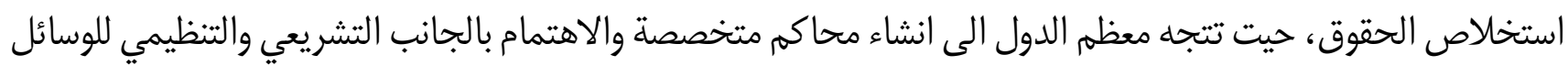

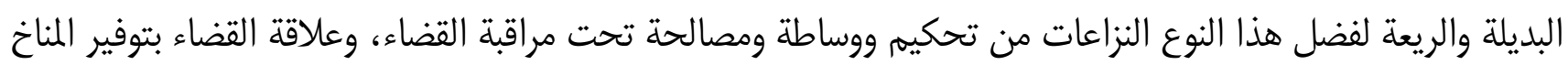
السليم والمحفز للاستثمار لا ترتبط بالقضاء التجاري فحسب رغم قرب هذا القضاء الوثيق من هذا المجال " ومن هنا نالناء

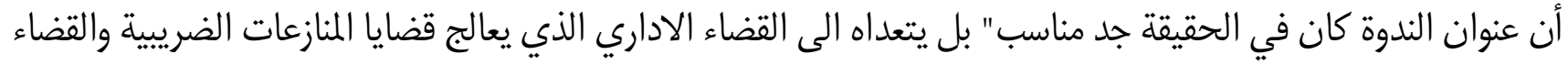

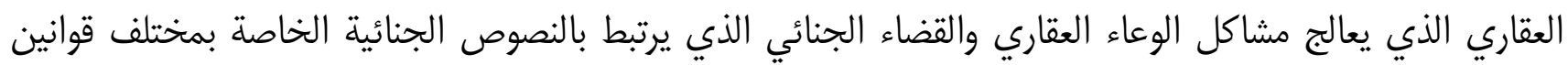

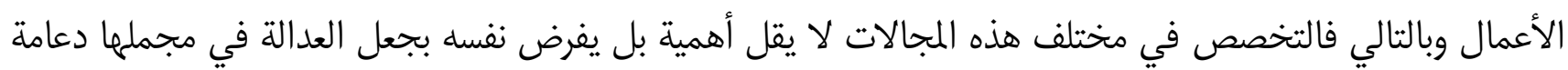
ناجحة في جلب الاستثمار في اطار سيادة دولة القانون في ميدان الأعمال.

\section{أولا: مرجعية وأهداف إحداث المحاكم التجارية بالمغرب}

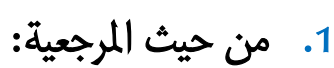

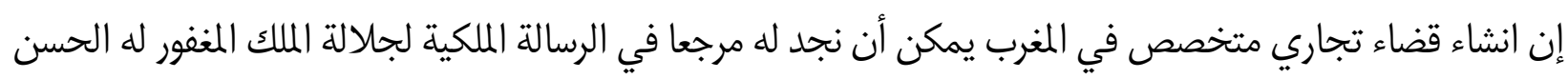

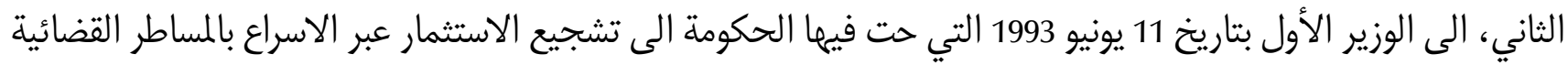

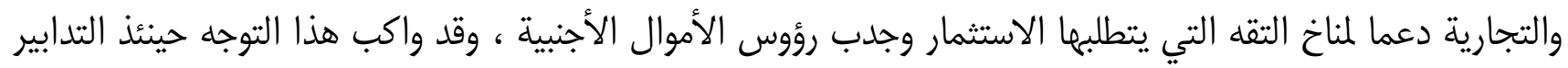

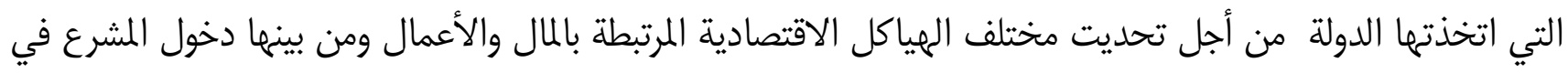

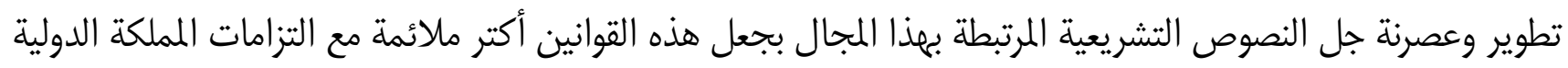

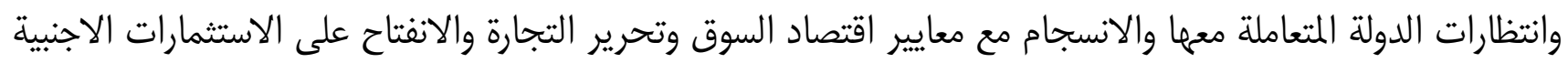

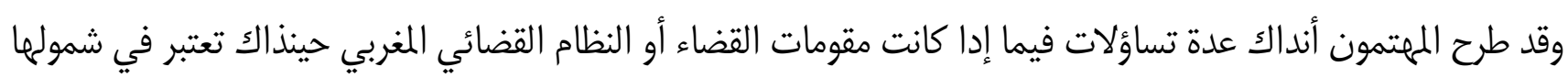

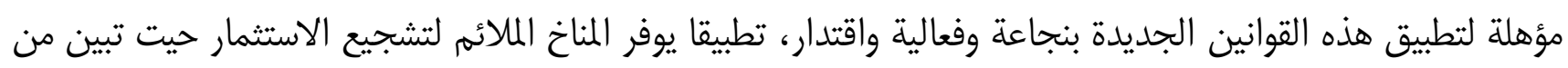

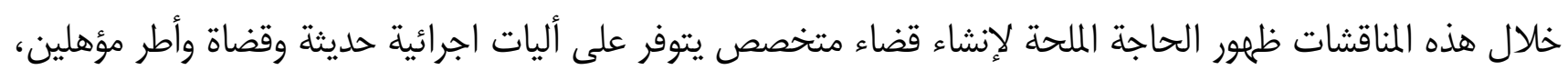

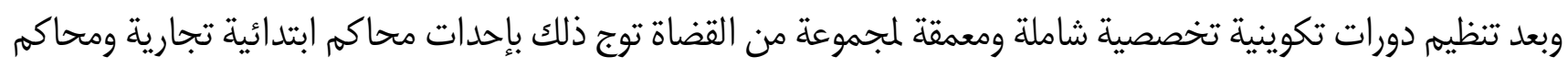

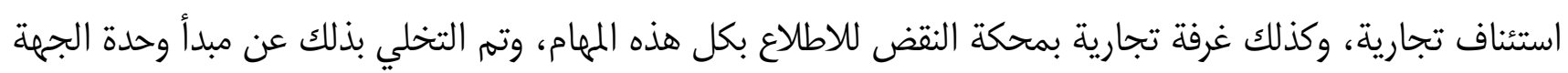

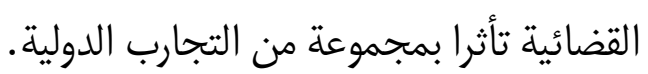

\section{2. من حيث الأهداف:}

لقد تلخصت الأهداف في تحقيق عدالة سهلة الولوج عير تبسيط المساطر القضائية عالية الكفاءة والمردودية سريعة

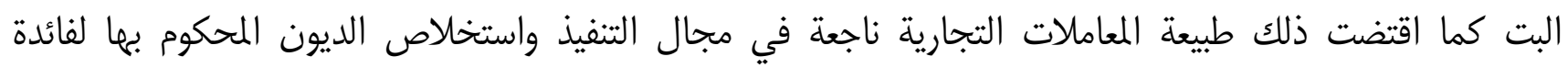

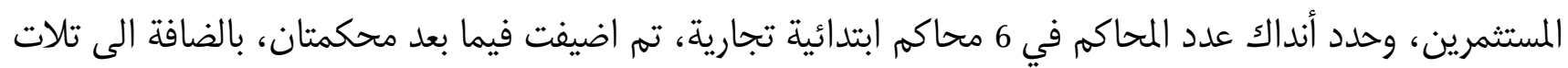




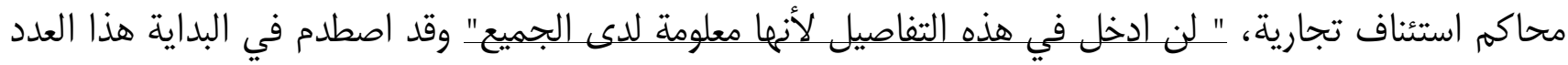
المحدود لهزذه المحاكم بواقع اتساع رقعة الخريطة القضائية للمملكة، وعلى سبيل المقارنة فان عدد المحاكم التجارية بفرنسا بلغ من 98 الى 230 محكمة تجارية، وحاليا هذا العدد قد تم تخفيضه الى 134 محكمة حسب المائ العائيات سنة 2017 ويصل

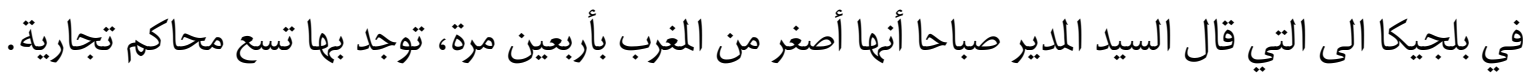

\section{ثانيا: المميزات التي جاء بها قانون الإحداث}

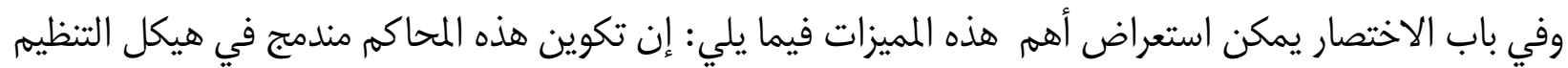

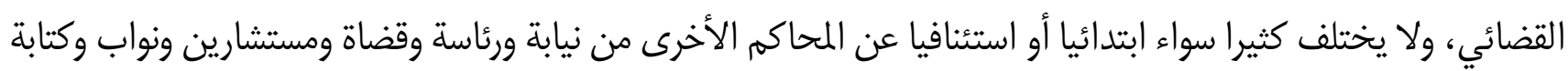

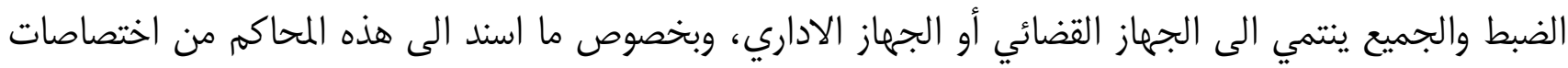

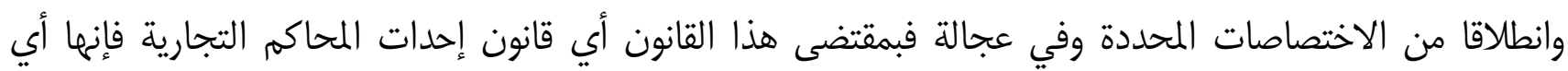

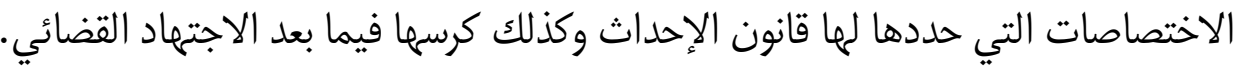

إدن تختص هذه المحاكم فقط بالنظر فيما نظمته مدونة التجارة الصادرة سنة 1997 بأجزائمبا الخمسة من أصول تجارية

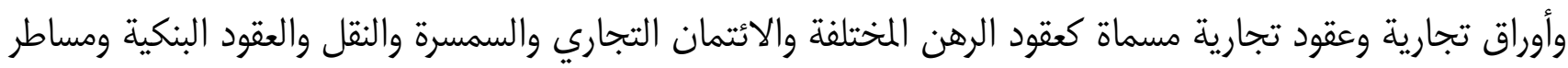
صعوبات المقاولة، بل يمتد اختصاصما الى فروع اخرى من القوانين والاعمال كقضايا التجارة البحرية الداخلية والخارجية

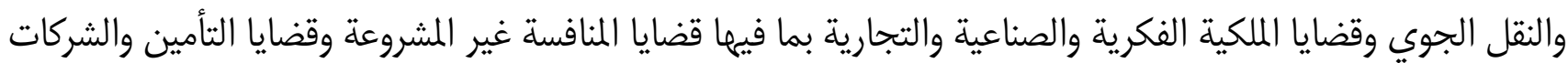
التجارية والأكرية التجارية وكلما مرتبطة بمجال الاستثمار .

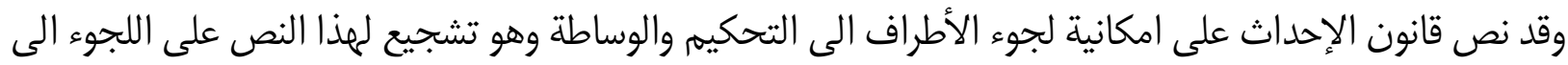

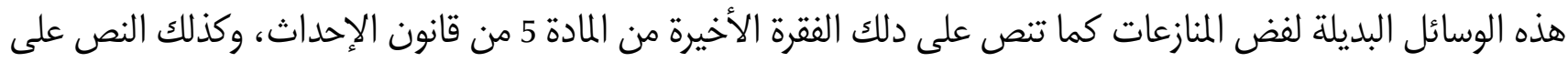

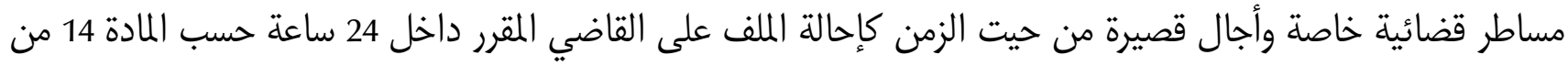

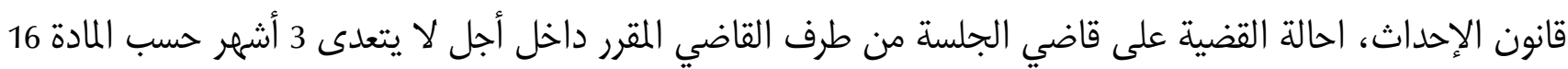

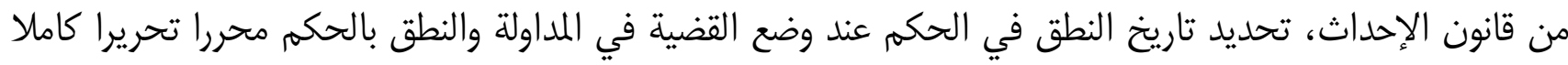

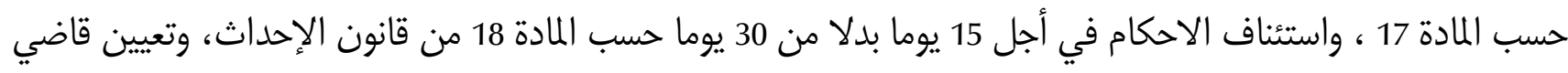

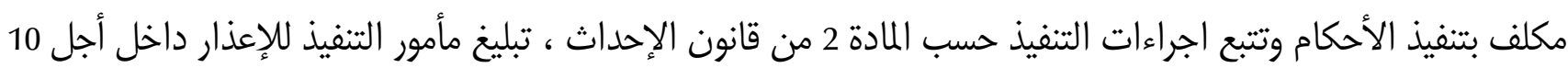

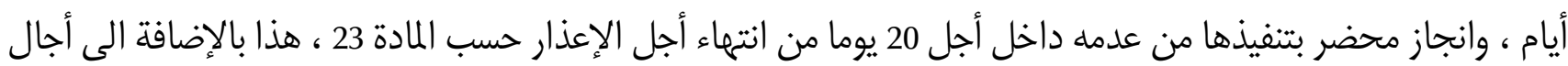

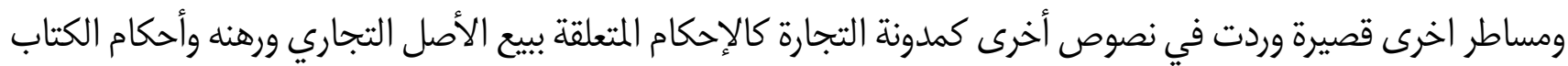

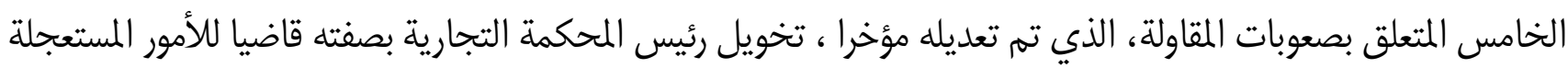

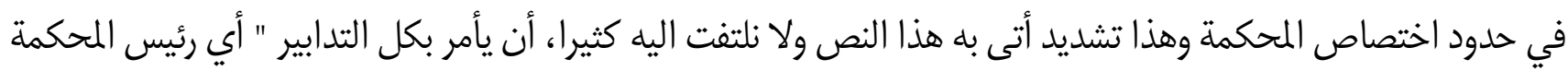

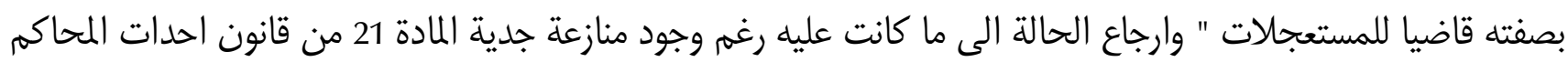

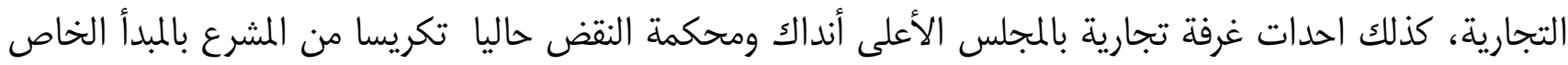


وتجدر الاشارة الى أن المجلس الأعلى أنداك كان رائدا وقبل صدور هدا القانون وقبل بداية العمل بمحاكم التجارية،

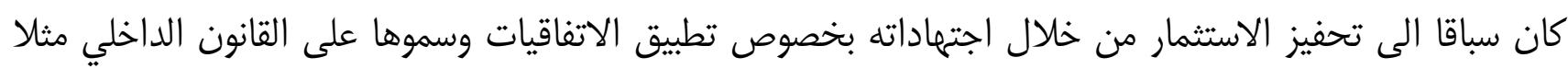

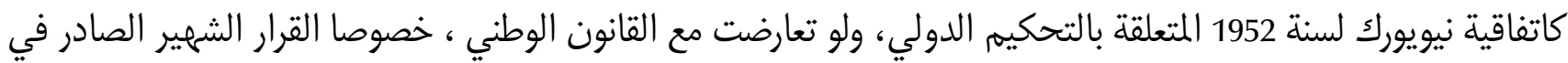
.1999/8/ 3

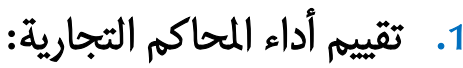

أ- أحصيلة

رأي حول حصيلة المحاكم التجارية، إن التقييم الموضوعي في الحقيقة ليس بالأمر الهين لا سيما ادا كان من أهل

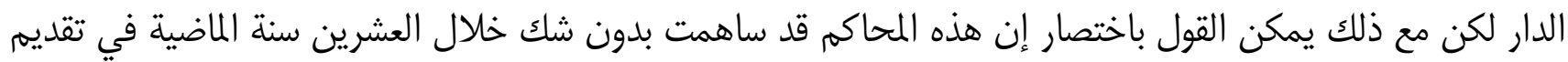

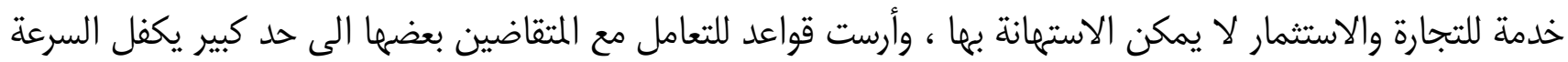

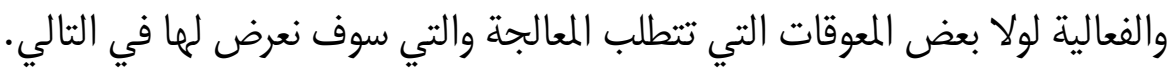

\section{ب- بعض المتسبات}

لقد حققت هذه المحاكم جملة من المكتسبات يمكن تلخيصها في تكريس العديد من المبادئ والاجتهادات القضائية،

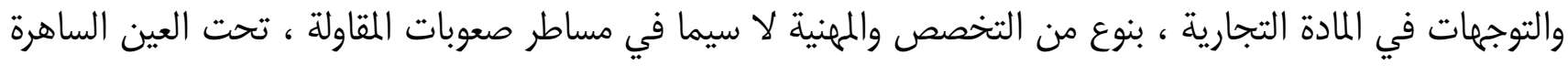

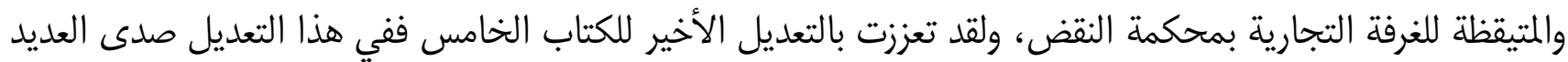

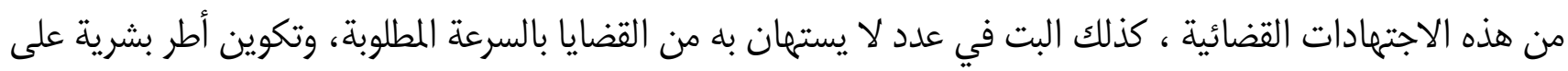

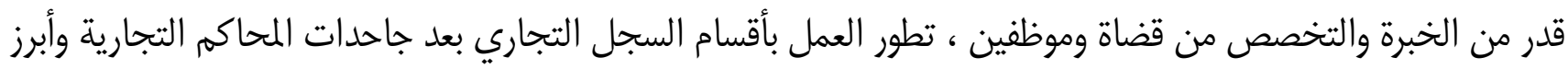

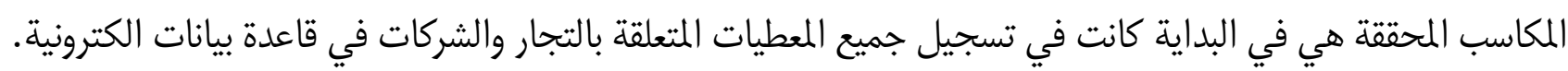

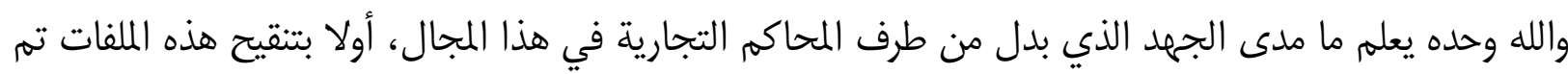

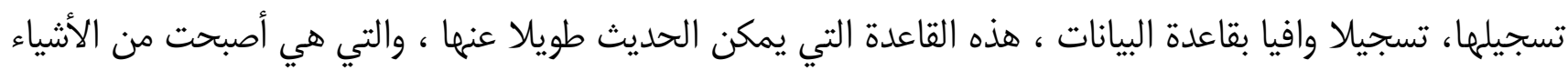

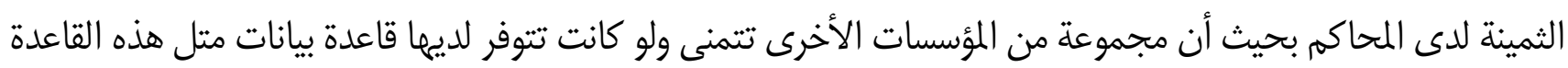

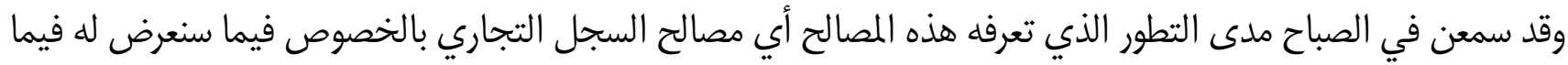

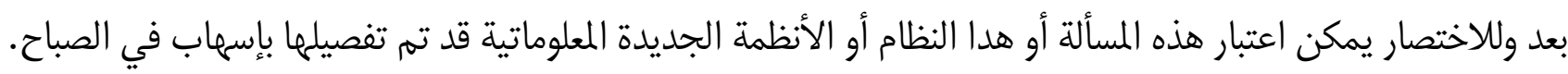

كذلك استعمال المعلوميات المتدخلة فيه ، بطبيعة الحال فالمحاكم باعتبارها كانت الواجهة للقضاء فمنذ نشأتها ساعدت

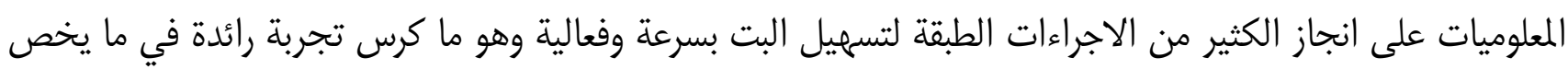

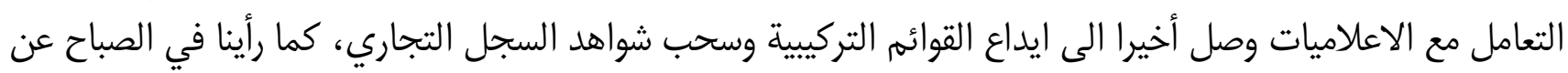

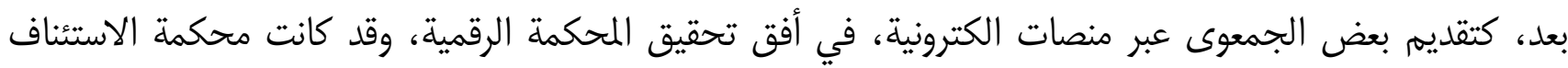

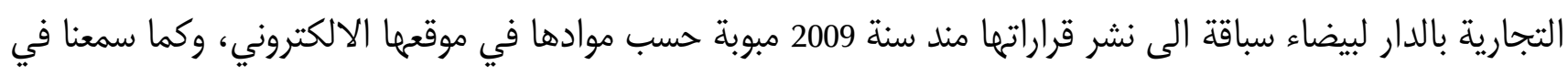

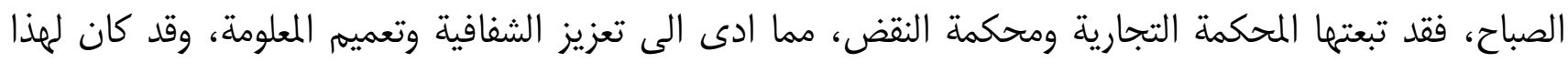

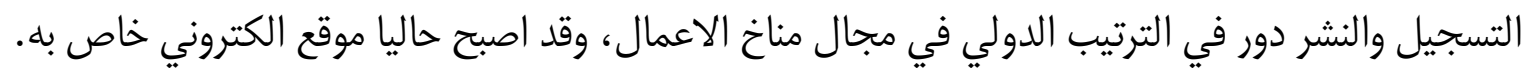




\section{ت- بعض المعوقات}

بعض المعوقات، أصبح من المعتاد عند الحديث على أبرز المعوقات، الت يتعوق ضور المحاكم التطرق إلى اشكالية التبليغ والتنفيذ التي تعاني منها هذه المحاكم، حيت يتعذر أحيانا التبليغ داخل دائرة نفس المحكمة التجارية أو المحكمة الابتدائية التجارية الساعة التوسع ، ذلك الشيء الذي لم يساعد على المعالجة المثالية لبعض القضايا التجارية بالسرعة المطلوبة للبت

وقد سمعنا في الصباح الأستاذ من أستاذنا الجليل الأستاذ محمد الادريسي العلمي المشيشي أراءه التي أضم صوتي إليها فيما يتعلق بأن الاصلاح يتعين أن يلتفت الى مجال التبليغ والتنفيذ، نفس الصعوبات يمكن أن نصف بها كذلك مباشرة قضايا التنفيذ داخل هذه الدوائر الشاسعة ، حيت أعتقد أنه يتعين التدخل تشريعيا لإصلاح قانون المفوضين القضائيين لإيجاد الحلول الكفيلة بتنقل المفوض القضائي الذي يعين أصلا في دائرة المحكمة الابتدائية ليتنقل داخل الدائرة الشاسعة سواء للمحكمة التجارية أو لمحكة الاستئناف التجاريتة، كذلك هناك مشاكل تتعلق بتعثر التبليغ بواسطة القيم، والبريد المضمون والتبليغ كذلك خارج الحدود، وفي انتظار صدور المسطرة المدنية الجديدة لإصلاح كل هذه المعوقات يمكن القول إن تحسين جودة مساطر التبليغ والتنفيذ وتبسيطها هو الكفيل باحدات قفزة نوعية حاسمة في تسريع البت في القضايا

$$
\begin{aligned}
& \text { التجارية وغيرها بشكل جدري. } \\
& \text { ث- بعض الانتقادات }
\end{aligned}
$$

إن ميثاق اصلاح العدالة الصادر سنة 2013 حدد في بنوده من 99 الى 102 الخطوط العريضة لهذه الافاق التي لا زالت تنتظر التحقيق على أرض الواقع وأبرزها ربط هذه المحاكم بالأقطاب التجارية والصناعية الكبرى وحدات أقسام تجارية متخصصة ببعض المحاكم الابتدائية احدات محاكم تجارية متخصصة بمحاكم الاستئناف للنظر في الاحكام الصادرة عن الاقسام التي ستلحق بالمحاكم الابتدائية.

وبقطع النظر عما سيتهم تنفيذه أو لا من البنود المذكورة يمكن بلورة العديد من التصورات لتحسين أداء القضاء التجاري بما يخدم الاستثمار ويشع الطمأنينة لدى الفاعلين الاقتصاديين ومنها: ضرورة الحفاظ على مكاسب التخصص والمهنية، والتي كرستها المحاكم التجارية، حيت يعتبرها المستثمرون مؤشرا على الاهتمام بمناخ الاعمال وعاملا من عوامل تحسينه، الرفع من تكوين القضاة في المجال التجاري ضمن رؤية جديدة، تضمن الانطالاق الدقيق والمستمر على كل المجالات ذات البعد الاقتصادي والتجاري، والقيام بتبادل وزيارات ميدانية بمختلف المؤسسات المتخصصة وتعزيز التكوين المستمر ، اعادة النظر في ادارة الدعوى القضائية و تدبير الزمن القضائي وهو ما تسير عليه حاليا الجاهات المتدخلة في الميدان القضائي، تحديت المساطر وتبسيطها كمساطر التنفيذ والحجز لدى الغير وتوسيع دائرة النفاد المعجل وزجر المتهربين من التنفيذ. وهنا كذلك أضم صوتي لصوت الاستاذ "المشيشي العلمي" على أنه له يعد ممكنا أن نترك الأشخاص الذين يحكم عليعم، ينفذون أو لا ينفذون حسب هواهم هذه الاحكام لا بد من ايجاد الية حقيقية للإجبار طبقا للقانون من اجل اجبار الاشخاص الذين يمتنعون بحكم أن المتضرر قد اضاع وقتا تمينا أمام المحاكم وفي الحال الذي تقوم فيه هذه المحاكم بكل ما يسعرا وبكل هذه المجهودات فإنه في الاخير هذا الشخص المنفذ عليه يقوم بإفشال جميع هذه المجهودات لكي يتهرب 


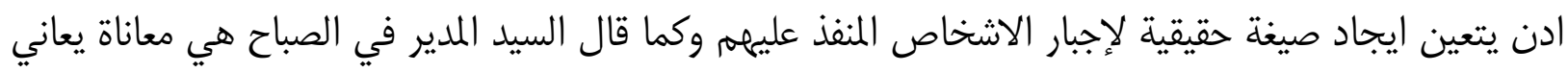

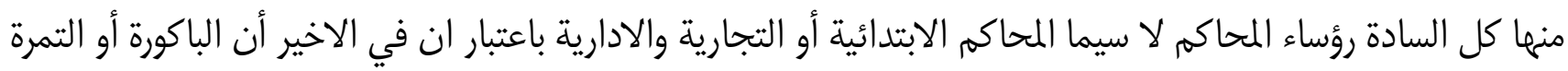

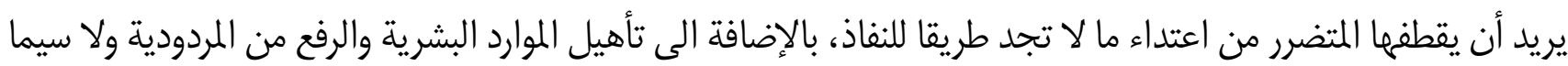

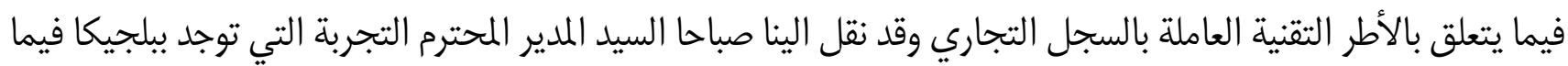

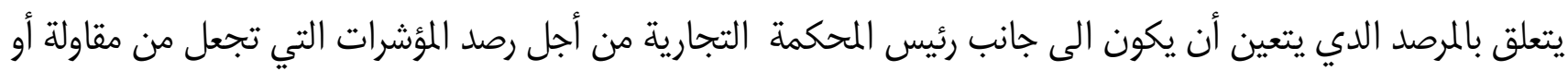
من تاجر يعرف صعوبات أولية أو ارهاصات أولية تنذر بإفلاسه.

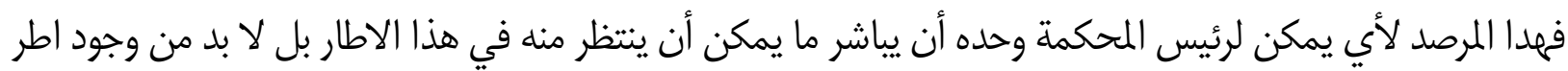
ذات تكوين عالي في المجال الاقتصادي والمجال المالي لدراسة القوائم التركيبية سنة بسنة وبطبيعة الحال دق ناقوس الخطر

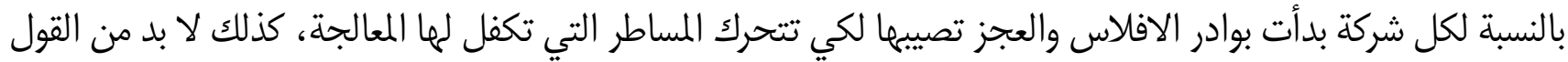

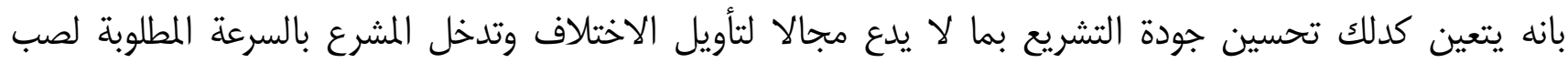

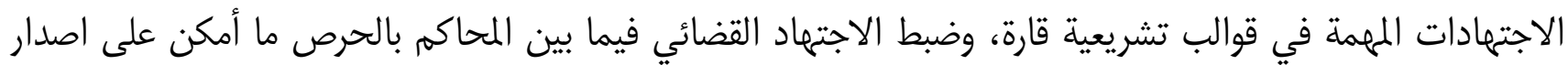

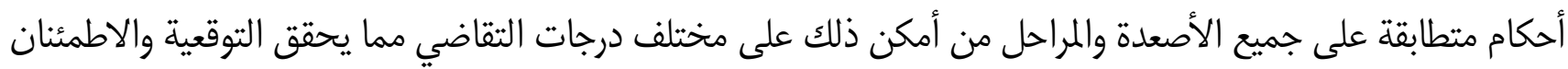
لدى المستثمر وكدلك اعادة النظر في منظومة الخبراء لأنه في مسألة الخبراء. هناك نقط جد هامة بالنسبة للقاضي التجاري، فهذا القاضي يقضي في قضايا ذات تقنيات أحيانا مغرقة في الصعوبة

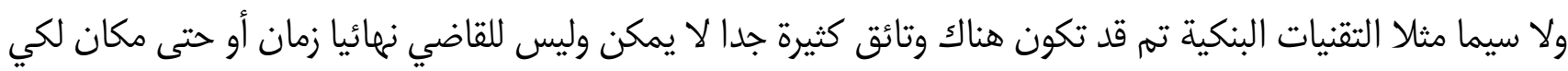

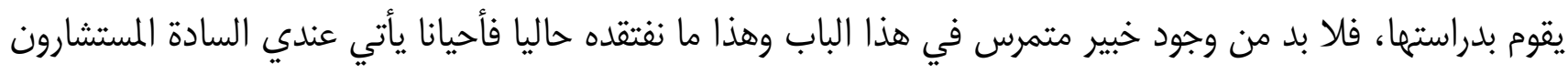

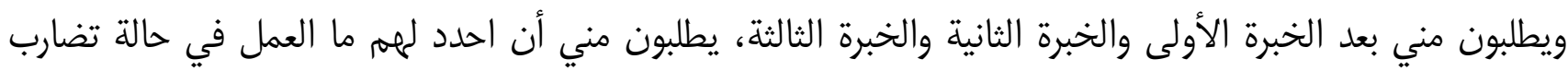

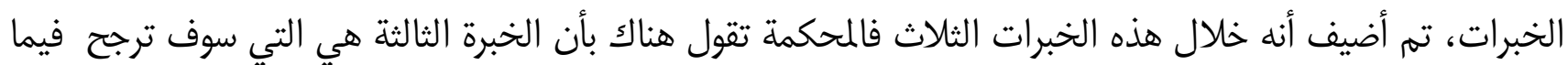

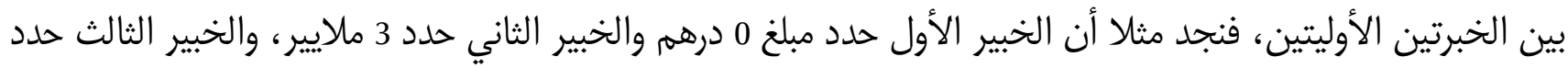

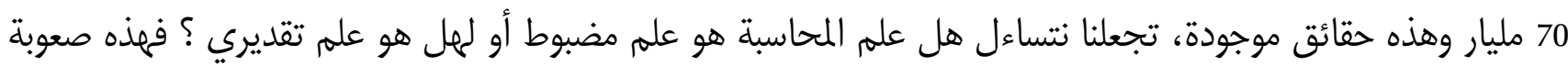

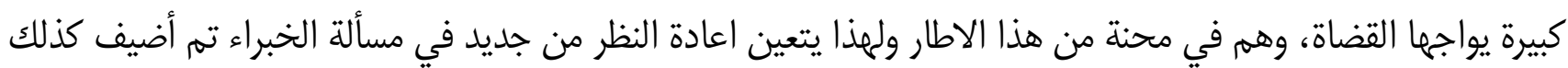

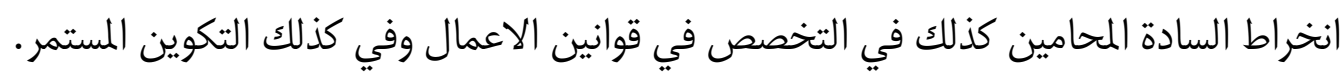

$$
\text { وشكرا لكم على تتبعكم. }
$$

كلمة السيد رئيس الجلسة: وقد قدم في هذا التعقيب بجرد كافة النقط الأساسية التي تطرق اليها السيد "عبدالرزاق

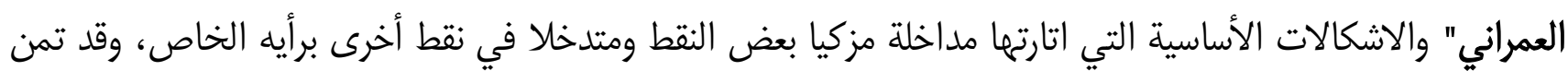

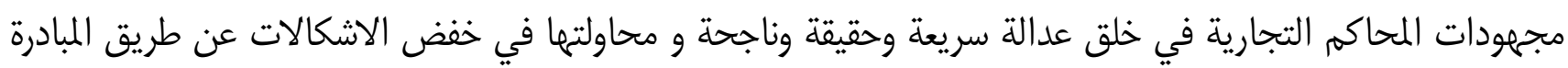
الفردية لمها بدون انتظار التدخل التشريعية. 


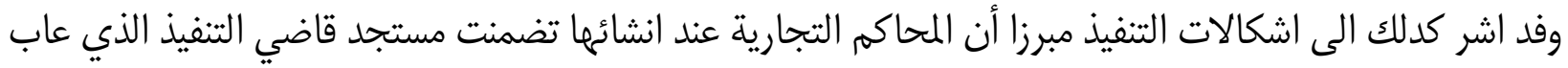

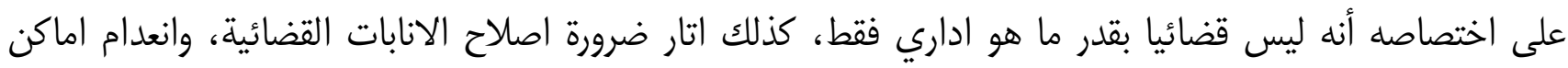

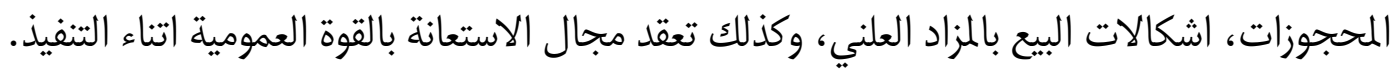
مختتما تعقيبه بتثمين مداخلة الاستاد "عبد الرزاق العمراني" لما تضمتته من معلومات ومستجدات، وشاكرا المستمعين

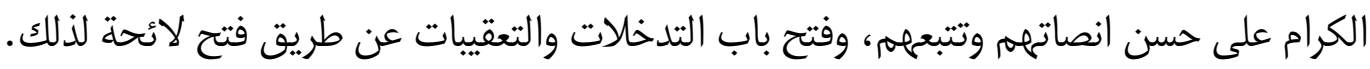

المحور الثالث: انتظارات الفاعلين الاقتصاديين من العدالة التجارية

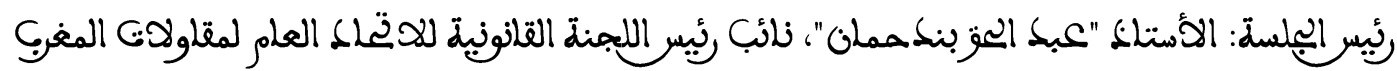
كلمة السيد رئيس الجلسة: افتتح رئيس الجلسة الأستاذ "عبدالحق بندحمان" الكلمة بالتحية للأستاذ عبدالواحد

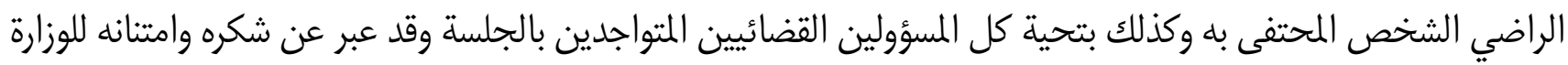
العدل والساهرين على تنظيم هذه الندوة ودعوة الاتحاد العام لمقاولات المغرب لهزذا الحفل.

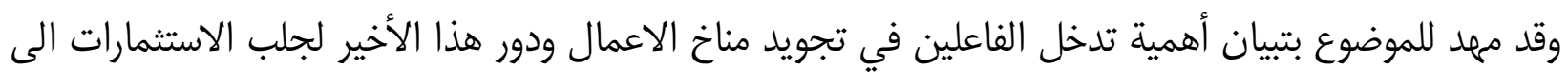

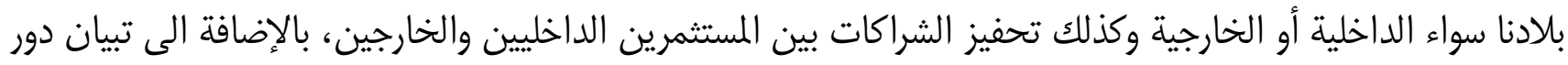
العدالة في تشجيع الاستثمار.

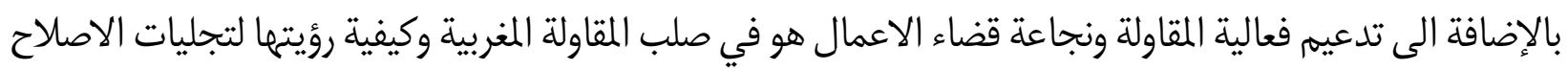

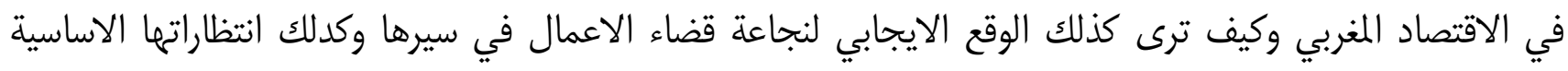

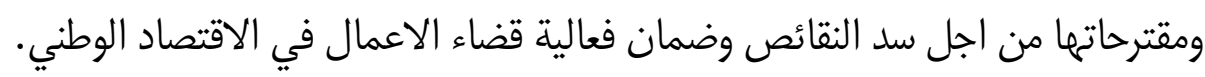
بعد ذلك مهد الأجواء للمداخلة الأولى مبينا محاورها الكبرى التي سيتولى تسليط الضوء عليها المتدخل الأول. موضوع المداخلة الأولى: نجاعة قضاء الأعمال من منظور المقاولة

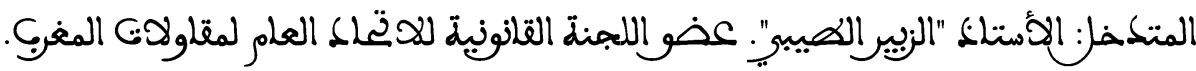
بعد تقديم شهادة موجزة في شخص الاستاذ "عبد الواحد الراضي"، وبعد شكر كل الفاعلين الساهرين على تنظيم هذه الندوة بشار في البسط لمداخلته، بسؤال كالتالي: كيف يمكن للقضاء أن يكون رافعة اقتصادية داعمة للمقاولة المواطنة ومحفزة على الاستثمار؟ مقدمة عامة:

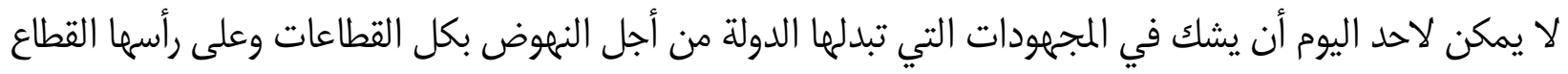

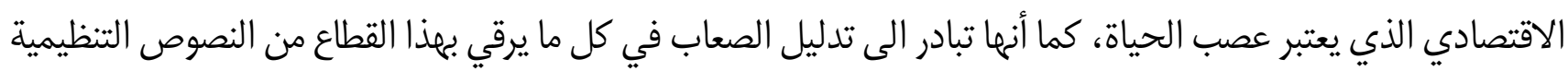

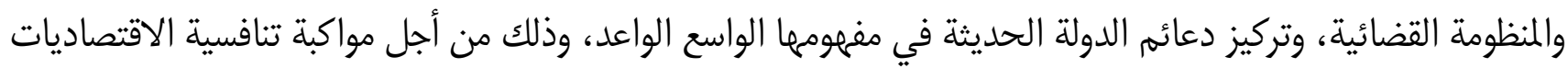

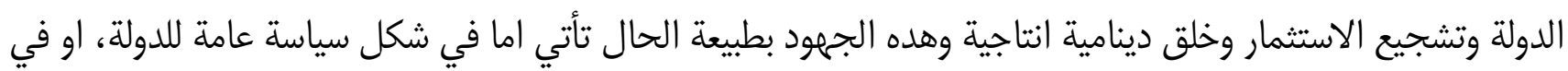


شكل استراتيجية وزارة مشرفة على تسيير قطاع معين أو في شكل مبادرات من منظمات غير حكومية تناضل من أجل

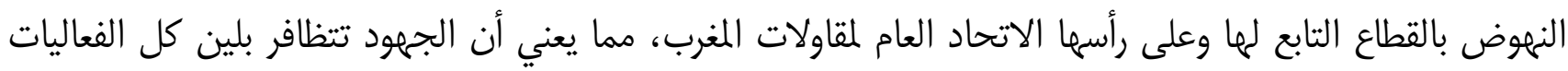

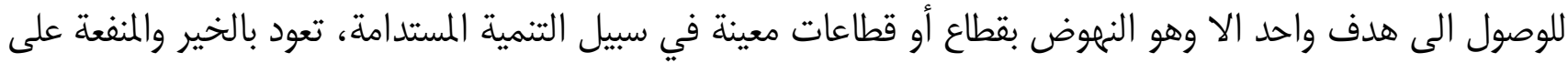
الوطن.

وعلى المستوى القضائي صرح السيد الرئيس الاول لمحكمة النقض خلال افتتاح السنة القضائية 2016، على أن العمر

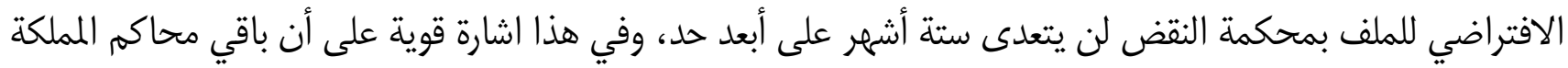

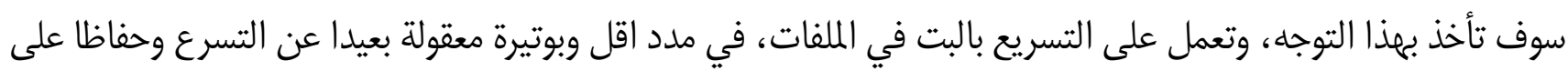

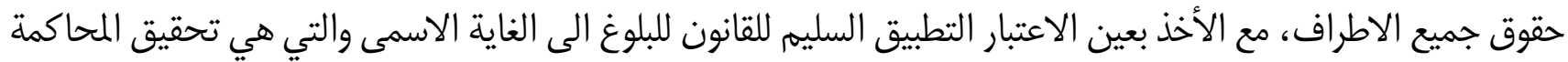
العادلة، تشجع باللجوء الى القضاء لحل النزاعات وعلى رأسها النزاعات التجارية.

\section{النقطة 1: على المستوى التشريعي والاداري}

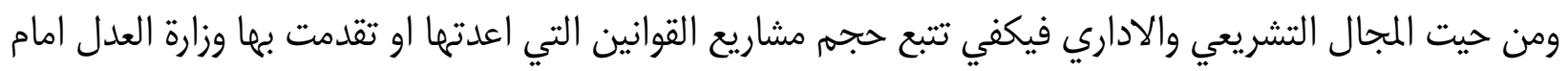

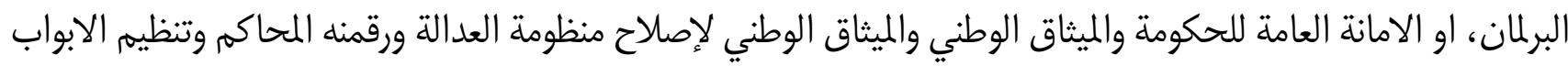

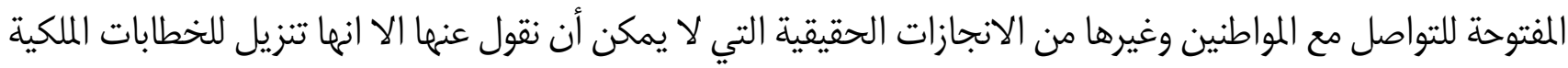

السامية ولإرادة حقيقية من اجل عدالة حديثة.

\section{النقطة 2: تنزيل ديمقراطية تشاركية}

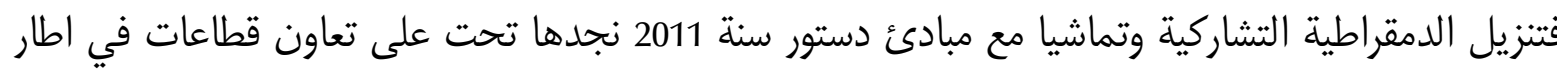

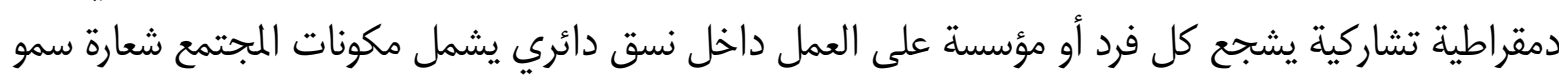

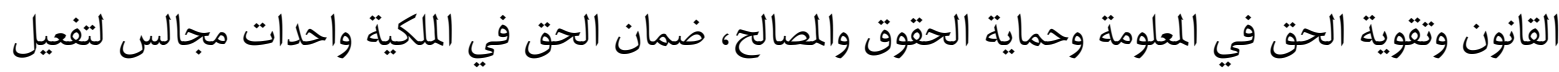
هذه المبادئ والسمر على تنزيلها على أرض الواقع. واعطاء ادوار مهمة لمنظمات حكومية في اعطائها رأيها من التشريعات القانونية والقضائية منها على وجه

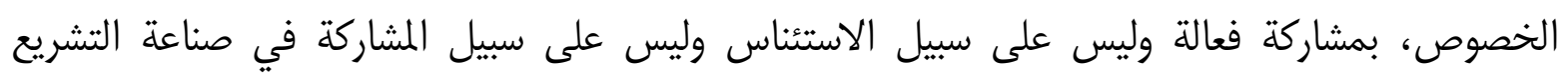

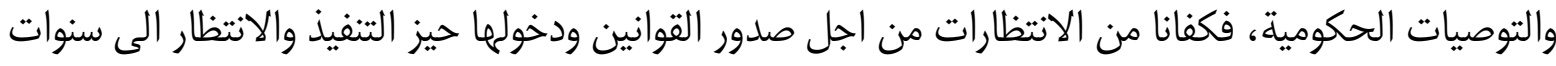

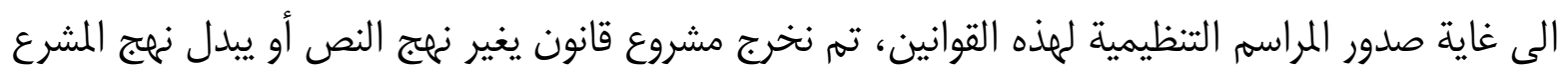
في ذلك القانون.

النقطة 3: انتظارات الاتحاد العام لمقاولات المغرب

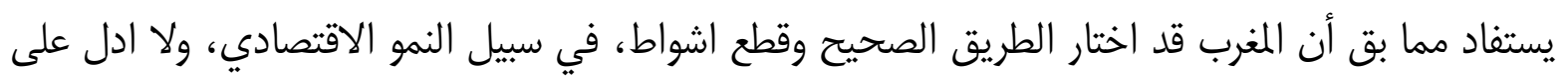

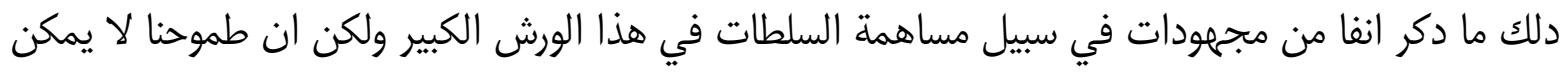

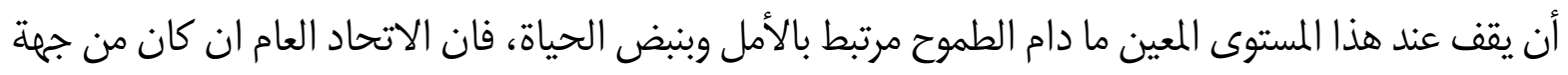


يتمن هذه المبادرات الى انه من جهة اخرى لا زالت لديه عدة انتظارات، يرى فيها مفتاح الاشكالات القانونية، والمشاكل اليومية التي تتخبط فيها القطاعات الاقتصادية، مما يبطئ من وتيرة تقدمها وقوة تنافسها. فانتظارات الاتحاد العام لمقاولات المغرب، يمكن تخليصا في: " تأمين وضمن حرية المقاولة وحرية المشاريع؛ خلق جو الاستثمار ووضوح الرؤية بالنسبة للمستثمر؛ الاسهام في ضمان التنافسية الواعدة والمستدامة؛ الاسمام في خلق فرص الشغل والاستثمار؛ • خلق القيمة المضافة المحلية؛ مواكبة التطورات والتغيرات الخارجية الاقتصادية تفاديا لكل تراجع؛ الاستخدام الفعال والناجع للتكنولوجيا الحديثة؛ مونيك جعل العدالة رافعة اقتصادية ومحفز على الاستثمار وذلك بإصلاح منظومة العدالة بكل مكوناتها وفعالياتها؛ - تحديت القوانين والخريطة القضائية بما يتماشى والمصلحة الاقتصادية

\section{النقطة 4: تأمين وضمان حرية المقاولة وإحداث المشاريع}

ففي اطار تأمين ضمان حرية المقاولة وإحدات المشاريع، وذلك من خلال التعامل الكامل مع المقاولة على اساس انها شخص كامل اعتباري مستقل كامل الاستقلال، وليس كشخص ذاتي اي عدم تجسيد المقاولة في شخص صاحبها، ولأسف نلاحظ ان هذه القوانين الحالية لا تتبنى هذا النهم سواء فيما هو جاري به العمل في المحاكم ، أو حتى في النظرة المستقبلية وخير متال على ذلك في مشروع القانون الجنائي الفصل 36-1 بشأن العقوبات الاضافية ينص على منع الشخص هـ هـ

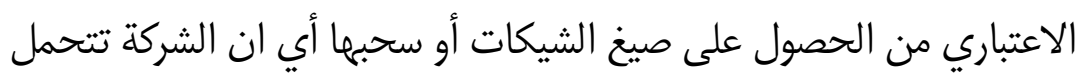
وزر افعال ممثلما القانوني الذي أصدر شيكات بدون رصيد فتمنع هي على الدوام من التعامل بالشيك. وفي هذا الصدد ام ان الاوان لفتح اوراش العمل مع جميع الفعاليات الحقوقية والاقتصادية وعموما فكل ما يدور في فلك الجسم القضائي والقانوني والمقاولاتي لإيجاد حل موضوعي لهذه الافة اي افة اصدار شيك بدون رصيد، وهنا الكل يعلم ان غالبية المتعاملين بالشيك بدون رصيد يصدرونه على سبيل الضمان وهنا اصبح امام علاج افة بأخرى والعدول على لي ارتكاب جنحة بأخرى ، ومن هذا المنبر اود سادتي ان اعرض عليكم مشكل اخر، من المشاكل اليومية التي تعيشها المقاولة المغربي، حول موضوع مصادرة وسائل النقل في مخالفات نقل البضائع والاشياء الممنوعة بمقتضى القانون، ذلك وان النيابة العامة وبعد حجز تلك الناقل يظل هذا الحجز ساريا الى غاية مدة غير محددة، بالرغمم من كون الشركة صاحبة الناقة غير

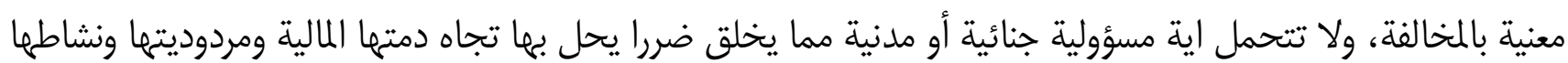
تجاه زبنائمها وهكذا تظل الناقلات المحجوزة عرضة للتمالك والتفكك في انتظار صدور حكم في الموضوع قد تطول مدته لتتحول بعدها الى اشلاء او خردة دون اي قيمة مالية تدكر، وتدفع الشركة ملايين الدراهم للمحجز عن مدة الحجز، ولوضع حد لمزهه المأساة يحق للمقاولة المتضررة أن تدخل لوضع تعديلات على القانون المطبق، وذلك بالتنصيص على اعطاء صلاحية 


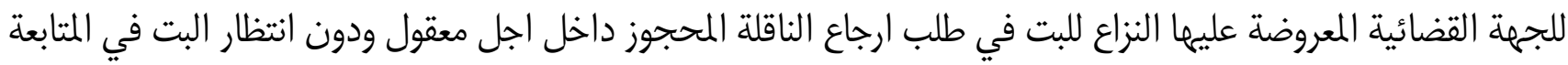

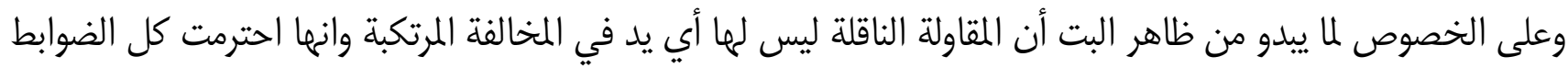

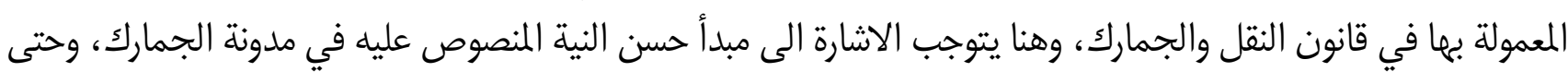

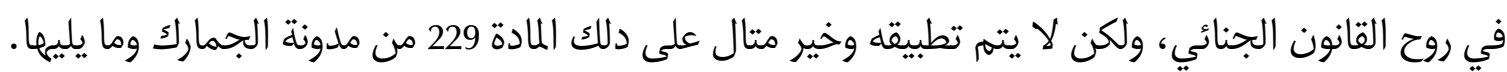

\section{النقطة 5: خلق جو من الاستقرار والوضوح للمستثمرين}

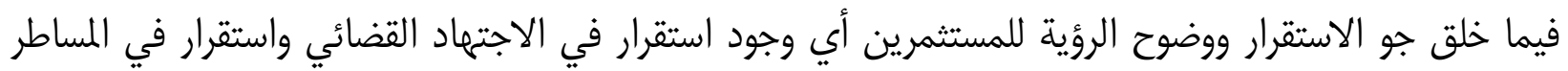

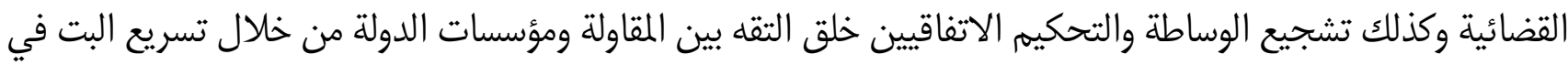
الدعاوى واعادة جدولة الديون ووضع مخططات على مدى العشرية أو العشرينية توضح وضوح الرؤية بين سياستها واستراتيجيتها التنموية.

\section{النقطة 6: الاسهام في ضمان التنافسية الواعدة والمستدامة}

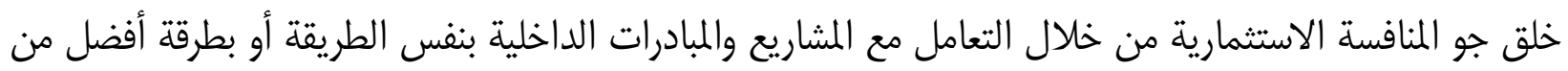

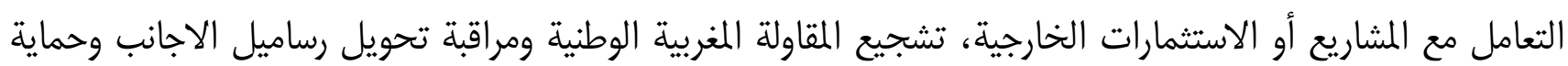

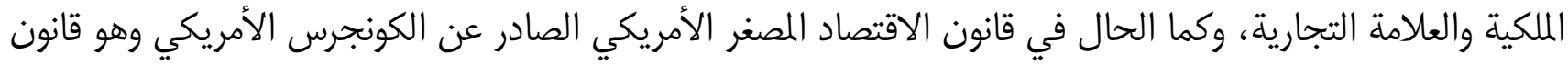

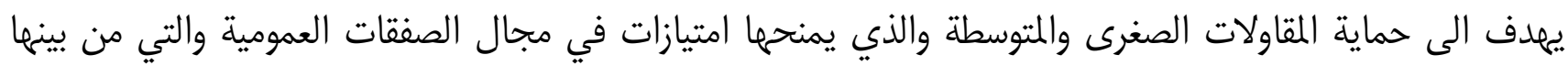

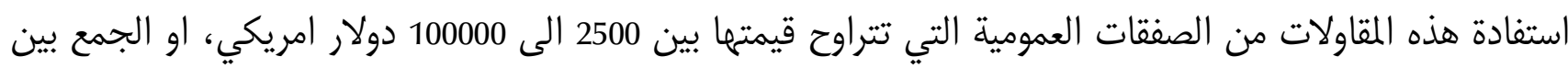
مقاولتين او اكتر للضفر بصفقة عمومية ،

بالإضافة الى تمكينها من الحصول على عقود المقاولة من الباطن، فالاقتصاد الامريكي يستهلك اربعين في المئة من

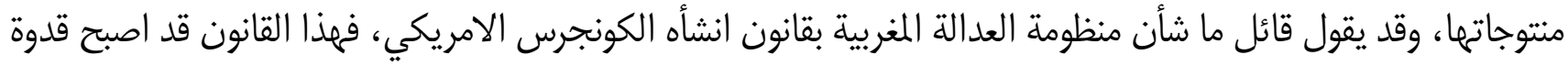
للمقاولات الصاعدة بان القضاء الامريكي التجاري قد استجاب للمقاولات الصغيرة والمتوسطة والصغيرة جدا مند نماية الصاية

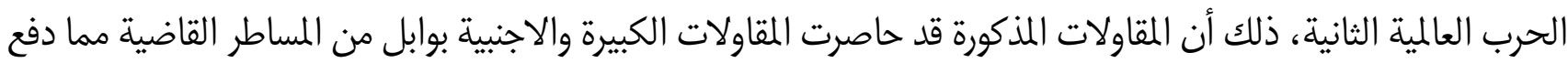

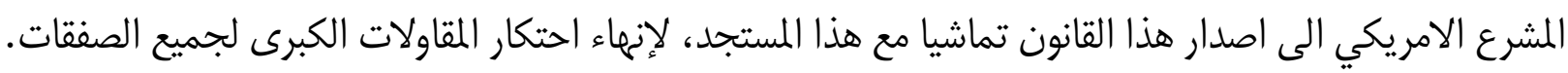
ولنا في هذا خير متال على تشجيع المقاولة الصغيرة والمتوسطة والصغيرة جدا بالإضافة للمقاولة الشبابية عن طريق تدعيم هذه الفئة الشابة والفتية.

\section{النقطة 7: الاسهام في خلق فرص شغل للاستثمار}

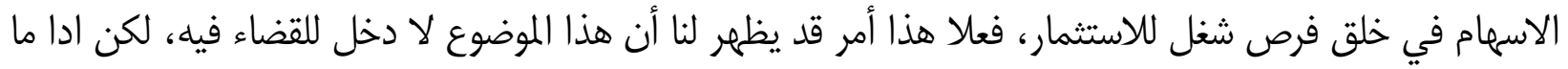

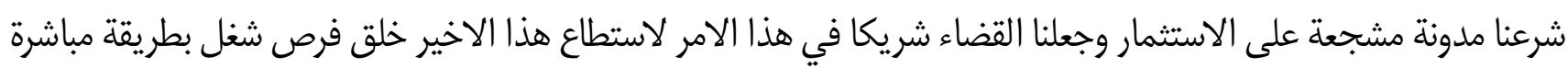

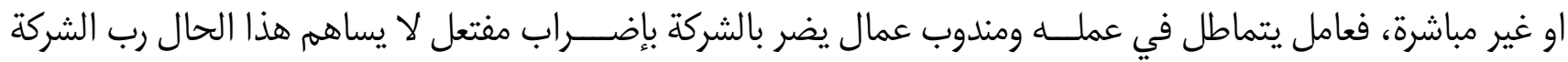

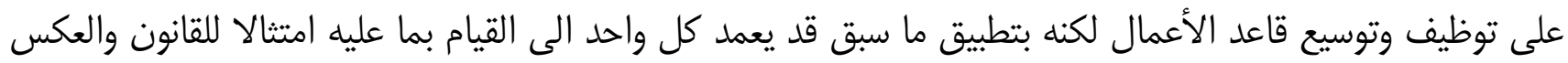




\section{النقطة 8: الاسهام في خلق القيمة المضافة المحلية}

الاسهام في خلق القيمة المضافة المحلية من خلال اعتماد اللاتمركز الاداري، بما في ذلك السلطة القضائية تفاديا لتركز جل الاستثمارات بالمناطق الكبرى وتهميش المناطق البعيد، وكذلك لتقريب مرفق القضاء من المواطنين في كل انحاء المغرب بدون اي تمييز، فبالرجوع لمشروع الميثاق الوطني للاتمركز الاداري والجهوية المتقدة والمعروض حاليا على البرلمان، سنجده لا يشير باي حال للخريطة القضائية للمملكة، لتكون مواتية ومنسجمة مع هذا التقسيم الجديد.

كما تعيش بعض المناطق في باب التشريع حيفا فيما يتعلق باحدات محاكم متخصصة، مما يؤثر سلبا على نمو اقتصادها، كما أن عدم استقرار النص القانوني وتغييره في مدد قليلة لا يساهم في الاستقرار والامن القانوني والقضائي، فمثلا نجد التنظيم القضائي الجديد يروم تقسيما جديدا للغرف بالمحاكم الابتدائية فخوف التحاد العام لمقاولات المغرب من التراجع على الاختصاص علما أن المحاكم التجارية قد اتبتت نجاعتها وكرست لنا اجتهادا قضائيا يلجأ له المواطن العادي قبل الخوض في اي نزاع قضائي.

\section{النقطة 9: مواكبة التطورات الاقتصادية والاجتماعية تفاديا لكل تراجع}

ومواكبة التطورات الاقتصادية والاجتماعية تفاديا لكل تراجع، يتطلق هذا الامر الايمان الراسخ والمتجرد بمبدأ التخصص والمهنية أي الرجل المناسب في المكان المناسب، فلا يعقل أن قاضيا يصول ويجول بين مختلف التفريعات القانونية وكذلك بين القضاء الجالس والواقع وتنظر منه ان يعطي اجتهادا قضائيا مستقرا وفعالا، وعلى سبيل المتال ومن باب التعاون القضائي بين المغرب والجمهورية الفرنسة ، قد انتقل وفد مغربي لتلقي تكوين في مجال قضايا الصحافة بفرنسا، في اطار زيارة للمحكمة الاستئنافية بباريس صرحت لهم احدى وكيلات الملك بكونها متخصص ل 15 سنة في جنحة التشهير، وان كانت هذه الجنحة لا تشكل الا جزءا من قضايا الصحافة التي تتجاوز 50 جنحة، مما يستفاد منه أن تهيئة قضاة متخصصين في مادة معينة يتطلب تكوينهم في الغرف والاقسام التي تنظر هذه المادة لصقل مكوناتهم ومكتسباتهم فيما لنحصل على عمل قضائي في منتهى الفنية والحكمة والعدالة.

\section{النقطة 10: مواكبة التطورات الاقتصادية والاجتماعية تفاديا لكل تراجع}

فيما يخص الاستغلال الفعال والقوي للتكنولوجيا الحديثة، فهذا موضوع يستلزم ندوة خاصة به نظرا لتأخر بلادنا ومنظومتنا القضائية في التعاطي مع هذه التقنيات فلا زلنا نتعامل مع اشكالية التوقيع الالكتروني وتنفيذ العقود وتبليغ الاستدعاءات، والرسائل الالكترونية والجلسات عبر تقنية الفيديو المباشر، وحتى اذا كانت الوزارة تعمل جاهزة على تعميم الرقمة فان العنصر البشري لا زال لا يجيد هذه التقنيات، حيت لازلنا نتوصل بأحكام بخط يد بالكاد يكون مقروءا، ونقدم هذه الاحكام كحجج أحيانا اما المنتظم الدولي.

\section{النقطة 11: جعل العدالة رافعة أساسية ومحفزة على الاستثمار}

جعل العدالة رافعة اساسية ومحفزة على الاستثمار فلا زلنا نرى مثلا ان النيابة العامة امام المحاكم الابتدائية لا زال دورها زجري فقط، ومصلحة السجل التجاري لا زالت محينه وانها تتلقى تصريحات التجار بدون التحقق من صحتها وكذلك تقرير الميزانية السنوية قد لا تجده بالنسبة لجميع الشركات، ومؤسسة المفوض القضائي لا زالت غير قادرة على التحقق من

$$
\text { هوية مستلم الاجراءات أو انه معني به. }
$$


خاتمة:

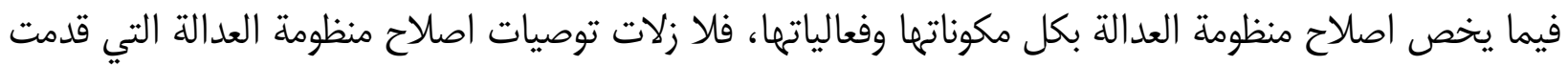

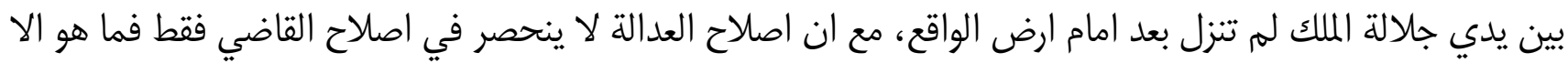

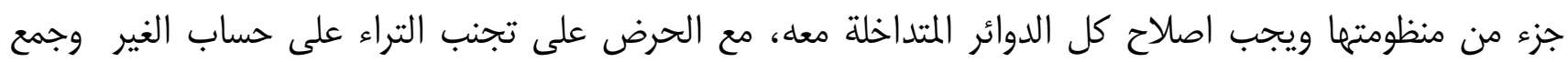

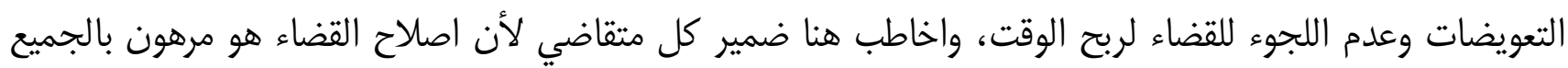

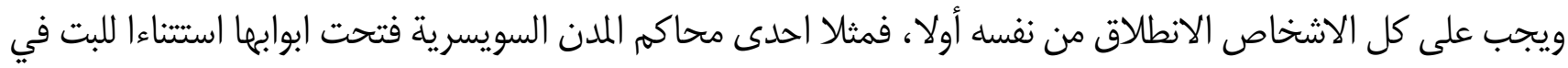

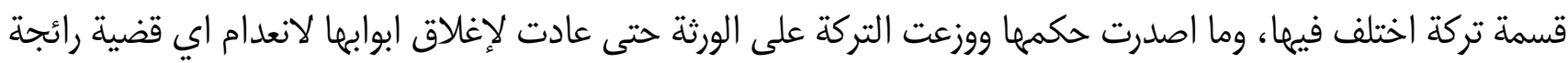

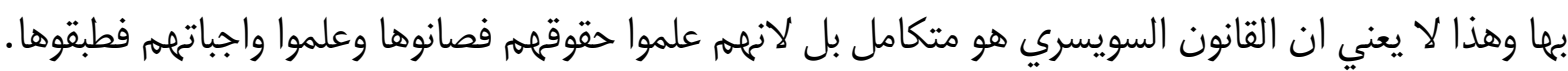

وشكرا

كلمة السيد رئيس الجلسة: بعد انهاء المتدخل لكلمته عقب السيد رئيس الجلسة عليها مباشرة مستعرضا خطوطها

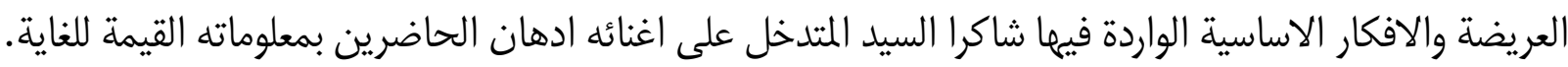
وكذلك مهد للمداخلة الثانية وعارضها الذي باشرها في القائها تلقائيا بعد ان تلقى ذلك من رئيس الجلسة.

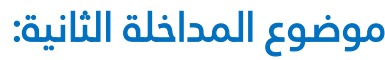

تجويد قانون الأعمال وأثره الإيجابي على المقاولة وتحسين صورة المغرب في التقارير الدولية.

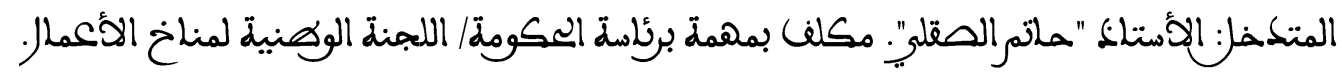

\section{مقدمة عامة:}

بدأ المداخلة بتقديم الشكر والتقدير لكل الساهرين في هذا الحفل العلمي البهيج وكذلك الادلاء ببعض الشهادات

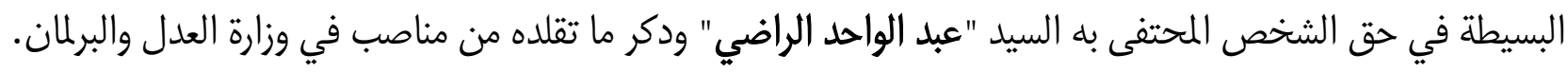
سأحاول قدر المستطاع ان ابين دور اللجنة التي انتمي اليها وهي اللجنة الوطنية لمناخ الاعمال، ودور ووزارة العدل في

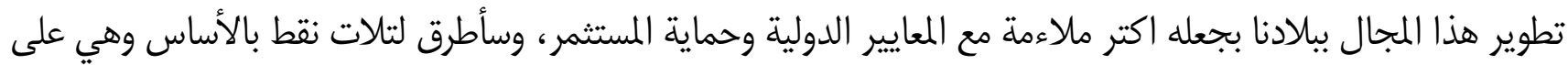

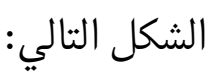

\section{النقطة 1: تذكير بالسياق العام وعمل اللجنة الوطنية لمناخ الأعمال}

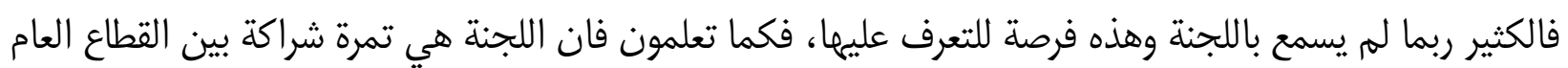

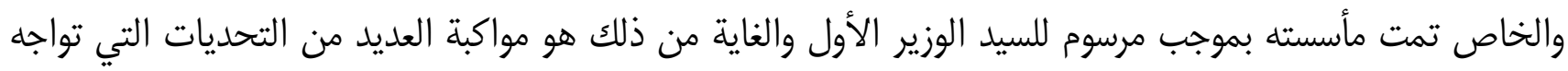

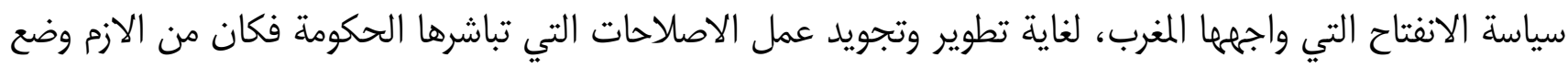

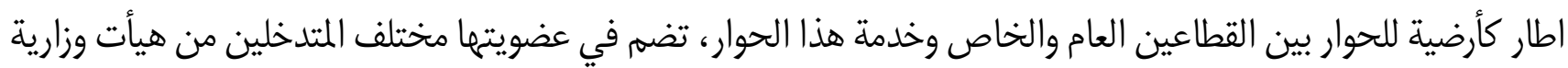
وقطاعات نقابية وغرف مهنية وابناك ومؤسسات الرقابة ومجموعة من المهنيين الذي يشاركوننا العمل كالموثقين والمحاسبين، 
وعملها يتجلى ضمن الاوراش الاقتصادية المهادفة لتحقيق نمو شامل وتعمل في اطار التوجيهات الكبرى التي يقدمها

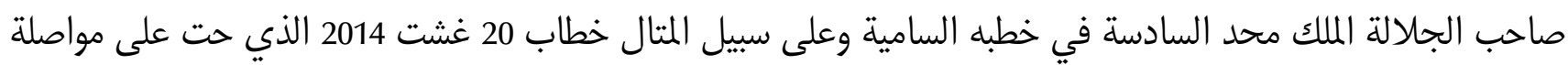
اصلاح قطاع الاعمال وجعله الية لولوج المغرب نادي الدول الصاعدة، واعادة النظر في نموذجنا التنموي الحالي الذي هو موضوع نقاش وعمل إقليمي.

كذلك عمل الندوة هو يندرج في اطار برنامج العمل الحكومي، الذي يحت على تقوية الاقتصاد والرفع من النمو اكتر

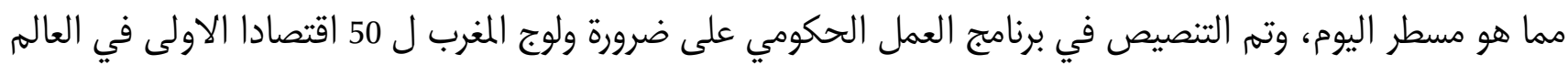

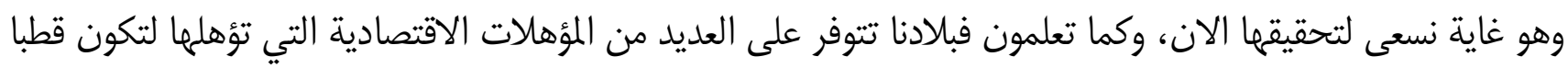

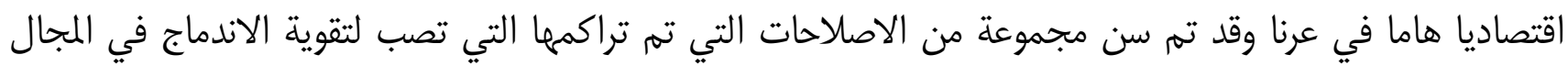

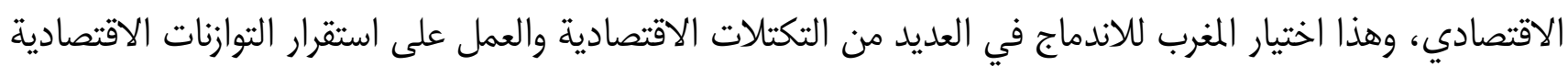

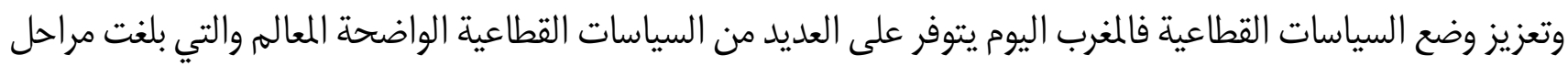

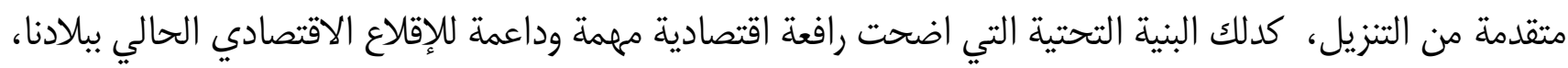
وتحسين مستمر لمناخ الاعمال ببلادنا وتحسين صورة المغرب في الساحة الدولية من الناحية الاقتصادية.

\section{النقطة 2: أهم الإصلاحات المتخذة لتحسين مناخ الأعمال}

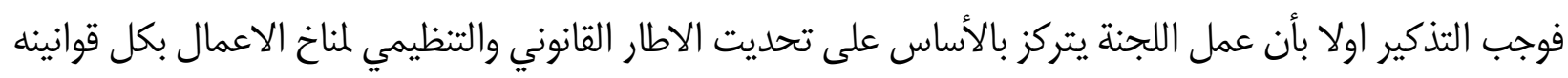

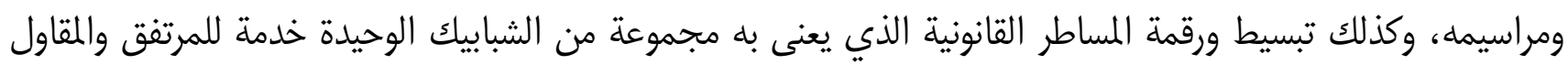

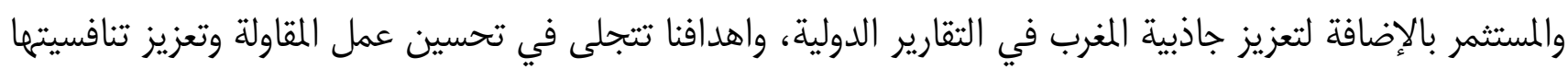

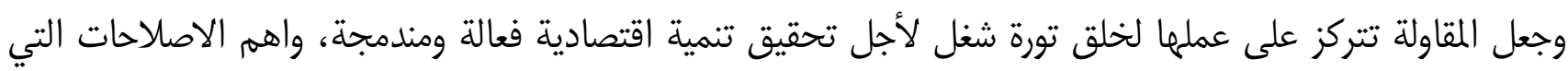
تدخلنا فيها تجلت في العمل على تعديل قانون شركات المساهمة، هذا القانون الذي تم تعديله في مناسبتين سنة 2015

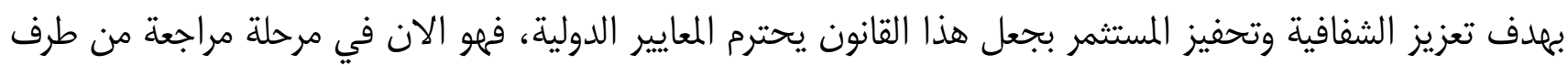

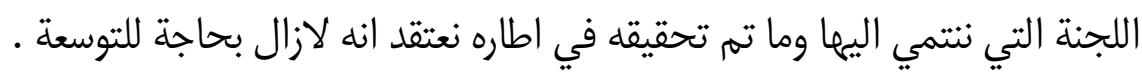

كذلك اعتماد قانون الشراكة بين القطاعين العام والخاص، فقد تم اخراج القانون وكذلك اصلاح قانون الامر بالأداء

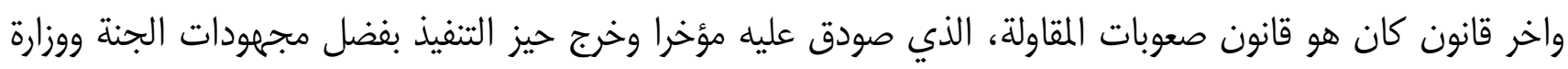

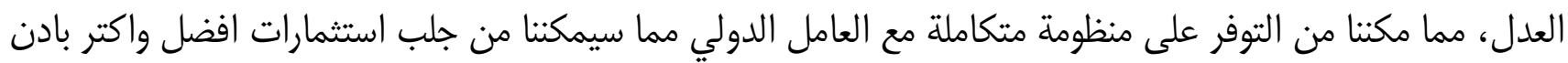

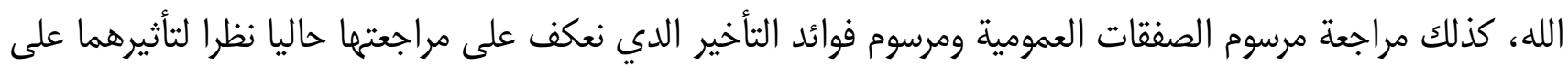

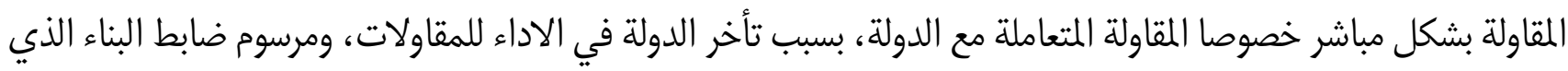

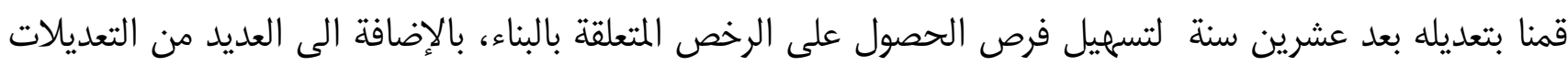

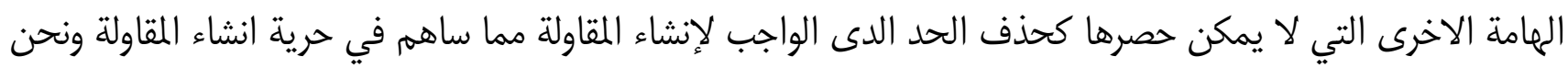

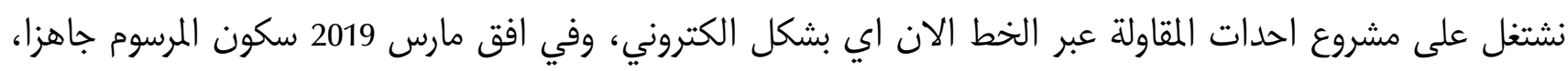

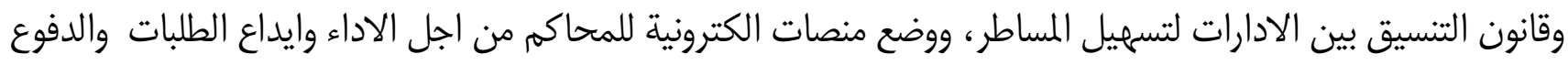

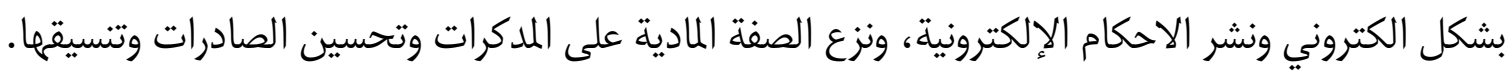




\section{النقطة 3: تذكير بالسياق العام وعمل اللجنة الوطنية لمناخ الأعمال}

فكما تعلمون ان الهدف يبقى دائما دو ارتباط دولي ودلك من اجل تحسين صورة المغرب دوليا ونحن الان نعمل على تحسين اليقظة على هذا المستوى من اجل استباق القدرات بتحسن تنافسية البلد ورصد المنافسين له واحترام المعايير الدولية مما سيؤثر على صورة وجاذبية البلاد، والتقارير الدولية بالنسبة لنا هي دات اولوية للاشتغال عليها، باعتبار انها يتم تداولها من مختلف المنابر الاعلامية لإشعاعما الدولي وتستعمل في تصنيف البلدان والمقارنة بين اقتصاديها وتحديد رتبها حسب جاذبيه اقتصادها.

بالإضافة الى اعتمادها من طرف العديد من المؤسسات المانحة للسيولة المالية كالبنك الدولي وغيره، ويلجا العديد من المستثمرين اليها لأخد قرار الاستثمار في البلد او لا، كذلك لها دور في المنافسة التي تتوجب متبعتها بشكل منتظم من طرف هيأت مختصة، وما نقوم به تقوم به العديد من الدول متل الامارات العربية التي سطرت الرتبة الاولى في العام 2021 وفرنسا ولوكسمبورغ وماليزيا وتركيا والبرازيل، كل هذه الدول تتوفر على هيأت مشابهة تقوم بنفس المرمة، وقد عملت اللجنة على انشاء منصة الكترونية لتتبع كل التقارير التي تتعدي 150 تقريرا المتعلقة بالجانب الاقتصادي من اجل تحديد نقاط القوة والضعف لتعزيز جاذبية المغرب، والحمد المغرب جنا تمار هذا العمل لعل اخره هو تقرير مناخ الاعمال الصادر مؤخرا في مني الاسبوع الماضي الذي صنف المغرب ضمن خانة 60 من دائرة اقتصاديات العالم، وهذا ليس سمالا ابدا نظرا لتعقد العديد من الاجراءات التي يتوجب القيام بها لتحسين جودة المغرب، ولنا شاهد بخصوص عمل اللجنة يتجلى في المقارنة بين وضعية تصنيف المغرب في التقارير الدولية حيت كان يتذيل الترتيب، لكن بعد انشاء اللجنة اصبح المغرب يحقق تطورا ملحوظا فمع كل سنة اصبحنا نحقق أو نربح العديد من النقاط والحمد لله ظفرنا بالمرتبة التالتة افريقيا والمرتبة الثانية في شمال افريقيا والشرق الاوسط بعد الامارات العربية المتحدة.

\section{خاتمة:}

وكإشارة ختامية نشير الى اننا نركز على المنهجية التشاركية بحت نحن نشتغل مع العديد من الفعاليات بشكل مشترك، ونراعي الجانب الدولي لأهميته، بالإضافة الى مراعات ضرورة تنزيل الاصلح على الجانب العملي بشكل يتوافق مع الوضع النظري له.

\section{وشكرا}

كلمة السيد رئيس الجلسة: اختتم السيد رئيس الجلسة كلمة المتدخل بعرض مجوعة من الافكار الاساسية التي تضمنتها مداخلته محللا ايها ومشيدا بعمل اللجنة الذي لا يخفى على الجميع. تم عمد الى فتح باب التدخلات من طرف السادة الحضور الكرام من باب المناقشة. 


\section{التوصيات المقترحة للندوة}

تنبغي الإشارة إلى أن الندوة لم تفرز توصيات عند اختتام المحاور المخصصة لما، إلا أن هذا لم يمنعنا من المبادرة شخصيا

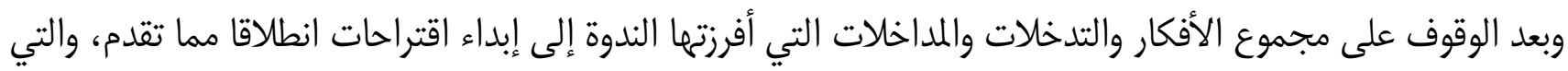

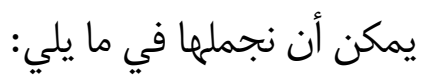

ضرورة اصلاح قطاع النفيذ والتبليغ لأنهما سبب في ضياع حقوق المقاولة والمتقاضين، فلا يعقل أن يتم استهلاك الماك

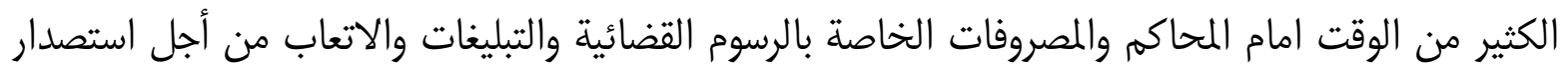

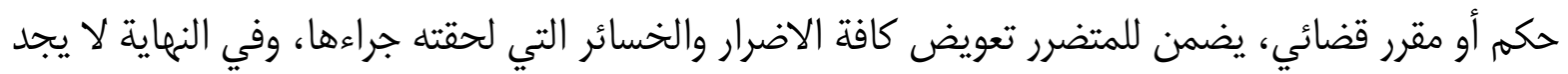

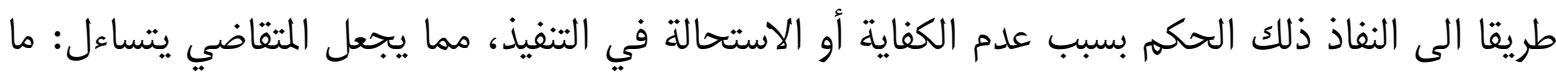

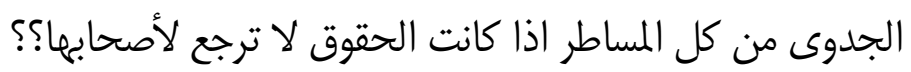

اعادة النظر في التوزيع الجغرافي للمحاكم وشساعة الخريطة القضائية لبعض المحاكم مما يطرح اشكالات أبرزها

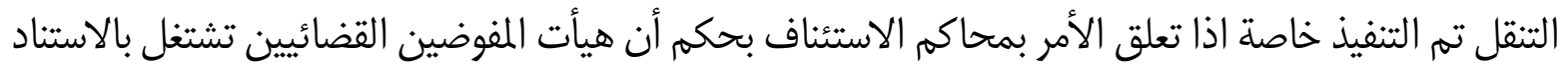

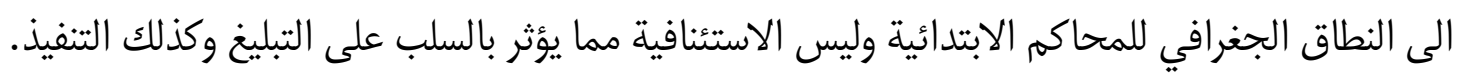
الاخذ بنظام الدمقراطية التشاركية في اصلاح قوانين التجارة والاعمال والاستثمار، وذبك باشراك كل الفاعلين

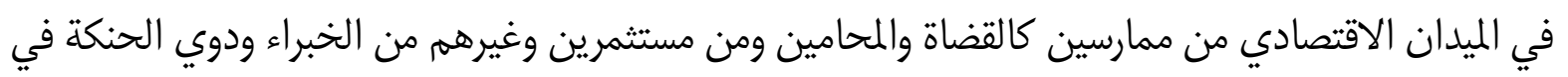
المجال الاقتصادي.

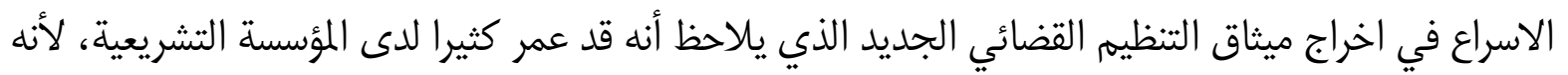

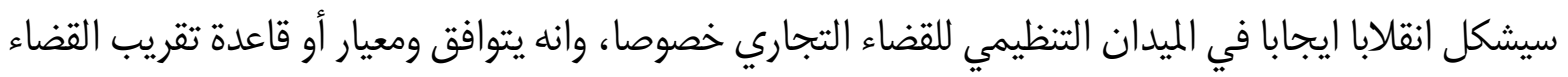
من المتقاضين.

تكوين الرصيد البشري للمنظومة القضائية على كافة الوسائل الرقمية استجابة لميثاق اصلاح منظومة القضاء، والانخراط في الاوراش العالمية بالاطلاع على تجارب الدول الرائدة في هذا المجال.

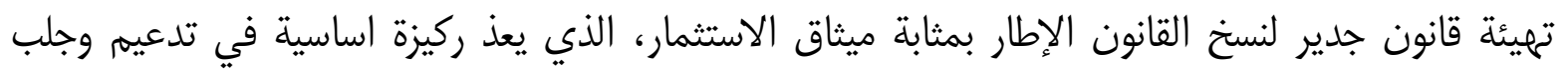

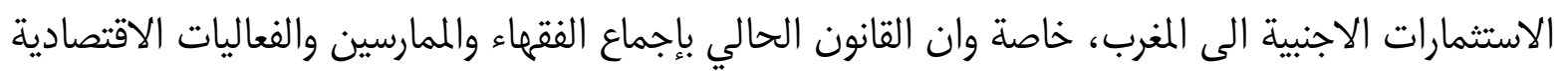

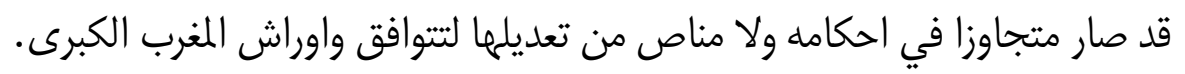
الحفاظ وتدعيم مبادئ التخصص القضائي التجاري التي راكما المغرب منذ سنوات إحدات المحاكم التجارية الى لى

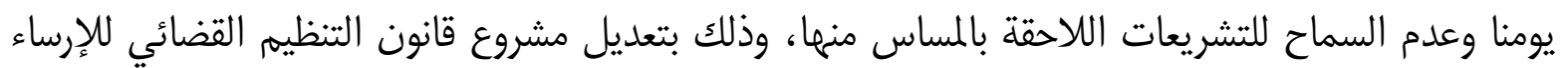
مبادئ الفصل بين التخصصات ودحض أي امكانية للتداخلية القضائية. 


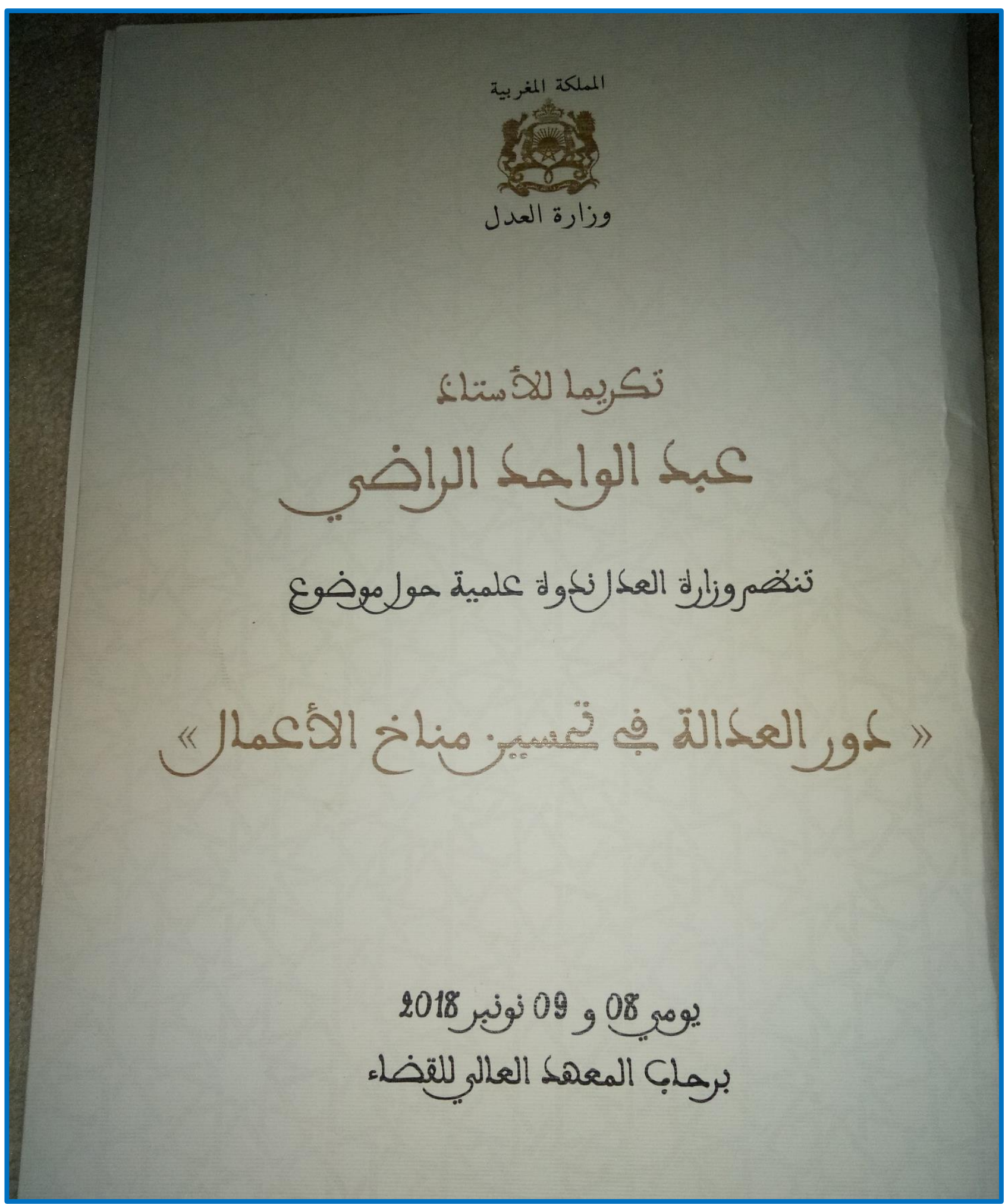



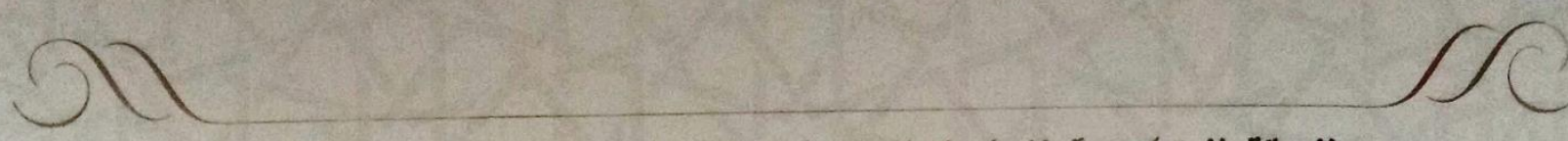

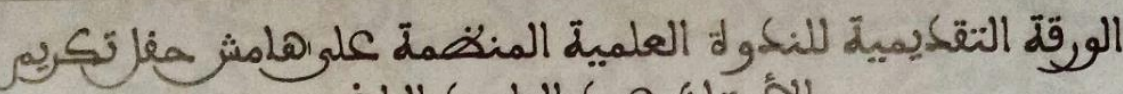

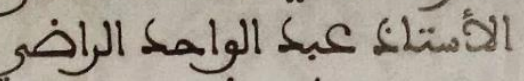
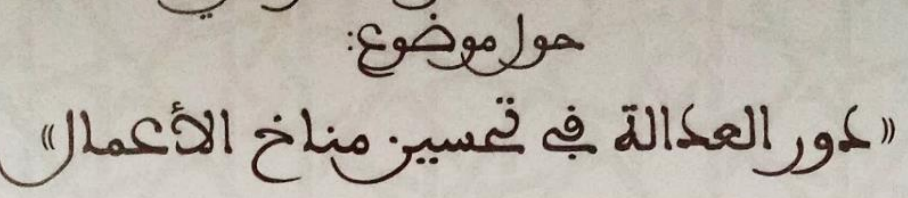

$$
\text { المعهك العالب للتضاء - } 08 \text { و09 نونبر } 2018
$$

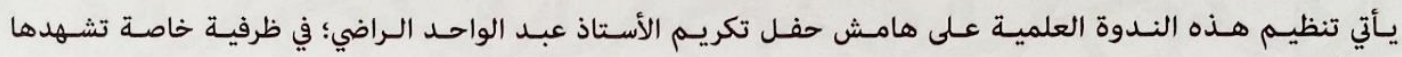

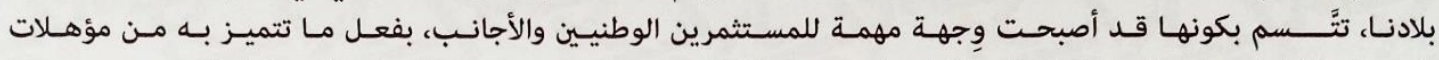

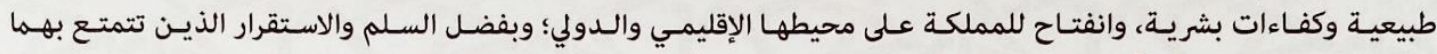

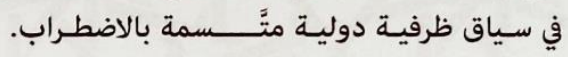

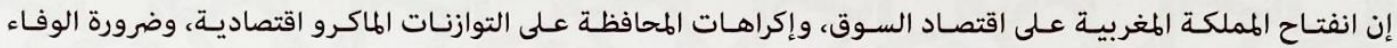

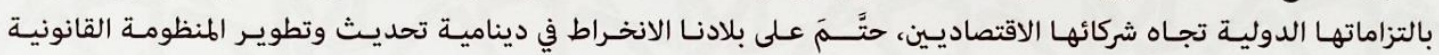

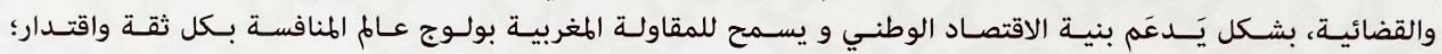

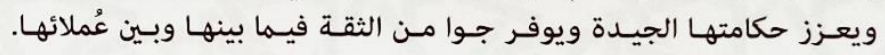

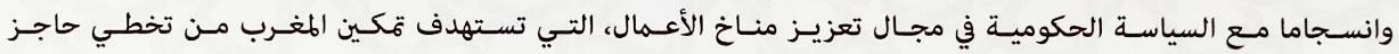

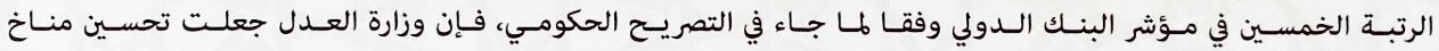

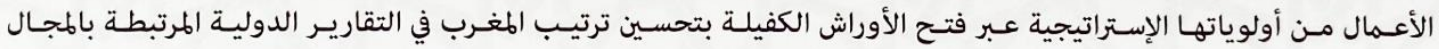

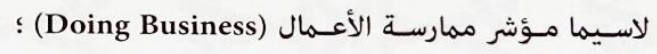

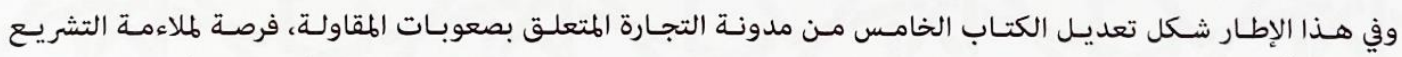

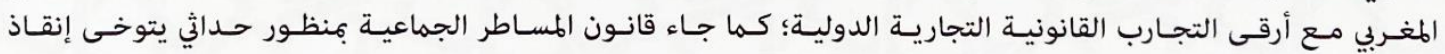

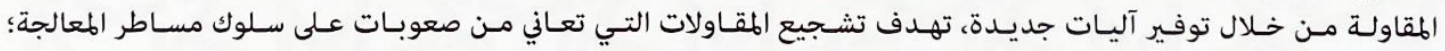

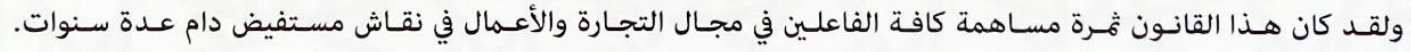

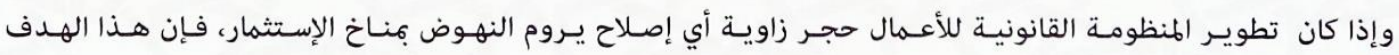

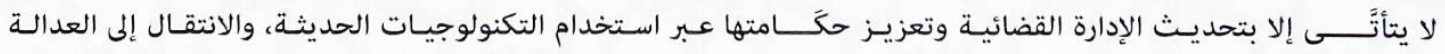

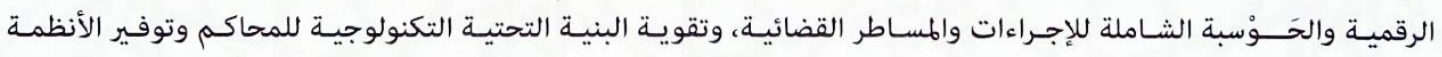
المعلوماتيـة الآمنـة، والبرامـج المتعلقـة بـإدارة القضايـا والطسـاطر.

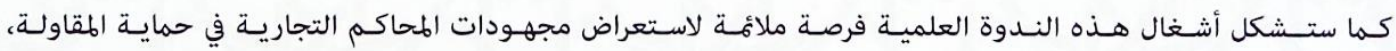

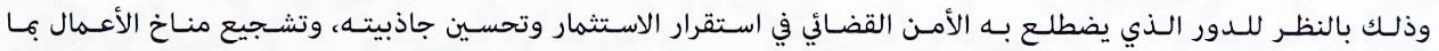

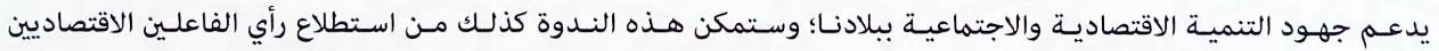

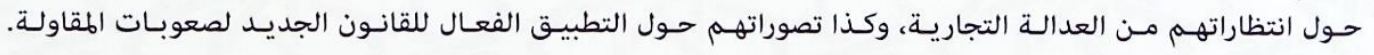




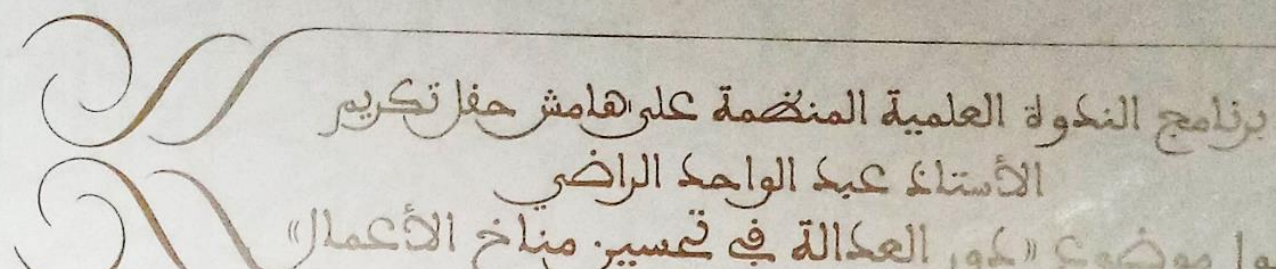

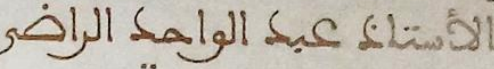

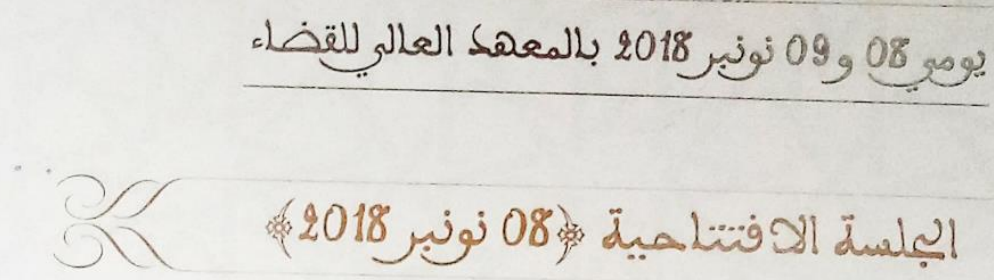

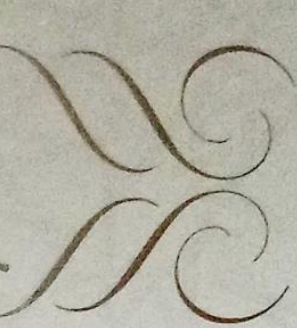

$$
\begin{aligned}
& \text { : استقبال الضـيوف. } \\
& 9.00-8.30 \\
& \text { : بلمبسة الافتتاحية. } \\
& \text { + كلمة السيد وزير العدل العاليس }
\end{aligned}
$$

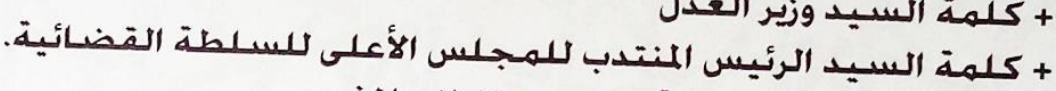

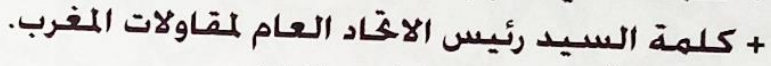

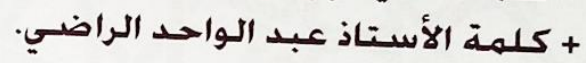

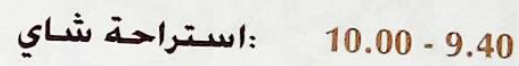

$$
\begin{aligned}
& 9.30-9.00
\end{aligned}
$$

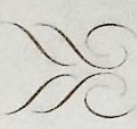

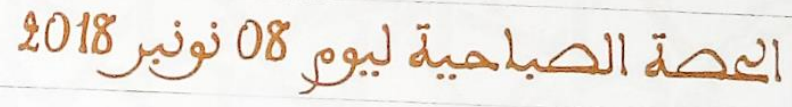

10.00 - 10.50 : المحسور الأول : دور وزارة العدل في النهـوض بمناخ الأعمال.

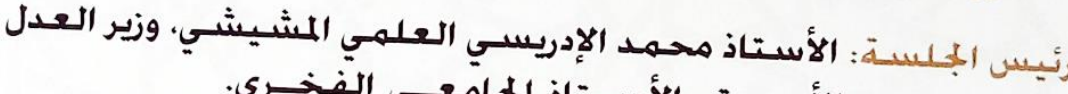

$$
\begin{aligned}
& \text { الأســبق والأســـاذ الجامعـــي الفــــري. }
\end{aligned}
$$

• مـوضـوع المـاخلـة الأولى : قانون مسـاطر صعوبات المقاولة الجلديد ودوره في حماية الإستثمار والمقاولة.

+ المتدخـل : الأستاذ الحسـن الكساسـم، مدير الشؤون المدنية بوزارة العدل.

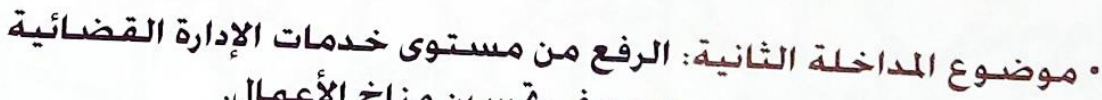

$$
\text { ودوره في ختسين مناخ الأعمال. }
$$

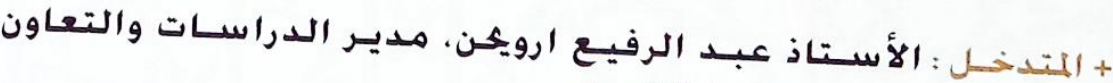

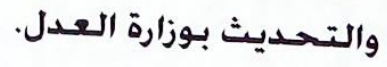

\section{* هدة كل مداخلة 20 دوقيقة *}

$13.30-10.50$

$$
15.00-13.30
$$




\section{إحة المسائية ليوم 08 نونبر 2018}

15.30 - 15.00

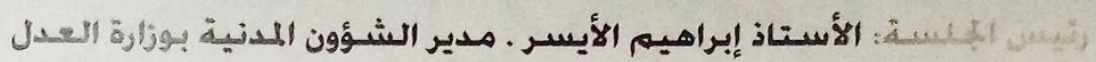

$$
\text { سبابـقا. }
$$

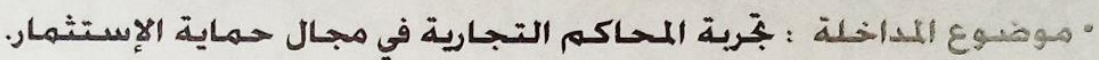

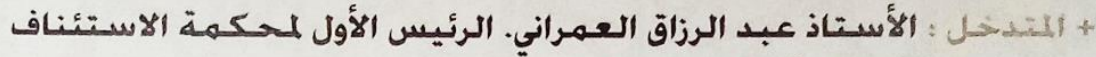

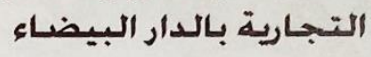

* مدة المبداخـلة 20 دقيـقةتة

15.30 - 17.00 : مناقشئة عامة.

$$
17.00
$$

\section{8 اعدة الصبلمية ليوز 09 نونير}

10.00 - 10.50 : المهـور الثالــث : انتظــارات الفـاعليين الاقتصـاديين من العدالة التجـاريـة.

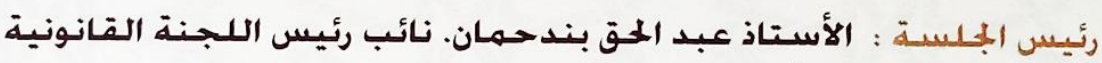

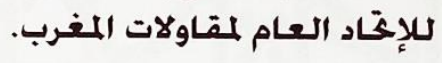

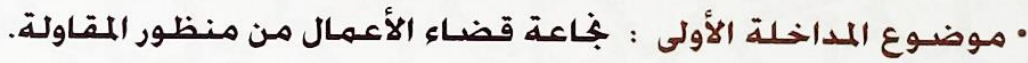

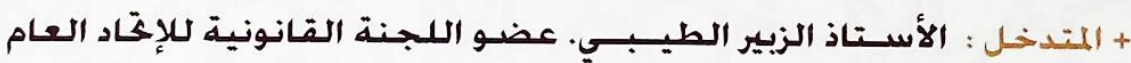

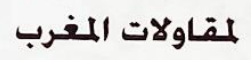

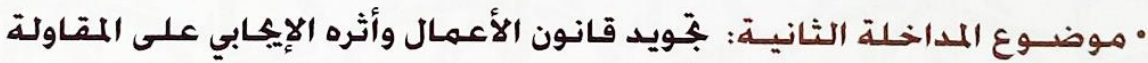
وحَسبين صـورة المغرب في التقارير آلدولية.

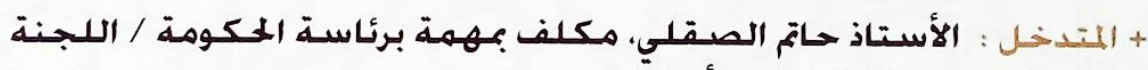

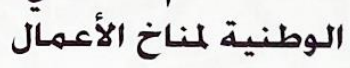

\section{* هدة كل هـداخلة 20 دقيقةت}

$11.10-10.50$

13.00 - 11.10

14.00

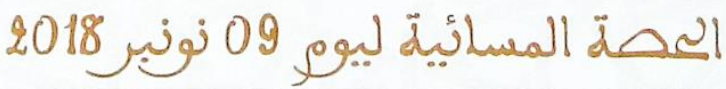 \\ : حفـل تكـريم الأسـتاذ عبــ الـواحـد الراضـي.}



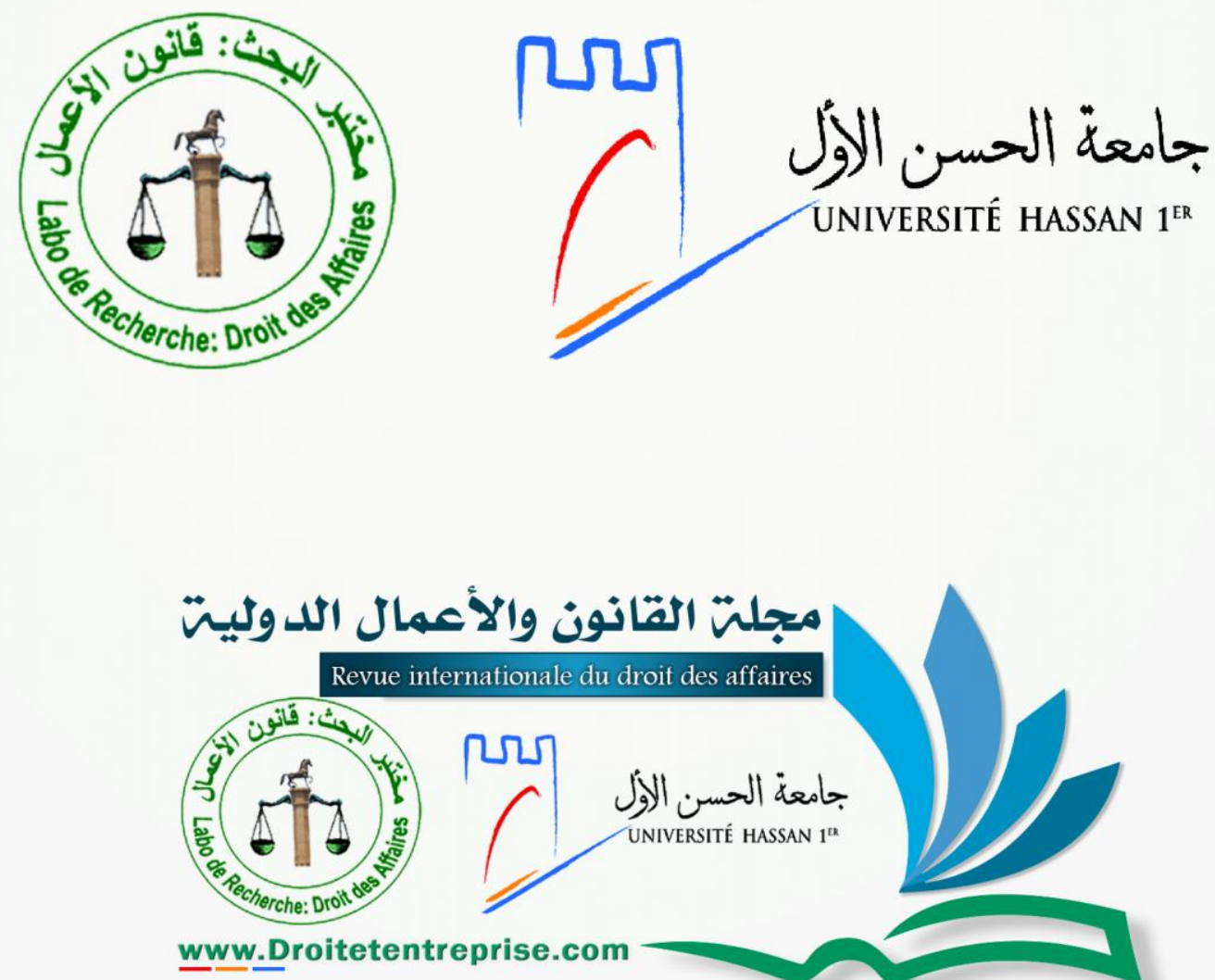

المركب الجامعي صندوق البريد: 539 طريق الدار البيضاء سطات 5723 البراء 26000 المغرب

$$
\begin{aligned}
& \text { الهاتف: 76/75 12 } 72523 \text { (212) } \\
& \text { الفاكس: } 741272523 \text { (212) } \\
& \text { البريد الإلكتروني: www.uhl.ac.ma }
\end{aligned}
$$

